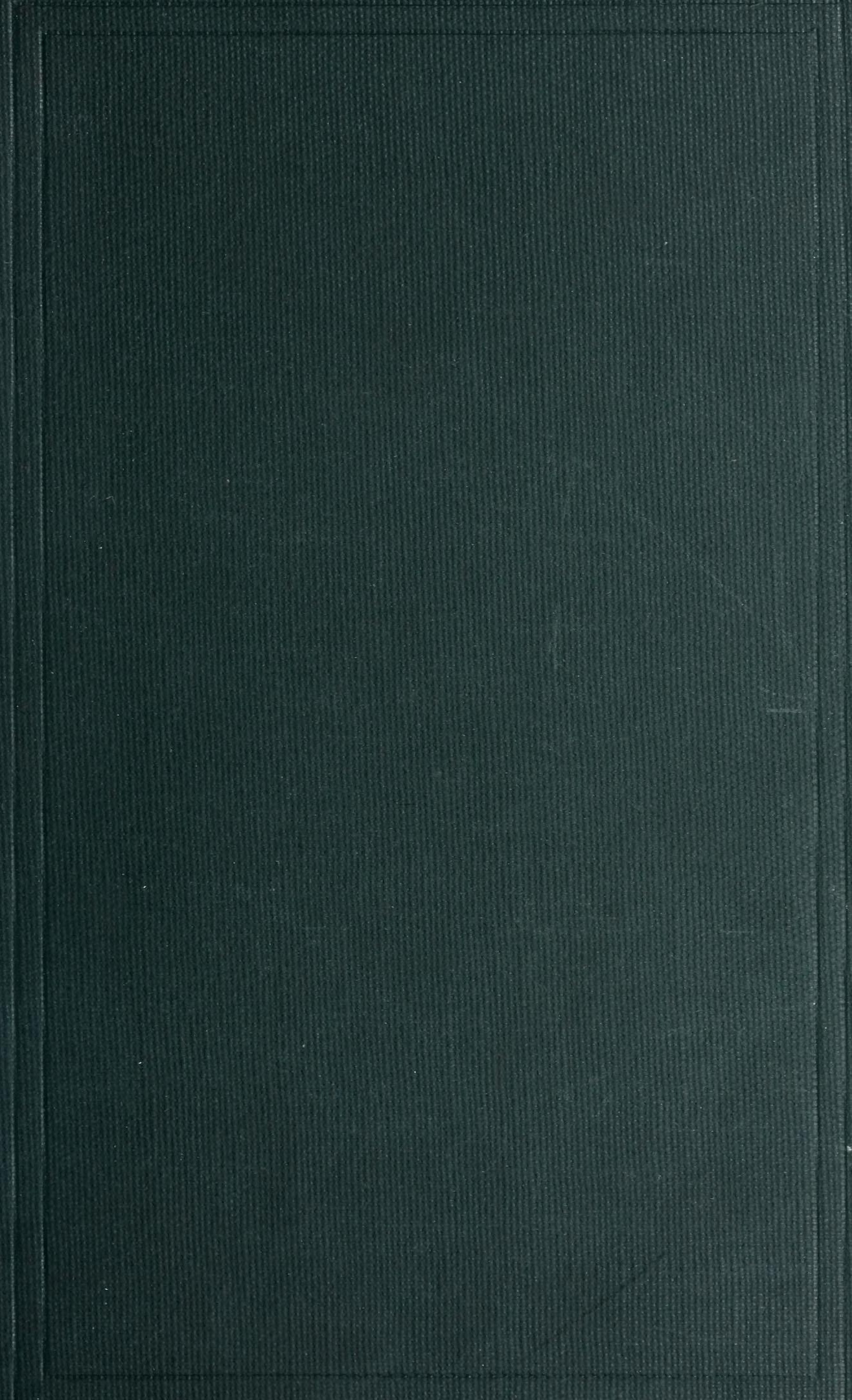





\section{Historic, archived document}

Do not assume content reflects current scientific knowledge, policies, or practices. 


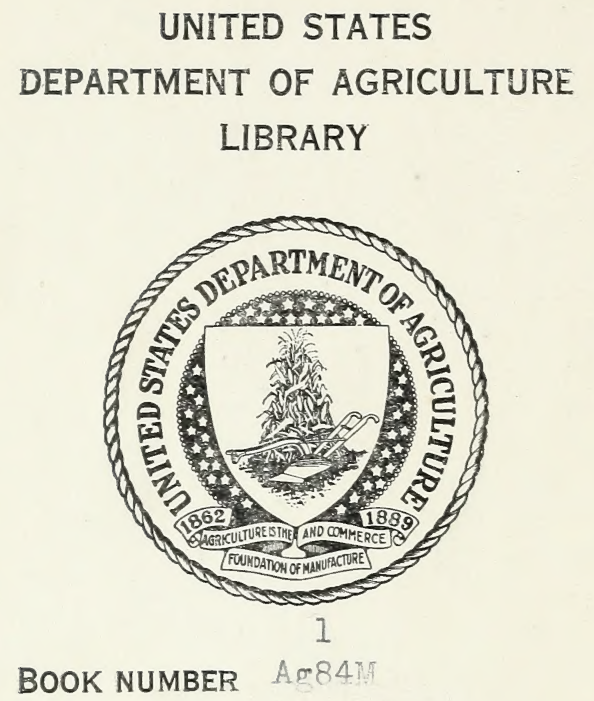

349224 




\title{
Manual of the \\ Grasses of the West Indies
}

\author{
By A. S. HITCHCOCK \\ Principal Botanist \\ Division of Plant Exploration and Introduction \\ Bureau of Plant Industry
}

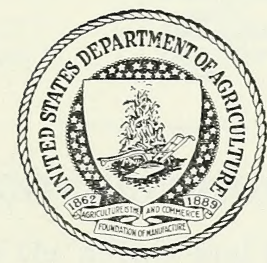

Miscellaneous Publication No. 243

United States Department of Agriculture

UNITED STATES

GOVERNMENT PRINTING OFFICE

WASHINGTON : 1936

For sale by the Superintendent of Documents, Washington, D.C. . . . . . Price $\$ 1.25$ (Buckram) 


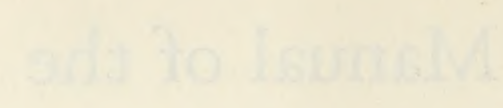

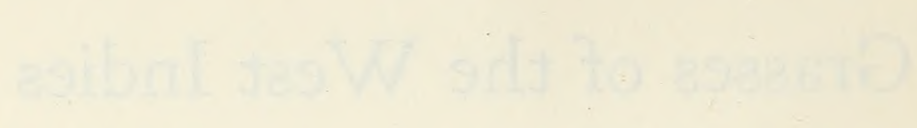




\section{UNITED STATES DEPARTMENT OF AGRICULTURE MISCELLANEOUS PUBLICATION No. 243}

Washington, D. C.

November 1936

\section{MANUAL OF THE GRASSES OF THE WEST INDIES}

By A. S. НІтснсоск, ${ }^{1}$ principal botanist, Division of Plant Exploration and Introduction, Bureau of Plant Industry

\section{CONTENTS}

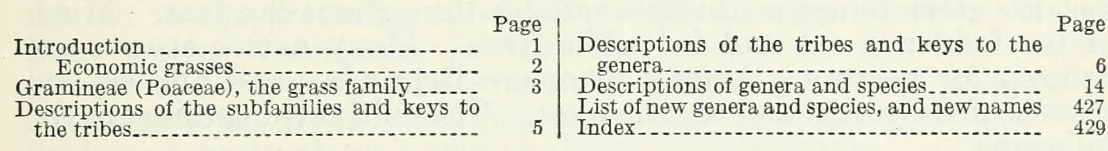

\section{INTRODUCTION}

More than 15 years ago the author and his associate, Agnes Chase, published a synoptical account of the grasses of the West Indies. ${ }^{2}$ Since the publication of that work a large amount of material has been added to the grass collection of the National Herbarium. The additions are from various sources, but consist chiefly of grasses collected in Cuba and Hispaniola by the late Erik L. Ekman, in Haiti by Emery C. Leonard, of the United States National Herbarium, and in Cuba by Brother Léon, of the Colegio de la Salle, Habana.

The present publication is more than a revision of the earlier work. In the first work the descriptions of genera and species were abbreviated for the most part to diagnoses and, although the known ranges of the species were given, there was no citation of specimens. The present work gives fuller descriptions, with at least one species of each genus illustrated, ${ }^{3}$ and cites specimens under each species, except for the few very common ones that are found throughout the region covered. The ranges of the species can now be indicated with much more exactness than was possible at the earlier date.

Considering the amount of attention given to the flora of the West Indies in earlier years the number of new species discovered and now described for the first time is unexpectedly large. However, the new species come for the most part from Hispaniola, the interior of which, until recently, has not been accessible, and from the larger island of

\footnotetext{
1 Died Dec. 16, 1935.

2 Contrib. U. S. Natl. Herb. 18: 261-471. 1917.

3 The habit drawings were mostly made by the late Mary Wright Gill and by Edna May Whitehorn. However, B. Y. Morrison, Mrs. George M. Mullett, and Agnes Chase each contributed a few. The
} spikelet drawings are by Agnes Chase. 
Cuba, which, though fairly well known to botanists, had many outof-the-way places that have yielded species of local distribution.

There are a few changes in names due to an increased knowledge of the taxonomy of the grass family, and several other changes have been made because the earlier work followed the American code whereas the present work is in accord with the International Rules of Botanical Nomenclature.

As in the earlier work, the term "West Indies" as here used includes not only the West Indies proper but also Bermuda, the Bahamas, Trinidad, and Tobago, but excludes the Dutch islands off the coast of Venezuela.

\section{ECONOMIC GRASSES}

The principal economic grasses of the West Indies are sugarcane and rice. Corn (Zea mays) is also widely grown, and grasses furnish the greater part of the forage for domestic animals.

\section{FORAGE GRASSES}

Only a few grasses are grown for forage. Hay is seldom produced because green forage is usually available throughout the year. Much of the fodder is cut and fed while fresh. Many native species are utilized for pasture. Among them are Bermuda grass and several species of Paspalum and of Axonopus. The cultivated species are the following:

Guinea grass (Panicum maximum). An erect rather robust perennial, propagated usually by division of the clump. Widespread at low altitudes as an escape from cultivation, Guinea grass is used for pasture and is cut and fed green. It is a native of Africa but is now distributed throughout the Tropics of both hemispheres. In Cuba it is called hierba Guinea.

Pará grass (Panicum purpurascens). A straggling perennial forming a tangled mass along the banks of streams and ditches. Pará grass is easily propagated from cuttings of the stems or from the long runners. It is used for pasture on wet land and is cut and fed green. It is widespread in the lowland Tropics of America and to a less extent in the Tropics of the Old World. Other common names are: Paraná, Dutch grass, Scotch grass, hierba Paral, hierba bruja, and malojilla, though the latter name applies more properly to Eriochloa polystachya.

Malojilla (mal-o-héya) (Eriochloa polystachya). This grass resembles Pará grass but differs in the spikelet characters. It grows in the same kind of habitat as does Pará grass and is not infrequently found growing with it. Malojilla is found rather commonly in Puerto Rico and infrequently in a few other islands. It appears to have the same forage value as Pará grass. In the United States this grass has been called Carib grass.

Sudan grass (Sorghum vulgare var. sudanense). An annual commonly grown in the southern United States and now rather frequently cultivated for green forage on the larger estates in the West Indies, especially in Cuba. Other sorghums, such as sorgo (sweet sorghum), kafir, and durra, are occasionally grown for green forage.

Napier grass (Pennisetum purpureum). This common tropical African forage grass was introduced rather recently into the semitropical parts of the United States and has been tried at several experiment stations in tropical America. It is now coming into favor 
for green feed on the larger estates. This grass is often known as elephant grass. It is a robust perennial growing to the height of 2 to $4 \mathrm{~m}$.

Pearl millet (Pennisetum glaucum; $P$. typhoideum). This robust annual is grown extensively by the natives of tropical Africa, and is used rather sparingly in the southern United States. It is occasionally grown in the West Indies.

Paspalum (Paspalum dilatatum). This grass comes from Argentina. It is a perennial, 30 to $100 \mathrm{~cm}$ tall ( 1 to 3 feet), growing in moderately dry to moist soil. It was introduced several years ago into the southern United States, where it is used for pasture and hay. It seems well adapted to conditions in the West Indies and its culture will probably increase there. It can be propagated by seed or by division of the tufts. In the United States this grass is called Dallis grass (after Mr. Dallis who was active in its introduction). Other common names are paspalum grass, water-grass, and water paspalum. Paspalum has proved valuable in Australia, South Africa, and especially in the Hawaiian Islands.

Vasey grass (Paspalum urvillei; P. vaseyanum). An erect perennial related to the preceding species but with a longer panicle. It has been grown occasionally in the West Indies on moderately dry ground and can be used for pasture. Vasey grass was introduced some years ago from Argentina, and is now commonly escaped into fields and waste places in the southern United States.

Bahia grass (Paspalum notatum). A low perennial with knotty rhizomes that soon form a firm sod. It is a native of Brazil and other parts of tropical America, where it is a constituent of native pasture land. It is now being cultivated for pasture in Central America and the subtropical United States. It gives much promise in the West Indies, especially in Cuba.

Carpet grass (Axonopus compressus). This is a common grass in open land at low altitudes throughout tropical America. In the United States it extends along the Coastal Plain from North Carolina to Texas. Carpet grass is one of the chief constituents of native pasture land in moist or mucky soil throughout the West Indies. It is propagated by division of the roots. It is a very satisfactory lawngrass in the Tropics where there is sufficient moisture.

Bermuda grass (Cynodon dactylon). This well-known species is widespread throughout the warm regions of the earth. It thrives on drier soil than is suitable for carpet grass. Bermuda grass may become a troublesome weed in cultivated soil because of its vigorous rhizomes and stolons, but as a pasture grass in open moderately dry soil it is without a competitor. It is also commonly used for lawns. In the English islands it is usually called Bahama grass. In the Spanish islands it is called grama, hierba fina, hierba del prado, pata de gallina, and several other names. A common French name is chiendent, and throughout the world it has a great variety of names.

Rhodes grass (Chloris gayana). This African grass was introduced into the United States several years ago and proved of value for hay and pasture in the irrigated sections of the Southwest. It is also used on the ranches of Hawaii. Rhodes grass has been tried in the West Indies and gives promise in drier regions.

Molasses grass (Melinis minutiflora). This African grass was early introduced into Brazil and has been used there extensively as 
a pasture grass. More recently it has spread northward and is now rather frequently seen in the West Indies. It escapes readily into brushland and soon furnishes much forage in such situations. Other names for this grass are catingueiro, yaragua, gordura, honey grass, Wynne grass, and Brazilian grass. The grass has a strong rather pleasant odor when fresh.

Natal grass (Tricholaena repens; T. rosea). A native of Africa, now widely introduced in tropical and subtropical regions of North America. It is very common in Florida where it furnishes forage on sandy lands that will grow little else. It is becoming common in the West Indies, and will be useful on light sandy lands. It is called Natal redtop in the Hawaiian Islands and wine grass in Cuba. The pink inflorescence in a mass is an attractive sight.

Jaraguá (Hyparrhenia rufa). An Old World grass early introduced into Brazil (there called capim jaraguá) where it is useful as a forage grass. In recent years it has been tried in the southern United States and is occasionally cultivated in the West Indies.

\section{GRASSES FOR OTHER PURPOSES THAN FOR FORAGE}

Sugarcane (Saccharum offcinarum) and rice (Oryza sativa) are the important standard agricultural crops.

Indian corn or maize, and the small grains, wheat, oats, rye, and barley, are grown more or less, the small grains only at upper elevations.

Certain oil grasses are met with here and there but are not grown on a commercial scale. These are citronella grass (Cymbopogon nardus) and lemon grass (C. citratus), found around dwellings, and vetiver (Vetiveria zizanioides), more commonly grown as a hedge plant. The aromatic roots of the latter are used in perfumery.

Wild cane (Gynerium sagittatum). A giant grass native in swampy places throughout the West Indies. The stems are used by the natives for lattices and light building purposes. In Cuba it is called caña de Castillo.

Giant reed (Arundo donax). A native of the Mediterranean region introduced in the warmer parts of North America, and now frequent in the West Indies along river banks and in moist soil. The stems are used for lattices and minor construction work. In Cuba it is called "güín."

The large bamboo (Bambusa vulgaris) is commonly cultivated around dwellings. The hollow stems with cross partitions are used for a great many purposes. The large species of bamboos are known in Cuba as caña brava. The bamboos are a promising source for paper. Dendrocalamus strictus, with nearly solid stems, is sometimes cultivated.

\section{GRAMINEAE (POACEAE), THE GRASS FAMILY}

Flowers perfect (rarely unisexual), small, with no distinct perianth, arranged in spikelets consisting of a shortened axis (rachilla) and 2 to many 2-ranked bracts, the lowest two being empty (the glumes, rarely one or both obsolete), the one or more succeeding ones (lemmas) bearing in their axils a single flower, and, between the flower and the rachilla a second 2-nerved bract (the palea), the lemma, palea, and 
flower together constituting the floret; stamens 1 to 6 , usually 3 , with very delicate filaments and 2-celled anthers; pistil 1, with a 1-celled 1-ovuled ovary, 2 (rarely 1 or 3 ) styles, and usually plumose stigmas; fruit a caryopsis with starchy endosperm and a small embryo at the base on the side opposite the hilum.

Herbs, or rarely woody plants, with hollow or solid stems (culms) closed at the nodes, and 2-ranked usually parallel-veined leaves, these consisting of two parts, the sheath, enveloping the culm, its margins overlapping or sometimes grown together, and the blade, usually flat; between the two on the inside, a membranaceous hyaline or hairy appendage (the ligule).

The spikelets are almost always aggregated in spikes or panicles at the ends of the main culms or branches. The perianth is usually represented by 2 (rarely 3 ) small hyaline scales (the lodicules) at the base of the flower inside the lemma and palea. The grain or caryopsis (the single seed and the adherent pericarp) may be free, as in wheat, or permanently enclosed in the lemma and palea, as in the oat. Rarely the seed is free from the pericarp, as in species of Sporobolus and Eleusine. The culms of bamboos are woody, as are also those of a few genera, such as Olyra and Lasiacis, belonging to other tribes. The culms are solid in the tribes Tripsaceae and Andropogoneae and in several other groups.

The parts of the spikelet may be modified in various ways. The first glume, and more rarely also the second, may be wanting. The lemmas may contain no flower, or even no palea, or may be reduced or rudimentary.

The division of the family into two subfamilies is somewhat artificial. The tribes Zoysieae, Oryzeae, Zizanieae, and especially Phalarideae, do not fall definitely into either of the recognized subfamilies. They are placed as indicated largely for convenience. The anomalous genus Streptochaeta cannot as yet be assigned to any established tribe.

\section{DESCRIPTIONS OF THE SUBFAMILIES AND KEYS TO THE TRIBES}

\section{SUBFAMILY 1. FESTUCOIDEAE}

Spikelets, 1- to many-flowered, the reduced florets, if any, above the perfect florets (except in Phalarideae; sterile lemmas below as well as above in Bambuseae and Uniola); articulation usually above the glumes; spikelets usually more or less laterally compressed.

Key to the Tribes of Festucoideae

Plants woody (scarcely so in Neurolepis), the culms perennial.

Plants herbaceous (except in Arundo), the culms annual.

1. Bambuseae (p. 6).

Stigmas 3

Stigmas 2

Spikelets with 2 sterile lemmas unlike and below the fertile lemma; no sterile or rudimentary floret above........................ 8. Phalarideae (p. 9).

Spikelets without sterile lemmas below the fertile floret (or these rarely present and like the fertile ones).

Spikelets unisexual, falling entire, 1-flowered, terete or nearly so.

10. ZizanieaE (p, 10). 
Spikelets perfect (rarely unisexual but then not as above), usually articulate above the glumes.

Spikelets articulate below the glumes, 1-flowered, very flat, the lemma and palea about equal, both keeled. Glumes small or wanting.

9. Oryzeae (p. 9).

Spikelets articulate above the glumes (rarely below, but the glumes, at least one, well developed).

Spikelets, 1-flowered (or the staminate 2-flowered), in groups (short spikes) of 2 to 5 (single in Zoysia), the groups racemose along a main axis, falling entire; lemma and palea thinner than the

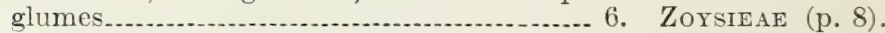

Spikelets not as above.

Spikelets sessile on a usually continuous rachis (short-pedicellate in Leptochloa; the rachis disarticulating in Hordeum).

Spikelets on opposite sides of the rachis; spike terminal, solitary.

3. HordeAE (p. 8).

Spikelets on one side of the rachis; spikes usually more than one, digitate or racemose................... 7. Chlorideat (p. 9), Spikelets pediceled in open or contracted, sometimes spikelike, panicles, rarely racemes.

Spikelets 1-flowered

Spikelets 2- to many-flowered.

Glumes as long as the lowest floret, usually as long as the spikelet (sometimes shorter in Sphenopholis); lemmas awned from the back (awnless in Sphenopholis).

4. Aveneae (p. 8).

Glumes shorter than the first floret.... 2. Festuceae (p. 7).

\section{SUBFAMILY 2. PANICOIDEAE}

Spikelets with one perfect terminal floret (disregarding those of the few monoecious genera and the staminate and neuter spikelets) and a sterile or staminate floret below, usually represented by a sterile lemma only, one glume sometimes (rarely both glumes) wanting; articulation below the spikelets, either in the pedicel, in the rachis, or at the base of a cluster of spikelets, the spikelets falling entire, singly, in groups, or together with joints of the rachis; spikelets, or at least the fruits, more or less dorsally compressed.

\section{Key to the Tribes of Panicoideae}

Glumes membranaceous, the sterile lemma like the glumes in texture.

Fertile lemma and palea scarcely firmer than the glumes.

11. Melinideae (p. 155).

Fertile lemma and palea indurate or at least firmer than the glumes.

12. PANiCEAE (p. 161). Glumes indurate; fertile lemma and palea, hraline or membranaceous, the sterile lemma like the fertile one in texture.

Spikelets unisexual, the pistillate below, the staminate above, in the same inflorescence or in separate inflorescences _...... 14. TRIPSACEAE (p. 423).

Spikelets in pairs, one scssile and perfect, the other pediceled and usually staminate or neuter (the pediceled one sometimes obsolete, rarely both pediceled)

13. AndROPOGONEAE (p. 376).

\section{DESCRIPTIONS OF THE TRIBES AND KEYS TO THE GENERA}

\section{TRIBE 1. BAMBUSEAE}

Culms woody, perennial, usually hollow; spikelets, 2- to severalflowered, in panicles or racemes, or in close heads or fascicles; often 1 or more sterile lemmas at base of spikelet; lemmas usually awnless; blades usually articulated with the sheath.

Culms climbing or clambering.

Spikelets 2- to several-flowered, racemose_.....3. Arthrostrlidium (p. 15).

Spikelets 1-flowered, in small panicles..............4. Chusocea (p. 22). 
Culms erect.

Spikelets 1-flowered, in a long dense terminal panicle; culm herbaceous.

5. Neurolepis (p. 23).

Spikelets several- to many-flowered, sessile in clusters, these somewhat remote on a common axis; culms woody.

Keels of palea projecting but not winged............. 1. BAmBUSA (p. 14).

Keels of palea winged ............................ Guadua (p. 14).

\section{TRIBE 2. FESTUCEAE}

Spikelets, more than 1-flowered, usually several-flowered, in open, narrow, or sometimes spikelike panicles (rarely in racemes); lemmas awnless or awned from the tip, rarely from between the teeth of a bifid apex; rachilla usually disarticulating above the glumes and between the florets.

Lemmas cleft at the summit into numerous awns; panicle contracted, elongate.

Lemmas with a single awn or awnless.

24. PAPPOPHORUM (p. 59).

Spikelets (at least the pistillate) with copious long silky hairs on the lemmas or the rachilla; tall reeds with large plumy panicles.

Spikelets unisexual; pistillate spikelets hairy, the staminate glabrous; plants dioecious

Spikelets perfect.

Lemmas hairy; rachilla glabrous 17. Gynerium (p. 49).

Lemmas glabrous; rachilla hairy 18. ARUNdo (p. 50). 19. Phragmites (p. 50). Spikelets not long-hairy, the hairs if present much shorter than the lemma. Glumes leaflike; spikelets concealed in the upper sheaths; plants dioecious.

Glumes not leaflike; spikelets exposed. 13. MoNanthOCHLÖ̈ (p. 45).

Stigmas elongate, wiry, coiled, tendrillike; spikelets in a long 1-sided

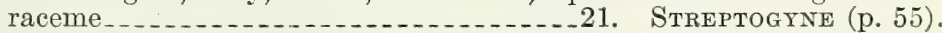

Stigmas not elongate nor wiry.

Blades broad, ovate to elliptic, showing transverse veins between the nerves.

Spikelets 3- to 5-flowered; glumes broad, truncate; panicles small.

23. ZEUGITES (p. 58).

Spikelets 1- or 2-flowered, the second floret commonly obsolete, the elongate rachilla only present; glumes acuminate; panicles large, diffuse..................... ORthoclada (p. 55).

Blades linear, no transverse veins showing.

Spikelets in 1-sided dense clusters, these at the ends of the few stiff panicle branches........ DACTYLIS (p. 49).

Spikelets not in 1-sided clusters.

Lemmas 3-nerved.

Nerves pubescent. . . . Triodia (p. 53).

Nerves glabrous ... Eragrostis (p. 33).

Lemmas 5 or more nerved.

Lowest 1 to 4 lemmas empty; spikelets firm, strongly compressed. Plants hermaphrodite, usually more than $50 \mathrm{~cm}$ tall.

Plants dioecious, usually less than $30 \mathrm{~cm}$ tall.

15. UNiola (p. 48).

Lowest lemmas fertile.

14. Distichlis (p. 47).

Florets horizontally spreading; lemmas cordate at base.

Florets ascending; lemmas not cordate.

11. BRIZA (p. 30).

Lemmas awnless; spikelets small.

Spikelets ovate or elliptic, few-flowered; lemmas keeled.

10. PoA (p. 29).

Spikelets linear, many-flowered; lemmas rounded on the back ................... 9. SCLEROPOA (p. 28).

Lemmas awned or mucronate (if awnless the spikelets large).

Awn from the tip.............. F. Festuca (p. 26).

Awn from a bifid apex or wanting -.-7. Bromus (p. 24). 


\section{TRIBE 3. HORDEAE}

Spikelets 1- to several-flowered, sessile on opposite sides of a jointed or continuous axis forming symmetrical spikes.

Spikelets solitary at each node of the continuous rachis___-26. LoLIUM (p. 61). Spikelets in threes at each node of the articulate rachis_-25. HordeUM (p. 61).

\section{TRIBE 4. AVENEAE}

Spikelets 2- to several-flowered in open or contracted panicles, or rarely in racemes; glumes usually as long as or longer than the first lemma, commonly longer than all the florets; lemmas usually awned from the back or from between the teeth of a bifid apex, the awn usually bent, often twisted, the callus and rachilla joints usually villous.

Articulation below the spikelet.

Second glume narrowed above; lemma of second floret awned on the back, the awn hooked................ Holcus (p. 68).

Second glume broadened above; lemmas awnless..28. Sphenopholis (p. 62). Articulation above the glumes and between the florets.

Plants annual.

Spikelets more than $1 \mathrm{~cm}$ long Spikelets less than $5 \mathrm{~mm}$ long-

Plants perennial.

Awn from between the teeth of the lemma, flat, twisted below.

Awn dorsal, terete, straight or twisted.

33. Danthonia (p. 70).

Panicle dense, spikelike; lemma acute

29. Trisetum (p. 64).

Panicle open, lemmas truncate, erose-dentate_30. Deschampsia (p. 64).

\section{TRIBE 5. AGROSTIDEAE}

Spikelets 1-flowered, usually perfect, in open, contracted, or spikelike panicles, but not in true spikes nor in one-sided racemes.

Lemmas awneä.

Awn trifid (lateral awns rarely minute)

40. Aristida (p. 87).

Awn simple.

Glumes awned; panicle contracted ............. 36. PolyPogon (p. 75).

Glumes awnless; panicle open or narrow, not contracted.

Awn from the tip of lemma; rachilla not prolonged.

Awn from back of lemma; rachilla prolonged.

38. Muhlenbergia (p. 77).

34. Calamagrostis (p. 71).

Lemmas awnless.

Inflorescence a cylindric spikelike panicle; glumes abruptly mucronate.

37. Phleum (p. 77).

Inflorescence an open or contracted panicle; glumes not abruptly mucronate.

Glumes not longer than the floret, usually much shorter.

39. Sporobolus (p. 80).

Glumes longer than the floret_................

\section{TRIBE 6. ZOYSIEAE}

Spikelets subsessile in short spikes of 2 to 5 (single in Leptothrium), each spike falling entire from the continuous axis, usually 1-flowered, all perfect, or perfect and staminate together in the same spike; glumes usually firmer than the lemma and palea, sometimes awned, the lemma awnless.

Spikelets solitary, finally reflexed; glumes subulate, awnless.

41. Leptothrium (p. 98) 
Spikelets 2 or more in a cluster, falling together.

Glumes smooth, connate at base, forming a pitcher-shaped false involucre.

42. Anthephora (p. 98).

Glumes covered with hooked spines, forming little burs, not connate.

\section{TRIBE 7. CHLORIDEAE}

Spikelets 1- to several-flowered, in two rows on one side of a continuous rachis, forming one-sided spikes or spikelike racemes, these solitary, digitate, or racemose along the main axis.

Plants monoecious or dioecious; pistillate spikelets many-awned; staminate spikelets awnless; plant stoloniferous.............57. OPIzIA (p. 140).

Plants with perfect spikelets.

Spike solitary (rarely 2 or 3 in Saugetia) terminating the culm.

Spikelets with 1 perfect long-awned floret_..._._. 53. SAUGeTia (p. 121).

Spikelets with several perfect short-awned florets__46. TRIPOGON (p 110).

Spikelets awnless....... Lepturidium (p. 111).

Spikes 2 or more on each culm.

Spikes racemosely arranged.

Spikelets articulate below the glumes, 1-flowered; maritime grasses with stout rhizomes ................... Spartina (p. 116).

Spikelets articulate above the glumes, 2-to several-flowered (the second floret rudimentary in Bouteloua).

Spikes short and relatively broad; upper floret often reduced to the awns.

Spikes long and slender; perfect florets 2 or more.

56. Bouteloua (p. 137).

Lemmas awnless or with minute awns, the upper floret reduced to an awnless small lemma........... 44. LePtochlоA (p. 102).

Lemmas with awns as long as the body, the upper floret reduced to a slender awn ..... Gournia (p. 108).

Spikes digitate or nearly so.

Spikelets with 2 or more perfect florets.

Rachis not extending beyond the spikelets_-_48. Eleusine (p. 113).

Rachis extending beyond the spikelets_49. Dactrloctenium (p. 113).

Spikelets with 1 perfect floret only.

Sterile floret wanting; lemma obtuse _.........50. Crnodon (p. 116).

Sterile floret present; lemma awned or mucronate.

Fertile floret raised on a long stipe; sterile florets reduced to long awns. 52. GyMnopogon (p. 118).

Fertile floret not raised on a stipe; sterile florets consisting of evident lemmas.

Fertile lemma 1-awned or awnless_.......54. CHLoris (p. 124).

Fertile lemma 3-awned....... Trichloris (p. 134).

\section{TRIBE 8. PHALARIDEAE}

Spikelets with one perfect terminal floret and, below this, a pair of staminate or neuter florets (one sometimes obsolete in Phalaris).

Spikelets not compressed; sterile florets exceeding the fertile floret, awned.

58. Anthoxanthum (p. 142).

Spikelets strongly compressed, the glumes keeled; sterile florets reduced to small scales adnate to the fertile floret........... 59 . Phalaris (p. 142).

\section{TRIBE 9. ORYZEAE}

Spikelets 1-flowered, perfect, strongly laterally compressed, paniculate; glumes reduced or wanting; palea apparently 1-nerved; stamens 6 .

Glumes present; lemmas usually awned. 60. ORYzA (p. 144).

Glumes wanting; lemmas awnless

61. Leersia (p. 147). 


\section{TRIBE 10. ZIZANIEAE}

Spikelets unisexual, the pistillate terete or nearly so; glumes shorter than the lemma, usually one or both obsolete, the pedicel disarticulating below the spikelet. Glumes well developed in Pharus, placed in this tribe provisionally.

Pistillate spikelet subglobose; glumes wanting; blades narrowly linear.

62. LUZIOLA (p. 149).

Pistillate spikelet cylindric, beaked; glumes present; blades broad, elliptic or oblanceolate-oblong ............................ Pharus (p. 151).

\section{TRIBE 11. MELINIDEAE}

Spikelets disarticulating below the glumes, these very unequal, the first minute, the second and the sterile lemma equal, membranaceous, strongly nerved, the latter bearing a slender awn from the notched summit; fertile lemma and palea thinner in texture, awnless.

Awn (of lemma) bent or twisted.............. 64 . Arundinella (p. 155).

Awns straight.

Glumes awned; lemma awnless.

Spikelets with a long pointed callus below _......65. Achlaena (p. 157).

Spikelets without a callus below ..............66. REYNAUdia (p. 159).

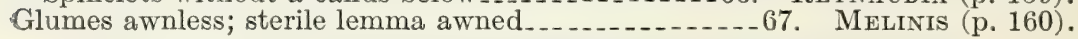

\section{TRIBE 12. PANICEAE}

Spikelets with one perfect terminal floret, and below this a sterile floret and two glumes; fertile lemma and palea indurate or at least firmer than the glumes and sterile lemma, a lunate line of thinner texture at the back just above the base, the rootlet protruding through this at germination; articulation below the spikelet.

Spikelets unisexual; plants monoecious.

Inflorescence of 2 digitate spikelike racemes, one pistillate, the other staminate.

Fertile floret obtuse -99. MNiochloa (p. 374).

Fertile floret narrowed into a slender awn ..._ 100. EkmaNochloA (p. 374).

Inflorescence paniculate, the panicle often much reduced.

Panicles large, terminal on the culms or leafy branches, the pistillate spikelets above, the staminate below in the same panicle.

96. Olyra (p. 366).

Panicles all axillary or axillary and terminal, the terminal when present wholly staminate.

Fruit laterally compressed, conspicuously gibbous on the upper dorsum.

Fruit dorsally compressed, lanceolate........... 98 . RADDIA (p. 372). Spikelets perfect.

Axis thickened and corky, the spikelets sunken in cavities in its joints, these disarticulating at maturity _.......... 72. STENotaPHRUM (p. 177).

Axis not thickened, the spikelets not sunken in it.

Spikelets subtended (only the terminal one in some species of Setaria) or surrounded by 1 to many bristles or spines (sterile branchlets), these distinct or more or less connate at base, forming a false involucre.

Bristles persistent.

Sterile palea at maturity becoming cartilaginous and winged, much exceeding the spikelet in width; spikelets secund along the branches of a simple panicle, each subtended by a single viscid bristle.

92. IXOPHORUS (p. 352). Sterile palea not enlarged at maturity _......... . 91 . Setaria (p. 332).

Bristles falling with the spikelets at maturity.

Bristles solitary, much exceeding the appressed spikelet.

93. Paratheria (p. 352). 
Bristles numerous below each spikelet or cluster of spikelets.

Bristles not united at base, usually slender, often plumose.

Bristles more or less united at the base, forming a bur.

94. Pennisetum (p. 355).

95. Cenchrus (p. 360).

Spikelets not subtended nor surrounded by bristles.

Fruit cartilaginous-indurate or (Triscenia) merely somewhat chartaceous, not rigid, papillose, usually dark colored, the lemma with white hyaline margins, these not inrolled.

Fruit open at the hyaline summit; inflorescence a narrow grayish silky panicle..... LEPTOCORYPHIUM (p. 163).

Fruit not open at the summit; inflorescence a narrow panicle or usually of slender racemes.

Inflorescence a narrow few-flowered panicle; first glume half as long as the spikelet, acute..............68. TRIscenia (p. 161).

Inflorescence 1 to many spikelike racemes.

Spikelets conspicuously long-silky; fruit lanceolate-acuminate; racemes in a flabellate panicle _..._70. TRICHACHNE (p. 163).

Spikelets with short pubescence or glabrous; fruit elliptic; racemes digitate or subdigitate_............

Fruit indurate, rigid (or if thin not hyaline-margined).

Sterile lemma splitting down the middle, the halves inrolled, appearing like two glumes side by side; raceme solitary, the rachis broadwinged.

Sterile lemma not splitting.

Spikelets solitary, subsessile, placed with the back of the fruit turned away from the rachis.

Inflorescence a solitary erect spikelike raceme, the spikelets

- swollen on the side toward the rachis and fitting into alternate hollows................... 74. Mesosetum (p. 180).

Inflorescence of 2 to many racemes or paniculate.

Rachilla joint and first glume forming a swollen ringlike callus at the base of the spikelet; inflorescence paniculate.

75. ERIOchloa (p. 182).

Rachilla joint and first glume not forming a callus at the base of the spikelet; inflorescence racemose.

Racemes racemose along the main axis; first glume present.

76. Brachiaria (p. 185).

Racemes aggregated at the summit of the culm; first glume wanting .................. Axonopus (p. 187).

Spikelets in twos or threes or solitary, placed with the back of the fruit turned toward the rachis or pedicellate in panicles.

Fruit long-acuminate, scarcely indurate, both glumes wanting; spikelet sessile, solitary, the stiff racemes horizontal or reflexed at maturity _............ ReIMAROCHLOA (p. 191).

Fruit not long-acuminate, indurate (if but slightly indurate both glumes present).

First glume typically wanting; spikelets planoconvex, subsessile in spikelike racemes...... 79. Paspalum (p. 193).

First glume present; spikelets usually in panicles, biconvex to globose.

Glumes or lemmas or both awned or, if short-pointed only, the summit of the fertile palea not enclosed and the spikelets crowded in short racemes.

Inflorescence of 1-sided racemes along a common axis; glumes 2-lobed (rarely entire), awned from between the lobes; fruit indurate, the palea enclosed at the summit........

Inflorescence paniculate.

Spikelets long-silky; first glume minute, remote.

90. Tricholanna (p. 331)

Spikelets not silky, often scabrous or hispid.

Spikelets with a long-pointed callus at the base.

89. Chaetium (p. 331).

Spikelets without a callus_88. EсHINOCHLOA (p. 325). 
Glumes and lemmas awnless (fruit pointed in Scutachne).

Lower floret of the spikelet perfect, usually fruitful; spikelets small, turgid, obtuse_..._.86. IsACHNE (p. 315). Lower floret staminate or neuter.

Second glume and sterile lemma leathery-indurate; fruit mucronate.......... S5. Scutachne (p. 313). Second glume and sterile lemma membranaceous; fruit not mucronate.

Inflorescence a cylindric or interrupted spikelike panicle; fruit either scarcely indurate, the palea not enclosed at the summit, or stipitate and the spikelets with a saccate second glume; aquatics or subaquatics.

Second glume inflated-saccate; fruit stipitate.

83. SACCIOLEPIS (p.310).

Second glume not inflated-saccate; fruit scarcely indurate, open at the summit, not stipitate.

84. HYMENACHNE (p. 312).

Inflorescence an open or contracted panicle or, if somewhat spikelike, the fruit not stipitate nor the second glume saccate; fertile lemma chartaceousindurate.

Culms woody, bamboolike; spikelets globose, large; fertile lemma and palea bony-indurate, a downy tuft at the apex...... 82 . LAsiacis (p. 302).

Culms not woody nor bamboolike.

Fertile lemma with either lateral appendages or excavations at the base, the margins usually not inrolled...... 81. IсHNANTHUS (p. 296).

Fertile lemma with neither lateral appendages nor excavations at base, the inrolled margins clasping the palea_.._80. PANICUM (p. 242).

\section{TRIBE 13. ANDROPOGONEAE}

Spikelets in pairs along a rachis, the usual arrangement being one of the pair sessile and fertile, the other pedicellate and staminate or neuter, rarely wanting, only the pedicel present; fertile spikelet consisting of one perfect terminal floret and, below this, a staminate or neuter floret, the lemmas thin or hyaline, and two awnless glumes, one or usually both firm or indurate.

Spikelets all perfect.

Inflorescence of 2 to several digitate racemes_.....116. Ischaemum (p. 416).

Inflorescence a densely flowered hairy panicle.

Spikelets awned.......

Spikelets awnless.

Rachis continuous...

Rachis disjointing

Spikelets not all perfect, the sessile usually perfect, the pedicellate usually staminate or rudimentary (pistillate in Eriochrysis).

Fertile spikelet with hairy-pointed callus formed of the attached supporting rachis joint or pedicel or of the upper part of the peduncle; awns usually long.

Racemes reduced to a single joint, long-peduncled in a simple open panicle 113. RHaphis (p. 410).

Racemes of few or many joints, not in an open panicle.

Rachis continuous; perfect spikelets pedicellate, disarticulating at the base of the pedicel; awns plumose 115 . TRACHYPOGON). (p. 415).

Rachis disarticulating, the joints attached to perfect spikelets next above, forming a callus to them.

Racemes solitary, not subtended by leaflike spathes; perfect spikelets several to many above; staminate spikelets several to many

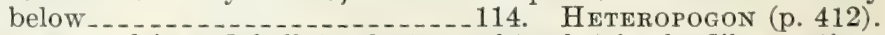

Racemes several in a flabellate cluster, subtended by leaflike spathes; perfect spikelet 1 in each raceme_.._._.120. THEMEDA (p. 420). 
Fertile spikelet without a callus, the rachis disarticulating immediately below the spikelet.

Inflorescence a dense golden-brown silky panicle; spikelets awnless, the pedicellate one pistillate............. 103. ERIOchrYSis (p. 380).

Inflorescence not a dense golden-brown silky panicle; pedicellate spikelet staminate or rudimentary.

Pedicel of the sterile spikelet thickened, appressed to the thickened rachis joint or adnate to it; spikelets awnless, appressed to the joint.

Rachis joint and pedicel adnate. Annuals.

Perfect spikelet globose; sterile spikelet conspicuous.

Perfect spikelet oblong; sterile spikelet minute. 119. HACKELOCHLOA (p. 420).

117. Rottboellia (p. 418).

Rachis joint and pedicel distinct, the sessile spikelet appressed to them, its first glume lanceolate............118. MANISURIS (p. 418).

Pedicel of the sterile spikelet distinct, this and the rachis joint usually slender.

Spikelets in reduced racemes of 1 to 5 (rarely 7 ) joints, these peduncled in open panicles; awns, if present, commonly deciduous.

Pedicellate spikelets staminate._._..._._111. Sorghum (p. 407). Pedicellate spikelets wanting, the pedicel only present.

112. Sorghastrum (p. 409).

Spikelets in evident racemes of several to many joints.

Blades cordate, thin; pedicellate spikelets obsolete or present only in the lower part of the delicate subdigitate racemes.

105. Arthraxon (p. 382).

Blades linear, not cordate; pedicellate spikelets present, at least as rudiments.

Inflorescence an elongate panicle of whorled long-peduncled slender glabrous racemes; spikelets muricate, awnless.

110. Vetiveria (p. 406).

Inflorescence not a panicle of long-peduncled racemes; spikelets not muricate; racemes commonly conspicuously woolly.

Margins of the first glume of the sterile spikelet involute, the sides rounded instead of sharply keeled. Racemes in pairs, reddish brown, $2 \mathrm{~cm}$ long, crowded in a large inflorescence. 109. H YPARRHENIA (p. 404).

Margins of the first glume of the sessile spikelet inflexed, the glume sharply 2-keeled, the back flat or grooved between the keels.

Pedicellate spikelets much larger than the sessile, almost concealing them, the first glume large and flat; racemes solitary on the branches............107. Diectomis (p. 402).

Pedicellate spikelets sometimes as large as the sessile, usually smaller, the first glume not large and flat.

Racemes single, in pairs, digitate, or numerous, sometimes supported by spathes; lowest pairs of spikelets like the upper, one fertile and sessile, the other pedicellate, staminate or reduced........106. ANDRopogon (p. 385).

Racemes in pairs subtended or enclosed by a broad spathe, aggregate in large compound panicles, the lowest pair of spikelets of one of the racemes alike, staminate or neuter. Aromatic grasses_..........108. Cүмвоpogon (p. 403).

\section{TRIBE 14. TRIPSACEAE}

Spikelets unisexual, the staminate in pairs, or sometimes in threes, 2-flowered, the pistillate usually single, 2-flowered, the lower floret sterile, embedded in hollows of the thickened articulate axis and falling attached to the joints, or enclosed in a thickened involucre or sheath; glumes membranaceous or thick and rigid, awnless; lemmas and palea hyaline, awnless. Plants monoecious.

Pistillate spikelets sunken in recesses in the thickened joints of the rachis; inflorescence of solitary or digitate racemes.........121. TRIPSACUM (p. 423). Pistillate spikelets enclosed in a bony beadlike involucre ...122. Corx (p. 423). 


\section{DESCRIPTIONS OF GENERA AND SPECIES}

\section{TRIBE 1. BAMBUSEAE}

1. BAMBUSA Retz., Obs. Bot. 5: 24. 1789. [As Bambos]

Spikelets, several- to many-flowered, sessile, solitary or in clusters on an elongate axis or the branches of a panicle, the glumes and sterile lemmas persistent after the fall of the florets; glumes small; lemmas firm, sharp-pointed or awn-tipped; keels of palea projecting but not winged; stamens 6 . Large usually erect bamboos of the Old World.

1. Bambusa vulgaris Schrad.; Wendl., Coll. Pl. 2: 26. pl. 47. 1810. Common вамвоо.

Bambusa sieberi Griseb., Fl. Brit. W. Ind. 528. 1864. Martinique. Arborescent, as much as $10 \mathrm{~m}$ tall, freely branching; flowering branches fascicled, elongate, leafless, the sessile spikelets radiate in clusters.

Cultivated in the Tropics of both hemispheres, the native country doubtful but not American. Often planted around dwellings. Called in Cuba "caña brava." The hollow stems are used for various purposes.

Cuba: Herradura, Léon ${ }^{4}$ 16091, 16094. Habana, Léon 16095. San Blas, Jack 6923, 8727. El Cristo, Ekman in 1922.

JAMAICA: Gordon Town, Hart 350a, 566. Castleton, Harris 11709.

Haiti: St. Michel de l'Atalaye, Leonard 7515.

Dominican Republic: Santiago, Ekman H 16267.

Leeward Islands: Guadeloupe, Duss 4122.

Windward Islands: Martinique, Duss 1285. Grenada, Broadway 1728 .

Trinidad: Port of Spain, Hitchcock 9986. Four Roads, Broadway 2246.

Toвago: Broadway 3412.

Bambusa nana Roxb. (Fl. Ind. 2: 199. 1832), 2 to $3 \mathrm{~m}$ tall, has spread from cultivation at Cinchona, Jamaica.

2. GUADUA Kunth, Syn. Pl. Aequin. 1: 252. 1822

Spikelets several-flowered, subterete, mostly elongate, sessile or nearly so ; stamens 6 ; palea winged. Large erect bamboos, our species spiny.

1. Guadua latifolia (Humb. and Bonpl.) Kunth, Syn. Pl. Aequin. 1: 254. 1822.

Bambusa latifolia Humb. and Bonpl., Pl. Aequin. 1: 68. pl. 21. 1808. Venezuela.

Arborescent, as much as $8 \mathrm{~m}$ tall, the summit nodding; spikelets cylindric, more or less falcate.

Damp forests, Trinidad and northern South America.

Trinidad: Botanic Gardens, "Planted, said to be native." Broadway 7174 (fertile).

1 On some of Brother Léon's collections a second name is associated with his, that of Brother Charles, Brother Clémente, Brother Hioram, or Brother Sergius, Father Roca, F. R. Cazañas, and others. Brother Léon has explained in a letter that these collections form a single series with his individual numbers; hence they are here listed under his name. 
3. ARThrostylidium Rupr., Mém. Acad. St. Pétersb. VI. Sci. Nat. $3^{1}$ : 117. 1839

Spikelets few-flowered, in racemes, the lower 1 or 2 lemmas empty, the rachilla disarticulating between the florets (rarely below the glumes); stamens 3. Mostly climbing or trailing shrubs, the short fertile branches in fascicles on the main cane. In Cuba the species are called "tibisi", as are those of Lasiacis.

Blades subcapillary, in dense fascicles, 1 to $3 \mathrm{~mm}$ wide, as much as $30 \mathrm{~cm}$ long,

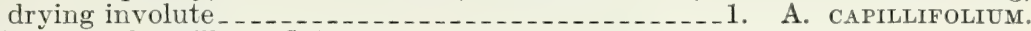

Blades not subcapillary, flat.

Tips of eulms and branches retrorse-scabrous.

Florets about $10 \mathrm{~mm}$ long. Blades 7 to $9 \mathrm{~mm}$ wide_..._. 2. A. EKMANII. Florets about $7 \mathrm{~mm}$ long.

Blades 3 to $6 \mathrm{~mm}$ wide _._. A. Haitiense.

Blades 10 to $12 \mathrm{~mm}$ wide, or those of the sterile branches as much as $3 \mathrm{~cm}$

Tips of culms and branches not retrorse-scabrous.

Blades not more than $5 \mathrm{~cm}$ long (rarely $6 \mathrm{~cm}$ long in young shoots).

Sheaths not bristly; inflorescence racemose_...... 5. A. SARMENTOSUM.

Sheaths conspicuously squarrose-bristly at summit; inflorescence elongate, consisting of distant groups of spikelets_........6. A. DISTICHUM.

Blades or some of them at least $8 \mathrm{~cm}$ long.

Bristles at summit of sheath very slender, 1 to $5 \mathrm{~cm}$ long.

Spikelets erect, appressed; bristles 1 to $2 \mathrm{~cm}$ long--7. A. Fimbriatum.

Spikelets reflexed by a bend in the lower part; bristles 4 to $5 \mathrm{~cm}$ long.

8. A. REFLEXUM.

Bristles at summit of sheath wanting or less than $1 \mathrm{~cm}$ long.

Blades 3 to $4 \mathrm{~mm}$ wide, as much as $25 \mathrm{~cm}$ long _- 9. A. ANG UStifolium.

Blades not so long and narrow.

Spikelets in dense mostly 1 -sided racemes_....._. 10. A. PRESToer.

Spikelets not in dense racemes.

Main eulms strigose. Blades linear-lanceolate, up to $15 \mathrm{~mm}$ wide; spikelets distant, appressed_........... A. PUBESCENs.

Main culms not strigose.

Blades puberulent, at least beneath, stiff, 5 to $10 \mathrm{~cm}$ long, 3 to 5 mm wide_............. URBANII.

Blades glabrous.

Rachis of short raceme strongly zigzag. Blades oblonglanceolate, as much as $15 \mathrm{~mm}$ wide_._13. A. EXCELSUM.

Rachis straight.

Racemes elongate, as much as $15 \mathrm{~cm}$ long; blades linearlanceolate, as much as $1 \mathrm{~cm}$ wide _... 14. A. CUBENsE.

Racemes short; blades as much as $8 \mathrm{~cm}$ long and $12 \mathrm{~mm}$

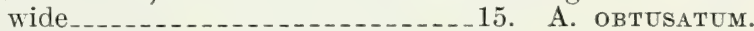

1. Arthrostylidium capillifolium Griseb., Mem. Amer. Acad. (n. s.)

8: 531. 1862. Eastern Cuba, Wright 738.

Arundinaria capillifolia Hack., Oesterr. Bot. Ztschr. 53: 69. 1903.

Climbing to a height of $15 \mathrm{~m}$ or more, repeatedly branching, swinging down from the trees in great curtains, or festooning lower growth, the linear or filiform blades crowded on short sterile branchlets, these arranged in dense whorls like great pompons at the distant nodes; inflorescence of numerous slender wiry, not zigzag racemes borne in the whorls of branchlets, the appressed rather distant spikelets about $1 \mathrm{~cm}$ long.

Dryish thickets and wooded slopes, northern West Indies.

Bahamas: New Providence, Eggers 4242; Brace and Britton 537; Geogr. Soc. Baltimore 46; Curtiss 94; Hitchcock in 1890; Field 319. 
Andros Island, Small and Carter 8917. Great Exuma, Britton and Millspaugh 2997.

Cuba: Guane, Britton and Cowell 9774. Cajálbana, Léon 4853, 4854. Paso Real, Van Hermann 780. Habana, Léon 900, 901, 2031; Ekman 13160. Jucaral, Britton and Wilson 5743. Banao Mountains, Léon 8074. Dumañuecos, Léon 15742. Buenos Aires, Bailey 12444. La Gloria, Shafer 560. Nuevitas, Shafer 831. Holguín, Shafer 1244, 1398a. Sierra de Nipe, Ekman 2285, 6389. Guara, Hitchcock 23391. Isla de Pinos, Britton and Wilson 15755.

Haiti: Gros-Morne, Leonard 9734. Ennery, Leonard 8907. St. Michel de l'Atalaye, Leonard 7462. Port-de-Pai, Ekman H 4560. L'Arcahaie, Ekman H 9286.

Dominican Republic: Loma Bagita, Valeur 101. San José de Ocoa, Ekman H 11667.

Puerto Rico: Maricao, Chase 6248; Hess in 1913. Sabana Grande, Sintenis 3891. Arecibo, Cowles 1166. Vieques Island, Shafer 2625.

Virgin Islands: St. Thomas, Shafer and Fitch 1467; Eggers in 1881

\section{Arthrostylidium ekmanii Hitchc., sp. nov. ${ }^{5}$}

Culms climbing, slender (the main cane $2 \mathrm{~mm}$ thick), at first scabrous, becoming glabrous, the branches in fascicles at the distant nodes (25 cm apart), drooping, 20 to $30 \mathrm{~cm}$ long, these branching, bearing several appressed branchlets; sheaths glabrous, striate, the summit bearing several flexuous implicate bristles 5 to $7 \mathrm{~mm}$ long; blades (only those of the fertile branches seen) ascending, linearlanceolate, glabrous except the pubescent tip, 3 to $6 \mathrm{~cm}$ long, 4 to 8 $\mathrm{mm}$ wide, the petiole about $1 \mathrm{~mm}$ long; spikelets single or 2 or 3 in a raceme at the ends of the branchlets, 3 to $5 \mathrm{~cm}$ long, the usually 4 or 5 fertile florets loosely arranged on a glabrous slightly zigzag rachilla (this not hidden by the florets); glumes narrow, somewhat unequal, the first 3 to $7 \mathrm{~mm}$ long, the second a little longer; lower lemma empty, longer than the glumes; fertile lemmas brownish (exposing the pale rachilla joints), 9 to $12 \mathrm{~mm}$ long, widest (about $1.5 \mathrm{~mm}$ ) about one-third above the base, gradually narrowed to an obtusish somewhat boat-shaped tip; palea from a little shorter to a little longer than the lemma, bowed out about the middle of the floret, flat and puberulent between the strongly compressed keels, the margins overlapping toward the tip; upper floret narrow, reduced.

Type in the United States National Herbarium, no. 1410884, collected on Massif de la Selle, Marigot, at Riviére Chotard, altitude 1,750 m, Haiti, April 10, 1927, by E. L. Ekman (no. H 7982).

The only other specimen seen is:

Dominican Republic: Cordillera Central, Loma la Campana, high ridge, altitude 1,000 m, Ekman $\mathrm{H} 11520$.

3. Arthrostylidium haitiense (Pilger) Hitchc. and Chase, Contrib. U. S. Natl. Herb. 18: 399. 1917.

Arundinaria haitiensis Pilger, in Urban, Symb. Antill. 5: 288. 1907. Haiti, Buch 929.

Culms slender, climbing, the young internodes very scabrous; branches numerous, about $20 \mathrm{~cm}$ long, in distant fascicles; blades

$\checkmark$ Culmi seandentes, internodiis junioribus asperis, ramis ad nodos fasciculatis $20-30 \mathrm{~cm}$ longis ramulosis: vaginae glabrae fimbriatae, fimbriis 5-7 mm longis; laminae lineari lanceolatae glabrae, apice pubescentes, 3-6 cm longae 4-8 $\mathrm{mm}$ latae, petiolo $1 \mathrm{~mm}$ longo; spiculae $3-5 \mathrm{~cm}$ longae, floribus fertilibus $3-5$; lemmata 9-12 $\mathrm{mm}$ longa. 
5 to $7 \mathrm{~cm}$ long, about $6 \mathrm{~mm}$ wide, with a petiole about $2 \mathrm{~mm}$ long; spikelets narrow, closely appressed to the axis, few in short racemes terminating the branches; lemmas about $7 \mathrm{~mm}$ long. The narrow but obtuse tip of the blades is minutely pubescent.

Mountain thickets, Hispaniola.

Haitr: Torbeek, Ekman H 5295, H 7460. Badeau, Ekman H 7779. La Selle Mountains, Pilkington in 1920, "grows in tangled masses over the jungle $(8,000 \mathrm{ft}$.) and is so tough and strong as entirely to prevent progress." Furcy, Buch 929. 'Sierra de Ocoa, Ekman H 11750 .

Dominican Republic: Bejucal, Ekman H 11750.

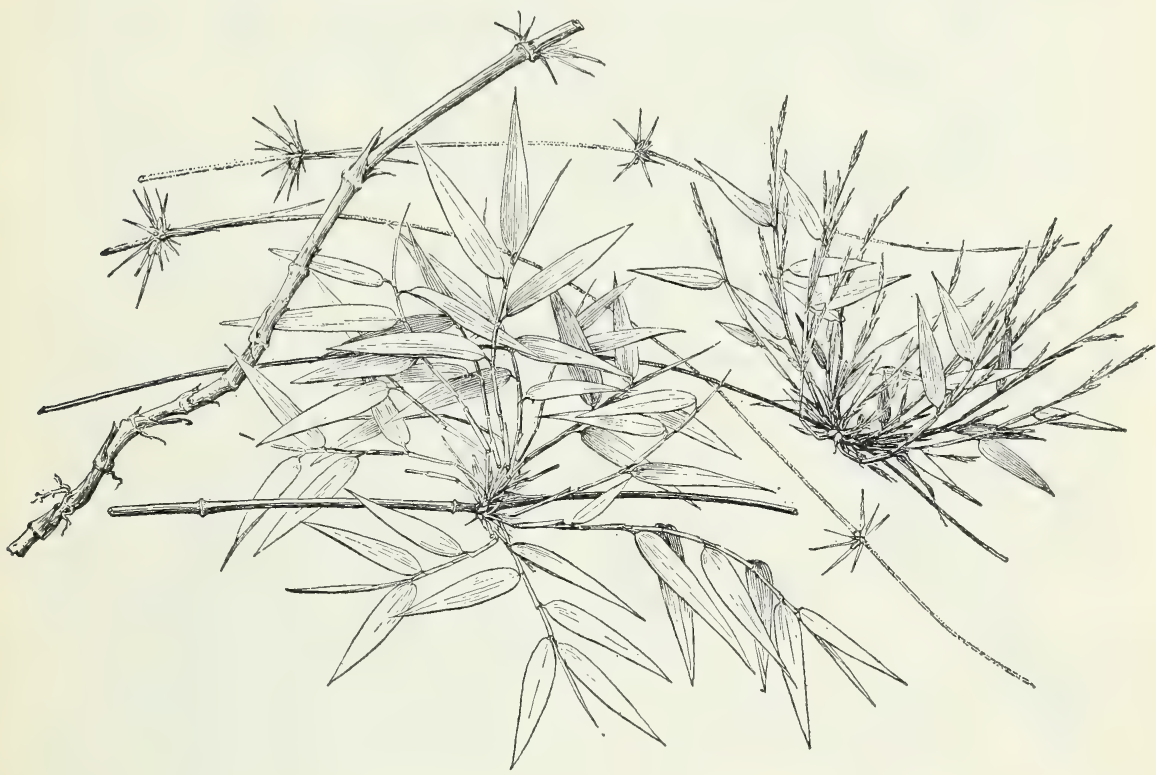

FIGURE 1.-Arthrostylidium multispicatum, $\times 1 / 2$ (Chase 6201, 6470).

4. Arthrostylidium multispicatum Pilger, in Urban, Symb. Antill. 2: 341. 1901. Puerto Rico, Sintenis 209.

Arundinaria multispicata Hack., Oesterr. Bot. Ztschr. 53: 69. 1903. Climbing high, the slender growing ends of the culms and branches beset with very short retrorse prickles, these ends, often $4 \mathrm{~m}$ long, swinging in the breeze like whiplashes until a support is found, the radiating short, sharp scale-covered branch buds then developing, these long grappling branches freely produced, forming a dense tangled mass; prickles deciduous, the old culms smooth; sterile branchlets whorled, 15 to $30 \mathrm{~cm}$ long, the spreading blades 6 to $8 \mathrm{~cm}$ long, 10 to $12 \mathrm{~mm}$ wide (on vigorous shoots sometimes larger), the floriferous branches rather shorter, bearing 1 to 3 leaves and slender terminal and axillary racemes, the spikelets appressed to the straight axis; spikelets 2 to $3 \mathrm{~cm}$ long; fertile florets usually 3 to 5 . Blades on sterile shoots are wider, rather broadly lanceolate, as much as $11 \mathrm{~cm}$ long and 3 $\mathrm{cm}$ wide, unevenly cuneate at base (fig. 1).

Mountain woods and thickets, Cuba to Puerto Rico; Trinidad. 
Cuba: Banao Mountains, Léon 4026 (sterile); Daiguirí, Ekman 1570 (fertile); Lomade Gato, Léon 10294, 10294b, 10612 (all sterile).

Haiti: Ganthier, Ekman H 7752. Petit Goave, Ekman H 6596. Mission, Leonard 3691, 3817, 3857, 3951. Morne Cabaio, Ekman H 1696. Ma Blanche, Ekman H 508. Furcy, Leonard 4641, 4783. Morne de la Selle, Buch 1139.

Dominican Republic: Constanza, Ekman H 14109.

Puerto Rico: Maricao, Chase 6201; Sintenis 209; Britton and Cowell 4222. Cayev, Chase 6751; Britton and Brown 6542. Adjuntas, Chase 6470; Sintenis 4106. Joyuya, Britton and Cowell 953. San Narciso, Britton 7300.

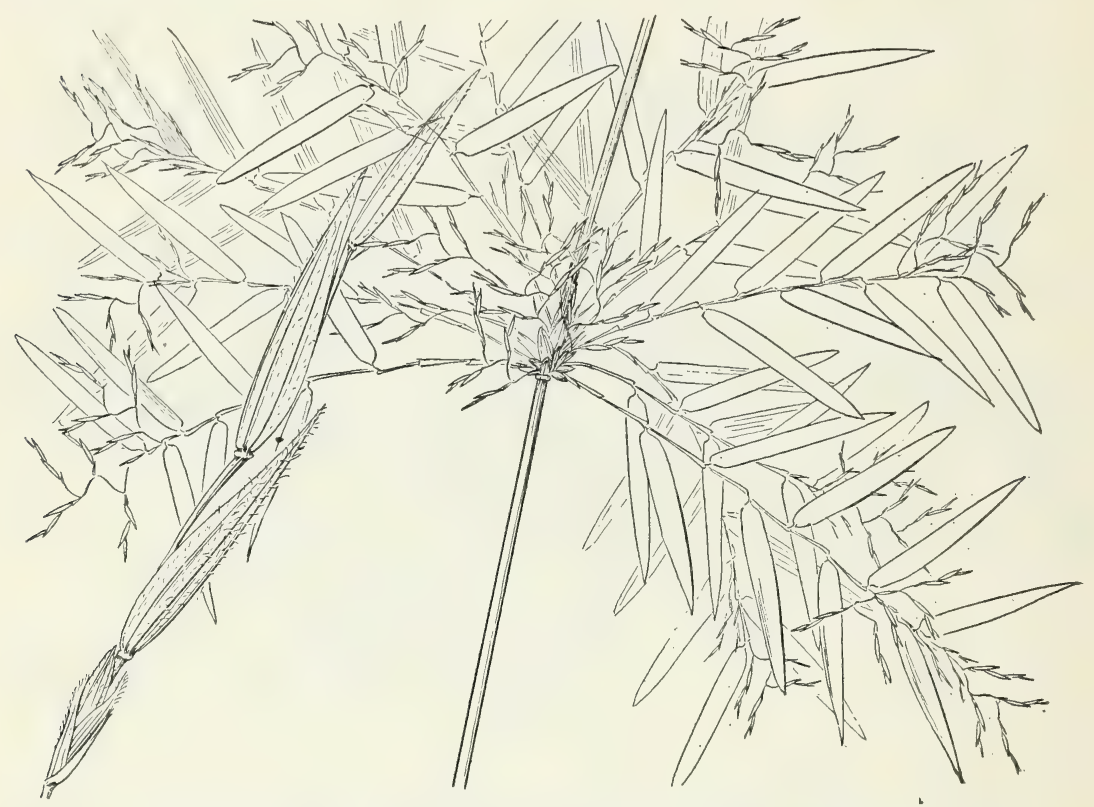

FIGURE 2.-Arthrostylidium sarmentosum. Plant, $\times 1 \frac{1}{2}$; spikelet, $\times 5$ (Chase 6730 ).

5. Arthrostylidium sarmentosum Pilger, in Urban, Symb. Antill. 4: 108. 1903. Puerto Rico, Heller 1089; Sintenis 354, 4046; all sterile specimens.

Culms apparently herbaceous, not more than $3 \mathrm{~mm}$ thick, highclimbing and pendent from trees, as in A. capillifolium; branchlets commonly 10 to $15 \mathrm{~cm}$ long, leafy, in distant usually dense whorls, the foliage pale green, drying glaucous, the divergent blades 3.5 to $5 \mathrm{~cm}$ long, 3 to $5 \mathrm{~mm}$ wide, rather thin; inflorescence of numerous short-exserted terminal and axillary zigzag racemes of 2 to 5 narrow pubescent spikelets (fig. 2).

Along streams and trails, wet mountain forests, at higher altitudes, Cuba, Hispaniola, Puerto Rico, and Trinidad. Nearly all the specimens are sterile.

CubA: South of Sierras de Moa, Shafer 8047. Guantánamo, Ekman 10253. Monte Verde, Léon 3825. Yateras, Maxon 4487a.

Haiti: Ennery, Leonard 9080a; Ekman H 2517. Marmelade, Leonard 8358. Morne Brigaut, Ekman H 2660. St. Louis du Nord, 
Leonard 14494. Jean Rabel, Leonard 13658. Port-de-Pai, Leonard 12246.

Dominican Republic: Tousaint, Ekman H 5709. San Francisco de Macoris, Abbott 2129. Laguna, Abbott 281. Loma Quita-Espuela, Ekman H 12275 (fertile). Samaná, Ekman H 15137. Lagunas de Cenobí, Valeur 52.

Puerto Rico: Maricao, Britton and Cowell 4209; Sintenis 354; Hess 1161/2; Chase 6190, 6223. El Yunque, Chase 6730 (fertile), 6731. Alta de la Piedra, Britton and Earle 6796. Rio Icaco, Shafer 3490. San Narciso, Britton 7283. Cayey, Chase 6738, 6749. Adjuntas, Chase 6468; Sintenis 4046; Britton and Shafer 2042. Jovuya, Britton, Cowell, and Brown 5236. Utuado, Britton and Cowell 493. Barrio de Maizales, Britton and Cowell 2180. Monte Torrecilla, Britton, Cowell, and Brown 5600.

Trinidad: Mount Tocuche, Britton, Hazen, and Mendelson 1289; Broadway 7140.

6. Arthrostylidium distichum Pilger, in Urban, Symb. Antill. 2: 342. 1901.

Branches solitary or in small fascicles; culms slender, a line of pubescence on one side, the nodes pubescent; sheaths bearing at summit several stiff bristles 5 to $15 \mathrm{~mm}$ long; blades approximate, regularly spaced, dorsiventral, lanceolate-acuminate, glabrous, scabrous on the margins, 1.5 to $3 \mathrm{~cm}$ long, 4 to $6 \mathrm{~mm}$ wide; spikelets 8 to 15,1 to $2 \mathrm{~cm}$ apart.

The type collection, Wright 3808, bears imperfectly developed spikelets. The only other collection with spikelets is Ekman 10946 and this also bears abortive spikelets. All the spikelets are reflexed above the base. A few spikelets of the Wright collection have two florets about $5 \mathrm{~mm}$ long above the empty glumes.

Rocky banks, Cuba and Hispaniola.

Cuba: Rangel (Pinar del Río), Wright 3808. Gorge of Rio Taco Taco, Léon 16165. San Diego de Tapias, Ekman 10646. Lomas de Siguanéa, Ekman 18493. San Blas, Jack 6773; Léon 13926.

Haiti: Miragoane, Eyerdam 535.

7. Arthrostylidium fimbriatum Griseb., Mem. Amer. Acad. (n. s.) 8: 531. 1862. Eastern Cuba, Wright 1554.

Branches solitary, appressed or slightly spreading; blades often reflexed, rather rigid, 5 to $10 \mathrm{~cm}$ long, 4 to $6 \mathrm{~mm}$ wide; racemes 15 to $30 \mathrm{~cm}$ long, the spikelets appressed, more or less imbricate or somewhat distant, the axis straight; spikelets usually with two perfect florets and a terminal narrow imperfect one; lemmas short-awned. At upper altitudes plants not more than 30 to $100 \mathrm{~cm}$ tall.

Rocky places in the higher mountains, Eastern Cuba.

CubA: Sierra del Cristal, Ekman 6817, 15964. South of Sierra de Moa, Shafer 8137. Loma Menqura, Shafer 3771. Eastern Cuba, Wright 1554.

\section{Arthrostylidium reflexum Hitchc. and Ekman, sp. nov. ${ }^{6}$}

Climbing vine; culms slender, glabrous, the branches solitary or few, appressed, the floriferous ones 25 to $35 \mathrm{~cm}$ long, bearing several leaves on the lower $15 \mathrm{~cm}$; sheaths glabrous, somewhat cross-veined

${ }^{6}$ Culmi graciles, ramis solitariis vel paucis appressis; vaginae glabrae, apice setas paucas $3-5 \mathrm{~cm}$ longas ferentes; laminae glabrae lineari-lanceolatae 5-15 cm longae 7-10 mm latae; panicula angusta gracilis elongata 10-20 cm longa; spiculae circa $6 \mathrm{~mm}$ longae reflexae. 
or tessellate, the summit bearing several slender bristles as much as $5 \mathrm{~cm}$ long; blades ascending, linear-lanceolate, rounded at base, acuminate, glabrous, scabrous on the margins, 5 to $15 \mathrm{~cm}$ long, 7 to 10 $\mathrm{mm}$ wide; panicles very slender, 10 to $20 \mathrm{~cm}$ long, the spikelets few to several on short distant appressed branches, the axis glabrous; spikelets terete, about $6 \mathrm{~mm}$ long, reflexed by a bend in the lower part; first glume $0.5 \mathrm{~mm}$ long; second glume a little longer than the first; first lemma sterile. The spikelets appear to be undeveloped or abortive, much as in $A$. distichum.

Type in the United States National Herbarium, no. 1502075, collected in dense thickets on the top of Sierra de Sitio Santo Tomás, Viñales, prov. Pinar del Río, Cuba, altitude $700 \mathrm{~m}$, November 10, 1923, by E. L. Ekman (no. 18020).

Other specimens, both from Viñales are: Sitio Santo Tomás, steep cliffs, $500 \mathrm{~m}$, Ekman 16627 and Loma de la Bandera, jurassic limestone, Ekman 16570 (sterile).

The spikelets of no. 16627 are better developed. There appears to be but one fertile floret above two sterile lemmas and a reduced floret above the fertile one. The spikelets are about $7 \mathrm{~mm}$ long; fertile lemma slightly inflated, about $5 \mathrm{~mm}$ long.

9. Arthrostylidium angustifolium Nash, Torreya 3: 172.1903. Cuba, Underwood and Earle 941.

Curms 2 to $3 \mathrm{~m}$ long, freely branching, clambering over shrubs; ultimate branches leafy, with short overlapping compressed sheaths; blades erect, somewhat scabrous, elongate, as much as $25 \mathrm{~cm}$ long, 3 to $4 \mathrm{~mm}$ wide; panicles strict, 20 to $30 \mathrm{~cm}$ long, the branches erect; spikelets narrow, 1 to $2 \mathrm{~cm}$ long, the rachilla straight; fertile lemmas 6 to $7 \mathrm{~mm}$ long.

Wooded mountain slopes, Cuba. Known only from the type collection, El Yunque, Baracoa, Cuba, Underwood and Earle 941.

10. Arthrostylidium prestoei Munro, Kew Bull. Misc. Inf. 1895: 186. 1895; Pilger, in Urban, Symb. Antill. 2: 338. 1901. Trinidad.

Culms rather robust, bearing at the distant nodes dense whorls of slender branches about $30 \mathrm{~cm}$ long, these bearing one or two rather thin elongate-lanceolate blades toward their summits and terminating in a densely flowered, mostly one-sided raceme; spikelets pale, about $15 \mathrm{~mm}$ long; lemmas about $8 \mathrm{~mm}$ long, short-awned.

Forests, Trinidad and Colombia. Described from specimens collected by Prestoe in Trinidad and from plants cultivated at Kew.

Trinidad: Bot. Gard. Herb. 1675. Caparo Forests, Broadway 4922.

11. Arthrostylidium pubescens Rupr., Mém. Acad. St. Pétersb. VI. Sci. Nat. $3^{1}: 119.1839$. Trinidad.

Arundinaria pubescens Hack., Oesterr. Bot. Ztschr. 53: 69. 1903. Culm 60 to $80 \mathrm{~cm}$ tall (fide Broadway), slender, roughish, the leafy sterile branches 8 to $10 \mathrm{~cm}$ long, rather rigid, divergent, in remote fascicles, the rough blades 8 to $15 \mathrm{~cm}$ long, 6 to $10 \mathrm{~mm}$ wide; racemes in dense fascicles, the spikelets appressed to the stiff axis; lemmas about $1 \mathrm{~cm}$ long.

Mountain tops, Trinidad, Tobago, and Venezuela.

Trinidad: Blanchisseuse Road, Broadway 5544. Heights of Aripo, Broadway 9927, 9928. Morne Bleu, Freeman in 1921. Without locality, Bailey T 3.

Toвago: Road to Roxborough, Broadway 4894. 
12. Arthrostylidium urbanii Pilger, in Urban, Symb. Antill. 2: 339. 1901. Cuba, Wright 3810.

Arundinaria urbanii Hack., Oesterr. Bot. Ztschr. 53: 69. 1903. Rather robust, as much as $7 \mathrm{~m}$ long, bearing stiff wiry branches in whorls at the distant nodes, the rather rigid sublinear blades often reflexed, readily falling from the crowded overlapping sheaths; branches terminating in slender racemes, the spikelets appressed to the straight axis; sheaths puberulent, the summit bearing several tangled yellow early deciduous bristles 3 to $5 \mathrm{~mm}$ long; blades puberulent beneath, sometimes on both surfaces, 5 to $13 \mathrm{~cm}$ long, 3 to $5 \mathrm{~mm}$ wide; racemes 5 to $15 \mathrm{~cm}$ long.

Banks of streams, bushy savannas, and low thickets, Cuba.

Cuba: Sabana de Monasterio (prov. Santa Clara) Léon 9228. Arroyo del Guanel, Banao Mountains, Léon 8043. La Cumbre, Ekman 13945. Savanna de Motembo, Léon 8230. Sancti Spíritus, Léon 7833. La Lanza, Manajanabo (prov. Santa Clara) Léon 5275. Cienfuegos, Léon 14738. Sierra de Nipe, Ekman 10016. Without locality, Wright 3810.

13. Arthrostylidium excelsum Griseb., Fl. Brit. W. Ind. 529. 1864. Trinidad, Purdie, Crueger.

Arundinaria excelsa Hack., Oesterr. Bot. Ztschr. 53: 69. 1903. High-climbing; branchlets whorled, 20 to $50 \mathrm{~cm}$ long, the blades commonly 8 to $12 \mathrm{~cm}$ long, 12 to $15 \mathrm{~mm}$ wide; racemes terminal and axillary, the axis strongly zigzag, the spikelets divergent, 7 to $15 \mathrm{~mm}$ long.

Mountain woods, Guadeloupe and Trinidad.

Leeward Islands: Guadeloupe, Duss 3978.

Trinidad: Crueger 82 and Rugel, both fragments.

14. Arthrostylidium cubense Rupr., Mém. Acad. St. Pétersb. VI. Sci. Nat. $3^{1}$ : 118. pl. 4. f. 13. 1839. Cuba, Sagra.

Arundinaria cubensis Hack., Oesterr. Bot. Ztschr. 53: 69. 1903.

Culms slender; blades of primary branches 10 to $15 \mathrm{~cm}$ long, 8 to $10 \mathrm{~mm}$ wide, those of the ultimate flowering branchlets elongate, linear, 3 to $4 \mathrm{~mm}$ wide; flowering branches very slender, 20 to $30 \mathrm{~cm}$ long, naked or with one or two narrow blades at base, bearing a few distant appressed spikelets toward their ends.

Pendent on cliffs, Cuba.

Cuba: San Diego de Tapias, Ekman 12649. San Diego de los Baños, Léon 4446, 16214. Campo Florido, Léon 591. San Sebastián, Wright 3811. Viñales, Léon 14327. Without locality, Wright 3809.

15. Arthrostylidium obtusatum Pilger, in Urban, Symb. Antill. 2: 340. 1901. Martinique, Duss 563, 1310.

Arundinaria obtusata Hack., Oesterr. Bot. Ztschr. 53: 69. 1903. Habit unknown; fertile branches slender, the branchlets appressed; blades glabrous, rather rigid, the larger as much as $8 \mathrm{~cm}$ long and $12 \mathrm{~mm}$ wide, those on the branchlets smaller, tapering from base to apex, the tip obtuse; spikelets 12 to $20 \mathrm{~mm}$ long, the fertile florets 4 or 5 , the rachilla straight or slightly zigzag; fertile lemmas 8 to 9 $\mathrm{mm}$ long, glabrous, rather strongly several-nerved, obtusish. Known only from Martinique.

Windward Islands: Martinique, summit of Morne d'Amour, Duss 563, 1310. 
4. CHLSQUEA Kunth, Syn. Pl. Aequin. 1: 254. 1822

Spikelets terete or nearly so, with 2 small or minute (sometimes obsolete) glumes, and 2 sterile lemmas usually shorter than the single fertile floret. Erect or climbing shrubs, the fertile shoots often in fascicles on the usually slender main culm; the panicles usually condensed, sometimes spikelike, rarely open.

1. Chusquea abietifolia Griseb., Fl. Brit. W. Ind. 529. 1864. Jamaica.

Arundinaria? microclada Pilger, in Urban, Symb. Antill. 5: 289. 1907. Haiti, Picarda 270, Buch 930.

Crawling and climbing to a height of $7 \mathrm{~m}$ or more, the slender culms festooning and forming an entanglement across mountain trails;

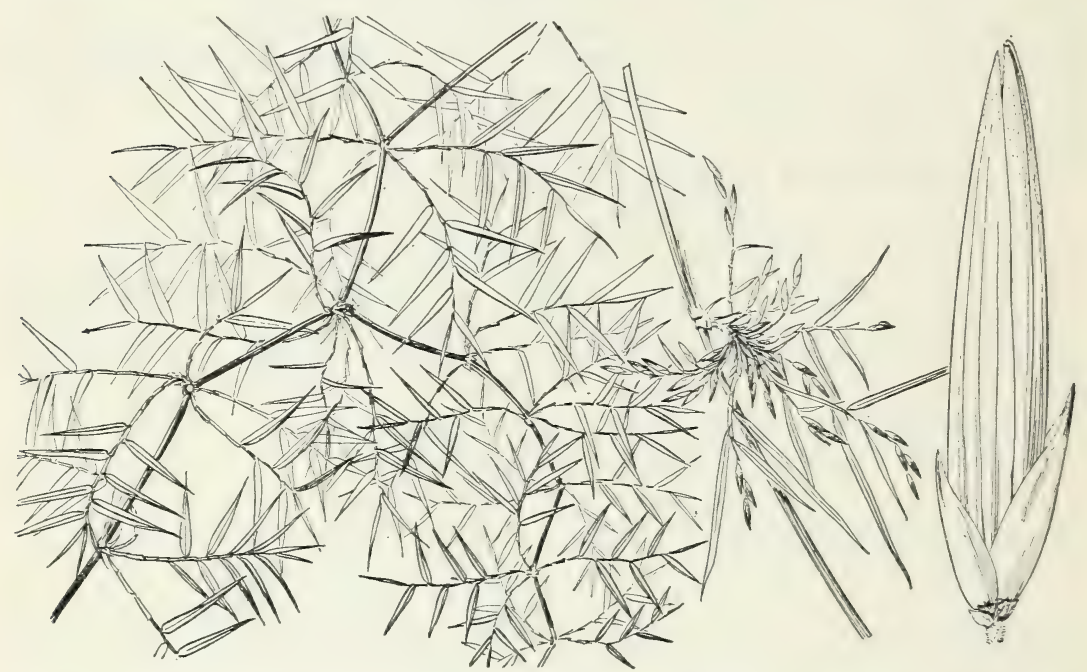
FIGtre 3.-Chusquea abietifolia. Plant, $\times \frac{1 / 2}{\text {; spikelet, }} \underset{\text { Ekman } 8009 \text { ). }}{\times}$ (sterile plant, Ekman 5718; flowering culm,

branchlets about $10 \mathrm{~cm}$ long, in whorls, the numerous rigid, spinetipped, scabrous-margined blades 2 to $3 \mathrm{~cm}$ long, drying glaucous; flowering branches leafy at base, terminating in a small few-flowered, nearly simple panicle, the spikelets short-pediceled; very rarely flowering (fig. 3).

Thet woods, mostly above $1,000 \mathrm{~m}$, Greater Antilles.

Cuba: Pico Potrerillo (prov. Santa Clara), Ekman 18969. Pico Tarquino, Bucher 84. Sierra de Imías, Léon 12319. Gato Mountain, Léon 10077. Loma de San Juan, Léon 10391. Campo San Benito, Shafer 4056. Alto de Iberia, Ekman 8319. Sierra del Cristal, Ekman 15945.

JAmaica: Cinchona, Nichols 168; Harris 12454 (fertile); Hitchcock 9715. Catherines Peak, Hitchcock 9734 (fertile); Harris 11355 (fertile). Blue Mountain Peak, Harris 12496 (fertile); Hitchcock 9375; Maxon 
and Killip 1122. Abbey Green, Hitchcock 9365. Cold Spring Gap, Harris in 1912 (Amer. Gr. Nat. Herb. 400). Trafalgar Gap, Maxon 8734. Morces Gap, Maxon and Killip 1064, 1291a. St. Helens Gap, Maxon and Killip 892. Vinegar Hill, Perkins 1088. Hardware Gap, Maxon and Killip 1265a.

Harti: Furcy, Leonard 4266; Buch 1384. Pétionville, Ekman H 1188, H 1696, H 8001 (fertile). Hinche, Ekman H. 6157. Port-auPrince, Ekman H 5426, H 5887 (fertile). Morne Calumette, Ekman H 7310. Grand Bois, Ekman H 5718. Marigot, Ekman H 5985, H 8009 (fertile).

Dominican Republic: Bejucal, Ekman H 11751. Loma Nalga de Maco, Ekman H 6306.

Puerto Rico: Monte Alegrillo, Hess 116 ; Sterens 4755.

5. NEUROLEPIS Meisn., Pl. Vas. Gen. 1: 426. 1836-1843; 2: $325 . \quad 1836-1843$.

(Platonia Kunth, Rév. Gram. 1: 139, 327, pl. 76. 1830. Not Platonia Mart., 1829. Planotia Munro, Linn. Soc. Trans. 26: 70. 1868.)

Spikelets with 2 glumes, 2 sterile lemmas and a terminal perfect floret, in elongate panicles; stamens 3. Culms erect, herbaceous or somewhat woody at base, the blades elongate, mostly more than 50 $\mathrm{cm}$ long and $6 \mathrm{~cm}$ wide.

1. Neurolepis virgata (Griseb.) Pilger, in Engl. and Prantl, Pflanzenfam. Ergänz. 2: 21. 1906.

Platonia virgata Griseb., Fl. Brit. W. Ind. 530. 1864. Trinidad, Mount Tocuche, Crueger.

Planotia virgata Munro, Linn. Soc. Trans. 26: 71. 1868.

Culms herbaceous, tall, robust, leafy below, the thickish blades commonly more than $1 \mathrm{~m}$ long, about $5 \mathrm{~cm}$ wide, long-attenuate, the margins serrulate; panicle much exceeding the leaves, about $75 \mathrm{~cm}$ long and $2 \mathrm{~cm}$ thick, compact, tawny, the small spikelets densely crowded.

Dense forests, mountains of Trinidad.

Trinidad: Without locality, Bot. Gard. Herb. 3371.

6. STREPTOCHAETA Schrad.; Nees, Agrost. Bras. 536.

1829

Spikelets, 1-flowered, terete, disarticulating below the glumes; empty bractlets (probably glumes and sterile lemmas) 4 , much shorter than the spikelet, more or less toothed; lemma coriaceous, gradually narrowed into a long much contorted awn; palea shorter than the lemma, bifid nearly to the base, coriaceous; inner bracts (lodicules) 3 , less coriaceous than the lemma, longer than the palea, imbricate; stamens 6 , monadelphous, the tube about as long as the lemma; style 1 , as long as the stamen tube, the slender stigmas 3. Broad-leaved perennials with the spikelets in elongate spikes. 
1. Streptochaeta spicata Schrad.; Nees, Agrost. Bras. 537. 1829. Brazil.

Lepideilema lancifolium Trin., Mém. Acad. St. Pétersb. VI. Math. Phys. Nat. 1:93. 1830. Brazil.

Perennial; culms erect or ascending at base in

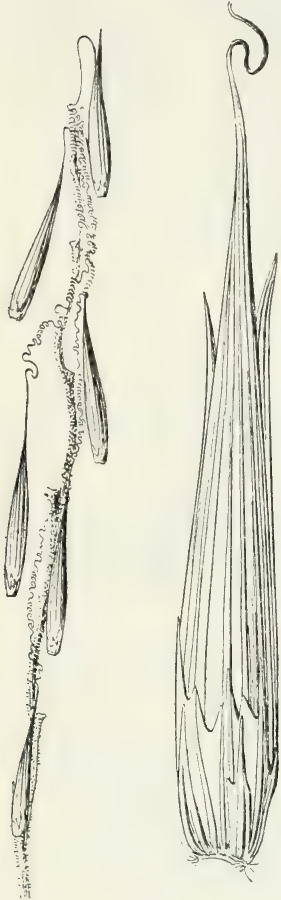

FIGURE 4.-Streptochaeta spicata. Inflorescence, $\times 1$; spikelet, $\times 5$ (Broadway 4929). small tufts about $1 \mathrm{~m}$ tall; blades flat, lanceolate or elliptic, rather thin, scabrous or glabrous, veins connected by transverse veinlets on under side, hispidulous on the collar, 6 to $15 \mathrm{~cm}$ long, 1.5 to $6 \mathrm{~cm}$ wide; spike erect, 7 to $20 \mathrm{~cm}$ long, the rachis angled, flexuous or zigzag at the insertion of the spikelets; spikelets 6 to 20, solitary at each node, appressed to the rachis, overlapping about half their length, 2 to $3 \mathrm{~cm}$ long, about $2 \mathrm{~mm}$ thick at the base, gradually narrowed upward (fig. 4).

Wet forests at low altitudes, Trinidad and Panama to Brazil.

Trinidad: Caparo Forests, Broadway 4929.

\section{TRIBE 2. FESTUCEAE}

\section{BROMUS L., Sp. Pl. 76. 1753. Bromegrass}

Spikelets several- to many-flowered, the rachilla disarticulating above the glumes and between the florets; glumes unequal, acute, the first 1- to 3nerved, the second usually 3 - to 5-nerved; lemmas convex on the back or keeled, 5- to 9-nerved, 2toothed at the apex, awnless or usually awned from between the teeth; palea usually shorter than the lemma, ciliate on the keels. Annuals or perennials with closed sheaths, flat blades, and open or contracted panicles of large spikelets.

Awn of lemma short or none...... 3.

Awn of lemma longer than the body.

Awns 2 to $3 \mathrm{~cm}$ long; panicle branches drooping -......... 1. B. STERILIS. Awns 4 to $5 \mathrm{~cm}$ long; panicle branches ascending ........ 2. B. RIGIDUS.

1. Bromus sterilis L., Sp. Pl. 77. 1753. Europe.

Annual; culms 50 to $100 \mathrm{~cm}$ tall; sheaths pilose; panicle 10 to $20 \mathrm{~cm}$ long, the branches drooping; spikelets 2.5 to $3.5 \mathrm{~cm}$ long; lemmas about $2 \mathrm{~cm}$ long, the awns 2 to $3 \mathrm{~cm}$ long (fig. 5 ).

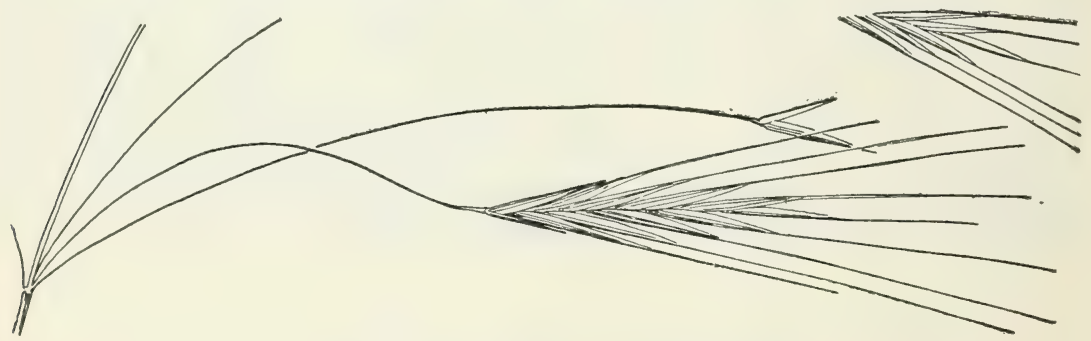

FIGURE 5.-Bromus sterilis, $\times 1$ (Boettcher 2423). 
A weedy grass introduced into America from Europe. Mountains of Haiti.

Haiti: Badeau, Ekman H 7616.

2. Bromus rigidus Roth, Mag. Bot. Roem. et Ust. 10: 21. 1790. Europe.

RIPGUT GRASS.

Bromus villosus Forsk. Fl. Aegypt, Arab. 23. 1775. Not B. villosus Scop., 1772.

Bromus maximus Desf., Fl. Atlant. 1: 95. pl. 26. 1798. Not B. maximus Gilib., 1792.

Annual; culms 40 to $70 \mathrm{~cm}$ tall; sheaths and blades pilose; panicle open, nodding, rather few-flowered, 7 to $15 \mathrm{~cm}$ long; the lower branches 1 to $2 \mathrm{~cm}$ long; lemmas 2.5 to $3 \mathrm{~cm}$ long, the awn 4 to $5 \mathrm{~cm}$ long (fig. 6). Open ground and waste places, introduced into America from Europe. Mountains of Jamaica.

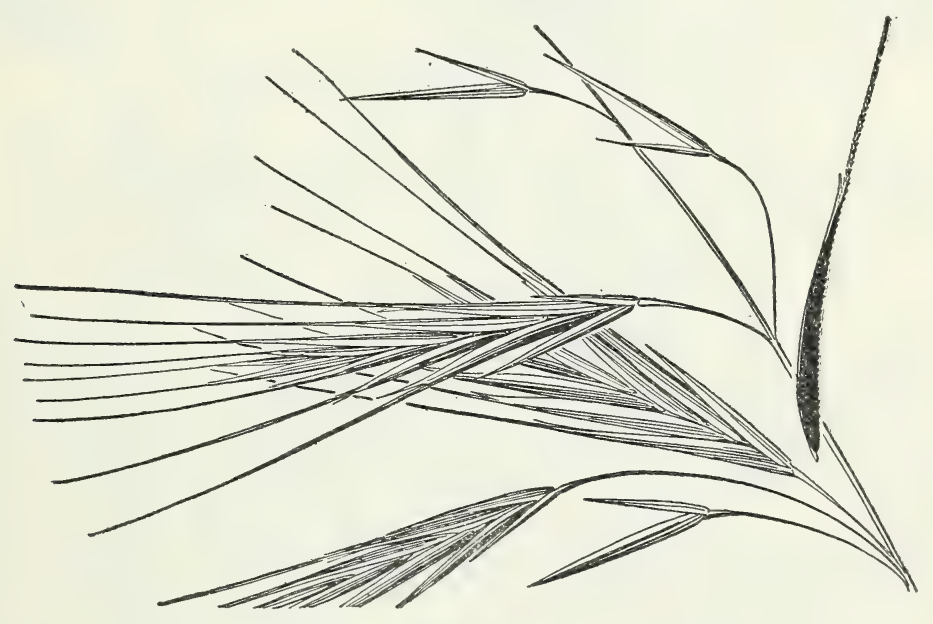

Figure 6.-Bromus rigidus, $\times 1$ (Tracy 4702).

Jamaica: Cinchona, Perkins 1075; Hitchcock 9714; Harris 10916, 11275, 12482a; Orcutt 5480. Arntully, Orcutt 5760. Strawberry Hill, Harris 11489. Gordon Town, Hart 738. Without locality, Wilson 486.

3. Bromus catharticus Vahl, Symb. Bot. 2: 22. 1791. Peru.

RESCUE GRASS.

Bromus unioloides H. B. K., Nov. Gen. et Sp. 1: 151. 1815. Ecuador.

Annual or biennial; culms as much as $1 \mathrm{~m}$ tall; sheaths glabrous or pubescent; panicle open, as much as $20 \mathrm{~cm}$ long; spikelets 2 to $3 \mathrm{~cm}$ long, 6- to 12-flowered; lemmas glabrous or scabrous, acuminate, about $1 \mathrm{~cm}$ long, awnless or with an awn 1 to $3 \mathrm{~mm}$ long (fig. 7 ).

Cultivated occasionally. Southern and western United States; Bermuda, Jamaica, and Haiti; introduced from Europe.

Bermuda: Collins 339; Brown, Britton, and Bisset 1911. 

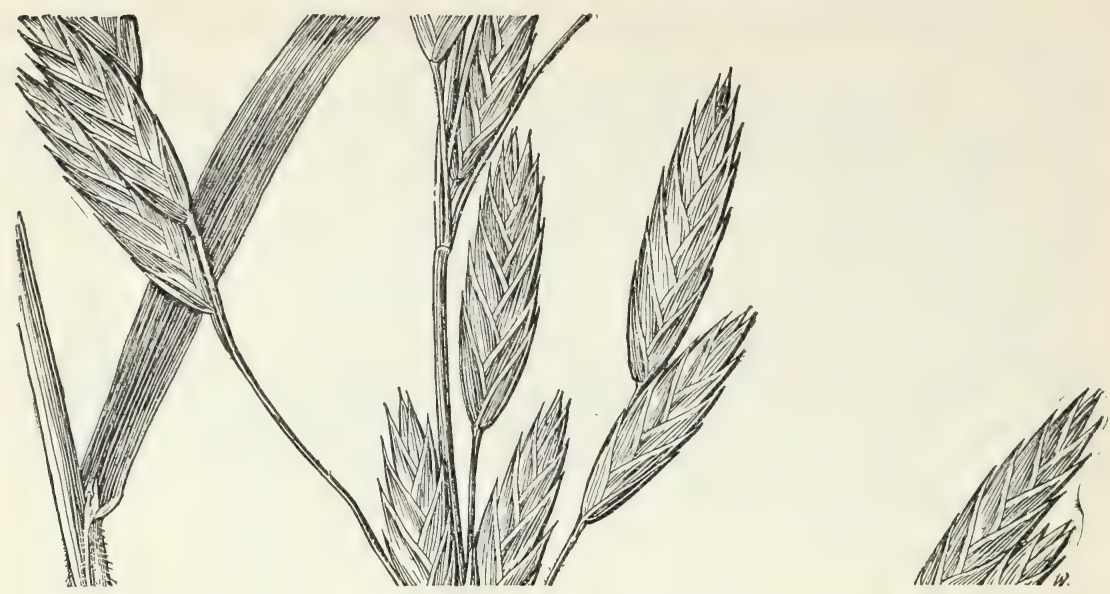

FIGURE 7.-Bromus catharticus, $\times 1$ (Peebles, Harrison, and Kearney 1271).

JAMAICA: Cinchona, Harris 10919, 11455, 12482; Hitchcock 9699. Hope Grounds, Harris 11250. Gordon Town, Hart 741.

Haiti: Massif de la Selle, Ekman H 7740.

\section{FESTUCA L., Sp. Pl. 73. 1753. Fescue}

Spikelets few- to several-flowered, the rachilla disarticulating above the glumes and between the florets; glumes narrow, acute, unequal, the first sometimes very small; lemmas rounded on the back, membranaceous or somewhat indurate, 5-nerved, the nerves often obscure, acute or rarely obtuse, awned from the tip or rarely from a minutely bifid apex.

First glume two-thirds to three-fourths as long as the second... 1. F. DERTONEnsis. First glume much shorter than the second, 1 to $2 \mathrm{~mm}$ long....... 2. F. MYURos.

1. Festuca dertonensis (All.) Aschers. and Graebn., Syn. Mitteleur. Fl. 2: 558. 1900.

Bromus dertonensis All., Fl. Pedem. 2: 249. 1785. Europe. Slender tufted annual; culms 30 to $50 \mathrm{~cm}$ tall; blades narrow; panicles narrow, nodding, nearly simple; spikelets 4- to 6-flowered, shortpediceled; first glume about $4 \mathrm{~mm}$ long, the second 6 to $7 \mathrm{~mm}$ long; lemma lanceolate, scabrous on the back toward the apex, 7 to $8 \mathrm{~mm}$ long; awn slender, 10 to $13 \mathrm{~mm}$ long (fig. 8, B).

Open and waste places in the United States, especially on the Pacific coast; uplands of Jamaica; introduced

This species was referred to $F$. bromoides L. in the Grasses of the West Indies. ${ }^{7}$

JAMAICA: Cinchona, Harris 9504, 10917, 11276, 11509, 11700, 12456; Hitcheock 9701. Morces Gap, Harris 12526. Abbey Green, Hitchcock 9353. Gordon Town, Hart 681, 750.

2. Festuca myuros L., Sp. Pl. 74. 1753. Europe.

Similar to $F$. dertonensis; culms weaker; panicle longer and narrower; spikelets 2- to 3 -flowered; first glume 1 to $1.5 \mathrm{~mm}$ long, the second 4 to $4.5 \mathrm{~mm}$ long (fig. $8, A$ ). 


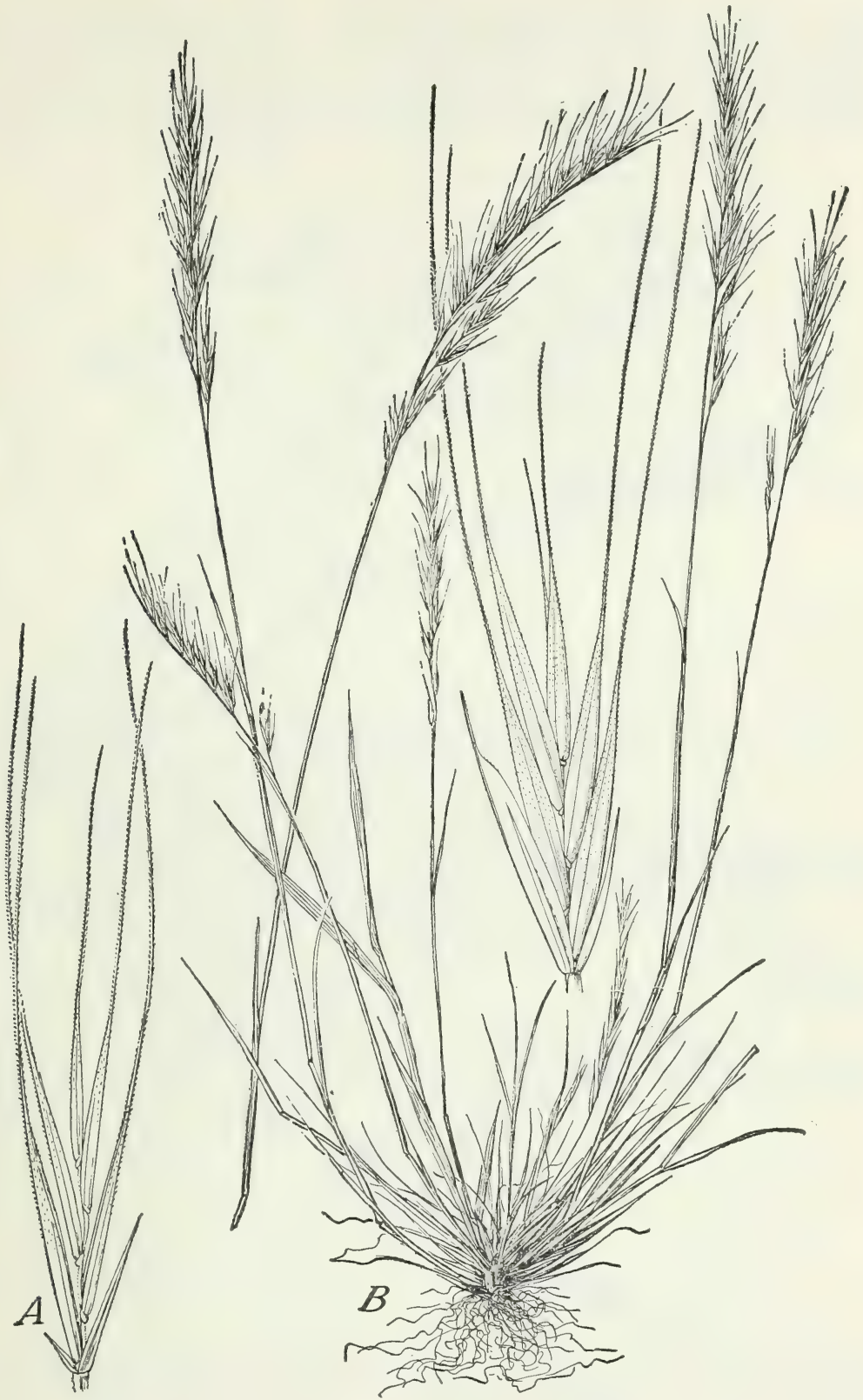

Figure 8.-A, Festuca myuros, spikelet, $\times 5$ (Chase 2393). $B, F$. dertonensis. Plant, $\times 16$; spikelet, $\times 5$ (Palmer 2041).

Waste places and open ground in the United States; Blue Mountains of Jamaica and in Haiti; introduced.

JaMAica: Abbey Green, Orcutt 5295. Farm Hill Gap, Harris 11564; Orcutt 5208. St. Helens Gap, Harris 11591. Salt Hill Pond, Harris 11604. Clifton, Harris 11391. 
HaItr: Furcy Leonard 4303, 4369, 4446, 4506, 4514, 4515; Buch 1675, 1463. Pétionville, Ekman H 1114. Badeau, Ekman H 7615.

Festuca elatior L., Sp. Pl. 75. 1753. Meadow Fescue. An erect perennial with awnless spikelets, frequently cultirated in the

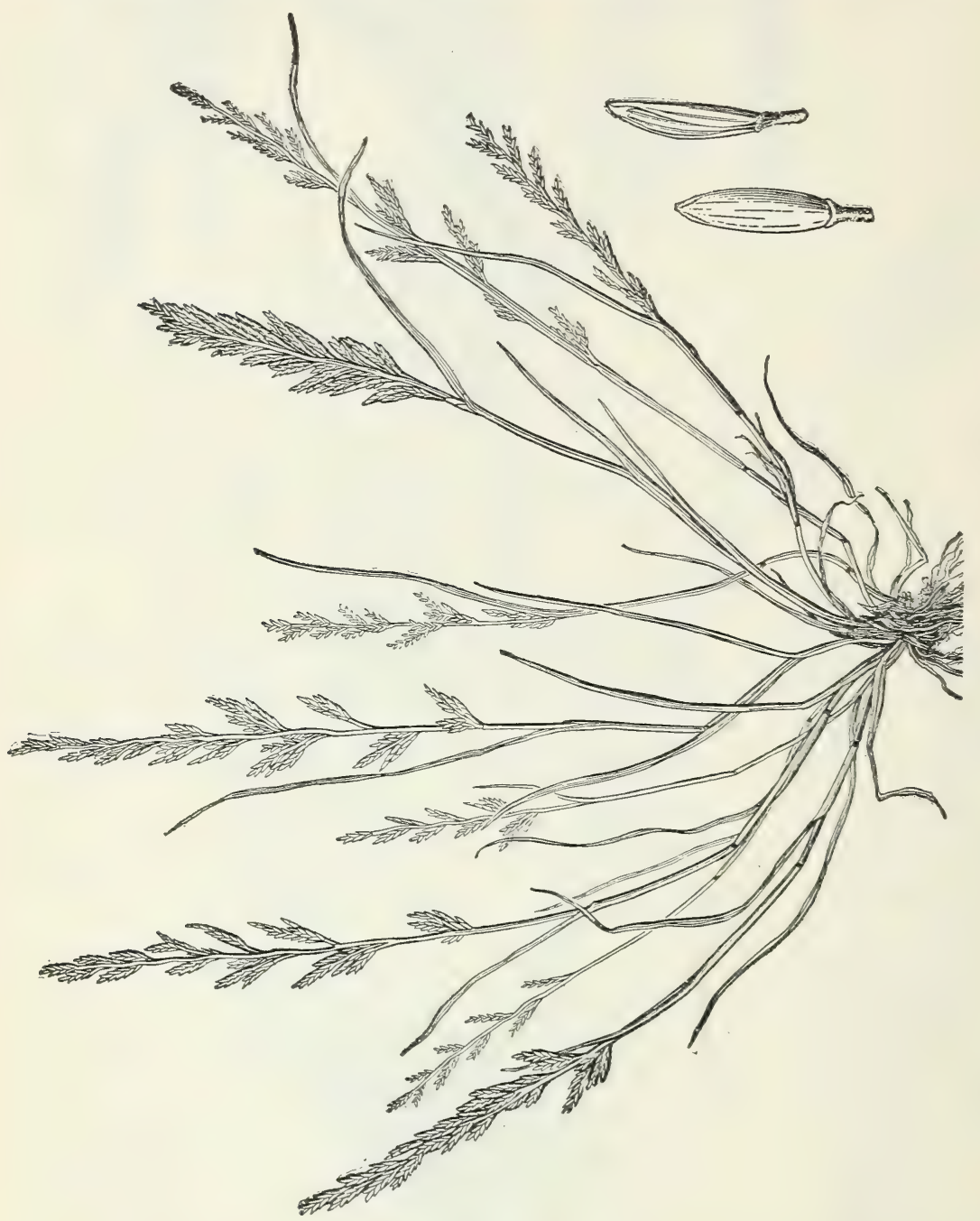

热

United States as a meadow grass; represented from Jamaica by a specimen without locality (Hart 743).

\section{SCLEROPOA Griseb., Spic. Fl. Rum. 2: 431. 1844}

Spikelets small, loosely sereral-flowered, turned to one side, short pediceled; glumes and lemmas firm, with scarious tips. Low decumbent or ascending annuals. 
1. Scleropoa rigida (L.) Griseb., Spic. Fl. Rum. 2: 431.1844. Poa rigida L., Cent. Pl. 1: 5. 1755. Europe.

Glabrous, usually not more than 10 or $15 \mathrm{~cm}$ tall, with soft linear blades and stiff spikelike few-flowered panicles (fig. 9).

Introduced in Bermuda.

Bermuda: Brown, Britton, and Bisset 1955; Brown 521, 601, 614.

\section{POA L., Sp. Pl. 67. 1753. Bluegrass}

Spikelets 2- to several-flowered, the rachilla disarticulating above the glumes and between the florets, the uppermost floret reduced or rudimentary; glumes acute, keeled, somewhat unequal, the first 1nerved, the second usually 3-nerved; lemmas somewhat keeled, acute or acutish, awnless, membranaceous, often somewhat scarious at the tip, 5-nerved, the nerves sometimes pubescent. Annual, or usually perennial, species of low or rather tall grasses, with spikelets in open or contracted panicles, the narrow blades flat or folded, ending in a navicular point.

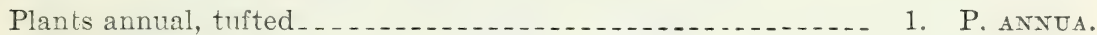

Plants perennial from creeping rhizomes.

Culms distinctly flattened........... 2. P. COMPRESSA.

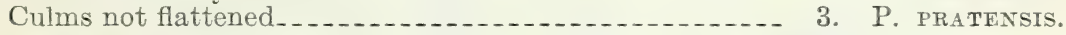

1. Poa annua L., Sp. Pl. 68. 1753. Europe. Annual Bluegrass.

Low tufted soft smooth annual; culms decumbent at base; panicles commonly about $5 \mathrm{~cm}$ long; pale, open; spikelets crowded, $3-$ to 6 flowered, about $4 \mathrm{~mm}$ long; lemmas not webbed at base, distinctly 5-nerved, the nerves pilose on the lower half (fig. 10).

Open ground and grassland throughout the temperate regions of North America and extending southward in the mountains; introduced from Europe.

Bermuda: Collins 158; Brown 474, 478.

CubA: Habana, Léon 760.

JAMAICA: Cinchona, Hitchcock 9712; Harris 10920,11266,11496. Blue Mountain Peak, Orcutt 5347, 5382. Abbey Green, Maxon 1448; Hitchcock 9357. Morces Gap, Harris 11323. Hardware Gap, Harris 10112, 10906, 11438. Catherines Peak, Harris 11553; Hitchcock 9740. Wallingford, Perkins 1480. Gordon Town, Hart 749.

Haitr: Furcy, Leonard 4763; Buch 1547; Cook, Scofield, and Doyle 33a, 34, 41. Mission, Leonard 3734, 3848. Pétionville, Ekman H 1751. Chapelle St. Michel, Ekman H 6586. Morne Brouet, Ekman H 1116.

2. Poa compressa L., Sp. Pl. 69. 1753. Europe.

Canada BLUEgrass.

Wiry perennial with extensively creeping rhizomes; culms slender, compressed; panicle narrow, rather densely flowered.

Open ground and grassland; throughout the United States, probably introduced from Europe; Jamaica, Haiti. 
JAMaICA: Blue Mountain Peak, Harris 12663; Hitchcock 9371.

Haitr: Massif de la Selle, Ekman H 6875. Mission, Leonard 3848. Morne Tranchant, Picarda 1019.

Poa trivialis L., Sp. Pl. 67. (Collins 340) may be this species.

3. Poa pratensis L., Sp. Pl. 67. 1753. Europe.

KeNTUCKY BLUEGRASS.

Erect perennial, with creeping rhizomes; culms 30 to $50 \mathrm{~cm}$ tall; panicles open, 4 to $10 \mathrm{~cm}$ long, the lower branches 3 to 5 , spreading; spikelets 3 - to 5 -flowered, 4 to $5 \mathrm{~mm}$ long; lemmas $3 \mathrm{~mm}$ long, copiously webbed at base, silky-pubescent on keel and marginal nerves, the intermediate nerves prominent (fig. 11).

Pastures and open ground in temperate regions; introduced from Europe. A standard grass for pastures and lawns in the cooler parts of the United States, but not suited to the West Indies.

BERMUdA: Brown 670.

JAmaICA: Blue Mountain Peak, Orcutt 5311.

Haitr: Massif de la Selle, Ekman H 1156, H 7821; Buch 1354, 1414. Mission, Leonard 3850. Furcy, Leonard 4371; Cook, Scofield, and Doyle 33.

\section{BRIZA L., Sp. Pl. 70. 1753. QUaking grass}

Spikelets, several-flowered, broad, often cordate, the florets crowded and spreading horizontally, the rachilla disarticulating above the glumes and between the florets, the uppermost floret reduced; glumes about equal, broad, papery-chartaceous, with scarious margins; lemmas papery, broad, with scarious, spreading margins, cordate at base, several-nerved, the nerves often obscure, the apex, in the species below, obtuse or acutish; palea much shorter than the lemma. Annuals or perennials, with erect culms, flat blades, and usually open, showy panicles.

Spikelets few, $1 \mathrm{~cm}$ wide Spikelets numerous, $0.5 \mathrm{~cm}$ wide.

1. Briza maxima L., Sp. Pl. 70. 1753. Europe.

BIG QUAKING GRASS.

Slender annuals 30 to $60 \mathrm{~cm}$ tall with flat roughish blades and fewflowered panicles, the large handsome spikelets nodding on long capillary pedicels (fig. 12, $B$ ).

Open ground and grassland, introduced occasionally in America.

Bermuda: Brown 679.

JAMAICA: Cinchona, Orcutt 5477; Harris 11274, 11621; Hitchcock 9713. Hardware Gap, Harris 10909.

2. Briza minor L., Sp. Pl.70. 1753. Europe. Little QUAKing Grass.

A weak-stemmed annual 30 to $50 \mathrm{~cm}$ tall with thin flat scabrous blades and loosely flowered panicles, the branchlets subcapillary but stiffly spreading, the spikelets triangular-ovate, nodding (fig. 12, A).

Open ground, sparingly introduced in America.

JamaICA: Cinchona, Hitchcock 9710; Harris 11414, 11603. Abbey Green, Maxon 1459; Orcutt 3242; Hitchcock 9356 (Amer. Gr. Nat. 


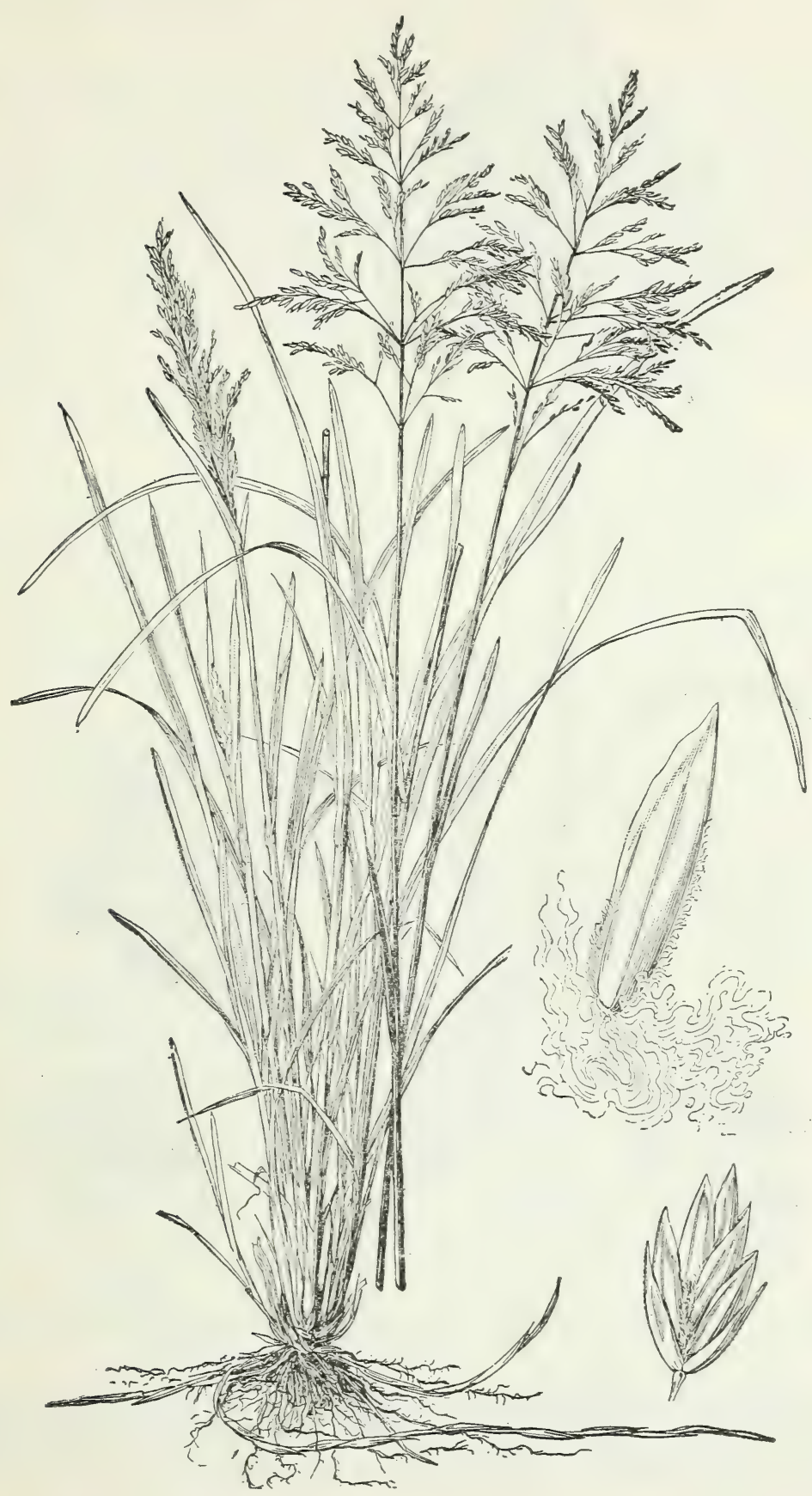

FIGURE 11.-Poa pratensis. Plant, $\times 1 / 2$; spikelet, $\times 5$; floret, $\times 10$ (Williams). 


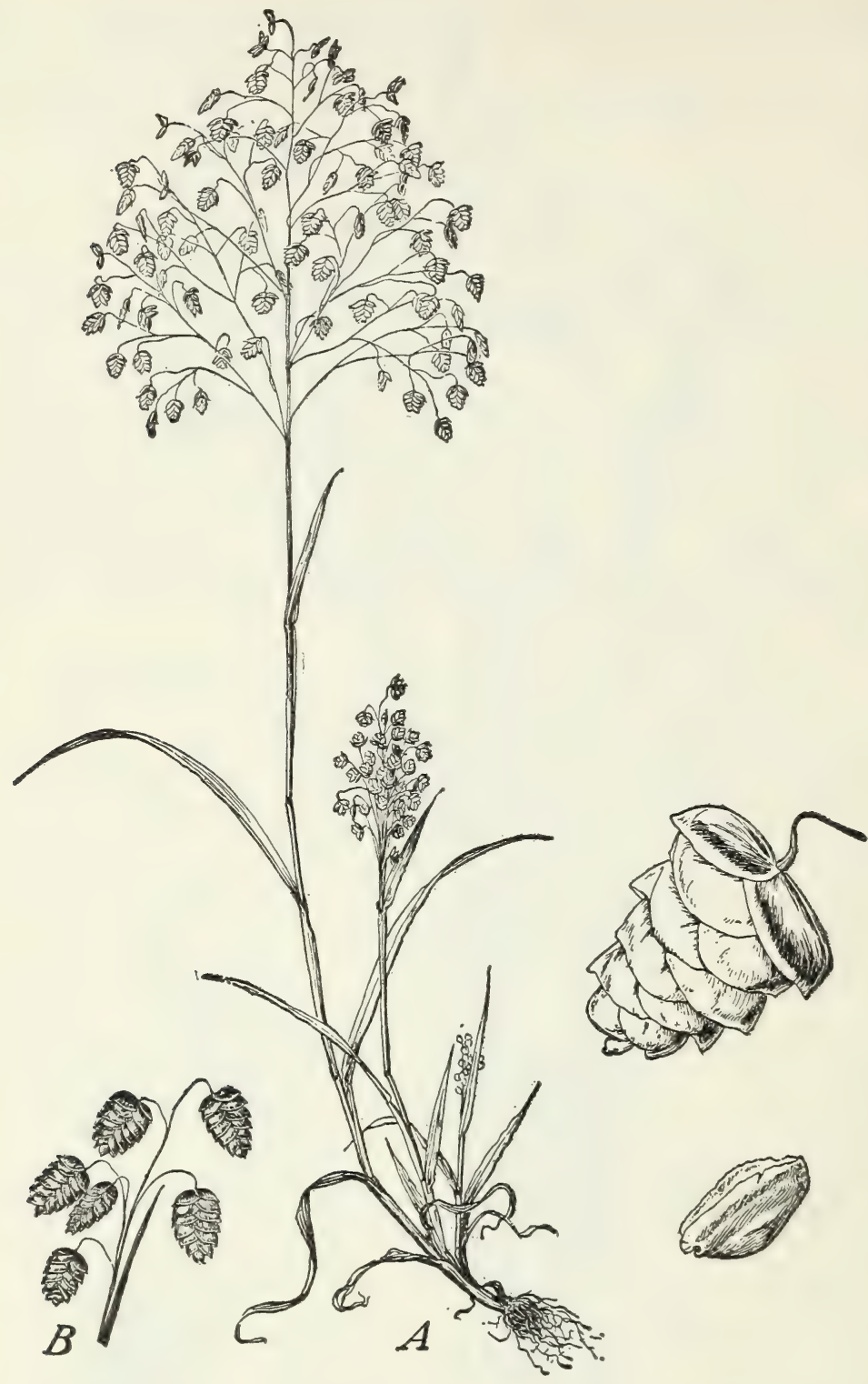

Figure 12.-A, Briza minor. Plant, $\times 12$; spikelet and floret, $\times 5$ (Hitchcock 2597). B, B. marima,

Herb. 699). Catherines Peak, Hitchcock 9739. Morces Gap, Nichols 40; Harris 11527. Hardware Gap, Harris 10907. New Haven Gap, Maxon 2652. Gordon Town, Hart 751. 
12. ERAGROSTIS Host, Icon. Gram. Austr. 4: 14. pl. 24.1809. LOVEGRASS

Spikelets few- to many-flowered, the florets usually closely imbricate, the rachilla disarticulating above the glumes and between the florets, or continuous, the lemmas deciduous, the paleas persistent; glumes somewhat unequal, acute or acuminate, 1-nerved, or the second rarely 3-nerved; lemmas acute or acuminate, keeled or rounded on the back, 3-nerved, the nerves usually prominent; palea 2-nerved, the keels sometimes ciliate. Annuals or perennials with open or contracted panicles.

Palea ciliate on the keels, the cilia conspicuous, usually as long as the width of the lemma.

Plants perennial, more or less viscid .................. E. GLUTINosa.

Plants annual, not viscid.

Pedicels as long as the spikelets or longer; panicle open, oblong.

Pedicels very short; panicle spikelike, more or less interrupted.

1. E. AMABilis.

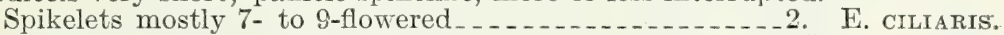

Spikelets mostly 12 - to 15 -flowered_............. 4 . E. URBaniana.

Palea scaberulous on the keels but not prominently ciliate.

Plants annual.

Plants creeping, forming mats _...................... E. HYPNOIDES.

Plants not creeping.

Lemmas glanduiar on the keel

Lemmas not glandu'ar.

Panicle elongate, contracted, the minute spikelets crowded or glomerate.

Panicle not elongate.

Spikelets $1.5 \mathrm{~mm}$ wide ........................... E. PILOSA

Spikelets $2 \mathrm{~mm}$ wide.

Sheaths and blades, at least the lower, sparsely pilose.

Sheaths and blades glabrous.

9. E. Berteroniana.

Spikelets ovate-lanceolate, mostly less than $5 \mathrm{~mm}$ long; panicle

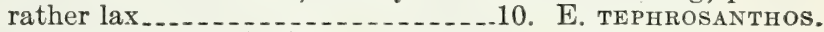

Spikelets linear, mostly 8 to $10 \mathrm{~nm}$ long; panicle rather firm, the branches and branchlets stiffly and divaricately spreading.

Plants perennial.

11. E. BARRELIERI.

Culms low, stiff and wiry, usually not more than $20 \mathrm{~cm}$ tall.

Inflorescence a strict raceme, the spikelets subsessile, rather remote.

Inflorescence a few-flowered, narrow panicle 2 to $8 \mathrm{~cm}$ long.

12. E. BAHAMENSIS.

13. E. CUBENSIS.

Culms taller, often robust, mostly more than $30 \mathrm{~cm}$ tall.

Branchlets of panicle elongate, capillary, stiffly spreading, bearing mostily single terminal spikelets ..................... E. ELIOTTII.

Branchlets of panicle bearing several mostly short-pedicellate spikelets.

Lemmas acuminate; axils of panicle with a tuft of long hairs.

15. E. ACUTIFLORA.

Lemmas acute or obtusish, axils of panicle naked or rarely sparsely pilose.

Panicle narrow, consisting of several more or less distant clusters of spikelets along a stiff elongate axis_........... E. E. EMANII.

Panicle open.

Spikelets somewhat terete, purple, long-pedicellate; lateral nerves of the lemma faint....... E. PURPURASCENS.

Spikelets compressed, mostly pale or green; lateral nerves of the lemma distinct.

Blades flat, pilose on the upper surface near the base.

18. E. EXCELSA. 
Blades glabrous.

Spikelets falcate; panicle oblong, rather dense, 8 to $12 \mathrm{~cm}$ long.

19. E. SALZMANNII.

Spikelets straight; panicle usually much more than $15 \mathrm{~cm}$, open. Blades involute ........... Blades flat, 2 to $5 \mathrm{~mm}$ wide, becoming involute.

21. E. DOMINGENSIS.

1. Eragrostis amabilis (L.) Wight and Arn.; Hook. and Arn., Bot. Beechey Voy. 251. 1841.

Poa amabilis L., Sp. Pl. 68. $1753 . \quad$ India.

Poa plumosa Retz., Obs. Bot. 4: 20. 1786. East Indies.

Eragrostis plumosa Link, Hort. Berol. 1: 192. 1827.

Annual; culms branching, slender, ascending or

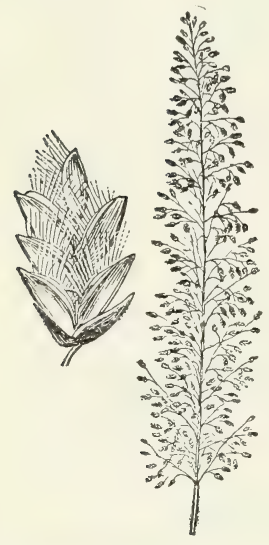

Figure 13.-Eragrostis amabilis. Pan cle, $\times 1 / 2$ spikelet, $\times 10$ (Meislahn 10).

loose, 5 to $15 \mathrm{~cm}$ long; spikelets subsessile, crowded, about $2 \mathrm{~mm}$ long, mostly 6-to 8-flowered, the palea prominently ciliate (fig. 14).

Open ground and waste places, warmer regions of both hemispheres. Apparently introduced in America. A common weed around towns. Probably to be found on all the West Indian islands.

Differs from the preceding in the dense narrow panicles, interrupted below, and in the larger crowded subsessile spikelets. The inflorescence of this species varies from the rather dense cylindrical panicle with short branches flowered to the base (the typical form) to one with stiffly ascending branches naked at the base (such as Curtiss 76 , Nassau, Bahamas) and to that with a lax panicle (E. ciliaris var. laxa).

2a. Eragrostis ciliaris var. laxa Kuntze, Rev. Gen. Pl. 2: 774. 1891. St. Thomas, Barbados, and Trinidad.

Panicle branches sometimes $3 \mathrm{~cm}$ long, the spikelets scarcely crowded. In the specimens from the Lesser Antilles the cilia on the keels are short.

Habitat the same as for the species. Apparently confined to the West Indies.

Bahamas: Turks Island, Nash and Taylor 3846. Caicos Islands, Wilson 7665 . 
Cuba: Cayo Paredon Grande, Shafer 2751. Cárdenas, Ekman in 1923. Sierra Guane, Shafer 10456. Santiago de Cuba, Léon 880. JamaICA: Hope Grounds, Harris 11242, 11243 (in part). Castleton, Harris 11384.

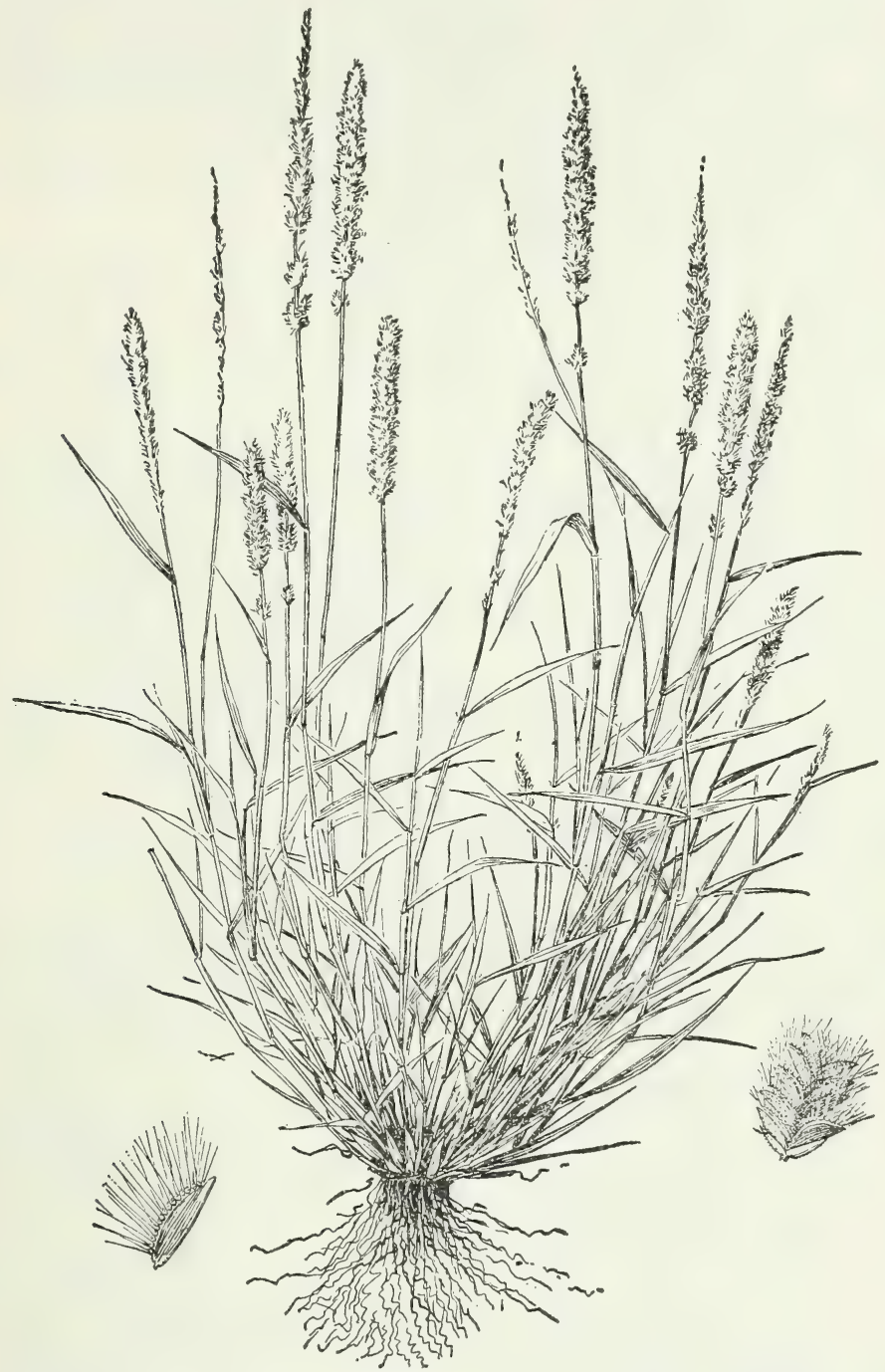

FIGURE 14.-Eragrostis ciliaris. Plant, $\times 1 / 2 ;$ spikelet, $\times 5$; floret, $\times 10$ (Nash 2104).

Haiti: Tortuga Island, Ekman H 9766. Jean Rabel, Leonard 12879a. Leeward Islands: Dominica, Duss.

Windward Islands: Martinique, Duss 740, 1305, 1307, 4023.

The above specimens are somewhat diverse. Many, such as the Jamaica specimens, differ only in the looser panicle. Shafer's 2751, Ekman's H 9766, and a few others differ in having stiffly spreading, 
few-flowered panicle branches. The Martinique specimens have loose panicles with ascending branches, but the cilia on the keels of the palea are short and scarcely conspicuous.

Eragrostis ciliaris var. Brachystachya Boiss., Fl. Orient. 5: 582. 1884. E. arabica Jaub. and Spach, Illustr. 4: 31, pl. 322. 1850-53. This variety is common in Curaçao and the neighboring islands. The panicles are dense and ovoid. Forms approaching this are sometimes found in the West Indies (Morillos de Cabo Rojo, Puerto Rico, Britton, Cowell, and Brown 4713).

3. Eragrostis glutinosa (Swartz) Trin., Mém. Acad. St. Pétersb. VI. Math. Phys. Nat. 1: 397. 1830.

Poa glutinosa Swartz, Prodr. Veg. Ind. Occ. 26. 1788. Jamaica. Eragrostis sudans Griseb., Cat. Pl. Cub. 227. 1866. Cuba, Wright 3422.

Eragrostis leonina Hitchc. and Chase, Contrib. U. S. Natl. Herb. 18: 388. 1917. Cuba, Léon 885.

Perennial, whole plant more or less viscid; culms many-noded, wiry, branching, erect or ascending, 10 to $30 \mathrm{~cm}$ tall; blades short, slender, involute; panicles open, oblong, 5 to $10 \mathrm{~cm}$ long, the branches stiffly ascending; spikelets 4 to $6 \mathrm{~mm}$ long, mostly 7- to 11-flowered; lemmas about $1.3 \mathrm{~mm}$ long; keels of palea rather prominently ciliate.

Sandy soil, Cuba and Jamaica; the type collection is the only one known from Jamaica.

Cuba: Zaza de Tunas, Léon 885, 6732. Camagüey, Britton 2374. Sábalo, Ekman 11413; Léon 15100. Guantanamo, Britton 2123. Without locality, Wright 3422. Isla de Pinos, Britton and Wilson 15612.

4. Eragrostis urbaniana Hitchc., in Urban, Symb. Antill. 7: 167. 1912. Bonaire, Dutch West Indies, Suringar.

Annual; culms spreading or prostrate, slender, 5 to $25 \mathrm{~cm}$ long; blades 1 to $4 \mathrm{~cm}$ long, 0.5 to $2 \mathrm{~mm}$ wide, of ten involute; panicle narrow, interrupted below, 2 to $5 \mathrm{~cm}$ long; spikelets yellow or purple, fascicled, sessile or subsessile, 10 - to 15 -flowered, 3 to $6 \mathrm{~mm}$ long; palea ciliate on the keels.

Sandy plains, Bahamas to Curaçao.

Bahamas: Caicos Islands, Wilson 7608, 7628; Millspaugh 9234. Turks Island, Millspaugh 9012, 9268, 9339 (in part), 9341. Great Ragged Island, Wilson 7828. Inagua, Nash and Taylor 1372.

HAItI: Jean Rabel, Ekman H4007.

Puerto Rico: Laguna de Tortuguero, Britton, Cowell, and Brown 3854.

Virgin Islands: Anegada, Britton and Fishlock 957.

5. Eragrostis hypnoides (Lam.) B. S. P., Prel. Cat. N. Y. 69. 1888. Poa hypnoides Lam. Tabl. Encycl. 1: 185. 1791.

Poa carinata Poir., in Lam., Encycl. 5: 86. 1804. Puerto Rico, Ledru.

Stoloniferous, forming mats, the flowering culms mostly 5 to 10 $\mathrm{cm}$ tall; blades 1.5 to $2 \mathrm{~cm}$ long, spreading; panicles small, more or less capitate, the pale, many-flowered spikelets commonly $1 \mathrm{~cm}$ long (fig. 15). 
Moist, open ground along streams throughout the United States, in the West Indies, and southward to Brazil.

Cuba: Galafre, Britton and Cowell 9830. Cabañas, Ekman 10934. Santa Cruz, Roig 3223. Anafe, Ekman 222; Léon 4268, 4269. Laguna Castellano, Baker and Abarca 4328. Santa Lucea, Shafer 961a. Río Cauto, Shafer 1666. Isla de Pinos, Britton and Wilson 15523, 15803; Curtiss 391 . Without locality, Wright 3826.

HaIti: Miragoane, Ekman H 7912. L'A baillon, Ekman H 843.

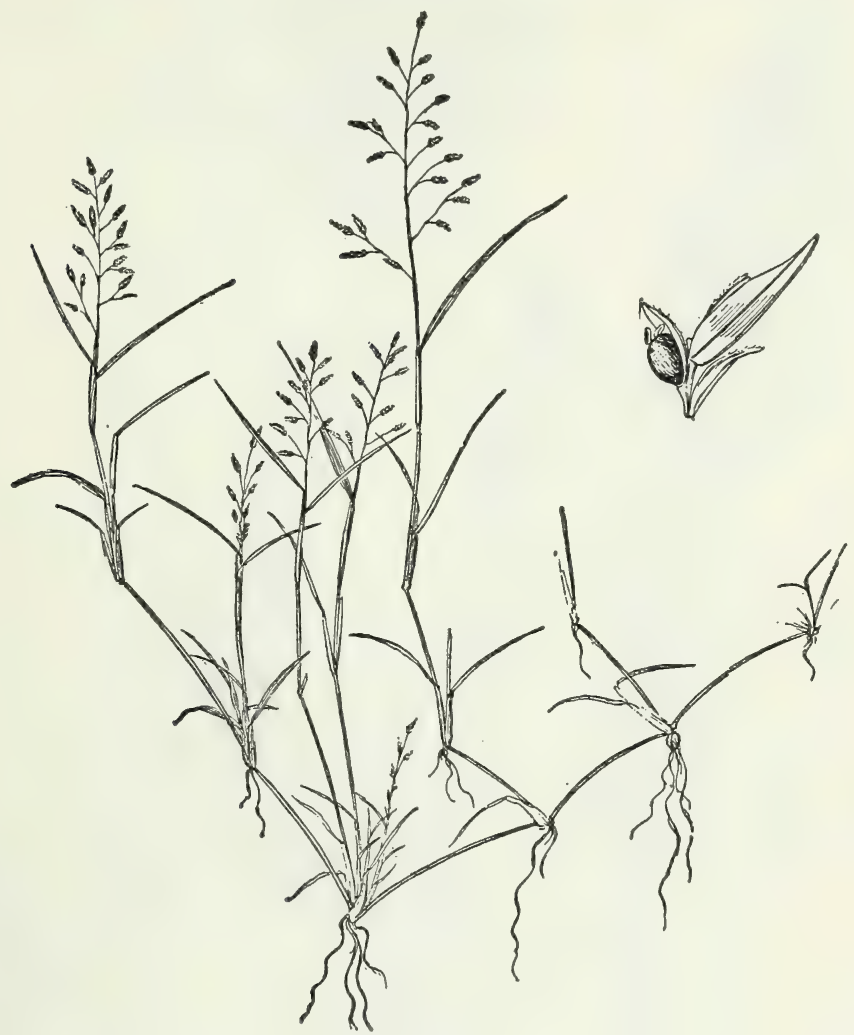

FIGURE 15.-Eragrostis hypnoides. Plant, $\times 1 \frac{1}{2}$; florets, $\times 10$ (Mearns 741).

Dominican Republic: Samaná, Abbott 1327, 1420. Pimentel, Abbott 639, 640. Samaná Peninsula, Abbott 2380. Sánchez, Rose 4328. San Pedro de Macorís, Rose 4228. Santo Domingo, Ekman H 11172. Río San Juan, Miller 1169. Río Muñoz, Eggers 2566.

Puerto Rico: Mayaguez, Britton and Marble 520. Fajardo, Britton and Shafer 1665. San Juan, Chase 6398. Rio Grande, Chase 6711 (Amer. Gr. Nat. Herb. 689). Los Mamayes, Eggers 1207. Vega Baja, Heller 649. Bayamon, Sintenis 1225. Cabo Rojo, Sintenis 674.

Trinidad: Bot. Gard. Herb. 3035; Crueger. 


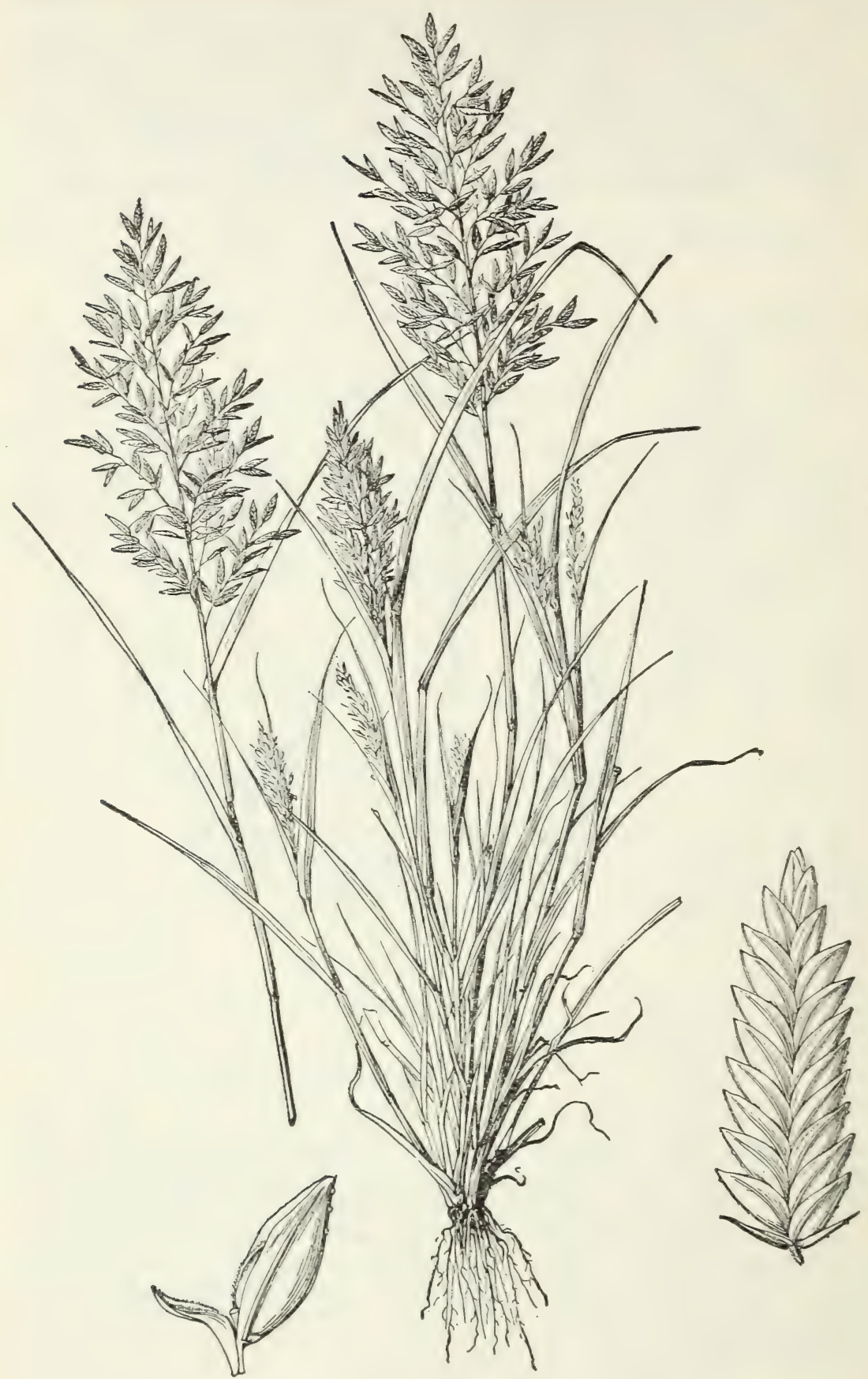

Figtre 16.-Eragrostis cilianensis. Plant, $\times 1$ /2; spikelet, $\times 5$; floret, $\times 10$ (Schuette 155 ). 
6. Eragrostis cilianensis (All.) Link; Vign., Lut. Malpighia 18: 386. 1904. STINKGRASS.

Poa cilianensis All., Fl. Pedem. 2: 246. 1785. Europe.

Eragrostis major Host, Icon. Gram. Austr. 4: 14. pl. 24. 1809. Europe.

Eragrostis megastachya Link, Hort. Berol. 1: 187. 1827. Europe.

Culms erect or spreading; panicles rather compact, 2 to $10 \mathrm{~cm}$ long, greenish or whitish, the spikelets many-flowered, larger than in the other annual species; spikelets 5 to $15 \mathrm{~mm}$ long, $3 \mathrm{~mm}$ wide, 10 - to 40 -flowered, the florets closely imbricate; pedicels and keels of the acute glumes and lemmas sparingly glandular; lemmas thin, the lateral nerves prominent (fig. 16).

A common weed in the United States; rare in the West Indies.

Bermuda: Collins 149.

Cuba: Habana, Léon 8826.

7. Eragrostis glomerata (Walt.) L. H. Dewey, Contrib. U. S. Natl. Herb. 2: 543. 1894.

Poa glomerata Walt., Fl.Carol.80. 1788. South Carolina.

Poa conferta Ell., Bot. S. C. and Ga. 1: 158. 1816. South Carolina.

Eragrostis conferta Trin., Mém. Acad. St. Pétersb. VI. Math. Phys. Nat. 1: 409. 1830.

Robust annual, sometimes as much as $2 \mathrm{~m}$ tall and appearing like a perennial, freely branching, the branches sometimes fascicled; blades elongate; panicles as much as $40 \mathrm{~cm}$ long, narrowly contracted, densely flowered, the spikelets about $2 \mathrm{~mm}$ long, 4- to 6-flowered, the lemmas scarcely $1 \mathrm{~mm}$ long (fig. 17).

Moist low ground, southeastern United States to Uruguay. In the West Indies known only from Trinidad.

Trinidad: O'Meara Savanna, Britton 2492. La Brea, Broadway 4979. Point-àPierre, Broadway 4940, 4941. San Fernando, Hitchcock 10110 (Amer. Gr. Nat. Herb. 690). Port-of-Spain, Hitcheock 10319. St.Joseph, Hitchcock 10024. Without locality, Bot. Gard. Herb. 3366.

8. Eragrostis pilosa (L.) Beauv., Ess Agrost. 162. 1812.

INDIA LOVEGRASS.

Poa pilosa L., Sp. Pl. 68. 1753. Europe

Weedy annual; culms slender, erect or ascending from a decumbent base, 10 to 50

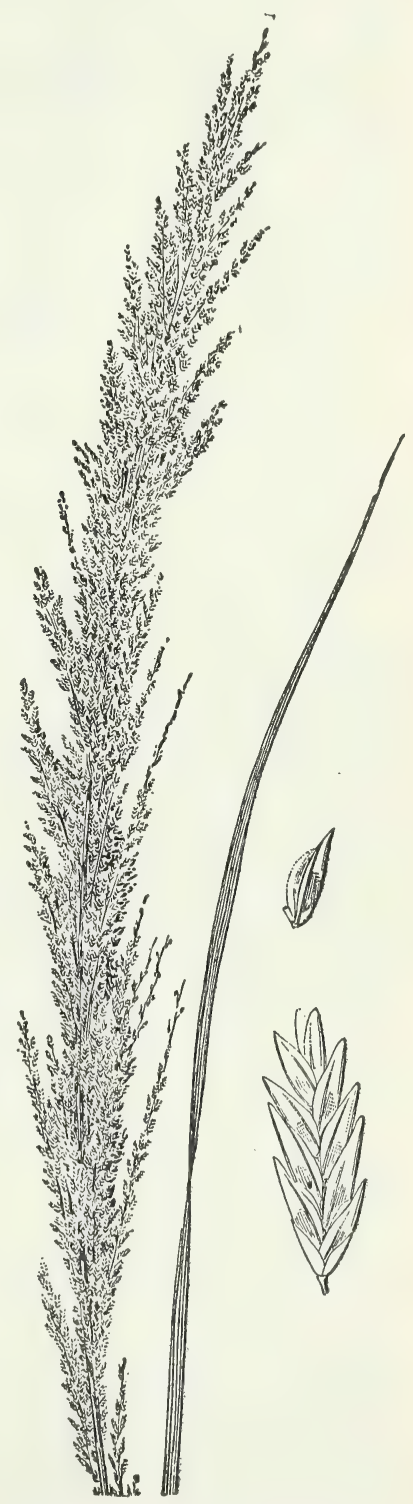

FIGURE 17.-Eragrostis glomerata. Panicle, $\times 1 / 2$; spikelet and floret, $\times 10$ (Eggert). 
$\mathrm{cm}$ tall; blades flat, 1 to $3 \mathrm{~mm}$ wide; panicle delicate, open, becoming somewhat diffuse, 5 to $20 \mathrm{~cm}$ long, the branches capillary, flexuous, ascending or spreading, finally somewhat implicate, the lower fascicled, sparsely long-pilose in the axils; spikelets gray to nearly black, linear, scarcely compressed, 3- to 9 -flowered, 3 to $5 \mathrm{~mm}$ long, about $1 \mathrm{~mm}$ wide, the pedicels spreading, mostly longer than the spikelets; glumes acute, the first a little less than, the second a little more than, $1 \mathrm{~mm}$

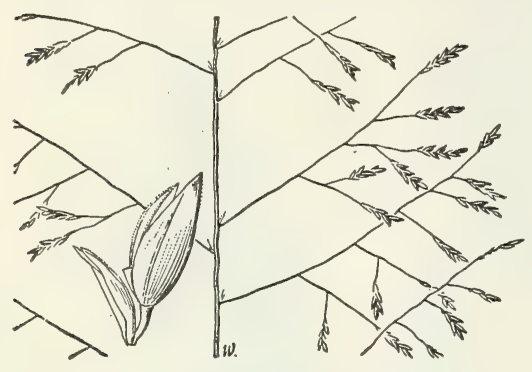

FIgURE 18.-Eragrostis pilosa. Panicle, $\times 1$; floret and palea, $\times 10$ (Ruth 514). long; lemmas loosely imbricate, the rachilla more or less exposed, rounded on the back, acute, 1.2 to $1.5 \mathrm{~mm}$ long, $0.5 \mathrm{~mm}$ wide from keel to margin, the nerves obscure; grain $0.6 \mathrm{~mm}$ long (fig. 18).

Open grounds, fields, and waste places, warm and temperate regions of both hemispheres. The West Indian specimens referred to this species are the form with more delicate, slender, flexuous panicle branches, apparently commoner in Asia and Africa than in Europe. Nash ${ }^{8}$ doubtfully refers these specimens to Eragrostis purshii Schrad. $\therefore$ 'broughout the West Indies at low altitudes.

J. Eragrostis berteroniana (Schult.) Steud., Nom. Bot. ed. 2. 1: 562. 1840.

Megastachya berteroniana Schult., Mant. 2: 330. 1824. Santo Domingo.

Poa berteroniana Kunth, Rév. Gram. 1: 112. 1829.

Annual; culms erect or usually decumbent at base, 10 to $20 \mathrm{~cm}$ tall or even as much as $30 \mathrm{~cm}$; sheaths, at least the lower, sparsely papillose-pilose, densely pilose at the summit; blades narrow, mostly involute, sparsely pilose; panicles oblong, somewhat condensed, 5 to $10 \mathrm{~cm}$ long, glabrous in the axils; spikelets short-pedicellate, ascending, pale or purplish, 7 to $13 \mathrm{~mm}$ long, 15- to 30-flowered; lemmas ovate, 1.5 to $1.8 \mathrm{~mm}$ long.

Open or rocky soil and dry thickets, Hispaniola.

Haiti: Jean Rabel, Leonard 12879, 12972, 13686 ; Ekman H 3617. Etang, Leonard 3560. Cabaret, Leonard 11832, 11835, 11867. Môle-St. Nicolas, Ekman H 4491. Fond Parisien, Leonard 4214. Morne-á-Cabrits, Ekman H 978. Plaine du Cul de Sac, Buch 2039.

Dominican Republic: Villa Vásquez, Ekman H 13129. Valverde, Ekman H 13097.

10. Eragrostis tephrosanthos Schult., Mant. 2: 316. 1824. Martinique.

Annuals, rather soft and lax; culms branching at base, erect or decumben $\hat{\mathrm{t}}$-spreading, 5 to $20 \mathrm{~cm}$ tall, sometimes taller; blades flat, usually 5 to $10 \mathrm{~cm}$ long, 1 to $2 \mathrm{~mm}$ wide; panicles open, mostly 4 to $10 \mathrm{~cm}$ long, about half as wide, the branches ascending or spreading, naked below, the spikelets appressed or ascending along the upper

${ }^{8}$ Bull. Torrey Bot. Club 30: 388. 1903. 
part, the lower axils pilose; spikelets, 6 - to 12 -flowered, 4 to $7 \mathrm{~mm}$ long, about $1.5 \mathrm{~mm}$ wide (fig. 19).

Open ground, fields, and waste places, West Indies to Brazil. Common in the Greater Antilles and Trinidad; less common in the Lesser Antilles. In Cuba called "ilusión."

Grisebach ${ }^{9}$ refers this species to $E$. poaeoides Beauv.

11. Eragrostis barrelieri Daveau, in Morot., Jour. Bot. 8: 289. 1894. Europe.

Annual; culms erect or decumbent, 20 to $50 \mathrm{~cm}$ tall; blades flat, rather short, 2 to $4 \mathrm{~mm}$ wide; panicle erect, open but narrow, 8 to $15 \mathrm{~cm}$ long, the branches ascending or stiffly spreading, few-flowered, spikelet-bearing nearly to base, the

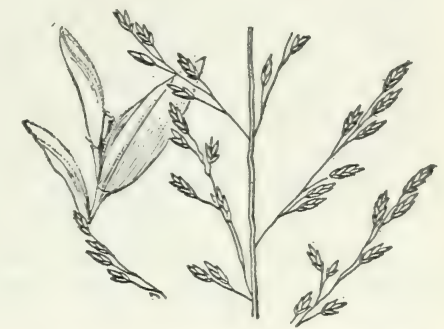

FIGL'RE 19.-Ercarostis $t$ - phrosinthos Panicle, $\times 1$; foret, $\times 10$ (Curtiss $5930)$. axils glabrous; spikelets linear, usually 12- to 1 -flowered, mostly about $1 \mathrm{~cm}$ long and $1.5 \mathrm{~mm}$ wide; lemmas $2 \mathrm{~mm}$ long or slightly longer (fig. 20).

Waste places. Texas to California; Hispaniola and St. Croix; introduced from Europe.

HaItI: Anse-à-Pitre, Ekman H6696. Cape St. Marc, Ekman H 6639 .

Dominican Republic: Guayubín, Abbott 877.

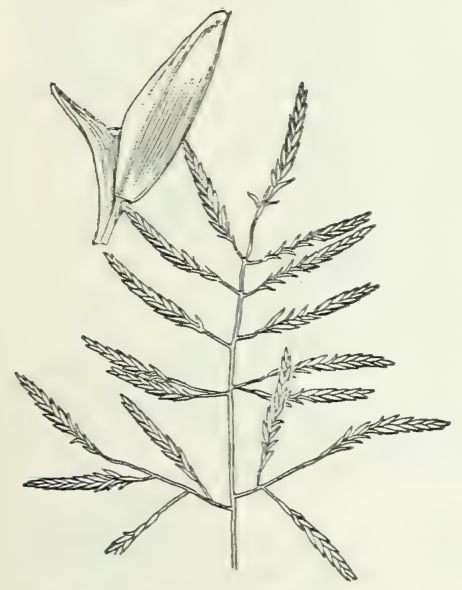

FIGTPE 20-E-agrostis barrelieri. Panicle $\times 1$; floret, $\times 10$ (Fitcheork 5280).

Virgin Islands: St.Croix, Thompson 5,302,996;Eggers in 1876 ; Ricksecker 221 .

12. Eragrostis bahamensis Hitchc., Mo. Bot. Gard. Rept. 4: 149. 1893. Inagua, Hitchcock.

Perennial; culms tufted, simple, spreading, wiry, usually about $15 \mathrm{~cm}$ tall; blades slender, firm, involute, a woolly tuft of hairs at the summit of the sheath; spikelets mostly in a raceme on the upper half of the culm, appressed, rather distant, short-pedicellate, 6 to $8 \mathrm{~mm}$ long, firm and hard, 10- to 20-flowered.

Rocky soil, Bahamas.

Bahamas: Rum Cay, Brace 3993. Little Inagua, Nash and Taylor 1217. Inagua, Hitchcock in 1890 . The species has been collected on other islands of the group.

13. Eragrostis cubensis Hitchc., Contrib. U. S. Natl. Herb. 12: 243. 1909. Isla de Pinos, Curtiss 420.

Perennial, culms slender, wiry, erect or spreading, tufted from a hard knotty base, mostly 10 to $20 \mathrm{~cm}$, sometimes $30 \mathrm{~cm}$, tall; blades narrow or filiform, mostly involute, erect; panicles few-flowered, 2 to $8 \mathrm{~cm}$ long, the few branches erect or ascending, the lower sometimes as much as $2 \mathrm{~cm}$ long, usually short and appressed; spikelets short 
pedicellate, the lateral pedicels often less than $1 \mathrm{~mm}$, linear, mostly 7 to $12 \mathrm{~mm}$, rarely as much as $25 \mathrm{~mm}$, long, 10 to 20 -flowered, the florets closely imbricate; lemmas firm, acute, about $1.8 \mathrm{~mm}$ long.

Sandy or rocky soil, Cuba and Jamaica. Grisebach ${ }^{10}$ refers this species to E. bahiensis Schrad.

Cuba: Herradura, Ekman 10696; Earle 650; Hitchcock 261; Tracy 9097. San Diego de los Baños, Léon 4559. Sumidero, Léon 3471. Sierra de Cabra, Britton and Gager 7271. Madruga, Shafer 68. Laguna Jovero, Shafer 10731. Pinar del Río, Hitchcock 23285. Baraguá, Hitchcock 23359, 23376. Zaza de Tunas, Léon 886. Without locality, Wright 3424, 3825. Isla de Pinos, Britton and Wilson 14194, 15382. Sábalo, Léon 15099.

Jamaica: New Forest, Hitchcock 9852 (Amer. Gr. Nat. Herb. 691). Lititz Savanna, Harris 11664, 11734, 12441, 12678.

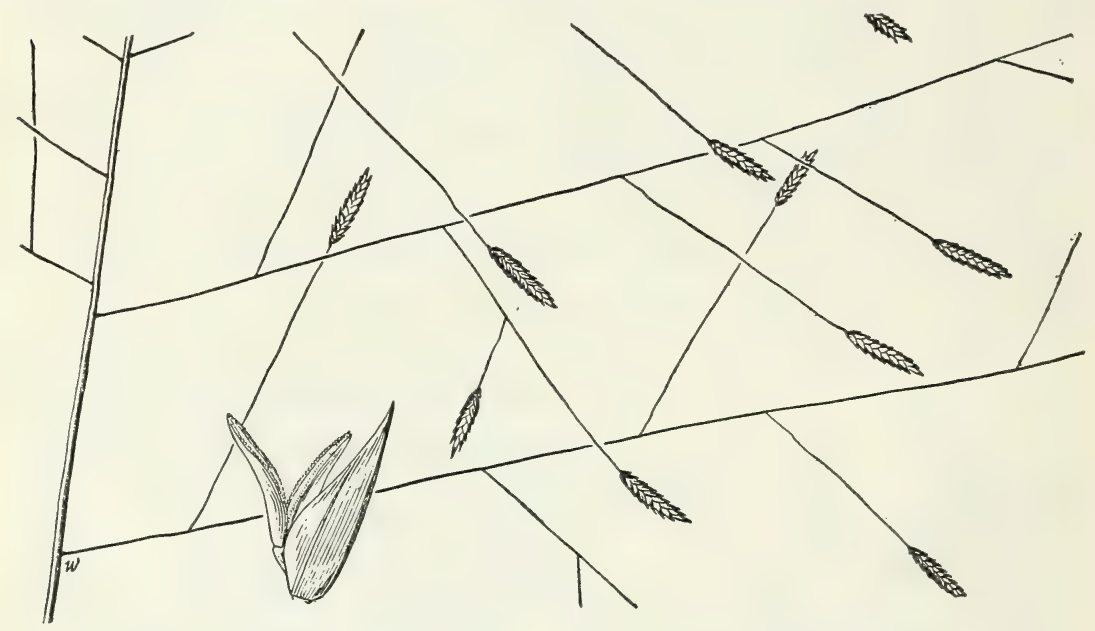

Figure 21.-Eragrostis elliottii. Panicle, $\times 1$; floret, $\times 10$ (Tracy 7384).

14. Eragrostis elliottii S. Wats., Amer. Acad. Proc. 25: 140.1890.

Poa nitida Ell., Bot.S. C. and Ga. 1: 162. 1816. South Carolina. Not Poa nitida Lam. 1791, nor Eragrostis nitida Link, 1827.

Eragrostis macropoda Pilger, in Urban, Symb. Antill. 4: 106.1903. Puerto Rico, Sintenis 1233.

Perennial; culms tufted, about $50 \mathrm{~cm}$ tall, the rather stiff leaves mostly clustered toward the base, the very diffuse few-flowered panicle more than half the entire height of the plant, the panicle axis and the capillary branches fragile; spikelets on long, rather stiff, slender pedicels, mostly 8 - to 15 -flowered, 5 to $12 \mathrm{~mm}$ long; lemmas closely imbricate, acute, about $2 \mathrm{~mm}$ long (fig. 21).

Sandy savannas and sterile hills, southeastern United States on the Coastal Plain and in the West Indies. ${ }^{11}$

Cuba: Herradura, Tracy 9096; Hitchcock 260. Guane, Léon 7310. Pinar del Río, Hitchcock 23289; Palmer and Riley 441; Baker and 
Abarca 3735. Camagüey, Britton 2373. Placetas del Sur, Léon 6425. Cojimar, Baker 5332. Madruga, Léon 8951. Baraguá, Hitchcock 23386. Manacas, Léon 5884. Isla de Pinos, Taylor 25; Palmer and Riley 948; Ekman 11657; Britton and Wilson

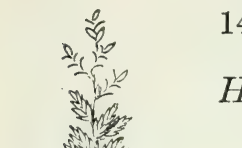
14708, 14944. Without locality, Wright 3423.
Jamaica: New Forest, Hitchcock 9854 (Amer. Gr. Nat. Herb. 692). Lititz Savanna, Harris 11661, 12435, 12680. HaIti: Acul-Samedi, Ekman H 9920.
Dominican Republic: Cuenca, Ekman H 13298. Monción, Valeur 145. Cotuy, Abbott 795.
Puerto Rico: Bayamon, Sintenis 1233. Santurce, Heller 584. Campo Alegre, Chase 6798 (Amer. Gr. Nat. Herb. 693). Sabana Abajo, Britton and Brown 5719. Joyuda, Britton, Stevens, and Hess 2396. Sàn Juan, Chase 6634.

15. Eragrostis acutiflora (H. B. K.) Nees, Agrost. Bras. 501. 1829.

Poa acutiflora H.B.K., Nov. Gen. et Sp. 1: 161. 1816. Colombia.

Perennial; culms tufted, rather rigid, sparingly branching, 20 to $40 \mathrm{~cm}$ tall, blades erect, flat or involute, 1 to $2 \mathrm{~mm}$ wide; panicles 10 to $20 \mathrm{~cm}$ long, the spikelets short-pedicellate, somewhat crowded along the stiffly ascending primary branches; spikelets 4 to $5 \mathrm{~mm}$ long, 6- to 10 -flowered; lemmas acuminate, $2 \mathrm{~mm}$ long.

Ditches and open moist soil, Trinidad and northern South America.

TrINIDAD: Piarco Savanna, Freeman 7533; Britton and Hazen 721; Hitchcock 10344. Aripo Road, Broadway 5827. Without locality, Broadway 7750.

\section{Eragrostis ekmanii Hitchc., sp. nov. ${ }^{12}$}

Perennial; culms erect, firm, wiry, 50 to $60 \mathrm{~cm}$ tall; sheaths glabrous, the summit glabrous or very sparsely pilose; blades erect, firm, flat, folded or involute, 5 to $15 \mathrm{~cm}$ long, 1 to $2 \mathrm{~mm}$ wide, sparsely long-pilose on the upper surface near the base, otherwise glabrous; panicle erect, stiff, consisting of several clusters of spikelets along an axis 9 to $14 \mathrm{~cm}$ long, the lower clusters 10 to $15 \mathrm{~mm}$ long, distant, the upper shorter, somewhat confluent; spikelets pale or slightly tinged with purple, about $5 \mathrm{~mm}$ long, mostly 9- to 13-flowered; florets closely imbricate, acute, firm, minutely roughened (under a lens) about $1.5 \mathrm{~mm}$ long, the lateral nerves distinct; nerves of palea scaberulous (fig. 22).

Type in the United States National Her-

Figure 22.-Eragrostis ekmanii.

Panicle, $\times 1$; floret, $\times 10$ (type). barium, no. 1387320 , collected in sandy pinelands, Los Indios, Isla de Pinos, November 8,

12 Planta perennis; culmi erecti caespitosi, 50-60 cm alti; vaginae glabrae, faucibus glabris; laminae erectae planae vel involutae 5-15 cm longae 1-2 mm latae, supra pilosae ad basen panicula erecta 7-14 cm longa spiculis fasciculatis, fasciculis inferioribus distantibus, superioribus confluentibus; spiculae 5 mm longae 9-13-florae; lemmata acuta arcte imbricata firma minute scaberula $1.5 \mathrm{~mm}$ longa, nervis distinctis. 
1920, by E. L. Ekman (no. 12143). This is the only specimen examined.

17. Eragrostis purpurascens (Spreng.) Schult., Mant. 2: 317.1824.

Poa purpurascens Spreng., Nov. Prov. Hal. 33. 1819. [Uruguay.]

Culms ascending or spreading, sparingly branching below; panicles commonly about one-third the entire height of the plant, about twothirds as wide as long, the slender flexuous branches, branchlets, and pedicels divergent; spikelets about $8 \mathrm{~mm}$ long, dark-colored, the lemmas thin, the lateral nerves obscure.

Open ground and rocky hills, Brazil to Argentina; also in Antigua (Duss 3;Box 17, 20; Wullschlaegel 644). This is the species described by Grisebach ${ }^{13}$ as Eragrostis prolifera. The plants from Antigua agree with Nees's description of Eragrostis purpurascens ${ }^{14}$ and with the Sello specimen cited by him, but they may not be Poa purpurascens of Sprengel.

18. Eragrostis excelsa Griseb., Cat. Pl. Cub. 227. 1866. Cuba, Wright 3425.

Perennial; culms erect, robust, 1 to $2 \mathrm{~m}$ tall; blades elongate, flat, becoming loosely involute in drying, as much as $7 \mathrm{~mm}$ wide, the base somewhat clasping, the summit of the sheaths and the upper surface of the blades at the base densely long-pilose; panicles large, somewhat open, as much as $50 \mathrm{~cm}$ long, the long branches ascending; spikelets 5 to $7 \mathrm{~mm}$ long, 4- to 8-flowered.

Thickets near the coast, Bahamas and Cuba.

Bahamas: Berry Islands, Britton and Millspaugh 2186.

Cuba: Vicinity of Habana, Léon 962, 963, 3444, 3678, 5270, 5651, 7485, 8420, 8421; Ekman 1206. Boca de Canasí, Léon 13690. Mariel, Britton and Gager 7561. Toscano, Wright 3425.

19. Eragrostis salzmannii Steud., Syn. Pl. Glum. 1: 277.1854. Bahia, Brazil.

Perennial; culms in large clumps, erect or ascending, 60 to $100 \mathrm{~cm}$ tall, branching above, the branches fascicled; sheaths glabrous at the summit or with a few long hairs; blades flat, becoming involute, 1 to $2 \mathrm{~mm}$ wide, tapering to a fine point; panicles oblong, rather dense, mostly 8 to $12 \mathrm{~cm}$ long, 2 to $3 \mathrm{~cm}$ wide, the branches short, spreading or ascending, densely many-flowered, the spikelets often spreading in all directions; spikelets 6 to $10 \mathrm{~mm}$ long, 10- to 20-flowered, often falcate; lemmas oblong, obtuse, imbricate, $1.5 \mathrm{~mm}$ long.

Sandy seacoasts and saline meadows, Cuba, Colombia, and Brazil.

Cuba: Río Tayabo, Britton and Wilson 5566; Casilda, Britton and Wilson 5510. Trinidad, Ekman 18913.

20. Eragrostis prolifera (Swartz) Steud., Syn. Pl. Glum. 1: 278. 1854.

Poa prolifera Swartz, Prodr. Veg. Ind. Occ. 27. 1788. St. Lucia, Guadeloupe.

Perennial; culms firm and hard, tufted, erect at base, leaning, branching above, about $1.5 \mathrm{~m}$ tall and $3 \mathrm{~mm}$ in diameter near the base, the branches more or less fascicled; summit of sheaths glabrous or sparsely pilose; blades elongate, slender, more or less involute, 0.5 to $2 \mathrm{~mm}$ wide when flat, attenuate to a fine point; panicle rather

it Agrost. Bras. 506. 1829. 
narrow, 15 to $45 \mathrm{~cm}$ long, the long branches more or less appressed; spikelets 5 to $8 \mathrm{~mm}$ long, 7 - to 15 -flowered; lemmas 1.5 to $1.8 \mathrm{~mm}$ long.

Ditches and marshes near the coast, Guadeloupe. Swartz, in the original description, gives the locality "Insulae caribaeae." In a later work ${ }^{15}$ he gives "Lucia, Guadeloupe."

Leeward Islands: Guadeloupe, Duss 3142; Hitchcock 16414, "Erect at base but branched above and more or less leaning. Panicles all slender and narrow. In ditches along road through brackish swamp."

21. Eragrostis domingensis (Pers.) Steud., Syn. Pl. Glum. 1: 278. 1854.

Poa domingensis Pers., Syn. Pl. 1: 88. 1805. Santo Domingo. Eragrostis gigantea Trin., Mém. Acad. St. Pétersb. VI. Math. Phys. Nat. 1: $403 . \quad 1830$. Santo Domingo.

Perennial; culms rather stout, erect, 0.5 to $1.5 \mathrm{~m}$ tall; sheaths glabrous or sparsely pilose at the summit; blades flat becoming more or less involute in drying, elongate, 2 to $5 \mathrm{~mm}$ wide; panicles 25 to $50 \mathrm{~cm}$ long, the branches ascending or appressed, usually rather closely flowered to the base, the lower sometimes distant; spikelets mostly short-pedicellate, 5 to $10 \mathrm{~mm}$ long, 10 - to 25 -flowered; lemmas 1.5 to $1.8 \mathrm{~mm}$ long.

Beaches and rocky soil near the coast, Cuba, Jamaica, Hispaniola, and a few other localities.

Cuba: Bahía Honda, Wilson 9257; Ekman 12696. Habana, Léon 5620, 5650. Santa Fé, Léon 15868. Yayales, Ekman 11192. Carabela Grande, Roig 3200.

Jamaica: St. Anns Bay, Ridley 87. Bushy Park, Harris 12518. Healthshire Hills, Harris 11618. Mouth of Cockpit River, Harris 12466. Portland, Britton 1923. Port Henderson, Ridley in 1916. Grand Cayman, Hitchcock in 1890; Millspaugh 1240.

Haiti: Bayeux, Ekman H 2604. Cocoa Point, Nash 1780. Tortuga Island, Leonard 11426, 12380, 12486, 13918; Ekman H 4211.

Leeward Islands: Guadeloupe, Duss 3422.

Windward Islands: Martinique, Duss 565.

\section{MONANTHOCHLOË Engelm., Acad. Sci. St. Louis, Trans.} 1: 436.1859

Plants dioecious; spikelets, 2- or 3-flowered, usually sessile in pairs, concealed in the upper sheaths; glumes leaflike, rigid, with membranaceous sheaths and short, strongly veined spreading blades, the first about equaling the uppermost floret; lemmas rather rigid, the palea with winged keels. Creeping wiry perennial, with clustered short subulate blades, the spikelets inconspicuous at the ends of the short branches, only a little exceeding the leaves.

1. Monanthochloë littoralis Engelm., Acad. Sci. St. Louis, Trans. 1: 437. pl. 13. 1859. Texas.

Culms tufted, the short branches erect; blades falcate, mostly less than $1 \mathrm{~cm}$ long (fig. 23).

Muddy seashores and tidal flats, in the warmer parts of America.

Cuba: Cayo Cruz, Shafer 2773.

15 Fl. Ind. Occ. 1: 216.1797. 

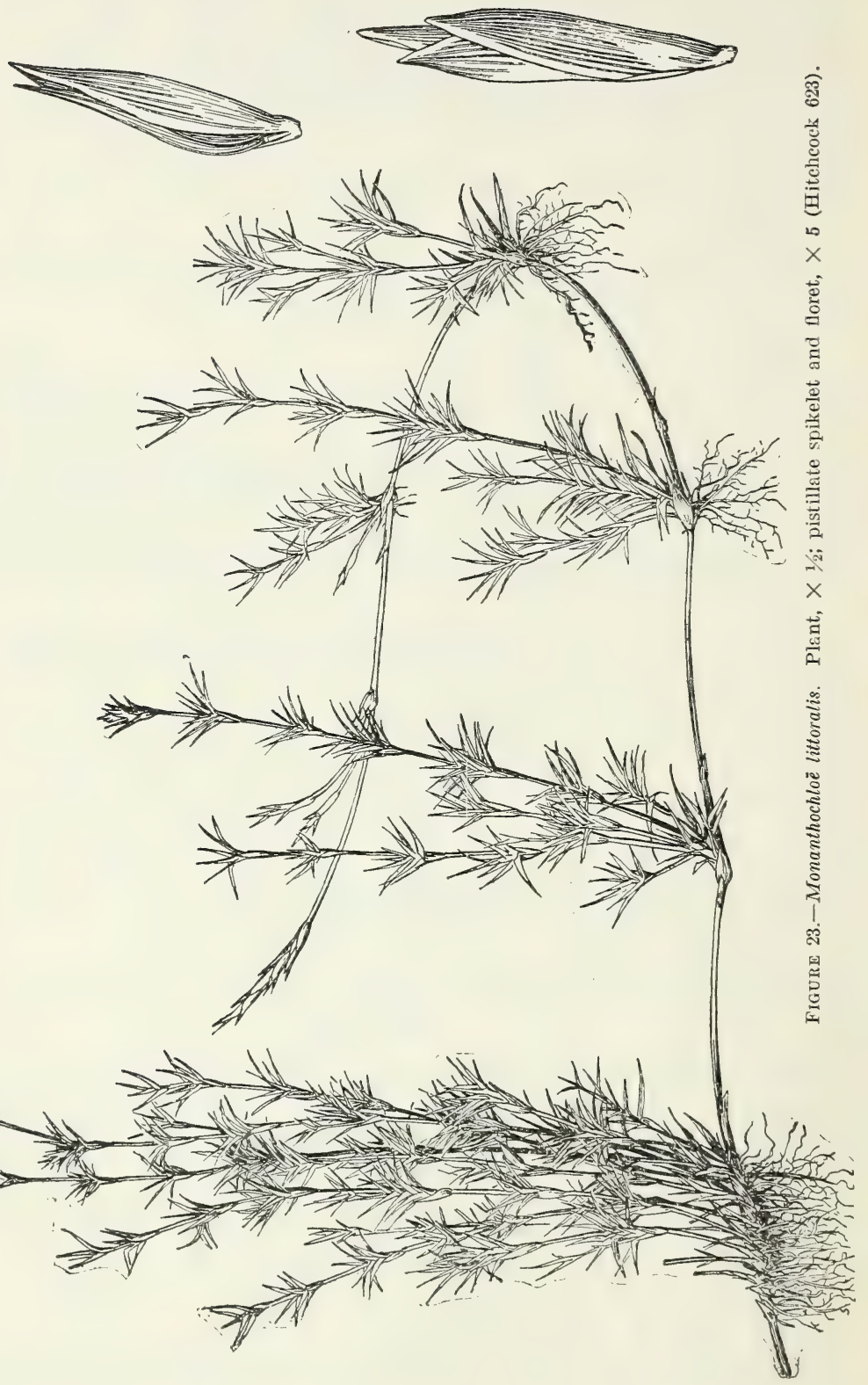
14. DistiCHLIS Raf., Jour. Phys. Chim. 89: 104. 1819. SAltGRASS

Plants dioecious; spikelets several- to many-flowered, the rachilla of the pistillate spikelets disarticulating above the glumes and between the florets; glumes unequal, broad, acute, keeled, mostly 3 -nerved, the lateral nerves sometimes faint or obscured by striations and intermediate nerves; lemmas closely imbricate, firm, the pistillate coriaceous, the margins bowed out near the base, acute or acutish, 3-nerved, with several intermediate nerves or striations; palea as long as the lemma or shorter, the pistillate coriaceous, enclosing the grain. Low perennials, with extensively creeping scaly rhizomes, erect, rather rigid culms, and short, dense, rather few-flowered panicles.

1. Distichlis spicata(L.) Greene, Calif. Acad. Sci. Bull. 2: 415. 1887.

Seashore saltgrass.

Uniola spicata L., Sp. Pl. 71. 1753. Atlantic coast of North America.

Low, erect, smooth perennial, with long running rhizomes, slender culms, spreading firm involute blades, and small compact panicles, the spikelets about $1 \mathrm{~cm}$ long. Extensive colonies of sterile plants may be recognized by the overlapping sheaths and conspicuously closely distichous stiff blades (fig. 24).

Salt marshes and alkaline meadows near the coast, United States, Mexico, and northern West Indies.

Bahamas: New Providence, Britton and Brace 417; Geogr. Soc. Baltimore 4. Watlings Island, Geogr. Soc. Baltimore 491. Inagua, Hitchcock in 1890.

CuBA: Colonia, Britton and Cowell 9853. Habana, Léon 3476. Batabanó, Léon 5757; Hitchcock 262; Baker and Wilson 2293, 2348; Ekman 892. Baraguá, Hitcheock 23344. Cayo Sabinal, Ekman 15485.

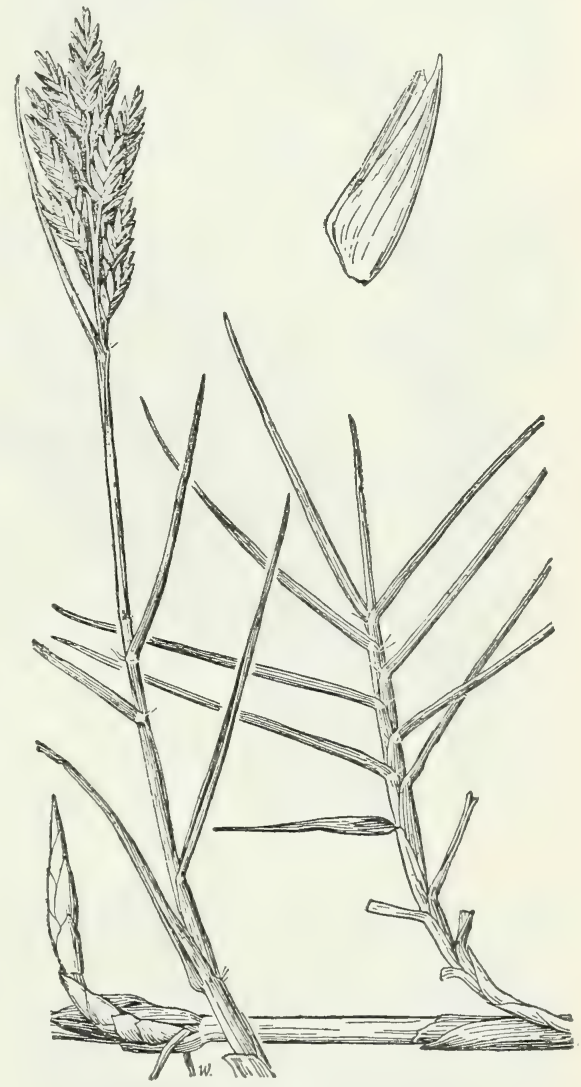

FIGURe 24.-Distichlis spicata. Plant, $\times 1$; floret, $\times 5$ (Hitcheock 2826).

Guantanamo Bay, Britton 2264. Isla de Pinos, Britton and Wilson 15199.

Haiti: Croix-des-Bouquets, Ekman H 2157.

Dominican Republic: Barahona, Ekman H 6957. 


\section{UNIOLA L., Sp. Pl. 71. 1753}

Spikelets, 3- to many-flowered, the lower 1 to 4 lemmas empty, the rachilla disarticulating above the glumes and between the florets; glumes compressed-keeled, rigid, usually narrow, nerved, acute or acuminate or rarely mucronate, lemmas compressed, sometimes conspicuously flattened, chartaceous, many-nerved, the nerves sometimes obscure, acute or acuminate, the empty ones at the base usually successively smaller, the uppermost usually reduced; palea rigid, sometimes bowed out in the winged keels. Rather tall, erect perennials,

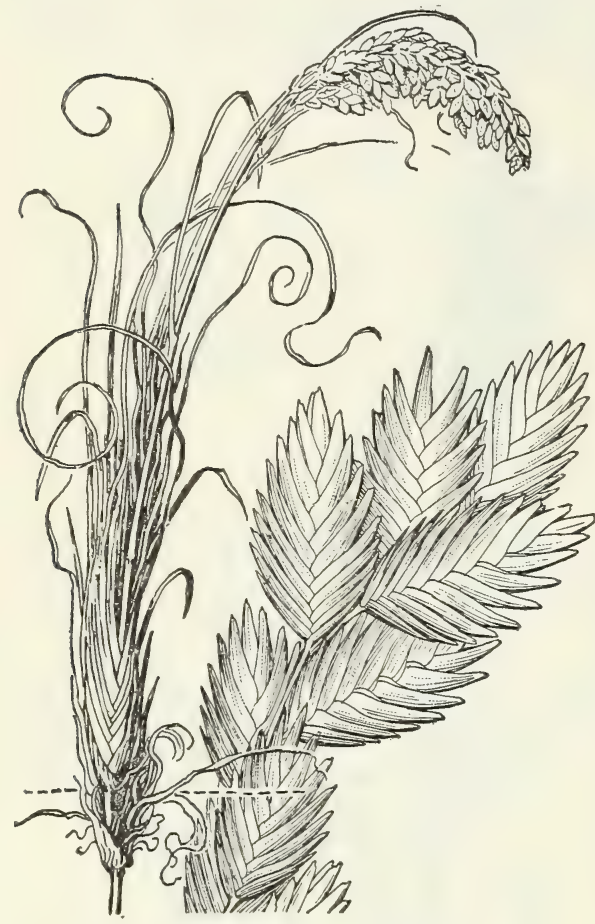

FIGURE 25.-Uniola paniculata. Plant, $\times 1 / 10$; spikelets, $\times 1$ (Kearney 2134$)$. with flat or convolute blades and narrow or open panicles of compressed spikelets.

Spikelets 8 to $10 \mathrm{~mm}$ broad, in a drooping panicle.

1. U. PANICULATA.

Spikelets 2 to $4 \mathrm{~mm}$ wide, in a narrow erect panicle.......

2. U. VIRGATA.

1. Uniola paniculata L., Sp. Pl. 71. 1753. Carolina. SEA-OATS.

A robust tufted smooth perennial, often $2 \mathrm{~m}$ tall, with long, tough, involute blades and long panicles of pale heavy spikelets, commonly $2.5 \mathrm{~cm}$ long; spikelets oval, 1.5 to $2.5 \mathrm{~cm}$ long; lemmas about $1 \mathrm{~cm}$ long (fig. 25).

Sandy seacoasts, Virginia to South America. In Cuba called "arana."

Bahamas: New Providence, Geogr. Soc. Baltimore 109; Dewey 570; Eggers 4119.

Cuba: Playa de Bacuranao, Léon 889. Bahía Honda, Ekman 10564. Playa de Marianao, Léon 964; Van Hermann 895. Cabañas, Palmer and Riley 751. Varedero Beach, Killip 13945. Cayo Sabinal, Shafer 701. Without locality, Wright 2823.

2. Uniola virgata (Poir.) Griseb., Fl. Brit. W. Ind. 531. 1864.

Poa virgata Poir., in Lam., Encycl. 5: 78. 1804. Santo Domingo.

Uniola racemiflora Trin., Mém. Acad. St. Pétersb. VI. Sci. Nat. $2^{1}: 55$. 1836. Santo Domingo.

Uniola sparta Trin., Linnaea 10: 307. 1836. Cuba.

Plants in large clumps with many sterile shoots, the culms less robust than in $U$. paniculata, 1 to $2 \mathrm{~m}$ tall, the closely involute blades hard and rery flexuous, the panicle stiffly erect, 40 to $60 \mathrm{~cm}$ long, the slender stiff branches narrowly ascending, 2 to $4 \mathrm{~cm}$ long; spikelets about $5 \mathrm{~mm}$ long. Panicle sometimes spikelike. Blades usually very scabrous on the margins. 
Rocky seacoast, West Indies.

Bahamas: Eleuthera, Geogr. Soc. Baltimore 349. New Providence, Geogr. Soc. Baltimore 7, 301; Curtiss 131; Eggers 4333.

Cuba: Boca de Canasí, Léon 13174. Postelillo, Ekman 15411. Cajobabo, Léon 12317. Guantanamo, Ekman in 1922; Hioram 2168. Punta Brava, Rugel 870. Uvero Alto, Léon 14674. Bahía de Manatí, Léon 15751.

JamaICA: Cane River Valley near coast, Harris 11312. Healthshire Hills, Harris 11622; Hitchcock 9761 (Amer. Gr. Nat. Herb. 698).

Haiti: Cabaret, Leonard 11801, 11857, 11861, 12043. Monte Cabrete, Cook, Scofield, and Doyle 72. Source-Matelas, Ekman H 2149. Jean Rabel, Leonard 12849, 13009. St. Marc, Leonard 3418. Randelle, Ekman H 677. Ennery, Leonard 8850a, 8880. Tortuga Island, Leonard 11527, 15394. Gonaïve Island, Leonard 3414.

Dominican Republic: Higüey, Ekman H 12224. Monción, Valeur 215, 799. Santo Domingo, Eggers 2361. Puerto Plata, Eggers 2517. Azua, Rose 3825. Barahona, Fuertes 808; Ekman H 6724. Guayubín, Abbott 873, 896. Puerto Francés, Abbott 1215. Sosúa, Ekman H 14477.

Puerto Rico: Guanica, Chase 6526; Britton, Cowell, and Brown 4890. Cabo Rojo, Sintenis 839, 840; Britton, Cowell, and Brown 4708. Guayanilla, Shafer 1992. Cayo Muertos, Britton, Cowell, and Brown 5002. Cayo Puerto Real, Shafer 2768. Puerto Diablo, Shafer 2938.

Virgin Islands: St. Thomas, Eggers in 1882. Little St. James Island, Britton and Rose 1414.

\section{DACTYLIS L., Sp. Pl. 71. 1753}

Spikelets few-flowered, compressed, finally disarticulating between the florets, nearly sessile in dense 1-sided fascicles, these borne at the ends of the few branches of a panicle; glumes unequal, carinate, acute, hispid-ciliate on the keel; lemmas compressed-keeled, mucronate, 5-nerved, ciliate on the keel. Perennials, with flat blades and fascicled spikelets.

\section{Dactylis glomerata L., Sp. Pl. 71. 1753. Europe. Orchard Grass.}

Rather coarse roughish perennial commonly about $1 \mathrm{~m}$ tall; blades flat; panicles of few to several branches naked at base, bearing toward the ends clusters of densely crowded, sparsely pilose spikelets 0.8 to $1 \mathrm{~cm}$ long.

Commonly cultivated in the United States as a meadow grass and frequent as an escape. In England called cocksfoot. Not grown in the West Indies.

JamaICA: Cinchona, Harris 11779. Without locality, Hart 744.

17. GYNERIUM Willd.; Beauv., Ess. Agrost. 138. pl. 24. f. 6. 1812

Plants dioecious; spikelets several-flowered; pistillate spikelets with long-attenuate glumes and smaller long-silky lemmas; staminate spikelets with shorter glumes and glabrous lemmas. Large perennial reed. 


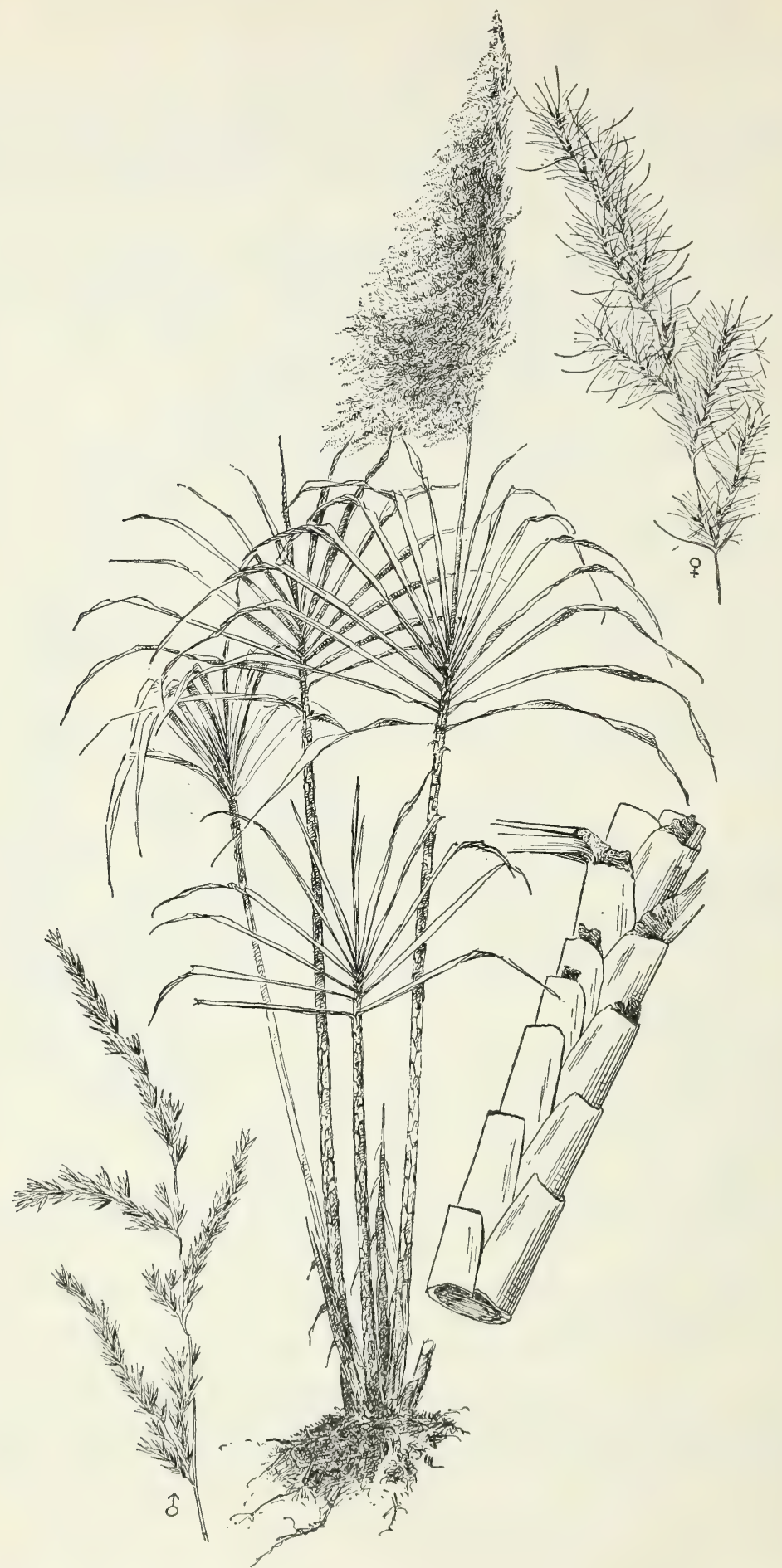

FIGURE 26.-Gynerium sagittatum. Plant, much reduced. Portion of culm showing imbricate"sheaths, $\times 1 / 2$; and staminate branch, $\times 1$ (Leonard 5309); pistillate branch, $\times 1$ (Chase 6442). 
1. Gynerium sagittatum (Aubl.) Beauv., Ess. Agrost. 138. pl. 24. f. 6.1812 .

WILD CANE.

Saccharum sagittatum Aubl., Pl. Guian. 1: 50. 1775. French Guiana.

Gynerium saccharoides Humb. and Bonpl., Pl. Aequin. 2: 105. pl. 115. 1813. Venezuela.

Arundo saccharoides Poir., in Lam., Encycl. Sup. 4: 703. 1816.

Aira gigantea Steud., Syn. Pl. Glum. 1: 224. 1854. Antilles.

Stout reeds often $10 \mathrm{~m}$ tall, the culms clothed below with old sheaths, the blades having fallen; blades sharply serrulate, commonly $2 \mathrm{~m}$ long and 4 to $6 \mathrm{~cm}$ wide (forming a great fan-shaped summit to the sterile culms); panicles pale, plumy, densely flowered, $1 \mathrm{~m}$ or more long, the main axis erect, the branches drooping; pistillate panicles silky from the villous florets; staminate panicles glabrous (fig. 26).

River banks and low 'ground, forming dense colonies, West Indies and southern Mexico to South America. Found throughout the West Indies except the Bahamas. Called in Cuba "caña de Castilla." The stems are used for lattices and light construction work.

\section{ARUNDO L., Sp. Pl. 81. 1753}

Spikelets several-flowered, the florets successively smaller, the summits of all about equal, the rachilla glabrous, disarticulating above the glumes and between the florets; glumes somewhat unequal, membranaceous, 3-nerved, narrow, tapering into a slender point, about as long as the spikelet; lemmas thin, 3-nerved, densely long-pilose, gradually narrowed at the summit, the nerves ending in slender teeth, the middle one longer, extending into a straight awn. Tall perennial reeds, with broad linear blades and large plumelike terminal panicles.

\section{Arundo donax L., Sp. Pl. 81. 1753. Europe.}

Giant Reed, Carrizo.

Culms stout, in large clumps, 2 to $6 \mathrm{~m}$ tall, sparingly branching, from thick knotty rhizomes; blades numerous, elongate, 5 to $7 \mathrm{~cm}$ wide on the main culm, conspicuously distichous, spaced evenly along the culm, the margins scabrous; panicle dense, erect, 30 to $60 \mathrm{~cm}$ long; spikelets $12 \mathrm{~mm}$ long (fig. 27).

River banks and moist ground, warmer parts of the Old World. Cultivated in America for ornament and occurring from Texas to California and southward to South America as an escape. Found on nearly all of the West Indian islands, including Bermuda and the Bahamas. In Cuba called "güin." The woody stems are used for lattices and light construction work.

\section{PHRAGMITES Trin., Fund. Agrost. 134. 1820.}

Spikelets several-flowered, the rachilla clothed with long silky hairs, disarticulating above the glumes and at the base of each joint between the florets, the lowest floret staminate or neuter; glumes 3-nerved, or the upper 5-nerved, lanceolate, acute, unequal, the first about half as long as the second, the latter shorter than the florets; lemmas 


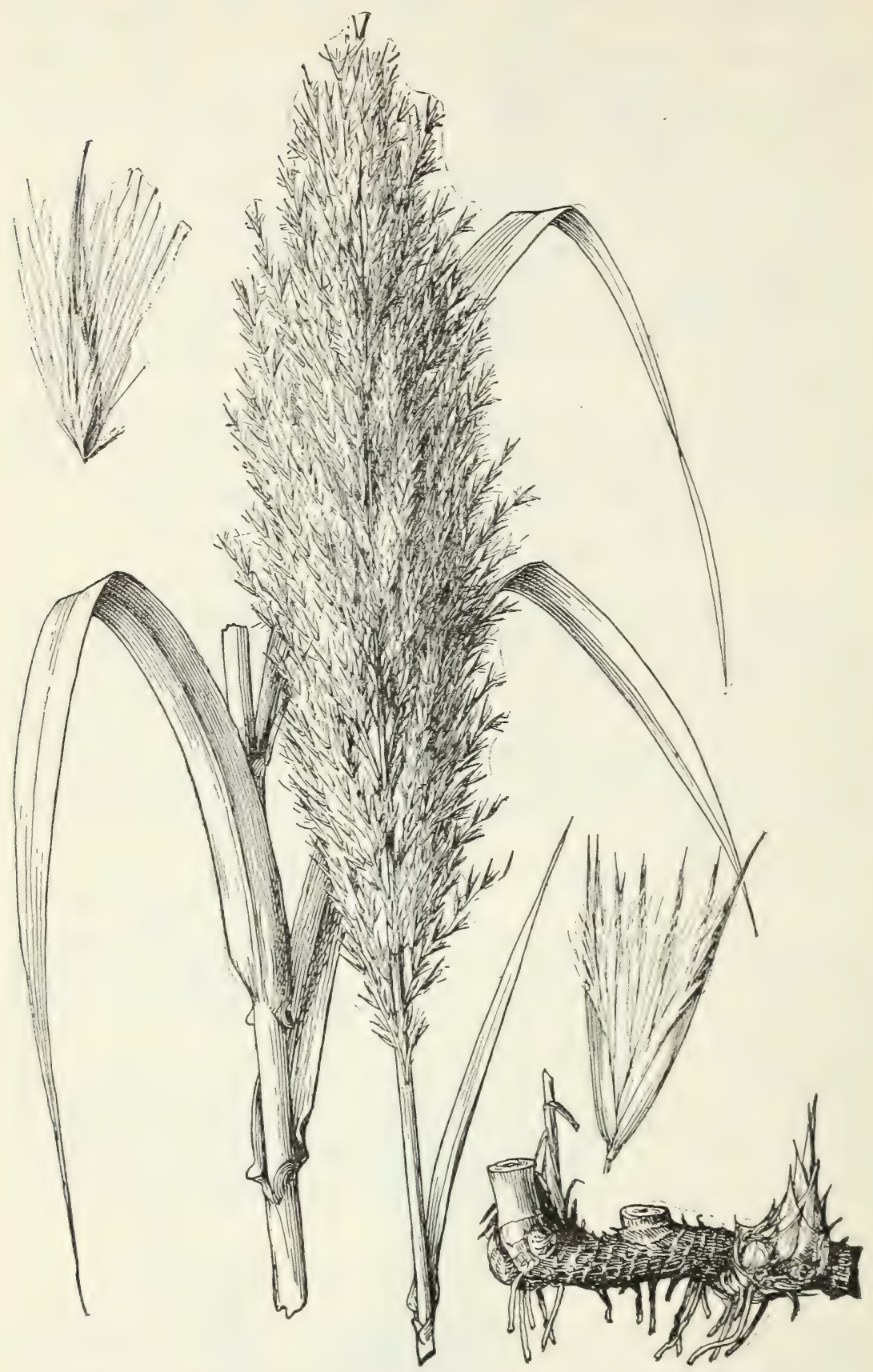

FigUrE 27.-Arundo donax. Plant, $\times$ 33: spikelet and floret, $\times 3$ (Biltmore Herb. 7514). 


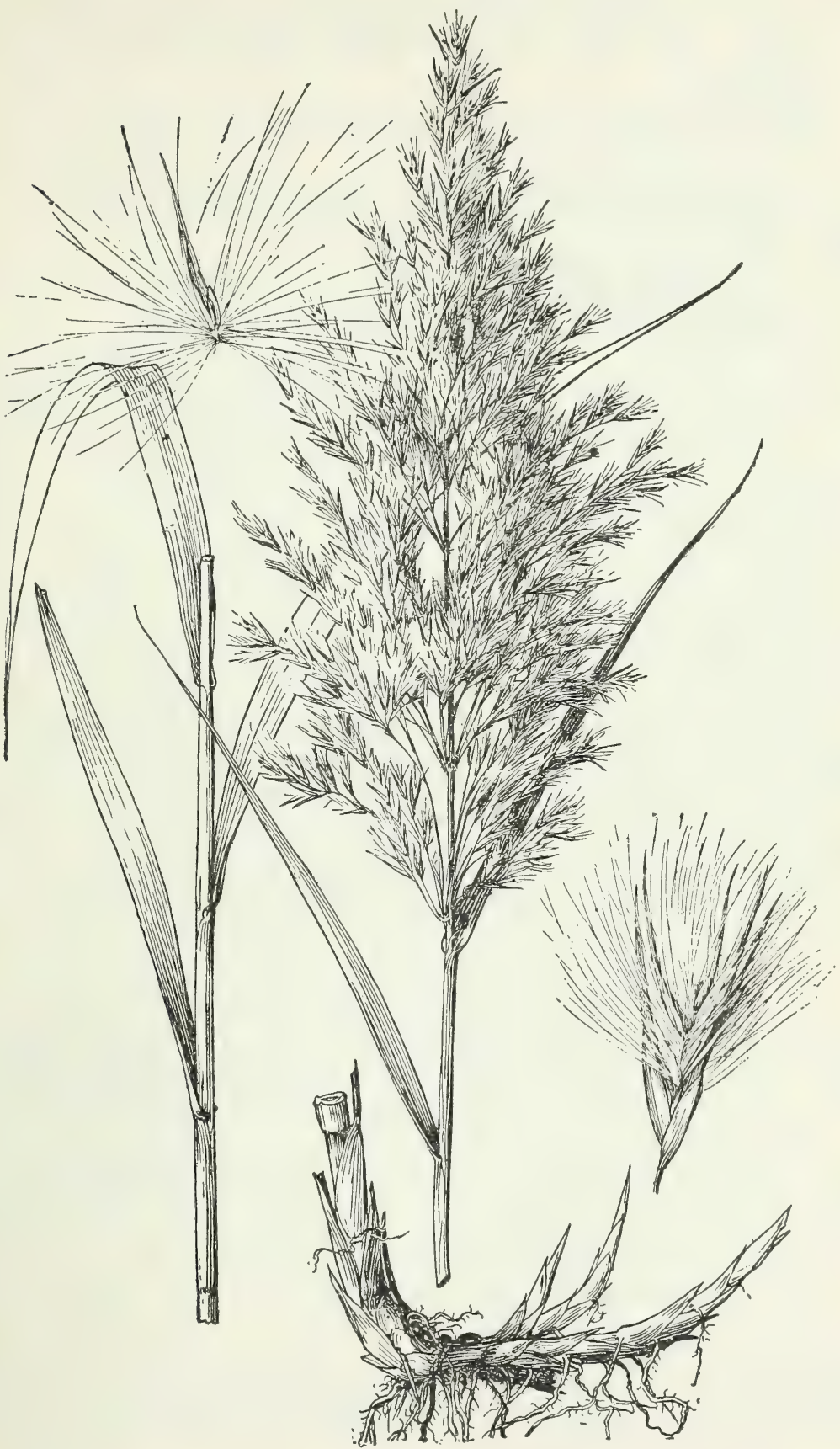

FiguRE 28.-Phragmites communis. Plant, $\times 1 / 3$; spikelet and floret, $\times 3$ (Hitcheock 5078). 
narrow, long-acuminate, glabrous, 3-nerved, the florets successively smaller, the summits of all about equal; palea much shorter than the lemma. Perennial reeds, with broad, flat linear blades and large terminal panicles.

1. Phragmites communis Trin., Fund. Agrost. 134. 1820.

Common ReEd.

Arundo phragmites L., Sp. Pl. 81. 1753. Europe.

Arundo occidentalis Sieber; Schult., Mant. 2: 289. 1824. Martinique, Sieber 31.

Phragmites martinicensis Trin.; Steud., Nom. Bot. ed. 2, 2: 324. 1841. Martinique, Sieber 31.

Phragmites phragmites Karst., Deutsch. Fl. 379. 1880.

Culms erect, 2 to $4 \mathrm{~m}$ tall, with stout creeping rhizomes and often also with stolons; blades flat, 1 to $5 \mathrm{~cm}$ wide; panicle tawny, 15 to 40 $\mathrm{cm}$ long, the branches ascending, rather densely flowered; spikelets 12 to $15 \mathrm{~mm}$ long, the florets exceeded by the hairs of the rachilla (fig. 28).

Swamps throughout the temperate regions of the world, extending into the Tropics. Called sometimes "wild cane."

Bahamas: New Providence, Brace 3901. Watlings Island, Geogr. Soc. Baltimore 521.

Jamaica: Ferry River, Maxon 2187; Harris 11576. Black River, Hitchcock 9648. Cockpit River, Ridley 95.

Haiti: Port-au-Prince, Ekman H 5935. Roche à Bateau, Ekman H 298.

Dominican Republic: Santo Domingo, Rose 3798; Ekman H 11167. Cabral, Abbott 1998. Arroyo Leonor, Valeur 513. Without locality, Faris 98; Wright, Parry, and Brummel 619.

Puerto Rico: Herrera, Eggers 1195. Humacao, Eggers 712. Guanica, Heller 6289.

Leeward Islands: Guadeloupe, Duss 4035.

Windward Islands: Martinique, Duss 1283. St. Lucia, Box 189. Toвago: Hitchcock 10231.

\section{TRIODIA R. Br., Prodr. Fl. Nov. Holl. 1: 182.1810}

Spikelets several-flowered; glumes nearly equal in length; lemmas broad, rounded on the back, the apex from minutely emarginate or toothed to deeply and obtusely lobed, 3-nerved, the lateral nerves near the margins, the midnerve excurrent between the lobes as a minute point or as a short awn, the lateral nerves often excurrent as minute points, usually all the nerves pubescent below. Erect tufted perennials, rarely rhizomatous or stoloniferous, the blades usually flat, the inflorescence an open or contracted panicle.

1. Triodia eragrostoides Vasey and Scribn., Contrib. U. S. Natl. Herb. 1: 58. 1890. Texas.

Culms slender, 50 to $100 \mathrm{~cm}$ tall; panicle open, 10 to $30 \mathrm{~cm}$ long; spikelets on slender pedicels, 1 to $10 \mathrm{~mm}$ long, oblong, mostly 6 - to 10-flowered, scarcely $5 \mathrm{~mm}$ long; lemmas about $2 \mathrm{~mm}$ long, obtuse, 
obscurely pubescent along the midnerve on the lower half, the margins pubescent, the midnerve minutely excurrent (fig. 29).

Dry ground, rocks, and cliffs, Florida Keys, Cuba, Texas, and northern Mexico.

Cuba: Viñales, Sierra de la Guazasa, Ekman 16606.

21. STREPTOGYNE Beauv., Ess. Agrost. 80. pl. 16. f. 8. 1812

Spikelets several-flowered, subsessile in a long 1-sided raceme; glumes unequal, much shorter than the elongate terete callustipped florets; lemmas firm, tapering into a slender awn; palea about as long as the lemma;

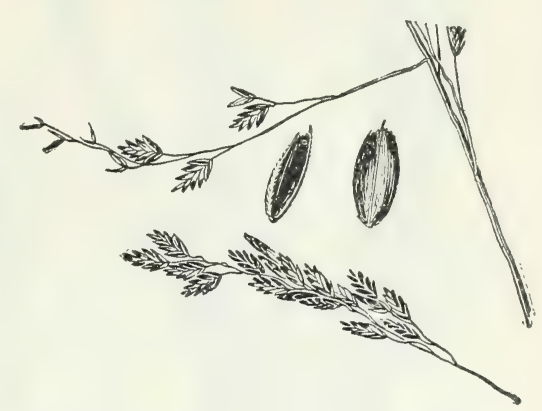

Figure 29.-Triodia eragrostoides. Panicle, $\times 1$; t.wo views of floret, $\times 5$ (Swallen 1471). stigmas 3, elongate, persistent, coiled, the mature fruits hanging by these entangled stigmas. Perennial with flat blades and slender erect raceme.

1. Streptogyne crinita Beauv., Ess. Agrost. 80. pl. 16. f. 8. 1812. Erect perennial, 1 to $1.5 \mathrm{~m}$ tall, with elongate leaves mostly aggregate at the base and reaching beyond the base of the inflorescence; blades 1 to $1.5 \mathrm{~cm}$ wide; raceme slender, 30 to $50 \mathrm{~cm}$ long, the axis rather firm, the short-pediceled slender spikelets appressed, about $3 \mathrm{~cm}$ long, excluding the slender awns and curled stigmas (fig. 30 ).

Rich woods, Veracruz and Trinidad to Brazil. "Carolina", the locality given with the original description, is an error. Beauvois also mentions Guiana.

Trinidad: Caparo Forest, Broadway 4932. Tabaquite, Hitchcock 10122. Without locality, Bot. Gard. Herb. 3367; Crueger.

22. ORTHOCLADA Beauv., Ess. Agrost. 69. pl. 14. f. 9.1812

Spikelets articulated below the glumes, 1-flowered with a prolongation of the rachilla, or 2-flowered, the florets distant; glumes and lemmas acuminate. A broad-leaved perennial with diffuse panicle.

1. Orthoclada laxa (L. Rich.) Beauv., Ess. Agrost. 70, 149, 168. 1812. Aira laxa L. Rich., Act. Soc. Hist. Nat. Paris 1: 106.1792. Cayenne.

Panicum rariflorum Lam., Encycl. 4: 746. 1798. Cayenne.

Orthoclada rariflora Beauv., Ess. Agrost. 70. pl. 14. f. 9. 1812.

Stoloniferous perennial; flowering culms ascending, leafy, simple, commonly $1 \mathrm{~m}$ long; blades slender-petioled, lanceolate, mostly 12 to $15 \mathrm{~cm}$ long, about $2.5 \mathrm{~cm}$ wide; panicle large, as broad as long, the long, slender, naked branches and capillary branchlets at first erect, finally stiffly divergent, bearing 1 to few spikelets at the extremities; glumes narrow, acute, 4 and $5 \mathrm{~mm}$ long; lemmas 6 to $7 \mathrm{~mm}$ long, acuminate or short-awned (fig. 31).

Rich woods, southern Mexico to Brazil; also in Guadeloupe and Trinidad. 


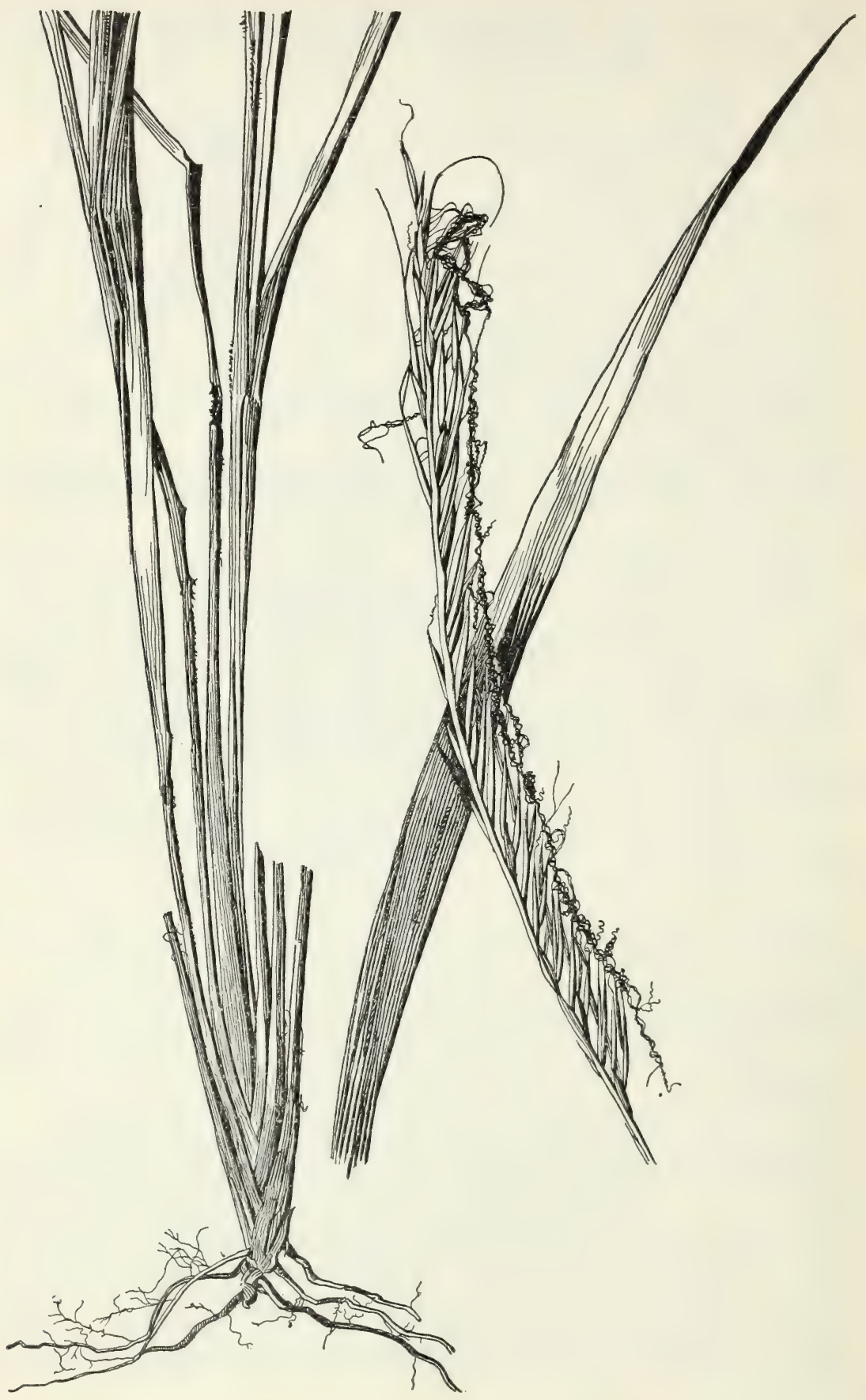

FiguRE 30.-Streptogyne crinita, $\times 1 / 2$ (Pittior 10602), 


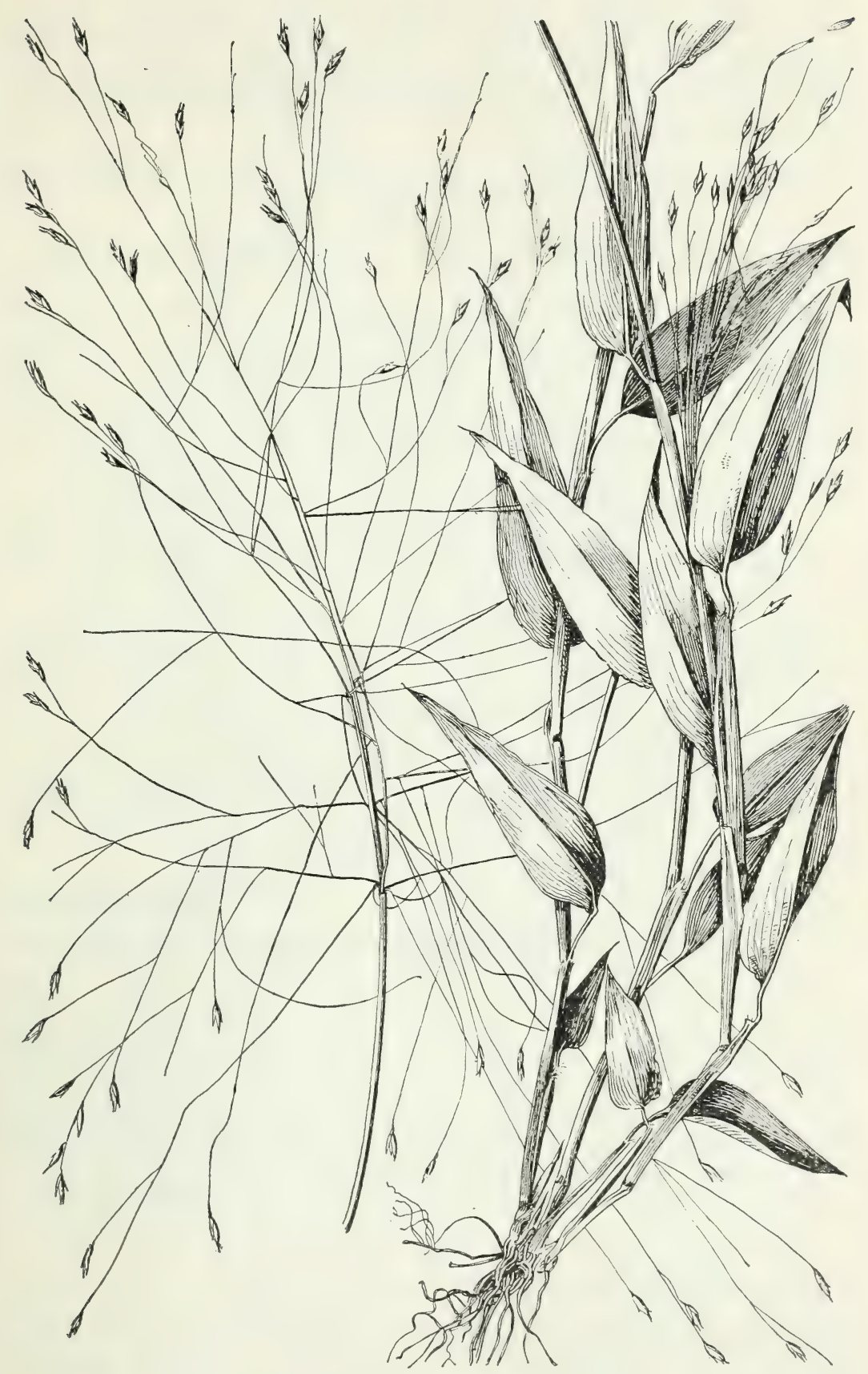

Figure 31.-Orthoclada lata, X 1/2 (Donnell Smith 8791, Tuerckheim II. 1036). 
Leeward Islands: Guadeloupe, Duss 3522.

Trinidad: Valencia, Eggers 1399; Broadway in 1926. Guiaco, Broadway 4954. Caparo Forest, Broadway 4927. Mount Tocuche, Britton, Hazen, and Mendelson 1365. Port-of-Spain, Hitchcock 9969 (Amer. Gr. Nat. Herb. 696). Tabaquite, Hitchcock 10128 (Amer. Gr. Nat. Herb. 697).

23. ZEUGITES P. Br., Civ. Nat. Hist. Jam. ed. 2, 341 and Index II. 1789

(Senites Adans., Fam. Pl. 2: 39, 604. 1763. No generic description.)

Spikelets few to several-flowered, the lowest floret perfect, the others staminate, the rachilla joint between the perfect and staminate florets elongate; glumes and fertile lemma herbaceous, broad, with transverse veins between the nerves, obtuse or truncate, the glumes about half as long as the lemma; sterile lemmas membranaceous, narrower, acute. Broad-leaved perennials, with terminal panicles.

Culms clambering; blades 2 to $4 \mathrm{~cm}$ long .............. Z. AMERICANA. Culms very slender, trailing, rooting at the nodes; blades 1 to $2 \mathrm{~cm}$ long.

2. Z. HAITIENSIS.

1. Zeugites americana Willd., Sp. Pl. 4: 204. 1805. Based on Apluda zeugites L.

Apluda zeugites L., Syst. Nat. ed. 10. 2: 1306. 1759. Jamaica.

Zeugites jamaicensis Raeuschel, Nom. Bot. ed. 3, 270. 1797. Name only. Jamaica.

Senites zeugites Nash; Hitchc., Contrib. U. S. Natl. Herb. 12: 127. 1908.

Loosely tufted branching glabrous clambering perennial 0.5 to $1 \mathrm{~m}$ tall; culms glossy brown or black, resembling fern stipes; blades on slender, often spreading petioles, ovate, 2.5 to $4 \mathrm{~cm}$ long; panicles mostly 5 to $7 \mathrm{~cm}$ long, loosely flowered, the branches and pedicels capillary; glumes and fertile lemma truncate (fig. 32).

Rich woods, above 1,000 m altitude. Blue Mountains, Jamaica, eastern Cuba and Hispaniola.

CubA: Sierra Maestra, Léon 11334; Bucher 61; Ekman 7071.

JamaICa: Cinchona, Perkins 1082; Harris 11418, 11431; Harris and Lawrence 15270; Maxon 1198; Hitchcock 9709. Gordon Town, Hart 789. Abbey Green, Hitchcock 9360 (Amer. Gr. Nat. Herb. 695); Harris 11584. Blue Mountain Peak, Nichols 115; Orcutt 2902. Catherines Peak, Hitchcock 9733; Eggers 3579. Sir Johns Peak, Harris 11596. Morces Gap Road, Harris 11327. Maccasucker Bump, Maxon 9593. Mossmans Peak, Maxon 9674. Sugar Loaf, Maxon 9972. New Haven Gap, Maxon 2673.

Haitr: Mission, Leonard 3863. Massif de la Selle, Ekman H 1282, H 1452 .

Dominican Republic: San José de Ocoa, Ekman H 12014.

2. Zeugites haitiensis (Pilger) Urban, Symb. Antill. 8: 51. 1920.

Zeugites americana subsp. haitiensis Pilger, in Urban, Symb. Antill. 6: 3. 1909. Haiti, Picarda 1523.

Senites haitiensis Hitchc, and Chase, Contrib. U. S. Natl. Herb. 18: 392. 1917. 


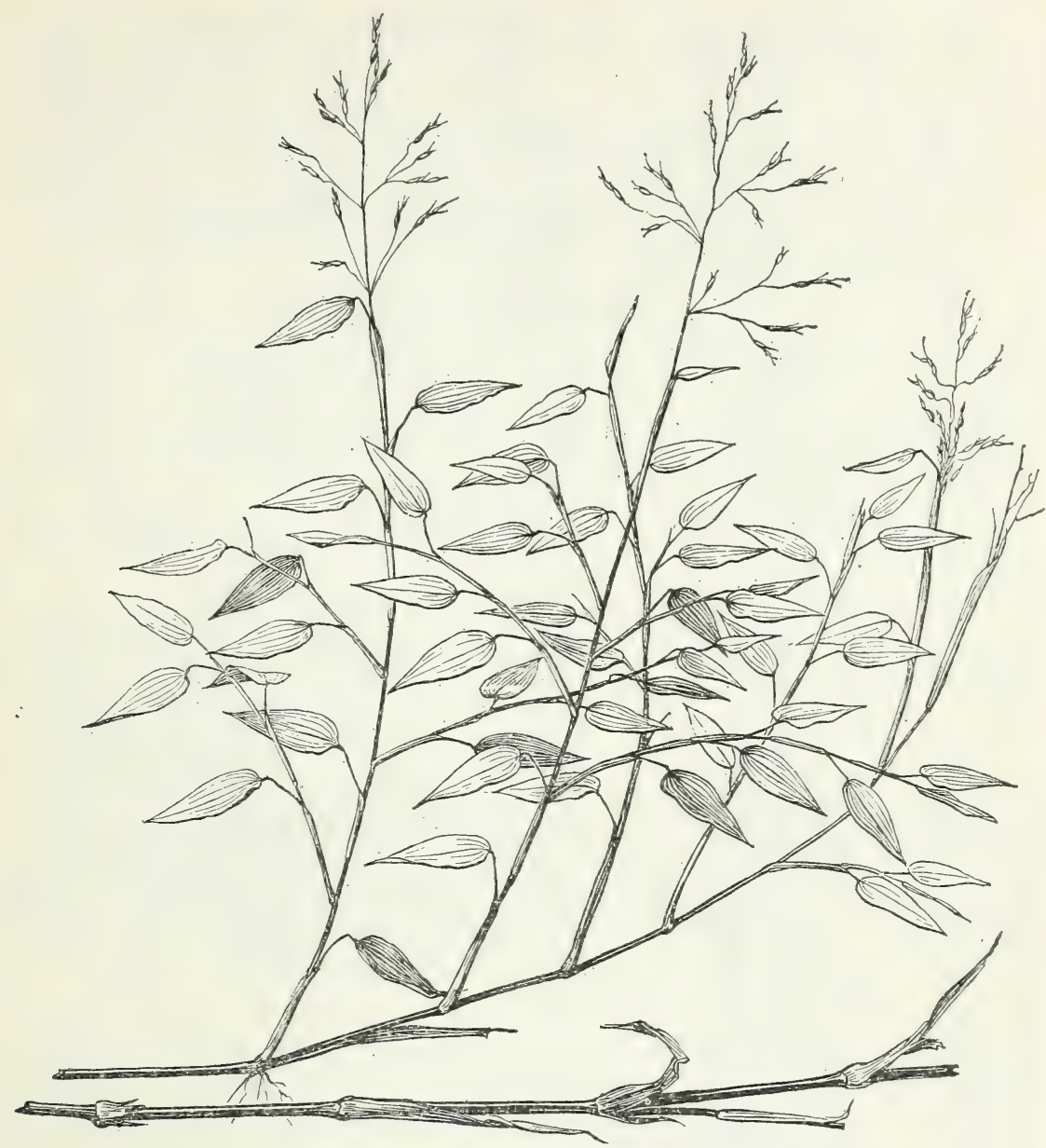

FIGURE 32.-Zeugites americana, $\times 1 / 2$ (Eitchcock 9709).

Culms very slender, trailing, rooting at the nodes; blades ovate, 1 to $2 \mathrm{~cm}$ long.

Rocky shaded places, Hispaniola.

Haits: Furcy, Picarda 1523. Ma Blanche, Ekman H 577. Morne la Visite, Ekman H 1650. Torbeek, Ekman H 5308. Petite Riviere de l'Artibonite Pérodin, Ekman H 3457.

Dominican Republic: Santiago, Ekman H 16325.

24. PAPPOPHORUM Schreb.; Vahl, Symb. Bot. 3: 10. 1794

Spikelets, 1- to 3-flowered, the upper sterile; glumes thin, subequal; lemma subindurate, dissolving at the summit into about 13 s!ender awns, the second and third florets reduced, closely appressed to the palea, the awns of all the florets together forming a pappuslike crown, falling attached to the fruit. Tufted perennials with narrow panicles. 


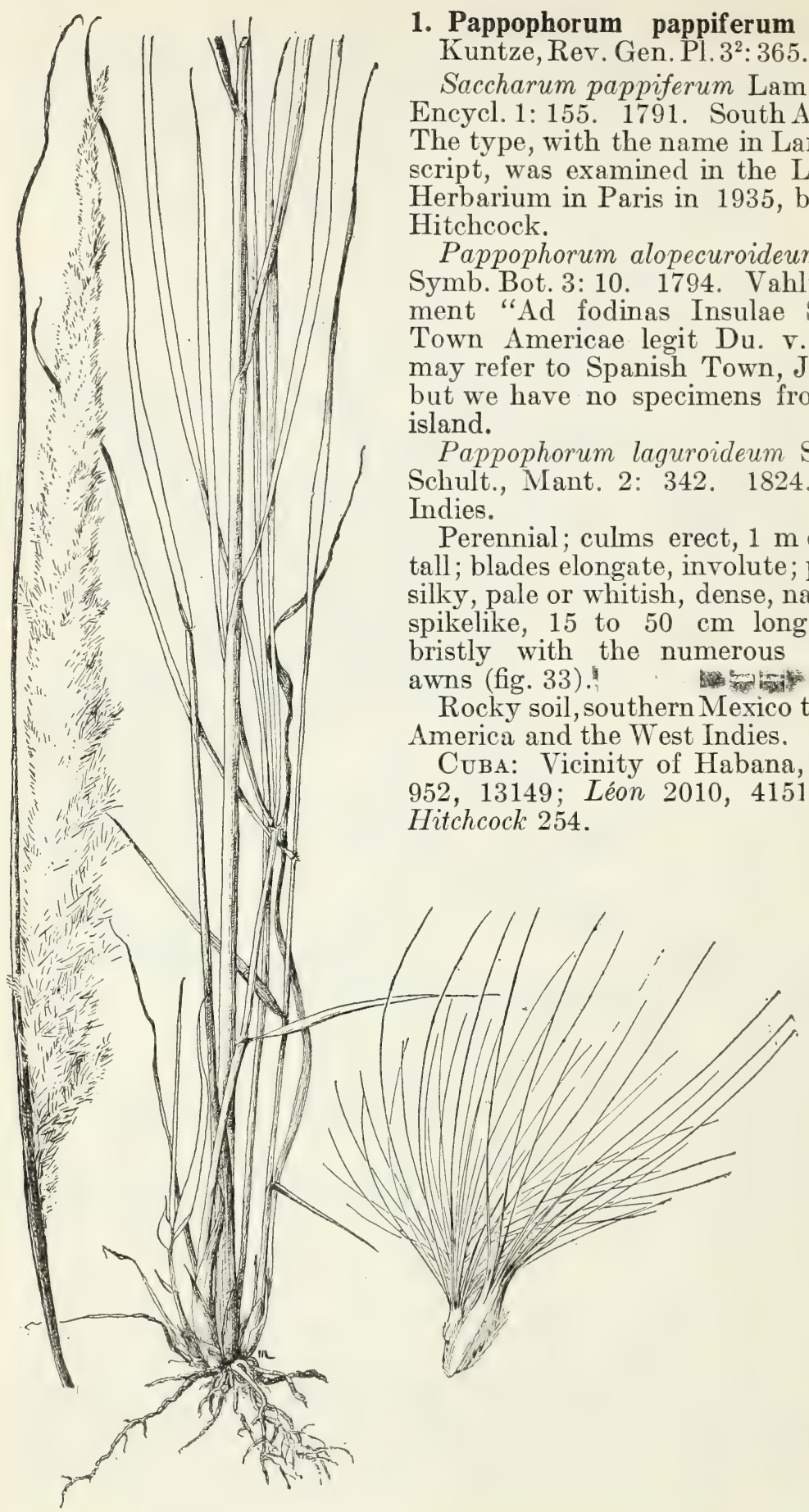

Figure 33.-Pappophorum pappiferum. Plant, $\times 1 / 2$; spikelet, $\times 10$ (Ekman 111 . 
Puerto Rico: Mona Island, Hess 444; Britton, Cowell, and Hess 1777. Desecheo, Hess 427, 1607. Punta Aguila, Britton, Cowell, and Brown 4689.

Virgin Islands: St. Thomas, Eggers in 1881, 1882.

Leeward Islands: Antigua, Box 69, 87, 106 . Guadeloupe, Duss 3164 .

Windward Islands: Martinique, Duss 1329.

Trinidad: Bot. Gard. Herb. 3310.

\section{TRIBE 3. HORDEAE}

\section{HORDEUM L., Sp. Pl. 84. 1753. BARLeY}

Spikelets 1-flowered, in clusters of 3 at each joint of an articulate rachis, the middle spikelet sessile, perfect, the lateral spikelets stipitate, reduced to the awnlike glumes; glumes and lemmas awned.

1. Hordeum pusillum Nutt., Gen. Pl. 1: 87. 1818. Missouri Valley. LiTTLE BARLEY.

Low, usually branched, annual with cylindric spikes 3 to $8 \mathrm{~cm}$ long, a part of the glumes dilated above the base.

Open dry ground, western United States, but introduced eastward and in Bermuda.

Bermuda: Brown 694.

Wheat (Triticum aestivum L.) and RYE (Secale cereale L.) are occasionally grown in the mountain regions and sometimes may be spontaneous but do not persist. Triticum spinulosum Lag. (Gen. et Sp. Nov. 7. 1816) described from Havana, collected by Balthazar Boldo, may belong to $T$. aestivum.

Pariana sylvestris Nees (Agrost. Bras. 295. 1829), a Brazilian species, is mentioned by Grisebach ${ }^{16}$ as having been found in St. Vincent by Guilding, "perhaps introduced."

\section{LOLIUM L., Sp. Pl. 83. 1753. RYegrass}

Spikelets several-flowered, solitary and sessile, placed edgewise to the continuous rachis, one edge fitting to the alternate concavities, the rachilla disarticulating above the glumes and between the florets; first glume wanting (except on the terminal spikelet), the second outward, strongly 3 - to 5-nerved, equaling or exceeding the second floret; lemmas rounded on the back, 5- to 7-nerved, obtuse, acute, or awned. Annuals or perennials, with flat blades and simple terminal flat spikes.

Glume longer than the spikelet; annual .................. L. TEMULENTUM. Glume shorter than the spikelet; perennial............ 2. L. MULTIFLORUM.

1. Lolium temulentum L., Sp. Pl. 83. 1753. Europe. Darnel. Lolium maximum Willd., Sp. Pl. 1: 462. 1797. Jamaica. Lolium temulentum var. leptochaeton A. Br., Flora 1: 252. 1834. Europe. 
Culms 60 to $90 \mathrm{~cm}$ tall; blades 3 to $6 \mathrm{~mm}$ wide; spike strict, 15 to $20 \mathrm{~cm}$ long; glume about $2.5 \mathrm{~cm}$ long. Our specimens are awnless, var. leptochaeton.

Introduced from Europe.

Cuba: Habana, Léon 1583, 5052.

2. Lolium multifiorum Lam., Fl. Franç. 3: 621. 1778. Europe.

ITALIAN RYEGRASS.

Lolium italicum A. Br., Flora 17: 241. 1834. Europe.

Culms 30 to $60 \mathrm{~cm}$ tall; blades 2 to $4 \mathrm{~mm}$ wide; spike often subfalcate, 15 to $25 \mathrm{~cm}$ long; spikelets 10 - to 20 -flowered; lemmas 7 to $8 \mathrm{~mm}$ long, at least the upper awned (fig. 34).

Introduced from Europe. Used for pasture in the United States, but not grown in the West Indies.

BERMUdA: Brown, Britton, and Bisset 2137.

JaMaICA: Gordon Town, Hart 739.

\section{TRIBE 4. AVENEAE}

\section{KOELERIA Pers., Syn. Pl. 1: 97. 1805}

Spikelets 2- to 4-flowered, compressed, the rachilla disarticulating above the glumes and between the florets, prolonged beyond the perfect florets as a slender bristle or bearing a reduced or sterile floret at the tip; glumes usually about equal in length but unequal in shape, the lower narrow and sometimes shorter, 1-nerved, the upper somewhat broader above the middle, wider than the lower, 3- to 5 -nerved; lemmas somewhat scarious and shining, the lowermost a little longer than the glume, obscurely 5-nerved, acute or shortawned, the awn, if present, borne just below the apex. Slender annuals or perennials with narrow blades and narrow dense panicles.

1. Koeleria phleoides (Vill.) Pers., Syn. Pl. 1: 97. 1805.

Festuca phleoides Vill., Fl. Delph. 7. 1785. Europe.

Annual; culms erect, 10 to $25 \mathrm{~cm}$ tall; sheaths and blades pilose, the blades flat, lax, 1 to $3 \mathrm{~mm}$ wide; panicles dense, spikelike, 1 to 4 $\mathrm{cm}$ long, 5 to $10 \mathrm{~mm}$ wide; glumes villous; lemmas glabrous, the lower about $3 \mathrm{~mm}$ long, the delicate awn 2 to $3 \mathrm{~mm}$ long.

Waste places, Bermuda. A native of Europe, introduced here and there in North America.

Bermuda: Brown 473, 600, 605, 617; Brown, Britton, and Bissett 1956.

\section{SPHENOPHOLIS Scribn., Rhodora 8: 142. 1906.}

\section{WEDGEGRASS}

Spikelets 2- or 3-flowered, the pedicel disarticulating below the glumes, the rachilla produced beyond the upper floret as a slender bristle; glumes unlike in shape, the first narrow, acute, 1-nerved, the second broadly obovate, 3 - to 5-nerved, somewhat coriaceous; lemmas firm, scarcely nerved, awnless, the first a little shorter or a little longer than the second glume. Slender perennials with flat blades and narrow panicles. 


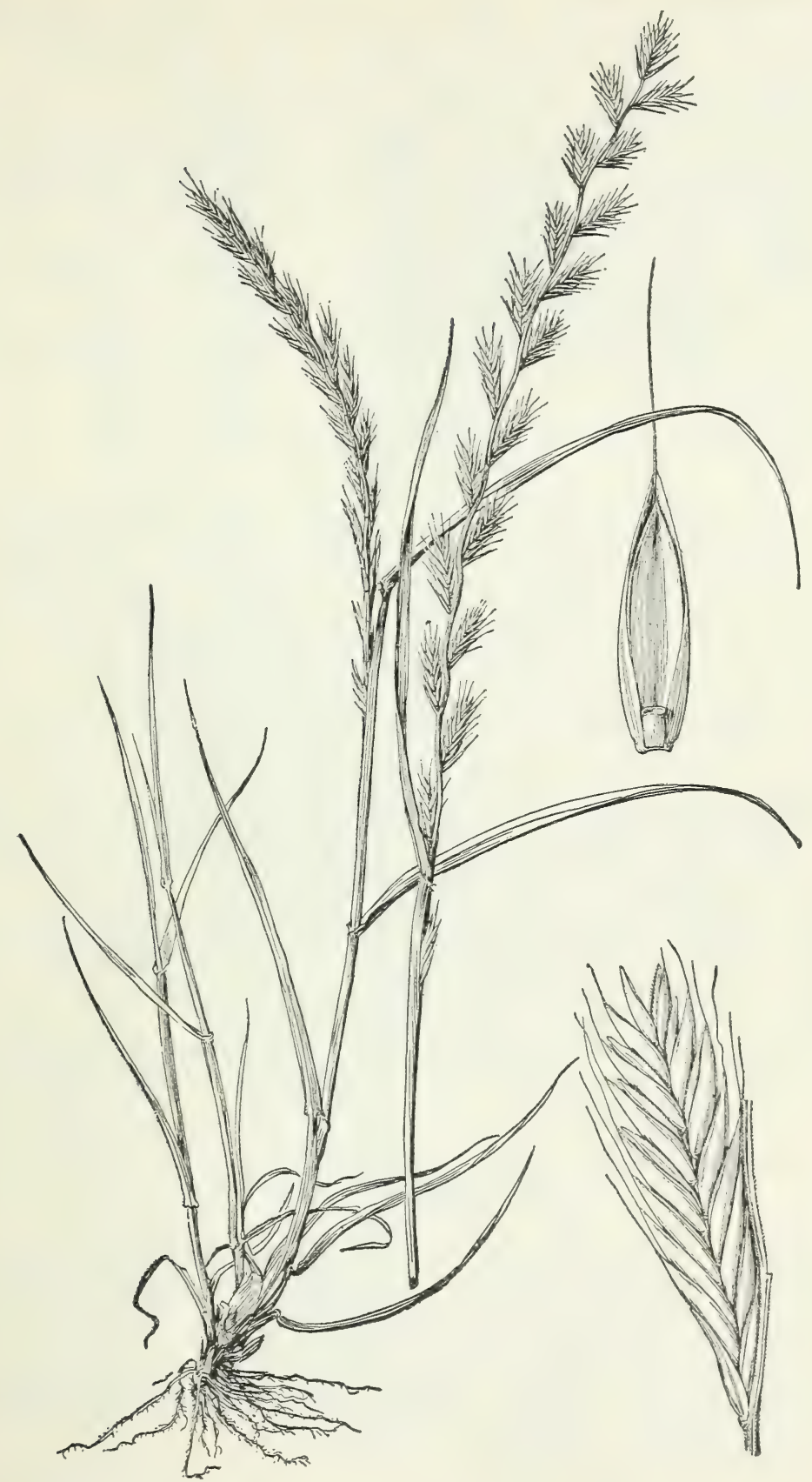

FIGURE 34.-Lolium multiflorum. Plant, $\times 1 / 2$; spikelet, $\times 3$; floret, $\times 5$ (Suksdorf 5142). $60256-36-5$ 
1. Sphenopholis obtusata (Michx.) Scribn., Rhodora 8: 144. 1906. Prairie wedgegrass.

Aira obtusata Michx., Fl. Bor. Amer. 1: 62. 1803. Florida.

Eatonia obtusata A. Gray, Man. ed. 2: 558. 1856.

Culms tufted, erect, 30 to $50 \mathrm{~cm}$ tall; blades flat, 1 to $5 \mathrm{~mm}$ wide; panicle narrow, contracted or spikelike, more or less lobed or interrupted, 3 to $8 \mathrm{~cm}$ long, pale or purplish; spikelets 2 to $3 \mathrm{~mm}$ long; glumes 2.3 to $2.5 \mathrm{~mm}$ long; lemmas scaberulous, about $2.5 \mathrm{~mm}$ long, the third, when present, reduced (fig. 35).

Pinelands and grassy plains, Hispaniola, at upper altitudes $(1,200$ to $2,300 \mathrm{~m}$ ); United States and Mexico.

Dominican Republic: Constanza, Tuerckheim 3319; Ekman H 13934. Valle Nuevo, Ekman H 13868. San José de Ocoa, Ekman H 12033 .

\section{TRISETUM Pers., Syn. Pl. 1: 97.1805}

Spikelets usually 2-flowered, sometimes 3- to 5-flowered, the rachilla prolonged behind the upper floret, usually villous; glumes somewhat unequal, acute, the second usually longer than the first floret; lemmas usually short-bearded at the base, 2-toothed at the apex, the teeth often awned, bearing from the back below the cleft apex a straight and included, or usually bent and exserted, awn. Tufted perennials with narrow blades and mostly dense panicles.

\section{Trisetum spicatum (L.) Richt., Pl. Eur. 1: 59. 1890.}

SPIKE TRISETUM.

Aira spicata L., Sp. Pl. 64. 1753. Lapland.

Culms tufted, erect, 30 to $70 \mathrm{~cm}$ tall; sheaths pubescent; blades flat, pubescent, mostly basal, 1 to $3 \mathrm{~mm}$ wide; panicle contracted, dense and spikelike or somewhat lobed or interrupted, 5 to $8 \mathrm{~cm}$ long; spikelets 5 to $7 \mathrm{~mm}$ long (fig. 36).

Open ground and pineland, at high altitudes, Hispaniola; Arctic regions of the Northern Hemisphere, extending south in the mountains to the Southern Hemisphere.

Haiti: Grand-Gosier, Ekman H 6867.

Dominican Republic: Sierra de los Comisarios, Ekman H 6803. Valle Nuevo, Eggers 2227, 2228; Tuerckheim 3133. San José de Ocoa, Ekman H 11714.

30. DESCHAMPSIA Beauv., Ess. Agrost. 91. pl. 18. f. 3. 1812. Hairgrass

Spikelets, 2-flowered, disarticulating above the glumes, the hairy rachilla prolonged behind the upper floret as a stipe, this sometimes bearing a reduced floret; glumes about equal, acute or acutish, membranaceous; lemmas thin, truncate and 2- to 4-toothed at the summit, bearing a slender awn from or below the middle, the awn straight, bent, or twisted. Slender annuals or perennials with shining spikelets in narrow or open panicles. 


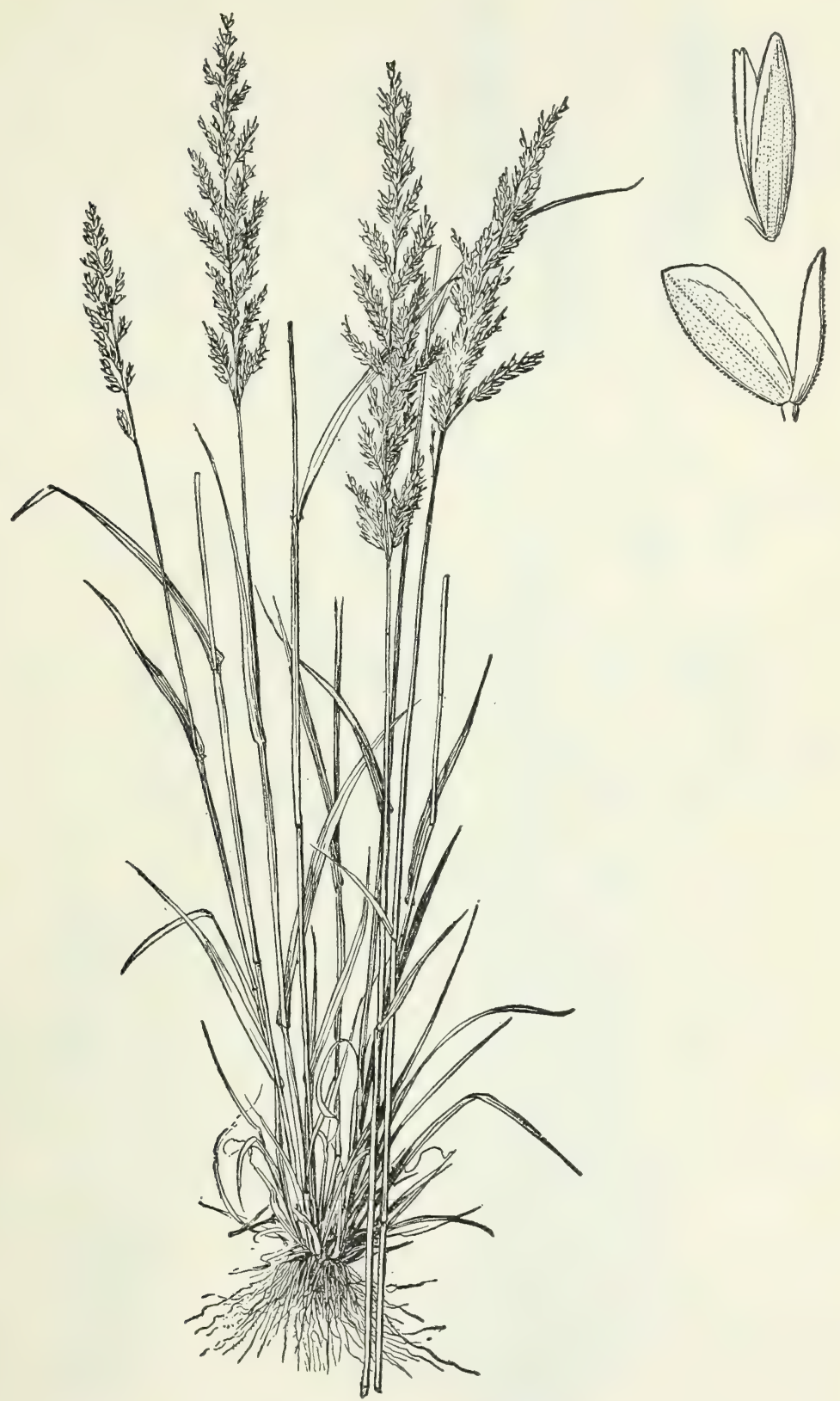

Figure 35.-Sphenopholis obtusata. Plant, $\times \frac{1}{2}$; glumes and floret, $\times 10$ (Hitchcock 1453). 


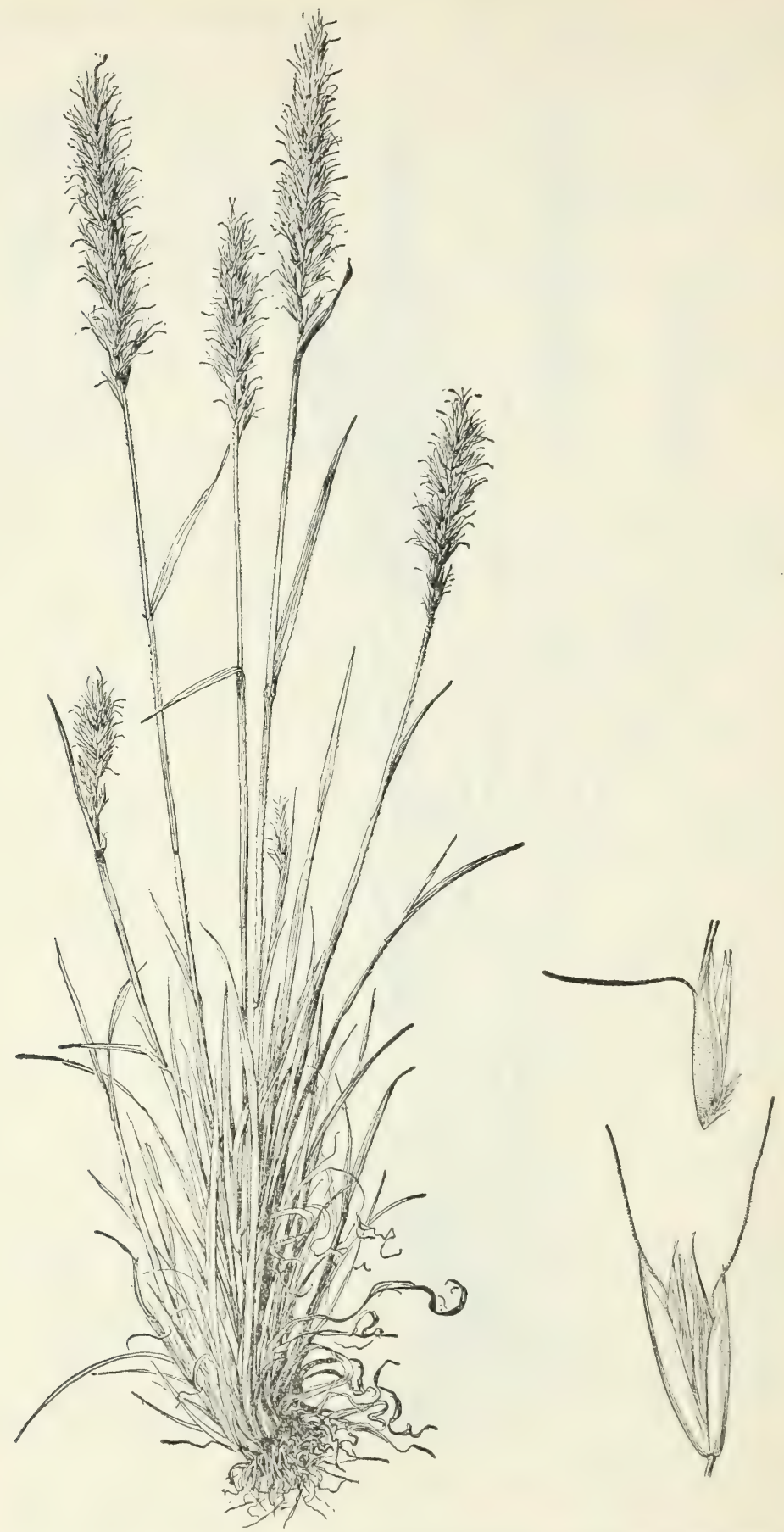

FIGURE 36. -T Tisetum s7 icatum. Plant, $\times \frac{1}{2} 2$; spikelet and foret, $\times 5$ (R J dberg and Besser 3593 ). 
1. Deschampsia domingensis Hitchc. and Ekman, sp. nor. ${ }^{17}$

Culms tufted, erect, 60 to $90 \mathrm{~cm}$ tall, from slender creeping rhizomes; sheaths glabrous, pale, somewhat paperr; ligule membranaceous, acuminate, $8 \mathrm{~nm}$ long; shorter on the innorations; blades folded or involute, glabrous, elongate, laxly upright, flexuous, mostly less than $1 \mathrm{~mm}$ wide when folded; panicle open, 10 to $20 \mathrm{~cm}$ long; the branches capillarr, flexuous, scabrous, spreading, usually naked for half their length or more, the lower as much as $10 \mathrm{~cm}$ or more long; spikelets on capillary pedicels, somewhat agoregate toward the ends of the branchlets; callus hairs 0.5 to $2 \mathrm{~mm}$ long, rather scant, the rachilla pilose; glumes 5 to 6 nim long; lemmas 2.5 to $4 \mathrm{~mm}$ long, thin, 4-toothed at summit, the teeth acuminate, the 2 outer $0.5 \mathrm{~mm}$ long; awn from near the base of the lemma, geniculate, the straight segment abore the bend about $5 \mathrm{~mm}$ long; palea as long: as the lemma (fig. 37).

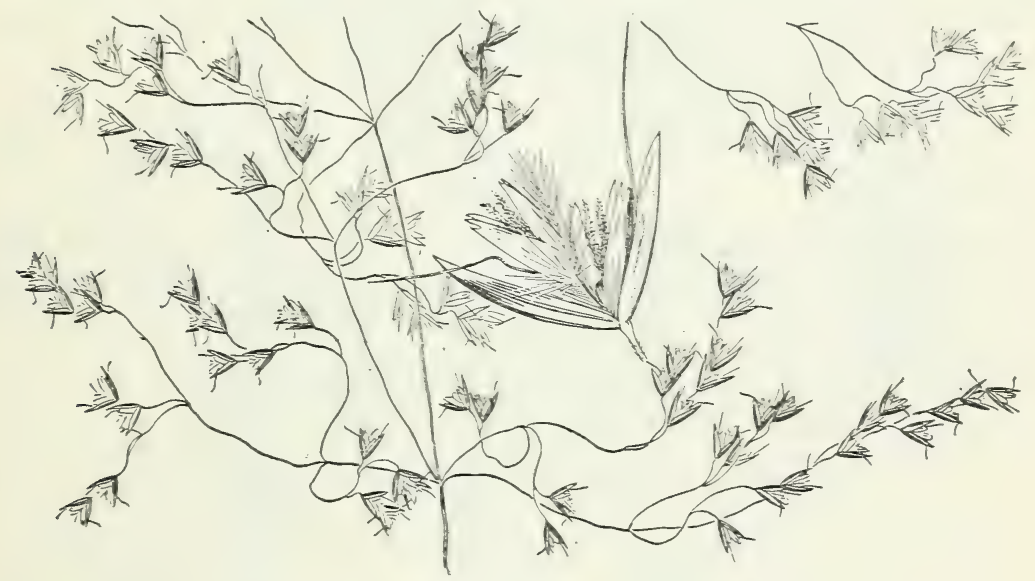

FIGURE 37. -Deschampsia domingensis. Portion of panicle, $\times 1$; spikelet, $\times 5$ (type).

Type in the United States National Herbarium, no. 1502064, collected in moist pinelands, in Los Tallecitos del Yaque, pror. Azua, Cordillera Central, Dominican Republic, altitude about $2,500 \mathrm{~m}$, October 2, 1929, by E. L. Ekman (no. H 13633b).

This species in habit resembles $D$. caespitosa (L.) Beaur., but differs in the slender rhizomes, the flexuous panicle branches, the insertion of the bent exserted awn at the base of the lemma, and in other details.

Dominican Republic: Los Tallecitos del Taque, Ekman H 13633a, H 13633b. Valle Nuevo, altitude $2,400 \mathrm{~m}$, on rocks at a brook, Ekman $\mathrm{H} 13747$. Sabana Alta, altituce $2,935 \mathrm{~m}$, moist pine forest, Ekman H 13802. San Juan, Lomas de la Medianía, altitude 2,500 $\mathrm{m}$, at the headwaters of a brook, "common abore 2,500 m", Ekman H 13554 .

1: Culmi caespitosi erecti $60-90 \mathrm{~cm}$ alti, e rhizomatibus gracilibus: lizula $8 \mathrm{~mm}$ longa: laminae intolutae graciles elongatae flexuosae circa $0.5 \mathrm{~mm}$ crisse: panicula paiens 11 -2.) cm longa. ramis carillaribus flexuosis scabris patentibus infra nuđis: glumae $5-6 \mathrm{~mm}$ longae; lemniata $2.5-4$ mim long:a. pauium supra basin arisiam geniculatum emittens, aristae parte recta cirea $5 \mathrm{~mm}$ longa. 


\section{AVENA I., Sp. Pl. 79. 1753}

Spikelets 2 to several-fiowered, the rachilla bearded, disarticulating above the glumes and between the florets; glumes about equal, membranaceous or papery, several-nerved, longer than the lower floret, usually exceeding the upper floret; lemmas indurate, except toward the summit, 5- to 9-nerved, bidentate at the apex, bearing a dorsal bent and twisted awn (this straight and reduced in Avena sativa). Annuals with open panicles of large spikelets.

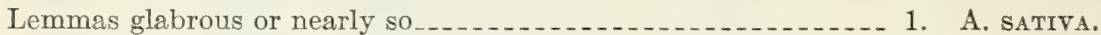
Lemmas pubescent with long brown hairs ............. 2. A. FAtua.

1. Avera sativa L., Sp. Pl. 79. $1753 . \quad$ ОАт.

Culms rather stout, erect, 50 to $100 \mathrm{~cm}$ tall; blades flat, 5 to 10 $\mathrm{mm}$ wide; panicle 5 to $20 \mathrm{~cm}$ long or, in cultivated specimens, larger; spikelets mostly 2-flowered; glumes 2 to $3 \mathrm{~cm}$ long, striate-nerved; lemmas glabrous or nearly so, the awn often poorly developed.

Widely cultivated in temperate regions, often escaped but not persistent. Seldom grown in the West Indies.

Bermuda: Collins 335 .

Cuba: Habana, Léon 809.

Jamaica: Summit of Blue Mountain Peak, Hitchcock 9369. Gordon Town, Hart.

2. Avena fatua L., Sp. Pl. 80. 1753.

WILD OAT.

Differing from $A$. sativa chiefly in the long stiff brownish hairs on the florets and rachilla; awn stout, geniculate, twisted below, 3 to $4 \mathrm{~cm}$ long (fig. 38).

A weed in temperate regions, rare in the Tropics.

JAMAICA: Gordon Town, Hart 1493.

\section{HOLCUS L., Sp. Pl. 1047. $1753^{18}$}

(Notholcus Nash; Hitchc., in Jepson, Fl. Calif. 1: 126. 1912)

Spikelets 2-flowered, the pedicel disarticulating below the glumes, the rachilla curred and somewhat clongate below the first floret, not prolonged above the second floret; glumes about equal, longer than the two florets; first floret perfect, its lemma awnless; second floret staminate, its lemma awned on the back. Perennials with flat blades and contracted panicles.

1. Holcus lanatus L., Sp. Pl. 1048. 1753. Europe. Velvet Grass. Notholcus lanatus Nash; Hitche., in Jepson, Fl. Calif. 1: 126. 1912.

Perennial, 0.5 to $1 \mathrm{~m}$ tall, grayish-velvety throughout, the pale, rather densely flowered narrow panicle usually 8 to $10 \mathrm{~cm}$ long; glumes about $4 \mathrm{~mm}$ long; first floret $2 \mathrm{~mm}$ long, the second smaller, with a hooklike awn.

Pastures and waste places at upper altitudes. A native of Europe; introduced in America and occasionally cultivated as a meadow grass. Not grown in the West Indies.

JamaicA: Without locality, Hart 748.

Haitr: Furcy, Cook, Scofield, and Doyle 35.

18 See p. 407 , footnote 9, for discussion of the name Holcus. 


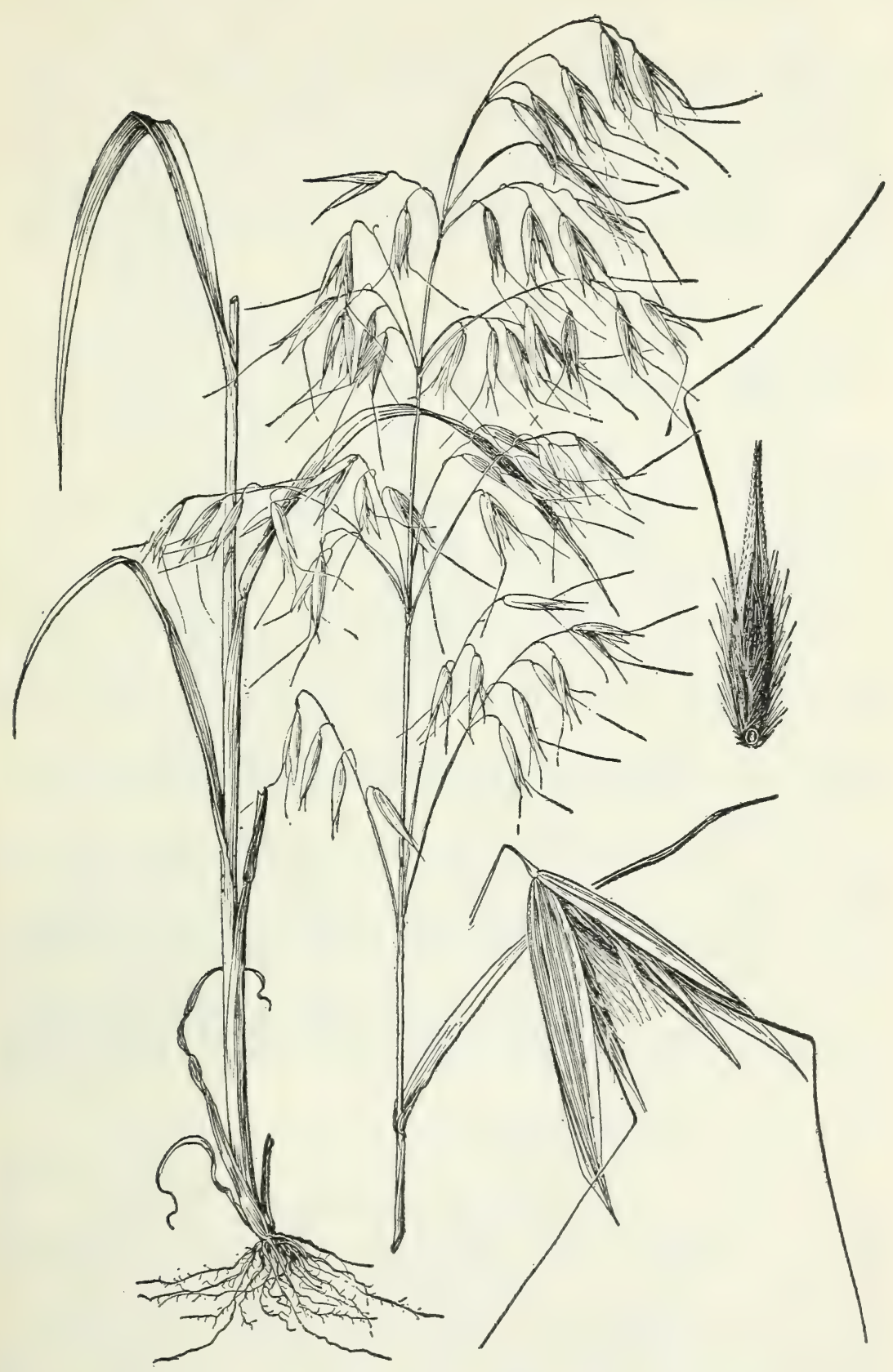

Figure 38.-Avena fatua. Plant, $\times \frac{1}{2}$; spikelet and floret, $\times 2$ (Umbach). 
33. DANTHONIA Lam. and DC., Fl. Franç. 3: 32. 1805. OAtgrass

Spikelets several-flowered, the rachilla readily disarticulating above the glumes and between the florets; glumes about equal, broad and papery, acute, mostly exceeding the uppermost floret; lemmas rounded on the back, obscurely several-nerved, the base with a strong callus, the apex bifid, the lobes acute, usually extending into slender awns, a stout awn arising from between the lobes; awn flat, tightly twisted below, geniculate, exserted, including three nerves of the lemma. Tufted perennials with few-flowered panicles of rather large spikelets.

Glumes 6 to 12 , rarely to 15 , $\mathrm{mm}$ long; lower lemmas 5 to $6 \mathrm{~mm}$ long.

1. D. DOMINGENSIS.

Glumes 20 to $22 \mathrm{~mm}$ long; lower lemmas 8 to $9 \mathrm{~mm}$ long .. 2. D. овтоRтA.

1. Danthonia domingensis Hack. and Pilger, in Urban, Symb. Antill. 6: 1. July 15, 1909. Santo Domingo, Eggers 2227b.

Danthonia shrevei Britton; Nash, Torreya 9: 210. October 26, 1909. Jamaica, Shreve in 1906.

Culms erect, 30 to $60 \mathrm{~cm}$ tall, finally forming large dense tussocks raised above the general level of the soil; leaves aggregate at the base, the blades usually elongate and overtopping the panicles, from rather coarse to subfiliform, involute, scabrous toward the ends; panicle 10 to $15 \mathrm{~cm}$ long, rather open; spikelets 12 to $15 \mathrm{~mm}$ long, 3 to 6 -flowered; glumes 6 to $12 \mathrm{~mm}$ long, rarely longer; lemmas villous, 5 to $6 \mathrm{~mm}$ long; the awned lobes nearly as long, the main awn spreading, the terminal segment about $1 \mathrm{~cm}$ long; rachilla joints villous, noticeable between the florets (fig. 39, A).

On cleared slopes near the summit of Sir Johns Peak, altitude about 2,000 $\mathrm{m}$, the only known locality in Jamaica, and Hispaniola in the mountains, 1,800 to $2,700 \mathrm{~m}$.

JAmaica: Sir Johns Peak, Harris 10914, 11429 (Amer. Gr. Nat. Herb. 647), 11594, 11629 (Amer. Gr. Nat. Herb. 648); Hitchcock 9720; Shreve in 1906.

Haiti: High ridge of La Selle, 2,400 to 2,500 m, "common", Ekman H 3153. Roberjot, Ekman H 1424. Pétionville, Ekman H 5997. Marigot, Ekman H 10048.

Dominican Republic: Sierra de los Comisarios, Ekman H 6809. Constanza, Tuerckheim 3414. Loma Rosilla, Fuertes 1776. Valle Nuevo, Eggers 2227b. Monción, Ekman H 12830. Los Vallecitos del Yaque, Ekman H 13659.

\section{Danthonia obtorta Chase, sp. nov. ${ }^{19}$}

Habit similar to that of the preceding, the lower sheaths somewhat firmer; blades elongate, equaling or overtopping the panicle, involute, slender, narrower at base than the firm summit of the sheath, the lower part curved forward, bringing the upper surface downward; this surface pilose with fragile hairs, the blades otherwise glabrous and smooth; panicle 13 to $16 \mathrm{~cm}$ long, loose; spikelets 2 to $2.5 \mathrm{~cm}$ long, 7 - to 9-flowered, the slender villous rachilla joints strongly zigzag; glumes 2 to $2.2 \mathrm{~cm}$ long; lemmas villous on the lower half, 8 to $9 \mathrm{~mm}$ long (to the base of central awn) the awned lobes nearly

19 Perennis caespitosa; culmi erecti, 40-55 cm alti; laminae elongatae involutae, basi tortae pilosae; panicula 13-16 cm longa, sublaxa; spiculae magnae; glumae 2-2.2 cm longae; lemmata 8-9 mm longa, basi pilosa; arista 17-20 mm longa. 


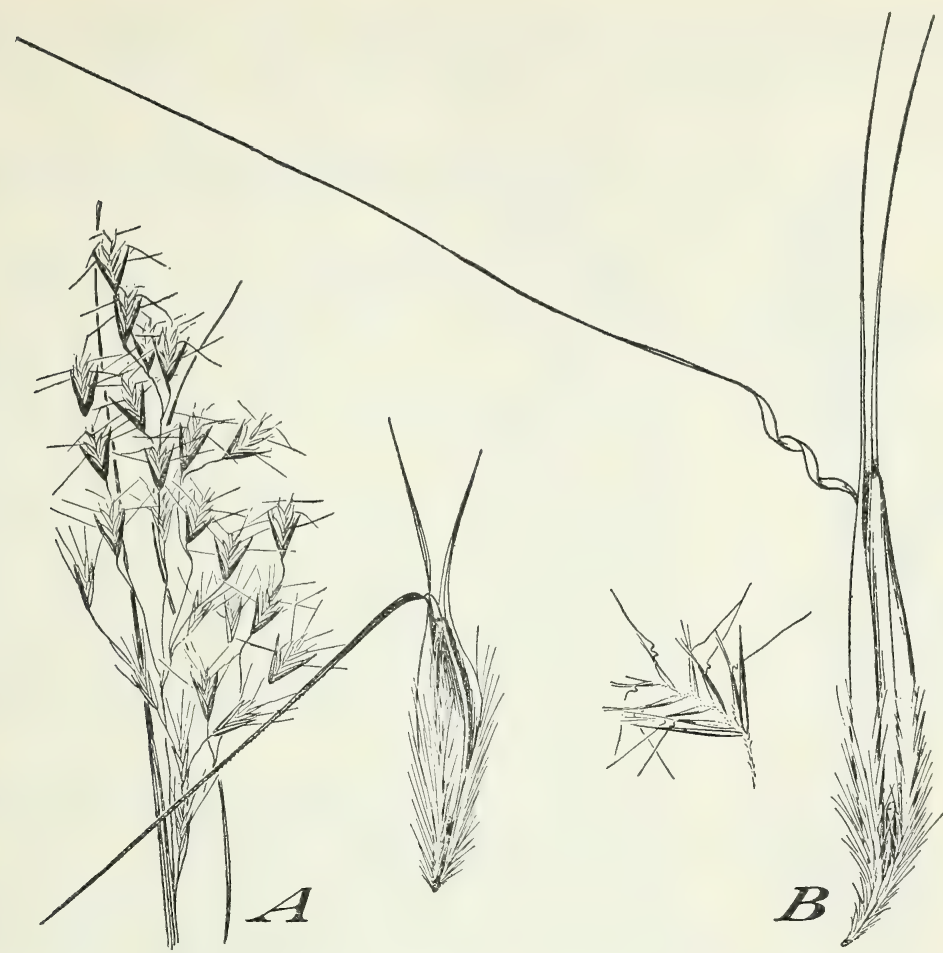

Figure 39.-A, Danthonia domingensis. Panicle, $\times 1 / 2$; floret, $\times 5$ (Ekman 12830). B, D. obtorta Spikelet, $\times 1$; floret, $\times 5$ (type).

as long, the main awn spreading, the terminal segment 15 to $17 \mathrm{~mm}$ long (fig. 39, $B$ ).

Closely related to Danthonia domingensis, but the spikelets much larger, the blades not widened at base, bent forward with a twist, a character found in some grasses of windswept areas, like high paramos. The specific name refers to this twisted base.

Type in the United States National Herbarium, no. 1385638, collected near the highest peak of Morne de la Selle, 2,700 m, Gauthier, Massif de la Selle, Haiti, February 1, 1925, by Erik L. Ekman (no. H 3164).

An immature specimen was collected at Valle Nंuevo, prov. La Vega, Dominican Republic, Ekman H 13748.

\section{TRIBE 5. AGROSTIDEAE}

34. CALAMAgROSTIS Adans.; Roth, Tent. Fl. Germ. 1:33. 1788. ReEDGRASS

Spikelets 1-flowered, the rachilla disarticulating above the glumes, usually prolonged behind the palea as a short, commonly hairy bristle; glumes about equal, acute or acuminate; lemma shorter and usually more delicate than the glumes, the callus bearing a tuft of hairs which are often copious and as long as the lemma, awned from the back, 
usually below the middle, the awn delicate and straight, or stouter and exserted, bent and sometimes twisted; palea shorter than the lemma. Slender perennials with small spikelets in open or narrow panicles.

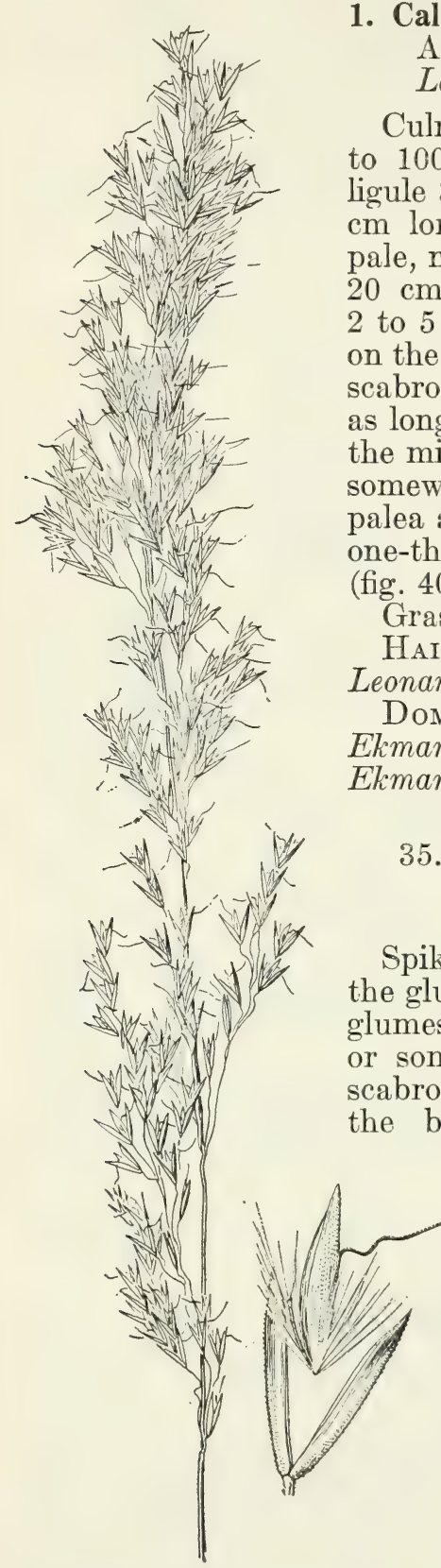

Figure 40.-Calamagrostis leonardii. Panicle, $\times 1$; spikelet, $\times 5$ (type).
1. Calamagrostis leonardii Chase, Jour. Wash. Acad. Sci. 17: 72. f. 1. 1927. Haiti, Leonard 4325.

Culms ascending from a geniculate base, 60 to $100 \mathrm{~cm}$ tall, producing slender rhizomes; ligule 3 to $4 \mathrm{~mm}$ long; blades lax, flat, 6 to 20 $\mathrm{cm}$ long, 2 to $5 \mathrm{~mm}$ wide, scabrous; panicle pale, nodding, narrow but rather loose, 12 to $20 \mathrm{~cm}$ long, the slender branches ascending, 2 to $5 \mathrm{~cm}$ long; glumes $4.5 \mathrm{~mm}$ long, scabrous on the back and keel; lemma about $4 \mathrm{~mm}$ long, scabrous, the callus hairs copious, about half as long as the lemma; awn from a little above the middle of the lemma, slender, divergent; somewhat flexuous at base, 4 to $5 \mathrm{~mm}$ long; palea about $3.5 \mathrm{~mm}$ long; rachilla joint about one-third the length of the lemma, long-pilose (fig. 40).

Grassy places, 1,300 to $2,100 \mathrm{~m}$, Hispaniola.

Haitr: Pétionville, Ekman H 1113. Furcy, eonard 4325, 4370.

Dominican Republic: San José de Ocoa, Ekman H 11949. Sierra de los Comisarios, Ekman H 6812. Valle Nuevo, Ekman H 13809.

\section{AGROSTIS L., Sp. Pl. 61. 1753. Bentgrass}

Spikelets, 1-flowered, disarticulating above he glumes, the rachilla usually not prolonged; glumes equal or nearly so, acute, acuminate, or sometimes awn-pointed, carinate, usually scabrous on the keel, and sometimes on the back; lemma obtuse, usually shorter and thinner in texture than the glumes, awnless or dorsally awned, often hairy on the callus; palea usually shorter than the lemma, 2-nerved in only a few species, usually small and nerveless or obsolete. Mostly perennials, the small spikelets in open or narrow panicles.

Palea present.

Panicle contracted, somewhat lobed, the branches floriferous nearly to base; glumes scabrous on back and keels.

1. A. verticillata.

Panicle open, the branches naked at base; glumes scabrous only on keels.

2. A. ALBA. 
Palea wanting.

Culms $60 \mathrm{~cm}$ tall, leafy, spikelets about $2 \mathrm{~mm}$ long

Culms 15 to $40 \mathrm{~cm}$ tall; the leaves mostly near the base; spikelets 2.5 to $3 \mathrm{~mm}$

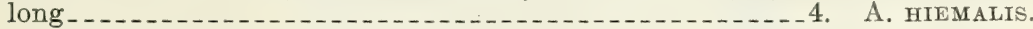

1. Agrostis verticillata Vill., Prosp. Pl. Dauph. 16. 1779. Europe. Culms decumbent or spreading, 20 to $40 \mathrm{~cm}$ or even as much as $1 \mathrm{~m}$ long; blades flat; panicles dense, more or less interrupted or lobed, 5 to $10 \mathrm{~cm}$, or sometimes $15 \mathrm{~cm}$, long; spikelets about $2 \mathrm{~mm}$ long; the glumes scabrous; lemma and palea about $1 \mathrm{~mm}$ long.

Ditches and moist places, Jamaica; a native of the Mediterranean region; widely introduced in warm temperate regions from southern United States to Argentina.

JAMAICA: Road to Strawberry Hill, Blue Mountains (altitude 1,300 m), Harris 12895.

2. Agrostis alba L., Sp. Pl. 63. 1753. Europe.

REDTOP.

Culms erect or ascending from a decumbent or more or less creeping base, 30 to $60 \mathrm{~cm}$ tall, or even taller; blades flat, 1 to $5 \mathrm{~mm}$ wide; panicles open but rather narrow, mostly 10 to $15 \mathrm{~cm}$ long, manyflowered, the lower branches spreading, verticillate; spikelets 2 to $2.5 \mathrm{~mm}$ long; glumes glabrous except the keels; palea about half as long as the lemma (fig. 41).

The West Indian specimens are mostly fine-leaved, with decumbent or creeping culms.

Open ground and moist places at upper altitudes in Jamaica and Hispaniola; a native of Europe; widely cultivated in temperate regions and introduced at high altitudes in the Tropics. Not grown in the West Indies.

JAMAICA: Blue Mountain Peak, Harris 12664, 12666; Hitchcock 9368. Yallahes River course, Harris 12492. Morces Gap, Harris 12894. North slope of Catherines Peak, Hitchcock 9735 (sterile). Gordon Town, Hart 927.

Haiti: Furcy (altitude 1,300 m), Leonard 4516.

3. Agrostis canina L., Sp. Pl. 62. 1753. Europe.

Velvet Bent.

Culms decumbent, about $60 \mathrm{~cm}$ tall; blades flat; panicle somewhat open, 5 to $15 \mathrm{~cm}$ long; spikelets $2 \mathrm{~mm}$ long; lemma awned, the awn geniculate, about $3 \mathrm{~mm}$ long.

Grassy summit of Blue Mountain Peak; native of Europe; occasional in pastures and lawns in the United States, and sometimes used there on golf greens. Not grown in the West Indies.

Jamaica: Blue Mountain Peak, Harris 12667.

The single specimen cited above is not representative. The tall culms are leafy and the panicle contracted and somewhat distorted as if diseased.

4. Agrostis hiemalis (Walt.) B. S. P., Prel. Cat. N. Y. 68. 1888.

TICKLE GRASS.

Cornucopiae hyemalis Walt., Fl. Carol. 73. 1788. South Carolina. Agrostis scabra Willd., Sp. Pl. 1:370. 1797. North America.

Culms tufted, erect or somewhat spreading at base, 15 to $40 \mathrm{~cm}$ tall; sheaths scaberulous; ligule membranaceous, thin, oblong, erose, $3 \mathrm{~mm}$ long; blades flat or, especially on the innovations, involute, scabrous, 3 to $10 \mathrm{~cm}$ long, 0.5 to $2 \mathrm{~mm}$ wide; panicles pale or purple, open, 5 to $15 \mathrm{~cm}$ long, pyramidal to oblong-pyramidal, the branches very scabrous, ascending or spreading, capillary, naked below for more 

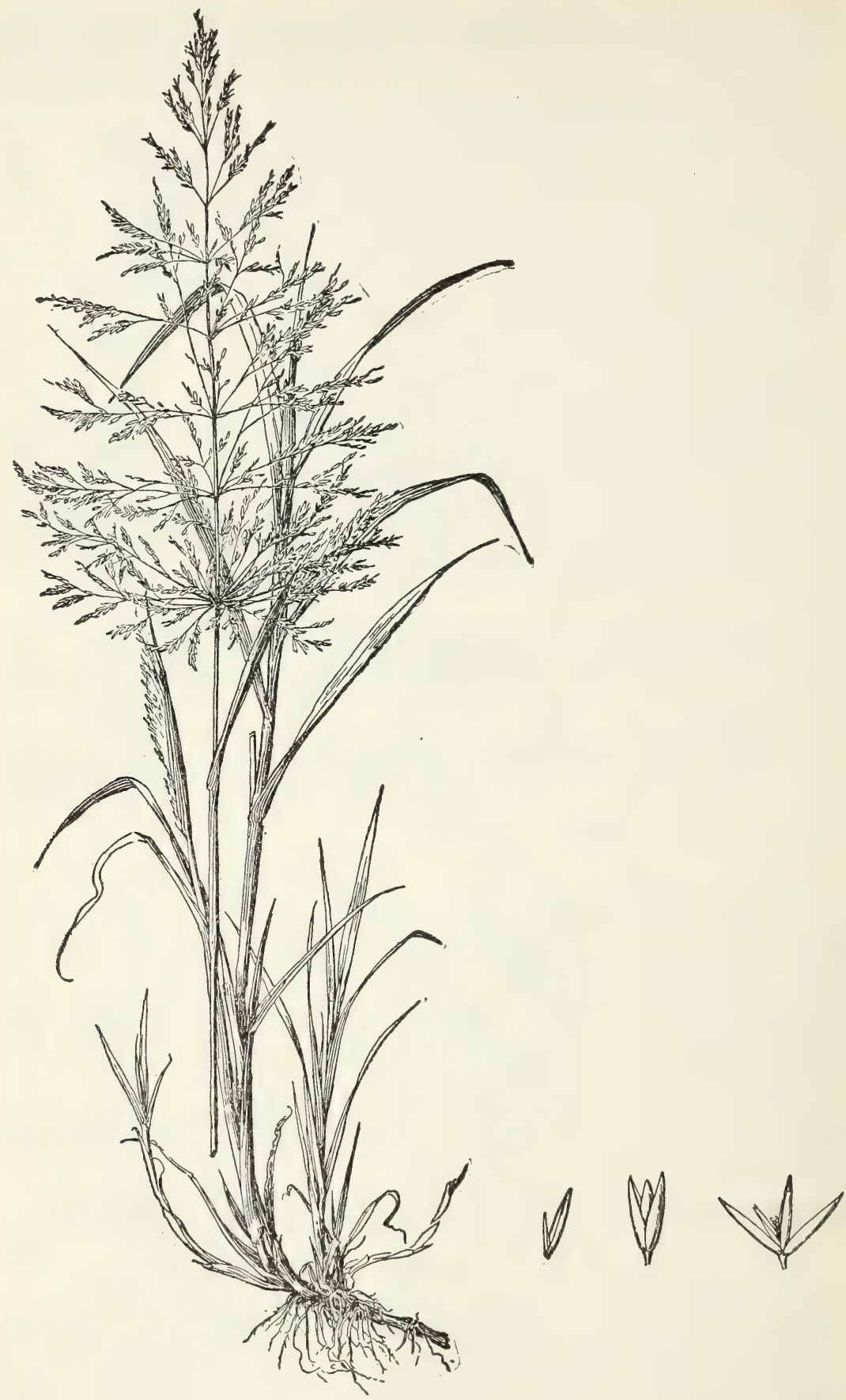

Figure 41.-Agrostis alba. Plant, $\times 1 / 2 ; 2$ spikelets and floret, $\times 5$ (Chase 5191 ). 
than half their length, the branchlets also naked below, the lower branches in verticils; spikelets somewhat approximate on the branchlets, slender-pediceled; glumes acute, glabrous except the scabrous keels, the first about 2.5 to $3 \mathrm{~mm}$ long, the second a little shorter; lemma obtuse, about $2 \mathrm{~mm}$ long, minutely pilose at base, awned or awnless, the awn when present attached above the middle, curved or bent but not twisted or distinctly geniculate, exserted about $1 \mathrm{~mm}$; palea wanting; anthers 0.4 to $0.5 \mathrm{~mm}$.

Pine woods and open ground, Hispaniola in the mountains, 1,000 to $2,500 \mathrm{~m}$ altitude.

Haitr: Pétionville, Ekman H 1115, H 10088. Croix-des-Bouquets, Ekman H 7693. Mérion, Ekman H 3181. Furcy, Leonard 4318, 4593.

Dominican Republic: Constanza, Tuerckheim 3227, 3413, 3558; Ekman H 14095. Loma Rosilla, Fuertes 1783. Valle Nuevo, Ekman H 13857. Top of Pelona $(3,150 \mathrm{~m})$, Ekman H 13648. Los Vallecitos del Yaque, Ekman H 13638. San José de Ocoa, Elıman H 11686.

This form of $A$. hiemalis approaches the mountain form found in the White Mountains of New Hampshire and in other mountains of the eastern part of the United States. It differs in being usually more lax and spreading. The mountain form ${ }^{20}$ referred to has been called Trichodium montanum Torr., Agrostis oreophila Trin., A. laxiflora var. montana Tuckerm., and A. torreyi Tuckerm. The spikelets are awned or awnless.

The West Indian specimens are rather diverse among themselves but no more so than specimens in the United States. Ekman's no. 11686 is $60 \mathrm{~cm}$ tall, leafy, rather lax, the blades $3 \mathrm{~mm}$ wide, while Ekman H 13857 is $10 \mathrm{~cm}$ tall, the blades about $0.5 \mathrm{~mm}$ wide. Dr. Ekman wrote "there is but one species in Santo Domingo of this group", that is, the diverse specimens all belong to one species. The following specimens cited above are awned, the others awnless; Ekman H 1115, H 3181, H 7693, H 10088; Leonard 4318, 4593; Tuerckheim 3227,3557 .

\section{POLYPOGON Desf., Fl. Atlant. 1: 66.1798}

Spikelets, 1-flowered, the pedicel disarticulating a short distance below the glumes, leaving a short-pointed callus attached; glumes equal, entire or 2-lobed, awned from the tip or from between the lobes, the awn slender, straight; lemma much shorter than the glumes, hyaline, usually bearing a slender straight awn shorter than the awns of the glumes. Annuals or perennials with flat blades and dense bristly panicles.

Plants annual; panicle dense and silky _.............. P. MonspeLiensis. Plants perennial; panicle lobed or interrupted, not silky _._. 2. P. LUTosus.

\section{Polypogon monspeliensis (L.) Desf., Fl. Atlant. 1: 67. 1798.}

RABBITFOOT GRASS.

Alopecurus monspeliensis L., Sp. Pl. 61. 1753. Europe.

Annual; culms 10 to $30 \mathrm{~cm}$ tall; blades flat, 2 to $4 \mathrm{~mm}$ wide, the sheaths inflated; panicles dense, 2 to $6 \mathrm{~cm}$ long, about $1 \mathrm{~cm}$ thick, silky with numerous awns; spikelets about $1.5 \mathrm{~mm}$ long, the awns about $5 \mathrm{~mm}$ long (fig. 42).

${ }^{20}$ For a further discussion of this form see North American Species of Agrostis, U. S. Dept. Agr., Bur. Plant Indus. Bull. 68: 43 . 1905. 


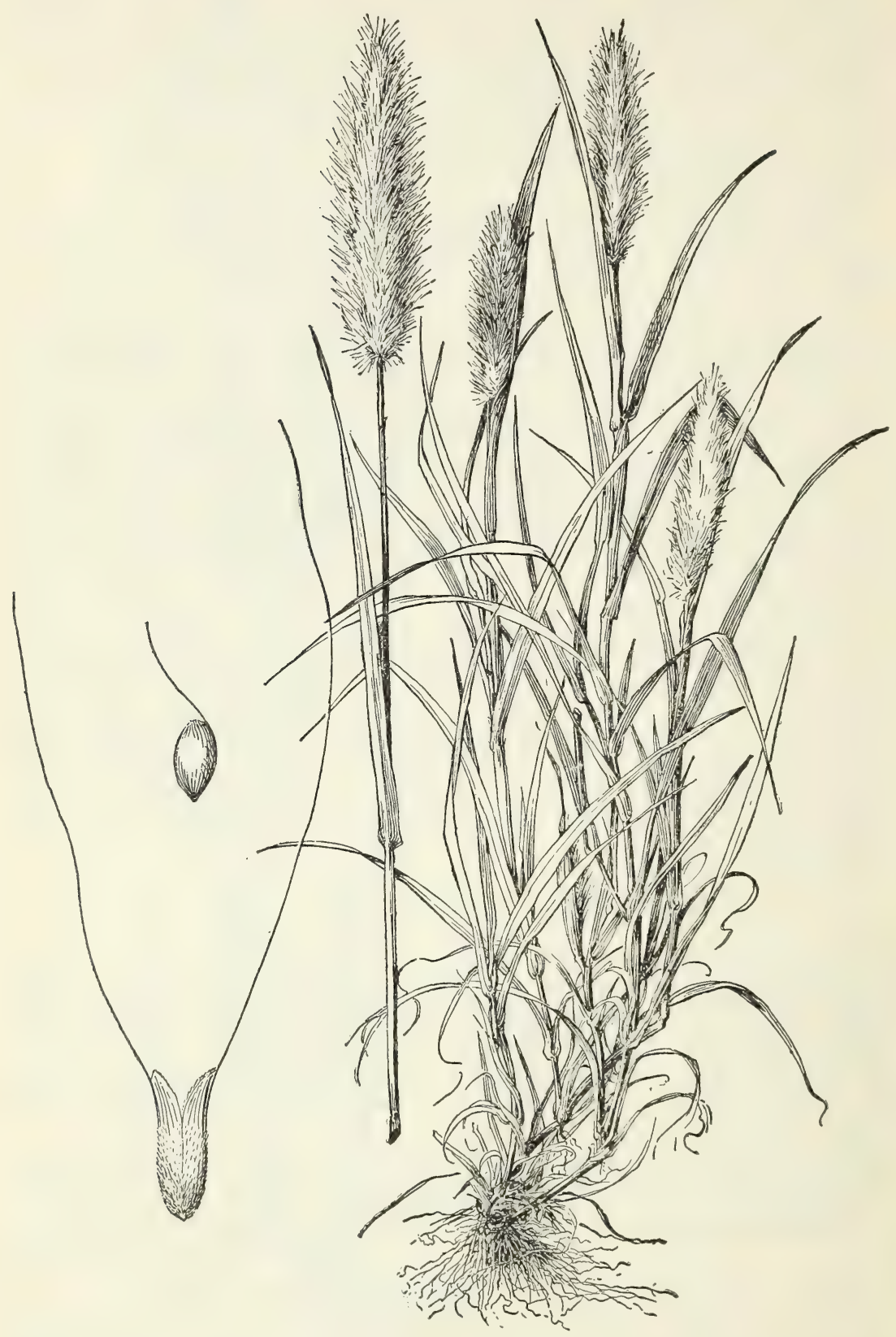

FIGURE 42.-Polypogon monspeliensis. Plant, $\times 1 \frac{1}{2}$; glumes and floret, $\mathbb{1} \times \_10$ (Chase 5584). 
Roadsides and waste places, Bermuda; native of the Old World, widely introduced in America.

Bermuda: Harshberger in 1905; Brown 714.

2. Polypogon lutosus (Poir.) Hitchc., U. S. Dept. Agr. Bull. 772: 138. 1920.

DitCH POLYPOGON.

Agrostis littoralis With., Bot. Arr. Veg. Brit. ed. 3. 2: 129. pl. 23. 1796. Not A. littoralis Lam., 1791. England.

Polypogon littoralis J. E. Smith, Comp. Fl. Brit. 13. 1800.

Agrostis lutosa Poir., in Lam., Encycl. Sup. 1: 249. 1810. Europe.

Perennial; culms geniculate at base, 30 to 80 cm tall; blades flat; panicle oblong, 5 to 15 $\mathrm{cm}$ long, more or less interrupted or lobed; spikelets about $2 \mathrm{~mm}$ long, the awns 2 to $3 \mathrm{~mm}$ long (fig. 43).

Ditches and waste places, Bermuda; native of Europe, widely introduced in the warmer parts of America.

Bermuda: Brown 698; Collins 138.

\section{PHLEUM L., Sp. Pl. 59. 1753}

Spikelets 1-flowered, laterally compressed, disarticulating above the glumes; glumes equal, membranaceous, keeled, abruptly mucronate or awned; lemma shorter than the glumes, hyaline, broadly truncate, 3- to 5-nerved; palea narrow, nearly as long as the lemma. Annuals or perennials, with erect culms, flat blades, and dense, cylindric panicles.

1. Phleum pratense L., Sp. Pl. 59. 1753. Europe.

Тімотну.

Culms tufted, erect, 50 to $100 \mathrm{~cm}$ tall; blades flat, 3 to $5 \mathrm{~mm}$ wide; panicle cylindric, dense, spikelike, mostly 5 to $10 \mathrm{~cm}$ long; spikelets 2 to $3 \mathrm{~mm}$ long (fig. 44 ).

Commonly cultivated as a meadow grass in temperate regions, but not grown in the West Indies. Established on the summit of Blue Mountain Peak around the rest house.

Jamaica: Blue Mountain Peak, Harris 12665; Hitchcock 9374.

38. MUHLENBERGIA Schreb.; Gmel., Syst. Nat. 2: 171. 1791

Spikelets 1-flowered, the rachilla disarticulating above the glumes; glumes usually shorter than the lemma, obtuse to acuminate or awned, the first sometimes small, rarely obsolete; lemma firmmembranaceous, 3- to 5- nerved, with a very short, usually minutely pilose callus, the apex acute, extending into a straight or flexuous awn, or sometimes only mucronate. Species of the West Indies perennial.

Panicle diffuse; blades involute, elongate ................ 1. M. CAPILLARIs. Panicle narrow, the branches appressed or ascending; blades flat, mostly less than $10 \mathrm{~cm}$ long .............................. MARVIGLUMIS. 


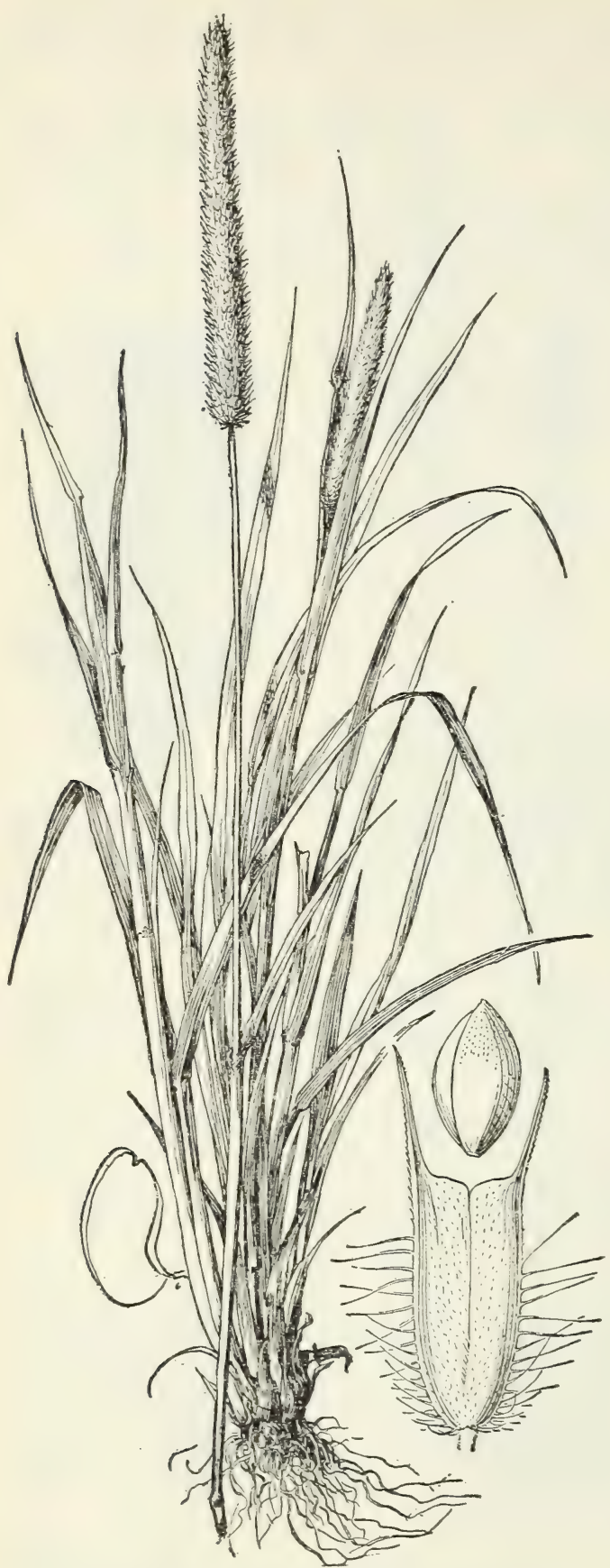

Figtre 44.-Phleum pratense. Plant, $\times 1 / 2$ glumes and floret, $\times 10$ (Mearns 2209).
1. Muhlenbergia capillaris (Lam.) Trin., Gram. Unifl. 191. 1824.

Stipa capillaris Lam., Tabl. Encycl. 1: 158. 1791. Carolina.

Culms tufted, slender, erect, 40 to $70 \mathrm{~cm}$ tall; blades inrolute, elongate, slender or almost capillary, numerous, commonly overtopping the panicle; panicle large, diffuse, purplish; the numerous branches capillary; spikelets narrow, $3 \mathrm{~mm}$ long; glumes acute, about $1 \mathrm{~mm}$ long, equal or nearly so; awn of lemma capillary, somewhat flexuous, 5 to $8 \mathrm{~mm}$ long (fig. 45).

Savannas and rocky soil, eastern United States and Mexico, and the northern West Indies.

BaHamas: Andros Island, Small and Carter 8794. New Providence, Britton and Brace 403.

Cuba: $\mathrm{R}$ e m at e s, Ekman 11186. Laguna Jovero, Shafer 11043. La Coloma, Roig and Chrysler 3293. Guanimar, Wright 3836 . Habana, Léon 2011. Batabanó, Léon 5756. Cayo Cruz, Shafer 2795. Isla de Pinos, Ekman 11631.

Puerto Rico: Arecibo, Chase 6557.

2. Muhlenbergia parviglumis Vasey, Contrib. U.S. Natl. Herb. 3: 71. 1892. Texas, Nealley.

Culms rather loosely tufted, erect or spreading and leaning, about $30 \mathrm{~cm}$ tall; blades flat, spread- 


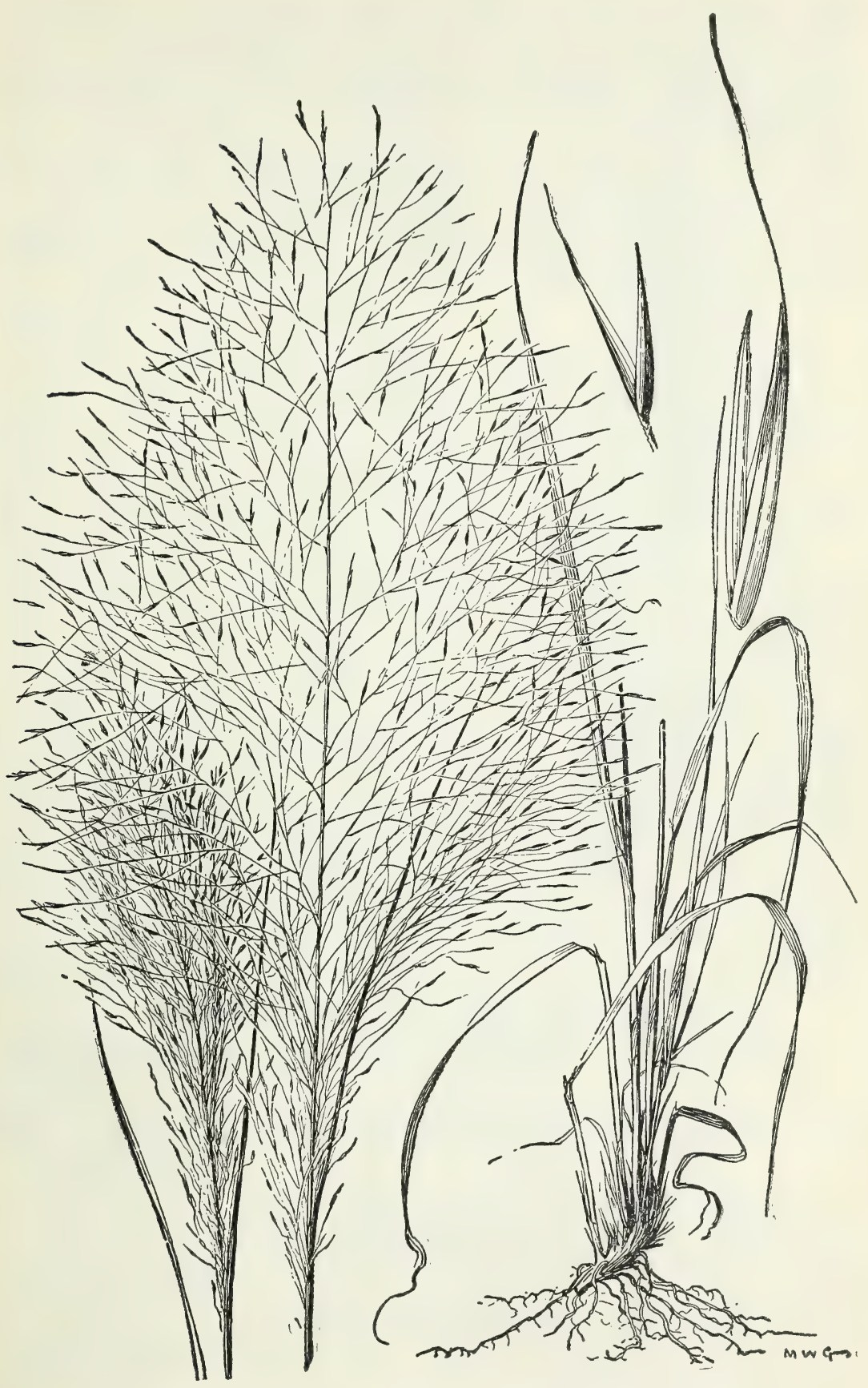

FIGURE 45.-Muhlenbergia capillaris. Plant, $\times \frac{1}{2}$; glumes and floret, $\times 10$ (Scribner). $60256-36-6$ 
ing, minutely scabrous, long-acuminate, 5 to $10 \mathrm{~cm}$ long, 1 to $2 \mathrm{~mm}$ wide; panicles narrow, 5 to $10 \mathrm{~cm}$ long, the branches appressed or ascending; glumes less than $0.5 \mathrm{~mm}$ long, somewhat unequal, obtuse or acutish; lemma narrow, scaberulous toward the narrowed minutely bifid tip, about $2 \mathrm{~mm}$ long; awn capillary, somewhat flexuous, about $1.5 \mathrm{~cm}$ long (fig. 46).

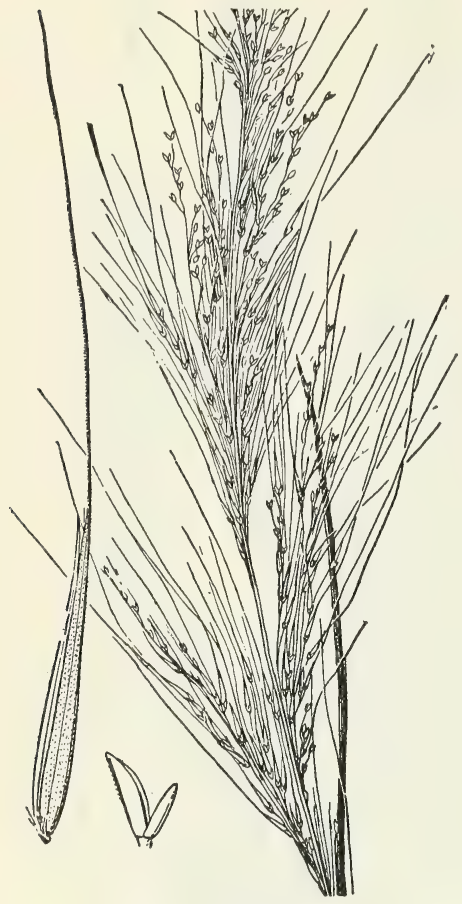

FIGURE 46.-Muhlenbergia parviglumis. Panicle, $\times 1$; glumes and floret, $\times 10$ (Vasey).
Limestone hills, Cuba; Texas and northern Mexico.

Cuba: Viñales, Loma de la Bandera, north of Pinar del Río, Ekman 16547.

\section{SPOROBOLUS R. Br., Prodr. Fl.}

Nov. Holl. $169.1810 . \quad$ DropseEd

Spikelets, 1-flowered, the rachilla disarticulating above the glumes: glumes usually unequal, the second often as long as the spikelet; lemma membranaceous, 1-nerved, awnless; palea usually prominent and as long as the lemma or longer; seed often free from pericarp. Species of West Indies all perennial, except $S$. bahamensis and S. tenuissimus.

$\mathrm{Pl}$ ants annual. Panicle open; spikelets about $1 \mathrm{~mm}$ long.

Glumes nearly equal, 0.3 to $0.4 \mathrm{~mm}$ long.

1. S. BAHAMENSIS.

Glumes unequal, the first one-fourth, the second half as long as the spikelet.

Plants perennial.

2. S. TENUISSIMUS.

Creeping rhizomes present. Panicles pale, spikelike; leaves conspicuously distichous .......... 10. S. VIRGINICUs.

Creeping rhizomes wanting.

Panicle large and diffuse, at least half the entire height of the plant.

3. S. BRASILIENSIS.

Panicle narrow, contracted or if somewhat open not diffuse, less than onethird the entire height of the plant.

Glumes both shorter than the spikelet.

Glumes nearly equal, about $0.5 \mathrm{~mm}$ long; branches of panicle slender, somewhat loosely arranged and spreading; basal sheaths scarcely compressed.

Glumes unequal, the first about one-third as long as the spikelet, the second a little longer; branches of the panicle short, contiguous, the panicle thus rather compact and spikelike; basal sheaths compressed . . . S. PolretII.

Glumes unequal, the second as long as the spikelet.

Spikelets $1.5 \mathrm{~mm}$ long; panicle pyramidal_._...6. S. PYRAMidatus. Spikelets 2 to $4 \mathrm{~mm}$ long; panicle elongate-oblong.

Panicle green or whitish; spikelets about $2 \mathrm{~mm}$ long.

Panicle purple; spikelets 3 to $4 \mathrm{~mm}$ long.

7. S. DOMINGENSIS.

Basal sheaths copiously felty-ciliate; spikelets about $4 \mathrm{~mm}$ long.

8. S. CUBENSIS.

Basal sheaths not felty; spikelets $3 \mathrm{~mm}$ long._. 9 . S. PURPURAscens. 
1. Sporobolus bahamensis Hack., Oesterr. Bot. Ztschr. 52: 56. 1902. Acklins Island, Bahamas, Eggers 3905.

Annual; culms slender, erect, 15 to $30 \mathrm{~cm}$ tall; blades loosely involute, mostly 4 to $6 \mathrm{~cm}$ long, about $1 \mathrm{~mm}$ thick, glabrous; panicle oblong, open, about half the length of the entire culm, 3 to $4 \mathrm{~cm}$ wide, the branches capillary, ascending or spreading, mostly solitary, glabrous, naked on the lower part; spikelets a little more than $1 \mathrm{~mm}$ long, somewhat clustered, short-pediceled, the lateral pedicels shorter than the spikelet, glabrous; glumes shorter than the spikelet, nearly equal, 0.3 to $0.4 \mathrm{~mm}$ long, the first acutish, the second broader, obtuse; lemma and palea equal, obtuse; fruit a little shorter than the lemma.

Known only from the Bahamas.

Bahamas: Acklins Island, Eggers 3905; Brace 4251.

In the Grasses of the West Indies ${ }^{21}$ this species was referred to $S$. atrovirens (H. B. K.) Kunth, of Mexico, which differs in being perennial and in having slightly smaller spikelets short-pediceled along one side of the branches, the first glume only $0.2 \mathrm{~mm}$ long.

2. Sporobolus tenuissimus (Schrank) Kuntze, Rev. Gen. Pl. $3^{2}$ : 369. 1898.

Panicum tenuissimum Schrank, Denkschr. Bot. Ges. Regensb. 2: 26. 1822. Brazil.

Agrosticula muralis Raddi, Agrost. Bras. 33. pl. 1. f. 2. 1823. Brazil.

Sporobolus muralis Hitchc. and Chase, Contrib. U. S. Natl. Herb. 18: 368.1917.

Annual; culms slender, erect, compressed, glabrous, 25 to $75 \mathrm{~cm}$ tall; blades flat, 5 to $15 \mathrm{~cm}$ long, 1 to $3 \mathrm{~mm}$ wide; panicles about half the length of the entire culm, narrow, open, 3 to $6 \mathrm{~cm}$ wide, the branches and branchlets glabrous, capillary, spreading; spikelets glabrous, about $1 \mathrm{~mm}$ long on slender glabrous pedicels; first glume about one-quarter, the second about half the length of the spikelet.

Waste ground, Lesser Antilles to Brazil.

Virgin Islands: St. John, Raunkaier 1333. Tortola, Britton and. Shafer 698. St. Croix, Ricksecker 290.

Windward Islands: Martinique, Duss 4508; Hitchcock 16460. St. Lucia, Box 183; Hitchcock 16470; Kemp 13, 33; Glasgow 6.

Leeward Islands: Guadeloupe, Stehlé 275.

Trinidad: Port-of-Spain, Broadway 7415. Botanic Garden, Broadway 7941.

3. Sporobolus brasiliensis (Raddi) Hack., Bull. Herb. Boiss. (2) $4^{3}$ : 278. 1904.

Aira brasiliensis Raddi, Agrost. Bras. 36. 1823. Brazil.

Eragrostis airoides Nees, Agrost. Bras. 509. 1829. Brazil.

Culms erect, about $1 \mathrm{~m}$ tall; blades elongate, flat or loosely involute, scabrous on the upper surface, 2 to $3 \mathrm{~mm}$ wide; panicles rather more than half the entire length of the plant, 6 to $15 \mathrm{~cm}$ wide, open, the slender branches, branchlets, and pedicels spreading; spikelets $1.3 \mathrm{~mm}$

\footnotetext{
${ }_{21}$ Contrib. U. S. Natl. Herb. 18: 369. 1917.
} 
long, often 2-flowered; glumes somethat unequal, a little shorter than the spikelet, acute.

Savannas, Cuba; Brazil.

Crba: Bahía Honda, Ekman 17438. Cuchillas de San Sebastián, Léon and Shafer 3467; Shafer and Léon 13722. Chirigota, ITright 3827 .

4. Sporobolus indicus (L.) R. Br., Prodr. Fl. Nor. Holl. 1: 170. 1810.

Agrostis indica L., Sp. Pl. 63. 1753. Jamaica.

Agrostis elongata Lam., Tabl. Encycl. 1: 162. 1791. Tropical America.

Sporobolus lamarckii Hamilt., Prodr. Pl. Ind. Occ. 4. 1825. Based on Agrostis elongata Lam.

Sporobolus jacquemontii Kunth, Rér. Gram. 2: 427. pl. 127. 1831. Santo Domingo.

Trilfa jacquemontii Trin., Mém. Acad. St. Pétersb. VI. Sci. Nat. 41: 92.1840.

Tilfa indica Trin.; Steud., Nom. Bot. ed. 2. 2: 767. 1841.

Culms tufted, erect, 60 to $100 \mathrm{~cm}$ tall, with numerous leafy shoots at base; sheaths not noticeablr compressed; blades elongate, slender, fiexuous, mostly 1 to $2 \mathrm{~mm}$ wide; panicles 15 to $30 \mathrm{~cm}$ long; spikelets short-pediceled, mostly along the under side of the branches, 1.5 to $1.8 \mathrm{~mm}$ long; glumes neariy equal, about $0.5 \mathrm{~mm}$ long (fig. $47, B$ ).

Grasse hills and drr sarannas, Bahamas and Mexico to Colombia and Brazil. Throughout the Bahamas and the Test Indies; probably to be found on all the islands. In Cuba called "espartillo" and "espartillo fino."

5. Sporobolus poiretii (Roem. and Schult.) Hitchc., Bartonia 14: 32. 1932.

SMutgrass.

Agrostis compressa Poir., in Lam., Encrcl. Sup. 1: 258. (no. 78) 1810. Not A. compressa Willd., 1790. Carolina.

Axonopus poiretii Roem. and Schult. Syst. Veg. 2: 318. 1817. Based on Agrostis compressa Poir., no. 78.

Agrostis tenuissima Spreng., Syst. Veg. 1:258. 1825. Not Sporobolus tenuissimus Kuntze, 1898. West Indies and South America.

Tilfa berteroana Trin., Mém. Acad. St. Pétersb. VI. Sci. Nat. $4^{1}$ : 100. 1840. Santo Domingo.

Sporobolus berteroanus Hitchc. and Chase, Contrib. U. S. Natl. Herb. 18: 370. 1917.

Culms erect, tufted, 50 to $100 \mathrm{~cm}$ tall, the basal sheaths compressed; blades elongate, flat, folded or loosely involute, tapering into a long slender involute flexuous tip, 1 to $4 \mathrm{~mm}$ wide; panicle sometimes almost spikelike, usually 15 to $30 \mathrm{~cm}$ long, often red-brown from the exposed fruits at maturity or blackish from the effects of a fungus; spikelets 1.7 to $2 \mathrm{~mm}$ long; glumes obtuse, somewhat erose, the first about one-third as long as the spikelet, the second a little longer; fruit red-brown, mucilaginous on wetting (fig. $47, A$ ).

Open ground, grassland, and waste places, southern United States to Argentina. Throughout the West Indies, probably to be found on all the islands. Because the inflorescence is frequently attacked br a black fungus the grass is often called smutgrass. This species was 


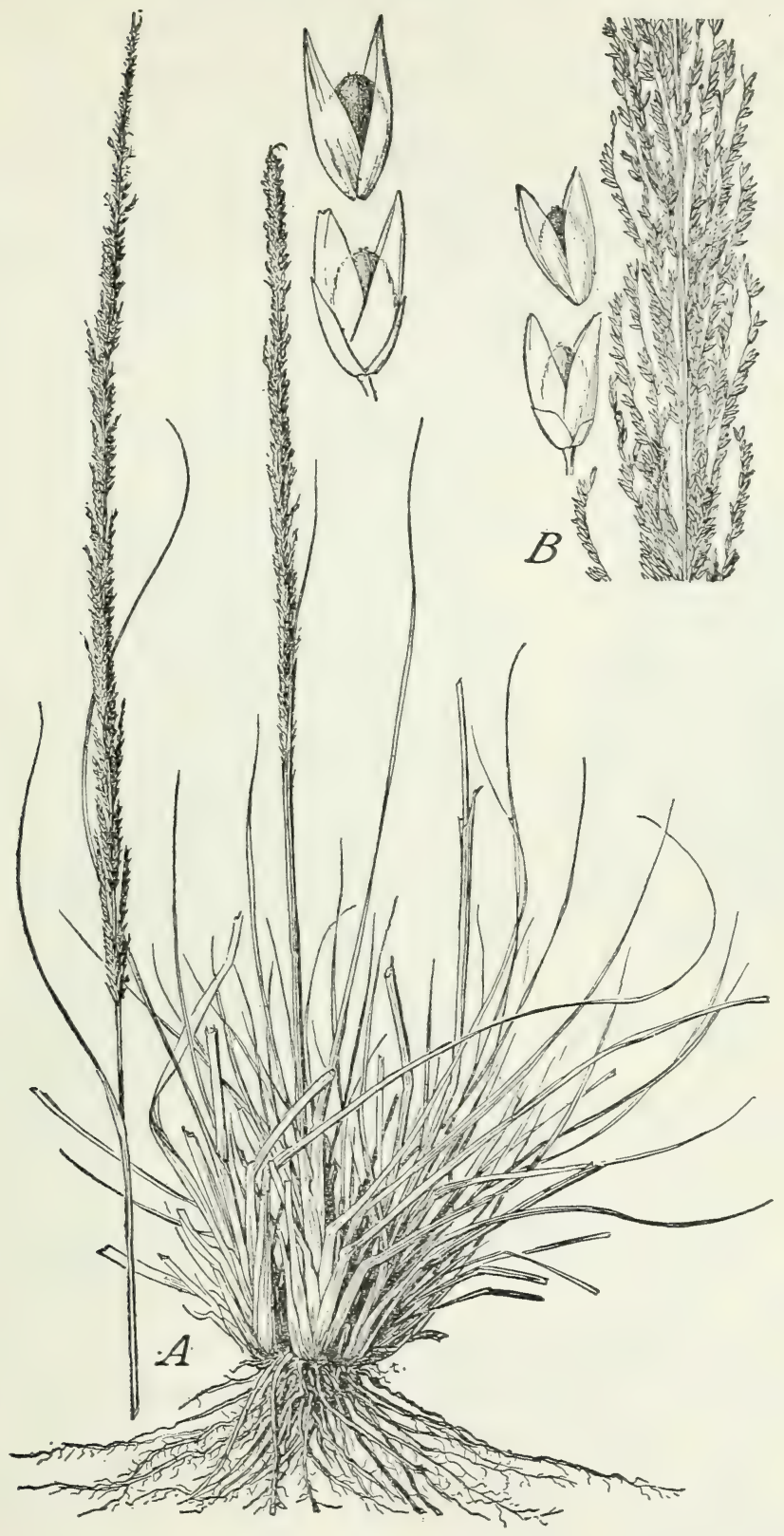

FIGURE 47. $-A$, Sporobolus poiretii. Plant, $\times 1 / 2$; spikelet and floret, $\times 10$ (Chase 7043). B, S. indicusPanicle, $\times 1$; spikelet and floret, $\times 10$ (Léon 867). 
included with the preceding under Sporobolus indicus by earlier botanists ${ }^{22}$ and has been described as Sporobolus indicus by others, the preceding species being distinguished as Sporobolus jacquemontii.

6. Sporobolus pyramidatus (Lam.) Hitchc.

Agrostis pyramidata Lam., Tabl. Encycl. 1: 161. 1791. South America, the specimen from Richard. The type was examined by A.

S. Hitchcock in the Lamarck Herbarium in 1935.

Vilfa arguta Nees, Agrost. Bras. 395. 1829. Brazil.

Sporobolus argutus Kunth, Rév. Gram. 1: Sup. XVII. 1830.

Vilfa richardi Steud., Syn. Pl. Glum. 1: 153. 1854. Antilles.

Agrostis pyramidalis Rich.; Steud., Syn. Pl. Glum. 1: 153.1854. As synonym of the preceding.

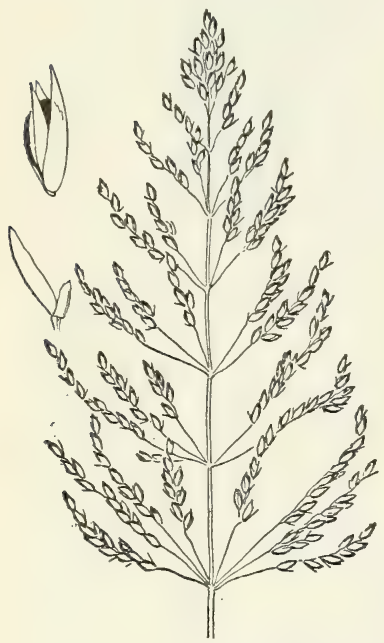

FIGURE 48--Sporobolus pyramidatus. Panicle, $\times 1$; glumes and floret, $X$ 10 (Hitchcock 5343).

Low tufted glabrous perennial; culms spreading; blades short, rather thick, subinvolute; panicles pale, many-flowered, at first contracted, at maturity narrowly pyramidal or oblong; spikelets $1.5 \mathrm{~mm}$ long; first glume about half as long as the spikelet, the second as long as the spikelet (fig. 48).

Open sandy or alkaline soil, at low altitudes, southwestern United States and the West Indies to Argentina.

Bahamas: Grand Turk Island, Millspaugh 9384. Long Cay, Brace 4133. ${ }^{23}$

Cuba: Habana, Léon 285, 868, 6185; Ekman 94, 142; Hitchcock 235; Baker 1799, 1818. Batabanó,Hitchcock 236. Gaza,Léon 5467. Cayo Sabinal, Ekman 15513. Guantánamo, Britton 2035. Without locality, Wright 3828. Isla de Pinos, Britton and Wilson 15092, 15404.

JAMAICA: Old Harbor, Ridley 131, 133. Cockpit River, Harris 12463, 12467 . Kingston, Harris 11503; Hitchcock 9318. Salt Ponds, Harris 11321. Healthshire Hills, Harris 11611; Hitchcock 9760. Rockfort, Harris 11306. Black River, Hitchcock 9640 (Amer. Gr. Nat. Herb. 634). Savanna-la-Mar, Hitchcock 9857.

Haiti: Cabaret, Leonard 11834. Port-au-Prince, Ekman H 319, H 9051. Etang, Leonard 3574. Gonaïves, Cook, Scofield, and Doyle 191, 193. Tortuga Island, Leonard 11415. Gonaïve Island, Leonard $3257,3272,3274$.

Dominican Refublic: Guayubín, Abbott 867, 1004. Barahona, Fuertes 1291. Santiago, Ekman H 15979.

Puerto Rico: Guanica, Sintenis 3416b; Britton and Shafer 1862, 1873. Punta Aguila, Britton, Cowell, and Brown 4684. Cuamo, Sintenis 3307. Cabo Rojo, Sintenis 549. Boqueron, Chase 6500. Ponce, Chase 6496. Mona Island, Britton, Cowell, and Hess 1780, 1875; Hess 453.

Virgin Islands: Anegada, Fishlock 53. St. Croix, Ricksecker 279. 
Leeward Islands: Antigua, Wullschlaegel; Box 78.

Windward Islands: Barbados, Freeman 5024; Hitchcock 16508.

Trinidad: Cedros, Broadway 4919; Hitchcock 10163.

7. Sporobolus domingensis (Trin.) Kunth, Rév. Gram. 1: Sup.

XVII. 1830.

Vilfa domingensis Trin., in Spreng., Neu. Entd. 2: 59. 1821. Santo Domingo.

Agrostis domingensis Schult., Mant. 3 (Add. 1): 570. 1827.

Sporobolus inordinatus Mez, Repert. Sp. Nov. Fedde 17: 294.1921. Cuba, Ramon de la Sagra.

Resembling S. pyramidatus; culms stouter, 30 to $80 \mathrm{~cm}$ tall; panicles contracted, densely flowered, the branches appressed, the lower sometimes ascending; spikelets $2 \mathrm{~mm}$ long or sometimes somewhat less (fig. 49).

Sandy or alkaline soil, Bahamas and Greater Antilles; southern Florida.

Bahamas: New Providence, Britton and Brace 336. Anguilla Isles, Wilson 8001. Soldiers Road, Geogr. Soc. Baltimore 260. Fortune Island, Hitchcock in 1890.

Cuba: Habana, Ekman in 1921. Caibarién, Fernando 1, 307. Cienfuegos Bay, Britton and Wilson 5758. Cayo Sabinal, Ekman 15470. Santa Lucea, Shafer 972. Cayo Guajaba, Shafer 691. Guantánamo Bay, Hioram 2, 5; Britton 2125. Manzanillo, Shafer 12344.

Jamaica: Montego Bay, Ridley 110.

Haiti: Cabaret, Leonard 11997, 11997a. Sources Puantes, Ekman H 2158. Gonaïve Island, Leonard 5203. Tortuga Island, Leonard $11422,15318,15319$.

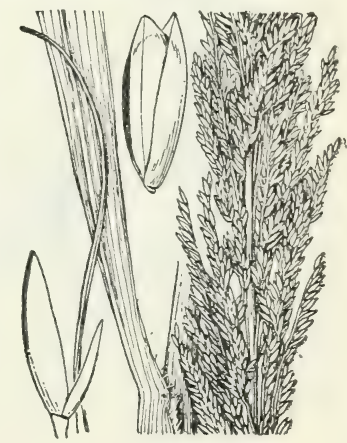

FIGURE 49.-Sporobolus domingensis. Plant, $\times 1$; glumes and floret, $\times 10$ (Hitcheock 530).

8. Sporobolus cubensis Hitchc., Contrib. U. S. Natl. Herb. 12: 237. 1909. Isla de Pinos, Curtiss 392.

Culms densely tufted, erect, 30 to $50 \mathrm{~cm}$ tall, the innovations numerous, lower sheaths felty-ciliate; blades flat or involute, firm and rather stiff, 10 to $15 \mathrm{~cm}$ long, 1 to $2 \mathrm{~mm}$ wide, ciliate near base; panicles narrowly pyramidal, erect, 10 to $15 \mathrm{~cm}$ long, usually bronzegreen, the branches in indistinct verticils, spreading or the lower finally reflexed, 2 to $3 \mathrm{~cm}$ long; spikelets about $4 \mathrm{~mm}$ long, acute, somewhat secund along the lower side of the branches, the lateral pedicels about $0.5 \mathrm{~mm}$ long; first glume gradually acute, a littie more than half as long as the spikelet, the second as long as the lemma. The basal part of the tuft usually shows the effect of fire burning off the upper part.

Sandy barrens, Cuba to Puerto Rico; British Guiana and Costa Rica to Bolivia.

CubA: Hanábana, Wright 3427. Herradura, Ekman in 1922; Hitchcock 237. Isla de Pinos, Ekman 12541; Britton and Wilson 14141, 14422, 14975; Curtiss 392.

Haiti: Maissade, Ekman H 3252.

Dominican Republic: Cuenca, Ekman H 13338.

Puerto Rico: Mayaguez, Heller 4590. 
9. Sporobolus purpurascens (Swartz) Hamilt., Prodr. Pl. Ind. Occ. 5. 1825.

Agrostis purpurascens Swartz, Prodr. Veg. Ind. Occ. 25. 1788. Jamaica.

Culms erect, 30 to $50 \mathrm{~cm}$ tall; blades mostly basal, 4 to $8 \mathrm{~mm}$ wide, ciliate near base; panicles condensed, brownish drab, 8 to $15 \mathrm{~cm}$ long,

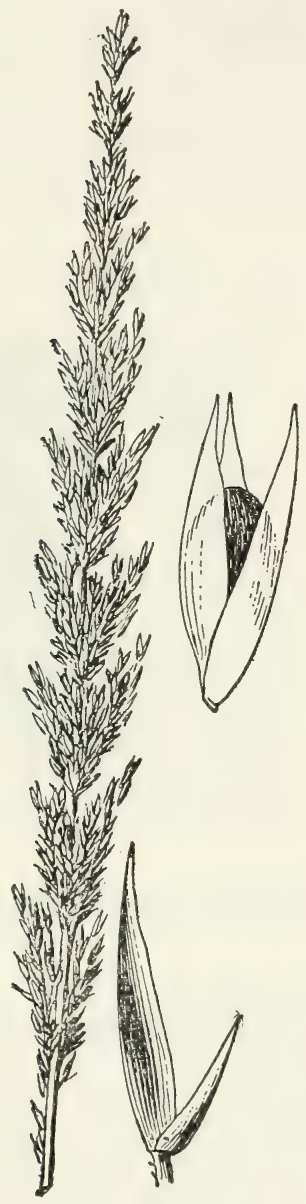

FIGURE 50.-Sporobolus purpurascens. Panicle, $\times 1$; glumes and floret, $\times 10$ (Hitcheock).

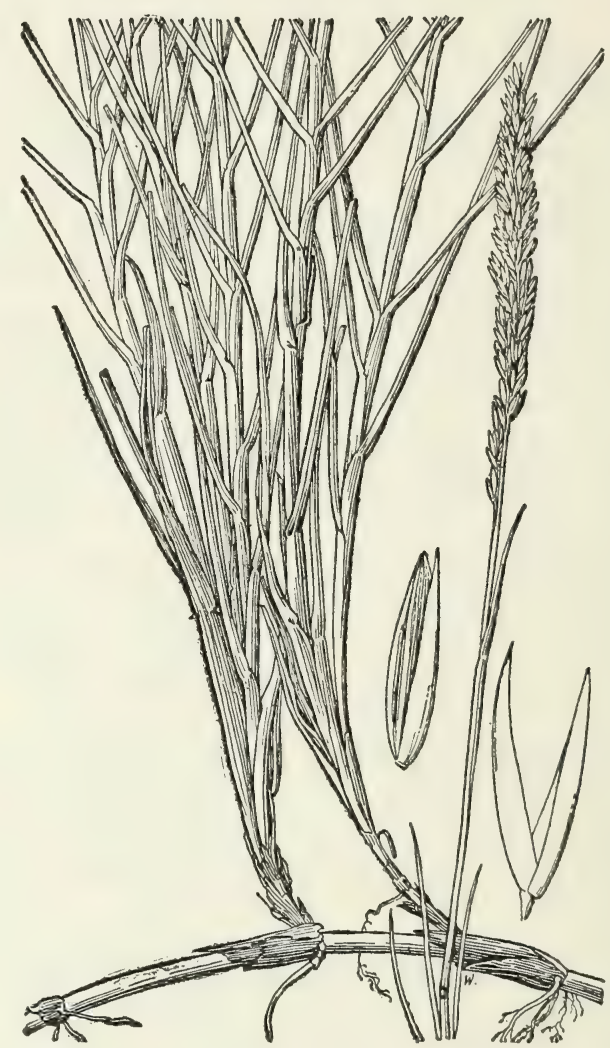

Figure 51.-Sporobolus virginicus. Plant, $\times 1$; glumes and floret, $X 10$ (Nash 2467).

the short branches in whorls; spikelets $3 \mathrm{~mm}$ long; first glume less than half as long as the spikelet; second glume as long as the spikelet (fig. 50).

Grassy slopes, pine barrens, and savannas, southern United States, West Indies, and eastern Mexico to Bolivia and Brazil.

CuBA: San Julián, Ekman 11115; Léon 6923, 6984. Herradura, Léon 15953. Pinar del Río, Wright 3427a; Britton 10022. Laguna Jovero, Shafer 10757. Isla de Pinos, Britton and Wilson 14292. 
JAMAICA: Testphalia, Harris 11434, 11568. Road to Salt Hill, Harris 11365. Below Sir Johns Peak, Harris 11598. Newcastle, Hitchcock 9340. Bull Head Mountain, Hitchcock 9525. Cinchona, Hitchcock 9716. Barican, Hitchcock 9573. North slope Catherines Peak, Hitchcock 9736. Gordon Town, Hart 735.

Windward Islands: Martinique, Duss.

10. Sporobolus virginicus (L.) Kunth, Rév. Gram. 1: 67. 1829. Agrostis virginica L., Sp. Pl. 63. 1753. Virginia.

Agrostis littoralis Lam., Tabl. Encycl. 1: 161. 1791. Tropical America.

Vilfa virginica Beauv., Ess. Agrost. 16, 149, 182. 1812

Sporobolus littoralis Kunth, Rév. Gram. 1: 68.1829.

Culms 15 to $70 \mathrm{~cm}$ tali or even as much as $1 \mathrm{~m}$, erect from extensively creeping hard scaly rhizomes; leaves numerous, conspicuously distichous, the sheaths overlapping; blades firm, involute-pointed, 3 to $15 \mathrm{~cm}$ long, 2 to $5 \mathrm{~mm}$ wide; panicles spikelike, somewhat narrowed abore and below, 2 to 10 , rarely to 15 , cm long; spikelets $2 \mathrm{~mm}$ long or slightly longer; first glume a little more than half as long as the spikelet, the second as long as the spikelet (fig. 51).

In the Grasses of the West Indies ${ }^{24}$ Sporobolus littoralis was recognized as distinct. Further collections show complete intergradation between large specimens referred to it and characteristic S. virginicus. Lamarck's type of Agrostis littoralis, examined in the Paris Herbarium in 1935 , proves to be an intermediate specimen, the panicle $6 \mathrm{~cm}$ long.

Saline or sandy soil along the coast, Virginia to Brazil, and all warm countries of the Eastern Hemisphere. Common throughout the West Indies. Extensive colonies of sterile plants often found along sandy beaches.

\section{ARISTIDA L., Sp. Pl. 82. 1753. Three-AwN}

Spikelets 1-flowered, the rachilla disarticulating obliquely above the glumes; glumes narrow, acute, acuminate, or awn-tipped; lemma indurate, narrow, terete, convolute, with a hard, sharp-pointed, usually minutely bearded callus at base, terminating above in a usually trifid awn. Species of the West Indies all perennial except A. adscensionis.

Lateral awns minute or obsolete

1. A. TERNIPES.

Lateral awns well developed (short in 4. laevigata).

Plants annual

Plants perennial.

Column of awn $10 \mathrm{~mm}$ long, twisted

Column of awn, if present, much shorter than $10 \mathrm{~mm}$.

Panicle open, the branches stiffly ascending or spreading. Lateral awns one-fourth as long as the central or less.

4. A. Laevigata.

Lateral awns half as long as thะ central or a little more.

A. Adscensionis.

3. A. SPICIFORMIS.

5. A. PRADANA.

Panicle narrow; the branches appressed or somewhat ascending; lateral awns usually about as long as the central, sometimes shorter but at least half as long.

First glume one-half to two-thirds as long as the second. Awns contorted at base, about $1 \mathrm{~cm}$ long........ 6 . A. Fragilis. Awns not contorted at base, 2 to $2.5 \mathrm{~cm}$ long ...... 7. A. EgGersir.

24 Contrib. U. S. Natl. Herb. 18: 369. 1917. 
First glume about as long as the second or a little shorter.

Beak of lemma 3 to $4 \mathrm{~mm}$ long, distinctly twisted..8. A. NEGLECTA. Beak of lemma, if present, not twisted.

Awns at maturity about equally divergent, not spirally contorted at base.

Blades flat at least toward the base.

Culms mostly more than $1 \mathrm{~m}$ tall; blades 3 to $5 \mathrm{~mm}$ wide.

9. A. ERECTA.

Culms mostly less than $70 \mathrm{~cm}$ tall; blades mostly not more than

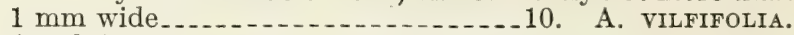

Blades involute.

Blades short and stiff, mostly less than $3 \mathrm{~cm}$ long, usually approximate in pairs; culms very stiff and wiry.

11. A. CURTIFolia.

Blades mostly more than $5 \mathrm{~cm}$ long, not approximate in pairs. Panicle loose; awns 2 to $3 \mathrm{~cm}$ long _- 12 . A. PORTORICENSIs. Panicle rather dense; awns 1 to $2.5 \mathrm{~cm}$ long.

Callus of lemma nearly $2 \mathrm{~mm}$ long; first glume $1 \mathrm{~cm}$ long; lemma a little longer than the glumes; awns $2 \mathrm{~cm}$ long.

Callus of lemma about $0.5 \mathrm{~mm}$ long.

13. A. CHASEAE.

Culms erect; blades as much as $30 \mathrm{~cm}$ long; first glume about $7 \mathrm{~mm}$ long; lemma about $8 \mathrm{~mm}$ long; awns 1.5 to $2.5 \mathrm{~cm}$ long Culms spreading and branching at base; blades 5 to $15 \mathrm{~cm}$ long; first glume 4 to $5 \mathrm{~mm}$ long; lemma 6 to $7 \mathrm{~mm}$ long; awns 1 to $1.5 \mathrm{~cm}$ long.

15. A. Cognata.

Awns at maturity unequally divergent or spirally contorted at base.

Central awn horizontally spreading or somewhat reflexed, the lateral awns erect; awns not contorted at base; blades flat toward base ............... A. AFrinis.

Central awn not more divergent than the others; awns all contorted at base; blades involute.

Awns 1.5 to $3 \mathrm{~cm}$ long.

Lemma $7 \mathrm{~mm}$ long, glabrous, the awns strongly contorted at base; plants rather stout, the blades as much as $20 \mathrm{~cm}$ long, the panicles as much as $30 \mathrm{~cm}$ long.

17. A. BRITTONORUM.

Lemma $10 \mathrm{~mm}$ long, scabrous on the upper half, the awns weakly contorted at base; plants slender, the blades 5 to $10 \mathrm{~cm}$ long, the panicles 7 to $15 \mathrm{~cm}$ long.

Awns about $1 \mathrm{~cm}$ long.

18. A. CALCICOLA.

First glume glabrous on the keel. . . . . 19 . A. Roser.

First glume scabrous on the keel..... A. REFRACTA.

1. Aristida ternipes Cav., Icon. Pl. 5: 46. 1799. Panama.

SPIDER GRASS.

Streptachne scabra H. B. K., Nov. Gen. et Sp. 1: 124. pl. 40. 1815. Mexico.

Aristida scabra Kunth, Rév. Gram. 1: 62. 1829.

Streptachne cubensis A. Rich., in Sagra, Hist. Cuba 11: 311. 1850. Cuba.

Erect perennial; culms 50 to $100 \mathrm{~cm}$ tall; blades flat, involute above, tapering into a fine point, 2 to $3 \mathrm{~mm}$ wide; panicle open, one-third to half the entire length of the culm, the branches few, distant, spreading, scabrous, mostly naked at base; spikelets appressed at the ends of the branches; glumes about equal, 8 to $10 \mathrm{~mm}$ long; lemma gradually narrowed into a laterally compressed scabrous falcate beak, this extending into a single arcuate awn 10 to $15 \mathrm{~mm}$ long; lateral awns minute or obsolete. In arid situations the blades may be narrow and nearly all involute (fig. 52). 
Rocky hills and dry plateaus, Arizona to Colombia; Bahamas, Cuba, and Hispaniola.

Bahamas: Nassau, Curtiss 75; Hitchcock in 1890. Inagua, Nash and Taylor 926.

Cuba: Pinar del Río, Wright 3835. Vicinity of Habana, Léon 280, 958, 959, 8518; Wilson 9488; Hitchcock 496, 497. Guanabacoa, Léon and Shafer 3443; Hitchcock 23238. Santiago de Cuba, Ekman 8474; Britton and Cowell 12857.

H Aiti: Port-de-Pai, Ekman H 3626.

Dominican Republic: Peninsula de Barahona, Ekman H 7029.

2. Aristida adscensionis L., Sp. Pl. 82. 1753. Ascension Island.

Aristida maritima Steud., Syn. Pl. Glum. 1: 137. 1854. Guadeloupe.

Aristida debilis Mez, Repert. Sp. Nov. Fedde 17: 151. 1921. Based in part on a specimen collected in Jamaica by $\mathrm{MacNab}$.

Annual, much branched at base; culms

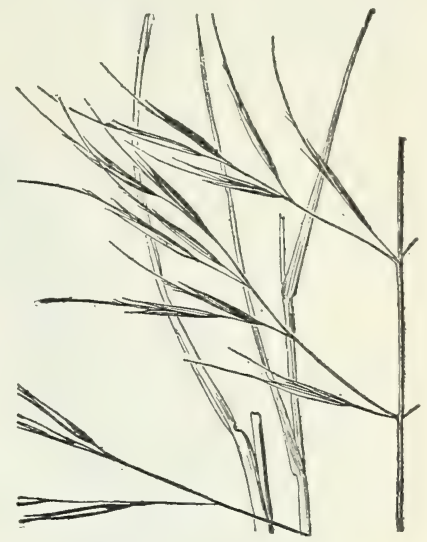

FIGURE 52.-Aristida ternipes, $\times 1$ (Griffiths 7271) 10 to $80 \mathrm{~cm}$ tall; panicles narrow, erect, 5 to $10 \mathrm{~cm}$ long in the smaller plants; first glume 5 to $7 \mathrm{~mm}$ long, the second 8 to $10 \mathrm{~mm}$ long; lemma 8 to $9 \mathrm{~mm}$ long, compressed toward the scarcely beaked summit;

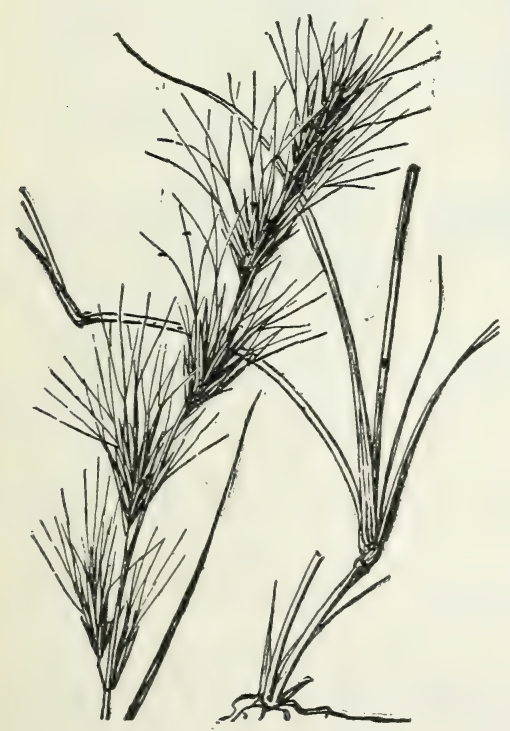

FIGURE 53.-Aristida adscenionis, $\times 1$ (Earle 559).

St.-Nicolas, Leonard 13343. C. St. Michel de l'Atalaye, Leonard 7095. Morne-à-Cabrits, Ekman H 960. equally divergent, flat and straight at base. Extremely variable in appearance, ranging from dwarf plants with narrow compact panicles to larger plants, as much as $70 \mathrm{~cm}$ tall, with flexuous panicles (fig. 53).

Open dry ground and waste places, throughout the warmer parts of America and the old World. Grisebach ${ }^{25}$ refers this species to A. stricta Michx.

Bahamas: Crooked Island, Brace 4633. Long Island, Britton and Millspaugh 6309. Long Cay, Brace 4077. Fortune Island, Hitchcock in 1890 .

JAMAICA: Kingston, Britton and Hollick 1746; Harris 11500, 12452. Gordon Town, Harris 11513. Flamstead, Harris 11474. Musgrave Road, Harris 11480.

H a I т: Port-au-Prince, Leonard 3451, 15878, 15881; Buch 2041. Jean Rabel, Leonard 12968. Môleawns about equal, 10 to $15 \mathrm{~mm}$ long, 
Dominican Republic: Guayubín, Abbott 955. Valverde, Ekman H 13096.

Puerto Rico: Boqueron, Chase 6506, 6510. Guanica, Sintenis 3438, 3766. Cabo Rojo, Sintenis 553. Mona Island, Hess 437.

Virgin Islands: St. Croix, Thompson 22; Ricksecker 64; Rose 3211.

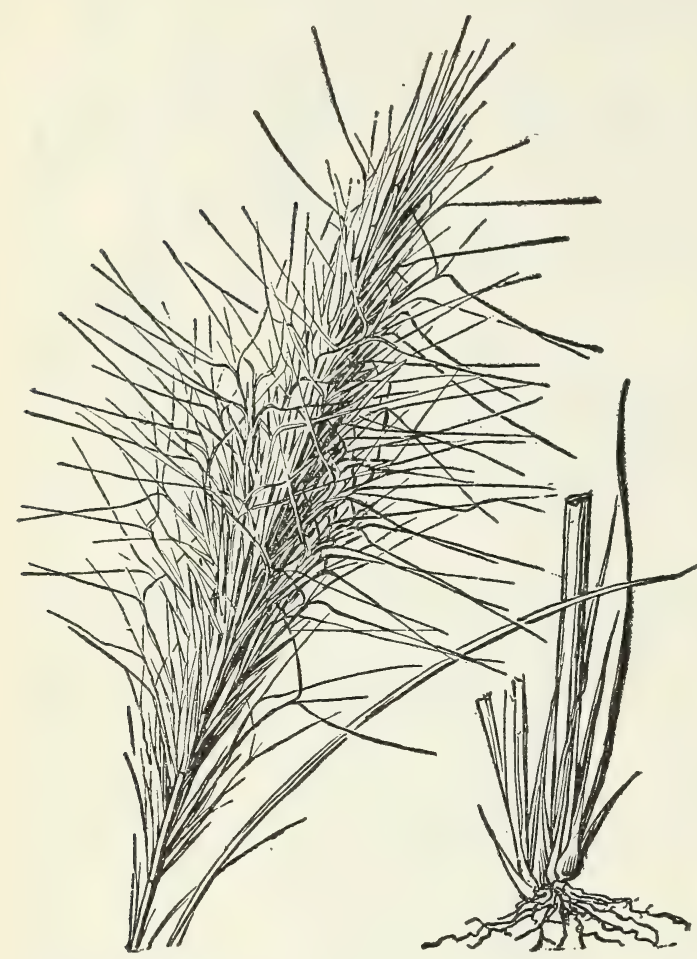

FIGURE 54.-Aristida spiciformis, $\times 1$ (Combs and Baker 1115).

LEEWARD IsLANDS: Antigua, Wullschlaegel; Box 127. Guadeloupe, Duss 3159 .

Windward IsLands: Montserrat, Shafer 18.

\section{Aristida spiciformis} Ell., Bot.S. C. and Ga. 1: 141. 1816. South Carolina.

Culms tufted, stiffly erect, 50 to $100 \mathrm{~cm}$ tall; panicle erect, dense and spikelike, mostly 10 to $15 \mathrm{~cm}$ long, the branches short and appressed, the whole panicle more or less spirally twisted; lemma, excluding the slender callus $1 \mathrm{~mm}$ long, about $4 \mathrm{~mm}$ long, extending into a twisted column $10 \mathrm{~mm}$ long; awns about equal, 1.5 to $2 \mathrm{~cm}$ long, spreading (fig. 54).

Some of the material from the United States has larger spikelets than that from the West Indies.

Sandy barrens in thickets or pine woods, southern United States, Cuba, and Puerto Rico.

Cuba: Pinar del Río, Ekman 17811. Isla de Pinos, Britton and Wilson 14198.

Puerto Rico: Campo Alegre, Chase 6614 (Amer. Gr. Nat. Herb. $765)$.

4. Aristida laevigata Hitchc. and Ekman, N. Amer. Fl. 17: 390. 1935. Cuba, Ekman in 1922.

Culms cespitose, erect, glabrous, several-noded, 60 to $100 \mathrm{~cm}$ tall; sheaths glabrous; ligule a ciliate membrane less than $0.5 \mathrm{~mm}$ long; blades closely involute, firm, somewhat curved or flexuous, 0.5 to $1 \mathrm{~mm}$ thick when rolled, smooth on the outer surface, 10 to $20 \mathrm{~cm}$ long, villous on the upper surface near the base and around the summit of the sheath; panicles long-exserted, 20 to $30 \mathrm{~cm}$ long, the branches mostly solitary, distant, stiffly ascending, the lowermost as much as $15 \mathrm{~cm}$ long, the branchlets appressed along the branches, the axis 
of the panicle and the branches glabrous; glumes nearly equal, 1nerved, obscurely scaberulous toward apex, otherwise glabrous even as to the keels, about $12 \mathrm{~mm}$ long, the first acuminate, the second mucronate from a rather broad bifid apex; lemma 12 to $14 \mathrm{~mm}$ long, including the $1 \mathrm{~mm}$ long short-pilose callus, glabrous, narrowed above but scarcely beaked, awns very unequal, the central widely spreading or somewhat reflexed, 12 to $20 \mathrm{~mm}$ long, obscurely scabrous at the base, the lateral divergent, 2 to $5 \mathrm{~mm}$ long, more slender than the central.

Known only from the type locality, pinelands at the headwaters of Río Piloto, Sierra de Nipe, pror. Oriente, Cuba, $750 \mathrm{~m}$ altitude. Besides the type collection, Ekman collected in the same locality nos. 2511, 9880, and 15058 . The species is allied to A.ternipes and A. divaricata Humb. and Bonpl.

5. Aristida pradana Léon, Bull. Torrey Bot. Club 53: 458. 1926. Cuba, Léon 12299.

Culms tufted, erect, wiry, 60 to $80 \mathrm{~cm}$ tall, "simple and naked, the upper leaves of the culm, if any, reduced to the elongate, strongly adherent and mostly bladeless sheath"; blades firm, closely involute from the base, flexuous, as much as $60 \mathrm{~cm}$ long or more; panicle 25 to $35 \mathrm{~cm}$ long, narrow, the branches appressed, "finally divergent or spreading", the lower ones distant, as much as $8 \mathrm{~cm}$ long; "glumes unequal, 10 to $12 \mathrm{~mm}$ long the first caducous"; lemma 15 to $17 \mathrm{~mm}$ long, including the $1 \mathrm{~mm}$ long short-pilose callus, narrowed above into an obscure beak; awns unequal, the central one spreading, 2 to $3 \mathrm{~cm}$ long, the lateral ascending, half as long as the central or a little more.

Arid rocky siliceous hillside, Peladeros de Jauco, southwest of Baricoa, Cuba, Léon 12299.

Known only from the type collection. The duplicate type specimen in the United States National Herbarium is incomplete and the first glume has disappeared. The quoted parts of the above description are taken from the original descrintion. The species is allied to A. pansa Woot. and Standl. of southwestern United States.

6. Aristida fragilis Hitchc. and Ekman, N. Amer. Fl. 17: 393.1935. Cuba, Ekman 16784.

Culms cespitose, erect, glabrous, wiry, 30 to $50 \mathrm{~cm}$ tall, two to sereral nodes approximate near the base; sheaths glabrous, the culmsheath 2 to $5 \mathrm{~cm}$ long, mostly bladeless, those of the innovations pilose at the summit, bearing involute blades 1 to $10 \mathrm{~cm}$ long; ligule a ciliate membrane $0.5 \mathrm{~mm}$ long; panicles narrow, rather soft, 10 to $20 \mathrm{~cm}$ long, the branches appressed, 1 to $3 \mathrm{~cm}$ long, the upper overlapping, the lower somewhat distant; glumes 1-nerved, acute, the first minutely scabrous on the keel and on the sides toward the sum mit, about $4 \mathrm{~mm}$ long; the second glabrous, somewhat narrowed toward the summit, about $7 \mathrm{~mm}$ long; lemma about $7 \mathrm{~mm}$ long including the minutely and softly pubescent rather slender callus a little more than $1 \mathrm{~mm}$ long; awns equal, finally horizontally spreading, contorted at base, about $1 \mathrm{~cm}$ long.

Pinelands on white sand, Cuba.

Cuba: San Juan y Martínez (Pinar del Río), Ekman 16784. La Grifa, Ekman 11247. Pábalo, Ekman 11417. 
7. Aristida eggersii Hitchc., Contrib. U. S. Natl. Herb. 22: 560. 1924. Cuba, Eggers 5389.

Culms tufted, slender, spreading or decumbent at base, 20 to 40 $\mathrm{cm}$ tall; blades involute, falcate or flexuous, mostly less than $10 \mathrm{~cm}$ long, of ten much shorter; panicle narrow, 3 to $10 \mathrm{~cm}$ long, the branches distant, short and appressed, few-flowered; glumes unequal, the first 5 to $6 \mathrm{~mm}$ long, about half as long as the second; lemma about $1 \mathrm{~cm}$ long, including the $1 \mathrm{~mm}$ long callus, gradually narrowed and scaberulous above; awns about equal, 2 to $2.5 \mathrm{~cm}$ long, all spreading nearly horizontally, flat at base and scarcely contorted. Ekman's no. H 13158 agrees with this description except that the glumes are longer (about 8 and $13 \mathrm{~mm}$ ).

Pastures and exposed hillsides, Cuba and Hispaniola.

Cuba: Guantánamo, Ekman 10227, 15755; Britton 2177. La Caimanera, Eggers 5389; Ekman 15742.

Dominican Republic: Monte Cristi, Ekman H 13158.

8. Aristida neglecta Léon; Hitchc., Contrib. U. S. Natl. Herb. 22: 567. 1924. Loma de las Jatas, Guanabacoa, Cuba, Ekman in 1921.

Culms loosely tufted, erect, wiry, several-noded, 40 to $60 \mathrm{~cm}$ tall; sheaths shorter than the internodes, distributed along the culm; blades stiff and firm, soon involute, sharp-pointed, usually not over $5 \mathrm{~cm}$ long, often shorter, less than $1 \mathrm{~mm}$ wide, or some of the earlier ones wider; panicles narrow, 5 to $10 \mathrm{~cm}$ long, the branches distant, rather stiffly ascending, 1 to $2 \mathrm{~cm}$ long, bearing 1 or 2 branchlets at base, few-flowered; glumes equal or nearly so, 7 to $9 \mathrm{~mm}$ long, acuminate or awn-pointed; lemma about $1 \mathrm{~cm}$ long, the callus less than $1 \mathrm{~mm}$ long, the body glabrous, gradually tapering into a scabrous twisted beak as long as or a little longer than the body; awns about equal, divergent, 10 to $15 \mathrm{~mm}$ long, slightly or distinctly contorted at base. With age the lower sheaths become open or flattened, and often lose their blades, giving the culms a naked knotty appearance.

Sandy savannas, pine barrens, and dry hills, Cuba and Hispaniola.

Cuba: Guane, Shafer 10364, 10630; Léon 7030, 7031. Pinar del Río, Hitchcock 23254, 23261, 23304, 23312. Viñales, Killip 13572. Herradura, Ekman 17731. Remates, Ekman 11165, 11300, 11339. San Diego de los Baños, Léon 4844; Ekman 17763. La Grifa, Ekman 11244. San Juan, Ekman 16785. Mantua, Ekman 11083. Consolación del Sur, Ekman 10868. San Juan y Martínez, Ekman 13793. Guanabacoa, Léon 871, 872, 874, 2875, 5015; Hitchcock 500, 23236; Wilson and Léon 11645; Ekman 45, 10897. Madruga, Léon 3455, 6374. Minas, Léon 5213. Soledad, Hitchcock 23328. Baragua, Hitchcock 23365. Placetas del Sur, Léon 6425. Manacos, Léon 5834. Sancti Spíritus, Léon 8993. Motembo, Léon 8639. Camagüey, Ekman 15323. Holguín, Shafer 1183. Guara, Hitchcock 23408. Victoria de las Tunas, Ekman 15584. Caimanera, Hioram and Ramsden 7. Eastern Cuba, Wright 737. Western Cuba, Wright 3433. Isla de Pinos, Britton and Wilson 14414.

Haiti: Marmelade, Leonard 8248. St. Michel de l'Atalaye, Leonard 7291, 7422, 7795. Mirebalais, Ekman H 2294. Camache, Buch 1075.

Dominican Republic: Moncion, Ekman H 12635. Santiago, Ekman H 16221. 
9. Aristida erecta Hitchc., Contrib. U. S. Natl. Herb. 12: 236.1909. Cuba, Wright 3432.

Culms erect, rather stout, as much as $1.5 \mathrm{~m}$ tall; blades flat, becoming involute especially toward the much-attenuate tip, as much as $1 \mathrm{~m}$ long, 3 to $5 \mathrm{~mm}$ wide; panicles narrow, as much as $50 \mathrm{~cm}$ long, the numerous very scabrous branches ascending or appressed, the lower as much as $10 \mathrm{~cm}$ long or even longer, all spikelet-bearing from the base, the spikelets crowded on erect rather stout pedicels 2 to $3 \mathrm{~mm}$ long; glumes acuminate or awn-tipped, the first 3-nerved, 12 to $15 \mathrm{~mm}$ long, the second 1-nerved, 2 to $3 \mathrm{~mm}$ shorter than the first; lemma 12 to $13 \mathrm{~mm}$; awns divergent, the central 2 to $3 \mathrm{~cm}$ long, the lateral somewhat shorter.

Savannas of western Cuba.

Cuba: Santa Cruz de los Pinos, Ekman 17681 (Amer. Gr. Nat. Herb. 787). Herradura, Hitchcock 23441; Tracy 9076. San Diego (Pinar del Río), Léon 4852. Gaune, Léon 6918. Without locality, Wright 3432. Isla de Pinos, Britton and Wilson 14959.

10. Aristida vilfifolia Henr., Med. Rijks Herb. Leiden 54B: 671. 1928. Cuba, Amer. Gr. Nat. Herb. 791.

Culms rather loosely tufted, erect, slender and wiry, 30 to $60 \mathrm{~cm}$ tall; blades flat or often involute, becoming curved or flexuous, thickened on the margins, mostly 3 to $5 \mathrm{~cm}$ long, sometimes as much as $8 \mathrm{~cm}$, on the innovations sometimes shorter, mostly not more than $1 \mathrm{~mm}$ wide; panicles erect, narrow, 5 to $15 \mathrm{~cm}$ long, the branches short and appressed, approximate or often distant, especially below; glumes about equal, acute, 6 to $8 \mathrm{~mm}$ long; lemma 6 to $7 \mathrm{~mm}$ long, including: the $0.5 \mathrm{~mm}$ long callus; central awn spreading, 10 to $15 \mathrm{~mm}$ long, the lateral awns erect or somewhat spreading, usually about two-thirds as long as the central, all nearly straight at base, sometimes contorted (Wright 3831, 3832).

Sandy woods and savannas, Bahamas, Cuba, and Hispaniola.

In the Grasses of the West Indies ${ }^{26}$ this species was referred to A. gyrans Chapm. of Florida. In the North American Species of Aristida ${ }^{27}$ it was referred to A. purpurascens Poir., of the southern United States.

Bahamas: New Providence, Eggers 4447.

Cuba: Pinar del Río, Hitchcock 23258, 23266, 23282, 23309. Los Palacios, Léon 7395. Herradura, Hitchcock 232; Tracy 9095. Chirigota, Wright 3831, 3832. Camagüey, Ekman (Amer. Gr. Nat. Herb. 791). Baraguá, Hitchcock 23375. Sierra de Nipe, Ekman 3086. Isla de Pinos, Taylor 20; Palmer and Riley 995.

HaIti: Acul-Samedi, Ekman H 9909.

Dominican Republic: Jarabaco, Ekman H 14160.

11. Aristida curtifolia Hitchc., Contrib. U. S. Natl. Herb. 12: 235. 1909. Cuba, Wright 736.

Culms densely tufted, stiffly erect, wiry, 20 to $60 \mathrm{~cm}$ tall, the alternate nodes often shortened, thus bringing the leaves together in approximate pairs; blades short, thickish, stiffly spreading, flat or mostly soon involute, 5 to $20 \mathrm{~mm}$ long, 0.5 to $1 \mathrm{~mm}$ wide, or the upper reduced to mere awns 2 to $3 \mathrm{~mm}$ long; panicles narrow, nearly

${ }^{26}$ Contrib. U. S. Natl. Herb. 18: 366. 1917.

${ }_{27}$ Contrib. U. S. Natl. Herb. 22: 571. 1924. 
simple, 5 to $10 \mathrm{~cm}$ long, the spikelets nearly sessile; glumes nearly equal, 8 to $9 \mathrm{~mm}$ long, acute; lemma 5 to $6 \mathrm{~mm}$ long, the callus $0.5 \mathrm{~mm}$ long; awns about equal, 10 to $12 \mathrm{~mm}$ long, spreading but not curved or contorted at base (fig. 55).

Dry hills and barrens, Cuba.

Cuba: Las Posas "in cuabales", Ekman 12739. Guanabacoa, Ekman 10898, 10899; Hitchcock 498, 23231; Léon 873, 4645; Baker and Hasselbring 7211. San Miguel de los Baños, Killip 13831, 13858, 13889, 13902. Pastelillo, Ekman 15410. Santiago de Cuba, Ekman 8953, 15628. Río Seboruco to Falls of Río Mayarí, Shafer 3694. Holguín, Ekman 15738. Mayarí, Ekman 15863. Without locality, Wright 736.

12. Aristida portoricensis Pilger, in Urban, Symb. Antill. 4: 100. 1903. Puerto Rico, Sintenis 77.

Culms tufted, often in large bunches, slender, erect or spreading at base, 30 to $50 \mathrm{~cm}$ tall; blades involute, somewhat curved or flexuous, mostly 5 to $10 \mathrm{~cm}$ long, scarcely $1 \mathrm{~mm}$ thick when rolled; panicles narrow, loose, few-flowered, mostly 3 to $8 \mathrm{~cm}$ long, the few distant branches rather stiffly ascending, mostly floriferous from the base; glumes awn-pointed, the first about $7 \mathrm{~mm}$ long, the second about 10 $\mathrm{mm}$ long; lemma 10 to $12 \mathrm{~mm}$ long including the $1 \mathrm{~mm}$ long callus and the 2 to $3 \mathrm{~mm}$ long slightly twisted scabrous neck; awns about equal, divergent or horizontally spreading, 2 to $3 \mathrm{~cm}$ long, slightly contorted at base.

Stony or barren slopes, Puerto Rico.

Puerto Rico: Mayaguez, Sintenis 77; Chase 6269, 6298, 6812; Britton, Cowell, and Brown 4361; Holm 40.

13. Aristida chaseae Hitche., Contrib. U. S. Natl. Herb. 22: 575. 1924. Boqueron, Puerto Rico, Chase 6507.

Culms few in a tuft, widely spreading, 50 to $60 \mathrm{~cm}$ long; blades involute, 10 to $15 \mathrm{~cm}$ long; panicles narrow, 10 to $15 \mathrm{~cm}$ long; glumes equal or somewhat unequal, 10 to $13 \mathrm{~mm}$ long, acuminate or awnpointed; lemma about $12 \mathrm{~mm}$ long, narrowed at the summit but scarcely beaked, scaberulous on the upper half; callus $1 \mathrm{~mm}$ long, densely pilose, the upper hairs about $1 \mathrm{~mm}$ long; awns equal, somewhat divergent, flat at base, not contorted, about $2 \mathrm{~cm}$ long.

Open stony hills, Puerto Rico, known only from the type collection.

14. Aristida swartziana Steud., Syn. Pl. Glum. 1: 137. 1854. Jamaica.

Culms tufted, with numerous erect innorations, 40 to $70 \mathrm{~cm}$ tall; blades involute; mostly erect, as much as $30 \mathrm{~cm}$ long, about $1 \mathrm{~mm}$ wide; panicles narrow, loose and interrupted, as much as $15 \mathrm{~cm}$ long, the branches ascending, 1 to $3 \mathrm{~cm}$ long, usually rather lax, severalflowered; first glume about $7 \mathrm{~mm}$ long, the second about $1 \mathrm{~mm}$ longer; lemma about as long as the second glume or a little longer; callus 0.5 $\mathrm{mm}$ long, the pubescence short and soft; awns about equal, ascending or somewhat spreading, 15 to $25 \mathrm{~mm}$ long:

Rocky savannas and open ground, Jamaica, Hispaniola, and Leeward Islands. Described by Swartz as A. adscensionis L.

JAmaica: New Forest, southern Manchester, Hitchcock 9845 (Amer. Gr. Nat. Herb. 790). Lititz Saranna, Harris 12440. Healthshire Hills, Harris 9542. Gordon Town, Hart 864. 


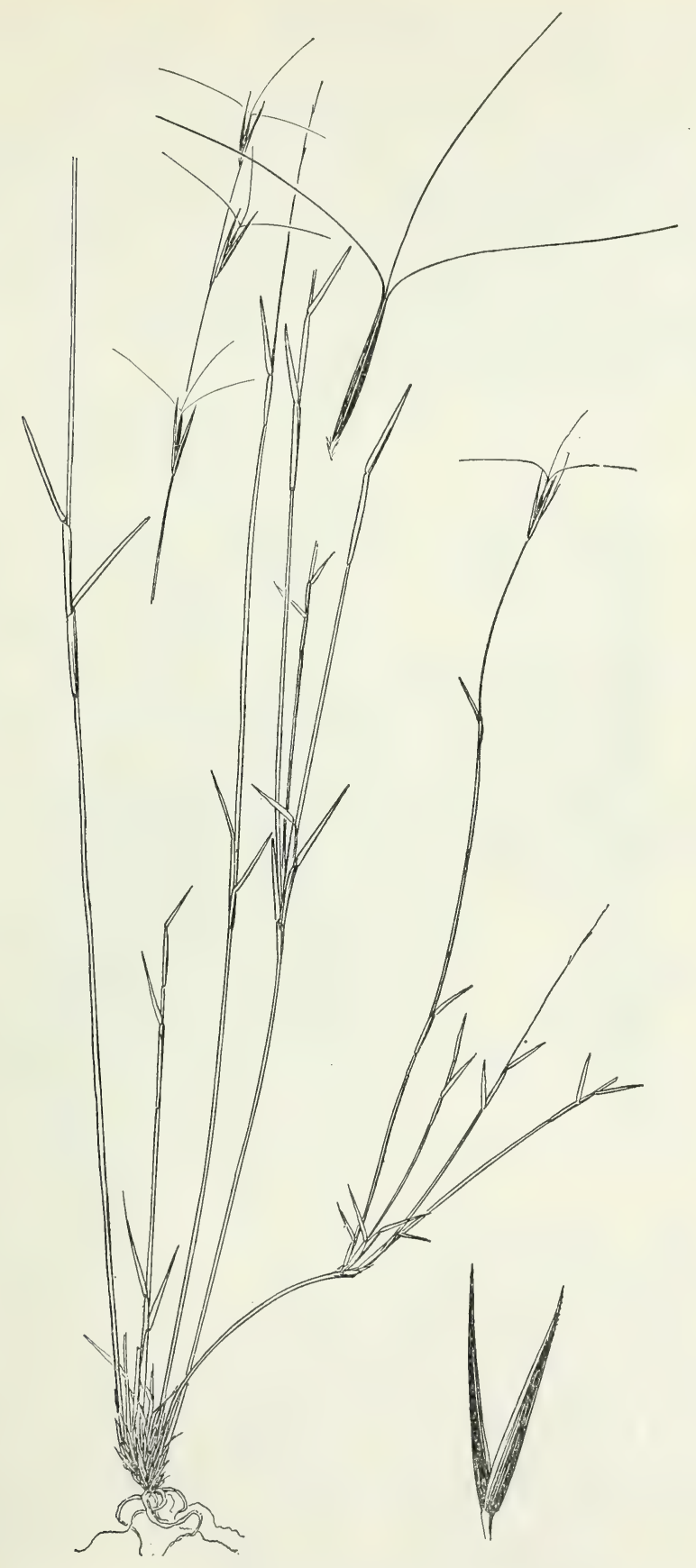

Figure 55.-Aristida curtifolia. Plant, $\times 1$; glumes and floret, $\times 2$ (type). $60256-36-7$ 
Harti: Port-au-Prince, Ekman H 2019.

Leeward Islands: Antigua, Box 38, 62.

15. Aristida cognata Trin. and Rupr., Mem. Acad. St. Pétersb. VI. Sci. Nat. $5^{1}: 127.1842$. St. Thomas.

Culms ascending, 20 to $40 \mathrm{~cm}$ tall; blades involute, 5 to $15 \mathrm{~cm}$ long, about $1 \mathrm{~mm}$ wide; panicles narrow, loose, 5 to $15 \mathrm{~cm}$ long, the branches rather distant, ascending, mostly closely flowered, 1 to $2 \mathrm{~cm}$ long; glumes acuminate, the first 4 to $5 \mathrm{~mm}$ long, the second 1 to $2 \mathrm{~mm}$ longer; lemma 6 to $7 \mathrm{~mm}$ long, gradually narrowed into a scaberulous beak about $1 \mathrm{~mm}$ long; callus about $0.7 \mathrm{~mm}$ long, the hairs short and soft, awns about equal, ascending, 10 to $15 \mathrm{~mm}$ long.

Dry hillsides, Virgin Islands and Montserrat.

Virgin Islands: St. Thomas, Britton and Shafer 119; Rose 3189; Eggers in 1882. St. Croix, Benzon.

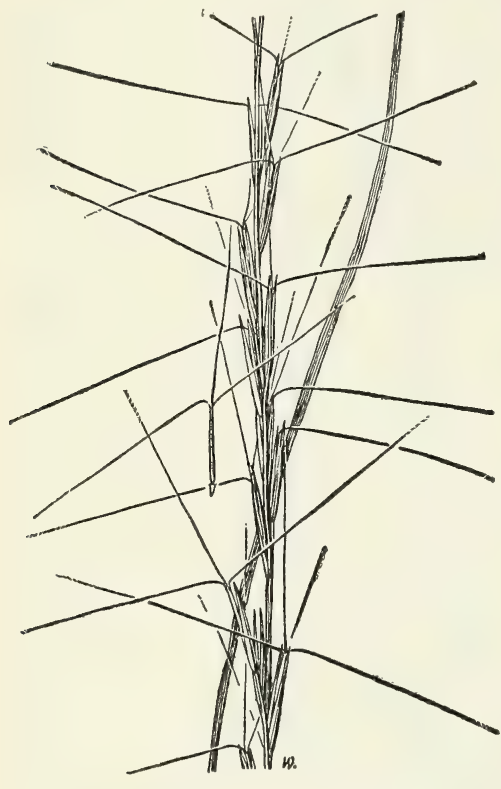

Figure 56.-Aristida affinis, $\times 1$ (Combs 688). St. John, Eggers 3003.

Wind WARD IsIands: Montserrat, Shafer 48, 430.

16. Aristida affinis (Schult.) Kunth, Rév. Gram. 1: 61.1829.

Chaetaria affinis Schult., Mant. 2: 210. 1824. Pennsylvania. Aristida virgata var.? palustris Chapm., Fl. South. U. S. 555. 1860. Florida.

Aristida palustris Vasey, Descr. Cat. Grasses U. S. 35.1885.

Culms tufted from a hard thickened base, stiffly erect, rather stout, 1 to $1.5 \mathrm{~m}$ tall; panicle narrow and virgate, as much as $50 \mathrm{~cm}$ long; glumes about equal, mucronate, about $12 \mathrm{~mm}$ long; lemma about 8 $\mathrm{mm}$ long, glabrous, the callus $1 \mathrm{~mm}$ long, short-pubescent; central awn horizontally spreading, 1.5 to $3 \mathrm{~cm}$ long, the lateral erect, two-thirds to three-fourths as long (fig. 56).

Low pine barrens, southern United States and Cuba.

Cuba: Pinar del Río, Ekman 17870. Remates, Ekman 11230.

17. Aristida brittonorum Hitchc., Contrib. U. S. Natl. Herb. 22: 584. 1924. Isla de Pinos, Britton, Britton, and Wilson 14169.

Culms rather stout, erect, 60 to $100 \mathrm{~cm}$ tall; blades firm, involute, stiffly erect, the basal as much as $30 \mathrm{~cm}$ long and $0.8 \mathrm{~mm}$ thick when rolled; panicles narrow, interrupted, 20 to $30 \mathrm{~cm}$ long, the branches appressed, the lower as much as $5 \mathrm{~cm}$ long; glumes acuminate, the first 7 to $10 \mathrm{~mm}$ long, the second 10 to $12 \mathrm{~mm}$ long; lemma about 7 $\mathrm{mm}$ long, the sharp callus $1 \mathrm{~mm}$ long, the pubescence fine and short, the beak about $1 \mathrm{~mm}$ long; awns abcut equal, 1.5 to $2 \mathrm{~cm}$ lor.g, widely spreading, all contorted at base.

White sand in pineland, Isla de Pinos, Cuba.

Cuba: Isla de Pinos, Britton, Britton, and Wilson 14169; Ekman 11983, 12024, 12495. 
18. Aristida calcicola Hitchc. and Ekman, N. Amer. Fl. 17: 405. 1935. Cuba, Ekman 15774.

Perennial; culms densely cespitose, erect, slender, wiry, glabrous, about 2-noded, sometimes branching, 30 to $50 \mathrm{~cm}$ tall; sheaths glabrous, pilose at the throat; ligule a ciliate membrane about $0.5 \mathrm{~mm}$ long; blades flat or mostly involute, glabrous beneath, scabrouspubescent on the upper surface, usually 5 to $10 \mathrm{~cm}$ long, those of the culms often shorter, mostly less than $1 \mathrm{~mm}$ wide when flat; panicles narrow, 7 to $15 \mathrm{~cm}$ long, the few branches appressed, bearing 1 to few spikelets; glumes somewhat unequal, acuminate, about $1 \mathrm{~cm}$ long, the first 1 to $2 \mathrm{~mm}$ shorter than the second, glabrous except the keel of the first; lemma 8 to $10 \mathrm{~mm}$ long, slender, scabrous on the upper part, the callus rather slender, densely short-pilose, about $1 \mathrm{~mm}$ long; awns about equal, about equally divergent, 1.5 to $3 \mathrm{~cm}$ long, somewhat contorted at base.

Limestone hillsides, Cuba and Hispaniola.

Cuba: Guantánamo, Ekman 15774.

Dominican Republic: Monte Cristi, Ekman H 13158.

19. Aristida rosei Hitchc., Contrib. U. S. Natl. Herb. 22: 584. 1924. Dominican Republic, Rose, Fitch, and Russell 4027.

Culms tufted, slender, wiry, often firm and stiff, erect, 30 to 80 $\mathrm{cm}$ tall; blades involute, ascending or spreading, from less than $5 \mathrm{~cm}$ to more than $15 \mathrm{~cm}$ long; panicles narrow, rather lax, 5 to $20 \mathrm{~cm}$ long, the branches and pecicels delicate, appressed or ascending, fewflowered, the lower distant; the first glumes acuminate, mucronate, 5 to $8 \mathrm{~mm}$ long, the second 1 to $2 \mathrm{~mm}$ longer; lemma 6 to $7 \mathrm{~mm}$ long, the callus $0.5 \mathrm{~mm}$ long, rather finely pubescent, the beak indistinct, about $1 \mathrm{~mm}$ long; awns about equal, divergent, only minutely scabrous, 1 to $1.5 \mathrm{~cm}$ long, contorted at base.

Dry or rocky slopes, Cuba and Hispaniola.

Cuba: Pinar del Río City, Ekman 17800.

Haiti: Ennery, Leonard 8824, 8850; Ekman H 2454. Cabaret, Leonard 12108. Môle-St.-Nicolas, Leonard 13215, 13313. Croixdes-Bouquets, Ekman H 2161, H 2316, H 2316b. Gros-Morne, Ekman H 4938. Habitation Prince, Picarda 1554. Port-au-Prince, Ekman H 2019, H 9281.

Dominican Republic: Azua, Rose, Fitch, and Russell 4027. Santiago, Ekman H 15965.

20. Aristida refracta Griseb., Cat. Pl. Cub. 228. 1866. Cuba, Wright 3431.

Culms usually densely tufted with numerous innovations, erect, slender, 20 to $60 \mathrm{~cm}$ tall; blades filiform-involute, mostly less than 10 $\mathrm{cm}$ long; sometimes as much as $20 \mathrm{~cm}$ long; panicles narrow, rather lax, 5 to $15 \mathrm{~cm}$ long, the branches ascending, at maturity rather stiff, few-flowered, sometimes as much as $3 \mathrm{~cm}$ long; glumes unequal or nearly equal, the second mucronate from a bifid apex; lemma about $4.5 \mathrm{~mm}$ long, the callus $0.5 \mathrm{~mm}$ long, short-pilose, the summit scarcely beaked; awns about equal, or the lateral a little shorter, about $1 \mathrm{~cm}$ long, contorted at base.

Dry slopes and pine woods, Greater Antilles.

Cuba: Pinar del Río, Wright 3833, 3834; Hitchcock 23255, 23262. Guane, Léon 6942, 6971, 7307, 7308, 8971; Shafer 10414. Mántua, Shafer 11254. Laguna Jovero, Shafer 10718, 10864. Cajálbana, Léon 
4846. San Diego de los Baños, Léon 4845. Herradura, Hitchcock 233, 499; Ekman 17749. San Julián, Ełkman 11107. Las Pozas, Ekman 12737. La Grifa, Ekman 11246. Chirigota, Léon 7444, 7454; Wright 3431. Guanabacoa, Baker and Hasselbring 7208; Hitchcock 231, 23226; Léon 875, 2641, 4646, 1718, 5605, 5606. Baraguá, Hitchcock 23373. Mianacas, Léon 5830, 5863, 5874. Motembo, Léon 11338, 11340, 11342; Ekman 16816a. Placetas del Sur, Léon 8179. Manajanabo, Léon 5276. Camagüey, Ekman in 1922 (Amer. Gr. Nat. Herb. 792), Woodfred, Shafer 2990, 3080. Cajobabo, Léon 12316. Guara, Hitchcock 23425, 23426. Holguín, Ekman 15719. Loma Menqura, Shafer 3858. Without locality, Wright 3430. Isla de Pinos, Britton and Wilson 15369.

JAMAICA: Ashley Hall, Harris 12734. Lititz Savanna, Harris 12433. New Forest, Hitchcock 9853 (Amer. Gr. Nat. Herb. 793).

Haitr: Acul-Samedi, Ekman H 9908. St. Michel de l'Atalaye, Ekman H 9402.

Dominican Republic: Monción, Ekman H 12634.

Puerto Rico: Miayaguez, Britton, Cowell, and Brown 4358. Boqueron, Chase 6508.

\section{TRIBE 6. ZOYSIEAE}

\section{LEPTOTHRIUM Kunth, Rév. Gram. 1: 156. 1829}

Spikelets solitary; glumes much exceeding the single minute floret, the tips diverging, the first subulate, not at all clasping, the second laterally compressed above; pedicel falling with the spikelet, forming a pointed callus. Densely tufted perennial with slender rigid shortjointed culms branching toward the summit, short stiff divergent blades, and partially included spikes of narrow spikelets along a slender axis.

1. Lepłothrium rigidum Kunth, Rév., Gram. 1: 156. 1829. “America calidior.'

Culms 30 to $40 \mathrm{~cm}$ tall; blades 1 to $3 \mathrm{~cm}$ long; spikes 5 to $10 \mathrm{~cm}$ long, flexuous; spikelets about $8 \mathrm{~mm}$ long, at first erect, becoming divergent or reflexed (fig. 57).

In sand along the seacoast, Jamaica, Venezuela, and Santa Marta, Colombia.

Janicica: Palisadoes, Port Royal, Hitchcock 9753; Harris (Amer. Gr. Nat. Herb. 287) 11357; Brition and Hollick 1729.

\section{ANTHEPHORA Schreb., Beschr. Gräs. 2: 105. pl. 44.1810}

Spikelets in clusters of 4 , the indurate first glumes united at base, forming a pitcher-shaped pseudo-involucre, the clusters subsessile and erect on a slender flexuous continuous axis; glumes rigid, acute, or prodiced into short awns. Ours annual with flat blades and narrow spikes.

1. Anthephora hermaphrodita (L.) Kuntze, Rev. Gen. Pl. 2: 759. 1891.

Tripsacum hermaphrodium L., Syst. Nat. ed. 10. 2: 1261.1759. Jamaica.

Anthe hera clegans Schreb., Beschr. Gräs. 2: 105. 1810. Jamaica. 


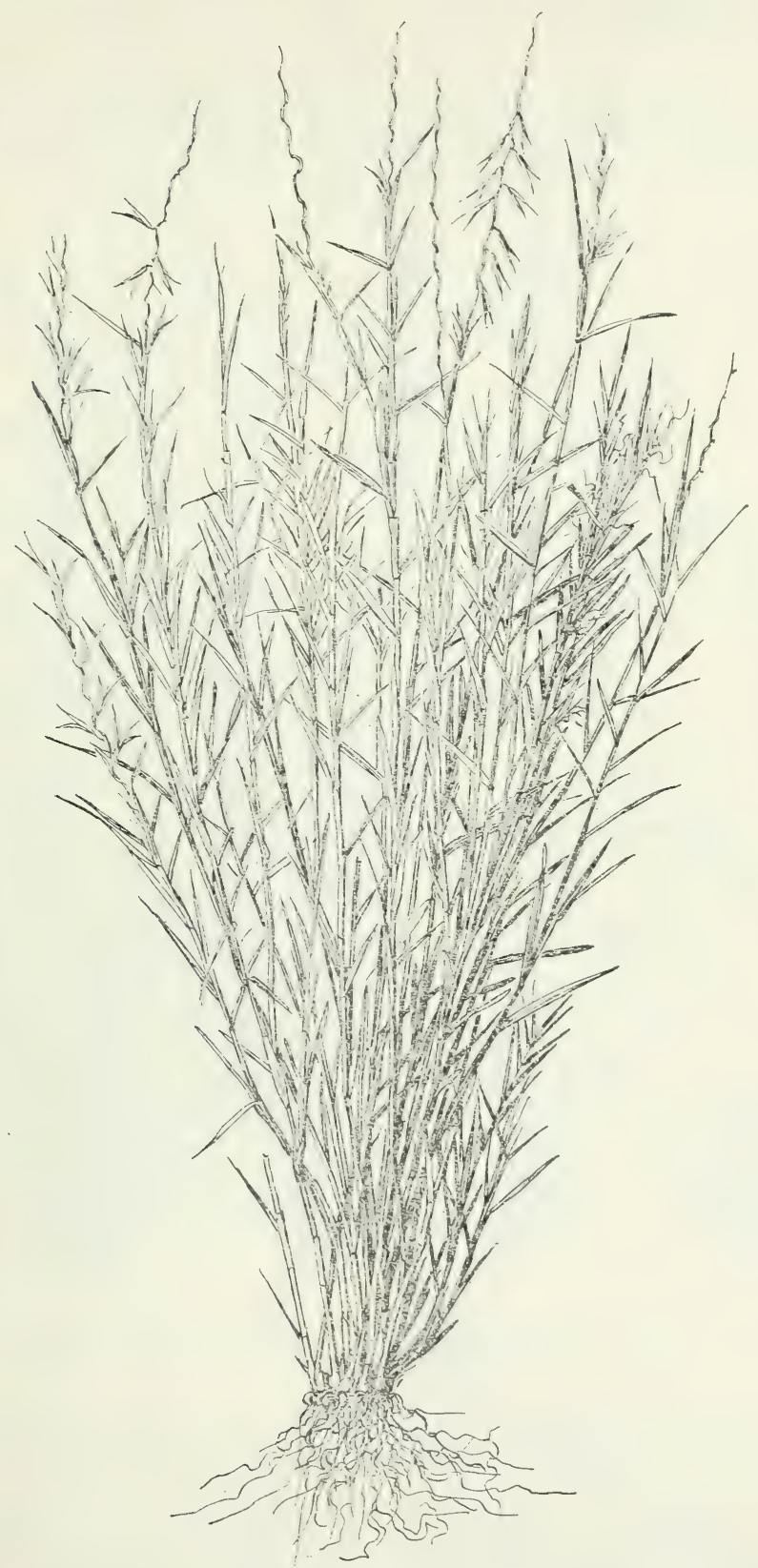

FIGURE 57.-Leptothrium rigidum. Plant, $\times 1 / 2$ (Harris, Amer. Gr. Nat. Herb. 287). 
Anthephora villosa Spreng., Neu. Entd. 3: 14. 1822. West Indies, the pubescent form.

Cenchrus villosus Spreng., Syst. Veg. 1: 301. 1825.

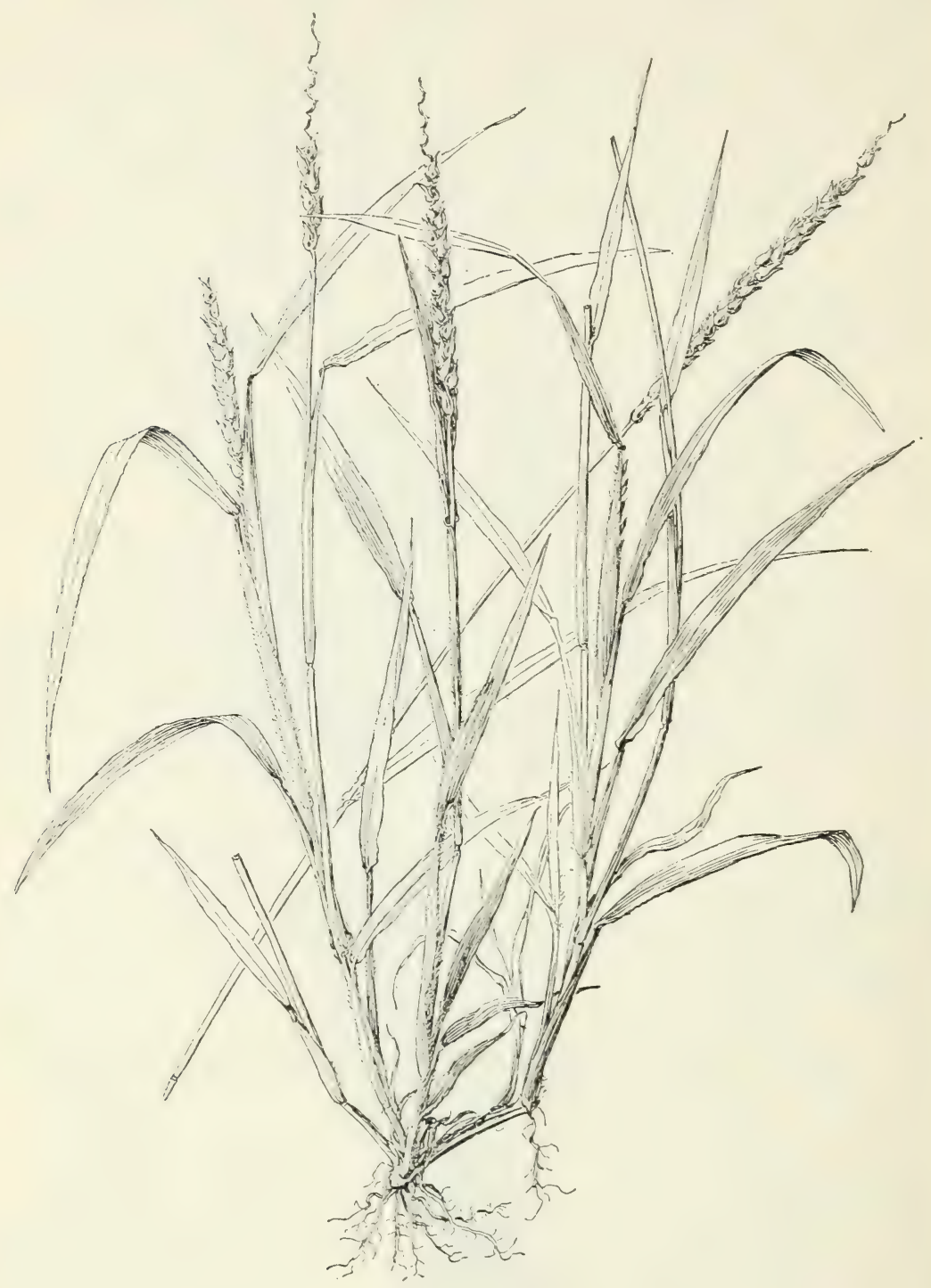

FIGLRE 58.-Anthephora hermaphrodita, $\times 1 / 2$ (Harris 12679).

Leafy ascending or decumbent branching annual; culms mostly 20 to $50 \mathrm{~cm}$ tall; blades flat, thin, 5 to $10 \mathrm{~mm}$ wide; spikes erect, 5 to $10 \mathrm{~cm}$ long; glumes 5 to $7 \mathrm{~mm}$ long (fig. 58 ).

A common weed throughout the West Indies and other parts of tropical America. 
43. TRAGUS Hall., Stirp. Helv. 2: 203.1768.

(Nazia Adans., Fam. Pl. 2: 581. 1763. No generic description)

Spikelets 1-flowered, in small spikes of 2 to 5 , the spikes subsessile, falling entire, the spikelets sessile on a very short zigzag rachis, the first glumes small, thin, or wanting, appressed to the rachis, the second glumes of the two lower spikelets strongly convex with 3

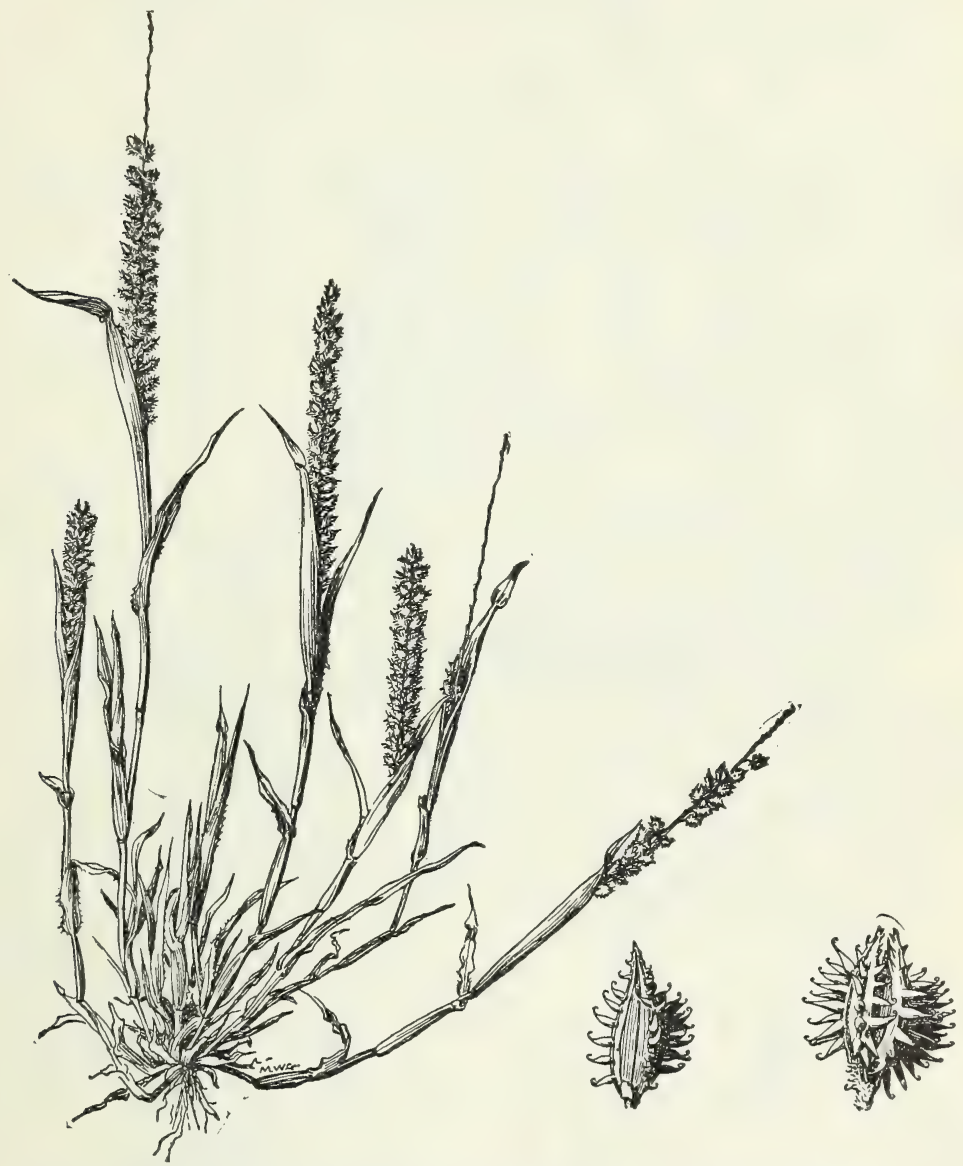

FIGURE 59.-Tragus berteronianus. Plant, $\times \frac{1}{2}$; bur and spikelet, $\times 5$ (Hitcheock 3745 ).

thick nerves bearing a row of squarrose, stout hooked prickles along each side, the 2 second glumes forming the halves of a little bur, the upper 1 to 3 spikelets reduced and sterile; lemmas and palea thin, the lemma flat, the palea strongly conver. Low annuals with flat blades and narrow spikes.

1. Tragus berteronianus Schult., Mant. 2: 205. 1824. Santo Domingo.

Culms branched at base, spreading, 10 to $40 \mathrm{~cm}$ long; blades firm, mostly less than $5 \mathrm{~cm}$ long, 2 to $4 \mathrm{~mm}$ wide, the cartilaginous 
margin bearing stiff white hairs or short slender teeth; racemes dense, 4 to $10 \mathrm{~cm}$ long, 4 to $5 \mathrm{~mm}$ thick; burs 2 to $3 \mathrm{~mm}$ long, nearly sessile, the apex scarcely exceeding the spines (fig. 5\%).

This species has been erroneously referred to Tragus alienus (Spreng.) Schult. (Lappago aliena Ŝpreng.; Tazia a'iena Scribn.).

Open arid ground, solithwestern United States and the Test Indies to Brazil. Occurs on probably all the islands.

\section{TRIBE 7. CHLORIDEAE}

\section{LEPTOCHLOA Beaur., Ess. Aorost. 71, 166. pl. 1.. f. 1. 1812 SPRANGLETOP}

Spikelets 2- to sereral-flowered, sessile or short-pediceled, approximate or somethat distant along one side of a slender rachis, the rachilla disarticulating abore the glumes and between the florets; glumes unequal or nearly equal, amnless or mucronate, 1-nerred, usually shorter than the first lemma; lemmas obtuse or acute, sometimes 2-toothed and mucronate or short-amned from between the teeth, 3-nerred, the nerres sometimes pubescent. Annuals or perennials with flat blades and numerous racemes scattered along a cornmon axis forming a long or sometimes short panicle.

Plants annual.

Sheaths, at least the upper, papillose-hispid.

Sheaths glabrous or scabrous.

Lemmas awned, the awn sometimes short

1. L. FILIFORMIS.

Lemmas awnless.

Florets acuminate; sheaths scabrous

2. L. FASCICULARIS.

Florets obtuse; sheaths glabrous or slightly scabrous.

Spikelets 5 to $7 \mathrm{~mm}$ long, 6-to 9-flowered, lead-color. 3. L. UNinervia

Plants perennial.

Spikes slender, 15 to $20 \mathrm{~cm}$ long.

Spikes mostly less than $10 \mathrm{~cm}$ long.

Blades involute.

Blades flat or loosely involute in drying.

Sheaths and blades glabrous, usually somewhat glaucous; amnless or the awns shorter than body of lemma

Sheaths sparsely papillose-hispid; blades sparsely villous on the upper surface near the base; awns or some of them about as long as their

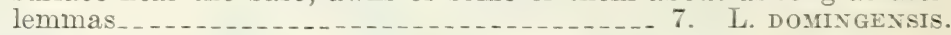

1. Leptochloa filiformis (Lam.) Beaur., Ess. Agrost. 71, 166.1812.

RED SPRANGLETOP.

Festuca filiformis Lam., Tabl. Encycl. 1: 191. 1791. Tropical America.

Eleusine mucronata Michx., Fl. Bor. Amer. 1: 65. 1803. Illinois.

Rabdochloa? mucronata Beaur., Ess. Agrost. 84, 176. 1512.

Leptochloa mucronata Kunth, Rér. Gram. 1: 91. 1829.

Leptochloa brachiata Steud., Srn. Pl. Glum. 1: 209. 15j4. Guadeloupe.

Plants often purplish or reddish; culms erect or often branching and geniculate below, 40 to $70 \mathrm{~cm}$ tall, or often dwarf: blades flat, thin, as much as $1 \mathrm{~cm}$ wide; panicle somewhat riscid, of numerous approximate slender racemes 5 to $15 \mathrm{~cm}$ long on an axis mostly half the entire length of the culm; spilielets, 3 - to t-lowered, 1 to $2 \mathrm{~mm}$ long; glumes acuminate, longer than the first floret, often as long as the spikelet; lemmas awnless, pubescent on the nerves, $1.5 \mathrm{~mm}$ long: (fig: 60). 


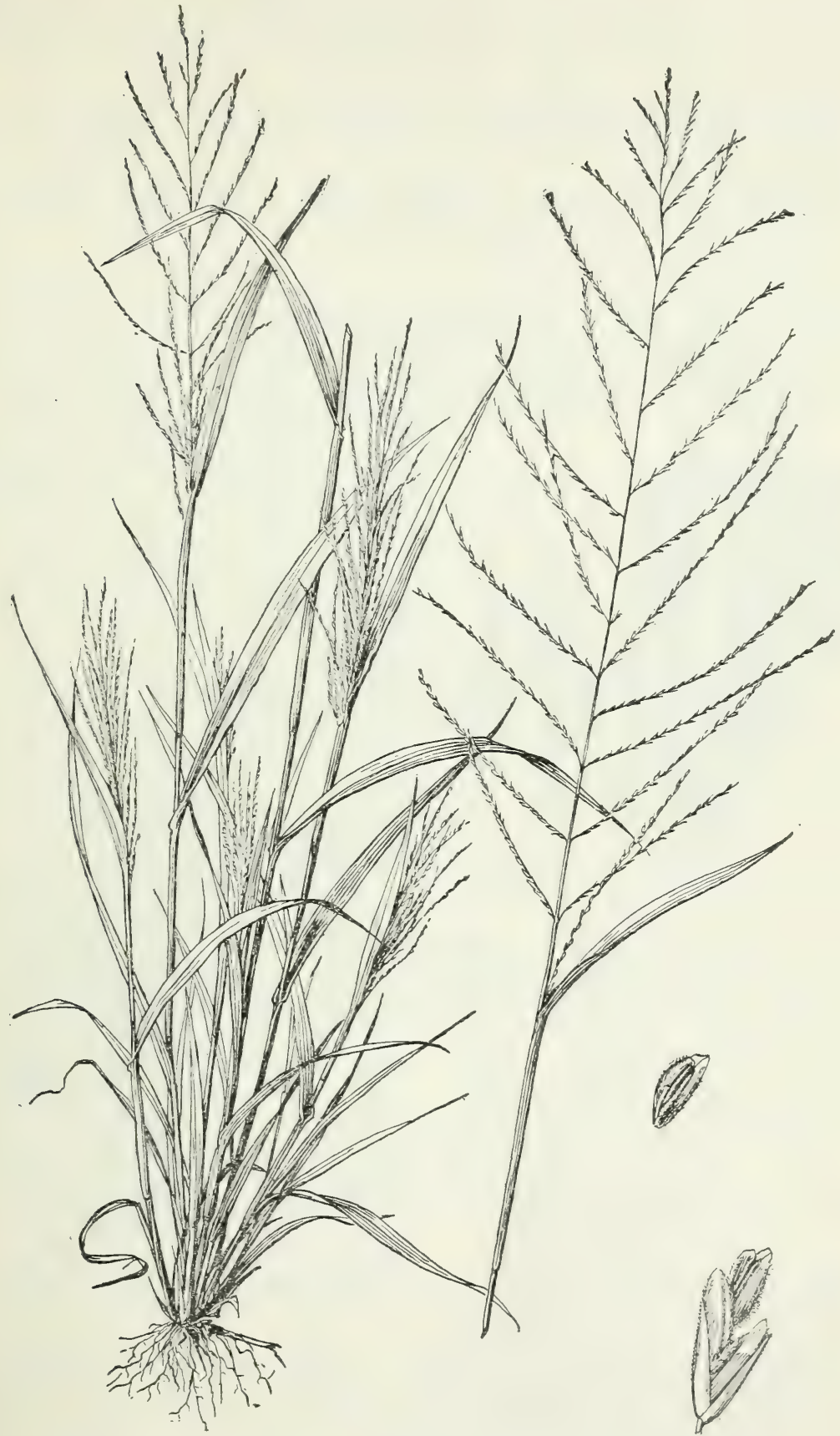

Figdre 60.-Leptochloa filiformis. Plant, $\times 1 \frac{1}{2}$; spikelet and floret, $\times 10$ (Ruth 51). 
Fields and open ground, Virginia to California, south to South America. A common weed in fields throughout the West Indies, except the Bahamas. Leptochloa mucronata var. multiflora Eggers ${ }^{28}$ is listed, without description, from St. Croix.

\section{Leptochloa fascicularis (Lam.) A. Gray, Man. 588. 1848.}

Festuca fascicularis Lam., Tabl. Encycl. 1: 189. 1791. South America.

Festuca polystachya Michx., Fl. Bor. Amer. 1: 66. 1803. Illinois. Festuca thouini Steud., Syn. Pl. Glum. 1: 311. 1854. Santo Domingo.

Somewhat succulent; culms erect to spreading or prostrate, freely branching, 30 to $100 \mathrm{~cm}$ tall; blades flat to loosely involute; panicles more or less included, mostly 10 to $20 \mathrm{~cm}$ long, often smaller, the racemes several to numerous, as much as $10 \mathrm{~cm}$ long, usually ascending or appressed, or at maturity spreading; spikelets usually overlap-

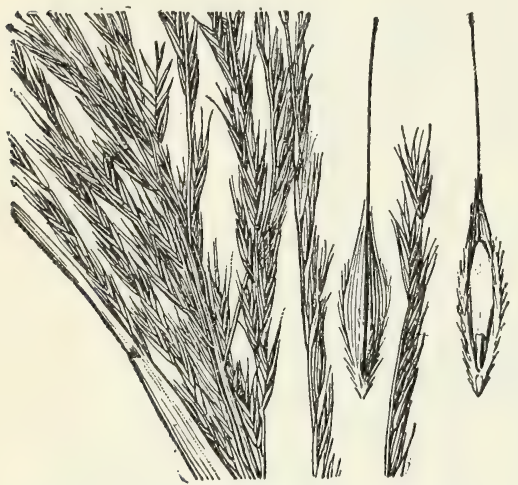

Figure 61.-Leptochloa fascicularis. Panicle, $\times$ 1 ; two views of floret, $\times 10$ (Hitchcock 7876). ping, 7 to $12 \mathrm{~mm}$ long, 6 - to $12-$ flowered; lemmas 4 to $5 \mathrm{~mm}$ long, the lateral nerves pubescent below, acuminate, the awn from short to as long as the body (fig. 61).

Ditches and moist ground, United States, Mexico, and the West Indies.

Bahamas: Great Exuma, Britton and Millspaugh 3108. New Providence, Britton and Brace 504.

Cuba: Habana, Léon 753, 864, 1509, 2020. Batabanó, Hitchcock 251; Ekman 889. Romelie, Eggers 4834. Corrientes Bay, Britton and Cowell 9984. Central Orosco, Ekman 10570. Baraguá, Hitchcock 23337. Guantánamo, Léo n

3911. Without locality, Wright 3812, 3822.

JAMAICA: Black River, Hitchcock 9643. Port Henderson, Ridley 132. Savanna-la-Mar, Hitchcock 9863. St. Anns Bay, Britton 2519. Ferry Pen, Harris 12498.

Haiti: Etang, Leonard 3520. Cape Haitien, Ekman H 2750. Port-au-Prince, Ekman H 2105; Buch 1801, 1869. Miragoane, Ekman H 7257. Gourjon, Ekman H 6453.

Virgin Islands: St. Croix, Thompson 407; Ricksecker 306.

Leeward Islands: Antigua, Box 8, 33, 34, 47.

3. Leptochloa uninervia (Presl) Hitchc. and Chase, Contrib. U. S. Natl. Herb. 18: 383. 1917.

Megastachya uninervia Presl, Rel. Haenk. 1: 283. 1830. Mexico. Leptochloa imbricata Thurb., in S. Wats., Bot. Calif. 2: 293.1880. California.

Perennial, resembling $L$. fascicularis, rather sparingly branching, usually strictly erect, the panicle more oblong in outline, with shorter,

${ }^{26}$ Vidensk. Medd. Naturhist. Forening. Copenhagen (III) 8: 151. 1876. 
denser-flowered racemes; spikelets, 5 to $7 \mathrm{~mm}$ long, 6- to 9-flowereci, lead-color; glumes broader, more obtuse; lemmas scarcely narrowed toward tip, apiculate but not awned, the lateral nerves more or less excurrent (fig. 62).

Ditches and wet open ground, southwestern United States, Cuba, and Jamaica, and south to Argentina and Chile.

CuBA: Guantánamo, Hioram 1359.

Jamaica: Salt Ponds, Harris 12309, 12311.

4. Leptochloa scabra Nees, Agrost. Bras. $435^{\circ}$ 1829. Brazil.

Annual; culms erect, about $1 \mathrm{~m}$ tall, somewhat robust and succulent; sheaths and blades scabrous, the blades elongate, 8 to $12 \mathrm{~mm}$ wide; panicle 20 to $40 \mathrm{~cm}$ long, not more than $7 \mathrm{~cm}$ wide, the slender racemes crowded, 4 to $8 \mathrm{~cm}$ long, ascending or somewhat drooping, usually curved or flexuous; spikelets crowded, mostly 3-flowered, about $3 \mathrm{~mm}$ long; lemmas acute, awnless, the nerves pubescent (fig. 63).

Ditches and shallow swamps, Louisiana, the West Indies, and Central America to Brazil.

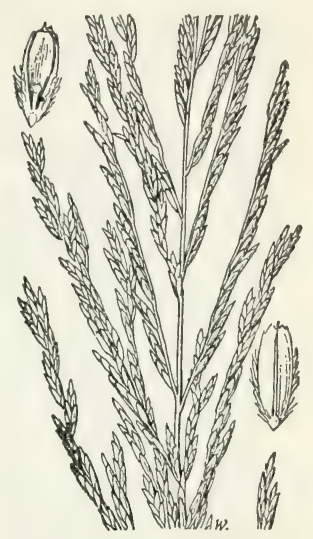

Figure 62.-Leptochloa uninervia. Panicle, $\times 1$; two views of floret, $\times 10$ ('Tharp 3123).

Dominican Republic: Villa Vásquez, Ekman H 13127a.

Puerto Rico: Aguirre, Britton and Earle 6495. Rio Piedras, Stevenson 2987. Cabo Rojo, Sintenis 844. Tabucoa, Sintenis 5103. Coamo, Sintenis 3282. Guayanilla, Shafer 1981. Bayamon, Hioram

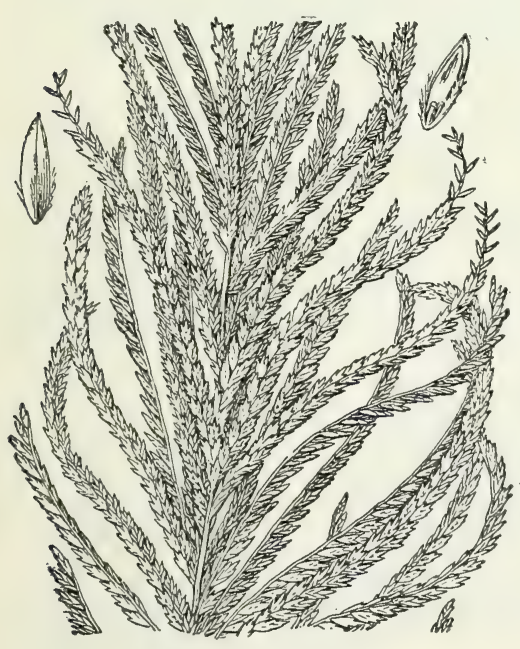

Figure 63.-Leptochloa scabra. Panicle, $\times 1$; two views of floret, $\times 10$ (Tracy 8388 ). 5, 325; Chase 6392. Anasco, Heller 4535. Ponce, Britton and Brown 5512; Chase 6493. Rio Grande, Chase 6715. Mayaguez, Chase 6289 .

Trinida D: Cedros, Broadway 4937; Hitchcock 10137. Arima, Hitchcock 10293. Cali fornia, Hitchcock 10106. Port-of-Spain, Hitchcock 10012. Pointe Gourde, Britton and Broadway 2652. Moruga, Britton and Broadway 2431. Palo Seco, Broadway 9238.

Toвago: Broadway 4739; Hitchcock 10259 .

\section{Leptochloa nealleyi Vasey, Bull.} Torrey Bot. Club 12: 7. 1885. Texas.

Annual, usually erect and rather robust; culms mostly 1 to $1.5 \mathrm{~m}$ tall, simple or sparingly branched at the base; sheaths glabrous or slightly scabrous, mostly keeled; blades elongate, flat to loosely involute; panicle commonly 25 to $50 \mathrm{~cm}$ long, not more than $4 \mathrm{~cm}$ wide, the racemes subverticillate, overlapping, 2 to $4 \mathrm{~cm}$ long, appressed or ascending; spikelets crowded, 3 - or 4 -flowered, 2 to $3 \mathrm{~mm}$ long; 
lemmas about $1.5 \mathrm{~mm}$ long, the apex obtuse, the nerves sparingly pubescent, the lateral close to the margin (fig. 64).

Wet woods, Texas, Mexico, and Cuba.

Cuba: Tiffin, Shafer 2904.

6. Leptochloa virgata (L.) Beauv., Ess. Agrost. 166. 1812.

Cynosurus virgatus L., Syst. Nat. ed. 10. 2: 876. 1759. Jamaica. Eleusine virgata Pers., Syn. Pl. 1: 87. 1805.

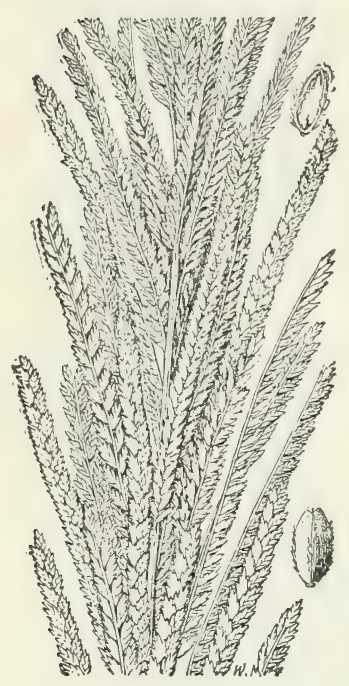

FIGURE 64.-Leptochloa nealleyi. Panicle. $X 1$; two views of floret, $\times 10$ (Fisher 25$)$.

Leptostachys virgata Meyer, Prim. Fl. Esseq. 74. 1818.

Oxydenia virgata Nutt.; Jacks., Ind. Kew. 3: 392. 1894 .

Leptochloa perennis Hack., Inf. Est. Centr. Agron. Cuba 1: 411. 1906. Cuba, Baker 4617.

Perennial; culms wiry, erect, 50 to $100 \mathrm{~cm}$ tall; blades flat; racemes several to many, slender, laxly ascending, 5 to $10 \mathrm{~cm}$ long, the lower distant, the others often aggregate; spikelets nearly sessile, mostly 3- to 5-flowered; lemmas 1.5 to $2 \mathrm{~mm}$ long, awnless or the lower with a short awn (fig. 65).

Open ground and grassy slopes, Mexico and the West Indies to South America. To be found on probably all of the West Indian islands.

7. Leptochloa domingensis (Jacq.) Trin., Fund. Agrost. 133. 1820.

Cynosurus domingensis Jacq., Misc. Austr. 2: 363. 1781. Probably Santo Domingo.

Rabdochloa domingensis Beau v. Ess. Agrost. 84, 176. 1812.

Chloris gracilis H. B. K., Nov. Gen. et Sp. Pl. 1:168. 1816. Peru. Leptochloa virgaía var. gracilis Nees; Griseb., Fl. Brit. W. Ind. 538. 1864 .

Leptochloa virgata var. domingensis Link; Griseb., Fl. Brit. W. Ind. 538.1864 .

Resembling L. virgata; sheaths and blades sparsely pilose; panicles more elongate, the racemes shorter and more numerous; lemmas

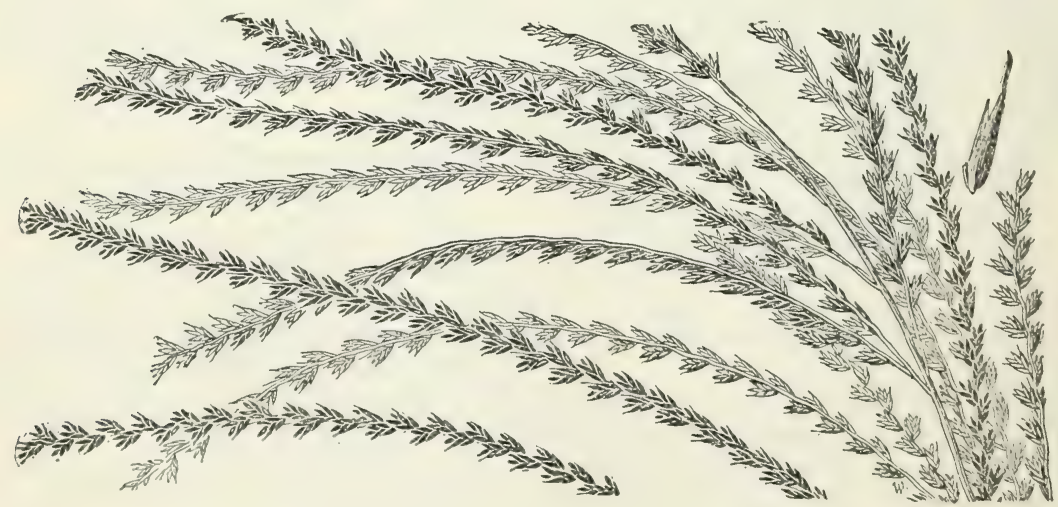

Figtre 65.-Leptochloa virgata. Panicle, $\times 1$; floret, $\times 10$ (Wilson 9402). 
appressed-pubescent on the internerves, awned, the awn of the lower florets of the spikelet 1 to $3 \mathrm{~mm}$ long (fig. 66).

Open ground and grassy banks, Florida, Mexico, and the West Indies.

Bahamas: New Providence, Hitchcock in 1890. Eleuthera, Hitchcock in 1890.

Cuba: Habana, Ekman 419a, 13122. Sancti Spíritus, Léon 863b. San Antonio, Eggers 5349. Santiago de Cuba, Léon 862, 865, 9767. Without locality, Wright 3436.

Jamaica: Hope Gardens, Ridley 120, 122. Kingston, Hitchcock 9253. Halls Delight, Harris 11261. Spanish Town, Ridley 128. Guava Ridge, Harris 11291, 11367, 11601. Barican, Hitchcock 9563. Ewarton, Hitchcock 9455. Alligator Pond, Hitchcock 9836; Harris 12447. East of Hope, Harris 12346. Lititz, Harris 11713, 11718.

Haitr: Gonaïve Island, Leonard 3106, 3300, 5123, 5145. Port-auPrince, Ekman H 1986. St. Marc, Leonard 2946. Tortuga Island, Leonard 15466. Bourdarie, Buch 1209.

Dominican Republic: Las Salinas, Fuertes 1428. Rincón, Fuertes 1283. Santiago, Ekman H 16042.

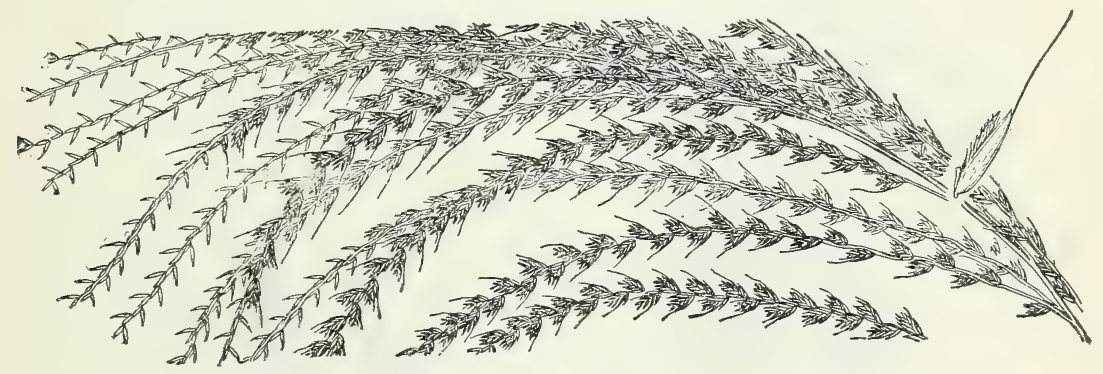

Figure 66.-Leptochloa domingensis. Panicle, $\times 1$; floret, $\times 10$ (Hiteheock 10055).

Leeward Istands: St. Kitts, Box 166. Antigua, Wullschlaegel.

Trinidad: Chacachacare, Hitchcock 10055 (Amer. Gr. Nat. Herb. 671). Mona Island, Broadway 5900. Port-of-Spain, Hitchcock 9994, 10196; Britton and Hazen 1689.

8. Leptochloa longa Griseb., Fl. Brit. W. Ind. 538. 1864. Trinidad.

Perennial; culms about $1.5 \mathrm{~m}$ tall, decumbent at base; blades 1.5 to $2.5 \mathrm{~cm}$ wide, the collar pilose; racemes several, very slender, spreading, loosely flowered, somewhat fascicled, 15 to $20 \mathrm{~cm}$ long; spikelets about 3 -flowered; lemmas about $3 \mathrm{~mm}$ long, the awn about as long as the lemma or a little longer.

Rich shady banks, Trinidad.

Trinidad: Manzanilla, Hitchcock 10377. San Fernando, Hitchcock 10082 (Amer. Gr. Nat. Herb. 672). Without locality, Bot. Gard. Herb. 3359 ; Crueger.

9. Leptochloa monticola Chase, Jour. Wash. Acad. Sci. 17: 73. f. 2. 1927. Haiti, Leonard 4751.

Perennial; culms densely tufted, erect, rigid, about $1 \mathrm{~m}$ tall; blades involute, 20 to $30 \mathrm{~cm}$ long, 2 to $6 \mathrm{~mm}$ wide (when flattened); panicle about $30 \mathrm{~cm}$ long, $8 \mathrm{~cm}$ wide, the numerous racemes approximate, stiffly ascending, the middle ones about $10 \mathrm{~cm}$ long; spikelets rather 
distant, 8 to $10 \mathrm{~mm}$ long, 6 - to 7 -flowered; lemmas about $5 \mathrm{~mm}$ long, densely pilose on the lower part of the nerves (fig. 67).

Higher mountains of Hispaniola.

Haitr: Pétionville, Ekman H 1352,H 1576. Badeau, Ekman H 7777. Furcy, Leonard 4751. Massif de la Selle, Ekman H 1576, H 3075.

Dominican Republic: San José de Ocoa, Ekman H 11874.

\section{GOUINIA Fourn., Mex. Pl. 2: 103.1886}

Spikelets, few-flowered, short-pedicellate, appressed, in slender elongate racemes, these racemosely arranged; glumes and lemmas keeled, the lemmas densely villous on the nerves, awned, the uppermost much reduced but awned. Erect or ascending perennials with linear blades and terminal panicles of slender racemes.

Blades 1 to $2 \mathrm{~mm}$ wide.

1. G. GRACILIS. Blades 5 to $12 \mathrm{~mm}$ wide

2. G. VIRGATA.

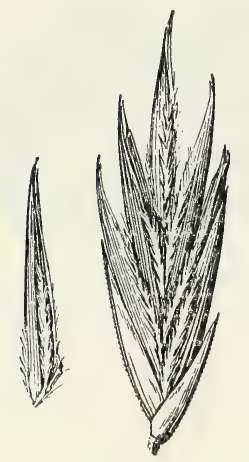

FIGURE 67 - Leptochloa monticola. Spikelet and floret, $\times 5$ (type).

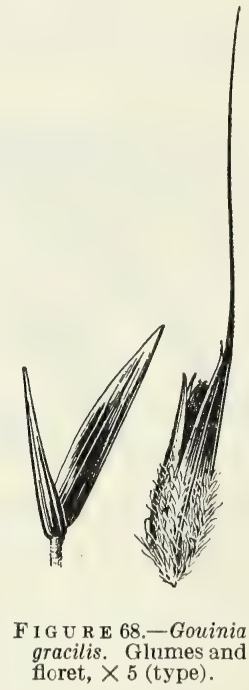

gracilis. Glumes an
floret, $\times 5$ (type)

1. Gouinia gracilis Ekman; Swallen, Amer. Jour. Bot. 22: 33. f. 1. 1935. Cuba, Ekman in 1922.

Culms slender, branching, sprawling or leaning, $70 \mathrm{~cm}$ long or more; blades flat or usually involute, as much as $14 \mathrm{~cm}$ long, not more than $2 \mathrm{~mm}$ wide; panicles 5 to $15 \mathrm{~cm}$ long, the branches stiffiy spreading or reflexed, the lower as much as $4.5 \mathrm{~cm}$ long; spikelets 2- or 3-flowered, short-pedicellate, stiffly and abruptly spreading or reflexed; lemmas 4 to $6 \mathrm{~mm}$ long, the awn 5 to $9 \mathrm{~mm}$ long (fig. 68).

Thickets, Cuba.

CubA: Holguín, Ekman in 1922, 3255. Mendoza, Ekman 11486.

2. Gouinia virgata (Presl) Scribn., U. S. Dept. Agr., Div. Agrost. Bull. 4: 10.1897.

Bromus virgatus Presl, Rel. Haenk. 1: 263. 1830. Mexico.

Festuen laxiflora A. Rich., in Sagra, Hist. Cuba 11: 318. 1850. Habana, Cuba. 


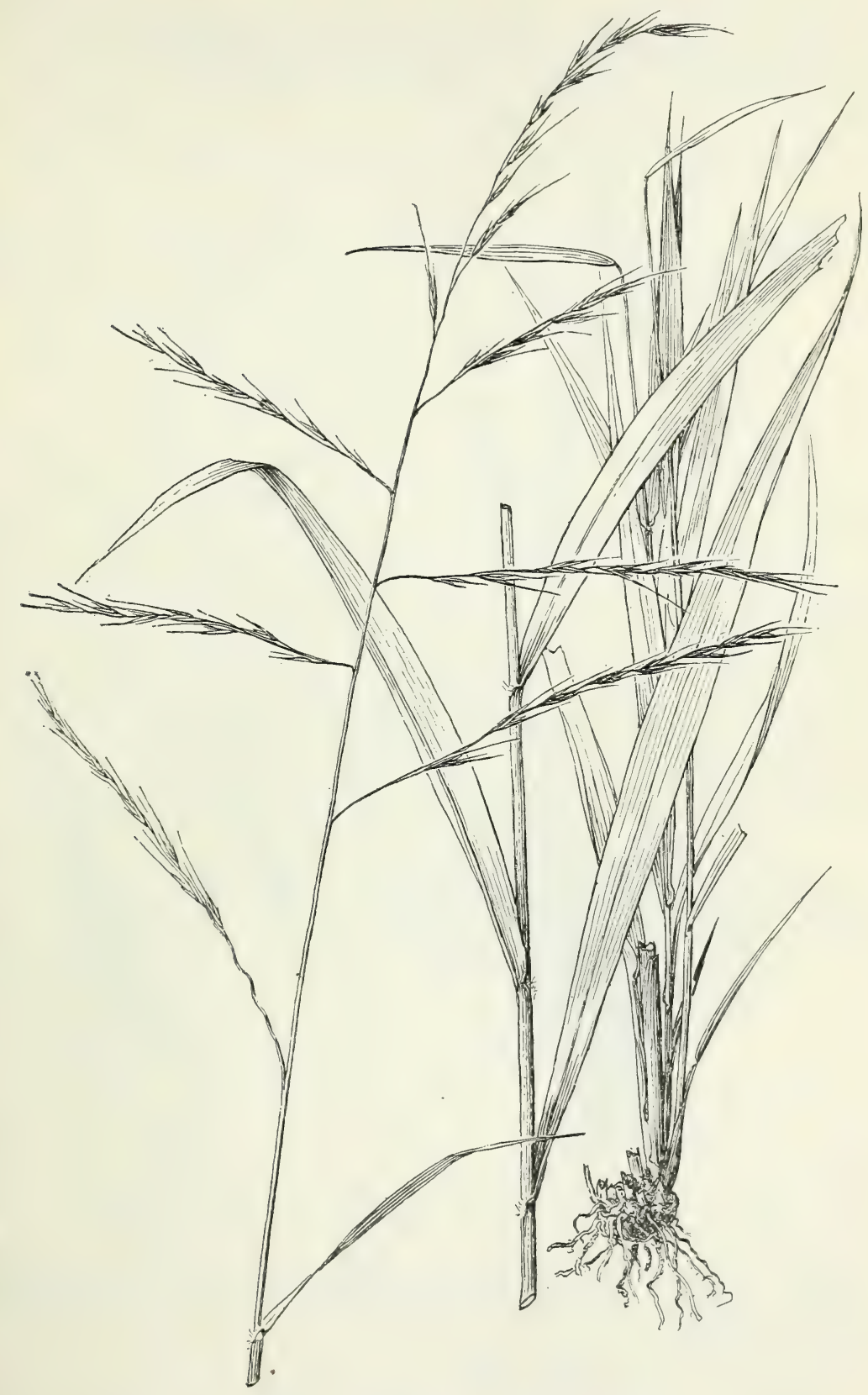

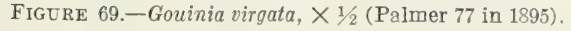


Diplachne virgata Hack., Oesterr. Bot. Ztschr. 52: 276. 1902.

Culms erect from a knotty base, usually about $1 \mathrm{~m}$ tall; blades flat, 5 to $15 \mathrm{~mm}$ wide; panicle 15 to $35 \mathrm{~cm}$ long, the branches stiffly spreading, the lower usually about $12 \mathrm{~cm}$ long, spikelet-bearing from the base; spikelets mostly 2- or 3 -fiowered; lemma 8 to $10 \mathrm{~mm}$ long, the awn 1 to $1.5 \mathrm{~cm}$ long (fig. 69).
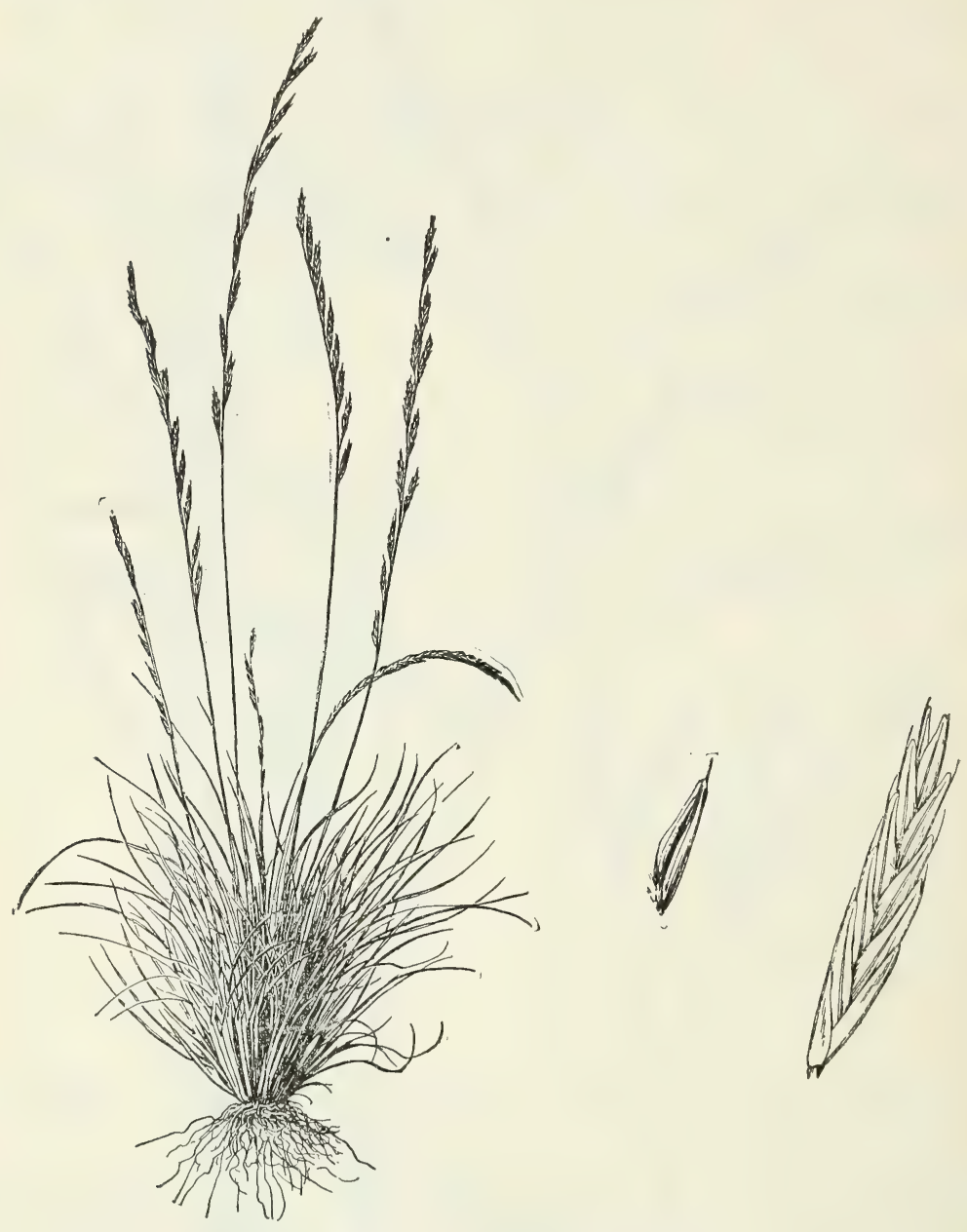

FIGURE 70.-Tripogon spicatus. Plant, $\times \frac{1}{2}$; spikelet and floret, $\times 5$ (Nealley 78).

Rocky brushy slopes, Mexico to Brazil and Bolivia; Cuba, Haiti.

Cuba: Cojímar, Léon 2014; Ekman 1359; Río Bacuranao, Wilson and Léon 11594.

Haitr: Hinche, Ekman H 6137.

46. TRIPOGON Roth; Roem. and Schult., Syst. Veg. 2: 600. 1817

Spikelets, several- to many-flowered, sessile, erect in a single spike; glumes shorter than the lowermost floret; lemmas awned from between the lobes of the minutely two-lohed summit. Low tufted perennials 
with narrow blades and slender solitary spikes, the spikelets somewhat distant.

1. Tripogon spicatus (Nees) Ekman, Arkiv. Bot. 114: 36. 1912. Bromus spicatus Nees, Agrost. Bras. 471. 1829. Brazil.

Tricuspis simplex Griseb., Mem. Amer. Acad. (n. s.) 8: 532. 1862. Cuba, Wright 1551.

Leptochloa spicata Scribn., Acad. Nat. Sci. Phila. Proc. 1891: 304. 1892 .

Culms slender, mostly less than $10 \mathrm{~cm}$ tall; blades subfiliform, aggregated at the base of the plant; spike about half the entire height of the plant; spikelets appressed, about $5 \mathrm{~mm}$ long (fig. 70).

Sterile hills, Texas to Argentina; central Cuba, Haiti.

Cuba: Santayana, Ekman 15356. Motembo, Léon 9416.

Haiti: St. Wichel, Ekman H 8371.

\section{LEPTURIDIUM Hitche. and Ekman, gen. nov. ${ }^{29}$}

Spikelets 2-flowered in two rows on one sde of a continuous triangular rachis, the pedicels very short; glumes about equal, awnless, the midnerve broad, greenish, firm, the margins thin, apparently no lateral nerves; lower floret slightly exceeding the first glume, the second floret more or less reduced, the internode of the rachilla slender, somewhat flexuous, the callus minutely pilose; lemma of first floret thin, minutely and rather sparsely villous, 3-nerved, the midnerve evident, the lateral nerves near the margins, obscure, the midnerve extending into a minute mucro becween two very short teeth; palea narrow, a little shorter than the lemma, deeply sulcate on the back, thin like the lemma; second lemma similar to the first, smaller or sometimes much reduced, the rachilla enlarged and pilose below the floret; paleap resent in the larger second florets, but empty; stamens 3 , brown.

Perennial with short firm distichous blades and terminal spikes.

The genus is not closeiy allied to any other genus. The structure wt the spikelet would place it near Gymnopogon which differs in having several spikes in an inflorescence and in having usually remote awned spikelets.

Type species, Lepturidium insulare Hitchc. and Ekman.

1. Lepturidium insulare Hitchc. and Ekman, sp. nov. ${ }^{30}$

Perennial; culms cespitose rather wiry, spreading, decumbent at base, or prostrate, 10 to $30 \mathrm{~cm}$ long; sheaths overlapping, several to many on the lower half of the flowering culms, pilose or villous around the summit and the base of the blade; blades stiffly ascending, rather conspicuously distichous, fiat, becoming involute, glabrous, 1 to $2 \mathrm{~mm}$ wide, mostly 1 to $2 \mathrm{~cm}$ long, the tip hard, obtuse, somewhat boat-shaped; spike solitary, erect, stiff, mostly 5 to $8 \mathrm{~cm}$ long, the base enclosed in the uppermost sheath or slightly exserted; glumes about $3 \mathrm{~mm}$ long, oblong-linear, the midnerve hard; lemma of first floret about $2.5 \mathrm{~mm}$ long; second floret nearly as long as the first or reduced to a minute rudiment, the rachilla joint slender, 1 to $1.5 \mathrm{~mm}$ long; stamens 3 , about $0.5 \mathrm{~mm}$ long (fig. 71).

29 Spiculae 2-florae multae in spica solitaria terminale; glumae aequales 1-nerviae; floscula inferior glumam primam subequans tenuis 3-nervia mucronata; floseula superior parva vel minuta, rachilla gracili.

${ }_{30}$ Planta perennis; culmi subrigidi $10-30 \mathrm{~cm}$ alti, nodis multis; laminae rigidae distichae $1-2 \mathrm{~cm}$ longae, 1-2 $\mathrm{mm}$ latae; glumae $3 \mathrm{~mm}$ longae; lemma inferius sparse villosum.

$60256-36-8$ 
Type in the United States National Herbarium, no. 1296125, collected in white sand, saline flats, Santa Bárbara, Isla de Pinos, Cuba, Norember 3, 1920, by E. L. Ekman (no. 12060).

Other specimens, both from Isla de Pinos, are: Santa Bárbara, Ekman 12023; Los Indios, Ekman 12155.

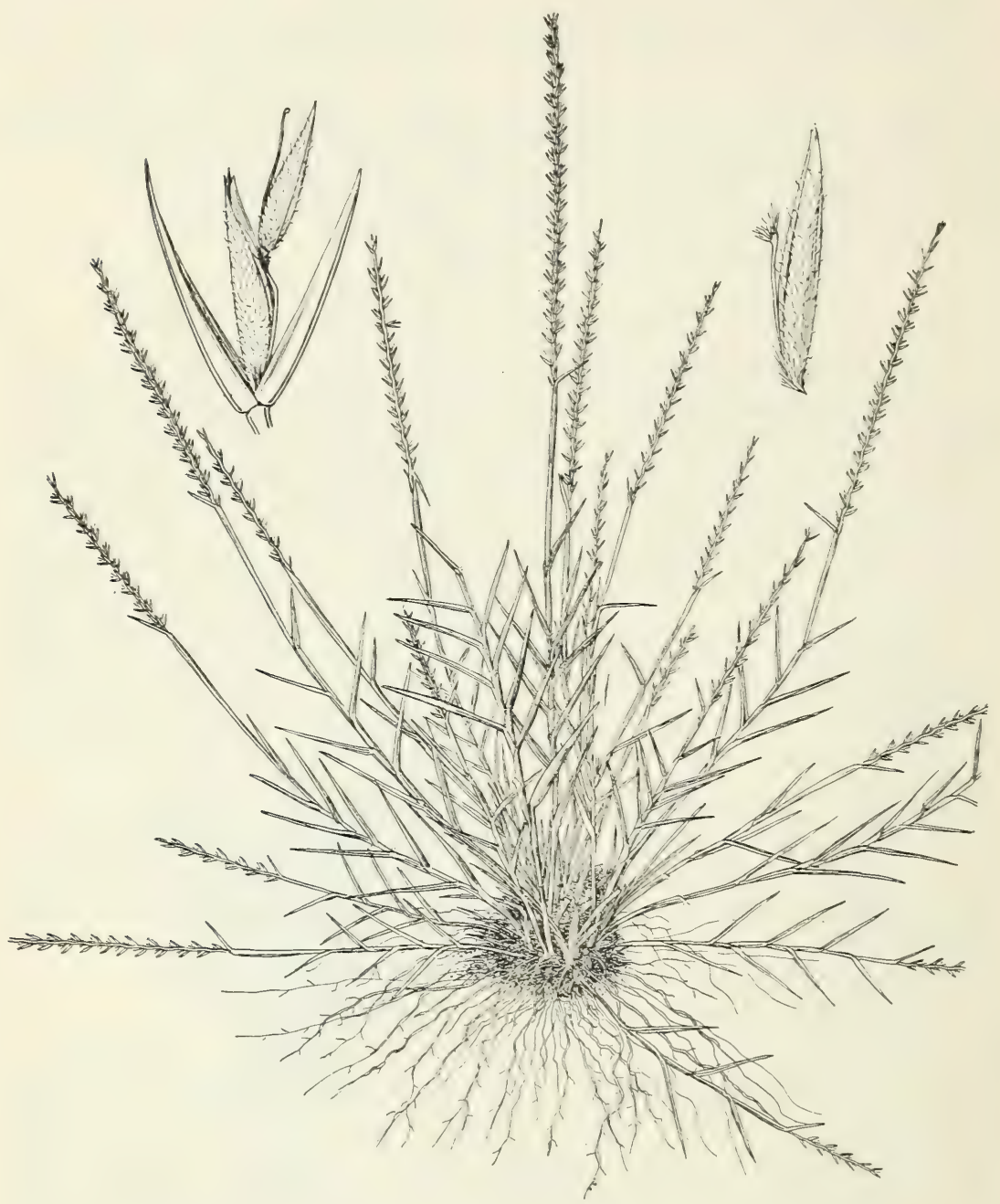

FIgURE 71.-Lepturidium insulare. Plant, $\times 1 / 2$; spikelet and floret, $\times 10$ (type).

No pistils have been found in the specimens examined. The species may be dioecious. On one specimen (no. 12155), there is an auriculate extension of the margin of the rachis below many of the spikelets, forming a glumelike point by the side of the spikelet. This appears to be an abnormality. In aspect the sterile plants somewhat resemble those of Cenchrus distichophyllus. 
48. ELEUSINE Gaertn., Fruct. et Sem. 1: 7.pl. 1. f. 11.1788

Spikelets, few- to sereral-flowered, compressed, sessile and closely imbricate, in two rows along one side of a rather broad rachis, the latter not prolonged beyond the spikelets; rachilla disarticulating above the glumes and between the florets, glumes unequal, rather broad, acute, 1-nerved, shorter than the first lemma; lemmas acute, with 3 strcng green nerves close together forming a keel, the uppermost somewhat reduced; seed dark brown, roughened by fine ridges, loosely enclosed in the thin pericarp. Annuals, with two to sereral rather stout spikes, digitate at the summit of the culms, sometimes with one or two a short distance below, or rarely with a single terminal spike.

Spikes in a terminal whorl, sometimes with a spike below _..... 1. E. INDicA. Spikes in more than one whorl................. Eerticillata.

1. Eleusine indica (L.) Gaertn., Fruct. et Sem. 1: 8. 1788.

Cynosurus indicus L., Sp. Pl. 72. 1753. India.

Goosegrass.

Branching at base, ascending or prostrate, rery smooth; culms compressed, usually less than $50 \mathrm{~cm}$ long; blades flat or folded, 3 to $8 \mathrm{~mm}$ wide; spikes mostly 2 to 6 , flat, 4 to $15 \mathrm{~cm}$ long (fig. 72 ).

Open ground and waste places. A common weed of warm and warm-temperate regions. Introduced in America. To be found on all the West Indian islands. In Cuba called "pata de gallina" and "grama de caballo."

\section{Eleusine verticillata Roxb., Fl. Ind. 1: 346. 1820. India.}

Annual; culms rather slender, 30 to $60 \mathrm{~cm}$ tall; spikes in a terminal whorl of 3 to 5 and several below in 2 or 3 whorls or opposite or alternate; spikelets 8- to 12-flowered; glumes aristulate; lemmas mucronate.

Pastures and open ground. Tropical regions of the Old World; introduced in Haiti.

Haitr: Cul-de-Sac, Ekman H 941. L'Arcahaie, Ekman H 6671.

\section{DACTYLOCTENILM Willd., Enum. Pl. 1029. 1809}

Spikelets, 3- to 5-flowered, compressed, sessile and closely imbricate, in two rows along one side of the rather narrow flat rachis, the end projecting in a point beyond the spikelets; rachilla disarticulating above the first glume and between the florets; glumes somewhat unequal, broad, 1-nerred, the first persistent upon the rachis, the second mucronate or short-awned below the tip, deciduous; lemmas firm, broad, keeled, acuminate or short-awned, 3-nerved, the lateral nerres indistinct, the upper floret reduced; the palea about as long as the lemma; seed subglobose, ridged or wrinkled, enclosed in a thin, early-disappearing pericarp. Annuals or perennials, with flat blades and two to sereral short thick spikes, digitate and widely spreading: at the summit of the culms.

1. Dactyloctenium aegyptium (L.) Richt., Pl. Eur. 1: 68. 1890.

CRowFoot GRASS.

Cynosurus aegyptius L., Sp. Pl. 72. 1753. Africa, Asia, America. Eleusine aegyptiaca Desf., Fl. Atlant. 1: 85. 1798. 
114 MisC. PUBLICATION 243, U. S. DEPT. OF AGRICULTURE

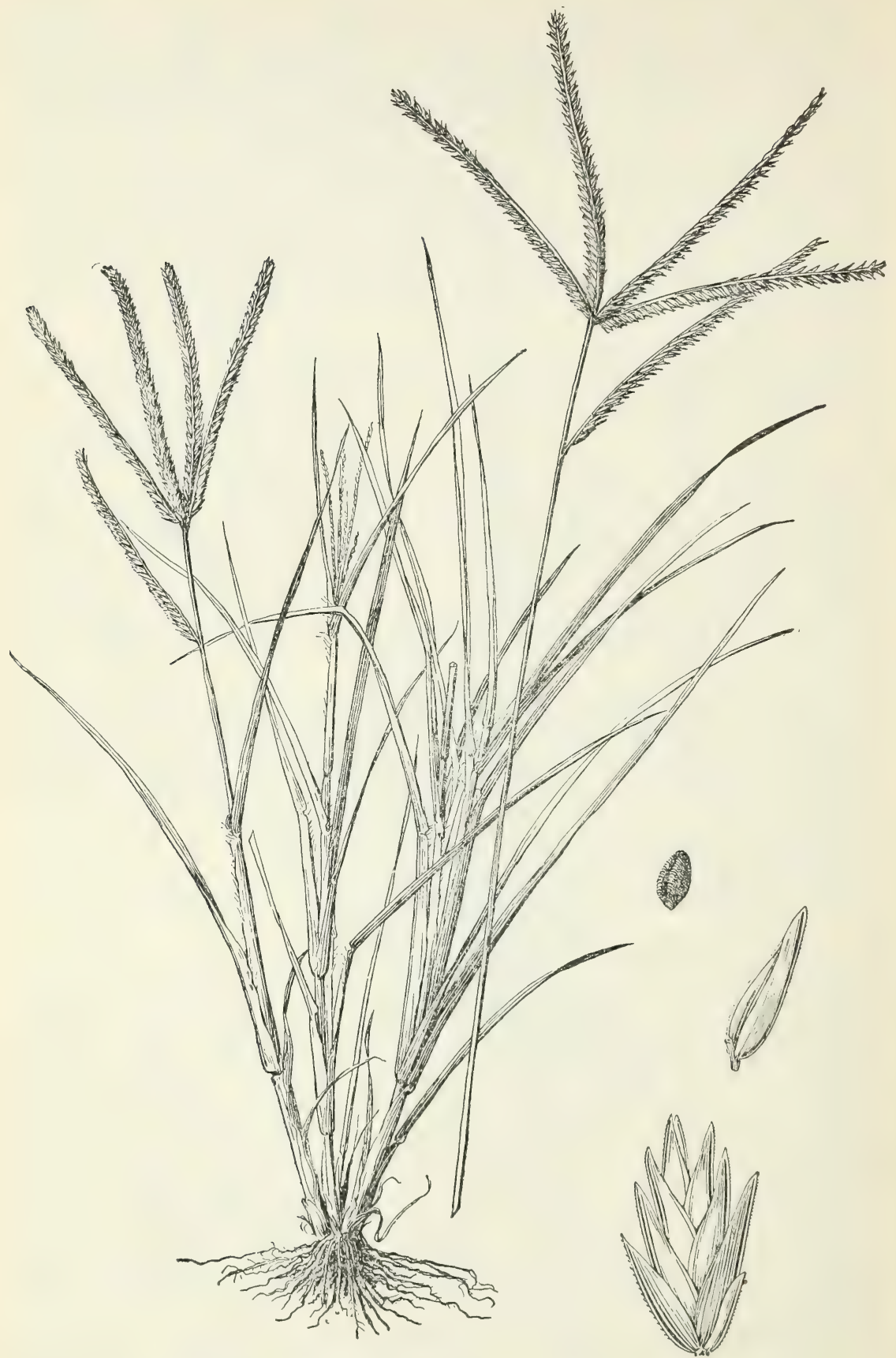

FIGURE $72,-$ Eleusine indica. Plant, $\times 1 / 2$; spikelet, floret, and seed (without pericarp), $\times 5$ (Fredholm 5331). 


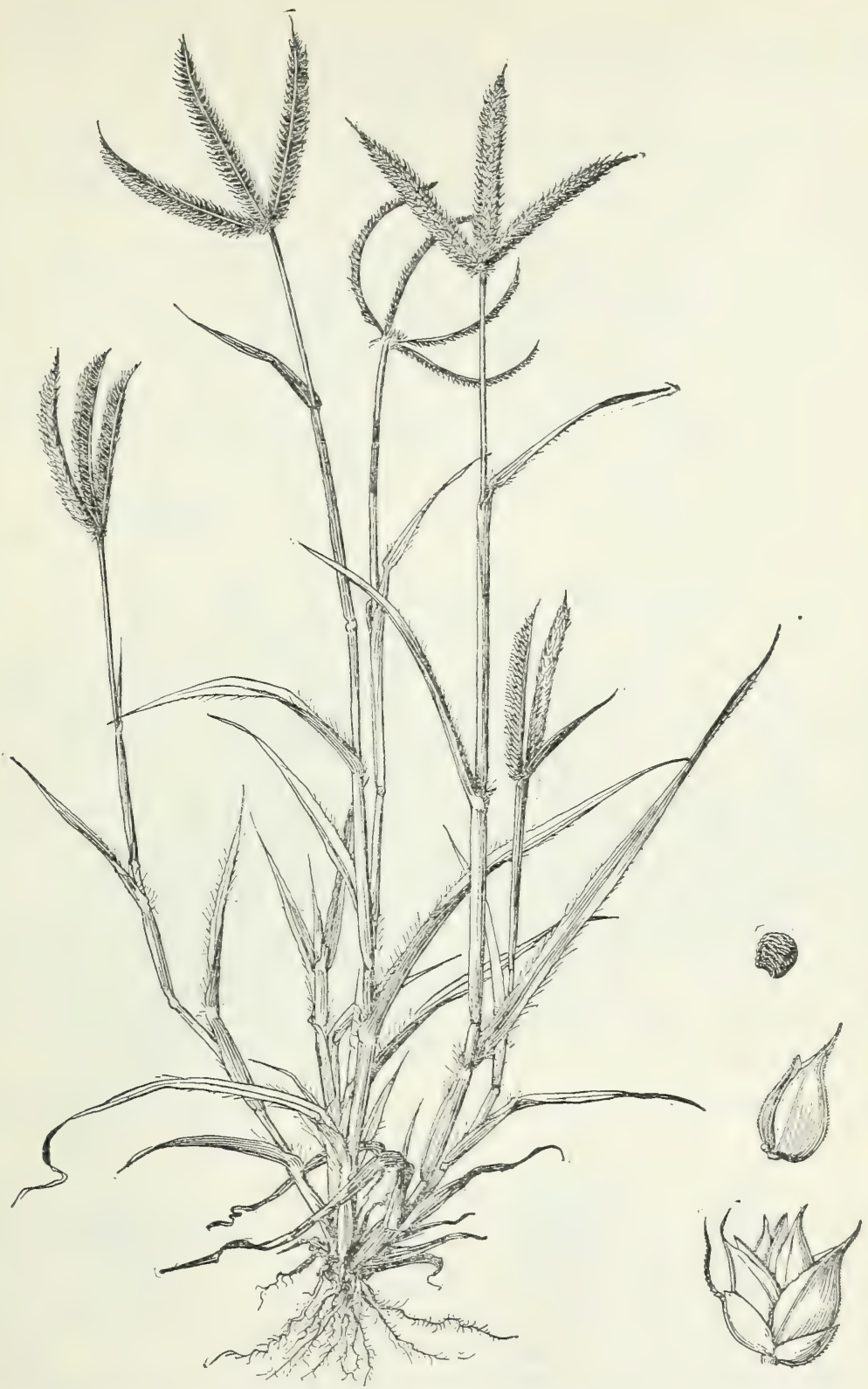

FIGURE 73.-Dactyloctenium aegyptium. Plant, $X 1$; spikelet, fioret, and seed (without pericarp), $\times \mathbf{5}$ (Small and Heller 378 ).

Culms compressed, spreading with ascending ends, rooting at the nodes, branching, commonly forming mats, usually 20 to $40 \mathrm{~cm}$ long; blades flat, ciliate; spikes 1 to $5 \mathrm{~cm}$ long (fig. 73). 
Open ground and waste places. A common weed in warm countries. Introduced in America. To be found on all the West Indian islands. In Cuba called "pata de gallina."

50. CYNODON L. Rich.; Pers., Syn. Pl. 1: 85. 1805

(Capriola Adans., Fam. Pl. 2: 31, 532. 1763. Ineffectively published)

Spikelets, 1-flowered, awnless, sessile in two rows along one side of a slender continuous rachis, the rachilla disarticulating above the glumes and prolonged behind the palea as a slender naked bristle, this sometimes bearing a rudimentary lemma; glumes narrow, acuminate, 1-nerved, about equal, shorter than the floret; lemma strongly compressed, pubescent on the keel, firm, 3-nerved, the lateral nerves close to the margins. Perennials with creeping stolons or rhizomes, short blades, and several slender digitate spikes.

\section{Cynodon dactylon (L.) Pers., Syn. Pl. 1: 85. 1805.}

BERMUDA GRASS.

Panicum dactylon L., Sp. Pl. 58. 1753. Europe.

Capriola dactylon Kuntze, Rev. Gen. Pl. 2: 764. 1891.

Culms low, extensively creeping, wiry, compressed, the flowering shoots 10 to $30 \mathrm{~cm}$ tall, or in moist shady places $50 \mathrm{~cm}$ tall or even more; blades on the stolons short and spre sding, flat, the sheath pilose at the throat; spikes usually 3 to 5 , digitate, slender, arcuatespreading, 2.5 to $5 \mathrm{~cm}$ long; spikelets about $2 \mathrm{~mm}$ long, the lemma longer than the glumes (fig. 74).

Common in open, rather dry ground in the warmer parts of both hemispheres; apparently introduced in America. To be found on probably all the islands of the West Indies. A common and wellknown pasture grass, called Bermuda grass in the United States and Bahama grass in the English West Indies. In the Spanish islands it is called "grama", "hierba fina", and "hierba del prado", and because of its digitate spikes, "pata de gallina." In Antigua it is called "devil's grass"; in Haiti called chiendent. Bermuda grass is commonly used for lawns and pasture throughout the West Indies.

\section{SPARTINA Schreb.; Gmel., Syst. Nat. ed. 13. 2: 123.1791 Cordgrass}

Spikelets, 1-flowered, much flattened laterally, sessile and usually closely imbricate, on one side of a continuous rachis, disarticulating below the glumes, the rachilla not produced beyond the floret; glumes keeled, 1-nerved, acute or short-awned, the first shorter, the second often exceeding the lemma; lemma firm, keeled, the lateral nerves obscure, narrowed to a rather obtuse point; palea 2-nerved, keeled and flattened, the keel between or at one side of the nerves. Stout perennials with tough leaves and 2 to many spikes racemose on a main axis.

Spikes ascending or somewhat spreading; spikelets closely imbricate; second

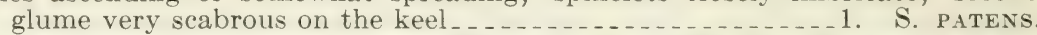
Spikes appressed in a narrow close inflorescence; spikelets imbricate only at the tip; second glume nearly glabrous

2. S. BRASILIENSIS. 
1. Spartina patens (Ait.) Muhl., Descr. Gram. 55. 1817.

Saltmeadow sordgrass.

Dactylis patens Ait., Hort. Kew. 1: 104. 1789.

Trachynotia juncea Michx., Fl. Bor. Amer. 1: 64. 1803. South Carolina.

Spartina juncea Willd., Enum. Pl. 81. 1809.

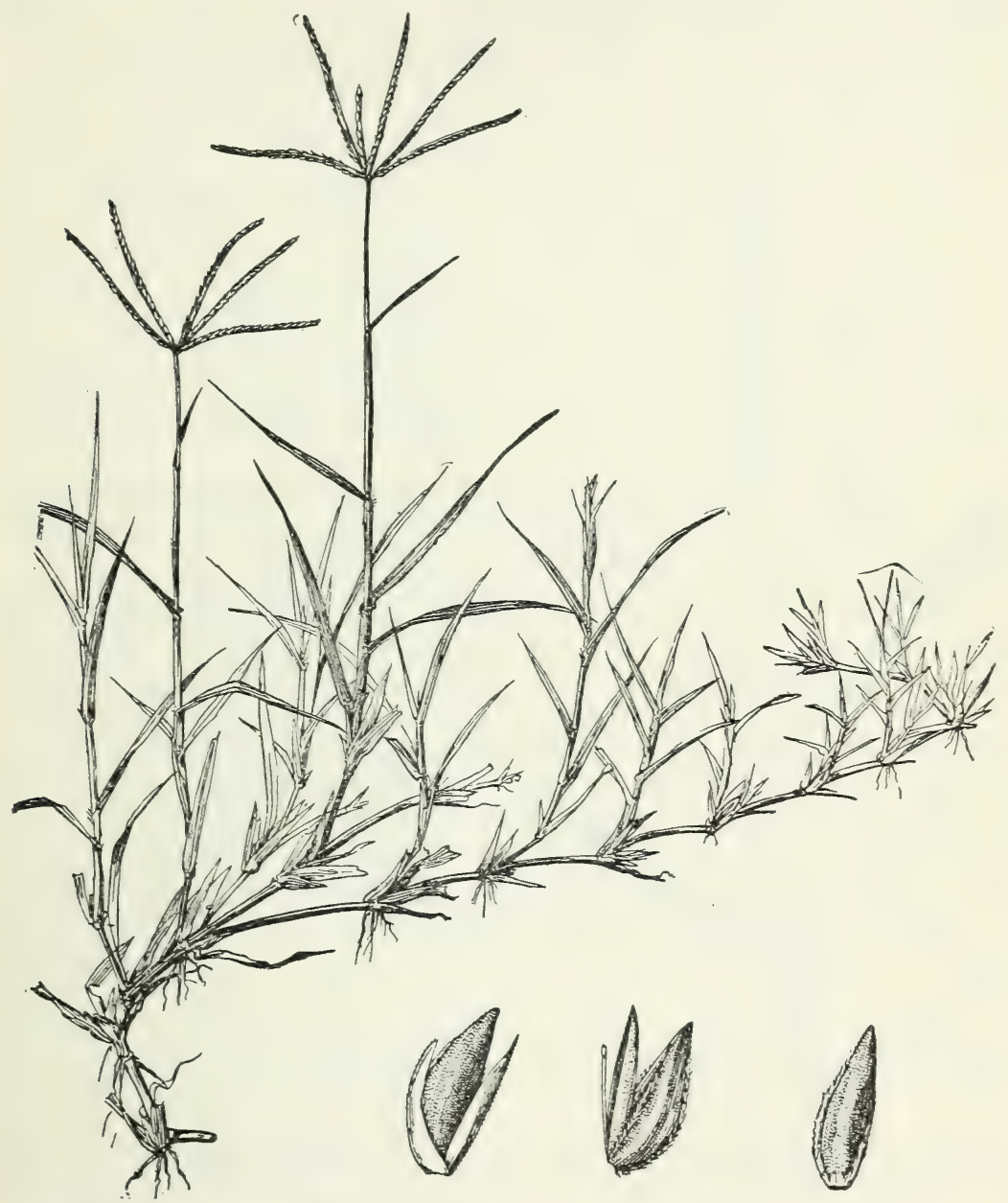

FIGURE 74.-Cynodon dactylon. Plant, $\times \frac{1}{2}$; spikelet and two views of floret, $\times 5$ (Kearney).

Spartina patens var. juncea Hitchc., Rhodora 8: 210. 1906.

Culms erect, usually $1 \mathrm{~m}$ or more tall, tough and wiry, with stout scaly creeping rhizomes; blades involute, extending into a long fine point; spikes mostly 2 to 8 , ascending or spreading, 4 to $6 \mathrm{~cm}$ long; spikelets closely imbricate, 6 to $8 \mathrm{~mm}$ long, the second glume scabrous on the keel (fig. 75). 
Sandy sea beaches and salt marshes, southeastern United States and the West Indies.

Bermuda: Brown and Britton 313; Collins 162.

Bahamas: Eleuthera, Geogr. Soc. Baltimore 415.

CuBA: Morillo, Ekman 17428.

JAMAICA: Black River, Hitchcock 9638.

Haiti: Aux Cayes, Ekman H 746.

Dominican Republic: Peninsula de Barahona, Ekman H 7060. Perrero, Ekman H 13169.

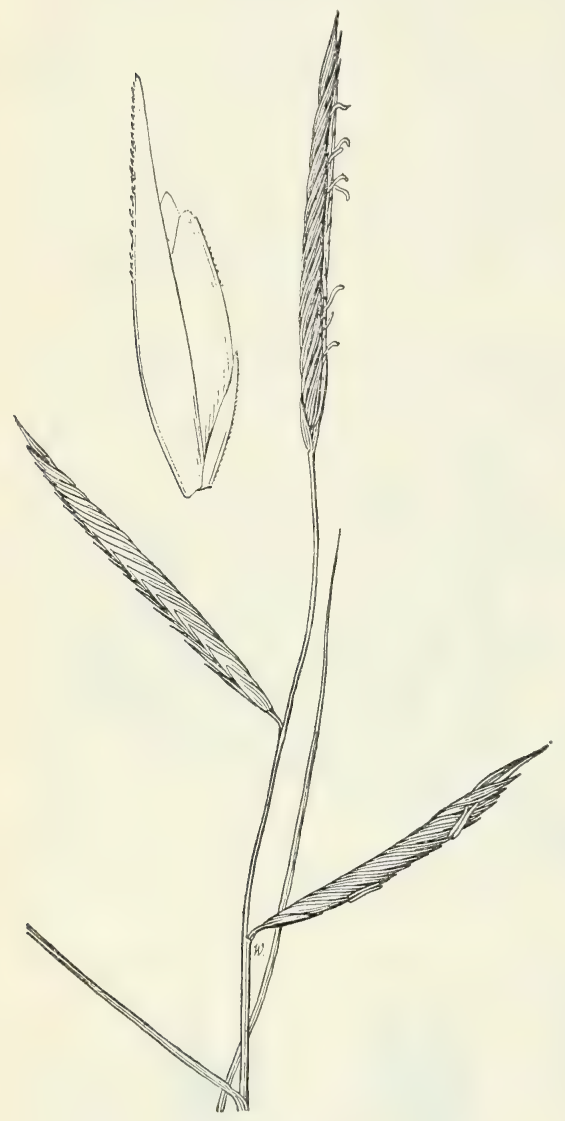

Figure 75.-Spartina patens. Panicle, $\times 1$; spikelet, $\times 5$ (Killip 6359).
Puerto Rico: Arecibo, Chase 6562. Santurce, Chase 6349. Aguada, Chase 6603. Guanajibo, Britton, Cowell, and Brown 4357. Vieques Island, Chase 6699.

Virgin Islands: St. Croix, Borgesen in 1906. Buck Island Borgesen in 1906.

Leeward Islands: Antigua, Box 102. Guadeloupe, Duss 3162

2. Spartina brasiliensis Raddi, Agrost. Bras. 21. 1823. Brazil.

Culms erect from extensively creeping rhizomes, 50 to 100 $\mathrm{cm}$ tall; blades erect, 3 to $5 \mathrm{~mm}$ wide; spikes few, appressed, 4 to $8 \mathrm{~cm}$ long; spikelets about 1 cm long, slightly overlapping; the second glume glabrous or nearly so on the keel.

Tidal flats, Trinidad to Brazil.

Trinidad: Erin Beach, growing in salt water, Broadway 9287.

Spartina cynosuroides (L.) Roth, Catal. Bot. 3: 10.1806. In the United States National Herbarium there is a specimen said to come from the Bahama Islands. The species occurs from Massachusetts to Florida and Louisiana but is not otherwise known from the Bahamas.

52. GYMNOPOGON Beauv., Ess. Agrost. 41. pl. 9. f. 3. 1812

Spikelets, 1- or rarely 2- or 3-flowered, nearly sessile, appressed and usually remote in two rows along one side of a slender continuous rachis, the rachilla disarticulating above the glumes and prolonged behind the 1 or more fertile florets as a slendei stipe, bearing a rudiment of a floret, this sometimes with 1 or 2 slender awns; glumes narrow, acuminate, 1-nerved, usually longer than the floret; lemmas 
narrow, 3-nerved, the lateral nerves near the margin, the apex minutely bifid, bearing between the teeth a slender awn, or rarely awnless. Perennials or rarely annuals, with short, flat, stiff blades, numerous stifi, slender, divergent spikes loosely scattered along the upper part of the culm, or sometimes aggregate toward the summit, the spikes often deflexed at maturity.

Spikes 2 to $4 \mathrm{~cm}$ long, aggregate at the summit of the naked culms; annual.

1. G. FOLIOSUS.

Spikes 10 to $25 \mathrm{~cm}$ long, scattered along the upper part of the culms; perennial.

Blades ovate-lanceolate, 2 to $5 \mathrm{~cm}$ long; culms mostly not more than $30 \mathrm{~cm}$ tall ...... G. AMBIGUUS.

Blades linear-lanceolate, 3 to $7 \mathrm{~cm}$ long; culms 50 to $100 \mathrm{~cm}$ tall_3. G. SPICATUs.

1. Gymnopogon foliosus (Willd.) Nees, Agrost. Bras. 426. 1829.

Chloris foliosa Willd., Sp. Pl. 4: 924. 1806. St. Thomas.

Biatherium foliosum Desv., Opuse. 72. 1831.

Annual; culms wiry, erect or decumbent at base, short-jointed, 15 to $50 \mathrm{~cm}$ tall; biades numerous, short, squarrose, mostly 1 to $2 \mathrm{~cm}$ long, sharp-pointed; spikes 3 to 7 , erect or ascending, 2 to $3 \mathrm{~cm}$ long; glumes 3 to $4 \mathrm{~mm}$ long; lemma $2.5 \mathrm{~mm}$ long, the awn $1.5 \mathrm{~cm}$ long.

White barren sands, Puerto Rico, Hispaniola, and St. Thomas to Brazil.

Puerto Rico: Laguna Tortuguero, Britton 7955. Campo Alegre, Chase 6611, 6789 (Amer. Gr. Nat. Herb. 661).

Doninican Republic: "Santo Domingo" in Trinius Herbarium.

2. Gymnopogon ambiguus (Michx.) B. S. P., Prel. Cat. N. Y. 69. 1888. lina.

Andropogon ambiguus Michx., Fl. Bor. Amer. 1: 58. 1803. Caro-

Culms 30 to $60 \mathrm{~cm}$ tall, in small clumps with short scaly rhizomes, suberect to spreacing, rigid, sparingly branching; leares numerous, approximate with overlapping sheaths, or the lower rather distant; blades spreading, 5 to $15 \mathrm{~mm}$, mostly about $10 \mathrm{~mm}$ wide, the tase rounded-truncate; spikes 10 to $20 \mathrm{~cm}$ long, floriferous from base, the lower spikelets often remote; glumes 4 to $6 \mathrm{~mm}$ long; lemma with an awn 4 to $6 \mathrm{~mm}$ long, the rudiment berring a delicate shorter awn (fig. 76).

Dry pine lands, southern United States; Hispaniola.

Dominican Republic: Constanza, Ekman H 14023. El Tetero, Ekman H 13721. San Juan, Ekman H 13538. San José de Ocoa, Ekman H 11932.

3. Gymnopogon spicatus (Spreng.) Kuntze, Rev. Gen. Pl. 32: 354. 1898.

Polypogon spicatus Spreng., Syst. Veg. 1: 243. 1825. Brazil. Gymnopogon filiformis Griseb., Fl. Brit. W. Ind. 538. 1864. Trinidad.

Perennial; culms slender, wiry, 50 to $100 \mathrm{~cm}$ tall; blades thickish, linear-lanceolate, 3 to $7 \mathrm{~cm}$ long; inflorescence commonly nearly half the entire length of the plant; spikes slender, divaricate, 15 to 25 $\mathrm{cm}$ long, naked or nearly so for the lower one-third to half their length.

Sterile hills, Trinidad to Argentina.

Trinidad: Without locality, Bot. Gard. Herb. 3361. 


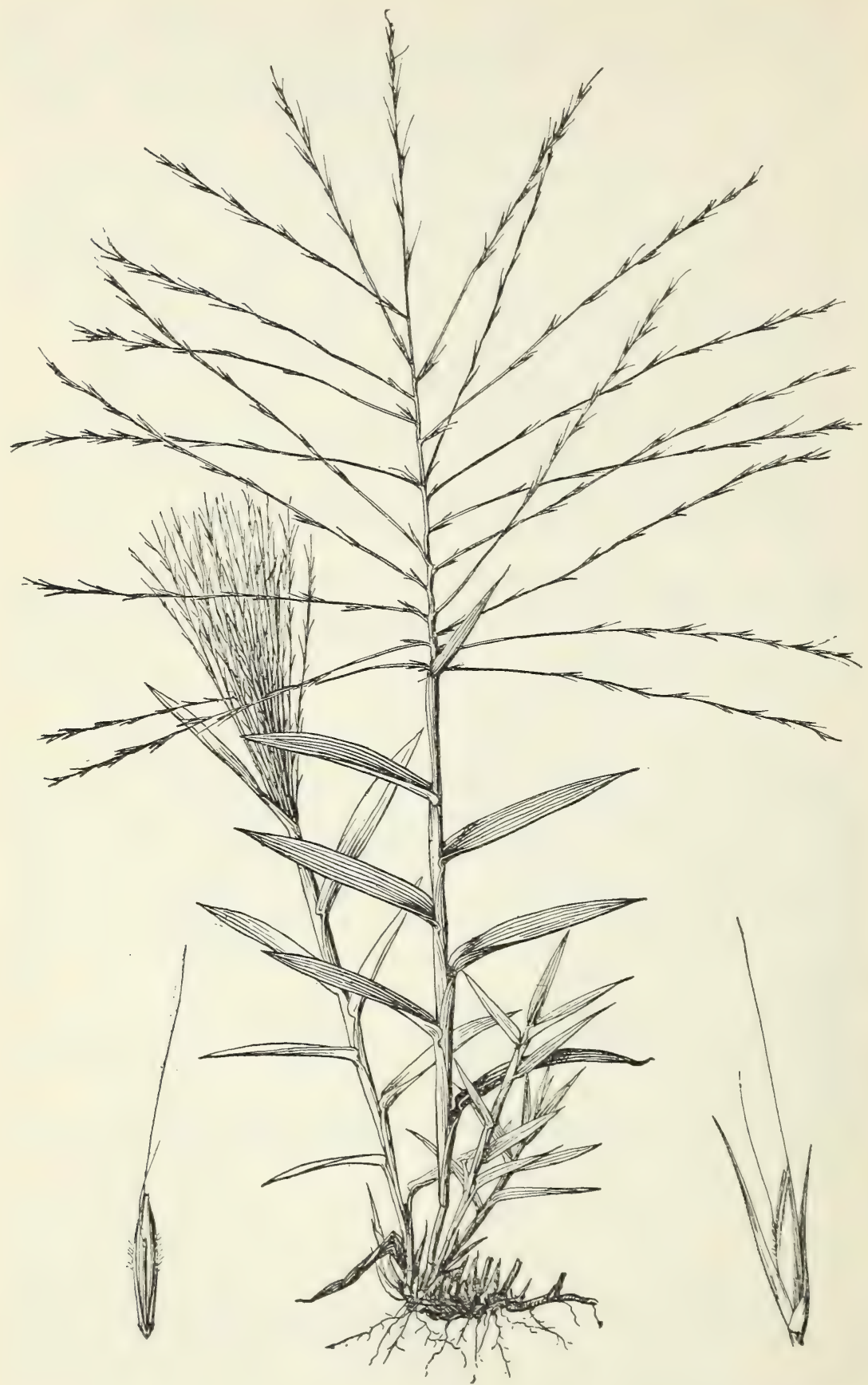

FIGURE 76.-Gymnopogon ambiguus. Plant, $\times 1 / 2$; spikelet and floret, $\times 5$ (Tracy 8292 ). 
53. SAUGETIA Hitchc. and Chase, Contrib. U.S. Natl. Herb. 18: 378. 1917

Spikelets, 2-flowered, the first perfect, the second neuter and much reduced; glumes thin, unequal, 1-nerved, acuminate, shorter than the floret; first floret stipitate, the lemma firm, minutely 2-toothed at the apex, 3-nerved, the midnerve produced into a delicate awn; palea slightly shorter than the lemma, acute, sulcate between the nerves; second floret reduced to a minute lemma on an elongate slender rachilla joint. Cespitose perennials with slender wiry branching culms, narrow blades, and 1 to 3 slender spikes, the spikelets subsessile, contiguous but scarcely imbricate along one side of a slender continuous rachis, closely appressed to it.

Plants 20 to $40 \mathrm{~cm}$ tall, the culms and blades slender and delicate; spikes soli-

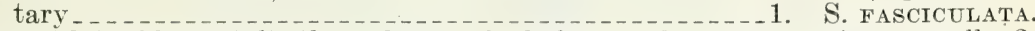
Plants 50 to $80 \mathrm{~cm}$ tall, the culms and blades much coarser; spikes usually 2, sometimes 1 or $3 \ldots \ldots \ldots$. S. Pleiostachya.

1. Saugetia fasciculata Hitchc. and Chase, Contrib. U. S. Natl. Herb. 18: 378. 1917. Cuba, Léon 6901.

Plants in dense hard tufts, glabrous throughout; culms 40 to 50 $\mathrm{cm}$ tall, erect or the summit leaning, the internodes elongate, branching at most of the nodes, the branches mostly fascicled, commonly one of them elongate, the others reduced to leafy shoots of overlapping sheaths and short spreading blades, these branchlets forming conspicuous tufts along the main culms and branches; sheaths 5 to 8 mim long, with broad papery margins, a tuft of delicate white hairs $1 \mathrm{~mm}$ long at the summit, these wanting on old sheaths, the sheaths of the branchlets reduced; ligule obsolete; blades filiform, crescentshaped in cross section, scarcely $0.5 \mathrm{~mm}$ wide when flattened out, flexuous, the primary blades as much as $10 \mathrm{~cm}$ long, those of the branchlets 1 to $3 \mathrm{~cm}$ long; spikes long-exserted, erect, 3 to $5 \mathrm{~cm}$ long, the rachis subfiliform, slightly concavo-convex, the spikelets fitting into the concavities; spikelets distant by about their own length to half their length, 3.6 to $3.8 \mathrm{~mm}$ long excluding the awn; glumes lanceolate-subulate, the first 0.7 to $0.8 \mathrm{~mm}$ long, the second 2 to 2.5 $\mathrm{mm}$ long; floret stipitate, the stipe $0.5 \mathrm{~mm}$ long, bearded with erect hairs 0.4 to $0.5 \mathrm{~mm}$ long; lemma $3.2 \mathrm{~mm}$ long (excluding the awn), about $0.4 \mathrm{~mm}$ wide, glabrous, the lateral nerves near the margin, the midnerve becoming strong toward the summit and produced into a delicate flexuous erect, minutely scabrous awn 12 to $16 \mathrm{~mm}$ long; palea minutely scabrous on the nerves; second floret reduced to a narrow pointed 1-nerved lemma about $1.2 \mathrm{~mm}$ long, the slender glabrous erect rachilla joint $1.8 \mathrm{~mm}$ long (fig. 77 ).

Limestone ground in thickets and on limestone cliffs, Cuba and Hispaniola.

Cuba: Mendoza, Ekman 18172. San Julián, south of Guane, Léon 6901, 7312, 7474; Wright 3894. Jauco Abajo, southern Baracoa region, Léon 12312.

Dominican Republic: Río Mao, Valeur 177. Monción, Ekman H 12606, H 13059, H 13081.

In one specimen (Léon 12312) some of the inflorescences consist of two spikes. In all the others the spikes are solitary. 


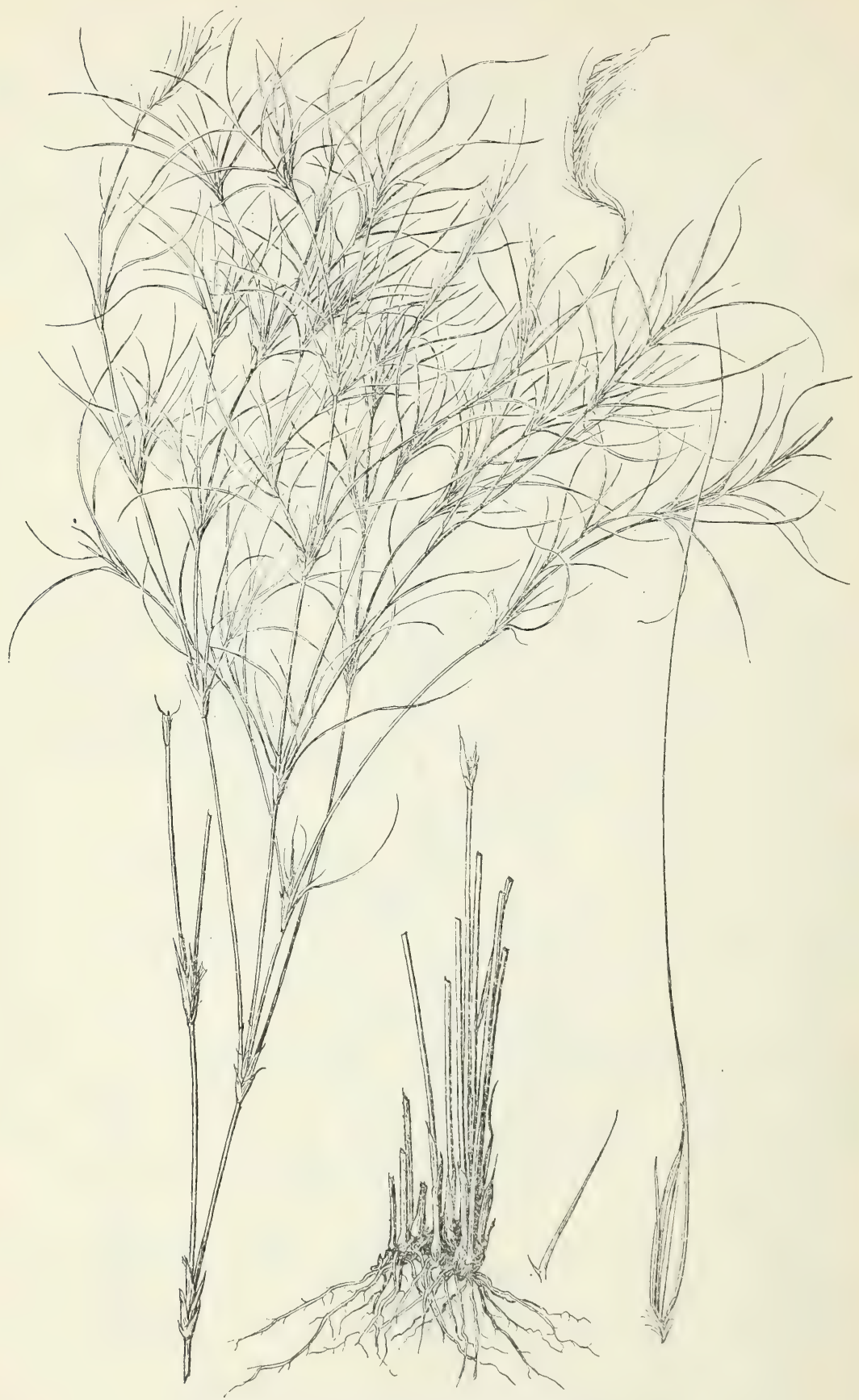

Figure 77. - Saugetia fasciculata. Plant, $\times$ 1/2; glumes and floret, $\times 5$ (Léon 7312). 
A fragmentary specimen of this peculiar grass was collected by Wright "in small skirts of woods bordering the Savana San Julián" in 1865 (no. 3894) and was listed in Sauvalle's Flora Cubana ${ }^{31}$ without description as "Muhlenbergia spicata "Nunn" and by Hitchcock ${ }^{32}$ as an unidentified specimen. The few weatherworn spikelets on the Wright specimen were too much broken to permit of diagnosis. Brother León at our request hindly visited the locality and sent us a specimen of this apparently very rare species. His letter in regard to this collection is of interest:

I visited the Savana San Julián in company with Father Modesto Roca of Guanabacoa. The first two days I did not see any kind of Bouteloua [from the broken Wright specimen we had guessed it to be a species of that genus], not knowing on what border of the savanna were the skirts of woods, and the savanna has a circuit of 40 to 50 kilometers. At last * * * we werit to a small wood (Cayo Gabino) on the northeastern border of the hacienda [of Señor D. J. M. Lamas] and there I saw a tufted grass which I supposed might be the long lost species of Wright, though at first sight it called to my mind the idea of a small Arthrostylidium, having some resemblance to my no. 4853 [Arthrostylidium capillifolium]. I noted with pleasure that it agreed exactly with your description. Unluckily there remained very few flowers. I entered the wood at different places all around but could not find more of it.

It is noteworthy that in his field notes Wright called his number 3894 "Arthrostylidium."

\section{Saugetia pleiostachya Hitchc. and Ekman, sp. nov. ${ }^{33}$}

Culms glabrous, many-noded, straggling, 50 to $80 \mathrm{~cm}$ tall, the branches appressed, often fascicled, the lower internodes elongate; sheaths glabrous, firm, shorter than the internodes, densely villous at the truncate summit; ligule a very short densely ciliate membrane; blades glabrous, slender, wiry, fiat and about $1.5 \mathrm{~mm}$ wide or mostly filiform, involute, the margins scabrous with fine sharp points; inflorescence of 1 to 3 falcate spikes, 8 to $12 \mathrm{~cm}$ long, the second and third spike attached 10 to $15 \mathrm{~mm}$ below the terminal one and closely appressed to it, the rachis slender, triangular; spikelets appressed, imbricate, about $1 \mathrm{~mm}$ apart on the rachis; first glume a slender minute bristle; second glume very narrow or setiform, 2 to $4 \mathrm{~mm}$ long; lemma slightly raised on a minutely pilose stipe, narrow, somewhat terete, acute, about $4 \mathrm{~mm}$ long, awned from just below the apex, the awn very slender, 1 to $2 \mathrm{~cm}$ long, the tip very fine, flexuous; palea narrow, about as long as the lemma, ending in 2 very fine teeth; rudiment minute, the rachilla joint about $2 \mathrm{~mm}$ long, lying in the sulcus of the incurved margins of the lemma, awnless or with a minute fine awn.

Type in the United States National Herbarium, no. 1296127, collected on jurassic limestone, top of Cerro de Mendoza, Mendoza, Province of Pinar del Río, Cuba, June 26, 1920, by E. L. Ekman (no. 11483).

Another collection from the same locality was made in 1923 by Dr. Ekman (no. 16746).

In its technical character this species agrees closely with S. fascicu- lata. It differs in its larger size, coarser foliage, the usually 2 spikes

32 Contrib. U. S. Nat. Herb. 12: 246. 1909

33 Perennis; culm: glabri multinodii tenues $50-80 \mathrm{~cm}$ alti ramosi, ramis appressis; laminae glabrae tenues planae rel plerumque filiformes, marginibus scabris; spicae 1-3 tenues falcatie $8-20 \mathrm{~cm}$ longae arpressae gluma prima minuta setiformis; gluma secunda setiformis 2-4 $\mathrm{mm}$ longa; lemma angustum, acutum circa $4 \mathrm{~mm}$ longum aristatum, arista tenuissima $1-2 \mathrm{~cm}$ longa; palea bisetosa; rudimentum minutum. 
nearly twice as long, and in the larger spikelets. S. fasciculata is now known from several localities. It is uniformly smaller and more delicate than S. pleiostachya.

\section{CHLORIS Swartz, Prodr. Veg. Ind. Occ.25. 1788. Fingergrass}

Spikelets with 1 perfect floret, sessile, in two rows along one side of a continuous rachis, the rachilla disarticulating above the glumes, produced beyond the perfect floret and bearing 1 to several reduced florets consisting of empty lemmas, these often truncate, and, if more than one, the smaller ones enclosed in the lower, forming a usually club-shaped rudiment; glumes somewhat unequal, the first shorter, narrow, acute; lemma keeled, usually broad, 1- to 5-nerved, of ten villous on the callus and villous or long-ciliate on the keel or marginal nerves, awned from between the short teeth of a bifid apex, the awn slender or sometimes reduced to a mucro, the sterile lemmas awned or awnless. Perennials or annuals with flat or folded blades and 2 to many often showy digitate spikes.

Lemmas awnless; spikes dark brown (Eustachys) _........... . C. Petraea. Lemmas awned; spikes pale or purplish.

Sterile floret narrow, the apex acute or obtuse but not truncate.

Plants 1 to $1.5 \mathrm{~m}$ tall, with stout creeping stolons _..........

Plants lower; stolons wanting or poorly developed.

Spikes numerous, at least 10 , ascending even when mature.

Spikes fewer than 10 , usually not more than 6 .

3. C. RADiATA.

Culms leafy throughout; spikes erect or ascending _- 4. C. RUPESTRIS. Culms naked or with a few remote short blades. Spikes often reflexed at maturity.

Spikelets divergent, somewhat distant. Plant delicate.

Spikelets appressed, imbricate.

5. C. CRUCIATA.

Culms slender, wiry; blades filiform or narrow _-_6. C. EKMANII.

Culms stouter; blades flat or folded, 1 to $3 \mathrm{~mm}$ wide.

Leaves pubescent; awns 1.5 to $2.5 \mathrm{~cm}$ long _... C. C. ARENARIA. Leaves glabrous; awns 1 to $2 \mathrm{~cm}$ long.

Lemma pilose-ciliate on upper part of margins; callus pilose; rudiment rather broad and prominent_-_8. C. CUBENSIS.

Lemmas minutely pilose or nearly glabrous on the margins; callus nearly glabrous; rudiment not prominent, mostly enclosed in the margins of the lemma -7 . C. SAGRAEANA.

Sterile floret broad, truncate, broadest at the summit. Spikelets pectinately arranged.

Plants perennial, commonly more than $1 \mathrm{~m}$ tall; spikes flexuous, 8 to $10 \mathrm{~cm}$ long....

Plants annual, usually less than $75 \mathrm{~cm}$ tall; spikes less than $8 \mathrm{~cm}$ long.

Awn of fertile lemma not longer than the body; lemma long-ciliate on keel and margins. ...... C.

Awn of fertile lemma at least twice as long as the body.

Sterile florets 2; sterile lemmas (rudiment) nearly as broad as long; fertile lemma without tuft of hairs_....... C. INFLATA.

Sterile floret 1; sterile lemma narrow, more than twice as long as broad, hairy on the keel and margins_....... 13. C. VIrGata.

1. Chloris petraea Swartz, Prodr. Veg. Ind. Occ. 25. 1788. Jamaica. Eustachys petraea Desv., Nouv. Bull. Soc. Philom. Paris 2: 189. 1810.

Schultesia petraea Spreng., Pl. Pugill. 2: 17. 1815.

Chloris swartzii C. Muell., Bot. Ztg. 19: 341. 1861. Based on C. petraea Swartz. 
Chloris swartziana Doell, in Mart., Fl. Bras. $2^{3}: 68$. 1878. Based on $C$. petraea Swartz.

Glabrous glaucous sparingly stoloniferous perennial; culms flat, ascending; sheaths keeled, often in pairs, especially in robust plants; blades flat, thickish, oblong or linear, obtuse; spikes few to several, the rachis and glumes pale green, the florets chestnut; spikelets $2 \mathrm{~mm}$ long; second glume bilobed, the midnerve excurrent as a short awn; lemma awnless, a little exceeding the second glume (fig. 78).

Open ground, mostly near the seashore, southern United States and eastern Mexico, to Trinidad and Panama.

Bermuda: Collins 144; Brown 523; Brown and Britton 60.

Bahamas: New Providence, Eggers 4092; Geogr. Soc. Baltimore 99, 261. Andros, Small and Carter 8918. Anguilla Isles, Wilson 7947.

CuBA: Habana, Ekman 369; Hitchcock 238; Léon 961; Liebmann 235. Cayo Sabinal, Shafer 716, Cayo Paredon Grande, Shafer 2739. Without locality, Wright 3817. Isla de Pinos, Britton and Wilson 14947; Palmer and Riley 969.

JAMAICA: Port Antonio, Fredholm 3305. Buff Bay, Hitchcock 9767. Mouth of Cockpit River, Harris 12464. Montego Bay, Maxon 1562; Hitchcock 9672. Claremont, Hitchcock 9485. Moneague, Hitchcock 9453. Savanna-la-Mar, Hitchcock 9883. Spanish Town, Hitchcock 9297. Ipswich, Hitcheock 9591. Black River, Harris 12543. Gordon Town, Hart 2079. Grand Cayman, Millspaugh 1255. Haiti: Miragoane, Eyerdam 402. Aux Cayes, Ekman H 44. Tortuga Island, Leonard 13889, 13893; Ekman H 4157. Dominican Republic: Santo Domingo City, Ekman H 11416.

Puerto Rico: Santurce, Heller 6422; Chase 6347. Condado, Britton and Brown 6629. Boqueron, Chase 6512. Cabo

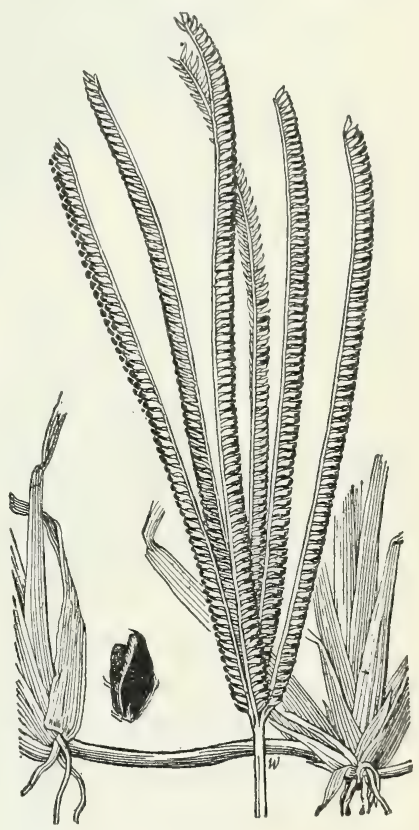

FIGURE 78.-Chloris petraea. Plant, $\times 1$; florets, $\times 5$ (Curtiss). Rojo, Sintenis 555. Bayamon, Sintenis 1031. Mayaguez, Chase 6183. Vega Baja, Heller 1317. Vieques Island, Chase 6702. Mona Island, Hess 446. Without locality, Eggers 708.

Windward Islands: Barbados, Hitchcock 16509; Miller 48.

Trinidad: Bot. Gard. Herb. 3377.

2. Chloris gayana Kunth, Rév. Gram. 1: 89. 1829; 2: 293. pl. 58. 1830. Africa.

RHODES GRASS.

Perennial; culms stout, erect or ascending, usually 1 to $1.5 \mathrm{~m}$ tall, with stout creeping stolons; blades flat, numerous, elongate, 2 to 5 $\mathrm{mm}$ wide; spikes several to numerous, digitate, 5 to $10 \mathrm{~cm}$ long, spikelets closely imbricate, about $4 \mathrm{~mm}$ long; lower floret glabrous on the keel, appressed hispid along the margin, the hairs longer toward the 
summit, about $3 \mathrm{~mm}$ long, the awn about $5 \mathrm{~mm}$ long; second floret smaller than the first but not much reduced, glabrous, the awn about $3 \mathrm{~mm}$ long; third fioret about $2 \mathrm{~mm}$ long, truncate, mucronate, sometimes a rudimentary fourth floret present (fig. 79).

Cultivated in the warmer parts of America for forage and soon escaping into fields and waste places. The West Indian specimens appear to be all cultivated, but the species is likely to be found naturalized. Rhodes grass gives promise of value in the drier parts of the West Indies.

CuBa: Soledad, Jack 6596, 8321.

Jamaica: Richmond Park, Harris 12707.

Haiti: Fond-Blanc, Ekman H 9890.

3. Chloris radiata (L.) Swartz, Prodr. Veg. Ind. Occ. 26.1788. Agrostis radiata L., Syst. Nat. ed. 10. 2: 873. 1759. Jamaica. Cynosurus scoparius Lam., Encycl. 2: 188. 1786. "St. Domingue." Chloris gracilis Durand, Chlor. Sp. 10. 1808. Jamaica. This work has not been seen. A specimen so named, apparently by Durand, in the herbarium of the Institus Botanique, Montpellier, is C. radiata.

Chloris durandiana Schult., Mant. 2:341. 1824. Based on Chloris gracilis Durand.

Chloris glaucescens Steud., Syn. Pl. Glum. 1:206. 1854. Guadeloupe.

Weedy branching decumbent-ascending annual; sheaths broaci compressed; blades thin, flat or folded, scaberulous or sparsely pilose; spikes slender, somewhat flexuous; second glume narrow, awn-pointed, $2 \mathrm{~mm}$ long; lemma narrow, $2.5 \mathrm{~mm}$ long, the awn 5 to $10 \mathrm{~mm}$ long; rudiment narrow, scarcely $1 \mathrm{~mm}$ long, diverging a little from the fertile lemma and not as long as this, the awn as much as $5 \mathrm{~mm}$ long (fig. 80).

Grassy banks, pastures, and waste places, Mexico and the West Indies to Paraguay. A common weed, to be found on probably all the West Indian islands.

4. Chloris rupestris (Ridley) Hitche.

Gymnopogon rupestris Ridley, Jour. Linn. Soc. 27:73. 1890. Brazil.

Chloris angustiflora Areschoug, Svensk. Freg. Eugenies Resa 1910: 118. 1910; Repert. Sp. Nov. Fedde 10: 300. 1912. Ecuador.

Chloris leptantha Hitche,, in Urban, Symb. Antill. 7: 166.1912. Bonaire.

Chloris luetzelburgii Hitche., Biol. Soc. Wash. Proe. 36: 197. 1923. Brazil.

Annual; culms 30 to $100 \mathrm{~cm}$ tail; blades flat, acuminate, scabrous, 5 to $15 \mathrm{~cm}$ long, 1 to $6 \mathrm{rmm}$ wide; spikes 5 to 8 , slender, ascending or appressed, 6 to $12 \mathrm{~cm}$ long, aggregate on an axis as much as $5 \mathrm{~cm}$ long; spikelets narrow, loosely imbricate, with 1 perfect floret and a narrow rudiment; lemma about $5 \mathrm{~mm}$ long, about $0.4 \mathrm{~mm}$ thick, the margins short-ciliate toward the summit, the awn about $5 \mathrm{~mm}$ long; rudiment 1 to $2 \mathrm{~mm}$ long, the awn a little shorter than that of the first floret. Slender spikes of cleistogamous spikelets borne in the lower sheaths.

Open dry ground, fields, and waste places, the West Indies to Brazi] and Ecuador. 


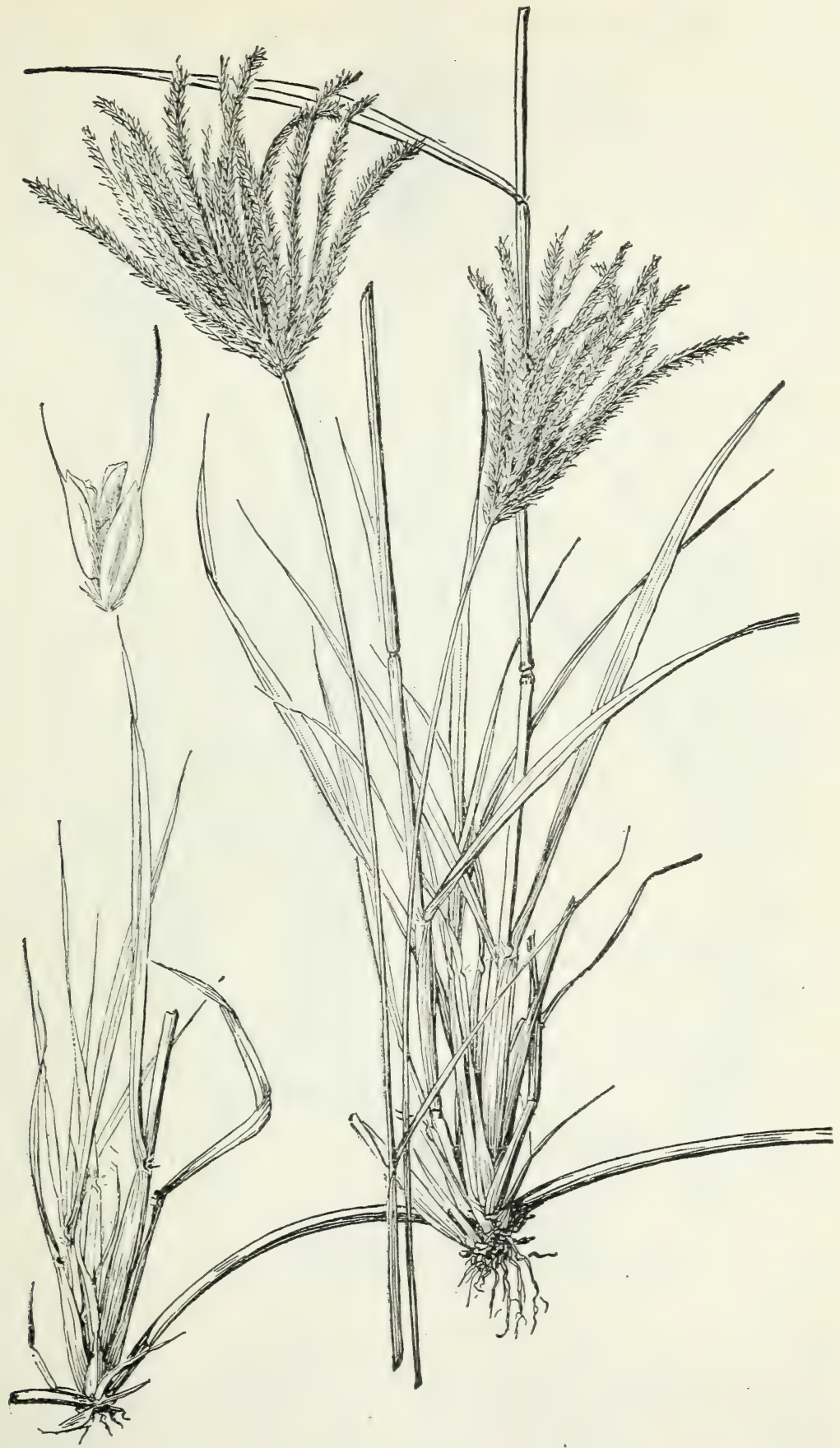

Figure 79.-Chloris gayana. Plant, $\times 1 / 2$; florets, $\times 5$ (Hitchcock 13667).

$60256-36-9$ 


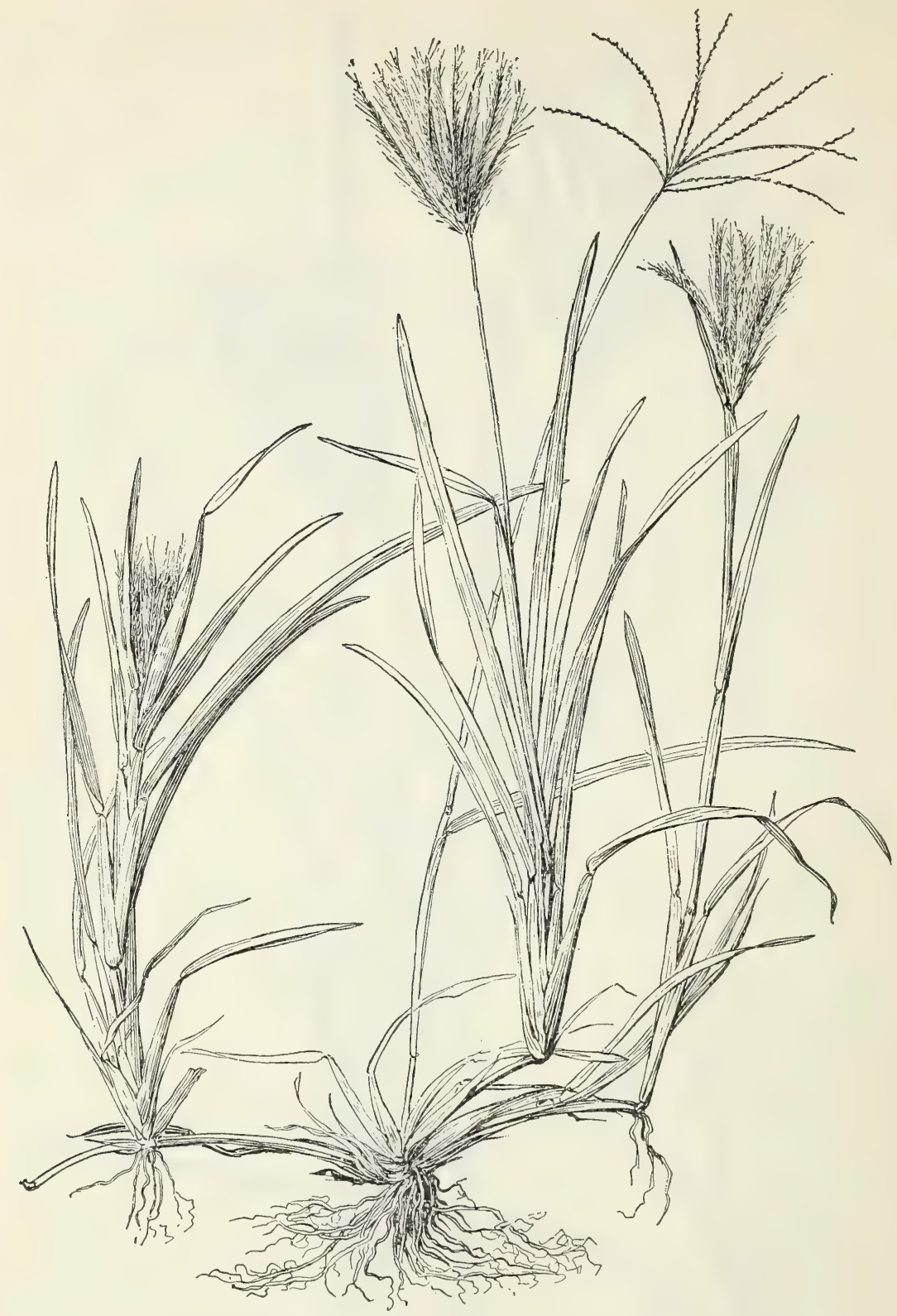

FIGURE 80.-Chloris radiata, $\times 1 / 2$ (Sintenis 28 ).

Cuba: Caimanera Naval Station, Hioram and Ramsden 1.

Jamaica: Port Fienderson, Ridley 130. Hope Gardens, Ridley 75, 90. Rockfort, Ridley 91; Harris 12675. Kingston, Ridley 115; Harris 11502, 12212. Gordon Town, Harris 11515. Grants Pen, Harris 12211. Spanish Town Road, Harris 12476. 
Haitı: Anse-à-Pitre, Ekman H 6999. Jean Rabel, Leonard 12581, 13797.

Dominican Republic: Las Salinas, Fuertes 1421.

5. Chloris cruciata (L.) Swartz, Prodr. Veg. Ind. Occ. 25. 1788. Agrostis cruciata L., Syst. Nat. ed. 10. 2: 893. 1759. Jamaica.

Chloris humboldtiana Steud., Syn. Pl. Glum. 1: 205. 1854. Cuba. Chloris brevigluma Wright, An. Acad. Cien. Habana 8: 200.1871. Cuba, Wright 1848 [error for 1548] in part.

Perennial but sometimes appearing to be annual; culms delicate, filiform, densely tufted, erect or geniculate at base, sometimes straggling, branching from the lower nodes, 10 to $30 \mathrm{~cm}$ tall; blades flat or usually folded or involute, slender, soft, mostly less than $5 \mathrm{~cm}$ long, the uppermost sometimes less than $1 \mathrm{~cm}$ long; spikes usually 2 to 4 , delicate, 1 to $3 \mathrm{~cm}$ long, finally widely spreading or somewhat reflexed; spikelets on distinct pedicels 0.2 to $0.5 \mathrm{~mm}$ long, finally horizontally spreading, pale, about $3 \mathrm{~mm}$ long; awns delicate, 5 to $10 \mathrm{~mm}$ long.

Stony slopes, Cuba, Jamaica, and Hispaniola.

CuBA: Guanabacóa, Curtiss 584; Ekman 279, 13547 ; Hitchcock 239, 240, 23233; Léon 896; Wilson and Léon 11637. Habana, Léon 4786, 11495, 11573. Hanábana, Wright 1548. Western Cuba, Wright 1549. Jamaica: Troy, Harris 12588, 12647. Yallahs Valley, Perkins 1481. Guava Ridge, Hart 680; Eggers 3724. Gordon Town, Hitchcock 9376; Hart 841. Ewarton, Hitchcock 9428. Red Hills, Hitchcock 9469. Stony Hill, Harris 11341. Clifton, Harris 11375. Mount Hybla, Harris 11393. Cold Spring Gap, Harris 11392. Alligator Pond, Hitchcock 9820. Kingston, Hitchcock 9276 (Amer. Gr. Nat. Herb. 651). Ipswich, Hitchcock 9597. Arntully, Orcutt 2592. Farm Hill, Orcutt 3380, 3739. Halberstadt, Maxon 8766.

Haits: Between Cerca-Carivajal and Bois-Charles, on rocks in River Samaná, Ekman H 6067.

\section{Chloris ekmanii Hitchc., sp. nov. ${ }^{34}$}

Perennial; culms densely tufted, slender or capillary, geniculate at base, 10 to $30 \mathrm{~cm}$ tall, rarely taller; blades slender, mostly folded or involute, usually less than $10 \mathrm{~cm}$ long and less than $1 \mathrm{~mm}$ wide when flat; spikes 2 to 5 , mostly 3 or 4 , slender, rather flexuous, usually 1.5 to $3 \mathrm{~cm}$ long, finally horizontally spreading or reflexed; spikelets loosely overlapping, appressed; glumes narrow, acuminate, the second about as long as the lemma, the first about half as long; lemma narrow, about $3 \mathrm{~mm}$ long, shining, pale, minutely pilose along the margin near the summit, otherwise glabrous, the awn 7 to $8 \mathrm{~mm}$ long; rudiment narrow, about $1 \mathrm{~mm}$ long, mostly hidden by the fertile lemma, the awn shorter than that of the fertile floret.

Type in the United States National Herbarium, no. 1387451, collected in pastures at Babujal, Jagüey Grande, prov. Matanzas, Cuba, August 2, 1923, by E. L. Ekman (no. 16954).

Dry grassy or rocky slopes or in pine woods, Cuba, Jamaica, and Hispaniola. The species differs from C. sagraeana in the more delicate habit, the narrower blades, the shorter and more slender spikes, and the less imbricate spikelets.

Cuba: Cajalbana, Léon 4855. La Grifa, Ekman 11252. Habana, Léon 287, 4788. Guanabacoa, Hitchcock 23229, 23240; Léon 856.

${ }^{34}$ A C. sagraeana differt plantis gracilioribus, laminis angustioribus, spicis tenuioribus brevibusque. 
Babujal, Ekman 16954. Soledad, Hitchcock 23329. Baragua, Hitchcock 23357, 23377, 23384. Pitajones, Shafer 12225. Trinidad, Ekman 13975. Sancti Spíritus, Sergius 2569. Iron mine, south of Guara, Hitchcock 23412, 23427.

Jamaica: Ewarton, Hitchcock 9458 (Amer. Gr. Nat. Herb. 652). Troy, Hitchcock 9810. New Forest, Hitchcock 9847. Montego Bay, Hitchcock 9695. Inverness, Harris 12727. Lititz, Harris 12434, 12697. Alligator Pond, Hitchcock 9823.

Haiti: Roche, Ekman H 723.

Dominican Republic: Guayubín, Abbott 916. El Maniclito, Ekman H 11310.

7. Chloris sagraeana A. Rich., in Sagra, Hist. Cuba 11:315. 1850. Cuba, Ramon de la Sagra.

Chloris eleusinoides Griseb., Fl. Brit. W. Ind. 539. 1864. Jamaica and Antigua.

Chloris morales-coelloi Léon, Bull. Torrey Bot. Club 53: 458. 1926. Cuba, Léon 12320.

Perennial; culms mostly slender, cespitose, erect or ascending from a geniculate base, 20 to $60 \mathrm{~cm}$ tall; blades flat or folded, 1 to $2 \mathrm{~mm}$ wide, glabrous, the sheaths compressed; spikes mostly 3 to 6 , sometimes more, mostly 3 to $5 \mathrm{~cm}$ long; spikelets imbricate; glumes narrow, acuminate, 2 and $3 \mathrm{~mm}$ long; lemma about $3 \mathrm{~mm}$ long, narrow, minutely pilose on the margins above and on the callus, the awn about $1 \mathrm{~cm}$ long, purplish, flexuous; rudiment small, narrow, usually enclosed in the margins of the lemma, the awn somewhat shorter than that of the lemma.

Dry or rocky soil, West Indies.

Chloris ekmanii, C. sagraeana, and $C$. cubensis form a polymorphous group. Most of the specimens fall into one of the three species, but there are a few intermediate specimens.

Bahamas: Nassau, Curtiss 81. Without locality, Geogr. Soc. Baltimore 97 in part.

Cuba: Guanabacoa, Léon 857; Hitchcock 23245. Vicinity of Habana, Léon 1965, 2560, 4783, 4787, 4807, 12453, 12454, 12455; Ekman 389; Baker in 1907; Ausovin 779; Hitchcock 242. Guantánamo, Hioram 1379. Monte Verde, Wright 1549. Eastern Cuba, Wright 1548, 3818.

JAMAICA: Ashley Hall, Harris 12738. Savanna-la-Mar, Hitchcock 9890 (Amer. Gr. Nat. Herb. 653).

HaIti: Grande Cayemite, Eyerdam 336. Gros-Morne; Leonard 9839. Dutreuil, Ekman H 10748. Cabaret, Leonard 12067. Jean Rabel, Leonard 12552, 13804. Môle-St.-Nicolas, Leonard 13255. Tortuga Island, Ekman H 4058, H 4171. Pétionville, Leonard 4984. Pignon, Cook, Scofield, and Doyle 138.

Dominican Republic: Mao, Abbott 1042.

Leeward Islands: Barbuda, Danforth 3. Antigua, Box 122; Wullschlaegel. Guadeloupe, Duss 4110.

Windward Islands: Barbados, Hitchcock 16499.

A robust form has been called $C$. morales-coelloi Léon, the type of which is Léon 12320, from Cajobabo, southern Baracoa region, Cuba. It resembles $C$. cubensis but is not pilose at base and lacks the cilia on the upper part of the margins of the lemma. Also the rudiment is smaller, as in $C$. sagraeana. The following specimens appear to 
belong to this form, though there is no definite line between these and the usual form of $C$. sagraeana.

Cuba: Triscornia, Hitchcock 241. Mariel, Ekman 12837. Cajobabo, Léon 12320.

Haiti: Port-de-Pai, Leonard 11051. Ennery, Leonard 8835. Port-au-Prince, Ekman H 2107. Miragoane, Ekman H 9042.

Dominican Republic: Vásquez, Ekman H 13128. Without locality, Wright, Parry, and Brummel 610.

\section{Chloris cubensis Hitchc. and Ekman, sp. nov. ${ }^{35}$}

Perennial; culms erect or spreading at base, sometimes decumbent and rooting, occasionally forming stolons, glabrous, more or less compressed, 50 to $75 \mathrm{~cm}$ tall; sheaths glabrous, somewhat villous at the throat, the basal usually rather strongly compressed and keeled, mostly shorter than the internodes; ligule a ciliate membrane about $0.3 \mathrm{~mm}$ long; blades flat or folded, scaberulous and sometimes sparsely villous on the upper surface especially at the base, glabrous beneath, mostly 5 to $10 \mathrm{~cm}$ long, the basal sometimes elongate, the upper reduced, 1 to 2 or rarely $3 \mathrm{~mm}$ wide; racemes usually 5 to 7 , distant, 5 to $7 \mathrm{~cm}$ long, ascending; spikelets rather closely imbricate, appressed or ascending, pale or purplish; glumes narrow, the first about $2 \mathrm{~mm}$ long, the second about $3 \mathrm{~mm}$ long; fertile lemma about $3 \mathrm{~mm}$ long, pilose at base, ciliate on the upper half of the margins, the hairs as much as $1 \mathrm{~mm}$ long, sometimes sparsely pilose along the middle of the keel, the awn from about $0.5 \mathrm{~mm}$ below the apex, 1 to $2 \mathrm{~cm}$ long, capillary, slightly flexuous; rudiment about $1.5 \mathrm{~mm}$ long, oblong, the awn shorter than that of the fertile floret.

Type in the United States National Herbarium, no. 1387446, collected at Gamboa, prov. Oriente, Cuba, August 26, 1922, by E. L. Ekman (no. 14960).

In the Grasses of the West Indies ${ }^{36}$ this species was referred to C. orthonoton Doell of Brazil which is strongly stoloniferous, with wider lemmas and shorter awns. The smaller specimens have been referred to C. sagraeana, which has more slender culms, and shorter, finally reflexed spikes.

Dry open ground, Cuba, Jamaica, Haiti, and Leeward Islands.

CuBA: Herradura, Hitchcock 243. Vicinity of Habana, Léon 859, 860, 12456; Ekman 13469. Gamboa, Ekman 14960. Holguín, Ekman in 1922.

Jamaica: Cockpit (Vere), Harris 12462.

HaIti: Tortuga Island, Leonard 12538; Ekman H 4058.

Leeward Islands: Antigua, Box 35.

9. Chloris arenaria Hitchc. and Ekman, sp. nov. ${ }^{37}$

Chloris eleusinoides var. vestita Greenm., in Combs, Acad. Sci. St. Louis Trans. 7: 477. 1897. Cuba, Combs 631.

Perennial; culms cespitose, erect or somewhat geniculate at base, glabrous, 30 to $50 \mathrm{~cm}$ tall; sheaths compressed-keeled, puberulent; ligule a ciliate membrane about $0.5 \mathrm{~mm}$ long; blades firm, flat or folded, puberulent, the basal 5 to $10 \mathrm{~cm}$ long, the culm blades shorter,

${ }^{35}$ A C. sagraeana differt planta robustiore spicis longioribus crassioribus ascendentibus, lemmate ad. basin et supra ad margines pilosociliato, rudimento majore.

${ }_{36}$ Contrib. U. S. Natl. Herb. 18: 376, 1917.

37 Perennis; culmi erecti glabri $30-50 \mathrm{~cm}$ alti; vaginae laminaeque puberulae, vaginis compressis, laminis planis vel conduplicatis 5-10 $\mathrm{cm}$ longis 1-2 mm latis; racemi 5-6 digitati ascendentes vel denique reflexi 3-6 cm longi; spiculae imbricatae; glumae acuminatae, prima $3 \mathrm{~mm}$ longa, secunda $5 \mathrm{~mm}$ longa; lemma fertile $3.5 \mathrm{~mm}$ longum, callo puberulo, marginibus superne pilosociliatis; arista 1.5-2.4 cm longa; rudimentum anguste oblongum $2 \mathrm{~mm}$ longum, arista 1-2 cm longa. 
the uppermost 5 to $10 \mathrm{~mm}$ long, the basal blades as much as $3 \mathrm{~mm}$ wide, but mostly much narrower; racemes mostly 5 or 6 , digitate, pubescent at base, ascending or finally reflexed, 3 to $6 \mathrm{~cm}$ long, stramineous; spikelets imbricate, appressed; glumes narrow, acuminate, the first $3 \mathrm{~mm}$ long, the second $5 \mathrm{~mm}$ long; fertile lemma $3.5 \mathrm{~mm}$ long, including the narrow, puberulent callus, pilose-ciliate along the upper part of the margins, the awn about 1.5 to $2.5 \mathrm{~cm}$ long; rudiment narrowly oblong, $2 \mathrm{~mm}$ long, the awn somewhat shorter than that of the fertile lemma.

Type in the United States National Herbarium, no. 1387449, collected in pinelands on white sand, La Grifa, prov. Pinar del Río,

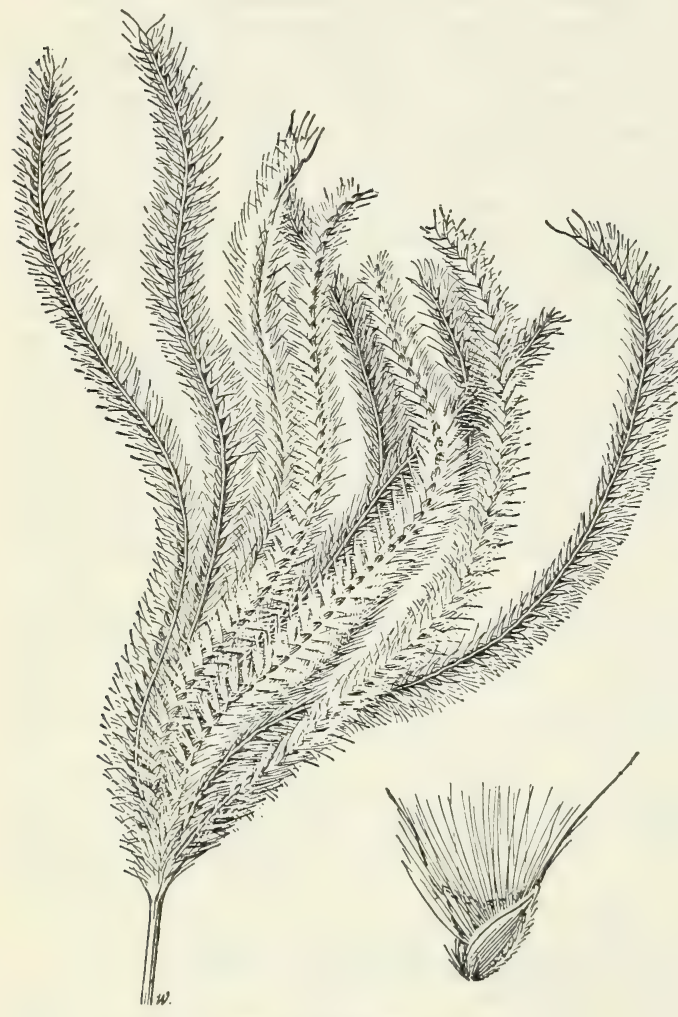

FIGURE 81.-Chloris polydactyla. Panicle, $\times 1$; florets, $\times 5$ (Simpson). June 14,1920 , by E. L. Ekman (no. 11253).

The species is allied to $C$. sagraeana from which it differs in the puberulent foliage, the longer glumes and awns, and in the firm erect innovations.

Pinelands, Cuba.

CuBa: La Grifa, Ekman 11252, 11253; Wright 3819. Cienfuegos, Combs 631.

\section{Chloris polydactyla}

(L.) Swartz, Prodr. Veg. Ind. Occ. 26. 1788 .

Andropogon barbatus L., Syst. Nat. ed. 10. 2: 1305.1759 . Jamaica.

Andropogon polydactylon L., Sp. Pl. ed. 2. 1483. 1763. Jamaica. Chloris barbata Nash, Bull. Torrey Bot. Club 25: 443. 1898. Not $C$. barbata Swartz, 1797 (this based on Andropogon barbatus L., 1771, from the East Indies).

Culms rather stout, commonly more than $1 \mathrm{~m}$ tall; blades about $1 \mathrm{~cm}$ wide; spikes 5 to 10 , pale, usually 8 to $10 \mathrm{~cm}$ long, strongly flexuous; spikelets closely imbricate, silky; first lemma about $2.5 \mathrm{~mm}$ long; broad, pubescent on the keel, long-ciliate on the margins, the hairs $2 \mathrm{~mm}$ long, the awn about as long as the lemma; second lemma shorter and narrower than the first, the awn about $2 \mathrm{~mm}$ long (fig. 81 ).

Savannas and grassy slopes, Florida and the West Indies to Brazil.

Bahamas: New Providence, Curtiss 80; Geogr. Soc. Baltimore 262.

JAMAICA: Ipswich, Maxon and Killip 1492; Hitchcock 9622. Inverness, Harris 12743. Lucea, Hitchcock in 1891. Ewarton, Hitchcock 
9459. Gordon Town, Hitchcock 9322 (Amer. Gr. Nat. Herb. 656); Hart 929. Bog Walk, Hitchcock 9302. Montego Bay, Hitchcock 9676. Savanna-la-Mar, Hitchcock 9865. New Forest, Hitchcock 9842. Lititz, Hitchoock 11654. Yardley Chase, Harris 9665. Without locality, Wullschlaegel 1116. Grand Cayman, Millspaugh 1271.

Haitr: Grande Cayemite, Eyerdam 329; Ekman H 8941. Aux Cayes, Ekman H 846.

Leeward Islands: Antigua, Hitchcock 16394; Box 26. Common on this island.

11. Chloris ciliata Swartz, Prodr. Veg. Ind. Occ. 25. 1788. Jamaica. loupe.

Chloris propinqua Steud., Syn. Pl. Glum. 1: 204. 1854. Guade-

Erect or spreading annual; culms 30 to $60 \mathrm{~cm}$ tall or sometimes taller; blades flat, as much as $5 \mathrm{~mm}$ wide; spikes pale, 4 to 6 , strongly flexuous, 3 to $6 \mathrm{~cm}$ long, the florets conspicuously silky-ciliate; fertile lemma about $2.5 \mathrm{~mm}$ long, strongly ciliate on the keel and marginal nerves, the awn 1 to $1.5 \mathrm{~mm}$ long; rudiment of 2 or 3 sterile lemmas, triangular-truncate, not longer than the fertile lemma, awnless (fig. 82).

Open ground and waste places, Texas and the West Indies to Argentina.

Bahamas: New Providence, Curtiss 72.

Cuba: Guane, Shafer 10393. Herradura, Hitchcock 245. Habana, Tracy 9085, 9106; Curtiss 600; Ekman 1192; Léon 574. Santiago de las Vegas, Tracy 9115; Hitchcock 244. Trinidad, Wright 743. Santiago de Cuba, Léon 8561⁄2.

JAMAICA: Southern Manchester, Harris 12689. Inverness, Harris 12755 . Ipswich, Hitchcock 9592. Ewarton, Hitchcock 9430 (Amer. Gr. Nat. Herb. 655). Montego Bay, Hitchcock 9671. Savanna-la-Mar, Hitchcock 9856. Halfmoon Bay, Hitchoock 9757. Hope Gardens, Hitchcock 9309. New Forest, Hitchcock 9829. Flamstead, Harris 11473.

Haiti: Ennery, Leonard 8814. Port-de-

Pai, Ekman H 4324. Jean Rabel, Leonard 12934. Port-au-Prince, Ekman H 8145; Hitchcock 19872, 22955. St. Marc, Leonard 2973. Gonaïve Island, Leonard 3371. Tortuga Island, Leonard 12444, 15584.

Dominican Republic: Barahona, Fuertes 908. Jaina, Ekman H 12486.

Puerto Rico: Ponce, Chase 6495.

Virgin Islands: St. Croix, Ricksecker 42; Thompson 13; Hitchcock 16338. St. Thomas, Eggers in 1882.

Leenard Islands: Barbuda, Danforth 6. Antigua, Hitchcock 16392; Box 31. Guadeloupe, Duss 3158b.

Windward Islands: Martinique, Duss 1273; Hahn. Barbados, Hitchcock 16514.

12. Chloris inflata Link, Enum. Pl. 1: 105. 1821.

Andropogon barbatum L., Mant. Pl. 2:302. 1771. Not A. barbatum L., 1759. East Indies. 
Chloris barbata Swartz, Fl. Ind. Occ. 1:200. 1797. Based on Andropogon barbatum L. Mant. 2: 302. 1771.

Chloris paraguaiensis Steud., Syn. Pl. Glum. 1: 204. 1854. Paraguay.

Tufted annual, 30 to $75 \mathrm{~cm}$ tall; culms and sheaths strongly compressed; blades long, lax; spikes about 10, usually flexuous, commonly purplish-tinged, 4 to $6 \mathrm{~cm}$ long; first lemma $2 \mathrm{~mm}$ long, the awn about $6 \mathrm{~mm}$ long; rudiment of 2 triangular-obtuse lemmas about 1 $\mathrm{mm}$ long, the awn of the first about as long as that of the fertile lemma, the awn of the second short (fig. 83).

Waste places, a common weed at low altitudes, Mexico and the West Indies to Argentina. Type grown in the Berlin Botanic Garden from seed said to come from "California," probably from Mexico. Probably to be found on all the West Indian islands.

13. Chloris virgata Swartz, Fl. Ind. Occ. 1: 203. 1797. Antigua. Feather fingergrass.

\section{Chloris elegans H. B. K., Nov. Gen. et Sp. 1: 166. pl. 49. 1816. Mexico.}

Culms ascending, 20 to $40 \mathrm{~cm}$ tall, scarcely compressed, the upper sheaths slightly inflated, glabrous in the throat; spikes mostly 5 or 6 , suberect, somewhat flexuous in age, 3 to $5 \mathrm{~cm}$ long; fertile lemma $3 \mathrm{~mm}$ long, broadest above the middle, villous on the keel to a little below the summit, and long pilose on the margins near the tip, the awn 5 to $8 \mathrm{~mm}$ long; rudiment a little more than $2 \mathrm{~mm}$ long gradually broadened to an oblique truncate apex, the awn somewhat shorter than that of the fertile lemma (fig. 84).

Open ground, fields, and waste places, the West Indies and southwestern United States to Argentina; a common weed in warm countries of both hemispheres.

Cuba: Candelaria, Ekman 17595. Herradura, Hitchcock 249. Campo Florido, Léon 3461. Vento, Shafer 483; Baker 1183. Mazarra, Baker 4023. Soledad, Hitchcock 23336. Fomento, Léon 6434. Sancti Spíritus, Léon 858. Corojo, Léon 3964. Bayamo, Shafer 12394.

HaIti: Port-au-Prince, Ekman H 9098; Hitchcock 19879. Artibonite Valley, Cook, Scofield, and Doyle 213. L'Arcahaie, Ekman H 9054.

Dominican Republic: Santiago, Ekman H 16020.

Leeward Islands: Barbuda, Danforth 5. Guadeloupe, Stehlé 108.

\section{TRICHLORIS Fourn., Mex. Pl. 2: 142. 1886}

Spikelets, 1- to few-flowered, neariy sessile, in two rows along one side of a continuous slender racbis, the rachilla disarticulating above the glumes and prolonged behind the uppermost perfect floret, bearing a reduced, usually awned floret; glumes unequal, acuminate or short-awned, the body shorter than the lower lemma; lemmas narrow, 3-nerved, the marginal nerves sometimes pubescent, these and the midnerve extending into awns, the central long and slender, the lateral often much shorter. Erect, slender, tufted perennials, with flat blades and numerous erect or ascending spikes, aggregate but scarcely digitate at the summit of the culms. 


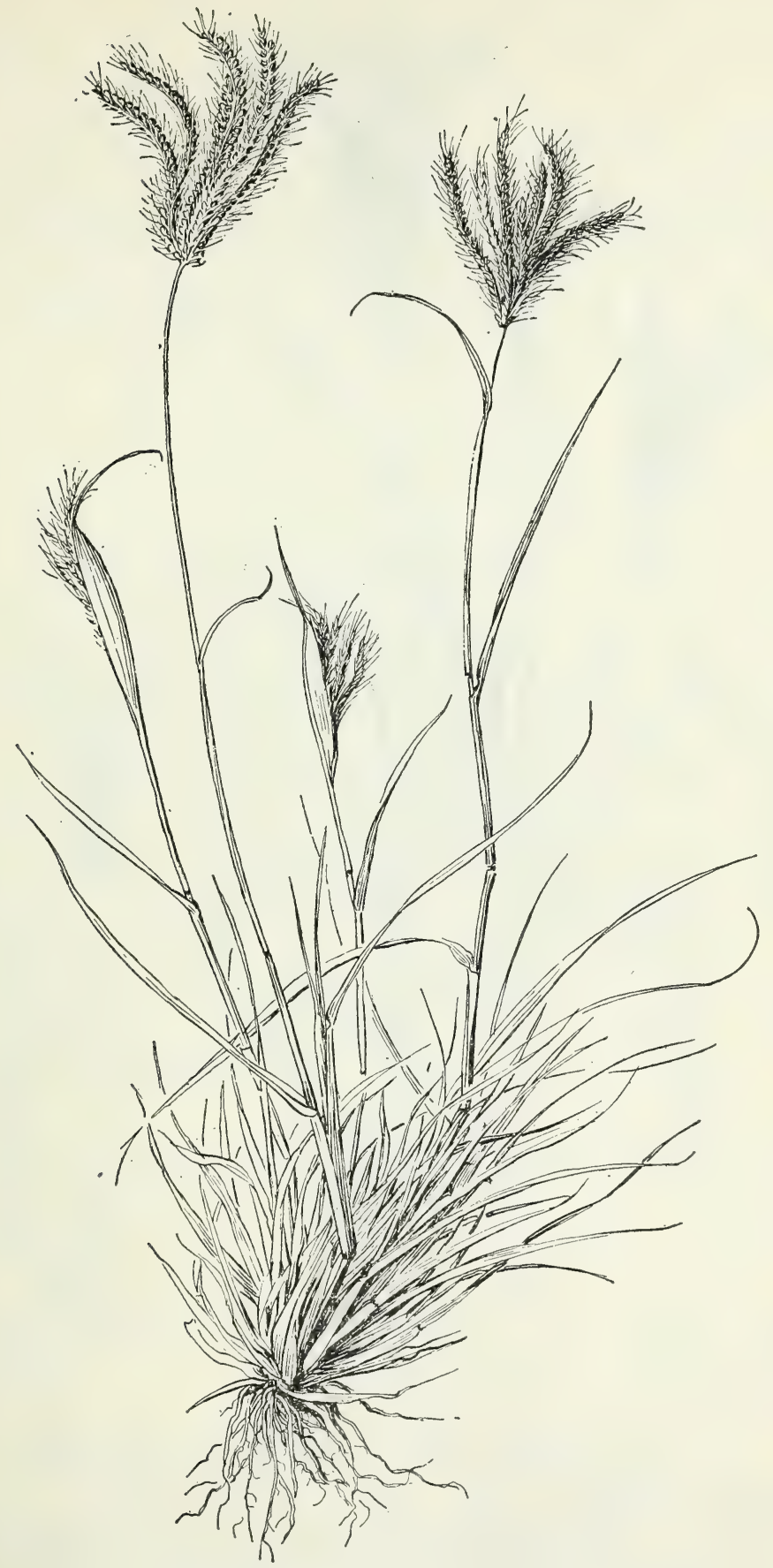

FIGURE 83.-Chloris inflata, $\times 1 / 2$ (Rose, Fitch, and Russel] 3534). 


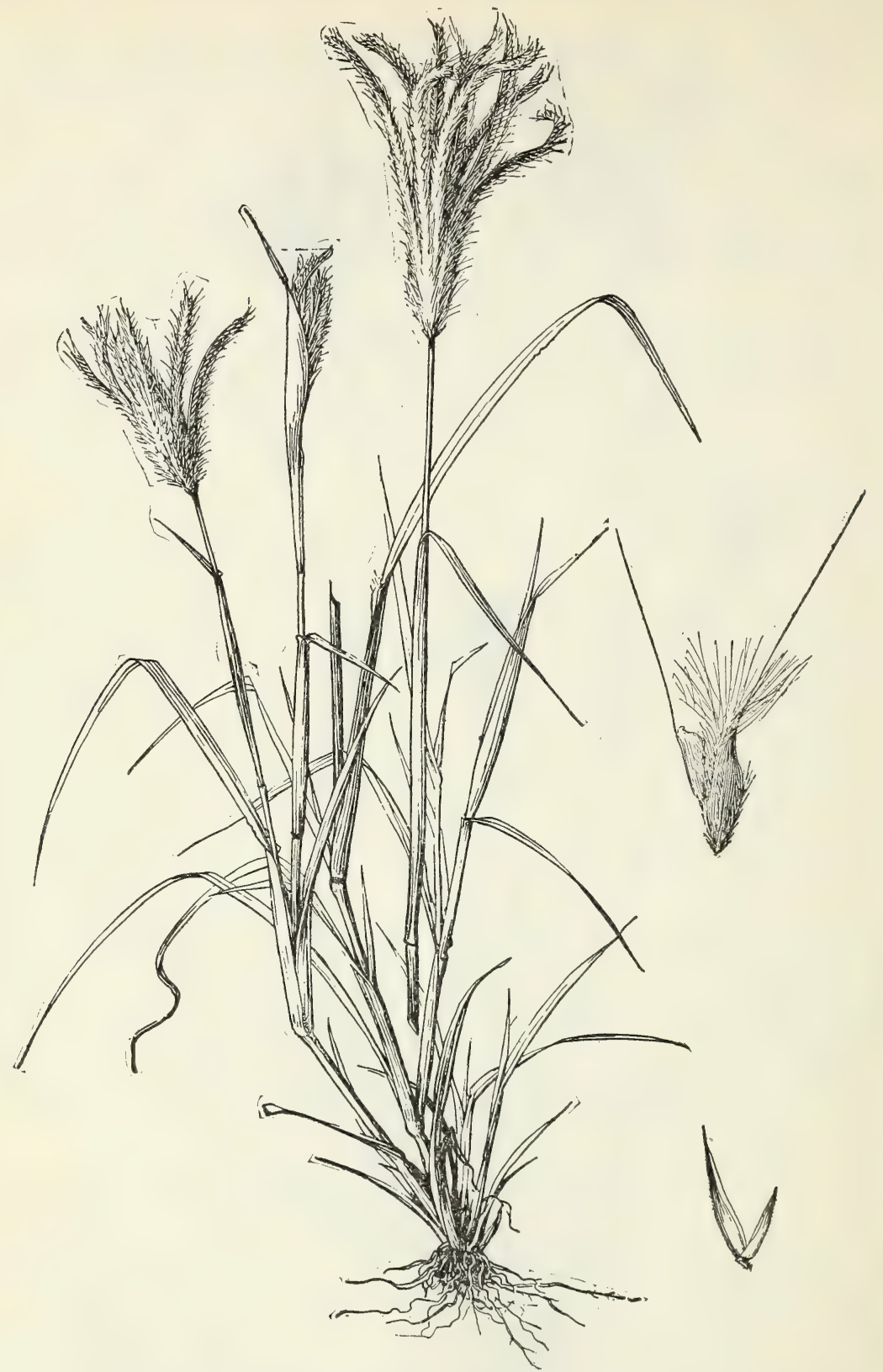

Figure 84.-Chloris virgata. Plant, $\times 1 / 2$; glumes and florets, $\times 5$ (Tracy 8173).

1. Trichloris pluriflora Fourn., Mex. Pl. 2: 142 . 1886.

Culms 50 to $100 \mathrm{~cm}$ tall; blades 5 to $10 \mathrm{~mm}$ wide; inflorescence somewhat loose and feathery; spikes 7 to $15 \mathrm{~cm}$ long; fertile lemma about $4 \mathrm{~mm}$ long, the others successively shorter, the middle awns of all 5 to $15 \mathrm{~mm}$ long, somewhat spreading, the lateral awns short or obsolete (fig. 85). 
Plains and dry woods, southern Texas and Mexico; Cuba; South America.

CubA: Casa Blanca, Habana, Ekman 16879.

56. BOUTElOUA Lag., Var. Cien. $2^{4}: 134$. 1805. Grama

Spikelets, 1-flowered, with the rudiments of 1 or more florets above, sessile, in two rows along one side of the rachis; glumes unequal, 1nerved, acuminate or awn-tipped, the first shorter and narrower; lemma as long as the second glume or a little longer, 3-nerved, the nerves extending into short or often rather long awns, the internerves usually ex-

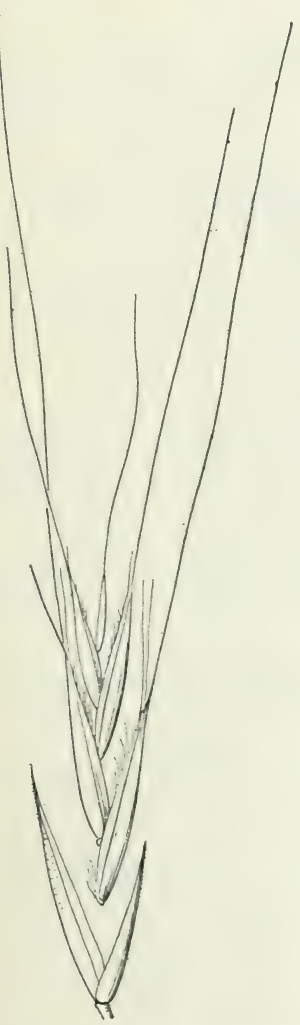

FIGURE 85.-Trichloris pluriflora. Glumes and florets, $\times 5$ (Griffiths 6484). tending into teeth; palea 2-nerved, sometimes 2awned; rudiment various, usually 3-awned, a second rudimentary floret sometimes present. Perennials or sometimes annuals, with few to many spikes racemose on a common axis, sometimes solitary, the spikelets few to many in each spike, rarely solitary, pectinate or more loosely arranged and appressed, the rachis of the spike usually produced beyond the insertion of the spikelets.

Plants annual. Culms widely spreading _.5. B. DIsTichA. Plants perennial.

Spikes numerous, usually more than 10 .

Awns very short; culms about $30 \mathrm{~cm}$ tall.

1. B. VANEEDENII.

Awns conspicuous, about as long as the spikelet; culms mostly less than $20 \mathrm{~cm}$ tall.

2. B. JUNCEA.

Spikes mostly less than 10.

Spikes divergent, rather distant, slender.

3. B. AMERICANA.

Spikesless distant, broader

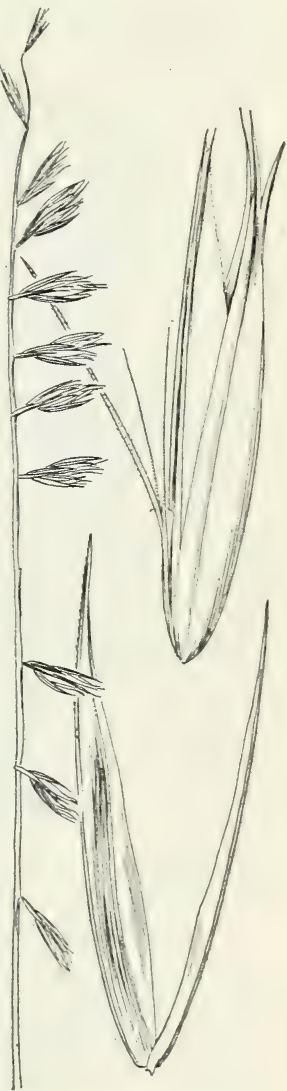

FIGURE 86.-Boutelout vaneedenii. Panicle $\times 1$; s pikelet, $\times 5$ (Ekman 15546). and shorter.

4. B. Heterostega.

1. Bouteloua vaneedenii Pilger, in Urban, Symb. Antill. 6: 2. 1909. Anguilla, Boldingh 3512.

Perennial; culms cespitose, erect, slender, about $30 \mathrm{~cm}$ tall; blades involute, filiform, glabrous; spikes 10 to 20 , on an axis 8 to $15 \mathrm{~cm}$ long, 2 to $5 \mathrm{~mm}$ apart, finally reflexed, 5 to $8 \mathrm{~mm}$ long; spikelets mostly 2 to each spike; awns very short (fig. 86). 
Dry littoral limestone rocks, Cuba, Anguilla, and Venezuela (Pittier 11338).

Cuba: Pastelillo, Ekman 15546.

Leeward Islands: Anguilla, Boldingh 3512.

2. Bouteloua juncea (Desv.) Hitchc., Contrib. U. S. Natl. Herb. 17: 343. 1913.

Triathera juncea Desv.; Beauv., Ess. Agrost. 40. pl. 9. f. 4.1812 Hispaniola.

Eutriana juncea Trin., Gram. Unifl. 238. 1824.

Eutriana ledebouri Trin., Gram. Unifl. 238. 1824. Haiti.

Atheropogon domingensis Spreng., Syst. Veg. 1: 2£3. 1825. Hispaniola.

Triaena juncea Griffiths, Contrib. U. S. Natl. Herb. 14: 354. 1912.

A low delicate perennial, prostrate below, geniculate at the lower nodes, the branches commonly in pairs or fascicles; nodes and summit of the sheaths pilose; blades flat or folded, 8 to $12 \mathrm{~mm}$ long, about $1.5 \mathrm{~mm}$ wide; racemes of few to several minute spikes, the spikelet solitary, pilose at base, 3 to $4 \mathrm{~mm}$ long; glumes lanceolate, acuminate, the first one-third, the second slightly over half the length of the spikelet; fertile lemma narrow, with 3 erect scabrous teeth at the summit, the palea 2-toothed, shorter; sterile floret about equaling the fertile lemma, consisting of 3 slender scabrous awns.

Arid open ground, eastern Cuba, Puerto Rico, and Hispaniola.

Cuba: Guantánamo, Britton 1964.

Haiti: Jean Rabel, Leonard 12622. Bombardopolis, Leonard 13593. Cabaret, Leonard 11788, 11853. Bassin Bleu, Leonard 14902. Artibonite, Cook, Scofield, and Doyle 212. St. Michel de l'Atalaye, Leonard 7096. Gros-Morne, Leonard 9868. Croix-desBouquets, Ekman H 2147. Cape Haitien, Ekman H 2717. Anse-àPitre, Ekman H 6683. Anse-à-Veau, Ekman H 5416. Gonaïves, Buch 1010.

Dominican Republic: Guayubín, Abbott 864. Monción, Ekman H 13058. San Juan, Ekman H 13393. Without locality, Poiteau.

Puerto Rico: Guanica, Britton, Cowell, and Brown 4918.

3. Bouteloua americana (L.) Scribn., Acad. Nat. Sci. Phila. Proc. 1891: 306.1891.

Aristida americana L., Syst. Nat. ed. 10. 2: 879. 1759. Jamaica. Aristida antillarum Poir., in Lam., Encycl. Sup. 1: 451.1810. Antilles.

Bouteioua litigiosa Lag., Gen. et Sp. Nov. 5. 1816. Jamaica.

Chactaria antillarum Beauv.; Roem. and Schult., Syst. Veg. 2: 395. 1817.

Aristida subbiflora Steud., Syn. Pl. Glum. 1: 138. 1854. Guadeloupe.

Eutriana antillarum Steud., Syn. Pl. Glum. 1: 217. 1854.

Bouteloua elatior Griseb., Fl. Brit. W. Ind. 537. 1864. Antigua.

Aristida adscensionis var. americana Kuntze, Rev. Gen. Pl. 3: 340. 1898.

Perennial, mostly prostrate-spreading; culms branching, 30 to 60 $\mathrm{cm}$ long; blades flat or loosely involute, 2 to $3 \mathrm{~mm}$ wide; spikes 3 to 7 , about $2 \mathrm{~cm}$ long; glumes 3 and $4 \mathrm{~mm}$ long; lemma 3 -awned, the central awn $3 \mathrm{~mm}$ long, the lateral $1 \mathrm{~mm}$; rudiment with 3 awns about $1 \mathrm{~cm}$ long (fig. 87). 
Open dry ground, West Indies and Central America to Brazil.

Cuba: Habana, Léon 780, 890, 4725, 4789; Curtiss 546 (in part). La Gloria, Shafer 244. Soledad, Hitchcock 23324. Guara, Hitchcock 23395. Isla de Pinos, Ekman 11789. Without locality, Wright 3816.

JAMAICA: Vicinity of Kingston, Harris 11369, 11372, 11500, 12674; Hitchcock 9743, 9744; Ridley 76, 112. Alligator Pond, Hitchcock 9824. Savanna-la-Mar, Hitchcock 9860. Black River, Hitchcock 4633 (Amer. Gr. Nat. Herb. 380). Mount Charles, Harris 11559. Mount Hybla, Harris 11443. Musgrave Road, Harris 11481. Mount Faraway, Harris 11451. Robertsfield, Harris 11394. Montego Bay, Hitchesck 9562. Gordon Town, Hart 559.

Haitr: St. Michel de l'Atalaye, Leonard 7205. Ennery, Leonard 9476. Gros-Morne, Leonard 9865. Etroite, Leonard 3403. Port-au-Prince, Ekman H 2188. St. Marc, Ekman H 6645.

Dominican Republic: Rincón, Fuertes 1376. Maniel de Ocoa, Tuerckheim 3616.

Puerto Rico: Coamo Springs, Chase 6539. Guayama, Chase 6754. Fajardo, Chase 6662. Vieques Island, Chase 6666; Shafer 2501.

Virgin Islands: St. Jan, Britton and Shafer 280, 633. St. Thomas, Eggers in 1876. St. Croix, Thompson 616; Ricksecker 78. Virgin Gorda, Fishlock 274.

Leeward Islands: Antigua, Box 117; Wullschlaegel 619. Guadeloupe, Duss 3160. Dominica, Jones 64.

Windward Islands: Montserrat, Shafer 215. Martinique,

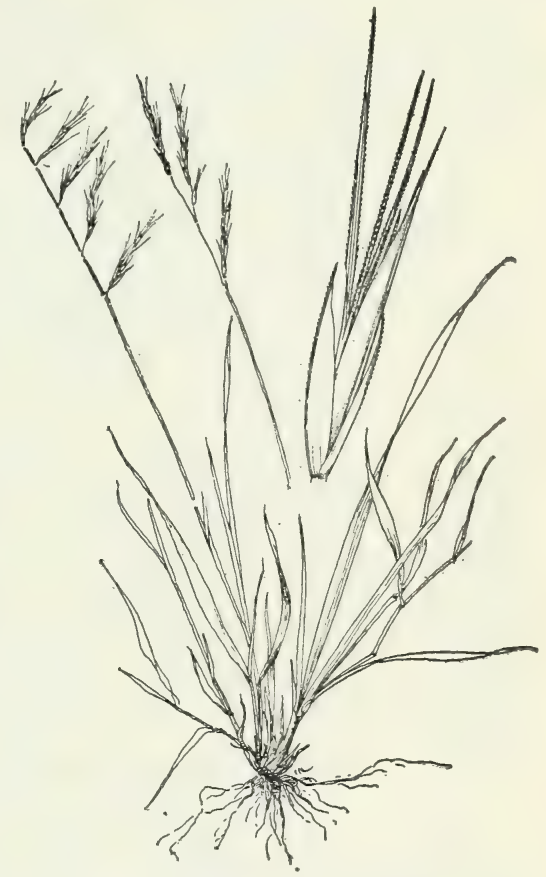

Figure 57.-Bouteloua americana. Plant, $\times 1 / 2$ spikelet, $\times 5$ (Harris 11451).

Dilss 1326. Grenada, Broadway 217, 1670 ; Elliott 138; Hitchcock 17666.

Tobago: Broadway 4385; Hitchcock 10215; Eggers 5650.

4. Bouteloua heterostega (Trin.) Griffiths, Contrib. U. S. Natl. Herb. 14: 414.1912.

Heterosteca juncifolia Desv., Nouv. Bull. Soc. Philom. Paris 2: 188. 1810. Antilles. Not Bouteloua juncifolia Lag., 1816.

Eutriana heterostega Trin., Gram. Unifl. 242. 1824. Antilles.

Bouteloua humboldtiana Griseb., Mem. Amer. Acad. n. ser. 8: 532. 1862. Cuba, Wright 734, 739.

Bouteloua porphyrantha Wright, Anal. Acad. Cienc. Habana 8: 201. 1871. Cuba, Wright:734, :39, 3816.

Heterosteca rhadina Nash, Bull. 'Torrey Bot. Club 30: 386. 1903. Puerto Rico, Heller 6057.

Perennial; culms usually widely spreading or leaning, 30 to $50 \mathrm{~cm}$ long or sometimes longer: blades flat or involute, filiform or as much 
as $2 \mathrm{~mm}$ wide; inflorescence 3 to $10 \mathrm{~cm}$ long; spikes mostly 3 to 7 , ascending or spreading, 1 to $2 \mathrm{~cm}$ long, oblong; spikelets mostly 4 to 8, rather closely imbricate; awns 3 to $8 \mathrm{~mm}$ long (fig. 88).

CuBa: Vicinity of Habana, Léon 293, 861, 3479, 4147, 4792, 8980; Hitchcock 460; Curtiss 546 (in part); Ekman 35, in 1921. Triscornia, Hitchcock 452; Tracy 9088; Van Hermann 1873. Guanabacoa, Hitchcock 23244; Léon 9124. Sancti Spíritus, Shafer 12060. Guantánamo, Britton 2148. Santiago de Cuba, Ekman 7913. Bayamo, Shafer 12386. Eastern Cuba, Wright 739. Isla de Pinos, Britton and Wilson 15155. Without locality, Wright 3815.

HAITI: Port-au-Prince, Ekman H 9108; Hitchcock 19881; Buch 2042. Etang, Leonard 3508. Hinche, Cook, Scofield, and Doyle 143, 145. St. Michel de l'Atalaye, Leonard 7111, 7336, 7789. Ennery, Leonard 8809. Gros-Morne, Leonard 9987. Miragoane, Eyerdam 575. Môle-St.-Nicolas, Leonard

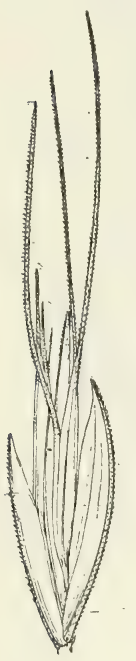

FIGURE 88.Bouteloua heterostega. Spikelet, $\times 5$ (Léon 861). 13219. Jean Rabel, Leonard 12562. St. Marc, Leonard 2880. St. Roc, Buch 1831.

Dominican Republic: Nigua, Faris 555. Guayubín, Abbott 934. Santiago, Raunkiaer 939; Ekman H 16495. Contanza, Tuerckheim 3275. Maniel de Ocoa, Tuerckheim 3600. Without locality, Wright, Parry, and Brummel in 1871.

Puerto Rico: Bayamon, Stahl 2. Mayaguez, Chase 6268, 6301; Holm 117; Britton and Cowell 4074. Maricao, Chase 6227. Ponce, Chase 6327, 6484, 64851/2; Britton and Cowell 1321; Britton, Cowell, and Brown 5382; Britton and Marble 1778. Boqueron, Chase 6504. Punta Melones, Britton and Brown 4648. San German, Britton and Cowell 4017. Cayey, Sintenis 2203. Arroyo, Sintenis 2267. Coamo, Britton and Brown 5947; Sintenis 1959. Palo Seco, Hioram 837.

5. Bouteloua disticha (H. B. K.) Benth., Jour. Linn. Soc. Bot. 19: 105. 1881.

Polyodon distichum H. B. K. Nov. Gen. et Sp. 1: 175. pl. 55. 1816. Ecuador.

Annual; culms widely spreading or straggling, 20 to $100 \mathrm{~cm}$ long; blades flat, more or less pilose on the margins and upper surface, 2 to $5 \mathrm{~mm}$ wide; spikes several to many, sometimes 30 or more, approximate on an axis 10 to $20 \mathrm{~cm}$ long, 5 to $10 \mathrm{~mm}$ long (excluding awns); spikelets mostly 2 to 5 in each spike; awns 5 to $10 \mathrm{~mm}$ long.

Open ground and dry hills, Ecuador and northern Peru; Cuba, probably introduced.

CubA: Vicinity of Habana, Ekman 13478; Léon 299, 749, 12467 ; Van Hermann 320; Wilson and Léon 11590; Curtiss 537; Wilson 9160; Johnston 1108; Hitchcock 23222.

\section{OPIZIA Presl, Rel. Haenk. 1: 293. pl. 41. f.1. 1830}

Plants monoecious (sometimes dioecious); pistillate spikelets in a single loose 1-sided spike; first glume minute or obsolete; second glume nearly as long as the floret; fertile lemma subindurate, broad, 3-awned, enclosing a broad palea with keels crested above, the rachilla 
joint below the 3-awned rudimentary floret adnate to the lower part of the keel; staminate spikelets awnless, imbricate in short spikes, these racemose. Low stoloniferous perennial with flat blades and small spikes.
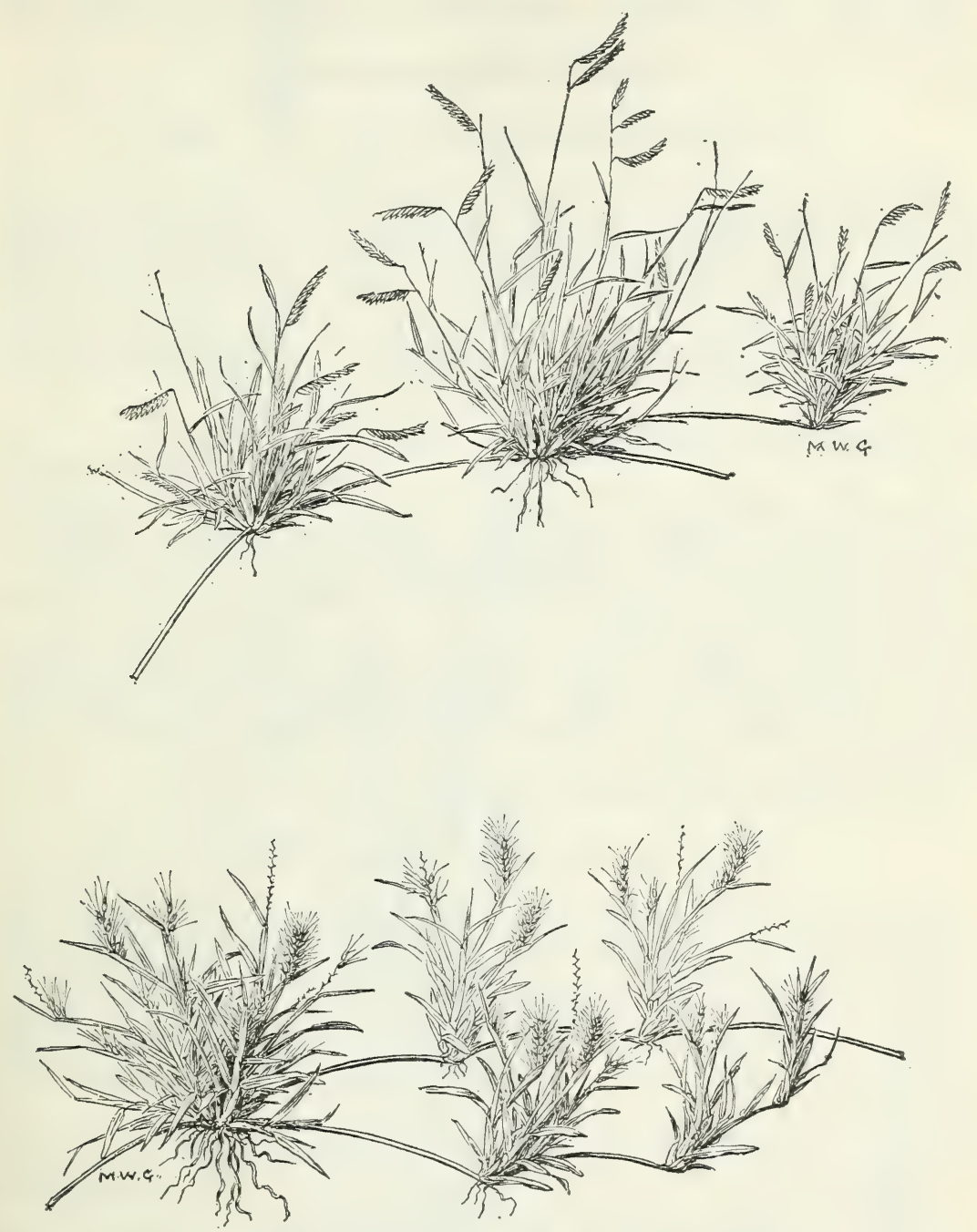

FIGURE 89.-Opizia stolonifera, $\times 1 / 2$ (Pringle 4566).

1. Opizia stolonifera Presl, Rel. Haenk. 1: 293. pl. 41. f. 1. 1830. Mexico.

Forming dense mats, the shoots on the stolons mostly fascicled, the slender flowering culms 5 to $10 \mathrm{~cm}$ tall; blades flat, 1 to $2 \mathrm{~mm}$ wide; pistillate spikes short-exserted, bristly with awns about $5 \mathrm{~mm}$ long; staminate spikes 1 to 3 , long-exserted, 1 to $1.5 \mathrm{~cm}$ long (fig. 89). 
Open ground and pastures, southern Mexico; Cuba, probably introduced; Trinidad, introduced.

CuBA: Ticinity of Habana, Ekman 36, 13251; Hitchcock 268, 23243; Curtiss 571; Léon 274, 288.

TRINIDAD: Port-of-Spain, introduced in lawns and parks, Bain 13082 .

\section{TRIBE 8. PHALARIDEAE}

\section{ANTHOXANTHUM L., Sp. Pl. 28. 1753}

Spikelets with 1 terminal perfect floret and 2 sterile lemmas, the rachilla disarticulating abore the glumes, the sterile lemmas falling attached to the fertile floret; glumes unequal, acute or mucronate; sterile lemmas shorter than the glumes, emptr, awned from the back; fertile lemma shorter than the sterile ones, awnless; palea 1-nerved, rounded on the back, enclosed in the lemma. Sweet-smelling annuals or perennials with flat blades and narrow panicles.

1. Anthoxanthum odoratum L., Sp. Pl. 28. 1753. Europe.

SWeet vernalgrass.

Perennial, culms erect, 30 to $60 \mathrm{~cm}$ tall: blades flat, 1 to $6 \mathrm{~mm}$ wide; panicles spikelike, oblong or lanceolate, greenish rellow or bronze, 2 to $7 \mathrm{~cm}$ long: spikelets about 6 to $8 \mathrm{~mm}$ long (fig. 90).

Cultivated and escaped in pastures in temperate regions of the world; introduced in America.

JAMAICA: Cinchona, Harris 9499, 11302, 11453, 11525, 11599, 11849, 12353, 12455, 12181; Hitchcock 969s. St. Helens Gap, Maxon and Killip 607. Morces Gap, Orcutt 5555. Gordon Town, Hart 742 .

Haiti: Pays-Pourri, Ekman H 7749.

\section{PHALARIS L., Sp. Pl. 54. 1753}

Spikelets laterally compressed, with 1 terminal perfect floret and 2 sterile lemmas below, disarticulating abore the glumes, arranged in usually dense spikelike panicles; glumes equal, boat-shaped, often winged on the keel; sterile lemmas reduced to 2 small scales (rarelr onlr 1); fertile lemma coriaceous, shorter than the glumes, enclosing the faintly 2-nerved palea. Annual or perennial erect grasses, with flat blades.

1. Phalaris canariensis L., Sp. Pl. 54. 1753. Europe and the Canary Islands.

CANARY GRASS.

Annual: culms erect, 30 to $60 \mathrm{~cm}$ tall: blades flat, 3 to $8 \mathrm{~mm}$ wide; panicles dense, oroid, 2 to $3 \mathrm{~cm}$ long: spikelets whitish, 5 to $6 \mathrm{~mm}$ long, the glumes with a green stripe down the side, the keel with a broad wing (fig. 91).

Taste places; a native of Europe and Africa but now widely distributed in temperate regions.

Bermuda: Brown, Britton, and Bisset 1963.

Cuba: Habana, Léon and Ekman 4265. 


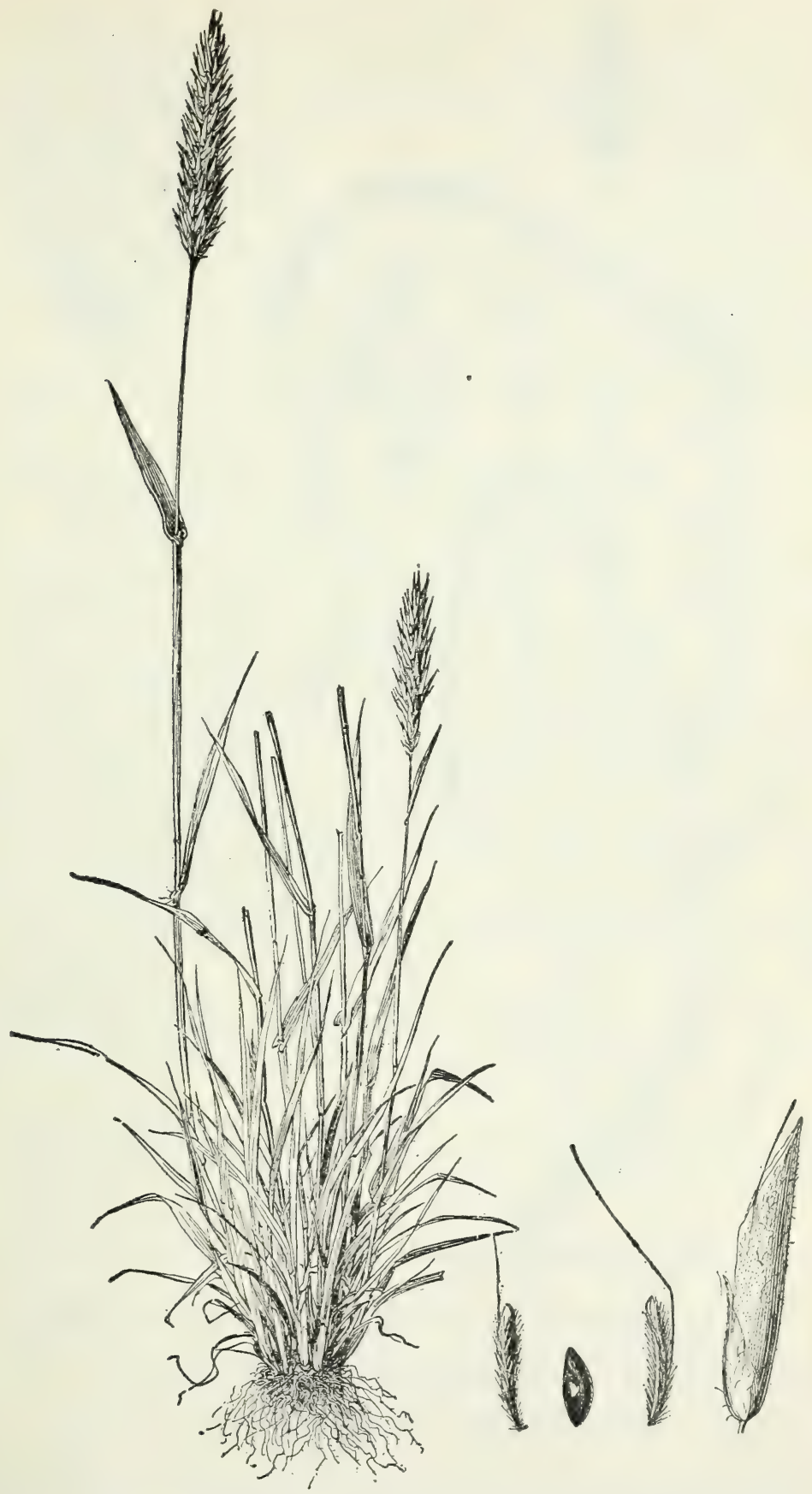

FIGURE 90.-Anthoxanthum"odoratum. Plant, $\times 1 / 2$; spikelet, sterile leinmas, and fertile floret, $\times 5$ (Biltmore Herb. $74 \mathrm{~b})$.

$60256-36-10$ 


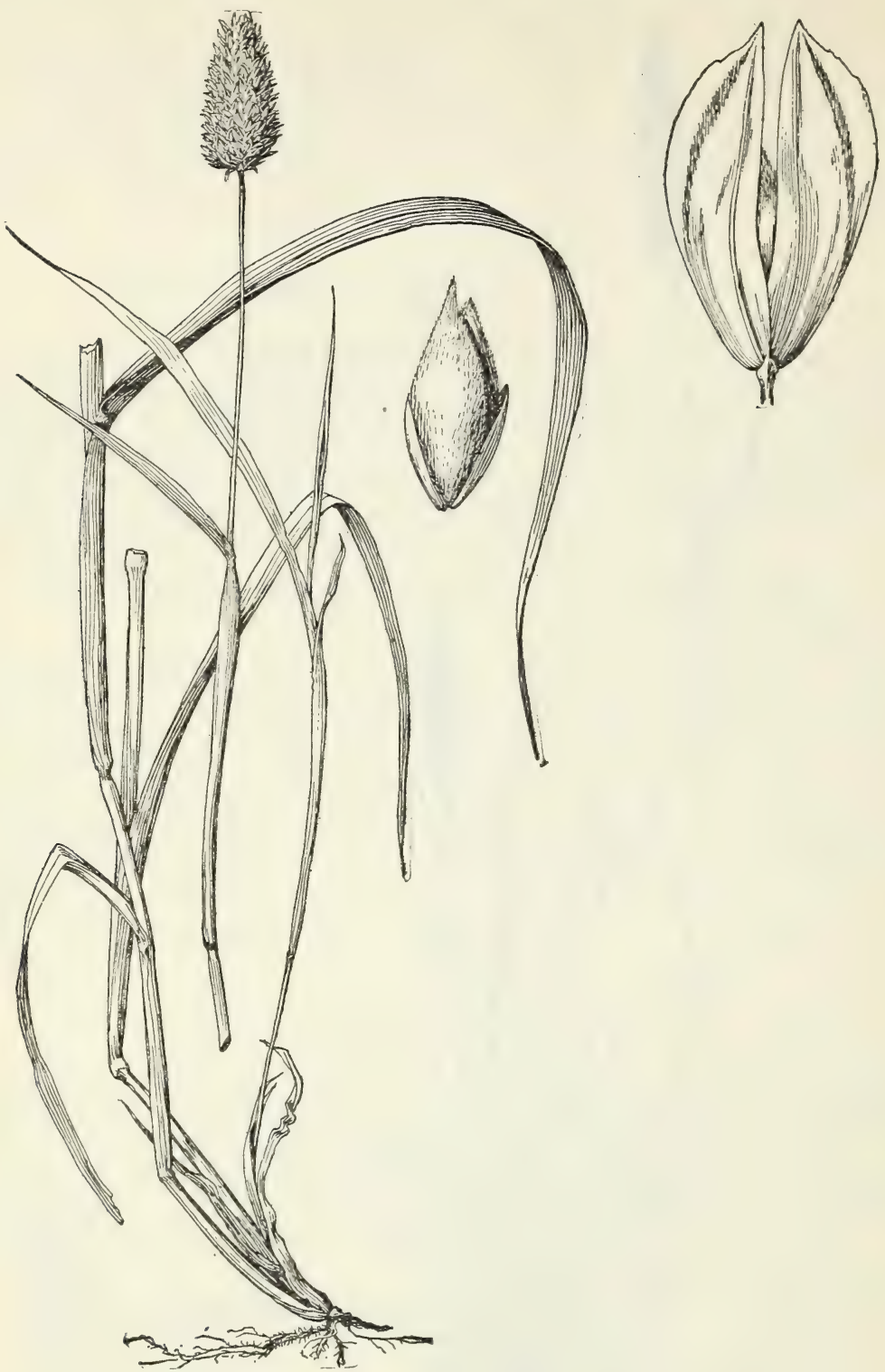

FIGURE 91.-Phalaris canariensis. Plant, $\times 1 / 2$; spikelet and

TRIBE 9. ORYZEAE

60. ORYZA L., Sp. Pl. 333.1753

Spikelets, 1-flowered, laterally compressed, disarticulating below the glumes; glumes 2, much shorter than the lemma, narrow; lemma rigid, keeled, 3-nerved (with 2 thin additional marginal nerves seen only in section), sometimes awned; palea similar to the lemma, 
narrower, keeled, 2-nerved near the margin, apparently no midnerve (a thin midnerve seen only in section). Annual or perennial swamp grasses with flat blades and spikelets in open or rather dense panicles.

Plants annual; cultivated and sparingly escaped. Spikelets 8 to $10 \mathrm{~mm}$ long.

Plants perennial; native species.

1. O. SATiva.

Spikelets about $9 \mathrm{~mm}$ long -

Spikelets about $5 \mathrm{~mm}$ long

2. O. PERENNIS.

1. Oryza sativa L., Sp. Pl. 333. 1753. Africa and India. RICE.

Erect annual up to $1 \mathrm{~m}$ or more in height; blades flat, as much as 1.5 $\mathrm{cm}$ wide; panicles rather compact, many-flowered, drooping when large or heary with fruit; spikelets oblong, 7 to $10 \mathrm{~mm}$ long; glumes 2 to $3 \mathrm{~mm}$ long; lemma hard, ridged by the lateral nerves, more or less hispidulous, the awn variable, several centimeters long or wanting (fig. 92).

Cultivated throughout tropica! and warm temperate regions at low altitudes; more or less persistent in fields and ditches.

The native species from which cultivated rice originated is not known with certainty. There are wild forms found in India and China which appear to be the prototype of rice or a degenerate form arising from rice which has gone wild. Such forms differ chiefly in habit, the culm often decumbent, widespreading, and rooting at the nodes.

2. Oryza perennis Moench, Meth. Pl. 197. 1794.

Perennial; culms erect, 1 to $2 \mathrm{~m}$ tall; blades elongate, 7 to $14 \mathrm{~mm}$ wide; panicle narrow, 15 to $20 \mathrm{~cm}$ long, the branches ascending or appressed; spikelets about $9 \mathrm{~mm}$ long, the tip of lemma and palea purple, the awn purplish, 7 to $10 \mathrm{~cm}$ long.

Swamps and wet places, Cuba, Hispaniola, and Brazil. The original specimens described by Moench were cultivated in the botanical garden at Marburg.

CubA: Pinar del Río, Ekman in 1923; Hitchcock 23275. Without locality (probably Pinar del Río), Wright 3838. Isla de Pinos, Ekman 12014.

Dominican Republic: Guerra, Ekman H 13349.

The author collected this wild rice in Cuba in situations where it seemed to be native. Dr. Ekman, who also collected it in Cuba, states:

It is not a weed and has never been found among cultivated rice. It grows in pineland swamps far from human dwellings as, for instance, in Ciénaga de Lanier, Isla de Pinos, where rice has never been cultivated. It is, I repeat it, absolutely out of the question that it could be an escaped form of the cultivated rice. It is, moreover, perennial, not annual, as $O$. sativa.

3. Oryza latifolia Desv., Jour. Bot. Desv. (II) 1: 77. 1813. Puerto Rico.

Oryza sativa var. latifolia Doell, in Mart., Fl. Bras. $2^{2}$ : 7.1871.

Rather robust perennial; culms $2 \mathrm{~m}$ or more tall; blades thin, flat, scabrous, commonly 50 to $60 \mathrm{~cm}$ long and 4 to $5 \mathrm{~cm}$ wide; panicles large many-flowered; spikelets about $5 \mathrm{~mm}$ long, the erect awn 10 to $15 \mathrm{~mm}$ long, short-pediceled along the upper half to two-thirds of the long slender ascending branches.

Swamps, ditches, and wet places, Guatemala and the West Indies to Brazil. The type locality, "Habitat in Carolina, insulaque Portorici", is clearly erroneous as to Carolina. The type specimen in the 


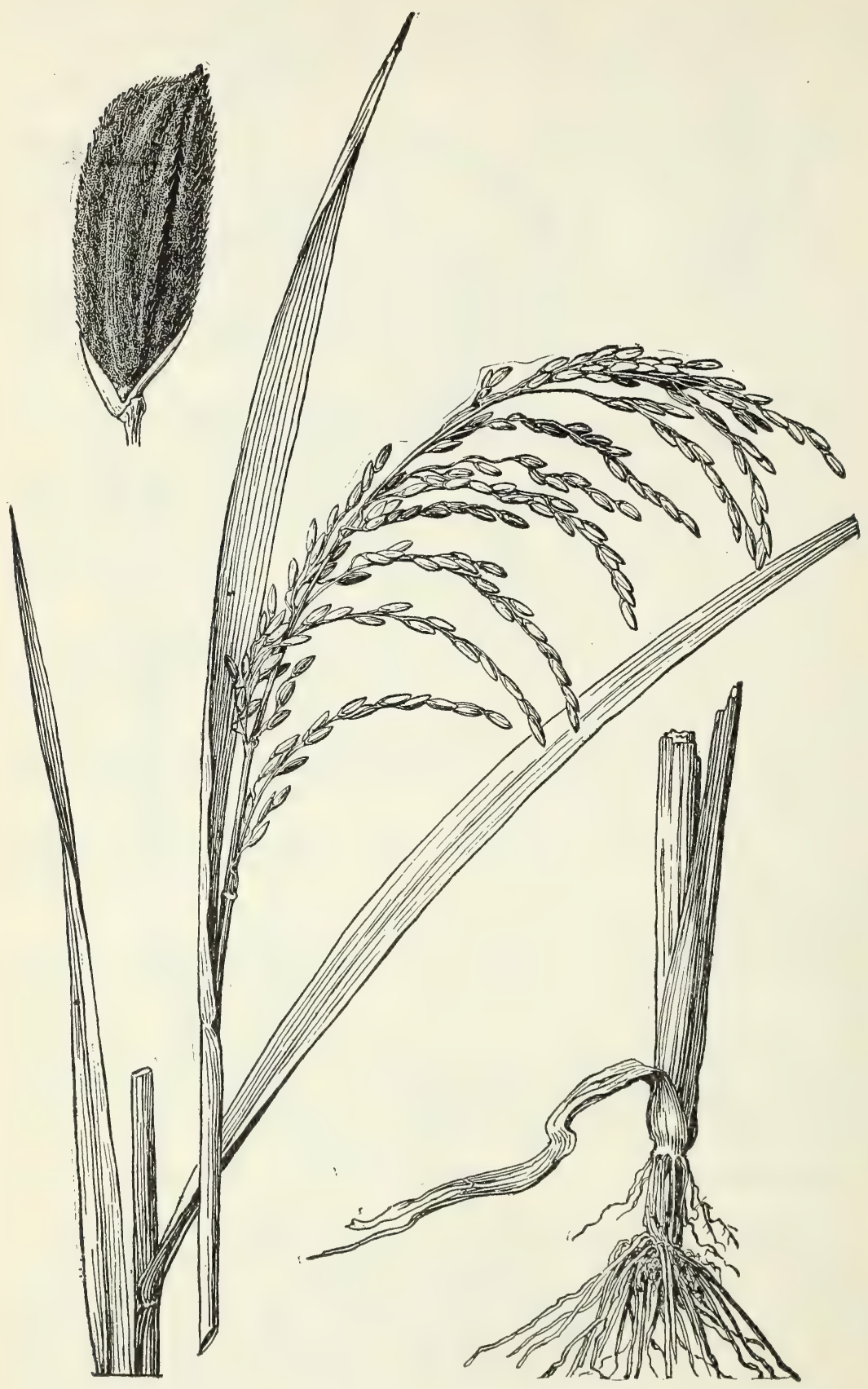

Figure 92.-Oryza sativa. Plant, $\times 1 / 2$; spikelet, $\times 5$ (cult.). 
Paris Herbarium is without locality. The awn is described by Desvaux as being "brevissima." Later, Hamilton ${ }^{38}$ described the species from a specimen in Desvaux's herbarium without mentioning the awn. In Desvaux's specimen the awns are about 10 to $14 \mathrm{~mm}$ long. The habitat is here given as "in parte Hispanica Hispaniolae."

Cuba: Sabanaso, Ekman 6540. Gamboa, Ekman in 1922.

Haiti: Port Margot, Ekman H 4806.

Dominican Republic: Sánchez, Abbott 2944.

Puerto Rico: Mayaguez, Hess 107.

Trinidad: St. Joseph, Hitchcock 10023. Cedros, Hitchcock 10144. Without locality, Bot. Gard. Herb. 1674; Crueger.

61. LEERSIA Swartz, Prodr. Veg. Ind. Occ. 21. 1788 (Conserved)

(Homalocenchrus Mieg., Act. Helv. Phys. Math. 4: 307. 1760.)

Spikelets, 1-flowered, strongly compressed laterally, disarticulating from the pedicel; glumes wanting; lemma chartaceous, broad, oblong, boat-shaped, usually 5-nerved, the lateral pair of nerves close to the margins, the intermediate nerves sometimes faint; palea as long as the lemma, much narrower, usually 3 -nerved, the lateral nerves close to the margins, the margins firmly held by the margins of the lemma; stamens six or fewer. Perennials usually with creeping rhizomes, flat scabrous blades, and open panicles.

Panicle contracted, the branches ascending, spikelet-bearing from near the base; spikelets hispid ........................... 1. L. HEXANDRA.

Panicle open, the branches slender, spreading, naked below; spikelets smooth or sometimes sparsely hispid.

Spikelets $2 \mathrm{~mm}$ long; blades about $5 \mathrm{~mm}$ wide........ 2. L. MONANDrA.

Spikelets $2.5 \mathrm{~mm}$ long; blades 1 to $2 \mathrm{~cm}$ wide........ 3 . L. GRANDIFLORA.

1. Leersia hexandra Swartz, Prodr. Veg. Ind. Occ. 21. 1788. Jamaica.

Oryza hexandra Doell, in Mart., Fl. Bras. $2^{2}$ : 10.1871.

Homalocenchrus hexandrus Kuntze, Rev. Gen. Pl. 2: 777. 1891.

Scabrous aquatic perennial; culms slender, 50 to 100 or even 200 $\mathrm{cm}$ tall, erect from a creeping base, often producing extensively creeping stolons with short, flat blades, mostly 15 to $20 \mathrm{~cm}$ long and about $8 \mathrm{~mm}$ wide; panicles contracted, many-flowered, pale or purplish, the branches ascending, spikelet-bearing from near the base; spikelets hispid, 3 to $3.5 \mathrm{~mm}$ long (fig. 93).

Swamps and ditches, southern United States and the West Indies to Argentina.

Cuba: Herradura, Ekman in 1923 (Amer. Gr. Nat. Herb. 986); Hitcheock 494. Mordozo, Léon 5944. Habana, Léon 1510, 4191, 5749. Baraguá, Hitchcock 23370, 23371. Ciénaga de Zapata, Léon 9514. Alto Cedro, Ekman 10059. Without locality, Wright 3434, 3837.

JamaICA: Castleton, Harris 12450. Temple Hill, Harris 12715. Ipswich, Hitchcock 9584.

HaIti: Petite Rivière de l'Artibonite, Ekman H 3371.

38 Prodr. Pl. Ind. Occ. 71825. 
Dominican Republic: Jarabaco, Ekman H 14142, H 14177. Sánchez, Abbott 62, 1118, 1440. Guayubín, Abbott 979.

Puerto Rico: Catano, Goll 846. Campo Alegre, Chase 6797, 6799. San Juan, Chase 6397, 6781. Mayaguez, Chase 6291.

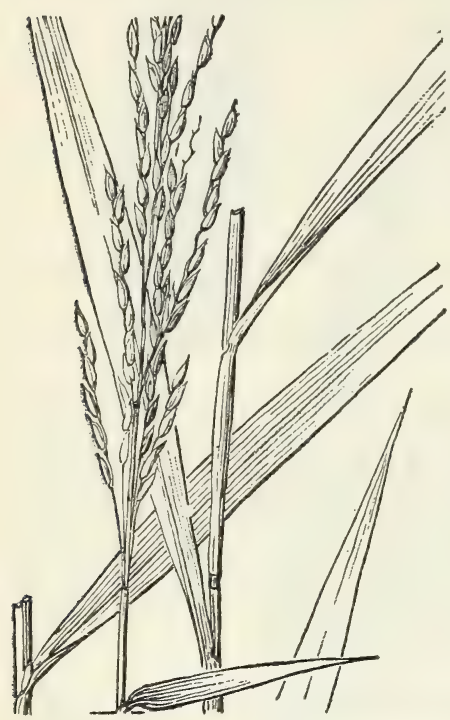

FIgURE 93.-Leersia hexandra, $\times 1$ (Wurzlow).

WINDWARD Islands: Martinique, Duss 4021.

Trinidad: St. Joseph, Hitchcock 10031. Manzanilla, Hitchcock 10367. Arima, Hitchcock 10315.

2. Leersia monandra Swartz, Prodr. Veg. Ind. Occ. 21. 1788. Jamaica.

Paspalum cubense Spreng., Neu. Entd. 3: 12. 1822. Cuba.

Oryza monandra Doell, in Mart., Fl. Bras. 22: 9.1871.

Homalocenchrus monandrus Kuntze, Rev. Gen. Pl. 2: 777.1891.

Densely tufted perennial; culms erect, 50 to $100 \mathrm{~cm}$ tall; blades elongate linear, often grayish, 3 to $6 \mathrm{~mm}$ wide; panicles open, mostly 10 to 15 $\mathrm{cm}$ long, the few very slender remote branches spreading, naked on the lower part; spikelets imbricate, pale, suborbicular, glabrous, $1.5 \mathrm{~mm}$ long (fig. 94).

Rocky woods and limestone hills, Florida to Brazil. In Cuba called "hierba de venado" and "guinea cimarrona."

Cuba: Sumidero, Shafer and Léon 13670; Léon and Shafer 3468. Mariel, Ekman in 1921. Pinar del Río, Hitchcock 23321. Sierra Guane, Shafer 10549. Tiffin, Shafer 1089. Río Jipero, Eggers 5404a. Guantánamo, Léon 3779. Guara, Hitchcock 23400. Bayate, Ekman 4825. Without locality, Wright 731 .

JAMAICA: Ferry River, Harris 11326, 11788; Hitchcock 9749. Gordon Town, Harris 11459. Guara Ridge, Harris 11331. Kingston, Hitchcock 9466. Alligator Pond, Hitchcock 9822. Inverness, Harris 12744. Bog Walk, Hitchcock 9307. Without locality, Hart 1525.

Haitr: St. Michel de l'Atalaye, Leonard 7473, 7625, 8485. St. Raphael, Leonard 7663. Port-de-Pai, Ekman H 3928. Jean Rabel, Leonard 12919. Goniave Island, Leonard 3080, 3082, 5126. Tortuga Island, Leonard 11691.

Dominican Republic: Monción, Ekman H

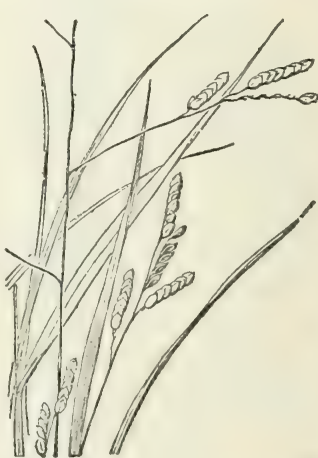

FiguRE 94.-Leersia monandra, $\times 1$ (Nealley). 13057. Mao, Abbott 1037.

Puerto Rico: Ponce, Chase 6490. Guanica Bay, Chase 6524. Coamo, Sintenis 3228; Britton and Brown 6057.

3. Leersia grandiflora (Doell) Prodoehl, Bot. Arch. Mez 1: 219. 1922.

Oryza monandra var. grandiflora Doell in Mart. Fl. Bras. 2²: 9. 1871. Brazil. 
Homalocenchrus grandiflorus Hitchc., Contrib. U. S. Natl. Herb. 17: 273.1913.

Culms erect, without rhizomes, 1 to $2 \mathrm{~m}$ tall; blades 1 to $2 \mathrm{~cm}$ wide; panicles large and open, the slender branches about $15 \mathrm{~cm}$ long; spikelets 2 to $2.5 \mathrm{~mm}$ long.

Shady banks and borders of streams, Mexico to Brazil; Guadeloupe and Martinique.

Leeward Islands: Guadeloupe, Duss 3146.

Windward Islands: Martinique, Duss 775.

\section{TRIBE 10. ZIZANIEAE}

62. LUZIOLA Juss.; Gmel., Syst. Nat. ed. 13. 2: 637.1791

Spikelets, unisexual, 1-flowered, disarticulating from the pedicel, the staminate and pistillate flowers in separate panicles on the same plant; both glumes wanting; lemma and palea about equal, thin, several to many nerved, lanceolate or oblong, acuminate; stamens several ("6 to 18"); stigmas long, plumose; grain free, globose, smooth. Perennials with flat blades and terminal and axillary panicles.

Blades 7 to $10 \mathrm{~mm}$ wide; inflorescence many-flowered.......3. L. SPRUCEANA. Blades 1 to $3 \mathrm{~mm}$ wide; inflorescence few-flowered.

Fruit $2 \mathrm{~mm}$ long

Fruit $1.5 \mathrm{~mm}$ long.

1. Luziola peruviana Gmel., Syst. Nat. ed. 13. 2: 637. 1791. Peru.

More or less decumbent, spreading, apparently annual; culms 10 to $30 \mathrm{~cm}$ long, blades flat, 1 to $2 \mathrm{~mm}$ wide; panicles spreading, 2 to $3 \mathrm{~cm}$ long; pistillate spikelets 2 to $3 \mathrm{~mm}$ long, with striate lemma and palea; fruit globose, smooth, a little more than $1 \mathrm{~mm}$ long; staminate spikelets $5 \mathrm{~mm}$ long (fig. 95).

Swamps, shallow water, and wet ground, southern United States and Cuba to Uruguay and Peru. Grisebach ${ }^{39}$ records this species from Trinidad.

Cuba: Mordazo, Léon 5941.

2. Luziola bahiensis (Steud.) Hitchc., Contrib. U. S. Natl. Herb. 12: 234. 1909.

Caryochloa bahiensis Steud., Syn. Pl. Glum. 1: 5. 1854. Bahia, Brazil.

Luziola alabamensis Chapm., Fl. South. U. S. 584. 1860. Alabama. Luziola longivalvula Doell, in Mart., Fl. Bras. $2^{2}: 17.1871 . \quad$ Brazil.

Plants stoloniferous; culms slender, tufted, about $10 \mathrm{~cm}$ tall; blades flat, narrow, linear, elongate, 2 to $4 \mathrm{~mm}$ wide, gradually narrowed toward the base; staminate panicles narrow terminating the main culm; spikelets about $4 \mathrm{~mm}$ long, striate-nerved; pistillate panicles open, the few branches spreading; spikelets 3 to $4 \mathrm{~mm}$ long, lanceolate; fruit obscurely striate, $2 \mathrm{~mm}$ long (fig. 96).

In streams or in mud, Alabama and Greater Antilles to Brazil. Extremely variable in appearance according to the depth of water in which the specimen grew. Plants growing in places from which water has receded are low and widely creeping.

3ง Fl. Brit. W. Ind. 535. 1864. 


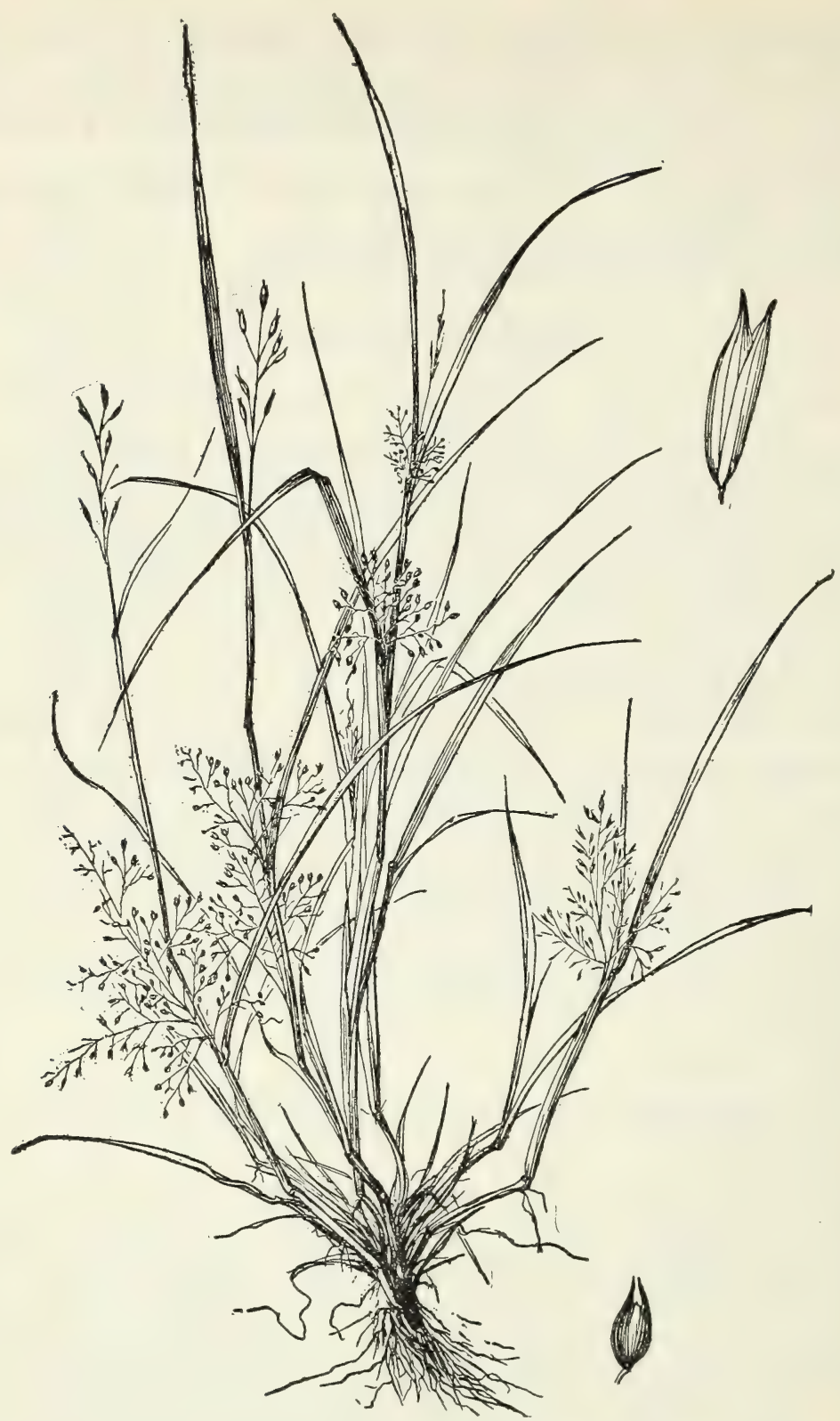

Figure 95.-Luziola peruviana. Plant, $\times 1 / 2 ;$; pistillate and staminate spikelets, $\times 5$ (Curtiss 6871).

Cuba: Pinar del Río, Wright 3813. Isla de Pinos, Britton and Wilson 15190; Ekman 12267.

Dominican Republic: Jarabaco, Ekman H 14132. Villa Alta. gracia, Ekman H 11207. Sánchez, Ekman H 15939. 
3. Luziola spruceana Benth.; Doell, in Mart., Fl. Bras. 2²: 18. 1871. Brazil.

Culms thick, soft and spongy, freely branching; sheaths broad, as much as $30 \mathrm{~cm}$ long; ligule delicate, as much as $3 \mathrm{~cm}$ long; blades firm, flat, as much as $50 \mathrm{~cm}$ long and $2 \mathrm{~cm}$ wide, narrowed and folded toward the base; staminate panicles open, 10 to $15 \mathrm{~cm}$ long; spikelets $5 \mathrm{~mm}$ long; stamens 6; pistillate panicles on shorter branches, the branches numerous, approximate on a short axis, finally reflexed; spikelets $5 \mathrm{~mm}$ long, acuminate: fruit about $2 \mathrm{~mm}$ long.

Ponds, lagoons, and quaking bogs, Cuba and Hispaniola; Trinidad to Brazil.

Cuba: Laguna de Ariguanabo (prov. Habana), Ekman 13436 (Amer. Gr. Nat. Herb. 987); Léon 4193 (growing in water $1 \mathrm{~m}$ deep).

Haiti: Bayeux, Ekman H 4802. Miragoane, Ekman $\mathrm{H} 6471$.

Dominican Republic: Jaina, Ekman H 13354 ; Faris 266, 394. Santo Domingo City, Ekman H 11589. Higüey, Ekman H 12173.

Trinidad: Without locality, Broadway 1626.

Tobago: Broadway 3100.

63. PHARUS L., Syst. Nat. ed. 10. 2: 1269 . 1759

Spikelets 1-flowered, unisexual, in pairs appressed along the main branches of the inflorescence, one pistillate and sessile, the other staminate and long-pediceled; pistillate spikelet terete; glumes about equal, membranaceous, several-nerved; lemma rather thin in anthesis but becoming indurate in fruit, longer than the glumes, with a minute bent beak, the back clothed to a varying degree with

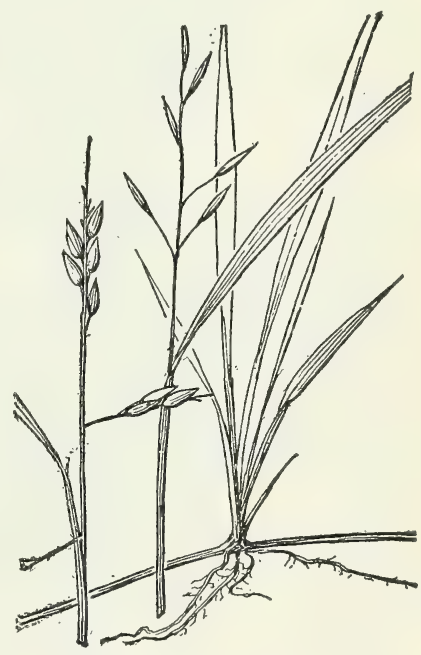

FIGURE 96.-Luziola bahiensis, $\times 1$ (Mohr). thickly set uninate hairs, these becoming adhesive organs in fruit, the edges sharply folded inward and the whole lemma becoming involute in fruit; palea very narrow, as long as the lemma, 2-nerved, membranaceous, folded around the long style; stigmas 3 ; staminate spikelet laterally compressed on a stifl pedicel as long as the pistillate spikelet; glumes thin, the first shorter, 1-nerved, the second 3-nerved; lemma as long as the second glume; stamens 6 . Erect perennials (the base sometimes decumbent) with broad flat blades and open panicles, the blades with fine transverse veins between the longitudinal nerves, petioled (the petiole with a single twist reversing the upper and under surfaces of the blade), the nerves running obliquely from midrib to margin.

Culms creeping at base . .

Culms erect or nearly so.

Fruit pubescent only at tip, slightly exceeding the glumes_._2. P. LAtifolius.

Fruit pubescent all over. 2 to 3 times as long as the glumes.... 1. P. GLABER. 
1. Pharus glaber H. B. K. Nov. Gen. et Sp. 1: $196.1816 . \quad$ Venezuela.

Pharus lappulaceus Lam., in Tuss., Fl. Antill. 2. pl. 8. 1818. Not P. lappulaceus Aubl., 1775. Jamaica.

Pharus brasiliensis Raddi, Agrost. Bras. 21. 1823. Brazil.

Pharus lancifolius Desv.; Hamilt., Prodr. Pl. Ind. Occ. 8. 1825. Antilles.

Erect glabrous perennial 50 to $75 \mathrm{~cm}$ tall; blades oblanceolate, acuminate, commonly 15 to $25 \mathrm{~cm}$ long and 3 to $5 \mathrm{~cm}$ wide; panicles large, open, fragile, the few branches stiffly ascending or spreading, the appressed oblong brown spikelets about $1 \mathrm{~cm}$ long; fruit densely clothed with hooked hairs, the panicles readily breaking up, the pieces attaching themselves by the hooked hairs to passing objects.

Rich woods, Mexico and the West Indies to Brazil. Found in the Greater Antilles and in the Lesser Antilles as far south as Martinique.

2. Pharus latifolius L., Syst. Nat. ed. 10. 2: 1269. 1759. Jamaica.

Pharus ovalifolius Desv.; Hamilt., Prodr. Pl. Ind. Occ. 8. 1825. Antilles.

Similar to $P$. glaber, the blades on the average broader, the fruits longer, tapering at the summit, pubescent only near the tip (fig. 97).

Rich woods, West Indies and Central America to Brazil. Sometimes called wild oats.

Cuba: Sumidero, Shafer and Léon 13544. Sierra de Anafe, Léon 1999. Guape, Linden 1811. Bayate, Ekmán 9853.

Jamaica: Mill Bank, Maxon 9335. Bath, Nichols in 1903. Ipswich, Harris 12365. Peckham Woods, Harris 12786. Mount Diablo, Ridley 71. Windsor, Miller 1441.

Harti: St. Louis du Nord, Ekman H 3771. Tortuga Island, Leonard 12390.

Dominican Republic: Barahona, Fuertes 614. Sánchez, Abbott 190. Without locality, Wright, Parry, and Brummel 605 (in part P. glaber).

Puerto Rico: Dorado, Chase 6627. Utuado, Britton and Cowell 1034.

Leeward Islands: Guadeloupe, Duss 2700.

Windward Islands: Martinique, Duss 781. Grenada, Broaduay in 1897 , in 1905.

Trinidad: Caparo, Broadway 4930. Port-of-Spain, Hitchcock 10042, 10046. San Fernando, Hitchcock 10103 (Amer. Gr. Nat. Herb. 312 ).

3. Pharus parvifolius Nash, Bull. Torrey Bot. Club 35: 301. 1908. Haiti, Nash and Taylor 1482.

Differing from $P$. glaber in having a creeping and rooting base; blades narrowly elliptic-lanceolate to narrowly elliptic-oblanceolate, rarely as much as $3 \mathrm{~cm}$ wide; inflorescence averaging smaller; spikelets about as in $P$. glaber (fig. 98).

Rich woods, West Indies to Brazil.

Cuba: Sierra Maestra, Ekman 10351; Léon 10317. Jagüey, Maxon 4155; Eggers 4939. Viñales, Léon 14372.

Jamaica: Claremont, Hitchcock 9474 (Amer. Gr. Nat. Herb. 313).

Harti: Port-de-Pai, Ekman H 3825. 


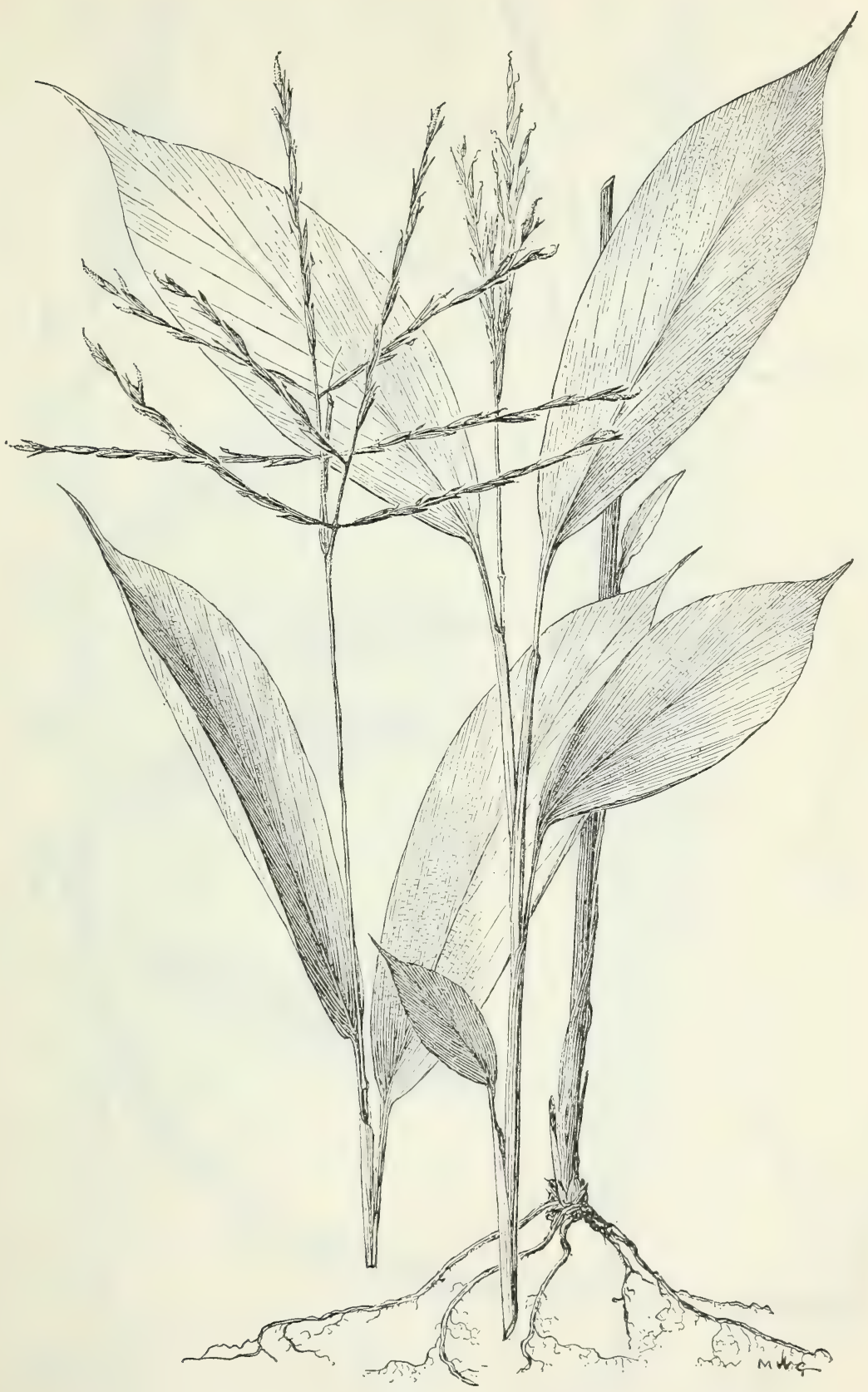

Figure_97.-Pharus latifolius, $\times 1 / 2$ (Hitchcock 10103, Amer. Gr. Nat. Herb. 312). 
154 MISC. PUBLICATION 243, U. S. DEPT. OF AGRICULTURE

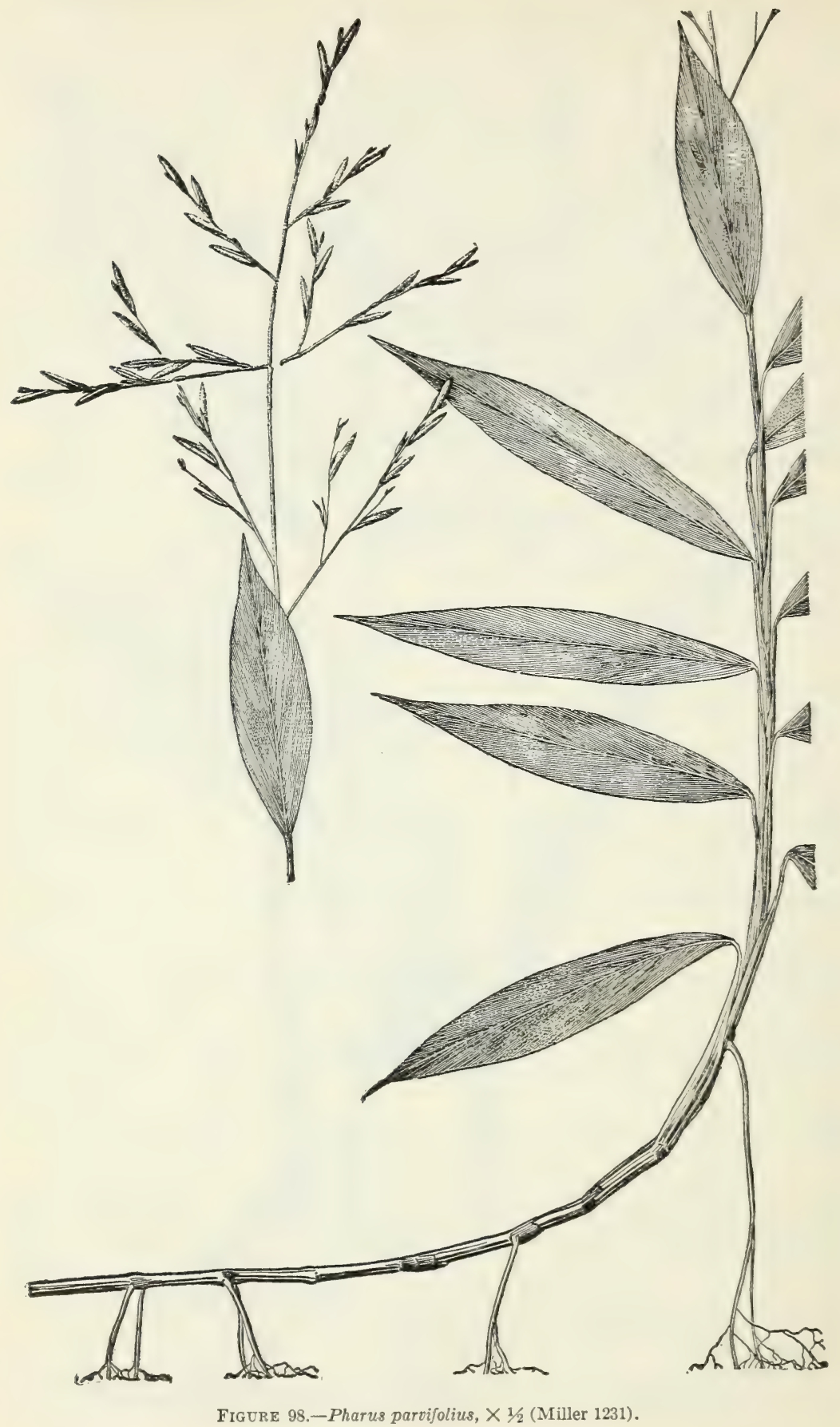


Dominican Republic: Villa Altagracia, Ekman H 11186. Sánchez, Abbott 197. Río San Juan, Miller 1231.

Trinid A D: Tabaquite, Britton, Freeman, and Nowell 2609; Hitchcock 10124. Southern Watershed Reserve, Britton, Hazen, and Mendelson 1097. Tamana, Broadway 4955. Siparia, Broadway 4988. Maracas Falls, Broadway 6703. Without locality, Bot. Gard. Herb. 3364.

\section{TRIBE 11. MELINIDEAE}

64. ARUNDINELLA Raddi, Agrost. Bras. 36. pl. 1. f. 3. 1823

Spikelets, short-pedicellate in large panicles; glumes acuminate, the tips widely spreading, the second longer than the first and the sterile lemma; fertile lemma minute, bearded on the callus, bearing a long slender awn from the apex. Perennial or sometimes annual, often robust grasses with narrow blades and open or contracted panicles.

Awn tightly twisted below, the column shorter than the second glume.

1. A. CONFINIS.

Awn not tightly twisted below, the part below the bend exceeding the glume.

Blades broad and flat, 1 to $2 \mathrm{~cm}$ wide; plants robust, 1.5 to $2 \mathrm{~m}$ tall; sheaths appressed-villous.

2. A. DEPPEANA.

Blades narrow and more or less folded or convolute; plants slender, mostly less than $1 \mathrm{~m}$ tall; sheaths usually smooth_... 3. A. BERTERONIANA.

1. Arundinella confinis (Schult.) Hitchc. and Chase, Contrib. U.S. Natl.Herb. 18: 290. 1917.

Piptatherum confine Schult., Mant. 2: 184. 1824. Martinique, Sieber 265.

Arundinella martinicensis Trin., Gram. Pan.62. 1826. Martinique. Sieber 262.

Tufted erect perennial with strong slender simple culms up to $2.5 \mathrm{~m}$ tall, flat blades, scabrous at least on the upper surface, and rather densely flowered oblong panicles 20 to $40 \mathrm{~cm}$ long (fig. 99).

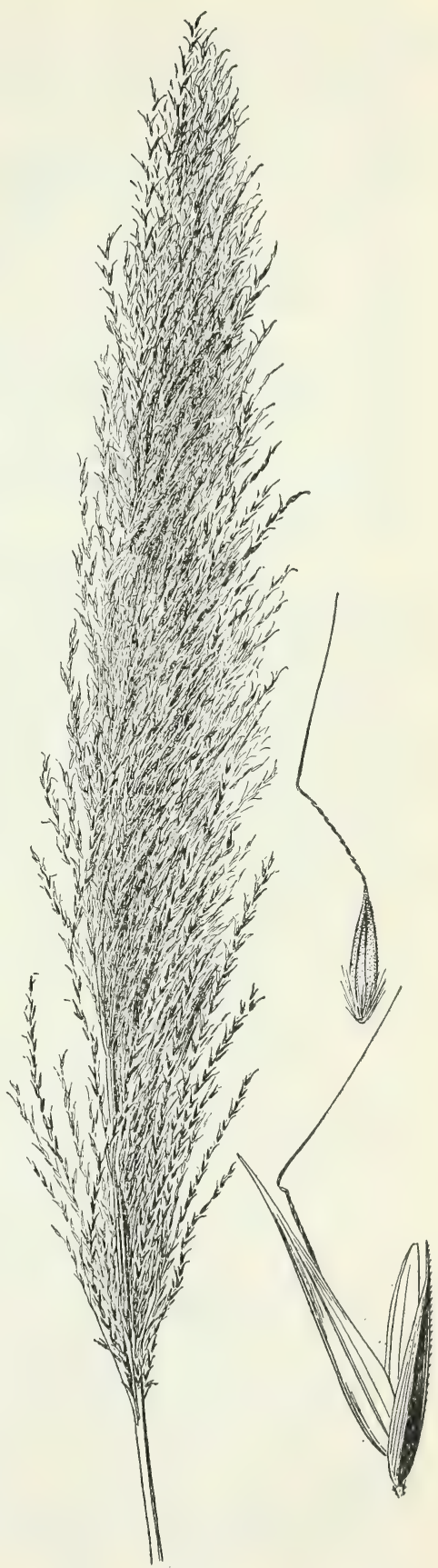

Figure 99.-Arundinella confinis. Panicle, $\times 1 / 2$; spikelet and floret, $\times 10$ (Chase 6815) 
Grassy slopes, West Indies and southern Mexico to Paraguay. The Cuban name is "cañuela de sabana."

Cuba: Pinar del Río, Roig 3154. Sancti Spíritus, Léon 6526. Baraguá, Hitchcock 23382. Caibarién, Ekman 16309. San Serapio, Léon 16202. Bayate, Ekman 6734. San Juan de Buenavista, Wright 3478. Loma Menqura, Shafer 3981.

Jamaica: Nevis Bank, Harris 11519. Troy, Harris 12652 ; Hitchcock 9814. Newcastle, Ridley 74.. Gordon Town, Hitchcock 9326. Upper Clarendon, Harris 12247. Abbey Green, Hitchcock 9383. Flamstead, Harris 11462; Eggers 3514. Berwick, Harris 11452, 11533.

Haiti: Plaisance, Leonard 9415. Ennery, Leonard 8968. Marmelade, Leonard 8220. Caille la Croix, Leonard 7860. Furcy, Leonard 4467. Pétionville, Ekman H 1833. Mirebalais, Ekman H 5509.

Dominican Republic: Cuenca, Ekman H 11062. Sánchez, Ekman H 14733. Pimentel, Abbott 668. Without locality, Wright, Parry, and Brummel 626.

Puerto Rico: Maricao, Britton and Cowell 4089; Sintenis 361. Utuado, Barrett 101; Britton and Cowell 895. Lares, Chase 6594. Ponce, Heller 6256. Aguada, Sintenis 5797. Mayaguez, Chase 6815; Heller 4355; Holm 75. Caguas, Heller 934.

Leenard Islands: Guadeloupe, Duss 4153. Dominica, Jones 2.

Windward Islands: Martinique, Duss 559.

Trinidad: St. Joseph, Hitchcock 10182; Broadway 9347. San Fernando, Hitchcock 10109. Without locality, Bot. Gard. Herb. 3227, 3375 .

Toвago: Broadway 4620; Hitcheock 10277, 10280 (Amer. Gr. Nat. Herb. 289).

2. Arundinella deppeana Nees, in Steud., Syn. Pl. Glum 1: 115. 1854. Mexico.

Arundinella phragmitoides Griseb., Cat. Pl. Cuba 234. 1866. Cuba, Wright 3479.

Culms erect, as much as $2.5 \mathrm{~m}$ tall; sheaths appressed-pilose, especially toward summit; blades flat, as much as $2.5 \mathrm{~cm}$ wide; panicle as much as $70 \mathrm{~cm}$ long, the branches ascending, very numerous, closely overlapping, mostly 10 to $15 \mathrm{~cm}$ long; spikelets approximate on the branches, overlapping, 4 to $5 \mathrm{~mm}$ long; awn about $1 \mathrm{~cm}$ long.

Moist places, Cuba; Mexico to Brazil.

Cuba: Pinar del Río, Britton 10048; Palmer and Riley 70. San Blas, Jack 6457. San Diego, Léon 4847. Madruga, Curtiss 662. Santa Clara, Léon 3973. Manacas, Léon 5916. El Porvenir, Britton and Wilson 5282. Without locality, Otto 268; Wright 3479. San Miguel de los Baños, Killip 13844. Cayajabos, Léon 13224.

3. Arundinella berteroniana (Schult.) Hitchc. and Chase, Contrib. U. S. Natl. Herb. 18: 290. 1917.

Trichochloa berteroniana Schult., Mant. 2: 209. 1824. Santo Domingo.

Muhlenbergia berteroniana Kunth, Rév. Gram. 1: 64. 1829.

Arundinella cubensis Griseb., Mem. Amer. Acad. (n. s.) 8: 533. 1862. Cuba, Wright 1552.

Smaller and more slender than A. deppeana; blades often folded or involute, usually less than $5 \mathrm{~mm}$ wide; panicle less dense and fewer flowered. 
Moist places and rocky river banks, Cuba and Hispaniola; Mexico to Brazil.

Cuba: Sancti Spíritus, Léon 2570. Banao Mountains, Léon 4009; Ekman 16211, 16212 (Amer. Gr. Nat. Herb. 988). Without locality, Wright 1552.

Haiti: Pétionville, Ekman H 1370. Las Caobas, Ekman H 3249. Dominican Republic: Santiago, Raunkiaer 934. Monción, Ekman H 12666.

\section{ACHLAENA Griseb., Cat. Pl. Cub. 228. 1866}

Spikelets jointed with the pedicel, disarticulating at maturity, the base narrowed to a pointed stipe or callus minutely barbed at the base or point; first glume subulate, extending into a slender awn; second glume narrow, somewhat indurate, narrowed into a slender awn; sterile lemma empty, rather hard, shorter than the second glume, awnless; fertile lemma rather thin, hyaline, awnless, acuminate, about as long as the sterile lemma, the palea like the glume but shorter. Tufted perennial with narrow blades and open panicle.

From Grisebach's description of the genus it is evident that he failed to note the palea, mistaking the sterile lemma for the fertile lemma (flos fertilis) and the fertile lemma for the palea, stating as he does that the palea is 1-nerved. Bentham and Hooker ${ }^{40}$ and Hackel ${ }^{41}$ follow Grisebach in this disposition of the genus, probably lacking material for verification of Grisebach's description. Hackel places the genus in Oryzeae, and elsewhere describes a specimen of Achlaena piptostachya as Arthropogon stipitatus. Grisebach states that there is but 1 stamen; we find 3, as did Hackel in the plant he described under Arthropogon. Achlaena is closely allied to the South American Arthropogon or is possibly congeneric.

1. Achlaena piptostachya Griseb., Cat. Pl. Cub. 229. 1866. Cuba, Wright 3487.

Arthropogon stipitatus Hack., Sitzungsber. Akad. Wiss. Math. Naturw. (Wien) $89^{1}: 125$. 1884. Cuba, Ramon de la Sagra.

Culms stiffly erect, 50 to $100 \mathrm{~cm}$ tall; blades linear, firm, flat or involute, abruptly sharp-pointed, mostly clustered toward the base; panicle long-exserted, erect, 7 to $15 \mathrm{~cm}$ long, the branches stiffly spreading or reflexed, fascicled below, somewhat glutinous; spikelets appressed along the outer half of the main branches of the panicle; first glume, including awn, 1 to $2 \mathrm{~cm}$ long; second glume scaberulous, about $4 \mathrm{~mm}$ long, the awn about $3 \mathrm{~cm}$ long (fig. 100).

Open woods, dry slopes, and savannas, Cuba and Jamaica.

CuBA: San Isidro, Britton, Wilson, and Léon 13945. Bahía Honda, Wilson 9215. San Diego de los Baños, Léon 4383. Pinar del Río, Hitchcock 23291; Baker and Abarca 3447; Britton and Cowell 9732. Viñales, Killip 13556. Soledad, Hitchcock 23333. San Miguel de los Baños, Killip 13837. Canasí, Léon 12940. Baraguá, Hitchcock 23347. Guara, Hitchcock 23410. Sierra de Nipe, Ekman 9688, in 1922 (Amer. Gr. Nat. Herb. 800). Isla de Pinos, Curtiss 236; Britton and Wilson 14316; Palmer and Riley 913. Without locality, Wright 3487.

JAMAICA: Askenish (Dolphin Head), Britton and Hollick 2194. 
158 Misc. PUBLICATION 243, U. S. DEPT. OF AGRICULTURE

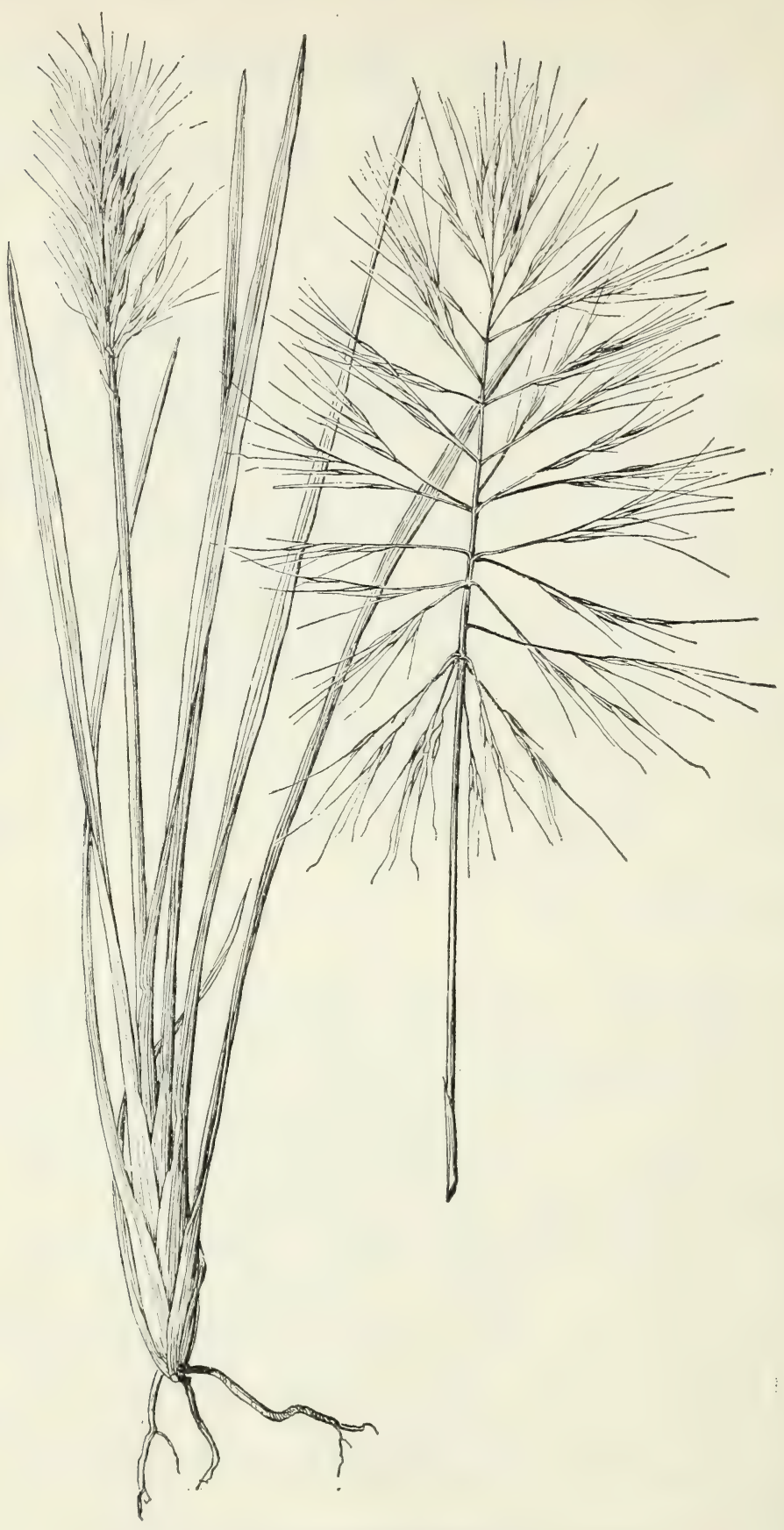

Figure'100.-Achlaena piptostachya, X 1/2 (Léon 4383). 


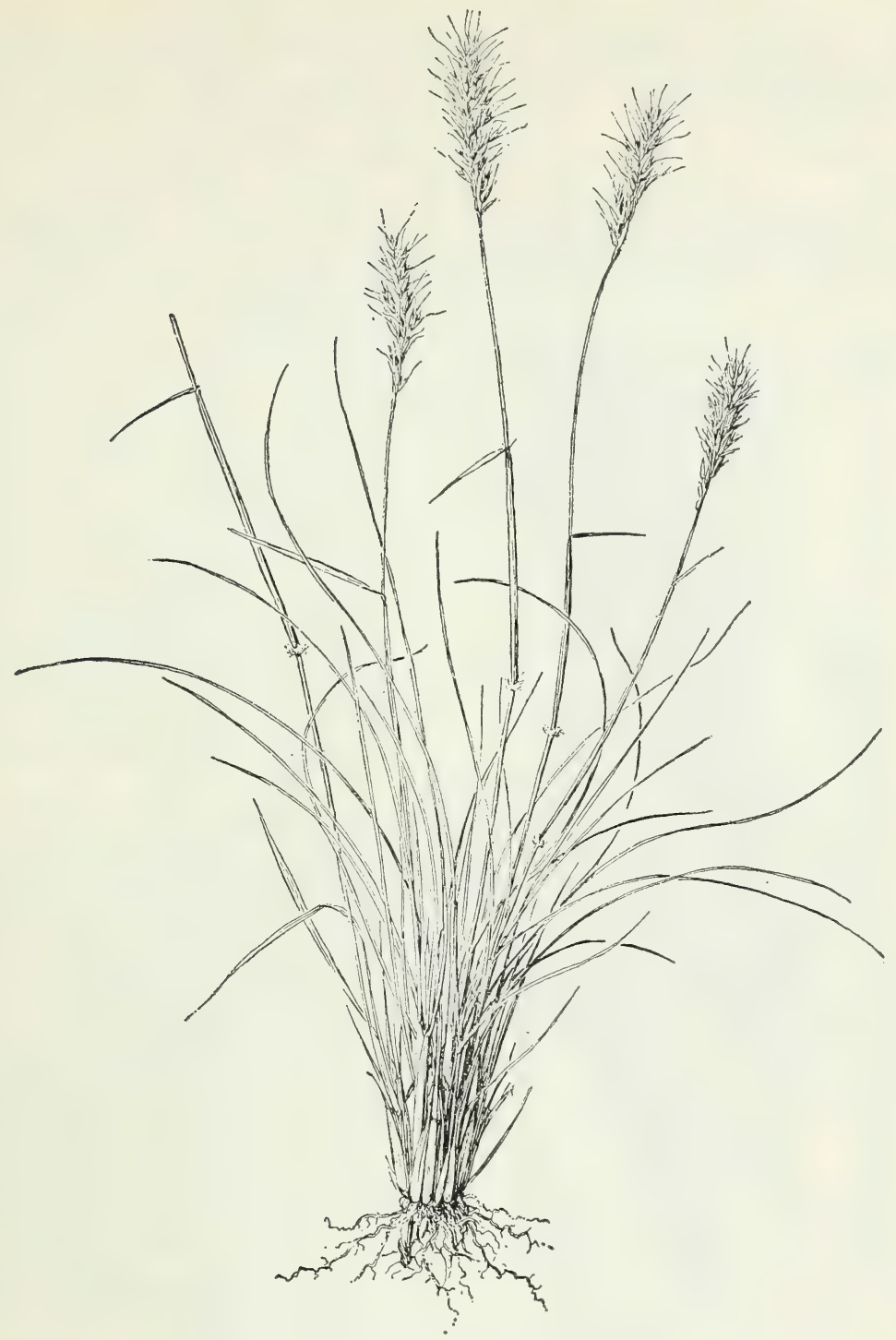

FigURE 101.-Reynaudia filiformis, $\times 1 / 2$ (Hitchcock 495).

66. REYNAUDIA Kunth, Rév. Gram. 1: 195. pl. 9. 1830

Spikelets perfect, articulated with the pedicel; glumes keeled, strongly nerved, awned from between the lobes of the bifid apex; sterile lemma awn-tipped from the bilobed summit; fertile lemma thin, nerveless, shorter than the sterile lemma, strongly compressed, keeled, the tip of the keel sometimes extended as a minute mucro, with 2 pairs of obscure lateral nerves; palea wanting; caryopsis flat, 
oblong, the embryo on the side next to the fertile lemma. Slender tufted perennial with involute blades and narrow panicle.

1. Reynaudia filiformis Kunth, Rév. Gram. 2: 195. 1830. Santo Domingo.

Polypogon cubensis A. Rich., in Sagra, Hist. Cuba 11: 313.1850. Cuba.

Culms erect or ascending, 15 to $40 \mathrm{~cm}$ tall, the nodes bearded; blades involute, slender, mostly basal; panicle erect, oblong to linear, contracted and rather densely flowered, 3 to $6 \mathrm{~cm}$ long; spikelets

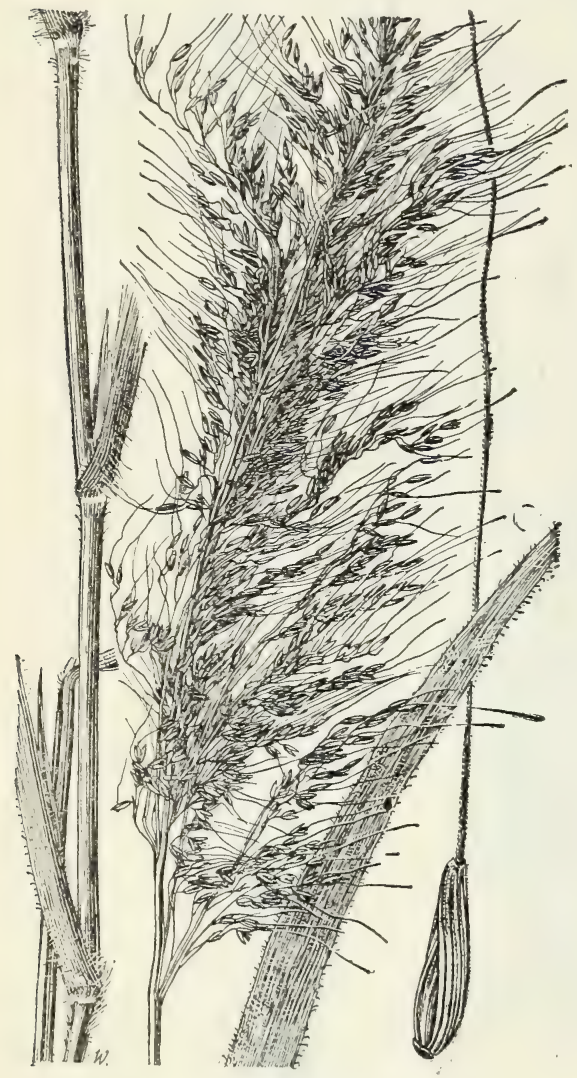

FIGURE 102.-Melinis minutiflora. Plant, $\times 1$; spikelet, $\times 1$. (Moldenke 453). compressed, 3 to $4 \mathrm{~mm}$ long, the summit purple-tinged; first glume 3-nerved or obscurely 5 -nerved, a little more than half as long as the spikelet, the awn slightly flexuous, purplish, 2 or 3 times as long as the glume; second glume a little shorter than the spikelet, 5-nerved, hispid on the lower hali of the margins, the awn similar to that of the first glume; sterile lemma similar to the second glume, 3-nerved, glabrous, the midnerve extended as a short mucro (fig. 101).

Savannas, palm barrens, and brushy slopes, Greater Antilles.

Cuba: Pinar del Río, Hitchcock 23260. Herradura, Hitchcock 495 ; I.éon 15950; Tracy 9070. Sumidero, Léon 3480. Guanabacoa, Wilson and Léon 11632; Léon 848. Baraguá, Hitchcock 23358. Motembo, Ekman 16815. Sagua la Grande, Léon 14221. Eastern Cuba, Wright 3428.42 Western Cuba, Wright 3428. Isla de Pinos, Curtiss 371; Taylor 44; Britton and Wilson 15188.

Jamaica: Manchester, Wullschlaegel 1370.

Haitr: Mount Organisé, Elkman H 6230.

Dominican Republic: Higüey, Ekman H 12208. Santo Domingo, Wright, Parry, and Brummel 623. Guarabo, Abbott 2804. Cotuy, Abbott 787a, 797. Pimentel, Abbott 663.

\section{MELINIS Beauv., Ess. Agrost. 54.pl. 11. f. 4. 1812}

Spikelets, 1-flowered with a sterile lemma below as in Panicum, disarticulating from the short slender pedicels; first glume very small, the second about equaling the sterile lemma, two-lobed at apex,

${ }^{42}$ Part of Wright 3428 came from western Cuba and part from eastern Cuba (Contrib. U. S. Natl. Herb. 12: 235. 1909). 
mucronate between the lobes, nerved; sterile lemma similar to the second glume, the awn straight, long, and slender; fertile lemma and palea whitish, somewhat cartilaginous, shorter than the sterile lemma, awnless; palea a little shorter than its lemma. Spreading branching perennial with small spikelets in panicles.

1. Melinis minutiflora Beauv., Ess. Agrost. 54. pl. 11. f. 4.1812. Brazil.

Molasses Grass.

Glandular throughout; culms $1 \mathrm{~m}$ or more long, rooting at the lower nodes, pubescent especially about the nodes; sheaths pilose; blades pubescent, 10 to $15 \mathrm{~cm}$ long, 5 to $10 \mathrm{~mm}$ wide; panicle 15 to $20 \mathrm{~cm}$ long, dark purple, rather closely flowered, the branches ascending; spikelets about $2 \mathrm{~mm}$ long, the straight delicate awn about $1 \mathrm{~cm}$ long. When fresh the plant emits a sweetish pungent odor (fig. 102).

Cultivated for forage. Called also zacate gordura. Described from Brazil where, however, it appears to be introduced. Native of Africa. As it escapes readily from cultivation it will undoubtedly soon become established here and there. Molasses grass is a good forage plant and its use will probably increase throughout the West Indies. The following are cultivated specimens.

Dominican Republic: Monción, Ekman H 12654.

Puerto Rico: Mayaguez, Chase 6826.

Leeward Islands: Dominica, Jones 1.

\section{TRIBE 12. PANICEAE}

68. TRISCENIA Griseb., Mem. Amer. Acad. n. ser. 8: 534.1862

Spikelets much as in Panicum, narrowly lanceolate, acuminate, deciduous from the pedicels; first glume acute, about half as long as the spikelet, 3-nerved, the base overlapping; second glume as long as the spikelet, acuminate, 5-nerved; sterile lemma similar to the second glume, 3-nerved, containing no palea or stamens; fertile lemma shorter than the second glume and sterile lemma, narrow, somewhat acuminate, thin but somewhat chartaceous, not green like the glumes and sterile lemma; palea like its lemma in texture, nearly enclosed in the flat edges of the lemma. Low tufted perennial with narrow few-flowered panicles.

This genus has been included in the tribe Melinideae by Hitchcock and Chase ${ }^{43}$ and in Tristegineae by Hackel ${ }^{44}$, but the structure of the spikelet is entirely that of Paniceae. The fertile floret is rather thin but papery and distinctly different from the glumes and sterile lemma; the structure is similar to that of Hymenachne, but the palea is nearly enclosed in the edges of the lemma. Triscenia also approaches Ichnanthus, but there are no wings at the base of the fertile lemma and no prominent scars as found in those species that lack wings.

1. Triscenia ovina Griseb., Mem. Amer. Acad. (n. s.) 8: 534. 1863. Cuba, Wright 756.

Panicum nudiculme Mez, Bot. Jahrb. Engler 56 (Beibl. 125): 6. 1921. Based on Triscenia ovina Griseb.

Culms slender, 20 to $50 \mathrm{~cm}$ tall; blades filiform, glabrous, mostly basal, about half as long as the culm, the innovations numerous;

${ }^{43}$ Contrib. U.S. Natl. Herb. 18: 265. 1917.

4 Engl. and Prantl, Pflanzenfam. 22: 32. 1887; True Grasses 68. 1890. 
panicles slender, few-flowered, the ascending branches distant; spikelets appressed, on short slender pedicels, glabrous, $3 \mathrm{~mm}$ long (fig. 103).

Stream borders in mountains or hills; Cuba, common in Oriente.

Cuba: Sierra Maestra, valley of Río Yara, Ekman in 1922 (Amer. Gr. Nat. Herb. 989). Nagua, Léon 10889. Sierra de Nipe, Ekman

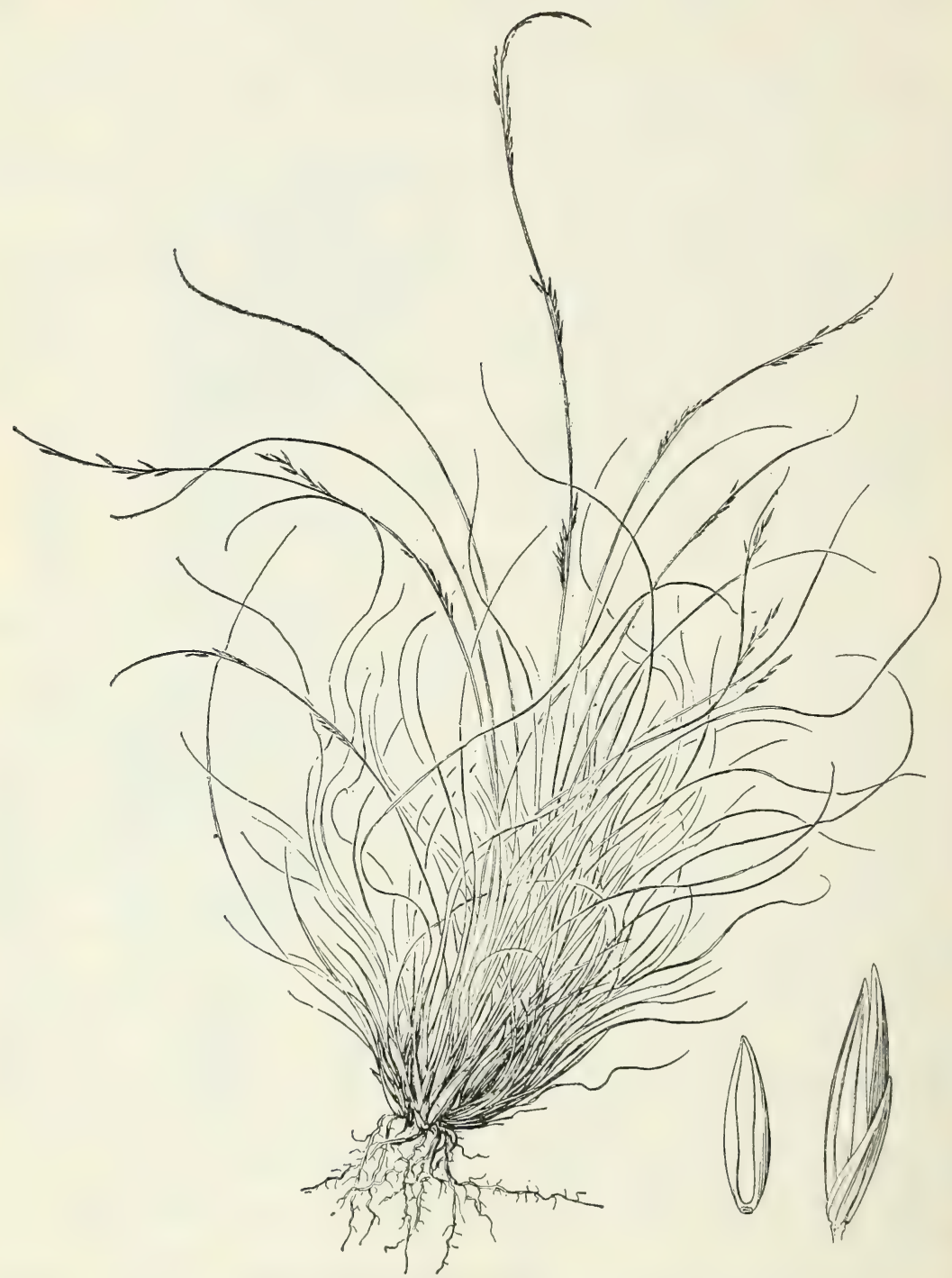

Figure 103.-Triscenia ovina. Plant, $\times 1 / 2$; spikelet and floret, $\times 10$ (Wright 756).

10148. Baracoa, Ekman 4324. Piedra Gorda, Shafer 3668. Pinal Creek, Wright 756.

Dr. Ekman states on one of his labels that the species is known also from Camagüey and from Pinar del Río, but the author has seen no specimens from there. 
69. LEPTOCORYPHIUM Nees, Agrost. Bras. 83. 1829

Spikelets lanceolate, 1-flowered with a sterile lemma below; first glume obsolete; second glume and sterile lemma 3- and 5-nerved, the latter a little longer than the former and about as long as the fruit; fertile lemma slightly cartilaginous-indurate, chestnut with a white delicate hyaline summit; palea not enclosed above, the 2 nerves obscurely visible. Tufted perennial with narrow blades and silky panicle.

1. Leptocoryphium lanatum (H. B. K.) Nees, Agrost. Bras. 84. 1829. Paspalum lanaíum H. B. K., Nov. Gen. et Sp. 1: 94. pl. 29. 1815. Mexico.

Milium lanatum Roem. and Schuit, Syst. Veg. 2: 322. 1817. Anthaenantia lanata Benth., Jour. Linn. Soc. Bot. 19: 39. 1881.

Slender erect perennial up to $1 \mathrm{~m}$ tall; blades long, narrow, often involute; panicles oblong, loose, many-flowered, pale, the branchlets capillary; spikelets silky-pilose, the hairs at first appressed, at maturity spreading (fig. 104).

Dry hills and pine barrens, southern Mexico and the West Indies to northern South America.

CubA: Herradura, Tracy 9048, 9071, 9132; Earle 682; Hitchcock 482; Ekman in 1922 (Amer. Gr. Nat. Herb. 707). San Diego de los Baños, Léon 4564. Sumidero, Léon 3465; Shafer and Léon 13609. Pinar del Río, Wright 3429; Hitchcock 23268; Palmer and Riley 440. Sabana de Motembo, Léon 9347. Manacas, Léon 5827. San Miguel de los Baños, Killip 13854. Sancti Spíritus, Léon 853. "La Magdalena" Cayamas, Baker 4555. Baraguá, Hitchcock 23367. Paso Estancia, Shafer 1683. Bayate, Elkman 4956. Isla de Pinos, Palmer and Riley 972; Curtiss 393; Britton and Wilson 14173.

Harti: St. Michel de l'Atalaye, Ekman H 3253; Sweet in 1925. Lamielle, Ekman H 6203. Bonao, Ekman H 5827.

Dominican Republic: Guerra, Ekman H 13348.

Puerto Rico: Mayaguez, Britton and Hess 2699; Chase 6272, 6810; Holm 192, 193.

Trinidad: San Fernando, Hart 3368. O'Meara Savanna, Britton and Hazen 1562.

\section{TRICHACHNE Nees, Agrost. Bras. 85. 1829}

\section{(Valota Adans., Fam. Pl. 2: 495. 1763. No generic description)}

Spikelets lanceolate, in pairs, short-pedicellate, in two rows along one side of a narrow rachis; first glume minute, glabrous; second glume and sterile lemma about as long as the fruit, 3 - to 5-nerved, copiously silky; fertile lemma cartilaginous, lanceolate, acuminate, usually brown, the flat white hyaline margins broad. Perennials, the slender racemes erect or nearly so, aggregate along the upper part of the main axis, forming a white or brownish silky panicle.

Racemes few, usually about 3; blades short, mostly not over $3 \mathrm{~cm}$ long; plants 20 to $40 \mathrm{~cm}$ tall Racemes numerous; blades elongate; plants usually more than $50 \mathrm{~cm}$ tall.

Lower panicle branches in a fascicle on one side of the axis; spikelets densely clothed with tawny or brown silky hairs much exceeding the spikelet. 2. T. INSULARIS.

Lower panicle branches in a whorl; spikelets sparsely villous, the hairs shorter than the spikelet 3. T. LAXA. 
164 MISC. PUBLICATION 243, U. S. DEPT. OF AGRICULTURE

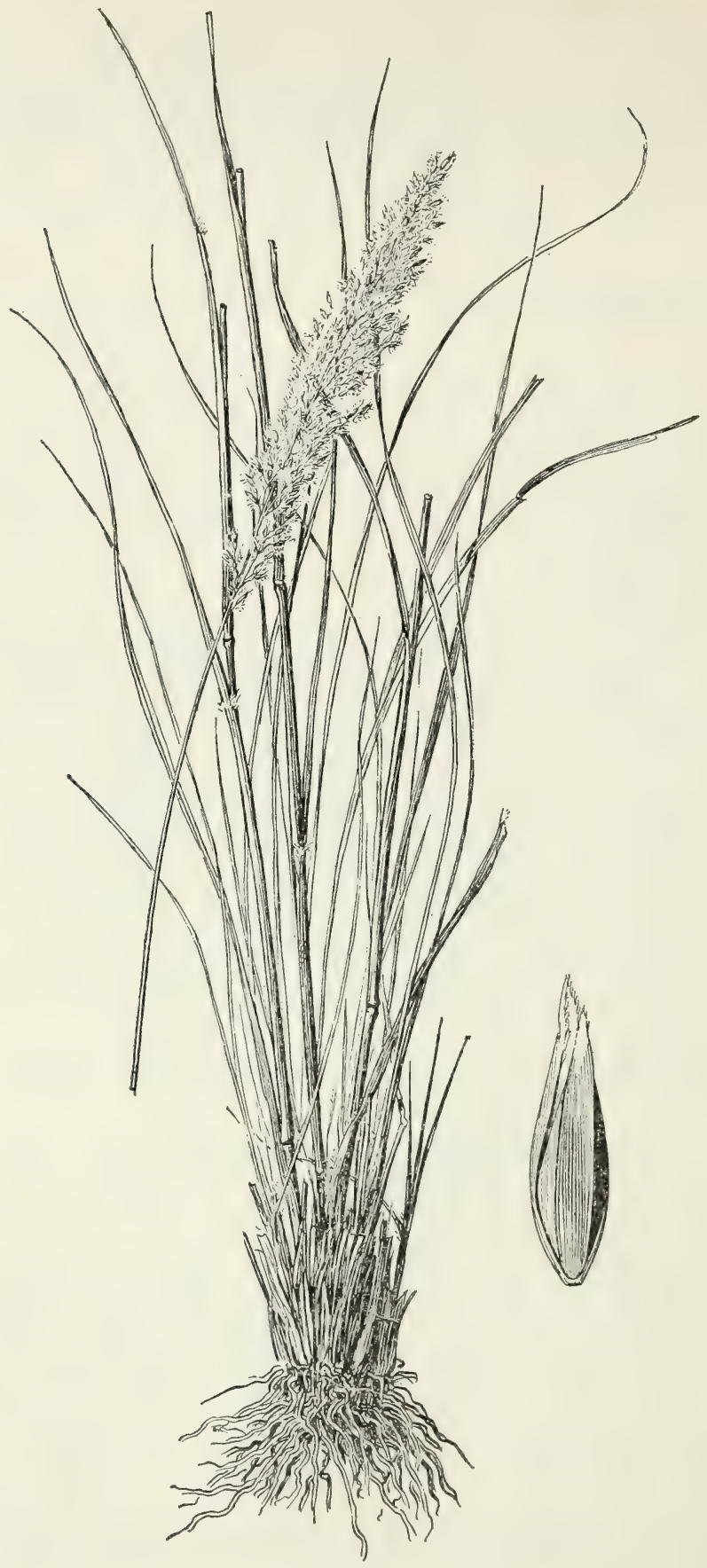

FIGURE 104.-Leptocoryphium lanatum. Plant, $\times 1 / 2$; floret, $\times 10$ (Chase 6272). 
1. Trichachne eggersii (Hack.) Henr., Med. Rijks Herb. Leiden 61: 10. 1930.

Panicum eggersii Hack., Oesterr. Bot. Ztschr. 51: 292. 1901. St. Thomas, Eggers 295.

Valota eggersii Hitchc. and Chase, Contrib. U. S. Natl. Herb. 18: 292. 1917.

Digitaria eggersii Henr., Blumea 1: 97. 1934.

Culms slender, branching, 20 to $40 \mathrm{~cm}$ tall, decumbent at base; blades flat, puberulent, 1 to $5 \mathrm{~cm}$ long, 2 to $4 \mathrm{~mm}$ wide; panicles of 2 or 3 erect racemes 2 to $5 \mathrm{~cm}$ long; spikelets 3 to $4 \mathrm{~mm}$ long.

Stony slopes, Virgin Islands.

Virgin Islands: St. Thomas, Eggers 3, 295. Virgin Gorda, Fishlock 209.

2. Trichachne insularis (L.) Nees, Agrost. Bras. 86. 1829.

SOURGRASS.

Andropogon insularis L., Syst. Nat. ed. 10. 2: 1304. 1759. Jamaica. Panicum lanatum Rottb., Act. Lit. Univ. Hafn. 1: 269. 1778. Jamaica.

Milium villosum Swartz, Prodr. Veg. Ind. Occ. 24. 1788. Jamaica. Panicum leucophaeum H. B. K., Nov. Gen. et Sp. 1: 97. 1815. Venezuela and Colombia.

Panicum insulare Meyer, Prim. Fl. Esseq. 60. 1818.

Saccharum polystachyum Sieb.; Kunth, Enum. Pl. 1: 124.1833. Martinique. Cuba.

Panicum saccharoides A. Rich., in Sagra, Hist. Cuba 11: 306.1850.

Panicum falsum Steud., Syn. Pl. Glum. 1: 67. 1854. Cuba.

Panicum duchaissingii Steud., Syn. Pl. Glum. 1: 93. 1854. Guadeloupe.

Tricholaena insularis Griseb., Abh. Ges. Wiss. Göttingen 7: 265. 1857.

Tricholaena saccharoides Griseb., Syst. Unt. Veg. Karaib. 117. 1857.

Digitaria leucophaea Stapf, in Thiselt. Dyer, Fl. Cap. 7: 382. 1898.

Syntherisma insularis Millsp. and Chase, Field Mus. Bot. 1: 473. 1902.

Valota insularis Chase, Biol. Soc. Wash. Proc. 19: 188. 1906.

Digitaria insularis Mez; Ekman, Arkiv. Bot. 13: 22. 1913.

Rather coarse tufted weedy grass; culms 50 to $150 \mathrm{~cm}$ tall; sheaths sparsely hirsute; blades flat, usually scabrous, as much as $25 \mathrm{~cm}$ long: and $1 \mathrm{~cm}$ wide; panicles silky, tawny at maturity, 10 to $30 \mathrm{~cm}$ long, the numerous racemes 10 to $15 \mathrm{~cm}$ long; spikelets about $4 \mathrm{~mm}$ long, very silky (fig. 105).

Open ground and waste places in the Tropies and Subtropies of America at low altitudes.

This species is often called "sourgrass", a name which is occasionally applied to other large unpalatable grasses such as species of Paspalum and Andropogon. In Cuba it is one of the grasses called "barba de indio", and "rabo de zorra." In St. Kitts it is called "long grass." To be found in probably all of the West Indian islands.

3. Trichachne laxa (Reichenb.) Hitchc.

Reimaria laxa Reichenb.; Spreng., Tent. Sup. Syst. Veg. 2. 1828. Surinam.

Valota laxa Hitchc. and Chase, Contrib. U. S. Natl. Herb. 18: 292. 1917. 


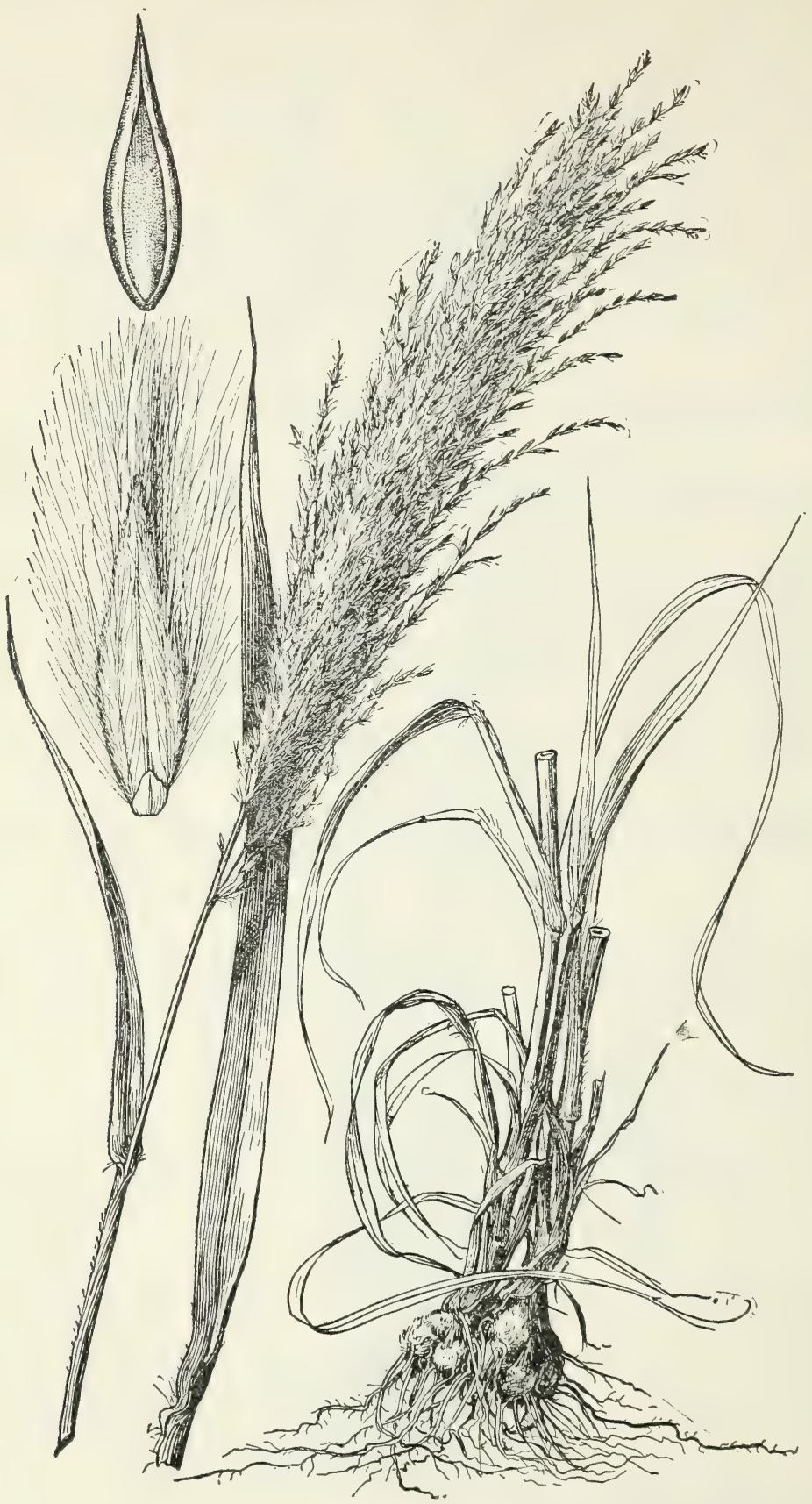

FIGURE 105.-Trichachne insularis. Plant, $\times 1 \frac{1}{2}$; spikelet and floret, $\times 10$ (Baker and Wilson 602). 
Digitaria laxa Paradi, Physis 9: 13, 18. 1928.

Culms in large tufts, decumbent at base, 1 to $2 \mathrm{~m}$ tall; sheaths tuberculate-hispid; blades flat, glabrous or nearly so, 5 to $20 \mathrm{~cm}$ long, 5 to $15 \mathrm{~mm}$ wide; panicle 15 to $25 \mathrm{~cm}$ long, the numerous rather slender racemes usually 15 to $20 \mathrm{~cm}$ long; widely spreading; spikelets narrowly lanceolate, acuminate, rather sparsely silky pilose, 4 to $5 \mathrm{~mm}$ long. The stiff hairs of the sheaths break off in handling and penetrate the skin.

Open moist ground, southern West Indies to Paraguay.

Windward Islands: Grenada, Broadway 1782.

Trinidad: Pitch Lake, Hitchcock 10084 (Amer. Gr. Nat. Herb. 553). Cedros, Hitchcock 10143. San Fernando, Bot. Gard. Herb. 3374. Port-of-Spain, Hirchcock 9954.

TоваGо: Hitchcock 10246; Broadway 4851.

\section{DIGITARIA Heist.; Scop., Fl. Carn. ed. 2. 1: 52.1772 Crabgrass}

\section{(Syntherisma Walt., Fl. Carol. 76. 1788)}

Spikelets solitary or in twos or threes, subsessile or short-pediceled, alternate in two rows on one side of a 3 -angled winged or wingless rachis; spikelets lanceolate or elliptic, plano-convex; first glume minute or wanting; second glume equaling the sterile lemma or shorter; fertile lemma cartilaginous, the hyaline margins pale. Erect or prostrate annuals or perennials, the slender racemes digitate or somewhat scattered, but aggregate along the upper part of the culms.

Rachis wing-margined, the green wings as wide as the whitish midrib or wider. First glume small but evident..... First glume obsolete-or wanting.

Rachis sparsely beset with spreading long hairs _._._. 2. D. HoRIzontalis.

Rachis with no long hairs.

Pedicels with a ring of short stiff hairs at summit; spikelets with stripes of

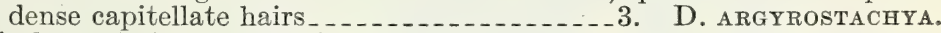

Pedicels not hairy at summit.

Second glume about half as long as the spikelet. Plant creeping and rooting at the nodes....... D. SEROTINA.

Second glume as long as the spikelet.

Spikelets $2 \mathrm{~mm}$ long._. D. ISCHAEMUM.

Spikelets $1.5 \mathrm{~mm}$ long.

Culms erect or decumbent at base......... 5. D. viouascens.

Culms forming long stolons ...... D. LONGIFLORA.

Rachis not winged or the margin much narrower than the midrib.

Spikelets glabrous or nearly so.

Spikelets $1.5 \mathrm{~mm}$ long; second glume shorter than the spikelet; obtusc.

10. D. CURVINERVIS.

Spikelets $2.5 \mathrm{~mm}$ long; second glume as long as the spikelet, acute.

Spikelets pubescent.

13. D. EKMANII.

Spikelets $1.5 \mathrm{~mm}$ long (disregarding the hairs extending beyond the end). Hairs on the spikelet extending beyond the apex as a stiff brownish brushlike tip . . . .

Hairs on spikelet not extending beyond the spikelet as a brushlike tip.

Spikelets 2 mim long.

9. D. PANICEA.

Hairs extending beyond the spikelet as a short brushlike tip.

12. D. PINETORUM.

Hairs not extending beyond the spikelet as a brushlike tip_8. D. VILLOSA. 


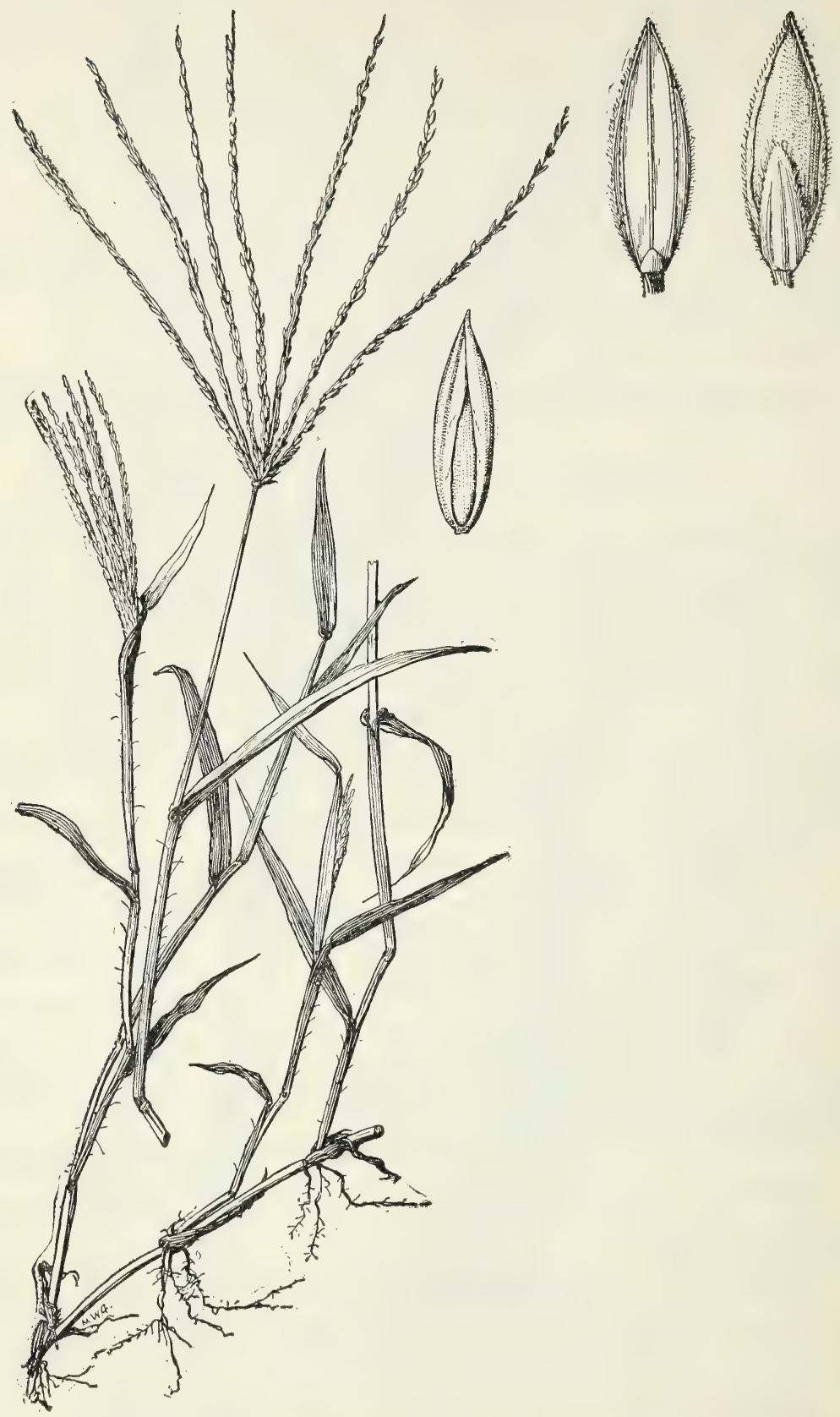

FIGURE 106.-Digitaria sanguinatis. Plant, $\times \frac{1}{2}$; two views of spikelet, and floret, $\times 10$ (Norton 566). 
1. Digitaria sanguinalis (L.) Scop., Fl. Carn. ed. 2. 1: 52.1772 .

Crabgrass.

Panicum sanguinale L., Sp. Pl. 57. 1753. America, Europe.

Digitaria marginata Link, Enum. Pl. 1: 102. 1821. Brazil.

Digitaria fimbriata Link, Hort. Berol. 1: 226. 1827. Brazil.

Syntherisma sanguinalis Dulac, Fl. Haut. Pyr. 77. 1867.

Syntherisma fimbriata Nash, Bull. Torrey Bot. Club 25: 302. 1898.

Spreading branching annual often rooting at the nodes; sheaths pilose; blades more or less pilose; racemes few to several, ascending or spreading, 5 to $10 \mathrm{~cm}$ long, in 1 or 2 whorls; spikelets about $3 \mathrm{~mm}$ long, the first glume small but distinct (fig. 106).

A common weed in cultivated soil and waste places throughout the temperate and tropical regions of both hemispheres. To be found on all the West Indian islands. An excellent fodder grass. In Cuba this is one of the grasses called "pata de gallina."

\section{Digitaria horizontalis} Willd., Enum. Hort. Berol. 92. 1809. Santo Domingo.

Milium digitatum Swartz, Prodr. Veg. Ind. Occ. 24. 1788. Jamaica. Not Digitaria digitata Buse, 1854.

Axonopus digitatus Beauv., Ess. Agrost. 12, 154 . 1812.

Digitaria setigera $\mathrm{R}$ oth; Roem. and Schult., Syst. Veg. 2:474. 1817. India.

Panicum horizontale Meyer, Prim. Fl. Esseq. 54. 1818.

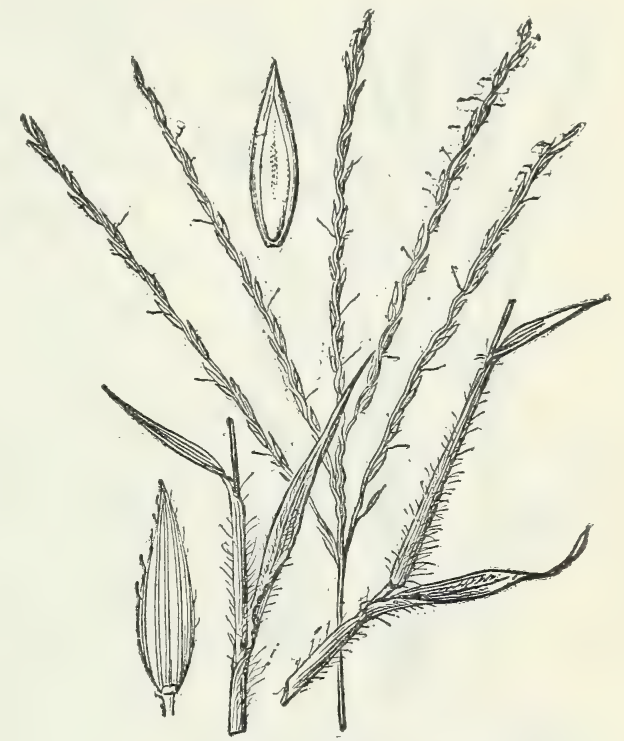

FIGURE 107.-Digitaria horizontalis. Plant, $\times 1$; spikelet and floret, $X 10$ (Nash 996)

Digitaria setosa Desv.; Hamilt., Prodr. Pl. Ind. Occ. 6. 1825. Antilles.

Digitaria jamaicensis Spreng., Syst. Veg. 1: 272. 1825. Jamaica.

Paspalum digitatum Kunth, Rév. Gram. 1: 24.1829.

Panicum hamiltonii Kunth, Rév. Gram. 1: Sup. IX. 1830. Antilles. Syntherisma setosa Nash, Bull. Torrey Bot. Club 25: 300. 1898.

Syntherisma digitata Hitchc., Contrib. U. S. Natl. Herb. 12: 142. 1908 .

Digitaria digitata Urban, Symb. Antill. 8: 24. 1920. Not Digitaria digitata Buse, 1854. Based on Milium digitatum Swartz.

Decumbent branching stoloniferous weedy annual with pilose sheaths and pubescent, often velvety, flat blades, and 5 to 15 very slender lax racemes up to $8 \mathrm{~cm}$ long, subdigitate or in fascicles along a slender axis; spikelets narrow, about $2.5 \mathrm{~mm}$ long; first glume obsolete or wanting (fig. 107). 
A common weed in fields, open ground, and waste places, tropical regions of both hemispheres. To be found in probably all of the West Indian islands. In Cuba sometimes called "pata de gallina fina" (fine henfoot).

3. Digitaria argyrostachya (Steud.) Fernald, Rhodora 22: 103.1920.

Panicum argyrostachyum Steud., Syn. Pl. Glum. 1: 40. 1854. Java.

Syntherisma argyrostachya Hitchc. and Chase, Contrib. U. S. Natl. Herb. 18: 294. 1917.

Annual; culms erect or spreading, 10 to $60 \mathrm{~cm}$ tall; sheaths glabrous; blades flat, 3 to $5 \mathrm{~mm}$ wide, sparsely pilose on the upper sur-

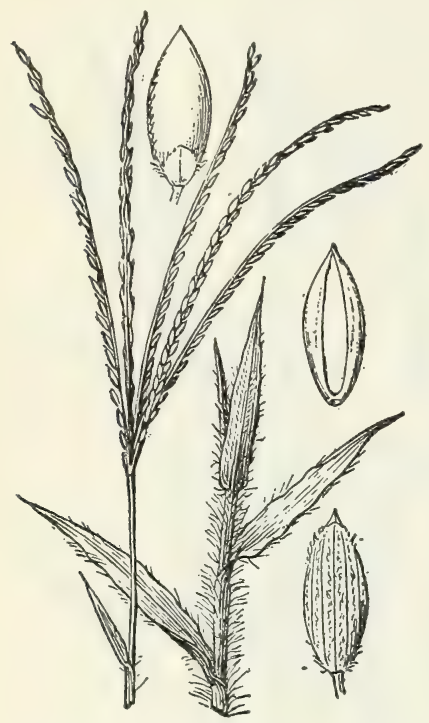

Figure 108.-Digitaria serotina. Plant, $\times 1$; two views of spikelet, and floret, $\times 10$ (Tracy 4653 ). face; racemes slender, erect or ascending, mostly 2 to 4,4 to $10 \mathrm{~cm}$ long; spikelets $2 \mathrm{~mm}$ long.

A weed in cultivated soil, introduced in Jamaica.

J A M A I C A : Cinchona, Harris 11271, 11413; Hitchcock 9705.

4. Digitaria serotina (Walt.) Michx., Fl. Bor. Amer. 1: 46.1803.

Syntherisma serotina Walt., Fl. Carol. 76. 1788. South Carolina.

Culms creeping and rooting, forming mats, the flowering ones ascending, 20 to $30 \mathrm{~cm}$ tall; sheaths and blades pilose; racemes 3 to 5 on an axis about $1 \mathrm{~cm}$ long, 3 to $5 \mathrm{~cm}$ long, the rachis flat, a little less than $1 \mathrm{~mm}$ wide, the margins wider than the midrib; spikelets oblongelliptic, minutely pubescent, about 1.5 $\mathrm{mm}$ long (fig. 108).

Sandy soil, Coastal Plain of the United States from Delaware to Mississippi; also in western Cuba.

Cuba: Laguna Jovero, Shafer 10769. Habana, Ekman 1057, 11515; Ĺéon 4332.

5. Digitaria violascens Link, Hort. Berol. 1: 229. 1827. Brazil. Panicum violascens Kunth, Rév. Gram. 1: 33.1829.

Paspalum chinensis Nees, in Hook. and Arn., Bot. Beechey Voy. 231. 1836. China.

Paspalum minutiflorum Steud., Syn. Pl. Glum. 1: 17. 1854. Not P. minutiflorum Desv., 1831. . China.

Syntherisma helleri Nash, Minn. Bot. Stud. 1: 798. pl. 44. 1897. Hawaii.

Syntherisma violascens Nash, in Brown, Acad. Nat. Sci. Phila. Proc. 61: 488. 1909.

Digitaria chinensis A. Camus, Not. Syst. Lecomte 4: 48. 1923. Not D. chinensis Hornem., 1819.

Syntherisma chinensis Hitchc., Contrib. U. S. Natl. Herb. 22: 468. 1922 .

Annual; culms decumbent and rooting at the base or sometimes erect, 30 to $60 \mathrm{~cm}$ tall; sheaths glabrous; blades glabrous, mostly 3 to $6 \mathrm{~mm}$ wide; racemes mostly 2 to 5 , sometimes 6 or 7 , slender, ascend- 
ing, often curved, 5 to $10 \mathrm{~cm}$ long; rachis flat, wing-margired, $1 \mathrm{~mm}$ wide or somewhat less, glabrous; spikelets elliptic, $1.5 \mathrm{~mm}$ long; cinereous-pubescent; first glume wanting; second glume and sterile lemma equal, about as long as the dark brown fertile lemma (fig. 109).

Open ground, fields, waste places, and moist grassland, China to India and Australia; introduced in the American Tropics.

Bermuda: Collins 146; Brown and Britton 57.

JamaICA: St. Andrew, Harris 12714. Cinchona, Harris 11269, 112711/2, 12484; Hitchcock 9703. Castleton, Harris 11283; Hitchcock 9396. Abbey Green, Hitchicock 9354 (Amer. Gr. Nat. Herb. 556). Gordon Town, Hart 688, 756; Hitchcock 9328.

Puerto Rico: Mayaguez, Chase 6255.

Trinidad: Port-of-Spain, Hitchcock 10008, 10328. Las Lilas, Britton 2515. Piarco Savanna, Britton and Hazen 716. Princes Town, Broadway 1922. Mora Forest, Broadway 7752. Tamana Main Road, Broadway 4961. Without locality, Bot. Gard. Herb. 3433.

6. Digitaria ischaemum (Schreb.) Schreb.; Muhl., Descr. Gram. 131. 1817. SMOOTH CRABGRASS.

Panicum ischaemum Schreb.; Schweigger and Koerte, Spec. Fl. Erlang. 16. 1804. Europe.

Digitaria humifusa Pers., Syn. Pl. 1: 85. 1805.

Syntherisma glabrum Schrad., Fl. Germ. 1: 163. 1806.

Digitaria glabra Beauv., Ess. Agrost. 51. 1812.

Syntherisma ischaemum Nash, N. Amer. Fl. 17: 151. 1912.

Spreading annual weed resembling $D$. sanguinalis, but with glabrous foliage; spikelets $2 \mathrm{~mm}$ long; first glume wanting.

Common in eastern United States; Virgin Islands; introduced from Europe.

Virgin Islands: St. Croix, Benzon.

7. Digitaria longiflora (Retz.) Pers., Syn. Pl. 1: 85. 1805.

Paspalum longiflorum Retz., Obs. Bot. 4: 15. 1786. India.

Panicum longiflorum Gmel., Syst. Nat. 2: 158. 1791.

Syntherisma longifiora Skeels, U. S. Dept. Agr., Bur. Plant Indus. Bull. 261: 30. 1912 .

Perennial; culms widely creeping; sheaths glabrous; blades flat, glabrous, those of the stolons 1 to $3 \mathrm{~cm}$ long; fertile culms ascending 20 to $40 \mathrm{~cm}$ long; racemes often 2, sometimes 3 or 4,3 to $6 \mathrm{~cm}$ long, usually curved, the rachis flat, 0.5 to $0.8 \mathrm{~mm}$ wide, the margin wider than the midrib; spikelets elliptic, minutely pubescent, $1.5 \mathrm{~mm}$ long (fig. 110).

Ditches and sandy savannas, tropical regions of the Old World; introduced in the American Tropics.

Cuba: Pinar del Río, Hitchcock 23269, 23279, 23286; Ekman 17288;

Roig 3954, 4200; Léon 12861, 16151, 16425.

Leeward Islands: Antigua, Box 63, 182.

Windward Islands: St. Lucia, Box 199.

Trinidad: Long Stretch, Broadway 6551.

8. Digitaria villosa (Walt.) Pers., Syn. Pl. 1: 85. 1805.

Syntherisma villosa Talt., Fl. Carol. 77. 1788. South Carolina.

?Panicum domingense Zuccagni, in Roemer, Coll. Bot. 123. 1809. Santo Domingo. 
172 MISC. PUBLICATION 243 , $\tau$. S. DEPT. OF AGRICULTURE

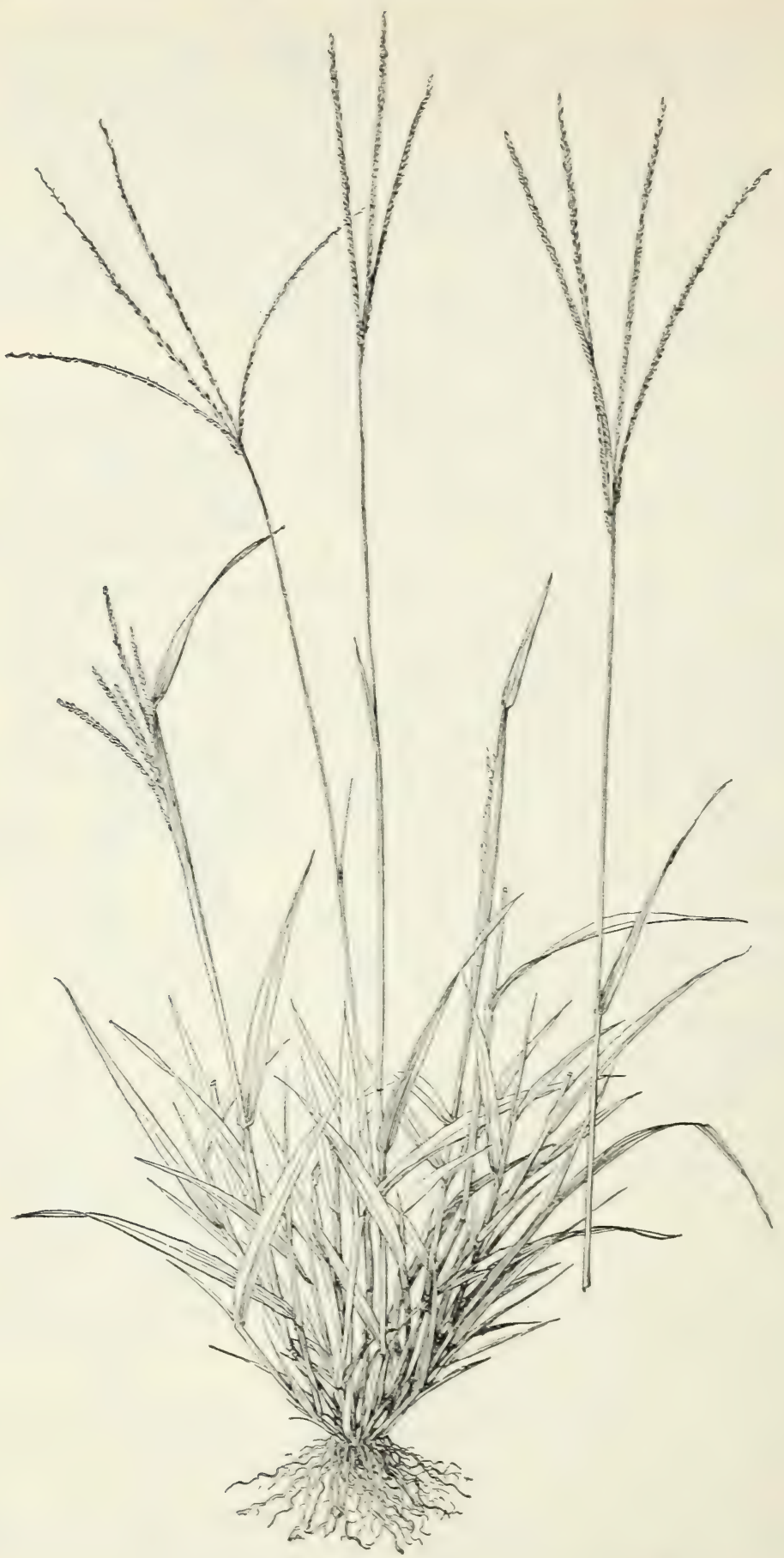

Figtre 109.-Digitaria riolascens. Plant, $\times 1 / 2$ (Hitchcock 10323). 
Panicum leucocomum Scribn., U. S. Dept. Agr., Div. Agrost. Bull. 7 (ed. 2): 58. 1898. Florida.

Syntherisma leucocoma Nash, Bull. Torrey Bot. Club 25: 295.1898. Florida.

Digitaria leucocoma Urban, Symb. Antill. 8: 24. 1920.

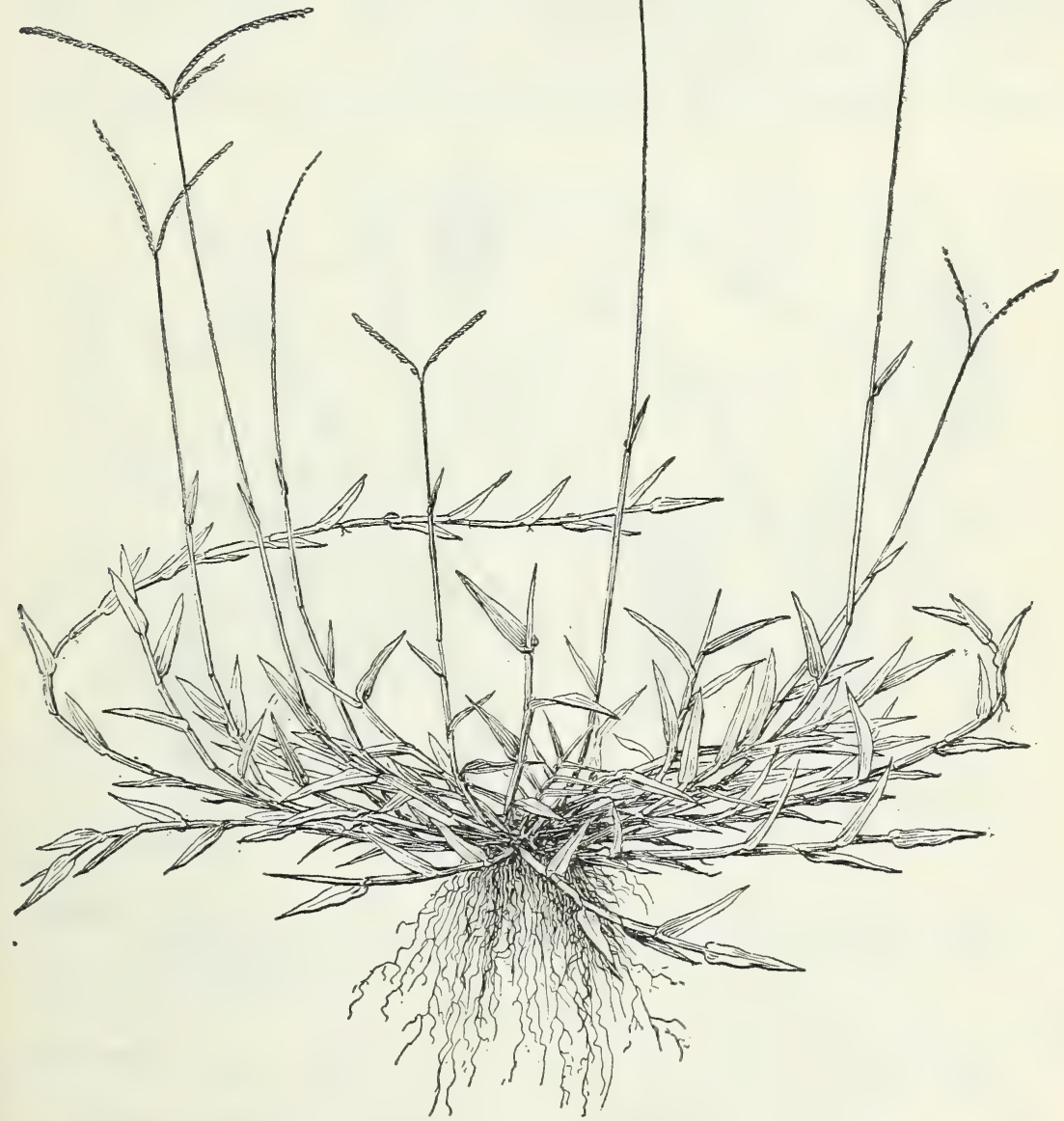

FIGURE 110.-Digitaria longiflora, $\times 1 / 2$ (Hitchcock 14186).

Erect cespitose perennial (or annual according to Ekman), 50 to $120 \mathrm{~cm}$ tall; sheaths pubescent or glabrate; blades narrow, sometimes loosely involute; panicles of several erect or ascending racemes 8 to $15 \mathrm{~cm}$ long, the rachis narrowly winged; spikelets about $2 \mathrm{~mm}$ long; first glume wanting; second glume a little shorter than the fruit, cinereous-pubescent, some of the hairs capitellate; sterile lemma like 
the second glume, about as long as the chestnut-apiculate fruit (fig. 111).

Sandy woods and open ground, southeastern United States, West Indies, and Central America. 701 .

Cuвa: La Grifa la Catolina, Wright 3884. Laguna Santa Bárbara, Ekman 18116. Pinar del Río, Hitchcock 23264. Matanzas, Ekman in 1923. Baraguá, Hitchcock 23385. Mordazo, Ekman 17026. Manacas, Léon 9289.

Haiti: Hinche, Cook, Scofield, and Doyle 146. Pétionville, Ekman H 1388, H 1747. Port-au-Prince, Ekman 1991. Gros-Morne, Ekman H 4920 .

Domivicax Republic: Constanza, Tuerckheim 3459 ; Ekman H 13904. Santiago, Ekman H 16377. Sánchez, Ekman H 15942. Monción,

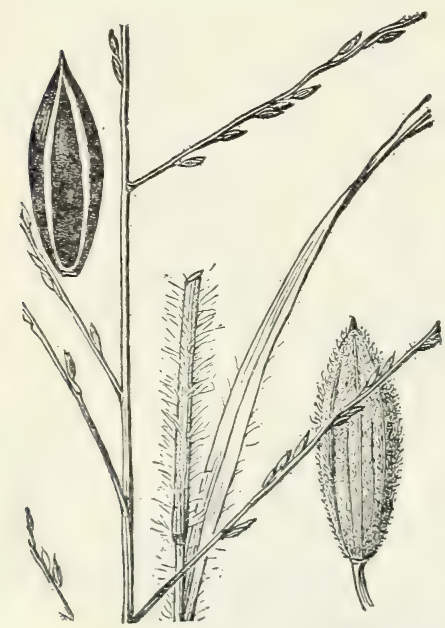

Figure 111.-Digitaria villosa. Plant, $\times 1$; spikelet and floret, $\times 10$ (Curtiss 5300 ).

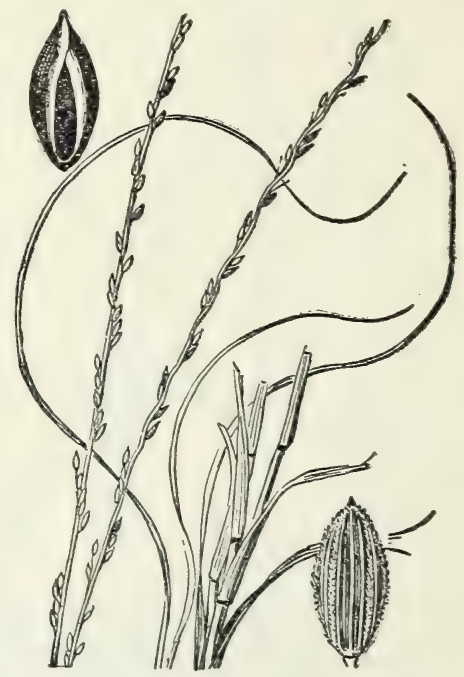

Figure 112.-Digitaria panicea. Plant, $\times 1$; spikelet and floret, $\times 10$ (Tracy 9058 ).

Ekman H 12637. Punta Icacos, Ekman H 15785. Azua, Ekman H 13509. Without locality, Wright, Parry, and Brummel 622.

Puerto Rico: Laguna Tortuguero, Britton, Cowell, and Brown 3858. San Juan, Chase 6784. Campo Alegre, Chase 6806.

9. Digitaria panicea (Swartz) Urban, Symb. Antill. 8: 23. February, 1920; Fernald, Rhodora 22: 103. June, 1920.

Milium paniceum Swartz, Prodr. Veg. Ind. Occ. 24. 1788. Jamaica. Agrostis jamaicensis Poir., in Lam., Encycl. Suppl. 1: 258.1810. Jamaica.

Axonopus paniceus Beaur., Ess. Agrost. 12, 154. 1812.

Syntherisma paniceum Nash, N. Amer. Fl. 17: 152. 1912.

More slender than $D$. villosa, probably annual; blades folded or involute, flexuous, about $1 \mathrm{~mm}$ wide; racemes mostly 1 to 3 , erect, 5 to $20 \mathrm{~cm}$ long, usually 10 to $15 \mathrm{~cm}$, rery slender, loosely flowered; spikelets about $1.5 \mathrm{~mm}$ long, the capitellate hairs rather stiff and appressed (fig. 112). 
There is a slight uncertainty in the application of the name Milium paniceum. The original description applies to the species described above. The amplified description ${ }^{45}$ also applies with the exception of "Raches 3-quetrae, margine membranaceae." The rachis is only minutely margined. There is no specimen of Milium paniceum in the Swartz Herbarium, but there are three specimens sent by Swartz to other herbaria, one at Munich, one at Madrid, and one in the DeCandolle Herbarium. All these specimens are Digitaria panicea as here understood. The habitat given by Swartz is "in aridis sabulosis Jamaicae australis." This species resembles D. filiformis of the United States under which name Grisebach ${ }^{46}$ and $\mathrm{Nash}^{47}$ include it, but differs in having longer, more numerous racemes, longer folded or subinvolute blades, and slightly larger spikelets with longer pubescence.

Open grassy places, subtropical Florida, West Indies, and Central America.

Bahamas: New Providence, Britton and Brace 486.

Cuba: Baraguá, Hitchcock 23361, 23379. Sancti Spíritus, Léon 952. Tunas, Léon 6745. Sierra de Nipe, Ekman in 1922. Eastern Cuba, Wright 1544 (in part). Isla de Pinos, Britton, Wilson, and Léon $6060,15247$.

JAMAICA: Barican, Hitchcock 9574.

Harti: Jean Rabel, Leonard 13032. Pétionville, Ekman H 1732.

Dominican Republic: Sierra de los Comisarios, Ekman H 6804.

Puerto Rico: Campo Alegre, Chase 6435.

10. Digitaria curvinervis (Hack.) Fernald, Rhodora 22: 103.1920.

Panicum curvinerve Hack., Oesterr. Bot. Ztschr. 51: 335. 1901. Cuba, Wright 1544 in part.

Syntherisma curvinervis Hitche. and Chase, Contrib. U. S. Natl. Herb. 18: 295. 1917.

Annual; culms slender, 20 to $60 \mathrm{~cm}$ tall; sheaths and blades sparsely or rather densely pilose or nearly glabrous, the blades flat, 2 to $5 \mathrm{~mm}$ wide; racemes mostly 2 to 4 , sometimes 1 or several, 2 to $10 \mathrm{~cm}$ long; spikelets elliptic, glabrous, strongly nerved, $1.5 \mathrm{~mm}$ long, rarely nearly $2 \mathrm{~mm}$ long, $0.5 \mathrm{~mm}$ wide; first glume wanting; second glume about three-fourths as long as the spikelet, the internerves hyaline, 3-nerved, the outer nerves incurved and joined with the midnerve near the apex; sterile lemma 5-nerved, the outer pair incurved to the midnerve at apex; fruit dark brown with a whitish tip.

Sandy soil, Cuba and Hispaniola. The type collection mixed with two other species.

Cuвa: Pan de Guajaibon, Ekman 17482. Santa Cruz de los Pinos, Ekman 17688. Las Pozas, Ekman 12738. Pinar del Río, Wright 1544. San Diego de los Baños, Léon 4439. Motembo, Léon 8689. Dominican Republic: San Juan, Ekman H 13399.

11. Digitaria argillacea (Hitchc. and Chase) Fernald, Rhodora 22: 104. 1920 .

Syntherisma argillacea Hitchc. and Chase, Contrib. U. S. Natl. Herb. 18: 296. 1917. Puerto Rico, Chase 6221.

45 Fl. Ind. Occ. 1: 179.1797.

46 Fl. Brit. W. Ind. 543.1864

47 Fl. N. Amer. 17: 150. 1912.

$60256-36-12$ 
Annual (according to Ekman); culms slender, erect or decumbent at base, 15 to $60 \mathrm{~cm}$ tall; blades flat, 3 to $4 \mathrm{~mm}$ wide, more or less pilose; panicles long-exserted; racemes usually 3 or 4,1 to $8 \mathrm{~cm}$ long, the rachis very narrowly margined; spikelets $2 \mathrm{~mm}$ long; first glume obsolete or wanting; second glume about three-fourths the length of the spikelet; sterile lemma as long as the spikelet, this and the glume densely pubescent, the hairs, some as much as $1 \mathrm{~mm}$ long, exceeding the spikelet as a brushlike tip, fruit dark brown.

Savannas and open rocky slopes, West Indies and Central America.

Cuba: Santa Cruz de los Pinos, Ekman 17687. Pinar de Cajálbana, Ekman 17309. Herradura, Tracy 9104. Habana, Léon 4785. Guanabacoa, Léon 4715; Hitchcock 23232. San Miguel de los Baños, Léon 8874, 8875. Manacas, Léon 5843. Notembo mines, Léon 8629. Zaza de Tunas, Léon 898. Sancti Spíritus, Léon 2790. Santiago de Cuba, Ekman 7700.

Haiti: Pétionville, Ekman H 1351. Hinche, Ekman H 6176.

Dominican Republic: Constanza, Ekman H 13903.

Puerto Rico: Mayaguez, Chase 6271, 6277. Maricao, Chase 6221.

\section{Digitaria pinetorum Hitchc., sp. nov..$^{48}$}

Perennial; culms slender, cespitose, sometimes loosely so, erect, 30 to $80 \mathrm{~cm}$ tall; sheaths glabrous or the lower pubescent; ligule a membrane $0.5 \mathrm{~mm}$ long; blades slender, flat or involute, mostly less than $2 \mathrm{~mm}$ wide, minutely pubescent or glabrate; racemes long-exserted, usually 1 or 2 , sometimes 3,4 to $10 \mathrm{~cm}$ long, sometimes as much as $20 \mathrm{~cm}$, the rachis about $0.3 \mathrm{~mm}$ wide, with a very narrow margin, the spikelets in pairs or threes, the longer pedicels $2 \mathrm{~mm}$ long; spikelets lanceolate-elliptic, 2 to $2.2 \mathrm{~mm}$ long, densely appressed-pubescent between the nerves, the brownish hairs extending a little beyond the spikelet as a brushlike tip; first glume wanting; second glume slightly shorter than the spikelet, 3-nerved; sterile lemma as long as the spikelet, 5-nerved; fruit dark brown at maturity.

Type in the United States National Herbarium, no. 1387398, collected in pinelands, Los Indios, towards La Siguanéa, Isla de Pinos, November 10, 1920, by E. L. Ekman (no. 12175).

Pinelands, Cuba.

Cuba: Herradura, Hitcheock 483, 484; Tracy 9077. Isla de Pinos, Ekman 12175; Britton and Wilson 15361, 15368.

\section{Digitaria ekmanii Hitchc., sp. nov. ${ }^{49}$}

Perennial; culms decumbent and rooting at base, glabrous, rather stout, 50 to $100 \mathrm{~cm}$ tall; sheaths compressed-keeled, glabrous or the lower papillose-hispid toward the base; ligule membranaceous, rather prominent, about $3 \mathrm{~mm}$ long; blades flat, finely pubescent, 5 to $15 \mathrm{~cm}$ long, 2 to $4 \mathrm{~mm}$ wide; racemes 7 to 10 , on an axis 2 to $3 \mathrm{~cm}$ long, erect or ascending, 7 to $12 \mathrm{~cm}$ long, the rachis triangular, scabrous, somewhat flexuous, $0.3 \mathrm{~mm}$ wide, the margins much narrower than the midrib; spikelets narrowly lanceolate, acute, glabrous

\footnotetext{
${ }_{48}$ Perennis; culmi graciles erecti $30-80 \mathrm{~cm}$ alti; laminae graciles, planae rel inrolutae $0.5-2 \mathrm{~mm}$ latae; racemi $1-2(-3), 4-10(-20) \mathrm{cm}$ longi, rachi $0.3 \mathrm{~mm}$ lata margine angustissimo; spiculae lanceolato-ellipticae2-2.2 mm longae dense pubescentes; fructus brunneus.

49 Perennis; culmi decumbentes 50-100 cm longi; vaginae glabrae vel inferiores nonnihil papilloso-hispidae; laminae planae tenuiter pubescentes $5-15 \mathrm{~cm}$ longae $2-4 \mathrm{~mm}$ latae; racemi $\bar{\tau}-10$ erecti rel ascendentes $7-12 \mathrm{~cm}$ longi, rachi $0.3 \mathrm{~mm}$ lata margine angustissimo; spiculae anguste lanceolatae acutae, glabrae $2.5 \mathrm{~mm}$ longae; gluma prima nulla; gluma secunda spiculam equans; fructus pallidus.
} 
or nearly so, about $2.5 \mathrm{~mm}$ long, in pairs, the longer pedicel 2 to 3 $\mathrm{mm}$ long; first glume obsolete or wanting; second glume as long as the spikelet, obtusish, 3-nerved; sterile lemma as long as the spikelet, acute, 5-nerved; fertile lemma as long as the spikelet, pale, acute.

Type in the United States National Herbarium, no. 1161280, collected in wet places in pinelands, Herradura, prov. Pinar del Río, Cuba, June 26, 1922, by E. L. Ekman.

This species has been referred to ${ }^{50}$ Syntherisma simpsoni (Tasey) Nash, of Florida, which differs in having spikelets $3 \mathrm{~mm}$ long, the second glume and sterile lemma 7 -nerved.

The type specimen has glabrous spikelets. In the other two specimens cited the spikelets are minutely pubescent along the nerves.

Cuba: Herradura, Ekman in 1922. Damují (Pinar del Río), Ekman 10938. Isla de Pinos, Curtiss 521.

\section{STENOTAPHRUM Trin., Fund. Agrost. 175. 1820}

Spikelets embedded in one side of an enlarged and flattened corky rachis disarticulating at maturity, the spikelets remaining attached; first glume small; second glume and sterile lemma about equal, the latter with a palea or staminate flower; fertile lemma chartaceous. Stoloniferous perennials with short flowering culms, rather broad short obtuse blades, and flat terminal and axillary racemes.

1. Stenotaphrum secundatum (Walt.) Kuntze, Rev. Gen. Pl. 2: 794. 1891.

St. Augustine grass.

Ischaemum secundatum Walt., Fl. Carol. 249. 1788. South Carolina.

Rottboellia stolonifera Poir., in Lam., Encycl. 6: 310. 1804. Puerto Rico.

Stenotaphrum americanum Schrank, Pl. Rar. Hort. Monac. pl. 98. 1820. Described from a cultivated plant.

Stenotaphrum glabrum var. americanum Doell, in Mart., Fl. Bras. $2^{2}: 300.1877$.

Stenotaphrum dimidiatum var. americanum Hack., in Stuck., An. Mus. Nac. Buenos Aires 21:57. 1911.

Extensively creeping, the flat stolons with long internodes and short leafy branches, the sheaths equitant; flowering culms 10 to $30 \mathrm{~cm}$ tall, the blades commonly 10 to $15 \mathrm{~cm}$ long; racemes 5 to $10 \mathrm{~cm}$ long; spikelets 4 to $6 \mathrm{~mm}$ long (fig. 113).

Open grassland, at low altitudes, especially near the coast, southern United States to Argentina. An excellent pasture grass. Used for lawns in loamy or mucky soils. In Cuba called "camalote", "cambute", "gramon de costa", and "cañamazo amargo." Bermuda Islands and Bahamas to Trinidad and Tobago; to be found on probably all the West Indian islands.

73. THRASYA H.B.K., Nov. Gen. et Sp. 1: 120. pl. 39.1815

Inflorescence a single terminal spikelike raceme, the rachis usually with membranaceous wings, partially embracing the row of spikelets; spikelets apparently subsessile and solitary in a single row, but actually in pairs, the spikelets of each pair back to back, the pedicel

${ }^{50}$ Contrib. U. S. Natl. Herb. 12: 210. 1909; 18: 294. 1917. 
of the primary spikelet adnate to the midnerve of the rachis; first glume minute, often hyaline; second glume shorter than the spikelet; sterile lemma subindurate, thinner down the middle, at maturity splitting to the base (the margins of the split rolling inward), or deeply sulcate only, the sterile palea

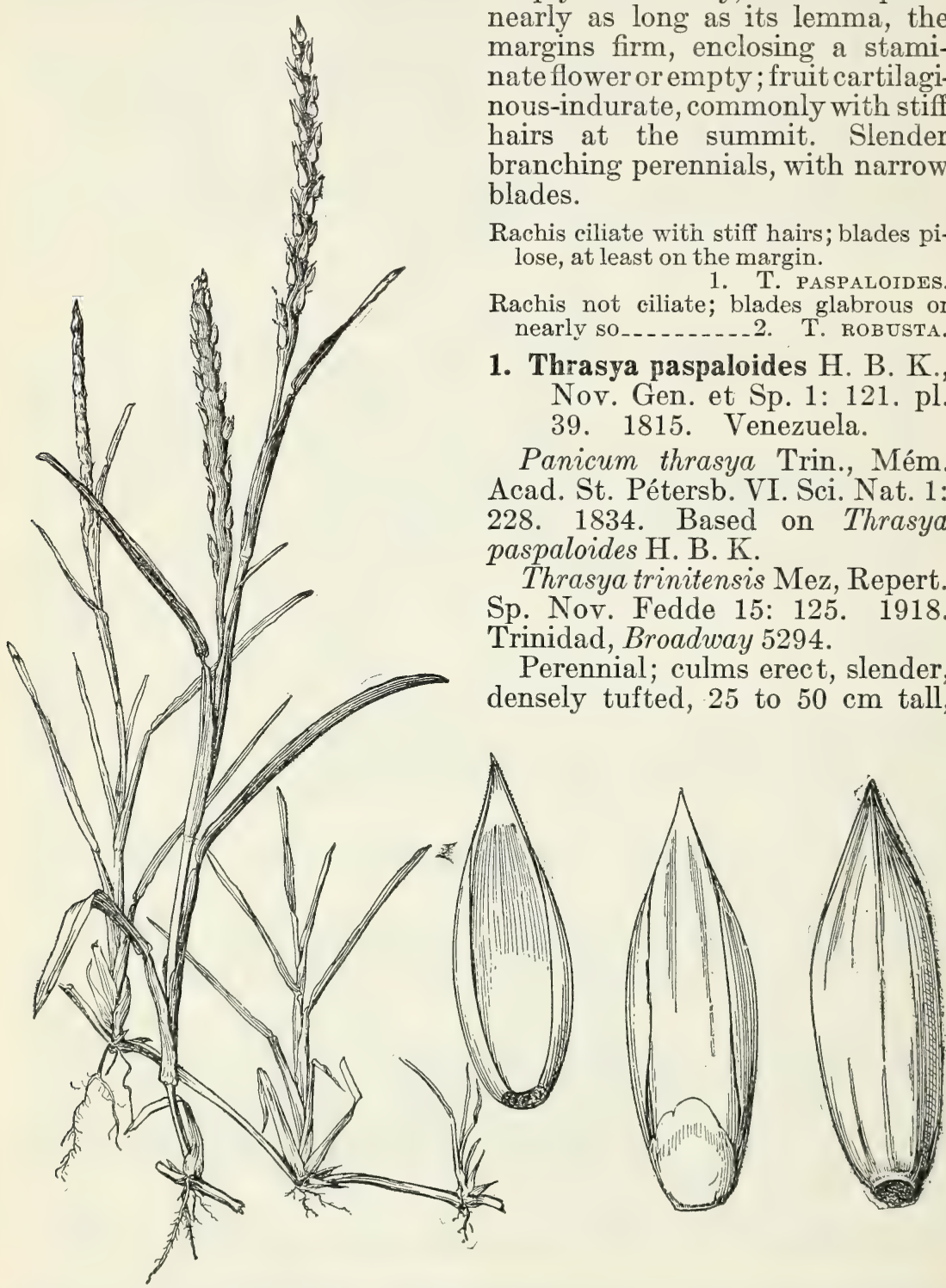

Figure 113.-Stenotaphrum secundatum. Plant, $\times 1 / 2$; two views of spikelet, and fertile floret, $\times 10$ (Tracy 1408).

at length branching from the upper nodes; blades flat, narrow, pilose at least on the margin; racemes arcuate, long-exserted, 3 to $5 \mathrm{~cm}$ long, the rachis ciliate with stiff hairs; spikelets stiffly ciliate, about $3 \mathrm{~mm}$ long (fig. 114). 


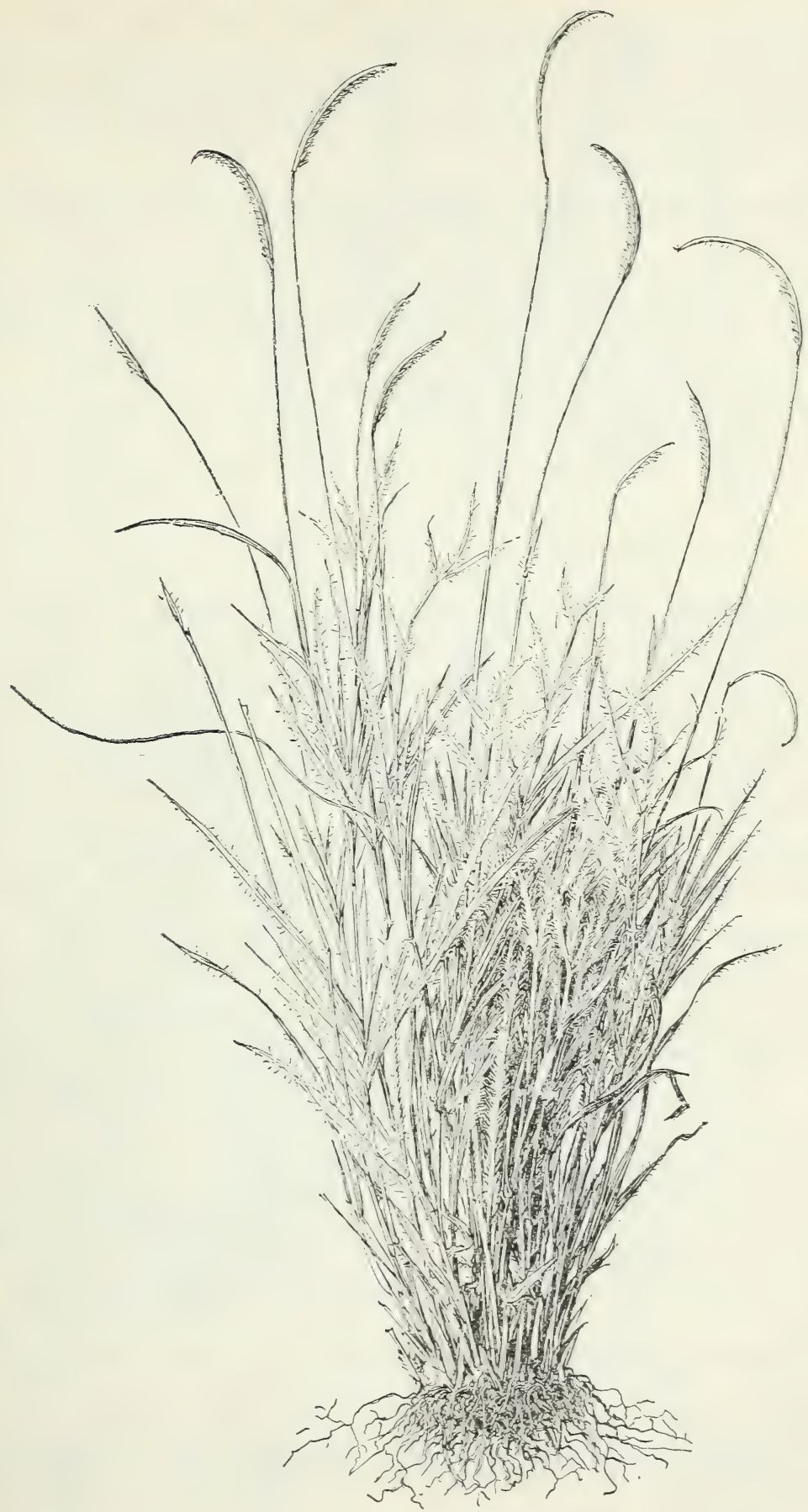

Figure 114. Thrasya paspaloides, $\times 1 / 2$ (Hitchcock 10335, Amer. Gr. Nat. Herb. 557). 
Wet sandy savannas, Trinidad and Venezuela. This is the species described by Grisebach ${ }^{51}$ as T. hirsuta.

Trinidad: Piarco Savanna, Hitchcock 10335; Broadway 5294. Aripo Savanna, Hitchcock 10081 (Amer. Gr. Nat. Herb. 557). O'Meara Savanna, Britton and Hazen 1576. Without locality, Bot. Gard. Herb. 3373; Crueger 43.

2. Thrasya robusta Hitchc. and Chase, Contrib. U. S. Natl. Herb. 18: 297. 1917. Trinidad, Hitchcock 10187.

Perennial; culms erect, rather stout, branching, 1 to $1.5 \mathrm{~m}$ tall; blades flat or folded, firm, ciliate, crisp puberulent on the upper surface, 15 to $30 \mathrm{~cm}$ long, 4 to $15 \mathrm{~mm}$ wide, the upper reduced: racemes 1 (or occasionally 2), arcuate, 8 to $14 \mathrm{~cm}$ long, the rachis 2 to $3 \mathrm{~mm}$ wide; spikelets $3.2 \mathrm{~mm}$ long, villous.

Savannas, Trinidad and Colombia ("Pipiral", southeast of Quetame, Pennell 1719).

Trinidad: St. Joseph, Hitchcock 10187. Piarco Savanna, Hitchcock 10352.

\section{MESOSETUM Steud., Syn. Pl. Glum. 1: 118. 1854}

Inflorescence a single erect terminal spikelike raceme, the spikelets subsessile, solitary, in two rows on one side of a slender rachis, the back of the fruit turned from the rachis, ventricose on the side toward the rachis and fitting into its concavities, the back of the spikelet flat or nearly so; glumes and sterile lemma usually bearing stiff hairs on the strong lateral nerves, the midnerve of the sterile lemma faint or suppressed; fruit ventricose on the palea side. Slender perennials.

Racemes 6 to $12 \mathrm{~cm}$ long; second glume (outer one) three-fourths as long as the spikelet._. M. LoLIIforme.

Racemes 3 to $4 \mathrm{~cm}$ long; second glume exceeding the spikelet _. 2. M. WRIGHTII.

1. Mesosetum loliiforme (Hochst.) Chase, Bot. Gaz. 51: 302. 1911. Panicum loliiforme Hochst.; Steud., Syn. Pl. Glum. 1: 56.1854. Surinam.

Culms tufted, erect, 15 to $60 \mathrm{~cm}$ tall, with long leafy stolons; blades flat, papillose-pilose, the lower 10 to $15 \mathrm{~cm}$ long, 1 to $4 \mathrm{~mm}$ wide, those of the stolons lanceolate, 2 to $3 \mathrm{~cm}$ long; spikes pale, long-exserted, 3 to $15 \mathrm{~cm}$ long: spikelets whitish, $4 \mathrm{~mm}$ long (fig. 115).

Sandy pine woods, Cuba, Trinidad, and south to Brazil.

Cuba: Pinar del Río, Hitchcock 23256, 23267, 23280, 23307; Léon 3469. Mangas, Ekman in 1921. Herradura, Ekman 10690, 10724; Tracy 9058: Hitcheock 485. Matatosa, Wright 3449. Manacas, Léon 5867. Baraguá, Hitchcock 23374. Isla de Pinos, Britton and Wilson 15353; Palmer and Riley 889, 986; Curtiss 396; Taylor 31.

Trinidad: Piarco Savanna, Hitchcock 10336.

2. Mesosetum wrightii Hitchc., Contrib. U. S. Natl. Herb. 12: 211: 1909. Cuba, Wright 3859.

Culms usually decumbent at base, tufted or ascending from the long leafy stolons, 10 to $20 \mathrm{~cm}$ tall; blades flat, sparsely hispidulous, 2 to $5 \mathrm{~cm}$ long, 1 to $2 \mathrm{~mm}$ wide, those of the stolons a little wider;

${ }^{81}$ Fl. Brit. W. Ind. 540. 1864. 


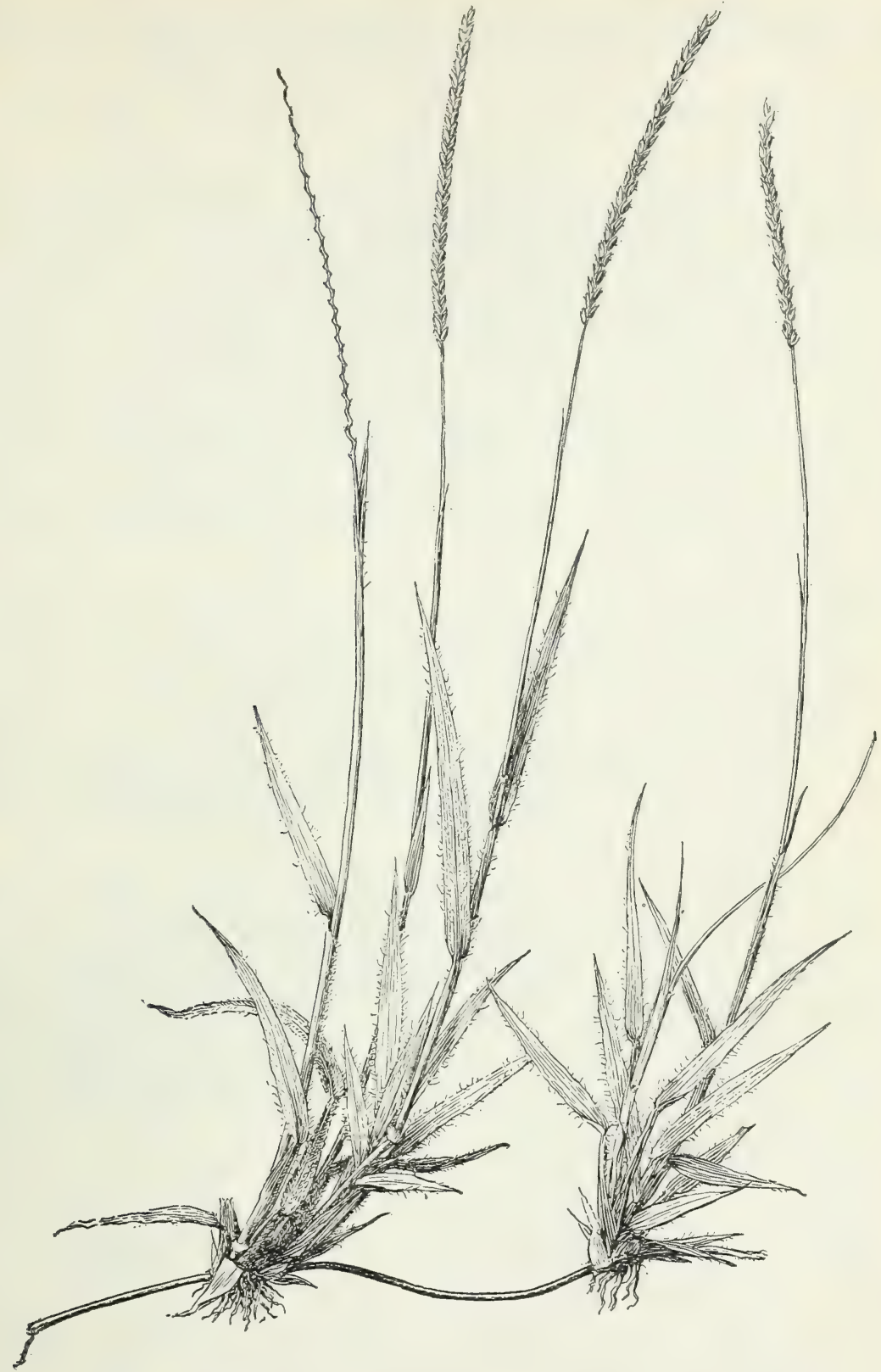

Figure 115.-Mesosetum loliiforme, $\times 1 / 2$ (Hitchcock 485).

spikes mostly 2 to $3 \mathrm{~cm}$ long; spikelets $4 \mathrm{~mm}$ long, greenish, less hirsute than the preceding. Sandy pine woods, Cuba. 
Cuba: Salado, Ekman 11552. La Caloma, Ekman in 1923 (Amer. Gr. Nat. Herb. 990). Dayaniguas, Wright 3859. Hatüey, Léon 9211. Placetas del Sur, Léon 6430. Camagüey, Ekman 15551.

\section{ERIOChloA H. B. K., Nov. Gen. et Sp. 1: 94.1815 Cupgrass}

Spikelets dorsally compressed, more or less pubescent, solitary or sometimes in pairs, short-pedicellate or subsessile, in two rows on one side of a narrow, usually hairy rachis, the pedicels often clothed with long, stiff hairs, the back of the fertile lemma turned from the rachis; lower rachilla joint thickened, forming a more or less ringlike, usually dark-colored callus below the second glume, the first glume reduced to a minute sheath about this and adnate to it; second glume and sterile lemma about equal, acute or acuminate; fertile lemma indurate, minutely papillose-rugose, mucronate or awned, the awn often readily deciduous, the margins slightly inrolled. Annuals or perennials with terminal panicles consisting of several or many spreading or appressed racemes, usually rather closely arranged along the main axis.

Blades filiform

Blades flat, 2 to $15 \mathrm{~mm}$ wide.

1. E. SETOSA.

First glume present; plant long-decumbent or stoloniferous.

First ghume obsolete; plants erect or decumbent at base.

Plants annual

Plants perennial.

Fertile lemma mucronate or with an awn as much as $0.2 \mathrm{~mm}$ long; racemes 2 to 6 ; culms 15 to $60 \mathrm{~cm}$ tall $\ldots \ldots \ldots$. Fertile lemma with an awn about $1 \mathrm{~mm}$ long; racemes several to many; culms usually $1 \mathrm{~m}$ or more tall .............. 4. E. PUNCTATA.

1. Eriochloa setosa (A. Rich.) Hitchc.

Piptatherum setosum A. Rich., in Sagra, Hist. Cuba 11: 311. 1850. Cuba. The type, bearing the name in Richard's script, was examined in the Paris Herbarium in 1935 and proves to be the same as Eriochloa filifolia. Richard's description is misleading in some respects, and the species was referred by Grisebach, ${ }^{52}$ on the description, to his Andropogon setosus, which is the basis of Sorghastrum setosum (Griseb.) Hitchc. Grisebach, however, gives a description of his own and, though using the same specific epithet, does not base his species on that of Richard.

Eriochloa filifolia Hitchc., Contrib. U. S. Natl. Herb. 12: 207. 1909. Guanabacoa, Cuba, Hitchcock in 1906.

Perennial; culms tufted, slender, 15 to $40 \mathrm{~cm}$ tall; blades filiform, 5 to $15 \mathrm{~cm}$ long, the uppermost reduced; inflorescence long-exserted; racemes usually 2 to 4,1 to $2 \mathrm{~cm}$ long, the rachis slender; spikelets mostly 5 to 8 , rather loosely arranged on pedicels as much as $1 \mathrm{~mm}$ long, lanceolate, about $3.5 \mathrm{~mm}$ long, appressed-villous, the second glume and sterile lemma acuminate or somewhat awn-tipped; fertile lemma about $2 \mathrm{~mm}$ long, tipped with a slender awn about $1 \mathrm{~mm}$ long.

Sterile hills, Cuba.

Cuba: Guanabacoa, Hitchcock in 1906, 23223; Léon 851, 2687, 5607, 9127 (Amer. Gro. Nat. Herb. 991); Wilson and Léon 11642;

s2 Cat. Pl. Cub. 235. 1866. 
Ekman 573, 1279. 10904. Batabanó, Léon 13709. San Miguel de los Baños, Léon 8856. Sabana de Motembo, Léon 9380, 11346.

\section{Eriochloa ekmanii Hitchc., sp. nov. ${ }^{53}$}

Perennial; culms slender, tufted, decumbent at base, branching, 15 to $60 \mathrm{~cm}$ tall, the nodes puberulent; sheaths puberulent, especialiy at the margins and around the throat and collar; ligule a row of stiff hairs 0.5 to $1 \mathrm{~mm}$ long; blades flat or somewhat involute, more or less puberulent, 3 to $15 \mathrm{~cm}$ long, 1 to $3 \mathrm{~mm}$ wide; panicle contracted, 3 to $8 \mathrm{~cm}$ long, the axis slender, scabrous and somewhat puberulent; racemes mostly 2 to 6 , appressed or ascending, 1 to 3 $\mathrm{cm}$ long, rather distant on the axis, the rachis slender, scaberulous; spikelets mostly solitary, sometimes in pairs, rather loosely arranged, 2.5 to $3 \mathrm{~mm}$ long, 0.8 to $1 \mathrm{~mm}$ wide, the pedicels 0.3 to $0.5 \mathrm{~mm}$ long, often bearing 1 or 2 stiff hairs; second glume and sterile lemma equal, rather sparsely appressed-pilose, acuminate or awn-tipped; fertile lemma 1.8 to $2 \mathrm{~mm}$ long, apiculate or with an awn as much as $0.2 \mathrm{~mm}$ long.

Type in the U. S. National Herbarium, no. 1385555, collected in savannas near Mir, prov. Oriente, Cuba, August 22, 1916, by Dr. E. L. Ekman (no. 7509).

The species differs from $E$. setosa in the flat blades and the apiculate or short-awned fertile lemma. In the Grasses of the West Indies ${ }^{54}$ it was referred to Eriochloa ramosa (Retz.) Kuntze, which differs in the stouter and taller culms, broader blades, larger panicles, paired spikelets, and in the usually naked base of the racemes.

Cuba: Tiffin (prov. Camagüey), Ekman 15391. Adelaida, Léon 15804. Zaza de Tunas (prov. Santa Clara), Léon 852. Mir, Ekman 7509. Without locality, Wright 3886.

3. Eriochloa boxiana Hitchc., in Swallen, Carneg. Inst. Wash. Publ. 436: 339. 1934. Antigua, Box 43.

Annual; culms branching, decumbent and spreading at base, rooting at the lower nodes, 30 to $40 \mathrm{~cm}$ tall, glabrous, minutely puberulent at the nodes; blades flat, ascending, glabrous beneath, puberulent on the upper surface, 5 to $12 \mathrm{~cm}$ long, 2 to $3 \mathrm{~mm}$ wide, the apex longacuminate; panicle contracted, 7 to $11 \mathrm{~cm}$ long, the racemes numerous; racemes appressed or ascending, overlapping, 1.5 to $2 \mathrm{~cm}$ long; spikelets in pairs, imbricate; lanceolate-acuminate, 4.5 to $5 \mathrm{~mm}$ long, including the awn-tip, appressed pilose on the lower two-thirds, the tip minutely scaberulous, the pedicels about $0.5 \mathrm{~mm}$ long, bearing a few slender hairs; basal ring not prominent, pale, the first glume wanting; second glume extending into an awn nearly $1 \mathrm{~mm}$ long; sterile lemma smaller and a little shorter than the glume, acuminatetipped rather than awned; fertile lemma elliptic-oblong, tipped with an awn $0.5 \mathrm{~mm}$ long (fig. 116).

Damp or swampy open land, Antigua, Yucatan, and Colombia. The species is named for Harold E. Box, entomologist at the Antigua

53 Perennis; culmi tenues caespitosi erecti, basi decumbentes glabri $20-60 \mathrm{~cm}$ alti; nodis puberulis; $\nabla a g i n a \theta^{-}$ puberulae, collo pubescente; laminae planae $5-15 \mathrm{~cm}$ longae $1-3 \mathrm{~mm}$ latae puberulae acuminatae; panicula contracta $3-8 \mathrm{~cm}$ longa, axi scabro tenue; racemi $2-6$ appressi $1-3 \mathrm{~cm}$ longi, a basi floriferi, rachi scabra; spiculae plerumque solitariae $2.5-3 \mathrm{~mm}$ longae $0.8-1 \mathrm{~mm}$ latae, pedicellis $0.3-0.5 \mathrm{~mm}$ longis; gluma secunda mucronata, arista usque ad $0.2 \mathrm{~mm}$ longa; lemma fertile $1.8-2 \mathrm{~mm}$ longum, arista usque ad $0.2 \mathrm{~mm}$ longa.

64 Contrib. U. S. Natl. Herb. 18: 298. 1917. 
Sugar Factory, who has submitted a fine collection of the grasses of Antigua. Mr. Box states that the species is frequent in one locality. Leeward Islands: Antigua, Parrys bridge, Box 43.

4. Eriochloa punctata (L.) Desv.; Hamilt., Prodr. Pl. Ind. Occ. 5. 1825.

Milium punctatum L., Syst. Nat. ed. 10. 2: 872. 1759. Jamaica. Agrostis punctata Lam., Encycl. 1: 58. 1783.

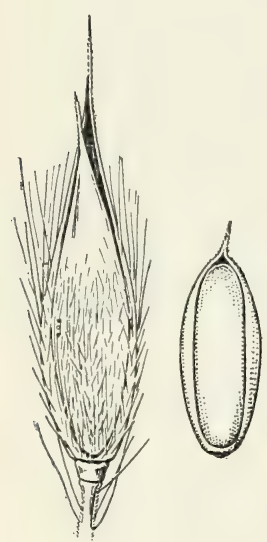

FIG U R E 116.-Eriochloa boxiana. Spikelet and floret, $\times 10$ (type).

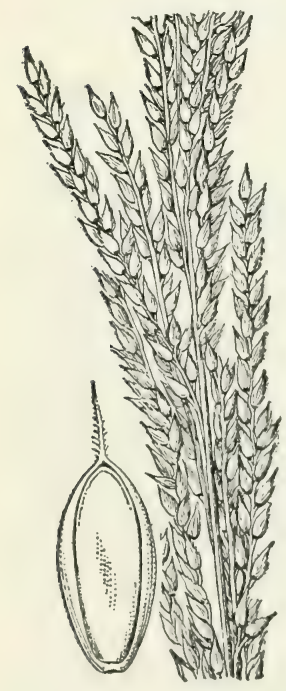

F I G U R E 117.-Eriochloa punctata. Panicle, $\times 1$; floret, $\times 10$ (Hitchcock 9661).

Oedipachne punctata Link, Hort. Berol. 1: 51. 1827.

Helopus punctatus Nees, Agrost. Bras. 16. 1829. Monachne punciaia Nash, Bull. Torrey Bot. Club 30: 374. 1903.

Glabrous branching perennial; culms ascending from a decumbent base, commonly $1 \mathrm{~m}$ or more tall; blades flat, 10 to $15 \mathrm{~mm}$ wide; racemes, several to many, narrowly ascending, the axis pubescent and villous; spikelets lanceolate, acute, about $4 \mathrm{~mm}$ long, appressed-pubescent on the lower half; fruit about $2 \mathrm{~mm}$ long, the awn hispidulous, about $1 \mathrm{~mm}$ long (fig. 117).

Swamps, ditches, and wet places, southern United States to Argentina.

Cuba: Habana, Léon 850, 2686, 3448, 4315. Coliseo, Léon 8828. Yumurí Mountains, Rugel 889. Eastern Cuba, Wright 1542. Isla de Pinos, Ekman 12037.

Jamaica: Mon tego B a y, Hitchcock 9679. Appleton, Hitchcock 9661 (Amer. Gr. Nat. Herb. 300). Windsor, Maxon and Killip 269.

Haiti: Fond-des-Negres, Ekman H 7161. Aux Cayes, Ekman H 759. Gourjon, Ekman H 6454. Miragoane, Ekman H 7232.

Dominican Republic: Santiago, Ekman H 16528. Sánchez, Ekman H 14791. Matanzos, Elkman H 15900.

Puerto Rico: Vega Baja, Britton and Cowell 1451. San Juan, Chase 6380; Hioram 361. Sierra de Luquillo, Chase 6712. Ponce, Heller 6298. Mayaguez, Chase 6251; Hess 122. Cayey, Sintenis 2386. Rio Piedras, Britton and Matz 7055. Adjuntas, Chase 6467, 6477; Sintenis 4253. Fajardo, Sintenis 1227b.

Virgin Islands: St. Croix, Ricksecker 467. St. Thomas, Eggers in 1881. Tortola, Fishlock 107 ; Britton and Shafer 761.

Leeward Islands: Antigua, Hitchcock 16387; Box 73; Wullschlaegel 607. Guadeloupe, Duss 2709. Dominica, Jones 36.

Windward Islands: Montserrat, Shafer 536. Martinique, Duss 540. Barbados, Dash 602. Grenada, Broadway 1530, 4617.

Trinidad: St. Joseph, Hitchcock 100311/2, 10167. Cedros, Hitchcock 10141 (Amer. Gr. Nat. Herb. 301).

Tоваqо: Hitcheock 10250; Broadway 4603. 
5. Eriochloa polystachya H. B. K., Nov. Gen. et Sp. 1: 95. pl. 31. 1815. Ecuador.

Malojilla.

Monachne subglabra Nash, Bull. Torrey Bot. Club 30: 374. 1903. Puerto Rico, Heller 380.

Eriochloa punctata var. subglabra Urban, Symb. Antill. 4: 85. 1903.

Eriochloa subglabra Hitchc., Contrib. U. S. Natl. Herb. 12: 208. 1909.

A stoloniferous perennial with erect flowering culms 1 to $2 \mathrm{~m}$ tall, bearded nodes, flat spreading blades, and terminal panicles of several to many loosely ascending or spreading branches, the spikelets usually in pairs, first glume developed as a minute broad loose membrane.

Swamps, ditches, and moist ground, West Indies to Brazil and Ecuador. A good forage grass. In Puerto Rico this species is confused with Pará grass, which it resembles in habit, and the name "malojilla" is applied to both. The two species are not infrequently found growing together.

Cuba: Habana, Ekman 18298.

JAMAICA: Savanna-la-Mar, Hitchcock 9859.

Puerto Rico: Dorado, Britton and Brown 6683. Condado, Britton and Brown 5769. Rio Piedras, Stevenson 2304; Chase 6360 (Amer. Gr. Nat. Herb. 302); Johnston 10. Mayaguez, Holm 56; Chase 6254, 6554; Britton 2366. Catano, Britton 8829. Lecheria, Goll 23. Pueblo Viejo, Hioram 134. Bayamon, Hioram 327; Sintenis 1228. Rio Canas, Britton 9336. Ponce, Britton and Brown 5513. Santurce, Chase 6350. Arecibo, Chase 6445. Vega Baja, Chase 6795. Sierra Luquillo, Chase 6714. Fajardo, Chase 6656; Britton and Shafer 1523. Utuado, Chase 6458.

Leeward Islands: Guadeloupe, Hitchcock 16400.

Trinidad: Port-of-Spain, Hitchcock 9951, 9970, 10332. Aripo Savanna, Hitchcock 10071. St. Anns, Broadway 7784.

\section{BRACHIARIA Griseb., in Ledeb., Fl. Ross. 4: 469. 1853.}

Spikelets dorsally compressed, solitary, rarely in pairs, subsessile in two rows on one side of a 3-angled, sometimes narrowly winged rachis, the first glume turned toward the axis; second glume and sterile lemma about equal, 5- to 7-nerved, the lemma enclosing a hyaline palea and sometimes a staminate flower; fertile lemma indurate, usually papillose-rugose, the margins inrolled, the apex rarely mucronate or bearing a short awn. Annuals or perennials with linear blades and several spreading or appressed racemes along a common axis.

Spikelets $2 \mathrm{~mm}$ long, pubescent

2. B. ERUCAEFORMIS. Spikelets $4 \mathrm{~mm}$ long, glabrous

B. EXTENSA.

1. Brachiaria extensa Chase, Contrib. U. S. Natl. Herb. 28: 240. 1929. Based on Paspalum platyphyllum Griseb.

Paspalum platyphyllum Griseb., Cat. Pl. Cub. 230. 1866. Not $P$. platyphyllum Schult. 1827. Cuba, Wright 3441.

Panicum platyphyllum Munro; Wright, An. Acad. Cien. Habana 8: 206.1871.

Brachiaria platyphylla Nash., in Small, Fl. Southeast. U. S. 81. 1903.

Glabrous; culms ascending from a creeping base, rather freely branching; blades flat, 5 to $10 \mathrm{~cm}$ long, about $1 \mathrm{~cm}$ wide; inflorescence 
included at base of 1 to 4 rather distant finall spreading racemes with a flat rachis and sessile oroid spikelets appearing to be in a single row (fig. 118).

Moist sandr soil, Louisiana, Texas, Cuba: also Argentina.

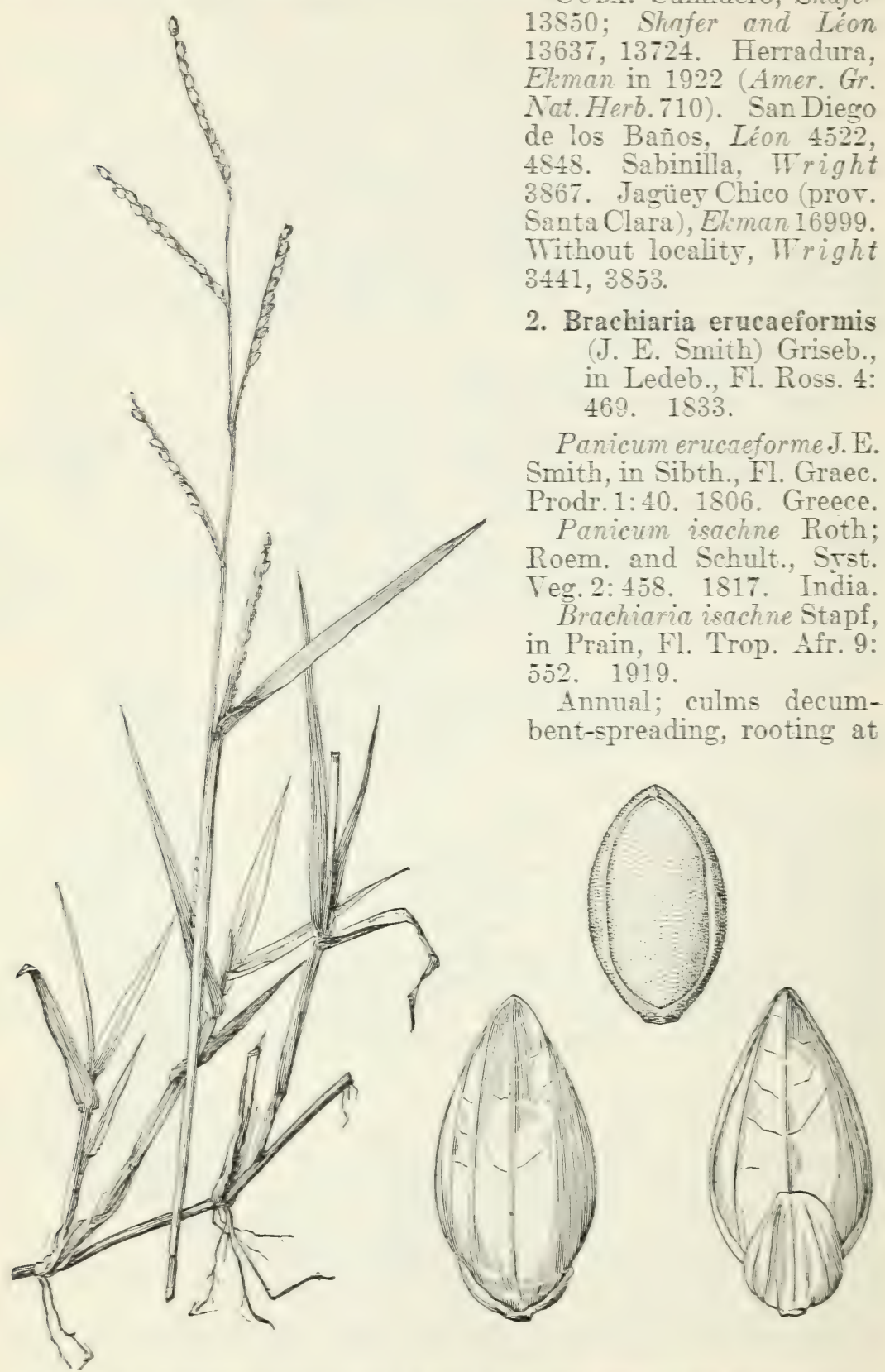

CudA: Sumidero, Shafer 13850; Shafer and Léon 13637, 13724. Herradura, Ekman in 1922 (Amer. Gr. Nat.Herb.710). San Diego de los Baños, Léon 4522, 4848. Sabinilla, Wright 3867. Jagüer Chico (prov. Santa Clara), Ekman 16999. Without locality, Wright 441, 3853

(J. E. Smith) Griseb., in Ledeb., Fl. Ross. 4: 469. 1833.

Panicum erucreforme J.E. Smith, in Sibth., Fl. Graec. Prodr. 1:40. 1806. Greece. Panicum isachne Roth; Roem. and Schult., Srst. Veg. 2: 458. 1817. India. Brachiaria isachne Stapf, in Prain, Fl. Trop. Afr. 9: 552. 1919.

Annual; culms decumbent-spreading, rooting at

Figtae 11s-Brachiaric ertenea. Plant, $X$ is: two riems of spikelet and foret, $X 10$ (Nealler). 
the lower nodes, branching, the flowering branches 20 to $30 \mathrm{~cm}$ tall; blades flat, sparsely pilose, 4 to $6 \mathrm{~cm}$ long, 3 to $5 \mathrm{~mm}$ wide; panicle 5 to $8 \mathrm{~cm}$ long; racemes several, appressed or ascending, 5 to 20 $\mathrm{mm}$ long; spikelets pubescent, $2 \mathrm{~mm}$ long (fig. 119).

A weed in cultivated fields, Barbados; warmer parts of the Old World.

Leeward Islands: Antigua, Box 9, 67.

Windward Islands: Barbados, Bot. Sta. Herb. 448; Hitchcock 16525 (Amer. Gr. Nat. Herb. 708).

\section{AXONOPUS Beauv., Ess. Agrost. 12, 154. 1812}

Spikelets depressed biconvex, not turgid, oblong, usually obtuse, solitary, sessile, and alternate, in two rows on one side of a 3-angled rachis, the back of the fertile lemma turned from the axis; first glume wanting; second glume and sterile lemma equal, the lemma without a palea; fertile lemma and palea indurate, the lemma oblong-elliptic, usually obtuse, the margins slightly inrolled. Stoloniferous or tufted perennials, rarely annuals, with usually flat or folded, abruptly rounded or somewhat pointed blades, and few or numerous, slender, spikelike racemes, digitate or racemose along the main axis.

Rachis bearing conspicuous stiff spreading golden yellow hairs. (Sec. CABRERA.)

Plants annual; rachis over $1 \mathrm{~mm}$ wide, extending beyond the spikelets....1. A. APPENDICULATUS.

Plants perennial; rachis slender, about $0.5 \mathrm{~mm}$ wide, not extending beyond the spikelets.

2. A. AUREUS.

Rachis not bearing stiff hairs. (Axonopus proper.)

Plants annual, the delicate racemes 2 or 3 .

Plants perennial.

3. A. CAPillaris.

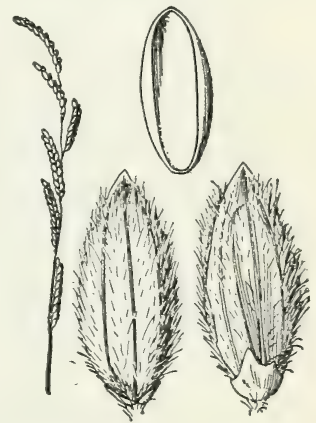

FIgURE 119.-Brachiaria erucaeformis. Panicle, $\times 1$; two views of spikelet, and floret, $\times 10$ (cult.).

Plants stoloniferous, the racemes 2 to 5 .

Spikelets about $2.5 \mathrm{~mm}$ long Spikelets 4 to $5 \mathrm{~mm}$ long

4. A. COMPRESSUS. Plants not stoloniferous.

Racemes 100 or more, the axis elongate........... A. ANCEPS. Racemes 4 to several.

Blades glabrous; racemes several; spikelets acute.

7. A. Leptostachys. Blades, at least when young, ciliate and more or less villous; racemes few; spikelets obtuse......................... A. EUITANS.

1. Axonopus appendiculatus (Presl) Hitchc. and Chase, Contrib. U.S. Natl. Herb. 18: 300. 1917.

Paspalum appendiculatum Presl, Rel. Haenk. 1: 211. 1830. Panama.

Slender sparingly branching annual with long smooth orange-colored internodes; blades flat, thin, yellowish green, sparsely hispid or glabrous; racemes 2 to 8 , subdigitate, 3 to $6 \mathrm{~cm}$ long, the flat green rachis bearing a row of stiff golden hairs on each margin and down the center between the 2 rows of small glabrous spikelets sunken in the rachis.

Open grassy hillsides, Trinidad to Brazil. A strikingly beautiful species.

Trinidad: St. Joseph, Hitchcock 10173 (Amer. Gr. Nat. Herb. 559). 
2. Axomopus aureus Beaur., Ess. Agrost. 12. 1812. Type locality not indicated.

Paspalum aureum H. B. K., Nov. Gen. et Sp. 1: 93. 1815.

Tall slender branching perennial; culms wiry, compressed; blades flat, rather firm, spreading; racemes 4 to 15 , subdigitate, slender, golden brown, the stiff orange-yellow hairs in tufts below the spikelets as well as along the margins; spikelets about $1.3 \mathrm{~mm}$ long, glabrous or sparingly appressed-hispid.

Wet sandy savannas, Puerto Rico and northern South America. This species is described by Grisebach ${ }^{55}$ under the name Paspalum pulchrum.

Puerto Rico: San Juan, Chase 6764 (Amer. Gr. Nat. Herb. 560). Rio Piedras, Stevenson 3282.

Trinidad: Piarco Savanna, Hitchcock 10339. Without locality, Crueger.

3. Axonopus capillaris (Lam.) Chase, Biol. Soc. Wash. Proc. 24: 133. 1911.

Paspalum capillare Lam., Tabl. Encycl. 1: 176. 1791. Tropical America.

Anastrophus capillaris Nash, N. Amer. Fl. 17: 161. 1912.

Annual; culms slender, glabrous, ascending, branching, 10 to $30 \mathrm{~cm}$ tall; blades thin, 2.5 to $5 \mathrm{~cm}$ long, about $4 \mathrm{~mm}$ wide; racemes 2 or 3 , delicate, about $2.5 \mathrm{~cm}$ long, on long subcapillary peduncles; spikelets glabrous, $1.3 \mathrm{~mm}$ long.

Forming patches on moist open ground, Central America to Trinidad and Brazil.

Trinidad: Pitch Lake, Hitchcock 10101 (Amer. Gr. Nat. Herb. 561).

4. Axonopus compressus (Swartz) Beauv., Ess. Agrost. 12. 1812.

Carpet grass.

Mitium compressum Swartz, Prodr. Veg. Ind. Occ. 24. 1788. Jamaica.

Paspalum platicaulon Poir., in Lam., Encycl. Sup. 5: 34. 1804. Puerto Rico.

Agrostis compressa Poir., in Lam., Encycl. Sup. 1: 259 [not 258]. 1810. Not A. compressa Willd., 1790.

Paspalum compressum Raspail, Ann. Sci. Nat. Bot. 5: 301. 1825.

Paspalum laticulmum Spreng., Syst. Veg. 1: 245. 1825. West Indies.

Digitaria platicaulis Desv., Opusc. 62. 1831.

Digitaria domingensis Desv.; Kunth, Enum. Pl. 1: 49. 1833, as synonym of Paspalum platycaule Poir.

Paspalum filostachyum A. Rich.; Steud., Syn. Pl. Glum. 1: 20. 1854. Antilles.

Anastrophus compressus Schlecht.; Doell, in Mart., Fl. Bras. 2² 102. 1877, as synonym of Paspalum platicaulon.

Anastrophus platycaulis Schlecht; Jacks., Ind. Kew. 1: 118. 1893. Paspalum raunkiaerii Mez, Repert. Sp. Nov. Fedde 15: 60. 1917. St. Jan.

Nearly glabrous perennial, under favorable conditions producing long leafy stolons with short broad obtuse blades; flowering culms.

${ }^{33} \mathrm{Fl}$. Brit. W. Ind. 543. 1864. 
erect or ascending, compressed; blades rather thin, 8 to $10 \mathrm{~mm}$ wide; racemes 2 to 5, slender, along a short axis, 2 or 3 axillary peduncles often produced from the upper node; spikelets glabrous or nearly so, 2 to $3 \mathrm{~mm}$ long (fig. 120).

This species is exceedingly variable in habit; in dry ground it

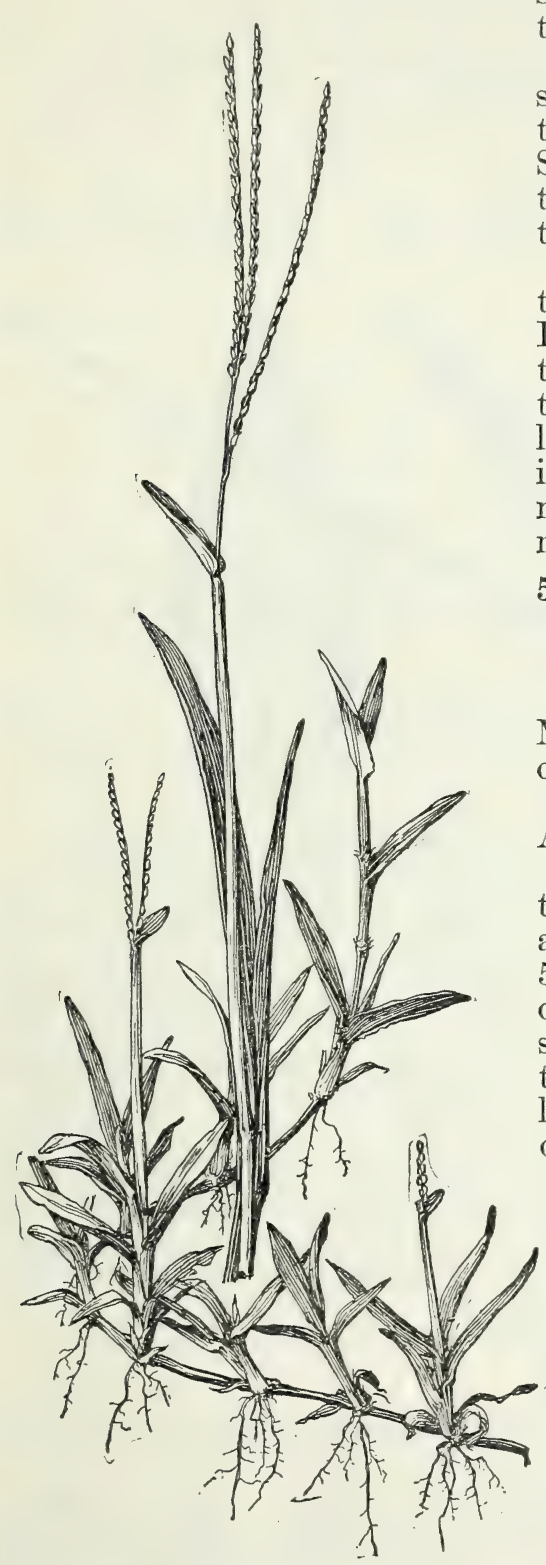
sometimes has blades not more than 2 or $3 \mathrm{~mm}$ wide.

Moist grassland, fields, partial shade, common at low altitudes, throughout the West Indies. Southern United States to Argentina; also in the warmer parts of the Old World.

An important pasture grass throughout the West Indies. Readily propagating by stolons, it tends to drive out other species, thus becoming dominant in lowland pastures. In Cuba this grass is called "cañamazo dulce", "cañamazo de sabana", and "cañamazo macho.'

5. Axonopus furcatus (Flüg ge) Hitchc., Rhodora 8: 205. 1906.

Paspalum furcatum Flügge, Monogr. Pasp. 114. 1810. Carolina.

Anastrophus furcatus Nash, N. Amer. Fl. 17: 162. 1912.

Plants stoloniferous; culms in tufts, erect or decumbent at base, as much as $1 \mathrm{~m}$ tall; blades mostly. 5 to $10 \mathrm{~mm}$ wide; glabrous, ciliate or even hirsute; racemes 2 at the summit of the culm, spreading, 5 to $10 \mathrm{~cm}$ long; spikelets 4 to $5 \mathrm{~mm}$ long, glabrous, acute, the midnerve of the glume evident (fig. 121).

Figure 120.-Axonopus compressus. Plant, $\times 1 / 2$; two views of spikelet, and floret, $\times 10$ (Combs 413). 
Marshes, river banks, and moist pine barrens, southern United States and Cuba.

Cuba: Habana, Ekman 16928.

6. Axonopus equitans Hitche. and Chase, Contrib. U. S. Natl. Herb. 18: 301. 1917. Trinidad, Hitchcock 9988.

Perennial; culms erect, 40 to $60 \mathrm{~cm}$ tall; blades rather stiffly ascending, flat from a folded base, ciliate, rather sparsely villous on the lower surface or the cauline glabrate, 15 to $20 \mathrm{~cm}$ long, 4 to 10 $\mathrm{mm}$ wide; racemes about 4 , erect or ascending, 7 to $15 \mathrm{~cm}$ long; spikelets oblong, $2 \mathrm{~mm}$ long.

Grassland, Trinidad.

Trividad: Port-of-Spain, Hitchcock 9988. St. Joseph, Hitchcock 10193.

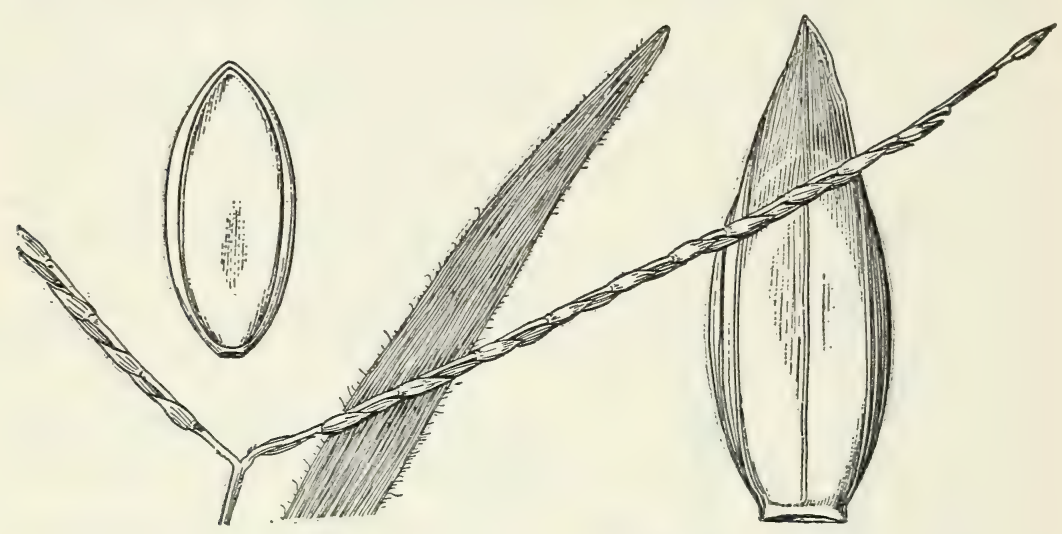

Figure 121.-Axonopus furcatus. Plant, $\times 1$; spikelet and floret, $\times 10$ (Combs 1205).

7. Axonopus leptostachys (Flügge) Hitche., Contrib. U. S. Natl. Herb. 22: 471.1922.

Paspalum leptostachyum Flügge, Monogr. Pasp. 123. 1810. Venezuela.

Axonopus macrostachyus Hitche. and Chase, Contrib. U. S. Natl. Herb. 18: 301. 1917. Trinidad, Hitchcock 10093.

Perennial; culms erect, 1 to $1.5 \mathrm{~m}$ tall; sheaths keeled but not strongly compressed; blades flat, stiffly erect, glabrous, as much as $50 \mathrm{~cm}$ long, 4 to $7 \mathrm{~mm}$ wide; racemes about 12 , slender, erect or stiffly ascending, 15 to $25 \mathrm{~cm}$ long, the main axis about $12 \mathrm{~cm}$ long; spikelets acute, $3 \mathrm{~mm}$ long, minutely silky at base and on the margins.

Low, open ground, Trinidad to Brazil.

Trinidad: Pitch Lake, Hitchcock 10093.

8. Axonopus anceps (Mez) Hitchc.

Paspalum anceps Mez, Repert. Sp. Nov. Fedde 15: 61. 1917. Brazil.

Perennial; culms flat, $1.5 \mathrm{~m}$ tall; sheaths broad, keeled, overlapping, hirsute, densely hairy on the collar; blades elongate, rather stiff, sparsely pilose; panicle $30 \mathrm{~cm}$ long; racemes numerous, laxly spreading, 6 to $12 \mathrm{~cm}$ long, densely woolly in the axils; spikelets plump, oval, $2 \mathrm{~mm}$ long, silky pubescent in lines. 
In Grasses of the West Indies ${ }^{56}$ this species was referred to Axonopus pellitus (Nees) Hitchc. and Chase. Nees' type of Paspalum pellitum and also Mez's of $P$. anceps have since been examined in the Berlin Herbarium.

Open grassland, Trinidad to Brazil.

Trinidad: Pitch Lake, Hitcheock 10094.

78. ReimarochloA Hitchc., Contrib. U. S. Natl. Herb. 12: 198. 1909

Spikelets strongly dorsally compressed, lanceolate, acuminate, rather distant, subsessile, and alternate in two rows along one side of a narrow, flattened rachis, the back of the fertile lemma turned toward it; both glumes wanting, or the second sometimes present in the terminal spikelet; sterile lemma about equaling the fruit, the sterile palea obsolete; fertile lemma scarcely indurate, faintly nerved, acuminate, the margins inrolled at the base only, the palea free nearly half its length. Spreading or stoloniferous perennials, with fiat blades and slender racemes, these subdigitate or racemose along the upper part of the culm, stiffly spreading or reflexed at maturity.

Spikelets 2 to $3 \mathrm{~mm}$ long, silky along the margin; racemes several.

1. R. BRASILIENSIS.

Spikelets about $5 \mathrm{~mm}$ long, glabrous; racemes 2 or $3 \ldots \ldots$... R. OLIGOSTACHYA.

1. Reimarochloa brasiliensis (Spreng.) Hitchc., Contrib. U. S. Natl. Herb. 12: 198. 1909.

Agrostis brasiliensis Spreng., Nov. Prov. Hal. 45. 1819. Brazil.

Reimaria brasiliensis Schlecht., Bot. Ztg. 10: 17. 1852.

Panicum oxyanthum Steud., Syn. Pl. Glum. 1: 41. 1854. Santo Domingo.

Culms tufted, branching, stoloniferous, the ascending flowering branches scarcely more than $10 \mathrm{~cm}$ tall; sheaths loose; blades flat, rather lax, mostly less than $10 \mathrm{~cm}$ long, pubescent or pilose; racemes delicate, digitate, about 10, finally spreading or reflexed, 2 to $3 \mathrm{~cm}$ long; spikelets about $3 \mathrm{~mm}$ long, acuminate, silky along the margin.

Wet ground around ponds, Cuba to Brazil.

Cuba: Hanábana, Wright 3437. Las Mangas, Ekman 13085. Habana, Ekman 757. Santiago de las Vegas, Ekman in 1923 (Amer. Gr. Nat. Herb. 992). San Francisco, Ekman 10976. Isla de Pinos, Curtiss 497.

Dominican Republic: Higüey, Ekman H 12176. Santo Domingo, Ekman H 10994. Without locality, Poiteau.

2. Reimarochloa oligostachya (Munro) Hitchc., Contrib. U.S. Natl. Herb. 12: 199. 1909.

Reimaria oligostachya Munro; Benth., Jour. Linn. Soc. Bot. 19: 34. 1882. Florida.

Stouter than the preceding, the flat culms often elongate, decumbent with ascending ends; racemes 1 to 3 , terminal and axillary, stiff, at maturity widely divergent or deflexed; spikelets glabrous, about 5 $\mathrm{mm}$ long (fig. 122).

Wet soil around ponds, Florida and Cuba.

Cuba: Hanábana, Wright 3854.

36 Contrib. U. S. Natl. Herb. 18: 301. 1917.

$60256-36-13$ 

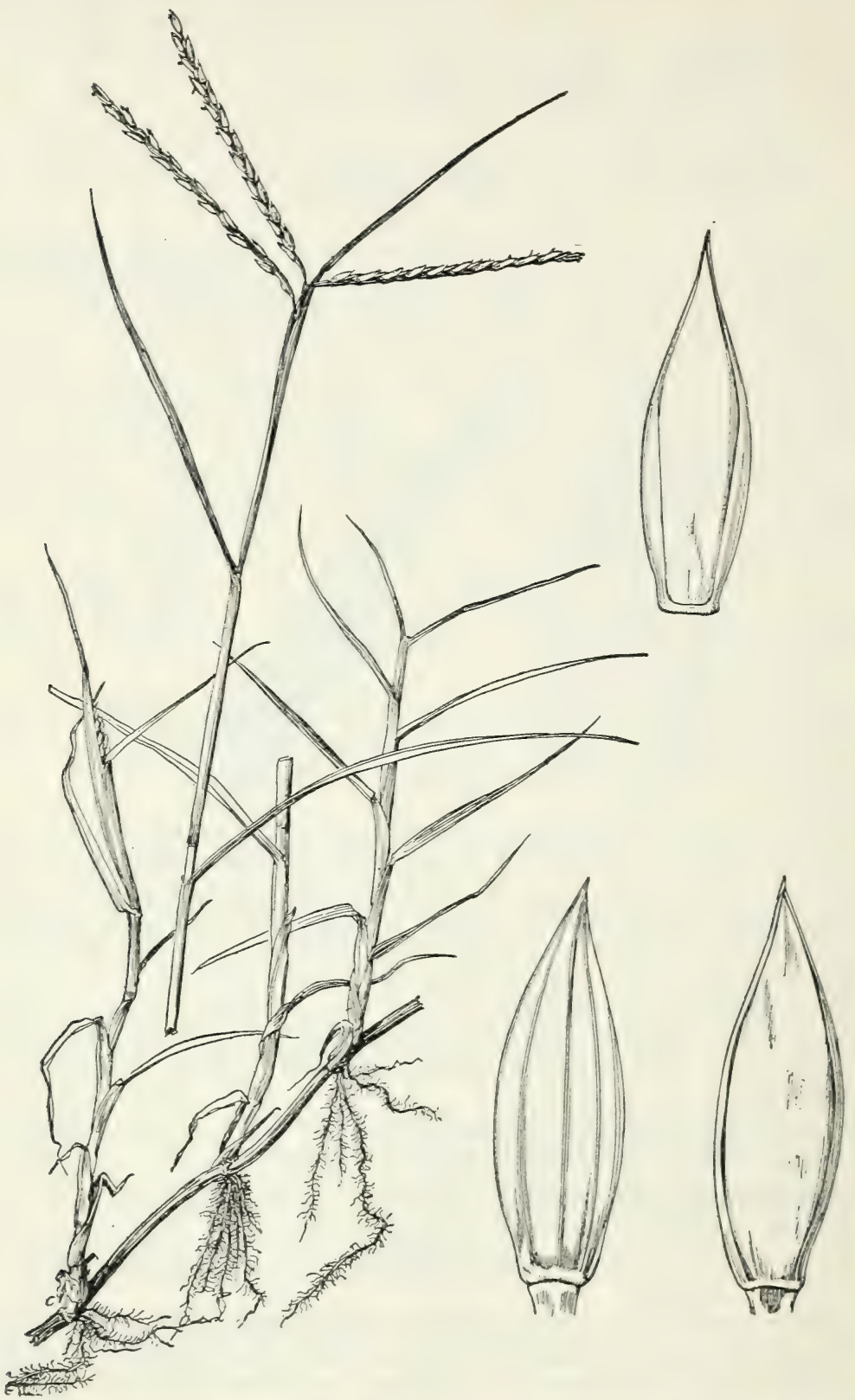

FIGURE 122.-Peimarochloa oligostachya. Plant, $\times 1$; two riews of spikelet, and floret, $\times 10$ (Curtiss 3596A). 


\section{PASPALUM L., Syst. Nat. ed. 10. 2: 855. 1759}

Spikelets plano-convex, usually obtuse, subsessile, solitary or in pairs, in two rows on one side of a narrow or dilated rachis, the back of the fertile lemma toward it; first glume usually wanting; second glume and sterile lemma commonly about equal, the former rarely wanting; fertile lemma usually obtuse, chartaceous-indurate, the margins inrolled. Annuals or perennials, with one to many spikelike racemes, these single or paired at the summit of the culms or racemosely arranged along the main axis.

Full synonymy and more complete descriptions are to be found in the North American Species of Paspalum. ${ }^{57}$

Rachis membranaceous or foliaceous, mostly broad and winged.

Spikelets clothed with long silky hairs; rachis brightly colored.

Ceresia.)

Culms simple; racemes solitary or paired

(Subgenus

P. STEllatum.

Culms branching; racemes not paired, 2 to 7 on the main culm, solitary on the branches........ P. HETEROTRICHON. Spikelets glabrous (or minutely pubescent in $P$. repens); rachis green or dull. Plants perennial.

Racemes persistent on the axis; rachis with a spikelet at the apex. Second glume developed.

Spikelets $2 \mathrm{~mm}$ long, obovate-oval _........... 3. P. Dissectum.

Spikelets more than $3 \mathrm{~mm}$ long, pointed

Racemes falling from the axis; rachis extending beyond the uppermost spikelet_._.

Plants annual ........ P. RACEMOSUM.

Rachis not membranaceous, foliaceous, nor winged. (Slightly winged in a few species but spikelets not silky.)

Inflorescence a large flabellate panicle of numerous racemes. Spikelets solitary. Spikelets glabrous or minutely ciliate__._._._._59. P. FAsciculatum. Spikelets obscured by their long silky hairs_......75. P. SACCHAROIdes.

Inflorescence not flabellate.

Racemes 2, conjugate or nearly so at the summit of the culm, rarely a third below.

Spikelets elliptic to narrowly ovate.

Plants with creeping rhizomes or stolons.

Second glume pubescent; spikelets relatively turgid_ 9. P. Distichum. Second glume and sterile lemma glabrous; spikelets flattened.

Blades erect or ascending, involute-setaceous _- 8. P. DISTACHYON. Blades spreading, tapering from base to apex, the margins involute ............. P. VAGINATUM.

Plants tufted, not rhizomatous or stoloniferous.

Spikelets not transversely wrinkled.......... 16. P. LINEARE.

Spikelets transversely wrinkled......... 44. P. INSULARE.

Spikelets suborbicular, broadly ovate, or obovate.

Spikelets concavo-convex, sparsely long-silky around the margins; plant stoloniferous.........

Spikelets plano-convex (rarely biconvex, not silky margined; plants not stoloniferous).

Plants annual, small, slender; spikelets not more than $1.5 \mathrm{~mm}$ long. Spikelets orbicular, some of them beaded with globular hairs.

Spikelets obovate, glabrous or minutely pubescent.

48. P. MULTiCAULE.

49. P. ClavUliferum.

Plants perennial; spikelets 1.8 to $3 \mathrm{~mm}$ long, solitary.

Spikelets golden brown, transversely marked with dark lines.

Spikelets green, not marked.

15. P. SERPENTINUM.

Rhizome stout, horizontal, forming tough sod.

Spikelets 2.5 to $3 \mathrm{~mm}$ long .... P. Notatum.

Spikelets less than $2.5 \mathrm{~mm}$ long ....... 13. P. MINUs.

Rhizome none or short and vertical....... 14. P. PUMILUM.

s? Contrib. U. S. Natl. Herb. 28: 1-310. 1929. 
Racemes 1 to many, racemose or fascicled on the axis, not conjugate.

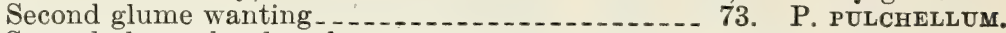
Second glume developed.

First glume developed on at least one of the pair of spikelets.

Plants with stout scaly rhizomes; spikelets glabrous. First glume often obsolete ..................... 24. P. UNISPICATUM.

Plants without rhizomes; culms more or less tufted.

Spikelets not more than $2 \mathrm{~mm}$ long.

Plants decumbent, creeping.

First glume small, about equally developed on all spikelets

First glume obsolete or only occasionally developed.

21. P. NUTANS.

Plants erect or ascending, not creeping. First glume of secondary spikelet elongate ....... 22. P. DISPAR.

Spikelets more than $2 \mathrm{~mm}$ long. Plants not decumbent.

Spikelets glabrous.......

Spikelets sparsely pubescent....

First glume normally wanting.

Racemes terminal and axillary, the axillary sometimes hidden in the sheaths; terminal inflorescence of 1 to 3 , rarely 6 , racemes.

Plants rooting at the lower nodes _......... 21. P. NUTANs.

Plants erect to widely spreading but not rooting at the nodes.

Blades densely grayish-villous, not ciliate.... 17. P. DEBILE.

Blades ciliate, not villous.

Spikelets about $2 \mathrm{~mm}$ long, not pointed_18. P. Ciliatifolium. Spikelets about $1.8 \mathrm{~mm}$ long, slightly pointed.

19. P. PROPINQUUM.

Racemes terminal on the primary culm or leafy branches, no truly axillary racemes.

Plants annual.

Spikelets with a broad firm notched margin _ 74. P. Fimbriatum. Spikelets not margined.

Spikelets not more than $1.5 \mathrm{~mm}$ long, elliptic; fruit pale. Plants annual.

Spikelets solitary.

Spikelets orbicular, usually beaded with globular hairs.

Spikelets elliptic not P. MULTICAULE.

Spikelets in pairs......... P. CLAvULIFERUM.

Spikelets 2 to $3 \mathrm{~mm}$ long; fruit dark brown.

Spikelets 2.4 to $3 \mathrm{~mm}$ long, commonly appressed-pubescent.

Spikelets not more than $2.2 \mathrm{~mm}$ long, glabrous.

70. P. CONVEXUM.

Rachis scarcely $1 \mathrm{~mm}$ wide....71. P. MELANOSPERMUM.

Rachis 2 to $2.5 \mathrm{~mm}$ wide....

Plants perennial.

Racemes solitary, subcylindric; spikelets solitary (sometimes paired in $P$. saugetii).

Plants stoloniferous. Culms rarely more than $10 \mathrm{~cm}$ tall.

Glume and sterile lemma not beaked nor wrinkled.

51. P. BREVE.

Glume and sterile lemma beaked beyond the fruit, deeply wrinkled......... P. EDONDI.

Plants not stoloniferous.

Sterile lemma wrinkled or crumpled.

Foliage conspicuously pubescent; blades flat or subinvolute.

Raceme cylindric; rachis straight_.....43. P. NANUM. Raceme rather flat, scarcely cylindric; rachis flexuous.

44. P. INSULARE.

Foliage glabrous or nearly so; blades concavo-convex in cross section.

Glume and sterile lemma scarcely crumpled.

40. P. FILIFORME 
Glume and sterile lemma inflated and crumpled.

Spikelets $2 \mathrm{~mm}$ long; glume and sterile lemma not pointed beyond the fruit.-41. P. Distortum.

Spikelets 2.7 to $3 \mathrm{~mm}$ long; glume and sterile lemma pointed beyond the fruit_42. P. LINDENIANUM.

Sterile lemma not wrinkled nor crumpled.

Spikelets 3 to $3.3 \mathrm{~mm}$ long.

Spikelets glabrous, in pairs

Spikelets pubescent, solitary.

Blades elongate, glabrous_-_38. P. ALTERNifLORUM.

Blades less than $20 \mathrm{~cm}$ long, conspicuously pilose.

Spikelets not more than $1.8 \mathrm{~mm}$ long.

39. P. ROTTBOELLIOIDES.

Blades not more than $1 \mathrm{~mm}$ wide, concavo-convex or subterete in cross section.

Plants delicate; blades capillary, subterete.

Plants wiry; blades concavo-convex.

\section{P. CAPILLIFOLIUM.}

40. P. FILIFORME.

Blades or some of them $2 \mathrm{~mm}$ or more wide; flat or involute.

Spikelets elliptic, glabrous_._._._. $45 . \quad$ P. RUPESTRE.

Spikelets oval, pubescent_........46. P. SAUGETII.

Racemes 2 to many.

Glume and sterile lemma conspicuously crumpled.

42. P. LINDENIANUM.

Glume and sterile lemma not crumpled or but slightly so.

Plants creeping, rooting at the nodes.

Spikelets suborbicular.

Spikelets more or less elliptic.

Spikelets pubescent, blunt_____.54. P. Reptatum.

Spikelets glabrous, or obscurely pubescent at base

only, subacute............ P. AMPHICARPUM.

Plants not creeping, sometimes rooting at 1 or 2 nodes of a decumbent base, if so, spikelets in pairs.

Spikelets conspicuously silky-ciliate around the margin, the hairs as long as the spikelet or longer.

Racemes commonly 3 to 5; culms geniculate at base.

Racemes commonly 12 to 18 ; culms erect.

57. P. Dilatatum.

58. P. URVILlei.

Spikelets not conspicuously ciliate.

Fruit dark brown and shining; spikelets glabrous or minutely appressed-pubescent.

Spikelets obovate, turgid; sterile lemma wrinkled just within the margin _._._66. P. PLICATULUM. Spikelets elliptic, depressed, not turgid.

Plants subaquatic; rachis 1.5 to $2 \mathrm{~mm}$ wide.

Plants terrestrial; rachis $1 \mathrm{~mm}$ wide.

67. P. WRIGHTII.

Racemes not more than $5 \mathrm{~cm}$ long; foliage glabrous . . . . 68 . P. MOTEMBENSE.

Racemes 8 to $15 \mathrm{~cm}$ long; sheaths and blades hirsute at their junction.

69. P. URBANIANUM.

Fruit pale to stramineous (brown but not shining in P. virgatum).

Plants robust; culms commonly more than $1 \mathrm{~m}$, often

$2 \mathrm{~m}$ tall; spikelets normally in pairs.

Culms freely branching. Racemes 10 to 45; spikelets elliptic, glandular-pubescent.

65. P. CORYPHAEUM. 
Culms simple or with a few simple branches. Blades firm, with sharp-cutting edges.

Spikelets pubescent, at least toward the summit; blades flat, more or less arcuatespreading . . PIRGATUM.

Spikelets glabrous; blades $V$-shaped in eross section, ascending.

Spikelets suborbicular, crowded; rachis ciliate.

Panicle not prramidal, the racemes rarely more than 50; glume and sterile lemma rather firm in texture.

63. P. MillegraNa.

Panicle elongate-pyramidal, the racemes commonly more than 70 , short and crowded at the summit; glume and sterile lemma fragile.

64. P. DENSCM.

Spikelets oborate-elliptic; rachis not ciliate.

Racemes slender; spikelets not crowded; rachis $0.7 \mathrm{~mm}$ wide__61. P. SECANS.

Racemes thick; spikelets somewhat crowded; rachis $1 \mathrm{~mm}$ wide.

62. P. ARTNDINACEUM.

Plants not robust; if more than $1 \mathrm{~m}$ tall, culms relatively slender.

Spikelets $2 \mathrm{~mm}$ or more long.

Spikelets about $3 \mathrm{~mm}$ long, pubescent.

Blades 6 to $14 \mathrm{~mm}$ wide; spikelets oval. 10. P. PCBIFLORCM.

Blades very narrow, involute; spikelets lanceolate _...38. P. ALTERNIFLORUM.

Spikelets 2 to $2.5 \mathrm{~mm}$ long, glabrous.

Spikelets broadest in the middle.

Racemes 2 to 4 , the rachis greenish, 1.2 to $1.5 \mathrm{~mm}$ wide _... 37 . P. ROCANCM.

Racemes mostly 4 to 7 , the rachis dark purple, 1.5 to $2 \mathrm{~mm}$ wide.

11. P. LIVIDCM.

Spikelets broadest above the middle.

Pedicels pubescent; spikelets 2.2 to 2.5 mm long ... 36 . P. PLEOSTACHYUM.

Pedicels glabrous or scaberulous; spikelets about $2 \mathrm{~mm}$ long.

Spikelets subangular-oborate, $1.4 \mathrm{~mm}$ wide_...27. P. OLIGOSTACHYCM.

Spikelets obovate-elliptic, $1.1 \mathrm{~mm}$ wide. 34. P. BAKERI.

Spikelets less than $2 \mathrm{~mm}$ long.

Spikelets glabrous, 1.6 to $1.9 \mathrm{~mm}$ long, oval. 26. P. NESIOTES.

Spikelets more or less pubescent.

Spikelets subhemispheric, 1.3 to $1.4 \mathrm{~mm}$ long, pubescent__28. P. PANICULATUM.

Spikelets elliptic or oval.

Racemes usually solitary, sometimes 2 . 46. P. SAUGetir.

Racemes usually more than 2 .

Spikelets $1.3 \mathrm{~mm}$ long, oral, pubescent.

30. P. BLODGETTII.

Spiketets 1.5 to $1.8 \mathrm{~mm}$ long, or as much as $2 \mathrm{~mm}$ in $P$. laxum.

Primary pedicel nearly as long as the spikelet, the spikelets not crowded ........32. P. MoLle. 
Primary pedicel much shorter than its spikelet, the spikelets crowded.

Nodes glabrous; spikelets pale, stramineous or brownish, 1.7 to $2 \mathrm{~mm}$ long 35 . P. LAXUM.

Nodes or some of them appressedpubescent; spikelets green or purplish.

Rhizomes long, scaly.

29. P. MARITIMUM.

Rhizomes wanting.

Ligule obsolete or minute. 31. P. Caespitosum.

Ligule 1.5 to $2 \mathrm{~mm}$ long. 33. P. ACutifolidm.

1. Paspalum stellatum Humb. and Bonpl., in Flügge, Monogr. Pasp. 62. 1810. Colombia.

Culms simple, erect, or decumbent at base, 40 to $80 \mathrm{~cm}$ tall, slender, wiry; sheaths papillose-hirsute, or the upper glabrate; blades involutesetaceous, papillose-pilose; racemes solitary or paired, 2.5 to $10 \mathrm{~cm}$ long; rachis 5 to $7 \mathrm{~mm}$ wide, the margins membranaceous; spikelets about $3 \mathrm{~mm}$ long, almost hidden under the dense glistening white hairs (fig. 123).

Savannas and open rocky slopes, southern Mexico to Argentina; Hispaniola.

Haiti: St. Michel, Leonard 7289, 7526, 7537a. Between Morne Sala and Morne Basil, Ekman H 2484. Hinche, Ekman H 6428. Mirebalais, Ekman H 2302. Miragoane, Ekman H 7246 .

Dominican RepubLIC: Leonor, Valeur 498. Monción, Ekman H 13015.

\section{Paspalum heterotri-} chon Trin., Gram. Icon. 3: pl. 285. 1831. Brazil.

Paspalum heterotrichum var. paucispicatum Hack., Notizbl. Bot. Gart. Berlin 1: 328. 1897. Haiti, Picarda

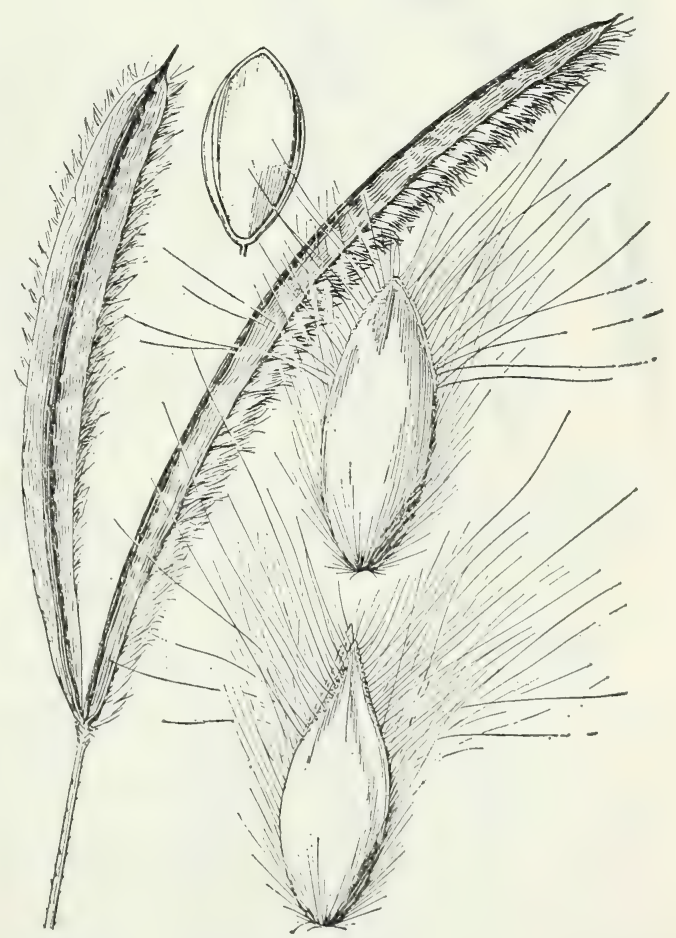

FIGURE 123.-Paspalum stellatum. Panicle, $\times 1$; two views of spikelet, and floret, $\times 10$ (Sello 5686 ). 1525 .

Culms very slender, 50 to $90 \mathrm{~cm}$ tall, finally branching and leaning or clambering among other vegetation; blades firm, more or less 
involute; racemes 2 to 7,1 to $2 \mathrm{~cm}$ distant, 1 to $6 \mathrm{~cm}$ long; rachis 3 to $4 \mathrm{~mm}$ wide, the margins membranaceous; spikelets about 2.5 $\mathrm{mm}$ long, partially hidden by the copious white hairs; one hair of the marginal fringe bristlelike, much exceeding the others (fig. 124).

Open grassy hillsides and savannas, Panama to Peru and southern Brazil; Hispaniola.

Haiti: St. Michel, Buch 1091; Leonard 7537, 7793, 7795a. Mire-

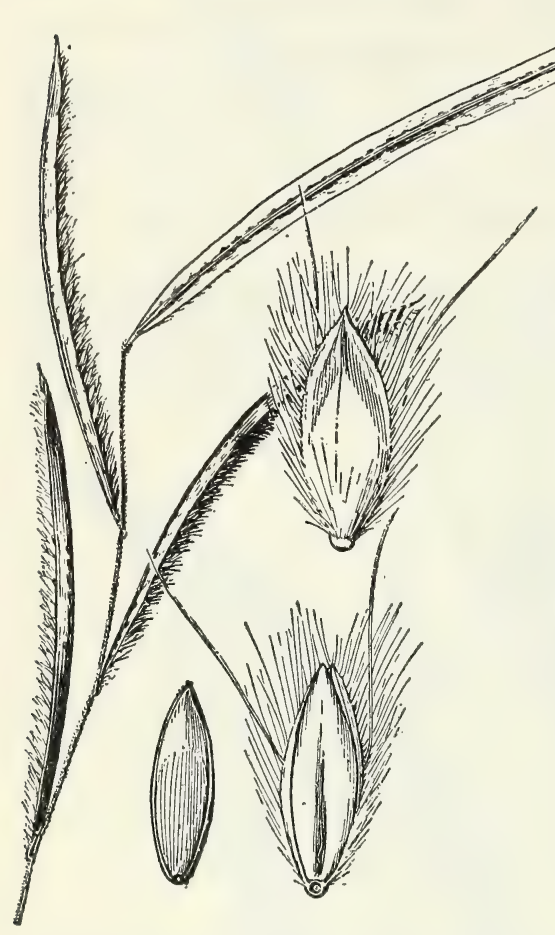

Figure 124.-Paspalum heterotrichon. Panicle, $\times 1$; two views of spikelet, and floret, $\times 10$ (type and Malme 1562B). balais, Ekman $\mathrm{H} 2274$. Ennery, Leonard 8957. Morne Faure, Christ 1800. Miragoane, Ekman $\mathrm{H}$ 7247. Trouin, Ekman H 2401. Furcy, Leonard 4298.

Dominican Republic: Constanza, Ekman H 14018. San Juan, Ekman H 13404.

3. Paspalum dissectum (L.) L., Sp. Pl. ed. 2. 81. 1762.

Panicum dissectum L., Sp. Pl. 57. 1753. (Probably Delaware.) Subaquatic perennial; culms creeping, rooting at the nodes, the flowering branches ascending; blades flat, thin, 3 to $6 \mathrm{~cm}$ long, 4 to $5 \mathrm{~mm}$ wide; inflorescence terminal and axillary; racemes 2 to 4 , 2 to $3 \mathrm{~cm}$ long, usually erect, falling entire, the rachis membranaceous, 2 to $3 \mathrm{~mm}$ wide; spikelets $2 \mathrm{~mm}$ long (fig. 125).

On muddy or sandy banks of ponds and ditches or in shallow water, southeastern United States; Cuba.

Cuba: Laguna Santa María, Ekman 17269. Hanábana, Wright 169 in 1865 . Eastern Cuba, Wright 3440 .

4. Paspalum serratum Hitchc. and Chase, Contrib. U. S. Natl. Herb. 18: 306. 1917. Jamaica, Hitchcock 9795.

Aquatic glabrous perennial; culms as much as $1.7 \mathrm{~m}$ long; blades flat, soft, thin, 4 to $9 \mathrm{~cm}$ long, 3 to $7 \mathrm{~mm}$ wide; racemes 2, rarely 1 , 12 to $15 \mathrm{~mm}$ distant, 3 to $5 \mathrm{~cm}$ long; rachis about $3 \mathrm{~mm}$ wide; spikelets about $3.3 \mathrm{~mm}$ long (fig. 126).

In ponds and sluggish streams, Cuba and Jamaica.

CuBa: Jagüey Chico, Ekman 16990.

Jamaica: Troy, Hitchcock 9795; Harris 12582, 12598. Inverness, Harris 12719. Without locality, Alexander.

5. Paspalum repens Bergius, Act. Helv. Phys. Math. 7: 129. pl. 7. 1762. Dutch Guiana.

Aquatic perennial, the submerged culms as much as $2 \mathrm{~m}$ long, with inflated sheaths; blades flat, 10 to $20 \mathrm{~cm} \mathrm{long}, 12$ to $15 \mathrm{~mm}$ 
wide; panicles 10 to $15 \mathrm{~cm}$ long; racemes numerous, solitary or 2 or 3 together, tardily falling entire, 3 to $5 \mathrm{~cm}$ long, the rachis $1.5 \mathrm{~mm}$ wide; spikelets 1.5 to $2 \mathrm{~mm}$ long, whitish, glabrous or pubescent (fig. 127).

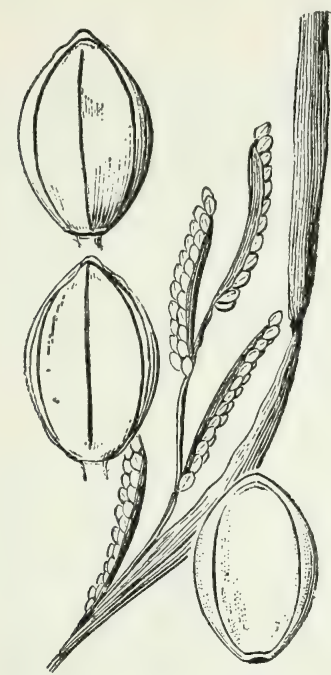

FIGURE 125.-Paspalum dissectum. Panicle $\times 1$; two views of spikelet, and floret, $\times 10$ (Commons 85)

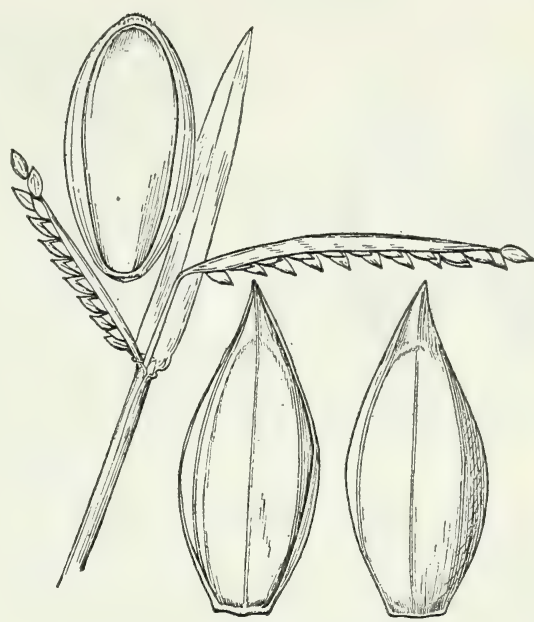

Figure 126.-Paspclum serratum. Panicle, $\times 1$; two views of spikelet, and floret, $\times 10$ (type).

Floating in sluggish streams or standing water or creeping in wet places, southeastern United States, West Indies, and Central America to Paraguay.

JAMAICA: Cornwall, Harris 12557. Shettlewood, Harris 11641. Westmoreland, Harris 11812. Middle Quarters, Hitchcock 9582.

T R I N D A D : Caroni Savanna, Hart 4194.

\section{Paspalum racemosum Lam.,} Tabl. Encycl. 1: 176. 1791. Peru.

Annual; culms widely spreading or clambering, as much as $1 \mathrm{~m}$ long; blades flat, thin, 4 to $12 \mathrm{~cm}$ long, 1 to $2 \mathrm{~cm}$ wide, acuminate, glabrous; panicle ferruginous or dark purple, 10 to $20 \mathrm{~cm}$ long; racemes numerous, falling entire, 1 to $2 \mathrm{~cm}$ long; rachis about $1 \mathrm{~mm}$ wide; spikelets about $2.7 \mathrm{~mm}$ long, the glume rugulose on the lower part, the sterile lemma fluted or deeply wrinkled crosswise (fig. 128).

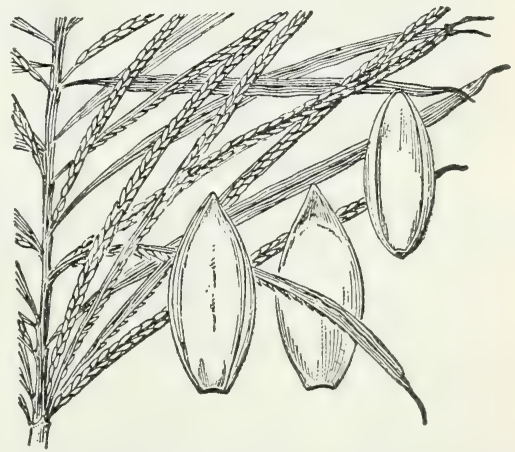

Figure 127.-Paspalum repens. Panicle, $\times 1$; two views of spikelet, and fioret, $\times 10$ (Hitchcock 9179).

In recently disturbed soil, fields, waste places, and roadsides, Ecuador and Peru; introduced as an ornamental in the West Indies and escaped.

Cuba: Habana, Léon 759.

Dominican Republic: Without locality, Poiteau. 
7. Paspalum vaginatum Swartz, Prodr. Veg. Ind. Occ. 21. 1788. Jamaica.

Digitaria foliosa Lag., Gen. et Sp. Nov. 4. 1816. Habana.

Paspalum brachiatum Trin.; Nees, Agrost. Bras. 62. 1829, as synonym. Martinique.

Paspalum foliosum Kunth, Rév. Gram. 1: 25.1829.

Paspalum inflatum A. Rich., in Sagra,

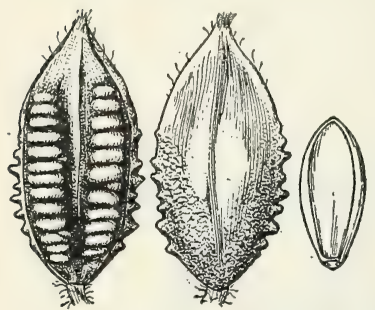

FIGURE 128.-Paspalum racemosum. Two views of spikelet, and floret, $\times 10$ (Peru). Hist. Cuba 11: 298. 1850. Habana. Paspalum distichum var.vaginatum Swartz; Griseb., Fl. Brit. W. Ind. 541. 1864.

Paspalum vaginatum var. nanum Doell, in Mart., Fl. Bras. $2^{2}$ : 75. 1877. Brazil.

Extensively creeping perennial with horizontal rhizomes and also stoloniferous, forming extensive colonies; flowering culms 8 to $60 \mathrm{~cm}$ tall; sheaths overlapping, broad and loose; blades 2.5 to $15 \mathrm{~cm}$ long, 3 to $8 \mathrm{~mm}$ wide; racemes usually 2, rarely as many as 5 , at first erect, spreading or reflexed at maturity, 1.5 to $7.5 \mathrm{~cm}$ long; rachis 1 to $2 \mathrm{~mm}$ wide; spikelets mostly 3.5 to $4 \mathrm{~mm}$ long, acute, pale, glabrous (fig. 129).

Seacoasts and brackish sands, southeastern United States, Mexico, and West Indies to Argentina, Baja California to Chile, Tropics of Eastern Hemisphere.

Bermuda: Brown and Britton 100.

Bahamas: Nassau, Geogr. Soc. Baltimore 546; Hog Island, Britton and Brace 340.

Cuba: Arroyo Mántua, Ekman 11003 . Habana, Curtiss 751; Ekman 13392; Léon 811, 14168. Playa del Rosario, Léon and Roca 7287. Playa de Marianao, Palmer and Riley 848. Tunas, Léon 6734. Santiago de Cuba, Léon and Voisard 930. Castillo de Jagua, Léon 15590. Western Cuba, Wright

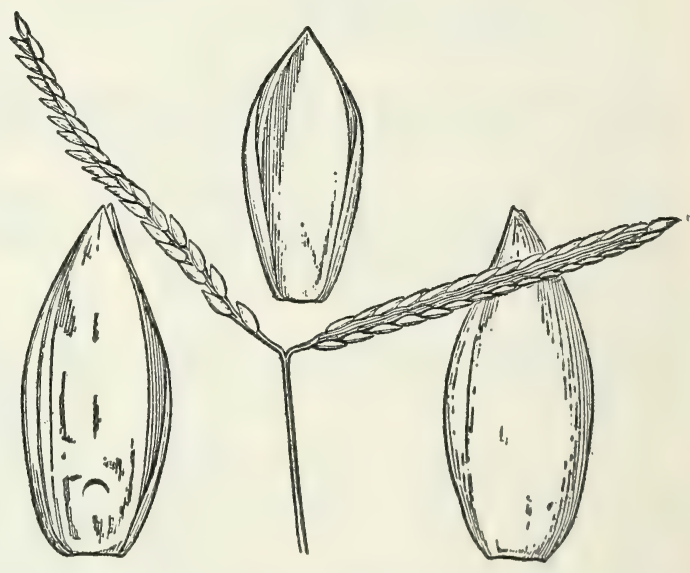

Figure 129.-Paspalum raginatum. Panicle, $\times 1$; two views of spikelet, and floret, $\times 10$ (Hitchccek 9866). 947,3854 .

JAmaICA: Montego Bay, Hitchcock 9667. Saranna-la-Mar, Hitchcock 9866. Black River, Hitchcock 9641. Buff Bay, Hitchcock 9775. Gordon Town, Hart 860. Kingston, Hitchcock 9317 (Amer. Gr. Nat. Herb. 563); Harris 12661.

Haitr: Cape Haitien, Ekman H 2756. Tortuga Island, Leonard 14096.

Dominican Republic: Higüey, Ekman H 12222. 
Puerto Rico: Mona Island, Hess 439. Mayaguez, Chase 6307; Sintenis 6857. Santurce, Chase 6343. Humacao, Eggers 691. Vieques Island, Chase 6694.

Virgin Islands: St. Croix, Benzon; Paulsen 313.

Leeward Islands: Antigua, Hitchcock 16383. Guadeloupe, Hitchcock 16409.

Windward Islands: Martinique, Duss 545 in part; Sieber 20, 367. Barbados, Bot. Station Herb. 277.

Trinidad: Port-of-Spain, Hitcheock 10050. San Fernando, Hitchcock 10108. Cedros, Hitchcock 10139.

Toвago: Scarborough, Broadway 4655; Hitchcock 10287. Studley Park, Broadway 3045.

8. Paspalum distachyon Poit.; Trin., Mém. Acad. St. Pétersb. VI. Sci. Nat. 1: 142. 1834. Santo Domingo.

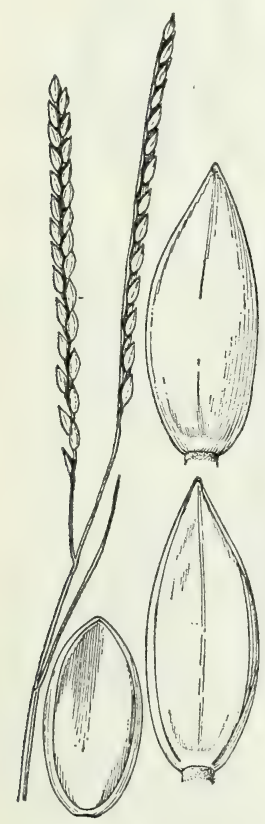

FigURE $130-P a s p a l u m$ distachyon. Panicle, $\times 1$ two views of spikelet, and floret, $\times 10$ (Hitchcock 9678).

Culms erect, 15 to $40 \mathrm{~cm}$ tall, slender, wiry, with hard yellow rhizomes; blades 6 to $15 \mathrm{~cm}$ long, 1 to $2 \mathrm{~mm}$ wide, drying involute; racemes 2, 1.2 to $5 \mathrm{~cm}$ long, erect; spikelets about $3 \mathrm{~mm}$ long (fig. 130).

Moist or dry brackish or alkaline soil, mostly near the coast, West Indies.

Cuba: H a b a n a, Léon 2614,2783 . Ciénaga de Zapata, Léon 9534. Baraguá, Hitchcock 23340, 23341. Tiffin, Shafer 2874, 2905. Guantánamo, Hioram 12. Tamaica, Hioram and Baptiste 1289. Júcaro, Léon 15639,15641 . Isla de Pinos, Ekman 12423.

JAMAICA: Montego Bay, Hitchcock 9678. Savannala-Mar, Hitch cock 9864. Black River, Harris 12548; Hitchcock 9642. Inverness, Harris 11695, 12716.

Haiti: Cape Haitien, Ekman H 2749, H 2756 . Port-au-Prince, Buch 1760.

Dominican Repubic:

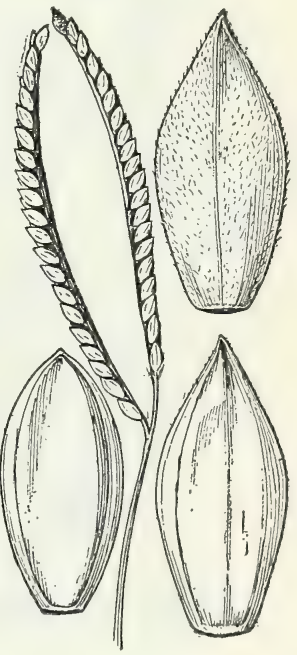

Figure 131.-Paspalum distichum. Panicle, $\times 1$; two views of spikelet, and floret, $\times 10$ (Hitchcock 9394).

Santiago, Ekman H 16536.

Leeward Islands: Dominica (probably Poiteau).

9. Paspalum distichum L., Syst. Nat. ed. 10. 2: 855. 1759. Jamaica.

KNotgrass.

Widely creeping perennial with slender rhizomes, extensively stoloniferous; flowering culms 6 to $50 \mathrm{~cm}$ tall; blades flat, 3 to $12 \mathrm{~cm}$ long, 2 to $6 \mathrm{~mm}$ wide; racemes usually 2 , rarely as many as 4 , erect to reflexed, commonly incurved, 1.5 to $7 \mathrm{~cm}$ long; spikelets 2.5 to 3.5 $\mathrm{mm}$ long, acute, the glume minutely appressed-pubescent; first glume frequently developed (fig. 131). 
Ditches and wet, rarely brackish places, southern United States to Chile; warm regions of Eastern Hemisphere. Common throughout the West Indies and to be found on probably all the islands.

10. Paspalum pubiflorum Rupr.; Fourn., Mex. Pl. 2: 11.1886. Mexico.

Culms rather robust, decumbent and rooting at base, 40 to $100 \mathrm{~cm}$ tall; blades flat, usually 10 to $15 \mathrm{~cm}$ long, 6 to $14 \mathrm{~mm}$ wide; racemes usually 3 to 5 , 2 to $10 \mathrm{~cm}$ long, rather thick; spikelets about $3 \mathrm{~mm}$ long, pubescent (fig. 132).

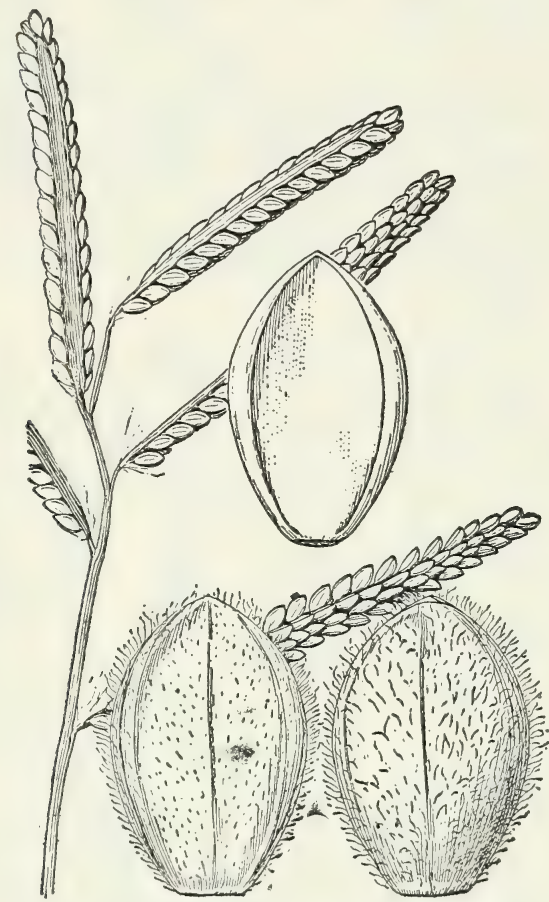

Figure 132.-Paspalum pubiflorum. Panicle, $\times 1$; two views of spikelet, and floret, $\times 10$ (Eitchcock $5555)$.

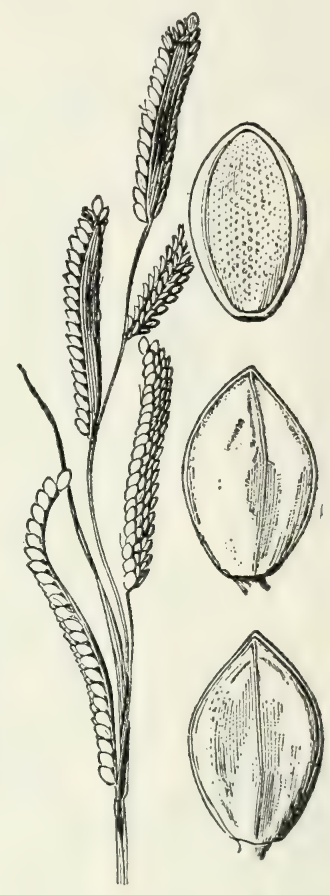

FIG URE 133.-Paspalum lividum. Panicle, $\times 1$; two views of spikelet, and floret, $\times 10$ (Arsêne 3176 ).

Moist open ground, Louisiana to Mexico; Cuba.

Cuba: Habana, Ekman 10 (Amer. Gr. Nat. Herb. 908), 16800; Léon 1986. Cerro, Ekman 938.

11. Paspalum lividum Trin., in Schlecht., Linnaea 26: 383. 1854. Mexico.

LONGTOM.

Culms 50 to $100 \mathrm{~cm}$ tall, from a decumbent or creeping base; blades usually 15 to $25 \mathrm{~cm}$ long, 3 to $6 \mathrm{~mm}$ wide; racemes usually 4 to 7 , thick, somewhat flexuous, erect or ascending, 1.5 to $5 \mathrm{~cm}$ long; rachis 1.5 to $2 \mathrm{~mm}$ wide, dark livid purple; spikelets 2 to $2.5 \mathrm{~mm}$ long (fig. 133).

Low ground, wet savannas, and swamps, and along streams and ditches, southern United States and Mexico to Argentina; Cuba. 
This species was referred to $P$. denticulatum Trin. in the Grasses of the West Indies.

CubA: Habana, Baker, Tracy, and Hasselbring 3096; Ekman 1253, 1257; Léon 571, 937, 4635; Tracy 9119. Arroyo Apolo, Léon 272. Marianao, Léon 588. Macagua, Ekman 16805.

12. Paspalum notatum Flügge, Monogr. Pasp. 106. 1810. St. Thomas.

BAHIA GRASS.

Paspalum taphrophyllum Steud., Syn. Pl. Glum. 1: 19. 1854. Martinique.

Culms 15 to $50 \mathrm{~cm}$ tall from short stout woody horizontal rhizomes; leaves mostly basal; racemes 2 , very rarely 3 , subconjugate, thick, usually 4 to $7 \mathrm{~cm}$ long; spikelets ovate to obovate, 2.5 to $3.8 \mathrm{~mm}$ long (fig. 134).

Open ground, savannas, and pastures, up to $2,000 \mathrm{~m}$, Mexico to Argentina and nearly throughout the West Indies. An important forage constituent of lowland pastures.

C U B A: Guane, Léon 6989. Sierra la Guira, Léon 5167. San Diego de los Baños, Léon 4526. Herradura, Baker 2968; Hitchcock 454. San Ramón, Ekman 13052. Mariel, Ekman in 1921 (Amer. Gr. Nat.Herb. 914). Habana, Baker, Tracy, and Hasselbring 3097; Ekman 1251; Léon 117b, 928; Tracy 9118. Guanabacoa, Hitchcock 23224; Léon in 1907. La Magdalena, Baker 2. Placetas del Sur, Léon 6423. Mordazo, Ekman 17096. Baraguá, Hitchcock 23360. Soledad, Jack 6125, 7576. Isla de Pinos, Palmer and Riley 1119. Without locality, Wright 3438 in part.

Jamaica: Troy, Hitchcock 9784.

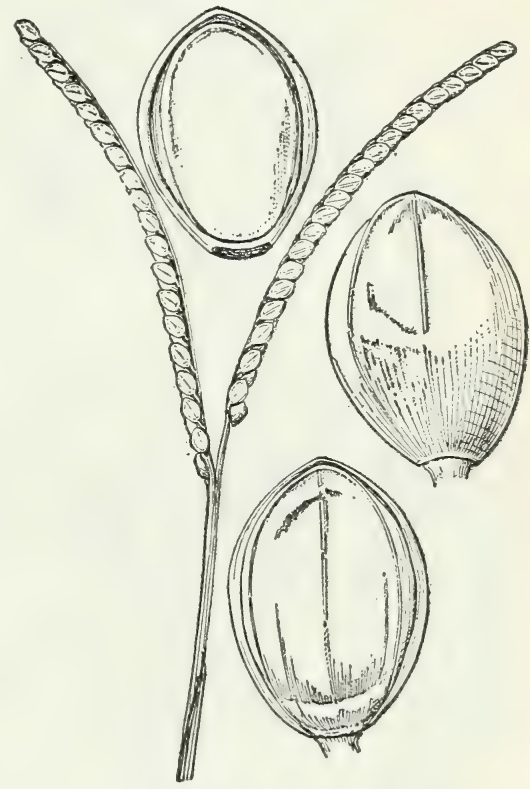

Figure 134.-Paspalum notatum. Panicle, $\times 1$; two views of spikelet, and floret, $\times 10$ (Chase 6639).

Claremont, Hitchcock 9495. Holly Mount, Hitchcock 9450 (Amer. Gr. Nat. Herb. 564). New Forest, Hitchcock 9821. Lititz Savanna, Harris 12443. Bull Head Mountain, Hitchcock 9540. Kingston, Hitchcock 9471. Westphalia, Harris 11570. Blue Mountains, Perkins 1488. Cinchona, Harris 9497; Hitchcock 9696, 9711. Castleton Gardens, Hitchcock 9395, Hardware Gap, Harris 11544. HaIti: Port-Margot, Ekman H 2927. Boche á Bateau, Ekman H 734. Aux Cayes, Ekman H 863.

Dominican Republic: Samaná Peninsula, Abbott 152; Ekman H 15607. Guerra, Ekman H 11016.

Puerto Rico: Mayaguez, Chase 6287, 6314; Holm 173. Maricao, Britton, Cowell, and Brown 4476; Chase 6236. Lares, Chase 6585. Bayamon, Hioram 347. Vega Beja, Chase 6424. San Juan, Chase 6344, 6401. Catano, Chase 6639. Rio Piedras, Chase 6779; Hioram 
807. El Yunque, Chase 6729. Colonia San Miguel, Britton and Shafer 1624.

Leeward Islands: Antigua, Wullschlaegel 593; Box 99, 142.

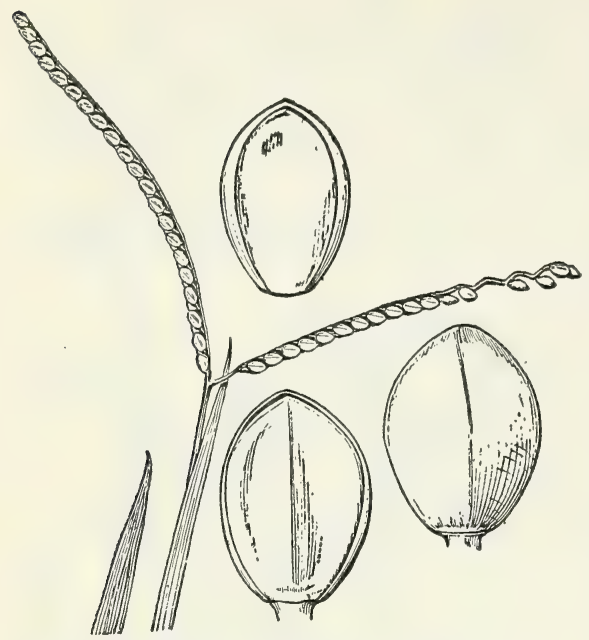

Figure 135.-Paspalum minus. Panicle, $\times 1$; two views of spikelet, and fioret, $\times 10$ (type collection).
Dominica, Hitchcock 16421.

WINDWARD IsLaNdS: Martinique, Duss 558. Grenada, Broadway $1793 \frac{1}{2}$

13. Paspalum minus Fourn., Mex. Pl. 2: 6.1886. Mexico.

Similar to $P$. notatum, commonly in denser mats, on the average smaller, the culms rarely more than $30 \mathrm{~cm}$ tall; racemes more slender, less rarely 3; spikelets 2 to $2.5 \mathrm{~mm}$ long (fig. 135).

Open slopes and savannas up to $1,500 \mathrm{~m}$, Texas, Mexico, and the West Indies to Paraguay and Bolivia.

Cuba: Arroyo del Sumidero, Léon and Shafer 13670; Shafer and Léon 13677. Herradura, Hitchcock 455, 23439; Tracy

9093. Cajálbana, Léon and Charles 4856. San Diego de los Baños, Léon 4468. Pinar del Río, Hitchcock 23284, 23305. Mordazo, Ekman 17093. Isla de Pinos, Britton and Wilson 14695; Palmer and Riley 978. Without locality, Wright 3438 in part.

JAMAICA: Bull Head

Mountain, Hitcheock $9540 \frac{1}{2}$.

Haiti: Las Cahobas, Cook, Scofield, and Doyle 103.

Dominican Republic: Cotuy, Abbott 830, 850 .

Puerto Rico: Trujillo Alto, Chase 6368.

\section{Paspalum pumilum}

Nees, Agrost. Bras. 52. 1829. Brazil.

Culms usually 15 to 35 $\mathrm{cm}$ tall, the rhizomes, if present, short and nearly vertical; blades 1.5 to 12 $\mathrm{cm}$ long, 2 to $7 \mathrm{~mm}$ wide, glabrous or pubescent; racemes 2 , recurved-

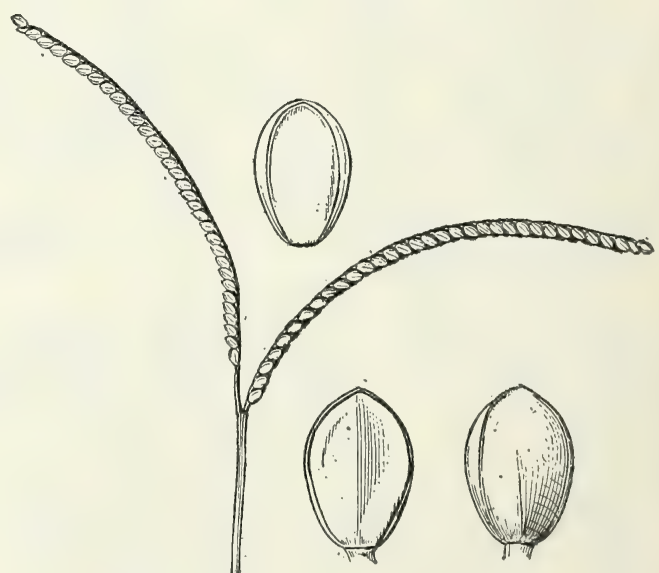

Figure 136.-Paspalum pumilum. Panicle, $\times 1$; two views of spikelet, and fleret; $\times 10$ (type and Hitcheock 10350).

ascending, 2 to $7 \mathrm{~cm}$ long, slender; spikelets 1.6 to $2 \mathrm{~mm}$ long, glabrous (fig. 136).

Sandy savannas and moist open ground, mostly at low altitudes, West Indies to Uruguay and Chile. 
Leeward Islands: Dominica, Jones 39.

Trinidad: Piarco Savanna, Hitchcock 10350; Warming 808. Valencia, Broadway 6946.

15. Paspalum serpentinum Hochst.; Steud., Syn. Pl. Glum. 1: 22. 1854. Dutch Guiana.

Culms simple, erect, 50 to $60 \mathrm{~cm}$ tall, naked above; lower sheaths crowded, grayish villous, the upper glabrous; blades firm, flat or involute, 3 to $5 \mathrm{~mm}$ wide; racemes 2 , subconjugate, 6 to $8 \mathrm{~cm}$ long; rachis slender, flexuous; spikelets suborbicular, flattish, $2.6 \mathrm{~mm}$ long, glabrous, yellowish brown with irregular transverse markings of dark brown (fig. 137).

Wet sandy savannas, Trinidad, the Guianas, and Brazil.

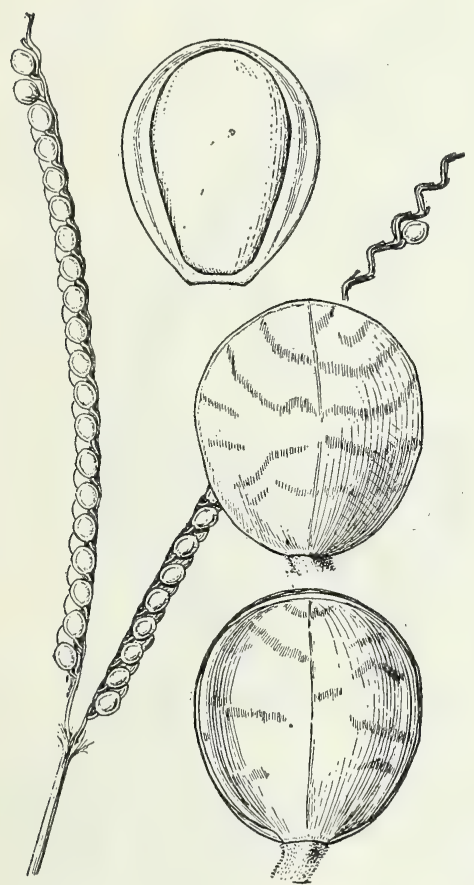

Figure 137.-Paspalum serpentinum. Panicle, $\times 1$; two views of spikelet, and floret, $\times 10$ (type and Hitcheock 10337).
Trinidad: Piarco Savanna, Hitchcock 10337.

16. Paspalum lineare Trin., Gram. Pan. 99. 826. Brazil. Paspalum neesii Kunth, Rév. Gram. 1: 25. 1829. Brazil. Culms slender, 40 to $80 \mathrm{~cm}$ tall,

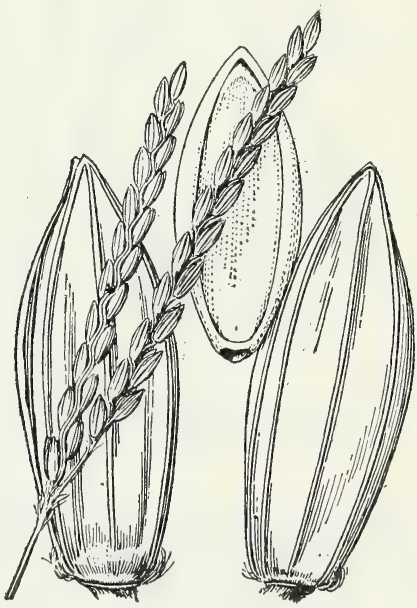

Figure 138.-Paspalum lineare. Panicle $\times 1$; two views of spikelet, and floret. $\times 10$ (type and Glaziou 22493).

the nodes appressed-pubescent; blades narrow, conduplicate, the upper surfaces grown together; racemes 2, approximate, erect, 3 to 5 cm long; spikelets not imbricate, elliptic, 4 to $4.5 \mathrm{~mm}$ long, glabrous except at the very base (fig. 138).

Savannas, Costa Rica to Argentina; Cuba and Hispaniola.

CuвA: Herradura, Baker 3459 ; Ekman 10737. Between Zarzal and Nagua, Léon 11336; Ekman 14146. Isla de Pinos, Britton and Wilson 15114 ; Curtiss 379.

Dominican Republic: Cuenca, Ekman H 11061, H 13338.

17. Paspaium debile Michx., Fl. Bor. Amer. 1: 44. 1803. Carolina.

Culms slender, ascending, with a cluster of short leafy shoots at base; blades flat, rather thin, pilose on both surfaces, conspicuously 
ciliate; racemes 4 to $6 \mathrm{~cm}$ long, usually 2 on the terminal culm, solitary on the axillary peduncles; spikelets broadly orate, 1.6 to $1.8 \mathrm{~mm}$ long, minutely pubescent (fig. 139).

Sandy, mostly dry soil, barrens, and pine woods, eastern United States, Mexico, and Cuba.

Cuba: Herradura, Hitchcock 471. Cojimar, Ekman 1094. Santa Fé, Léon 8783.

18. Paspalum ciliatifolium Michx., Fl. Bor. Amer. 1: 44. 1803. Carolina.

Culms slender, erect to spreading, 35 to $90 \mathrm{~cm}$ tall; sheaths glabrous or pubescent along the margin, or the lower pubescent: blades flat, 7 to $20 \mathrm{~mm}$ wide, usually ciliate along the margin; racemes 1 to 3 ,

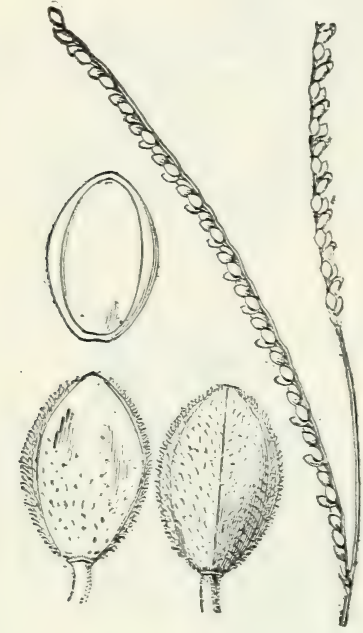

F I G UR E 139.-Paspalum debile. Panicle, $\times 1$; two views of spikelet, and floret, $\times 10$ (Nash 946).

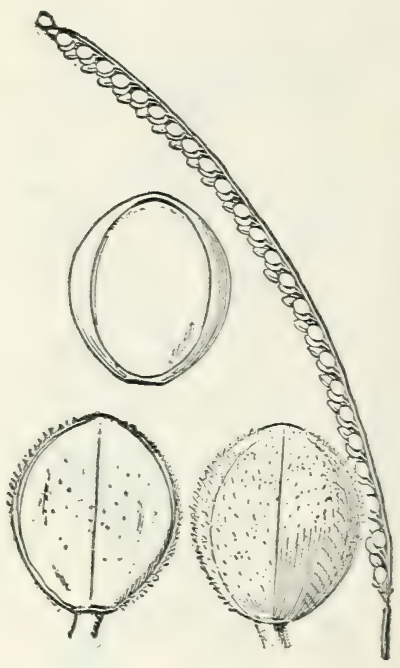

FigURE 140.-Paspalum ciliatifolium Raceme, $\times 1$; two views of spikelet and floret, $\times 10$ (Nash 1426).

slender, arching, commonly 7 to $10 \mathrm{~cm}$ long; spikelets about $2 \mathrm{~mm}$ long, elliptic-oborate, glabrous or minutely pubescent (fig. 140).

Open ground or open woods, mostly sandy soil, southeastern United States, Honduras, and the West Indies.

Cuba: Western Cuba, Wright 3442. Marianao, Léon 779. Baraguá, Hitcheock 23342.

Haiti: Aux Cayes, Ekman H 66.

19. Paspalum propinquum Nash, Bull. N. Y. Bot. Gard. 1: 291. 1899. Florida.

Differing from $P$. ciliatifolium in having a more strongly dereloped rhizome; blades narrower and firmer; spikelets smaller (about 1.8 $\mathrm{mm}$ long), slightly pointed (fig. 141).

Sandr sarannas and sand barrens orerlying limestone, peninsular Florida and the West Indies; Veracruz to Panama.

This species was referred by Gi isebach ${ }^{58}$ to $P$. setaceum.

b5 Fl. Brit. W. Ind. 542.1864 
Bermuda: Hillerest, Collins 155 in part. Hamilton, Brown and Britton 56.

BaHamas: Inagua, Hitchcock in 1890.

Cuba: Arroyo Mántua, Ekman 10960, 11021. Candeleria, Léon 12702. Bacunagua, Léon 15068. Savanna de Chirigota, Léon 7455. Habana, Léon 2738, 3478, 7521, 13604, 15824. Cojimar, Léon 5604. Isla de Pinos, Ekman 11652; Britton and Wilson 15665. Without locality, Wright 3845.

JamaICA: Claremont, Hitchcock 9520. Appleton, Hitchcock 9654. Ipswich, Hitchcock 9598.

Нагті: Vallière, Ekman H 4501. Bayeux, Ekman H 2601.

Dominican Republic: Jaina, Faris 11; Ekman H 12484. Santo Domingo City, Ekman H 11385. Peninsula de Samana, Ekman H 15365.

Puerto Rico: Mayaguez, Chase 6282. Quebradillas, Chase 6572. Barcelonita, Chase 6439. Campo Alegre, Chase 6433, 6613. Vega Baja, Britton, Britton, and Brown 6950. San Juan, Chase 66341/12. Playa de Fajardo, Chase 6661.

Leeward Islands: Antigua, Wullschlaegel 697; Box 103, 108.

Windward Islands: Barbados, Hitchcock 16500. St. Lucia, Box 321.

20. Paspalum decumbens Swartz, Prodr. Veg. Ind. Occ. 22. 1788. Jamaica.

Panicum decumbens Roem. and Schult., Syst. Veg. 2: 429.1817.

Culms spreading or creeping, freely branching, 10 to $70 \mathrm{~cm}$ long; blades fiat, commonly 5 to $10 \mathrm{~cm}$ long, 6 to $12 \mathrm{~mm}$ wide, more or less

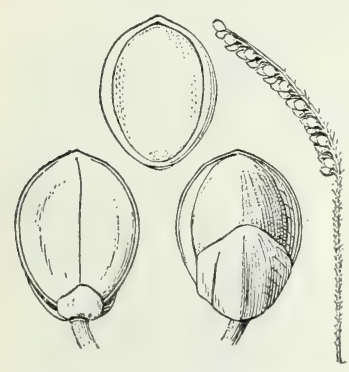

FIGURE 142.-Paspalum decumbens. Raceme, $\times 1$; two views of spikelet, and floret, $\times 10$ (Hitchcock 9562 .

Range, Hitchcock 9562. Hardware Gap, Harris 11545. Castleton, Harris 11606. Seamens Valley, Maxon and Killip 58. Claverty Cottage, Harris 11522. Mattis River, Maxon and Killip 190; Perkins 1485.

Haiti: Port-de-Pai, Ekman H 3693. Plaisance, Leonard 9336. Pérodin, Ekman H 3483. Caille la Croix, Leonard 7840, 7855.

Dominican Republic: Villa Altagracia, Ekman H 11182. most sheath; racemes solitary (very rarely 2), 1 to $3.5 \mathrm{~cm}$ long, arcuate; spikelets crowded, $1.7 \mathrm{~mm}$ long, obovate; first glume present; second glume about half as long as the spikelet (fig. 142).

Open or partly shaded slopes, up to 1,600 $\mathrm{m}$, often a weed in waste ground, Guatemala and the West Indies to Brazil and Bolivia.

Cuba: Pinar del Río, Wright 3851. San Diego de los Baños, Léon 4569. Sierra de los Organos, Ekman 12966. Isla de Pinos, Curtiss 327.

JAMAICA: Bull Head Mountain, Hitchcock 9553 (Amer. Gr. Nat. Herb. 573). Upper Clarendon, Harris 12255. Ram's Horn pubescent; peduncles 2 to 8 from the upper$60256-36-14$ 
Puerto Rico: Mayaguez, Chase 6170, 6176, 6186; Holm 88. Rosario, Chase 6264. Monte Alegrillo, Chase 6235. Monte Montoso, Britton and Cowell 4118. Yauco, Britton 7225. Adjuntas, Britton and Shafer 2135; Chase 6473; Heller 6354. San Juan, Chase 6399, 6648. Trujillo Alto, Chase 6361. Las Cruces, Britton and Britton

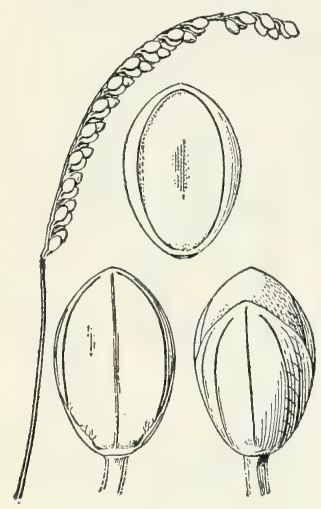

Figure 143.-Paspalum nutans, Raceme, $\times 1$; two views of spikelet, and floret, $\times 10$ (Raddi).

9068. Cayey, Chase 6340. Rio Grande, Chase 6718. Mameyes, Cowgill 627. Fajardo, Britton and Shafer 1680.

Trinidad: St. Ann, Britton and Hazen 1688. Port-of-Spain, Hitchcock 99571/2. St. Joseph, Hitchcock 10175. Arima, Hitchcock 10308. Piarco Savanna, Hitchcock 10353. O'Meara Savanna, Britton and Hazen 1582. Masacas, Broadway in 1925. Cedros, Hitchcock 10135. Aripo Road, Broadway 8030. Without locality, Finlay 39; Bot. Gard. Herb. 2271.

21. Paspalum nutans Lam., Tabl. Encycl. 1: 175. 1791. South America.

Paspalum lloydii Nash, N. Amer. Fl. 17: 178. 1912. Dominica, Lloyd 590.

Resembling $P$. decumbens in habit; primary peduncle often with 2 to 4 racemes, the others with only one; racemes 2 to $6 \mathrm{~cm}$ long; spikelets 1.8 to $2 \mathrm{~mm}$ long; first glume obsolete or occasionally developed especially on the secondary spikelet; second glume three-fourths as long as the spikelet (fig. 143).

Partly shaded slopes and banks and mossy cliffs, to 1,000 m altitude, Honduras and the Leeward Islands to Brazil.

Leeward Islands: St. Kitts, Hitchcock 16351; Box 147, 153. Nevis, Box 167. Guadeloupe, Duss 4059. Dominica, Bryant 5.

WINDWARD IsLANDS: "Martinique et Guadeloupe", Husnot 77. Grenada, Broadway 1729. St. Lucia, Box 188.

Trinidad: St. Ann, Broadway 4914, 5331. Port-of-Spain, Chase 9930; Hitchcock 9957, 9982, 10040, 10200. St. Joseph, Hitchcock 10015. Mount Tucuche, Britton, Hazen, and Mendelson 1249. Arima, Hitchcock 10299, 10301. Belmont, Broadway 2811. Blanchisseuse Road, Broadway 7665.

22. Paspalum dispar Chase, Contrib. U. S. Natl. Herb. 28: 96. f. 50. 1929. Dominican Republic, Ekman $\mathrm{H} 6248$.

Culms erect or ascending, 12 to $35 \mathrm{~cm}$ tall, the nodes pilose; blades flat, 4 to $15 \mathrm{~cm}$ long, 3 to $6 \mathrm{~mm}$ wide, finely pubescent; peduncles 2 or 3 from the upper sheath, the secondary ones at first concealed; racemes solitary, 1.5

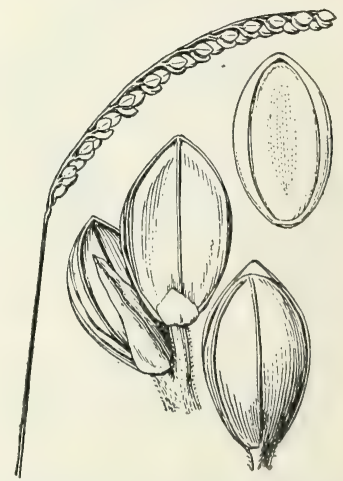

Figure 144.-Paspalum dispar. Raceme, $\times 1$; two views of spikelet, and floret, $\times 10$ (type). to $4.5 \mathrm{~cm}$ long, arcuate; spikelets elliptic-obovate, $1.9 \mathrm{~mm}$ long; first glume small and nerveless on the primary spikelet, 1-nerved, pointed, and two-thirds as long as the spikelet on the secondary (fig. 144).

Brushy slopes, and pinelands, Hispaniola.

Dominican Republic: Restauración, Ekman H 6248. Constanza, Ekman H 13928. San José de Ocoa, Ekman H 11595. Villa 
Altagracia, Ekman H 11255. Bayaguana, Ekman H 11095. Monción, Ekman H 12629. San Juan, Ekman H 13426.

23. Paspalum pilosum Lam., Tabl. Encycl. 1: 175. 1791. Tropical America.

Dimorphostachys pilosa Fourn., Mex. Pl. 2: 14. 1886.

Culms ascending or spreading, 40 to $115 \mathrm{~cm}$ tall; blades flat or the margins revolute, 10 to $40 \mathrm{~cm}$ long, 3 to $8 \mathrm{~mm}$ wide, harshly pubescent; peduncles slender, elongate, 1 to 4 from the upper and middle sheaths; racemes solitary, arcuate, 6 to $17 \mathrm{~cm}$ long; spikelets 2.6 to $3 \mathrm{~mm}$ long, elliptic; first glume minute on the

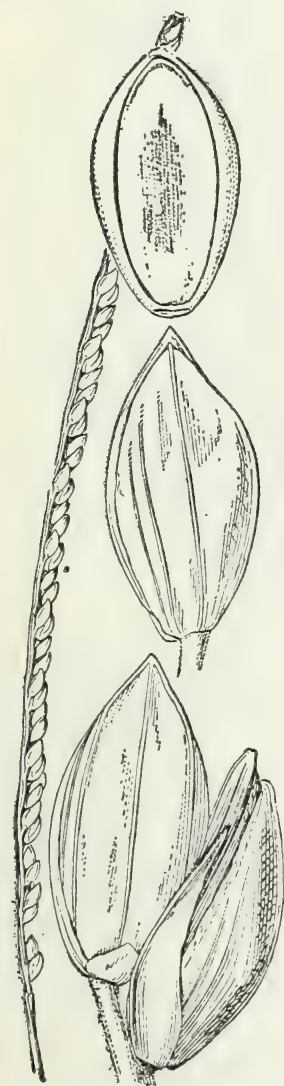

FIGURE 146.-PCspalum unispicatum. Racem e, $\times 1$; two views of spikelet, and floret, $\times 10$ (type).

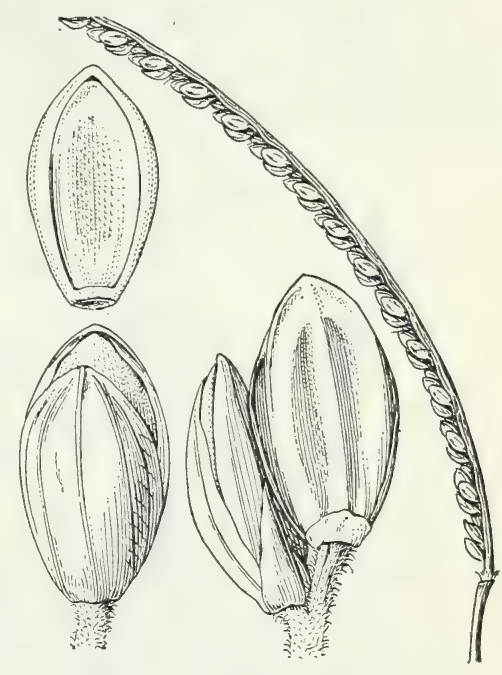

F I G U R E 145.-Paspalum pilosum. Raceme, $\times 1$; two views of spikelet, and floret, $\times 10$ (Hitcheock 8130). $\mathrm{m}$, Costa Rica to Bolivia and primary spiketet, small to half the length of the spikelet, pointed and eccentric on the secondary (fig. $145)$.

Open sparsely wooded slopes and brushy savannas, mostly in rather moist soil, lowlands, and up to 1,500 southern Brazil; Trinidad.

Trinidad: Port-of-Spain, Hitchcock 9987. St. Joseph, Hitchcock 10189. A Aripo Savanna, Hitchcock 10075. Pitch Lake, Broadway 2603; Hitchcock 10088. La Brea, Broadway 4969.

24. Paspalum unispicatum (Scribn. and Merr.) Nash, N. Amer. Fl. 17: 193.1912.

Panicum unispicatum Scribn. and Merr., U.S. Dept. Agr., Div. Agrost. Bull. 24: 14. 1901. Mexico.

Culms erect, 50 to $80 \mathrm{~cm}$ tall; blades flat, 10 to $30 \mathrm{~cm}$ long, 8 to $15 \mathrm{~mm}$ wide, stiffly papilloseciliate on the margin, and more or less so on the surface; peduncles commonly 2 from the upper sheath; racemes 1 or sometimes 2,6 to $20 \mathrm{~cm}$ long; spikelets 3 to $3.5 \mathrm{~mm}$ long; first glume minute on the primary spikelet, larger and acuminate on the secondary (fig. 146).

Meadows, savannas, open slopes, and banks, up to $1,500 \mathrm{~m}$, southern Texas to Venezuela and Argentina; Cuba.

Cuba: Guane, Ekman 11093. Habana, Léon 2401. Zaza de Tunas, Léon 947. Sancti Spíritus, Clements 2427; Léon 4099, 5582; Sergius 2411, 2682. Soledad, Jack 6149, 8273. 
25. Paspalum langei (Fourn.) Nash, N. Amer. Fl. 17: 179. 1912. Dimorphostachys langei Fourn., Mex. Pl. 2: 14. 1886. Mexico.

Dimorphostachys ciliifera Nash, in Small, Fl. Southeast. U. S. 78, 1327. 1903. Florida.

Paspalum cilifferum Hitchc., Contrib. U. S. Natl. Herb. 12: 201. 1909.

Culms ascending, 30 to $100 \mathrm{~cm}$ tall; blades flat, 10 to $40 \mathrm{~cm}$ long, 6 to $15 \mathrm{~mm}$ wide, usually glabrous or nearly so; peduncles slender, 1 to 3 from the upper sheath; racemes 2 to 5 , arcuate, 3.5 to $11 \mathrm{~cm}$ long, rather distant; spikelets 2.2 to $2.6 \mathrm{~mm}$ long, finally brown, pubescent; first glume minute on the primary spikelet, larger and acuminate on the secondary (fig. 147).

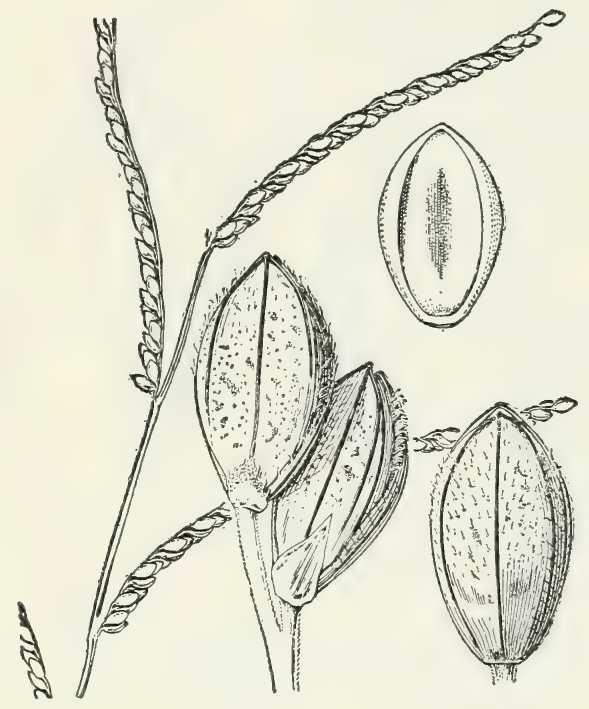

FIGURE 147.-Paspalum langei. Panicle, $\times 1$; two views of spikelet, and floret, $\times 10$ (Pringle 3991).

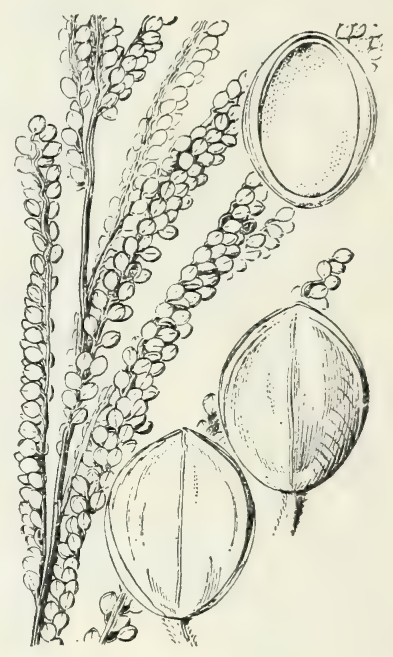

FIGURE 148.-Paspalum nesiotes. Panicle, $\times 1$; two views of spikelet, and floret, $X 10$ (type).

Moist woods and shaded slopes and banks mostly at low altitudes, Florida and Texas to Venezuela.

CubA: Mariel, Ekman 11497 (Amer. Gr. Nat. Herb. 934). Habana, Léon 934. Guatao, Léon 6321. Tapaste, Léon 4183. Arroyo Naranjo, Léon 587. Marianao, Léon 1511. Rio Bacuranao, Wilson and Léon 11602. Matanzas, Britton and Wilson 148.

Haitr: Míorne Cap-Rouge, Ekman H 5948. Trouin, Ekman H 2376.

26. Paspalum nesiotes Chase, Contrib. U. S. Natl. Herb. 28: 117. f. 67 . 1929. St. Lucia, Hitchcock 16471.

Culms 45 to $120 \mathrm{~cm}$ tall; blades flat or folded, 25 to $50 \mathrm{~cm} \mathrm{long,} 6$ to $11 \mathrm{~mm}$ wide, glabrous or scabrous; panicles long-exserted; racemes 5 to 11 , arching, 4 to $10 \mathrm{~cm}$ long; spikelets about $2 \mathrm{~mm}$ long, glabrous (fig. 148).

Known only from St. Lucia and Martinique.

Windward Islands: Martinique, Duss in 1879. St. Lucia, Hitchcock 16471. 
27. Paspalum oligostachyum Salzm.; Steud., Syn. Pl. Glum. 1: 23. 1854. Bahia.

Culms ascending to spreading, 25 to $75 \mathrm{~cm}$ tall; sheaths softly pubescent with spreading hairs; blades flat, densely velvety pubescent, 8 to $25 \mathrm{~cm}$ long, 7 to $13 \mathrm{~mm}$ wide; racemes usually 3 to 5 , spreading, 3 to $10 \mathrm{~cm}$ long; spikelets $2 \mathrm{~mm}$ long, obovate, bronzegreen, mottled with purplish brown, obscurely appressed-pubescent (fig. 149).

Wooded slopes and clay banks, Trinidad to eastern Brazil.

Trinidad: Monos, Broadway 7437.

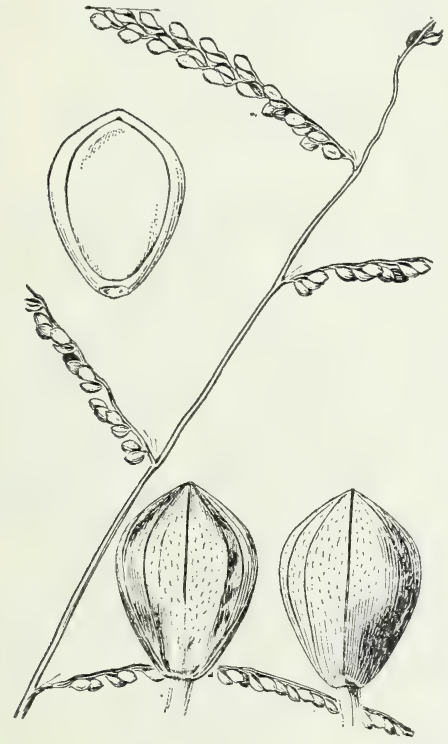

FIGURE 149.-Paspalum oligostochyum. Panicle, $\times 1$; two views of spizelet, and floret, $\times 10$ (type collection).

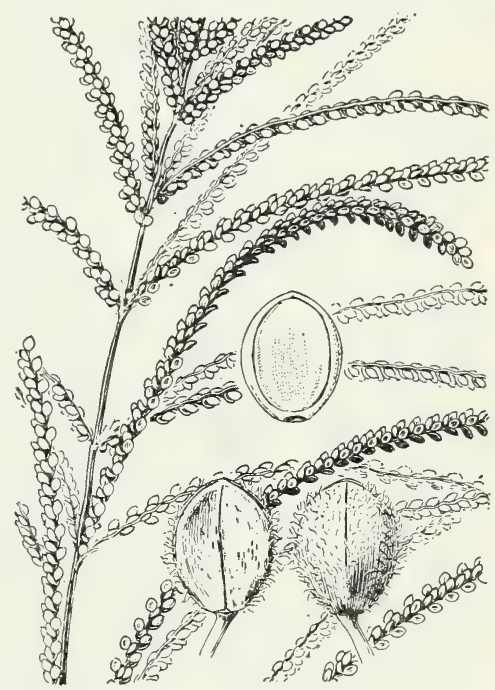

Figure 150.-Paspalum paniculatum. Panicle, $\times 1$; two views of spikelet, and floret, $\times 10$ (Ledru, and Duss 549).

28. Paspalum paniculatum L., Syst. Nat. ed. 10. 2: 855. 1759. Jamaica.

Paspalum hemisphericum Poir., in Lam. Encycl. 5: 31. 1804. Puerto Rico.

Paspalum strictum Pers., Syn. Pl. 1: 86. 1805. Santo Domingo. Paspalum affine Bello, An. Soc. Espan. Hist. Nat. 12: 125.1883. Puerto Rico.

Panicum paniculatum Kuntze, Rev. Gen. Pl. $3^{2}: 363.1898$.

Paspalum paniculatum minor Scribn., Field Mus. Bot. 2: 24. 1900. Jamaica.

Culms erect or decumbent at base, mostly 50 to $100 \mathrm{~cm}$ tall; sheaths papillose-hispid; blades flat, mostly 10 to $25 \mathrm{~cm}$ long, 10 to 20 $\mathrm{mm}$ wide, more or less hispid; panicle usually 8 to $20 \mathrm{~cm}$ long, of several to many arched-spreading, somewhat fascicled racemes, the lower 4 to $12 \mathrm{~cm}$ long; spikelets about $1.3 \mathrm{~mm}$ long, subhemispheric, pubescent (fig. 150). 
Moist open ground and brushy slopes, along ditches, and a weed in cultivated and waste places, up to $2,000 \mathrm{~m}$, Mexico and the West Indies to Argentina.

29. Paspalum maritimum Trin., Mém. Acad. St. Pétersb. VI. Sci. Nat. 1: $148 . \quad 1834 . \quad$ Bahia, Brazil.

Culms ascending to spreading, 30 to $50 \mathrm{~cm}$ tall, sometimes branching, with hard scaly horizontal rhizomes, often stoloniferous; sheaths ciliate on the margin and pilose on the keel toward the summit; blades flat, rather firm, 6 to $50 \mathrm{~cm}$ long, 8 to $20 \mathrm{~cm}$ wide, bearded back of the ligule; racemes mostly 3 to 7 (1 or 2 on the branches), ascendingarcuate, 4 to $9 \mathrm{~cm}$ Jong, somewhat approximate; spikelets 1.7 to 2 $\mathrm{mm}$ long, brown-speckled and softly pilose. Often forms extensive sterile colonies.

Sandy or rocky soil near the coast, Cuba, the Guianas, and Brazil.

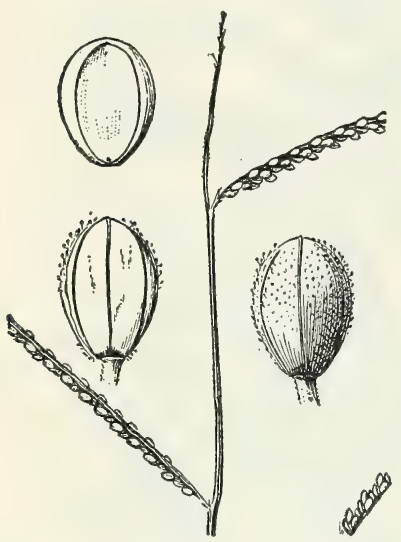

F I G U R E 151.-Paspalum blodgettii. Panicle, $\times 1$; two views of spikelet, and floret, $\times 10$ (Simpson).

Cuba: San José, Matanzas, Léon and Acuña 4471.

30. Paspalum blodgettii Chapm., Fl. South. U. S. 571. 1860. Florida.

Paspalum simpsoni Nash, Bull. Torrey Bot. Club 24: 39. 1897. Florida.

Culms erect, 40 to $100 \mathrm{~cm}$ tall; sheaths more or less pubescent; blades flat, 5 to $25 \mathrm{~cm}$ long, 5 to $10 \mathrm{~mm}$ wide; racemes commonly 3 to 8 , remote, or the upper approximate, 2 to $8 \mathrm{~cm}$ long; spikelets about $1.3 \mathrm{~mm}$ long, glandular-pubescent (fig. 151).

Open or brushy calcareous soil; southern Florida, Yucatan, Honduras, and the West Indies.

Bahamas: Nassau, Curtiss 165; Hitchcock in 1890.

Cuba: Madruga, Léon 6354. Batabanó, Ekman 12604; Hitchcock $470 . \quad$ Motembo, Léon 8628. Sabana de San Marcos, Léon 9182. Baraguá, Hitchcock 23346. Santiago de Cuba, Léon 954. Jauco, Léon 11690, 11719. Isla de Pinos, Britton, Britton, and Wilson 15359; Britton, Wilson, and Léon 15790; Millspaugh 1408. Eastern Cuba, Wright 3443 in part.

Jamaica: Montego Bay, Hitchcock 9668. Savanna-la-Mar, Hitchcock 9874. Troy, Harris 12620; Hitchcock 9816. Ipswich, Hitchcock 95991/2, 9624; Maxon and Killip 1519. Black River, Harris 12546. New Forest, Hitchcock 9833. Between Ewarton and Linstead, Hitchcock 9417, 9464. Bog Walk, Harris 12560. Between Bog Walk and Spanish Town, Hitchcock 9295 (Amer. Gr. Nat. Herb. 571). Claremont, Hitchcock 9476, 9480. Buff Bay, Hitchcock 9766. Stony Hill, Harris 12703. Mount Diablo, Maxon and Killip 459; Ridley 3. Kingston, Hitchcock 9470.

Haiti: St. Louis du Nord, Leonard 14381. Môle-St.-Nicolas, Leonard 13216. Aux Cayes, Ekman H 42. Rousselin, Ekman H 10478. Tortuga Island, Leonard 11472, 13890, 13903, 13933, 15504, 15550. 
Dominican Republic: Santo Domingo City, Ekman H 11415. Higüey, Ekman H 12230. Peninsula de Samaná, Ekman H 15000.

Puerto Rico: Joyuda, Britton, Sterens, and Hess 2398. Aguadilla, Chase 6579, 6580, 6605 .

31. Paspalum caespitosum Flügge, Monogr. Pasp. 161. 1810. Santo Domingo.

Paspalum gracile Poir., in Lam., Encycl. Supp. 4: 313. 1816. Not $P$. gracile Rudge, 1805 . Santo Domingo.

Paspalum heterophyllum Desv.; Poir., in Lam., Encycl. Sup. 4: 315. 1816. Santo Domingo.

Paspalum poiretii Roem. and Schult., Syst. Veg. 2: 878. 1817. Based on P. gracile Poir.

Culms densely cespitose, erect, slender, 30 to $60 \mathrm{~cm}$ tall, the base hard and slightly enlarged; blades flat in sheltered situations but commonly folded or involute, 5 to $20 \mathrm{~cm}$ long, 4 to $10 \mathrm{~mm}$ wide, narrowed to the base; racemes commonly 3 to 5 , remote, rather thick, ascending or somewhat spreading, usually 1.5 to $4 \mathrm{~cm}$ long; spikelets crowded, about $1.5 \mathrm{~mm}$ long, sparsely appressed-pubescent or nearly glabrous (fig. 152).

Mostly in partly shaded humus in limestone soil, or rock, southern Florida, Central America, and the West Indies.

Bahamas: Andros Island, Brace 5258; Small and Carter 8658, 8823. Great Exuma, Britton and Millspaugh 3089.

Cuba: Habana, Ekman 176; Léon 768, 2381, 3701, 7501, 8981. Río Almendares, Ekman 331. Columbia, Léon 268, 935, 936. Cojimar, Hitchcock 464, 465. Tapaste, Léon 3676. Triscornia, Hitchcock 467; Tracy 9087. Batabanó, Hitchcock 466. Sagua de Grande, Léon 9469. Caya Paloma, Shafer 2578. Guara, Hitcheock 23419. Santiago de Cuba, Léon 953. Guantánamo, Britton 2175; Ekman 2890. Jauco, Léon 11713, 12314. Isla de Pinos, Britton and Wilson 14890. Without locality, Wright 769, 3443 in part.

JAMAICA: Montego Bay, Maxon and Killip 1609.

Lititz, Harris 12699. Walderston, Harris 12758. New Forest, Hitchcock 9832 (Amer. Gr. Nat. Herb. 568). Inverness, Harris 12726, 12748. Cane River Valley, Harris 11408, 12317. Mount Diablo, Maxon and Killip 504.

Haiti: St. Michel de l'Atalaye, Leonard 7186, 7418. Môle-St.Nicolas, Leonard 13283, 13284, 13305a, St. Marc, Leonard 2911, 2915. Morne-à-Cabrits, Ekman H 1017. Gonaïve Island, Leonard 5126. Port-de-Pai, Leonard 12359. Port-au-Prince, Hitchcock 19885; Leonard 2827. Etang Saumatre, Leonard 4216. Jean Rabel, Leonard 12708, 13005. Tortuga Island, Leonard 11315, 11333, 15552, 15586.

Dominican Republic: Jaina, Faris 4, 109. Without locality, Poiteau. Santo Domingo City, Ekman H 11144.

Puerto Rico: Mona Island, Britton, Cowell, and Hess 1656, 1839; Hess 435, 436. Quebradillas, Chase 6574 (Amer. Gr. Nat. Herb. 569). Penuelas, Chase 6489. Vega Baja, Chase 6427. 
32. Paspalum molle Poir., in Lam., Encycl. 5: 34. 1804. St. Thomas.

Paspalum portoricense Nash, Bull. Torrey Bot. Club 30: 377. 1903. Puerto Rico, Heller 524.

Culms slender, spreading, 10 to $50 \mathrm{~cm}$ tall; blades flat or, in exposed situations, involute, 6 to $12 \mathrm{~cm}$ long, 2 to $7 \mathrm{~mm}$

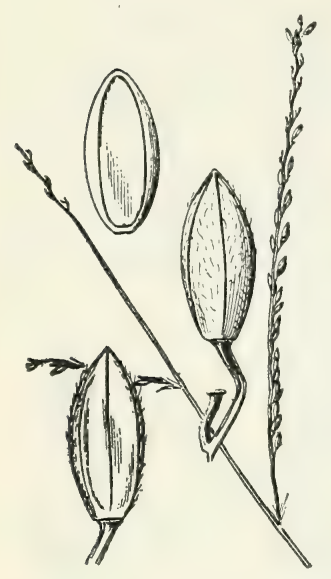

FIGURE 153.-Paspalum molle. Panicle, $\times 1$; iwo views of spikelet, and floret, $\times 10$ (Chase 6232, Amer. Gr. Nat. Herh. 570). wide; racemes commonly 2 or 3 , slender, distant, ascending or arcuate-spreading, 1.5 to 7 cm long; spikelets about $1.7 \mathrm{~mm}$ long, elliptic, sparsely appressed-pubescent (fig. 153).

Open but humid slopes, mostly in red clay, West Indies to Brazil.

Bahamas: Crooked Island, Brace 4805.

Puerto Rico: Mayaguez, Chase 6262, 6322, 6820. Monte Alegrillo, Chase 6232 (Amer. Gr. Nat. Herb. 570). Aguadilla, Chase 6607, 6608. Vega Baja, Chase 6428. Cayey, Chase 6338, 6741; Heller 524; Sintenis 2451.

Virgin Islands: St. Thomas, Ledru (Lamarck Herb., Paris).

Leeward Islands: Antigua, Box 93, 100.

33. Paspalum acutifolium Léon, in Britton, Mem. Torrey Bot. Club 16: 58. 1920. Cuba, Léon and Roca 8164.

Culms erect or geniculate below, 20 to 40 $\mathrm{cm}$ tall, the nodes appressed-pilose; blades firm, flat from a folded base, 6 to $17 \mathrm{~cm}$ long, 4 to $8 \mathrm{~mm}$ wide; racemes 2 to 4 , ascending to arcuate spreading, 2 to $8 \mathrm{~cm}$ long, the common axis 1 to $3.5 \mathrm{~cm}$ long; spikelets about $1.8 \mathrm{~mm}$ long, oblong-elliptic, obscurely pubescent near the margin or glabrous (fig. 154).

Sandy or gravelly siliceous soil, palm barrens and savannas, Cuba. Originally described from Motembo, prov. Santa Clara.

Cuba: Canasí, Léon 13079, 13119. La Cumbre, Ekman 18980. Sabana de Motembo (Placetas del Sur), Léon and Roca 8164.

34. Paspalum bakeri Hack., Inf. Est. Centr. Agron. Cuba 1: 410. 1906. Cuba, Baker 1824.

Culms widely spreading, 20 to $55 \mathrm{~cm}$ long; blades folded at base, commonly flat above, 2 to $10 \mathrm{~cm}$ long, 2 to $4 \mathrm{~mm}$ wide; racemes 2 to 4 , stiffly ascending, 2.5 to $7 \mathrm{~cm}$ long, the common axis 1 to $5 \mathrm{~cm}$ long; spikelets about $2 \mathrm{~mm}$ long, glabrous (fig. 155).

Sandy seashores and coral reefs, Baha-

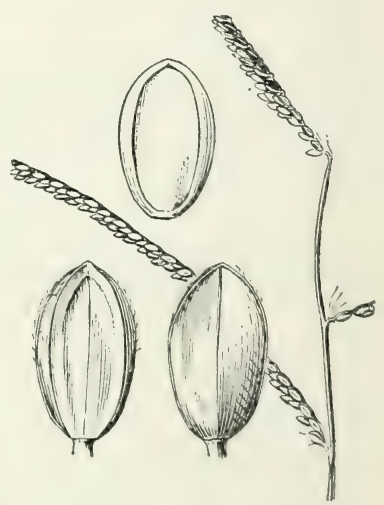

FIGURE 154.-Paspalum acutifolium. Panicle, $\times 1$; two views of spikelet, and floret, $\times 10$ (type). mas, western Cuba, and Leeward Islands.

BAHAMAs: Inagua, Nash and Taylor 1353.

Cuba: Mariel, Ekman 12838 (Amer. Gr. Nat. Herb. 942). Habana, Léon 956, 2625. Between Morro and Cojimar, Ekman 798. Triscornia, Hitchcock 475. Yumuri Mountains, Rugel 869. Ma- 
tanzas, Ekman 17207; Léon 14675. Palma Sola, Wright 298. Isla de Pinos, Britton and Wilson 14939; Britton, Wilson, and Léon 15294, 15337.

Leeward Islands: Barbuda, Danforth 1.

35. Paspalum laxum Lam., Tabl. Encycl. 1: 176. 1791. (Probably St. Croix.)

Paspalum glabrum Poir., in Lam., Encycl. 5: 30. 1804. Puerto Rico.

Paspalum milioideum Desv.; Poir., in Lam., Encycl. Sup. 4: 315. 1816. Puerto Rico.

Paspalum miliare Spreng., Syst. Veg. 1: 247. 1825. Based on $P$. milioideum Desv.

?Paspalum sinuosum Desv., Opusc. 57. 1831. Antilles.

Paspalum floribundum Desv., Opusc. 58. 1831. Antilles?

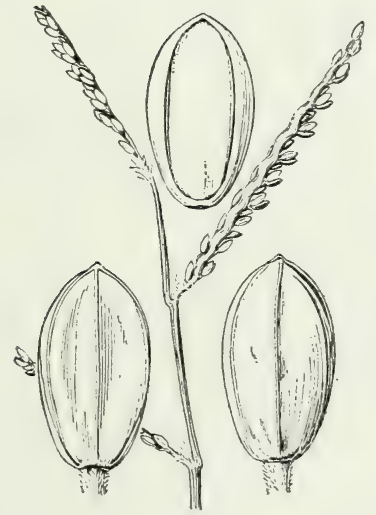

F I GURE 155.-Paspalum bakeri. Panicle, $X 1$; two views of spikelet, and floret, $\times 10$ (type).

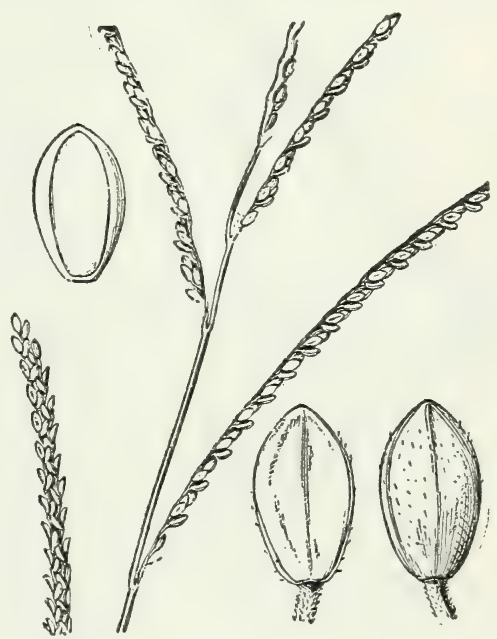

Figure 156.-Paspalum laxum. Panicle, $\times 1$; two views of spikelet, and floret, $\times 10$ (Richard's specimen in Paris Herbarium).

Paspalum richardii Steud., Syn. Pl. Glum. 1: 17. 1854. Antilles, probably St. Croix.

Paspalum rhizomatosum Steud., Syn. Pl. Glum. 1: 17. 1854. Guadeloupe.

Paspalum koleopodum Steud., Syn. Pl. Glum. 1: 18. 1854. Guadeloupe.

Paspalum helleri Nash, Bull. Torrey Bot. Club 30: 376. 1903. Puerto Rico.

Paspalum tenacissimum Mez, Bot. Jahrb. Engler 56 (Beibl. 125): 11. 1921. Puerto Rico.

Culms mostly erect, 50 to $75 \mathrm{~cm}$ tall; blades commonly more or less involute, mostly 20 to $30 \mathrm{~cm}$, sometimes to $50 \mathrm{~cm}$, long, 3 to 8 $\mathrm{mm}$ wide, narrowed to the base; racemes usually 3 to 5 , sometimes more, arcuate-spreading, 3 to $10 \mathrm{~cm}$ long; spikelets 1.7 to $2 \mathrm{~mm}$ long, elliptic-obovate, the glume appressed-pubescent (fig. 156).

Sandy and limestone soils, Key West and the West Indies. 
Bahamas: New Providence, Britton and Brace 404; Curtiss 156; Geogr. Soc. Baltimore 267. Andros Island, Geogr. Soc. Baltimore 197. Fortune Island, Hitcheock in 1890.

Cuba: Between Carabela Grande and Carabela Chica, Roig 3204. Habana, Léon 3446, 15825. Cayo Paloma, Shafer 2569. Guara, Hitchcock 23418. Preston, Ekman 3475. Santiago de Cuba, Léon 951. Guantánamo, Britton 1902. Jauco, Léon 12305, 12313.

JAmaICA: Montego Bay, Hitchcock 9674.

Haitr: St. Louis du Nord, Leonard 14281, 14396, 14410. MôleSt.-Nicolas, Leonard 13155, 13179. Port-de-Pai, Ekman H 3593, H 3624; Leonard 11034, 11110, 12335, 12356, 15244, 15656 . Port-à-lEcu, Leonard 13882. Bayeux, Ekman H 2555. Cabaret, Leonard 11998. Jean Rabel, Leonard 12884, 13789. Aux Cayes, Ekman H 43. Morne-à-Bateau, Ekman H 8043. Gonaïve Island, Ekman H 8837;

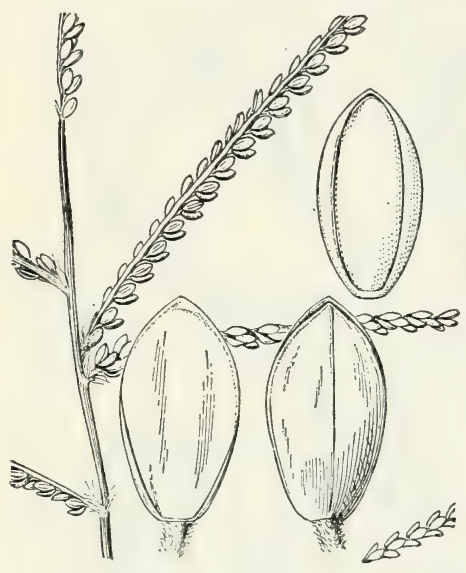

FigURE 157.-Paspalum pleostachyum. Panicle, $\times 1$; two views of spikelet, and fioret, $\times 10$ (Ekman 15756). Leonard 3339. Navassa Island, Ekman H 10812. Tortuga Island, Ekman H 4156; Leonard 11314, 11318.

Dominican Republic: Jaina, Faris 105. Jovero, Abbott 2880a. Cape Samaná, Abbott 1172. Santo Domingo City, Ekman H 11365 . Higüey, Ekman H 12231. Peninsula de Samaná, Ekman H 15336, H 15359 , H 15808. Matanzas, Ekman H 15910. Without locality, Wright, Parry, and Brummel 607, 617, 618.

Puerto Rico: Mona Island, Hess 434. Desecheo, Hess 425. Aguadilla, Chase 66051/2. Aguada, Chase 6601. Mayaguez, Chase 6182, 6279, 6300, 6313. Joyuda, Chase 6306 (Amer. Gr. Nat. Herb. 572); Britton, Stevens, and Hess 2395. Boqueron, Britton, Cowell, and Brown 4636, 4639; Chase 6499. Punta Aguila, Britton, Cowell, and Brown 4686, 4690. Morillos de Cabo Rojo, Britton, Cowell, and Brown 4717. Quebradillas, Chase 6573, 6575. Lares, Chase 6584, 6591. Arecibo, Chase 6446. Campo Alegre, Chase 6437, 6618, 6625. Manati, Chase 6609. Guanica, Britton, Cowell, and Brown 4909. Condado, Britton and Brown 6630. Vega Baja, Chase 6423. Catano, Chase 6635. Santurce, Chase 6346; Heller 10, 164; Hioram 804. Cangrejos, Stevenson 2292. Bayamon, Chase 6408. Pueblo Viejo, Chase 6402; Hioram 111, 2717. Rio Piedras, Chase 6759. Trujillo Alto, Chase 6367, 6369. Cayo Muertos, Britton, Cowell, and Brown 5041. Salinas, Chase 6756. Between Rio Grande and Fajardo, Britton and Brown 7038. Fajardo, Chase 6658. Humacao, Eggers in 1881. Culebra Island, Britton and Wheeler 190. Vieques Island, Chase 6678, 6697.

Virgin Islands: St. Thomas, Eggers in 1876, 1880, 1881, 1882 ; Friedrichsthal 183; Hitchcock 16313. St. Croix, Hitchcock 16336; Ricksecker 410; Thompson 449, 463. Anagada, Britton and Fishlock 986, 1041. Virgin Gorda, Fishlock 108. Tortola, Britton and Shafer 694, 880. St. John, Britton and Shafer 257, 292, 506. 
Leeward Islands: Antigua, Hitchcock 16378; Box 23, 24, 32, 40, 42, 46, 97, 107. St. Kitts, Box 134, 163, 164. Barbuda, Danforth 9. Dominica, Jones 47.

Windward Islands: Martinque, Duss 551. Barbados, Dash 584; Freeman 5026. Grenada, Broadway in 1905.

36. Paspalum pleostachyum Doell, in Mart., Fl. Bras. 2²: 58. 1877. Brazil.

Culms ascending to spreading, 40 to $100 \mathrm{~cm}$ tall; sheaths ciliate on the margin, usually villous on the collar; blades firm, flat from a folded base, often drying subinvolute, 15 to $25 \mathrm{~cm}$ long, 4 to $8 \mathrm{~mm}$ wide; racemes 3 to 15 , commonly 4 to 8 , at length stiffly spreading, 7 to $14 \mathrm{~cm}$ long, on an axis 4 to $11 \mathrm{~cm}$ long; spikelets 2.2 to $2.5 \mathrm{~mm}$ long, elliptic-obovate, glabrous (fig. 157).

On rocks or in sand or clay, seacoast, Cuba to Brazil.

Cuba: Guantánamo, Ekman 15756.

Haiti: Cabaret, Leonard 11982. Tortuga Island, Ekman H 4132; Leonard 11529, 13902, 13940.

Windward Islands: Grenada, Broadway in 1905.

37. Paspalum rocanum Léon, in Britton, Mem. Torrey Bot. Club 16: 57. 1920. Cuba, Léon and Roca 8233.

Culms simple, 40 to $75 \mathrm{~cm}$ tall; sheaths keeled; blades conduplicate, 10 to $30 \mathrm{~cm}$ long, 3 to $7 \mathrm{~mm}$ wide (flattened out); racemes 2 to 4 , ascending to spreading, 2.5 to $9 \mathrm{~cm}$ long, 1 to $2 \mathrm{~cm}$ distant on the slender axis; spikelets 2.1 to $2.5 \mathrm{~mm}$ long, elliptic, minutely pointed (fig. 158).

Palm barrens, sometimes in moist places and brushy sarannas, Cuba.

Cuba: Sabana de Motembo, Léon and

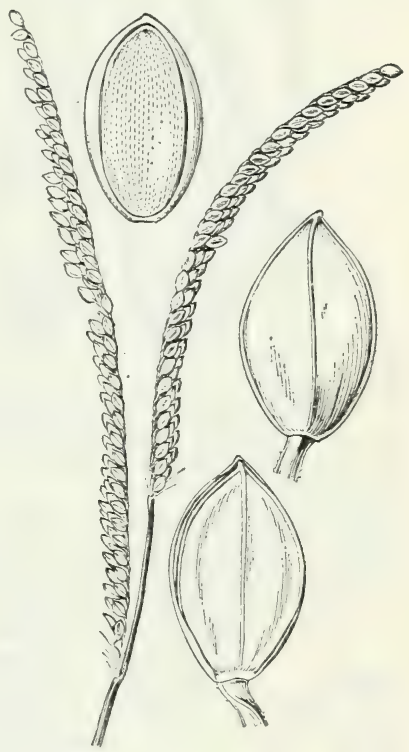

Figtre 158.-Paspalum rocanum. Panicle, $\times 1$; two views of spikelet, and fioret, $\times 10$ (duplicate type).

Roca 8233; Léon and Loustalot 9382, 11337; Ekman 16819 (Amer. Gr. Nat. Herb. 943). Baños de Santa Rosalia, Léon and Loustalot 9392. San Miguel de los Baños (prov. Míatanzas), Léon and Roca 8871.

38. Paspalum alterniflorum A. Rich., in Sagra, Hist. Cuba 11: 299. 1850. Cuba.

Paspalum dolichophyllum Hack., Inf. Est. Centr. Agron. Cuba 1: 409. 1906. Habana, Baker and Zarragoitia 4545.

Culms 30 to $100 \mathrm{~cm}$ tall; blades erect at base, elongate, nearly equaling the culm, mostly 1.5 to $3 \mathrm{~mm}$ wide, drying involute; racemes 1 to 5 , commonly 2 or 3 , suberect or ascending, 7 to $12 \mathrm{~cm} \mathrm{long,} 1$ to $3 \mathrm{~cm}$ distant on the axis; spikelets $3 \mathrm{~mm}$ long, orate-oblong, subacute or blunt; glume and sterile lemma silky pubescent on the lower part, pointed beyond the fruit (fig. 159).

Open ground, pastures, and sarannas, Cuba, common in the western part, rare eastward, and in Haiti. 
Cuba: Mariel, Ekman in 1921 (Amer. Gr. Nat. Herb. 944). Habana, Baker, Tracy, and Hasselbring in 1907; Léon 2556, 3473; Tracy 9105. Marianao, Léon 581. Arroyo Apolo, Léon 564, 585. Vibora, Baker 2587 ; Léon 943, 945. Guanabacoa, Ekman 594; Léon 2561. Calabazar,

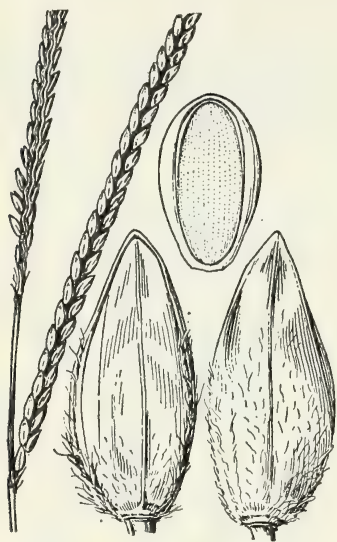

Figure 159.-Paspalum alterniflorum. Panicle, $\times 1$; two views of spikelet, and fioret, $\times 10$ (Baker, Tracy, and Hasselbring).

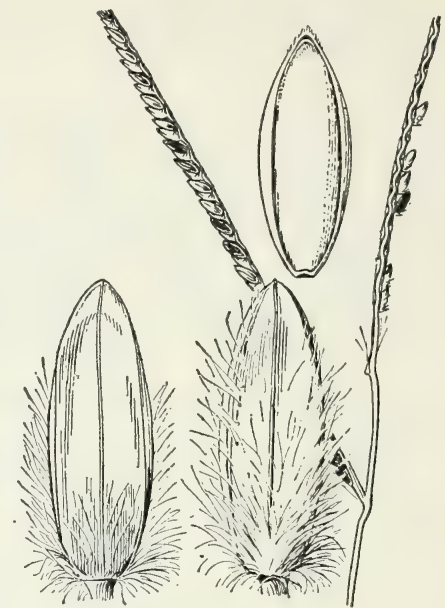

FIGURE 160.-Paspalum rottboellioides. Panicle, $\times 1$; two views of spikelet, and floret, $\times 10$ (duplicate type).

Baker and Zarragoitia 4545. Hanábana, Wright 167 in 1865. Caibarien, Fernando 36. Manatí, Léon 5680. Cupey, Ekman 6294. Without locality, Liebmann 194, 201; Rugel 753a; Wright 3841.

Haiti: St. Michel, Ekman H 8351; Nash and Taylor

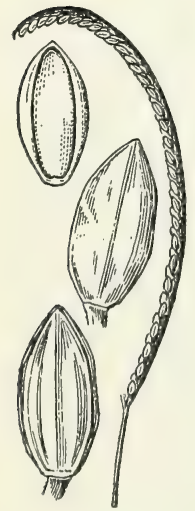

FIGURE 161.-Paspalum filiforme. Raceme, $\times 1$; two views of spikelet, and floret, $\times 10$ (type). 1445. Between Anse-à-Veau and Petit Trou des Nippes, Ekman H 5401.

39. Paspalum rottboellioides Wright, An. Acad. Cien. Habana 8: 204. 1871. Cuba, Wright 3864.

Culms slender, 20 to $75 \mathrm{~cm}$ tall; blades spreading, 5 to $18 \mathrm{~cm}$ long, 1 to $1.5 \mathrm{~mm}$ wide, mostly involute, papillose-pilose; racemes 1 or 2 , ascending or spreading, straight or nearly so, 4 to $12 \mathrm{~cm}$ long, the axis 1 to $2 \mathrm{~cm}$ long; spikelets 3 to $3.3 \mathrm{~mm}$ long, oblong-elliptic, the glume long-villous, the sterile lemma villous at base (fig. 160).

Sandy pinelands and savannas, western Cuba and Isla de Pinos.

Cuba: Herradura, Ekman in 1922 (Amer. Gr. Nat. Herb. 945). Vuelto-abajo, Wright 3864. Isla de Pinos, Britton and Wilson 14697; Curtiss 375; Ekman 12219; Taylor 41.

40. Paspalum filiforme Swartz, Prodr. Veg. Ind. Occ. 22. 1788.

Paspalum swartzianus Flügge, Monogr. Pasp. 96. 1810. Based on $P$. filiforme Swartz.

Paspalum leptocaulon Nash, N. Amer. Fl. 17: 181. 1912. Jamaica, Britton 1475. 
Culms densely cespitose in large tussocks, reclining, slender, 20 to $70 \mathrm{~cm}$ long, with short flowering culms intermixed; blades mostly 20 to $50 \mathrm{~cm}$ long, about $1 \mathrm{~mm}$ wide, plano-convex; raceme solitary, arcuate, 3 to $8 \mathrm{~cm}$ long; spikelets 1.6 to $1.8 \mathrm{~mm}$ long, ovate-elliptic, glabrous (fig. 161).

Savannas, open or wooded slopes, Cuba, Jamaica, and Hispaniola.

CubA: Guane, Ekman 11095. Remates, Ekman 11197. El Rangel, Léon 14047. Sabana de Chirigota, Léon 7452. Mariel, Ekman in 1921 (Amer. Gr. Nat. Herb. 946). San Miguel de Casanova, Léon 12472, 12558. Sabana de Motembo, Léon 9346. Manatí, Léon 6009. Without locality, Wright 3848.

JAmaica: Savanna-la-Mar, Hitchcock 9885. Troy, Hitchcock 9809 (Amer. Gr. Nat. Herb. 566). Lacovia, Britton 1475.

Harti: "Hispaniola", Swartz.

Dominican Republic: Santo Domingo City, Ekman H 10908. Higüey, Ekman H 12234. Peninsula de Samaná, Ekman H 15829.

41. Paspalum distortum Chase, Contrib. U.S. Natl. Herb. 28: 142. f. 85. 1929. Jamaica, Harris 12569.

Culms siender, 15 to $50 \mathrm{~cm}$ tall; blades 15 to $40 \mathrm{~cm}$ long, 1 to $1.5 \mathrm{~mm}$ wide, involute, commonly somewhat tortuous; raceme solitary, arcuate, 2.5 to $6 \mathrm{~cm}$ long; spikelets $2 \mathrm{~mm}$ long, ovate to somewhat rhomboid, the glume and sterile lemma irregularly crumpled, glabrous (fig. 162).

Open hillsides, especially on serpentine rocks, Cuba, Haiti, and Jamaica.

Cuba: Cajálbana, Léon 4857. Habana, Léon 946. Guanabacoa, Léon 7057. San Miguel de Casanova, Léon 12473. Sabana del Tibisial, Léon 6661. Manajanabo, Léon 5273. Banao Mountains, Léon 8042. B araguá, Walker in 1925. Sierra Maestra, Ekman 14691. El Yunque, Shafer 7732. Baracoa, Ekman 3597. Isla de Pinos, Curtiss 374.

JAMaICA: Troy, Harris 12564, 12569; Hitchcock 9789. Cockpit Country, Britton 465.

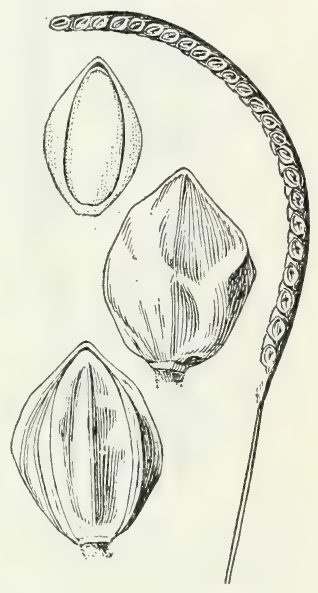

FIGURE 162.-Paspalum distortum. Raceme, X 1; two views of spikelet, and floret, $\times 10$ (type).

Bull Head Mountain, Hitchcock 9544. Claremont, Hitchcock 9518. Between Ewarton and Linstead, Hitchcock 94381/2.

Haiti: Aux Cayes, Ekman H 7. Cotrail, Ekman H 10740.

Dominican Republic: Puerta Plata, Ekman H 14584.

42. Paspalum lindenianum A. Rich., in Sagra, Hist. Cuba 11: 299. 1850. Cuba, Linden 1813.

Paspalum longifolium Steud., Syn. Pl. Glum. 1: 21. 1854. Not P. longifolium Roxb., 1820. Cuba, Linden 1813.

Paspalum megaphyllum Steud., Syn. Pl. Glum. 1: 464. 1854. Based on $P$. longifolium Steud.

Culms commonly 40 to $70 \mathrm{~cm}$ tall, cespitose in dense tussocks, the leaves of the numerous sterile shoots usually about equaling the culm; blades 20 to $50 \mathrm{~cm}$ long, $1 \mathrm{~mm}$ wide, plano-convex; racemes 1 or 2 , rarely 3 or 4 , arcuate or nearly straight, mostly 6 to $10 \mathrm{~cm}$ long; 
spikelets 2.5 to $2.8 \mathrm{~mm}$ long, irregularly ovate-rhomboid, the glume and sterile lemma deeply crumpled (fig. 163).

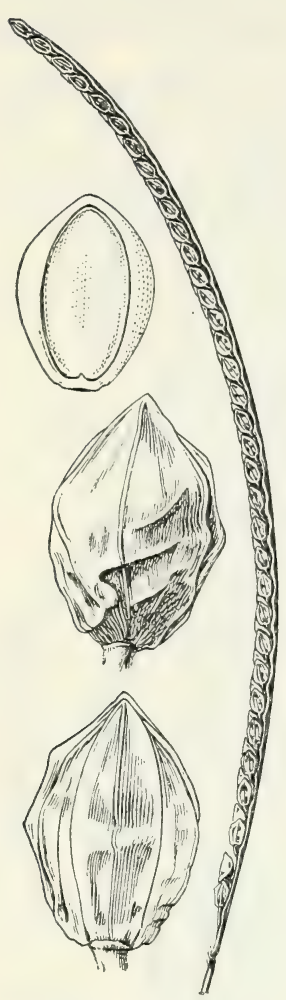

Figure 163.-Paspalum lindenianum. Raceme, $\times 1$; two views of spikelet, and floret, $\times 10$ (it it h cock 9873).

Open or brushy places, mostly on limestone hills, Cuba, Jamaica, and Haiti.

Cuba: Mariel, Ekman 12908 (Amer. Gr. Nat. Herb. 947). Playa de Marianao, Léon 5272. Habana, Léon in 1909. Guanabacoa, Ekman 264; Hitchcock 463, 23242; Léon 944, 7346. Madruga, Léon 3457. Calvarin, Léon 945b. La Sierra, Jack 7848. San Miguel de Casanova, Léon 12471. Hanábana, Wright 769. Saltadura, Linden 1813. Baraguá, Hitchcock 23348, 23363. Soledad, Hitchcock 23326. Isla de Pinos, Curtiss 523; Palmer and Riley 949.

J A M A I A : Montego Bay, Hitchcock 9663. Savanna-la-Mar, Hitcheock 9873. Cornwall, Harris 12551. Between Ewarton and Linstead, Hitchcock 9438. Between Bog: Walk and Spanish Town, Hitchcock 9294. Lucea, Harris 12559.

Haiti: Marmelade, Leonard 8434. Mirebalais, Cook, Scofield, and Doyle 87. Pétionville, Leonard 4830. Between Décayette and Dupréné, Ekman H 2045.

Dominican Republic: Moca, Ekman H 12557.

43. Paspalum nanum Wright; Griseb., Cat. Pl. Cuba 230. 1866. Cuba, Wright 176.

Paspalure caudicatum Wright, An. Cienc. Habana 8: 205. 1871. Cuba, Wright 3866.

Culms erect, mostly 15 to $25 \mathrm{~cm}$ tall; sheaths densely pubescent; blades 3 to $13 \mathrm{~cm}$ long; 3 to $4.5 \mathrm{~mm}$ wide, flat or drying involute, the lower surface velvety, the upper pilose; raceme solitary, 1.5 to $4 \mathrm{~cm}$ long, arcuate or nearly straight; spikelets 2.4 to $2.8 \mathrm{~mm}$ long, oval-elliptic, the glume and sterile lemma somewhat crumpled (fig. 164).

Low sandy pinelands and brushy savannas, central and western Cuba and Isla de Pinos. Apparently rare.

Cuba: La Coloma, Ekmán 17831. Santiago de los Baños, Léon 4570. Herradura, Ekman 10784, 14093 (Amer. Gr. Nat. Herb. 948), 14104; Hitchcock 462. Vuelto-abajo, Wright 3866. Hanábana, Wright 176. Isla de Pinos, Ekman 12190. Without locality, Wright 3842 .

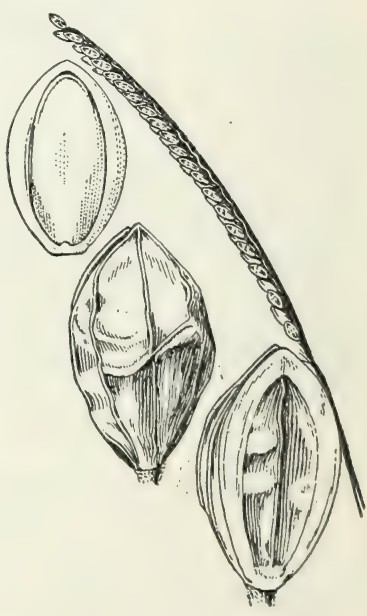

F I G Y E 164.-Paspalum nanum. Raceme, $X 1$; two views of spiko let, and furet, $\times 10$ (Wright 3842 ).

44. Paspalum insulare Ekman; Chase, Contrib. U. S. Natl. Herb. 28: 145. f. 88. 1929. Isla de Pinos, Ekman 11957.

Culms erect or ascending, 40 to $55 \mathrm{~cm}$ tall, the nodes densely appressed-pubescent; sheaths densely papillose-pilose; blades flat, 


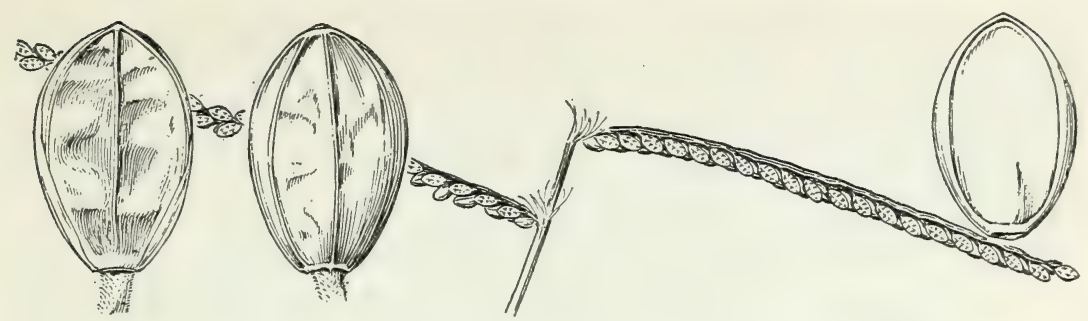

FIGURE 165.-Pospalum insulare. Racemes, $\times 1$; two views of spikelet, and floret, $\times 10$ (type).

6 to $16 \mathrm{~cm}$ long, 3 to $5 \mathrm{~mm}$ wide, papillose-pilose; racemes 1 or 2 , approximate, arcuate to horizontally spreading, 3 to $6.5 \mathrm{~cm}$ long; spikelets about $2.5 \mathrm{~mm}$ long, obovate-elliptic, cross-wrinkled (fig. 165).

Sandy savannas, pinelands, and moist places, Isla de Pinos.

Cuba: Isla de Pinos, Sant Bárbara, Ekman 11957, 12220; Taylor 40.

45. Paspalum rupestre Trin., Linnaea 10: 293. 1836. Cuba.

Paspalum leoninum Chase, in Hitchc., Bot. Gaz. 51: 301. 1911 Cuba, Léon 950.

Culms from suberect to radiate-reclining; blades folded at base, flat above, or subinvolute, 3 to $12 \mathrm{~cm}$ long, 1.5 to $4 \mathrm{~mm}$ wide, glabrous; raceme solitary, straight or falcate, 1.2 to $4.5 \mathrm{~cm}$ long; spikelets mostly about $1.3 \mathrm{~mm}$ long, elliptic (fig. 166).

Open rocky slopes, mostly serpentine, Cuba, Haiti, and Puert, Rico.

Cuba: San Claudio, Ekman 12998. Guanabacoa, Hitchcock 23234 Léon 949, 2691, 11010. San Miguel de Casanova, Léon 12470. Campo Florido, Léon 3482. Amaro, Léon 9142. Ciénaga de Zapata, Roig and Cremata 2116. Sancti Spíritus, Léon 950. Guara, Hitchcock 23417,

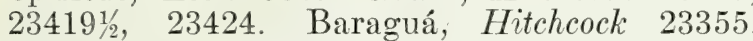
Sierra de Nipe, Ekman in 1922 (Amer. Gr. Nat. Herb. 949). El Yunque, Shafer 7729. Jauco, Léon 12302. Baracoa, Wright 3445 in part.

Haiti: Gros-Morne, Ekman H 4919.

Dominican Republic: Monción, Ekman H 12630.

Puerto Rico: Mayaguez, Chase 6178 (Amer.

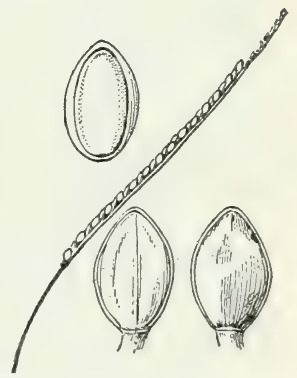

Figure 166.-Paspalum rupestre. Raceme, $\times 1$; two views of spikelet, and floret. $\times 10$ (Léon 950 ).

Gr. Nat. Herb. 567), 6259, 6274, 6275, 6299, 6312, 6315, 6323, 6811, 6813; Holm 152. Maricao, Chase 6220, 6246.

46. Paspalum saugetii Chase, Contrib. U. S. Natl. Herb. 28: 147. f. 90. 1919. Cuba, Léon 8982.

Culms slender, wiry, leaning or spreading, 15 to $40 \mathrm{~cm}$ tall, more or less twisted and tortuous; blades rather thick, usually flat when fresh, folded or involute in drying, more or less tortuous, 3 to $15 \mathrm{~cm}$ long, 3 to $7 \mathrm{~mm}$ wide; racemes commonly solitary, sometimes a second 1 to $1.5 \mathrm{~cm}$ distant, 2 to $4 \mathrm{~cm}$ long; spikelets 1.3 to $1.6 \mathrm{~mm}$ long, oval, appressed-pubescent (fig. 167).

Rocky, mostly limestone soil in the Greater Antilles.

This species has been confused with Paspalum rupestre Trin., from which it differs in its less delicate habit and longer foliage, and in the 
larger pubescent spikelets. It is named for Brother Léon, Joseph Sylvestre Sauget. When $P$. leoninum was described it was differentiated from this species, which was supposed to be $P$. rupestre Trin. In the Grasses of the West Indies this was tentatively referred to $P$. poiretii Roem. and Schult., but that proves to be the same as P. caespitosum.

Bahamas: Fortune Island, Eggers 3995.

Cuba: Between Cape San Antonio and Morro de Piedras, Roig 3255.

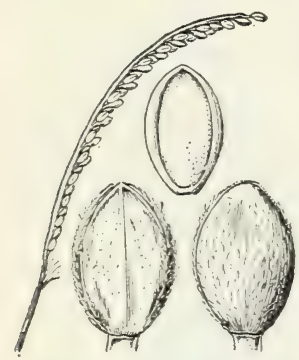

Figure $167 .-P$ aspalum saugetii. Raceme, $\times 1 ;$ two views of spikelet, and floret, $\times 10$ (type).

Chase, Harris 9674 Hitchcock 9765.

Habana, Ekman 697; Léon 286, 948, 1527, 3694, 4664, 7499, 8982 . Cojimar, Baker and O'Donovan 4417; Ekman 16904 (Amer. Gr. Nat. Herb. 950); Hitchcock 459, 461; Léon 5602; 13671. Triscornia, Hitchcock 458. Puentes Grandes, Léon 935b. Banao Mountains, Léon 3980. Cupey, Ekman 6337. Guantánamo, Hioram 2633. Jauco, Léon 12450. Baracoa, Shafer 3951; Wright 3444 in part, 3445 in part.

Jamaica: Troy, Harris 12620a. Ipswich, Hitchcock 9599. New Forest, Hitchcock 9832. Bull Head Mountain, Hitchcock 9533. Between Ewarton and Moneague, Hitchcock 9442. Between Ewarton and Linstead, Hitchcock 9465. Claremont, Hitchcock 9482, 9516. Yardley Constant Spring, Hitchcock 9275. Buff Bay,

Haiti: Tortuga Island, Ekman H 4228. Ennery, Leonard 8810, 10030. Môle-St.-Nicolas, Leonard 13208, 13283a. Port-au-Prince, Ekman H 2210; Leonard 15750. Hitchcock 19886, 19890. Mission, Leonard 3627. Fond Parisien, Leonard 4075. Etang Pénéte, Ekman H 334. Morne à Cabrits, Ekman H 1018. Morne Rouge, Ekman H 690. Aux Cayes, Ekman H 61. Jean Rabel, Leonard 13762.

Dominican Republic: Jaina, Faris 89, 107. Azua, Rose, Fitch, and Russell 4079. San José de Ocoa, Ekman H 11921. Guerra, Ekman H 11018. Santo Domingo City, Ekman H 11121, H 12512. Constanza, Ekman H 13927.

Puerto Rico: Aguada, Chase 6598. Lares, Chase 6588. Between Aguadilla and San Sebastian, Chase 6597.

47. Paspalum capillifolium Nash, N. Amer. Fl. 17: 181. 1912. Cuba, Britton and Wilson 6116.

Culms few, delicate, reclining, 10 to $35 \mathrm{~cm}$ long, sometimes loosely twisted and sinuous with a mass of filiform curled foliage at base; blades folded and curled, 3 to $15 \mathrm{~cm}$ long, about $0.3 \mathrm{~mm}$ wide as folded; racemes solitary, straight, 2 to $4 \mathrm{~cm}$ long, very slender, mostly cylindric; spikelets $1.7 \mathrm{~mm}$ long, elliptic (fig. 168).

Palm barrens and savannas, Cuba.

CuBA: Santa Clara, Britton and Wilson 6116. Sabana de Motembo Léon 8223. Baños de Santa Rosalia, Léon 9376. Santayana, Ekman 19046. Holguín, Ekman 7565.

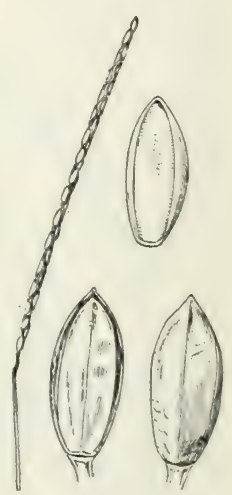

FIGTRE 168.-Prspalum capillifolium. Raceme, $\times 1$; two views of spikelet, and floret, $x$; (Léon 9376). 
48. Paspalum multicaule Poir., in Lam., Encycl. Sup. 4: 309. 1816. Brazil.

Annual; culms in dense tufts, often forming mats, spreading or ascending, 20 to $45 \mathrm{~cm}$ tall; blades flat, drying revolute and often tortuous, 2 to $15 \mathrm{~cm}$ long, 1.5 to $2.5 \mathrm{~mm}$ wide, papillose-pilose; racemes 2 , paired, divergent, commonly 2 to $4 \mathrm{~cm}$ long, yellowish; spikelets 1.2 to $1.4 \mathrm{~mm}$ long, subhemispheric, beaded with subglobular hairs (fig. 169).

Moist eroded places in savannas and open usually disturbed or washed ground, southern Mexico to Brazil and Bolivia.

Cuba: Laguna Santa Bárbara, Ekman 18115. Mendoza, Shafer 10862. Herradura, Baker and Abarca 4185; Hitchcock 472. Chiragota, Wright 3844 in part. Isla de Pinos, Britton and Wilson 14805.

Dominican Republic: Cotuy, Abbott $850 \mathrm{~b}$. Cuenca, Ekman H 11005.

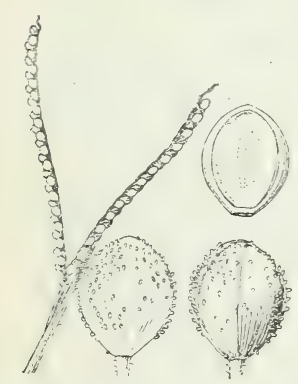

FIGURE 169.-Paspalum multicaule. Racemes, $X$ and fioret, $\times 10$ (Otto).

Trinidad: Piarco Savanna, Broadway 2126; Hitchcock 10340 ; Warming 839 . O'Meara Savanna, Britton and Hazen 1572. Pitch Lake, Hitcheock 10102 (Amer. Gr. Nat. Herb. 574).

49. Paspalum clavuliferum Wright, An. Acad. Cien. Habana 8: 203. 1871; Fl, Cub.195. 1873. Cuba, Wright 3444 in part.

Annual; culms erect to spreading, branching, 5 to $45 \mathrm{~cm}$ tall; blades flat, 3 to

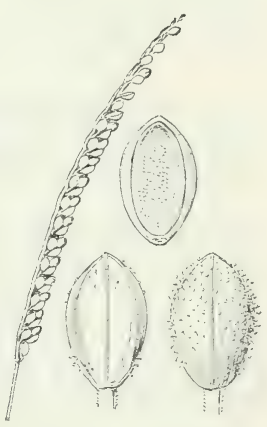

FIGUPE 170.-Paspalum claivliferum. Raceme. $\times 1 ;$ two views of spikelet, and floret, $\times 10$ (duplicate type).

\section{$16 \mathrm{~cm}$ long, 1.5 to $3 \mathrm{~mm}$}

wide, papillose-pilose; racemes solitary or paired, rarely with a third below, arcuate, 1 to $5.5 \mathrm{~cm}$ long; spikelets 1.2 to $1.4 \mathrm{~mm}$ long, elliptic-obovate, the glume pubescent with capitellate hairs (ifg. 170).

Moist spots in sandy savannas and barrens, eroded places in open and brushy slopes, waste and cultivated ground, southern Mexico to Brazil; Cuba to Puerto Rico.

Cuba: La Coloma, Ekman in 1923 (Amer. Gr. Nat. Herb. 954). Cajálbana, Léon 4858. Jagüey Chico, Ekman 16982. Gavilanes, Léon 6655. Placetas del Sur, Léon 6417, 6418. Zaza de Tunas, Léon 942. Baraguá, Hitchcock 233791/2. Guara, Hitchcock 23430. Eastern Cuba, Wright 3444 in part.

Haiti: Acul-Samedi, Ekman H 9911.

Dominican Republic: San Juan, Ekman H 13402. Higüey, Ekman H 12209. Monción, Ekman H 12631. Guerra, Ekman H 11019 .

Puerto Rico: Campo Alegre, Stevenson 2454.

50. Paspalum parviflorum Rohdé; Flügge, Monogr. Pasp. 98. 1810. Puerto Rico.

Annual, densely tufted, conspicuously pilose; culms branching, ascending or spreading, 4 to $17 \mathrm{~cm}$ tall; blades 1.5 to $6.5 \mathrm{~cm}$ long, 1 to $2 \mathrm{~mm}$ wide; racemes 2 to 4,2 to $10 \mathrm{~mm}$ distant, spreading or $60256-36-15$ 
reflexed, 6 to $25 \mathrm{~mm}$ long, the rachis strongly zigzag; spikelets not imbricate, $0.8 \mathrm{~mm}$ long, oblong-elliptic, the glume and sterile lemma tearing apart in the middle and reduced to a rim around the spikelet (fig. 171).

Sandy savannas and sand barrens, Panama to Brazil; Puerto Rico. Puerto Rico: Tithout locality, Rohdé in 1809 (British Museum).

51. Paspalum breve Chase, in Urban, Symb.

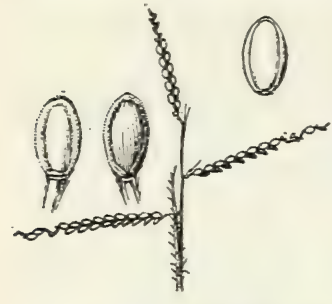

FIG ERE 171.-Paspalum parviflorum. Panicle, $\times 1$; two views of spikelet, and floret, $\times 10$ (Chase 8001). Antill. 7: 166. 1912 . Cuba, Léon 1996.

Stoloniferous perennial often forming dense leafy mats; culms subfiliform, 5 to $10 \mathrm{~cm}$ tall; blades mostly 3 to $6 \mathrm{~cm}$ long, 2 to $4 \mathrm{~mm}$ wide, flat or folded or subinvolute in drying; racemes usually solitary about 10 $\mathrm{mm}$ long; spikelets $1.4 \mathrm{~mm}$ long, broadly oval, fruit brownish (fig. 172).

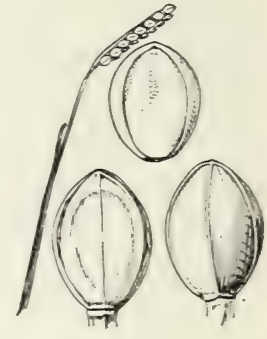

FIgtRE 172.-Paspalum brere. Raceme, $\times 1$; two riews of spikelet, and floret, $\times 10$ (type)

Stony, mostly calcareous, slopes, $\mathrm{Cuba}$ and Hispaniola.

CubA: Gorge of Taco Taco River, Léon 15060. Marianao, Léon 1996, 3477. Serro de Esperón, Killip 13512. Cojimar, Léon 1997. Bacuranao, Wilson and Léon 2872, 11599. Sierra de Anafe, Ekman

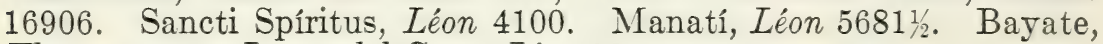
Ekman 9843. Loma del Gato, Léon 9811.

HaIti: La Source, Ekman H 3379. Grande Riviere, Ekman H 449.

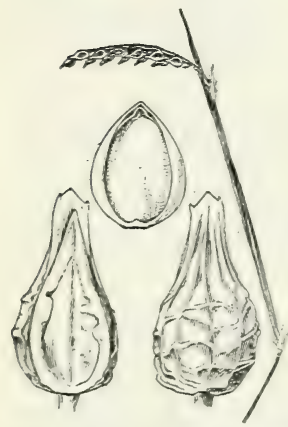

FIG TRE 173.-Paspalum edmondi. Raceme, $\times 1$. two riews of spikelet, and floret, $\times 10$ (duplicate type). Pestel, Eyerdam 357. Dame-Marie, Ekman H 10480.

Dominican Republic: Santo Domingo City, Ekman H 10957.

52. Paspalum edmondi Léon, in Britton, Mem. Torrey Bot. Club 16: 58. 1920. Cuba, Léon and Edmond 8607.

Low stoloniferous perennial with short slender rhizomes; culms filiform, 2 to $6 \mathrm{~cm}$ tall, the stolons as much as $15 \mathrm{~cm}$ long; foliage conspicuously spreading-pilose; blades flat, 1 to $6 \mathrm{~cm}$ long, 1 to $2 \mathrm{~mm}$ wide; raceme solitary, 10 to 15 $\mathrm{mm}$ long; spikelets 1.5 to $2 \mathrm{~mm}$ long, broadly ovate, the apex prolonged into a prominent beak; glume irregularly transversely wrinkled, less so at maturity; fruit brown (fig. 173).

Palms barrens on serpentine, Cuba.

Cuba: Motembo, Ekman 16822; Léon and Edmond 8607, 8682.

53. Paspalum orbiculatum Poir., in Lam., Encycl. 5: 32. 1804. Puerto Rico.

Paspalum pusillum Tent.; Flügge, Monogr. Pasp. 100. 1810. St. Thomas and Puerto Rico.

Paspalum lenormandi Husnot, Bull. Soc. Linn. Normand. (II)

5: 259. 1871. Martinique. 
Low creeping perennial, with long leafy stolons, often forming dense mats; culms 10 to $60 \mathrm{~cm}$ long, decumbent and rooting at the nodes, the flowering branches 5 to $20 \mathrm{~cm}$ tall; blades flat, 1 to $6 \mathrm{~cm}$ long, 1.5 to $7 \mathrm{~mm}$ wide; racemes commonly 3 or 4 , ascending or spreading, 0.6 to $2.3 \mathrm{~cm}$ long, 1 to $10 \mathrm{~mm}$ distant; spikelets 1 to $1.2 \mathrm{~mm}$ long, subhemispheric, greenish golden, turning brown between the pale margins; fruit reddish (fig. 174).

Moist open ground along streams and ditches, in savannas and old fields, southern Mexico and the West Indies to Paraguay.

Cuba: Guantánamo, Ekman 15806. Cajóbabo, Léon 12315.

Dominican Republic: Cuenca, Ekman H 10959. Jarabaco, Ekman H 14191.

Puerto Rico: Mayaguez, Britton and Hess 2835. Guaynabo, Whetzel, Kern, and Toro in 1924. Pueblo Viejo, Sintenis 1229. San Juan,

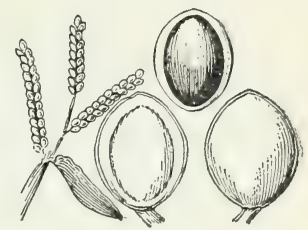

FIGURE 174.-Paspalum orbiculatum. Panicle, $\times 1$. two views of spikelet, and floret, $\times 10$ (duplicate type). Heller 664. Cayey, Chase 6739. Sierra de Naguabo, Britton and Cowell 2186.

Windward Islands: Antigua, Box 187. Martinique, Duss 4507. St. Lucia, Box 187.

Trinidad: St. Joseph, Hitchcock 10016 (Amer. Gr. Nat. Herb. 575). Oropuche Lagoon, Britton, Hazen, and Freeman 1139.

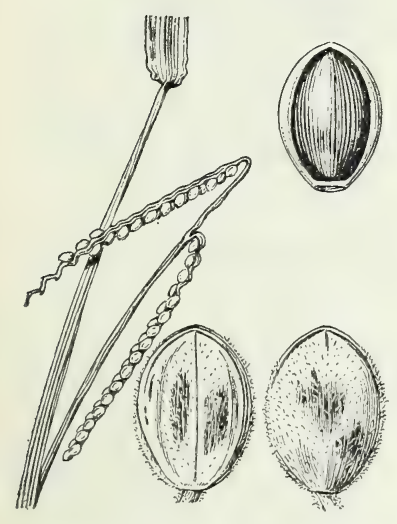

FiguRE 175.-Paspalum reptatum. Racemes, $\times 1$; two views of spikelet, and floret, $\times 10$ (type).

54. Paspalum reptatum Hitchc. and Chase, Contrib. U. S. Natl. Herb. 18: 318. 1917. Cuba, Léon and Cazanas 5850.

Creeping subaquatic perennial; culms 30 to $100 \mathrm{~cm}$ or more long, decumbent and rooting at the nodes; blades flat, 3 to $10 \mathrm{~cm}$ long, 2 to $5 \mathrm{~mm}$ wide, velvety pubescent to glabrous; racemes 2 or 3, commonly overtopped by the upper leaf, divergent or reflexed, 1 to $4 \mathrm{~cm}$ long, 5 to $10 \mathrm{~mm}$ distant; spikelets 1.5 to $1.7 \mathrm{~mm}$ long, elliptic-obovate, finely pubescent, yellowish green blotched with brown; fruit reddish brown. Cleistogamous spikelets are borne in minute sheaths at the very base (fig. 175).

In mud or shallow water, margins of ponds and depressions in savannas, Cuba and Jamaica.

Cuba: Pinar del Río, Ekman 18249 (Amer. Gr. Nat. Herb. 957). Manacas, Léon 5850. Jagüey Chico, Ekman 16983. JAMAICA: Inverness, Harris 12717.

55. Paspalum amphicarpum Ekman, in Chase, Contrib. U. S. Natl. Herb. 28: 161. f. 103. 1929. Cuba, Ekman 17565.

Glabrous widely creeping aquatic or subaquatic perennial with solitary cleistogamous spikelets borne on short subterranean branches from the base or from rooting nodes; culms 50 to $75 \mathrm{~cm}$ or 
more long. decumbent and rooting at the nodes, the flowering branches 30 to $40 \mathrm{~cm}$ long: blades folded at base, flat abore. 5 to $15 \mathrm{~cm}$ long. 3 to $6 \mathrm{~mm}$ wide: racemes 2 or 3 . dirergent. 2 to $4.5 \mathrm{~cm}$ long. 4 to $15 \mathrm{~mm}$ distant: spikelets 2.5 to $2.7 \mathrm{~mm}$ long. elliptic. subacute, pointed berond the fruit: fruit brownish; subterranean spikelets 4 to $5 \mathrm{~mm}$ long (fig. 176).

Edge of ponds. known onls from Pinar del Río. Cuba.

Ctв.s: Laguna de Piedras, Mangas, Elman 17565 (Amer. Gr. Tat. Herb. 958).

56. Paspalum conjugatum Bergius, Act. Helr. Phrs. Math. 7: 129. pl. 8. 1762. Dutch Guiana.

SOUR PASPaLTM.

Extensirelr creeping perennial, with long leafr stolons: culms as much as $2 \mathrm{mllong}$, rooting at the nodes, compressed, wirt, the flowering branches 20 to $50 \mathrm{~cm}$ tall: blades flat, commonly 5 to $12 \mathrm{~cm}$ long. 5 to $15 \mathrm{~mm}$ wide: racemes 2, paired or nearly so. rarelr a third below.

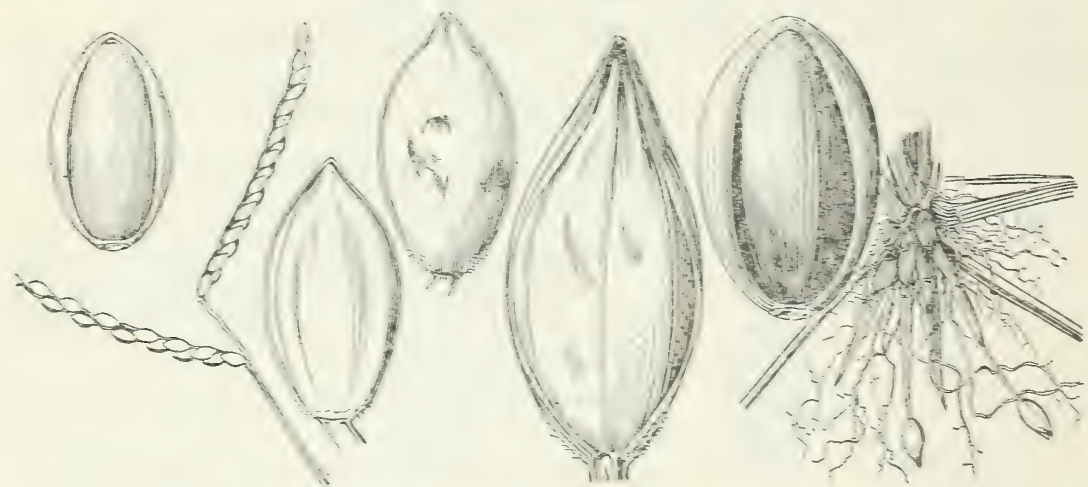

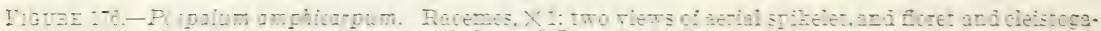

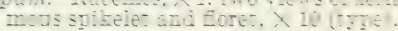

widely diraricate: often arcuate, usually $s$ to $12 \mathrm{~cm}$ long: spikelets 1.4 to $1.5 \mathrm{~mm}$ long. flattened, orate, pale rellow, the margin fringed with long silkt hairs (fig. 177).

A common weed in cultirated and waste ground, southern Lnited States to Argentina; throughout the Mest Indies. The species is said br some to be an excellent forage grass, but Maza and Roig state that it is eaten br cattle only when they are driven to it br hunger. The common mame "sour grass" giren to this species by Grisebach would indicate that it was unpalatable. In Cuba it is called "cañamazo" and "cañamazo hembro."

56a. Paspalum conjugatum rar. pubescens Doell, in Mart. Fl. Bras. $22: 55$. 1877. Brazil.

On the arerage coarser, the blades somewhat firmer, pubescent: spikelets 1.7 to $2.2 \mathrm{~mm}$ long, the silky hairs more copious.

Along ditches and banks, Mexico ind the Lesser Antilles to Brazil.

Tirgix Islands: St. Thomas, Eggers in 1881.

Mindward Islaxds: Grenada, Broaduay 1744. St. Kitts, Box 150 .

"Est. Expt. Agron. Bol. 22: ง?. 1914. 


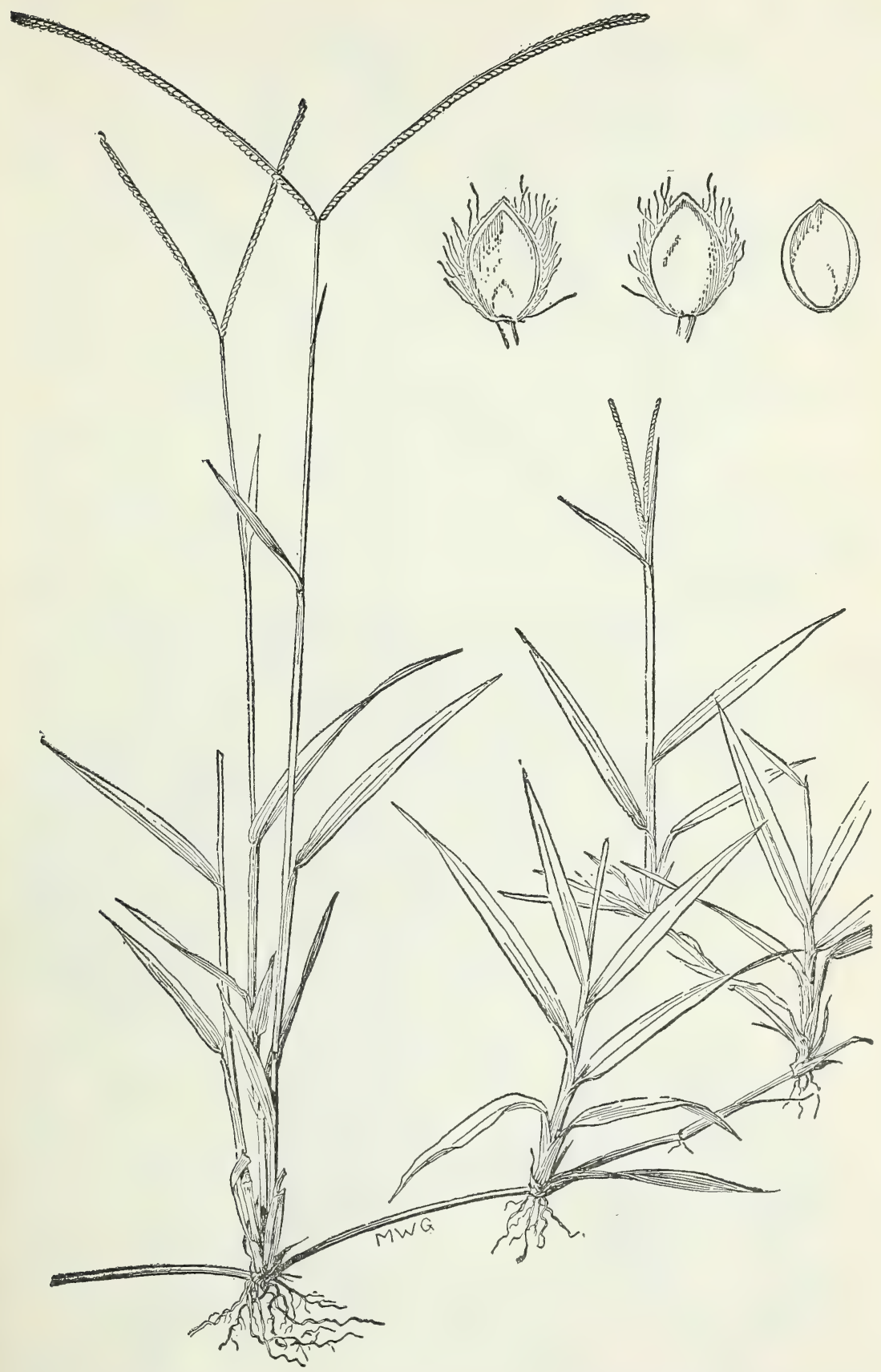

FigURE 177.-Paspalum conjugatum. Plant, $\times 1 / 2$; two views of spikelet, and floret, $\times 10$ (Baker 90 ). 


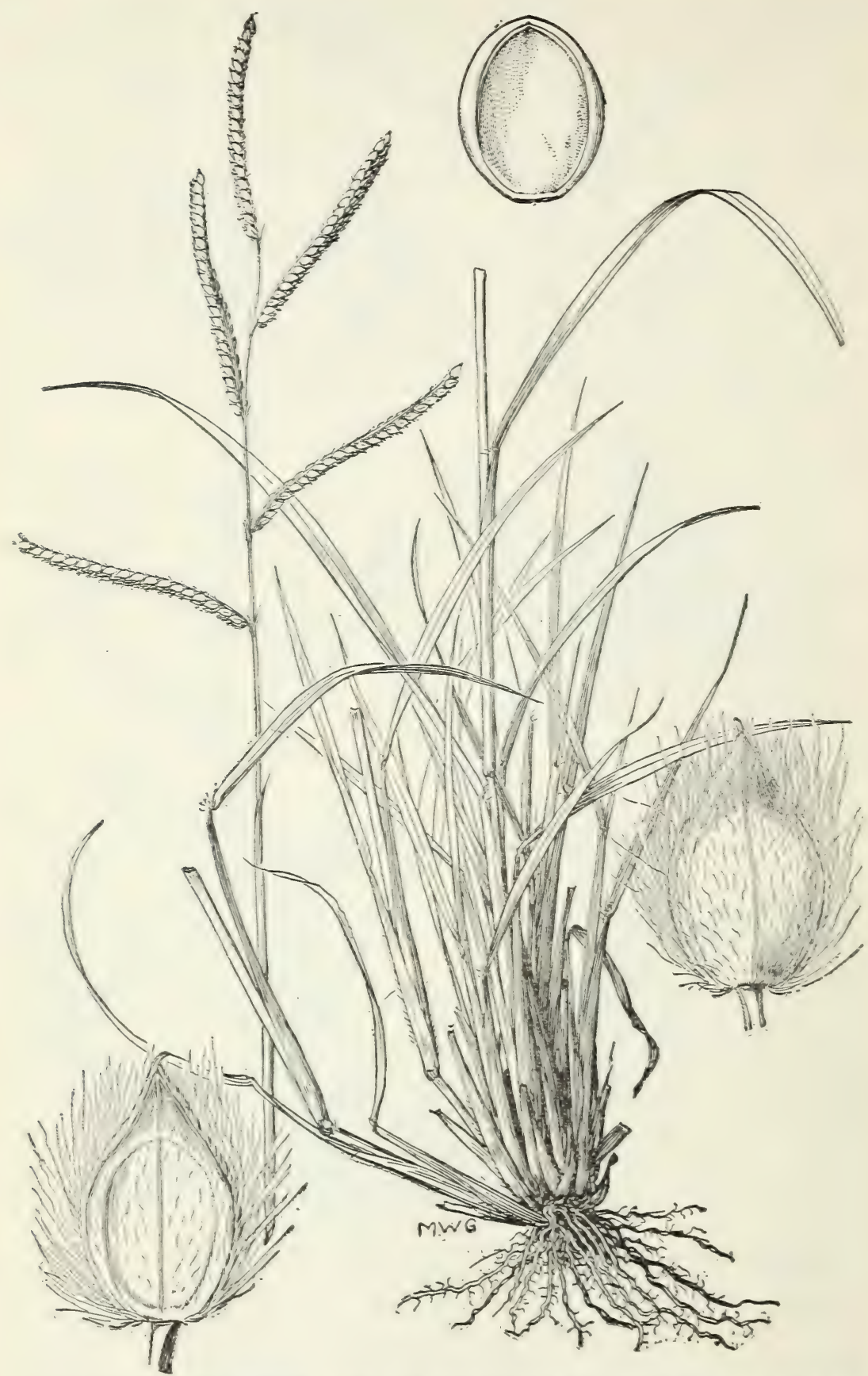

FIGCRE 178.-Paspalum dilatatum. Plant, $\times \frac{1}{1}$; $;$ two viers of spikelet, and floret, $\times 10$ (Hitcheock 297). 
57. Paspalum dilatatum Poir., in Lam., Encycl. 5: 35. 1804. Argentina. Paspalum.

Culms ascending or erect, 40 to $175 \mathrm{~cm}$ tall; blades flat, commonly 10 to $25 \mathrm{~cm}$ long, 3 to $12 \mathrm{~mm}$ wide; racemes commonly 3 to 5 , ascending or drooping, about 6 to $8 \mathrm{~cm}$ long; spikelets 2.8 to $3.8 \mathrm{~mm}$ long, ovate, pointed, depressed plano-convex, fringed with long white silky hairs (fig. 178).

Pastures and waste ground, sparingly introduced in the West Indies; southeastern United States; native of South America from Brazil to Argentina. Cultivated in the southern United States, where it is considered a valuable pasture grass. Called paspalum or paspalum grass and recently Dallis grass.

Bermuda: Agricultural Station, Brown, Britton, and Bisset 2005. Shelley Bay, Collins 156.

Cuba: Mariel, Ekman 12855 (Amer. Gr. Nat. Herb. 962).

JAMAICA: Richmond Park, Harris 12708.

Haiti: St. Louis du Nord, Leonard 14387.

Dominican Republic: Jaina, Faris 329.

58. Paspalum urvillei Steud., Syn. Pl. Glum. 1: 24. 1854. Brazil.

VASEY GRASS.

Paspalum larrañagai Arech., An. Mus. Nac. Montevideo 1: 60. pl.2. 1894. Uruguay.

Paspalum vaseyanum Scribn., U. S. Dept. Agr., Div. Agrost. Bull. 17: 32. f. 328. 1899. Southern United States.

Culms erect, 1 to $2.5 \mathrm{~m}$ tall; lower sheaths hirsute; blades flat, commonly 20 to $30 \mathrm{~cm}$ long, 3 to $15 \mathrm{~mm}$ wide; panicle erect, 10 to 40 cm long; racemes mostly 12 to 18 , ascending, approximate, the lower 7 to $14 \mathrm{~cm}$ long, the upper gradually shorter; spikelets about $2.5 \mathrm{~mm}$ long (2 to $3 \mathrm{~mm}$ ), ovate, abruptly pointed, flattened, fringed with long, silky hairs (fig. 179).

Along ditches and roadsides, and in waste ground, southern United States; native from Brazil to Argentina; introduced sparingly in Cuba. Known as Vasey grass in the United States, where it is sometimes cut for hay.

CubA: Baraguá, Hitchcock 23353.

59. Paspalum fasciculatum Willd.; Flügge, Monogr. Pasp. 69. 1810. Brazil.

Large extensively creeping leafy stoloniferous perennial, the stolons as much as $5 \mathrm{~m}$ long; culms as much as $2 \mathrm{~m}$ tall and $1 \mathrm{~cm}$ thick at base; blades flat, ascending to spreading, 20 to $60 \mathrm{~cm}$ long, 1.2 to $3 \mathrm{~cm}$ wide; panicle flabellate, of usually 12 to 20 ascending racemes, 7 to $17 \mathrm{~cm}$ long, aggregate on a short axis; spikelets 4 to $4.5 \mathrm{~mm}$ long, elliptic, silky-ciliate on the margin (fig. 180).

Borders of streams, low ground, and swamps, southern Mexico to Ecuador and Argentina.

Windward Islands: St. Lucia, Box 191 (sterile).

Trinidad: St. Joseph, Hitchcock 10029.

Tobago: Plymouth, Hitchcock 10281.

60. Paspalum virgatum L., Syst. Nat. ed. 10. 2: 855. 1759. Jamaica.

Cortadero.

Paspalum virgatum var. jacquinianus Flügge, Monogr. Pasp. 190. 1810. Caribbean Islands. 


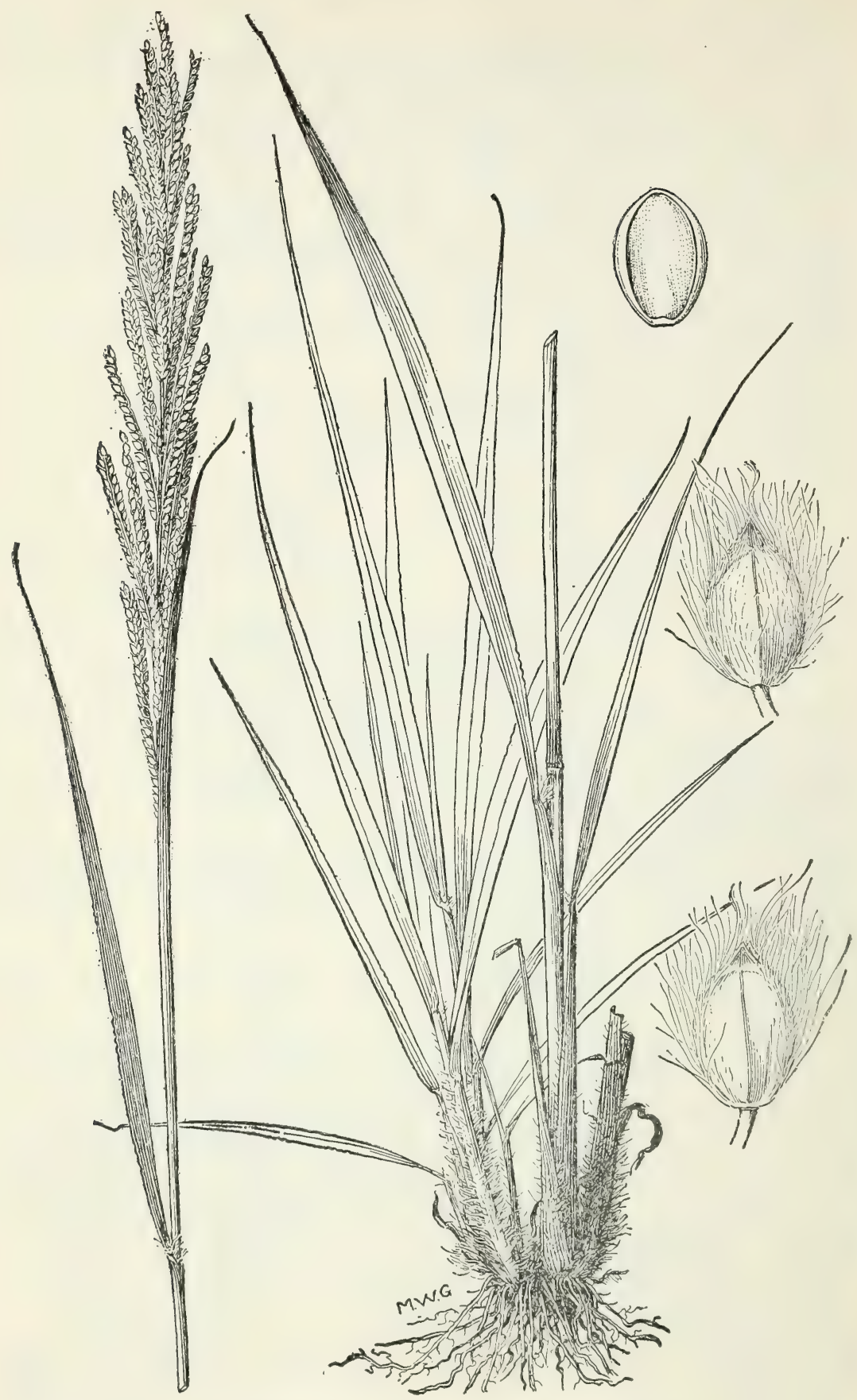

Figure 179.-Paspalum urvillei. Plant, $\times 1 / 2$; two views of spikelet, and floret, $\times 10$ (Chase 4388). 


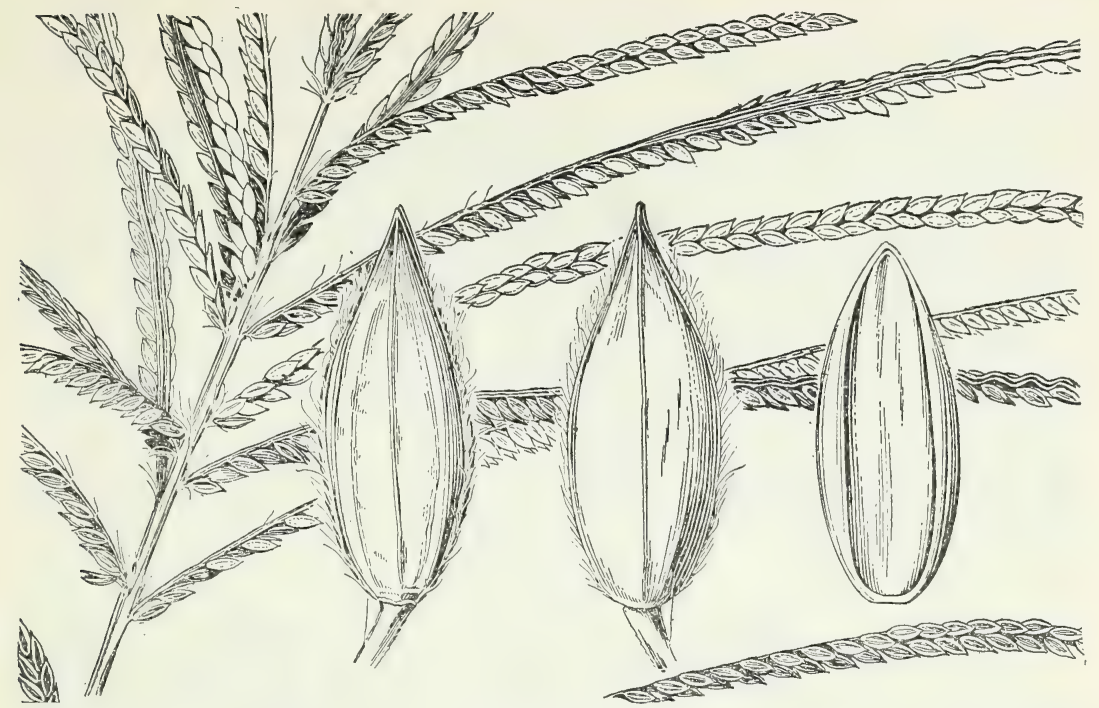

FIGURE 180.-Paspalum fasciculatum. Panicle, $\times 1$; two views of spikelet, and floret, $\times 10$ (Hitchcock 7899)

Paspalum virgatum var. stramineum Griseb., Fl. Brit. W. Ind. 543 1864. Jamaica and Antigua.

Paspalum leucocheilum Wright, An. Acad. Cien. Habana 8: 203. 1871. Isla de Pinos, Blain.

Culms robust, 1 to $2 \mathrm{~m}$ tall; blades flat, elongate, 1 to $2.5 \mathrm{~cm}$ wide; panicle 15 to $25 \mathrm{~cm}$ long; racemes mostly 10 to 16 , ascending to drooping, the lower 5 to $15 \mathrm{~cm}$ long; spikelets about $2.5 \mathrm{~mm}$ long, obovate, pubescent along the margin (fig. 181).

Open moist or swampy ground, Mexico and throughout the West Indies to Brazil.

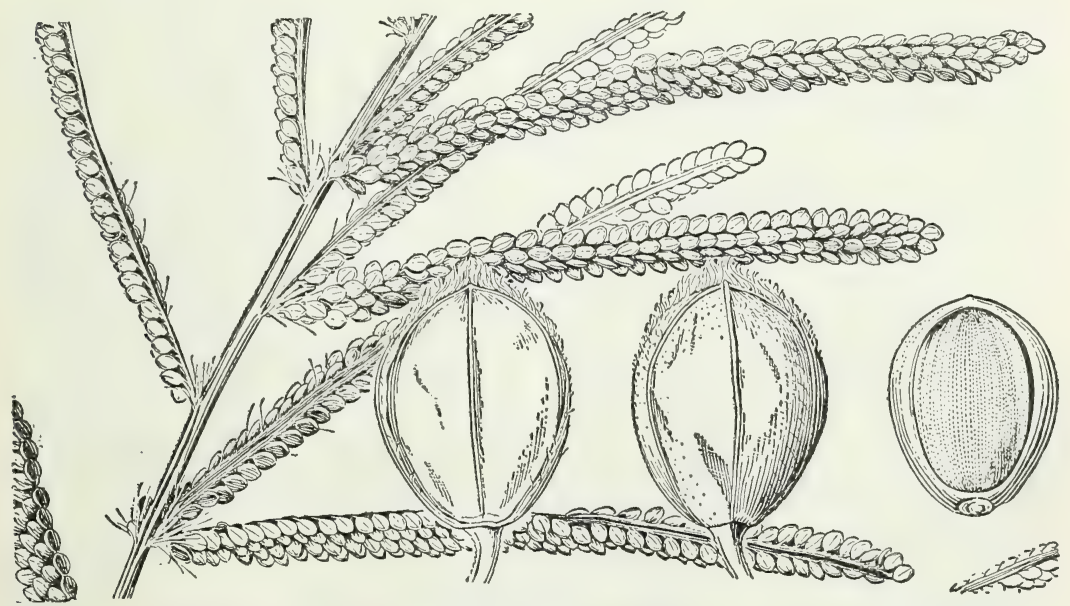

FIGURE 181.-Paspalum virgatum. Panicle, $\times 1$; two views of spikelet, and floret, $\times 10$ (Hitchcock 9555 ). 
In Puerto Rico this and other species of this group are called "cortadero" because of the cruel cutting edges of the blades. Called "caguazo" in Cuba.

61. Paspalum secans Hitchc. and Chase, Contrib. U. S. Natl. Herb. 18: 319. 1917. Puerto Rico, Chase 6174.

Culms robust, erect, 1 to $1.5 \mathrm{~m}$ tall; blades elongate, 5 to $10 \mathrm{~mm}$ wide, the margins very sharp; racemes mostly 7 to 12 , slender, spreading or arching, 6 to $15 \mathrm{~cm}$ long; spikelets pale, about $2.5 \mathrm{~mm}$ long, obovate-elliptic (fig. 182).

Open brushy slopes and savannas, West Indies.

Bahamas: New Providence, Britton and Brace 598. Inagua, Nash and Taylor 956.

Cuba: Santiago de los Baños, Léon 4366\%ํ․․ Habana, Léon 931b, 932. Soledad, Jack 6201. Cano, Ekman 184. Tunas, Léon 6743. Canasí, Léon 12961. Baraguá, Hitchcock 23343. Isla de Pinos, Ekman 12223.

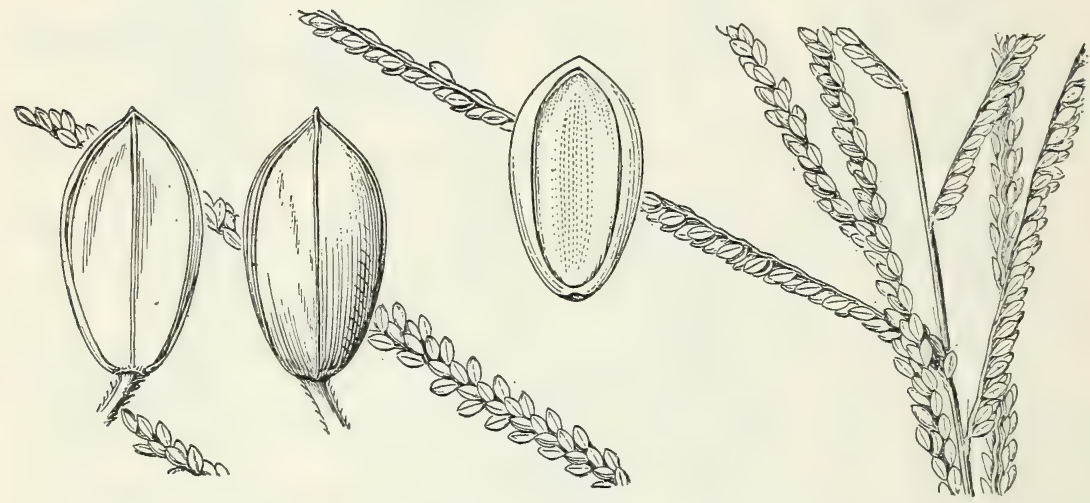

FigURe 182.-Paspalum secans. Panicle, $\times 1$; two views of spikelet, and floret, $\times 10$ (type).

Jamaica: Montego Bay, Hitchcock 9670. Black River, Hitchcock 9649.

Haiti: Gourjon, Ekman H 6451. Between Les Anglais and Chardonnier, Ekman H 384. Tortuga Island, Leonard 11702.

Dominican Republic: Monción, Ekman H 12611; Valeur 417. Matanzas, Ekman H 15899. Peninsula de Samaná, Ekman H 15362.

Puerto Rico: Mayaguez, Chase 6261 (Amer. Gr. Nat. Herb. 577), Chase 6150, 6174, 6309; Holm 84. Maricao, Chase 6193, 6238. Arecibo, Chase 6444, 6559. Lares, Chase 6581. Between Utuado and Adjuntas, Chase 6465. Campo Alegre, Chase 6787. Between Ponce and Santa Isabel, Britton and Brown 5518. Bayamon, Chase 6382, 6387, 6409. Catano, Chase 6641. Rio Piedras, Chase 6372; Wetmore 167. Trujillo Alto, Sein 321. Caguas, Britton and Cowell 1405; Sintenis 2539. Rio Grande, Chase 6707, 6716, 6723. Loma Icaco, Shafer 3415. Vieques Island, Chase 6698.

Virgin Islands: St. Thomas, Foster. St. Croix, Hitchcock 16323; Ricksecker 434.

Leeward Islands: Antigua, Wullschlaegel 603; Box 41, 56, 96, 113. Guadeloupe, Hitchcock 16408. 
62. Paspalum arundinaceum Poir., in Lam., Encycl. Sup. 4: 310. 1816. Cayenne.

Culms robust, erect, 1 to $2 \mathrm{~m}$ tall; blades elongate, 5 to $10 \mathrm{~mm}$ wide; racemes usually 12 to 18 , rather thick, ascending, 8 to $20 \mathrm{~cm}$ long, approximate or fascicled, the axis 10 to $20 \mathrm{~cm}$ long; spikelets about $2.5 \mathrm{~mm}$ long, obovate-elliptic (fig. 183).

In marshes and low open ground, West Indies, Guatemala, and French Guiana.

Cuba: Pinar del Río, Hitchcock 23293. Herradura, Hitchcock 478. Guanajay, Palmer and Riley 813. Habana, Tracy 9125, 9126. Cano, Ekman 184. Batabanó, Baker and Wilson 2303; Hitchcock 477. Hanábana, Wright 3446 in part. Cayamas, Baker 3626.

J A M A I C A : Black River, Harris 12544; Hitchcock 9644. Bull Head Mountain, Hitchcock 9536. Between Ewarton and Linstead, Hitchcock 9457. Annotta Bay, Harris 12469a.

HaItr: Plaisance, Cook, Scofield, and Doyle 174. Trouin, Ekman H 2435. Gourjon, Ekman H 6452. Fond Parisien, Leonard 4174, 4187. Ennery, Leonard 9079. Bassïn Bleu, Leonard 15033.

Dominican Republic: Pimentel, Ekman H 13240. Santo Domingo City, Ekman H 11576. Santiago, Ekman H 16091.

Leeward Islands: Antigua, Hitchcock 16375.

63. Paspalum millegrana Schrad., in Schult., Mant. 2: 175. 1824. Brazil.

Paspalum underwoodii Nash, Bull. Torrey Bot. Club 30: 375. 1903. Puerto Rico, Underwood and Griggs 149.

Culms erect, robust, 1 to $2 \mathrm{~m}$ tall; blades elongate, 7 to $15 \mathrm{~mm}$ wide; racemes commonly 12 to 25 , rather thick, ascending to spread-

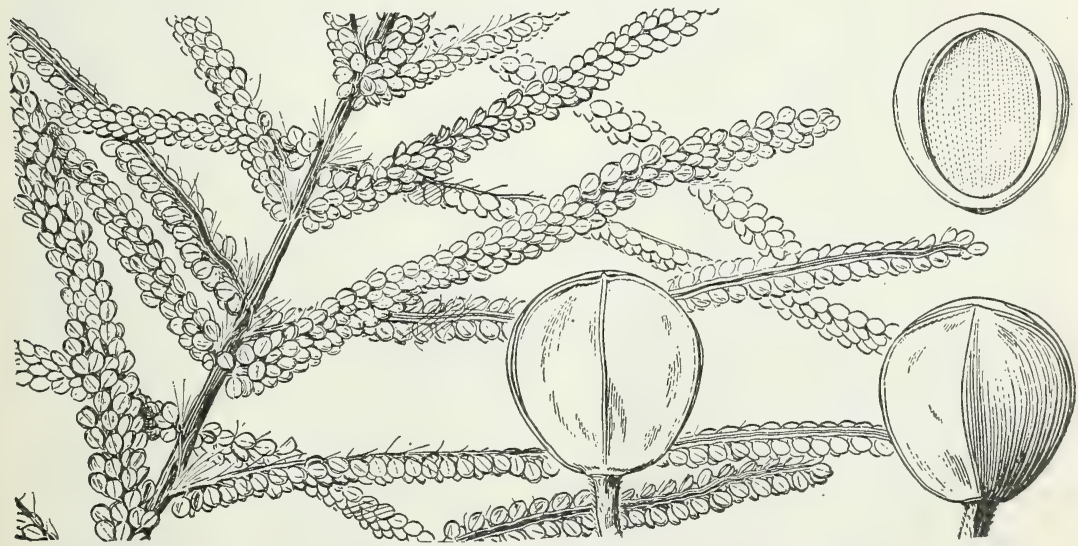

Figure 184.-Paspalum millegrana. Panicle, $\times 1$; two views of spikelet, and floret, $\times 10$ (Chase $7840)$. 
ing, approximate, 6 to $16 \mathrm{~cm}$ long; spikelets 2 to $2.4 \mathrm{~mm}$ long, obovatesuborbicular, flattened, pale to leaden-purplish (fig. 184).

Moist savannas, along ditches, and in low open ground. Central America and the West Indies to Brazil.

Bahamas: New Providence, Krebs (Copenhagen Herb).

Cuba: Santiago de Los Baños, Léon 4364. Pinar del Río, Hitchcock 23259. Habana, Léon 931, 4157, 4160; Tracy 9121. Guanabacoa, Léon 2870. Bajucal, Van Hermann 347. Cano, Léon 1987. Santiago de las Vegas, Van Hermann 142. Tunas, Léon 6735. San Marcos Savanna, Léon 9183. San Miguel de los Baños, Killip 13920. Lagoon Mojabraga, Léon 9413. Between Camagüey and Santayana, Britton 2361. Baraguá, Hitchcock 23366. Sierra de Nipe, Ekman 10118. Bayate, Ekman 6176. Without locality, Wright 3446 in part, 3840 .

Jamaica: Savanna-la-Mar, Hitchcock 9869. Troy, Harris 12657. Bull Head Mountain, Hitchcock 9557. Savoy, Harris 11620. Ashley Hall, Harris 12730. Annotta Bay, Harris 12469, 12534, 12658, 12660. Buff Bay, Hitchcock 9776.

Haitr: Aux Cayes, Ekman H 256, H 861.

Dominican Republic: Jaina, Faris 267. Pimentel, Ekman H 13242. Sabana Guabatico, Ekman H 13322.

Puerto Rico: Mayaguez, Chase 6316 (Amer. Gr. Nat. Herb. 578); Chase 6153, 6164, 6187, 62571/2, 6303; Goll 923; Heller 4368; Sintenis 1223 in part; Underwood and Griggs 149. Maricao, Chase 6237. Arecibo, Chase 6441, 6565. Campo Alegre, Chase 6626. Vega Baja, Britton and Cowell 1449; Chase 6793, 6794. Bayamon, Chase 6373, 6646. Catano, Chase 6637. San Juan, Chase 6356, 6359, 6785. Rio Piedras, Cowgill 691; Wetmore 176. Trujillo Alto, Chase 6761 $6775 \frac{1}{12}$. Mameyes, Chase 6650. Rio Grande, Chase 6725. Fajardo, Chase 6655, 6704. Humacao, Eggers 676. Vieques Island, Chase 6687.

Leeward Islands: Antigua, Box 186. Guadeloupe, Balbis in 1822; Hitchcock 16411.

Windward Islands: St. Lucia, Box 186.

Trinidad: Cedros, Broadway 4921; Hitchcock 10145. Icacos, Hitchcock 10156. Dabadie, Broadway. Manzanilla, Hitchcock 10366.

Toвago: Scarborough, Hitchcock 10285. Milford Road, Broadway 3066. Old Grange Road, Broadway 4696.

64. Paspalum densum Poir., in Lam., Encycl. 5: $32.1804 . \quad$ Puerto Rico.

Paspalum paniceum J. E. Smith, in Rees's Cycl. 26: no. 14. 1813. Jamaica.

Culms erect; robust, 1 to $2 \mathrm{~m}$ tall; blades elongate, 1 to $2 \mathrm{~cm}$ wide; panicle 12 to $30 \mathrm{~cm}$ long, dense, tapering upward; racemes 50 to 100 , rather thick, the lower 5 to $9 \mathrm{~cm}$ long, the others successively shorter and more crowded, the rachis conspicuously ciliate with stiff hairs 2 to $5 \mathrm{~mm}$ long; spikelets about $2 \mathrm{~mm}$ long, suborbicular, tan to brownish or purplish (fig. 185).

Marshes, wet savannas, and low open ground, or in shallow water, West Indies to Panama and Brazil.

Cuba: Mántua, Ekman 11085. Hanábana, Wright 3447. Rodrigo, Léon 9135. Placetas del Sur, Léon 6420. Baraguá, Hitchcock 23381. 


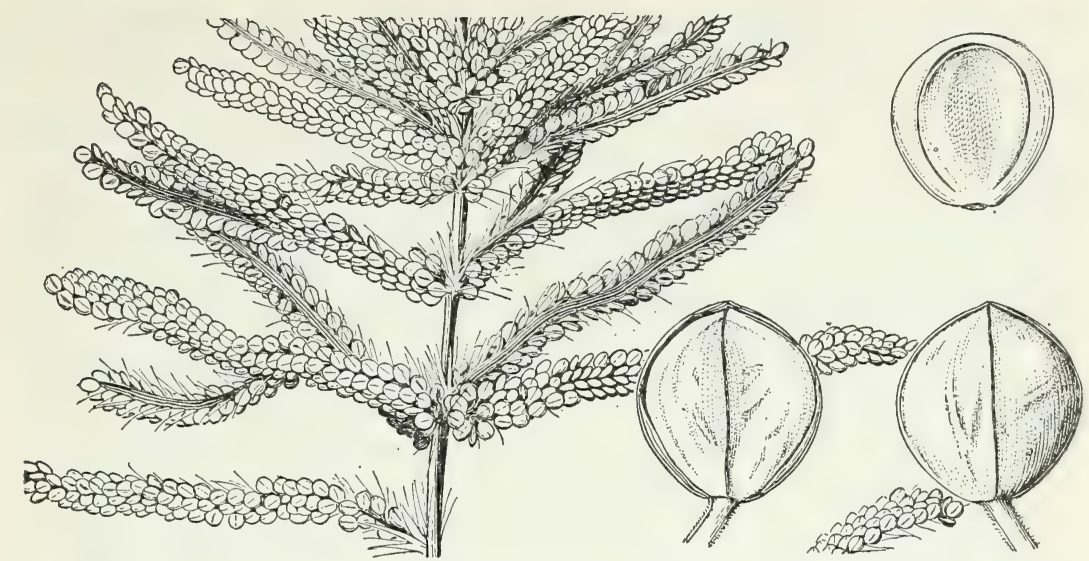

Figure 195.-Paspalum densum. Panicle $\times 1$; two views of spikelet, and floret, $\times 10$ (Chase 6791 ).

Jamaica: Bull Head Mountain, Hitcheock 9556 (Amer. Gr. Nat. Herb. 579), Killits, Harris 11149. Appleton, Hitchcock 9657. Bog Walk, Harris 12214.

Haiti: Marmelade, Leonard 8357. Caille la Croix, Leonard 7989. St. Michel de l'A talaye, Ekman H 9416. Petite-Riviere de l'Artibonite, Ekman H 3430.

Dominican Republic: Pimentel, Abbott 671; Ekman H 13241. Leonor, Valeur 505. Sabana de la Mar, Ekman H 15663.

Puerto Rico: Vega Baja, Chase 6791. Between Bayamon and Cantano, Siahl 42.

Virgin Islands: St. Thomas, Riedley.

Leeward Islands: Guadeloupe, Duss.4224.

Trinidad: St. Joseph, Hitchcock 10025. St. Augustine, Hart 2155. Longdenville, Broadway 2618. Claxton Bay, Hitchcock 10115.

65. Paspalum coryphaeum Trin., Gram. Pan. 114. 1826. Brazil. Paspalum violascens Mez, Repert. Sp. Nov. Fedde 15: 73. 1917. Trinidad, Bot. Gard. Herb. 2175.

Culms 1 to $4 \mathrm{~m}$ tall, with short hard rhizomes; blades flat, elongate, 1 to $2 \mathrm{~cm}$ wide, puberulent to nearly glabrous; racemes 10 to 45 , some-

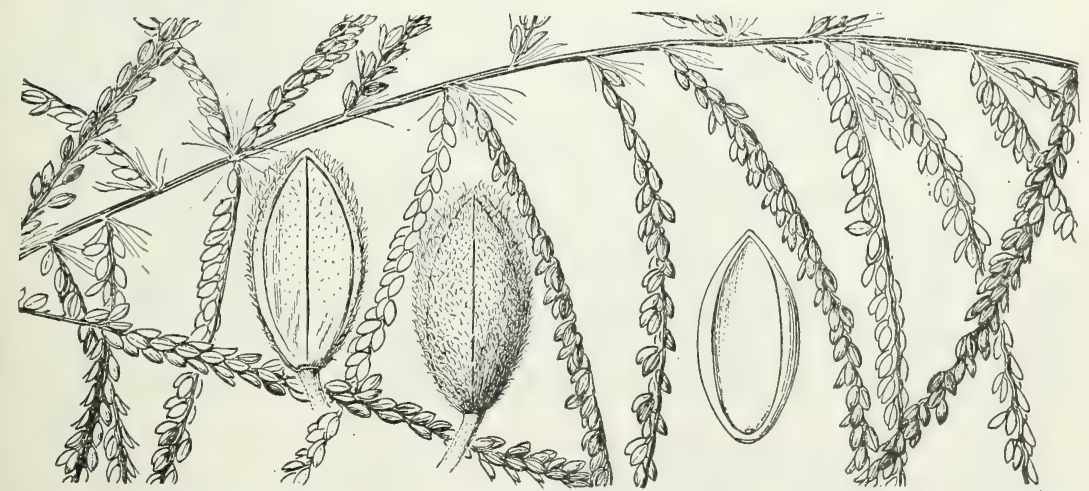

FIGURE 186.-Paspalum coryphaeum. Panicle, $\times 1$; two views of spikelet, and floret, $\times 10$ (Langsdorff, and Chase 9058). 
what distant, nodding, the lower 6 to $12 \mathrm{~cm}$ long, the common axis 10 to $25 \mathrm{~cm}$ long; spikelets 2 to $2.5 \mathrm{~mm}$ long, elliptic, finely glandularpubescent (fig. 186).

Savannas, brushy slopes, and river banks, Panam» and Trinidad to Brazil.

Trinidad: Botanic Garden, Broadway 2175, 5947. St. Joseph, Hitchcock 10183, 10184, 10186, 10192. California, Hitchcock 10107. La Brea, Bot. Gard. Herb. 2262. Brighton, Hitchcock 10092.

66. Paspalum plicatulum Michx., Fl. Bor. Amer. 1: 45.1803. Georgia and Florida.

Paspalum undulatum Poir., in Lam., Encycl. 5: 29. 1804. Puerto Rico.

Paspalum antillense Husnot, Bull. Soc. Linn. Normand. (II) 5: 260.

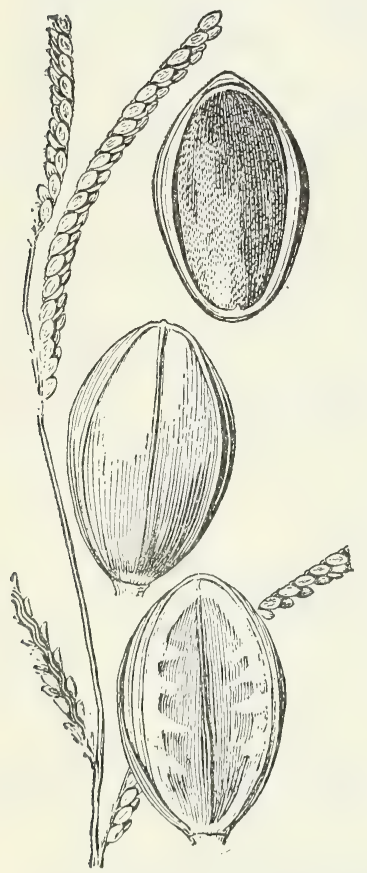

FIGURE 187,-Paspalum plicatulum. Panicle, $\times 1$; two views of spikelet, and fioret, $\times 10$ (Chase 7061).
1871. Guadeloupe.

Panicum plicatulum Kuntze, Rev. Gen. Pl. $3^{2}$ : 363 . 1898.

Culms erect or ascending, 50 to 100 cm tall, rather slender; blades mostly folded at base, elongate, 3 to $10 \mathrm{~mm}$ wide; racemes 2 to several, usually 3 to 10,2 to $10 \mathrm{~cm}$ long; spikelets usually 2.5 to $2.8 \mathrm{~mm}$ long, obovate-oval, the sterile lemma wrinkled transversely just inside the margin; fruit dark brown (fig. 187).

Open ground or wood borders, southeastern United States to A r g e n t i n a ; throughout the West Indies.

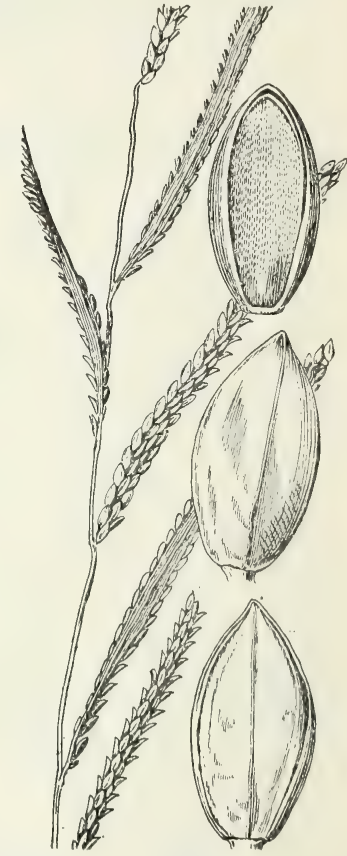

Figure 188.-Paspalum wrightii. Panicle, $X 1$; two views of spikelet, and floret, $\times 10$ (type).

67. Paspalum wrightii Hitchc. and Chase, Contrib. U. S. Natl. Herb. 18: 310. 1917. Cuba, Wright 3843.

Subaquatic; culms about $1.5 \mathrm{~m}$ tall, erect from a decumbent or floating base; blades flat, elongate, about $5 \mathrm{~mm}$ wide, long-pilose just back of the ligule; racemes 5 to 9 , ascending, 4 to $8 \mathrm{~cm}$ long, the axis 8 to $10 \mathrm{~cm}$ long; spikelets about $2.5 \mathrm{~mm}$ long, elliptic; fruit brown (fig. 188).

Margin of pools and streams, Gulf Coast, Texas, and western Cuba, sometimes forming dense colonies.

Cuba: Pinar del Río, Wright 3843. Arroyo Mateo Sánchez, Ekman 17910 (Amer. Gr. Nat. Herb. 978). 
68. Paspalum motembense Léon, in Britton, Bull. Torrey Bot. Club 53: 457. 1926. Cuba, Léon and Loustalot 9354.

Culms about $60 \mathrm{~cm}$ tall, erect, with a short rhizome; blades mostly folded, elongate, 5 to $8 \mathrm{~mm}$ wide; racemes several, ascending, the lower about $5 \mathrm{~cm}$ long, the upper gradually shorter, the axis about $15 \mathrm{~cm}$ long; spikelets $2.5 \mathrm{~mm}$ long, elliptic; fruit brown (fig. 189).

Grassy places, Cuba. Known only from the type collection, from Motembo, Province of Santa Clara.

69. Paspalum urbanianum Ekman, sp. nov ${ }^{60}$

Perennial with a short scaly rhizome; culms 80 to $100 \mathrm{~cm}$ tall erect, appressed branches from the lower nodes, the lower part slightly spongy, clothed with overlapping old sheaths; leaves numerous, crowded toward

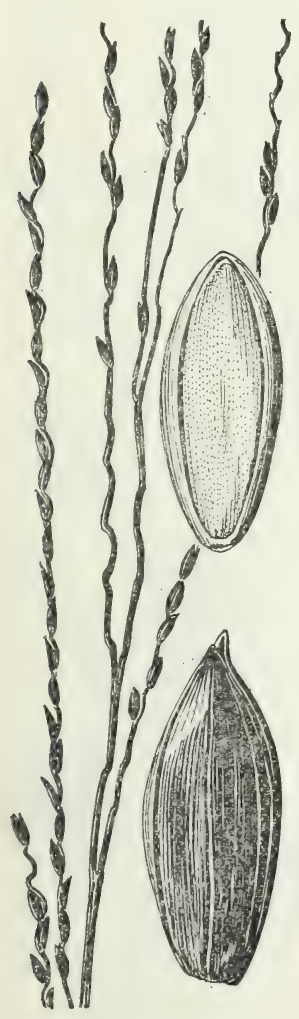

Figure 190.-Paspalum urbanianum. Panicle, $\times 1$; spikelet and floret, $\times 10$ (type). the base, the sheaths papillose-hirsute toward the summit, usually conspicuously so on the collar; ligule membranaceous, scarcely $1 \mathrm{~mm}$ long; blades terete, the margins grown together above the hispid base, stiff but rather brittle, 30 to $60 \mathrm{~cm}$ long (the

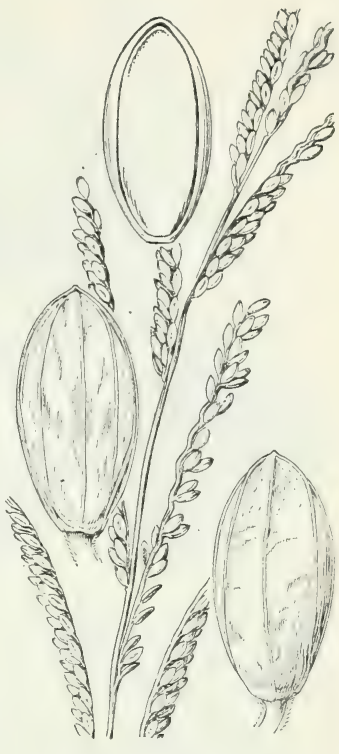

FIGURE 189.-Paspalum motembense. Panicle, $\times 1$; two views of spikelet, and fioret, $\times 10$ (type). uppermost reduced) 1.5 to $2 \mathrm{~mm}$ thick, erect or ascending, sharp-pointed; racemes 3 to 5 , slender, narrowly ascending, purplish-brown, 8 to $15 \mathrm{~cm}$ long, 3 to $5 \mathrm{~cm}$ distant on a slender common axis; rachis 0.7 to $0.8 \mathrm{~mm}$ wide, flexuous, sometimes naked at base; spikelets in pairs or solitary on short scabrous pedicels, not crowded, sometimes distant, often unsymmetrical, 3.5 to 3.8 $\mathrm{mm}$ long, about $1.5 \mathrm{~mm}$ wide, elliptic, acute; glume and sterile lemma equal, pointed beyond the fruit, glabrous or very obscurely pubescent, 5-nerved, the outer pair of nerves obscure, thin, the lemma sometimes faintly wrinkled; fruit $3 \mathrm{~mm}$ long, minutely papillosestriate, chestnut-brown, the apex and margin of the lemma paler (fig. 190).

Type in the United States National Herbarium, no. 1502227 , collected in a moist place, about $2,000 \mathrm{~m}$ altitude, Loma Tina, prov. Azua, in the Cordillera Central, Dominican Republic, October 9, 1929, by E. L. Ekman (no. H 13712).

60 Perenne; culmi $80-100 \mathrm{~cm}$ alti erecti; folia numerosa; vaginae summo hispidae; laminae elongata suberectae cylindricae subrigidae pungentes; racemi $3-5$ purpurei $8-15 \mathrm{~cm}$ longi; rachis $0.7-0.8 \mathrm{~mm}$ lata spiculae geminae $3.5-3.8 \mathrm{~mm}$ longae $1.5 \mathrm{~mm}$ latae acutae glabrae vel obscure pubescentes; fructus $3 \mathrm{~mm}$ longus castaneus. 
The base of the type specimen and of Ekman H 13603 suggest that the plants were growing in deep humus, such as is often found in open ground above timberline. A note by Dr. Ekman on H 13603 reads:

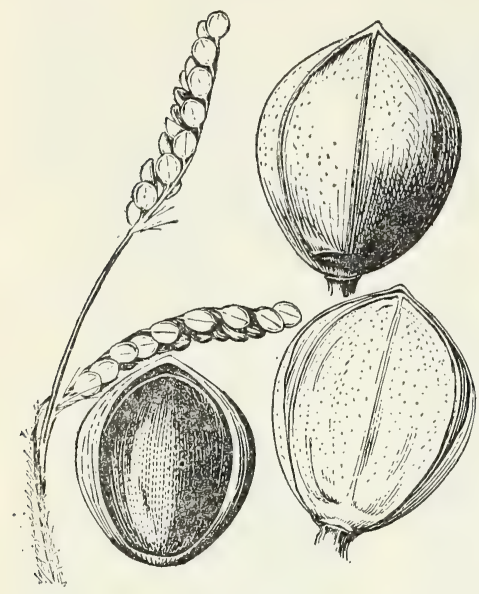

Figure 191.-Paspalum convexum. Panicle, $\times 1$; two views of spikelet, and floret, $\times 10$ (Palmer 592 in 1866). "Silt flats, about $1,950 \mathrm{~m}$, very abundant. One of the very few plants characteristic of the high mountain group west of Constanza. As a rule all plants found in this region grow also in the Los Valles region." No.H 13542 is said to form vast colonies. Known only from Cordillera Central, prov. Azua, Dominican Republic.

Dominican Republic: Loma Tina, Ekman H 13712. San Juan, Arroyo del Oro, Ekman H 13542; Lomas de la Medianía, Ekman H 13603.

70. Paspalum convexum Humb. and Bonpl., in Flügge, Monogr. Pasp. 175. 1810. Mexico.

Paspalum hemicryptum Wright, An. Acad. Cien. Habana 8: 204. 1871. Cuba, Wright 3847.

Tufted leafy branching usually spreading annual; culms usually 20 to $40 \mathrm{~cm}$ tall; blades flat, ratherlax, 5 to $20 \mathrm{~cm}$ long, 3 to $11 \mathrm{~mm}$ wide; racemes usually 2 or 3 , thick, 2 to $4 \mathrm{~cm}$ long; spikelets 2.2 to $3 \mathrm{~mm}$ long, obovate-suborbicular, appressed-pubescent to glabrous; fruit dark brown (fig. 191).

Open ground, cultivated and waste places, Mexico to Brazil; Cuba and Trinidad, probably introduced.

Cuba: El Salado, Wright 3847. Gamboa, Ekman 15008.

Trinidad: La Brea, Broadway 4983. Pitch Lake, Broadway 9012 $\frac{1}{2}$.

71. Paspalum melanospermum Desv., in Poir., in Lam., Encycl. Sup. 4: 315. 1816. Cayenne.

Paspalum olivaceum Hitchc. and Chase, Contrib. U. S. Natl. Herb. 18: 310. 1917. Guadeloupe, Duss 3915.

Leafy nearly glabrous annual; culms 40 to $70 \mathrm{~cm}$ long, ascending from a decumbent base; blades lax, flat, 10 to $15 \mathrm{~cm}$ long, 5 to $10 \mathrm{~mm}$ wide; racemes 2 to 7 , arcuate-spreading, 1 to 6 $\mathrm{cm}$ long, the slender subflexuous axis 4 to $8 \mathrm{~cm}$ long; spikelets $2 \mathrm{~mm}$ long, obovate, brown; fruit dark brown (fig. 192).

Open moist ground, northern South America; Guadeloupe and Martinique, probably introduced.

Leeward IslaAnd: Guadeloupe, Duss 3915; Husnot 76 in part.

Windward Islands: Martinique, Duss 4012; Hitchcock 16445. 
72. Paspalum boscianum Flügge, Monogr. Pasp. 170. 1810. Carolina.

Bull paspalum.

Rather succulent branching annual; culms mostly 20 to $60 \mathrm{~cm}$ long, ascending to widely spreading; blades flat, mostly 15 to $30 \mathrm{~cm}$ long, 8 to $10 \mathrm{~mm}$ wide; racemes usually 4 to $11,2.5$ to $9 \mathrm{~cm}$ long,
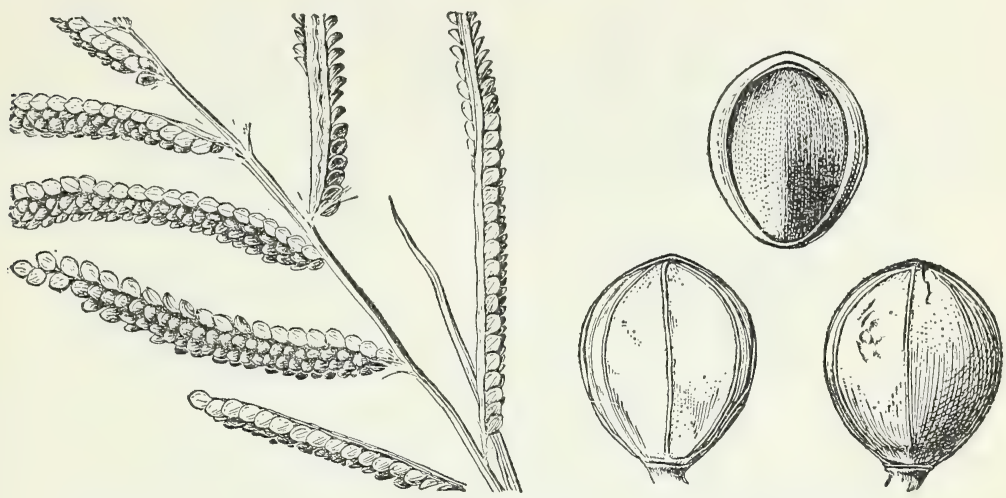

Figure 193.-Paspalum boscianum. Panicle, $\times 1$; two views of spikelet, and floret, $\times 10$ (Kearney 152).

the rachis 2 to $2.5 \mathrm{~mm}$ wide; spikelets 2 to $2.2 \mathrm{~mm}$ long, obovatesuborbicular; fruit brown (fig. 193).

In the Grasses of the West Indies this species was described under $P$. melanospermum Desv.

Moist or wet open ground, along ditches and ponds, sometimes a weed in cultivated soil, southeastern United States; West Indies to Brazil.

Dominican Republic: Azua, Ekman $\mathrm{H}$ 13673. Cuenca, Ekman H 11002. Higüey, Ekman H 12177. Constanza, Ekman H 14070. Sabana de la Mar, Ekman H 15551.

Puerto Rico: Mayaguez, Chase 6172. Maricao, Chase 6234. Sierra Luquillo, Chase 6724; Hioram 367.

Virgin Islands: St. Thomas, Herb. Ventenat (Delessert Herb.).

73. Paspalum pulchellum Kunth, Mèm. Mus. Hist. Nat. 2: 68. 1815. Based on Reimaria elegans Humb. and Bonpl.

Reimaria elegans Humb. and Bonpl.; Flügge, Mionogr. Pasp. 216. 1810. Not Paspalum elegans Flügge, op. cit. 183. Venezuela.

Culms erect, slender, 25 to $75 \mathrm{~cm}$ tall; blades flat, becoming involute, 5 to $25 \mathrm{~cm}$ long, 1.5 to

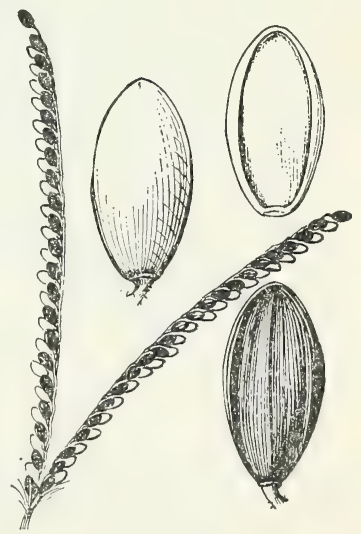

FIGURE 194.-Paspalum pulchellum. Racemes, $\times 1$; two views of spikelet, and floret, $\times 10$ (Hitcheock 10066).

$4 \mathrm{~mm}$ wide, papillose-pilose; racemes usually 2 , approximate, or somewhat distant, 2 to $9 \mathrm{~cm}$ long; spikelets 1.7 to $2 \mathrm{~mm}$ long, elliptic, the glume wanting, the sterile lemma often dark purple (fig. 194).

Sandy mostly moist savannas and pinelands, Guatemala to Brazil; Cuba, Hispaniola, and Trinidad. 


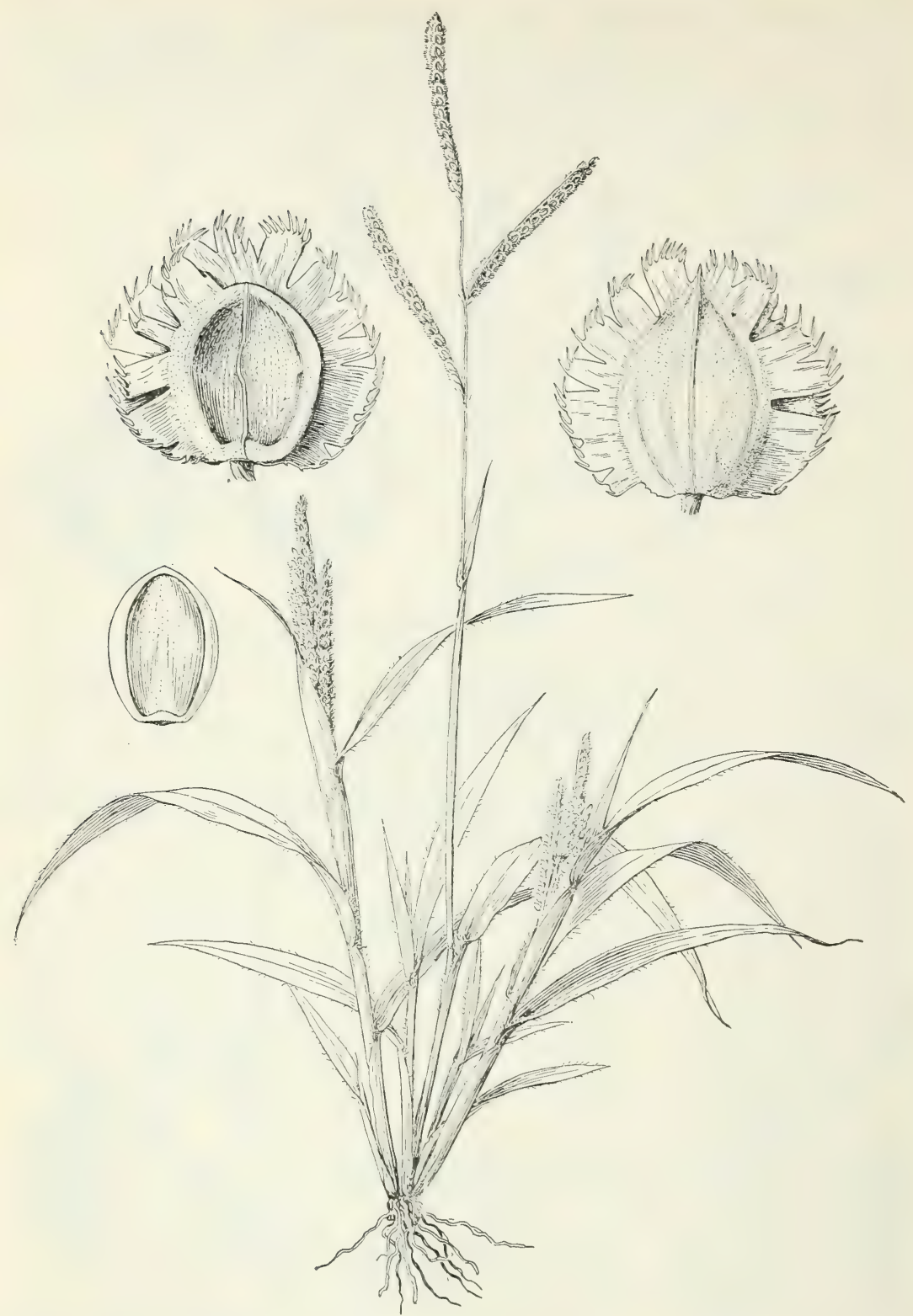

FIGURE 195.-Paspalum fimbriatum. Plant, $\times 1 / 2$ (Chase 6296 ); two views of spikelet, and floret, $\times 10$ (Hitcheock 9773).

Cuba: Guane, Léon 6936. Herradura, Baker and Dimmock 4813; Ekman in 1922 (Amer. Gr. Nat. Herb. 984); Hitchcock 469. Hanábana, Wright 171. San Marcos, Léon 9185. Placetas del Sur, Léon 8156. Nagua, Léon 11344. Isla de Pinos, Britton and Wilson 14282; Ekman 11715. Without locality, Wright 3439. 
Dominican Republic: Matas, Eggers 2439. Cuenca, Ekman H 13304. Monción, Ekman H 13014. Sabana de la Mar, Ekman H 15609 .

Trinidad: Comuto Station, Hitchcock 10066. Arouca, Hitchcock 10338.

74. Paspalum fimbriatum H. B. K., Nov. Gen. et Sp. 1: 93. pl. 28. 1815. Colombia.

Annual; culms erect, 25 to $100 \mathrm{~cm}$ tall; blades flat, mostly 10 to $20 \mathrm{~cm}$ long, 5 to $12 \mathrm{~mm}$ wide; racemes 3 to 8 , ascending or spreading, 2.5 to $8 \mathrm{~cm}$ long, the axis 8 to $10 \mathrm{~cm}$ long; spikelets about $2.3 \mathrm{~mm}$ long, with a broad firm notched wing, the wing and spikelet together about $3 \mathrm{~mm}$ long and wide (fig. 195).

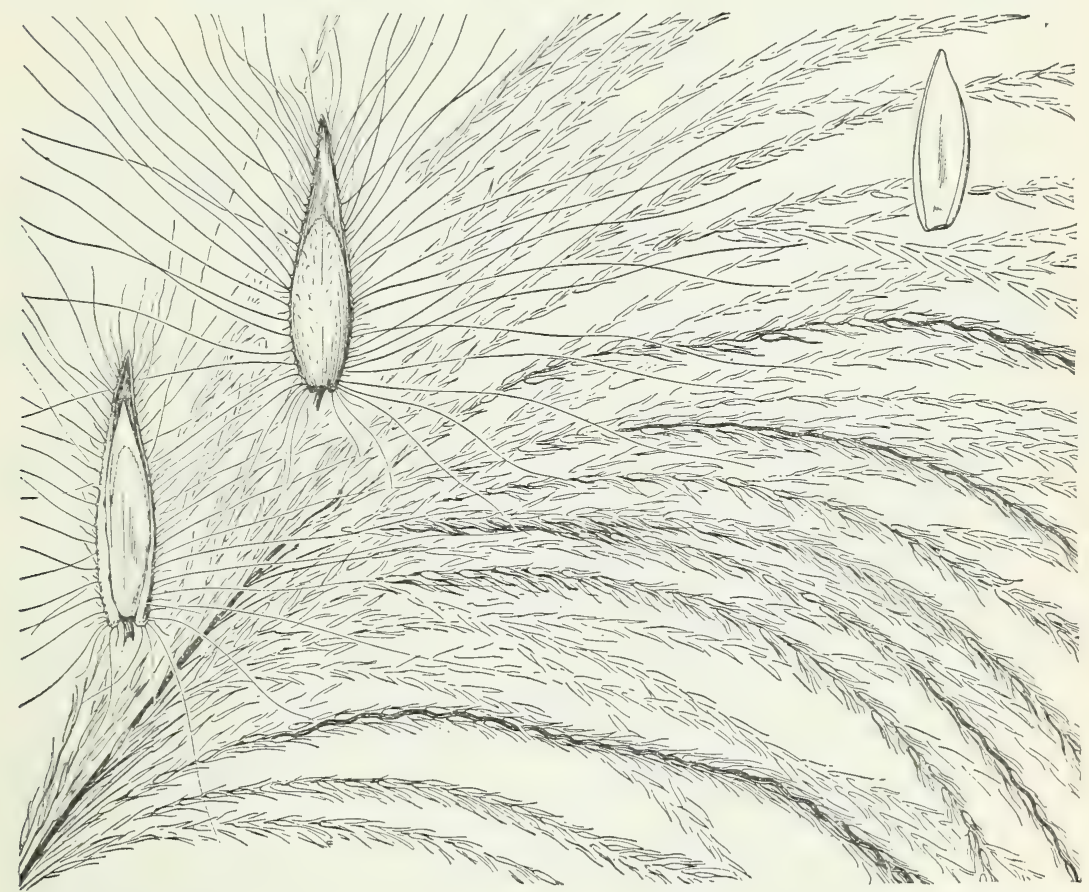

FIGURE 196.-Paspalum saccharoidcs. Panicle, $\times 1 / 2$; two views of spikelet, and floret, $\times 10$ (Hitchcock 7904)

Savannas, open and waste ground, Panama, the West Indies, and northern South America. To be found on probably all the islands of the West Indies.

75. Paspalum saccharoides Nees, in Trin., Gram. Icon. 1: pl. 107. 1827. Based on Saccharum polystachyum Swartz.

Saccharum polystachyum Swartz, Prodr. Veg. Ind. Occ. 21. 1788. Not Paspalum polystachyum R. Br., 1810. St. Christopher.

Panicum saccharoides Kunth, Rév. Gram. 2: 237. pl. 30. 1830.

Tricholaena saccharoides Griseb., Syst. Unt. Veg. Karaib. 117. 1857.

Paspalum polystachyum Kuntze, Rev. Gen. Pl. 2: 786. $1891 . \quad$ Not P. polystachyum R. Br., 1810. 
Robust branching perennial growing in tough clumps; culms 1 to $2 \mathrm{~m}$ long, often decumbent or creeping at base; blades flat, 15 to 30 $\mathrm{cm}$ long, 8 to $15 \mathrm{~mm}$ wide; panicle subflabellate, feathery; racemes numerous, slender, silky, drooping, 15 to $30 \mathrm{~cm}$ long, the axis short; spikelets 2.5 to $3 \mathrm{~mm}$ long, lanceolate, acuminate, bearing a fringe of pale silky hairs as much as 5 to $8 \mathrm{~mm}$ long (fig. 196).

Open brushy or jungly slopes, mostly in moist spots, Costa Rica and the Lesser Antilles to Bolivia.

Leeward Islands: St. Kitts, Box 151. Dominica, Imray 311.

Windward Islands: Martinique, Duss 1317. Grenada, Broadway 62, 2919, and in 1905; Smith 192, 843.

Trinidad: Cedros, Hitchcock 10134. Without locality, Broadway in 1919.

Toвago: Adelphi, Broadway 3979. Center of island, Hitchcock 10278.

\section{PANICUM L., Sp. Pl. 55. 1753}

Spikelets more or less compressed dorsiventrally, arranged in open or compact panicles, rarely in racemes; glumes herbaceous, nerved, usually very unequal, the first often minute, the second typically equaling the sterile lemma, the latter of the same texture and simulating a third glume, bearing in its axil a membranaceous or hyaline palea and sometimes a staminate flower, the palea rarely wanting; fertile lemma chartaceous-indurate, typically obtuse, the nerves obsolete, the margins inrolled over an enclosed palea of the same texture. Annuals or perennials of various habit.

1a. Axis of branchlets proaiuced beyond the base of the uppermost spikelet as a point or bristle 1 to $6 \mathrm{~mm}$ long, sometimes nearly obsolete. Culms cespitose, a slender rhizome developed in some species, usually found in $P$. leonis, often in $P$. utowanaeum, but rarely in the others (Subgenus PaURochaetidm).

Second glume about as long as fruit, this and the sterile lemma faintly reticulate; first glume rounded or truncate_....... P. CHAPMANI.

Second glume about two-thirds as long as fruit, neither this nor the sterile lemma reticulate; first glume usually acute.

Panicles strict, 15 to $35 \mathrm{~cm}$ long; spikelets spreading_-_92. P. PRADANUM.

Panicles not strict, mostly subflexuous, not more than $10 \mathrm{~cm}$ long; spikelets not spreading (a few sometimes slightly spreading).

Blades 4 to $7 \mathrm{~mm}$ wide, thickish, mostly flat, 5 to $15 \mathrm{~cm}$ long.

Blades 1 to $3 \mathrm{~mm}$ wide, flat to involute.

94. P. LEONIS. Spikelets 1.4 to $1.5 \mathrm{~mm}$ long Spikelets 1.8 to $2.5 \mathrm{~mm}$ long.

Blades flat or folded toward the apex, mostly 3 to $8 \mathrm{~cm}$ (rarely to 12 $\mathrm{cm})$ long, the basal crowded in a tuft, those of the culm spreading .

Blades of the innovations involute, 8 to $20 \mathrm{~cm}$ long, ascending, the basal not in a dense tuft

93. P. UTOWANAEUM.

1b. Axis of branchlets not produced into a bristle. (In P. geminatum the somewhat flattened axis pointed but not bristle-form.)

2a. Basal leaves usually distinctly different from those of the culm, forming a winter rosette; culms at first simple, the spikelets of the primary panicle not perfecting seed, later usually becoming much branched, the small secondary panicles with cleistogamous fruitful spikelets (Subgenus Dichanthelium).

Foliage soft and lax, the flat blades prominently ciliate; plants branching from the base, finally forming rosettes or cushions (Laxiflora).

Spikclets papillose-pilose; sheaths retrorsely pilose_..59. P. XALAPENsE. Spikelets glabrous; sheaths not retrorsely pilose.

Blades glabrous on the surface.

60. P. POLYCAULON.

Blades pilose on the surface

61. P. Strigosum. 
Foliage not soft and lax; plants branching from the culm nodes.

3a. Blades long, stiff, conspicuously striate, tapering from base to apex; autumnal phase bushy-branched above; spikelets turgid, attenuate at base, mostly pustulose-pubescent (Angustifolia).

Nodes bearded

62. P. CHRYsopsidifolium.

Nodes not bearded.

Autumnal blades flat; lower panicle branches spreading or deflexed.

64. P. ANGUSTIFOLIUM.

Autumnal blades involute; lower panicle branches more or less ascending.

Spikelets 3 to $3.5 \mathrm{~mm}$ long, pointed

63. P. FUSIFORME.

Spikelets less than $3 \mathrm{~mm}$ long, not pointed or obscurely so.

Plants glabrous or nearly so; autumnal culm erect.

Plants pubescent, at least on the lower half.

66. P. NEURANTHUM.

Spikelets about $2.4 \mathrm{~mm}$ long; vernal blades 7 to $12 \mathrm{~cm}$ long; autumnal blades not falcate_.....65. P. ARENICOLOIDES. Spikelets about $2 \mathrm{~mm}$ long; vernal blades 4 to $6 \mathrm{~cm}$ long; autumnal blades much crowded, falcate.

67. P. aCicUlare.

3b. Blades not long and stiff; culms not bushy-branched.

Spikelets subglobose or pyriform.

Blades spreading, rarely over $5 \mathrm{~cm}$ long and $5 \mathrm{~mm}$ wide; spikelets

pyriform; autumnal phase bushy-branching (Lancearia).

Spikelets about $1.5 \mathrm{~mm}$ long............ 83. P. PORTORICENSE.

Spikelets about $2 \mathrm{~mm}$ long.

Blades firm, glabrous above; culms stiffly ascending.

85. P. LANCEARIUM.

Blades lax, softly puberulent on both surfaces; culms decumbent. 84. P. PATULUM.

Blades erect, 7 to $13 \mathrm{~cm}$ long, 7 to $14 \mathrm{~mm}$ wide, spikelets sphaeroidal (Sphaerocarpa).

Culms spreading; panicle nearly as broad as long; spikelets about 1.7 $\mathrm{mm}$ long .....................

Culms erect or ascending; panicle never more than two-thirds as broad as long; spikelets about $1.1 \mathrm{~mm}$ long.

79. P. ERECTIFOLIUM.

Spikelets not subglobose nor pyriform-elliptic.

4a. Ligule of conspicuous hairs usually 3 to $5 \mathrm{~mm}$ long.

Sheaths glabrous or only the lowermost somewhat pubescent; spikelets not more than $1.3 \mathrm{~mm}$ long (Spreta).

Culms and sheaths glabrous _._._._. 73 . P. LONGILIGULATUM.

Culms and sheaths appressed-pubescent.

Spikelets 1.2 to $1.3 \mathrm{~mm}$ long._._. Spikelets $1 \mathrm{~mm}$ long.

Sheaths strongly pubescent (Lanuginosa).

Spikelets about $2 \mathrm{~mm}$ long. (See also $P$. viscidellum.)

Spikelets about $1.5 \mathrm{~mm}$ long.

74. P. ACUMinatum.

Blades velvety-puberulent with long hairs intermixed.

75. P. ALBEMARLENSE. Blades villous . . .

4b. Ligule obsolete or nearly so (manifest in $P$. viscidellum).

Spikelets about $3 \mathrm{~mm}$ long, elliptic, pubescent; blades somewhat cordate (Commutata)

Spikelets less than $3 \mathrm{~mm}$ long.

Blades of midculm elongate; plant villous or velvety (Scoparia). Spikelets $2.5 \mathrm{~mm}$ long._._._........86. P. SCOPARIUM. Spikelets less than $2 \mathrm{~mm}$ long..... P. Viscidellum.

Blades of midculm not elongate.

Nodes bearded (Dichotoma) .............68. P. NiTidum.

Nodes not bearded.

Sheaths crisp- or appressed-pubescent (Columbiana).

Sheaths glabrous.

77. P. WILMingtonense.

Culms slender, rarely less than $40 \mathrm{~cm}$ tall (Dichotoma).

Spikelets about $1.5 \mathrm{~mm}$ long_-_70. P. CAERULESCENS.

Spikelets about $2 \mathrm{~mm}$ long.....69. P. ROANOKEnse. 
Culms delicate, usually less than $40 \mathrm{~cm}$ tall, spikelets not more than $1.5 \mathrm{~mm}$ long (Ensifolia).

Spikelets about $1 \mathrm{~mm}$ long; blades not white-margined.

82. P. CHAMAELONCHE.

Spikelets about $1.5 \mathrm{~mm}$ long; blades white-margined. Uppermost culm blades much reduced.

80. P. ALBOMaRginatum. Uppermost culm blades about as long as the others.

81. P. TRIFOLIUM.

2b. Basal leaves similar to the culm leaves, not forming a winter rosette; spikelets all fertile.

5a. Plants annual.

Spikelets laterally compressed; second glume carinate. Panicles small, few-flowered ................... Spikelets not laterally compressed; second glume not carinate.

Spikelets plano-gibbous, the second glume swollen, bristly and burlike at maturity; first glume nearly as long as the minute spikelet.

Spikelets not plano-gibbous nor burlike.

58. P. HIRTUM.

Panicles consisting of more or less secund spikelike racemes; fruit transversely rugose; glumes and sterile lemma usually reticulateveined (Fasciculata).

Spikelets strongly reticulate-veined, 2 to $3 \mathrm{~mm}$ long, glabrous.

Spikelets scarcely reticulate-veined or only near the apex.

4. P. FASCICULATUM. Spikelets not more than $2 \mathrm{~mm}$ long, glabrous_- 3. P. REPTANS. Spikelets more than $3 \mathrm{~mm}$ long, pubescent.

Rachis pilose with bristly hairs; plants more or less velvety.

Rachis scabrous but not bristly.

5. P. MOLLE.

Spikelets glabrous _...... Spikelets tuberculate-hispid... 6. P. Echindlatum. Panicles more or less diffuse.

Blades ovate-lanceolate.............. 43. P. TRICHOIDES.

Blades linear.

First glume not more than one-fourth the length of the spikelet, truncate or triangular-tipped.... 8. P. DICHотомIFLORUM.

First glume usually as much as half the length of the spikelet, acute or acuminate.

Inflorescence elongate, composed of several approximate implicate panicles........

Inflorescence not as above.

Panicles more than half the length of the entire plant.

13. P. CAPILLARE.

Panicles not more than one-third the entire height of the

5b. Plants perennial. plant...... 14. P. HirTicaule.

6a. Spikelets short-pediceled along one side of the panicle branches, forming more or less spikelike racemes.

Spikelets more or less pubescent or hispid.

Spikelets $4 \mathrm{~mm}$ long; blades 2 to $4 \mathrm{~cm}$ wide_- 55 . P. ASPERIFOLIUM.

Spikelets less than $3 \mathrm{~mm}$ long; blades mostly less than $1 \mathrm{~cm}$ wide.

Sterile lemma glandless; second glume inflated-gibbous.

Sterile lemma bearing a pair of crateriform glands.

48. P. VenezUelae. 41. P. PULCHELLUM.

Spikelets glabrous.

Blades lanceolate or ovate-lanceolate; glumes strongly carinate.

Blades not more than $5 \mathrm{~cm}$, usually 2 or $3 \mathrm{~cm}$, long; second glume rather blunt and shorter than the sterile lemma.

39. P. STOLONIFERUM.

Blades 5 to $11 \mathrm{~cm}$ long; second glume acute, nearly equaling the sterile lemma ................... 40. P. Frondescens. 
Blades linear, often elongate; glumes not carinate or but slightly so. Fruit transversely rugose.

Nodes bearded..... 2. P. PURPURASCENS. Nodes not bearded................ 1 . P. GEMiNATUM. Fruit not rugose.

Spikelets not expanded at maturity by an enlarged sterile palea, pointed... P. POLYGONATUM. Spikelets expanded at maturity by the enlarged sterile palea.

Blades narrowed toward the base.......... P. P. LAXUM. Blades cordate or truncate at base.

Spikelets $2 \mathrm{~mm}$ long; panicle branches erect or nearly SO . . P. STEVENSIANUM.

Spikelets not more than $1.6 \mathrm{~mm}$ long; panicle branches spreading or ascending.

Panicles one-third to half as wide as long; spikelets not conspicuously secund, somewhat irregularly disposed; blades cordate-clasping _- 35. P. BOLIVIENse.

Panicles rarely one-fourth as wide as long; spikelets conspicuously secund and regularly disposed.

Culms as much as $2 \mathrm{~m}$ long; panicles 25 to $30 \mathrm{~cm}$ long . Culms not more than $1 \mathrm{~m}$ tall; panicles 5 to $15 \mathrm{~cm}$ long . . PILOSUM.

$6 \mathrm{~b}$. Spikelets in open or sometimes in contracted or congested panicles, but not in 1-sided spikelike racemes.

Fruit transversely rugose

Fruit not transversely rugose.

Culms more or less succulent. Plants glabrous or nearly so throughout, aquatic or subaquatic.

First glume not more than one-fifth the length of the spikelet.

Spikelets 4 to $5 \mathrm{~mm}$ long; fruit long-acuminate-

Spikelets 2 to $3 \mathrm{~mm}$ long; fruit not acuminate.

Spikelets $2 \mathrm{~mm}$ long.

Spikelets about $3 \mathrm{~mm}$ long

First glume one-third to one-half the length of the spikelet.

Culms erect, panicle contracted.......... 31 . P. CONDENSUM.

Culms long-decumbent at base; panicle open_-.54. P. GRANDE.

Culms not succulent.

First glume not more than one-fifth the length of the spikelet or wanting (occasionally a long glume developed in $P$. discrepans.)

Fruit felty villous at base and apex; first glume often minute or wanting; fruit keeled, pubescent at apex_57. P. DISCREPANS.

Fruit not felty villous; first glume evident; fruit not keeled, sparsely pubescent all over......... 42. P. SCHIFFNERI.

First glume more than one-fifth the length of the spikelet.

Sterile palea enlarged and indurate at maturity, expanding the spikelet... P. ExIGUIFLOROM.

Sterile palea, if present, not enlarged and indurate.

First glume less than one-third the length of the spikelet, blunt....... P. BARTOWENSE.

First glume usually more than one-third the length of the spikelet.

7a. Plants forming conspicuous hard creeping rhizomes.

First glume less than half the length of the spikelet; spikelets not more than $2.5 \mathrm{~mm}$ long.

Panicle loosely flowered; first glume truncate, about onefifth the length of the spikelet_-_-20. P. REPENS.

Panicles rather densely flowered; first glume triangular, about one-third the length of the spikelet........

21. P. GOUINI.

First glume more than half the length of the spikelet; spikelets 3 to $4 \mathrm{~mm}$ long.

Culms decumbent or creeping at base, mostly 2 to 4 $\mathrm{m}$ tall............ P. ALTUM. 
Culms erect.

Panicles strongly contracted, elongate; seacoast plants growing in large bunches.

24. P. AMARULUM.

Panicles open, rather narrow; plants of low ground but not littoral, the culms solitary or few in a clump _......22. P. VIRGATUM var. CUBENSE.

7b. Plants not forming creeping scaly rhizomes.

Fruit crested at apex; spikelets 5.5 to $6 \mathrm{~mm}$ long.

Fruit not crested.

56. P. ZIZANIOIDES.

Panicles narrow and few-flowered; culms erect and wiry; blades drying involute.

Second glume and sterile lemma exceeding the fruit; spikelets somewhat pointed.

Pedicels bearing a few long hairs_26. P. TENERUM.

Pedicels puberulent, without long hairs.

30. P. BEYERI.

Second glume and sterile lemma not exceeding the fruit; spikelets rather blunt.

Pedicels bearing a few long stiff erect hairs at the

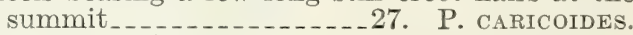

Pedicels not hairy.

Spikelets attenuate at base, about $2 \mathrm{~mm}$ long; leaves more or less pilose.

28. P. STENODOIDES.

Spikelets not attenuate at base, about $1.5 \mathrm{~mm}$

long; leaves glabrous_._-29. P. STENODES.

Panicles open or contracted.

Panicles 40 to $60 \mathrm{~cm}$ long, the numerous elongate branches in verticils._._._. 52. P. MERTENSII.

Panicles mostly much less than $40 \mathrm{~cm}$ long; branches not verticillate.

First glume not pointed, two-thirds the length of the spikelet or more; spikelets blunt.

Panicles not more than $6 \mathrm{~cm}$ long; plants somewhat glaucous, relatively small; blades mostly less than $8 \mathrm{~cm}$ long.

Culms very slender, decumbent or creeping; blades 1 to $3 \mathrm{~cm}$ long 45 . P. PARVIFolium.

Culms firm, erect or decumbent at base only; blades 3 to $8 \mathrm{~cm}$ long_ 46 . P. CYANESCENS.

Panicles 10 to $20 \mathrm{~cm}$ long, diffuse; plants tall or stout.

Blades gradually narrowed from a elasping base, stiff, striate, erect or ascending.

47. P. NERVOSUM.

Blades not clasping at base. Spikelets viscid, $3 \mathrm{~mm}$ long.

50. P. GLUTiNosum.

Spikelets not viscid, 2 to $2.3 \mathrm{~mm}$ long.

49. P. SELLOWII.

First glume pointed, usually less than two-thirds as long as the spikelets.

Spikelets sparsely hirsute_.....51. P. RUDGEI.

Spikelets glabrous.

Culms straggling; spikelets minute.

Culms erect or stiffly ascending.

44. P. TRICHANTHUM.

Culms tall and stout, usually more than $1 \mathrm{~m}$ tall.

Sheaths hirsute ...... 18. P. Hinsutum. Sheaths glabrous

Culms slender, less than $1 \mathrm{~m}$ tall.

Blades 1 to $3 \mathrm{~mm}$ wide; plants spreading or ascending _._. 16 . P. DIFFUSUM.

Blades mostly more than $5 \mathrm{~mm}$ wide; plants erect__.17. P. GHIESBREGHTII. 
1. Panicum geminatum Forsk., Fl. Aegypt. Arab. 18. 1775. Egypt. Paspalidium geminatum Stapf, in Prain, Fl. Trop. Afr. 9: 583. 1920.

Perennial, glabrous throughout; culms cespitose, 25 to $80 \mathrm{~cm}$ tall, spreading from a decumbent base; blades 10 to $20 \mathrm{~cm}$ long, 3 to $6 \mathrm{~mm}$ wide, flat; panicle 12 to $30 \mathrm{~cm}$ long, the racemes 12 to 18, erect, or nearly so, rather distant; spikelets glabrous, a little more than $2 \mathrm{~mm}$ long (fig. 197).

Moist ground, ditches, and swamps, mostly near the coast, tropical regions of both hemispheres, in America extending north into southern Florida and Texas; throughout the West Indies.

This species has sometimes been referred to $P$. paspalodes Pers.

2. Panicum purpurascens Raddi, Agrost. Bras. 47. 1823. Brazil. PARA GRASS.

Panicum barbinode Trin., Mém. Acad. St. Pétersb. VI. Sci. Nat. 1: 256. 1834. Bahia.

Panicum guadaloupense Steud., Syn. Pl. Glum. 1: 61. 1854. Guadeloupe.

Perennial, sending out widely creeping stolons; culms decumbent at base, rooting at the lower nodes, 2 to $6 \mathrm{~m}$ long or even more, sometimes ascending into bushes and trees; nodes densely villous; sheaths villous; blades 10 to $15 \mathrm{~mm}$ wide, glabrous; panicle 12 to $20 \mathrm{~cm}$ long, .with several rather distant racemes; spikelets $3 \mathrm{~mm}$ long, glabrous (fig. 198).

Cultivated and waste ground, especially in moist places, tropical America. To be found on all the West Indian islands.

A valuable forage grass in the Tropics at low altitudes, used for pasture and for cut green feed. In common with Eriochloa polystachya called "malojilla" in Puerto Rico; in Cuba called "hierba del Paral", "hierba bruja", and "paraná"; in the English islands called "Dutch grass" and "Scotch grass."

Panicum purpurascens Raddi had previously been discarded because of the earlier $P$. purpurascens Opiz (1822) which, however, is a nomen nudum.

Some botanists have referred this species to Panicum muticum Forsk. described from Egypt, or to P. numidianum Lam., also described from Egypt ("Nubia"). In the author's opinion P. purpurascens is different from $P$. numidianum to which $P$. muticum should probably be referred. The Egyptian plant differs in haring pubescent but not villous nodes, more acute spikelets, no long hairs on the rachis and pedicels, and a larger first glume. Panicum purpurascens occurs in tropical Africa whence it may have been introduced into Brazil.

3. Panicum reptans L., Syst. Nat. ed. 10. 2: 870. 1759. Jamaica. Panicum grossarium L., Syst. Nat. ed. 10. 2: 871. 1759. Jamaica. Panicum prostratum Lam., Tabl. Encycl. 1: 171. 1791. Santo Domingo.

Panicum caespitosum Swartz, Fl. Ind. Occ. 1: 146. 1797. Jamaica. Panicum insularum Steud., Syn. Pl. Glum. 1: 61. 1854. Lesser Antilles.

Brachiaria prostrata Griseb., Abh. Ges. Wiss. Göttingen 7: 263. 1857. 


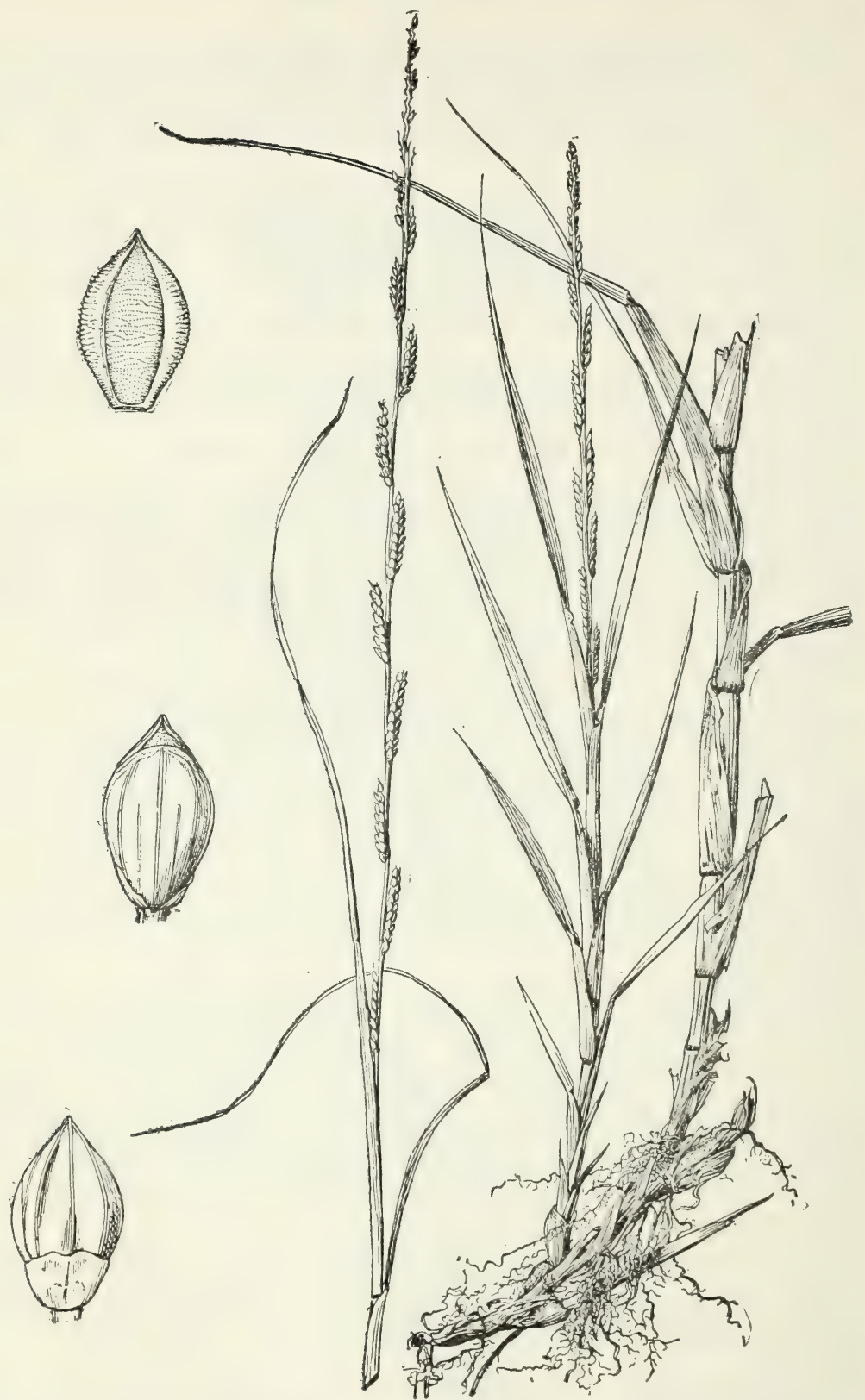

Figure 197.-Panicum geminatum. Plant, $\times 1 / 2$; two views of spikelet, and floret, $\times 10$ (Tracy 9395). 


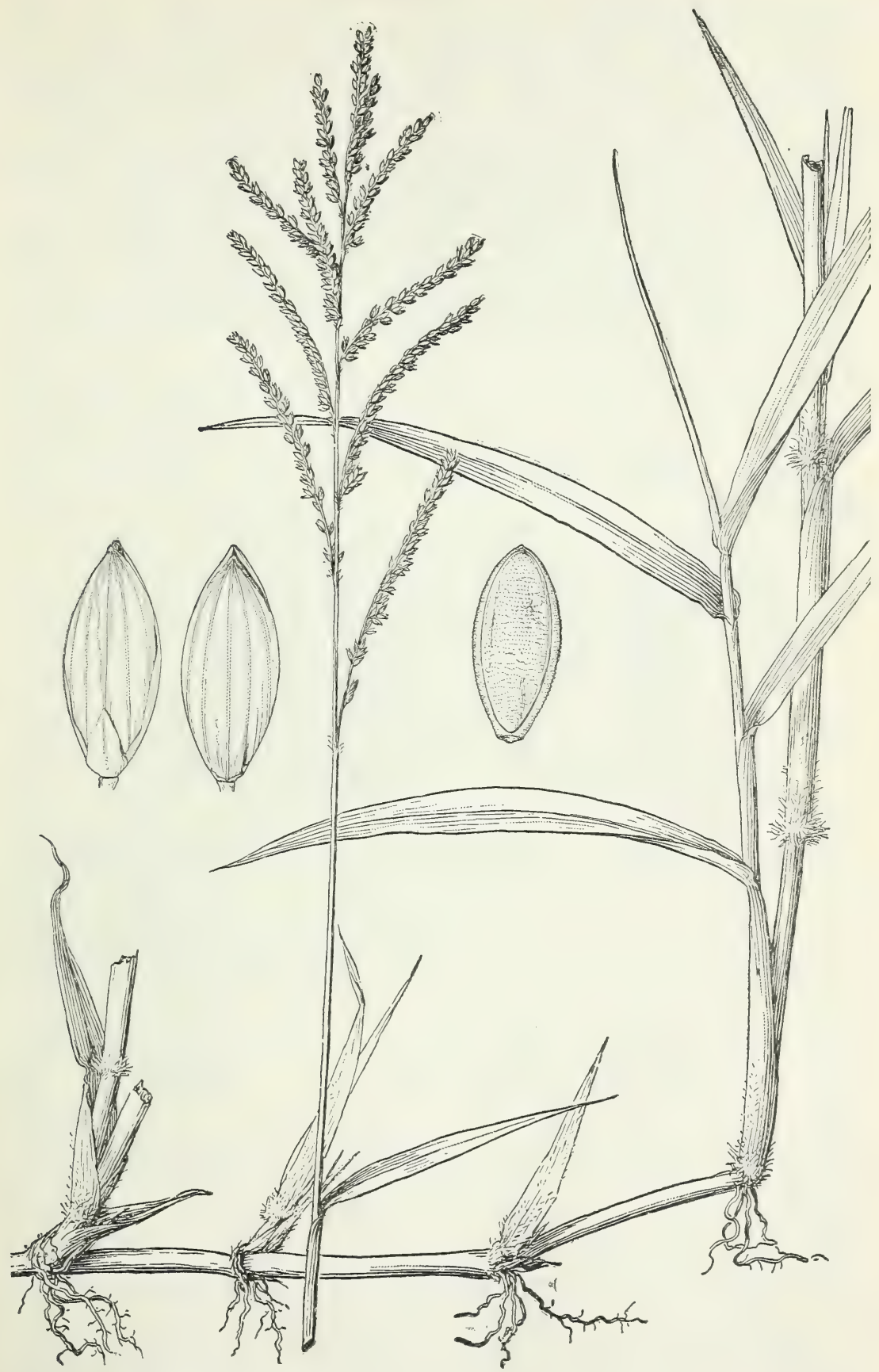

FIGURE 198.-Panicum purpurascens. Plant, $\times 1 / 2$; two views of spikelet, and floret, $\times 10$ (Hitchcock 9693). 
Panicum prostratum var. pilosum Eggers, Fl. St. Croix and Virgin Isl. 104. 1879. St. Croix.

Urochloa reptans Stapf, in Prain, Fl. Trop. Afr. 9: 601. 1920.

Plants annual, spreading, usually prostrate; culms slender, freely branching, 10 to $30 \mathrm{~cm}$ tall; blades lanceolate or orate-lanceolate, 1.5 to $6 \mathrm{~cm}$ long, 4 to $12 \mathrm{~mm}$ wide, cordate, glabrous or puberulent, ciliate at base; inflorescence long-exserted, 2 to $6 \mathrm{~cm}$ long; racemes spikelike, 3 to 12,2 to $3 \mathrm{~cm}$ long; spikelets about $2 \mathrm{~mm}$ long, glabrous; first glume rounded or truncate, less than $0.5 \mathrm{~mm}$ long (fig. 199).

Moist open ground and a frequent weed in waste places and cultivated soil, Florida to Texas, southward to northern South America; also in tropical regions of the Eastern Hemisphere. Probably to be found on all the West Indian islands. In Cuba called "San Juan de Castillo."

4. Panicum fasciculatum Swartz, Prodr. Veg. Ind. Occ. 22. 1788. Jamaica.

BRoWNTOP MiLleT.

Panicum fuscum Swartz, Prodr. Veg. Ind. Occ. 23. 1788. Jamaica.

Panicum flavescens Swartz, Prodr. Teg. Ind. Occ. 23. 1788. Jamaica.
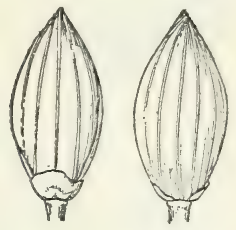

FIGU RE 199.-Panicum reptans. Two views of spikelet, and floret, $\times 10$ (type of $P$. prostratum Lam.).
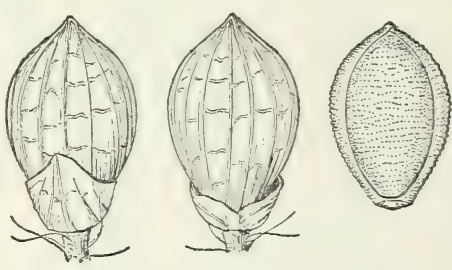

FIGURE 200.-Panicum fasciculatum. Two views of spikelet, and floret, $\times 10$ (type).

Panicum chartaginense Swartz, Prodr. Teg. Ind. Occ. 22. 1788. Cartagena.

Panicum fusco-rubens Lam., Tabl. Encycl. 1: 171. 1791. Caribbean Islands.

Panicum fastigiatum Poir., in Lam., Encycl. Sup. 4: 277. 1816. Based on $P$. fasciculatum Swartz.

Panicum illinoniense Desv., Opusc. 91. 1831.

Panicum reticulatum Griseb., Abh. Ges. Wiss. Göttingen 7: 264. 1857. Caribbean Islands or Panama.

Panicum fuscum var. fasciculatum Griseb., Fl. Brit. W. Ind. 547. 1864

Panicum fasciculatum var. flavescens Doell, in Mart., Fl. Bras. 22: 205. 1877 .

Panicum fasciculatum var. fuscum Doell, in Mart., Fl. Bras. 2²: 205. 1877 .

Annual, erect or spreading from a decumbent base, 30 to $100 \mathrm{~cm}$ tall; sheaths glabrous or papillose-hispid: blades flat, 6 to $20 \mathrm{~mm}$ wide, glabrous or sparsely hispid; panicle 10 to $20 \mathrm{~cm}$ long, of several racemes 5 to $10 \mathrm{~cm}$ long, solitary or fascicled along the main axis; spikelets 2 to $2.5 \mathrm{~mm}$ long, bronze to yellow or brown, glabrous, pointed, reticulate-reined; first glume one-third as long as the spikelet (fig. 200). 
Moist open ground, often a weed in fields and waste places, southern Florida and Texas, Mexico, and throughout the West Indies to central South America. In Cuba called "súrbana."

5. Panicum molle Swartz, Prodr. Veg. Ind. Occ. 22. 1788. (Probably Jamaica.)

Annual, resembling $P$. fasciculatum but more or less pubescent all over; spikelets about $3.5 \mathrm{~mm}$ long, pilose (fig. 201).

Open ground, often a weed in fields, Greater Antilles, Mexico, and Central America to Argentina. In Cuba called "súrbana." This species was referred by Grisebach ${ }^{61}$ to Panicum chartaginense.

Cuba: Gamboa, Ekman 14953. Without locality, Reed.

Jamaica: Hope Gardens, Hitcheock 9350 (Amer. Gr. Nat. Herb. 9). Kingston, Alexander in 1849; Hitchcock in 1890. Fealthshire Hills. Hitchcock 9758. Gordon Town, Hitchcock 9323; Harris 11504. Musgrave Road, Harris 11483.

Haiti: Croix-des-Bouquets, Ekman H 971. Cape St. Míarc, Ekman H 6650.

6. Panicum echinulatum $\mathrm{Mez}$, Notizbl. Bot. Gart. Berlin 7: 62. 1917. Paraguay.

Differing from $P$. adspersum chiefly in the tuberculate-hispid spikelets.

Fields and waste places, West Indies, probably introduced, Paraguay and Bolivia.

Cuba: Between Pastelillo
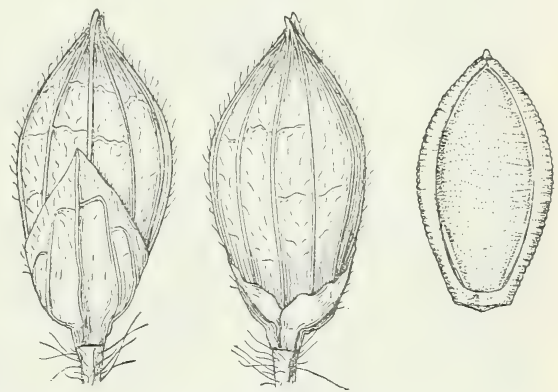

FIGURE 201.-Panicum molle. Two views of spikelet, and floret, $\times 10$ (type). and Tarafa, low forest, Ekman 15451. Trinidad, on the railroad track, Ekman 14023. Haiti: Les Gonaïves, Ekman H 8515.

Dominican Republic: Villa Vásquez, Ekman H 13126. Santiago, Ekman H 16387.

Virgin Islands: St. Croix, Eggers in 1876.

Leeward Islands: Nevis, Box 175.

7. Panicum adspersum Trin., Gram. Pan. 146. 1826. Santo Domingo.

Panicum thomasianum Steud.; Doell, in Mart., Fl. Bras. 22: 188. 1877. St. Thomas.

Panicum keyense Mez, Notizbl. Bot. Gart. Berlin 7: 61. 1917. Florida.

Culms ascending or spreading, commonly branching and rooting at the lower nodes, the flowering branches 30 to $100 \mathrm{~cm}$ tall; blades 5 to $15 \mathrm{~cm}$ long, 8 to $20 \mathrm{~mm}$ wide; panicles 6 to $15 \mathrm{~cm}$ long, the racemes spikelike, few to many, 3 to $10 \mathrm{~cm}$ long; spikelets fusiform, abruptly acuminate, 3.2 to $4 \mathrm{~mm}$ long, more or less hispidulous especially toward the summit (fig. 202).

Moist open ground, Florida and the West Indies.

Bahamas: Nassau, Curtiss 113. Anguilla Isles, Wilson 8066.

${ }^{61}$ Fl. Brit. W. Ind. 546. 1864. 
Cuba: Herradura, Tracy 9102. Sierra de Anafe, Wilson 11491. Cabanas, Palmer and Riley 746, 771. Habana, Hitchcock 159; Ekman 109; Léon 291, 570, 1978; Curtiss 748. Santiago de las Vegas, Hitchcock 147, 148; Baker and Wilson 512; Tracy 9109. Guines, Léon 924. Baraguá, Hitchcock 23350. Sancti Spíritus, Léon 925. Zaza del Sur, Léon 2776. Without locality, Wright 3869.

Jamaica: Hope Gardens, Harris 11247; Hitchcock 9282 (Amer. Gr. Nat. Herb. 11), 9351 (Amer. Gr. Nat. Herb. 10). Gordon Town, Harris 11343, 11512. Yallahs Valley, Harris 11498. Black River, Hitchcock 9630. Ferry River, Hitchcock 9750; Harris 11785. Alligator Pond, Hitchcock 9830. Lititz, Harris 11714.

Haiti: Tortuga Island, Leonard 11447, 11956, 12096, 14067. Port-de-Pai, Leonard 11155. Port-au-Prince, Hitchcock 19882; Ekman H 323, H 8149. Gonaïves, Cook, Scofield, and Doyle 194. St. Marc, Leonard 2934, 2968. Fond Parisien, Leonard 4138. Pétionville, Leonard 4875. Cape Haitien, Leonard 5286. Tiburon, Ekman H 373.

Dominican Republic: Barahona, Fuertes 43. Guayubín, Abbott
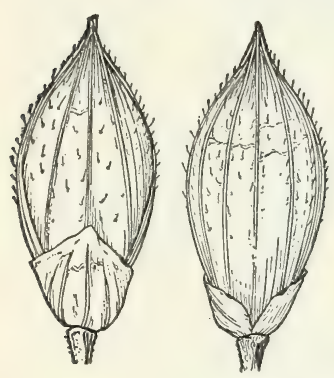

FIgURE 202.-Panicum adspersum. Two views of spikelet, and floret, $\times 10$ (type).

955a. Jaina, Faris 350. Santo Domingo, Ekman H 12528. Santiago, Ekman H 16385.

Puerto Rico: Mona Island, Britton, Cowell, and Hess 1761. Cayo Muertos, Britton, Cowell, and Brown 4991. Mayaguez, Britton and Cowell 4069; Chase 6286, 6302. Guanica Bay, Chase 6514. Aibonito, Chase 6333; Sintenis 1957. Bayamon, Hioram 315. Vieques Island, Chase 6686.

VIRgin Islands: St. John, Britton and Shafer 334. Tortola, Britton and Shafer 711. St. Croix, Hitchcock 16334; Thompson 14, 443; Ricksecker 66, 384. St. Thomas, Hitchcock 16315, 16316. Virgin Gorda, Fishlock 48, 53, 243.

Leeward Islands: St. Kitts, Box 157. Antigua, Hitchcock 16379; Box 59, 118. Guadeloupe, Duss 3180 .

8. Panicum dichotomiflorum Michx., Fl. Bor. Amer. 1: 48. 1803. Illinois.

Annual; culms freely branching, ascending or spreading from a geniculate base, 50 to $100 \mathrm{~cm}$ tall; sheaths glabrous; blades flat or more or less folded, glabrous, 10 to $50 \mathrm{~cm}$ long, 3 to $10 \mathrm{~mm}$ wide; panicles terminal and axillary, many-flowered, 10 to $20 \mathrm{~cm}$ long, the branches ascending to spreading; spikelets oblong-lanceolate, acute, glabrous, about $2.3 \mathrm{~mm}$ long; first glume truncate or broadly triangular, one-fifth to one-fourth the length of the spikelet; second glume and sterile lemma equal, 7-nerved (fig. 203).

Moist open ground, United States to Argentina.

Bermuda: Millspaugh 126.

Bahamas: Hog Island, Eggers 4405, 4512. Watling Island, Geogr. Soc. Baltimore 489. Cat Cay, Brace 3742. Nassau, !Curtiss 177. 
Cuba: Herradura, Tracy 9055, 9342; Britton and Earle 6566. Remates, Ekman 11212. Laguna del Ariguanabo, Léon 2774, 2775, 4328, 7693. Santiago de las Vegas, Hitchcock 151. Batabanó, Hitchcock 150. Cayo de los Pavos, Léon 9507.

Haits: Étang, Leonard 3493, 4233. Manneville, Ekman H 3060. Miragoane, Ekman $\mathrm{H} 7233$.

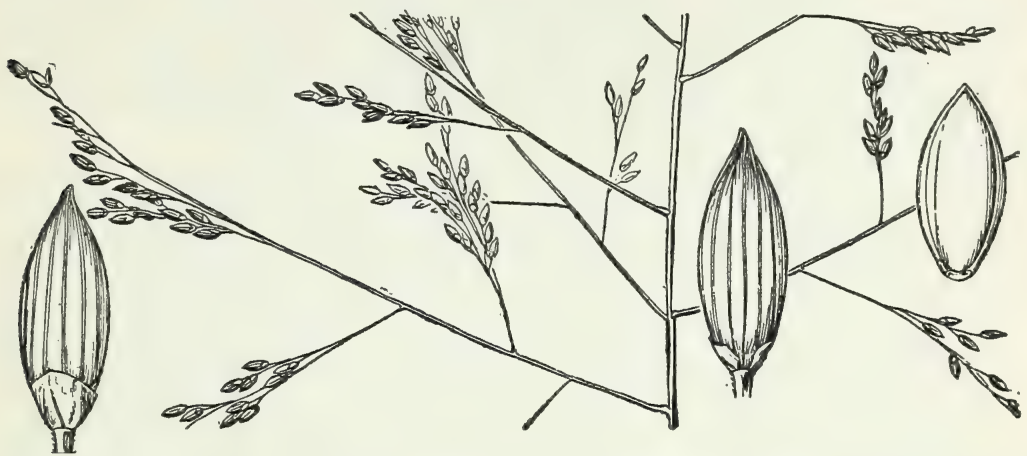

FIgure 203.-Panicum dichotomiflorum. Panicle, $\times 1$; two views of spikelet, and floret, $\times 10$ (Deam).

9. Panicum bartowense Scribn. and Merr., U. S. Dept. Agr., Div. Agrost. Circ. 35: 3. 1901. Florida.

Simple or sparingly branched; culms erect or decumbent at base, sometimes only 20 to $30 \mathrm{~cm}$ tall but often $1 \mathrm{~m}$ or even $2 \mathrm{~m}$ tall; sheaths papillose-hispid; blades pilose on the upper surface; panicle and spikelets about as in P. dichotomiflorum (fig. 204).

Low moist ground, Florida to Cuba and Jamaica.

Bahamas: Great Bahama,Britton and Millspaugh 2706. North Bimini, Brace 3467 (both in Field Mus. Herb.).

Cuba: Carabela Grande, Roig 3205. Guanajay, Ekman 13013. Marianao, Léon 6142. Guines, Léon 7289. Batabanó, Hitchcock 149. Caibarién, Fernando 636. Without locality, Wright 3860. Isla de Pinos, Ekman 12400 ; Britton, Wilson, and Léon 15257.

JamaicA: Black River, Hitchcock 9645 (Amer. Gr. Nat. Herb. 18).

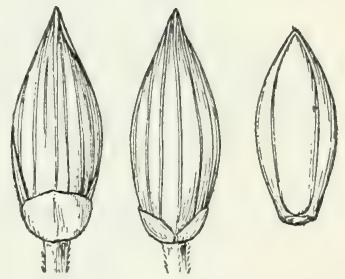

FIGURE 204.-Panicum bartowense. Two views of spikelet, and floret, $\times 10$ (type).

\section{Panicum lacustre Hitchc. and Ekman, sp. nov. ${ }^{62}$}

Perennial; culms erect, glabrous, rather succulent below, 1 to 1.5 $\mathrm{m}$ tall, rooting at the lower nodes when growing in the water; sheaths glabrous (under water bladeless); ligule a laciniate membrane dissected into bristles, 1 to $2 \mathrm{~mm}$ long; blades flat, or folded at base, the middle and upper 15 to $30 \mathrm{~cm}$ long, about $2 \mathrm{~mm}$ wide, slightly scabrous, sparsely pilose on the upper surface, the lower shorter; panicle

${ }^{62}$ Culmi perennes erecti glabri succulenti 1-1.5 m alti; vaginae glabrae; laminae planae $15-30 \mathrm{~cm}$ longae $2 \mathrm{~mm}$ latae; panicula patens $20-30 \mathrm{~cm}$ longa, radiis ascendentibus, radiis secondariis appressis; spiculae oblongo-lanceolatae glabrae $2 \mathrm{~mm}$ longae; gluma prima $0.5-0.7 \mathrm{~mm}$ longa truncata; gluma secunda 5 -nervis; lemma sterile glumam secundam aequans 7 -nervis. 
open, many-flowered, 20 to $30 \mathrm{~cm}$ long, the branches ascending, scabrous, the lower fascicled, the others solitary or in pairs, the branches of the second order appressed along the main branches, the basal part of the latter naked; spikelets oblong-lanceolate, glabrous, about $2 \mathrm{~mm}$ long, tinged with purple, the ultimate lateral pedicels 1 to 2 $\mathrm{mm}$ long; first glume truncate or broadly triangular,

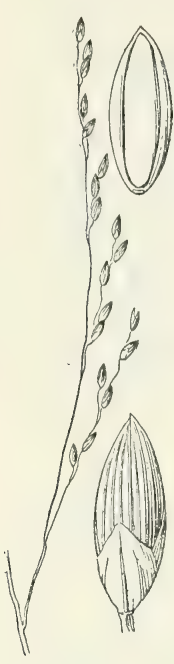

FIGURE 205.Panicum lacustre. Panicle branch, $\times 1$; spikelet and flo ret, $\times 10$ (type). one-fourth to one-third as long as the spikelet; second glume and sterile lemma equal, the glume 5-nerved, the lemma 7-nerved, without stamens or palea; fertile lemma smooth, slightly shorter than the spikelet, rather thin; anthers $1 \mathrm{~mm}$ long (fig. 205).

Type in the United States National Herbarium, no. 1387529 , collected in water of 30 to $60 \mathrm{~cm}$ depth in Laguna de la Máquina, prov. Pinar del Río, Cuba, October 31, 1923, by Dr. E. L. Ekman (no. 17878).

Known only from the type collection, but Dr. Ekman states that the species occurs in practically all lagunas of the western part of Pinar del Río Province. The species differs from $P$. dichotomiflorum in being an erect perennial with smaller spikelets, and from $P$. aquaticum in the erect habit and smaller spikelets.

11. Panicum aquaticum Poir., in Lam., Encycl. Sup. 4: 281. 1816. Puerto Rico.

Panicum proliferum var. strictum Griseb., Cat. Pl. Cub. 232. 1866. Cuba, Wright 3456.

Perennial; culms usually decumbent at base and rooting at the nodes, the erect flowering branches 30 to $100 \mathrm{~cm}$ tall; sheaths glabrous; blades linear, 5 to $10 \mathrm{~mm}$ wide, flat or folded, usually pilose on the upper surface at least toward the base; panicles similar to those of $P$. dichotomiflorum but averaging smaller; spikelets 3 to $3.4 \mathrm{~mm}$ long, acuminate; fruit shorter than the spikelet, somewhat pointed (fig. 206).

Wet places or in shallow water, margins of streams and ponds at low altitudes, Mexico and the West Indies to Paraguay.

Cuba: Herradura, Hitchcock 23444; Shafer 10912. Jovero, Léon 15367. Pinar del Río, Hitchcock 23290; Wright 3861. El Sábalo, Léon 15097. Almacigos, Wright 3456 (in part). Habana, Léon 4155. Ariguanabo lagoon, Léon 1975, 1976. El Cano, Léon 1974. Guanabacoa, Léon 919. Puentes Grandes, Ekman 502, 18294. Motembo, Léon 9410. Manacas, Léon 5823, 5998. Marianao, Léon 5702. Isla de Pinos, Britton and Wilson 14803.

Puerto Rico: Rio Piedras, Stevenson 3566; Chase 6778. Campo Alegre, Chase 6804. Adjuntas, Chase 6471. Utuado,

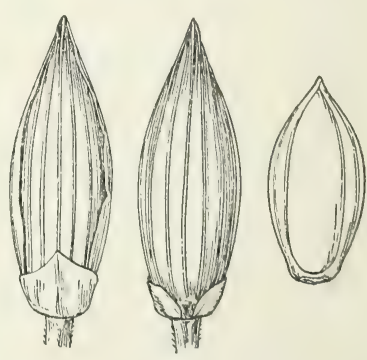

FIGURE 206.-Panicum aquaticum. Two views of spikelet, and floret, $\times 10$ (type). Britton and Cowell 432.

LeEWARD Is L A N S: Guadeloupe, Duss 3178.

Trinidad: Pitch Lake, Hitchcock 10099 (Amer. Gr. Nat. Herb. $502)$. 
12. Panicum elephantipes Nees, Agrost. Bras. 165. 1829. Brazil.

Perennial; culms ascending from a decumbent, often widely creeping base, rooting at the nodes, succulent, as much as $2 \mathrm{~cm}$ thick, 1 $\mathrm{m}$ or more tall; blades flat, as much as $20 \mathrm{~mm}$ wide; panicles large and open, as much as $40 \mathrm{~cm}$ long, the short branchlets appressed along the ascending branches; spikelets 4 to $5 \mathrm{~mm}$ long, lanceolate, acuminate, glabrous; first glume one-fifth to one-fourth the length of the spikelet, obtuse or acutish (fig. 207).

Ponds and shallow water at low altitudes, sometimes in large colonies, Central America and the West Indies to Argentina.

Cuba: Cabañas, Ekman 10504. Laguna de los Indios, Roig 3186. Habana, Léon 335, 9039. Laguna Origuanabo, Léon 13312. San Antonio, Hitchcock 152. Soledad, Hitchcock 23335.

JAMAICA: Saranna-la-Mar, Hitchcock 9878. Cabaritta River, Harris 11813. Montego Bay, Ridley 127. Middle Quarters, Hitchcock 9586 (Amer. Gr. Nat. Herb. 19).

Haiti: Miragoane, Ekman H 6539, H 7254. Dessolines, Ekman H 3024.

Dominican Republic: Jaina, Faris 393; Ekman H 13352. Santo Domingo City, Ekman H 11149.

Puerto Rico: Fajardo, Sintenis 938. San Juan, Chase 6407. Vega Baja, Chase 6415.

13. Panicum capillare L., Sp. Pl. 58. 1753. Virginia.

Witcharass.

Annual; culms erect, 20 to $80 \mathrm{~cm}$ tall; sheaths densely papillose hispid; blades 10 to $25 \mathrm{~cm}$ long, 5 to $15 \mathrm{~mm}$ wide, hispid on both surfaces; panicle diffuse, often half the length of the entire plant, breaking away at maturity; spikelets $2 \mathrm{~mm}$ long, glabrous, acute; first glume about half as long as the spikelet, acute (fig. 208).

Open ground and waste places, eastern

United States; introduced in Bermuda and the Virgin Islands.

Bermuda: Collins 151, 152; Brown and Britton 21.

Virgin Islands: St. Croix, Benzon 42.

14. Panicum hirticaule Presl, Rel. Haenk. 1: 308. 1830. Mexico.

Annual; culms erect, 15 to $70 \mathrm{~cm}$ tall, glabrous or papillose-hispid, the nodes and sheaths hispid; blades flat, mostly glabrous or nearly so, 4 to $13 \mathrm{~mm}$ wide; panicles 5 to $15 \mathrm{~cm}$ long, open, usually reddishbrown; spikelets about $3 \mathrm{~mm}$ long, acuminate, glabrous; first glume half to three-fourths the length of the spikelet, acuminate (fig. 209).

Rocky or sandy soil, southwestern Lnited States to Boliria; Cuba and Haiti.

Cuba: Gamboa, Ekman 15009.

Haiti: Damien, Ekman H 9154, H 9991. Petite Rivière de l'Artibonite, Picarda 1654.

Dr. Ekman notes that this species is rery common in fields around Port-au-Prince (no. H 9991).

$60256-36-17$ 


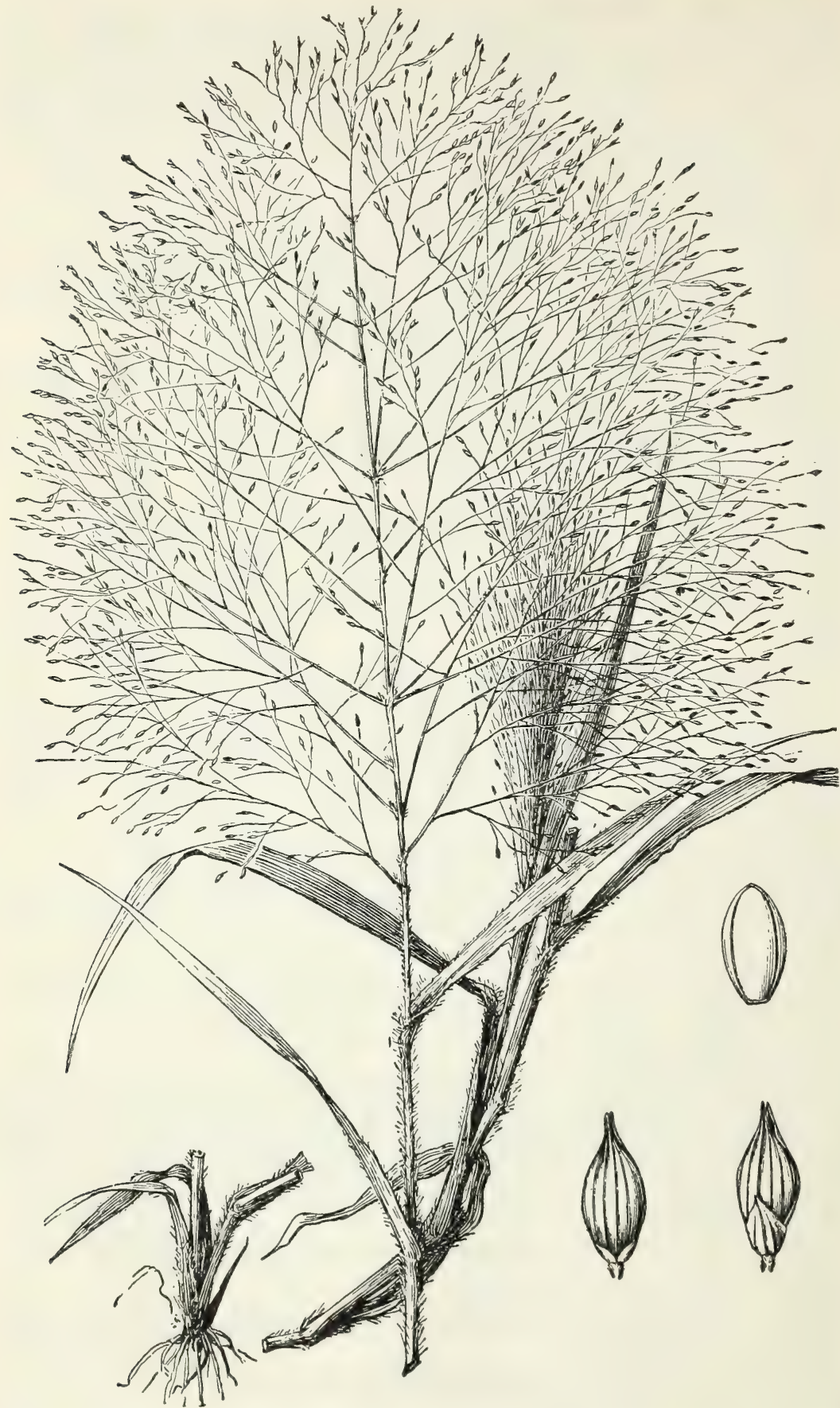

Figure 208.-Panicum capillare. Plant, $\times 1 / 2$; two views of spikelet, and floret, $\times 10$ (V. H. Chase 774). 
Panicum miliaceum L., Sp. Pl. 58. 1753. Hog millet, broomcorn millet, introduced from the Old World and escaped from cultivation in the United States, has been found in Puerto Rico (Stevenson 3052) and St. Croix (Benzon).

15. Panicum cayennense Lam., Tabl. Encycl. 1: 173. 1791. Cayenne.

Annual; culms erect, often much branched at base, 20 to $50 \mathrm{~cm}$ tall; sheaths and blades pilose, the latter 4 to $10 \mathrm{~mm}$ wide; panicles terminal and axillary, open, 8 to $20 \mathrm{~cm}$ long; spikelets a little more than $2 \mathrm{~mm}$ long, obovoid, turgid, strongly nerved; first glume acute, half as long as the spikelet (fig. 210).

Open ground and pine woods, West Indies and Honduras to Brazil.

Cuba: Herradura, Britton, Earle, and Gager 6520; Tracy 9073. Pinar del Río, Wright 3865. Sierra de Cabra, Britton and Gager 7275. Laguna Jovero, Shafer 10910. Sumidero, Léon and Shafer 13717, 13719. Bayate, Ekman 10028. Isla de Pinos, Curtiss 267; Taylor 34; Palmer and Riley 1086; Britton, Wilson, and Selby 14455.

JAMAICA: Hallis Savanna, Harris 12226.

Dominican Republic: Lagunas de Cenobí, Valeur 7. Bonao, Ekman H 11490. Cuenca, Ekman H 13306. El Valle, Ekman H' 15694.

16. Panicum diffusum Swartz, Prodr. Veg. Ind. Occ. 23. 1788. Jamaica or Hispaniola.

Perennial; culms densely tufted, spreading or ascending from a decumbent base, 25 to $50 \mathrm{~cm}$ tall; sheaths glabrous or the lower some-

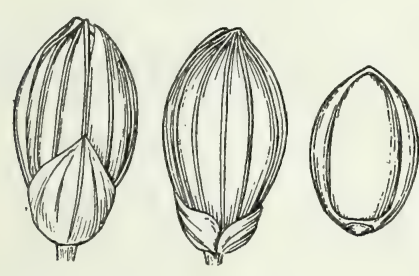

Figure 210.-Panicum ca ennense. Two views of spikelet, and floret, $\times 10$ (type).

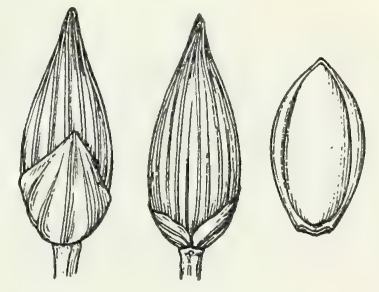

Figure 211.-Panicum diffusum. Two views of spikelet, and floret, $\times 10$ (type).

times sparsely pubescent; blades 5 to $20 \mathrm{~cm}$ long, 1 to $3 \mathrm{~mm}$ wide, flat or drying subinvolute, sparsely pilose on the upper surface; panicles 5 to $10 \mathrm{~cm}$ long, the few branches stiffly spreading at maturity, bearing a few short-pediceled spikelets toward the ends; spikelets about $2.3 \mathrm{~mm}$ long, somewhat acuminate, glabrous; first glume acute, about half as long as the spikelet (fig. 211).

Banks, cliffs, and savannas, West Indies.

Bahamas: New Providence, Britton and Brace 424. 
Céba: Bahía, Wilson 9443. Guanajay, Palmer and Riley 802. Habana, Léon 190, 305 in part, 923, 2532. Santiago de las Vegas, Wilson 1405; Van Hermann 1444; Tracy 9111 ; Baker and Wilson 511. Triscornia, Tracy 9082. Cojimar, Léon 2559. Campo Florido, Léon 3449; Ekman 995. Jaimanito, Ekman 1200. Guanabacoa, Hitcheock 23227, 23239. Zaza de Tunas, Léon 923c. La Gloria, Shafer 385. Baraguá, Hitchcock 23368. Holguín, Shafer 1512. Manatí, Léon 5681. Mir, Ekman 7511. Retiro, Wright 3852, 3877. Eastern Cuba, Wright 1540. Isla de Pinos, Curtiss 384, 494.

JAMAICA: Ewarton, Hitchcock 9463.

Haiti: St. Michel de l'Atalaye, Leonard 7449. Aux Cayes, Ekman H 20. Source Matelas, Ekman H 2151. Mirebalais, Cook, Scofield, and Doyle 78. Jean Rabel, Leonard 12590, 13609, 13828. Port-de-Pai, Leonard 12237. Môle-St.-Nicolas, Leonard 13147. Bassin Bleu, Leonard 15090. Cabaret, Leonard 11875, 11900. Tortuga Island, Leonard 11576.

Dominican Republic: Pimentel, Abbott 690. Guayubín, Abbott 1027. Azua, Rose 4410. San Juan, Ekman H 13390. Santiago, Ekman H 16237. Porto Plata, Wright, Parry, and Brummel 627.

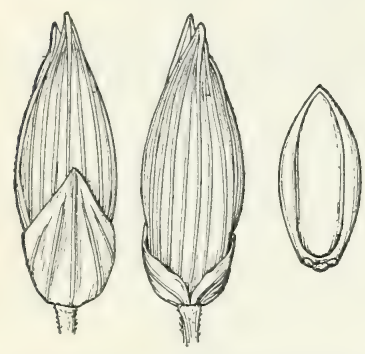

Figtre 212.-Panicum ghiesbreghtii. Two views of spikelet, and floret, $\times 10$ (type)

Puerto Rico: Mayaguez, Chase 6308; Britton and Cowell 4064. Quebradillas, Chase 6567, 6577 (Amer. Gr. Nat. Herb. 205).

VIRgIn Islands: St. Thomas, Britton and Shafer 382; Eggers in 1882; St. Croix, Eggers in 1874; Benzon. St. John, Eggers 3068. LeEWARD Islands: Antigua, W̆ullschlägel 64.

Windward Islands: Martinique, Hahn 1232 ; Duss 536.

17. Panicum ghiesbreghtii Fourn., Mex. Pl. 2: 29. 1886. Mexico.

Panicum hirtivaginum Hitche., Contrib. U. S. Natl. Herb. 12: 223. 1909. Cuba, Wright 758 .

Perennial; culms erect, hispid, 60 to $80 \mathrm{~cm}$ tall, the nodes and sheaths hirsute; blades elongate, flat, hirsute, about $1 \mathrm{~cm}$ wide; panicle open, oblong, 20 to $30 \mathrm{~cm}$ long; spikelets $3 \mathrm{~mm}$ wide, glabrous, acute; first glume half as long as spikelet (fig. 212).

Low moist open ground and pastures, Mexico and West Indies to Brazil.

Bahamas: Crooked Island, Brace 4812.

Cuba: Herradura, Hitchcock 23443; Tracy 9068. Viñales, Léon 15339. Pinar del Río, Hitchcock 23292. San Diego de los Baños, Léon 4362, 4601. Bahía Honda, Ekman 12686. Habana, Ekman 776. El Calvario, Léon 922, 2674. Santiago de las Vegas, Tracy 9116. Soledad, Hitchcock 23322; Eggers 5406. Baraguá, Hitchcock 23351. Placetas del Sur, Léon 6429. Retiro, Wright 758. Baracoa, Léon 12304. Manatí, Léon 6005. La Perla, Léon 3783. Santiago de Cuba, Léon 3747. Guayabal, Léon 922b. Guara, Hitchcock 23397.

Jamaica: Inverness, Harris 11691, 12161.

Haiti: Pilate, Leonard 9607. Plaisance, Leonard 9417. Port-auPrince, Ekman H 1987; Leonard 15754. St. Nichel de l'Atalaye, Leonard 7745. Marmelade, Leonard 8344. Port-à-Piment, Ekman H 420. St. Louis du Nord, Leonard 14338. Jean Rabel, Leonard 13744. Pétionville, Leonard 4901. 
Dominican Republic: Santiago, Ekman H 16129.

Puerto Rico: Cayey, Chase 6744. Coamo Springs, Chase 6547. Tabucoa, Sintenis 4983 .

Leeward Islands: Antigua, Hitcheock 16382; Box 18, 39, 49, 89. Guadeloupe, Duss 3184.

18. Panicum hirsutum Swartz, Fl. Ind. Occ. 1: 173. 1797. Jamaica.

Perennial; culms robust, erect, as much as $1.5 \mathrm{~m}$ tall and $1 \mathrm{~cm}$ thick; sheaths hirsute with prickly fragile hairs; blades flat, mostly glabrous, 20 to $35 \mathrm{~mm}$ wide; panicles open, densely flowered, 20 to $35 \mathrm{~cm}$ long; spikelets about $2 \mathrm{~mm}$ long, acute, glabrous; first glume half as long as spikelet (fig. 213).

Open moist soil, Mexico and the West Indies to Brazil.

Cuba: Mangas, Ekman 17578. Caibarién, Ekman 16312. Matanzas, Wright in 1865. Guantánamo, Léon 3913. Preston, Ekman 3419. Guaro, Hitchcock 23396. Bayate, Ekman 6118, 6183, 10068.

Haiti: Anse-à-Taleur, Ekman H 4392. Aux Cayes, Ekman H 755.

Dominican Republic: Pimentel, Ekman H 13275. Río Yaque del Sur, Ekman H 5791.

Leeward Islands: Guadeloupe, Duss 3917. Antigua, Box 176.

WINDWARd Islands: St. Lucia, Box 190.

Trinidad: Burkes pasture, Bot. Gard. Herb. 2295. La Brea, Broadway 4980. Mayaro, Broadway 2629. Manzanilla, Myers 4189.

Tоваgo: Broadway 4586, 4895.

19. Panicum maximum Jacq., Coll. Bot. 1: 76 .

1786. Guadeloupe. Guinea Grass.

Panicum polygamum Swartz, Prodr. Veg. Ind. Occ. 24. 1788. Jamaica.

Panicum laeve Lam., Tabl. Encycl. 1: 172. 1791. Santo Domingo and Mauritius.

Panicum jumentorum Pers., Syn. Pl. 1: 83. 1805. Based on P. polygamum Swartz.

Panicum trichocondylum Steud., Syn. Pl. Glum. 2: 74. 1854. Guadeloupe.

Perennial; culms cespitose, erect, 1 to $2.5 \mathrm{~m}$ tall, glabrous, the nodes densely hirsute; sheaths hirsute or glabrous; blades flat, elongate, 1 to $3.5 \mathrm{~cm}$ wide, glabrous except the margin, or hirsute on the upper surface near the base; panicle open, 20 to $50 \mathrm{~cm}$ long, the lower branches in whorls; spikelets oblong, glabrous, about $3 \mathrm{~mm}$ long; first glume one-third as long as spikelet; fruit transversely rugose (fig. 214).

Open ground, at low altitudes, escaped from cultivation, southern Florida, through Mexico and the West Indies to South America; a native of Africa and now widespread in the warmer parts of the Old World. An important forage grass throughout the Tropics of the world at low altitudes. Used for pasture, or cut and fed green. In Cuba called "hierba Guinea." To be found on all the islands.

20. Panicum repens L., Sp. Pl. ed. 2. 1: 87. 1762. Spain.

Perennial from extensively creeping rhizomes; culms erect, 30 to 80 $\mathrm{cm}$ tall; blades 2 to $5 \mathrm{~mm}$ wide; panicles open, 7 to $12 \mathrm{~cm}$ long, the branches stiffly ascending, naked at the base; spikelets about $2.5 \mathrm{~mm}$ long, glabrous; first glume one-fifth as long as spikelet, broad, truncate (fig. 215). 


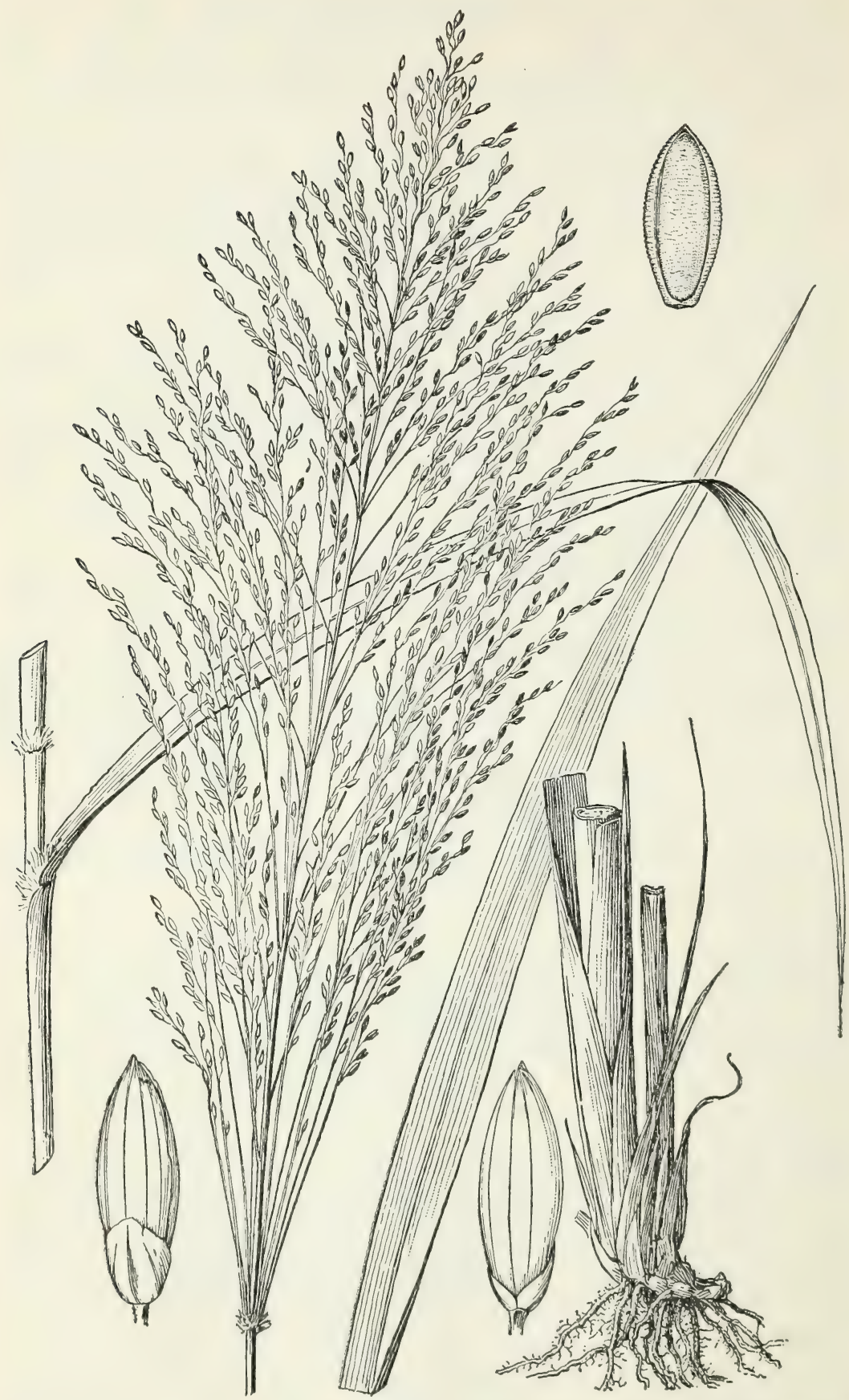

Figure 214.-Panicum maximum. Plant, $\times \frac{1}{2}$; two views of spikelet, and floret, $\times 10$ (Combs and Baker $1170)$ 


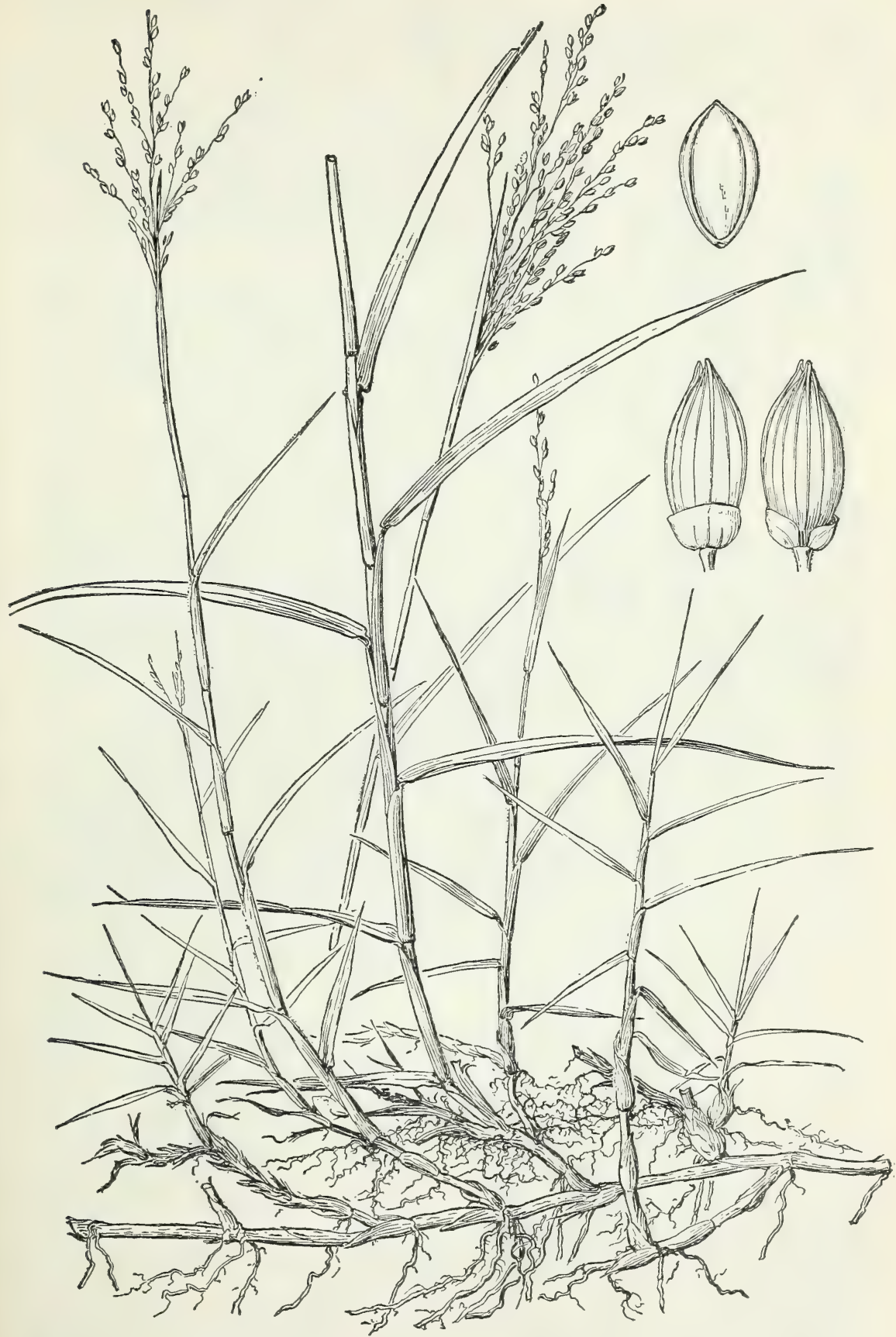

FIGURE 215.-Panicum repens. Plant, $\times 1 / 2$; two views of spikelet, and floret, $\times 10$ (Hitchcock 14145). 
Sea beaches, extensively creeping, southern United States to Brazil; tropical regions of the Old World.

Cuba: Habana, Léon 296, 563; Ekman 702, 16301.

21. Panicum gouini Fourn., Mex. Pl. 2: 28. 1886. Mexico.

Plants like $P$. repens in habit; culms
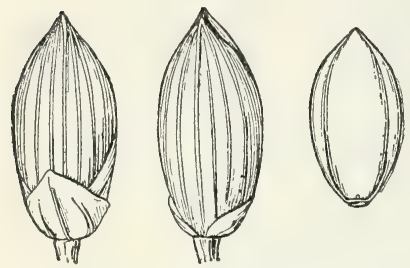

FigURE 216.-Panicum gouini. Two views of spikelet, and floret, $\times 10$ (type).

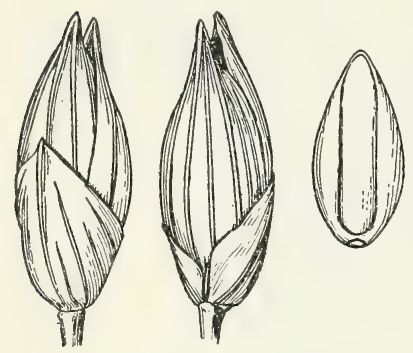

FIgURE 217.-Panicum virgatum var. cubonse. Two views of spikelet, and floret, $\times 10$ (type). on the average lower, rarely more than $30 \mathrm{~cm}$ tall; panicle smaller, more densely flowered, commonly purple (fig. 216).

Sea beaches, Alabama to Louisiana; Cuba; Veracruz.

Cuba: Lomas de Camoa (prov. Habana), at a small laguna, Ekman 17554 .

22. Panicum virgatum var. cubense Griseb., Cat. Pl. Cub. 233. 1866. Cuba, Wright in 1865.

Panicum virgatum var. scorteum Linder, Rhodora 24: 14. 1922. Bermuda, Moore, 2850.

Culms erect, slender, solitary or few in a clump, 1 to $2 \mathrm{~m}$ tall, from scaly creeping rhizomes; blades 10 to $60 \mathrm{~cm}$ long, 3 to $12 \mathrm{~mm}$ wide, gradually longacuminate, flat; panicles open oblong, 15 to $30 \mathrm{~cm}$ long; spikelets 2.8 to $3.2 \mathrm{~mm}$ long, glabrous, acute, the first glume about half as long as the spikelet (fig. 217).

Coastal marshes and wet places, Coastal Plain of the United States; Cuba.

Cuba: Remates, Ekman 11372, 11390,

La Fé, Ekman 11322 . Hanábana, Wright 3873. Laguna Jovero, Shafer 10927. Batabanó, Ekman 901, 12576; Baker in 1905; Palmer and Riley 1134; Hitchcock 153; Killip 13609 ; Léon 5754,5755. Guanimar, Léon 7697, 14180, 14181. Guaní, Fernando 445. Baraguá, Hitchcock 23338. Ciénaga de Zapata, Léon 9575. Guines, Léon 7262; Ekman 16939.

23. Panicum altum Hitche. and Chase, Contrib. U. S. Natl. Herb. 17: 488. f. 57. 1915. Panama.

Culms decumbent and straggling forming tangled masses, reedlike, as much as 6 $\mathrm{mm}$ in diameter, ascending to a height of 2 to $4 \mathrm{~m}$, smooth and glaucous; blades flat, firm, 30 to $45 . \mathrm{cm}$ long, 8 to $15 \mathrm{~mm}$ wide; panicles ovoid, open, rather densely flowered, 20 to 30 cm long; spikelets 3.2 to $4 \mathrm{~mm}$ long, turgid, glabrous; first glume about two-thirds the length of

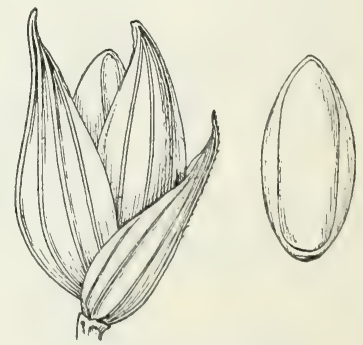

FIgURE 218.-Panicum altum. Spikelet and floret, $\times 10$ (type). the spikelet (fig. 218).

Sandy marshes or flats near the coast, British Honduras to Trinidad. Trinidad: Debadie, Broadway 5949. Port-of-Spain, Hitchcock 10053. Cedros, Hitchcock 10154, 10159.

Toвago: Hitchcock 10233; Broadway 3068. 
24. Panicum amarulum Hitche, and Chase, Contrib. U. S. Natl. Herb. 15: 96. f. 87. 1910. Virginia.

Plant glabrous throughout and somewhat glaucous, growing in large bunches; culms 1 to $2 \mathrm{~m}$ tall, robust; blades flat, more or less involute toward the slender tip, 20 to $50 \mathrm{~cm}$ long, 5 to $12 \mathrm{~mm}$ wide; panicle slightly nodding, manyflowered, compact, 15 to $30 \mathrm{~cm}$ long; spikelets ovate, acuminate, 4 to $5 \mathrm{~mm}$ long (fig. 219).

Sandy seashores, southeastern United States, Mexico, Bahamas, and Cuba.

Bermuda: Collins 139.

BaHamas: Great Bahama, Britton and Millspaugh 2739. New Providence, Britton and Brace 307, 493 (all in Field Mus. Herb.).

Cuba: Bahía Honda, Ekman 17290, 17291. Cayo Paredon Grande, Shafer 2735. Cayo Sabinal, Ekman 15500. Bahía de Manatí, Léon 16027.

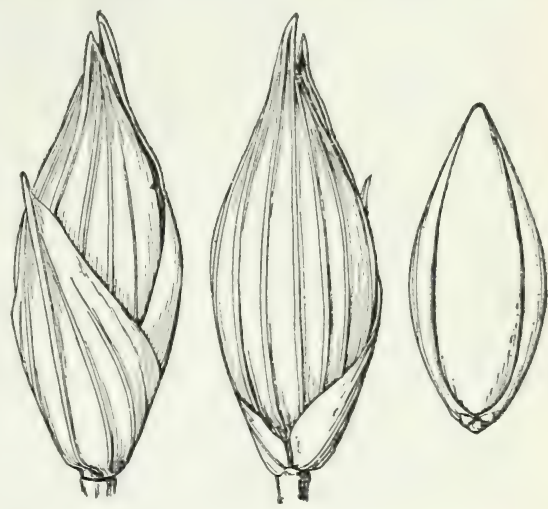

Figtre 219.-Panicum amarulum. Two riews of spikelet, and floret, $\times 10$ (type).

\section{Panicum petersonii Hitchc. and Ekman, sp. nor. ${ }^{63}$}

Perennial; culms erect, tough, firm, glabrous, sparingly branched, about $2 \mathrm{~m}$ tall, the nodes not swollen; sheaths glabrous, passing in-

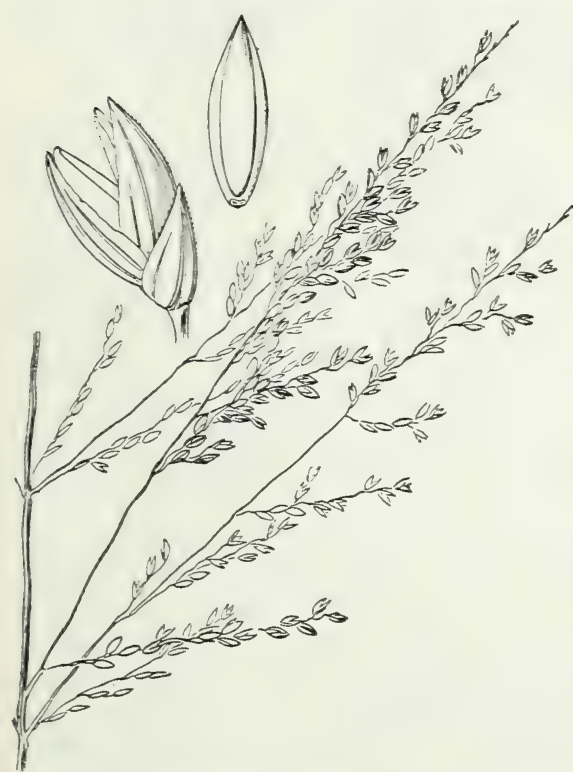

FIGtRE 220.-Panicum petersonii. Portion of panicle, $\times 1$; spikelet and floret, $\times 10$ (type). sensibly into the blade, the lower coriaceous; ligule a very short densely ciliate membrane; blades erect, coriaceous, thick, crescent-shaped in cross section toward base, the edges sharp but smooth, gradually narrowed toward the tip and becoming flat with scabrous edges, the midrib appearing to occupy most of the tissue, $1 \mathrm{~m}$ long or more, the apex fine and scabrous, the middle part of the blade 2 to $3 \mathrm{~mm}$ wide; panicles terminal and axillary, the terminal ovoid, open but rather densely flowered, 15 to $25 \mathrm{~cm}$ long, the axis scabrous, the branches rather closely set, more or less fascicled, ascending, floriferous nearly to the base; spikelets short-pediceled and rather crowded on the branches of the second or third order, ovoid, glabrous, rather blunt, about $2.3 \mathrm{~mm}$ long; first glume

${ }_{63}$ Culmi erecti duri $2 \mathrm{~m}$ alti; vaginae glabrae; laminae durae rigidae erectae angustae $1 \mathrm{~m}$ longae $2-3 \mathrm{~mm}$ latae; panicula nonnihil patens $15-25 \mathrm{~cm}$ longa $10 \mathrm{~cm}$ lata; spiculae $2.3 \mathrm{~mm}$ longae glabrae obtusae; gluma prima circa $1 \mathrm{~mm}$ longa 3-nervis; gluma secunda 5-nervis; lemma sterile 5-nerve, quam gluma secunda paulo longius, palea et staminibus praeditum; lemma fertile lemma sterile aequans. 
3- to 5-nerved, half as long as the spikelet or a little less; second glume 5-nerved, slightly shorter than the spikelet; sterile lemma 5 -nerved, as long as the spikelet, staminate, the palea as long as the lemma, scabrous on the keels; fertile lemma as long as the sterile, pale, rather acute (fig. 220).

Type in the United States National Herbarium, no. 1296166, collected in temporarily flooded places, Mendoza, prov. Pinar del Río, Cuba, November 16, 1923, by E. L. Ekman (no. 18085).

Dr. Ekman also collected this species at Jagüey Chico, on the Hanábana River, prov. Santa Clara (no. 17010). Dr. Ekman states on the label that it is found on both sides of the Hanábana River (Santa Clara and Matanzas Provinces).

The species appears to be allied to $P$. prionitis Nees, of Brazil, agreeing closely in the habit and foliage but with larger spikelets. Dr. Ekman wished to have the species named for Mr. F. J. Peterson, a good friend who aided him greatly in Cuba.

26. Panicum tenerum Beyr., in Trin., Mém. Acad. St. Pétersb. VI. Sci. Nat. 1: 341 . 1834. Georgia.

Plants in small tufts from a knotted crown; culms erect, stiff, wiry, 40 to $90 \mathrm{~cm}$ tall; blades erect, firm, 4 to $15 \mathrm{~cm}$ long, 2 to $4 \mathrm{~mm}$ wide; panicles 3 to $8 \mathrm{~cm}$ long, narrow, the branches appressed, the pedicels

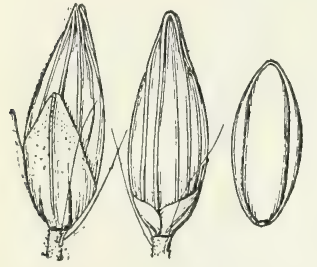

FIgURE 221.-Panicum tenerum. Two views of spikelet, and floret, $\times 10$ (type). usually with a few long hairs at the summit; spikelets about $2.5 \mathrm{~mm}$ long, narrowly ovate, glabrous (fig. 221).

Margins of swamps and wet places near the coast, southeastern United States, Bahamas, Cuba, and Puerto Rico.

BaHamas: Andros Island, Brace 7019, 7132 (both in Field Mus. Herb.).

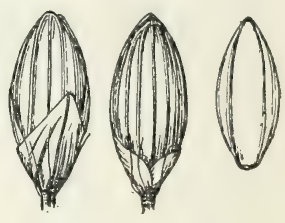

FIGURE 222.-Panicum caricoides. Two views of spikelet, and floret, $\times 10$ (type).

Cuba: Pinar del Río, Wright 3870; Hitchcock 23272. Herradura, Hitchcock 154; Tracy 9080; Ekman 10759. Laguna Jovero, Shafer 10750. Laguna los Indios, Shafer 10807. Guane, Léon 6919. Jagüey Grande, Ekman 16965. Barag'uá, Hitchcock 23378. Mordazo Léon 5977. Manacas, Léon 5856. Placetas del Sur, Léon 6416. Isla de Pinos, Britton and Wilson 14741, 15364, 15380, 15385.

Dominican Republic: Cuenca, Ekman H 11009, 13331. El Valle, Ekman H 15653, H 15670, H 15701.

Puerto Rico: Campo Alegre, Chase 6617.

27. Panicum caricoides Nees; Trin., Gram. Pan. 149. 1826; Agrost. Bras. 108. 1829. Brazil.

Culms tufted, erect, stiff and wiry, as much as $90 \mathrm{~cm}$ tall; blades appressed, narrower than the sheath, involute, 1 to $5 \mathrm{~cm}$ long; panicles narrow, nearly simple, 1 to $1.5 \mathrm{~cm}$ long, the pedicels bearing long erect white hairs at the summit; spikelets 1.5 to $1.8 \mathrm{~mm}$ long, glabrous (fig. 222).

Wet savannas, Trinidad to Brazil; Cuba.

Cuba: Manacas, Léon 9305. Mordazo, Ekman 17048. Isla de Pinos, Britton and Wilson 14282, 14701.

Trinidad: Aripo Savanna, Hitchcock 10069. O'Meara Savanna, Britton and Hazen 1564. 
28. Panicum stenodoides Hubb., Amer. Acad. Proc. 49: 497. 1913. British Honduras.

Perennial; culms in dense tufts, erect, slender, wiry, 20 to $40 \mathrm{~cm}$ tall; blades erect, flat at base, involute toward the apex, 3 to $8 \mathrm{~cm}$ long, 1 to $2 \mathrm{~mm}$ wide, more or less papillose-pilose; panicles about 1 $\mathrm{cm}$ long, narrow, bearing 3 to 7 spikelets about $2 \mathrm{~mm}$ long; first glume half as long as the spikelet (fig. 223).

Open grassland and moist savannas, Central America, Trinidad.

TRINIDAD: Piarco Savanna, Hitchcock 10346.

29. Panicum stenodes Griseb., Fl. Brit. W. Ind. 547. 1864. Jamaica.

Perennial; culms in small tufts, slender and wiry, 25 to $50 \mathrm{~cm}$ tall, erect or reclining; blades 1 to $4 \mathrm{~cm}$ long, 1 to $2 \mathrm{~mm}$ wide, involute; panicles 1 to $2 \mathrm{~cm}$ long, 1 to $2 \mathrm{~mm}$ wide; spikelets about $1.5 \mathrm{~mm}$ long (fig. 224).

Borders of ponds and wet savannas at low altitudes, Central America and the West Indies to Brazil.

CuBA: El Salado, Wright 3871. Herradura, Hitchcock 155; Léon 15955. Guane, Léon 6998, 15354. Pinar del Río, Hitchcock 23263, 23281, 23297. Manacas, Léon 5868, 6045. Banao Mountains, Léon 5402. Isla de Pinos, Britton and Wilson 15346, 15623.

JAmaICA: Bull Head Mountain, Hitchcock 9534 (Amer. Gr. Nat.

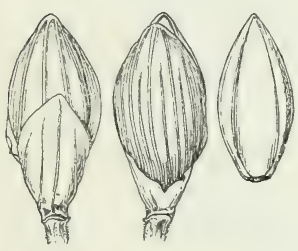

FIgure 223.-Panicum steno doides. Two views of spikelet, and floret, $\times 10$ (type). Herb. 46). Hollis Savanna, Harris 12227. Without locality, Orcutt 7829. HaItr: Acul-Samedi, Ekman H 9919.

Dominican REPUBLIC: Santo Domingo, Wright, Parry, and Brummel 624. Sabana de la Mar, Ekman H 15610.

Puerto Rico: San Juan, Chase 6769.

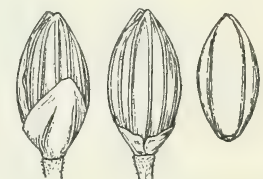

FIGURE"224. - Panicum stenodes. Two views of spikelet, and floret, $\times 10$ (Wright 192).

Trinidad: Piarco Savanna, Hitchcock 10347; Broadway 2151a. Aripo Savanna, Hitchcock $100691 \frac{1}{2}$.

30. Panicum beyeri Hitchc. and Ekman, sp. nov. ${ }^{64}$

Culms densely tufted, slender, weakly erect or reclining, glabrous, 50 to $130 \mathrm{~cm}$ tall; sheaths glabrous; ligule a line of hairs less than 0.5 $\mathrm{mm}$ long; blades numerous, glabrous, flat or mostly involute, very slender, elongate, 20 to $40 \mathrm{~cm}$ long or more, the broader ones as much as $1.5 \mathrm{~mm}$ wide, mostly less than $1 \mathrm{~mm}$ wide, lax or reclining; panicles very slender and elongate, as much as $35 \mathrm{~cm}$ long, the branches few, remote, appressed, few-flowered, 5 to $15 \mathrm{~mm}$ long, the axis and branches very minutely puberulent or scaberulous; spikelets somewhat oblique on the puberulent pedicels, narrowly elliptic, acute, often gaping, glabrous, about $3 \mathrm{~mm}$ long; first glume broadly acute, 3nerved, $1 \mathrm{~mm}$ long; second glume and sterile lemma equal, narrowed to an obtuse point, 5-nerved, the lemma with a palea nearly as long as itself but with no stamens; fertile lemma rather soft, acute, a

${ }^{64}$ Culmi dense caespitosi gracillimi glabri $50-130 \mathrm{~cm}$ alti debiles vel reclinati; laminae gracillimae debiles planes vel involutae elongatae $20-40 \mathrm{~cm}$ longae, interdum $1.5 \mathrm{~mm}$ latae, plerumque $0.5-1 \mathrm{~mm}$ latae; panicula gracillima elongata $30-35 \mathrm{~cm}$ longa, ramis paucis remotis appressis paucifloris $5-15 \mathrm{~mm}$ longis; spiculae angustae glabrae acutae $3 \mathrm{~mm}$ longae. 
little shorter than the spikelet, very minutely scaberulous at the tip, 5-nerved, the midnerve evident only at the tip, the intermediate pair indistinct, the lateral pair distinct near the margin on the ventral

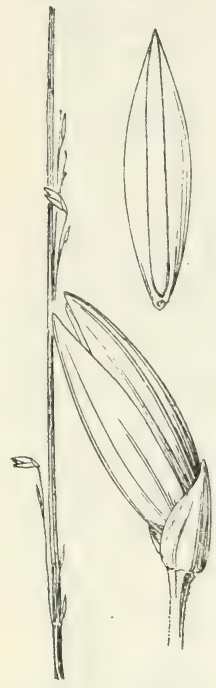

Figure 225.-Panicum beyeri. Portion of panicle, $x$ 1 ; spikelet and floret, $\times 10$ (type). side of the floret, the margins of the lemma approximate but not in contact along the middle of the face; palea nearly as long as the lemma, scaberulous like the lemma at the acute tip, convex on the back, the 2 nerves wide apart, the apex enclosed at the tip (fig. 225).

Type in the United StatesNational Herbarium, no. 1387466, collected along the edge of the Río Piloto, at $300 \mathrm{~m}$ altitude, Sierra de Nipe, prov. Oriente, Cuba, September 8, 1922, by E. L. Ekman (no. 15045).

The species was collected by Dr. Ekman (no. 10085) at the same locality, October 19, 1919, growing in moist sloping "manacales", 65 but the specimens are sterile. The species is said by Dr. Ekman to be very rare. It is named for M. K. Beyer, a Norwegian, who accompanied Dr. Ekman on many Sierra de Nipe excursions.

The species is not closely allied to any other, but for convenience is assigned to the group Tenera in which the culms are stiff and wiry. In habit it resembles $P$. distantiflorum, but the branches of the panicle do not end in a bristle, but frequently bear abortive spikelets, suggesting a trend toward elimination of the spikelet, as in $P$. distantiflorum and its allies.

31. Panicum condensum Nash, in Small, Fl. Southeast. U. S. 93.1903. Florida.

Culms erect, 1 to $2 \mathrm{~m}$ tall; lower sheaths, especially on the innovations, compressed-keeled; blades flat from a usually folded base; panicles condensed, terminal and axillary, 10 to $25 \mathrm{~cm}$ long, rarely over $5 \mathrm{~cm}$ wide, the long solitary or fascicled branches erect, naked at base, with appressed branchlets bearing crowded spikelets on short pedicels; spikelets about $2.5 \mathrm{~mm}$ long, glabrous, acuminate (fig. 226).

Borders of streams and ponds and in wet places, southeastern United States and the West Indies.

Bahamas: Nassau, Curtiss 174.

Cuba: Remates, Ekman 11178, 11389, 11393. San Diego de Tapias, Ekman 10616. Carabela Grande, Roig 3193. Hanábana, Wright 3862 in part.

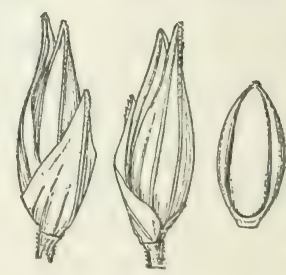

Figtre 226.-Panicum condensum. Two riews of spikelet and floret, $X$ 10 (type). Guanimar, Léon 5062. Batabanó, Léon 13430, 13434, 13623, 13624, 14197, 14203; Ekman 12587. Campo Florido, Léon 4141; Ekman 13239. Sabana de San Marcos, Léon 9207. Sabana de Motembo, Léon 9344; Ekman 16820. Ciénaga de Zapata, Léon 9500, 9518; Ekman 16945. Santayana, Ekman 15362. Caibarién, Léon 468, 475, 478.

65 "Wet forests up to $800 \mathrm{~m}$ in Cuba, characterized by a palm named 'manaca' (Calyptrogyne occidentalis)."-Letter from Brother Léon. 
Holguín, Shafer 1438. Isla de Pinos, Britton and Wilson 14621; Ekman 11795, 12444.

JAMaica: Black River, Hitchcock 9652 (Amer. Gr. Nat. Herb. 47). Savanna-la-Mar, Hitchcock 9884. Grosmond Marsh, Harris 11750.

Haiti: Port-au-Prince, Ekman H 2171; Leonard 10087 ; Buch 2047. Aux Cayes, Ekman H 25, H 264.

Puerto Rico: San Juan, Chase 6351. Campo Alegre, Chase 6802. Leeward Islands: Guadeloupe, Duss 3919.

32. Panicum polygonatum Schrad., in Schult., Mant. 2: 256.1824. Brazil.

Panicum potamium Trin., Gram. Pan. 239. 1826. Brazil.

Perennial; culms branching, widely spreading or creeping, as much as $100 \mathrm{~cm}$ long, the nodes densely pubescent; blades 3 to $13 \mathrm{~cm}$ long, 8 to $15 \mathrm{~mm}$ wide, cordate; panicles 7 to $20 \mathrm{~cm}$ long, the branchlets secund from the lower side of the branches, the rachises sparsely pilose with long weak hairs; spikelets $1.5 \mathrm{~mm}$ long, pointed, glabrous (fig. 227).

Swamps and moist soil along roadsides and in open woods, Mexico and Trinidad to Paraguay.

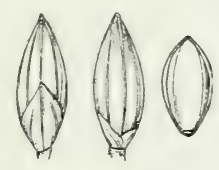

Figtre 227.-Panicum polygonatum. Two views of spikelet, and floret, $\times 10$ (type).

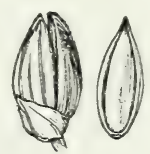

Figure 228.-Panicum milleflorum. Spikelet and floret, $\times 10$ (type).

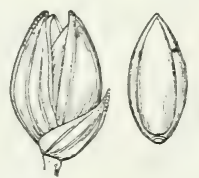

Figtre 229.-Panicum pilosum Spikelet and floret, $\times 10$ (type).

Trinidad: Port-of-Spain, Chase 9935; Hitchcock 9953. Penal Rock Road, Britton, Hazen, and Mendelson 1091. Caparo, Broadway 2837. Aripo Savanna, Hitchcock 10077. Arima, Hitchcock 10297, 10306. Ortoire River, Britton, Freeman, and Nowell 2663. Tabaquite, Hitchcock 10132 (Amer. Gr. Nat. Herb. 57).

Tobago: Broadway 4476.

33. Panicum milleflorum Hitchc. and Chase, Contrib. U. S. Natl. Herb. 17: 494. f. 70. 1915. Canal Zone.

Panicum distichum var. lancifolium Griseb., Fl. Brit. W. Ind. 548. 1864. Trinidad, Crueger 84.

Differs from $P$. pilosum in its larger size, as much as $2 \mathrm{~m}$ tall, in its longer blades, as much as $40 \mathrm{~cm}$ long, in its longer panicles, as much as $35 \mathrm{~cm}$ long, and in its slightly smaller spikelets, $1.3 \mathrm{~mm}$ long (fig. 228).

Swamps near the coast, British Honduras to Brazil; Trinidad.

Trinidad: Without locality, Crueger 84 (Bot. Gard. Herb. 3195).

34. Panicum pilosum Swartz, Prodr. Veg. Ind. Occ. 22. 1788. Jamaica.

Panicum distichum Lam., Encycl. 4: 731. 1798. Jamaica.

Perennial; culms decumbent or creeping and rooting at the nodes, the branches and sometimes the main culms erect; nodes villous or 
sometimes glabrous; blades 4 to $20 \mathrm{~cm}$ long, 7 to $15 \mathrm{~mm}$ wide, broadest near the cordate or truncate base; panicles of 10 to 20 spikelike densely flowered racemes along an axis 5 to $15 \mathrm{~cm}$ long, the racemes 1 to 3 $\mathrm{cm}$ long, the rachis pilose; spikelets $1.5 \mathrm{~mm}$ long, glabrous (fig. 229).

Moist ground, ditches, and swamps, Mexico and the West Indies to Paraguay.

Cuba: Daraniguas, Wright 3451. Sumidero, Shafer 13505, Shafer and Léon 13533, 13535. Buenaventura, Wilson 9444. Herradura, Van Hermann 763; Tracy 9063. Marianao, Léon 1977. Sancti Spíritus, Léon 908. Banao Mountains, Léon 3982. Jauco, Léon 12306. Isla de Pinos, Curtiss 305; Taylor 36; Britton and Wilson 14638, 15807.

JamaICA: Castleton, Harris 11280a; Hitchcock 9407. Troy, Harris 12566; Hitchcock 9782. Claverty Cottage, Harris 11524. Hollis Savanna, Harris 12254. Ipswich, Hitchcock 9626. Ramble, Hitchcock 9517. Bull Head Mountain, Hitchcock 9548. Ewarton, Hitchcock 9423. Port Morant, Hitchcock in 1890. Gordon Town, Hart 732. Navy Island, Millspaugh 1859. East of Seamens Valley, Maxon and Killip 106a. Mill Bank, Maxon and Killip 196. Mount Diablo, Maxon and Killip 489. Cedar Hurst, Harris 11547.

Dominican Republic: Samaná Peninsula, Abbott 313; Ekman H 14835. Guarabo, Abbott 2802. La Nassa, Faris 268. Higüey,

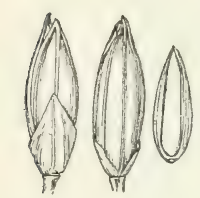

FIGURE 230.-Panicum boliviense. Two views of spikelet, and floret, $\times 10$ (type). Ekman H 12133, H 12236; Villa Altagracia, Ekman H 11183.

Leeward Islands: St. Kitts, Box 137. Guadeloupe, L'Herminier; Duss 4154. Dominica, Imray 151, 312; Hitchcock 16441; Jones 20.

WindwaRd Islands: Martinique, Hitchcock 16449. St. Lucia, Hitchcock 16478; Kemp 18. Grenada, Broadway 148.

Trinidad: Mount Tocuche, Britton, Hazen, and Mendelson 1252. Arima, Hitchcock 10309. Piarco Savanna, Hitchcock 10358. Tabaquite, Hitchcock 10121. Port-of-Spain, Bot. Gard. Herb. 3293; Hitchcock 9961, 10045. Cedros, Hitchcock 10147 (Amer. Gr. Nat. Herb. 59). Oropuche Lagoon, Britton, Hazen, and Freeman 1153. O'Meara Savanna, Britton and Hazen 1578. Ortoire River, Britton, Freeman, and Nowell 2533. La Brea, Broadway 4986.

Tobago: Broadway 4063; Hitchcock 10208, 10242, 10265; Eggers 5534.

35. Panicum boliviense Hack., Repert. Sp. Nov. Fedde 11: 19. 1912. Bolivia.

Perennial; culms decumbent, branching, as much as $1.5 \mathrm{~m}$ long; nodes glabrous; blades flat, gradually narrowed from a cordate-clasping base, 8 to $15 \mathrm{~cm}$ long, 1 to $2 \mathrm{~cm}$ wide; panicle 10 to $25 \mathrm{~cm}$ long, open; spikelets $1.5 \mathrm{~mm}$ long, glabrous (fig. 230).

Ditches, banks of streams, and moist open woodland, southern Mexico and Cuba to Paraguay.

Cuba: Mariel, Ekman 11499. Mendoza, Léon 6952. Baños San Vicente, Britton and Gager 7452. San Miguel de Casanova, Léon 12469. San Nicolás, Léon 7297. Marianao, Léon 1977. Batabanó, Léon 14234. Baraguá, Hitchcock 23369. Sancti Spíritus, Léon 909, 6515, 6574, 6606. Caibarién, Fernando 374. Omaro, Léon 9441. Manacas, Léon 5906. Banao, Léon 5460. Santa Rosa, Léon 10336. Guara, Hitchcock 23405. Isla de Pinos, Curtiss 464. 
Haitr: Étang-Dérémond, Ekman H 10473. Aux Cayes, Ekman H 754 .

Dominican Republic: Cuenca, Ekman H 10980, H 13305. Villa Altagracia, Ekman H 11204. Sosúa, Ekman H 14533.

LeEward Islands: Guadeloupe, L'Herminier 17. Dominica, Hitchcock 16419, 16435.

Windward Islands: Martinque, Hitchcock 16446. St. Lucia, Box 184, 322; Hitchcock 16483.

36. Panicum laxum Swartz, Prodr. Veg. Ind. Occ. 23. 1788. Jamaica.

Panicum diandrum Kunth, Rév. Gram 2: 393. pl. 110. 1831. Guadeloupe and Brazil.

More or less spreading, often rooting at the nodes of the decumbent base, culms 40 to $100 \mathrm{~cm}$ long; blades conduplicate or flat, 5 to 15 $\mathrm{mm}$ wide, narrowed to a rounded or subcordate base; panicles oblong, 5 to $30 \mathrm{~cm}$ long, composed of many slender, racemelike branches, the lower distant, spreading, the upper ascending; branchlets mostly secund on the lower side of the branches, bearing 2 or 3 acutish spikelets 1 to $1.5 \mathrm{~mm}$ long: (fig. 231).

Ditches, banks, moist woods, and wet savannas, Mexico and the West Indies to Paraguay. Common in Cuba, Jamaica, Puerto Rico, and Trinidad. Other localities are listed below.

Haiti: Lamielle, Ekman H 6204.

Dominican Republic: Pimentel, Abbott 687, 688. Cuenca, Ekman H 10981. La Cumbre, Ekman H 12390 .

Virgin Islands: Tortola, Britton and Shafer 791, 808.

LeEWard Istands: Antigua, Wullschlaegel 623; Box 74, 82. Truadeloupe, Duss 3179. Dominica, Jones 21, 25.

Windward Islands: Barbados, Dash 450. St. Lucia, Kemp 11, 42 .

Grenada: Broadway 1870, 3712, 4668.

Tоваgо: Hitchcock 10245, 10272.

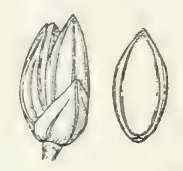

Figure 231.-Panicum laxum. Spikelet and floret, $\times 10$ (type).

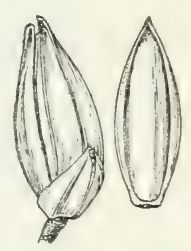

Figure 232,-Panicum stevensianum. Spikelet and floret, $\times 10$ (type).

37. Panicum stevensianum Hitchc, and Chase, Contrib. U. S. Natl. Herb. 17: 498. f. 76. 1915. Puerto Rico, Chase 6616.

Perennial; culms compressed, prostrate-spreading, rooting at the nodes, 30 to $60 \mathrm{~cm}$ long, the flowering branches ascending; blades flat, 4 to $10 \mathrm{~cm}$ long, 5 to $10 \mathrm{~mm}$ wide, truncate-cordate at base; panicles 6 to $10 \mathrm{~cm}$ long, narrow, consisting of several appressed or ascending spikelike branches; spikelets about $2 \mathrm{~mm}$ long, glabrous, acute; first glume about one-fourth the length of the spikelet (fig. 232). Rico.

Borders of pools, ditches, and other wet places, Cuba and Puerto

Cuba: Batabanó, Ekman 12630, 13093; Léon 14200. Laguna Ariguanabo, Ekman 11516, 16929; Léon 9030. Laguna de Castellano, Wilson 9558; Ekman 16796.

Puerto Rico: Campo Alegre, Chase 6616.

38. Panicum exiguiflorum Griseb., Cat. Pl. Cub. 234. 1866. Based on P. minutiflorum Rich.

Panicum minutiflorum A. Rich., in Sagra, Hist. Cuba 11: 305. 1850. Not P. minutiflorum Rasp., 1825. Cuba. 
Panicum laxum var. variegatum Griseb., Cat. Pl. Cub. 233. 1866. Cuba, Wright 3450.

Panicum tricolor Hack., Oesterr. Bot. Ztschr. 51: 370. 1901. Fortune Island, Eggers 3978.

Perennial; culms tufted, sometimes sending out prostrate stolons, decumbent at base, 15 to $50 \mathrm{~cm}$ tall; blades 2 to $6 \mathrm{~cm}$ long, 0.5 to $1.5 \mathrm{~mm}$ wide, glabrous; panicles 3 to $10 \mathrm{~cm}$ long, the branches few, spreading or reflexed at maturity; spikelets $1.5 \mathrm{~mm}$ long, glabrous, clustered on short branchlets; sterile palea enlarging at maturity, expanding the spikelet (fig. 233).

Low savannas and moist sandy woods, Cuba and Haiti.

BaHAmas: Fortune Island, Hitchcock in 1890.

Cuba: Santa Cruz de los Pinos, Ekman in 1923 (Amer. Gr. Nat. Herb. 702). Herradura, Hitchcock 179; Tracy 9075. Pinar del Río, Hitchcock 23273, 23278. Guane, Léon 6948, 7004, 7008. Guanabacoa, Ekman 572; Léon 911, 913, 5608, 5624; Hitchcock 23241. Madruga, Léon 6377, 14690. San Juan de Buena Vista, Wright 755. Chirigota, Wright 3450, 3877 in part. Zaza de Tunas, Léon

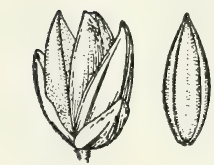

Figure 233.-Pani c $u m$ exiguiflorum. Spikelet and floret $\times 10$ (Wright 3450 ).

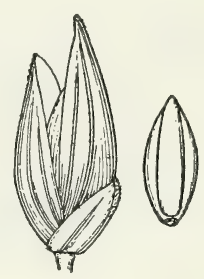

Figure 234.-Panicum stoloniferum. Spikelet and floret, $\times 10$ (type).

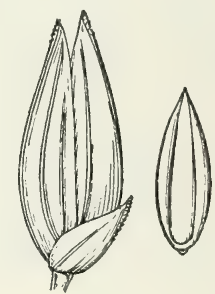

Figure 235.-Pani. cum frondescens Spikelet and floret, $\times 10$ (type).

902, 6730. Sancti Spíritus, Léon 2566. Gavilanes, Léon 6654. Manacas, Léon 9277. Soledad, Hitchcock 23330. Baraguá, Hitchcock 23356. Bayate, Ekman 2443. Isla de Pinos, Britton and Wilson 14699, 15381; Taylor 35.

Haiti: Morne Belanse, Ekman H 4916.

39. Panicum stoloniferum Poir., in Lam., Encycl. Sup. 4: 274.1816. Cayenne.

Perennial; plants creeping, branching, 10 to $50 \mathrm{~cm}$ long; blades flat, 1 to $5 \mathrm{~cm}$ long, 3 to $15 \mathrm{~mm}$ wide; panicles 1 to $5 \mathrm{~cm}$ long, with few to several racemes 5 to $10 \mathrm{~mm}$ long; spikelets about $2.5 \mathrm{~mm}$ long, glabrous (fig. 234).

Moist shady places, Central America and the Lesser Antilles to Brazil.

Windward Islands: Martinique, Duss 1291 (Krug and Urban Herb.).

Trinidad: Maracas, Broadway 6078, 7239. Ortoire River, Britton, Freeman, and Nowell 2539. Caura River, Britton and Hazen 1204. Port-of-Spain, Bot. Gard. Herb. 2293. Arima, Broadway 2370. Oropuche, Broadway 5582. Blanchisseuse, Broadway 6907. Chaguanas, Bot. Gard. Herb. 3747. Without locality, Crueger 79. 
40. Panicum frondescens Meyer, Prim. Fl. Esseq. 56. 1818. British Guiana.

Hymenachne frondescens Fourn., Mex. Pl. 2: 36. 1886.

Culms erect or ascending from a creeping base, 30 to $50 \mathrm{~cm}$ tall; blades 5 to $11 \mathrm{~cm}$ long, 12 to $20 \mathrm{~mm}$ long, acuminate, glabrous; panicles 5 to $11 \mathrm{~cm}$ long, with numerous approximate racemes 10 to $25 \mathrm{~cm}$ long; spikelets about $2.7 \mathrm{~mm}$ long, glabrous (fig. 235).

Swamps and wet places at low altitudes, Mexico and Lesser Antilles to Brazil.

\section{Leeward Islands: Guadeloupe, L'Herminier 137.}

Windward Islands: Smith and Smith 187 (Krug and Urban Herb.).

Trinidad: Blanchisseuse, Broadway 2390. Arima, Broadway 2371. Oropuche, Broadway 6171. Mount Tamana, Broadway 7980. Without locality, Crueger 85.

41. Panicum pulchellum Raddi, Agrost. Bras. 42. 1823. Brazil.

Perennial; culms spreading or creeping, branching, the nodes pubescent; blades thin,

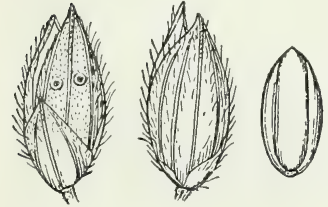

FIGURE 236.-Panicum pulchellum. Two views of spikelet, and floret, $\times 10$ (Raddi). flat, 1.5 to $4 \mathrm{~cm}$ long, 4 to $15 \mathrm{~mm}$ wid e; panicles oblong, 2 to $12 \mathrm{~cm}$ long, the racemes 5 to $15 \mathrm{~mm}$ long; spikelets about $2 \mathrm{~mm}$ long, hispid, bearing on the sterile lemma 2 sessile glands (fig. 236).

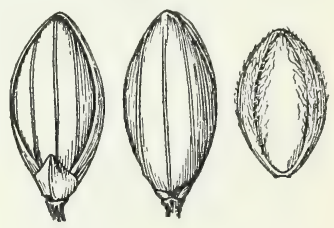

FIGURE 237.-Panicum schiffneri Two views of spikelet, and floret, $\times 10$ (type)

Moist shady places, southern Mexico and Windward Islands to Brazil.

Windward Islands: Martinique, Duss 767 (Krug and Urban Herb.).

42. Panicum schiffneri Hack., Ergeb. Bot. Exped. Akad. Wiss. Sudbras. 11. 1906. Brazil.

Perennial, branching and rooting at the nodes; culms ascending, 2 to $3 \mathrm{~m}$ long; sheaths papillose-hispid; blades 10 to $15 \mathrm{~cm}$ long, 12 to $25 \mathrm{~mm}$ wide, scabrous; panicles 10 to $15 \mathrm{~cm}$ long, the few slender scabrous branches remote, the spikelets approximate along the upper part; spikelets glabrous, elliptic, about $2 \mathrm{~mm}$ long; first glume less than one-fourth the length of the spikelet; fruit elliptic, $1.5 \mathrm{~mm}$ long, sparsely silky (fig. 237).

Wet shady banks and slopes, Mexico and the West Indies to Brazil.

Haitr: Pétionville, Ekman H 1927. Le Borgne, Ekman H 4791.

Dominican Republic: Polo, Abbott 1808. Jarabaco, Ekman H 14178. Loma Diego de Ocampo, Ekman H 16301. Sierra de Ocoa, Ekman H 11646.

Puerto Rico: Maricao, Chase 6198, 6247 (Amer. Gr. Nat. Herb. 512). Adjuntas, Chase 6474. Cayey, Chase 6745.

Windward Islands: Martinique, Hahn 616.

60256-36-18 
43. Panicum trichoides Swartz, Prodr. Veg. Ind. Occ. 24.1788. Jamaica.

Panicum capillaceum Lam., Tabl. Encycl. 1: 173. 1791. Puerto Rico.

Annual; culms erect or branched and spreading, the ascending ones 20 to $40 \mathrm{~cm}$ long; sheaths papillose-hirsute; blades ovate or ovate-lanceolate, thin, cordate, 2 to $6 \mathrm{~cm}$ long, 1 to $2 \mathrm{~cm}$ wide, glabrous or sparsely hirsute; panicles open and spreading, 5 to $20 \mathrm{~cm}$ long, the branches and pedicels capillary; spikelets about $1.3 \mathrm{~mm}$ long, elliptic, sparsely hirsute; first glume about half as long as the spikelet (fig. 238).

Damp shady places, often a weed in fields and groves, throughout tropical America. To be found on all the islands.

This species has been referred in some American floras to $P$. brevifolium L., of India.

44. Panicum trichanthum Nees, Agrost. Bras. 210. 1829. Brazil.

Perennial; culms branching and straggling, the ascending fertile ones 1 to $2 \mathrm{~m}$ long; blades oblong-lanceolate, 10 to $15 \mathrm{~cm}$ long, 10 to $15 \mathrm{~mm}$ wide, cordate, rather strongly nerved; panicles 10 to $30 \mathrm{~cm}$

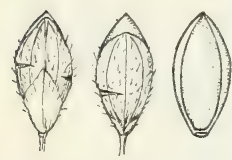

FIGURE 238.-Panicum trichoides. Two views of spikelet, and floret, $\times 10$ (type).

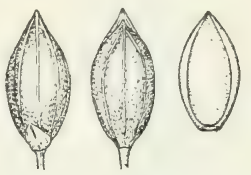

Figure 239.-Panicum trichanthum. Two views of spikelat, and floret, $\times 10$ (Fendler 1643).

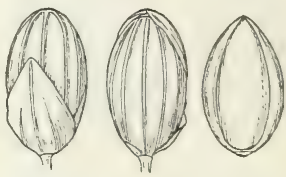

Figure 240.-Panicum parvifolium. Two views of spikelet, and floret, $\times 10$ (type).

long, open and spreading; spikelets about $1.5 \mathrm{~mm}$ long, elliptic, acute; first glume less than one-fifth the length of the spikelets (fig. 239).

Moist thickets and river banks, Central America and the West Indies to Paraguay.

Cuba: Vento, Curtiss 598; Léon 557. Trinidad, Wright 753. Bayate, Ekman 4559, 6553. Romelia, Eggers 5350.

$J_{\text {AMAICA: Port Antonio, Hitcheock in } 1890 .}$

Haiti: Dondou, Leonard 8571. Port-de-Pai, Leonard 12269. Ennery, Leonard 9157. Cabaillon, Ekman H 845.

Dominican Republic: Polo, Abbott 1773. Gros-Figuier, Ekman H 6763.

Puerto Rico: Ponce, Chase 6487. Cayey, Chase 6748; Sintenis 2471. Rio Piedras, Johnston 143.

Trinidad: Arima, Eggers in 1883. Cedros, Hitchcock 10146. Port-of-Spain, Hitchcock 9943. Siparia, Broadway 4973.

45. Panicum parvifolium Lam., Tabl. Encycl. 1: 173. 1791. Tropical America.

Panicum oplismenoides Nash, Bull. Torrey Bot. Club 30: 381. 1903. Puerto Rico, Heller 1316.

Perennial, more or less glaucous; culms branching and creeping, rooting at the nodes, the ascending fertile ones 20 to $80 \mathrm{~cm}$ long; 
blades 1 to $3 \mathrm{~cm}$ long, 2 to $6 \mathrm{~mm}$ wide, oblong-lanceolate, rounded or subcordate, spreading or reflexed, glabrous; panicles open, loosely few-flowered, 2 to $4 \mathrm{~cm}$ long; spikelets turgid, blunt, glabrous, 1.5 $\mathrm{mm}$ long; first glume a little more than half the length of the spikelet (fig. 240).

Wet savannas and margins of ponds and streams, Costa Rica and the West Indies to Paraguay.

Cuba: Pinar del Río, Hitchcock 23277; Britton and Gager 7075. Los Almacigos, Wright 3458. Herradura, Hitchcock 181, 23435; Baker 2078; Britton, Earle, and Gager 6494; Tracy 9060, 9079. Remates, Ekman 11359. Guane, Shafer 10659; Léon 6944, 15399. Laguna los Indios, Shafer 10803 . Isla de Pinos, Britton and Wilson 14235, 15624; Britton, Wilson, and Leon 6053.

Jamaica: Hollis Savanna, Harris 12221. James Hill Savanna, Harris 12839.

Dominican Republic: Cuenca, Ekman H 10968. Rincón, Ekman H 13290. Jovero, Abbott 2539.

Puerto Rrco: Carolina, Britton and Brown 5720. Vega Baja, Chase 6796. Aguada, Sintenis 5719. San Juan, Chase 6358, 6630, 6763, 6786. Campo Alegre, Chase 6615, 6788. Catano, Sintenis 5719 .

Trinidad: O'Meara Savanna, Broadway 2372. Aripo Savanna, Hitchcock 10065, 10080 (Amer. Gr. Nat. Herb. 72). Pitch Lake, Hitchcock 10100 (Amer. Gr. Nat. Herb. 210). Without locality, Broadway in 1918; Crueger 224.

46. Panicum cyanescens Nees; Trin., Gram. Pan. 202. 1826; Agrost. Bras. 220. 1829. Brazil.

Perennial, bluish or glaucous; culms tufted, 30 to $50 \mathrm{~cm}$ tall; blades flat, rather firm, erect to spreading or reflexed, 3 to $8 \mathrm{~cm}$ long, 4 to 5

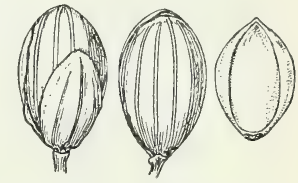

Figure 241.-Panicum cyanescens. Two views of spikelet, and floret, $\times 10$ (type). $\mathrm{mm}$ wide, oblong-lanceolate, glabrous; panicles open, 3 to $6 \mathrm{~cm}$ long; spikelets $1.5 \mathrm{~mm}$ long, turgid or subglobose, obtuse, glabrous; first glume obtuse, two-thirds as long as spikelet (fig. 241).

Swamps and wet savannas, Trinidad to Brazil; Cuba; British Honduras.

CuBA: Isla de Pinos, Ekman 12148; Britton and Wilson 14748a.

Trinidad: Aripo Savanna, Hitchcock 10067. Piarco Savanna, Hitchcock 10349, 10354, 10364. Without locality, Finlay 88; Crueger 20.

47. Panicum nervosum Lam., Encycl. 4: 747. 1798. Cayenne.

Stouter than $P$. cyanescens, the lower sheaths much overlapping; blades strongly nerved, cordate-clasping, widest near the base, gradually narrowing to a sharp point; panicle 10 to $15 \mathrm{~cm}$ long, open, the branches ascending.

Savannas, Trinidad to Brazil.

Trinidad: Aripo Savanna, Broadway 2377.

48. Panicum venezuelae Hack., Oesterr. Bot. Ztschr. 51: 368. 1901. Venezuela.

Panicum ineptum Hitchc. and Chase, Contrib. U. S. Natl. Herb. 17: 509. f. 98 . 1915. Santo Domingo, Bertero 817. 
Panicum berteronianum Mez, Bot. Jahrb. Engler 56 (Beibl. 125): 5. 1921. Not P. berteronianum Schult., 1854. Santo Domingo, Bertero 817.

Perennial; culms slender, widely spreading or creeping, the flowering branches ascending, 10 to $15 \mathrm{~cm}$ tall, the nodes pilose; sheaths pilose; blades flat, 3 to $7 \mathrm{~cm}$ long, 3 to $6 \mathrm{~mm}$ wide, pubescent on both surfaces; panicles 3 to $5 \mathrm{~cm}$ long, of few to sereral short spreading densely flowered branches, remote along the main pilose axis, the branches 4 to $6 \mathrm{~mm}$ long, bearing 1 to 8 subsessile spikelets about $2.5 \mathrm{~mm}$ long; first glume pubescent, half as long as the spikelet; second glume

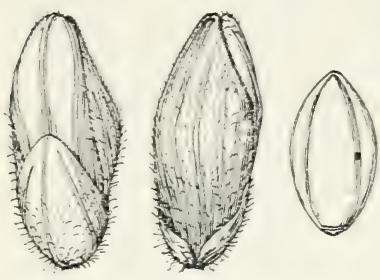

FIGTRE 242-Panicum renezuelat. Two riews of spikelet, and floret, $\times 10$ (t.pe of P. in:ptum). pubescent, gibbous, equaling the glabrous sterile lemma, both inflated (fig. 242).

Crevices of rocks and stony slopes, Cuba, Dominican Republic, Venezuela, and Brazil.

Cuba: Loma Barbí, Sierra Maestra, Ekman 15661. Loma del Gato, Ekman in 1922 (Amer. Gr. Nat. Herb. 703); Léon 10190.

Dominicax Reptblic: Monción, Ekman H 12608, H 13085. San José de las Matas, Ekman H 14602. Bajaboníco, Ekman H 14499. Without locality, Bertero 817 (Krug and Urban Herb.).

49. Panicum sellowii Nees, Agrost. Bras. 153. 1829. Brazil.

Panicum ralenzuelanum A. Rich, in Sagra, Hist. Cuba 11: 304. 1850. Cuba.

Panicum rugulosum rar. hirtiglume Griseb., Cat. Pl. Cub. 233. 1866. Cuba, i'right 3455.

Perennial; culms branching and straggling, as much as $1 \mathrm{~m}$ long; blades thin, orate-lanceolate, 4 to $15 \mathrm{~cm}$ long, 10 to $30 \mathrm{~mm}$ wide, more or less pubescent or relretr; panicles open, 10 to $20 \mathrm{~cm}$ long, the branches ascending or spreading; spikelets short-pediceled along the upper part, about $2 \mathrm{~mm}$ long, oborate, obtuse, papillose-hispidulous; first glume about two-thirds as long as the spikelet (fig: 243).

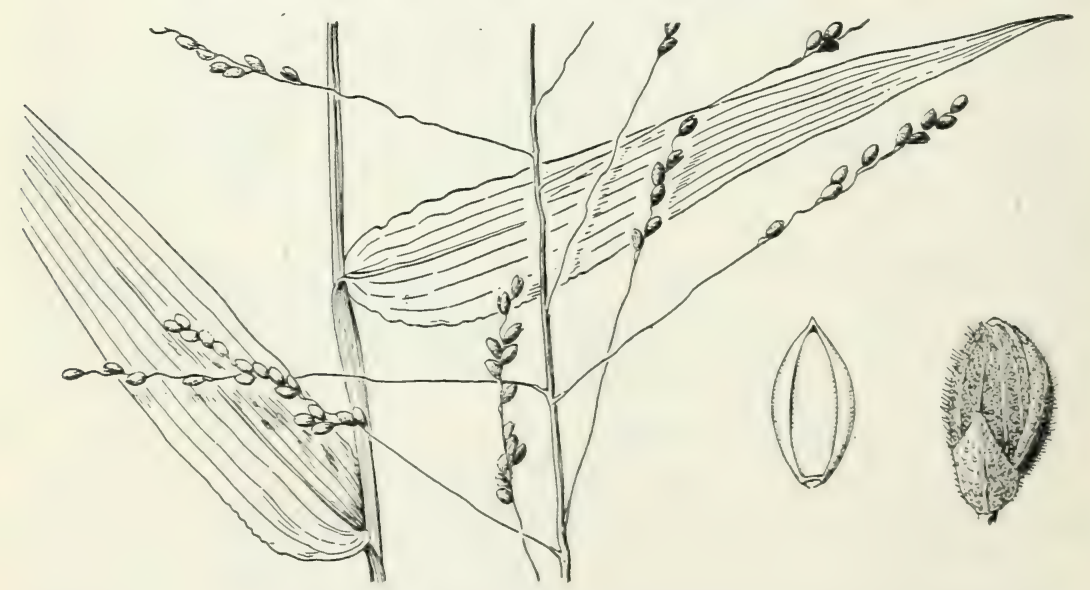

Figtre 243.-Panicum sellowii. Plant, $\times 1$; spikelet, and floret, $\times 10$ (type and Hitchcock 23295). 
In Grasses of the West Indies this species was referred to Panicum millegrana Poir. That species, differing chiefly in having longpedicelled spikelets, is not known from North America, except for the type specimen of $P$. patentissimum Desv., said to be from "SaintDomingue [and] la Nourelle-Espagne." The type, in the Paris Herbarium, is labeled "Hispaniola." Like many localities cited by Desvaux it is probably erroneous.

Damp woods and shady banks, Mexico and Trinidad to Paraguay.

Cuba: Herradura, Ekman 10828; Hitchcock 180, 23440; Tracy 9098. Pinar del Río, Hitchcock 23296; Wright 3855. Viñales, Killip 13549. La Catalina, Wright 3455. Sumidero, Shafer and Léon 13562. Sierra de Cabra, Britton and Gager 7201. Cajálbana, Léon 4836. San Diego de los Baños, Léon 4595, 4602.

Trinidad: Port-of-Spain, Hitcheock 9979; Broadway 5909. Pitch Lake, Hitchcock 10087.

50. Panicum glutinosum Swartz, Prodr. Veg. Ind. Occ. 24. 1788. Jamaica.

Panicum obtusiflorum A. Rich., in Sagra, Hist. Cuba 11: 305. 1850. Cuba, Linden 2143.

Panicum lindeni Griseb., Cat. Pl. Cub. 233. 1866. Cuba, Linden 2143.

Perennial; culms erect from a geniculate or creeping and rooting base, 1 to $2 \mathrm{~m}$ tall; blades elongatelanceolate, acuminate, 15 to $50 \mathrm{~cm}$ long, 15 to $25 \mathrm{~mm}$ wide; panicles open, 15 to $30 \mathrm{~cm}$ long, the lower branches verticillate, stiffly ascending; spikelets $3 \mathrm{~mm}$ long, turgid, obovoid, obtuse, glabrous but viscid; first glume nearly as long as the spikelet (fig. 244).

Mountain woods 500 to $2,000 \mathrm{~m}$, Mexico and the West Indies to Paraguay.

Cuba: Sancti Spíritus Mountains, Léon 6620. Banao Mountains, Léon 3998. La Perla, Léon 3790; W'right 757. Gran Piedra, Shafer 9014. Alto de Iberia, Ekman 8298. Guara, Hitchcock 23416. Without locality, Linden 2143.

JAMAICA: Gordon Town, Hart 792; Hitchcock 9321; Harris 12431. Troy, Maxon 2816; Hitchcock 9785; Harris 12607. Ewarton, Hitchcock 9451. Abbey Green, Hitchcock 9370. Ipswich, Hitchcock 9627. Mount Diablo, Ridley 25, 38; Maxon and Killip 443. Cinchona, Harris 11264, 11440, 11508; Hitchcock 9708. Arntully, Orcutt 2643, 3110. Red Hills, Harris 11836. Salt Hill, Harris 11395. Newport, Britton 3193. Above Mattis River, Maxon and Killip 185. St. Helens Gap, Maxon and Killip 595. Without locality, Wullschlägel 1163.

Haitr: Kenskoff, Buch 956. Marmelade, Leonard 8212. Caille la Croix, Leonard 7854. Furcy, Buch 1540; Leonard 4337. Source Rouillé, Ekman H 6827. Ma Blanche, Ekman H 623.

Dominican Republic: San Juan, Ekman H 13431. Lagunas de Cenobí, Valeur 54. Sabaneta, Valeur 520. 
Puerto Rico: Mayaguez, Sintenis 357. Cerro Gordo, Sintenis 2609. Maricao, Chase 6199, 6250 (Amer. Gr. Nat. Herb. 211). Adjuntas, Chase 6469.

51. Panicum rudgei Roem. and Schult., Syst. Veg. 2: 444.1817. Based on $P$. scoparium Rudge.

Panicum scoparium Rudge, Pl. Guian. 1 : 21. pl. 29. 1805. Not P. scoparium Lam., 1798. British Guiana.

Perennial; culms robust, 30 to $100 \mathrm{~cm}$ tall, erect or somewhat geniculate; sheaths hirsute; blades thick, linear, 15 to $40 \mathrm{~cm}$ long, 5 to $10 \mathrm{~mm}$ wide, rather rigidly ascending, flat or folded, usually densely hirsute; panicles terminal and lateral, forming an oblong inflorescence, open, the branches stiff, the pedicels divaricate; spikelets $3.5 \mathrm{~mm}$ long, turgid, strongly nerved, sparsely hirsute; glumes and sterile lemma acuminate or abruptly pointed (fig. 245).

Savannas at low and medium altitudes, Central America and Jamaica to Brazil.
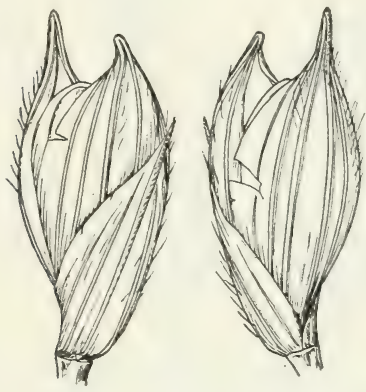

FigURE 245.-Panicum rudgei. Two views of spikelet, and floret, $\times 10$ (Salzmann).

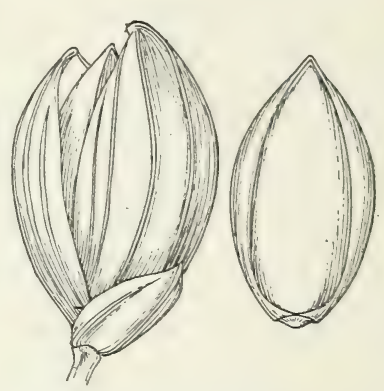

F I G URE 246.-Panicum mertensii. Spikelet and floret, $\times 10$ (type of $P$. altissimum Meyer).

JAMAICA: Upper Clarendon, Harris 12235, 12845. Bunkers Hill Savanna, Harris 11170. Bull Head Mountain, Hitchcock 9528.

Trinidad: Piarco Savanna, Britton and Hazen 688. O'Meara Saranna, Britton and Hazen 1563. Pitch Lake, Hitchcock 10083 (Amer. Gr. Nat. Herb. 75). St. Joseph, Hitchcock 10181. Without locality, Crueger.

52. Panicum mertensii Roth, in Roem. and Schult., Syst. Veg. 2: 458. 1817. British Guiana.

Panicum altissimum Meyer, Prim. Fl. Esseq. 63. 1818. Not P. altissimum DC., 1813. British Guiana.

Panicum megiston Schult., Mant. 2: 248. 1824. Based on P. altissimum Meyer.

Perennial; culms robust, 1 to $2 \mathrm{~m}$ tall; sheaths papillose-hispid; blades elongate, 1.5 to $3 \mathrm{~cm}$ wide, glabrous; panicles 40 to $60 \mathrm{~cm}$ long, the stiff main axis striate-angled, the branches in distant verticils as many as 20 to 30 in a verticil; spikelets about $3.5 \mathrm{~mm}$ long, globularoboroid, glabrous; first glume less than one-third the length of the spikelet (fig. 246).

Swamps and banks of ponds and rivers, Mexico and Trinidad to Paraguay; Cuba. 
Cuba: Damnjí, Ekman 11004. Santa Cruz de los Baños, Wright 3872 .

Trinidad: Cedros, Broadway 9286. Caroni Savanna, Hart 4197. Without locality, Crueger.

53. Panicum trigonum Retz., Obs. Bot. 3: 9. 1783. India.

Cyrtococcum trigonum A. Camus, Bull. Mus. Hist. Nat. [Paris] 27: 118. 1921.

Annual; culms branching, slender, 10 to $30 \mathrm{~cm}$ long; blades flat, lanceolate, sparsely pilose, 1 to $3 \mathrm{~cm}$ long, 3 to $5 \mathrm{~mm}$ wide; panicles few-flowered, 1 to $3 \mathrm{~cm}$ long, open or contracted; spikelets somewhat laterally compressed, pilose, about $1.7 \mathrm{~mm}$ long, the second glume keeled and bulged out at the middle.

Shady places, Trinidad; introduced.

Trinidad: Port-of-Spain, forming a thick carpet under trees in the Botanic Garden, Hitchcock 17661; Broadway 4891, 8017 (Amer. Gr. Nat. Herb. 706 ); Bailey in 1921.

54. Panicum grande Hitchc. and Chase, Contrib. U. S. Natl. Herb. 17: 529. f. 143. 1915. Canal Zone.

Panicum myrianthum Mez, Bot. Jahrb. Engler 56: Beibl. 125: 3. 1921. Guiana.

Perennial, gregarious, producing extensively creeping or floating leafy stolons about $5 \mathrm{~mm}$ thick; culms 1.5 to $2 \mathrm{~m}$ tall, the nodes densely hirsute; blades flat, as much as $1 \mathrm{~m}$ long and $6 \mathrm{~cm}$ wide, narrowed toward base and apex, glabrous, somewhat plicate; panicles as much as $60 \mathrm{~cm}$ long and $40 \mathrm{~cm}$ wide, open; spikelets

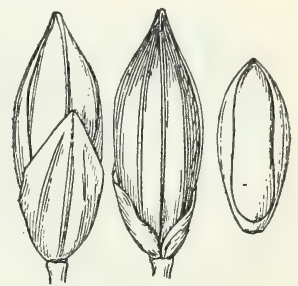

FIGURE 247.-Panicum grande. Two views of spikelet, and floret, $\times 10$ (type). $2.5 \mathrm{~mm}$ long, pointed, glabrous (fig. 247).

Lakes, ponds, and swamps, near the coast, growing in the water, Central America to Brazil; Cuba, Trinidad.

Cuba: Baracoa, Ekman 3487.

Trinidad: St. Joseph, Hitchcock 10022. Manzanilla, Hitchcock 10376. Caroní, Broadway 5859. Cedros, Hitchcock 10148; Broadway 4957. Naset, Broadway 9110.

55. Panicum asperifolium (Desv.) Hitchc., Contrib. U. S. Natl. Herb. 22: 489. 1922.

Streptostachis asperifolia Desv., Nouv. Bull. Sci. Philom. Paris 2: 190. 1810. Tropical America.

Panicum streptostachys Spreng., Syst. Veg. 1: 316. 1825. Based on Streptostachys aspera Desv. (error for asperifolia).

Plants about $1 \mathrm{~m}$ tall from a decumbent base; sheaths glabrous or hirsute; blades thin, as much as $20 \mathrm{~cm}$ long and $3.5 \mathrm{~cm}$ wide, cordateclasping; panicle of a few distant spreading branches, the spikelets and branchlets appressed; spikelets $4 \mathrm{~mm}$ long, oblong, obtuse, pubescent, the base hardened and ringlike; first glume as long as the spikelet.

Damp forests at low altitudes, Trinidad to Brazil.

Trinidad: Chaguasamas, near the sea, Broadway 6741. 
56. Panicum zizanioides H. B. K., Nov. Gen. et Sp. 1: 100.1815. Colombia.

Panicum oryzoides Swartz, Prodr., Veo. Ind. Occ. 23. 1788. Not P. oryzoides Ard., 1764. Jamaica.

Acroceras oryzoides Stapf, in Prain, Fl. Trop. Afr. 9: 622. 1920.

Perennial; culms decumbent and rooting at base, 50 to $100 \mathrm{~cm}$ tall, glabrous; sheaths glabrous except margins; blades flat, 4 to $15 \mathrm{~cm}$ long, 1 to $3 \mathrm{~cm}$ wide, cordate-clasping, glabrous or rarely pubescent; panicles 10 to $25 \mathrm{~cm}$ long, with a few ascending stiff branches 3 to $10 \mathrm{~cm}$ long, bearing appressed branchlets; spikelets 5.5 to $6 \mathrm{~mm}$ long, glabrous, abruptly short-pointed; first glume two-thirds as long as the spikelet (fig. 248).

Moist, usually shaded places at low altitudes, Mexico and the West Indies to Paraguay.

Cuba: Damují, Ekman 10936. Sumidero, Shafer and Léon 13635. Anafe, Ekman 226. Rincón, Van Hermann 545, $4477 . \quad$ Laguna Cas-

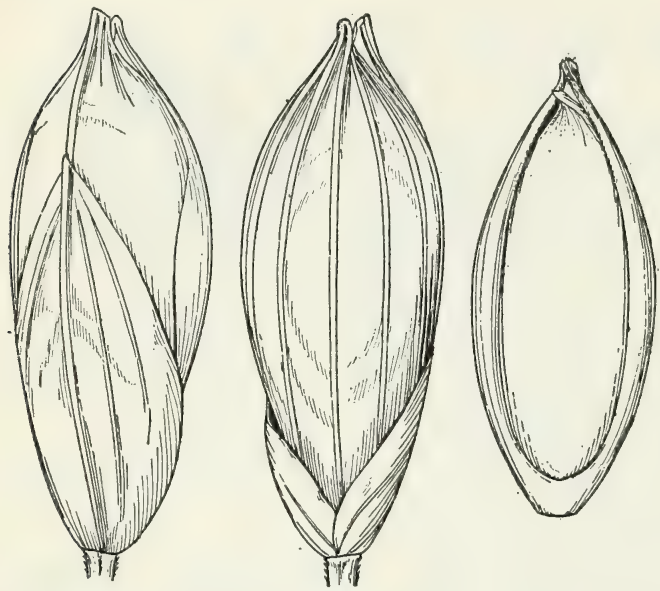

FIGURE 248.-Panicum zizanioides. Two views of spikelet, and floret, $\times 10$ (Bonpland).

Harris 12654. Buff Bay, Hitchcock 9779. Montego Bay, Hitchcock 9684. Without locality, Wullschlaegel 1108; Alexander Prior in 1850.

HaIti: Mount Organisé, Ekman H 6219.

Dominican Republic: Cuenca, Ekman H 11059. Pimental, Abbott 652. Los Haitises, Ekman H 15564.

Trinidad: Port-of-Spain, Hitchcock 9958. Toco, Broadway 2563. Mount Pleasant Estate, Bot. Gard. Herb. 2286. Blanchisseuse Road, Broadway 6740. Without locality, Bot. Gard. Herb. 3188.

Toваgo: Eggers 5810; Hitchcock 10258; Broadway 4556.

57. Panicum discrepans Doell, in Mart., Fl. Bras. 2²: 252.1877. Brazil.

Perennial; culms glabrous, ascending from a decumbent base, 20 to $40 \mathrm{~cm}$ tall; sheaths minutely pubescent or glabrous, the lowermost felty-pubescent; blades ascending or appressed, more or less pubescent, the lower often densely so, the upper sometimes glabrous, flat, those of the midculm 3 to $5 \mathrm{~cm}$ long, 3 to $5 \mathrm{~mm}$ wide; panicles ovoid, 
open but densely flowered, 4 to $7 \mathrm{~cm}$ long, pilose in the lowermost axil, the axis and branches smooth; spikelets elliptic, somewhat turgid, glabrous, about $1.3 \mathrm{~mm}$ long; first glume narrow, variable in length, sometimes half as long as spikelet, often wanting; second glume and sterile lemma equal, 3-nerved, the glume gibbous in the middle; fertile lemma felty-villous at base and apex, gibbous at the middle (fig. 249).

Edges of ponds and lagoons, Brazil; Cuba.

Cuba: Sábalo, edge of lagoon, Ekman in 1923 (Amer. Gr. Nat. Herb. 705). Herradura, moist places in pinelands, Ekman 14089.

58. Panicum hirtum Lam., Encycl. 4: 741. 1798. Cayenne.

Annual; culms slender, branching, decumbent, 20 to $40 \mathrm{~cm}$ tall; blades flat, thin, ovate to lanceolate, cordate-clasping at base; sparse-

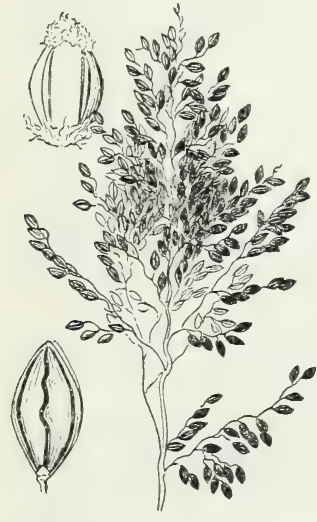

Figure 249.-Panicum discrepans. Panicle, $\times 1$ (Ekman 14089); spikelet and floret, $\times 10$ (type).

ly hispid, 2 to $6 \mathrm{~cm}$ long, 0.8 to $2 \mathrm{~cm}$ wide; panicles ovoid, 3 to $7 \mathrm{~cm}$ long, the branches delicate but stiffly ascending at a uniform angle, the spikelets recurved at right angles on capillary pedicels; spikelets strongly plano-convex, turgid, hispid, $1.2 \mathrm{~mm}$ long (fig. 250).

Damp shady places, British Honduras; Trinidad to Brazil. In the Lamarck Herbarium at Paris is a specimen of this species "de Portorico le Dru", but the locality is probably an error, as it is not otherwise known from north of Trinidad.

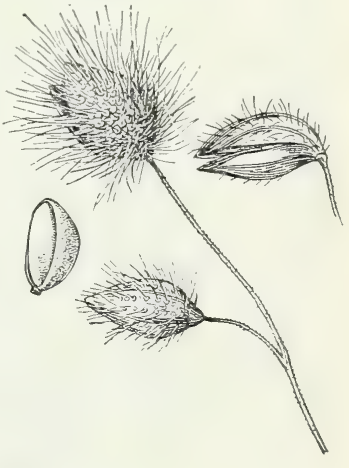

FIGURE 250.-Panicum hirtum. Spikelets and floret, $\times 10$ (type)

Trinidad: Port-of-Spain, Hitchcock 10320. St. Joseph, Hitchcock 10177. Aripo Road, Broadway 6450. Dibe Valley, Britton and Coker 1754. Arima, Hitchcock 10310 (Amer. Gr. Nat. Herb. 546). Piarco Savanna, Hitchcock 10363. Blanchisseuse Road, Broadway 5929. Without locality, Bot. Gard. Herb. 3194.

59. Panicum xalapense H. B. K., Nov. Gen. et Sp. 1: 103. 1815. Mexico.

Vernal phase with slender culms 20 to $60 \mathrm{~cm}$ tall, the nodes bearded with reflexed hairs; sheaths retrorsely pilose; blades 7 to $12 \mathrm{~mm}$ wide, pilose on both surfaces; panicles 5 to $10 \mathrm{~cm}$ long, open, fewflowered, the branches flexuous; spikelets $2 \mathrm{~mm}$ long, obovate, obtuse, pilose.

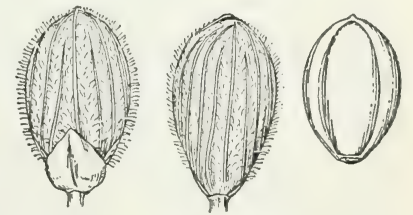

FIGURE 251.-Panicum xalapense. Two views of spikelet, and floret, $\times 10$ (type). Autumnal phase branching at the base, forming soft prostrate tufts or rosettes (fig. 251).

Moist banks and open woods at low and medium altitudes, eastern and southern United States and Mexico to Costa Rica; Cuba and Hispaniola. 
Cuba: Consolación del Sur, Ekman 10860.

Haiti: Furcy, Cook, Scofield, and Doyle 36; Leonard 4346, 4501. Caille la Croix, Leonard 7920. St. Louis du Nord, Leonard 14503; Ekman H 4743. Mission, Leonard 3801, 3852. Pétionville, Ekman H 1095. Morne de la Selle, Buch 1364.

Dominican Republic: Constanza, Tuerckheim 3059. Jarabaco, Eggers H 2129. Azua, Ekman H 11855. Jicomé, Valeur 293, 756. 60. Panicum polycaulon Nash, Bull. Torrey Bot. Club 24: 200. 1897. Florida.

Culms tufted, soon forming small mats or dense rosettes, the vernal culms 10 to $20 \mathrm{~cm}$ tall, the autumnal culms prostrate, scarcely

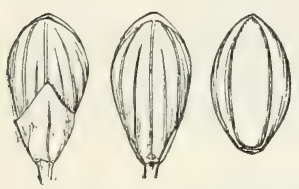

FIgURE 252.-Panicum polycaulon. T w o views of spikelet, and floret, $\times 10$ (type). exceeding the leaves; blades flat, mostly 3 to 6 $\mathrm{cm}$ long, 3 to $6 \mathrm{~mm}$ wide, usually strongly ciliate; panicles ovoid, few-flowered, 3 to $4 \mathrm{~cm}$ long, about as wide, the axis pilose; spikelets about $1.5 \mathrm{~mm}$ long, glabrous or rarely pubescent (fig. 252).

Sandy pine woods, Florida to Mississippi and the Greater Antilles.

Cuba: Pinar del Río, Hitchcock 23299. Herradura, Hitchcock 115; Ekman 10083. Sábalo, Ekman 11436a. Guara, Hitchcock 23411, 23429. Woodfred, Shafer 3083. Without locality, Wright 3875 in part. Isla de Pinos, Ekman 12123; Palmer and Riley 990.

Jamaica: James Hill, Harris 12852. Hollis Savanna, Harris 12225. Barican, Hitchcock 9561. Bull Head Mountain, Hitchcock 9550.

Dominican Republic: Cuenca, Ekman H 11068.

Puerto Rico: Mayaguez, Chase 6276; Holm 59a. San Juan, Chase 6767. Campo Alegre, Chase 6621. Aguada, Sintenis 5724.

61. Panicum strigosum Muhl., in Ell., Bot. S. C. and Ga. 1: 126. 1816. Southern United States.

Vernal phase with culms 5 to $30 \mathrm{~cm}$ tall, the nodes pubescent; blades 3 to $6 \mathrm{~cm}$ long, 3 to $8 \mathrm{~mm}$ wide, ciliate and pilose; panicles 3 to $5 \mathrm{~cm}$ long, open, the branches pilose; spikelets about $1.5 \mathrm{~mm}$ long, glabrous. Autumnal phase a dense mat, as in $P$. xalapense (fig. 253).

Sandy woods and open moist ground, at low and medium altitudes, eastern and southern United States, and Mexico to Panama; Greater Antilles.

Cuba: Pinar del Río, Ekman 17874. El Guama, Palmer and Riley 213. Cajálbana, Léon 4829. Without locality, Wright 3875 in part. Isla de Pinos, Britton and Wilson 14411.

J A M A I A: Bull Head Mountain, Hitchcock 9551. Haiti: Grand-Gosier, Ekman H 6857.

Dominican Republic: El Tetero, Ekman H 13720.

62. Panicum chrysopsidifolium Nash, in Small, Fl. Southeast. U. S. 100. 1903. Florida.

Vernal culms ascending or spreading, grayish-villous, the nodes bearded; sheaths villous; blades 5 to $10 \mathrm{~cm}$ long, 3 to $5 \mathrm{~mm}$ wide, tapering from base to apex, conspicuously pointed, villous on both surfaces; panicles 4 to $6 \mathrm{~cm}$ long; spikelets $2 \mathrm{~mm}$ long, pubescent. Autumnal phase spreading and forming mats; blades flat, papery with age (fig. 254). 
Sandy pine woods and palm barrens and wet savannas, southern United States and the Greater Antilles.

Cuba: Cajálbana, Léon 4835, 4840. Cayajabos, Léon 13227, 13566. Consolación del Sur, Palmer and Riley 481. Guane, Shafer 10639; Léon 7005. Herradura, Hitchcock 116. La Guira, Léon 5177. Banao Mountains, Léon 7944. Placetas del Sur, Léon 6422. Motembo, Ekman 16851. Without locality, Wright in 1865 . Isla de Pinos, Palmer and Riley 982.

JamaICA: Hollis Savanna, Harris 12228. Pedro Morass, Harris 11163. Bull Head Mountain, Hitchcock 9535 (Amer. Gr. Nat. Herb. 89).

Haiti: Gros-Morne, Ekman H 4907. Acul du Nord, Ekman H 2908. GrandGosier, Ekman H 6856.

Dominican Republic: Constanza, Ekman H 14093. La Cumbre, Ekman H 11431. Monción, Ekman H 12680. Cotuy, Abbott 858. Monte Jicomé, Valeur 299.

Puerto Rico: San Juan, Chase 6766.

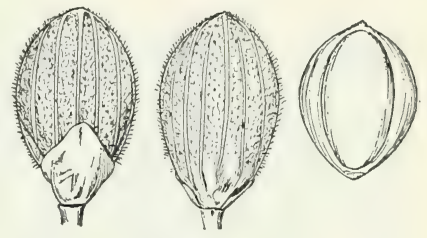

Frgure 254.-Panicum chrysopsidifolium. Two views of spikelet, and floret, $\times 10$ (type).

Santurce, Heller 982 . Tabonico, Sintenis 5985. Sierra de Naguabo, Shafer 3530 in part [with $P$. leucothrix].

63. Panicum fusiforme Hitchc., Contrib. U. S. Natl. Herb. 12: 222. 1909. Based on P. neuranthum var. ramosum Griseb.

Panicum neuranthum var. ramosum Griseb., Cat. Pl. Cub. 232. 1866. Not P. ramosum L., 1767. Cuba, Wright 3454.

Vernal culms erect, 30 to $70 \mathrm{~cm}$ tall; blades flat, gradually pointed, ascending, rather stiff, mostly 5 to $10 \mathrm{~cm}$ long, 4 to $8 \mathrm{~mm}$ wide, the lowermost softly pubescent beneath; panicles 4 to $10 \mathrm{~cm}$ long, the
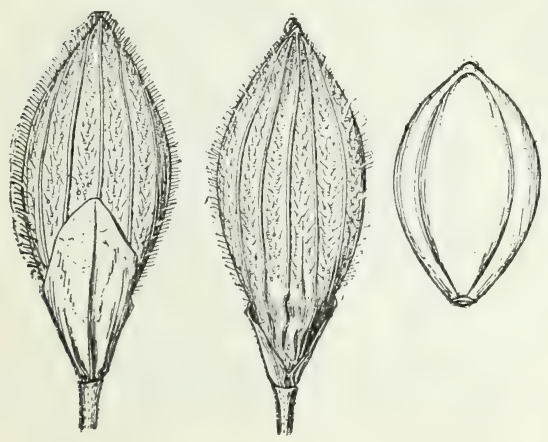

Figure 255.-Panicum fusiforme. Two views of spikelet, and floret, $\times 10$ (type).

lower branches often reflexed; spikelets pubescent, fusiform, attenuate at base, about $3.5 \mathrm{~mm}$ long. Autumnal phase erect or reclining; blades soon involute, 3 to $5 \mathrm{~cm}$ long (fig. 255).

Sandy pine woods, Georgia to Mississippi, Greater Antilles; British Honduras.

C ч в A : Herradura, Hitchcock 117, 23434; Baker and Dimmock, 4846; Caldwell and Baker 7139; Tracy 9074. Pinar del Río, Hitchcock 23257. Guane, Shafer 10484; Léon 7007. Laguna Jovero, Shafer 11049. Sabana de Chirigota, Léon 7451. Manacas,

Léon 5840. La Cumbre, Ekman 13952. Guara, Hitchcock 23431. Western Cuba, Wright 3453 in part, 3454. Isla de Pinos, Ekman 11654. JAMAICA: Bull Head Mountain, Hitchcock 9552. Hollis Savanna, Harris 12234.

64. Panicum angustifolium Ell., Bot. S. C. and Ga. 1: 129. 1816. Florida.

Vernal culms erect or nearly so, 30 to $50 \mathrm{~cm}$ tall, the lowermost internodes gray crisp-villous, the nodes glabrous; lower sheaths some- 
what appressed-villous; blades stiffly ascending, long-acuminate, 8 to $12 \mathrm{~cm}$ long, 4 to $8 \mathrm{~mm}$ wide, the lowermost shorter and broader; panicles 4 to $10 \mathrm{~cm}$ long, loosely flowered, the branches at anthesis widely spreading, often reflexed; spikelets 2.5 to $3 \mathrm{~mm}$ long, autumnal phase stiffly ascending or somewhat topheavy-reclining, the blades flat, rather thin, and papery (fig. 256).

Sandy woods, southeastern United States; Cuba; Puerto Rico; Nicaragua.

Cuba: Isla de Pinos, Curtiss 406; Britton and Wilson 14305.
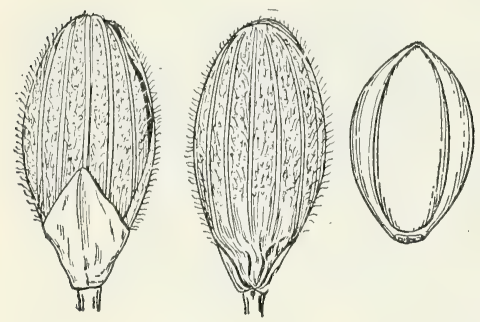

Figure 256.-Panicum angustifolium. Two views of spikelet, and floret, $\times 10$ (type). 7628.

Puerto Rico: El Yunque, Britton

65. Panicum arenicoloides Ashe, Jour. Elisha Mitchell Sci. Soc. 16: 89. 1900. North Carolina.

Panicum orthophyllum Ashe, Jour. Elisha Mitchell Sci. Soc. 16: 90. 1900. North Carolina.

Vernal phase similar to that of $P$. angustifolium; spikelets about $2.5 \mathrm{~mm}$ long. Autumnal phase similar to that of $P$. angustifolium, but the blades soon involute (fig. 257).

Sandy pine woods, southeastern United States; Cuba; Guatemala; Honduras.

Cuba: Sierra de Nipe, Ekman 15189.

66. Panicum neuranthum Griseb., Cat. Pl. Cub. 232. 1866. Cuba, Wright 3453.

Vernal culms tufted, stiff, erect, glabrous, 30 to $60 \mathrm{~cm}$ tall; sheaths glabrous; blades erect or ascending, glabrous, 10 to $15 \mathrm{~cm}$ long, 3 to 5 $\mathrm{mm}$ wide; panicles narrow, 5 to $9 \mathrm{~cm}$ long, the branches narrowly ascending; spikelets $2 \mathrm{~mm}$ long, glabrous, not much attenuate at
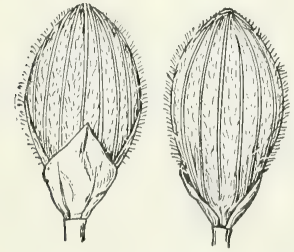

FIGURE 257.-Panicum arenicoloides. Two views of spikelet, and floret, $\times 10($ type $)$.

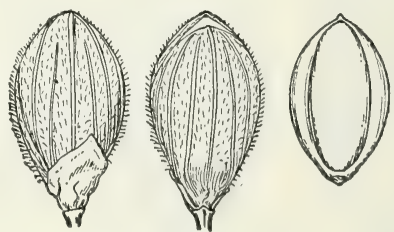

Figure 258.-Panicum neuranthum Two views of spikelet, and floret, $\times 10$ (type).

base. Autumnal phase similar to the vernal, but the blades shorter and involute (fig. 258).

Savannas and open ground, southern Florida to Mississippi; Bahamas; Cuba.

Bahamas: New Providence, Britton and Brace 599 (Field Mus. Herb.).

Cuba: Remates, Ekman 11182. Yaguaramas, Ekman 18395. Sabana del Guaní, Fernando 488. Mordazo, Léon 9245. Baracoa, Wright 3453 in part. 
67. Panicum aciculare Desv.; Poir., in Lam. Encycl. Sup. 4: 274. 1816. Probably Puerto Rico.

Panicum setaceum Muhl., Descr. Gram. 99. 1817. Georgia.

Vernal phase similar to that of $P$. angustifolium but lower and more slender; spikelets about $2 \mathrm{~mm}$ long, very obtuse. Autumnal phase bushy-branched, the blades involute (fig. 259).

Pine woods, southeastern United States; the Greater Antilles; Honduras. The type is erroneously said to come from the East Indies, but it probably came from the West Indies.

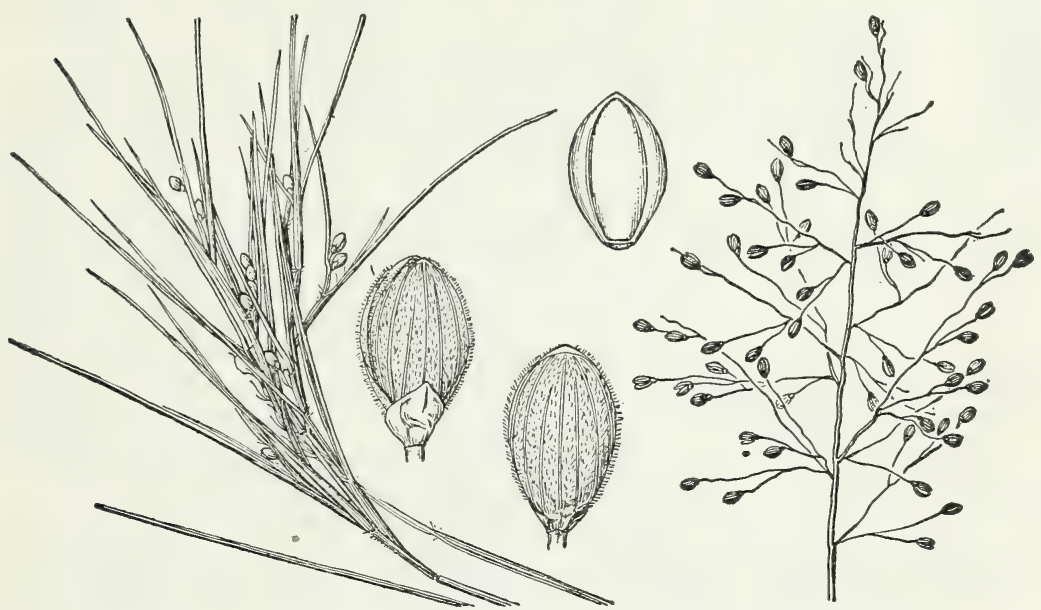

Figure 259. - Panicum aciculare. Plant, $\times 1$; two views of spikelet, and floret, $\times 10$ (vernal phase, Chase 7143; auiumnal phase, Hitchcock 317).

Cuba: Pinar del Río, Hitchcock 23253, 23298; Ekman 12794, 17891; Britton and Gager 7064. Remates, Ekman 11374; Léon 15355. Laguna Jovero, Shafer 10733, 10823. Mordazo, Léon 9236, 9576. Sierra de Nipe, Ekman 1847, 1848, 2212, 6030, 9066; Shafer 2968. Guaro, Hitchcock 23428. Without locality, Wright 3454, 3461. Isla de Pinos, Ekman 11946, 11996, 12189.

Jamaica: Peckham, Harris 12812.

Haiti: Pétionville, Ekman H 1312.

Dominican Republic: Cuenca, Ekman H 11056, H 11430.

Puerto Rico: Mayaguez, Holm 47, 47a, $47 \mathrm{~b}$; Chase 6273. Campo Alegre, Chase 6624. Sierra de Naguabo, Shafer 3531.

68. Panicum nitidum Lam., Tabl. Encycl. 1: 172. 1791. Carolina.

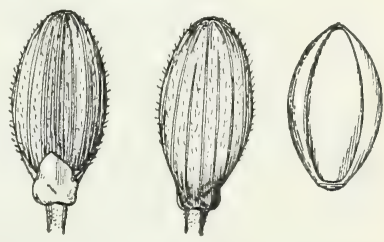

FIGURE 260.-Panicum nitidum. Two views of spikelet, and floret, $\times 10$ (type).

Vernal culms erect or nearly so, 30 to 60 $\mathrm{cm}$ tall, the nodes bearded; sheaths glabrous or the lower pubescent, more or less mottled or glandular; blades glabrous, 5 to $12 \mathrm{~cm}$ long, 5 to $10 \mathrm{~mm}$ wide, the upper often reflexed; panicles ovoid, 5 to 8 cm long, the branches ascending; spikelets elliptic, pubescent, $2 \mathrm{~mm}$ long. Autumnal phase with large clusters of branches from the nodes, the reduced blades numerous (fig. 260). 
Low moist or marshy ground, southeastern United States; Bahamas; Greater Antilles.

BAHAMAs: Great Bahama, Britton and Millspaugh 2736.

CubA: Remates, Ekman 11169. Manacas, Léon 5898. San Marcos, Léon 9203. Banao Mountains, Léon 7938. La Guanaja, Léon 16208. Sierra de Nipe, Shafer 2999, 3001; Ekman 2647. Guara, Hitchcock 23404, 23415. Isla de Pinos, Britton and Wilson 15184.

JAMAICA: Bull Head Mountain, Hitchcock 9532.

Dominican Republic: Monción, Ekman
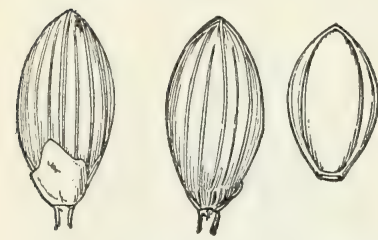

Figure 261.-Panicum roanoliense. Two views of spikelet, and floret. $\times 10$ (Ashe).

H 12697. Constanza, Ekman H 13932, H 14011, H 14123. San José de Ocoa, Ekman H 11895, H 11942.

69. Panicum roanokense Ashe, Jour. Elisha Mitchell Sci. Soc. 15: 44. 1898. North Carolina.

Vernal culms erect or ascending, 50 to $100 \mathrm{~cm}$ tall, the nodes glabrous; sheaths glabrous; blades flat, glabrous, 6 to $9 \mathrm{~cm}$ long, 3 to $8 \mathrm{~mm}$ wide; panicles 4 to $8 \mathrm{~cm}$ long, the branches spreading; spikelets $2 \mathrm{~mm}$ long, turgid, strongly nerved, glabrous. Autumnal phase erect or decumbent, branching at the middle and upper nodes, the branches numerous but not in tufts (fig. 261).

Open swampy woods or wet peaty meadows, southeastern United States; Jamaica, in open clay ground among other grasses.

Jamaica: Bull Head Mountain, Hitchcock 9530.

70. Panicum caerulescens Hack.; Hitchc., Contrib. U. S. Natl. Herb. 12: 219. 1909. Florida.

Vernal culms slender, 30 to $75 \mathrm{~cm}$ tall; blades commonly purplish beneath, 5 to $8 \mathrm{~cm}$ long, 4 to $7 \mathrm{~mm}$ wide; panicles 3 to $7 \mathrm{~cm}$ long, half as wide or less, the branches narrowly ascending; spikelets glabrous, turgid, $1.5 \mathrm{~mm}$ long. Autumnal phase erect or leaning, producing densely fascicled branches at the middle and upper nodes, the reduced blades more or less involute, the reduced panicles with a few long-pediceled spikelets (fig. 262).

Marshes and swampy woods, southeastern United States and Mexico; Bahamas, Cuba.

BaHAmas: Great Bahama, Bruce 3524 ; Britton and Millspaugh 2506, 2668. Andros, Brace 7015. New Providence, Britton and Brace

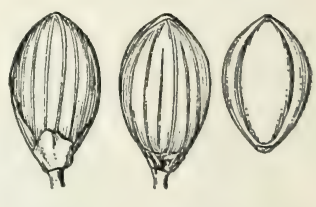

FIGCRE 262--Panicum caerulescens. Two riews of spikelet, and floret, $\times 10$ (type). 597; Millspaugh 2182; Northrup 248 (all in Field Mus. Herb.); Eggers 4305 (Hackel Herb.).

Cuba: Cajáo, Léon 14386. Ciénaga de Zapata, Ekman 18376; Léon 2206, 2213. Mordazo, Ekman 17035; Léon 9262; Caibarién, Léon 489. Batabanó, Léon 6152. Without locality, Wright 3463.

71. Panicum leucothrix Nash, Bull. Torrey Bot. Club 24: 41. 1897. Florida.

Vernal culms erect or ascending, appressed papillose-pilose, 25 to $45 \mathrm{~cm}$ tall, the nodes pubescent; sheaths papillose-pubescent; ligule pilose, $3 \mathrm{~mm}$ long; blades rather firm, puberulent beneath, usually glabrous on the upper surface, 3 to $7 \mathrm{~cm}$ long, 3 to $7 \mathrm{~mm}$ wide; panicles 3 to $8 \mathrm{~cm}$ long, rather densely flowered, the axis appressed-pubescent; 
spikelets about $1.3 \mathrm{~mm}$ long, pubescent. Autumnal phase ascending, usually decumbent at base, finally with more or less fascicled branchlets, the blades not greatly reduced (fig. 263).

Low pinelands, southeastern United States; Cuba, Hispaniola, and Puerto Rico.

Cuba: Herradura, Hitchcock 554, 560, 23438. Guane, Léon 6903. San Julián, Ekman 11138. Western Cuba, Wright 3460, 3463.

Puerto Rico: San Juan, Chase 6770. Sierra de Naguabo, Shafer 3530 .

Dominican Republic: Matanzas, Ekman H 15886. Sabana de la Mar, Ekman H 15636.

72. Panicum wrightianum Scribn., U. S. Dept. Agr., Div. Agrost. Bull: 11: 44. f. 4. 1898. Cuba, Wright 3463.

Vernal culms weak and slender, ascending from a decumbent base, minutely puberulent; sheaths glabrous or puberulent; blades spreading, glabrous or puberulent; 2 to $4 \mathrm{~cm}$ long, 3 to $5 \mathrm{~mm}$ wide; panicles 3 to $6 \mathrm{~cm}$ long; spikelets $1 \mathrm{~mm}$ long, pubescent. Autumnal phase decumbent-spreading, becoming bushy-branched, the flat or subinvolute blades not much reduced (fig. 264).

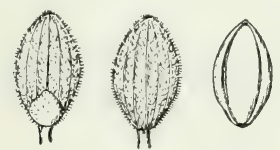

F I G U R E 263.-Panicum leucothrix. Two views of spikelet, and floret, $X$ 10 (type).

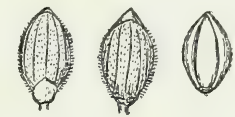

F I G U R 264.-Panicum wrightian $u$. Two views of spikelet, and floret, $\times 10$ (type).

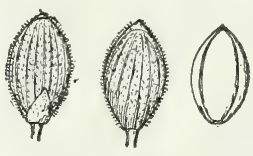

FIGURE 265.-Panicum longiligulatum. Two views of spikelet, and floret, $\times 10$ (type).

Margins of streams and ponds, southeastern United States and British Honduras; Cuba.

Cuba: Damují, Ekman 10937. Pinar del Río, Britton and Gager 6952. Vuelto Abajo, Wright 3463. Remates de Guane, Léon 15428. Remates, Ekman 11215, 11360. La Grifa, Ekman 11266. Sábalo, Ekman 11438. Herradura, Ekman 11586. Laguna Santa María, Ekman 17239.

73. Panicum longiligulatum Nash, Bull. Torrey Bot. Club 26: 574 . 1899. Florida.

Vernal culms erect or ascending at base, glabrous, relatively stout, 30 to $70 \mathrm{~cm}$ tall; sheaths glabrous; ligule 2 to $3 \mathrm{~mm}$ long; blades rather thick and firm, glabrous on the upper surface, puberulent beneath, 4 to $8 \mathrm{~cm}$ long, 4 to $8 \mathrm{~mm}$ wide; panicles 3 to $8 \mathrm{~cm}$ long; spikelets a little exceeding $1 \mathrm{~mm}$ long, pubescent. Autumnal phase more or less reclining, the branchlets crowded, the reduced blades subinvolute (fig. 265).

Pine barrens and swamps, southeastern United States and British Honduras; Hispaniola.

Dominican Republic: Cuenca, Ekman H 11058. Bayaguana, Ekman H 11099.

74. Panicum acuminatum Swartz, Prodr. Veg. Ind. Occ. 23. 1788. Jamaica.

Panicum ornatum Desv.; Hamilt., Prodr. Pl. Ind. Occ. 11. 1825. Puerto Rico. 
Panicum dichotomum var. acuminatum Swartz; Griseb., Fl. Brit. W Ind. 553. 1864.

Panicum comophyllum Nash, Bull. Torrey Bot. Club 30: 380. 1903. Puerto Rico, Heller 12.

Vernal culms ascending from a geniculate base, densely villous with soft-spreading hairs, 20 to $70 \mathrm{~cm}$ tall, the nodes more or less bearded, sheaths velvety papillose-villous or the upper glabrate; ligule 2 to $3 \mathrm{~mm}$ long; blades lanceolate, slightly cordate at base, sharply acuminate, usually ciliate, 4 to $8 \mathrm{~cm}$ long, 6 to $13 \mathrm{~mm}$ wide, the upper surface more or less villous, velvety beneath; panicles 3 to $10 \mathrm{~cm}$ long, the axis usually villous, the branches flexuous, the lower sometimes reflexed; spikelets slightly less than $2 \mathrm{~mm}$ long (fig. 266).

Sandy pine woods, moist banks, and open ground, Greater Antilles; Colombia.

Cuba: Herradura, Hitchcock 140, 23436; Tracy 9078; Britton, Earle, and Gager 6505. Sumidero, Léon 3472; Shafer and Léon 13544, 13615. Río Guao, Britton and Cowell 9673. San Sebastián, Léon and Shafer 13719. Pinar del Río, Palmer and Riley 447; Hitchcock 23271, 23295; Léon, Bailey, and Roig 14821. Viñales, Léon 14711. Guane, Léon 6902. Cajálbana, Léon 4833, 4841. San Diego de los Baños, Léon 4371, 4558. San Cristóbal, Wright 3874. Isla de Pinos, Curtiss,

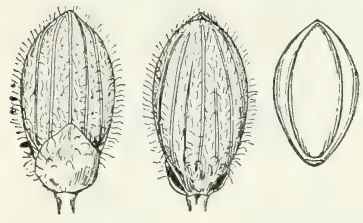

FI GURE 266.-Panicum acuminatum. Two views of spikelet, and floret, $\times 10$ (type). 307, 328; Palmer and Riley 989, 1083; Taylor in 1901; Britton and Wilson 14224, 14228, $14320,15674$.

JAMAICA: Abbey Green, Hitchcock 9355 (Amer. Gr. Nat. Herb. 133). Cinchona, Harris 11315, 11371; Hitchcock 9697, 9722; Maxon and Killip 917. St. Helens Gap, Harris 11494; Maxon and Killip 594. Claverty Cottage, Perkins 1083. Morces Gap, Maxon and Killip 1072a. James Hill Savanna, Harris 12848. Catherines Peak, Harris 11554; Hitchcock 9738. Barican, Hitchcock 9564. Below Sir Johns Peak, Harris 11597. Clyde River, Harris 11444. Monkey Hill, Harris 11435. Upper Clarendon, Harris 11109. Bull Head Mountain, Hitchcock 9538. Arntully, Orcutt 5181, 5744,6776. Without locality, Hart 736; Hort. Bot. Jamaica 736.

Haitr: Marmelade, Leonard 8199. Caille la Croix, Leonard 7838. Furcy, Leonard 4328, 4402, 4701; Ekman H 1216; Cook, Scofield, and Doyle 37; Buch 497, 1541. Grand-Gosier, Ekman H 6856. Pétionville, Ekman H 1216. Morne de la Selle, Christ 1850. Mission, Leonard 3821, 3851, 3972.

Dominican Republic: La Cumbre, Ekman H 11547. San José de Ocoa, Ekman H 11685.

Puerto Rico: Maricao, Britton and Cowell 4090; Chase 6249; Sintenis 355. San Juan, Chase 6378, 6647, 6765. Adjuntas, Chase 6475. Sierra de Loquillo, Chase 6719. Cayey, Chase 6752. Mayaguez, Holm 59b. Santurce, Heller in 1903. Lares, Sintenis 5908. Fajardo, Sintenis 1224.

75. Panicum albemarlense Ashe, Jour. Elisha Mitchell Sci. Soc. 16: 84. 1900. North Carolina.

Vernal phase olivaceous, grayish-villous; culms slender, at first erect, soon geniculate, 25 to $45 \mathrm{~cm}$ long; ligule pilose, 1 to $2 \mathrm{~mm}$ long; 
blades 4 to $7 \mathrm{~cm}$ long, 3 to $6 \mathrm{~mm}$ wide, the upper surface puberulent as well as villous; panicles 2 to $4 \mathrm{~cm}$ long; spikelets about $1.4 \mathrm{~mm}$ long, pubescent. Autumnal phase widely decumbent-spreading, the blades reduced, flat (fig. 267).

Sandy woods, eastern United States; Hispaniola.

Dominican Republic: Monción, Ekman H 12798. San José de Ocoa, Ekman H 12011.

76. Panicum auburne Ashe, N. C. Agr. Expt. Sta. Bull. 175: 115. 1900. Alabama.

Vernal phase grayish, velvety-villous throughout, the culms geniculate at base, widely spreading, rather slender, 20 to $50 \mathrm{~cm}$ tall;

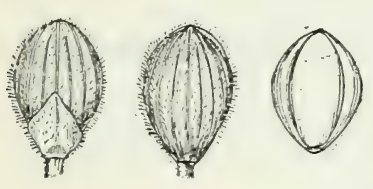

FIGURE 267.-Panicum albematlense. Two views of spikelet, and floret, $\times 10$ (type). ligule 3 to $4 \mathrm{~mm}$ long; blades rather thin, 3 to $7 \mathrm{~cm}$ long, 3 to $5 \mathrm{~mm}$ wide, the upper surf a ce long-pilose, the lower velvety; panicle 3 to $5 \mathrm{~cm}$ long, the axis villous; spikelets about $1.4 \mathrm{~mm}$ long, pubescent. Autumnal phase

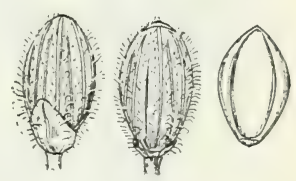

FIgURE 268.-Panicum auburne. Two views of spike. let, and floret, $\times 10$ (type).

early becoming diffusely branched at all the nodes, prostrate spreading, forming large mats (fig. 268).

Sandy woods, southeastern United States; Cuba.

Cuba: Motembo, Ekman 16841.

77. Panicum wilmingtonense Ashe, Jour. Elisha Mitchell Sci. Soc. 16: 86. 1900. North Carolina.

Panicum alabamense Ashe, N. C. Agr. Expt. Sta. Bull. 175: 116. 1900. Not P. alabamense Trin., 1854. Alabama.

Vernal phase bluish green; culms erect from an ascending base, pilose with soft ascending hairs, 20 to $40 \mathrm{~cm}$ tall, the nodes pubescent with soft reflexed hairs; sheaths pubescent like the culms, densely villousciliate at the summit; ligule pilose, less than $1 \mathrm{~mm}$ long; blades rather stiff, ascending, 4 to $9 \mathrm{~cm}$ long, 3 to $7 \mathrm{~mm}$ wide, glabrous on the upper surface, softly pubescent to nearly glabrous beneath, strongly ciliate on the margin near the base, the thick cartilaginous margin white at least when dry; panicles 5 to $8 \mathrm{~cm}$ long; spikelets $2 \mathrm{~mm}$ long, pubescent. Autumnal
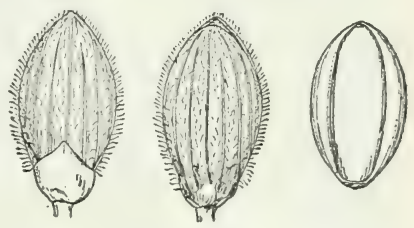

FIGURE 269.-Panicum wilmingtonense. Two views of spikelet, and floret; $X$ 10 (type). form branching from the middle and upper nodes, the branches rather crowded, the blades reduced, flat (fig. 269).

Sandy woods, southeastern United States; Cuba.

CuвA: Woodfred, Ekman 9099.

78. Panicum sphaerocarpon Ell., Bot. S. C. and Ga. 1: 125. 1816. Georgia.

Vernal phase light green; culms radiate-spreading, 20 to $50 \mathrm{~cm}$ long, the nodes pubescent; sheaths glabrous; ligule obsolete; blades firm, 6 to $10 \mathrm{~cm}$ long, 7 to $14 \mathrm{~mm}$ wide, subcordate, rough on upper surface, smooth beneath, ciliate toward base; panicles 5 to $10 \mathrm{~cm}$ long, the 
axis with viscid spots; spikelets nearly spherical, about $1.7 \mathrm{~mm}$ long, puberulent. Autumnal phase prostrate-spreading, rather sparingly branching (fig. 270).

Sandy soil and gravelly banks at low and medium altitudes, eastern

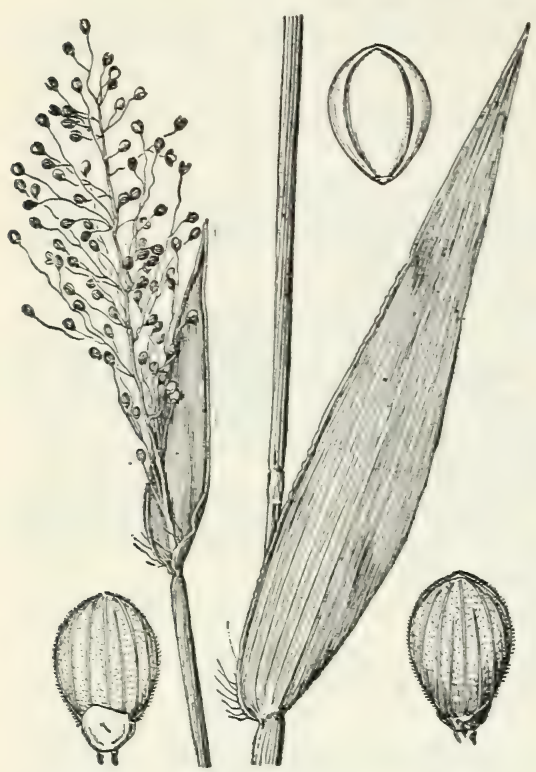

Figure 270.-Panicum sphaerocarpon. Plant, $X$ two riews of spikelet, and floret, $\times 10$ (Deam).

United States and Mexico to Venezuela; Cuba.

C UBA: Isla de Pinos, Ekman 11820 .

79. Panicum erectifolium Nash, Bull. Torrey Bot. Club 23: 148. 1896. Based on $P$. sphaerocarpon var. floridanum Vasey.

Panicum sphaerocarpon var. floridanum Vasey, U. S. Dept. Agr. , Div. Bot. Bull. 8: 33. 1889. Not P. floridanum Trin., 1834. Florida.

Panicum floridanum Chapm., Fl. South. U. S. ed. 3. 585. 1897.

Vernal culms erect or ascending usually stout, glabrous, 30 to $70 \mathrm{~cm}$ tall; sheaths glabrous except the ciliate margin; ligule about $0.3 \mathrm{~mm}$ long; blades thick, firm, ascending or erect, 7 to 13 $\mathrm{cm}$ long, 6 to $12 \mathrm{~mm}$ wide, the crowded lower ones usually much longer than the others, tapering from the cordate base to the acuminate apex, smooth on both surfaces, ciliate toward the base; panicles 6 to $12 \mathrm{~cm}$ long, half as wide, densely flowered; spikelets about $1 \mathrm{~mm}$ long, subspherical, densely puberulent. Autumnal phase remaining erect and simple, finally producing a few erect branches (fig. 271).

Moist pine barrens, swamps, and borders of ponds, southeastern United States; Cuba.

Cuba: Remates, Ekman 11188 . Vuelto abajo, Wright 3462. Laguna del Bufeo, Shafer 11021. Laguna Santa Maria, Britton and Gager 7170. Motembo, Léon 8615. Isla de Pinos, Britton and Wilson 14150, 14705, 15706.

80. Panicum albomarginatum Nash, Bull. Torrey Bot. Club 24: 40. 1897. Florida.

Ternal phase usually grarish green, often purplish; culms densely tufted, slender but firm, ascending or spreading, glabrous, 15 to $40 \mathrm{~cm}$ tall; leaves crowded at the base, distant above; blades thick and firm, those of the midculm 4 to $6 \mathrm{~cm}$ long, 4 to $6 \mathrm{~mm}$ wide, glabrous, the margin

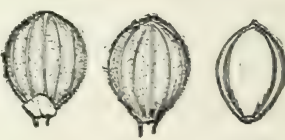

FIGURE 271.-Panicum erectifolium. Two riews of spikelet, and floret, $\times 10$ (type).
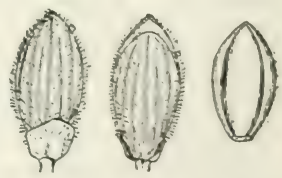

Figtre 2\%2.-Panicum"albomarginatum. Two views of spikelet, and floret, $X ! 10$ (type). (when drr) prominent, white, cartilaginous, the crowded basal blades as much as $11 \mathrm{~cm}$ long, the uppermost usually much reduced; panicles 3 to $6 \mathrm{~cm}$ long; spikelets about $1.5 \mathrm{~mm}$ long, pubescent. Autumnal phase spreading, the primary culms branching from the base and lower nodes, forming bushy tufts (fig. 272). 
Sandy woods, southeastern United States; Cuba; Central America; Florida.

Cuba: Herradura, Ekman 10687; Hitchcock 555, 23433. Guane, Léon 7009, 15395. Sumidero, Léon 3466, 7006. Isla de Pinos, Taylor 32 ; Britton and Wilson 14283, 15383.

81. Panicum trifolium Nash, Bull. Torrey Bot. Club 26: 580. 1899. Georgia.

Similar to $P$. albomarginatum, differing chiefly in the following: Culms in smaller tufts, more slender, erect; leaves less conspicuously crowded at the base, not so stiff, and the basal proportionately not so much longer than those of the midculm; sheaths much shorter than the elongate internodes; blades 3 to $5 \mathrm{~cm}$ long, 4 to $5 \mathrm{~mm}$ wide, less thick and firm, the uppermost blade not reduced. Autumnal phase erect or leaning,

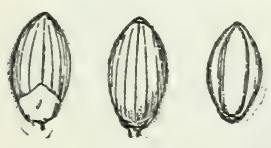

FIG ORE 274.-Panicum chamaelonche. Two views of spikelet, and floret, $\times 10$ (type). sparingly branched from the middle and upper nodes (fig. 273).

Sandy woods, southeastern United States; Cuba.

Cuba: Pinar del Río, Hitchcock 23270, 23300. Herradura, Hitchcock 23437. San Diego de los Baños, Léon 4454. Guane, Léon 6943. Banao Mountains, Léon 2749.

\section{Panicum chamaelonche Trin., Gram.} Pan. 242. 1826. North America.

Vernal culms densely tufted, glabrous, ascending or erect, 10 to $20 \mathrm{~cm}$ tall; sheaths glabrous; ligule $0.2 \mathrm{~mm}$ long; blades firm, ascending, 1.5 to $4 \mathrm{~cm}$ long, 2 to $3 \mathrm{~mm}$ wide, more or less involute-pointed, glabrous; panicles 2.5 to $5 \mathrm{~cm}$ long; spikelets a little more than $1 \mathrm{~mm}$ long, glabrous. Autumnal phase freely branching from the base and lower nodes, forming dense cushions, the scarcely reduced blades drying involute (fig. 274).

Open sandy soil and low pine barrens, southeastern United States and British Honduras; Cuba, found in "white sand."

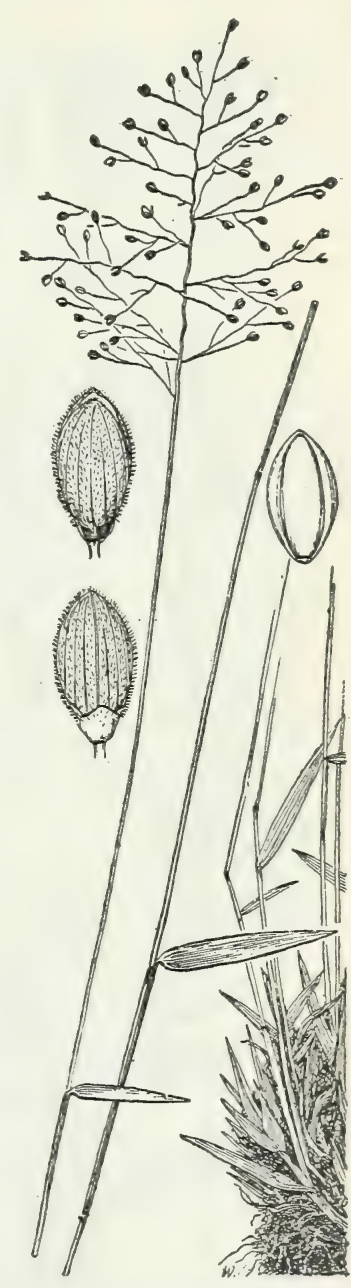

Figure 273.-Panicum trifolium Two views of spikelet, and floret, $\times 10$ (type).

Cuba: Damují, Ekman 11047. Pinar del Río, Ekman 11465. Isla de Pinos, Britton and Wilson 14218, 14221; Ekman 12098, 12152.

83. Panicum portoricense Desv.; Hamilt., Prodr. Pl. Ind. Occ. 11. 1825. Puerto Rico.

Vernal culms erect or geniculate at base, slender, stiff and wiry, crisp-puberulent to nearly glabrous, 15 to $30 \mathrm{~cm}$ tall; sheaths much shorter than the internodes, glabrous or crisp-puberulent; blades firm, 2 to $5 \mathrm{~cm}$ long, 3 to $6 \mathrm{~mm}$ wide, glabrous to puberulent; panicles 2 to 
4 cm long, the lower branches often reflexed; spikelets $1.5 \mathrm{~mm}$ long, puberulent. Autumnal phase much branched at all except the uppermost nodes forming a bushy mass (fig. 275).

Sandy woods, southeastern United States; Cuba, Puerto Rico.

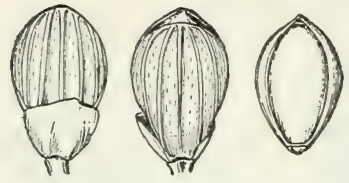

Figure 275.-Panicum porto riicense. Two views of spikelet, and floret, $\times 10$ (Ashe).
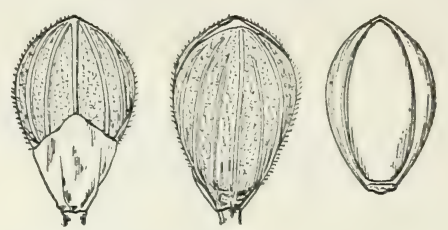

FigURe 276.-Panicum patulum. Two views of spikelet, and floret, $\times 10$ (type).

Cuba: Loma Pelada, Wright 3876. Isla de Pinos, Britton and Wilson 14216.

Puerto Rico: Sardinera, Britton 8701. San Juan, Chase 6357, 6631, 6783. Carolina, Britton and Brown 5718. Laguna Tortuguero, Britton, Cowell, and Brown 3836; Britton and Chardon 6831. Campo

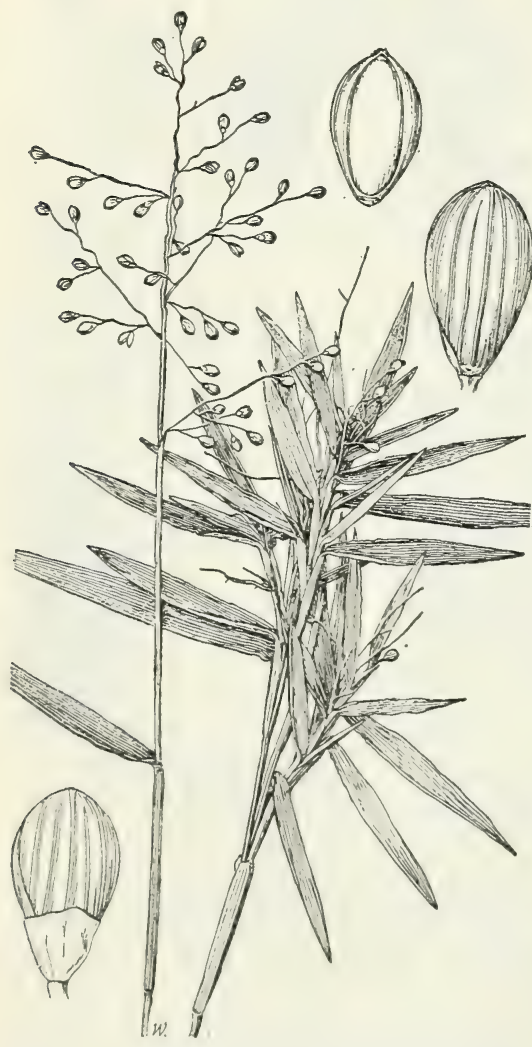

FIGURE 277.-Panicum lancearium. Plint, $\times 1$; two views of spikelet, and floret, $X 10$ (Chase 4545 ).
Alegre, Chase 6434. Dorado, Britton and Brown 6651, 6740. Vega Baja, Heller 639; Underwood and Griggs 955 . Santurce, Heller 982b, 6442. Sabana Llana, Stevenson 2783.

84. Panicum patulum (Scribn. and Merr.) Hitchc., Rhodora 8: 209. 1906.

Panicum nashianum patulum Scribn. and Merr., U. S. Dept. Agr., Div. Agrost. Circ. 27: 9. 1900. Florida.

Differing from $P$. lancearium chiefly in the decumbent vernal habit and the lax blades pubescent on both surfaces; spikelets densely pubescent, more globularpyriform. Autumnal phase more freely branching, forming large mats (fig. 276).

Low woods, southeastern United States; Hispaniola.

Dominican Republic: Monción, Ekman 12705.

85. Panicum lancearium Trin., Gram. Pan. 223. 1826. North America.

Vernal phase usually purplish; culms wiry, 20 to $50 \mathrm{~cm}$ tall, minutely crisp-puberulent; blades 2 to $6 \mathrm{~cm}$ long, 3 to $7 \mathrm{~mm}$ wide, 
usually glabrous on the upper surface and puberulent beneath; panicles 3 to $6 \mathrm{~cm}$ long; spikelets $2 \mathrm{~mm}$ long, glabrous or puberulent. Autumnal phase geniculate-spreading, with fascicles of short branches (fig. 277).

Sandy pine woods, southeastern United States and British Honduras; Cuba, Hispaniola.

Cuba: La Grifa, Ekman 11261. Lagunillas, Ekman 13808. Sábalo, Ekman 11427; Perez and Léon 15094. Damují, Ekman 10952, 11022. San Claudio, Ekman 10543. Banao Mountains, Léon 5406. Sierra Maestra, Ekman 1634, 14674, 15290, 16111. Bayamo, Ekman 5064. Eastern Cuba, Wright 3460. Isla de Pinos, Britton and Wilson 14226, 14747, 15379; Ekman 12026, 12161.

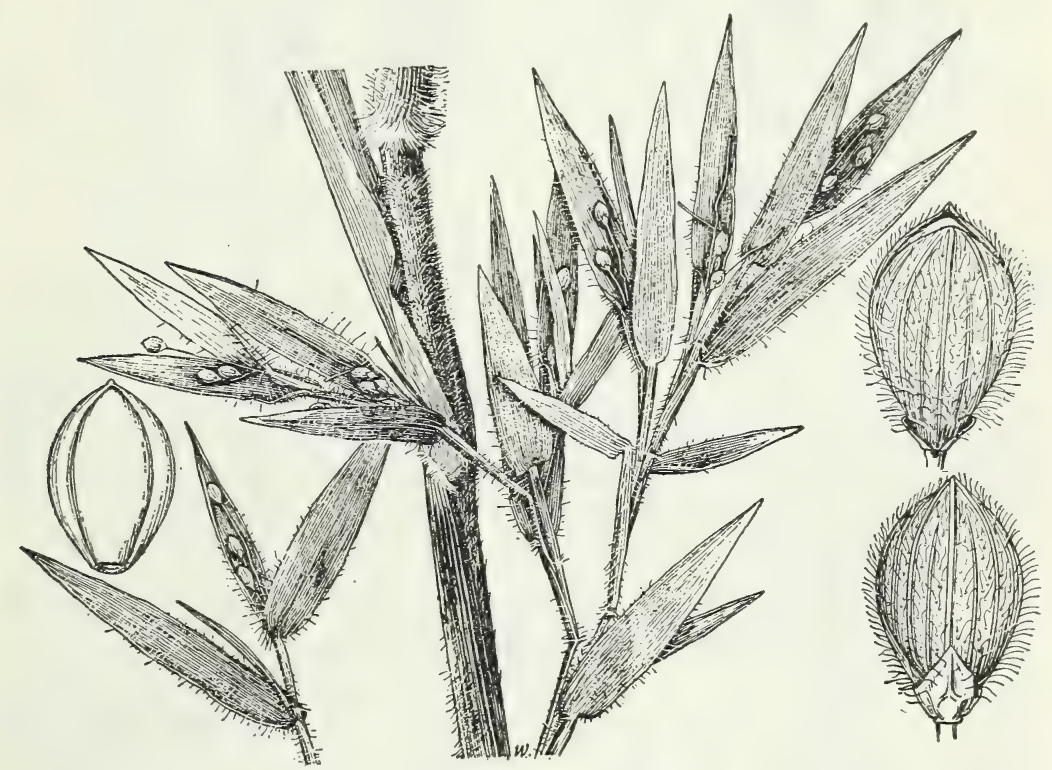

Figure 278.-Panicum scoparium. Plant, $\times 1$; two views of spikelet, and floret, $\times 10$ (McGregor 212).

Dominican Republic: Lagunas de Cenobí, Valeur 4. Constanza, Tuerckheim 3321; Ekman H 14094. Monción, Ekman H 12704.

86. Panicum scoparium Lam., Encycl. 4: 744. 1798. Carolina.

Vernal phase grayish olive-green, velvety pubescent throughout except as noted; culms erect or ascending, usually geniculate at base, 80 to $130 \mathrm{~cm}$ tall, the nodes villous with reflexed hairs, a glabrous viscid ring below; sheaths glabrous on the back toward the summit, the surface here viscid when fresh; ligule $1 \mathrm{~mm}$ long; blades 12 to 20 $\mathrm{cm}$ long, 10 to $18 \mathrm{~mm}$ wide; panicles 8 to $15 \mathrm{~cm}$ long, the branches with viscid blotches; spikelets about $2.5 \mathrm{~mm}$ long, papillose-pubescent. Autumnal phase leaning or spreading, branches from the middle nodes, finally forming flabellate fascicles with much reduced blades (fig, 278). Rico.

Wet or damp soil, southeastern United States; Cuba to Puerto 
Cuba: Pinal Mayarí, Wright 3467. Woodfred, Shafer 2997, 3018; Ekman 9101a. Sierra de Nipe, Ekman 2118, 2207, 3201; Hitchcock 23414. Pinar de Micara, Ekman 15896.

Haitr: Pérodin, Ekman H 3431. Carmillan, Ekman H 5688.

Dominican Republic: Monción, Ekman H 12943. La Cumbre, Ekman H 11432.

Puerto Rico: Sierra de Naguabo, Shafer 3481.
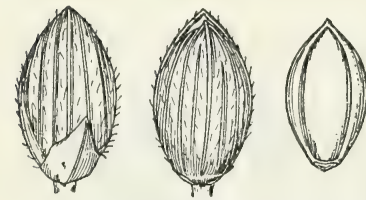

FIGURE 279.-Panicum viscidellum Two views of spikelet, and floret, $\times 10$ (type).

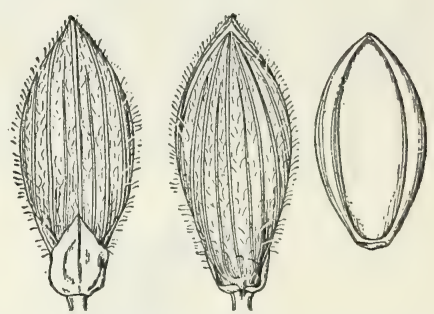

Figure 280,-Panicum joorii. Two views of spikelet, and floret, $\times 10$ (type).

87. Panicum viscidellum Scribn., U. S. Dept. Agr., Div. Agrost. Circ. 19: 2. 1900. Mexico.

Vernal phase with culms ascending from a spreading or creeping base, villous; nodes bearded; sheaths villous; ligule 2 to $4 \mathrm{~mm}$ long; blades velvety-pubescent, 5 to $13 \mathrm{~cm}$ long, 9 to $13 \mathrm{~mm}$ wide, subcordate; panicles 4 to $11 \mathrm{~cm}$ long, rather densely flowered; spikelets about $2 \mathrm{~mm}$ long, sparsely pubescent (fig. 279).

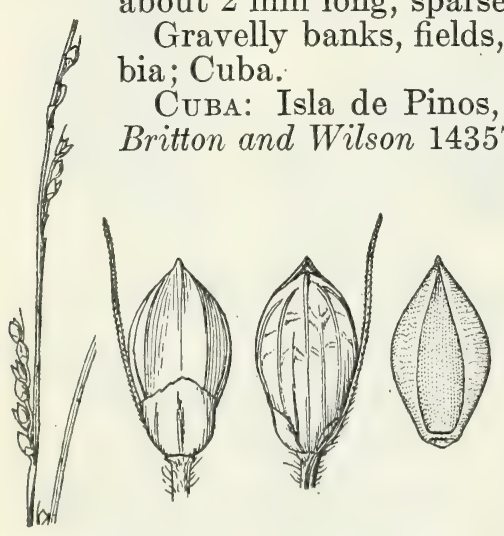

Figure 281.-Panicum chapmani. Panicle, $\times 1$; two views of spikelet, and floret, $\times 10$ (type).
88. Panicum joorii Vasey, U. S. Dept. Agr., Div. Bot. Bull. 8: 31. 1889. Louisiana.

Vernal culms spreading or ascending from a decumbent base, glabrous, 20 to $50 \mathrm{~cm}$ long; blades mostly 10 to $15 \mathrm{~cm}$ long and 10 to $15 \mathrm{~mm}$ wide, often somewhat falcate, glabrous; panicle 5 to $8 \mathrm{~cm}$ long; spikelets about $3 \mathrm{~mm}$ long, elliptic, pubescent. Autumnal phase widely spreading, branching, the ultimate branches in short dense fascicles (fig. 280).

Low swampy or sandy woods, southeastern United States; eastern Mexico; Nicaragua; Greater Antilles.

CubA: Batabanó, Ekman 12596; Léon 14201. Sancti Spíritus Mountains, Léon 6457, 6595. Ciénaga de Zapata, Roig 2205. Guantánamo, Ekman 10297.

Haiti: Lomielle, Ekman H 6189. 
89. Panicum chapmani Vasey, Bull. Torrey Bot. Club 11: 61. 1884. Florida.

Culms ascending or spreading, 40 to $100 \mathrm{~cm}$ tall; blades erect, linear, 15 to $40 \mathrm{~cm}$ long, 2 to $5 \mathrm{~mm}$ wide, flat to subinvolute when dry; panicles elongate, sometimes as much as $30 \mathrm{~cm}$ long, the appressed distant branches bearing few to several spikelets, the bristle 3 to $6 \mathrm{~mm}$ long; spikelets about $2 \mathrm{~mm}$ long, obovate; first glume about one-third the length of the spikelet, obtuse or truncate; second glume nearly as long as the fruit (fig. 281).

Coral sand, southern Florida, the Bahamas, and Cuba.

Bahamas: New Providence, Britton and Brace 401. Rose Island, Britton and Millspaugh 2137. Great Exuma, Britton and Millspaugh 3076 (all in Field Mus. Herb.).

Cuba: Batabanó, Ekman 12615. Cayo Sabinal, Ekman 15521.

90. Panicum ophiticola Hitchc. and Ekman, sp. nov. ${ }^{66}$

Culms densely cespitose, very slender, erect or spreading, 30 to $50 \mathrm{~cm}$ tall, the nodes mostly glabrous; sheaths scarcely compressed, villous around the summit; ligule a dense line of short hairs; blades flat or usually folded, especially those of the dense basal tuft, often pilose on the upper surface, mostly less than 10 $\mathrm{cm}$ long, commonly much shorter, 1 to 2 $\mathrm{mm}$ wide, rarely to $3.5 \mathrm{~mm}$ wide, the culm blades several, commonly flat; panicles terminal and axillary from the upper sheaths, slender, 2 to $7 \mathrm{~cm}$ long, fewflowered, the branches short and appressed; spikelets 2 to $2.8 \mathrm{~mm}$ long, the bristle minute (fig. 282).

Type in the United States National Herbarium no. 1387464, collected in "cuabales", on serpentine, Loma Cajálbana, prov. Pinar del Río, Cuba, January 2, 1921, by E. L. Ekman (no. 12712).

Rocky slopes, mostly on serpentine, Cuba.

Cuba: Loma de Coca (prov. Habana), Ekman 1220. San Miguel de Casanova, Léon 12481. Madruga, Léon 6372. Minas, Léon 4784; Ekman in 1921. Canasí (prov. Matanzas), Léon 13117. Holguín, Ekman 15722.

91. Panicum distantiflorum A. Rich., in Sagra, Hist. Cuba 11: 304. 1850. Cuba.

Culms cespitose, 30 to $50 \mathrm{~cm}$ tall, slender, wiry, sometimes geniculate at the lower nodes, producing slender, sometimes fascicled

${ }^{66}$ A $P$. utowanaeo differt foliis brevibus planis 1-3 mm latis, in pagina superiore sparse villosis; spiculis 2-2.8 mm longis. 
branches from all the nodes; blades 3 to $12 \mathrm{~cm}$ long, 1 to $3 \mathrm{~mm}$ wide, flat to strongly involute; panicles numerous, 2 to $8 \mathrm{~cm}$ long, very narrow, the branches appressed; branchlets bearing 1 to 3 subsessile spikelets, 1.4 to $1.5 \mathrm{~mm}$ long, the bristle shorter than the spikelet (fig. 283).

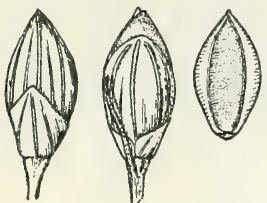

FIgURE 283.-Panicum distantiflorum. Two views of spikelet, and floret, $\times 10$ (type).

Limestone hills at low altitudes, Bahamas and Cuba.

BaHAmas: Inagua, Hitchcock in 1890; Nash and Taylor 893 (both in Field Mus. Herb.).

CuвA: Yayales, Ekman 11191. Mariel, Ekman in 1921. Hanábana, Wright 3452. Marianao, Ekman 434; Léon in 1909. Cojimar, Baker 2670; Hitchcock 144. Río Almendares, Ekman 951; Léon 2382, 12468. Habana, Léon 6299. Cayo de los Patos, Léon 9489. Cayo Romano, Shafer 2512. Santiago de Cuba, Léon 912, 917. Baracoa, Léon 12307. Guantánamo, Ekman 2894, 10167. Isla de Pinos, Britton, Wilson, and Léon 15272.

\section{Panicum pradanum Léon, $\mathrm{sp}$. nov ${ }^{67}$}

Culms cespitose, ascending, 50 to $90 \mathrm{~cm}$ long, slender, wiry; sheaths shorter than the internodes, ciliate at the auriculate summit; ligule a ring of short hairs; blades flexuous to curled, strongly involute from base to apex, much narrower at base than the summit of the sheath, finally often becoming flat from the middle towards the apex, 15 to $30 \mathrm{~cm}$ long, not more than $2 \mathrm{~mm}$ wide, often sparsely pubescent with short hairs on the upper surface, slightly scabrous on the margin; panicles 15 to $35 \mathrm{~cm}$ long, the branches remote, appressed, the lower not more than $2 \mathrm{~cm}$ long, bearing few to several spikelets, the bristle from nearly obsolete to as long as the spikelet or longer; spikelets spreading, 1.8 to $2 \mathrm{~mm}$ long, somewhat beaked; first glume about two-fifths the length of the spikelet, acute, 3-nerved; second glume about two-thirds the length of the spikelet, 5-nerved, rarely 7nerved; sterile lemma 5-nerved, pointed; fruit $1.8 \mathrm{~mm}$ long, minutely rugose, slightly beaked at the acute apex (fig. 284).

Type in the United States National Herbarium no. 1258962, collected in open thickets on slope of Mesa de Prada, Lower Jauco Valley, Jauco, Province Oriente, Cuba, July 17 to August 4, 1924, by Brother Léon (no. 11710).

Open thickets and rocky slopes, eastern Cuba to Puerto Rico.

Cuba: Jauco, Léon 11710. Santiago de Cuba, Ekman 8952.

Harti: Port-au-Prince, Ekman H 2020. Morne à Cabrits, Ekman H 1027. Port-de-Pai, Ekman H 5108; Leonard 11032, 11078. Caba-

67 A $P$. utowanaeo differt foliis longioribus, involutis, vaginis vix compressis, paniculis longioribus (usque ad $30 \mathrm{~cm}$ ), ramis remotis appressis; spiculis $1.8-2 \mathrm{~mm}$ longis. 
ret, Leonard 11837. Gonaïve Island, Leonard 3348; Eyerdam 45. Tortuga Island, Ekman 4054.

Dominican Republic: Guayabín, Abbott 1006. Navarette, Abbott 1085. Los Charcos, Fuertes 1427. Rincón, Fuertes 1284. Valverde, Ekman H 13102.

Puerto Rico: Cayo Muertos, Britton, Cowell, and Brown 5012. Mona Island, Hess 455.

93. Panicum utowanaeum Scribn., in Millsp., Field Mus. Bot. 2: 25. 1900. Puerto Rico, Pl. Utow. 702.

Panicum sintenisii Nash, Bull. Torrey Bot. Club 30: 382. 1903. Puerto Rico, Sintenis 3463.

Culms cespitose, ascending or somewhat spreading, 30 to $70 \mathrm{~cm}$ tall, the nodes glabrous; blades ascending, 8 to $20 \mathrm{~cm}$ long, 1 to $3 \mathrm{~mm}$ wide, flat to involute, often laxly flexuous; pan-

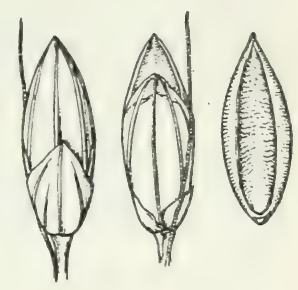

Figure 285.-Panicum utowanaeum. Two views of spikelet, and floret, $\times 10$ (type). icles very slender, 4 to $10 \mathrm{~cm}$ long, the erect branches 1 to $3 \mathrm{~cm}$ long, the bristle equaling or exceeding the spikelet; spikelets about $2 \mathrm{~mm}$ long, glabrous (fig. 285).

Open rocky soil, mostly near the coast, Cuba and Puerto Rico to Guadeloupe.

Cuba: San Miguel de Casanova, Léon 11569. Santa Clara City, Ekman 14040. Sabana de Motembo, Léon 9363. (The Cuban specimens scarcely characteristic.)

Puerto Rico: Guanica Bay, Chase 6520 (Amer. Gr. Nat. Herb. 201), 6533, 6535; Sintenis 3365, 3416, 3463 . Boqueron, Britton, Cowell, and Brown 4617. Playa Sucia Bay, Britton, Cowell, and Brown 4754. Desecheo Island, Hess 422; Britton, Cowell, and Brown 1601. Mona Island, Britton, Cowell, and Hess 1698, 1734; Hess 431, 457.

Virgin Islands: Anegada, Fishlock 45.

Leeward Islands: Barbuda, Danforth 10. Antigua, Box 45. Guadeloupe, Duss 3177.

\section{Panicum leonis Ekman, sp. nov. ${ }^{68}$}

Loosely cespitose, the slender rhizome better developed than in the other species, the culms slender, erect, or spreading, freely branching, 30 to $60 \mathrm{~cm}$ tall, the nodes, at least the lowermost, pubescent, sometimes obscurely so; sheaths somewhat compressed, the lower rarely pubescent, a pubescent line across the collar, short-pilose along the margin at summit; ligule a dense line of short hairs; blades 5 to $15 \mathrm{~cm}$ long, 4 to $7 \mathrm{~mm}$ wide (rarely but $3 \mathrm{~mm}$ wide), flat, narrower than the sheath at base; panicles from all the

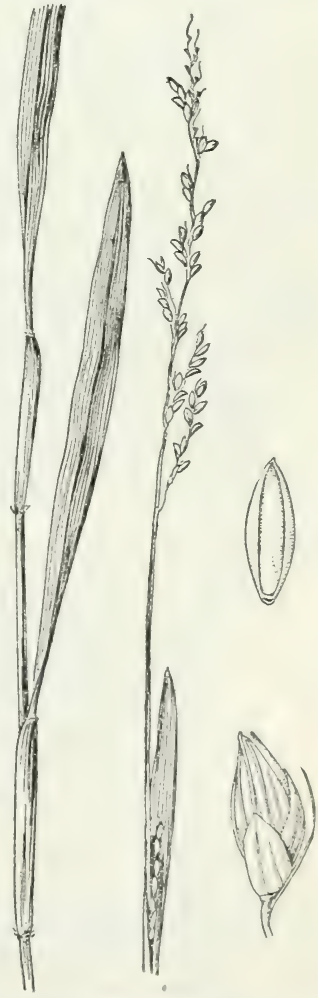

Figure 286.-Panicum leonis. Plant, $X 1$; spikelet and floret, $\times 10$ (type). upper nodes, usually 2 to $5 \mathrm{~cm}$ long, relatively dense; spikelets 1.7 to 2 $\mathrm{mm}$ long, the bristle from minute to longer than the spikelet (fig. 286).

\footnotetext{
${ }^{68}$ A P. utowanaeo differt laminis planis latioribus (usque ad $7 \mathrm{~mm}$ ); nodis inferioribus pubescentibus paniculis brevioribus densiusculis; spiculis $1.7-2 \mathrm{~mm}$ longis.
} 
Trpe in the United States National Herbarium, no. 1502160, collected "in fruticetis littoralibus", Cojimar, near Habana, Cuba, September 9, 1921, by E. L. Ekman (no. 1315j).

The type specimen and other collections with broad flat rather thick blades are strikingly different from any other species, but there are sereral specimens with blades only about $4 \mathrm{~mm}$ wide and more slender panicles which approach $P$. utowanaeum.

Rocky slopes and clearings, Cuba and Hispaniola.

Cева: Cojimar, Ekman 13155, Willson 9197; Léon 305 in part, 567, 5603, 7504: Hitcheock 141; Tracy 9089. Pastellilo, Ekman 15408; Caro Guajaba, Shafer 2830. Antilla, Ekman 7308. Jauco, Léon 11709 .

\section{Haitr: Môle-St.-Nicolas, Leonard 1330j. Port-de-Pai, Ekman H 3974 .}

Domicax Republic: Valverde, Ekman H 13103.

\section{ICHNANTHUS Beaur., Ess. Agrost. 56. pl. 12. f. 1.1812}

Inflorescence and spikelets as in Panicum (but more or less laterally compressed), the first glume often nearly as long as the spikelet, the fruit acute or subacute, the margins of the lemma usually flat, the rachilla produced below the lemma into a minute stipe, this bearing on either side membranaceous appendages adnate to the base of the lemma and free abore, the appendages often wanting and indicated by minute excarations only; spikelets mostly shortpedicellate along the subsimple branches of a panicle. Mostly perennial, often decumbent at base or straggling.

Appendages of fertile lemma well developed wings.

Sheaths densely long-villous.

Sheaths more or less pubescent but not long-villous.

Blades lanceolate-elliptic, not more than 6 times longer than wide; spikelets short-pediceled................................... IEMORALIS.

Blades lanceolate-linear, many times longer than wide; spikelets longAppendages of fertile lemma reduced to scars.

Blades petiolate, usually less than $5 \mathrm{~mm}$ wide, the petiole 1 to $15 \mathrm{~mm}$ long.

1. I. MAYARENSIS.

Blades more or less clasping, usually more than $10 \mathrm{~mm}$ wide $(4$ to $10 \mathrm{~mm}$ in I. tenuis).

Glumes, at least the first, with attenuate tips, usually exceeding the sterile lemma and floret; blades thin, more or less pilose.

Spikelets with a few long stiff hairs near the margin toward the summit of both glumes; plants delicate; blades rarely more than $4 \mathrm{~cm}$ long and $1 \mathrm{~cm}$ wide.................................... TENUIS.

Spikelets glabrous or scabrous on the midnerves only; blades up to $7 \mathrm{~cm}$ long and $2 \mathrm{~cm}$ wide_......................... I. NEMOROSUS.

Glumes acute or acuminate but not attenuate, the first shorter than the spikelet.

Plants delicate, the fertile culms 3 to $8 \mathrm{~cm}$ tall; blades thin, 5 to $18 \mathrm{~mm}$

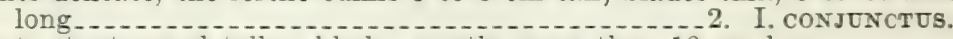

Plants stouter and taller; blades mostly more than $10 \mathrm{~cm}$ long.

Blades lanceolate, 1 to $2 \mathrm{~cm}$ wide, glabrous Blades oval to ovate-lanceolate, 1.5 to $3.5 \mathrm{~cm}$ wide, often pubescent

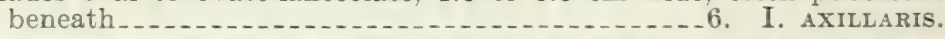

1. Ichnanthus mayarensis (Wright) Hitchc., Contrib. U. S. Natl. Herb. 12: 228. 1909.

Panicum mayarense Wright, An. Acad. Cien. Habana 8: 206. 1871. Cuba, Wright 3468.

Ichnanthus urightii Hitchc., Contrib. U. S. Natl. Herb. 12: 229. 1909. Cuba, Wright 3880. 
Culms slender, straggling or spreading, 20 to $40 \mathrm{~cm}$ long; blades lanceolate to narrowly elliptic, 2 to $5 \mathrm{~cm}$ long, 3 to $6 \mathrm{~mm}$ wide, glabrous, abruptly narrowed into a petiole 1 to $5 \mathrm{~mm}$ long or on sterile shoots as much as $15 \mathrm{~mm}$ long; panicles 2 to $10 \mathrm{~cm}$ long, the few main branches rather stiffly spreading or ascending, as much as $3 \mathrm{~cm}$ long; spikelets about $3 \mathrm{~mm}$ long, lanceolate, nearly terete, acute, glabrous, the pedicels 0.5 to $2 \mathrm{~mm}$ long.

Dry pine woods and palm barrens, Cuba.

Cuba: Arroyo Hondo, Wright 3880. Río Santa Cruz, Ekman 17647. Sierra de las Guacamayas, Ekman 17992. Madruga, Léon 6373. Campo Florido, Léon 3450, 4143; Ekman 13246. Minas, Ekman 13139. San Miguel de los Baños, Léon 8885. Banao Mountains, Léon 8045, 80451/2. Soledad, Hitchcock 23331. Sierra de Nipe, Ekman 2166, 2243, 3327, 9990; Shafer 2966, 3058. Guara, Hitcheock 23406, 23421. Jauco River, Léon 12322. Baracoa, Ekman 3569, 4325. Guantánamo, Ekman 10289. Isla de Pinos, Ekman 12294, 12304, 12447.

2. Ichnanthus conjunctus Hitchc. and Ekman, sp. nov. ${ }^{69}$

Culms branching and creeping, rooting at the nodes, slender, glabrous except for a
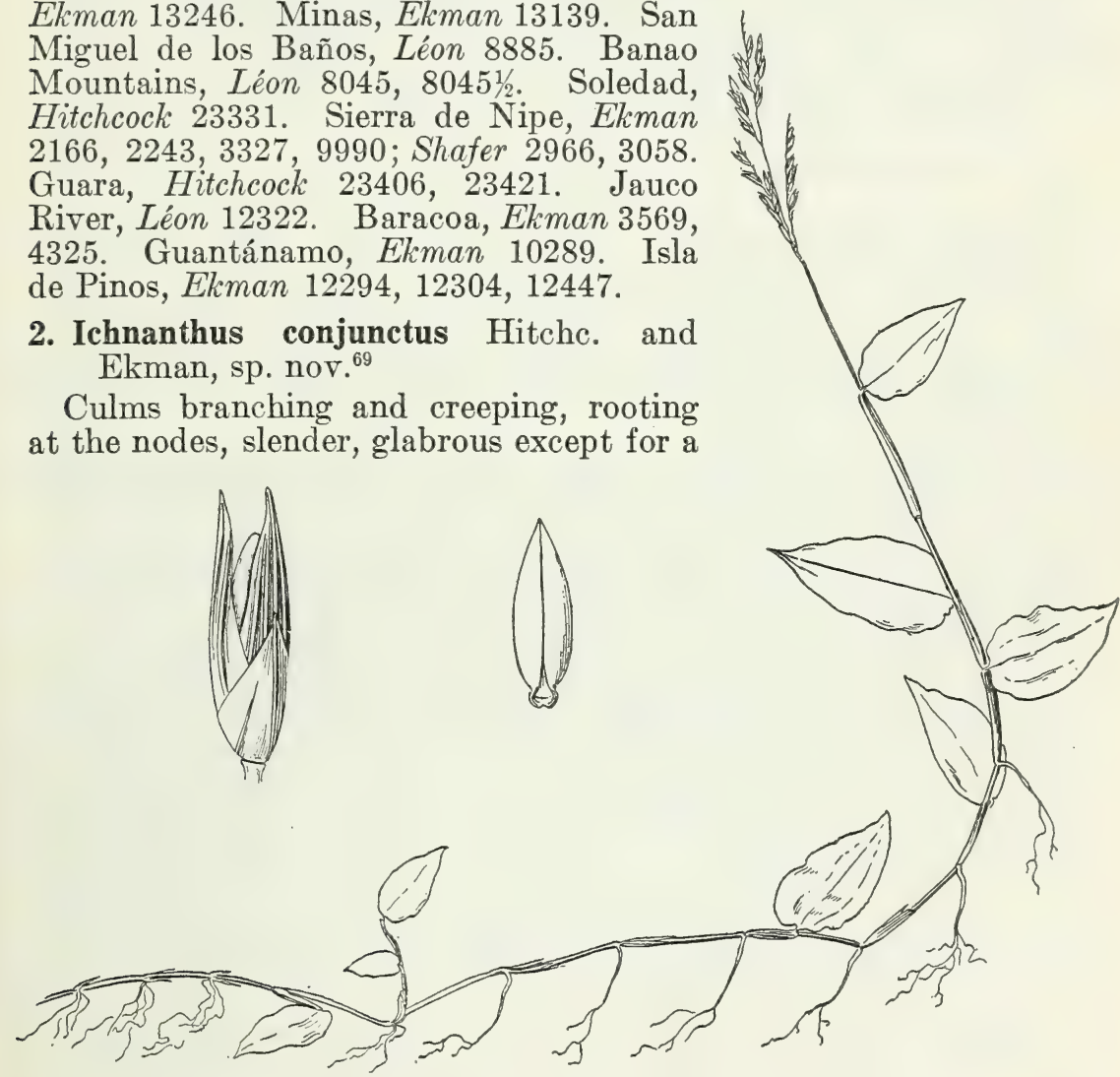

FIGURE 287.-Ichnanthus conjunctus. Plant, $\times 1$; spikelet and floret, $\times 10$ (type).

rather indistinct pubescent line, sulcate, the node sparsely and minutely pubescent, the fertile branches ascending, 3 to $8 \mathrm{~cm}$ long; sheaths half as long as the nodes or less, sulcate, glabrous except the ciliate margin and throat; ligule a ciliate membrane about $0.5 \mathrm{~mm}$ long; blades ovate to ovate-lanceolate, thin, 5 to $18 \mathrm{~mm}$ long, as

68 Culmi ramosi repentes graciles, ramis fertilibus adscendentibus 3-8 cm longis; laminae ovatae vel ovato-lanceolatae tenues $5-18 \mathrm{~mm}$ longae glabrae; paniculae angustae pauciflorae $2 \mathrm{~cm}$ longae, ramis appressis 5-10 mm longis; spiculae lanceolatae acutae glabrae $3 \mathrm{~mm}$ longae; gluma prima $1.5 \mathrm{~mm}$ longa acuta 3-nervis; lemma fertile non alatum. 
much as $9 \mathrm{~mm}$ wide, rounded or somewhat cordate at base with a petiole about $0.5 \mathrm{~mm}$ long, minutely scaberulous on the nerves on the upper surface, glabrous beneath except for a little pubescence near the base; panicles narrow, few-flowered, 2 to $2.5 \mathrm{~cm}$ long, the few branches narrowly ascending or appressed, 5 to $15 \mathrm{~mm} \mathrm{long,} \mathrm{the} \mathrm{lateral} \mathrm{pedicels}$ $0.3 \mathrm{~mm}$ long; spikelets lanceolate, nearly terete, acute or acuminate, glabrous, strongly nerved, $3 \mathrm{~mm}$ long; first glume half as long as the spikelet, 3-nerved; second glume and sterile lemma equal, 5-nerved, acuminate; fertile lemma pale, a little shorter than the spikelet, acute, the wings wanting (fig. 287).

Type in the United States National Herbarium no. 1387342, collected on moist logs in forest, Sabanos, prov. Oriente, Cuba, by E. L. Ekman (no. 6536). Known only from the type collection.

3. Ichnanthus tenuis (Presl) Hitchc. and Chase, Contrib. U. S. Natl. Herb. 18: 334. 1917.

Oplismenus tenuis Presl, Rel. Haenk. 1: 319. 1830. Mexico, Panama.

Panicum exile Steud., Nom. Bot. ed. 2. 2: 256. 1841. Based on Oplismenus tenuis Presl.

Panicum alsinoides Griseb., Fl. Brit. W. Ind. 550. 1864. Trinidad.

Ichnanthus alsinoides Munro; Hemsl., Biol. Centr. Amer. Bot. 3: 500. 1885 .

Apparently annual; culms slender, spreading or creeping, rooting at the nodes, much branched, the fertile shoots ascending, 10 to 20 $\mathrm{cm}$ high; blades lanceolate, 2 to $5 \mathrm{~cm}$ long, 4 to $10 \mathrm{~mm}$ wide, thin, glabrous or puberulent; panicles terminal and axillary, 2 to $4 \mathrm{~cm}$ long, mostly on long slender peduncles; spikelets narrowly lanceolate, $3 \mathrm{~mm}$ long, acuminate, hispid.

Grisebach's description of Panicum alsinoides applies to $I$. tenuis which is not known from Jamaica. Grisebach gives as original localities, "Hab. Jamaica!, March; St. Kitts!; Trinidad!, Pd." March's specimen (sterile) in the Gray Herbarium is Oplismenus setarius. Purdie's specimen at Kew Herbarium is I. tenuis.

Damp shady places, at low and medium altitudes, Central America, Colombia, and Trinidad.

Trinidad: Maracas, Broadway in 1925. Maraval, Broadway 4912, 4913. Arima, Hitchcock 10313. St. Joseph, Hitchcock 10174 (Amer. Gr.Nat.Herb. 580). Port-of-Spain, Hitchcock 10052, 10199. Blanchisseuse Road, Broadway 5539.

4. Ichnanthus nemorosus (Swartz) Doell, in Mart., Fl. Bras. 22: 289. 1877.

Panicum nemorosum Swartz, Prodr. Veg. Ind. Occ. 22. 1788. Jamaica.

Milium nemorosum Moench, Meth. Sup. 67. 1802.

Echinolaena nemorosa Kunth, Rév. Gram. 1: 54. 1829.

Differing from $I$. pallens in the more prostrate habit, thinner, usually proportionately broader, sparsely pilose blades and the blunter spikelets.

Shady banks and rich woods, West Indies, Mexico, and Central America. 
Cuba: Retiro, Wright 3881. Arroyo Hondo, Wright 3858. Mogote de Mono, Wright 3882. San Blas, Jack 6766. Cabañas, Ekman 12967. Mogote de la Bandera, Roig 3271. Sierra de Anafe, Léon 2873; Wilson and Léon 11538. Mendoza, Léon 3635. Banao Mountains, Léon 3997, 7866. La Perla, Léon 3908. Bayote, Ekman 2383. Sierra Maestra, Léon 10078, 10153; Ekman 1569, 8299, 8815. Sierra de Nipe, Ekman 9872.

JamaICA: Gordon Town, Harris 11476; Hart 923. Claremont, Hitchcock 9523 (Amer. Gr. Nat. Herb. 582). Catherines Peak, Hitcheock 9741. Castleton, Harris 11296. Clyde River, Harris 11447. Troy, Hitchcock 9798; Harris 12595. Windsor, Miller 1516.

Haitr: Mission, Leonard 3975. Pétionville, Leonard 4858, 5052. Port-au-Prince, Ekman H 9105, H 9505. Morne Cabaio, Ekman H 1680.

Dominican Republic: Old Heart River, Abbott 1366. Sánchez, Abbott 172.

Puerto Rico: Cayey, Sintenis 2406.

Leeward Islands: St. Kitts, Box 139, 141, 144, 145; Britton and Cowell 632. Nevis, Box 168.

Windward Islands: Grenada, Broadway 177.

Trinidad: Mount Tucuche, Britton, Hazen, and Mendelson 1328. Blanchisseuse Road, Broadway 6004. Balandra Bay, Britton and Hazen 432. Caparo, Broadway 4931. Port-of-Spain, Hitchcock 10041.

\section{Ichnanthus pallens (Swartz) Munro; Benth., Fl. Hongk. 414. 1861.}

Panicum pallens Swartz, Prodr. Veg. Ind. Occ. 23. 1788. Jamaica.

Culms much branched, spreading, creeping at the base, rooting at the nodes, the fertile culms ascending, 30 to $80 \mathrm{~cm}$ long, puberulent; blades lanceolate, often somewhat falcate, 5 to $10 \mathrm{~cm}$ long, 1 to $2 \mathrm{~cm}$ wide, somewhat clasping at the asymmetric narrowed base, glabrous or nearly so, but more or less scaberulous on the upper surface; panicles terminal and from several of the upper axils, 5 to $10 \mathrm{~cm}$ long, the spikelets appressed along the ascending branches; spikelets 3 to $3.5 \mathrm{~mm}$, glabrous, the glumes and sterile lemma acuminate or more or less attenuate-pointed; appendages of fertile lemma reduced to scars (fig. 288).

Shady banks and rich woods, tropical regions of America in low and medium altitudes. To be found on probably all the West Indian islands from the Greater Antilles to Trinidad.

6. Ichnanthus axillaris (Nees) Hitchc. and Chase, Contrib. U. S. Natl. Herb. 18: 334. 1917.

Panicum axillare Nees, Agrost. Bras. 141. 1829. Brazil.

Differing from $I$. pallens in the firmer broader blades (ovate or ovate-lanceolate), often very scabrous on the upper surface, cordateclasping at base, larger panicles, and often sparsely pilose spikelets.

Moist more or less shaded slopes in the uplands, Central America to Brazil; Hispaniola, Puerto Rico; Trinidad, Tobago.

HaIti: Plaisance, Leonard 9190.

Dominican Republic: Los Haitises, Ekman H 15512. La Cumbre Ekman H 14215. Bayaguana, Ekman H 11096. Altagracia, Ekman H 11256, H 11257. 
Puerto Rico: Adjuntas, Chase 6472; Sintenis 4610; Britton and Shafer 2018. Aybonito, Sintenis 2869. Utuado, Britton and Cowell 1008. Cayey, Chase 6735. Mayaguez, Heller 4479.

Trinidad: Tabaquite, Hitchcock 10125, 10129 (Amer. Gr. Nat. Herb. 585), 10133. Maraval, Bot. Gard. Herb. 5425; Britton, Freeman, and Nowell 2607. Maracas Waterfall, Britton, Hazen, and Mendelson 1647. Maracas

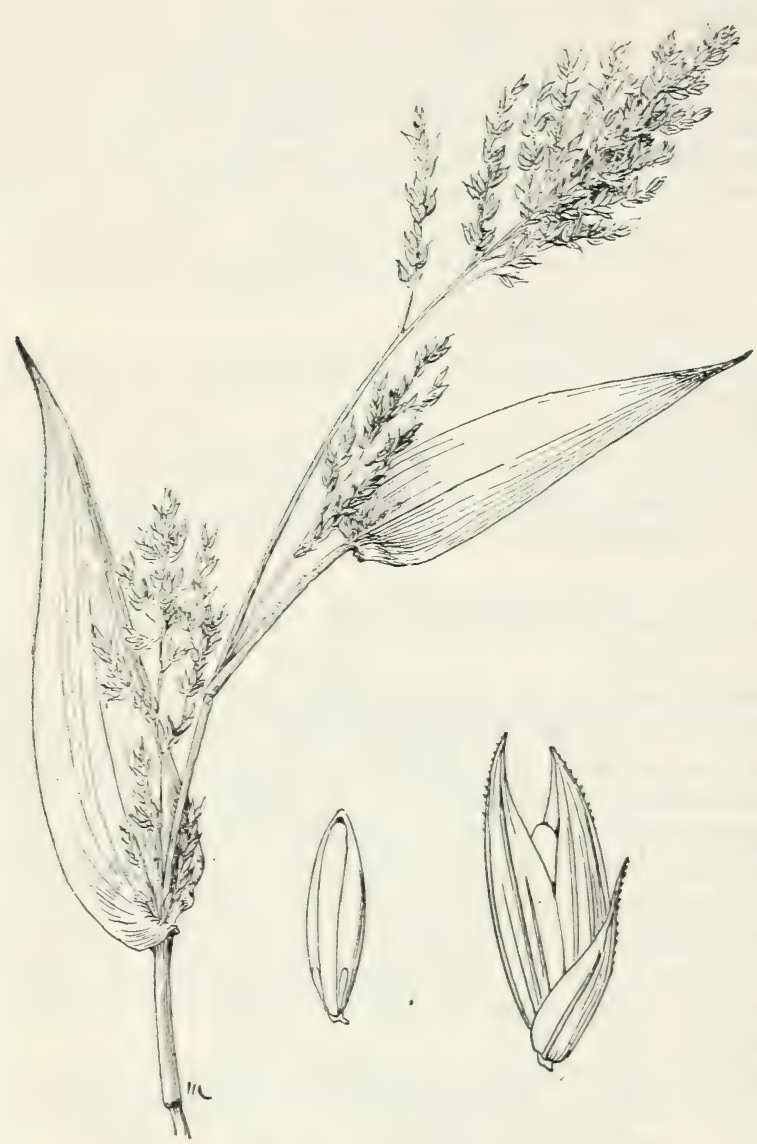

Bay, Broadway 8950. TоваGO: Hitchcock 10263.

7. Ichnanthus nemoralis (Schrad.) $\mathrm{Hitchc}$. and Chase, Contrib. U.S. Natl. Herb. 18: 334. 1917.

Panicum nemorale Schrad.; Schult., Mant. 2: 255.1824. Brazil.

Culms as much as $1 \mathrm{~m}$ tall, more or less decumbent at base, pubescent or glabrous; sheaths more or less pubescent, villous on the collar; ligule a ciliate membrane about $1 \mathrm{~mm}$ long; blades elliptic or narrowly lanceolate, up to about 10 or $15 \mathrm{~cm}$ long, as much as $3 \mathrm{~cm}$ wide, narrowed into a petiole 1 to $2 \mathrm{~mm}$ long, manynerved, pubescent on both surfaces or glabrous above; panicle 10 to $15 \mathrm{~cm}$ long, the

FIGURE 288.-Ichnanthus pallens. Plant, $\times$ 33; spikelet and floret, $\times 10$ (Ekman 9504) few stout branches stiffly ascending, pubescent at base; spikelets about $4.5 \mathrm{~mm}$ long, glabrous, or the glumes slightly roughened on the internerves toward the apex; fruit $3.5 \mathrm{~mm}$ long, the appendages $1.5 \mathrm{~mm}$ long.

Among shrubs, Trinidad to Brazil. This species was described under Panicum lagotis Trin., by Grisebach. ${ }^{70}$

Trinidad: Without locality, Bot. Gard. Herb. 2278; Crueger 78, 82.

Toвago: Broadway 4472.

$70 \mathrm{Fl}$. Brit. W. Ind. 550.1864. 
8. Ichnanthus leiocarpus (Spreng.) Kunth, Rév. Gram. 1: Sup. X. 1830.

Panicum leiocarpon Spreng., Neu. Entd. 1: 243. 1820. Brazil.

Culms 1 to $2 \mathrm{~m}$ tall, pubescent; sheaths villous or lanate; ligule a ciliate membrane, the hairs 1 to $2 \mathrm{~mm}$ long; blades narrowly lanceolate, 10 to $20 \mathrm{~cm}$ long, 1 to $3 \mathrm{~cm}$ wide, pilose on both surfaces; panicle large and open, about $30 \mathrm{~cm}$ long, obovoid, the axis villous below, scabrous above, the branches spreading, pubescent at base, these and the branchlets somewhat flexuous; spikelets about $4 \mathrm{~mm}$ long, glabrous; first glume about half as long as spikelet; fruit narrow, brownish, 3 $\mathrm{mm}$ long, the appendages about $1 \mathrm{~mm}$ long (fig. 289).

Wooded slopes, Trinidad to Brazil.

Trinidad: Without locality, Bot. Gard. Herb. 3318.

9. Ichnanthus ichnodes (Griseb.) Hitchc. and Chase, Contrib. U. S. Natl. Herb. 18: 335.1917.

Panicum ichnodes Griseb., Fl. Brit. W. Ind. 551. 1864. Trinidad.

Ichnanthus trinitensis Mez, Repert. Sp. Nov. Fedde 15: 130. 1918. Trinidad.

Erect from a somewhat decumbent base, bearing short knotty, rhizomes and forming colonies; culms 1 to $2 \mathrm{~m}$ tall, glabrous, or sparingly villous below; sheaths keeled, the lower overlapping, glabrous or sparsely villous, densely villous on the margin and on the collar; ligule about $1 \mathrm{~mm}$ long; blades narrowly lanceolate to linear, the lower as much as $30 \mathrm{~cm}$ long, 1 to $2 \mathrm{~cm}$ wide, narrowed below, scabrous, sometimes sparsely villous, densely villous above near base; panicle oblong, as much as $30 \mathrm{~cm}$ long,

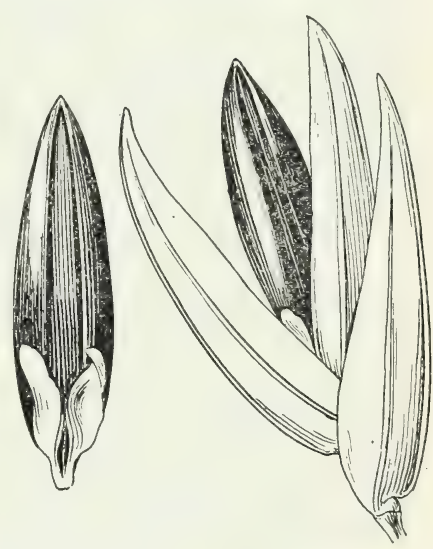

FIGURE 289.-Ichnanthus leiocarpus. Spikelet and floret, $\times 10$ (type). the branches fascicled or branched at base, finally spreading; spikelets blunt, about $2.5 \mathrm{~mm}$ long; first glume more than half as long as spikelet, often sparsely villous; second glume roughened toward apex; sterile floret often staminate; fruit 2 $\mathrm{mm}$ long, the appendages $0.5 \mathrm{~mm}$ long.

The elongate blades and the large, much-branched, many-flowered panicles of blunt spikelets give this species the aspect of a species of Panicum, but the appendages at the base of the fertile lemma show that the species belongs to Ichnanthus.

Wood borders in partial shade, Trinidad to Brazil.

Trinidad: St. Joseph, Hitchcock 10178, 10179, 10191. Port-ofSpain, Hitchcock 9999 (Amer. Gr. Nat. Herb. 586), 10003 (Amer. Gr. Nat. Herb. 587); Bot. Gard. Herb. 3182; Broadway 5060. Piarco Savanna, Hitchcock 10357. Pitch Lake, Bot. Gard. Herb. 2299. Without locality, Crueger 77. 


\section{LASIACIS (Griesb.) Hitchc., Contrib. U. S. Natl. Herb. 15: 16. 1910. Tibisee}

(Panicum section Lasiacis Griseb., Fl. Brit. W. Ind. 551. 1864) Spikelets subglobose, placed obliquely on their pedicels; first glume broad, somewhat inflated-rentricose, usually not more than one-third the length of the spikelet; second glume and sterile lemma about equal, broad, abruptlr apiculate, papers-chartaceous, shining, manynerred, glabrous, or lanose at the apex onlr, the lemma enclosing a membranaceous palea and sometimes a staminate flower: fertile lemma white, bonr-indurate, oboroid, obtuse, this and the palea of the same texture bearing at the apex in a slight crateriform depression a tuft of woollr hairs, the palea concare below, gibbous abore, the apex often free at maturity. Large branching perennials with woody culms, often clambering, mostly firm blades narrowed into a minute petiole, and open or slightly compact panicles.

Main culm prostrate, the fertile shoots prostrate, ascending, or erect.

Blades lanceolate, mostly less than $5 \mathrm{~cm}$ long; fertile shoots strongly dorsiventral

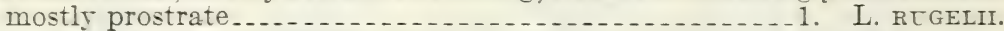

Blades linear-lanceolate, mostly 10 to $12 \mathrm{~cm}$ long; fertile shoots ascending or erect from a decumbent base, not dorsiventral ....... 2. L. GRISEBACHII.

Main culm clambering or much branched and forming a tangled mass.

Ligule noticeable, brownish, about $2 \mathrm{~mm}$ long.

Blades glabrous beneath, scabrous on both surfaces, elongate, more than 10 times as long as wide; plants not forming a strong central clambering

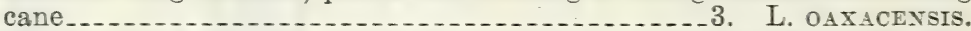

Blades puberulent beneath, glabrous or scabrous on the upper surface, less than 10 times as long as wide; plants forming a strong central clambering

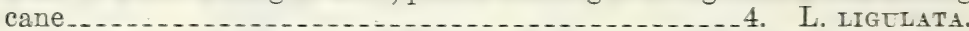

Ligule inconspicuous, hidden within the mouth of the sheath, rarely as much as $1 \mathrm{~mm}$ long.

Plants not high-climbing, decumbent and rooting at base, forming a tangled mass, with no strong central cane; spikelets clustered toward the ends of the branches................................. L. RHIzOPHORA.

Plants high-climbing, forming a strong central cane; spikelets not clustered toward the ends of the branches.

Blades glabrous on both surfaces, often more or less scabrous.

Blades narrow, usually 3 to $4 \mathrm{~mm}$, sometimes $5 \mathrm{~mm}$, wide, 8 to $10 \mathrm{~cm}$

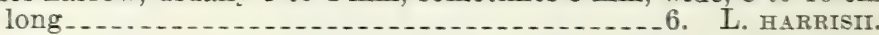

Blades more than $5 \mathrm{~mm}$ wide, if as much as $10 \mathrm{~cm}$ long.

Panicles fer-flowered, 5 to $10 \mathrm{~cm}$ long; branches strongly zigzag, the branchlets strongly divaricate or reflexed; blades narrowly lanceolate, firm, mostly less than $1 \mathrm{~cm}$ mide (sometimes wider on vigorous shoots) ................... L. DIVARICATA.

Panicles many-flowered, usually 15 to $25 \mathrm{~cm}$ long or more on the primary branches; branches straight or arcuate, not zigzag; blades mostly more than $1.5 \mathrm{~cm}$ wide.

Spikelets 4.5 to $5 \mathrm{~mm}$ long, on short stiff appressed pedicels; blades oblong-orate or elliptic-lanceolate.......... \&. L. SLOANEI.

Spikelets 3.5 to $4 \mathrm{~mm}$ long on fleruous spreading pedicels, blades lanceolate or narrowly lanceolate ...... 9. L. PATENTIFLORA.

Blades pubescent on one or both surfaces (rarely nearly glabrous in L. ruscifolia).

Blades narromly lanceolate, areraging $\delta$ to 10 times as long as wide; panicle large and open; spikelets 4 to $5 \mathrm{~mm}$ long.

10. L. SORGHOIDEA.

Blades orate-lanceolate or elliptic, sometimes lanceolate, often more or less cordate-clasping; panicle of ten compact, or at least the branches commonly compactly flowered; spikelets 3 to $4 \mathrm{~mm}$ long.

Sterile lemma 1 ................................ RUSCIFolia.

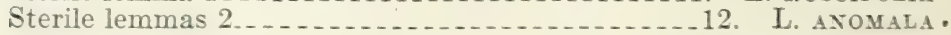


1. Lasiacis rugelii (Griseb.) Hitchc., Bot. Gaz. 51: 302. 1911.

Panicum rugelii Griseb., Cat. Pl. Cub. 233. 1866. Cuba, Rugel 188.

Culms much branched, prostrate, the main culms slender, mostly about $2 \mathrm{~mm}$, sometimes $2.5 \mathrm{~mm}$, thick, appressed-hispidulous, the sterile shoots prostrate, dorsiventral, the leaves strongly distichous, approximate, the fertile shoots sometimes ascending toward the end; sheaths overlapping, hispidulous, villous on the margin and around the summit; ligule inconspicuous; blades lanceolate or oblong-lanceolate, 2 to $5 \mathrm{~cm}$ long, 4 to $12 \mathrm{~mm}$ wide, hispidulous or puberulent on both surfaces; panicles few-flowered, usually not more than $5 \mathrm{~cm}$ long, the few branches spreading, the axes pubescent, scabrous on the angles; spikelets $5 \mathrm{~mm}$ long.

Rich thickets, Cuba and Hispaniola.

Cuba: Valestina, Wright 3465. Sierra de Anafe, Wilson 11449. San Antonio, Hitchcock 176. Boco de Canasí, Léon 13698. Canasí, Ekman 16489. Camoa, Ekman 13516. San Miguel de Casanora, Léon 12458, 12459, 12460, 12461, 12462. Guantánamo, Ekman 10306. Niquero, Ekman 16151. Santiago de Cuba, Ekman 7699. Sierra de Nipe, Ekman 15242. Isla de Pinos, Britton and Wilson 14860; Ekman 12446.

Haiti: Tortuga Island, Ekman H 4254.

Dominican Republic: Sosúa, Ekman H 14531.

2. Lasiacis grisebachii (Nash) Hitchc., Bot. Gaz. 51: 302. 1911.

Panicum grisebachii Nash, Bull. Torrey Bot. Club 35: 301. 1908. Cuba, Britton and Shafer 758.

Plants much branched, the main culms creeping and rooting at the nodes, as much as $2 \mathrm{~mm}$ in diameter, the fertile shoots erect or ascending, 20 to $40 \mathrm{~cm}$ tall; ligule inconspicuous; blades narrowly lanceolate, 6 to $12 \mathrm{~cm}$ long, 5 to $10 \mathrm{~mm}$ wide, puberulent beneath, glabrous above; panicles ovate, mostly 5 to $6 \mathrm{~cm}$ long, the few branches rather stiffly ascending, few-flowered; spikelets $4 \mathrm{~mm}$ long.

Rich woods and shady banks, carpeting the floor of dark thickets, Cuba; eastern Mexico and Central America.

Cuba: Sierra del Brujo, Léon 12916. Viñales, Hitchcock 23315; Killip 13528. Valestina, Wright 3457. Sierra de Anafe, Wilson and Léon 2874, 11467; Wilson 11309. Cabanas, Ekman 10506. Bahia Honda, Shafer 12006. Taco Taco, Baker 3817. Buenaventura, Wilson 9238, 9332. Matanzas, Rugel 187. Madruga, Britton and Shafer 758. Guanajay, Baker and Van Hermann 4269. San Antonio, Hitchcock 131. Manatí, Léon 5685. Peninsula de Zapata, Ekman 18340. Boca de Canasí, Léon 15106. Lomas de Camoa, Léon 1972; Ekman 13462, 13531. Gerardo, Ekman 12646.

3. Lasiacis oaxacensis (Steud.) Hitchc., Biol. Soc. Wash. Proc. 24: 145. 1911.

Panicum oaxacense Steud., Syn. Pl. Glum. 1: 73. 1854. Mexico.

Straggling and branching, but not high-climbing nor with a strong central cane; culms decumbent and geniculate at base, rooting at the lower nodes, the ascending branches 1 to $2 \mathrm{~m}$ long, glabrous; sheaths glabrous or rarely appressed-pubescent, the margin villous; ligule $60256-36-20$ 
prominent, 2 to $5 \mathrm{~mm}$ long, brownish; blades narrowly lanceolate, 10 to $25 \mathrm{~cm}$ long, 1 to $2 \mathrm{~cm}$ wide, abruptly narrowed at base, long-tapering at apex, scabrous on both surfaces; panicles open, as much as 30 $\mathrm{cm}$ long and nearly as wide, the slender scabrous branches and branchlets ascending or the lower finally spreading, naked below, the spikelets clustered toward the tips, no smaller secondary panicles developed; spikelets $4 \mathrm{~mm}$ long, elliptic, often purple.

Edges of woods, thickets, and copses, Mexico to Ecuador; Jamaica, Hispaniola.

JAmaICA: Peckham, Harris 12828. Troy, Hitchcock 9800. Lindos Hill, Harris 11832. Ipswich, Hitchcock 9608. Mount Diablo, Ridley 27.

HaIti: Buttet, Ekman H 7153. Port-Margot, Ekman H 2841. Caille la Croix, Leonard 7997. Marmelade, Leonard 8192. Dondou, Leonard 8572. Plaisance, Leonard 9391.

Dominican Republic: Sanchéz, Abbott 180.

4. Lasiacis ligulata Hitchc. and Chase, Contrib. U. S. Natl. Herb. 18: 337. 1917. Trinidad, Hitchcock 10007.

Panicum divaricatum var. puberulum Griseb., Fl. Brit. W. Ind. 551. 1864. Trinidad, Crueger.

Clambering to a height of 5 to $10 \mathrm{~m}$, the robust glabrous central cane as much as $1 \mathrm{~cm}$ in diameter, the wide-spreading main branches and the arcuate secondary ones not in fascicles, not zigzag; sheaths ciliate on the overlapping margin, otherwise glabrous; ligule a ciliate membrane, brown, 1 to $2 \mathrm{~mm}$ long; blades flat, firm, 6 to $12 \mathrm{~cm}$ long, 0.8 to $1.5 \mathrm{~cm}$ wide, lanceolate, acuminate, narrowed to the base, glabrous on the upper surface, puberulent beneath, the margins scabrous; panicles terminating the numerous branches, exserted or partly included, oval in outline, rather open, 5 to $10 \mathrm{~cm}$ long, usually half to three-fourths as wide, the branches few, spreading, finally reflexed, branching or flowering from near the base, usually bearing 5 to 10 short-pedicled spikelets; spikelets about $4 \mathrm{~mm}$ long, obovoid and purplish black at maturity, the glumes and sterile lemma as well as the fruit with a lanate tuft at the tips.

Copses and edges of woods, Central America and the West Indies to Ecuador and Brazil.

Dominican Republic: Río San Juan, Miller 1184. Sanchéz, Abbott 121.

Puerto Rico: Lares, Sintenis 5918. Cayey, Chase 6734, 6747. Maricao, Sintenis 215. Loquillo Mountains, Wilson 350. Arecibo, Chase 6454. Mayaguez, Britton and Marble 678.

Virgin Islands: Tortola, Shafer 1147. St. Thomas, Britton and Marble 1230.

Trinidad: Port-of-Spain, Hitchcock 9962. St. Joseph, Hitchcock 10020. Morne Bleu, Britton, Freeman, and Bailey 2266. Aripo, Broadway 9929. Diego Martin, Bot. Gard. Herb. 7717. Caparo, Broadway 4923. Tamana, Broadway 4952, 4959. Tabaquite, Hitchcock 10120. Moruga, Broadway 7915. Cedros, Hitchcock 10151.

ToвAGo: Hitchcock 10261, 10262, 10269, 10275; Broadway 3551, 4038. 
5. Lasiacis rhizophora (Fourn.) Hitchc., Biol. Soc. Wash. Proc. 24: 145. 1911.

Panicum rhizophorum Fourn., Mex. Pl. 2: 31. 1886. Mexico.

Branching and straggling, not forming a strong central cane, decumbent at base and rooting at the lower nodes, the fertile culms ascending, 30 to $100 \mathrm{~cm}$ long, glabrous or pubescent; sheaths appressed-hispidulous or glabrescent, villous on the margin; ligule inconspicuous; blades lanceolate to ovate-lanceolate, 7 to $14 \mathrm{~cm}$ long, 1.5 to $3 \mathrm{~cm}$ wide, somewhat cordate at base, rather abruptly narrowed above to an acuminate point, scabrous above, pubescent or scabrous beneath; panicles 8 to $15 \mathrm{~cm}$ long, the branches stiffly ascending, naked below, the spikelets clustered toward their tips, the axes scabrous; spikelets 3 to $4 \mathrm{~mm}$ long, ovoid.

Copses and moist forest, Mexico and Central America; Cuba; Hispaniola.

CuBA: Lomas de Camoa (prov. Habana), Ekman 13511, 13530. Sierra de los Órganos, Ekman 17542. Mariel, Ekman 13046. Pan de Matanzas, Ekman 16464.

Dominican Republic: Santiago, Ekman H 13200 (sterile specimen which appears to be this species).

6. Lasiacis harrisii Nash, Torreya 13: 274. 1913. Jamaica, Marble 222.

Plants bright green, clambering among bushes to the height of $5 \mathrm{~m}$ or more, the main canes slender but strong, the very slender branches pendent, the young twigs commonly rosy purple; sheaths slender, glabrous except the margin and throat, or rarely the young ones sparsely hispid; ligule inconspicuous; blades linear-lanceolate, 5 to $10 \mathrm{~cm}$ long, 2 to $6 \mathrm{~mm}$ wide, gradually narrowed to an acuminate apex, thin and lax, glabrous, the margins scabrous; panicles narrow, mostly less than $5 \mathrm{~cm}$ long, often partially included in the uppermost sheath, the branches short and appressed, the longer usually not more than $1 \mathrm{~cm}$ long, and bearing not more than 4 spikelets; spikelets similar to those of $L$. divaricata but less turgid.

This species is easily recognized by its long narrow blades and pendent branches.

Shaded slopes at higher altitudes, West Indies and Colombia.

JAMAICA: Catherines Peak, Hitchcock 9726, 9730; Harris 11552. Cold Spring Gap, Harris 11354. Strawberry Hill, Harris 11487. Abbey Green, Harris 11587; Hitchcock 9363 (Amer. Gr. Nat. Herb. 588). Farm Hill, Orcutt 3544.

Dominican Republic: Polo (prov. Barahona), Abbott 1876. Jarabaco, Ekman H 14176.

Puerto Rico: Maricao, Chase 6224, 6228; Stevens and Hess 4882. Cayey, Chase 6742. Quebradillas, Chase 6578.

Virgin Islands: St. John, Eggers 3121.

7. Lasiacis divaricata (L.) Hitchc., Contrib. U. S. Natl. Herb. 15: 16. 1910.

Panicum divaricatum L., Syst. Nat. ed. 10. 2: 871. 1759. Jamaica.

Panicum bambusioides Desv.; Hamilt., Prodr. Pl. Ind. Occ. 10. 1825. Puerto Rico. 

loupe.

Panicum chauvinii Steud., Syn. Pl. Glum. 1: 68. 1854. Guade-

Panicum divaricatum var. stenostachyum Griseb., Fl. Brit. W. Ind. 551. 1864. Jamaica.

Usually glabrous throughout except the margin of the sheaths; culms woody, much branched, clambering over shrubs to the height of 3 to $4 \mathrm{~m}$, the main culm strong, as much as $6 \mathrm{~mm}$ in diameter, the main branches often fascicled, the vigorous secondary sterile shoots usually strongly divaricate or zigzag; sheaths sometimes hispid on the collar; ligule inconspicuous; blades narrowly lanceolate, 5 to 12 $\mathrm{cm}$ long, 5 to $15 \mathrm{~mm}$ wide, or on the vigorous sterile shoots much larger, narrowed at the base, gradually acuminate, scabrous on the margin and sometimes slightly on the surface, the older ones deciduous from the sheaths, the basal portion of the fertile shoots bearing the old sheaths but otherwise naked; panicles terminating the main culm and the fertile branches, ovate or oblong, 5 to $20 \mathrm{~cm}$ long, loosely flowered, the branches distant, spreading, or often reflexed, the axes angled, scabrous, flexuous, the lower usually 2 to $4 \mathrm{~cm}$ (sometimes as much as $10 \mathrm{~cm}$ ) long, the main branches ordinarily 5 to 10 flowered; spikelets ovoid, about $4 \mathrm{~mm}$ long (fig. 290).

Among shrubs at low altitudes, southern Florida to Central and South America; throughout the West Indies. Panicum divaricatum and $P$. sloanei were included by Richard ${ }^{71}$ under the name $P$. glutinosum. In Cuba called "pito de bejuco."

The commonest West Indian species of the genus, growing on all the islands, especially near the coast.

\section{Lasiacis sloanei (Griseb.) Hitchc., Bot. Gaz. 51: 302. 1911.}

Panicum latifolium Hamilt., Prodr. Pl. Ind. Occ. 10. 1825. Not P. latifolium L., 1753 . Antilles.

Panicum sloanei Griseb., Fl. Brit. W. Ind. 551. 1864. Jamaica.

Climbing to a height of 3 or $4 \mathrm{~m}$, forming a strong central cane; branches solitary or 2 or 3 together, elongate; blades parchmentlike in texture at maturity, commonly 12 to $15 \mathrm{~cm}$ long and 2 to $3 \mathrm{~cm}$ wide, narrowed into a very short pubescent petiole; panicles commonly as much as $20 \mathrm{~cm}$ long, nearly as wide, the branches rather rigid. The spikelets are larger in this species than in any other of the genus in the region.

Climbing among bushes and small trees, West Indies to Central and South America.

Cuba: Sierra Mendoza, Shafer 11147. Sierra de Anafe, Wilson 11421. Valestina, Wright 3878. Santiago de los Baños, Léon 4563, 5148. Mariel, Ekman 12853. Las Pozas, Ekman 12743. Guanajay, Ekman 13035; Baker 4587. Camoa Hills, Léon 766. Jamaica, Léon 1969. Cojimar, Léon 1973. San Antonio, Hitchcock 128. Ariguanabo, Léon 9751. Almendares River, Léon 12463. Malanga, Rugel 872. Boca de Canasí, Léon 13171. Loma Descada, Ekman 15319. Soledad, Jack 5187. Amaro, Léon 9435. Mayarí Arriba, Ekman 15851. Isla de Pinos, Britton and Wilson 15134.

Jamaica: Montego Bay, Ridley 35; Maxon and Killip 1673. Troy, Hitchcock 9801; Harris 12614, 12615. Ipswich, Hitchcock 9606. Ewarton, Hitchcock 9413. Bog Walk, Maxon 10502; Hitchcock 9305 (Amer. Gr. Nat. Herb. 591). Ferry River, Harris 11325. Halls

\footnotetext{
71 Richard, in Sagra, Hist. Cuba 11: 307. 1850
} 
Delight, Harris 11260. Gordon Town, Harris 11454. Bryans Hill, Harris 11531. Kingston, Hitchcock 9267 (Amer. Gr. Nat. Herb. 590), 9280 .

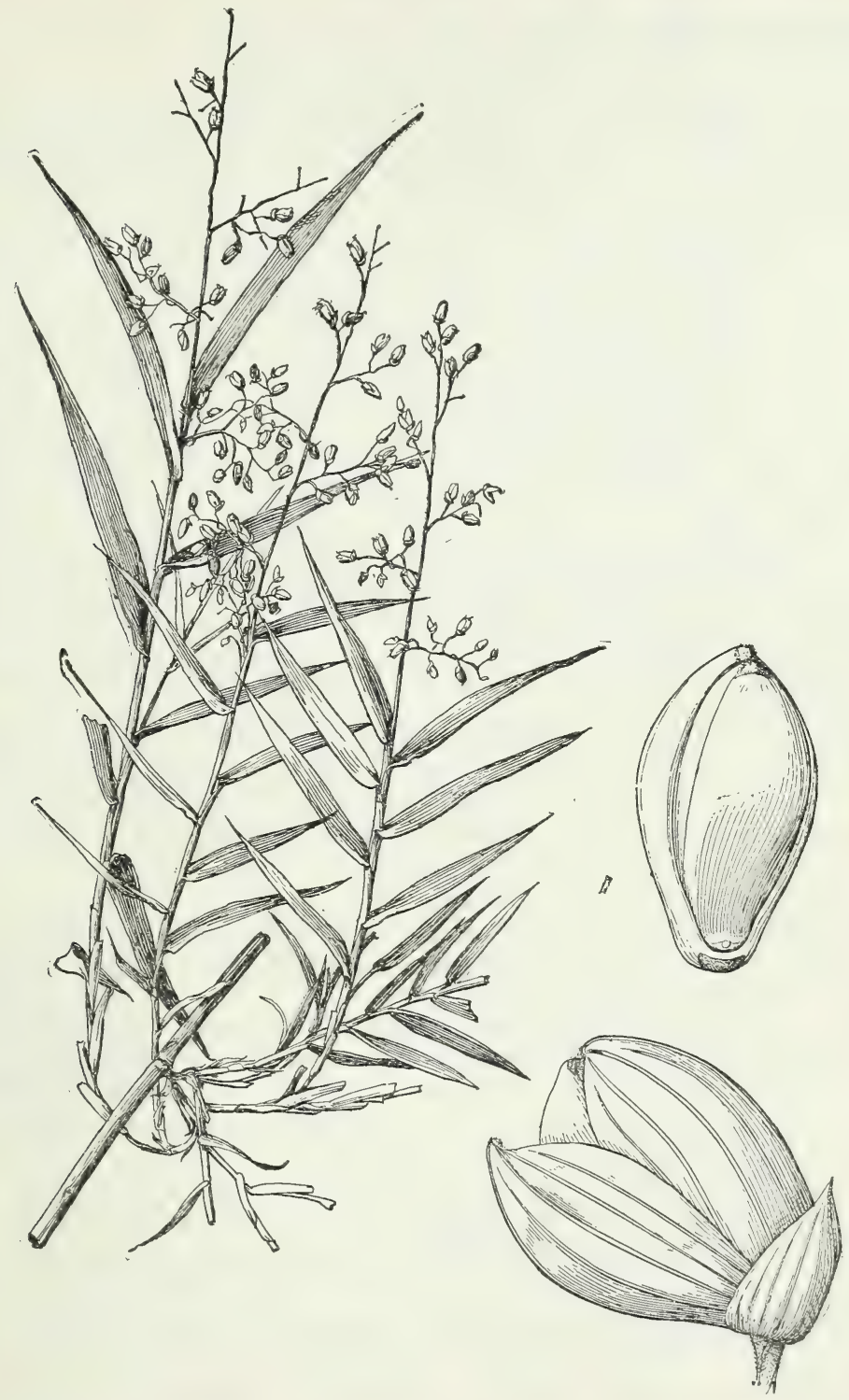

FIGURE 290.-Lasiacis divaricata. Plant, $\times 1 / 2$; spikelet and floret, $\times 10$ (Curtiss 5530).

Haitr: Pétionville, Leonard 4883, 5024, 5054; Ekman H 2190. Port-de-Pai, Ekman H 4438. St. Raphael, Leonard 7650. Ennery, Leonard 9466. Gonaïve Island, Leonard 3105, 3290, 5121. Anse-àFoleur, Ekman H 4330.

Dominican Republic: La Romana, Ekman H 12094. 
Puerto Rico: Vieques Island, Shafer 2549. Mayaguez, Chase 6824,6825 .

Leeward Islands: Antigua, Box 119.

9. Lasiacis patentiflora Hitchc. and Chase, Contrib. U. S. Natl. Herb. 18: 338. 1917. Tobago, Hitchcock 10268.

High-climbing with a strong central cane as much as $8 \mathrm{~mm}$ thick, glabrous throughout except at the summit of the sheaths; branches numerous, solitary, widely spreading and finally repeatedly branching; sheaths with a ring of hairs at the summit or at least a tuft of hairs on either side, sometimes pubescent on the margins toward the summit; ligule about $0.5 \mathrm{~mm}$ long; blades on vigorous shoots as much as $14 \mathrm{~cm}$ long, and $2.5 \mathrm{~cm}$ wide, but mostly about 8 to $12 \mathrm{~cm}$ long and 1.5 to $2 \mathrm{~cm}$ wide, acuminate, rounded-tapering to the base, usually somewhat asymmetric, glabrous, scabrous on the margin and somewhat so on both surfaces; panicles numerous, mostly 12 to $20 \mathrm{~cm}$ long, nearly as wide, the slender axis and distant spreading flexuous branchlets angled, scabrous, the pedicels flexuous, spreading; spikelets pale, blotched with dark blue or purple at maturity, 3.4 to $3.8 \mathrm{~mm}$ long, globose-obovoid.

In habit and general appearance $L$. patentiflora resembles $P$. sloanei, from which it differs in the narrower average width of the blades and the more loosely flowered, rather large panicles with smaller spikelets on flexuous spreading pedicels.

Borders of woods and jungles, West Indies and Central America to Venezuela.

HAiti: St. Michel de l'Atalaye, Leonard 7776. Thibaud, Ekman H 2624. St. Louis du Nord, Leonard 14292. Miragoane, Eyerdam 594.

Dominican Republic: Without locality, Wright, Parry, and Brummel 614 .

Puerto Rico: San Juan, Chase 6412.

Leeward Islands: Dominica, Jones 49; Ramage in 1889.

Windward Islands: St. Vincent, Eggers 6546. Grenada, Broadway 227, 947, 1385, 4666, 4674a.

Trinidad: Manzanilla, Hitchcock 10374. Port-of-Spain, Hitchcock 9990 (Amer. Gr. Nat. Herb. 592), 10034, 10037, 10323, 10324.

Tobago: Broadway 4841; Hitchcock 10255, 10257, 10268, 10270.

10. Lasiacis sorghoidea (Desv.) Hitchc. and Chase, Contrib. U. S. Nat. Herb. 18: 338. 1917.

Panicum lanatum Swartz, Prodr. Veg. Ind. Occ. 24. 1788. Not P. lanatum Rottb., 1776 . Jamaica.

Panicum sorghoideum Desv.; Hamilt., Prodr. Pl. Ind. Occ.10. 1825. Puerto Rico.

Panicum lanatum var. sorghoideum Griseb., Fl. Brit. W. Ind. 551. 1864.

Panicum martinicense Griseb., Fl. Brit. W. Ind. 552. 1864. Martinique.

Panicum swartzianum Hitchc., Contrib. U. S. Natl. Herb. 12: 140. 1908. Based on P. lanatum Swartz.

Lasiacis swartziana Hitchc., Bot. Gaz. 51: 302. 1911.

Culms much branched, erect or clambering to a height of 5 to $7 \mathrm{~m}$, the strong central cane as much as $1 \mathrm{~cm}$ thick, glabrous or pubescent, 
the main branches sometimes $1 \mathrm{~m}$ long or more, bearing slender branchlets toward the pendent ends, or the branchlets fascicled on the main culm; young shoots usually pubescent; sheaths pubescent, especially on the margin and collar, the surface sometimes glabrate; ligule inconspicuous; blades lanceolate or elliptic-lanceolate, those of the main culm or of vigorous shoots as much as $20 \mathrm{~cm}$ long and $3 \mathrm{~cm}$ wide, those of the fertile branches usually 8 to $12 \mathrm{~cm}$ long and $1.5 \mathrm{~cm}$ wide, on the fascicled branchlets smaller, often falcate, velvety on both surfaces or puberulent to glabrate above; panicles on the main culm and larger branches usually 10 to $20 \mathrm{~cm}$ long, at maturity as wide or wider, rather compactly many-flowered; spikelets 4 to $5 \mathrm{~mm}$ long.

Ravines, wood borders, and hedges, Mexico and West Indies to Argentina and Bolivia. Rather infrequent in Cuba, but there are numerous collections from the Greater Antilles, and the other islands except Trinidad, and at least one collection from Virgin Gorda, St. John, St. Croix, St. Thomas, St. Kitts, Antigua, Guadeloupe, Dominica, Montserrat, Martinique, St. Lucia, Grenada, and Tobago.

Cuba: Soledad, Hitchcock 23325. Rincón to Banao, Shafer 12323. Sierra de Nipe, Ekman 10095, 10108. Papayo, Ekman 10318. Pinar de Bayamita, Sierra Maestra, Ekman 10324. San Blas, Jack 6443. El Rosario, Léon 14118. Lomas de Siguanca, Ekman 13878.

Urban ${ }^{72}$ takes up Panicum maculatum Aubl. for this species. Aublet's meager description ${ }^{73}$ does not identify the plant. The synonym cited refers to an unpublished plate at Berlin which Urban states probably represents Lasiacis sorghoidea. The plate was based on a plant from Martinique. Aublet's flora treats of the plants of French Guiana.

11. Lasiacis ruscifolia (H. B. K.) Hitchc., Biol. Soc. Wash. Proc. 24: 145. 1911.

Panicum ruscifolium H. B. K., Nov. Gen. et Sp. 1: 101.1815. Mexico.

Panicum compactum Swartz, Adnot. Bot. 14. 1829. Jamaica.

Lasiacis compacta Hitchc., Bot. Gaz. 51: 302. 1911.

More robust than any other species, freely branching, the shoots usually strongly dorsiventral; culms becoming several meters long, glabrous or rarely puberulent; sheaths sometimes hispidulous toward the apex, glabrous to villous on the margin, especially near the summit, the collar glabrous or villous; ligule inconspicuous; blades ovatelanceolate or elliptic, sometimes lanceolate, the primary ones 10 to $15 \mathrm{~cm}$ long, 3 to $6 \mathrm{~cm}$ wide, narrowed or often cordate-clasping at the asymmetric base, rather abruptly narrowed to an acuminate but not attenuate apex, puberulent or glabrous beneath, glabrous or scabrous above, the secondary blades similar or reduced; panicles 5 to $20 \mathrm{~cm}$ long, narrow and compact, rarely somewhat open, with spreading, implicate but rather closely flowered branches; spikelets 3 to $4 \mathrm{~mm}$ long, nearly globose at maturity. This species is variable as to pubescence.

Climbing over bushes at low altitudes, Mexico to Peru; Cuba.

CubA: Sabanaso, Ekman 6535. Palo Seco, Ekman 15318. Sancti Spíritus, Léon 905. Guantánamo, Léon 3778. Ensenada de Mora, Britton, Cowell, and Shafer 12979. Rioja, Ekman 4903. Santiago de

72 Repert. Sp. Nov. Fedde 16: 149. 1919.

73 Pl. Guian. 1: 51 . 1775. 
Cuba, Ekman 7681. Isla de Pinos, Curtiss 520; Palmer and Riley 904; Britton and Wilson 14659, 15065; Ekman 11721.

12. Lasiacis anomala Hitchc., Jour. Wash. Acad. Sci. 9: 37. 1919. Trinidad, Amer. Gr. Nat. Herb. 595.

Differing from $L$. ruscifolia in having a second sterile lemma.

This species has been confused with $L$. ruscifolia and was included under that name in Grasses of the West Indies, in which the following statement appears: "In all the Trinidad specimens the spikelets contain a second sterile lemma, a character not found in any other species known to us. This second sterile lemma equals the first, contains a hyaline palea, and infolds the fruit rather more closely than the sterile lemma commonly does in other species. The fruit borne one joint higher on the rachilla consequently faces in the direction opposite to the one usual in Paniceae; that is, the palea side of the fruit faces the second instead of the first glume." A reconsideration ${ }^{74}$ of the group led the writer to the conclusion that, "we have here a distinct species, for not only is there this unusual character of a second sterile lemma but also a distinct geographical range. Of the group to which it had been referred, all the specimens from Trinidad, the lower Orinoco, and eastern Brazil have a second sterile lemma; outside of this range, that is, north and west, there is but one sterile lemma in all the specimens examined. In other respects, such as shape of blades and panicle, pubescence, and shape and size of spikelets, this species does not differ from $L$. ruscifolia. The specimens of $L$. anomala agree closely among themselves in all these characters, but also agree with many specimens referred to the more variable species, L. ruscifolia."

Copses and edges of forests, Trinidad and Venezuela to eastern Brazil.

Trinidad: Moros, Broadway 7447. Chaguaramus, Broadway 6739, 7721. Lopinot Road, Broadway 6736. Chacachacare, Hitchcock 10063. Port-of-Spain, Hitchcock 9977 (Amer. Gr. Nat. Herb. 595), 10001. St. Joseph, Hitchcock 10021. San Fernando, Hitchcock 10117. Brighton, Britton 2905. Cedros, Bot. Gard. Herb. 7297; Hitchcock 10136. Moruga, Broadway 2504. Mayaro, Broadway 2627. Tetron Bay, Broadway 6775. Point Gourde, Broadway 8081, 8083. Without locality, Eggers 13480; Broadway 2564; Bot. Gard. Herb. 2303.

\section{SACCIOLEPIS Nash, in Britton, Man. 89. 1901}

Spikelets oblong-conic; first glume small, much shorter than the spikelet; second glume broad, inflated-saccate, strongly many-nerved; sterile lemma narrower, flat, fewer nerved, its palea nearly as long, often subtending a staminate flower; fertile lemma stipitate, elliptic, chartaceous-indurate, the margins inrolled, the palea not enclosed at the summit. Aquatic or subaquatic perennials or annuals, with dense narrow panicles.

Spikelets $4 \mathrm{~mm}$ long on slender pedicels_............... STRIATA. Spikelets 2 to $3 \mathrm{~mm}$ long, subsessile.

Spikelets $3 \mathrm{~mm}$ long; panicle of ten interrupted _....... S. VILvoIdes.

Spikelets $2 \mathrm{~mm}$ long; panicle dense .................... S. MYRos.

74 Jour. Wash. Acad. Sei. 9: 37. 1919. 
1. Sacciolepis striata (L.) Nash, Bull. Torrey Bot. Club 30: 383. 1903.

Holcus striatus L., Sp. Pl. 1048. 1753. Virginia.

Panicum striatum Lam., Tabl. Encycl. 1: 172. 1791.

Hymenachne striata Griseb., Fl. Brit. W. Ind. 554. 1864.

Aquatic or semiaquatic perennial, glabrous or the sheaths sometimes pubescent; culms 1 to $2 \mathrm{~m}$ tall, rooting at the geniculate lower nodes, bearing a few erect flowering shoots; blades flat, linear-lanceolate, 8 to 15 $\mathrm{cm}$ long, 5 to $10 \mathrm{~mm}$ wide; panicles 10 to $15 \mathrm{~cm}$ long, the branches appressed, or the lower somewhat spreading, as much as $5 \mathrm{~cm}$ long; spikelets glabrous, about $3.5 \mathrm{~mm}$ long, the pedicels slender, flexuous or curved (fig. 291, A).

Swamps and ditches, southeastern United States and the West Indies.

Cuba: Pinar del Río, Wright 3885. Herradura, Ekman 10747. San Fran-

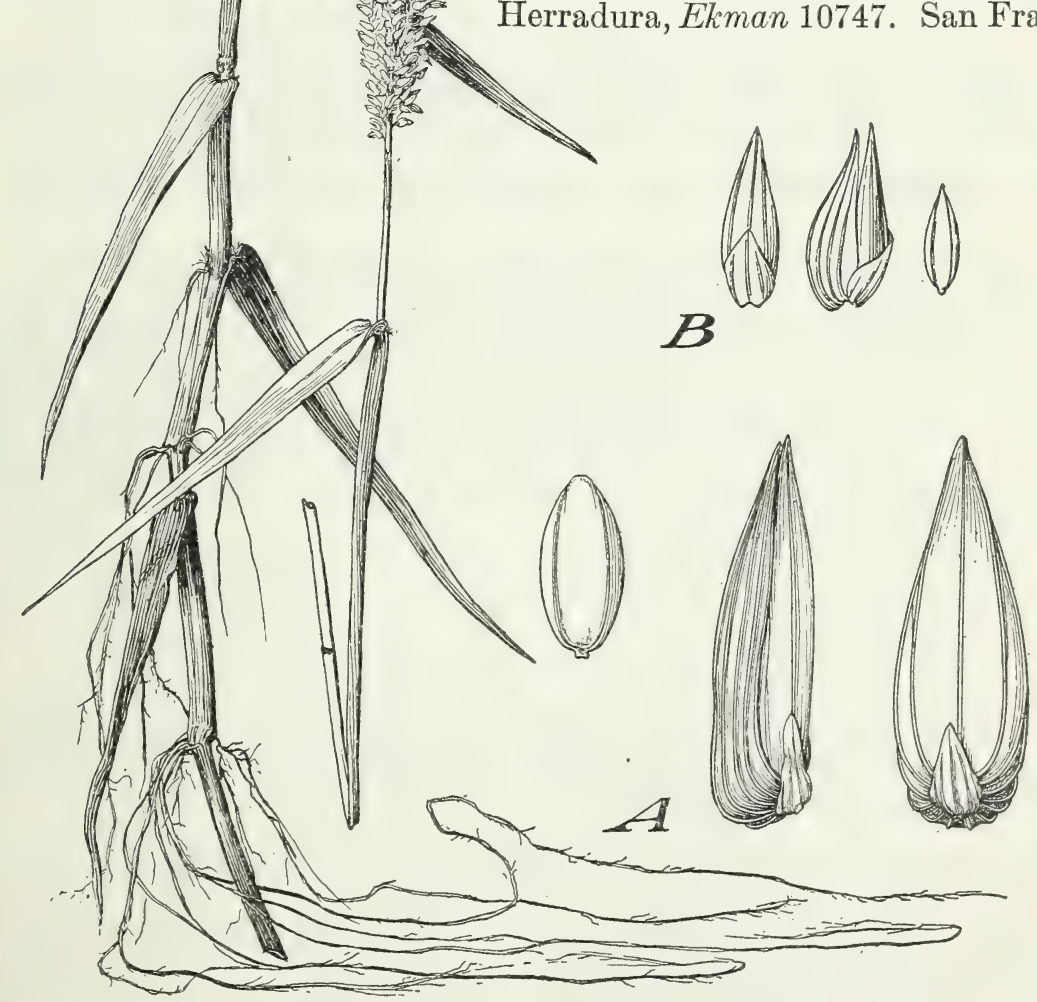

FIGURE 291.-A, Sacciolepis striata. Plant, $\times 1 / 2$; two views of spikelet and floret, $\times 10$ (Chase 4240 ). B, S. myuros, $\times 10$ (type). 
cisco, Ekman 10984. Remates, Ekman 11173. Laguna de Ariguanabo, Ekman 11512. Habana, Léon 5750. Cayo La Rosa, Ekman in 1921 (Amer. Gr. Nat. Herb. 993). Ciénaga de Zapata, Léon 9520. Isla de Pinos, Ekman 12426.

JAMAICA: Grasmond Marsh, Harris 11749.

Haiti: Miragoane, Eyerdam 168; Ekman H 6527. Port-Margot, Ekman H 2884.

Dominican Republic: Jarabaco, Ekman H 14141. Sabana del Guabatico, Ekman H 11049.

Puerto Rico: San Juan, Chase 6353. Humacao, Eggers 666. Campo Alegre, Chase 6801.

2. Sacciolepis vilvoides (Trin.) Chase, Biol. Soc. Wash. Proc. 21: 7. 1908.

Panicum vilvoides Trin., Gram. Pan. 171. 1826. Brazil.

Hymenachne fluviatilis Nees, Agrost. Bras. 273. 1829. Brazil.

Glabrous, apparently annual; aquatic; culms erect, branched only slightly from the base, succulent below, usually as much as $1 \mathrm{~m}$ tall or even taller; blades 15 to $20 \mathrm{~cm}$ long, usually narrow, sometimes as much as $5 \mathrm{~mm}$ wide; panicles elongate, mostly 20 to $40 \mathrm{~cm}$ long, about $8 \mathrm{~mm}$ thick, compact or more or less interrupted, especially toward the base, the branches very short; spikelets about $3 \mathrm{~mm}$ long, glabrous.

Marshes and wet places, northern South America; Cuba.

Cuba: Pinar del Río, Ekman 17917; Hitchcock 23276. Los Almacigos, Wright 3470. Herradura, Ekman 17793. Isla de Pinos, Curtiss 304; Britton and Wilson 15009, 15679; Ekman 12210.

3. Sacciolepis myuros (Lam.) Chase, Biol. Soc. Wash. Proc. 21: 7. 1908.

Panicum myuros Lam., Tabl. Encycl. 1: 172. 1791. Cayenne.

Hymenachne myuros Beauv., Ess. Agrost. 49, 165. 1812.

Slender glabrous annual as much as $1 \mathrm{~m}$ tall; culms usually erect, branched only from the base, the lower part often succulent; blades elongate, erect, flat, narrow, sometimes as much as $7 \mathrm{~mm}$ wide; panicles erect, compact, spikelike, usually elongate, sometimes as much as $40 \mathrm{~cm}$ long, 3 to $5 \mathrm{~mm}$ wide, the branches usually very short, rarely the lower (appressed) as much as $3 \mathrm{~cm}$ long; spikelets glabrous, 1.5 to $2 \mathrm{~mm}$ long (fig. 291, $B$ ).

Marshes and wet places, Mexico to Brazil and Bolivia; Cuba.

Cuba: Isla de Pinos, Curtiss 428; Ekman 11980, 12176; Britton and Wilson 14155, 14709.

Dominican Republic: Cuenca, Ekman H 10971.

Trinidad: O'Meara Savanna, Britton and Hazen 1566. Piarco Savanna, Britton and Hazen 712; Broadway 2142; Hitchcock 10356. Pitch Lake, Hitchcock 10085 (Amer. Gr. Nat. Herb. 303). Without locality, Bot. Gard. Herb. 3354.

84. HYMENACHNE Beauv., Ess. Agrost. 48. pl. 10. f. 8.1812

Spikelets acuminate, short-pedicellate in long dense spikelike or interrupted panicles; first glume one-third to half as long as the spikelet, remote, a distinct stipe below the second glume; sterile lemma 5-nerved, acuminate, exceeding the lanceolate stramineous fruit; lemma and palea membranaceous, the margins of the lemma thin 
(not broad and hyaline), not inrolled; palea not enclosed above. Aquatic perennials with succulent sparingly branching culms, flat blades, and soft dense panicles.

Inflorescence dense, spikelike

1. H. AMPlexicaulis. Inflorescence long and narrow with ascending branches, not spikelike.

2. H. DONACIFOLIA.

1. Hymenachne amplexicaulis (Rudge) Nees, Agrost. Bras. 276. 1829.

Panicum amplexicaule Rudge, Pl. Guian. 1: 21. pl. 27. 1805. British Guiana.

Agrostis monostachya Poir., in Lam., Encycl. Sup. 1: 256. 1810. Puerto Rico.

Panicum hymenachne Desv., Opusc. 82. 1831. Puerto Rico.

Culms commonly $1 \mathrm{~m}$ or more tall; blades 20 to $35 \mathrm{~cm}$ long, 2 to 3 $\mathrm{cm}$ wide, cordate-clasping; panicles about $8 \mathrm{~mm}$ thick and 20 to 50 cm long; spikelets acuminate, 3 to $4 \mathrm{~mm}$ long (fig. 292).

Marshes and shallow water, often forming pure colonies, Tropics of both hemispheres. Common on all the Greater Antilles and Trinidad. Specimens have been seen also from Guadeloupe, Dominica, Martinique, and St. Lucia. Grisebach ${ }^{75}$ misapplies the name Hymenachne myurus to this species.

2. Hymenachne donacifolia (Raddi) Chase, Jour. Wash. Acad. Sci. 13: 177.1923.

Panicum donacifolium Raddi, Agrost. Bras. 44. 1823. Brazil.

Panicum auriculatum Willd., in Spreng., Syst. Veg. 1: 322.1825. Tropical America.

Hymenachne patula Fourn., Mex. Pl. 2: 37. 1886. Cuba, Liebmann 402.

Hymenachne auriculata Chase, Biol. Soc. Wash. Proc. 21: 5. 1908.

Similar to $H$. amplexicaulis, olivaceous throughout (at least when dry); panicles of numerous ascending, densely flowered branches, the lower distant; spikelets about $3 \mathrm{~mm}$ long.

Marshes and shallow water, Panama to Brazil; Cuba.

Cuba: Mendoza, Ekman 11481, 11492. Habana, Léon 808. Between La Mulata and Las Posas, Ekman 17368.

Trinidad: St. Francique, Broadway 4978. Oropuche Lagoon, Britton, Hazen, and Freeman 1149. Without locality, Bot. Gard. Herb. 3355 .

85. SCUTACHNE Hitchc. and Chase, Biol. Soc. Wash. Proc. 24: 148. 1911

Inflorescence paniculate, the spikelets short-pediceled along the slender, simple or nearly simple branches; spikelets fusiform, acuminate, the base attenuate, the internodes of the rachilla elongate, the lowermost forming a stipe, the first glume adnate to it; first glume membranaceous, about half the length of the spikelet, broad, the margins connate below; second glume and sterile lemma subequal, a manifest internode of the rachilla between them, leathery-indurate, brown or brownish, 5-nerved, the lemma enclosing a palea of similar texture (and in $S$. dura a staminate flower); fruit but slightly more indurate than the second glume and sterile lemma, elliptic in outline,

78 Fl. Brit. W. Ind. 553. 1864. 


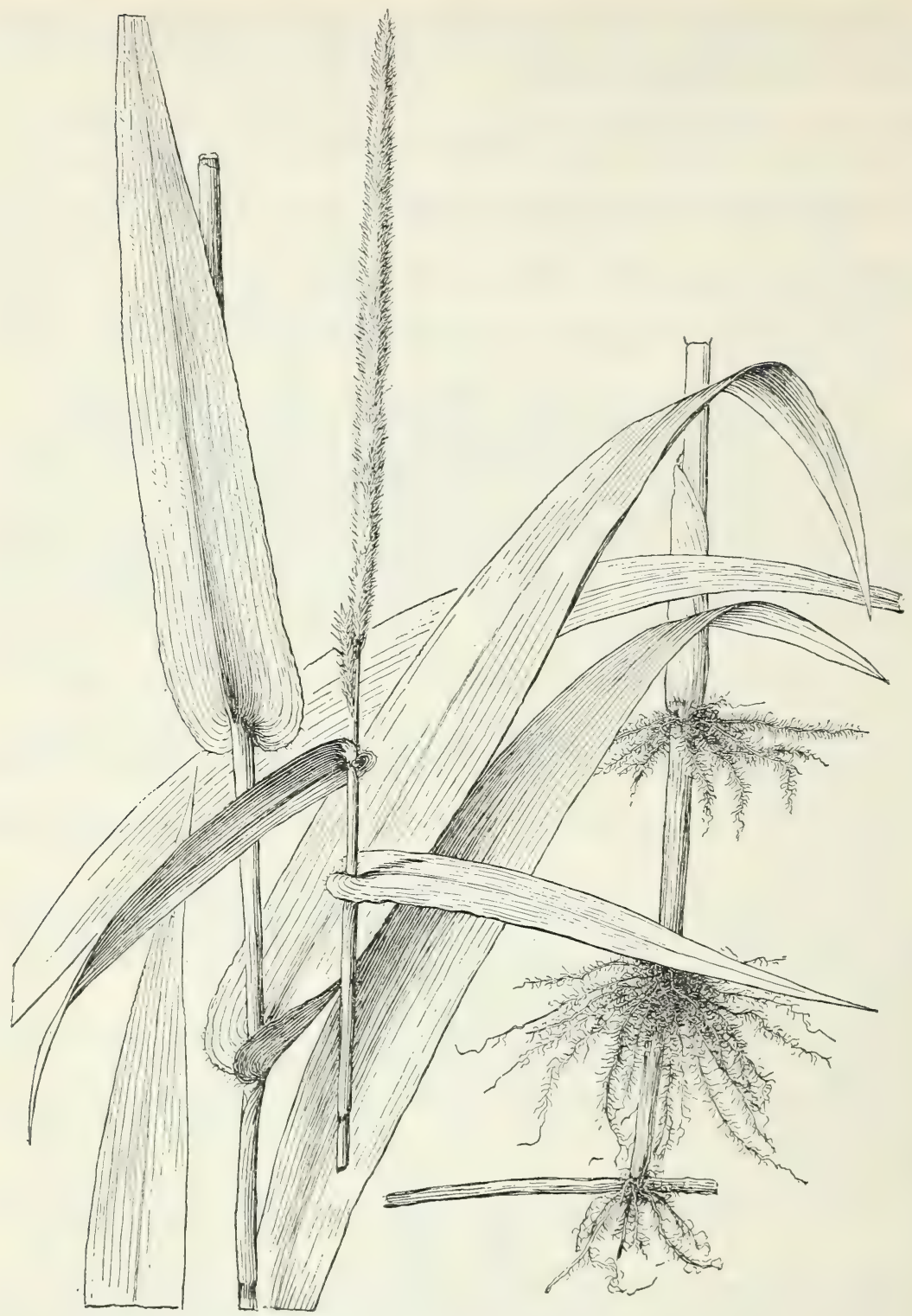

FigURE 292.-Iymenachne amplexicaulis, $\times 1 / 2$ (Chase 6317$).$

the lemma abruptly acuminate into a slender, densely pubescent tip, the margins slightly inrolled below, membranaceous, flat and pubescent above, the summit of the palea not enclosed, densely pubescent on the margin. Tufted wiry perennials with firm blades.

Culms leafy, the blades elongate; panicles terminal only, of several branches.

1. S. DURA.

Culms nearly naked, the leaves reduced to the sheaths or nearly so, the basal leaves with blades; panicles terminal and axillary, simple.

2. S. AMPHISTEMON. 
1. Scutachne dura (Griseb.) Hitchc. and Chase, Biol. Soc. Wash. Proc. 24: 149. 1911.

Panicum durum Griseb., Mem. Amer. Acad. (n. s.) 8: 533. 1862. Cuba, Wright 1539.

Alloteropsis dura Hitchc., Contrib. U. S. Natl. Herb. 12: 211. 1909

Culms erect, 40 to $70 \mathrm{~cm}$ tall, the nodes glabrous or puberulent; blades flat or more or less involute, rather stiff, sharply acuminate, elongate, usually 4 to $6 \mathrm{~mm}$ wide, sometimes as much as $10 \mathrm{~mm}$ wide; panicles 6 to $10 \mathrm{~cm}$ long, the branches ascending; spikelets elliptic, attenuate at base, acute, about $5 \mathrm{~mm}$ long, the glabrous first glume a lighter color than the brown pubescent second glume and sterile lemma (fig. 293).

Rocky hills, Cuba, Jamaica, and Hispaniola.

Cuba: Río Taco Taco, Ekman 17624. Pastelillo, Ekman 15406, 15433, in 1922 (Amer. Gr. Nat. Herb. 995). "Farallones, N. Sophie", Wright 1539. Valestina, Wright 3868. Baconao, Ekman 8229.' Guantánamo, Ekman in 1922 (Amer. Gr. Nat. Herb. 996), 2893, 15770.

Jamaica: Albion Mountain, St. Thomas, Harris 12163.

Haitr: St. Marc, Leonard 2923. Môle-St.-Nicolas, Leonard 13187. Port-á-Piment, Ekman H 322. Morne-à-Cabrits, Ekman H 898.

Dominican Republic: Barahona, Fuertes 1423, 1426. San Juan, Ekman H 13478.

2. Scutachne amphistemon (Wright) Hitchc. and Chase, Biol. Soc. Wash. Proc. 24: 149. 1911.

Panicum amphistemon Wright, An. Acad. Cien. Habana 8: 207. 1871. Cuba, Wright 3464.

Alloteropsis amphistemon Hitchc., Contrib. U. S. Natl. Herb. 12: 211.1909.

Culms tufted, slender, 25 to $40 \mathrm{~cm}$ tall; leaves clustered at the base; blades glabrous, thick, erect, flat or folded, 10 to $20 \mathrm{~cm}$ long, 2 to $4 \mathrm{~mm}$ wide; panicles narrow, few-flowered, 3 to $8 \mathrm{~cm}$ long; spikelets nearly glabrous, 7 to $8 \mathrm{~mm}$ long.

Rocky slopes, Cuba.

Cuba: San Miguel de los Baños, Léon 8855. Canasí, Ekman 17193. Ponce, Ekman 17168. Tiffin, Ekman 15381. Pastelillo, Ekman 15434. Mayarí Abajo, Wright 3464. Sierra de Nipe, Ekman in 1922 (Amer. Gr. Nat. Herb. 994), 15162. Holguín, Ekman 15727. Jauco, Léon 12300.

86. ISACHNE R. Br., Prodr. Fl. Nov. Hoil. 196. 1810

Spikelets obovoid to subglobose; glumes membranaceous, about equal and as long as the fruits or at maturity exceeded by them; lower floret perfeet or staminate, its lemma and palea indurate and similar in form and texture to those of the upper floret; both florets (or fruits) plano-convex, obtuse, equal in size or the upper shorter, the pair usually remaining attached by the minute rachilla joint between them. Mostly perennials with firm blades and open or contracted panicles. Isachne polygonoides is exceptional in that the lower floret is unlike the upper. In all the species the lower floret of some of the spikelets may fail to perfect a grain. When sterile the 


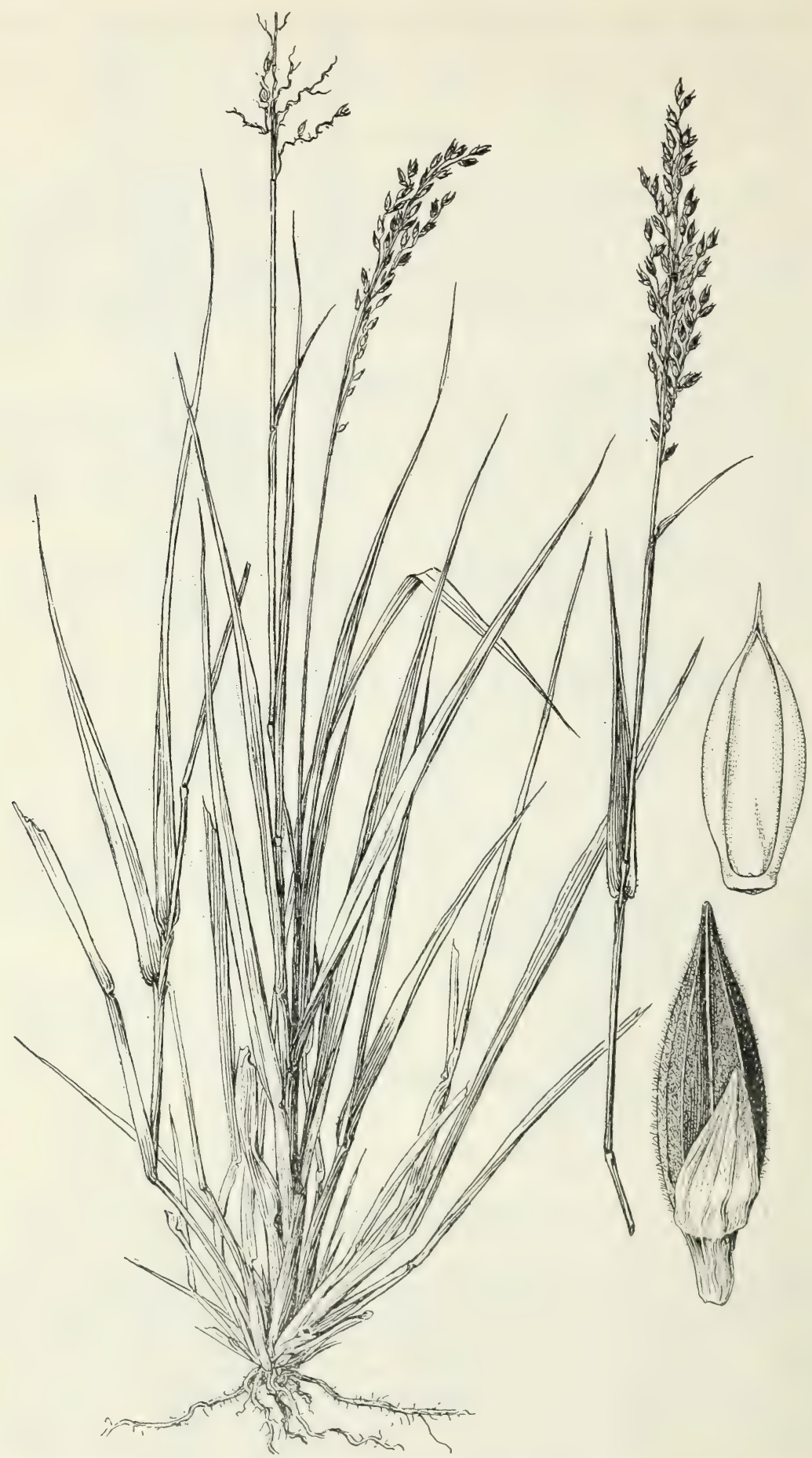

FIGt'RE 293.-Scutachne dura. Plant, $\times 1 \frac{1}{2}$; spikelet andliforet, $\times 10$ (Fuertes 1423). 
floret is often longer and the lemma less convex than when fertile, the spikelets on the same panicle thus having a somewhat diverse appearance.

Florets appressed-pubescent.

Blades ovate-clasping ....... I. POLYGONOIDES.

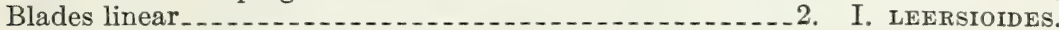

Florets glabrous, or the palea minutely hispidulous.

Panicle contracted, spikelike, not more than $3 \mathrm{~cm}$ long, the branches appressed or the lower sometimes ascending; plants low and spreading_._3. I. PYGMAEA.

Panicle open, the branches spreading or ascending.

Blades about $3 \mathrm{~mm}$ wide, thick, rigid, pungent, with conspicuously thickened midrib . .

Blades mostly 5 to $20 \mathrm{~mm}$ wide, firm but not pungent nor with thickened midrib.

Plants trailing; blades rarely more than $5 \mathrm{~cm}$ long $\ldots . . . .5$. I. RIGENS.

Plants clambering; blades mostly more than $5 \mathrm{~cm}$ long.

Glumes pubescent; blades firm, not more than $12 \mathrm{~cm}$ long and $1 \mathrm{~cm}$ wide........ I. ANGUSTIFOLIA.

Glumes glabrous (rarely obscurely pubescent at the tips); blades mostly more than $15 \mathrm{~cm}$ long and $1.5 \mathrm{~cm}$ wide.

Spikelets aggregate toward the ends of the branches and branchlets.

7. I. ARUNDINACEA.

Spikelets not aggregate; panicle loosely flowered....8. I. DISPERMA

1. Isachne polygonoides (Lam.) Doell, in Mart., Fl. Bras. 22: 273. 1877.

Panicum polygonoides Lam., Encycl. 4: 742. 1798. Cayenne.

Apparently annual; flowering shoots 20 to $30 \mathrm{~cm}$ tall, erect from a long creeping, freely branching culm, rooting at the nodes, the whole plant often a meter in length, the erect shoots finally bearing fascicled branchlets; sheaths hispid; blades spreading, lanceolate-ovate, very scabrous; panicles included at base, about $5 \mathrm{~cm}$ long and as broad, loosely many-flowered.

This is distinguished from all others of the West Indies by the ovate clasping blades and by the dissimilarity of the two fiorets.

Moist ground, often in water, British Honduras and Guatemala to Trinidad and Brazil; Cuba, Hispaniola.

Cuba: Isla de Pinos, Ekman 11702.

Dominican Republic: Cotuy, Abbott 748. Jarabaco, Ekman H 14139. Villa Altagracia, Ekman H 11222. Sánchez, Ekman H 14718. Tomas, Ekman H 13020.

Trinidad: Piarco Savanna, Britton and Hazen 704; Hitchcock 10362 (Amer. Gr. Nat. Herb. 598).

In the Florence Herbarium there is a specimen of this species said to be collected by LeDru in Puerto Rico. No other specimen from that island has been seen.

2. Isachne leersioides Griseb., Mem. Amer. Acad. (n. s.) 8: 533. 1862. Cuba, Wright 755.

Culms slender, branched, trailing, glabrous, striate, 1 to $2 \mathrm{~m}$ long; sheaths on the main culms much shorter than the elongate internodes, overlapping on the flowering branches, appressed papillose-hispid or nearly glabrous; ligule a very short membrane, ciliate with stiff hairs about $1 \mathrm{~mm}$ long; blades linear, ascending, rather firm, 5 to $15 \mathrm{~cm}$ long, 0.5 to $4 \mathrm{~mm}$ wide, long-acuminate, cartilaginous-margined, scabrous or hispidulous on both surfaces; panicles terminating the branches, ovoid or oblong, 5 to $15 \mathrm{~cm}$ long, as much as $7 \mathrm{~cm}$ wide, the branches mostly single, rather stiffly ascending or spreading, 
bearing from near the base stiffly spreading branchlets, the spreading pedicels 2 to $3 \mathrm{~mm}$ long; spikelets about $1 \mathrm{~mm}$ long; glumes hispidulous; florets appressed-pubescent.

Dry cliffs, slopes, and pine barrens, Cuba.

Cuba: Cajálbana, Léon 4843. San Diego de los Baños, Léon 5078. Bahía Honda, Ekman 12678. Zaza de Tunas, Léon 6730. Sancti Spíritus Mountains, Léon 6520. La Perla, Shafer 3013, 8561. Sierra Maestra, Ekman 1633. Baracoa, Ekman 3981. Guara, Hitchcock 23403, 23413. Eastern Cuba, Wright 755.

3. Isachne pygmaea Griseb., Fl. Brit. W. Ind. 553. 1864. Jamaica, Macfayden.

Plants low, the slender branches spreading, glabrous, the flowering shoots usually less than $15 \mathrm{~cm}$ tall, rarely as much as $30 \mathrm{~cm}$ long; sheaths glabrous, ciliate on the margins; ligule a very short hispidulous ring; blades narrowly oblong-lanceolate, 0.5 to $2 \mathrm{~cm}$, or rarely $3 \mathrm{~cm}$, long, rarely more than $2 \mathrm{~mm}$ wide, spreading, glabrous or puberulent, the white cartilaginous margin somewhat scabrous; panicles longexserted, narrow, compact and spikelike, usually less than $2 \mathrm{~cm}$ long, the lower branches short and somewhat distant, appressed or rarely ascending; spikelets about $1.3 \mathrm{~mm}$ long, nearly sessile; glumes glabrous, about two-thirds as long as the spikelet; florets glabrous.

Grassy banks. This grass has a very limited distribution, being known only from a small area in the Blue Mountains of Jamaica between Newcastle and Cinchona, at about 1,500 $\mathrm{m}$ altitude.

Jamaica: Vinegar Hill, Perkins 1085. Cold Spring Gap, Hitchcock 9742 (Amer. Gr. Nat. Herb. 419); Harris 11314, 12490. Moodys Gap, Britton 3375. Arntully, Orcutt 5756.

4. Isachne rigidifolia (Poir.) Urban, Symb. Antill. 4: 85. 1903.

Agrostis rigidifolia Poir., in Lam., Encycl. Sup. 1:257. 1810. Santo Domingo.

Milium rigidifolium Roem. and Schult., Syst. Veg. 2: 319. 1817.

Panicum rigidifolium Kunth, Rév. Gram. 1: 37.1829.

Culms spreading and branching, the flowering shoots firm and rigid, 15 to $40 \mathrm{~cm}$ tall; sheaths glabrous, stiffly ciliate on the margin, overlapping on the flowering shoots; ligule a very short, lacerate or ciliate membrane; blades oblong, 2 to $4 \mathrm{~cm}$ long, 2 to $4 \mathrm{~mm}$ wide, firm, rigidly spreading, pungently pointed, glabrous, the cartilaginous margin and thick midrib whitish; panicles long-exserted, open, oblong, rather narrow, 2 to $5 \mathrm{~cm}$ long, the branches ascending or spreading, bearing the branchlets mostly on the lower side, the pedicels rigid, 1 to $2 \mathrm{~mm}$ long; spikelets about $2 \mathrm{~mm}$ long, purplish, borne obliquely upon the pedicels; glumes glabrous or sparsely appressed-hispidulous near apex; florets smooth.

The species is easily recognized by its smooth, rigid, spreading, pungently pointed, conspicuously distichous blades.

Mountain bogs and limestone ridges, West Indies.

Cuвa: Sierra del Cristal, Ekman 6839.

Haiti: Mission, Leonard 3829, 3890. Furcy, Leonard 4324, 4569. Pérodin, Ekman H 3473. Pétionville, Ekman H 1437. Petite Goave, Ekman H 7311.

Dominican Republic: Río Yague, Fuertes 1729. Lagunas de Cenobí, Valeur 29. Loma Diego de Ocampo, Ekman H 16326. San José de Ocoa, Ekman H 11872. 
Leeward Islands: Guadeloupe Duss 3190. St. Kitts, Box 313. Windward Islands: Martinique, Hahn 1435; Duss 1312.

5. Isachne rigens (Swartz) Trin., Gram. Pan. 252. 1826.

Panicum rigens Swartz, Prodr. Veg. Ind. Occ. 23. 1788. Jamaica.

Culms tufted, glabrous, slender, wiry, trailing, 1 to $2 \mathrm{~m}$ long, as much as $2 \mathrm{~mm}$ thick, the numerous flowering shoots curving upward, 10 to $30 \mathrm{~cm}$ long; sheaths glabrous or puberulent, ciliate on the margin; ligule a ring of stiff hairs about $0.5 \mathrm{~mm}$ long; blades narrowly oblonglanceolate 2 to $5 \mathrm{~cm}$ long, 2 to $5 \mathrm{~mm}$ wide, spreading, moderately, firm but not stiff and rigid, scabrous on both surfaces and on the cartilaginous margin; panicles ovoid or oblong, 2 to $5 \mathrm{~cm}$ long, the branches and branchlets stiffly ascending or spreading, the pedicels 1 to $2 \mathrm{~mm}$ long; spikelets 1.8 to $2 \mathrm{~mm}$ long; glumes minutely hispidulous; rachilla between the two florets minutely villous; palea of upper floret sparsely appressed-hispidulous.

Damp shady banks, Blue Mountains, Jamaica, at 1,000 to 2,000 $m$ altitude; Venezuela to Ecuador.

Jamaica: St. Helens Gap, Maxon and Killip 614. Catherines Peak, Hitchcock 9732. Abbey Green, Hitchcock 9362; Harris 11585. Cinchona, Harris 11316, 11333, 11417, 11432, 12480; Hitchcock 9706 (Amer. Gr. Nat. Herb. 420), Sir Johns Peak, Harris 11595. Hardware Gap, Harris 11543. Clyde River, Harris 11445. Cold Spring Gap, Harris 11336, 12489.

6. Isachne angustifolia Nash, Bull. Torrey Bot. Club 30: 377. 1903. Puerto Rico, Wilson 160.

Culms clambering, as much as $2 \mathrm{~m}$ long and $2 \mathrm{~mm}$ thick, hard and wiry, with a long naked base, branching from the upper nodes, the branches long, leafy, nearly parallel, bearing secondary branches. toward the ends, the whole forming a wide, flabellate or loosely corymbose mass, in its most characteristic development pushing through the jungle of stream bank or trail side and hanging over bushes; sheaths appressed papillose-pilose or roughened with papillae, or glabrous, the margin ciliate; ligule a ring of very short stiff hairs less than $0.5 \mathrm{~mm}$ long; blades narrowly lanceolate, 3 to $15 \mathrm{~cm}$ long, but mostly more than $5 \mathrm{~cm}$ long, 5 to $12 \mathrm{~mm}$ wide, rather firm and stiffly spreading, scaberulous or glabrate, papillose-ciliate at base or papillose only; panicles ellipsoid or oblong, as much as $15 \mathrm{~cm}$ long, the branches stiffly ascending or finally spreading, the branchlets and pedicels finally divaricate, these and the main axis scabrous; spikelets about $1.5 \mathrm{~mm}$ long; glumes minutely hispidulous toward the tip; florets and rachilla glabrous.

Rocky slopes among brush, Puerto Rico and Leeward Islands.

Puerto Rico: El Yunque, Wilson 160; Sintenis 1355. Sierra Loquillo, Hioram 369. Adjuntas, Sintenis 4045. Rio Icaco, Shafer 3477. Utuado, Sintenis 6421. Monte Torrecilla, Britton, Cowell, and Brown 5595. Cayey, Chase 6750. Maricao, Britton and Cowell 4271; Britton, Stevens, and Hess 2566; Chase 6222.

Leeward Islands: Guadeloupe, Duss 2705. St. Kitts, Box 146, 314. 7. Isachne arundinacea (Swartz) Griseb., Fl. Brit. W. Ind. 553. 1864.

Panicum arundinaceum Swartz, Prodr. Veg. Ind. Occ. 24. 1788. Jamaica.

Culms climbing among shrubs or small trees to a height of as much as $6 \mathrm{~m}$, as much as $5 \mathrm{~mm}$ thick at base, with strong canes and elongate

$60256-36-21$ 
branches; sheaths glabrous, or rarely slightly scabrous, ciliate on the margin, sometimes a little papillose near the summit, overlapping on the flowering shoots; ligule of stiff hairs as much as $5 \mathrm{~mm}$ long; blades narrowly lanceolate, as much as $20 \mathrm{~cm}$ long and $2 \mathrm{~cm}$ wide, long-acuminate, scabrous, sometimes becoming smoothish, often papillose on the margin at base; panicles ovoid or ellipsoid, as much as $12 \mathrm{~cm}$ long and $10 \mathrm{~cm}$ wide, rounded at summit, the branches ascending or the lower finally spreading, branched from about the middle, the spikelets somewhat aggregate on the branchlets, the panicle thus rather compactly flowered at the periphery, the pedicels 0.5 to $2 \mathrm{~mm}$ long; spikelets about $1.5 \mathrm{~mm}$ long; glumes glabrous or with a few short stiff hairs at the summit; florets glabrous (fig. 294).

Wooded hillsides, Jamaica, at 1,000 to 2,000 m altitude; Mexico to Bolivia and Trinidad.

JAmaica: Catherines Peak, Hitchcock 9728 (Amer. Gr. Nat. Herb. 418); Eggers 3583. Hardware Gap, Ridley 14. Track to Mabess River, Perkins 1089. Mount Lebanon, Harris 12487. Bryans Hill, Harris 11529. Content Gap, Harris 11517. Wallenford, Harris 11551, 11567. Cuna Cuna Gap, Maxon 9160. Morces Gap, Maxon and Killip 745. Abbey Green, Hitchcock 9386. Cold Spring Gap, Harris 11337, 12491. Flamstead, Harris 11468, 11581. Whitfield Hall, Harris 11583. Farm Hill, Orcutt 3679. Gordon Town, Hart 708.

Leeward Islands: St. Kitts, Box 152 . Nevis, Box 169.

Trinidad: Blanchisseuse Road, Broadway 6746.

8. Isachne disperma (Lam.) Doell, in Mart., Fl. Bras. 22: 274.1877. Panicum dispermum Lam., Tabl. Encycl. 1: 173. 1791. Tropical America.

Panicum multinerve Desv.; Poir., in Lam., Encycl. Sup. 4: 279. 1816. Antilles.

Panicum confertum Desv.; Poir., in Lam., Encycl. Sup. 4: 279. 1816. Antilles.

Aspect of plant as in I. arundinacea; sheaths glabrous or rarely papillose-hispidulous; ligule hairs as much as $2 \mathrm{~mm}$ long; blades on the average larger than in $I$. arundinacea, glabrous, scabrous toward the apex; panicles as much as $20 \mathrm{~cm}$ long, the branches and branchlets spreading, the spikelets in twos or threes at the ends of the branchlets, the panicle thus more open and flowered more equally throughout than in $I$. arundinacea, the spikelets not strongly aggregate toward the periphery; spikelets slightly over $1 \mathrm{~mm}$ long; glumes and florets glabrous.

Mountain woods, Lesser Antilles.

Leeward Islands: St. Kitts, Britton and Cowell 395. Guadeloupe, Duss 3189. Dominica, Jones 38; Eggers 1056.

Windward Islands: Martinique, Duss 1311. Grenada, Broadway 76 .

Toвago: Hitchcock 10279 (Amer. Gr. Nat. Herb. 597).

87. OPLISMENUS Beauv., Fl. Owar. 2: 14. pl. 68. f. 1. 1809

Spikelets terete or somewhat laterally compressed, subsessile, solitary or in pairs, in two rows, crowded or approximate on one side of a narrow scabrous or hairy rachis; glumes about equal, emarginate or 2-lobed, awned from between the lobes; sterile lemma exceeding 
the glumes and fruit, mucronate or short-awned, enclosing a hyaline palea; fertile lemma elliptic, acute, convex or boat-shaped, the firm margins clasping the palea, not inrolled. Freely branching, creeping,

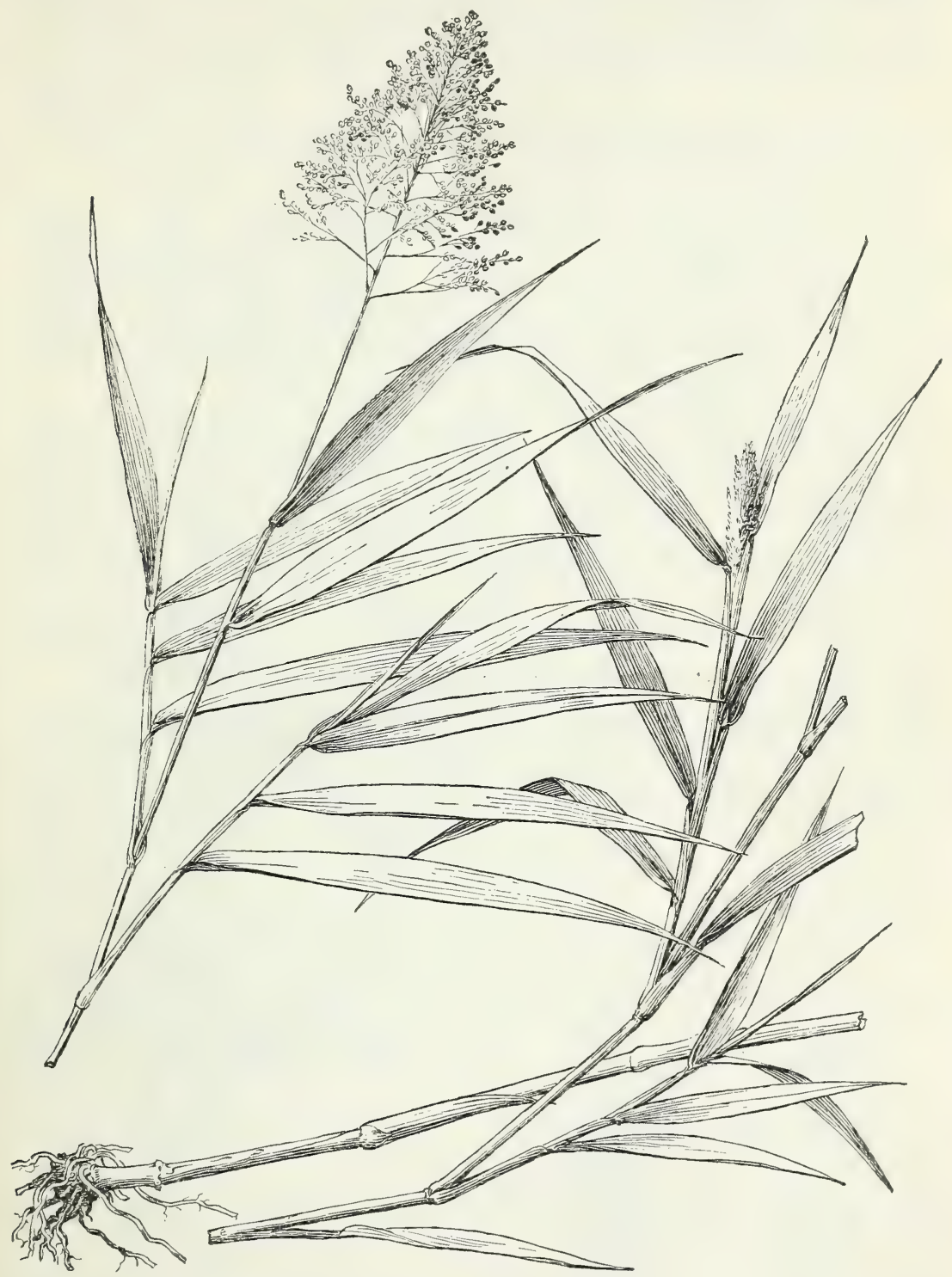

Figure 294.-Isachne arundinacea, X1/2 (Hitchcock 9728, Amer. Gr. Nat. Herb. 418).

shade-loving annuals or perennials, with erect flowering shoots, flat, thin, lanceolate or ovate acuminate blades, and several one-sided, thickish, short racemes rather distant on a main axis. 
Awns antrorsely scabrous; racemes villous with long hairs; plants annual.

Awns smooth or obscurely roughened; 1 . O. BURMANNI. hairs only; plants perennial.

Rachis of racemes mostly 2 to $3 \mathrm{~mm}$ long, bearing usually not more than 5 spikelets; blades 1 to $3 \mathrm{~cm}$ long, 4 to $10 \mathrm{~mm}$ wide $\ldots . . .2$. O. SETARIUS.

Rachis of lower racemes more than $1 \mathrm{~cm}$ long, bearing usually more than 8 spikelets; blades mostly more than $4 \mathrm{~cm}$ long, 1 to $2 \mathrm{~cm}$ wide.

3. O. HiRtellus.

1. Oplismenus burmanni (Retz.) Beauv., Ess. Agrost. 54. 1812.

Panicum burmanni Retz., Obs. Bot. 3: 10. 1783. India.

Orthopogon burmanni Trin., Fund. Agrost. 181. 1820.

Low, creeping, freely branching annual; sheaths pilose; blades broadly lanceolate-elliptic; racemes 3 to 5 , pale villous, ascending, approximate along a flexuous axis; awns slender, about $1 \mathrm{~cm}$ long.

Waste places, open ground, and partial shade, a common weed at low alcitudes in the Tropics of both hemispheres, introduced in North America. Cuba and Hispaniola.

CuBa: Papayo, Ekman 10335.

Haitr: Pétionville, Ekman H 2346. St. Michel de l'Atalaye, Leonard 7224, 7542. Furcy, Leonard 4343, 4645.

Dominican Republic: Ocoa, Tuerckheim 3610. Constanza, Tuerckheim 2883. Majagüitas, Ekman H 13626.

2. Oplismenus setarius (Lam.) Roem. and Schult., Syst. Veg. 2: 481. 1817.

Panicum setarium Lam., Tabl. Encycl. 1: 170. 1791. Tropical America.

Orthopogon setarius Spreng., Syst. Veg. 1: 306.1825.

Slender creeping branching perennial, the ascending flowering culms 20 to $30 \mathrm{~cm}$ high; blades 1 to $3 \mathrm{~cm}$ long, 4 to $10 \mathrm{~mm}$ wide, conspicuously undulate-margined; racemes distant, very short, the spikelets appearing to be in clusters on the rather strict axis; awns 4 to $8 \mathrm{~mm}$ long (fig. 295).

Shady places, southern United States, Mexico, and the West Indies to Paraguay.

Bermuda: Brown and Britton 13; Harris 424; Collins 150.

BaHAMAS: Britton 3200.

CubA: Pinar del Río, Hitchcock 23311, 23316. Cojimar River, Léon 4720. Campo Florido, Léon 4139. Caibarién, Fernando 141. Sierra Maestra, Léon 10380. Bayate, Ekman 3411. Guara, Hitchcock 23401. Prov. Santa Clara, Jack 6351. Eastern Cuba, Wright 1543.

JAMAICA: Troy, Hitchcock 9783; Maxon 2951; Harris 12577. Clyde River, Harris 11446. Bryans Hill, Harris 6826. Hardware Gap, Harris 11843. Stony Hill, Harris 11339. Mount Hybla, Harris 11307. Kingston, Hitchcock 9468. Claremont, Hitchcock 9521. Abbey Green, Hitcheock 9353. Castleton, Harris 11342; Hitchcock 9388 (Amer. Gr. Nat. Herb. 600). Savanna-la-Mar, Hitchcock 9871. Barican, Hitchcock 9568. Montego Bay, Hitchcock 9681. Ipswich, Hitcheock 9621. Newcastle, Hitchcock 9337. Ewarton, Hitchcock 9415. Catherines Peak, Hitchcock 9731, 9737. Blue Hole, Fredholm 3196. Ferry, Ridley 56. Roaring River Falls, Ridley 54. Farm Hill, Orcutt 3701. Content Gap, Harris 11364. Gordon Town, Hart 578. 
HAIti: St. Michel de l'A talaye, Leonard 7010, 7265, 7808. Marmelade, Leonard 8414. Plaisance, Leonard 9238. Port-au-Prince, Ekman H 9106. St. Louis du Nord, Leonard 14130. Port-de-Pai,

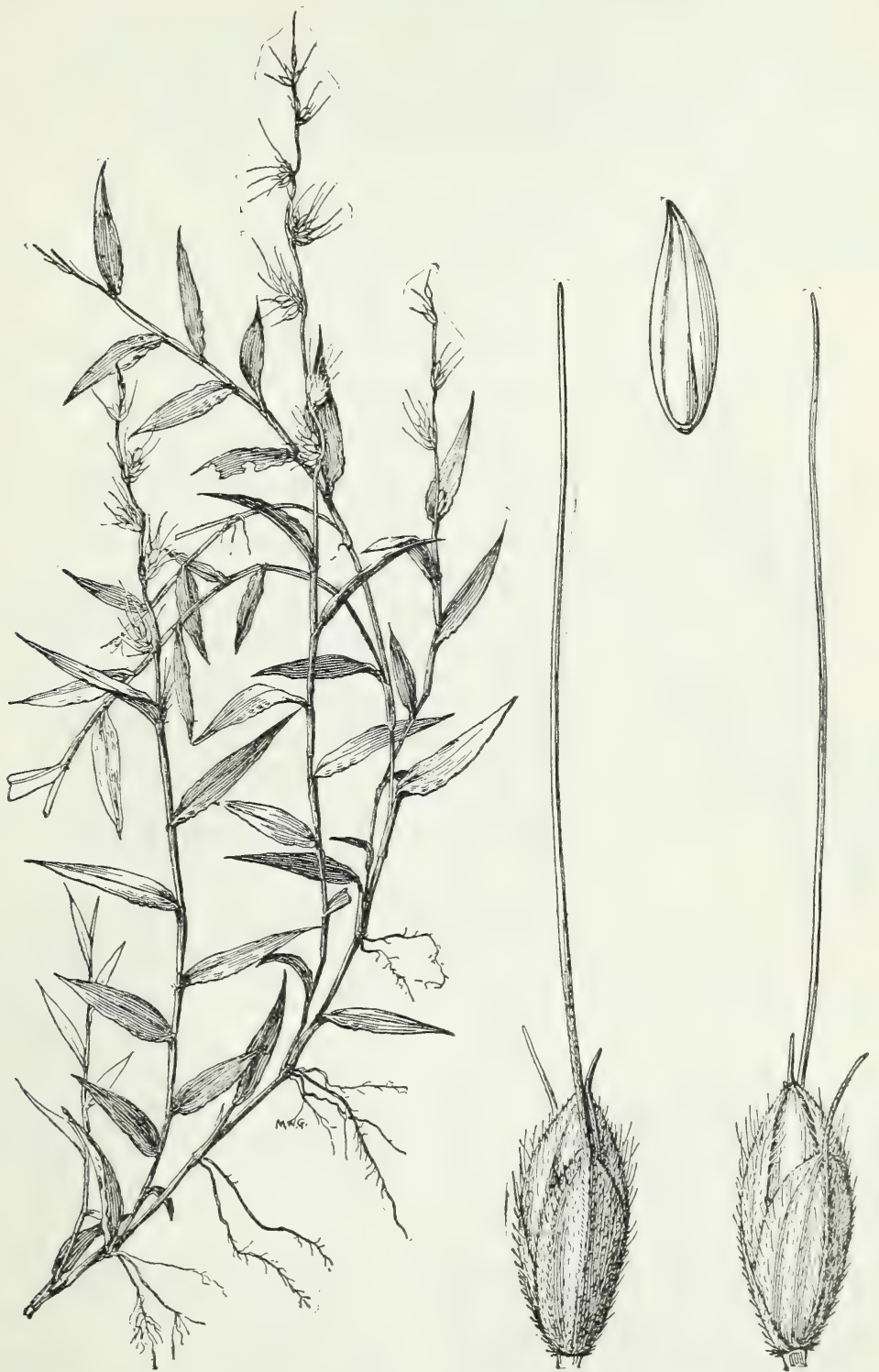

FIGURE 295.-Oplismenus setarius. Plant $\times \frac{1}{2}$; two views of spikelet, and floret, $\times 10$ (Curtiss 5553).

Leonard 12132. Fond Parisien, Leonard 4217. Tortue Island, Leonard 11458. Gonaïve Island, Leonard 3038.

Dominican Republic: Rincón, Fuertes 1282. Las Lagunas, Ekman H 16209. Sabaneta, Valeur 482. 
Puerto Rico: Mayaguez, Holm 124; Sintenis 72b. Cayey, Sintenis 2225, 2286. Rio Grande, Chase 6721. Vega Baja, Chase 6413. Arecibo, Chase 6556. Vieques Island, Chase 6682; Shafer 2626. Culebra, Britton and Wheeler 106.

Virgin Islands: St. Thomas, Hitchcock 16307; Eggers in 1881. St. Croix, Rose 3625; Ricksecker 250. Virgin Gorda, Fishlock 116.

Leeward Islands: St. Kitts, Hitchcock 16355; Box 143. Antigua, Rose 3485; Wullschlaegel 626. Guadeloupe, Duss 2714.

Windward Islands: Martinique, Hitchcock 16450; Duss 7786. St. Lucia, Kemp 55.

Trinidad: Tabaquite, Hitchcock 10126.

\section{Oplismenus hirtellus (L.) Beauv., Ess. Agrost. 54, 168.1812.}

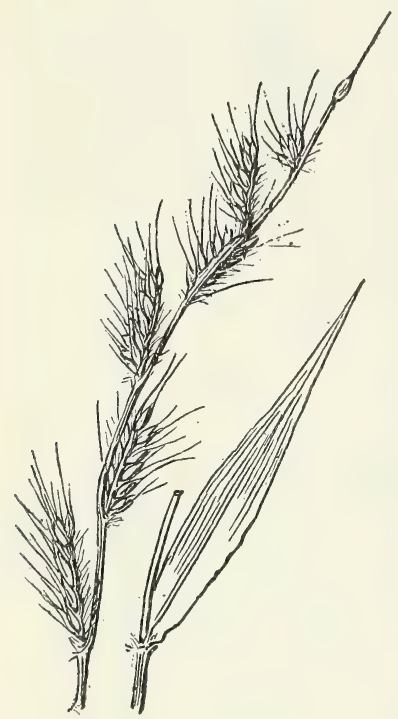

Figure 296.-Oplismenus hirtellus, $\times 1$ (Hitchcock 10005, Amer. Gr. Nat. Herb. 602).

Panicum hirtellum L., Syst. Nat. ed. 10. 2: 870. 1759 . Jamaica.

Orthopogon cubensis Spreng., Syst. Veg. 1: 307. 1825. Cuba.

Echinochloa cubensis Schult., Mant. 3 (Add. 1): 596. [1827.]

Oplismenus cubensis Kunth, Rév. Gram. 1: 45.1829.

Panicum cubense Steud., Nom. Bot. ed. 2. 2: $255 . \quad 1841$.

Perennial; culms widely creeping and branching, the fertile culms usually erect from an ascending base, 20 to $70 \mathrm{~cm}$ tall (usually about $30 \mathrm{~cm}$ ); sheaths glabrous to densely papillose-hispid; blades 5 to $10 \mathrm{~cm}$ long and 1 to $2 \mathrm{~cm}$ wide; panicles 5 to 10 $\mathrm{cm}$ long with 3 to 7 ascending or spreading rather distant racemes 1 to $2 \mathrm{~cm}$ long; awns smooth, usually purple, the longer 5 to 10 $\mathrm{mm}$ long (fig. 296).

There are two forms of this species, one with glabrous sheaths and one with hispid sheaths, which appear, when growing, rather distinct. The forms differ in no other way, however, and are found growing together under the same conditions, but all the shoots originating from a given plant are of one form. Grisebach ${ }^{76}$ refers the form with glabrous sheaths to Orthopogon loliaceus Spreng. (Oplismenus loliaceus (Lam.) Beauv.), an Asiatic species. Richard 77 refers the pubescent form to Oplismenus undulatifolius. In Cuba the species is called "pitillo."

Moist woods and shady banks at low and medium altitudes, Mexico and the West Indies to Argentina. A common species to be found on probably all the islands.

A variegated form, with blades striped with white, is cultivated as a basket plant. It is naturalized in a few places in the Lesser Antilles.

Leeward Islands: Guadeloupe, Duss 3155. Dominica, Jones 37.

Windward Islands: Martinique, Duss 1325. Grenada, Hitchcock 17674. St. Lucia, Box 194. 
88. ECHINOCHLOA Beauv., Ess. Agrost. 53. pl. 11. f. 2.1812

Spikelets plano-convex, often stiffly hispid, subsessile, solitary or in irregular clusters on one side of the panicle branches; first glume about half the length of the spikelet, pointed; second glume and sterile lemma equal, pointed, mucronate, or the glume short-awned and the lemma long-awned, sometimes conspicuously so, enclosing a membranaceous palea and sometimes a staminate flower; fertile lemma plano-convex, smooth and shining, acuminate-pointed, the margins inrolled below, flat above, the apex of the palea not enclosed. Coarse, often succulent, annuals or perennials with compressed sheaths, linear flat blades, and rather compact panicles composed of short, densely flowered racemes along a main axis.

Ligule a dense line of stiff yellowish hairs; plants perennial.

Fruit about $2.5 \mathrm{~mm}$ long; awn of sterile lemma less than two $\mathrm{mm}$ long.

1. E. PYRAMIDALIS.

Fruit about $4 \mathrm{~mm}$ long; awn of sterile lemma usually 5 to $10 \mathrm{~mm}$ long.

2. E. POLYSTACHYA.

Ligule wanting, the ligular area sometimes pubescent; plants annual.

Racemes simple, rather distant, 1 to $2 \mathrm{~cm}$ long; spikelets crowded in about

4 rows, the awn of the sterile lemma reduced to a short point; blades 3 to

$6 \mathrm{~mm}$ wide......... E. COLONUM.

Racemes more or less branched, usually more than $2 \mathrm{~cm}$ long; spikelets irregularly crowded and fascicled, usually not arranged in rows, the awn of the sterile lemma variable; blades usually more than $5 \mathrm{~mm}$ wide.

Sheaths, at least the lower, papillose-hispid; panicle dense (small in depauperate specimens), the spikelets long-awned _._._._. 4. E. WALTERI.

Sheaths smooth; awns variable, but the panicle not a dense mass of longawned spikelets.

Panicles soft and nodding; spikelets inconspicuously hispid.

5. E. CRUS-PAVONIS.

Panicles erect and rather stiff; spikelets conspicuously hispid.

6. E. CRUSGalli.

\section{Echinochloa pyramidalis (Lam.) Hitchc. and Chase, Contrib.} U. S. Natl. Herb. 18: 345. 1917.

Panicum pyramidale Lam., Tabl. Encycl. $1: 171$. 1791. Senegal.

Panicum spectabile var. guadeloupense Hack., Notizbl. Bot. Gart.

Berlin 1: $328 . \quad$ 1897. Guadeloupe, Duss 3176.

Echinochloa guadeloupensis Wieg., Rhodora 23:63. 1921.

Perennial; culms erect, rather fleshy, 1.5 to $2.5 \mathrm{~m}$ tall, glabrous; sheaths glabrous; ligule a dense row of stiff yellowish hairs 1 to $2 \mathrm{~mm}$ long; blades 40 to $60 \mathrm{~cm}$ long, 5 to $10 \mathrm{~mm}$ wide, glabrous above, scabrous on the margins and on the nerves beneath; panicle 20 to $40 \mathrm{~cm}$ long, the axis scabrous; racemes numerous, ascending, 2 to $7 \mathrm{~cm}$ long, single or somewhat fascicled, distant below but overlapping, stiffly pilose at base and sparsely so along the scabrous or hispidulous rachis; spikelets about $3 \mathrm{~mm}$ long, rather loosely arranged along the rachis, scabrous or slightly hispidulous on the nerves, glabrous or nearly so on the internerves; sterile lemma mucronate or with an awn 1 to $2 \mathrm{~mm}$ long; fruit about $2.5 \mathrm{~cm}$ long, mucronate (fig. 297).

Brackish marshes and ditches, Guadeloupe. Common in tropical Africa; introduced in Guadeloupe. ${ }^{78}$

78 In 1919 the author observed this species on the island of Guadeloupe, where it is abundant in one locality. Later he had the opportunity of examining Echinochloa pyramidalis in tropical Africa where it is common, and he is of the opinion that the Guadeloupe plant is the same as the African species. Wiegand (Rhodora 23: 63. 1921) described the Guadeloupe plant as a distinct species. 
Leeward Islands: Guadeloupe, Duss 3175, 3176, 3920; Hitchcock 16412 (Amer. Gr. Nat. Herb. 711); L'Herminier 61.

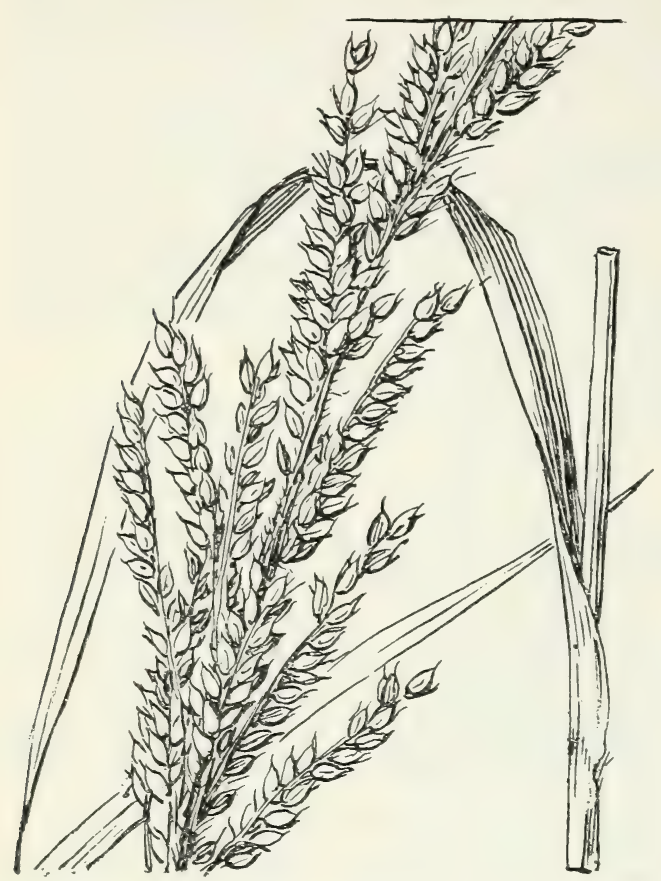

FIGURE 297.-Echinochloa pyramidalis, $\times 1$ (Duss 3175).

\section{Echinochloa polystachya}

(H. B. K.) Hitchc., Contrib. U. S. Natl. Herb. 22: 135. 1920.

Oplismenus polystachyus H. B. K., Nov. Gen. et Sp. 1: 107. 1815. Colombia.

Panicum spectabile Nees, in Trin., Gram. Pan. 138. 1826. Brazil.

Echinochloa spectabilis Link, Hort. Berol. 2: 209. 1833.

Perennial, usually in colonies; culms coarse, 1 to $2 \mathrm{~m}$ tall, from a long creeping rooting base, glabrous; nodes densely hispid with appressed yellowish hairs; sheaths glabrous or papillose-hispid; ligule a dense line of stiff yellowish hairs as much as $4 \mathrm{~mm}$ long; blades as much as 2.5 $\mathrm{cm}$ wide, scabrous on the margins and upper surface; panicle 10 to $30 \mathrm{~cm}$ long, rather dense; racemes ascending, the lower mostly 3 to $6 \mathrm{~cm}$ long, densely hispid at base, the rachis very scabrous and more or less papillose-hispid; spikelets rather closely set, nearly sessile, about $5 \mathrm{~mm}$ long; sterile floret staminate, the awn 2 to 10 $\mathrm{mm}$ long; fruit rather soft, about $4 \mathrm{~mm}$ long, extending into a point about $0.5 \mathrm{~mm}$ long (fig. 298).

Marshes and ditches near the coast, Mexico, and the West Indies to Argentina.

Cuba: Habana, Léon 4168; Ekman 13524. Almendares, Ekman in 1921. Sierra de Imías, Léon 12451 (cultivated). Habana, Ekman 13405.

JAMAICA: Savanna-la-Mar, Hitchcock 9868.

Haitr: Dessalines, Ekman H 8532. Port-Margot, Ekman H 4798.

Dominican Republic: San Francisco de Macoris, Ekman H

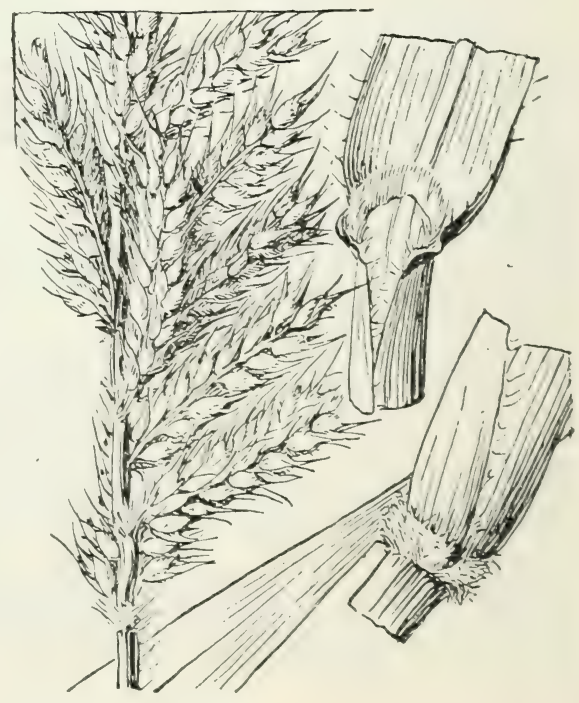

FIGURE 298,-Echinochloa polystachya, $\times 1$ (Pittier 4383). 
12318. Sánchez, Taylor 66. Rincón, Fuertes 1419. Jaina, Ekman 12473; Faris 100, 400. Santiago, Ekman H 16392.

Puerto Rico: Mayaguez, Chase 6290, 6319. Bayamon, Hioram 324 in part. Caguas, Sintenis 2543. Lares, Chase 6583.

Leeward Islands: Antigua, Wullschlaegel 635; Box 110.

Windward Islands: Martinique, Duss 542. St. Lucia, Box 198. Toвago: Broadway 4896; Hitchcock 10284.

\section{Echinochloa colonum (L.) Link, Hort. Berol. 2: 209. 1833.}

Panicum colonum L., Syst. Nat. ed. 10. 2: 870. 1759. Jamaica.

Milium colonum Moench, Meth. Pl. 202. 1794.

Oplismenus colonus

H. B. K., Nov. Gen. et Sp.

1: 108.1815.

Panicum zonale Guss., Fl. Sic. Prodr. 1: 62. 1827. Sicily.

Panicum colonum var. zonale L. H. Dewey, Contrib. U. S. Nat. Herb. 2: 502. 1894.

Echinochloa colonum var. zonalis Woot. and Standl., N. Mex. Coll. Agr. Bull. 81: 45. 1912 .

Annual, usually much branched at base; culms prostrate-spreading, ascending or erect, usually 20 to $40 \mathrm{~cm}$ long, glabrous; sheaths glabrous; blades rather lax, 5 to $10 \mathrm{~cm}$ long, rarely longer, 3 to 6 rarely $10 \mathrm{~mm}$ wide, somewhat scabrous on the margin, occasionally bearing transverse purple bands(zonate); panicles 5 to 10 or even 15 cm long; racemes several, 1 to $2 \mathrm{~cm}$ long, rarely longer, appressed or ascending, the lower usually distant as much as $1 \mathrm{~cm}$; spikelets

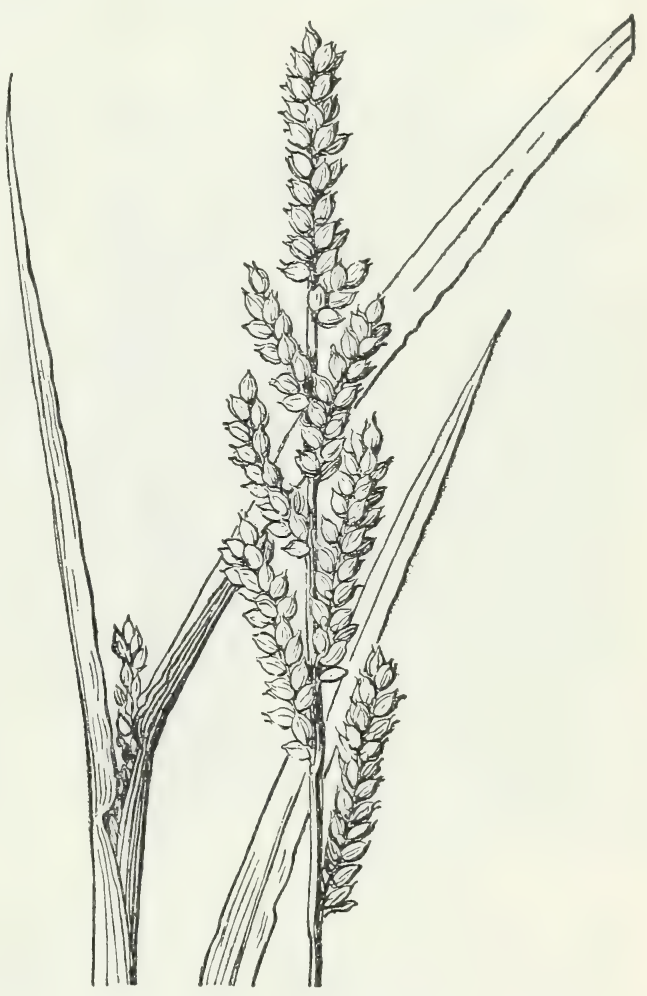

FIGURE 299.-Echinochloa colonum, $\times 1$ (Bentley). about $3 \mathrm{~mm}$ long, crowded, nearly sessile, in about 4 rows; awn reduced to a short point (fig. 299).

Ditches and moist places, a common weed in the warmer parts of both hemispheres; introduced in the Americas where it is found from Virginia and Missouri to Argentina; originally described from India, the type being, however, from Jamaica, collected by Patrick. Browne. The word "colonum" appears to be a genitive plural. To be found on probably all the islands. ${ }^{79}$

\footnotetext{
79 See Hitchcock, Contrib. U. S. Natl. Herb. 17: 256. 1913.
} 
4. Echinochloa walteri (Pursh) Heller, Cat. N. Amer. Pl. ed. 2. 21. 1900.

Panicum hirtellum Walt., Fl. Carol. 72. 1788. Not P. hirtellum L., 1759. South Carolina.

Panicum walteri Pursh, Fl. Amer. Sept. 66. 1814. Based on P. hirtellum Walt.

Annual; erect, often succulent and rooting at the lower nodes when growing in mud or water, 1 to $2 \mathrm{~m}$ high, as much as $2.5 \mathrm{~cm}$ thick at base; sheaths papillose-hispid, or papillose only, rarely glabrous, the collar more or less pubescent; ligule wanting, the ligular area often pubescent; blades usually 10 to $15 \mathrm{~mm}$ wide sometimes as much as $3 \mathrm{~cm}$ wide, mostly scabrous on both surfaces; panicle dense, as much as $30 \mathrm{~cm}$ long, erect or nodding; racemes appressed or ascending, approximate or the lower somewhat distant, as much as $10 \mathrm{~cm}$ long;

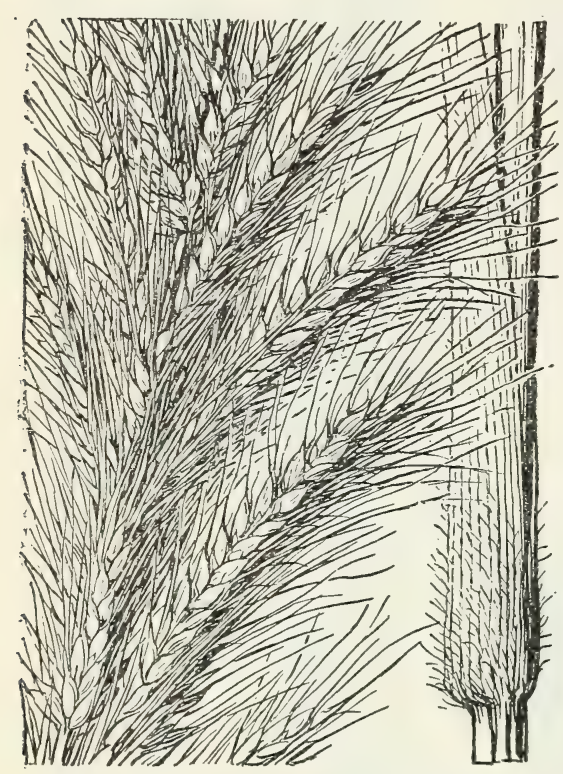

Figure 300,-Echinochloa walteri, $\times 1$ (Chase 1426). spikelets closely arranged, mostly long-awned, often purple, about $3 \mathrm{~mm}$ long; sterile lemma with an awn usually 1 to $2 \mathrm{~cm}$ long, sometimes longer, rarely reduced to a short point (fig. 300).

Marshes, lagoons, and wet places, eastern United States; Cuba, Hispaniola.

Cuba: Ciénaga de Zapata, Ekman 16947. Los Coyuelos, Roig 3231. Hanábana, Wright 3879 in part.

JAMAICA: Black River, Hitchcock 9650.

Haiti: Étang de l'Abovane, Ekman H 375. Solon, Ekman H 826. Aux Cayes, Ekman H 758. Dame-Marie, Ekman H 10450.

5. Echinochloa crus-pavonis (H. B. K.) Schult., Mant. 2: 269. 1824.

Oplismenus crus-pavonis H. B. K., Nov. Gen. et Sp. 1: 108. 1815. Venezuela.

Panicum sabulicola Nees, Agost. Bras. 258. 1829. Brazil.

Panicum crus-pavonis Nees, Agrost. Bras. 259. 1829.

Panicum aristatum Macfad., Bot. Misc. Hook. 2: 115. 1831. Not $P$. aristatum Retz., 1786 . Jamaica.

Oplismenus jamaicensis Kunth, Enum. Pl. 1: 147. 1833. Based on Panicum aristatum Macfad.

Panicum jamaicense Steud., Nom. Bot. ed. 2. 2: 257.1841.

Echinochloa sabulicola Hitchc., Contrib. U. S. Natl. Herb. 17: 257. 1913.

Echinochloa crusgalli var. crus-pavonis Hitchc., Contrib. U. S. Natl. Herb. 22: 148. 1920.

Annual; culms erect or sometimes decumbent at base, as much as $1 \mathrm{~m}$ or even $1.5 \mathrm{~m}$ tall, glabrous; sheaths glabrous; ligule wanting, the ligular area sometimes slightly pubescent; blades 5 to $15 \mathrm{~mm}$ wide, 
scabrous on the margins, sometimes on the upper surface; panicles 10 to $20 \mathrm{~cm}$ long, more $\mathrm{nr}$ less nodding; racemes mostly ascending or appressed, the lower somewhat distant, the upper approximate; spikelets crowded, excluding the awns about $3 \mathrm{~mm}$ long, hispid on the nerves, hispidulous on the intervenes; sterile lemma with an awn 1 to $10 \mathrm{~mm}$ long (fig. 301 ).

Marshes and wet places, often in the water, at Jow and medium altitudes, Mexico and the West Indies to Argentina.

Bermuda: Collins 343.

Cuba: Habana, Léon 747, 2588, 2785, 7646, 11467; Ekman 241. Liebmann 378; Rugel 889. Yumuri Mountains, Rugel 884. Caibarién, Ekman 16308. Gamboa, Ekman 14977. Without locality, Wright in 1865, Ekman 13130.

Jamaica: Grosmond Marsh, Harris 11751. Meylersfield, Harris 11824. Savanna-la-Mar, Hitchcock 9862 .

Haiti: Miragoane, Eyerdam 493; Ekman H 6523. Dessalines, Ekman H 3518, 8533. Port-Margot, Ekman H 2681.

Dominican Repunlic: Santo Domingo, Ekman H 12254. Jarabaco, Ekman H 14135.

Puerto Rico: Loiza Road, Britton 9235. Humacao, Sintenis 1889. Canovanas, Stevenson 5388. San Juan, Chase 6352, 6396. Lares, Chase 6596. Rio Piedras, Stevenson and Rose 6428. Trujillo Alto, Britton and Matz 7049. Vega Baja, Britton 7960. Without locality, Eggers 685.

Leeward Islands: Guadeloupe, Duss 3161.

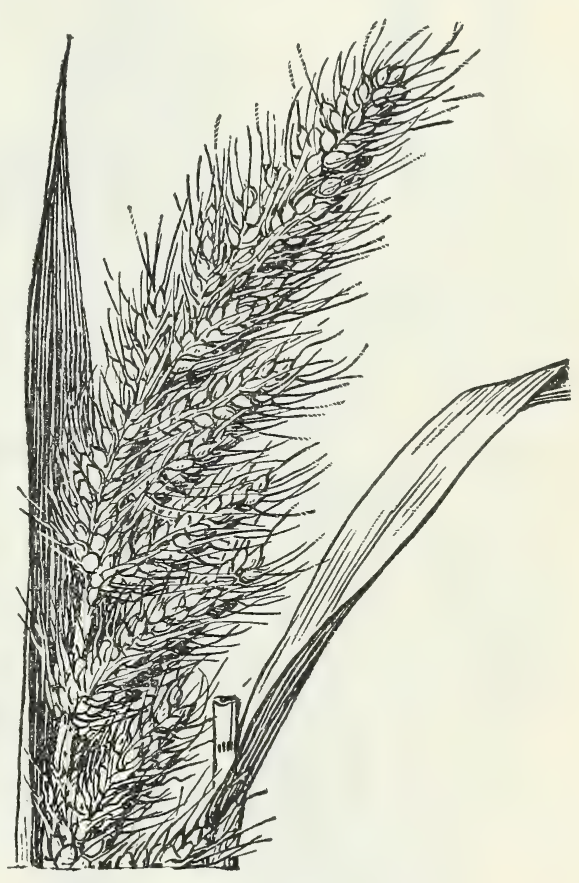

FIGURE 301.-Echinochloa crus-panonis, $\times 1$ (Sintenis 1889).

Trinidad: Oropuche Lagoon, Britton, Hazen, and Freeman 1143. Without locality, Bot. Gard. Herb. 1678.

6. Echinochloa crusgalli (L.) Beauv., Ess. Agrost. 53, 161, 169. 1812. BARNYARD GRASS.

Panicum crusgalli L., Sp. Pl. 56. 1753. Europe and Virginia.

Resembling E. crus-pavonis; differing in the stiffer panicle, erect or nodding only when large and heavy, the somewhat larger spikelets, and especially in the strongly hispid or papillose-hispid nerves of the second glume and sterile lemma (fig. 302).

The species is common in the United States and Mexico but rare in the West Indies. It is not always easy to distinguish it from E. crus-pavonis, especially in small or depauperate specimens, for which reason the latter has often been considered to be a variety of the former. The awn is variable in length in E. crusgalli, whereas in 

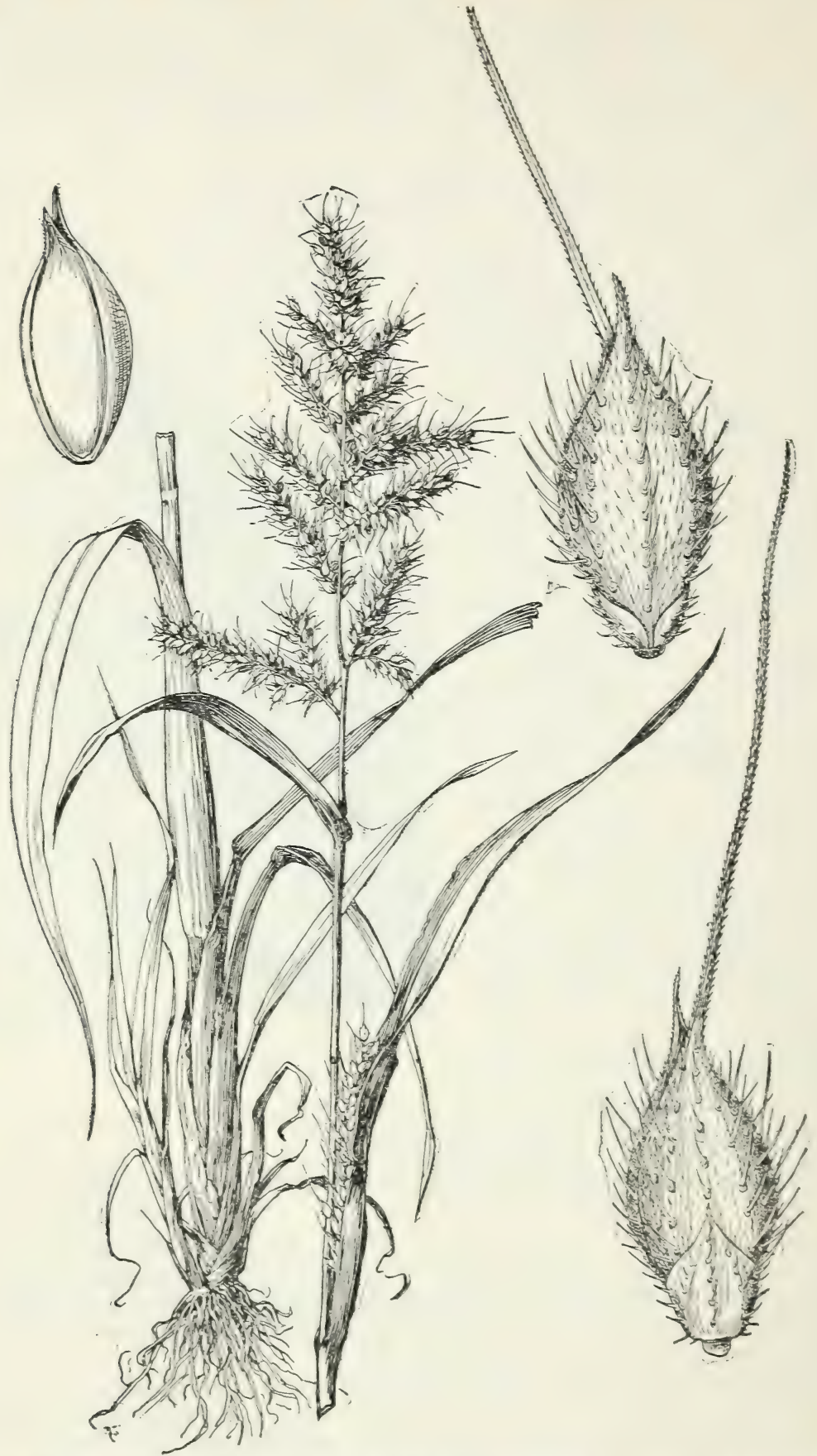

FIGTRE 302.-Echinochloa crusgalli. Plant, $\times{ }_{12}$; two riems of spikelet, and floret, $\times 10$ (Somes 3725 )。 
E. crus-pavonis it is usually short, not more than $1 \mathrm{~cm}$ in length. The most noticeable difference is the soft nodding panicle of E. cruspavonis as compared with the stiffer erect panicle (unless large and heavy) of $E$. crusgalli. The spikelets of $E$. crusgalli are usually conspicuously papillose-hispid. In E. crus-pavonis the spikelets are more or less hispid but the strong hairs on the nerves are less conspicuous. The following specimens have been referred to $E$. crusgalli.

Bermuda: Brown, Britton, and Bisset 1961.

CuBA: Batabanó, Léon 13447.

Haiti: Manneville, Ekman H 3061.

89. CHAETIUM Nees, Agrost. Bras. 269. 1829

Spikelets short-pediceled, dorsally compressed, lanceolate, the joint of the rachilla between the glumes elongate, the bearded base of the first glume adnate to it, forming a long slender callus; glumes bearing awns 3 to 4 times the length of the body of the spikelet, the first reduced to the awn or the pair broadened and enclosing the rest of the spikelet; sterile lemma bearing a shorter awn or awn-tipped only; fruit subindurate, lanceolate, the lemma acuminate into a scabrous awn or point, the thin margins flat, the summit of the palea not enclosed. Perennials with long narrow blades and dense narrow panicles.

1. Chaetium cubanum (Wright) Hitchc., Contrib. U. S. Natl. Herb. 12: 232. 1909.

Perotis? cubana Wright, Ann. Acad. Cien. Habana 8: 288. 1871. Cuba, Wright 735.

Culms tufted, stiffly erect, 40 to $60 \mathrm{~cm}$ tall; blades flat or loosely involute, 5 to $10 \mathrm{~cm}$ long, 1 to $4 \mathrm{~mm}$ wide, puberulent on the upper surface; panicles narrow, few-flowered, 4 to $7 \mathrm{~cm}$ long, the branches appressed; spikelets about $6 \mathrm{~mm}$ long, the fertile lemma about $4.5 \mathrm{~mm}$ long (fig. 303).

Dry hills, Cuba.

Cuba: Canasí, Léon 13074; Ekman 16474. El Cobre, Ekman 15699, in 1922 (Amer. Gr. Nat. Herb. 796). Eastern Cuba, Wright 735. Motembo, Ekman 16827.

\section{TRICHOLAENA Schrad.; Schult., Mant. 2: 163.1824}

Spikelets on short capillary pedicels; first glume minute; second glume and sterile lemma equal, raised on a stipe above the first glume, emarginate or slightly lobed, short-awned, covered, except toward the apex, with long silky hairs, the palea of the sterile lemma well developed, fertile lemma shorter than the spikelet, cartilaginous, smooth, boat-shaped, obtuse, the margins thin, not inrolled, the palea not enclosed. Perennials or annuals with rather open panicles of silky spikelets.

1. Tricholaena repens (Willd.) Hitchc.

Saccharum repens Willd., Sp. Pl. 1: 322. 1797. "Guinea."

Tricholaena rosea Nees, "Cat. Sem. Hort. Vratisl. a. 1836"; Fl. Afr. Austr. 1: 17. 1841. South Africa.

Rhynchelytrum roseum Stapf and Hubb.; Bews, World's Grasses 223. 1929 .

Rhynchelytrum repens C. E. Hubb., Kew Bull. Misc. Inf. 1934: 110. 1934. 


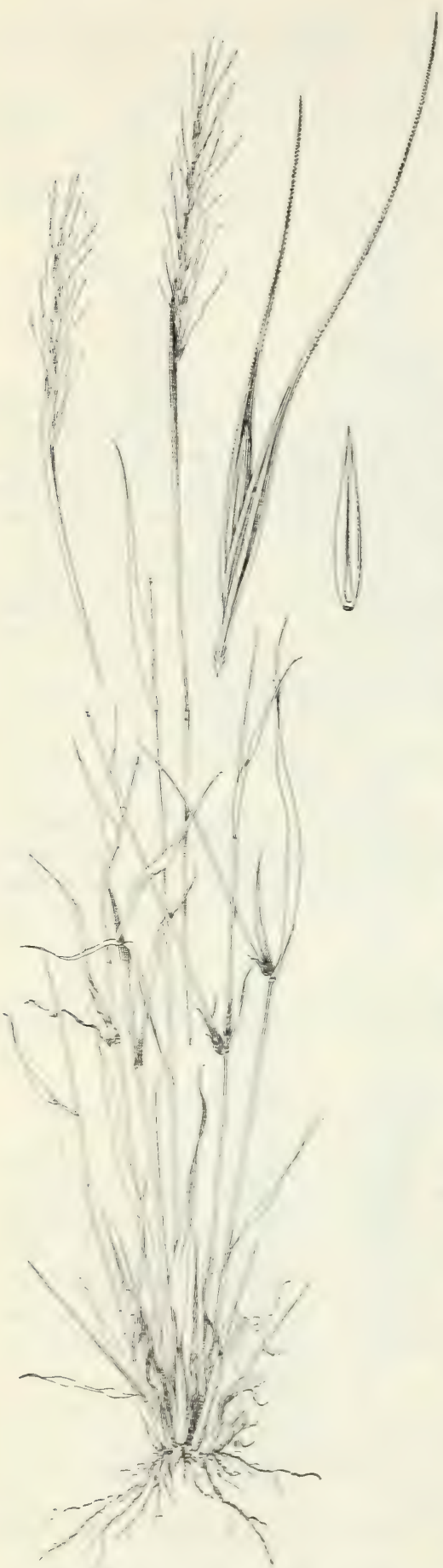

FIGTDE 303 -Chactium curanum. Plant, $\times 16$ : spikelet and floret, $\times 5$ (Ekman 15099).
Annual or short-lived perennial; culms tufted, slender, often decumbent at base, about $1 \mathrm{~m}$ tall; sheaths sparsely papillose-hirsute; blades flat, 5 to $15 \mathrm{~cm}$ long, 2 to $7 \mathrm{~mm}$ wide; panicles beautifully silky, rosy-purple or sometimes pale, 10 to $15 \mathrm{~cm}$ long; spikelets about $5 \mathrm{~mm}$ long, the hairs extending 4 to $5 \mathrm{~mm}$ beyond (fig. 304).

Waste ground, becoming rather common in the warmer regions of North America; introduced from South Africa. This species has some value for forage and can be utilized on poor sandy soil.

CUBA: Santiago de las Tegas, Juzepezuk 1987. Habana, Léon 817, 6361; Ekman 29. Campo Florido, Léon 4146. Matanzas, Britton and Wilson 13996: Covell 13334. Cienfuegos, Grey in 1919. Santiago de Cuba, Ekman 7999. San Miguel de los Baños, Killip 13937 .

JAmaica: Botanical Garden, Cousins in 1925 (grown from seed from Colombia; will probably escape).

HAiti: Fond-Blanc, Ekman H 9889 .

Domincan Reptiblic: Monción, Ekman H 12691; Valeur 162. Jaina, Ekman H 5801; Faris 5. Constanza, Ekman H 14087.

Puerto Rico: Rio Piedras, Britton and Matz 7056. Sardinera, Britton 8703.

LEEWARD IsLANDS: Antigua, Box 25. Guadeloupe, Franceschi in 1892; Stehlé 41.

MINDWARd Istands: Barbados, Hitcheoch 16511.

Trinidad: Port-of-Spain, Broadway 4962 (cultirated).

91. SETARIA Beaur., Ess. Agrost. 51. pl. 13. f. 3.1812

(Chatochloa Scribn., L.S.Dept.Agr., Div. Agrost. Bull. 4: 38. 1897)

Spikelets subtended by one to sereral bristles (sterile branchlets) falling free from the bristles, awnless; first glume broad, usually less 


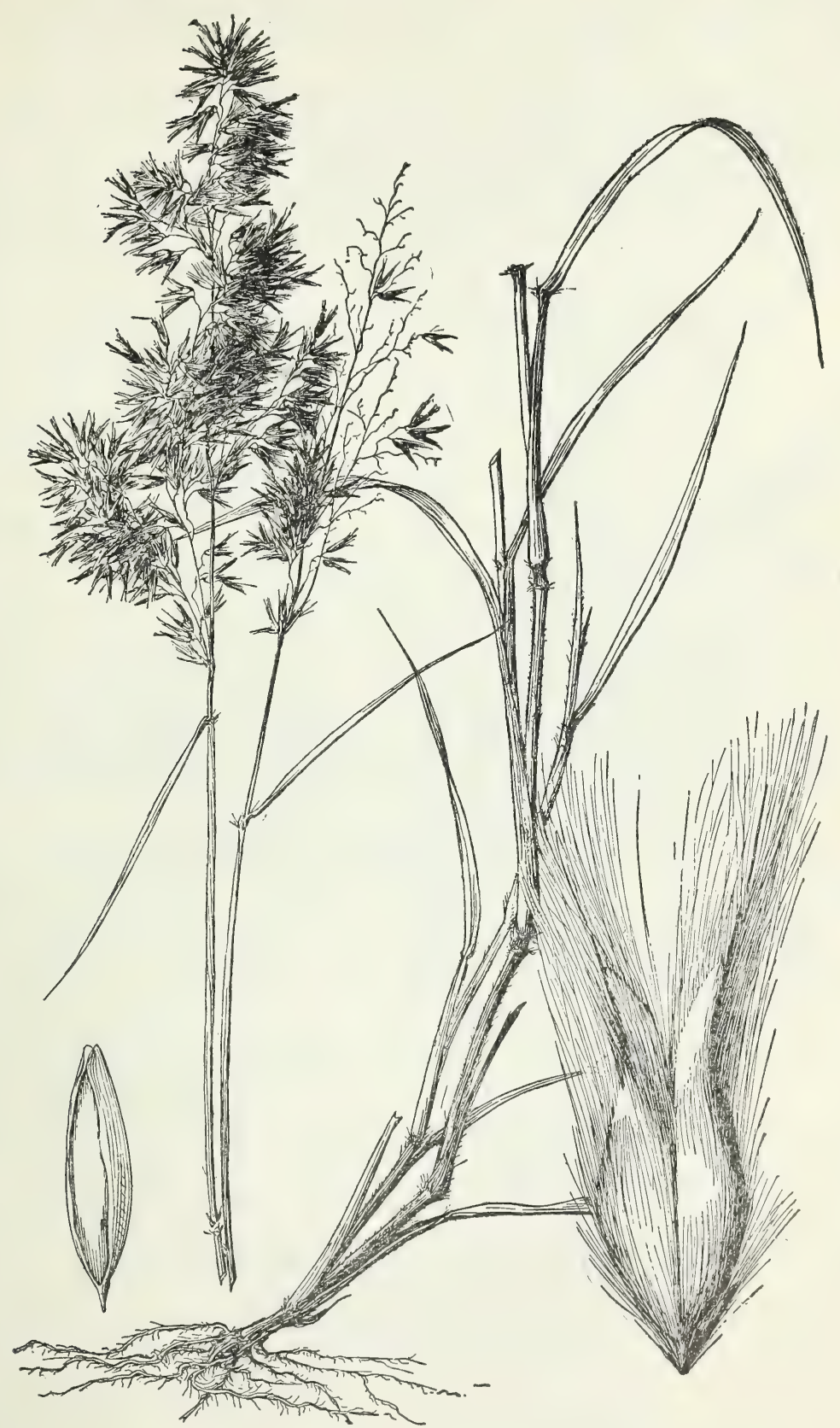

FIGURE 304.-Tricholaena repens. Plant, $\times 1 / 2$; spikelet and floret, $\times 10$ (Tracy 9365). 
than half the length of the spikelet, 3 - to 5-nerred; second glume and sterile lemma equal, or the glume shorter, sereral-nerved; fertile lemma coriaceous-indurate, smooth or rugose. Annuals or perennials with narrow terminal panicles.

Blades narrowly elliptic, plaited; bristles below only a part of the spikelets (Subgenus Ptychophyllum).

Plant annual; blades usually less than $2 \mathrm{~cm}$ wide_._._._._. 1 . S. BARBATA. Plants perennial; blades usually more than $3 \mathrm{~cm}$ wide.

Panicle of numerous approximate, more or less 1-sided racemes, spikeletbearing to the base, 2 to $5 \mathrm{~cm}$ long, rarely the lower much longer.

2. S. POIRETIANA.

Panicle of more or less fascicled branches, not or scarcely 1-sided, some of them elongate and naked at base.

Branches of panicle as much as $10 \mathrm{~cm}$ long; bristles usually not more than twice as long as the spikelets, inconspicuous; blades as much as $6 \mathrm{~cm}$

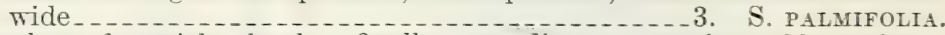
Branches of panicle slender, finally spreading, as much as $20 \mathrm{~cm}$ long; bristles as much as $15 \mathrm{~mm}$ long; blades as much as $10 \mathrm{~cm}$ wide.

4. S. PANICULIFERA.

Blades linear-lanceolate, narrow; bristles below all the spikelets.

Bristles below each spikelet numerous, at least more than five. Panicles dense, cylindric, spikelike.

Plants annual; spikelets $3 \mathrm{~mm}$ long _............ 5. S. LUTESCENS.

Plants perennial; spikelets 2 to $2.5 \mathrm{~mm}$ long

Bristles below each spikelet 1 or by abortion of the spikelets, 2 or 3 .

Bristles more or less retrorsely scabrous.

Plants perennial; spikelets globose or nearly so

Plants annual; spikelets not globose.

Spikelets about $2 \mathrm{~mm}$ long Spikelets about $1.5 \mathrm{~mm}$ long.

Panicles usually green, rarely as much as $8 \mathrm{~cm}$ long, less than $5 \mathrm{~mm}$ thick, the bristles 2 to $3 \mathrm{~mm}$ long -...... S. S. SCANDENS.

Panicles usually purple, as much as $15 \mathrm{~cm}$ long and $1 \mathrm{~cm}$ thick, the bristles about $1 \mathrm{~cm}$ long............ S. TENACISSIMA.

Bristles antrorsely scabrous only.

Plants annual.

Fertile lemma at maturity finely cross-veined or nearly smooth.

Plants as much as $3 \mathrm{~m}$ tall

Plants less than $1 \mathrm{~m}$ tall $\ldots \ldots \ldots$. S. VIRIdis.

Fertile lemma coarsely transversely rugose...... 13. S. Corrugata. Plants perennial.

Spikelets $3 \mathrm{~mm}$ long. Panicle large, rather loose.

Spikelets 2 to $2.5 \mathrm{~mm}$ long.

18. S. MACROSPERMA.

Panicle narrowed somewhat at summit but not attenuate.

Primary panicle large and dense, as much as $25 \mathrm{~cm}$ long, rellowish or brownish, the bristles 1 to $2 \mathrm{~cm}$ long; blades as much as $2 \mathrm{~cm}$ wide................... SULPISETA.

Primary panicle 5 to $10 \mathrm{~cm}$ long, green, the bristles 5 to $10 \mathrm{~mm}$ long; blades 3 to $5 \mathrm{~mm}$ wide..... 14. S. MACROSTACHYA. Panicle attenuate at apex.

Fertile lemma acuminate, not turgid; obscurely cross-lined.

Fertile lemma acute, turgid, sharply cross-ridged.

20. S. SUBTRANSIENS.

Blades linear-lanceolate, more than $5 \mathrm{~mm}$ wide; panicle interrupted or branched, the branches 1 to $3 \mathrm{~cm}$ long.

Blades usually pubescent on one or both surfaces, thickish, usually less than $1 \mathrm{~cm}$ wide......... S. SETOSA. Blades glabrous, thin, usually 1 to $2 \mathrm{~cm}$ wide.

16. S. LEIOPHYLLA.

Blades slender, mostly less than $5 \mathrm{~mm}$ wide; panicle slender, very narrow ............................ RARIFLORA. 
1. Setaria barbata (Lam.) Kunth, Rév. Gram. 1: 47. 1829.

Panicum barbatum Lam., Tabl. Encycl. 1: 171. 1791. Mauritius. Chaetochloa barbata Hitchc. and Chase, Contrib. U. S. Natl. Herb. 18: 348.1917.

Branching annual; culms decumbent, spreading, often rooting at the lower nodes, glabrous, scabrous, or villous near the pubescent nodes, as much as $2 \mathrm{~m}$ long, but often much less; blades narrowly elliptic, flat and rather thin, as much as $30 \mathrm{~cm}$ long and $2.5 \mathrm{~cm}$ wide, distinctly plicate in large specimens, obscurely so in dwarf ones; panicles green, as much as $20 \mathrm{~cm}$ long, the branches ascending or spreading, as much as 4 cm long; spikelets oblongelliptic, glabrous, about $2.5 \mathrm{~mm}$ long, tending to be in two rows along the branches, at leastalong the upper part, often clustered on branchlets on the lower part of the branches, the bristles flexuous, 5 to 10 $\mathrm{mm}$ long, usually rather numerous (fig. 305).

Thickets and waste places, tropical Asia; introduced in the Americas, West Indies to Brazil. Grisebach ${ }^{80}$ and Hooker ${ }^{81}$ described this species under Panicum flavescens Swartz.

Common in the Lesser Antilles and in Jamaica. No specimens have been seen from Cuba. Called "Mary grass" in Tobago.

JAMAICA: Castleton, Hitchcock 9391 (Amer. Gr. Nat. Herb. 603). Moneague, Maxon and Killip 367. Ferry, Ridley 43;

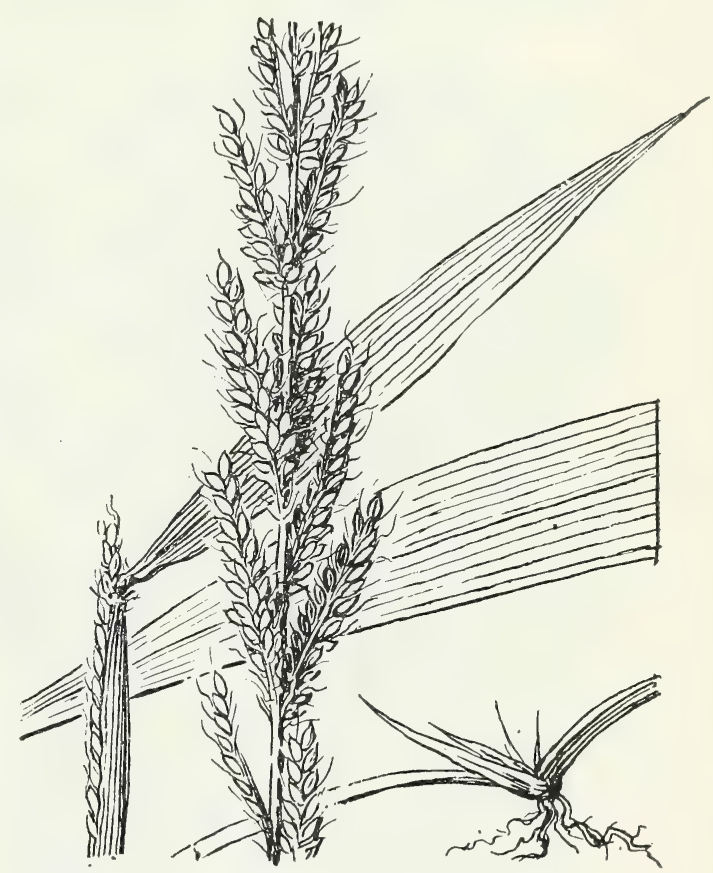

Figure 305.-Setaria barbata, $\times 1$ (Hitchcock 9391 , Amer. Gr. Nat. Herb. 603).

Harris 11782. Bog Walk, Hitcheock 9308; Ridley 59. Troy, Harris 12587; Hitchcock 9793. Kingston, Cockerell in 1892; Hitchcock 9270, 9277,9473. Ipswich, Hitchcock 9604. Alligator Pond, Hitchcock 9834. Buff Bay, Hitchcock 9768. Montego Bay, Hitchcock 9694. Mavis Bank, Harris 11602. Temple Hall, Harris 11360. Gordon Town, Harris 11511. Claremont, Hitchcock 9515. Ewarton, Hitchcock 9412.

Dominican Republic: Río San Juan, Miller 1143. Sosúa, Ekman H 14521. Los Haitises, Ekman H 15494. Samaná, Ekman H 14889, H 14931, H 14989. 
Puerto Rico: Mayaguez, Heller 4373, 4488; Chase 6159; Holm in 1915.

Leeward Islands: Antigua, Hitchcock 16381; Box 66; Rose 3391; Wullschlaegel 618. Guadeloupe, Duss 3175; Hitchcock 16399. Dominica, Jones 43 ; Hitchcock 16429.

Windward Islands: Martinique, Duss 544; Hitchcock 16463. Barbados, Eggers 7128; Hitchcock 16498. St. Lucia, Glasgow 10; Hitchcock 16495; Kemp 39. Grenada, Broadway in 1904; Hitchcock 17680 .

Trinidad: Port-of-Spain, Britton and Hazen 1690; Hitchcock 9965. St. Anns, Broadway 7783. San Fernando, Broadway 7950.

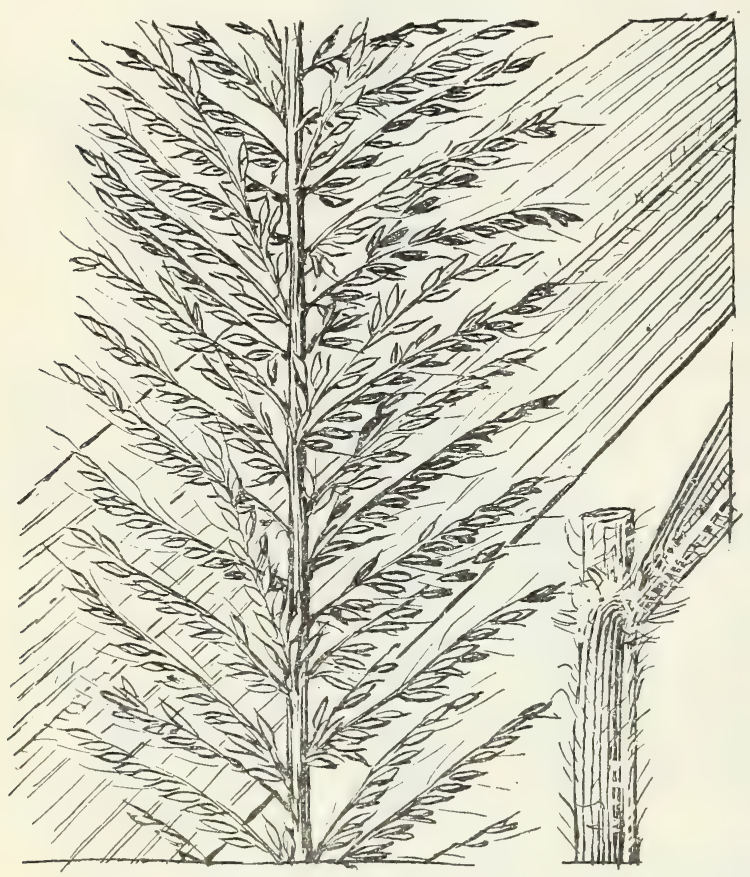

FIGURE 306.-Setaria poiretiana, $\times 1$ (Pringle 3921).

Tobago: Broadway 4335, 4737; Hitchcock 10225, 10251.

\section{Setaria poiretiana}

(Schult.) Kunth,

Rév. Gram. 1:

47. 1829

Panicum elongatum Poir., in Lam., Encycl. Sup. 4: 278. 1816. Not $P$. elongatum Salisb., 1796. Brazil.

Panicum sulcatum Bertol., Opusc. Sci. 4: 230. 1820; Excerpt. 14. 1820. Not $P$. sulcatum Aubl., 1775. Brazil.

Setaria sulcata Raddi, Agrost. Bras. 50. 1823. Based on Panicum sulcatum Bertol.

Panicum poiretianum Schult., Mant. 2: 229. 1824. Based on $P$. elongatum Poir.

Chaetochloa poiretiana Hitchc., Contrib. U. S. Natl. Herb. 22: 159. 1920.

Tufted perennial; culms erect, 1 to $1.5 \mathrm{~m}$ tall; sheaths papillose-hispid; blades strongly plicate, flat, as much as $1 \mathrm{~m}$ long and $10 \mathrm{~cm}$ wide, narrowed toward each end, the base resembling a petiole; panicles erect, densely flowered, commonly purple, long-exserted, as much as $60 \mathrm{~cm}$ long and $10 \mathrm{~cm}$ wide, the branches ascending, irregularly clustered, approximate, usually somewhat falcate, the lower usually 3 to $5 \mathrm{~cm}$ long; spikelets secund on the branches, narrowly ellipsoid, about $3 \mathrm{~mm}$ long (fig. 306).

Moist woods, Mexico to Brazil; Trinidad and Tobago. Called gamalote in Trinidad, where it is a troublesome weed in cocao groves.

Trinidad: Port-of-Spain, Hitchcock 9978, 10043 (Amer. Gr. Nat. Herb. 604), 10171.

ToвAgo: Hitchcock 10282. 
3. Setaria palmifolia (Willd.) Stapf, Jour. Linn. Soc. Bot. 42: 186. 1914.

Palmgrass.

Panicum plicatum Willd., Enum. Pl. 1033. 1809. Not P.plicatum Lam., 1791. India.

Panicum palmifolium Willd.; Poir., in Lam., Encycl. Sup. 4: 282. 1816. Probably India.

Panicum plicatum var. haitiense Kunth; Griseb., Fl. Brit. W. Ind. 547. 1864. Haiti.

Chamaeraphis palmifolia Kuntze, Rev. Gen. Pl. 2: 771. 1891.

Chaetochloa palmifolia Hitchc. and Chase, Contrib. U. S. Natl. Herb. 18: 348. 1917.

Perennial; culms 1 to $1.5 \mathrm{~m}$ tall; sheaths papillose-hispid or glabrate; blades strongly plicate, flat, pubescent or glabrate, elliptic, narrowed to a petiolelike base, as much as $50 \mathrm{~cm}$ long and $6 \mathrm{~cm}$ wide; panicles loose and open, as much as $40 \mathrm{~cm}$ long, the branches ascending or spreading, scattered, somewhat distant, especially below, 5 to $10 \mathrm{~cm}$ long, compound; spikelets lanceolate, a cute, about $3 \mathrm{~mm}$ long, closely arranged on short branchlets appressed along the main branches, forming interrupted compound racemes, the bristles inconspicuous, usually not more than twice as long as the spikelets, often short and imperfectly developed;

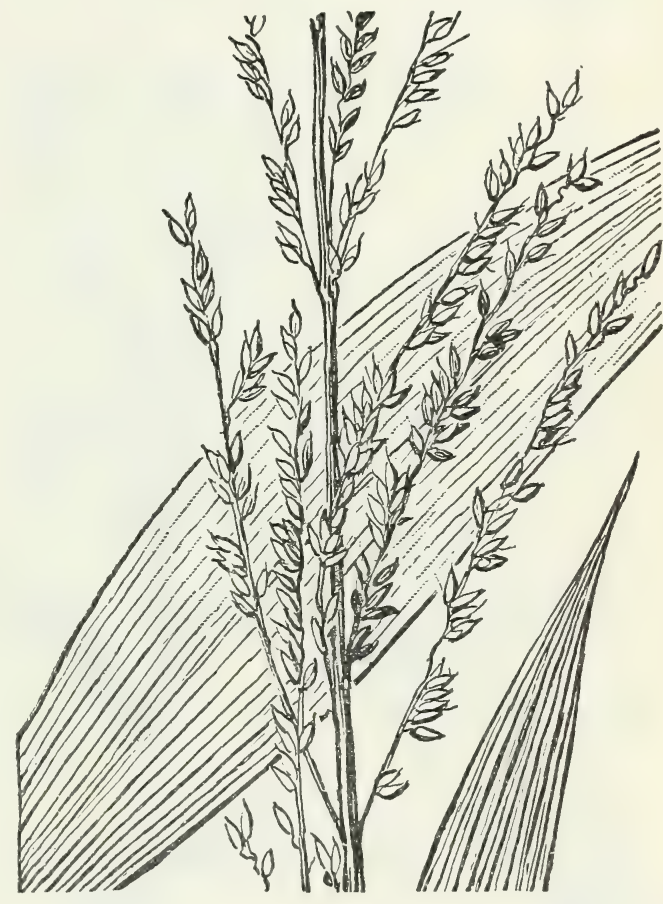

FIGURE 307.-Setaria palmifolia, $\times 1$ (Hitchcock 9727). sterile floret with a palea but without stamens (fig. 307).

Rocky woods and shady banks, often growing in large colonies, a native of southeastern Asia; introduced in Jamaica. The varietal name ascribed by Grisebach to Kunth was probably a herbarium name. It is not found in any of Kunth's works so far as we know. The name Panicum plicatum Lam. has been applied to this species by many authors, $P$. palmifolium Willd. being based upon $P$. plicatum as described by Willdenow. ${ }^{82}$ Panicum palmaefolium Koen., ${ }^{83}$ an earlier nomen nudum, is probably the same species.

JAmaICA: Hardware Gap, Ridley in 1916; Harris 10911. St. Helens Gap, Maxon and Killip 586. Catherines Peak, Hitchcock 9727. Buff Bay, Hitchcock 9762. Buff River, Orcutt 3786. Gordon Town,

82 Enum. Pl. 1033. 1809.

83 Naturf. 23: 208. 1788. 
Hitchcock 9320 (Amer. Gr. Nat. Herb. 605); Hart 815. Mount Hybla, Harris 11535. Cinchona, Hitchcock 9719; Harris and Lawrence 15232. Castleton, Harris 11286. Morces Gap, Nichols 37.

4. Setaria paniculifera (Steud.) Fourn.; Hemsl., Biol. Centr. Amer. Bot. 3: 505. 1885.

Panicum sulcatum Aubl., Pl. Guian. 1: 50. 1775. Not Setaria sulcata Raddi, 1823, based on Panicum sulcatum Bertol., 1820, which is Setaria poiretiana. French Guiana.

Panicum paniculiferum Steud., Syn. Pl. Glum. 1: 54. 1854. Mexico.

Chamaeraphis paniculifera Kuntze, Rev. Gen. Pl. 2: 770. 1891.

Chamaeraphis sulcata

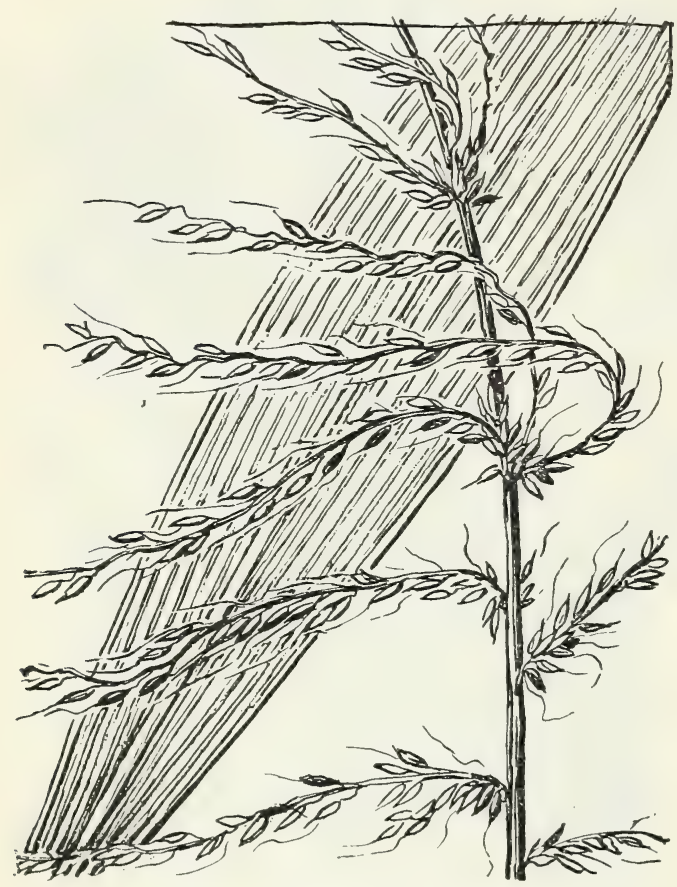

Figure 308.-Setaria paniculifera, $\times 1$ (Collins and Goll 09). Kuntze, Rev. Gen. Pl. 2: 770. 1891.

Chaetochloa sulcata Hitchc., Contrib. U. S. Natl. Herb. 17: 260. 1913. Setaria sulcata A. Camus, Bull. Mus. Hist. Nat. 30: 108. 1924. Based on Panicum sulcatum Aubl. Not S. sulcata Raddi, 1823.

Robust perennial; culms as much as $4 \mathrm{~m}$ tall, glabrous; sheaths papillose-hispid all over or only at the margin and on the collar; blades flat, strongly plicate, somewhat scabrous, as much as $1 \mathrm{~m}$ long and 10 $\mathrm{cm}$ wide at the middle, tapering toward each end, the lower into a long petiole-like base; panicles green or purplish, often very large, as much as $70 \mathrm{~cm}$ long, the branches ascending, finally spreading, as much as $20 \mathrm{~cm}$ long, these branching and rebranching, the panicle often becoming loose and open; spikelets usually loosely arranged, elliptic-lanceolate, about $3 \mathrm{~mm}$ long, obscurely nerved, scabrous-pubescent, the flexuous bristles as much as $15 \mathrm{~mm}$ long (fig. 308).

Moist ground and shady banks, southern Mexico and Guadeloupe to Colombia. Often called palmgrass; in Tobago called gamalote (not the gamalote of Trinidad, which is $S$. poiretiana).

Leeward Islands: Guadeloupe, Duss 3185. Dominica, Jones 3.

Windward Islands: Martinque, Duss 4656. Grenada, Broadway 123; Buckmire 1382.

TоваGо: Eggers 5682; Hitchcock 10276. 
5. Setaria lutescens (Weigel) F. T. Hubb., Rhodora 18: 232.1916. YELLOW BRISTLEGRASS.

Panicum lutescens Weigel, Obs. Bot. 20. 1772. Germany.

Chaetochloa lutescens Stuntz, U. S. Dept. Agr., Bur. Plant Indus. Inventory Seeds 31: 36, 86. 1914.

This species has been commonly known as Panicum glaucum, Setaria glauca, and Chaetochloa glauca. However, Panicum glaucum of Linnaeus should apply to the species usually known as Pennisetum typhoideum L. Rich. or Penicillaria spicata Willd., commonly called in the United States pearl millet. ${ }^{84}$ The following synonyms are based on Panicum glaucum L. as to name but refer to Setaria lutescens as to plant.

Setaria glauca Beauv., Ess. Agrost. 51, 169, 178. 1812.

Chamaeraphis glauca Kuntze, Rev. Gen. Pl. 2: 767. 1891.

Ixophorus glaucus Nash, Bull. Torrey Bot. Club 22: 423. 1895.

Chaetochloa glauca Scribn., U. S. Dept. Agr., Div. Agrost. Bull. 4: 39. 1897.

Erect annual, often much branched at base, the culms becoming geniculate below or in open ground spreading or even prostratespreading; culms rather succulent below, 25 to $50 \mathrm{~cm}$ tall (in the West Indies); sheaths smooth, compressed-keeled; blades flat, 5 to $20 \mathrm{~cm}$ long, 4 to $7 \mathrm{~mm}$ wide, scabrous on the upper surface, glabrous beneath; panicles dense, nearly cylindric, spikelike, yellow at maturity, mostly 2 to $8 \mathrm{~cm}$ long, almost $1 \mathrm{~cm}$ thick (including the bristles); bristles antrorsely scabrous, yellow, the longer ones 2 to 3 times as long as the spikelet; spikelets about $3 \mathrm{~mm}$ long, strongly convex on one side; fertile floret marked with numerous transverse ridges (fig. 309).

A common weed in cultivated soil and waste places in the eastern United States, rare in the Tropics; introduced from Europe.

Jamaica: Cinchona, Hart 740; Hitchcock 9702; Harris 11272, 11457. Resource, Perkins 1141.

Haitr: Pétionville, Ekman H 3233, H 10027. Kenskoff Mountain, Buch 1452. Furcy, Leonard 4388, 4394, 4424, 4452.

6. Setaria geniculata (Lam.) Beauv., Ess. Agrost. 51, 178.1812. KNOTROOT BRISTLEGRASS.

Panicum geniculatum Lam., Encycl. 4: 727 (err. typ. 737). 1798. Guadeloupe. Rico.

Cenchrus parviflorus Poir., in Lam., Encycl. 6: 52. 1804. Puerto

Panicum imberbe Poir., in Lam., Encycl. Sup. 4: 272. 1816. North America and Brazil.

Setaria berteroniana Schult., Mant. 2: 276. 1824. Santo Domingo. Rico.

Setaria ventenatii Kunth, Rév. Gram. 1: 251. pl. 37. 1830. Puerto

Setaria glauca var. imberbis Griseb., Fl. Brit. W. Ind. 554. 1864.

Chaetochloa geniculata Millsp. and Chase, Field Mus. Bot. 3: 37. 1903.

These names have been referred to Panicum, Setaria, Chaetochloa, and Chamaeraphis. ${ }^{85}$

\footnotetext{
${ }^{84}$ For further discussion see Chase, Amer. Jour. Bot. 8: 41. 1921; and Contrib. U. S. Natl. Herb. 22: 216. 1921.

${ }_{85}$ For full synonymy see Hitchcock, U. S. Dept. Agr., Misc. Pub. 200: 943. 1935.
} 


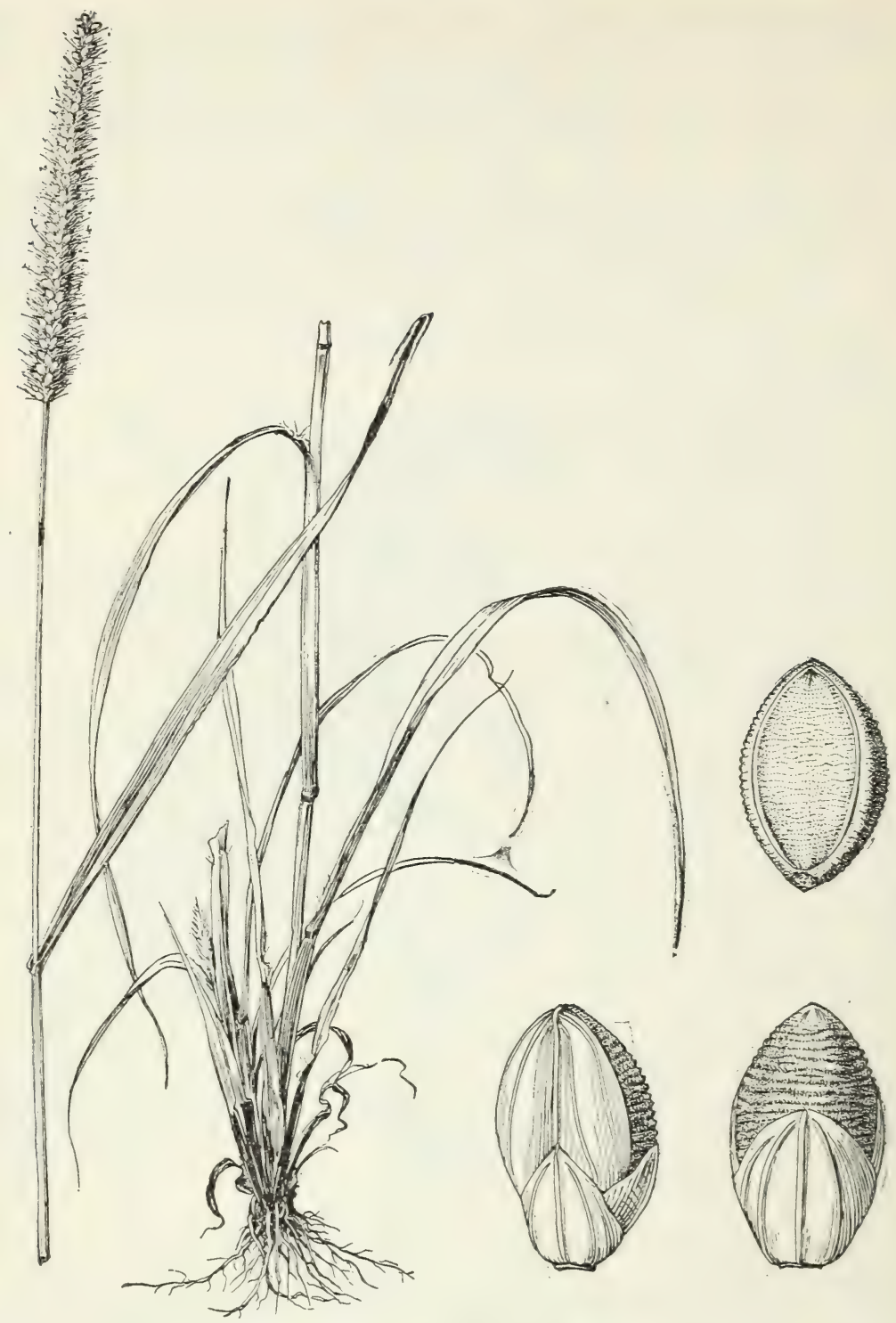

Figure 309.-Setaria lutescens. Plant, $\times \frac{1}{2}$; two views of spikelet, and floret, $\times 10$ (Chase 2986).

Perennial, producing short knotty branching rhizomes as much as $4 \mathrm{~cm}$ long; culms erect to nearly prostrate, as much as $1 \mathrm{~m}$ tall, sometimes dwarfed, the base usually hard and wiry, often more slender than the upper part; blades flat, scabrous, often more or less villous toward the base on the upper surface, commonly 10 to $20 \mathrm{~cm}$ long and 4 to $8 \mathrm{~mm}$ wide; panicle erect, cylindric, densely flowered, rounded or truncate (not narrowed), at summit, 1 to $10 \mathrm{~cm}$ long or in robust specimens longer, 4 to $8 \mathrm{~mm}$ thick (excluding the bristles), yellow, purple, tawny, or greenish; bristles mostly 8 to 12 , yellow or 
purple, 1 to 3 times as long as the spikelets, sometimes longer; spikelets 2 to 2.5 or even $3 \mathrm{~mm}$ long, ovoid, planoconvex; fertile lemma transversely rugose with close narrow ridges (fig. 310 ).

This species is exceedingly variable in general appearance, due to the variation in the color and length of the bristles, which are long early in the season and in cultivated soil and short in plants in dry situations.

Open ground pastures, cultivated soil, and moist ground, United States to Argentina; common at low and medium altitudes. To be found on all the West Indian islands.

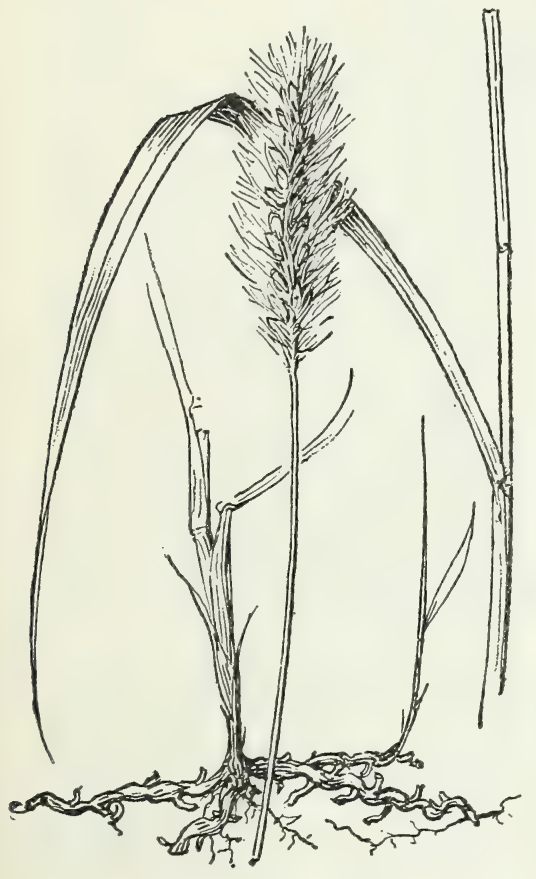

Figure 310.-Setaria geniculata, $\times 1$ (Chase 2981).

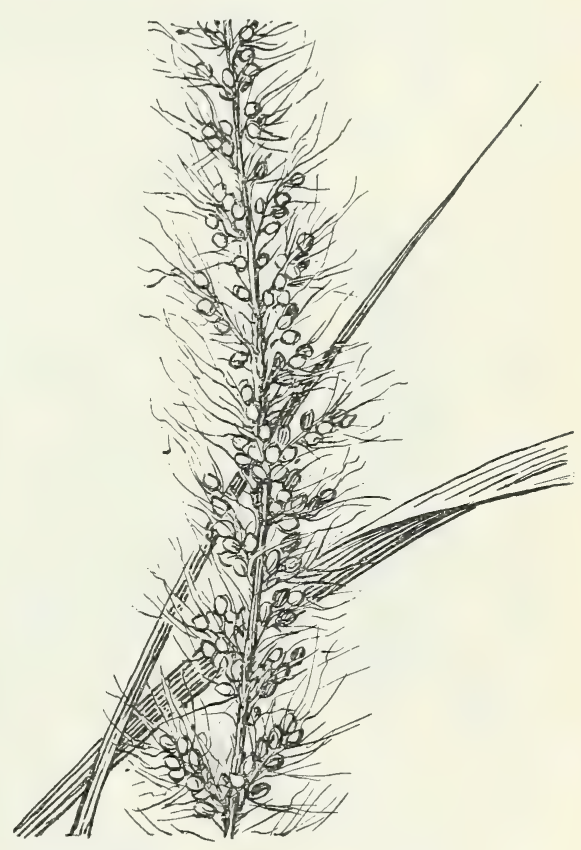

FiguRE 311.-Setatia tenax, $\times 1$ (Tracy 9090).

7. Setaria tenax (L. Rich.) Desv., Opusc. 78. 1831.

Panicum tenax L. Rich., Act. Soc. Hist. Nat. Paris 1: 106.1792. Cayenne.

Setaria biconvexa Griseb., Fl. Brit. W. Ind. 555. 1864. Trinidad.

Chaetochloa tena.r Hitchc., Contrib. U. S. Natl. Herb. 22: 176. 1920.

Perennial; culms scabrous below the panicle, 1 to $1.5 \mathrm{~m}$ tall, often geniculate at base; sheaths villous on the margin, densely hispid on the collar; ligule densely pilose, 2 to $3 \mathrm{~mm}$ long; blades flat, as much as $35 \mathrm{~cm}$ long and $2 \mathrm{~cm}$ wide, narrowed at base, acuminate; panicles rather densely flowered, narrowed toward summit but not attenuate, 15 to $30 \mathrm{~cm}$ long, 2 to $3 \mathrm{~cm}$ wide, the branches ascending, the lower about $2 \mathrm{~cm}$ long; bristles 1 or 2 below each spikelet, 1 to $2 \mathrm{~cm}$ long, flexuous, retrorsely scabrous and often also antrorsely toward the base, sometimes barblets directed both ways intermixed, pale or tawny, becoming implicate and somewhat one-sided with age; spike- 
lets subspheric, about $2 \mathrm{~mm}$ long, very turgid on one side and somewhat convex on the other; fertile lemma rather indistinctly crosswrinkled (fig. 311).

Savannas, rocky banks, and open woods, Mexico and the West Indies to Brazil.

This was described by Grisebach ${ }^{86}$ as Setaria onurus and by Hitcheock and Chase ${ }^{87}$ as Chaetochloa onurus, but a reconsideration of the type leads to the conclusion that the original Panicum onurus Willd. in Trin. ${ }^{88}$ from Montevideo, collected by Sello, is a different species, later described as Setaria caespitosa Hack. and Arech., not known from North America.

Cuba: Las Mangas, Ekman 13069. Bahía Honda, Wilson 9411, Triscornia, Tracy 9090. Campo Florido, Léon 4145. Madruga. Léon 3456. San Miguel de los Baños, Léon 8911. Yumuri, Rugel 880. Guanabacoa, Wright 3474. Soledad, Hitchcock 23327. Sancti Spíritus, Léon 828. Baraguá, Hitchcock 23349; Walker in 1925.

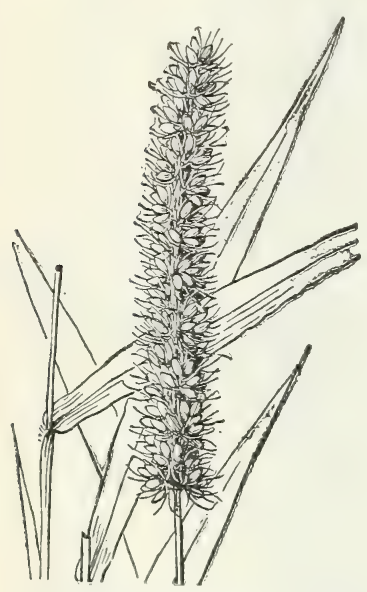

FIGURE 312.-Setaria verticillata, $\times 1$ (Steele). Zaza del Sur, Sergius 2712. Manati, Léon 5684. Woodfred, Shafer 3020. Guara, Hitchcock 23392. Without locality, Wright 3887.

Jamaica: Two-Mile-Wood Pen, Harris 12065. New Forest, Hitchcock 9891 (Amer. Gr. Nat. Herb. 608). Lititz, Harris 11657. Yardley Chase, Harris 9673.

Haiti: Cap-à-Faux, Ekman H 10848. Tortuga Island, Ekman H 4136.

Windward Islands: Barbados, Dash 603.

Trinidad: Port-of-Spain, Hitchcock 9991, 10000 (Amer. Gr. Nat. Herb. 609). St. Joseph, Hitchcock 10180. St. Anns, Broadway 7368 .

8. Setaria verticillata (L.) Beauv., Ess. Agrost. 51, 178. 1812. BUR BRISTLEGRASS.

Panicum verticillatum L., Sp. Pl. ed. 2. 1: 82. 1762. Europe.

Ixophorus verticillatus Nash, Bull. Torrey Bot. Club 22: 422.1895.

Chaetochloa verticillata Scribn., U. S. Dept. Agr., Div. Agrost. Bull. 4: 39.1897.

Annual, often much branched at base and geniculate-spreading; blades flat, rather thin, usually 10 to $20 \mathrm{~cm}$ long and 5 to $10 \mathrm{~mm}$ wide; scabrous on both surfaces, often more or less pilose; panicles erect but not stiff, subcylindric, more or less lobate or interrupted, especially toward base, mostly 5 to $15 \mathrm{~cm}$ long, 7 to $15 \mathrm{~mm}$ wide; bristles 1 to 3 times as long as the spikelets, somewhat flexuous, retrorsely scabrous to base; spikelets about $2 \mathrm{~mm}$ long, oblong-elliptic, not very turgid on the convex side; fertile lemma finely cross-wrinkled (fig. 312).

Fields and waste places, temperate and warm regions of both hemispheres, introduced in America. Called in Cuba "pega-pega" and "amor seco."

Bermuda: Collins 161; Brown and Britton 116, 302; Harshberger in 1905; Millspaugh 99, 127; Brown 676.

${ }^{87}$ Contrib. U. S. Natl. Herb. 18: 349. 1917. First published by Scribn. and Merrill, U. S. Dept. Agr., 
Cuba: Habana, Curtiss 693; Hitchcock 491; Léon 555; Liєbmann 346, 347, 348; Ekman 110, 13120.

9. Setaria scandens Schrad.; Schult., Mant. 2: 279. 1824.

Panicum scandens Trin., Gram. Pan. 166. 1826.

Chaetochloa scandens Scribn., in Donn. Smith, Enum. Pl. Guat. 5: 91. 1899.

Slender annual, much branched below, erect or soon geniculatespreading; culms sometimes rooting at the lower nodes, as much as $80 \mathrm{~cm}$ long; blades flat, linear-lanceolate, as much as $10 \mathrm{~cm}$ long and $1 \mathrm{~cm}$ wide, scabrous, especially on upper surface, usually sparsely, sometimes densely, pilose on both surfaces; panicles slender, erect, cylindric, densely flowered, sometimes interrupted, especially at base, often purplish, as much as $8 \mathrm{~cm}$ long, mostly less than $5 \mathrm{~mm}$ thick, the axis softly pubescent and also longvillous, the scattered hairs often longer than the spikelets; bristles somewhat flexuous but not becoming implicate, 1 to 2 times as long as the spikelets, antrorsely scabrous except near the tip, there more or less retrorsely scabrous; spikelets about 1.5 $\mathrm{mm}$ long, ovoid, turgid on the convex side; fertile lemma transversely striate or weakly rugose (fig. 313).

Open ground, Guatemala to Paraguay; Cuba, Jamaica, Hispaniola. Originally described from a garden specimen in Vienna, the native country unknown. A weed in fields and waste places in Jamaica where it appears to be introduced.

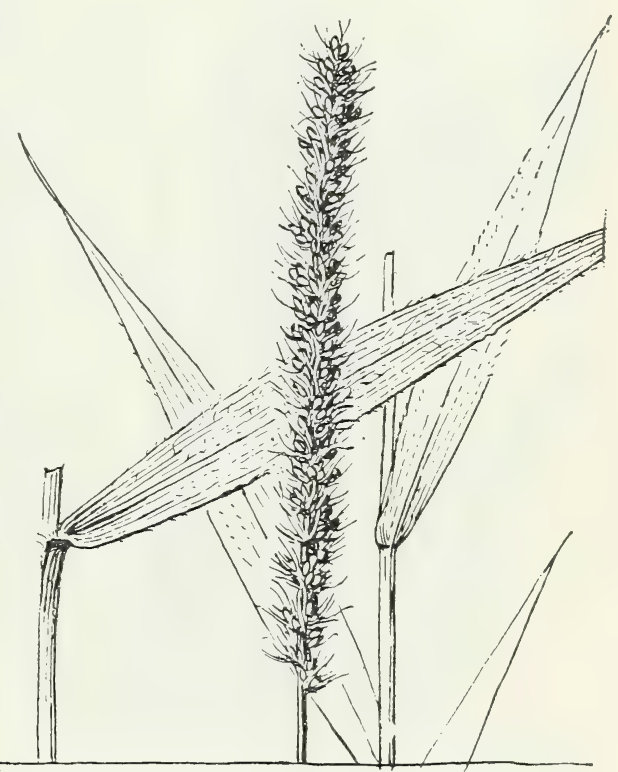

Figure 313,-Setaria scandens, $\times 1$ (Hitchcock 9723).

Cuba: Sierra de Nipe, Ekman 9798.

Jamaica: Cinchona, Hitcheock 9718, 9723. Portland Gap, Orcutt 5419. Killits, Harris 11157. Mount Hybla, Harris 11380. Chapelton, Ridley 58. Malvern, Harris 9739. 'Troy, Hitchcock 9812. Ewarton, Hitchcock 9408. Davids Hill, Harris 12668. Resource, Perkins 1140. Arntully, Orcutt 2732, 3063. Gordon Town, Hart 796, 1487. Haiti: Marmelade, Nash 693; Leonard 8112, 8257. Port-au-Prince, Cook, Scofield, and Doyle 62, 67; Ekman H 6633; Buch 1682, 1738. Caille la Croix, Leonard 7964. Dondou, Leonard 8565. Ennery, Leonard 8853, 9498. Furcy, Leonard 4555. Mission, Leonard 3705. Pétionville, Ekman H 1354. Morne Basil, Ekman H 2487. Bom bardopolis, Leonard 13475.

Dominican Republic: Lagunas de Cenobí, Valeur 10. San José de Ocoa, Ekman H 12029. 
10. Setaria tenacissima Schrad.; Schult., Mant. 2: 279. 1824. Brazil.

Panicum tenacissimum Nees, Agrost. Bras. 238. 1829.

Chaetochloa tenacissima Hitchc. and Chase, Contrib. U. S. Natl. Herb. 18: 352. 1917.

Slender annual, mostly simple or little branched; culms erect, 1 to 2 $\mathrm{m}$ tall, leaning on or clambering over other vegetation; blades flat, very scabrous on both surfaces and more or less pubescent, especially beneath, mostly 10 to $15 \mathrm{~cm}$, sometimes as much as $20 \mathrm{~cm}$ long, mostly not more than $8 \mathrm{~mm}$ wide, tapering to a long-acuminate apex, rather abruptly narrowed at base; panicles somewhat nodding or

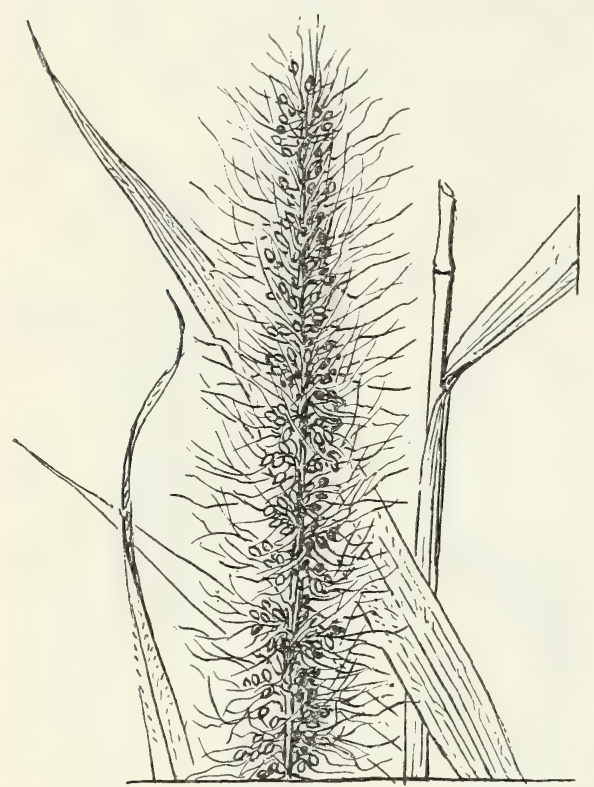

FIGURE 314.-Setaria tenacissima, $\times 1$ (Hitcheock 10002, Amer. Gr. Nat. Herb. 610).

flexuous, rather densely flowered and tapering toward the summit, somewhat interrupted toward the base, as much as $15 \mathrm{~cm}$ long and $1 \mathrm{~cm}$ thick (excluding bristles), the axis densely pubescent and sparsely villous with long weak hairs; bristles flexuous, becoming implicate, about $1 \mathrm{~cm}$ long, scabrous, antrorsely below, retrorsely above; spikelets about $1.5 \mathrm{~mm}$ long, often dark purple; fertile lemma transversely rugose with numerous fine ridges (fig. 314).

Brushy hillsides, Central America and West Indies to Brazil.

Haitr: St. Michel de l'Atalaye, Leonard 8053.

Dominican REPUBIC: Lagunas de Cenobí, Valeur 12; Ekman H 12768. B onao, Ekman H 11481.

Puerto Rico: Utuado, Sintenis 6498.

Trinidad: Port-of-Spain, Hitchcock 10002 (Amer. Gr. Nat. Herb. 610).

11. Setaria magna Griseb., Fl. Brit. W. Ind. 554. 1864. Jamaica, Purdie.

Giant BRISTlegrass.

Chamaeraphis magna Beal, Grasses N. Amer. 2: 152. 1896.

Chaetochloa magna Scribn., U. S. Dept. Agr., Div. Agrost. Bull. 4: 39. 1897.

Robust erect annual, usually not branched at base, sparingly branched above, the branches erect; culms as much as $4 \mathrm{~m}$ tall, rarely taller, and $2 \mathrm{~cm}$ thick at base; blades flat, scabrous, as much as 50 $\mathrm{cm}$ long and $3.5 \mathrm{~cm}$ wide; panicles densely flowered, nodding, often interrupted at base, tapering at each end, as much as $40 \mathrm{~cm} \mathrm{long}$ and $3 \mathrm{~cm}$ thick, those of the branches much smaller; bristles somewhat flexuous, 1 or 2 below each spikelet, 1 to $2 \mathrm{~cm}$ long; spikelets about $2 \mathrm{~mm}$ long; fertile lemma smooth (fig. 315). 
Marshes and wet places along the coast, eastern United States, West Indies, Costa Rica.

Bermuda: Munro in 1864. The species is not known to grow in Bermuda now.

JAMAICA: Black River, Hitchcock 9646.

Puerto Rico: Campo Alegre, Chase 6800. Without locality, Eggers 709.

Windward Islands: Martinique, Duss 3918.

12. Setaria viridis (L.) Beauv., Ess. Agrost. 51, 178. 1812.

Green BRISTlegrass.

Panicum viride L., Syst. Nat. ed. 10. 2: 870. 1759. Europe.

Chamaeraphis viridis Millsp., Fl. W. Va. 466. 1892.

Ixophorus viridis Nash, Bull. Torrey Bot. Club 22: 423. 1895.

Chaetochloa viridis Scribn.,U. S. Dept. Agr., Div. Agrost. Bull. 4: 39. 1897.

Annual, sometimes geniculatespreading; culms 20 to $50 \mathrm{~cm}$ tall; blades fiat, usually less than $15 \mathrm{~cm}$ long, commonly less than $1 \mathrm{~cm}$ wide; panicle densely flowered, green or purple, tapering a little at the summit (the smaller ones ovate), 5 to $10 \mathrm{~cm}$ long, commonly 5 to 8 $\mathrm{mm}$ thick (excluding bristles); bristles 1 to 3 below each spikelet, mostly three to four times as long as the spikelet; spikelets 2 to $2.5 \mathrm{~mm}$ long, elliptic, not $\mathrm{much}$ turgid on the convex side; fertile lemma finely transversely wrinkled.

Cultivated soil and waste ground, temperate regions of both hemispheres, rare in the Tropics; introduced in America.

Bermuda: Collins 159, 160.

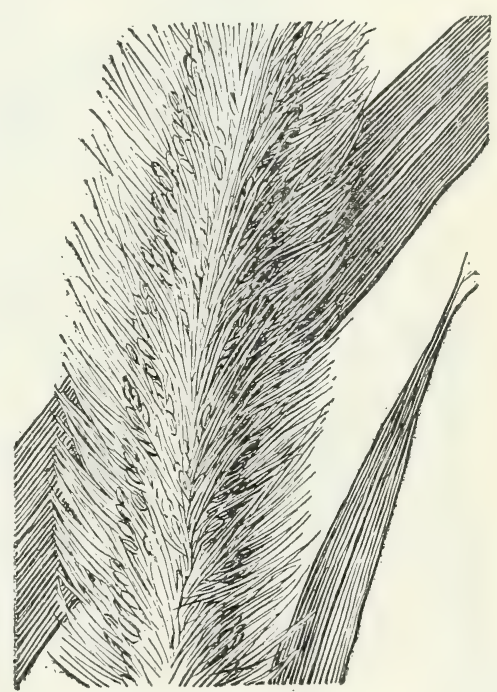

Figure 315.-Setaria magna, $\times 1$ (Nash 1279).

Setaria italica (L.) Beauv., Ess. Agrost. 51, 170, 178.1812. The common millet, differing from $S$. viridis in the larger size, the panicle often lobed or interrupted, is said by Grisebach ${ }^{89}$ to be naturalized in Jamaica. In the herbarium of the New York Botanical Garden is a specimen from Martinique (Duss 1315).

13. Setaria corrugata Schult., Mant. 2: 276. 1824.

Panicum corrugatum Ell., Bot. S. C. and Ga. 1: 113.1816. Georgia.

Chamaeraphis corrugata Kuntze, Rev. Gen. Pl. 2: 770.1891.

Chaetochloa corrugata Scribn., U. S. Dept. Agr., Div. Agrost. Bull. 4: 39.1897.

Chaetochloa hispida Scribn. and Merr., U. S. Dept. Agr., Div. Agrost. Bull. 21: 25. f. $13.1900 . \quad$ Cuba, Wright in 1865.

Setaria hispida Schum., Just's Bot. Jahresber. $28^{1}$ : 417.1902.

30 F!. Brit. W. Ind. 554. 1864. 
Annual, branched at base, erect or geniculate-spreading; culms scabrous or the lower part smooth, 50 to $100 \mathrm{~cm}$ tall; sheaths compressed-keeled, scabrous at least toward the summit, sometimes appressed-pilose; blades flat, scabrous, usually 15 to $25 \mathrm{~cm}$ long and 3 to $5 \mathrm{~mm}$ wide; panicles cylindric, densely flowered, usually 3 to $5 \mathrm{~cm}$ long, the axis densely hispid-scabrous and also rather densely villous; spikelets about $2 \mathrm{~mm}$ long, the bristles about 5 to $6 \mathrm{~mm}$ long; fertile lemma coarsely transversely rugose (fig. 316 ).

Sandy woods, southeastern United States; Cuba.

Cuba: La Grifa, Wright in 1865. Laguna Santa Bárbara, Ekman 18118. Isla de Pinos, Britton and Wilson 14817.

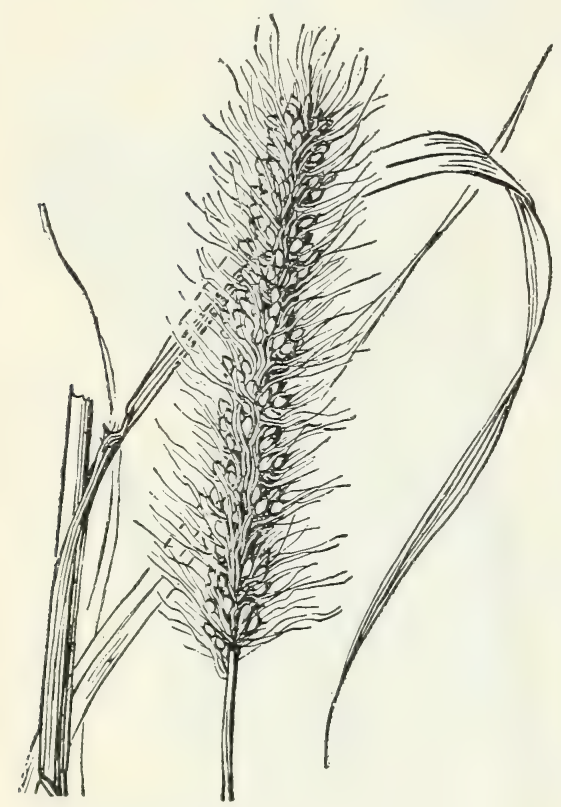

FIGURE 316.-Setaria corrugata, $\times 1$ (Pollard and Collins 253).

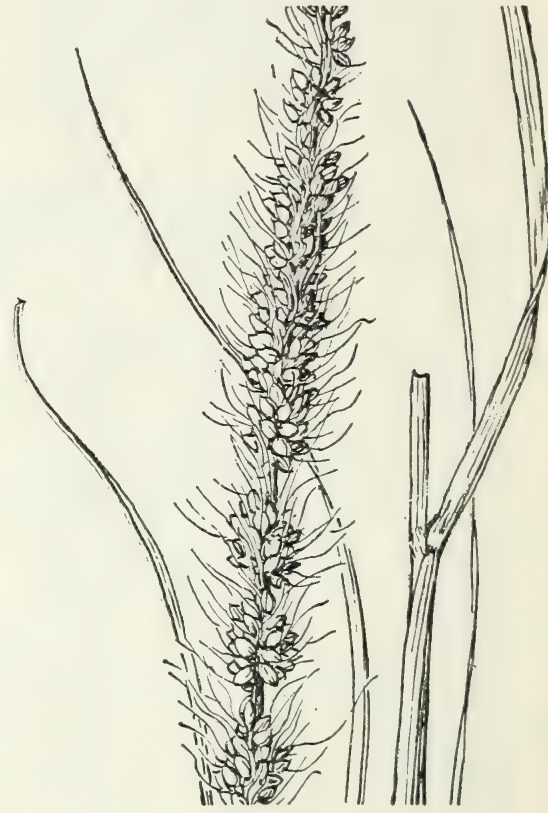

Figure 317.-Setaria macrostachya, $\times 1$ (Hitchcock 13605)

14. Setaria macrostachya H. B. K., Nov. Gen. et Sp. 1: 110.1815. Mexico.

Prairie bristlegrass.

Chaetochloa macrostachya Scribn. and Merr., U. S. Dept. Agr., Div. Agrost. Bull. 21: 29. f. 16.1900.

Perennial, tufted, usually pale or glaucous; culms erect or geniculate at base, scabrous below the panicle, 40 to $120 \mathrm{~cm}$ tall; sheaths more or less compressed-keeled; blades flat or folded, 15 to $40 \mathrm{~cm}$ long, 3 to $5 \mathrm{~mm}$ wide; panicles erect, spikelike, mostly 5 to $10 \mathrm{~cm}$ long, slightly tapering above but not attenuate, densely flowered, or somewhat interrupted or lobed below; spikelets about $2 \mathrm{~mm}$ long, the bristles 5 to $10 \mathrm{~mm}$ long; fertile lemma rather sharply but finely marked with cross-wrinkles (fig. 317).

Open dry ground and dry woods, southwestern United States to Oaxaca; Hispaniola. 
Harti: Fond Parisien, Leonard 4155, 4155a. Cabaret, Leonard 12038.

Dominican Republic: Jarabaco, Ekman H 14161.

15. Setaria setosa (Swartz) Beauv., Ess. Agrost. 51, 171, 178.1812. Panicum setosum Swartz, Prodr. Veg. Ind. Occ. 22. 1788. Jamaica.

Panicum caudatum Lam., Tabl. Encycl. 1: 171. 1791. "E Brasilio, Commerson, * * * Cayenna, Richard." The type, bearing the name in Lamarck's script, is from Richard.

Panicum brachiatum Poir., in Lam., Encycl. Sup. 4: 282. 1816. Antilles.

Setaria caudata Roem. and Schult., Syst. Veg. 2: 495. 1817.

Setaria elongata Spreng.; Schult., Mant. 2: 280. 1824. Santo Domingo.

Setaria brachiata Kunth, Rév. Gram. 1: 47. 1829.

Panicum paractaenoides Trin., Mém. Acad. St. Pétersb. VI. Sci. Nat. 1: 219. 1834. Crab Island [Vieques].

Panicum dumetorum A. Rich.; Steud., Syn. Pl. Glum. 1: 49.1854. "Antilles" (the type specimen from St. Croix).

Panicum restitutum Steud., Syn. Pl. Glum. 1: 53. 1854. Based on Setaria elongata Spreng.

Setaria setosa rar. caudata Griseb., Fl. Brit. W. Ind. 555. 1864.

Chamaeraphis setosa Kuntze, Rer. Gen. Pl. 2: 768. 1891.

Chamaeraphis caudata Britton, Ann. N. Y. Acad. 7: 264. 1893.

Chaetochloa setosa Scribn., U. S. Dept. Agr., Dir. Agrost. Bull. 4: 39. 1897.

Chaetochloa caudata Scribn., Mo. Bot. Gard. Rept. 10: 52.1899.

Setaria paractaenoides Urban, Repert. Sp. Nor. Fedde 15: 98. 1917.

Perennial; culms erect, often wiry, finally branching, sometimes becoming decumbent or even prostrate and woody at base, with upright branches, mostly not more than $1 \mathrm{~m}$ tall; sheaths often overlapping below; blades flat or folded, rather firm and stiffly spreading, usually pubescent, commonly 15 to $25 \mathrm{~cm}$ long and 6 to $10 \mathrm{~mm}$ wide; panicles mostly narrow, from loosely spikelike to rather open, attenuate at summit, usually 10 to $20 \mathrm{~cm}$ long, the branches short and crowded or ascending and 1 to $2 \mathrm{~cm}$ long, approximate or, especialiy the lower, 1 to $3 \mathrm{~cm}$ distant, these rarely to $\tilde{\mathrm{cm}}$ long and spreading or reflexed; spikelets about $2 \mathrm{~mm}$ long, the bristles 5 to $10 \mathrm{~mm}$ long, sometimes scarcely exceeding the spikelets; fertile lemma acutish, finely but strongly cross-ridged (fig. 318).

This species is exceedingly variable. On dry slopes the culms are sometimes rigid, decumbent, and rooting at the nodes with erect flowering branches. The panicles in such plants may be subspikelike or open with spreading distant branches, 1 to $4 \mathrm{~cm}$ long. In Chase 6519 both forms of panicle were borne on the same individual. Open-panicled plants were described as Panicum brachiatum, $P$. paractaenoides, and $P$. dumetorum. Numerous intermediate specimens connect this form with typical Setaria setosa (fig. 319).

Dry or rocky woods, West Indies to Brazil.

Bahamas: Water Cay, Geogr. Soc. Baltimore 522.

Cuba: Mendoza, Ekman 11484. Cayo Paloma, Shafer 2565. Jauco, Léon 11939, 12385. Santiago de Cuba, Léon 118, 829, 830, 
831, 3946. Guantánamo, Ekman 10233; Léon 3775, 3776; Britton 1930, 2105. Isla de Pinos, Palmer and Riley 1000.

JamaICA: Kingston, Maxon and Killip 310; Hitchcock 9315, 9316 (Amer. Gr. Nat. Herb. 606), 9745; Ridley 61, 62; Alexander Prior in 1853. Long Mountain Road, Harris 11301, 11303. Gordon Town, Harris 11348; 11458; Hitchcock 9325. Musgrave Road, Harris 11479. Spanish Town Road, Harris 9297, 12477. Inverness, Harris 12745. New Forest, Hitchcock 9846. Hope, Harris 11292. Without locality, Hart 826, 829.

Haiti: Port-à-l'Ecu, Leonard 13881. Tortuga Island, Leonard 11325, 11721, 15298; Ekman H 4161. Gonaïve Island, Leonard 3136,

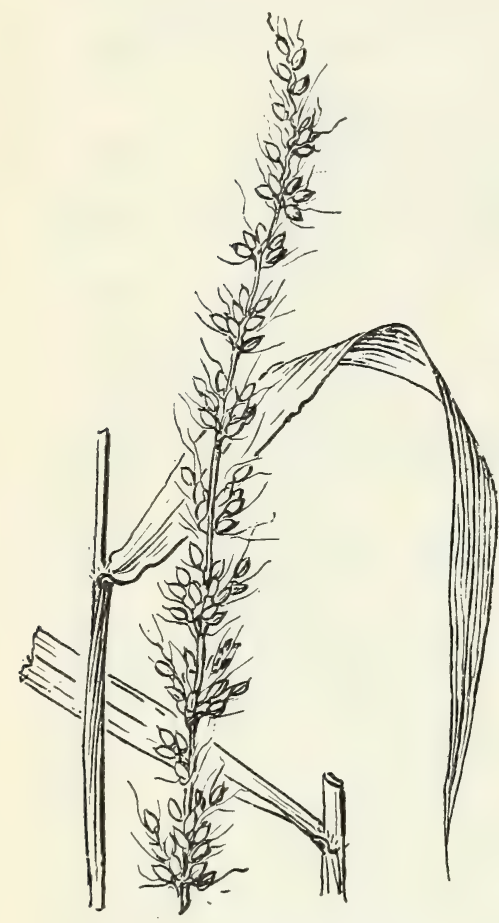

Figure 318.- Setaria setosa, $\times 1$ (Hitchcock 9846).

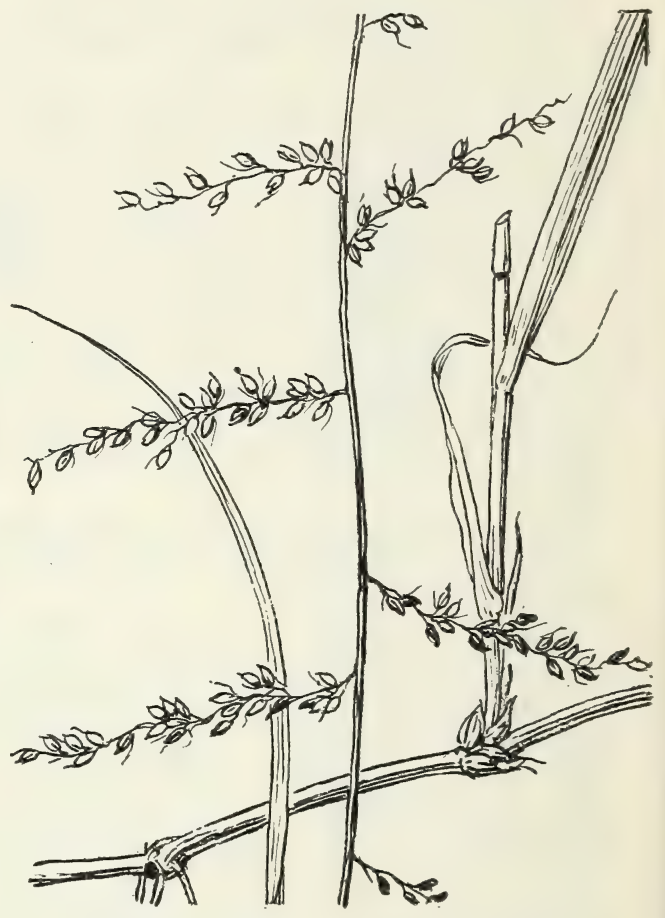

FIgURE 319.-Setaria setosa, open panicled form, $\times 1$ (Chase 6519)

5150, 5200, 5226. Jean Ravel, Leonard 13033. St. Marc, Leonard 2889, 2984. Pétionville, Leonard 4945. St. Michel de l'Atalaye, Leonard 7475a, 7743. Ennery, Leonard 8838. Port-de-Pai, Ekman 3598, 3939. Port-au-Prince, Leonard 15849; Buch 1986. Port-àPiment, Erman H 691.

Dominican Republic: Guayubín, Abbott 939, 951, 954, 1023. Mao, Abbott 1044. Rincón, Fuertes 1378. Santiago, Eggers 2378; Ekman H 15973, H 16520.

Puerto Rico: Coamo, Sintenis 2987, 3197; Chase 6541. Guanica, Sintenis 3577; Britton and Shafer 1901; Johnston 1027; Chase 6518 (Amer. Gr. Nat. Herb. 607), 6519, 6536. Boqueron, Chase 6505. Cabo Rojo, Sintenis 853. Mona Island, Hess 447. Desecheo Island, 
Britton, Cowell, and Hess 1604; Hess 424. Culebra Island, Britton and Wheeler 18, 233.

Virgin Islands: St. Croix, Thompson 343, 446, 488; Ricksecker 407. St. Thomas, Eggers in 1882; Hitchcock 16303, 16312. Virgin Gorda, Fishlock 57. St. John, Britton and Shafer 631.

Leeward Islands: Antigua, Box 109. Guadeloupe, Duss 2698, 3188; Stehlé 289. Nevis, Box $174 . \quad$ Dominica, Jones 34.

TRINIDAD: Chacachacare, Hitchcock 10059.

16. Setaria leiophylla (Nees) Kunth, Rév. Gram. 1: Sup. XII. 1830.

Panicum leiophyllum Nees, Agrost. Bras. 249. 1829. Brazil.

Differing from Setaria setosa in the thinner broader flat, glabrous blades as much as $2 \mathrm{~cm}$ wide; panicle as much as $30 \mathrm{~cm}$ long, the branches ascending or spreading, as much as 3.5 $\mathrm{cm}$ long, overlapping or the lower distant.

Shady places, in damp or rather dry soil, West Indies, rare; Brazil.

HaItr: St. Marc, mountain slopes, common, Leonard 2992.

Puerto Rico: Ponce, dry brushy limestone hillside, Chase 6488. Desecheo, shade of mixed forest, Hess 426.

LeEward Islands: Antigua, shady wooded places, $B o x 16$, rocky damp ground by roadside in woodland, $B o x$ 83 ; woods on dry limestone hill, Box 88 .

17. Setaria rariflora Mikan; Trin., in Spreng., Neu. Entd. 2: 78. 1821 . Brazil.

Setaria vaginata Spreng., Syst. Veg. 4: Cur. Post. 33. 1827. Brazil.

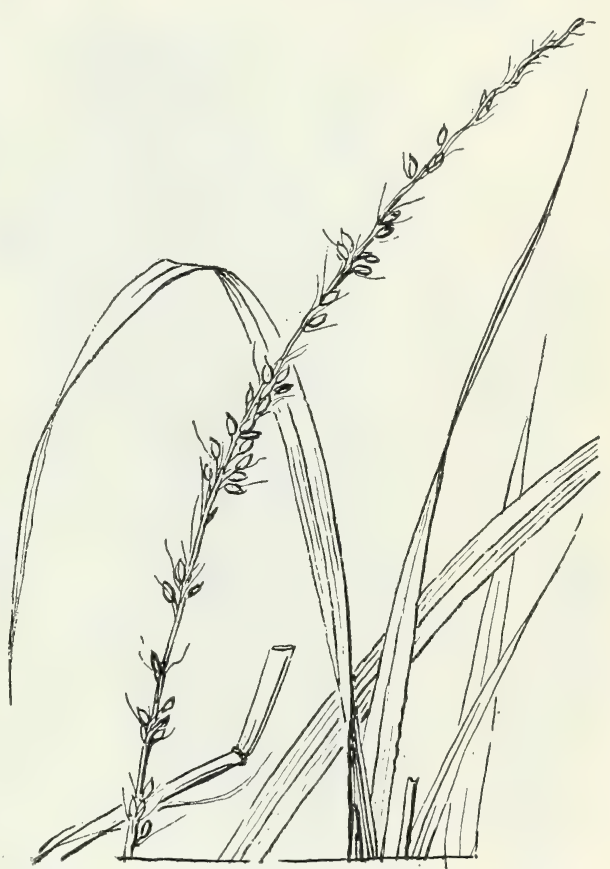

FIgURE 320.-Setaria rariflora, $\times 1$ (Ricksecker 67).

Chaetochloa rariflora Hitchc. and Chase, Contrib. U. S. Natl. Herb. 18: 349.1917.

Perennial; culms erect or decumbent at base, 30 to $60 \mathrm{~cm}$ tall; sheaths pubescent or glabrate, keeled, mostly overlapping; blades elongate, pubescent on both surfaces, narrow at base, usually 2 to 3 $\mathrm{mm}$ wide; panicles narrow, tapering above, 10 to $15 \mathrm{~cm}$ long, often less, the branches ascending, the lower 5 to $10 \mathrm{~mm}$ long, often shorter; spikelets about $2 \mathrm{~mm}$ long, the bristles 4 to $7 \mathrm{~mm}$ long; fertile lemma finely and sharply cross-ridged (fig. 320).

This species differs from $S$. setosa chiefly in the long narrow blades and the usually narrower and less bristly panicle. The second glume is shorter and usually 7-nerved. The two forms are given specific rank because the specimens from Brazil agree in having slender, rather 
lax blades and narrow, few-flowered, interruptedly spikelike panicles like the type of $S$. rariflora. Setaria setosa is confined to the West Indies and adjacent parts of South America.

Dry hills, West Indies to Brazil.

Cuba: Isla de Pinos, Ekman 11728.

Puerto Rico: Boqueron, Chase 6502.

Virgin Islands: St. Croix, Ricksecker 67. St. Thomas, Orsted.

Leeward Islands: Antigua, Wullschlaegel 629.

18. Setaria macrosperma (Scribn. and Merr.) Schum., Just's Bot. Jahresber. 281: 417. 1902.

Chaetochloa macrosperma Scribn. and Merr., U. S. Dept. Agr., Div. Agrost. Bull. 21: 33. f. 18. 1900. Florida.

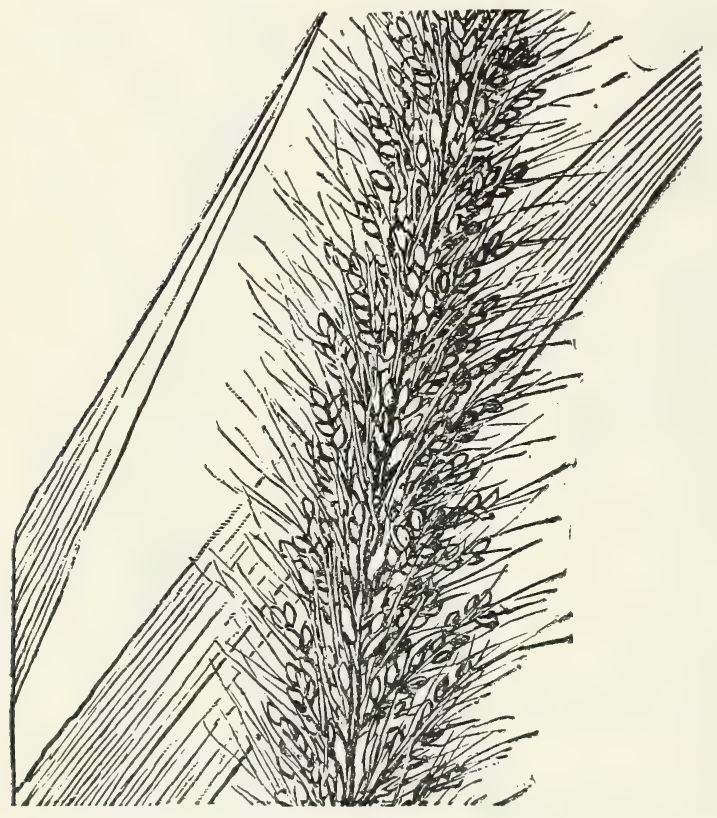

FIGURE 321.-Setaria macrosperma, $\times 1$ (Curtiss 3617 ).

Plant perennial, often in large tufts; culms usually more or less geniculate at base and often rooting at the lower nodes, smooth, scabrous below the panicle, rather stout, 1 to $1.5 \mathrm{~m}$ tall; blades flat, very scabrous on the upper surface, smooth or scaberulous beneath, as much as 50 cm long and $2 \mathrm{~cm}$ wide; panicle rather loose, tapering above, as much as $25 \mathrm{~cm}$ long (the secondary panicles much smaller and more compact), the branches ascending, as much as $2 \mathrm{~cm}$ long, about equally distributed, the panicle thus not interrupted or lobed; spikelets about $3 \mathrm{~mm}$ long, lanceolateovate, the bristles 1.5 to $3 \mathrm{~cm}$ long; fertile lemma acute, finely and not very distinctly cross-wrinkled (fig. 321 ).

Open ground, mostly on coral rock or coral sand, Florida and the Bahamas.

Bahamas: Frozen Cay, Berry Islands, Britton and Millspaugh 2203 (N. Y. Bot. Gard. Herb.).

19. Setaria vulpiseta (Lam.) Roem. and Schult., Syst. Veg. 2: 495. 1817.

Panicum vulpisetum Lam., Encycl. 4: 735 (err. typ. 745). 1798. Santo Domingo.

Chaetochloa vulpiseta Hitche. and Chase, Contrib. U. S. Natl. Herb. 18: 350.1917.

Perennial, branching at base, often in large tufts; culms stout, often decumbent at base, as much as $2 \mathrm{~m}$ tall; blades flat, gradually narrowed from the middle toward both ends, the larger somewhat plaited, 
scabrous, especially beneath, as much as $50 \mathrm{~cm}$ long and $3 \mathrm{~cm}$ wide; panicles rather densely and evenly flowered, tapering toward the apex and often somewhat tapering at base, as much as $30 \mathrm{~cm}$ long and 4 or $5 \mathrm{~cm}$ wide (secondary panicles much smaller, sometimes only $5 \mathrm{~cm}$ long), the branches stiffly ascending or spreading, as much as 2 or 3 $\mathrm{cm}$ long and of about equal length except toward the summit, the axis densely villous; bristles 1 or 2 at the base of each spikelet, slightly flexuous, brownish, antrorsely scabrous, mostly 1 to $2 \mathrm{~cm}$ long, appearing secund on the branches after the fall of the spikelets; spikelets ovoid, 2 to $2.5 \mathrm{~mm}$ long, pale; fertile lemma strongly and rather coarsely cross-wrinkled (fig. 322 ).

Open ground and brushy slopes at low and medium altitudes, West Indies and Central America to Peru and Argentina.

Puerto Rico: Rio Piedras, Stevenson 3024; Chase 6371. Humacao, Eggers in 1881. Joyuya, Sintenis 6335 ("cult.").

TRINidad: Without locality, Bot. Gard.Herb. 3304; Crueger.

Toвago: Broadway 4898.

\section{Setaria subtransiens}

Hitchc. and Ekman, sp. nov. ${ }^{90}$

Perennial; culms tufted, erect, slender, glabrous, 60 to $100 \mathrm{~cm}$ tall, the nodes glabrous, or the lower pubescent; sheaths glabrous, keeled, somewhat auricled at summit (the auricle on one side sometimes conspicuous); ligule less than $1 \mathrm{~mm}$ long, membranaceous below, densely ciliate above; blades mostly erect, flat or involute, scabrous or puberulent on the upper

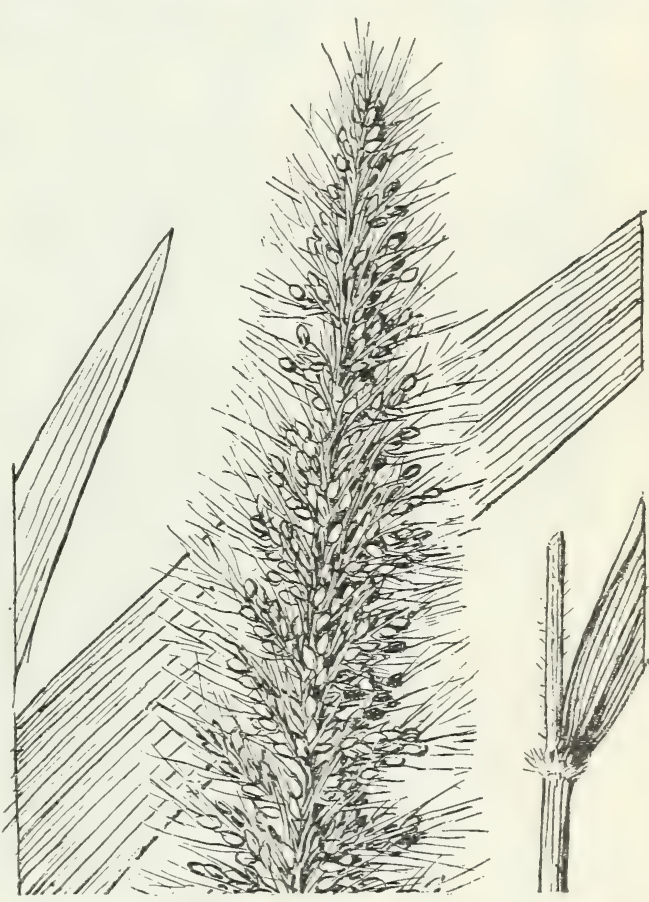

FIGURE 322.-Setaria vulpiseta, $\times 1$ (Sterenson 3024). surface, glabrous beneath, 10 to $20 \mathrm{~cm}$ long, 1 to $3 \mathrm{~mm}$ wide, gradually narrowed toward the base; panicles slender, interrupted, especially below, attenuate at summit, 5 to $15 \mathrm{~cm}$ long, the branches appressed, short, the lower sometimes as much as $2 \mathrm{~cm}$ long, the axis scabrous; bristles mostly single below each spikelet, sometimes wanting below some of the spikelets, appressed, about $5 \mathrm{~mm}$ long or some of them shorter; spikelets 2 to $2.5 \mathrm{~mm}$ long, somewhat oblique upon the short pedicel, lanceolate, acute, glabrous; first glume 3-nerved, about one-third as long as the spikelet; second glume 5-nerved, about

10 Planta perennis; culmi caespitosi erecti graciles $60-100 \mathrm{~cm}$ alti; nodis glabris vel infimis pubescentibus; laminae erectae planae vel involutae, supra scabrae vel puberulentae, $10-20 \mathrm{~cm}$ longae $1-3 \mathrm{~mm}$ latae, a basi sensim angustatae; paniculae angustae, superne attenuatae, 5-15 cm longae, axi scabro; setae infra spiculas solitariae, circa $5 \mathrm{~mm}$ longae; spiculae lanceolatae acutae glabrae $2 \mathrm{~mm}$ longae; lemma fertile acuminatum obscure transversim striatum. 
half as long as the spikelet; sterile lemma 5- to 7-nerved, about as long as the fertile lemma, without stamens but with a palea as long as the lemma; fertile floret acuminate, not strongly turgid on the

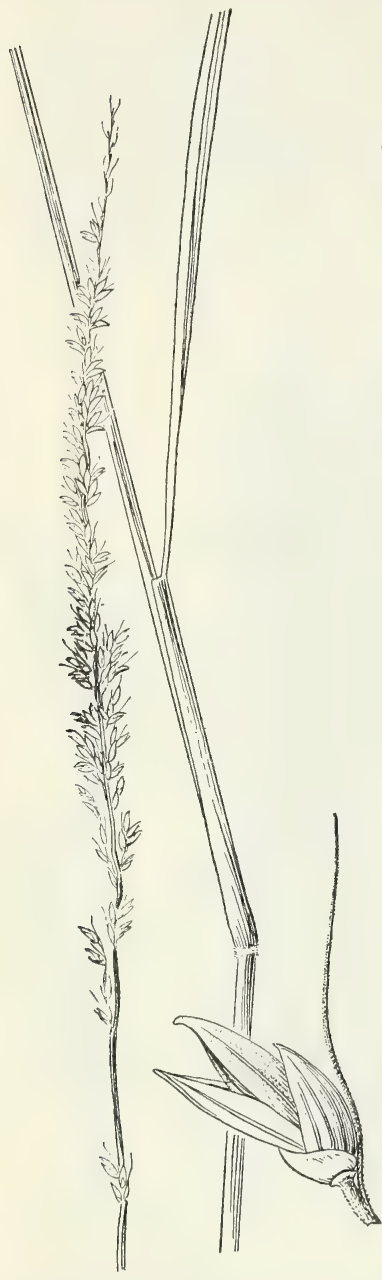

FIGURE 323.-Setaria subtransiens, $\times 1$; spikelet, $\times 10$ (type). convex side, obscurely cross-lined (fig. 323).

Type in the United States National Herbarium, no. 1161839, collected in thickets on serpentine, "cuabales", Motembo, prov. Santa Clara, Cuba, June 27, 1923, by Erik L. Ekman (no. 16828).

Also collected by Dr. Ekman in the Province of Oriente: Holguín, Ekman 3267, 7572; Sierra de Nipe, Ekman 2510.

\section{IXOPHORUS Schlecht., Linnaea 31: 420.1862}

Spikelets lanceolate, glabrous, shortpediceled, the pedicel bearing a flexuous bristle just below the spikelet; first glume about one-fourth as long as the spikelet, rounded, 3-nerved; second glume and sterile lemma equal, pointed, the latter enclosing: a palea and staminate flower, the palea at maturity cartilaginous and winged, much wider than the spikelet; fertile floret shorter than the sterile lemma, indurate, minutely roughened. A succulent annual with flat blades and narrow panicles of numerous ascending 1-sided racemes along a main axis.

1. Ixophorus unisetus (Presl) Schlecht., Linnaea 31: 420, 747. 1862.

Urochloa uniseta Presl, Rel. Haenk. 1: 319. 1830. Mexico.

Erect or spreading, 50 to $150 \mathrm{~cm}$ tall; blades 15 to $30 \mathrm{~cm}$ or even as much as 60 cm long, as much as $4 \mathrm{~cm}$ wide; panicles 10 to $20 \mathrm{~cm}$ long, the racemes approximate, 3 to $6 \mathrm{~cm}$ long; spikelets about $4 \mathrm{~mm}$ long, the bristles 3 to $10 \mathrm{~mm}$ long (fig. 324).

Low thickets, ditches, and wet places, at low altitudes, Mexico to Colombia; Cuba, introduced or escaped from cultivation. Said to have some forage value.

Cuba: Soledad, Jack 6265, 8318. Santiago delas Vegas, Hitchcock 23250. Isla de Pinos, Ekman 12173.

\section{PARATHERIA Griseb., Cat. Pl. Cub. 236. 1866}

Inflorescence a spikelike panicle, the solitary spikelets appressed to slender erect branches, the ends of the branches produced beyond the spikelets as slender bristles, the articulation at the base of the branch, this forming a sharp callus below the attached acuminate spikelet; glumes minute or obsolete; sterile lemma equaling the sub- 


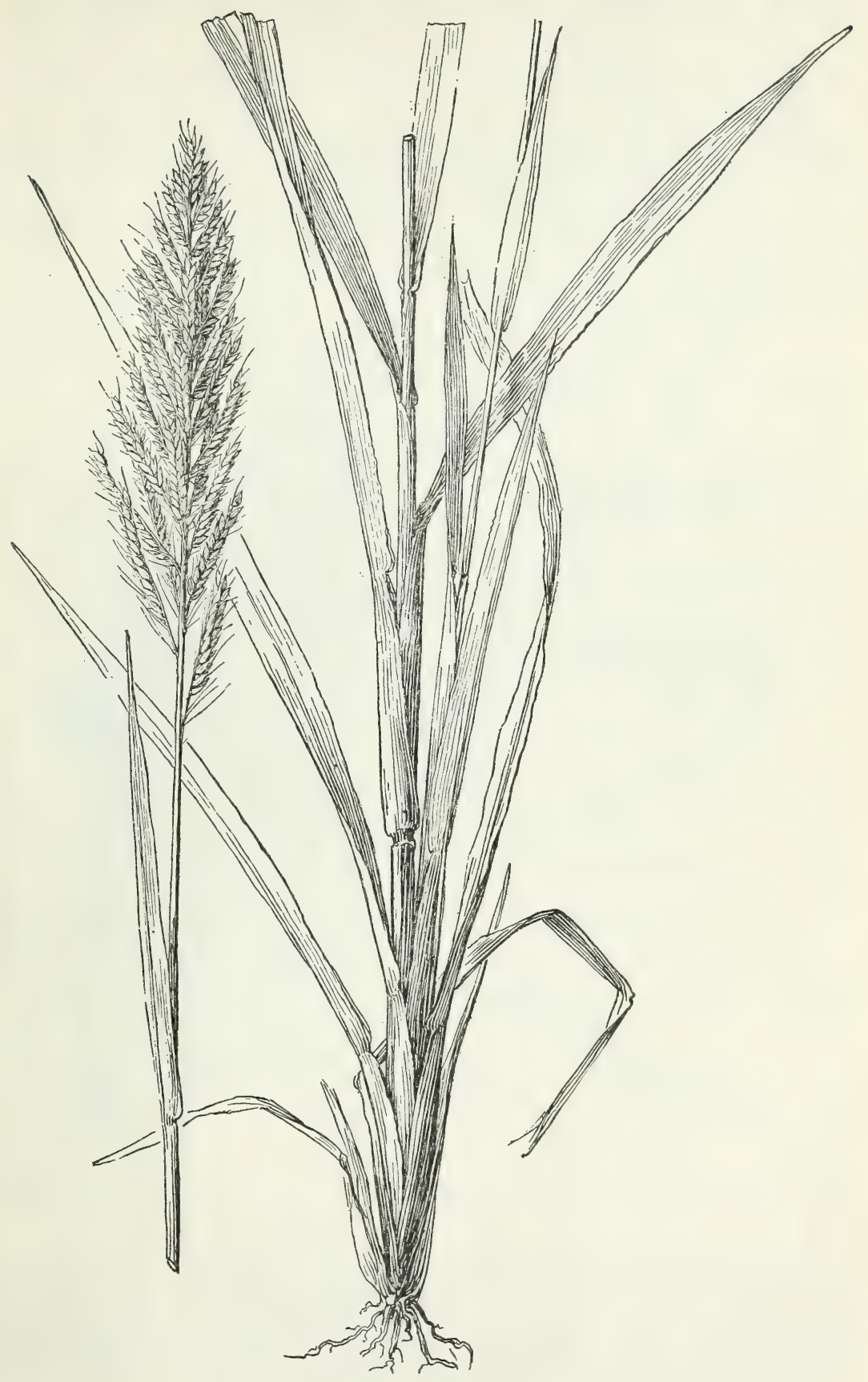

FIGURE 324,-Ixophorus unisetus, $\times 1 / 2$ (Pringle 8493). 
indurate fruit, 3-nerved; fertile lemma 3-nerved; palea similar to the lemma but a little shorter, 2-nerved. Decumbent-spreading leafy perennial with flat blades and slender panicles.

1. Paratheria prostrata Griseb., Cat. Pl. Cub. 236. 1866. Cuba, Wright in 1865.

Chamaeraphis parvigluma Munro; Wright and Sauv., An. Acad. Cien. Habana 8: 208. 1871, nomen nudum.

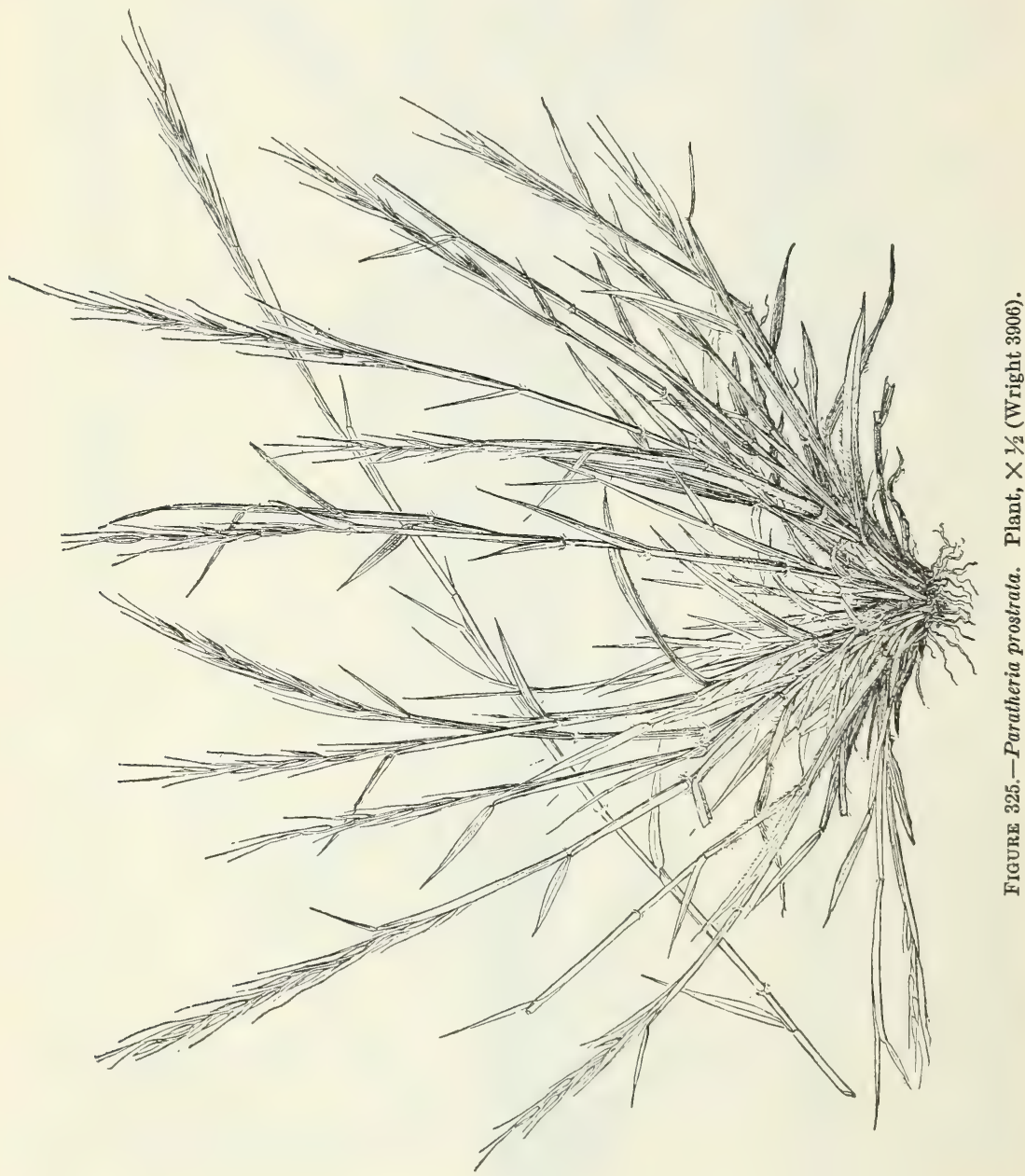

Culms tufted, several-noded, sparingly branching, 20 to $60 \mathrm{~cm}$ long, the nodes pubescent; blades pubescent, mostly 3 to $5 \mathrm{~cm}$ long, sometimes longer, 2 to $3 \mathrm{~mm}$ wide; panicles 5 to $15 \mathrm{~cm}$ long, more or less included in the uppermost sheath, the bristles appressed; spikelets about $7 \mathrm{~mm}$ long, a few slender hairs at the base (fig. 325).

Low moist ground, Cuba and Hispaniola; Brazil. 
Cuba: Río Feo (Pinar del Río), Ekman 17248 (Amer. Gr. Nat. Herb. 798). Without locality, Wright 3906, in 1865. Isla de Pinos, Curtiss 461.

Dominican Republic: Cuenca, Ekman H 13303.

\section{PENNISETUM L. Rich., in Pers., Syn. Pl. 1: 72. 1805}

Spikelets solitary or in groups of 2 or 3 , surrounded by an involucre of bristles, these not united except at the very base, often plumose, falling attached to the spikelets; first glume shorter than the spikelet, sometimes minute or wanting; second glume shorter than or equaling the sterile lemma; fertile lemma chartaceous, smooth, the margin thin, enclosing the palea. Annuals or perennials with usually flat blades and dense spikelike panicles.

Bristles about $4 \mathrm{~cm}$ long; panicles oval, feathery; spikelets 10 to $12 \mathrm{~mm}$ long. 1. P. Villosum.

Bristles rarely over $2 \mathrm{~cm}$ long, most of them shorter; panicles cylindric or nearly so; spikelets not more than $7 \mathrm{~mm}$ long.

Grain at maturity subglobose, bursting through the lemma and palea; panicle solidly dense, $2 \mathrm{~cm}$ or more thick; plants annual_.......4. P. GLAUCUM.

Grain permanently enclosed in the lemma and palea; panicles less than $2 \mathrm{~cm}$ thick, not solid; plants perennial.

Culms 2 to $4 \mathrm{~m}$ tall, robust; panicles mostly more than $15 \mathrm{~cm}$ long, very dense. Blades flat............. P. PURPUREUM. Culms mostly less than $2 \mathrm{~m}$ tall or if taller, slender and branching.

Bristles naked. Spike not more than $5 \mathrm{~cm}$ long, loose; spikelets about $4 \mathrm{~mm}$ long

Bristles or some of them plumose.

Culms low and spreading; involucre with a turbinate naked base.

Culms erect, tall and rather stout; involucre with no naked base.

Spikelets about $3 \mathrm{~mm}$ long, solitary in the sessile involucre.

6. P. SETOSUM.

Spikelets about $5 \mathrm{~mm}$ long, 2 or more in the peduncled involucre.

2. P. ORIENTALE var. TRIFLORUM.

1. Pennisetum villosum R. Br., in Fres. Mus. Senckenb. Abh. 2: 134.

1837. Abyssinia.

Feathertop.

Plant perennial; culms densely tufted from a knotted crown, 15 to $50 \mathrm{~cm}$ tall; blades elongate, 3 to $6 \mathrm{~mm}$ wide; panicles tawny, very dense, oval, 3 to $15 \mathrm{~cm}$ long, 3 to $5 \mathrm{~cm}$ wide including the bristles; fascicles short-peduncled; bristles slender, spreading, the longest 4 to $5 \mathrm{~cm}$ long, the inner plumose below; spikelets 1 to 4 in a fascicle, 10 to $12 \mathrm{~mm}$ long (fig. 326).

A native of East Africa; cultivated for ornament in America and occasionally escaped.

JAMAICA: Resource, Harris 12402 (probably cultivated or escaped from cultivation).

2. Pennisetum orientale var. triflorum (Nees) Stapf, in Hook. Fl. Brit. Ind. 7: 86. 1896.

Pennisetum triflorum Nees, in Steud., Syn. Pl. Glum. 1: 107.1854. India.

Plant perennial, forming tough clumps from knotted crowns, culm erect from an ascending base, usually $1 \mathrm{~m}$ or more tall, rather robust, simple or sparingly branched, pubescent or scabrous below the panicle; blades flat, lax, 5 to $10 \mathrm{~mm}$ wide, elongate; panicles 12 to $20 \mathrm{~cm}$ long, 15 to $20 \mathrm{~mm}$ thick, purplish, rather loose at least toward the base, 
nodding; fascicles peduncled, spreading or reflexed; bristles slender, flexuous, unequal, the outer shorter, scabrous only, the inner mostly 1 to $1.5 \mathrm{~cm}$ long, plumose below, the innermost one a little stronger and 2 to $2.5 \mathrm{~cm}$ long; spikelets 1 to several in a fascicle, 5 to $7 \mathrm{~mm}$ long (fig. 327).

Native of India, introduced in the West Indies, where it is called Himalaya grass and is said to be a good forage grass; escaped from cultivation and found along trails in open grassland.

Cuba: Habana, Ekman 12820; İéon 10613.

Jamaica: Cinchona, Hitchcock 9700, 9725 (Amer. Gr. Nat. Herb. 613); Harris 11300, 11433.

Trinidad: Port-of-Spain, Hitchcock 10169.

3. Pennisetum ciliare (L.) Link, Hort. Berol. 1: 213. 1827.

Cenchrus ciliaris L., Mant. Pl. 302. 1771. South Africa.

Pennisetum cenchroides L. Rich., in Pers., Syn. Pl. 1: 72. 1805. Based on Cenchrus ciliaris L.

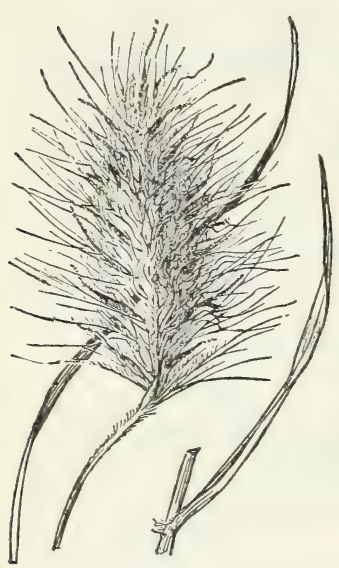

FIGURE 326.-Pennisetum villosum, $\times 1 / 2$ (Eastwood 172).

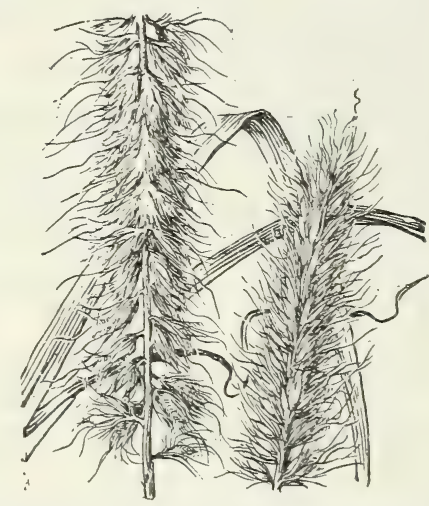

FIGURE 327.-Pennisetum orientale var. triflorum, $\times 2 / 3$ (Hitcheock 9725, Amer. Gr. Nat. Herb. 613).

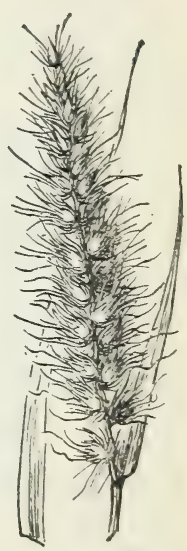

FigURE 328,-Pennisetum ciliare, $X$ 2/3 (Drummond).

Perennial, tufted from a knotted crown; culms geniculate, 10 to $50 \mathrm{~cm}$ tall, sometimes taller, sparingly branching; blades flat or folded; panicle 1.5 to $10 \mathrm{~cm}$ long, not dense, purplish, mostly flexuous; the fascicles spreading; bristles united at the rery base, flexuous, unequal, the outer short, slender, scabrous only, the inner thicker, about twice the length of the spikelet, ciliate, the innermost one a little longer than the rest; spikelets 1 to 5 in a fascicle (fig. 328).

Arid open ground, Eastern Hemisphere, introduced in Central America and Puerto Rico.

Puento Rico: Ponce, Britton, Cowell, and Brown 5380.

4. Pennisetum glaucum (L.) R. Br., Prodr. Fl. Nov. Holl. 1: 195. 1810 .

Pearl millet.

Panicum glaucum L., Sp. P1. 56. $1753 .^{91}$

Holcus spicatus L., Syst. Nat. ed. 10. 2: 1305. 1759.

Pennisetum typhoideum L. Rich., in Pers., Syn. Pl. 1: 72. 1805.

${ }^{91}$ For the nomenclatural history of the species see CHASE, Contrib. U. S. Natl. Herb. 22: 216. 1921; Amer. Jour. Bot. 8: 41-49. 1921. 
Penicillaria spicata Willd., Enum. Pl. 1037. 1809.

Plant annual; culms robust, as much as $2 \mathrm{~m}$ or more tall (depauperate escaped plants much smaller), densely villous below the panicle; blades flat, cordate at base, as much as $1 \mathrm{~m}$ long and $5 \mathrm{~cm}$ wide; panicles cylindric, stiff, very dense, as much as 40 to $50 \mathrm{~cm}$ long and 2 to $2.5 \mathrm{~cm}$ thick, pale, bluish or tawny; bristles about as long as the spikelets.

Known only in cultivation. Common in Africa and occasional in the southern United States and other American countries. Not grown in the West Indies, but depauperate specimens have been collected along the roadsides in Haiti.

Haiti: Port-au-Prince, Ekman H 3014. Ennery, Leonard 8830.

5. Pennisetum purpureum Schumach., Beskr. Guin. Pl. 64. 1827. Guinea.

NAPIER GRASS.

This tropical African species is being introduced as fodder in various parts of tropical America under the name of Napier grass and elephant grass. It is a robust leafy tufted branching perennial, 2 to $4 \mathrm{~m}$ tall, with elongate blades 2 to $3 \mathrm{~cm}$ wide, and dense stiff, tawny or purplish panicles, the fascicles sessile, the sparsely plumose bristles exceeding the 2 or 3 unequally pediceled spikelets. The plants escape occasionally from cultivation.

Cuba: Áspiro, Léon 15555. Experiment Station, Santiago de las Vegas, Hitchcock 23247, 23251. Cruz de Piedra, Léon 14247.

Haiti: Port-au-Prince, Ekman H 9127.

Dominican Republic: Jaina, Faris 92.

Puerto Rico: Joyuya, Perkins in 1928.

Virgin Islands: St. Croix, Thompson 466.

Leeward Islands: Antigua, Box 101.

6. Pennisetum setosum (Swartz) L. Rich., in Pers., Syn. Pl. 1: 72. 1805.

Cenchrus setosus Swartz, Prodr. Veg. Ind. Occ. 26. 1788. West Indies,

Pennisetum alopecuroides Desv.; Hamilt., Prodr. Pl. Ind. Occ. 11. 1825. Not $P$. alopecuroides Spreng., 1825. West Indies.

Pennisetum erubescens Desv.; Hamilt. Prodr. Pl. Ind. Occ. 11. 1825. St. Thomas.

Pennisetum hamiltonii Steud., Nom. Bot. ed. 2. 2: 297. 1841. Based on P. alopecuroides Hamilt.

Perennial, in loose clumps, sometimes of 30 or more culms; culms usually 1 to $2 \mathrm{~m}$ tall, slender to robust, subcompressed, ascending or suberect from the more or less geniculate, sometimes rooting lower nodes, bearing one to several flowering branches from the lower and middle nodes, scabrous below the panicle, otherwise glabrous; blades mostly rather firm, 10 to $40 \mathrm{~cm}$ long, 4 to $18 \mathrm{~mm}$ wide; panicles terminating the primary culm and branches, occasionally one or two axillary panicles borne in the upper sheaths, 10 to $25 \mathrm{~cm}$ long, 8 to $10 \mathrm{~mm}$ thick, excluding the elongate bristles, rather dense, usually somewhat nodding, from pale yellow to dusky purple or brown; fascicles sessile, at first ascending, spreading or reflexed in age; bristles unequal, the outer delicate, most of them shorter than the spikelet, the inner densely silky-plumose below, the hairs directed inward, those of the erect lower part of adjoining bristles matted and beautifully crimped; spikelets solitary (fig. 329). 


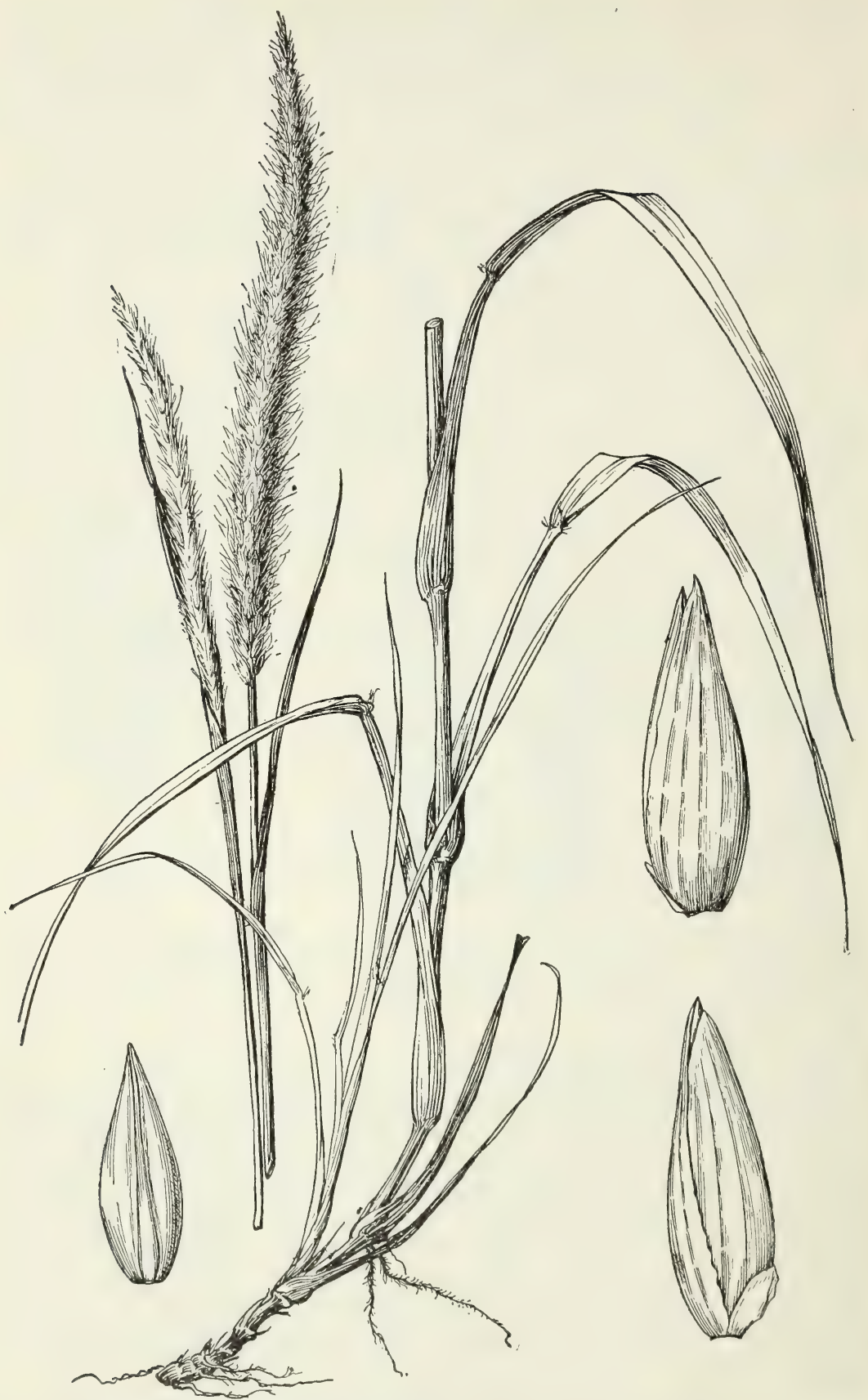

FIgURE 329.-Pennisetum setosum. Plant, $\times 1 / 2$; two views of spikelet, and fertile floret, $\times 10$ (Garber). 
Open slopes and savannas, southern Florida and Mexico to Bolivia and Brazil.

Cuba: San Juan de Buenavista, Wright 3471. Río San Juan, Ekman 18069.

JAMAICA: There is a specimen in the Trinius Herbarium sent from Jamaica by Swartz, but it may not have been collected there. The species is not known to occur in Jamaica.

Haiti: Mirebalais, Ekman H 5508. La Source, Ekman H 3386. St. Michel de l'Atalaye, Leonard 7411, 8059. Caille la Croix, Leonard 7888. Ennery, Leonard 8975.

LEemard Is ands: St. Kitts, Fairchild 2662; Hitchcock 16349; Thompson 559; Box 136. Guadeloupe, Duss 4152. Dominica, Jones 5; Hitchcock 16436.

Windward Islands: Martinique, Duss 1136, 4017; Hahn 1012. Barbados, Hitchcock $16504 ;$ Dash 346.

Trinidad: St. Joseph, Hitcheock 10176 (Amer. Gr. Nat. Herb.612). Icacos, Broadway 4964; Hitcheock 10153 (Amer. Gr. Nat. Herb. 611).

Toвago: Broadway 4683; Hitchcock 10235.

7. Pennisetum domingense (Spreng.) Spreng., Syst. Veg. 1: 302. 1825.

Gymnothrix domingensis Spreng.; Schult., Mant. 2: 284. 1824. Santo Domingo.

Perennial, glabrous; culms slender, rigid, glaucous, as much as $7 \mathrm{~m}$ tall, branching, the branches borne singly or in fascicles of 2 to 4 , about equaling the main culm, stiffly spreading at an angle of about $30^{\circ}$; nodes mostly swollen; blades 0.5 to $4 \mathrm{~cm}$ long, 1 to $2 \mathrm{~mm}$ wide, involute, divergent, firm, finally falling from the sheaths; panicles 2 to $5 \mathrm{~cm}$ long, terminal only, loosely flowered; bristles unequal, most of them 4 to $10 \mathrm{~mm}$ long, the innermost less slender

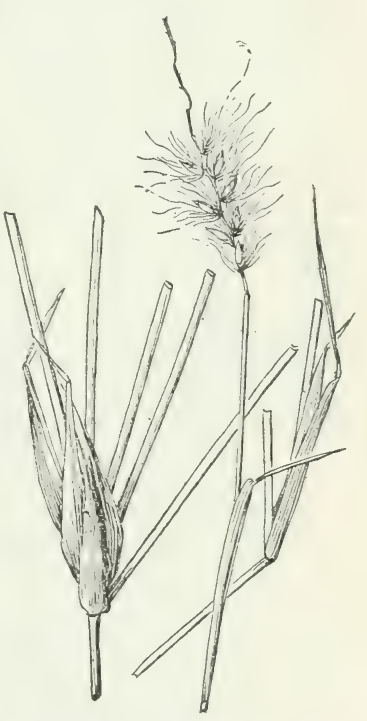

FIGURE 330.-Pennisetum domin. gense, $\times 1$ (Tuerckheim 3669). and 15 to $20 \mathrm{~mm}$ long; spikelets 4.2 to $4.5 \mathrm{~mm}$ long (fig. 330). On dry shrubby hillsides, Cuba and Hispaniola.

Cuba: Eastern Cuba, Wright 1547.

Dominican Republic: Los Furnios, Ekman H 9859. Maniel de Ocoa, Tuerckheim 3669. San José de Ocoa, Ekman H 11673. Monción, Ekman H 13087.

In Grasses of the West Indies ${ }^{92}$ Pennisetum antillarum (Poir.) Desv. is included, the type, marked "Antilles", having been examined in the herbarium of the Botanical Garden at Florence and a fragment deposited in the United States National Herbarium. In 1932 C. E. Hubbard, of Kew Herbarium, sent us specimens of Pennisetum hordeoides (Lam.) Steud., from West Africa, for comparison with the fragment. As Mr. Hubbard suggested, the two proved to belong to

${ }^{02}$ Contrib. U. S. Natl. Herb. 18: 353. 1917. 
the same species. "Antilles" is probably an error, though possibly the species may have been introduced in the slave trade, but failed to persist.

\section{CENCHRUS L., Sp. P1. 1049. 1753}

Spikelets sessile, 1 to several together, permanently enclosed in a bristly or spiny involucre or bur, composed of more or less coalesced sterile branchlets; burs sessile or nearly so on a slender, compressed, or angled axis, its apex produced into a short point beyond the uppermost bur, the burs falling entire, the grains germinating within them; involucre (especially in our species) somewhat oblique, its body irregularly cleft, the lobes rigid, in most species resembling the spines, the cleft on the side of the bur next to the axis reaching to the tapering, abruptly narrowed or truncate base, the bristles or spines barbed, at least toward the summit; spikelets mostly glabrous or nearly so; first glume 1-nerved, usually narrow, sometimes wanting; second glume and sterile lemma 3 - to 5-nerved, the lemma enclosing a well-developed palea and usually a staminate flower; fruit usually turgid, indurate, the lemma acuminate, the nerves visible toward the summit, the margins thin, flat. Annuals or perennials, with terminal racemes of burs.

Plants perennial.

Bristles and lobes of the involucre slender and terete or nearly so.

Burs about $5 \mathrm{~mm}$ high; involucral lobes united at base only.

1. C. MYOSUROIDES.

Burs about $7 \mathrm{~mm}$ high; involucral lobes united a short distance above the base............. E. EMANIANUS.

Bristles unlike, the outer slender, terete, the inner, or the lobes of the involucre, flattened at base.

Lobes of involucre as long as spikelet; thick base of bur nearly as broad as the

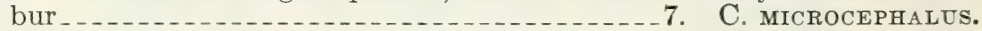

Lobes of involucre longer than the spikelets; base of bur triangular, narrower than the bur.

Blades involute, squarrose, conspicuously distichous, not more than $2.5 \mathrm{~cm}$ long, about $1 \mathrm{~cm}$ apart............ C. DISTICHOPHYLLUs.

Blades not involute and squarrose, nor conspicuously distichous, much longer and further apart

Plants annual.

Involucre with a ring of slender bristles at base.

Burs, excluding the bristles, not more than $4 \mathrm{~mm}$ wide, numerous, crowded in a long spike; lobes of involucre interlocking, not spinelike.

4. C. BROWNII.

Burs, excluding bristles, about $5.5 \mathrm{~mm}$ wide, not densely crowded; lobes of the involucre erect or nearly so or rarely one or two lobes loosely interlocking, the tips spinelike...... C. ECHINATUs. Involucre with flattened spreading spines, no ring of slender bristles at base.

Burs, including spines, 7 to $8 \mathrm{~mm}$ wide, finely pubescent.

Burs, including spines, 10 to $12 \mathrm{~mm}$ wide, usually densely woolly.

9. C. TRIBULOIDEs.

1. Cenchrus myosuroides H. B. K., Nov. Gen. et Sp. 1: 115. pl. 35. 1815. Cuba. Flamingo Key (near Batabanó), Humboldt and Bonpland.

Pennisetum myosuroides Spreng., Syst. Veg. 1: 303.1825.

Cenchropsis myosuroides Nash, in Small, Fl. Southeast. U. S. 109, 1327. 1903 .

Plants perennial; culms solitary or in small clumps, usually 1 to $2 \mathrm{~m}$ tall, glabrous, rather robust and woody, commonly glaucous, 
often branching; blades firm, 15 to $40 \mathrm{~cm}$ long, 5 to $12 \mathrm{~mm}$ wide, tapering from the rounded flat base to an attenuate, often involute tip; spike 10 to $25 \mathrm{~cm}$ long, strict, dense; burs 1-flowered, about $5 \mathrm{~mm}$ high, the bristles united at the base only, the lowest row shorter, the inner slender about equaling the spikelet (fig. 331).

Moist, sandy open ground or scrubland near the coast, southern Georgia to Texas, south through Mexico to Argentina; Greater Antilles.

Cuba: Santiago de Cuba, Léon 835. Guantánamo, Ekman 2858. Haiti: Miragoane, Eyerdam 216. Peninsula de Barahona, Ekman H 7059. Môle-St.-Nicolas, Ekman H 4493. Tortuga Island, Ekman H 4143 .

Dominican Republic: Monte Chico, Ekman H 13171.

Puerto Rico: Cabo Rojo, Hess 118. Mona Island, Hess 443; Britton, Cowell, and Hess 1674.

\section{Cenchrus ekmanianus Hitchc., sp. nov ${ }^{93}$}

Perennial; culms erect, branched, glabrous, 80 to $100 \mathrm{~cm}$ tall; sheaths loose, overlapping; ligule about $2 \mathrm{~mm}$ long, membranaceous below, ciliate above; blades folded, glabrous, 15 to $20 \mathrm{~cm}$ long, 3 to $5 \mathrm{~mm}$ wide, attenuate to a fine involute point; spikes shortexserted or partially included, 8 to $12 \mathrm{~cm}$ long, the burs crowded, the axis angled, flexuous, rather stout, pubescent; burs about $7 \mathrm{~mm}$ high (including the bristles), the broad turbinate base puberulent; bristles united for a short dis-
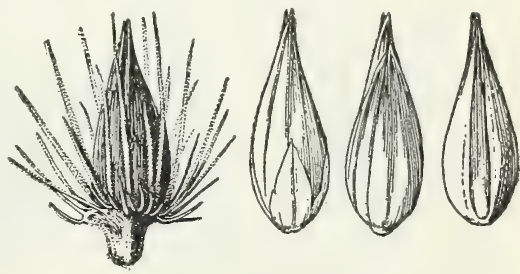

FIGURE 331.-Cenchrus myosuroides. Bur, two views of spikelet, and floret, $\times 5$ (Léon 835 ). tance above the base, the outer 2 to $3 \mathrm{~mm}$ long, scabrous, the inner erect or somewhat spreading, puberulent at base; spikelets 1 or 2 , about $5 \mathrm{~mm}$ long, about as long as the inner spines; first glume half as long as the spikelet; second glume a little shorter than the sterile and fertile lemmas, these 7-nerved.

Type in the United States National Herbarium, no. 1502107, collected in sandy open soil, Monte Chico, Los Siete Hermanos, prov. Monte Cristi, Dominican Republic, July 14, 1929, by E. L. Ekman (no. H 13172).

This species is related to $C$. myosuroides from which it differs in the larger burs, the bristles more united at base, and in the stouter, more flexuous axis of the spike. Known only from the type collection.

3. Cenchrus distichophyllus Griseb., Cat. Pl. Cub.234. 1866. Cuba, Wright 3475.

Plants perennial; culms tufted, rigid, erect or ascending from a curved base, the numerous internodes very short, the long leafless upper part of the culm appressed-pubescent; blades 1.5 to $2.5 \mathrm{~cm}$ long, about $1.5 \mathrm{~mm}$ wide, conspicuously distichous, stiffly spreading at a uniform angle and usually about $1 \mathrm{~cm}$ apart, involute, sharp-pointed; spike 2 to $3 \mathrm{~cm}$ long, bearing usually 5 to 7 spreading yellow burs; burs, including the spines, 5 to $6 \mathrm{~mm}$ long, the body puberulent;

\footnotetext{
${ }^{93}$ Perennis: culmi glabri ramosi $80-100 \mathrm{~cm}$ alti; laminae glabrae $15-20 \mathrm{~cm}$ longae 3-5 mm latae plicatae longe-attenuatae; spicae $8-12 \mathrm{~cm}$ longae: involucrum circa $7 \mathrm{~mm}$ altum; spiculae una vel duae in quoque involucro; setae longitudine spicularum, exteriores breviores; gluma prima dimidiam spiculam aequans.
} 
outer spines shorter, subterete, the lobes of the involucre about 10 ; spikelet solitary, about $3.3 \mathrm{~mm}$ long (fig. 332).

Dry, sandy pine barrens, Province of Pinar del Río, Cuba.

CuBA: La Grifa, Ekman 11250. Pinar del Río, Ekman 17845. Laguna Santa Bárbara, Ekman 18102. Guane, Léon 7475 (Amer. Gr. Nat. Herb. 434). San Julián, Léon 6941. Laguna Jovero, Shafer 10717. Western Cuba, Wright 3475.

4. Cenchrus brownii Roem. and Schult., Syst. Veg. 2: 258. 1817. Based on $C$. inflexus R. Br.

Cenchrus inflexus R. Br., Prodr. Fl. Nov. Holl. 1: 195. 1810. Not C. inflexus Poir., 1804. Australia.

Cenchrus viridis Spreng., Syst. Veg. 1: 301. 1825. Guadeloupe.

Cenchrus echinatus var. viridis Spreng.; Griseb., Fl. Brit. W. Ind. 556. 1864.

Culms often rather robust, 30 to $100 \mathrm{~cm}$ tall or more, erect from a more or less geniculate base, sparingly branching from the base or
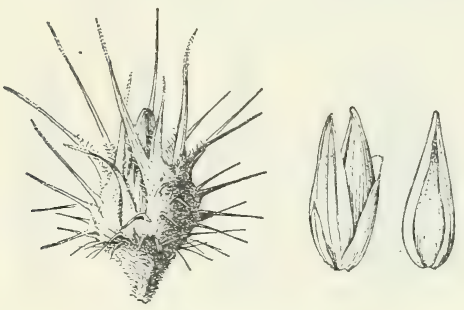

Figure 332.-Cenchrus distichophyllus. Bur, spikelet, and floret, $\times 5$ (type).

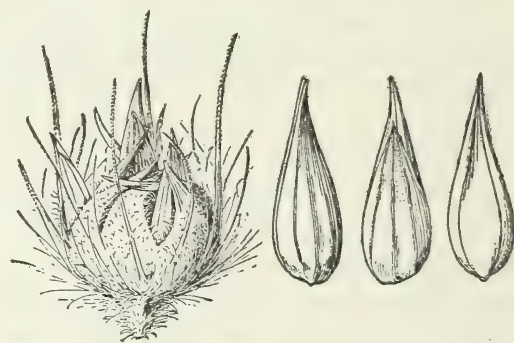

Figure 333.-Cenchrus brownii. Bur, two views of spikelet, and floret, $\times 5$ (type).

lower nodes; blades thin, flat, lax, mostly 10 to $30 \mathrm{~cm}$ long, 6 to 12 $\mathrm{mm}$ wide; spike usually short-exserted, 4 to $10 \mathrm{~cm}$ long, rarely longer, dense; burs depressed-globose, the body about $4 \mathrm{~mm}$ high, as broad or broader, villous, tawny, the outer bristles numerous, very slender, crowded toward the base, the inner usually exceeding the body and the spikelets, erect or spreading, the lobes of the body usually 6 to 8, interlocking at maturity; spikelets usually 3 (fig. 333).

Open ground and waste spaces, often a weed in cultivated fields, southern Florida and Mexico to Brazil.

BaHamas: Andros Island, Small and Carter 8711.

Cuba: Sierra Mendoza, Shafer 11152. Habana, Léon 5618. Sancti Spíritus, Léon 837; Clemente 3442. Camaguey, Léon 3963. Cayo Ballena to Grande, Shafer 1022. Manatí, Léon 5683,6007. El Cuero, Britton and Cowell 12798. Santiago de Cuba, Pollard, Palmer, and Palmer 284. Woodfred, Shafer 3172. Without locality, Wright 3889. Isla de Pinos, Britton, Wilson, and Léon 15296.

Jamaica: Tyre, Harris 12617. Hope Gardens, Harris 11237; Hitchcock 9314; Maxon 1640. Spanish Town, Harris 12479. Bog Walk, Hitcheock 9300. Ipswich, Hitcheock 9588. Ewarton, Hitchcock 9440. New Forest, Hitchcock 9841. Gordon Town, Hart 783. Grand Cayman, Millspaugh 1268.

Haiti: Port-au-Prince, Hitchcock 19870, 19877; Leonard 2762. Fond Parisien, Leonard 4215. Gonaïve Island, Leonard 3084, 5156. 
St. Marc, Leonard 2969. Pétionville, Ekman H 2337. Miragoane, Eyerdam 568. Tortuga Island', Leonard 11519, 15579. St. Michel de l'Atalaye, Leonard 7461. Ennery, Leonard 8855.

Dominican Republic: Santo Domingo, Millspaugh 808. Azua, Rose 3948. Jaina, Faris 12, 108. San Juan, Ekman H 13617. Guayubín, Abbott 888. Without locality, Parry and Brummel 621.

Puerto Rico: Juana Diaz, Sintenis 2904. Guanica Bay, Chase 6517. Cayo Muertos, Brition, Cowell, and Brown 4986. Vieques Island, Chase 6667; Shafer 2653. Culebra Island, Millspaugh 619; Britton and Wheeler 122.

VIrgin Islands: St. Thomas, Hitchcock 16294.

Leeward Islands: 'Guadeloupe, Duss 2718.

Windward Islands: Martinique, Duss 790.

Trinidad: Port-of-Spain, Hitchcock 9995. Palo Seco, Britton and Hazen 1164. Jawuba Ridge, Bot. Gard. Herb. 579. San Juan, Broadway 2609. Cedros, Broadway 4916.

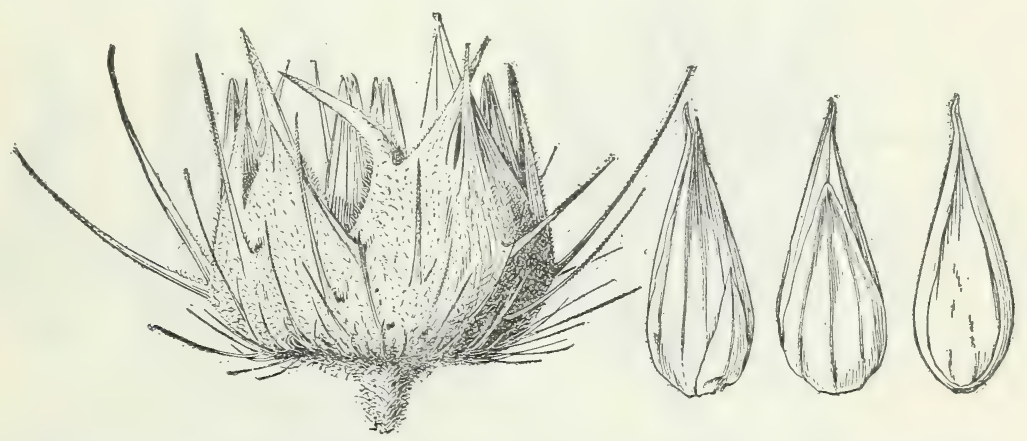

FIGURE 334.-Cenchrus echinatus. Bur, two views of spikelet, and floret, $\times 5$ (Hitchcock 9379).

5. Cenchrus echinatus L., Sp. Pl. 1050. 1753. Jamaica and Curaçao.

Culms ascending from a geniculate or decumbent base, often rooting at the lower nodes, branching from the base and usually from the lower nodes, commonly 25 to $60 \mathrm{~cm}$ long, sometimes as much as $1 \mathrm{~m}$ long; blades commonly 6 to $20 \mathrm{~cm}$ long and 3 to $8 \mathrm{~mm}$ wide; spikes finally rather long-exserted, 3 to $10 \mathrm{~cm}$ long (commonly not more than $7 \mathrm{~cm}$ long), not very dense; burs truncate at base, the body 4 to 7 $\mathrm{mm}$ high, as broad or broader, pubescent, tawny or plumbeous, the outer bristles slender, the inner stout, broadened at base, the longest of them usually about equaling the lobes of the body, ascending or spreading, the lobes of the body commonly 10 , erect or bent inward, the tips hard and spinelike, retrorsely barbed; spikelets about 4 (fig. 334).

Open ground and waste places, a common weed throughout the American Tropics at low and medium altitudes. To be found on probably all the West Indian islands.

6. Cenchrus gracillimus Nash, Bull. Torrey Bot. Club 22: 299. 1895. Florida.

Plants perennial, at length forming dense clumps, glabrous as a whole; culms 20 to $80 \mathrm{~cm}$ tall, slender, wiry, erect or ascending; blades usually folded and stiffy flexuous, 5 to $20 \mathrm{~cm}$ long, usually 2 to $3 \mathrm{~mm}$ 
wide; spikes 2 to $6 \mathrm{~cm}$ long, the burs not crowded; burs 3.5 to $5 \mathrm{~mm}$ wide (excluding the spines), somewhat tapering at the base, glabrous; spines spreading or reflexed, all slabrous and flat, broadened at the base, the lowest shorter, the upper 5 to $6 \mathrm{~mm}$ long; spikelets 2 or 3 , 5.5 to $7 \mathrm{~mm}$ long (fig. 335 ).

Sandy open ground, Florida, Cuba, Jamaica, and Hispaniola.

Cuba: Morillo, Ekman 17402. Isla de Pinos, Britton and Wilson 14934.

JAMAICA: Southern Manchester, Harris 12690; Hitchcock 9851 (New Forest).

Haimi: Tortuga Island, Ekman H 9760.

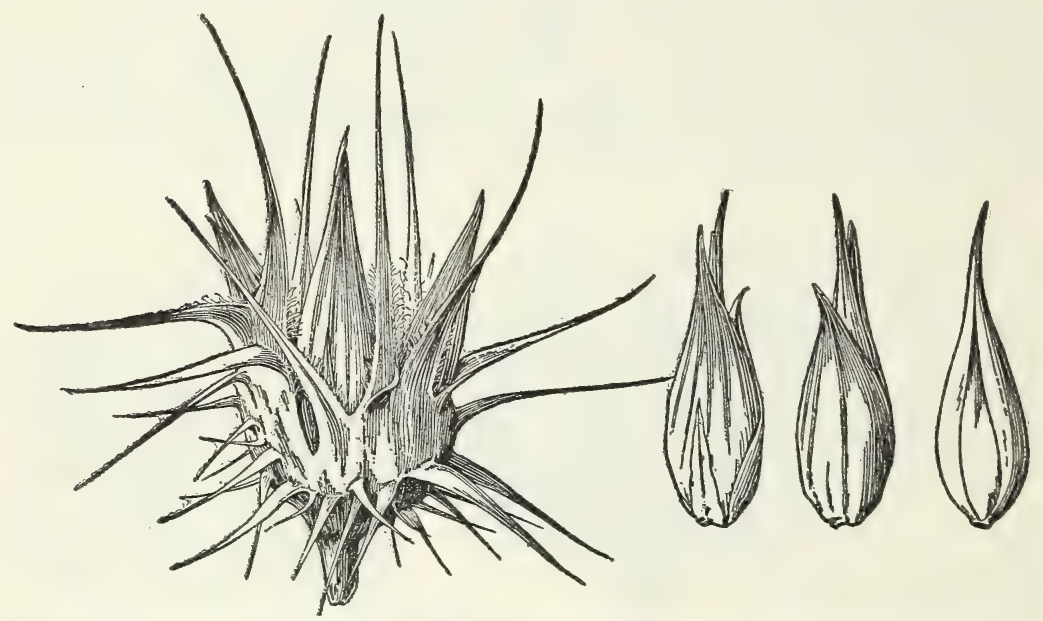

FIGURE 335.-Cenchrus gracillimus. Bur, two views of spikelet, and floret, $\times 5$ (type collection).

Dominican Republic: Matanzas, Ekman H 15909. Punto Icacos, Ekman H 15786.

7. Cenchrus microcephalus Nash, Contrib. U. S. Natl. Herb. 18: 356. 1917. Bahamas, Britton and Millspaugh 2249.

Plants probably perennial, tufted, with numerous leafy sterile shoots at the base, glabrous as a whole; culms 30 to $70 \mathrm{~cm}$ tall, slender,

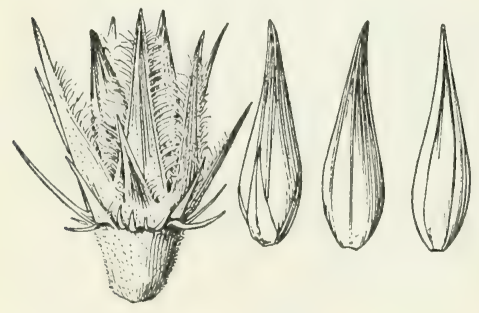

FiguRE 336.-Cenchrus microcephalus. Bur, two views of spikelet, and floret, $\times 5$ (type). scabrous below the spike, ascending from a decumbent base, branching from the middle and upper nodes; blades folded at base, of ten flat above, rather thin, 10 to $20 \mathrm{~cm}$ long, 2 to $3 \mathrm{~mm}$ wide, pilose on the upper surface; spikes 3 to $5 \mathrm{~cm}$ long; burs (including the bristles) about $6 \mathrm{~mm}$ long and $5 \mathrm{~mm}$ wide, the body scarcely wider than the thick base; spines flat, broadened at the base, the lowest short and spreading, the upper stout, ciliate at base, shorter than the 5 or 6 lobes of the involucre, these erect or ascending, ciliate nearly to the summit, spikelets usually 2,4 to $4.5 \mathrm{~mm}$ long (fig. 336).

Known only from the Berry Islands.

Bahamas: Berry Islands, Britton and Millspaugh 2211, 2249. 
8. Cenchrus pauciflorus Benth., Bot. Voy. Sulph. 56. 1840. Baja California.

Field sandbur.

Sometimes forming large mats; culms 20 to $90 \mathrm{~cm}$ long, rather stout, spreading to ascending from a decumbent base, usually freely branching; blades from flat to subinvolute or folded, 3 to $15 \mathrm{~cm}$ long, 2 to $7 \mathrm{~mm}$ wide; spikes numerous, short-exserted or partly included, 3 to $10 \mathrm{~cm}$ long; burs rather crowded (excluding the spines), 3 to 7 $\mathrm{mm}$ wide (commonly 4 to $6 \mathrm{~mm}$ ), pubescent, often densely so, rarely nearly glabrous; spines numerous, spreading or reflexed, flat, broadened at base, the lowermost shorter and relatively slender, some of the upper ones commonly 4 to $5 \mathrm{~mm}$ long, usually villous at the base; body of the bur often with one deep cleft on the outer face, the lobes commonly about 8 , usually villous at the base, rigid and spinelike; spikelets usually 2 (fig. 337 ).

This is the species to which the name Cenchrus tribuloides was commonly applied until 1908 when it was shown ${ }^{94}$ that this name

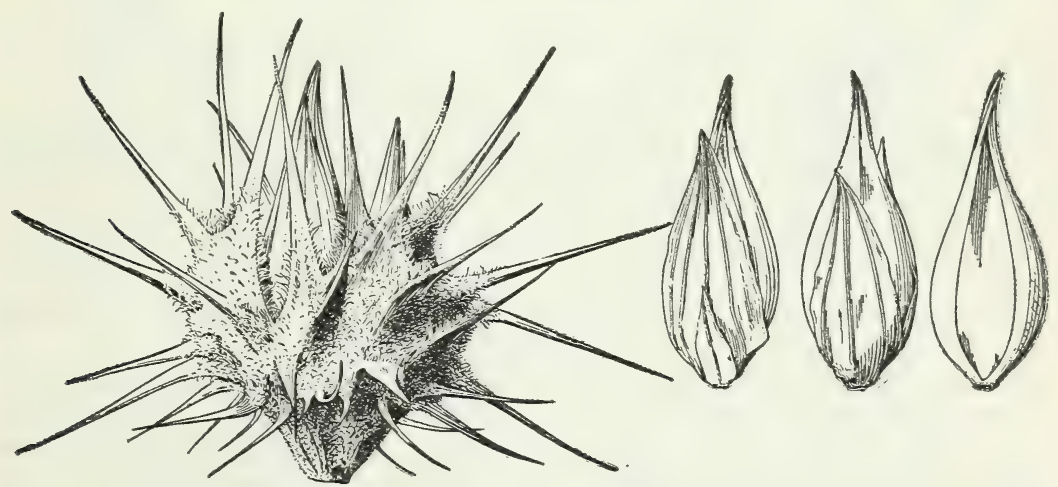

Figure 337.-Cenchrus pauciflorus. Bur, two views of spikelet, and floret, $\times 5$ (Hitchcock 13582).

should apply to the large-burred coastal plant which had been distinguished as $C$. macrocephalus. The name $C$. carolinianus Walt. was then applied to this species, but Walter's diagnosis does not agree with its characters and it haś not been found in Walter's region.

Sandy open ground, United States, Mexico, and the West Indies to Argentina.

Bahamas: Nassau, Geogr. Soc. Baltimore 101.

CubA: Laguna Santa Bárbara, Ekman 18102a, Sábbalo, Ekman 11446. Vicinity of Habana, Hitchcock 492, 493, 23445; Léon 1881/2, 836, 2391, 3445, 3453; Ekman 799; Palmer and Riley 1146. Bahía de Manatí, Léon 15755, 16026. Without locality, Wright 3476.

Jamaica: Black River, Hitchcock 9637. Pigeon Island, Maxon and Killip 1569.

Haitr: Gonaïve Island, Leonard 3050. Tortuga Island, Leonard 13898, 15330; Ekman H 4160.

Dominican Republic: Higüey, Ekman H 12228. Los Siete Hermanos, Ekman H 13167.

Puerto Rico: Santurce, Chase 63451/2.

94 Contrib. U. S. Natl. Herb. 12: 127. 1908. 
Virgin IslaAnd: St. Thomas, Raunkiaer 634.

Leeward Islands: Antigua, Wullschlaegel 634; Box 104. Barbuda, Danforth 7. Guadeloupe, Stehle 197.

9. Cenchrus tribuloides L., Sp. Pl. 1050. 1753. Virginia.

DUNE SANDBUR.

Plants annual, very leafy; culms stout, at first erect, soon branching and becoming radiate-decumbent, 15 to $60 \mathrm{~cm}$ long, the ends ascending, rooting at the nodes and with numerous ascending branches 10 to $30 \mathrm{~cm}$ tall; sheaths usually overlapping, sharply keeled, those below the spikes inflated; spikes numerous, 3 to $9 \mathrm{~cm}$ long, the burs crowded; burs 5 to $6 \mathrm{~mm}$ wide, 8 to $9 \mathrm{~mm}$ high (excluding the spines), usually conspicuousily villous, but sometimes short-pubescent only, the base puberulent; spines finally spreading, flat, the lowermost relatively short and slender, the upper broadened at the base, sometimes as much as $3 \mathrm{~mm}$ broad, some of these 5 to $8 \mathrm{~mm}$ long, long-villous on the inner face and margins of the broad base; spikelets usually 2,7 to $8 \mathrm{~mm}$ long: (fig. 338).

In loose sands of the coast, eastern United States and the West Indies, and Brazil.

Bermuda: Collins 143; Brown and Britton 128.

BaHamas: Nassau, collector unknown. Andros Island, Small and Carter 8972. Water Key, Wilson 8151. Anguilla Isles, Wilson 7936.

Cuba: Habana, Léon 5634. Cayo Sabinal, Shafer 700. Cayo Paredon Grande, Shafer 2737.

Carman Islands: Grand Cayman, Millspaugh 1249. Cayman Brac, Millspaugh 1162.

Haiti: Port-de-Pai, Ekman H 3941. Gonaïre Island, Eyerdam 88.

Puerto Rico: Arecibo, Chase 6561. Aguadilla, Chase 6604. Cabo Rojo, Sintenis 29b. Cayo Muertos, Britton, Cowell, and Brown 5046. Mona Island, Hess 440. Vieques Island, Chase 6696.

\section{OLYRA L., Syst. Nat. ed. 10. 2: 1261. 1759}

Plants monoecious; inflorescence paniculate; pistillate spikelets borne on the upper branches and on the ends of the lower branches of loose terminal panicles, the smaller staminate spikelets pedicellate along the lower branches; pistillate spikelets rather large; first glume wanting; second glume and sterile lemma herbaceous, caudateacuminate; fruit bony-indurate; staminate spikelets readily deciduous; glumes and sterile lemma wanting, the lemma and palea membranaceous. Erect or clambering often woody perennials with broad blades.

Fruit smooth and shining; plants usually more than $3 \mathrm{~m}$ tall.

1. O. LATIFOLIA. Fruit clothed with thick silky hairs at base and summit; plants less than $1 \mathrm{~m}$ tall.

1. Olyra latifolia L., Syst. Nat. ed. 10. 2: 1261. 1759. Jamaica. Olyra paniculata Swartz, Prodr. Veg. Ind. Occ. 21. 1788. Jamaica. Olyra arundinacea H. B. K., Nov. Gen. et Sp. 1: 197.1816. Colombia.

Olyra latifolia var. arundinacea Griseb., Fl. Brit. W.Ind. 535. 1864. 


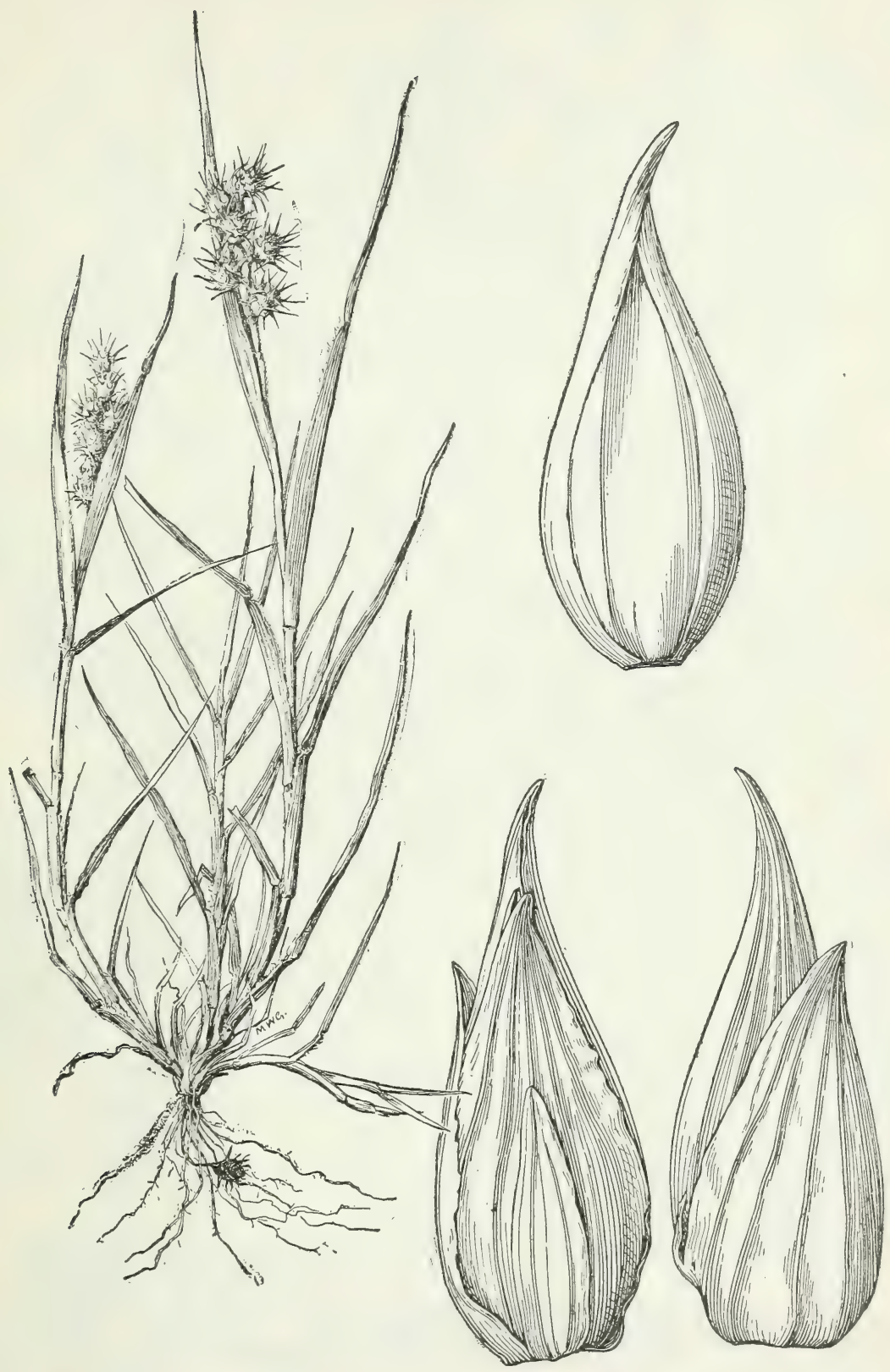

FIGURE 338.-Cenchrus tribuloides. Plant, $\times \frac{1}{2}$; two views of spikelet, and floret, $\times 10$ (Kearney). $60256-36-24$ 
Glabrous perennial, bamboolike in aspect, commonly $5 \mathrm{~m}$ tall, the strong hollow culms sometimes $1 \mathrm{~cm}$ thick, erect and unsupported, the summit only arching (or weaker culms leaning among brush), the lower half to two-thirds simple and naked, the short sheaths bladeless or nearly so, the elongate internodes blotched with dull purple, branching from the upper nodes, the branches commonly fascicled, divaricate, often $1 \mathrm{~m}$ long, sometimes again branching; blades convolute in the bud, spreading, flat, firm, unsymmetrically lanceolate-oblong, abruptly acuminate, commonly $20 \mathrm{~cm}$ long and $5 \mathrm{~cm}$ wide, those of the ultimate branches smaller, the lowermost on both primary culm and branches rudimentary; panicles 10 to $15 \mathrm{~cm}$ long, about two-thirds as wide, those of the secondary branches reduced, the branches stiffly ascending or spreading, each bearing a single large long-acuminate pistillate spikelet at the thickened summit and several small slender-pediceled staminate spikelets along the rachis (fig. 339).

The form described as Olyra arundinacea, has glabrous sheaths and more loosely flowered green panicles. It is found in the West Indies chiefly from Puerto Rico to Trinidad and extends to Brazil. The typical form of $O$. latifolia, with hispid sheaths and denser purple panicle, is found chiefly in Cuba and Jamaica, but extends from Mexico to Brazil. The differences mentioned above are best seen in the primary culms and panicles.

Copses and shady banks, Mexico and West Indies to South America. In Cuba this is one of the grasses called "tibisi." The species is to be found on probably all the West Indian islands. It has not been observed in Bermuda or in the Bahamas.

\section{Olyra ciliatifolia Raddi, Agrost. Bras. 19. 1823. Brazil.}

Culms erect, mostly simple, in small clumps but gregarious, glabrous, mostly 40 to $80 \mathrm{~cm}$ tall; sheaths hispidulous or the lower glabrate; blades flat, glabrous, oblong-elliptic, 8 to $15 \mathrm{~cm}$ long, 2 to 4 $\mathrm{cm}$ wide, asymmetric at base, one side rounded, the other side straight for 1.5 to $4 \mathrm{~cm}$ at an angle of $30^{\circ}$ to $45^{\circ}$, the tip acuminate; panicles 10 to $15 \mathrm{~cm}$ long, the lower half or two-thirds staminate, the pistillate spikelets in the upper part of the panicle and at the ends of the upper branches; staminate spikelets narrow, about $5 \mathrm{~mm}$ long, short-awned; pistillate spikelets elliptic on thickened pedicels, glabrous, acuminate, about $1 \mathrm{~cm}$ long, the first glume bearing an awn 1 to $2 \mathrm{~cm}$ long; fruit loosely clothed with silky hairs.

Shade of trees, Trinidad to Brazil. Referred by Grisebach ${ }^{95}$ to O. semiovata Trin.

Trinidad: Port-of-Spain, Hitcheock 10133; Broadway 9194. Without locality, Broadway in 1918; Purdie 26.

\section{LITHACHNE Beauv., Ess. Agrost. 135. pl. 24. f. 2. 1812}

Plants monoecious; spikelets in small axillary panicles, these with a single pistillate spikelet at the summit and 1 to several staminate spikelets below; terminal panicle if present wholly staminate; first glume of pistillate spikelet wanting; second glume and sterile lemma herbaceous, long-acuminate; fruit bony-indurate, laterally subcom-

98 Fl. Brit. W. Ind. 535. 1864. 


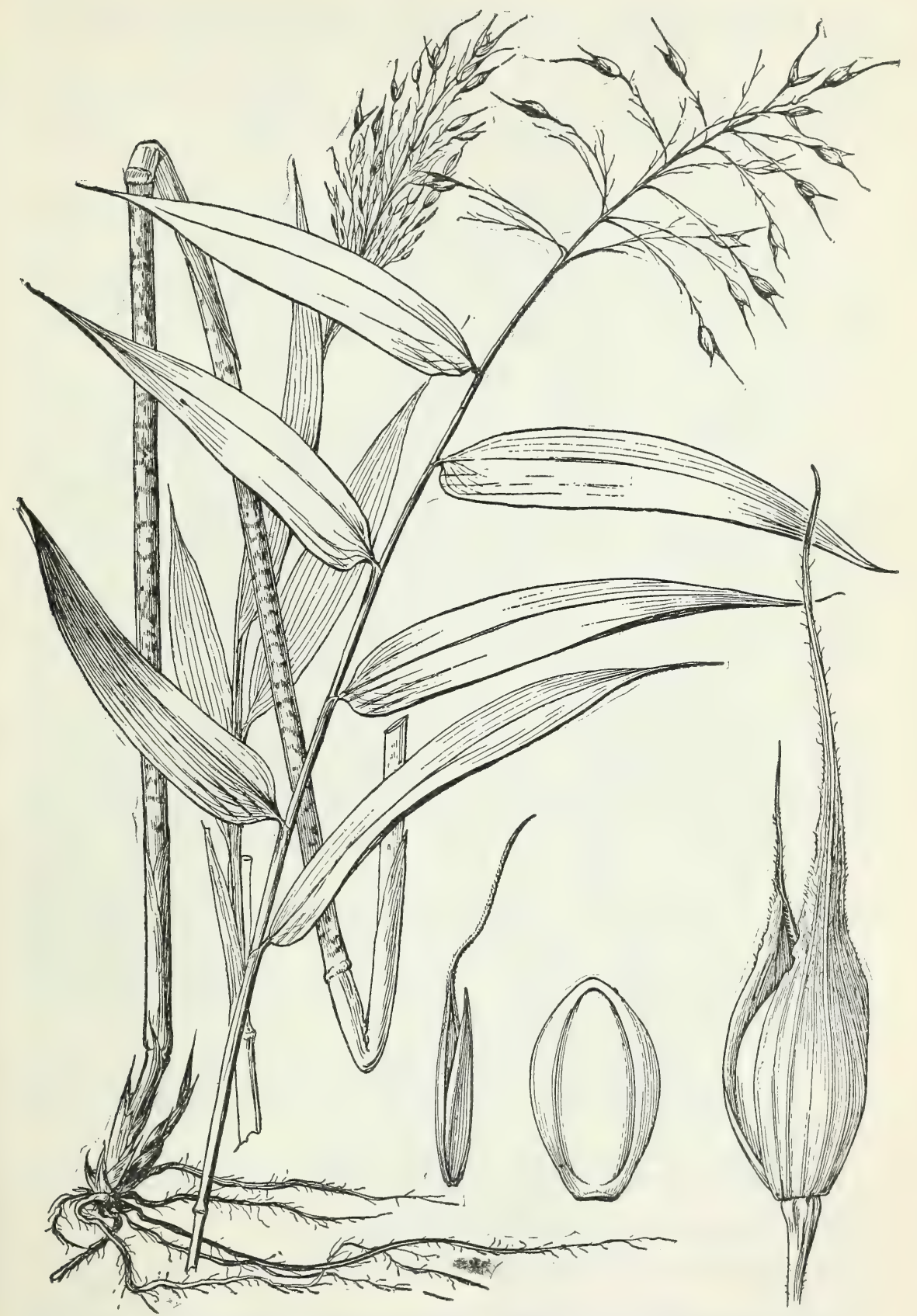

FIGURE 339.-Olyra latifolia. Plant, $\times 1 / 2$; pistillate and staminate spikelets, and fertile floret, $\times 5$ (Chase 6416). 
pressed, the lemma greatly swollen or gibbous on the back, the narrow palea slightly convex; staminate spikelets reduced to the lemma and palea. Slender perennials with wiry culms and flat blades.

Blades 1.5 to $3 \mathrm{~cm}$ wide

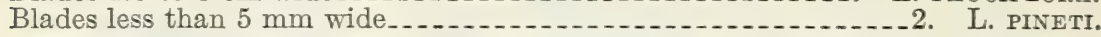

1. Lithachne paucifiora (Swartz) Beauv.; Poir., Dict. Sci. Nat. 27: 60. 1823.

Olyra pauciflora Swartz, Prodr. Veg. Ind. Occ. 21. 1788. Jamaica.

Tufted perennial; culms slender, hard, geniculate and naked below, ascending and leafy above, commonly 30 to $50 \mathrm{~cm}$ tall; blades flat, usually 5 to $8 \mathrm{~cm}$ long, asymmetric, rhombic-lanceolate, acuminate, spreading, crowded toward the summit, the small axillary panicles produced from the upper sheaths; fruit 4 to $5 \mathrm{~mm}$ long, white (fig. $340)$.

Moist woods up to about 2,000 m, Mexico and the Test Indies to Argentina. In Cuba called "pito enano."

CuBA: Pinar del Río, Hitchcock 23313. Herradura, Hitchcock 265. Sumidero, Shafer and Léon 13533. Sierra Guane, Shafer 10553. El Guama, Palmer and Riley 105. Loma Esperon, Ekman 644. Madruga, Curtiss 661. Laguno de Castellano, Wilson 9560. Habana, Léon 584. Santiago de las Vegas, Hitchcock 264. Cumbre Hermosa, Wilson and Léon 11620. San Antonio, Hitchcock 266. Cienfuegos, Pringle 54; Jack 6159. Pozo Azul, Eggers 5356. San Blas, Bailey 12426; Jack 7836. La Gloria, Shafer 53. Bayate, Ekman 5842. Guara, Hitchcock 23399. Isla de Pinos, Britton and Wilson 15549. Eastern Cuba, Wright 732.

JamaICA: Chapleton, Ridley 69. Roaring River Falls, Ridley 73. Kingston, Hitchcock 9263. Castleton, Hitchcock 9402; Harris 11279. Flamstead, Harris 11467. Sir Johns Peak, Harris 11593. Buff Bay, Hitchcock 9770. Savanna-la-Mar, Hitchcock 9872. Trov, Hitchcock 9815; Harris 12575. Ewarton, Hitchcock 9424. Ipswich, Hitchcock 9613. Claremont, Hitchcock 9522. Blue Hole, Fredholm 3193. Johns Hall, Harris 12834.

Haiti: Port-au-Prince, Leonard 5266; Ekman H 2178. Cap Haitien, Leonard 5283. Pétionville, Leonard 4879. St. Louis du Nord, Leonard 14188. Port-de-Pai, Leonard 12278. Bombardopolis, Leonard 13553. Caille la Croix, Leonard 7998. Marmelade, Leonard 8176. Dondou, Leonard 8573. Ennery, Leonard 8952. Plaisance, Leonard 9379. Pilate, Leonard 9597.

Dominican Republic: Higüey, Ekman H 12136.

Puerto Rico: Mayaguez, Chase 6265, 6311. Quebradillas, Chase 6569. Arecibo, Chase 6456. Bayamon, Chase 6410. Cayey, Sintenis 2396.

Virgin Istands: St. Croix, Thompson 372.

Leeward Islands: Antigua, Box 76; Rose 3486. Guadeloupe, Duss 3178.

Windward Islands: Martinique, Duss 733.

2. Lithachne pineti (Wright) Chase, Biol. Soc. Wash. Proc. 21: 182. 1908.

Olyra pineti Wright; Griseb., Mem. Amer. Acad. (n. s.) 8: 532. 1862. Eastern Cuba, Wright 1536.

Perennial; culms tufted, filiform, lax, spreading, 10 to $20 \mathrm{~cm}$ long; blades ovate to lanceolate, soon reflexed, 10 to $15 \mathrm{~mm}$ long, 3 to $7 \mathrm{~mm}$ 


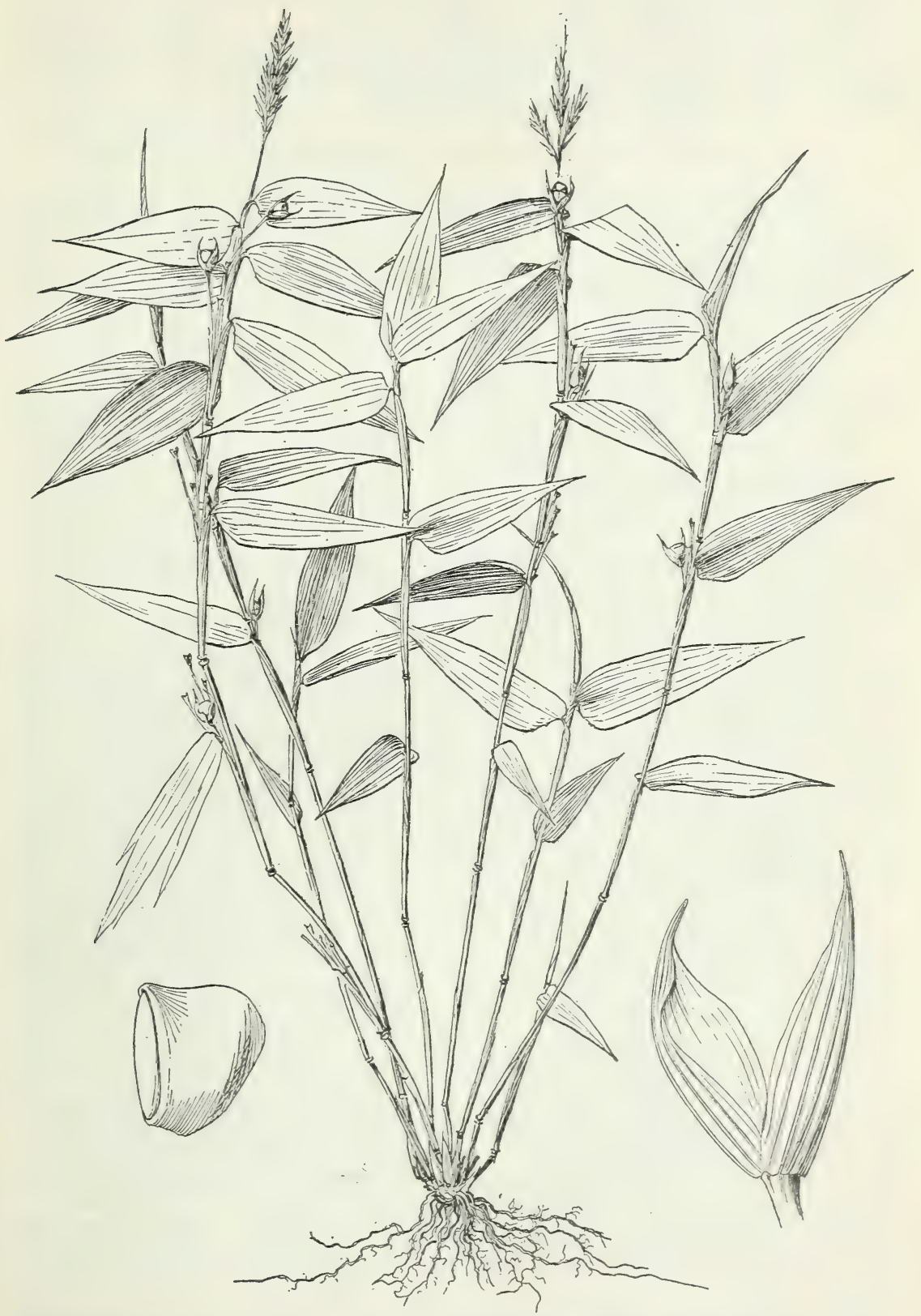

FIGURE 340.-Lithachne pauciflora. Plant, $\times \frac{1}{2}$; glumes and floret of pistillate spikelet, $\times 5$ (Shafer 53). 
wide; staminate spikelets narrow, 3 to $4 \mathrm{~mm}$ long; glumes of pistillate spikelets acuminate, $5 \mathrm{~mm}$ long; fruit about $3 \mathrm{~mm}$ long.

Moist places in pine woods, eastern Cuba.

Cuba: Sierra de Nipe, edge of Río Piloto, in "carrascales", Ekman 19160 ; on the border of "manacales", Ekman 2560; in pinelands, Ekman 2287. Eastern Cuba, Wright 1536.

\section{RADDIA Bertol., Opusc. Sci. Bologna 3: 410. 1819}

Plants monoecious; staminate and pistillate spikelets in distinct small panicles, the staminate terminal or from the upper nodes, the pistillate axillary; first glume of the pistillate spikelets wanting, the second glume and sterile lemma membranaceous, acuminate; fruit dorsally subcompressed, narrow, bony-indurate. Slender perennial with flat blades and narrow panicles.

Fruit pubescent; blades 5 to $7 \mathrm{~cm}$ long. ......... R. SYMPODICA.

Fruit glabrous; blades not over $4 \mathrm{~cm}$ long.

Blades about $3 \mathrm{~cm}$ long; fruit 6 to $7 \mathrm{~mm}$ long _........ 2. R. GUIANENsis.

Blades 1 to $1.5 \mathrm{~cm}$ long; fruit about $2 \mathrm{~mm}$ long

1. Raddia sympodica (Doell) Hitche.

Olyra sympodica Doell, in Mart., Fl. Bras. 22: 322. 1877. French Guiana.

Raddia biformis Hitchc. and Chase, Contrib. U. S. Natl. Herb. 18: 358. 1917. Trinidad, Broadway 2375.

Culms tufted, simple, slender, erect, or ascending from strongly geniculate lower nodes, 15 to $30 \mathrm{~cm}$ tall, the sterile culms naked below, bearing 5 to 7 crowded leaves at the summit; blades flat, lanceolate, rounded at base, glabrous or sparsely hispid on upper surface, sparsely hispid and paler beneath, 3 to $7 \mathrm{~cm}$ long, 6 to $12 \mathrm{~mm}$ wide; staminate inflorescence consisting of small spikelike panicles of 2 to 5 spikelets borne in the upper axils and at the ends of the leafy culms the lateral spikelets staminate, subsessile, about $3 \mathrm{~mm}$ long, $0.8 \mathrm{~mm}$ wide, acuminate, minutely puberulent, strongly nerved, the terminal spikelets in appearance like the pistillate ones, 7 to $8 \mathrm{~mm}$ long, on short obconic pedicels, neutral or with a rudimentary pistil; pistillate inflorescence consisting of small spikelike panicles of 2 or 3 fertile spikelets on short thickened pedicels and a few more or less rudimentary subsessile staminate ones borne at the ends and in the upper slightly inflated sheaths of low slender naked culms arising from the base; fertile spikelets on short thickened pedicels, 7 to $8 \mathrm{~mm}$ long, $2 \mathrm{~mm}$ wide, subterete, oblong-elliptic; glume and sterile lemma subequal, puberulent, strongly nerved, acuminate into short setaceous scabrous tips about $1 \mathrm{~mm}$ long; fruit $6.5 \mathrm{~mm}$ long, about $1.5 \mathrm{~mm}$ wide, elliptic, apiculate, becoming lead-colored at maturity, clothed with soft silky appressed hairs, a glabrous stripe down the back, the margins of the lemma nearly meeting over the palea.

Shady forest floors, Trinidad and French Guiana. "A dwarf grass in sandy soil on slopes unaier the shade of large forest trees" (Broadway).

Trinidad: Tabaquite, Hitchcock 10127. Ortoire River, Guayaguayari Road, Britton, Freeman, and Nowell 2530. Caparo, Broadway 2375. 
2. Raddia guianensis (Brongn.) Hitchc.

Strephium guianense Brongn., Bull. Soc. Bot. France 7: 471. 1860. French Guiana.

Raddia urbaniana Hitchc. and Chase, Contrib. U. S. Natl. Herb. 18: 359. 1917. Tobago, Hitchcock 10267.

Olyra urbaniana Mez, Notizbl. Bot. Gart. Berlin 7: 47. 1917. Tobago, Eggers 5841.

Culms tufted, slender, ascending from more or less geniculate lower nodes, 20 to 45 $\mathrm{cm}$ tall, naked below, toward the summit bearing 12 to 24 approximate leaves with overlapping sheaths and distichous spreading blades; blades flat, glabrous, oblong-lanceolate, rounded at both ends, mucronate, 2 to $3.5 \mathrm{~cm}$ long, 4 to 8 $\mathrm{mm}$ wide; staminate panicles several to many from the axils of the upper sheaths, narrow, few-flowered, the axis and pedicels angled, scabrous, the spikelets 5 to $6 \mathrm{~mm}$ long, acuminate-pointed; pistillate panicles 1 or 2 from the middle nodes, bearing 2 to 5 spikelets on short clavate pedicels; spikelets lanceolate, the glume $8 \mathrm{~mm}$ long, much exceeding the fruit, the sterile lemma $5 \mathrm{~mm}$ long, both acuminate-setaceous; fruit $4 \mathrm{~mm}$ long, about 1 $\mathrm{mm}$ wide, bluntly acuminate, whitish, glabrous (fig. 341).

Shady banks and floor of forest, Tobago to Brazil.

Tо в A G: Hitchcock 10267 (Amer. Gr. Nat. Herb. 626); Broadway 3004, 4360; Eggers 5841.

3. Raddia nana (Doell) Chase, Biol. Soc. Wash. Proc. 21: 185. 1908.

Olyra nana Doell, in Mart., Fl. Bras. $2^{2}$ : 329 . 1877. Brazil.

Culms tufted, delicate, lax or straggling, nearly simple,

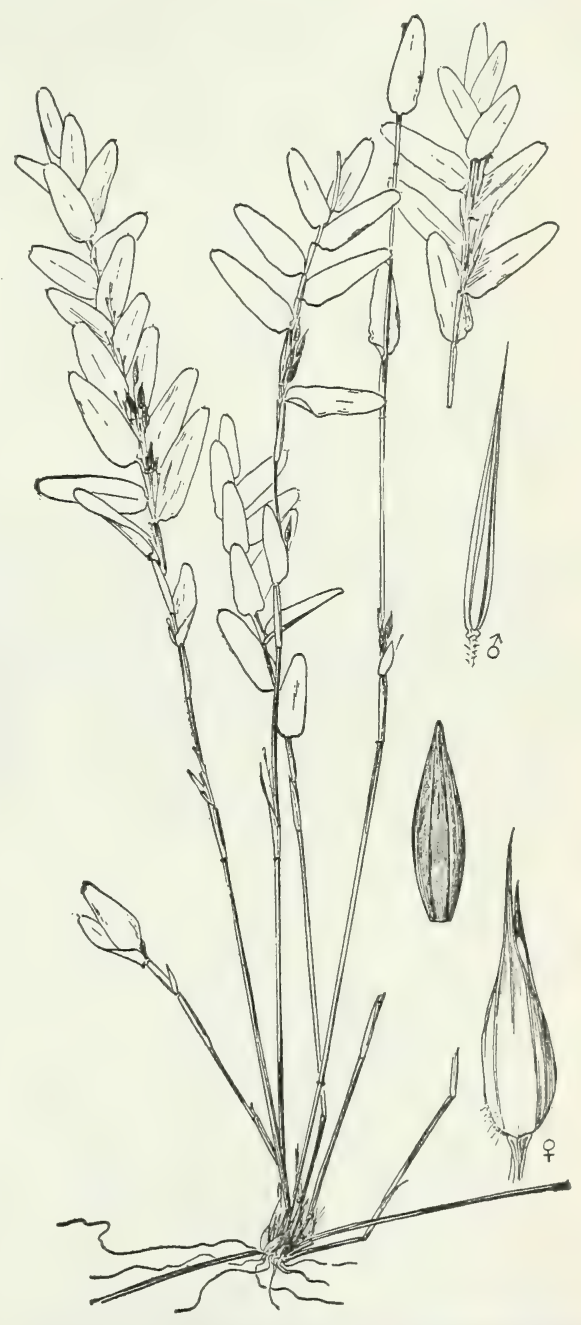

Figure 341.-Raddia guianensis. Plant, $\times 1 / 2$; staminate and pistillate spikelets and pistillate floret, $\times 5$ (Hitchcock 10267, Amer. Gr. Nat. Herb. 626).

10 to $30 \mathrm{~cm}$ long, naked below; blades flat, oblong- to ovate-triangular, spreading or reflexed, 10 to $12 \mathrm{~mm}$ long, 5 to $7 \mathrm{~mm}$ wide, mucronate at the rounded apex; racemes small and few-flowered, axillary, scarcely exserted from the upper sheaths; pistlllate spikelets ovoid, $2 \mathrm{~mm}$ long, the glumes puberulent. 
Wet sandy savannas, Trinidad to Brazil.

Trinidad: Aripo Savanna, Hitchcock 10079; Broadway 7685. Bot. Gard. Herb. 6671.

\section{MNIOCHLOA Chase, Biol. Soc. Wash. Proc. 21: 185.1908}

Plants monoecious; inflorescence a pair of slender racemes, one pistillate, the other staminate, at the summit of a naked culm; pistillate spikelets subsessile; first glume wanting; second glume and sterile lemma subequal, obtuse, or subacute; fruit white, cartilaginous, subindurate; staminate spikelets smaller, reduced to the lemma and palea. Slender perennials with flat firm subpetiolate blades.

Flowering culms much exceeding the sterile ones; fruit glabrous.

1. M. PULCHELLA.

Flowering culms mostly shorter than the sterile culms; fruit pubescent.

2. M. STREPHIOIDES.

1. Mniochloa pulchella (Griseb.) Chase, Biol. Soc. Wash. Proc. 21: 186. pl. 4. 1908.

Digitaria pulchella Griseb., Cat. Pl. Cub. 231. 1866. Cuba, Wright 3448.

Strephium? pulchellum Wright, An. Acad. Cienc. Habana 8: 202. 1871.

Culms tufted, filiform, lax and spreading, the sterile 5 to $10 \mathrm{~cm}$ long, the flowering culm erect or ascending, 10 to $20 \mathrm{~cm}$ tall, bearing a single sheath about the middle and another near the base; blades lanceolate-oblong, flat, sparsely hispidulous on the upper surface, scabrous beneath, 10 to $18 \mathrm{~mm}$ long, 4 to $7 \mathrm{~mm}$ wide; racemes 2 to 3 $\mathrm{cm}$ long; pistillate spikelets about $2.7 \mathrm{~mm}$ long; staminate spikelets about $1.4 \mathrm{~mm}$ long (fig. 342).

On shady limestone rocks, rare, eastern Cuba.

Cuba: El Yunque de Baracoa, Wright 3448; Ekman 3916.

2. Mniochloa strephioides (Griseb.) Chase, Biol. Soc. Wash. Proc. 21: 186.1908.

Olyra strephioides Griseb., Cat. Pl. Cub. 229. 1866. Cuba, Wright 3435 .

Culms lax, erect or more or less spreading, the sterile usually 10 to $15 \mathrm{~cm}$ tall, the fertile 4 to $7 \mathrm{~cm}$ tall, bearing a single sheath about the middle; blades oblong to ovate-triangular, flat, finely puberulent or scabrous, truncate at base, 5 to $15 \mathrm{~mm}$ long, 3 to $8 \mathrm{~mm}$ wide; racemes 1.5 to $2 \mathrm{~cm}$ long; pistillate spikelets about $4.5 \mathrm{~mm}$ long; staminate spikelets $1.5 \mathrm{~mm}$ long.

Shady banks and ravines, western Cuba.

Cuba: Cayabos, Ekman 12945. Cabanas, Ekman in 1921. San Diego de los Baños, Léon 4391, 4572, 4593; Caldwell and Baker 7011. Pinar del Río, Hitchcock 23310. Habana, Ekman 1238. Campo Florido, Léon 4140 . Western Cuba, Wright 3435.

\section{EKMANOCHLOA Hitchc., gen. nov. ${ }^{96}$}

Plants monoecious; inflorescence a pair of slender racemes, one pistillate, the other staminate, at the summit of leafy culms; pistillate spikelets short-pediceled along a slender rachis; first glume wanting;

${ }^{86}$ Planta monoica; racemi bini, uno masculo, uno femineo; spiculae femineae: Gluma prima nulla; gluma secunda et lemma sterile subaequalia, 3-5-nervia; lemma fertile subteres, cartilagineum, versus apicem angustatum, aristatum; arista tenui; palea in lemmate inclusa; spiculae masculae: Lemma et palea subaequalia acuta lemmate 3 -nervio. 
second glume and sterile lemma somewhat unequal, 3- to 5-nerved; fertile lemma subterete, cartilaginous, gradually narrowed into a slender awn; palea as long as the body of the lemma and enclosed within it; staminate spikelets smaller, reduced to subequal lemma and palea. Slender tufted perennials with flat narrowly lanceolate blades, often reduced. The genus is named for the late Dr. Erik L. Ekman, indefatigable botanical explorer.

Type species, E. subaphylla Hitchc.

Glume and sterile lemma much shorter than the floret.

1. E. SUBAPHYLLA.

Glume and sterile lemma about as long as the body of the foret...2. E. ARISTAta.

1. Ekmanochloa subaphylla Hitchc., sp. nov. ${ }^{97}$

Perennial; culms cespitose, slender, erect, rather wiry, glabrous, 50 to 100 $\mathrm{cm}$ tall; sheaths shorter than the internodes, glabrous; ligule very minute; blades from minute to well developed, flat, 1 to 3.5 $\mathrm{cm}$ long, 1 to $4 \mathrm{~mm}$ wide, narrowly lanceolate, rather distinctly nerved, scaberulous or puberulent, with a puberulent petiole $1 \mathrm{~mm}$ long or less; racemes conjugate, erect, appressed or approximate, the pistillate one 3 to $4 \mathrm{~cm}$ long, the staminate about half as long, the rachis slender, terete or somewhat angular, glabrous; pistillate spikelets appressed, distant (4 to $6 \mathrm{~mm}$ ), about $6 \mathrm{~mm}$ long excluding the awn, the pedicel $1 \mathrm{~mm}$ long or a little less, rather thick; second glume 1.5 to $2 \mathrm{~mm}$ long, 3-nerved, glabrous,

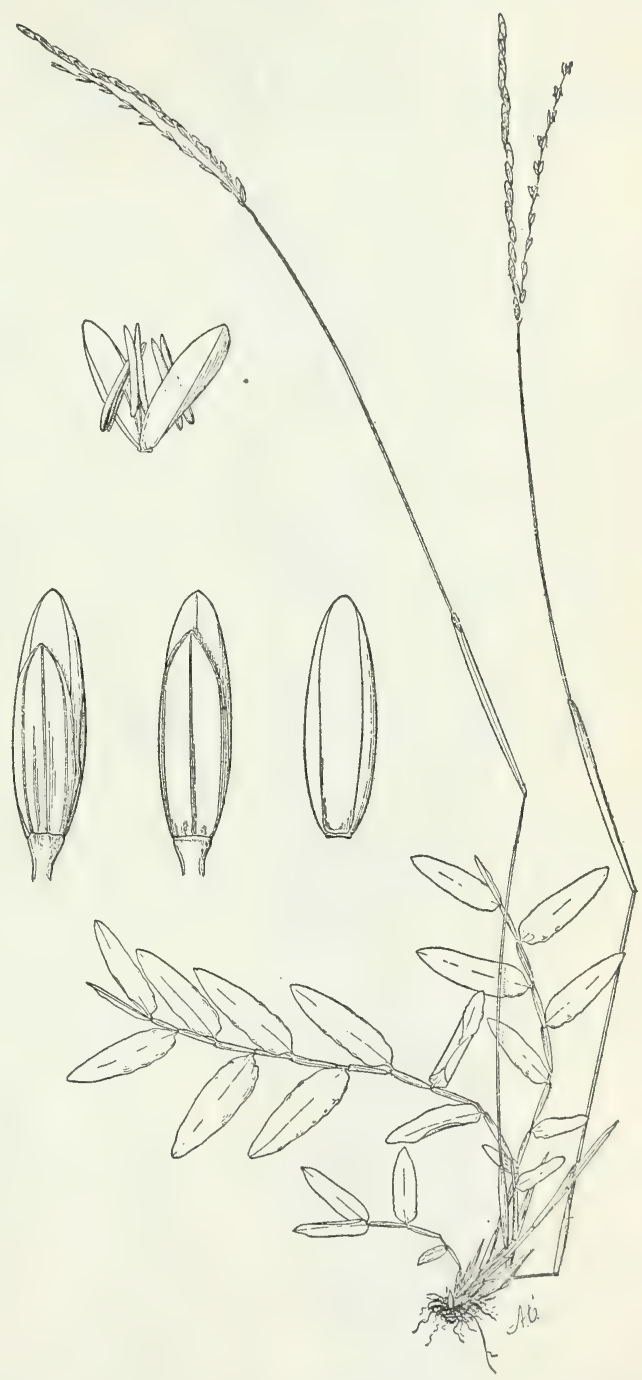

Figure 342.-Mniochloa pulchella. Plant, $\times 1$; staminate spikelet, two views of pistillate spikelet, and floret, $\times 10$ (Wright 3448).

the sterile lemma similar but a little longer; fertile lemma glabrous, broadest about $2 \mathrm{~mm}$ above the base (about $0.7 \mathrm{~mm}$ thick), gradually narrowed above, the awn somewhat flexuous, slightly scaberulous, 1

97 Perennis culmi caespitosi tenues erecti glabri 50-100 cm alti; vaginae plerumque sine laminis; laminaeperfectae planae anguste lanceolatae, minute scaberulae, usque ad $3 \mathrm{~cm}$ longae $1-4 \mathrm{~mm}$ latae; racemi appressi erecti, feminei 3-4 cm longi, masculi breviores; spiculae femineae arista exclusa $6 \mathrm{~mm}$ longae; gluma 1.5-2 mm longa; spiculae masculae $2 \mathrm{~mm}$ longas. 


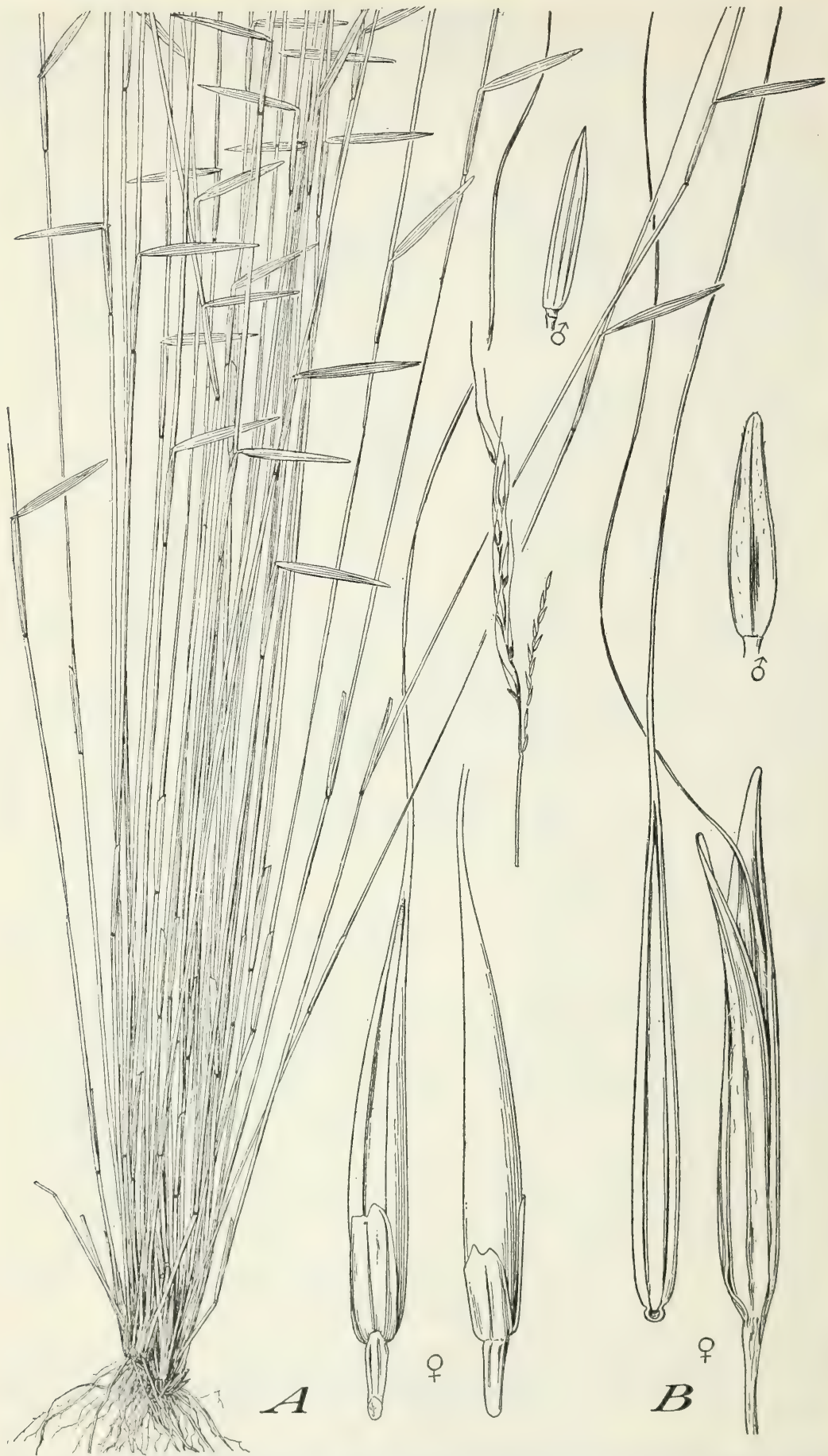

FigURE 343.-A, Ekmanchloa subaphylla. Plant, $\times 1 / 2$; inflorescence, $\times 1$; two views of pistillate spikelet and staminate spikelet, $\times 10$ (ty pe). $B, E$. aristata. Pistillate and staminate spikelets, and fruit, $\times 10$ (type). 
to $1.5 \mathrm{~cm}$ long; staminate spikelets about $2 \mathrm{~mm}$ apart, appressed, about $2 \mathrm{~mm}$ long, the lemma and palea subequal, acute, the lemma 3-nerved, the pedicel less than $1 \mathrm{~mm}$ long (fig. 343, A).

Type in the United States National Herbarium, no. 1259999, collected on overhanging limestone rocks of Loma Picote, Sierra de Nipe, prov. Oriente, Cuba, altitude 500 m, November 2, 1922, by E. L. Ekman.

Only known from province of Oriente, Cuba, the other specimen seen being from Sierra de Nipe, in limestone hills at Río Jimbambay, Ekman 9870.

2. Ekmanochloa aristata Ekman, sp. nov. ${ }^{98}$

Similar to E. subaphylla, about $50 \mathrm{~cm}$ tall; sheaths shorter, with a few long hairs at the summit; blades, except the lower, developed, 1 to $3.7 \mathrm{~cm}$ long, 1.5 to $4 \mathrm{~mm}$ wide; inflorescence few-flowered, the staminate and pistillate spikelets each 4 or 5 ; pistillate spikelets 8 to $9 \mathrm{~mm}$ long excluding the awn, the glume and sterile lemma equaling the body of the fertile floret, 3 and 5 nerved, obscurely pubescent between the nerves; awn of the fertile floret about $15 \mathrm{~mm}$ long; staminate spikelets 3 to $3.2 \mathrm{~mm}$ long, obscurely pubescent (fig. $343, B$ ).

Type in the United States National Herbarium no. 1385553, collected "in carrascales-pinales, between Taco and Nibujon, prov. Oriente, very rare", December 4, 1914, by E. L. Ekman (no. 3729). Only known from the type collection.

\section{TRIBE 13. ANDROPOGONEAE}

\section{IMPERATA Cyrillo, Pl. Rar. Neap. 2: 26. 1792}

Spikelets all alike, awnless, in pairs, unequally pedicellate on a slender continuous rachis, surrounded by long silky hairs; glumes about equal, membranaceous; sterile lemma, fertile lemma, and palea thin and hyaline. Slender erect perennials with terminal narrow silky panicles.

Panicle rarely more than $15 \mathrm{~cm}$ long; spikelets $4 \mathrm{~mm}$ long_ 1 . I. BRAsiliensis. Panicle as much as $40 \mathrm{~cm}$ long; spikelets $3 \mathrm{~mm}$ long _...... 2. I. CONTRACTA.

1. Imperata brasiliensis Trin., Mém. Acad. St. Pétersb. VI. Math. Phys. Nat. 2: 331 . 1832. Brazil.

Perennial, erect, tufted, with scaly rhizomes; culm slender, simple, 0.5 to $1 \mathrm{~m}$ tall; leaves mostly clustered toward the base, the blades flat, 5 to $10 \mathrm{~mm}$ wide; panicle pale, narrow (fig. 344 ).

Open rather dry ground at low altitudes, Bahamas and southern Mexico to Brazil.

Bahamas: Andros Island, Small and Carter 8910. Eleuthera, E. Britton 6506.

Cuba: Sierra de los Organos, Ekman 10678. Herradura, Van Hermann 575. Consolación del Sur, Palmer and Riley 472. Paso Real, Léon 4262. Calvario, Léon 1582. Loma Menqura, Shafer 3856. Riverside, Shafer 1145. Without locality, Wright 3486. Isla de Pinos, Jennings 296; Britton and Wilson 14397, 14399.

JamaICA: Lititz, Harris 11660, 11742, 12880.

${ }^{98} \mathrm{Ab} \mathrm{E.} \mathrm{subaphylla} \mathrm{differt} \mathrm{vaginis} \mathrm{brevioribus,} \mathrm{spicula} \mathrm{femina} \mathrm{8-9} \mathrm{mm}$ longa; gluma et lemmate sterili lemma fertile aequantibus. 


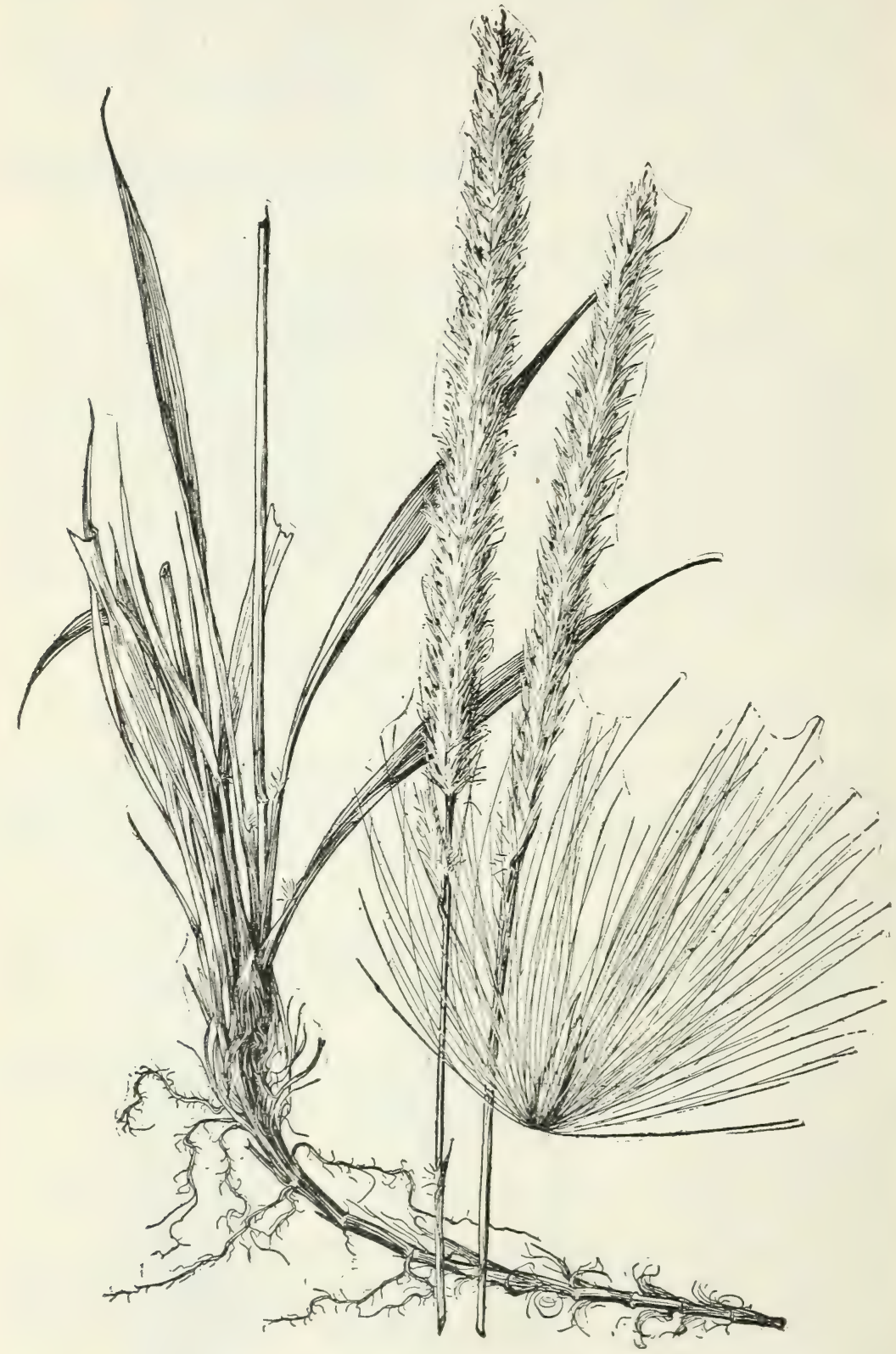

FIGURE 344.-Imperata brasiliensis. Plant, $\times 1 / 2$; spikelet, $\times 5$ (Chapman) 
HaItr: Mission, Leonard 3830. Massif du Nord, Gros-Morne, Ekman H 5020.

Dominican Republic: Monción, Ekman H 12894.

Trinidad: O'Meara Savanna, Britton and Hazen 1577. Pitch Lake, Hitchcock 10095 (Amer. Gr. Nat. Herb. 232). Jerningham Junction, Broadway 4787.

2. Imperata contracta (H. B. K.) Hitchc., Rep. Mo. Bot. Gard. 4: 146.1893.

Saccharum contractum H. B. K., Nov. Gen. et Sp. 1: 182.1816. Colombia.

Saccharum caudatum Meyer, Prim. Fl. Esseq. 68. 1818. British Guiana.

Anatherum caudatum Schult., Mant. 2: 445. 1824.

Rico.

Anatherum portoricense Spreng., Syst. Veg. 1: 290. 1825. Puerto

Imperata caudata Trin., Mém. Acad. St. Pétersb. VI. Math. Phys. Nat. 2: 331. 1832.

Taller than the preceding, the culms leafy, the panicle as much as $40 \mathrm{~cm}$ long.

Swamps and moist open ground, southern Mexico and the West Indies to Brazil.

Cuba: Colonia San Rafael, Léon 5682. La Prenda, Hioram 2408. Bayate, Ekman 5877.

JAMAICA: Berwick, Harris 11532. Westphalia, Harris 11569. Troy, Hitchcock 9804; Harris 12619. Resource, Harris 12416. Without locality, Wilson. Grand Cayman, Hitchcock in 1891.

Haitr: Morne Basil, Ekman H 2488. Massif de la Hotte, Ekman $\mathrm{H}$ 7341. Aux Cayes, Ekman H 255.

Dominican Republic: Valle del Cibao, Ekman H 13284. Jarabaco, Ekman $\mathrm{H} 14127$.

Puerto Rico: Hato Grande, Sintenis 2720. Cayey, Chase 6746. Arecibo, Chase 6438. Without locality, Eggers 602.

Leeward Islands: Guadeloupe, Duss 3886.

Windward Islands: Martinique, Duss 1306.

Trinidad: Icacos, Broadway 4963. Cedros, Hitchcock 10142. St. Joseph, Hitchcock 10027. California, Hitchcock 10119. Without locality, Bot. Gard. Herb. 3379.

TOBAGO: Hitchcock 10273.

Miscanthus sinensis Anderss., Ofv. Svensk. Vet. Akad. Forh. 12: 166. 1856.

Eulalia.

Tall reed growing in large bunches, 1 to $3 \mathrm{~m}$ tall, with flat mostly basal blades, about $1 \mathrm{~m}$ long and $1 \mathrm{~cm}$ wide, gradually narrowed to a slender point; panicle fan-shaped, consisting of numerous silky racemes 10 to $20 \mathrm{~cm}$ long, aggregate at the summit of the culm. Occasionally cultivated for ornament. Native of Asia.

CuBa: Habana, Léon 2012.

\section{SACCHARUM L., Sp. Pl. 54. 1753}

Spikelets in pairs, one sessile, the other pedicellate, both perfect, awnless, arranged in panicled racemes, the axis disarticulating below the spikelets; glumes somewhat indurate, sterile lemma similar but hyaline; fertile lemma hyaline, sometimes wanting. Tall perennials with feathery panicles. 
1. Saccharum officinarum L., Sp. Pl. 54. 1753. India. Stgarcane. Saccharum violaceum Tussac, Fl. Antill. 1: 160. pl. 25. 1808. Jamaica.

Gigantic perennial with broad leares, the orerlapping sheaths falling from the short-jointed lower part of the culms, the great plumy panicles pinkish silvers; forming seed sparingly (fig. 345 ).

Cultirated in Tropics and Subtropics of both hemispheres. The West Indian specimens in herbaria are probabl $\Gamma$ all from cultivated plants. The Spanish name is "caña de azúcar." Called in Haiti "canne à sucre."

Sacchartur ciliare Anderss., Öfr. Srensk. Vet. Akad. Förh. 12: 155. 1855. An Asiatic species with elongate blades and long narrow featherr panicles, sparingly cultirated for ornament, escaped in St. Kitts (Box 162.)

\section{ERIOCHRYSIS Beaur., Ess. Agrost. 8. pl. 4 f. 11.1812}

Spikelets awnless, the sessile spikelets perfect, the pedicellate spikelets pistillate, smaller but fruitful, readily falling, the rachis rather tardily disjointing; racemes short, crowded in a narrow, dense, silky interrupted spikelike panicle. Erect perennials with yellow or brown compact woolly inflorescence.

1. Eriochrysis cayennensis Beaur., Ess. Agrost. 8. pl. 4 f. 11.1812.

(Beaurois spells the name "Caranensis.") Carenne.

Saccharum cayennense Benth., Jour. Linn. Soc. Bot. 19: 66. 1881.

Erect perennial 1 to $2 \mathrm{~m}$ or more tall, the long narrow blades denselr relretr, the compact silky golden brown panicle 10 to $12 \mathrm{~cm}$ long (fig. 346).

Moist slopes and sarannas, southern Mexico and the Test Indies to Uruguar. The trpe locality is presumably Carenne, though no locality is mentioned in the original description.

HAiti: Marmelade, Leonard 8242a, 8243. Ridge between Morne Darras and Morne Beaubrun, Ekman H 478i. Pérodin, Ekman H 3410. Mount Organisé, Ekman H 6224.

Domicax Reptblic: Lagunas de Cenobí, Taleur 21. Valle del Cibao, Elman H 13281. Sabana del Guabatico, Elman H 11050. San Juan, Ekman H 13613. Monción, Ekman H 12993. Sánchez, Ekman H 14734. El Valle, Ekman H 15662.

Pterto Rico: Maricao, Hioram 818; Britton and Cowell 4265. San Juan, Chase 6762.

Trinidad: Arima, O’Meara Saranna, Broaduay 2374.

\section{ERIANTHUS Michx., Fl. Bor. Amer. 1: 54. 1803}

Spikelets all alike, in pairs along a slender axis, one sessile, the other pedicellate, the rachis disarticulating below the spikelets, the rachis joint and pedicel falling attached to the sessile spikelet; glumes coriaceous, equal, usually copiously clothed, at least at the base, with long silky spreading hairs; sterile lemma thin and hyaline; fertile lemma hraline, the midnerve extending into a slender awn; palea small and hyaline. Robust reedlike perennials, with flat blades and terminal oblong, usually dense silky panicles. 


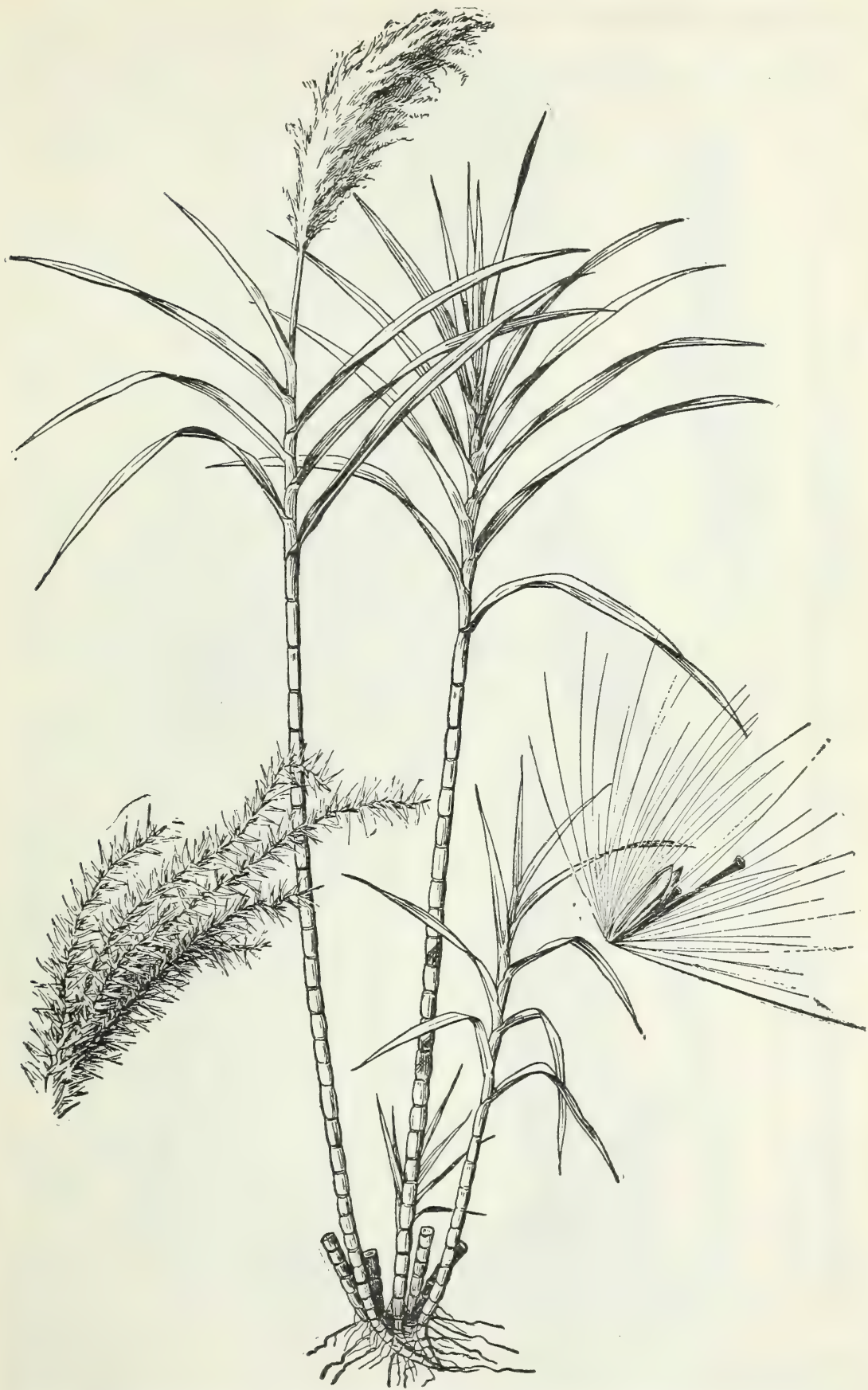

FIGURE 345.-Saccharum officinarum. Plant, much reduced; racemes, $\times 1 / 2$; spikelet with pedicel and rachis joint, $\times 5$ (Pringle) 
1. Erianthus giganteus (Walt.) Muhl., Cat. Pl. 4. 1813.

Sugarcane Plumegrass. Anthoxanthum giganteum Walt.,Fl.Carol.65. 1788. South Carolina.

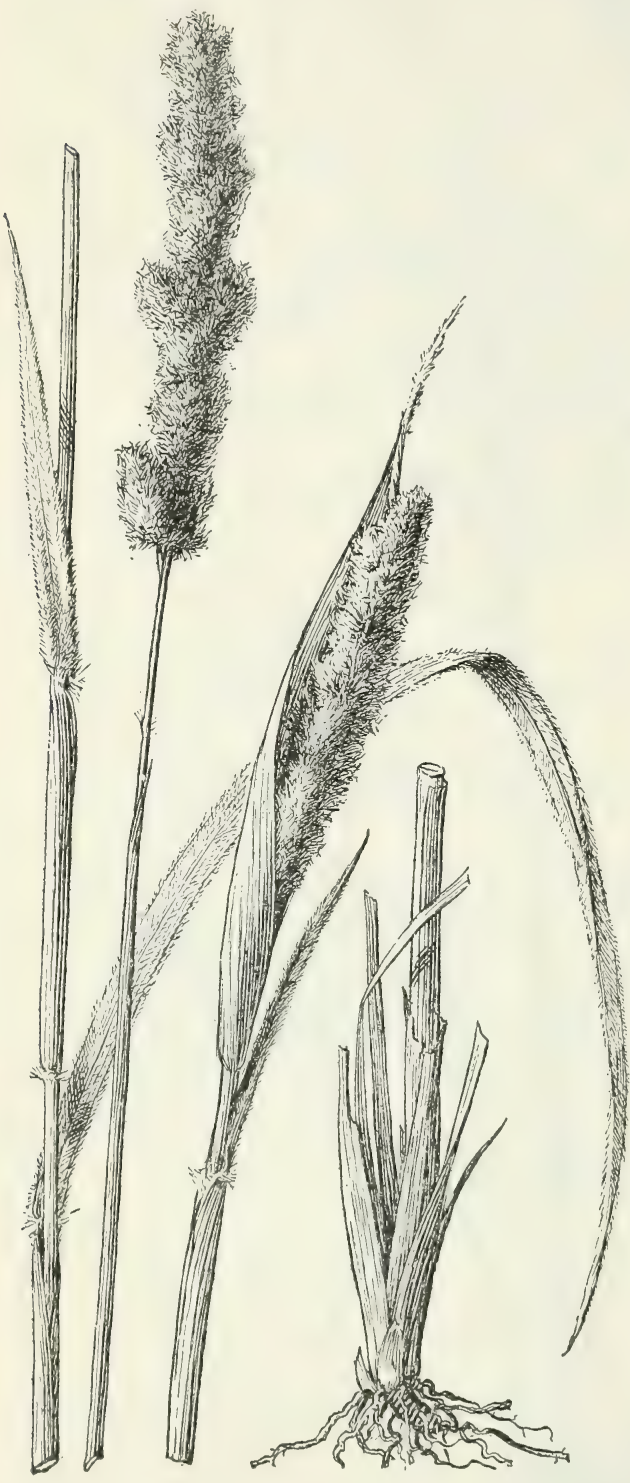

FIGURE 346.-Eriochrysis cayennensis, $\times 1 / 2$ (Hioram 818).

Erianthus saccharoides Michx., Fl. Bor. Amer. 1: 55. 1803. Carolina to Florida.

Robust tall erect perennial with long harshly pubescent blades and tawny or purplish plumy panicles up to $40 \mathrm{~cm}$ long (fig. 347 ).

Swamps and moist soil from New Jersey to Florida and Texas on the Coastal Plain; also in Cuba.

CuBA: Laguna San Mateo, Wright 3903. Laguna Jovero to Laguna Herradura, Shafer 10934. Batabanó, Ekman 12586; Léon 13443. Cayo de los Pavos, Ciénaga de Zapata, Léon 9529. Sabana del Guaní, Fernando 434.

Dominican RePUBLIC: Sánchez, Ekman H 15937.

Erianthus RAVENNAE (L.) Beauv., Ess. Agrost. 14, 162, 177. 1812. (Saccharum jamaicense Trin., Erianthus jamaicensis Anderss.; E. ravennae var. jamaicensis Hack.) was described by Trinius from Jamaica, but his specimen was doubtless a cultivated plant, the species being grown for ornament in warm climates.

\section{A R THRAX O N Beauv., Ess. Agrost. 111. pl. 11.f. 6.1812}

Perfect spikelets awned, sessile, the secondary spikelet and its pedicel wanting or present only at the lower joints of the filiform articulate rachis; racemes terminating the branches of a dichotomously forking panicle, in appearance subdigitate or fascicled. Branching annuals with broad blades and slender racemes. 


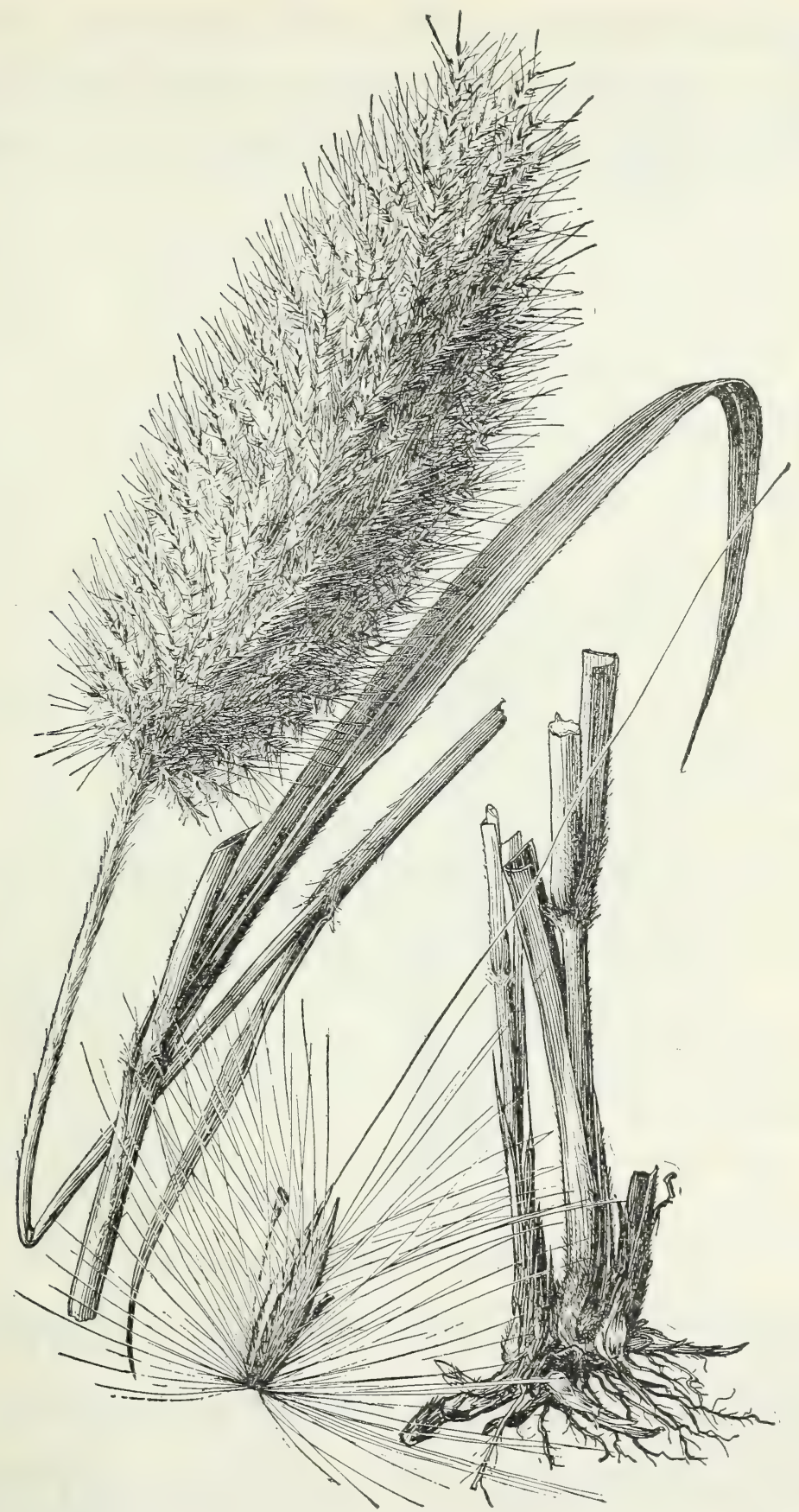

FIGURE 347:-Erianthus giganteus. Plant, $\times 1 / 2$; spikelet with pedicel and rachis joint, $\times 5$ (Langlois 96 ). $60256-36-25$ 
384 MISC. PUBLICATION 243, U. S. DEPT. OF AGRICULTURE

1. Arthraxon quartinianus (A. Rich.) Nash, N. Amer. Fl. 17: 99. 1912.

Alectoridia quartiniana A. Rich., Tent. Fl. Abyss. 2: 448. 1852. Abyssinia.

Arthraxon ciliaris subsp. quartinianus Hack., in DC. Monogr. Phan. 6: 356. 1889.

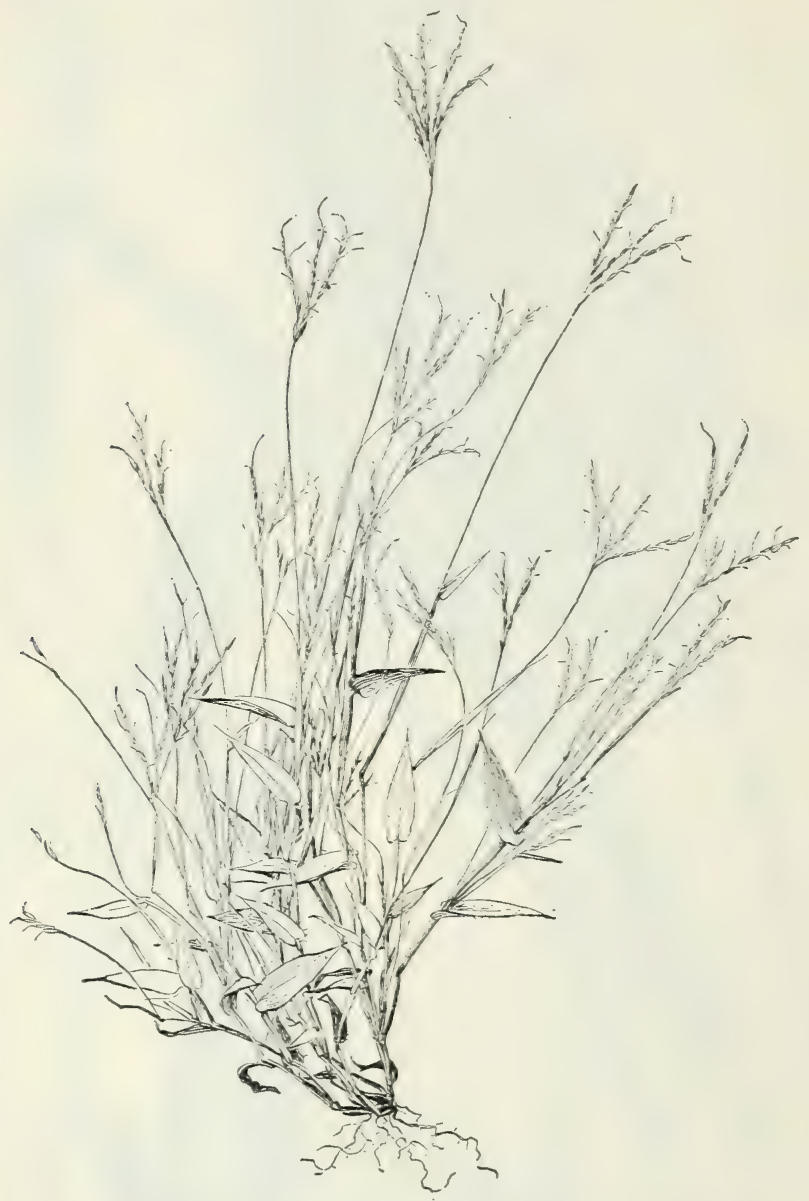

FIGURE 348.-Arthraxon quartinianus, $\times 1 / 2$ (Duss 2712).

Weak-stemmed, laxly branching creeping annual, with ascending flowering branches, bearing flat thin ovate blades cordate at base, and flabellate fascicles of slender racemes (fig. 348).

Shady banks, Jamaica and Guadeloupe, introduced from the Tropics of the Old World.

Jamaica: Hardware Gap, Ridley 105; Harris 10910. Wallingford, Perkins 1484; Harris 11550. St. Helens Gap, Maxon and Killip 589. Whitefield, Harris 11563. Halls Delight, Harris 11536. Cold Spring Gap, Harris 11708. Cinchona, Harris 11309, 11416.

Leeward Islands: Guadeloupe, Duss 2712, 3136. 


\section{ANDROPOGON L., Sp. Pl. 1045. 1753. Beardgrass}

Spikelets in pairs at each node of an articulate rachis, one sessile and perfect, the other pedicellate and either staminate, neuter, or reduced to the pedicel, the rachis and the pedicels of the sterile spikelets often villous, sometimes conspicuously so; glumes of the fertile spikelet coriaceous, narrow, awnless, the first rounded, flat, or concave on the back, several-nerved, the median nerve weak or wanting; sterile lemma hyaline; fertile lemma hyaline, narrow, usually bearing a bent and twisted awn from the apex or from between apical lobes; pedicellate spikelet usually awnless, sometimes staminate and about as large as the sessile spikelet, sometimes consisting of one or more reduced glumes, sometimes wanting, only the pedicel present. Usually coarse perennials, with solid culms, the spikelets arranged in racemes, these numerous, aggregate on an exserted peduncle, or single, in pairs, or sometimes in threes or fours, the common peduncle usually enclosed by a spathelike sheath, these sheaths often numerous, forming a compound inflorescence, usually narrow, but sometimes in dense subcorymbose masses.

Lower 1 or 2 pairs of spikelets of the raceme differing from those above in consisting of two similar staminate spikelets. Racemes 1 to several, digitate or aggregate; sessile and pediceled spikelets alike in size and shape, the former (when fertile) awned, the latter awnless. (Section Dichanthium).

Racemes several, on slender flexuous peduncles....... 1. A. CONDYLOTRICHUs. Racemes, if more than 1 , on short straight peduncles.

Racemes usually 3 to 6 ; spikelets slightly overlapping, the pedicels usually in part visible.... A. ANNULATUS.

Racemes usually 1 , sometimes 2 , rarely more; spikelets closely overlapping, the pedicels hidden.

Culms glabrous below racemes . . . . . . . . . . 3. A. CARICosus.

Culms pubescent below racemes_.....

Lower pairs like the others, the sessile spikelet fertile, usually awned, the pediceled spikelet staminate or neuter, usually smaller than the sessile one, of ten much reduced.

Racemes solitary at the ends of the culms and branches, from bladeless sheaths or spathes. (Section Schizachyrium, except A. virgatus of section HyPOGYNitM.)

Plants annual.

Culms weak, decumbent, trailing or vinelike; blades obtuse, mostly 1 to 3 em long; peduncles capillary ................. 5. A. BREVIFOLIUS.

Culms erect, relatively stout; blades acute, mostly 5 to $10 \mathrm{~cm}$ long; peduncles slender but not capillary ........ . A. MalacosTachy US.

Plants perennial.

Rachis slender, nearly straight or usually conspicuously zigzag, the spikelets spreading.

Blades flat; racemes very numerous in a corymbose panicle; plants robust . . . . . . . . . .

Blades folded or involute; racemes few; plants slender (tall in A. reedii). (See also $A$. urbanianus.)

Racemes densely white-villous with long hairs; awns 1 to $2 \mathrm{~cm}$ long.

8. A. GRACILIS.

Racemes sparsely or moderately villous; awns mostly less than $1 \mathrm{~cm}$ long.

Pedicellate spikelet about as long as the sessile; racemes moderately villous _. . . . . REEDII.

Pedicellate spikelet much reduced; racemes sparsely villous.

10. A. CUBENSIS.

Rachis straight, more or less thickened, the spikelets appressed or narrowly ascending.

Spikelets awnless.

Racemes about $1 \mathrm{~cm}$ long, partly enclosed in the subtending spathe, numerous, aggregate in a narrow panicle _....17. A. virgatus. 
Racemes 3 to $8 \mathrm{~cm}$ long, few, exserted.

Culm blades 10 to $20 \mathrm{~cm}$ long............ A. SAlzMaryi.

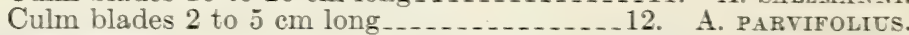
Spikelets awned.

First glume of sessile spikelet villous

First glume of sessile spikelet glabrous or nearly so. Blades terete, filiform; sessile spikelet $1.5 \mathrm{~mm}$ broad.

16. A. MULTINERTOSUS. Blades flat or folded or sometimes involute toward the apex.

Sessile spikelet about $4 \mathrm{~mm}$ long, $1 \mathrm{~mm}$ wide; blades not more than $1.5 \mathrm{~mm}$ wide .................... 15 . A. TENER. Sessile spikelet about $5 \mathrm{~mm}$ long; blades 2 to $5 \mathrm{~mm}$ wide.

14. A. SEMIBERBIS Racemes more than one at the summit of the culms and branches (one of the pair occasionall 5 abortive in $A$. urbanianus).

Racemes several or numerous in an exserted panicle.

Pedicellate spikelet about as large as the sessile.

First glume of sessile spikelet pitted on the back _.._30. A. PERTUsts.

First glume of sessile spikelet not pitted ........31. A. ISCHAEMUM.

Pedicellate spikelet much smaller than the sessile...29. A. SAcCHAROIDEs.

Racemes 2 to 4 (sometimes more in 1 . selloanus), fascicled, subtended br a

bladeless sheath (spathe), exserted or partly included.

Spikelets amnless.

Plants robust, 1.25 to $2 \mathrm{~m}$ tall; spathes aggregate in a corymbose, usually dense inflorescence...................... A. BICORIIS.

Plants slender, usually less than $1 \mathrm{~m}$ tall; spathes not aggregate.

Sessile spikelets about $3 \mathrm{~mm}$ long; blades usually not more than $2 \mathrm{~mm}$ wide, the apex acuminate _....... 19. A. LEUCOSTACHYCS.

Sessile spikelets about $4 \mathrm{~mm}$ long; blades 3 to $5 \mathrm{~mm}$ wide, the aper Spikelets awned. boat-shaped .............................. A. SELLOANUS.

Pedicellate spikelet as large as the sessile

Pedicellate spikelet reduced.

Racemes densely white-woolly, the hairs almost hiding the spike-

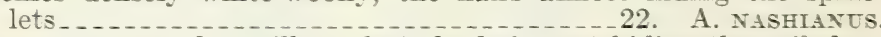

Racemes more or less villous, but the hairs not hiding the spikelets. Blades involute, firm

Blades flat or folded, comparatively soft.

Sheaths, especially the upper, long and inflated, more or less aggregate, the spathes inconspicuous_....24. A. ELLIOTTII. Sheaths not conspicuously inflated.

Spathes aggregate in a compound flabellate or club-shaped inflorescence.................... ALOMERATUS.

Spathes sometimes numerous but not aggregate in a compound club-shaped inflorescence.

Peduncle of the 2 racemes 3 to $5 \mathrm{~cm}$ long. Pedicellate spikelet wanting or nearly so.

27. A. REINOLDII. Pedicellate spikelet prominent but the awn reduced.

28. A. Axgustatus.

Peduncle of racemes less than $1 \mathrm{~cm}$ long.

26. A. VIRGINicus.

1. Andropogon condylotrichus Hochst.; Steud., Syn. Pl. Glum. 1:3 77. 1854. Abyssinia.

Andropogon piptatherus Hack., in Mart., Fl. Bras. 23: 293. 1883. Brazil.

Sorghum piptatherum Kuntze, Rer. Gen. Pl. 2: 792. 1891. Amphilophis piptatherus Nash, N. Amer. Fl. 17: 127. 1912.

Euclasta condylotricha Stapf, in Prain, Fl. Trop. Afr. 9: 181. 1917.

Teak-stemmed branching annual; culms 1 to $2 \mathrm{~m}$ long, the nodes rillous: blades 15 to $20 \mathrm{~cm}$ long, 4 to $8 \mathrm{~mm}$ wide, setaceous-pointed; racemes sereral, fascicled, 2 to $5 \mathrm{~cm}$ long, on slender flexuous peduncles; pediceled spikelets about $5 \mathrm{~mm}$ long; spikelets, rachis joints, and pedicels loosely pilose. 
Moist cliffs and shady banks, Mexico and Cuba to Brazil; also in tropical Africa.

CuBA: Holguín, Ekman 15732.

Jamaica: Halls Delight, Harris 12460. Barican, Hitcheock 9565. Mount Charles, Harris 11558. Flamstead, Harris 11471. Narbrook, Harris 12712.

Haitr: St. Michel de l'Atalaye, Leonard 7383. Ennery, Ekman H 2472. Port-au-Prince, Ekman H 2184; Leonard 15838; Buch 1777, 1899 .

Dominicax Reptblic: Constanza, Ekman H 13964.

2. Andropogon annulatus Forsk., Fl. Aegypt. Arab. 173. 1775. Egypt.

Andropogon bladhii Retz., Obs. Bot. 2: 27. 1781. China.

Andropogon annulatus var. bladhii Hack., in DC., Monogr. Phan. 6: $572 . \quad 1889$.

Dichanthium annulatum Stapf, in Prain, Fl. Trop. Afr. 9: 178. 1917.

Culms ascending from a decumbent base, 50 to $100 \mathrm{~cm}$ long, the nodes pubescent; blades flat, 5 to $20 \mathrm{~cm}$ long, tapering to a fine point; racemes usually 3 to 6 , sometimes more (rar. bladhii (Retz.) Hack.), 3 to $7 \mathrm{~cm}$ long; sessile and pedicellate spikelets alike, the first glumes imbricate, oblong, rounded at summit.

Ditches, roadsides, and open ground, sparingly introduced; a native of the Old World.

Cuba: Paso Real to San Diego, Léon 5077. Jibacoa, Léon 14215. Corral Nuevo, Léon 15463.

Haiti: Port-au-Prince, Ekman H 9126 (rar. bladhii).

Puerto Rico: Aguirre, Britton and Earle 6494.

3. Andropogon caricosus L., Sp. Pl. ed. 2. 1840. 1763. India. Andropogon annulatus rar. subrepens Hack., Notizbl. Bot. Gart. Berlin 1: 327. 1897. Guadeloupe, Duss 3678.

Decumbent, freely branched low perennial with flat blades 2 to $8 \mathrm{~cm}$ long and solitary or paired racemes, the sterile spikelets as conspicuous as the fertile ones, giring the appearance of a flat 2-ranked scaly spike; awns slender, twisted, and bent.

Traste places; introduced in a few places in the West Indies from southern Asia.

Crba: Habana, Ekman 1263, 18300: Léon 2389. Santiago de las Vegas, Juzepczuk 4055. Guanabacoa, Witson 9163; Hitchcoch 23228, 23235; Léon 2013, 2574, 15111, 15112.

Leemard Islands: Guadeloupe, Duss 3678; Hitchcock 16413.

Windward Islands: St. Lucia, Watts in 1909.

4. Andropogon nodosus (Tillem.) Nash, N. Amer. Fl. 17: 122. 1912. Dichanthium nodosum Willem., Ann. Bot. Usteri 18: 11. 1796. Mauritius.

Similar to A. caricosus (possibly only a rariety of that species), somewhat larger, the blades and racemes longer; culm pubescent below the inflorescence.

Traste places; introduced in a few places in the West Indies from the Tropies of the Old World.

Cuba: Jibacoa, Léon 13854. 
Leeward Islands: Antigua, Rose 3382, 3415; Box 37, 112, 123. Guadeloupe, Duss 3678.

Windward Islands: Barbados, Bot. Sta. Herb. 443. Grenada, Hitchcock 17679; Meyers 4590.

5. Andropogon brevifolius Swartz, Prodr. Veg. Ind. Occ. 26. 1788. Jamaica.

Andropogon obtusifolius Poir., in Lam., Encycl. Sup. 1: 583.1810. Puerto Rico.

Pollinia brevifolia Spreng., Pl. Pugill. 2: 13.1815.

Schizachyrium brevifolium Nees; Kunth, Enum. Pl. 1: 488. 1833.

Sorghum brevifolium Kuntze, Rev. Gen. Pl. 2: 791. 1891.

Slender trailing or reclining glabrous branching annual; culms from $15 \mathrm{~cm}$ to as much as $1 \mathrm{~m}$ long; blade. flat, obtuse; racemes delicate, 1 to $2 \mathrm{~cm}$ long; spikelets about $3 \mathrm{~mm}$ long; awns 4 to $8 \mathrm{~mm}$ long.

Moist banks, tropical regions of both hemispheres. To be found jn probably all of the West Indian islands from Cuba to Trinidad. Not represented in collections from Bermuda and the Bahamas.

6. Andropogon malacostachyus Presl, Rel. Haenk. 1: 337. 1830. Mexico.

Schizachyrium malacostachyum Nash, N. Amer. Fl. 17: 102.1912.

Rather slender erect or spreading, glabrous, pale or reddish brown annual; culms 30 to $100 \mathrm{~cm}$ long; blades flat, 1 to $4 \mathrm{~mm}$ wide; racemes slender, 2 to $3 \mathrm{~cm}$ long, more or less enclused in the spathes on the erect branches along the upper part of the culm; sterile pedicels and joints of the rachis villous; sessile spikelet $7 \mathrm{~mm}$ long, the awn about $1 \mathrm{~cm}$.

Dry slopes and rocky hills, southern Mexico to Colombia; Cuba.

CuBa: Habana (Vibora), Léon 1956. Guanabacoa, Hitchcock 479, 23225; Léon 1529. Without locality, Ekman 13559.

7. Andropogon condensatus H. B. K., Nov. Gen. et Sp. 1: 188. 1816. Colombia.

Andropogon microstachyus Desv.; Hamilt., Prodr. Pl. Ind. Occ. 8. 1825. Antilles.

Schizachyrium condensatum Nees, Agrost. Bras. 333. 1829.

Pollinia microstachya Desv., Opusc. 70. 1831.

Robust tufted erect glabrous perennial, 1 to $1.5 \mathrm{~m}$ tall; culm repeatedly branching toward the summit, forming a large corymbose compound inflorescence; blades 10 to $20 \mathrm{~cm}$ long, 5 to $10 \mathrm{~mm}$ wide, usually stiffly spreading; racemes 2 to $3 \mathrm{~cm}$ long, the slender rachis very flexuous, the pedicels and rachilla joints long-villous; awns delicate, about $12 \mathrm{~mm}$ long.

Open, rather dry ground, eastern Mexico and the southern West Indies to Argentina.

Leeward Islands: Guadeloupe, Duss 3817. Dominica, Hitchcock 16432 ; Jones 8.

Windward Islands: Martinique, Hitchcock 16464; Duss 1297, 4026; Hahn 690. St. Lucia, Hitchcock 16472; Brooks 30; Kemp 6; Box 192. St. Vincent, Eggers 6577. Grenada, Broadway 1783.

Trinidad: Port-of-Spain, Hitchcock 9998, 10038. Point-á-Pierre, Broadway 4945. Cedros, Broadway 4949. Burkes Pasture, Bot. Gard. Herb. 3383.

Toвago: Broadway 4799; Hitchcock 10206. 
8. Andropogon gracilis Spreng., Syst. Veg. 1: 284. 1825. Hispaniola. Andropogon juncifolius Desv.; Hamilt., Prodr. Pl. Ind. Occ. 9. $1825 .^{99}$ St. Croix.

Sorghum gracile Kuntze, Rev. Gen. Pl. 2: 791. 1891.

Schizachyrium gracile Nash, in Small, Fl. Southeast. U. S. 60. 1903.

Densely tufted slender erect wiry glabrous perennial with filiform blades and delicate pale feathery racemes 2 to $5 \mathrm{~cm}$ long, the delicate awns 1 to $1.5 \mathrm{~cm}$ long; culms 20 to $60 \mathrm{~cm}$ tall; racemes silvery, longexserted, the rachis slender, very villous; sessile spikelet about $5 \mathrm{~mm}$ long; pedicellate spikelet reduced to an awned or awnless glume, the pedicel very villous (fig. 349).

Rocky hills and banks, southern Florida and the West Indies.

Bahamas: New Providence, Curtiss 152; Eggers 4444.

Cuba: Sumidero, Shafer 13529; Shafer and Léon 13715, 13720. San Diego de los Baños, Léon 5085, 5168. La Grifa, Ekman 18167. Cajálbana, Wright 204. Pinar del Río, Hitchcock 23314. Herradura, Tracy 9067. Candelaria, Earle and Wilson 1637. Habana, Ekman 850, 1005; Léon 562. Santiago de las Vegas, Juzepczuk 4052. Sancti Spiritus, Léon 820, 825, 826. Gavilanes, Léon 6652. Baraguá, Hitchcock 23362. Guara, Hitchcock 23390, 23432. Sierra de Nipe, Shafer 2988. Loma Menqura, Shafer 3855. Sabinilla, Shafer 8397. Eastern Cuba, Wright 1557. Without locality, Wright 3484. Isla de Pinos, Curtiss 380; Jennings 58.

JAMAICA: Cascade River, Maxon 10571. Ipswich, Maxon and Killip 1492a; Hitchcock 9616. Bog Walk, Hitchcock 9296 (Amer. Gr. Nat. Herb. 257). New Forest, Hitchcock 9844. Cinchona, Hitchcock 9707; Hart 689, 754; Harris 9503, 11265, 11332, 11412. Abbey Green, Hitchcock 9384. Barican, Hitchcock 9576. New Castle, Hitchcock 9342. Narbrook,

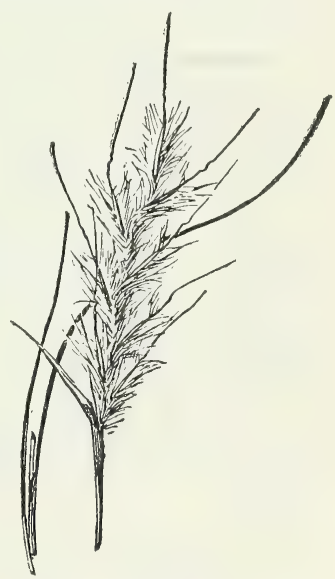

FIGURE 349.-Andropogon gracilis, $\times 1$ (Hitcheock 682). Harris 12710. Lititz, Harris 11656, 11720. Flamstead, Harris 11578. Cane River Valley, Harris 9622, 11370. Guava Ridge, Harris 11318, 11338 .

Haiti: Bassin Bleu, Leonard 15002. Port-au-Prince, Ekman H 1648, H 7121; Buch 1213. St. Michel de l'Atalaye, Leonard 7405a, 7423; Buch 1071. Marmelade, Leonard 8226. Ennery, Leonard 9010. Plaisance, Leonard 9419. Fond Parisien, Leonard 4204.

Dominican Republic: Jarabaco, Eggers 2321 (in part). Valle Nuevo, Ekman H 13852.

Puerto Rico: Mayaguez, Chase 6816. Lares, Chase 6589. Arecibo, Chase 6558.

Leeward Islands: Guadeloupe, Duss 2719.

ANDROPOGON GRACILIS var. FIRMIOR Hitchc., var. nov. ${ }^{1}$

Differing from $A$. gracilis in having erect or somewhat spreading or leaning, firm, hard, branching culms, 60 to $100 \mathrm{~cm}$ tall.

Type in the United States National Herbarium, no. 1296100, collected near Morne Fort Jacques, Pétionville, Massif de la Selle,

00 It is uncertain which of these names is the earlier.

A A. gracile culmis patulis, firmis, duris, ramosis, $60-100 \mathrm{~cm}$ altis, foliis firmioribus et crassioribus differt. 
Haiti, 1,200 m altitude, September 18, 1924, by E. L. Ekman (no. H 1944).

Dry slopes and sterile pinelands, Hispaniola.

Haiti: Port-au-Prince, Ekman H 7120. Ennery, Leonard 8832. Pétionville, Ekman H 1944, H 2329.

Dominican Republic: San José de Ocoa, Ekman H 11885. Valle Nuevo, Ekman H 13853, H 13854, H 13862.

9. Andropogon reedii Hitchc. and Ekman, sp. nor. ${ }^{2}$

Culms erect, cespitose, slender, glabrous, about $1 \mathrm{~m}$ tall; sheaths glabrous, keeled but not much compressed; ligule a membrane about $0.5 \mathrm{~mm}$ long; blades rarely flat, usually folded or involute, erect, firm, as much as $30 \mathrm{~cm}$ long, 0.5 to $1.5 \mathrm{~mm}$ wide, scaberulous on the upper surface and sparsely pilose near the base, glabrous bencath, the midrib prominent beneath, the margins scabrous and also papillosepilose toward the base; inflorescence about one-third the entire height of the culm, branched, the branches sereral or numerous, appressed; racemes solitary, 2 to $4 \mathrm{~cm}$ long, finally exserted from the spathes, the rachis slender, somewhat flexuous or nearly straight, the internodes about $3 \mathrm{~mm}$ long, pilose with hairs 3 to $5 \mathrm{~mm}$ long; sessile spikelet $4 \mathrm{~mm}$ long, the first glume concave on the back but not channeled, hispidulous on the angles toward the tip; awn about 1 $\mathrm{cm}$ long, geniculate, twisted below; pedicellate spikelet prominent, mostly 4 to $5 \mathrm{~mm}$ long, sometimes less, awnless, the pedicel 3 to 4 $\mathrm{mm}$ long, pilose like the internode.

Type in the United States National Herbarium, no. 1161264, collected in sarannas at Minas, prov. Camagüey, Cuba, October 5, 1922 , by E. L. Ekman.

At Dr. Ekman's suggestion the species is named for A. C. Reed, general manager of the Cuba Railroad, who had extended courtesies to him.

Sarannas and serpentine hills, Cuba, only known from the province of Camagüey.

Cuba: Minas, Ekman in 1922. Canasí, Ekman 17186; Léon 13121.

10. Andropogon cubensis Hack., Flora 68: 121. 1885. Cuba, Wright 3898.

Sorghum cubense Kuntze, Rev. Gen. PI. 2: 791. 1891.

Schizachyrium cubense Nash, N. Amer. Fl. 17: 109. 1912.

Culms slender, erect from a loose rhizomatous base, 50 to $70 \mathrm{~cm}$ tall; blades involute, very slender, rather soft, the lowermost culm blade about $5 \mathrm{~cm}$ long, the upper successively shorter; peduncles long-exserted, 1 terminal and 1 or 2 from the upper sheaths; racemes erect or nodding, inconspicuously silky, 4 to $6 \mathrm{~cm}$ long, loosely flowered, the rachis slender, flexuous, pilose, the joints 3 to $10 \mathrm{~mm}$ long; sessile spikelet about $4 \mathrm{~mm}$ long, the awn 4 to $8 \mathrm{~mm}$ long; pedicellate spikelet much reduced, the pedicel slender, usually becoming recurved-spreading.

Sandy soil, Cuba.

Cuba: Damují (Pinar del Río), Eliman 11049; Laguna del Perro, Ekman 18122. Without locality, Wright 3898. Isla de Pinos, Britton and Wilson 14291.

${ }_{2}$ Culmi erecti caespitosi graciles, circa $1 \mathrm{~m}$ alti; laminae plerumque complicatae rel inrolutae; racemi solitarii 2-4 cm longi. rachide saenius leviter undulata longe pilosa; spiculae sessiles 4 mm longae, arista gracili $1 \mathrm{~cm}$ longa; spiculae pedicellatae 4-5 $\mathrm{mm}$ longae; pedicelli longe pilosi. 
11. Andropogon salzmanni (Trin.) Hack., in Repert. Sp. Nov. Fedde 6: 341. 1909.

Rottboellia salzmanni Trin.; Steud., Syn. Pl. Glum. 1: 361.1854. Brazil.

Andropogon imberbis var. muticus Hack., in DC., Monogr. Phan. 6: 380.1889.

Culms ascending, about $50 \mathrm{~cm}$ tall; sheaths compressed; blades long, linear, curled or flexuous, 2 to $3 \mathrm{~mm}$ wide; racemes yellow, nearly glabrous, 5 to $7 \mathrm{~cm}$ long; sessile spikelets appressed, awnless, about $6 \mathrm{~mm}$ long.

Sandy hills, southern Mexico to Brazil; Lesser Antilles.

Leeward Islands: Guadeloupe, Duss 3171.

Windward Islands: Martinique, Duss 784, 4022.

\section{Andropogon parvifolius Hitche., sp. nov. ${ }^{3}$}

Culms in small tufts, slender, erect or somewhat spreading at base, glabrous, mostly 4- or 5-noded, 15 to $30 \mathrm{~cm}$ tall; sheaths glabrous, striate, shorter than the internodes; ligule less than $0.5 \mathrm{~mm}$ long; blades flat, smooth beneath, scabrous on the upper surface, 2 to 5 cm long, the uppermost about $1 \mathrm{~cm}$ long, $1 \mathrm{~mm}$ or less wide; racemes solitary, slender, terminating the main culms, glabrous throughout, 3 to $5 \mathrm{~cm}$ long, the rachis rather thick; sessile spikelet oblong-lanceolate, acute, weakly several-nerved, awnless, about $5 \mathrm{~mm}$ long, the internodes of the rachis about $3 \mathrm{~mm}$ long; pedicellate spikelet reduced, 2 to $3 \mathrm{~mm}$ long.

Type in the United States National Herbarium, no. 1387467, collected in moist pinelands south of railroad, Herradura, Cuba, June 22, 1922, by E. L. Ekman (no. 14094).

Known only from the type collection. Related to Andropogon salzmanni, but differing in the smaller size of the culms, leaves, and racemes.

\section{Andropogon hirtiflorus (Nees) Kunth, Rév. Gram. 1: Sup. XXXIX. 1830.}

Streptachne domingensis Spreng.; Schult., Mant. 2: 188.1824. Not Andropogon domingensis Steud. 1821. Santo Domingo.

Schizachyrium hirtiflorum Nees, Agrost. Bras. 334. 1829. Brazil. Aristida? domingensis Kunth, Rév. Gram. 1: 62. 1829.

Andropogon semiberbis var. incertus Hack., in DC., Monogr. Phan. 6: 370. 1889. Cuba, Wright 1558.

Schizachyrium domingense Nash, N. Amer. Fl. 17: 103.1912.

Andropogon domingensis F. T. Hubb., Amer. Acad. Sci. Proc. 49: 493. 1913. Not A. domingensis Steud. 1821.

Slender erect tufted perennial; culms compressed, 0.5 to $1.5 \mathrm{~m}$ tall; blades flat, 2 to $4 \mathrm{~mm}$ wide; racemes mostly 4 to $8 \mathrm{~cm}$ long; rachis joints and pedicels villous; sessile spikelet 5 to $6 \mathrm{~mm}$ long, its first glume more or less villous on the rounded back; awn about $1 \mathrm{~cm}$ long (fig. 350).

Rocky or gravelly hills or flats, Florida, through the West Indies to Paraguay.

Cuba: Sancti Spíritus, Léon 4094. Eastern Cuba, Wright 1558. Jamaica: New Forest, Hitchcock 9855 (Amer. Gr. Nat. Herb. 260). Lititz, Harris 12704.

${ }^{3}$ Culmi graciles $15-30 \mathrm{~cm}$ alti; laminae planae 2-5 cm longae, 0.5-1 mm latae glabrae, supra scabrae; racemi solitarii graciles $3-5 \mathrm{~cm}$ longi; spicula sessilis, plurinervia, oblongo-lanceolata, acuta, mutica $5 \mathrm{~mm}$ longa; spicula pedicellata reducta $2-3 \mathrm{~mm}$ longa. 
Haitr: Las Cahobas, Cook, Scofield, and Doyle 99. Ennery, Leonard 8937, 8958, 9492. Pétionville, Ekman H 1733. Port-au-Prince, Buch 1811, 1856; Ekman H 7122. Aux Cayes, Ekman H 251.

Dominican Republic: Jarabaco, Ekman H 14157.

Puerto Rico: Maricao, Chase 6202.

Trinidad: St. Joseph, Hitcheock 10194 (Amer. Gr. Nat. Herb. 550. This is labeled $A$. semiberbis. It is better referred to $A$. hirtiflorus, though it is an intermediate specimen).

14. Andropogon semiberbis (Nees) Kunth, Rév. Gram. Sup. 1: XXXIX. 1830.

Schizachyrium semiberbis Nees, Agrost. Bras. 336. 1829. Brazil.

Closely resembling $A$. hirtiflorus, which may be a variety of this; usually stouter and taller, often glaucous, blades averaging wider; first glume of sessile spikelet smooth on the back; rachis joints and pedicels sparingly villous, the racemes appearing nearly smooth (those of $A$. hirtiflorus appearing whitish-villous) (fig. 351).

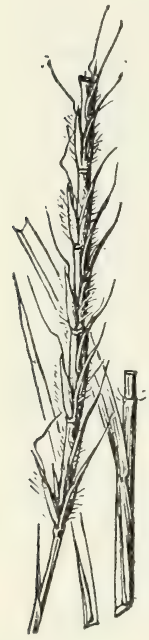

FIGURE 350.Andropogon hirtiflorus, $\times 1$ (Chase 1943)

Grassy hills and savannas, Florida, through the West Indies and eastern Mexico to Argentina and Ecuador; also in tropical Asia and Africa.

Bahamas: New Providence, Britton and Brace 432; Geogr. Soc. Baltimore 542.

Cuba: Pinar del Río, Hitchcock 23301. Herradura, Baker and Abarca 4179. Guanabacoa, Léon 2877, 12452, 12465; Hitchcock 23225 $\frac{1}{2}$, 23246. Manacas, Léon 5994, 9295. Mordazo, Ekman 17097. Baraguá,Hitchcock 23364. Sancti Spíritus, Léon 854, 855; Sergius 2791. Bayate, Ekman 2816. Holguín, Shafer 2936; Ekman 15733. Guara, Hitchcock 23393. Nagua, Ekman 11339. Without locality, Wright 3891. Isla de Pinos, Britton and Wilson 14420, 14792.

Haiti: Port-au-Prince, Christ 2158. Los Angeles, Ekman H 382. Etang Ténété, Ekman H 332. Pétionville, Ekman H 1725. St. Michel de l'Atalaye, Leonard 7159,8055 .

Dominican Republic: Azua, Fuertes

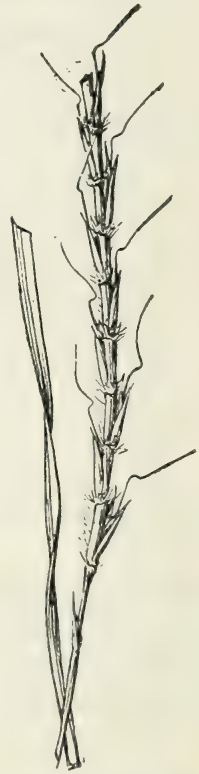

FIGURE 351.-An dropogon semiberbis, $\times 1$ (C. H. Baker 327).

1886. Polo, Abbott 1865. Monción, Ekman H 12656. Puerto Rico: Las Marias, Sintenis 5988. Mayaguez, Holm 178; Chase 6161, 6818. Campo Alegre, Chase 6623, 6807. San Juan, Chase 6771.

Virgin Islands: St. Croix, Thompson 257.

15. Andropogon tener (Nees) Kunth, Rév. Gram. 1: Sup. XXXIX. 1830.

Schizachyrium tenerum Nees, Agrost. Bras. 336. 1829. Brazil. Densely tufted bunch grass; culms slender, reclining, 30 to $100 \mathrm{~cm}$ long; blades subinvolute, 1 to $3 \mathrm{~mm}$ wide; racemes slender, 2 to $5 \mathrm{~cm}$ long, nearly glabrous; lower half of first glume of sessile spikelet light colored, giving the raceme a somewhat zonate appearance; awn about $1 \mathrm{~cm}$ long (fig. 352 ).

Grassy hills and rocky cliffs, southern United States to Argentina. 
CubA: Herradura, Tracy 9068. Pinar del Río, Ekman 17287; Hitchcock 23306. Sumidero, Léon 3397. Madruga, Léon 6326. Placetas del Sur, Léon 6432. Manacas, Léon 5818. Almacigos, Wright 3482.

JamaICA: Jacks Hill, Harris 12865. Hope, Harris 12686. Newcastle, Hitchcock 9343. Barican, Hitchcock 9575. Without locality, Harris 11439.

Haiti: Nouvelle Touraine, Buch 1686. Corail, Ekman H 10763. Furcy, Ekman H 1744.

Dominican Republic: Rincón, Ekman H 13289.

16. Andropogon multinervosus (Nash) Hitchc. and Chase, Contrib. U. S. Natl. Herb. 18: 280.1917.

Schizachyrium multinervosum Nash, N. Amer. Fl. 17: 109.1912. Cuba, Britton and Shafer 608.

Wiry, sparingly branching perennial with filiform blades and few racemes; culms 20 to $40 \mathrm{~cm}$ tall; racemes 3 to $6 \mathrm{~cm}$ long; sessile spikelet 4 to $5 \mathrm{~mm}$ long, glabrous, minutely bearded at base, the awn about $1 \mathrm{~cm}$ long; pedicellate spikelet much reduced, the pedicel ciliate above on one side.

Rocky hills and palm barrens, Cuba.

CubA: Canasí, Ekman 17187; Léon 13058, 13120. Santayana, Ekman 19038; Britton 2414. Madruga, Léon 6326; Britton and Shafer 608. Santa Clara City, Léon $14960,15610$.

17. Andropogon virgatus Desv.; Hamilt., Prodr. Pl. Ind. Occ. 9. 1825. Antilles.

Hypogynium spathiflorum Nees, Agrost. Bras. 366 . 1829. Brazil.

Anatherum virgatum Desv., Opusc. 71. 1831.

Andropogon spathiflorus Kunth, Rév. Gram. 1: Sup. XL. 1830 .

Andropogon inermis Steud., Syn. Pl. Glum. 1: 390. 1854. Colombia.

Anatherum spathiflorum Griseb., Cat. Pl. Cub. 236. 1866.

Anatherum inerme Griseb., Cat. Pl. Cub. 236. 1866.

Glabrous tufted perennial; culms compressed, rigid, about $1 \mathrm{~m}$ tall; blades 2 to $4 \mathrm{~mm}$ wide; inflorescence

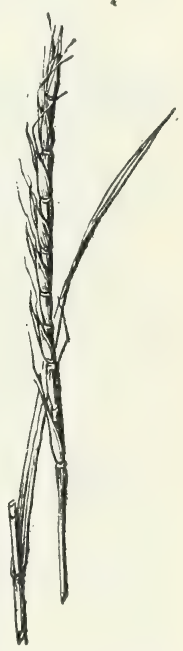

FIGURE 352 . Andropogon tener, $\times 1$ (Rolfs 986). elongate, of numerous glabrous racemes about $1 \mathrm{~cm}$ long, partly enclosed in rufous or purplish spathes; spikelets 3 to $4 \mathrm{~mm}$ long, awnless.

Wet, sandy open swamps or savannas, West Indies and Central America to Brazil.

CubA: Laguna Santa María, Ekman 17258. Pinar del Río, Hitchcock 23274. Herradura, Baker and Dimmock 4814. Guane, Léon 6988. Los Almacigos, Wright 3480, 3481. Isla de Pinos, Taylor 23; Curtiss 460; Britton and Wilson 14310.

Dominican Republic: Cotuy, Abbott 812, 846, 2805a, 2814. Cuenca, Ekman H 11010. Without locality, Wright, Parry, and Brummel 625.

Puerto Rico: San Juan, Chase 6633, 6768. Campo Alegre, Chase 6620. Lares, Sintenis 5902.

Trinidad: Arima, Broadway 2373. Arouca, Hitchcock 10348. Comuto Station, Hitchcock 10070. 
18. Andropogon bicornis L., Sp. Pl. 1046. 1753. Brazil, Jamaica. Anatherum bicorne Beauv., Ess. Agrost. 128. 1812.

Saccharum bicorne Griseb., Abh. Ges. Wiss. Göttingen 7: 266. 1857.

Sorghum bicorne Kuntze, Rev. Gen. Pl. 2: 791. 1891.

Robust tufted perennial; culms mostly 1 to $2 \mathrm{~m}$ tall; blades 2 to $5 \mathrm{~mm}$ wide, scabrous on the margin; inflorescence large, corymbose, of delicate flexuous racemes 2 to $3 \mathrm{~cm}$ long, whitish or tawny, feathery with hairs as much as $5 \mathrm{~mm}$ long; 1 , sometimes 2 , of the uppermosi pedicellate spikelets larger than the fertile ones, the other pedicellate spikelets rudimentary.

Grassy hills and banks, southern Mexico to Brazil and widely distributed in the West Indies. Probably to be found on all the islands from Greater Antilles southward. In West Indies called foxtail and sometimes "ridging grass."

19. Andropogon leucostachyus H. B. K., Nov. Gen. et Sp. 1: 187. 1816. Venezuela.

Anatherum domingense Roem. and Schult., Syst. Veg. 2: 809. 1817. Santo Domingo.

Andropogon domingensis Steud., Nom. Bot. 45. 1821.

Andropogon leucostachyus subvar. subvillosus Hack., in DC., Monogr. Phan. 6: 420. 1889. Brazil.

Sorghum leucostachyum Kuntze, Rev. Gen. Pl. 2: 792. 1891.

Slender, densely tufted erect perennial; culms 30 to $50 \mathrm{~cm}$ tall; blades 1 to $3 \mathrm{~mm}$ wide, with a deeply impressed midvein; ligule about $2 \mathrm{~mm}$ long; racemes 2 or 3, whitish, 1.5 to $3 \mathrm{~cm}$ long, on slender exserted peduncles, the spikelets obscured by the copious long silky hairs. Foliage villous in some of the Trinidad specimens, the subvar. subvillosus Hack.

Cliffs and grassy slopes, West Indies and southern Mexico to Brazil.

Cuba: Sumidero, Shafer and Léon 13613, 13717. Herradura, Tracy 9046. Consolación del Sur, Palmer and Riley 480. Madruga, Léon 3459. Minas, Léon 6222. Banao Mountains, Léon 5407. Placetas del Sur, Léon 6428, 6431. Sancti Spíritus, Léon 827. Sancti Spíritus Mountains, Léon 6529. Pasto Estancia, Shafer 1639, 1681. Loma del Gato, Léon 10324. Isla de Pinos, Britton and Wilson 15110; Ekman 12203.

JAMAICA: Port Antonio, Fredholm 3334. Bull Head Mountain, Hitchcock 9546. Barican, Hitchcock 9577. Mount Hybla, Harris 12458. Hollis Savanna, Harris 12244. Below Content Gap, Harris 11349.

Haiti: Aux Cayes, Ekman H 230. Furcy, Leonard 4312; Buch 1573. Marmelade, Leonard 8242, 8258. Plaisance, Leonard 9348. Caille la Croix, Leonard 7883. Pétionville, Ekman H 1746. San Michel, Miller 301; Sweet in 1925.

Dominican Republic: Jarabaco, Eggers H 2321 (in part). Monción, Ekman H 12769.

Puerto Rico: Adjuntas, Sintenis 4481. Mayaguez, Heller 4396; Britton and Marble 654; Britton and Hess 2813; Chase 6163, 6819. Holm 76. San Juan, Chase 6366, 6383, 6636, 6776; Sein 322. Cayey, Chase 6733. Maricao, Chase 6216; Britton and Cowell 4267; Britton, 
Cowell, and Brown 4477. Rio Piedras, Hioram 214; Cowgill 686. Without locality, Heller 933, 984.

Trinidad: Brighton, Hitchcock 10097. O'Meara Savanna, Britton and Hazen 1579. Port-of-Spain, Broadway 5040. Piarco Savanna, Hitcheock 10345. Aripo Saranna, Hitchcock 10072. Without locality, Bot. Gard. Herb. 3382.

20. Andropogon selloanus (Hack.) Hack., Bull. Herb. Boiss. (II) 4: 266. 1904.

Euklastaxon tenuifolius Steud., Syn. Pl. Glum. 1: 412. 18j̃. Not Andropogon tenuifolius Steud. Brazil.

Andropogon leucostachyus subsp. selloanus Hack., in DC., Monogr. Phan. 6: 420. 1889. Brazil.

Similar to A. leucostachyus, differing in the somewhat stouter culms, shorter and broader blades with a boat-shaped tip, shorter ligule (less than $1 \mathrm{~mm}$ long); racemes often 3 to 5 , more densely villous, tawny rather than white.

Savannas and open ground, West Indies to Paraguay.

Cuba: Santa Cruz de los Pinos, Léon 7435. Hanábana, Wright 3900. Pror. Santa Clara, Léon 6424, 9159. Isla de Pinos, Ekman 12103; Curtiss 314; Taylor 16.

Trinidad: St. Joseph, Hitchcock 10188. La Brea, Broadway 3258, 4981.

Toвago: Broadway 2982, 4044.

21. Andropogon lateralis Nees, Agrost. Bras. 329. 1829. Brazil. Andropogon incanus Hack., in DC., Monogr. Phan. 6: 431. 1889. Uruguay.

Andropogon lateralis var. incanus Henr., Med. Rijks Herb. Leiden 40: 42. 1921.

Culms stout, erect, about $1.5 \mathrm{~m}$ tall; blades elongate, folded or involute; racemes in pairs, often of unequal length, 2 to $5 \mathrm{~cm}$ long, the rachis slender, straight or somewhat flexuous, rather sparsely long-pilose; sessile spikelet about $4 \mathrm{~mm}$ long, the awn weak, about $5 \mathrm{~mm}$ long; pedicellate spikelet prominent, larger than the sessile, about $5 \mathrm{~mm}$ long, the pedicel long-pilose like the rachis.

Grassy hills, Brazil to Ecuador and Peru; Cuba.

Cuba: Laguna Santa María, Pinar del Río, Ekman 17264,17271. Remates (Pinar del Río), Ekman 11362; Léon 15357.

These specimens belong to the form described as var. incanus (Hack.) Henr., in which the racemes are usually two.

22. Andropogon nashianus Hitchc., Contrib. U. S. Natl. Herb. 12: 193. 1909. Cuba, Wright 3899.

Culms solitary or few in a cluster, slender, erect, 30 to $45 \mathrm{~cm}$ tall from short branching rhizomes; blades narrow, folded, glabrous, those of the upper culm much reduced; racemes in pairs, 3 to $4 \mathrm{~cm}$ long, very villous with tawny hairs 5 to $7 \mathrm{~mm}$ long; sessile spikelet 3 to $4 \mathrm{~mm}$ long; pedicellate spikelet much reduced.

Sandy barrens, Cuba.

Cuba: Pinar del Río, Wright 3899; Hitchcock 23265. Laguna. Jovero to Mendoza, Shafer 10850. Herradura, Tracy 9069; Hitchcock 481; Ekman in 1922. San Diego de los Baños, Léon 4453, 4560. Loma del Gato, Ekman 15652. Isla de Pinos, Britton and Wilson. 14804 ; Taylor 17. 


\section{Andropogon urbanianus Hitchc., Bot. Gaz. 54: 424. 1912.}

Dominican Republic, Fuertes 1420.

Culms erect or ascending, 75 to $150 \mathrm{~cm}$ tall; blades 10 to $30 \mathrm{~cm}$ long, involute, firm, rather stiff, appressed; racemes numerous along the upper third of the plant, the terminal mostly in pairs, the axillary in pairs or sometimes solitary, 2 to $4 \mathrm{~cm}$ long, partly enclosed in the spathe or exserted, the slender rachis and pedicels long-pilose; sessile spikelet $5 \mathrm{~mm}$ long, the awn 1 to $2 \mathrm{~cm}$ long; pedicellate spikelets narrow, 2 to $4 \mathrm{~mm}$ long or sometimes rather prominent.

Dry slopes and rocky hills, Hispaniola.

Haitr: St. Michel de l'Atalayé, Leonard 7374, 7392, 7830, 8061a. Port-au-Prince, Ekman H 2087. Torbeek, Ekman H 5358. Ennery,

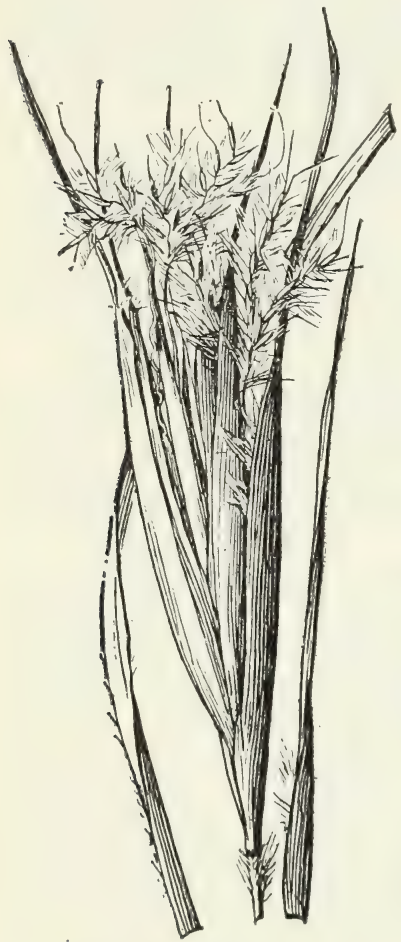

Figure 353.-Andropogon elliottii $\times 1$ (Commons 115).

Leonard 8976. Pétionville, Ekman H 1434, H 1936. Mission, Leonard 3716, 3826, 3853. Furcy, Buch 961. St. Michel ad l'Amache, Buch 1074, 1077.

Dominican Republic: Las Salinas, Fuertes 1420. Constanza, Ekman H 14092. San José de Ocoa, Ekman H 11920.

24. Andropogon elliottii Chapm., Fl. South U. S. 581. 1860. Florida.

ElLiott BeARDGRAss.

Sorghum elliottii Kuntze, Rev. Gen. Pl. 2: 791.1891.

Culms erect, 30 to $80 \mathrm{~cm}$ tall; sheaths more or less villous, the upper inflated and aggregate; racemes in pairs (rarely 3 or 4), 3 to $4 \mathrm{~cm}$ long, some of the peduncles exserted from the appressed spathe and from the inflated sheath; sessile spikelet 4 to $5 \mathrm{~mm}$ long, the awn 10 to $15 \mathrm{~mm}$ long, geniculate, twisted (fig. 353).

Open ground and old fields, Coastal Plain of the eastern United States; Cuba.

CubA: Bayamo (prov. Oriente), Ekman 5067.

25. Andropogon glomeratus (Walt.) B. S. P., Prel. Cat. N. Y. 67. 1888.

Bushy BEARDGRASS.

Cinna glomerata Walt., Fl. Carol. 59. 1788. South Carolina.

Andropogon macrourus Michx., Fl. Bor.

Amer. 1: 56. 1803. Virginia or Carolina.

Andropogon densus Desv.; Hamilt., Prodr. Pl. Ind. Occ. 8. 1825. Antilles.

Anatherum macrourum Griseb., Mem. Amer.Acad.(n.s.) 8: 534. 1863. Andropogon tenuispatheus Nash, N.Amer. Fl.17:113. 1912. Florida.

Rather robust, densely tufted perennial; culms compressed, 1 to $1.5 \mathrm{~m}$ tall; lower sheaths crowded, keeled; blades flat or folded, mostly 3 to $5 \mathrm{~mm}$ wide; inflorescence dense, feathery, club-shaped; racemes in pairs, 1.5 to $3 \mathrm{~cm}$ long, villous with whitish or tawny hairs;rachis slender, flexuous; sessile spikelet 3 to $4 \mathrm{~mm}$ long, the awn about 1.5 cm long (fig. 354). 
Moist or open ground, southeastern United States through Mexico and the West Indies to northern South America.

Bahamas: Eleuthera, Hitchcock in 1890. Andros Island, Brace 4951. New Providence, Wilson 8267; Hitchcock in 1890.

Cuba: Guane, Shafer 10385. Habana, Léon 572, 821, 821b; Schott 103. Batabanó, Ekman 902. Santiago de las Vegas, Wilson 2207. Guanabacoa, Léon 193, 565, 8838. Cayo Ramano, Shafer 2614. San Miguel de los Baños, Léon 8391. Manacas, Léon 5821. Manajanabo, Léon 5302. Baraguá, Hitchcock 23372. Guara, Hitchcock 23389. Sierra de Nipe, Ekman 9807; Shafer 3007. Orientes Grandes, Léon 823. Isla de Pinos, Jennings 283. Without locality, Wright 1555.

JAMaICA: Rockport, Ridley 80. Port Antonio, Fredholm 3291; Maxon and Killip 288. Black River, Harris 12545; Hitchcock 9647. Troy, Hitchcock 9806; Maxon 2811, 2945; Harris 12586, 12592. Cinchona, Harris 12483, 13399; Hart 682 in part. Claremont, Hitchcock 9486. Ewarton, Hitchcock 9446. Castleton, Hitchcock 9406. Newcastle, Hitchcock 9348. Bog Walk, Hitchcock 9291. Mouth of Cockpit River, Harris 12465. Kingston, Cockerell in 1892. Arntully, Orcutt 2621. Gordon Town, Hart 869. Ipswich, Hitchcock 9620. Buff Bay, Hitchcock 9763. Montego Bay, Hitchcock 9677.

Haiti: Port-au-Prince, Buch 2048; Cook, Scofield, and Doyle 58. Gonaïve Island, Leonard 3253, 3333; Eyerdam 107a. St. Michel de l'Atalaye, Leonard 7284, 7373. Tortuga Island, Leonard 13923; Ekman H 4263. Aux Cayes, Ekman H 72. Morne la Selle, Buch 1352.

Dominican Republic: Prov Barahona, Fuertes 1281. Jaina, Faris 402. Punta Icacos, Ekman H 15787.

Puerto Rico: Maricao, Hioram 816; Chase 6203. Mayaguez, Chase 6165. San Juan, Chase 6355. Ponce, Chase 6480. Arecibo, Chase 6555. Lares, Chase 6586.

Leeward Islands: St. Kitts, Hitchcock 16361. Antigua, Box 54, 128. Nevis, Box 170. Guadeloupe, Duss 3548, 3937.

Windward Islands: Martinique, Duss 1301.

26. Andropogon virginicus L., Sp. Pl. 1046. 1753. Virginia.

BRoomsEDGe.

Densely tufted, with a mass of long leaves at the base; culms 1 to $1.5 \mathrm{~m}$ tall; sheaths compressed-keeled, glabrous or somewhat appressed villous; blades 2 to $4 \mathrm{~mm}$ wide; inflorescence slender, one-third to one-half the length of the plant; racemes 1.5 to $3 \mathrm{~cm}$ long, more or less included in the spathes; rachis slender, flexuous, this and the pedicels villous with white hairs 3 to $5 \mathrm{~mm}$ long; awn delicate, straight, 10 to $15 \mathrm{~mm}$ long (fig. 355 ).

Sterile hills and open woods, eastern United States to the West Indies and Panama. Virginia.

Bermuda: Brown and Britton 225. 


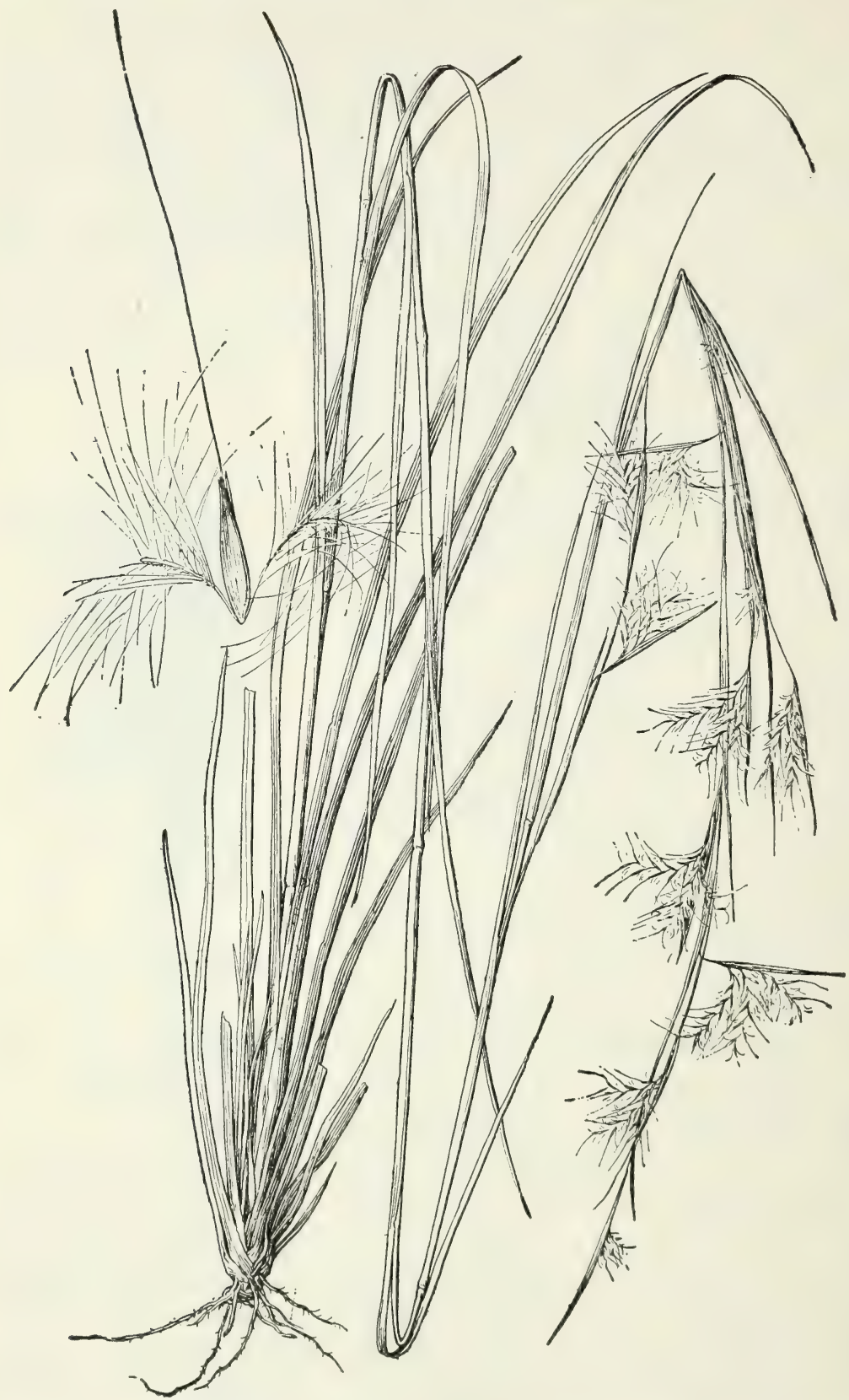

FigURe 355.-Andropogon virginicus. Plant, $\times 1 / 2$; spikelet with rachis joint and pedicel, $\times 5$ (Earle 4 ). 
Bahamas: New Providence, Wilson 8285. Elbow Cay, Geogr. Soc. Baltimore 569 .

Cuba: Cajálbana, Léon 4851. Pinar del Río, Hitchcock 23294. Viñales, Léon 15862. Laguna de Ariguanabo, Ekman 11520. Santiago de las Vegas, Baker and Wilson 599. San Miguel de los Baños, Léon 8853. Loma del Gato, Hioram 7609. Prov. Santa Clara, Léon 824, 5400, 5972, 6656, 7924. Without locality, Wright 3901.

Jamaica: Upper Clarendon, Harris 12851. Lititz, Harris 12682. Lower Clarendon, Harris 12732. Cinchona, Hitchcock 9704; Harris

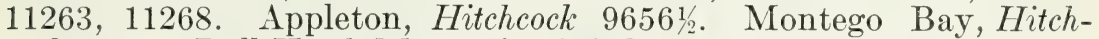
cock 9680. Bull Head Mountain, Hitchcock 9542. Ewarton, Hitchcock 9460. Newcastle, Hitchcock 9338. Abbey Green, Hitchcock 9361, 9385. Castleton, Harris 11295. Salt Hill, Harris 11362. Cold Spring Gap, Harris 11378. Ramble, Hitchcock 9481, 9488 (Amer. Gr. Nat. Herb. 275). Port Antonio, Fredholm 3333. Gordon Town, Hart $692,734,831$.

Haitr: Pétionville, Ekman H 1846. Dondou, Leonard 8622. Ennery, Leonard 9077. Furcy, Leonard 4576, 4576a. Godet, Buch 1666.

Dominican Republic: Monción, Ekman H 12771. Pimentel, Ekman H 13254.

26a. Andropogon virginicus var. graciliformis Léon, in Britton, Bull. Torrey Bot. Club 53: 457. 1926. Cuba, Léon 11343.

Culms slender, usually less than $50 \mathrm{~cm}$ tall; basal sheaths not compressed-keeled; blades, especially of the innovations, very slender, folded, becoming flat and flexuous with age, usually not more than 1 to $2 \mathrm{~mm}$ wide when flat; spathes few. Distinguished from the species by the more delicate culms, terete rather than compressed sheaths, more slender blades, and fewer pairs of racemes.

Sandy savannas, Cuba.

CubA: Pinar del Río, Hitchcock 23283, 23288. Chirigota, Léon 7437. Sabana de Motembo, Léon 11343.

27. Andropogon reinoldii Léon, Mem. Soc. Cub. Hist. Nat. Poey 5. 1922. Cuba, Léon 9932.

Culms tufted, erect, 50 to $80 \mathrm{~cm}$ tall; sheaths glabrous, the basal ones somewhat compressed but not so strongly as in $A$. virginicus; ligule visible from the side view of the sheath, about $1 \mathrm{~mm}$ long; blades flat or, especially at the base, folded, glabrous, somewhat scabrous, 10 to $35 \mathrm{~cm}$ long, 2.5 to $5 \mathrm{~mm}$ wide; racemes in pairs, the pairs several along the upper part of the culm; racemes 2 to $4 \mathrm{~cm}$ long, villous but the spikelets not hidden by the hairs, the peduncle enclosed in the spathe, 3 to $5 \mathrm{~cm}$ long, the racemes partly enclosed in the spathe or barely exserted; sessile spikelet $3 \mathrm{~mm}$ long, the awn nearly straight, about 7 or $8 \mathrm{~mm}$ long; pedicellate spikelet wanting or nearly so. Differs from $A$. virginicus in the long peduncles, the smaller spikelets, and the less compressed basal sheaths.

Gravelly soil and pastures, open slopes, Cuba.

Cuba: Loma del Gato, Sierra Maestra, Cobre, Léon 9832, 9932; Ekman in 1922. Herradura, Ekman 14081.

$60256-36-26$ 


\section{Andropogon angustatus (Presl) Steud., Syn. Pl. Glum. 1: 370.} 1854 .

Diectomis laxa Nees, Agrost. Bras. 340. 1829. Not Andropogon laxus Willd., 1806. Brazil.

Diectomis angustata Presl, Rel. Haenk. 1: 333. 1830. Mexico.

Andropogon apricus Trin., Mém. Acad. St. Pétersb. VI. Sci. Nat. $2^{1}$ : 83. 1836. Brazil.

Erect slender perennial about $1 \mathrm{~m}$ tall; blades flat, elongate, 1 to 2 $\mathrm{mm}$ wide; racemes in pairs, 2 to $3 \mathrm{~cm}$ long, the pairs on slender branches from sereral of the upper leares, forming a loose inflorescence, each branch at first enclosed in a spathe but finall exserted $\tilde{5}$ to $10 \mathrm{~cm}$; pedicels and joints of rachis stiffly ciliate with whitish hairs; fertile (sessile) spikelet about $6 \mathrm{~mm}$ long, la terally compressed, nearly glabrous, the callus sharp, barbate, $1 \mathrm{~mm}$ long; first glume narrow, deeply sulcate on the back; second glume compressed, keeled, bearing from the apex a slender divergent awn $1 \mathrm{~cm}$ long; awn of fertile floret geniculate, twisted, brown, scabrous-hispidulous, 3 to 4 $\mathrm{cm}$ long.

Dry savannas, Mexico to Brazil; Cuba.

Crba: Manacas, Léon 5841. Holguín, Ekman in 1922. Isla de Pinos, Ekman 12520.

29. Andropogon saccharoides Swartz, Prodr. Teg. Ind. Occ. 26. 1788. Jamaica.

Andropogon saccharoides subsp. leucopogon subrar. paucirameus Hack., in DC., Monogr. Phan. 6: 497. 1889. Cuba, Wright 1556. Sorghum saccharoides Kuntze, Rer. Gen. Pl. 2: 792. 1891.

Holcus saccharoides Kuntze, in Stuckert, An. Mus. Nac. Buenos Aires 11: 48. 1904.

Amphilophis saccharoides Nash, N. Amer. Fl. 17: 125. 1912.

Andropogon saccharoides var. surius Krause, Bot. Centbl. Beihefte 32: 334. 1914. Barbados, Wiegand 2085.

Erect perennial; culms simple, brittle, 60 to $150 \mathrm{~cm}$ tall; nodes white-hispid; blades flat, glabrous or nearly so, 2 to $8 \mathrm{~mm}$ wide; panicles exserted, 5 to $15 \mathrm{~cm}$ long, oblong, pale, silky, of numerous crowded, ascending racemes; awns 1.5 to $2 \mathrm{~cm}$ long (fig. 356 ).

Rocky hills and grassy slopes, southwestern United States to South America and the West Indies. The Cuban specimens were referred by Hitchcock ${ }^{4}$ to $A$. leucopogon Nees. Sereral of them and a few from other islands are the form with fewer racemes described as subrar. paucirameus. This is one of the grasses called "rabo de zorra" in Cuba.

Crвa: Viñales, Léon 15346. Habana, Léon 2557, 4716. Sancti Spíritus, Léon 893, 955, 4097, 4101, 5357; Shafer 12073. Manajanabo, Léon 527 7 5301. Manatí, Léon 6008. Isla de Pinos, Curtiss 382; Ekman 12195.

JavaICA: Liguanea Ridge, Harris 12213. Maris Bank, Harris 11449. Newcastle, Harris 11396; Hitchcock 9345. Halls Delight, Harris 11293. Ashley Hall, Harris 12736. Lititz, Harris 11655, 11781, 12698. Ipswich, Harris 12501. Gordon Town, Hart 570; Hitchcock 9377. New Forest, Hitchcock 9848. Barican, Hitchcock 9578 (Amer. Gr. Nat. Herb. 267).

4Contrib. U. S. Natl. Herb. 12: 193. 1909. 
Harti: St. Michel de l'Atalaye, Leonard 7156, 8447. Dondou, Leonard 8756. Ennery, Leonard 8883, 8938, 8977. Bombardopolis, Leonard 13478. Port-au-Prince, Ekman H 7128; Buch 1806, 1855. Furcy, Leonard 4824. Mission, Leonard 3849. Étang Ténéllé, Ekman H 331. Grand-Gosier, Ekman H 6866. Hinche, Ekman H 6132.

Dominican Republic: Constanza, Tuerckheim 2882. Monción, Ekman H 12679. Without locality, Wright, Parry, and Brummel 631.

Puerto Rico: Mayaguez, Chase 6270, 6817. Mariaco, Chase 6226.

Leeward Islands: St. Kitts, Box 155. Antigua, Box 95, 98, 316.

30. Andropogan pertusus (L.) Willd., Sp. Pl. 4: 922. 1806.

Holcus pertusus L., Mant. Pl. 2: 301. 1771. India.

Andropogon panormitanus Parl., "in Diar. Congr. Venezia 1847"; Fl. Ital. 1: 140. 1848. Italy.

Andropogon pertusus var. panormitanus Hack., in DC., Monogr. Phan. 6: 481. 1889. Amphilophis pertusa Stapf, in Prain, Fl. Trop. Afr. 9: 175. 1917.

Culms ascending, branching, 20 to 100 $\mathrm{cm}$ tall, the nodes bearded or (in var. panormitanus) glabrous; blades 10 to $20 \mathrm{~cm}$ long, 1 to $4 \mathrm{~mm}$ wide, pubescent or nearly glabrous; racemes flabellately aggregate on a short axis, few to several, 2 to $6 \mathrm{~cm}$ long, villous; first glume with a pit or pinhole in the middle of the back; awn of sessile spikelet twice-geniculate, brown, about $15 \mathrm{~mm}$ long. The var. panormitanus differs only in the glabrous nodes, less pubescent blades, and often more numerous racemes.

Roadsides and open grassy places, Tropics of the Old World; introduced in the West Indies.

Called "sourgrass" in Tobago and "Barbados sourgrass" in many of the islands. A somewhat more slender form with, on the average, fewer racemes, is called in the Virgin Islands "hurricane grass."

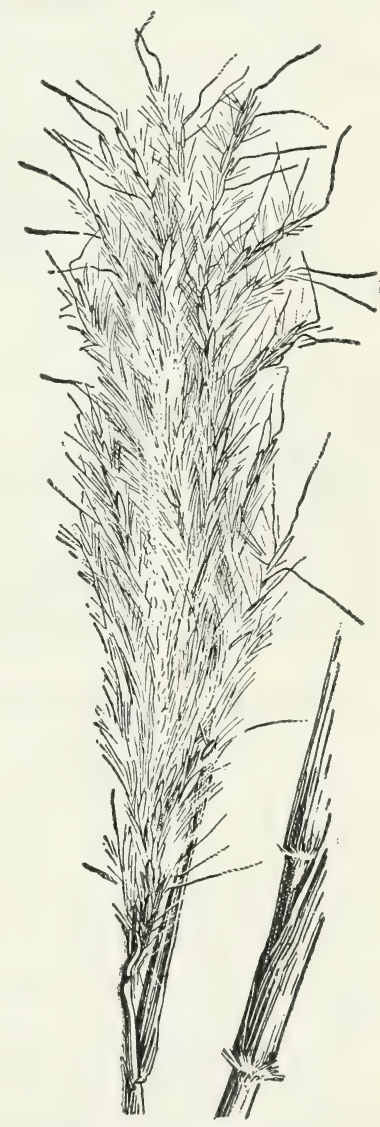

Figure 356.-Andropogon saccharoides, $\times 1$ (Hitchcock 5370 ). This form is said to be relished by stock and makes more satisfactory forage than does Barbados sourgrass.

Cuba: Habana, Léon 11388, 12466. Santiago de las Vegas, Léon 9757. Sancti Spíritus, Léon 7826. Gamboa, Ekman 14941. Marianao, Léon 15093.

Jamaica: Constant Spring, Hitchcock 9387 (Amer. Gr. Nat. Herb. 265); Harris 11262. Gordon Town, Harris 11514. Kingston, Ridley 77; Hitchcock 9472. Hope Gardens, Harris 12517. Musgrave Road, Harris 11478. Alligator Pond, Harris 12694.

Dominican Republic: Between Nizao and Baní, Ekman H 13358. 
Virgin Islands: St. Croix, Rose 3523, 3533; Thompson 9; Baker in 1929 ; Ricksecker 209 ; Hitchcock 16330. St. Thomas, Hitchcock 16317.

Leeward Islands: Antigua, Box 3, 181 . Nevis, Box 173. Dominica, Bot. Gard. 1.

Windward Islands: Barbados, Hitchcock 16518. Grenada, Hitchcock 17683.

Trinidad: Bot. Gard. Herb. 5064.

Toвago: Eggers 5654; Broadway 4727; Hitchcock 10220, 10234.

31. Andropogon ischaemum L., Sp. Pl. 1047. 1753. Europe.

Andropogon ischaemum var. americanus Hack., in DC., Monogr. Phan. 6: 476. 1889. Venezuela and Antigua.

Sorghum ischaemum Kuntze, Rev. Gen. Pl. 2: 792. 1891.

Amphilophis ischaemum Nash, N. Amer. Fl. 17: 124.1912.

Differing from $A$. pertusus in the absence of a pit on the back of the first glume of the sessile spikelet.

Introduced; open ground, Leeward Islands; Tropics of the Old World.

Leeward Islands: Antigua, Wullschlaegel.

107. DIECTOMIS H. B. K. Nov. Gen. et Sp. 1: 193. pl. $64.1816^{5}$

Spikelets arranged as in Andropogon; raceme solitary, subtended by a spathe; first glume of pediceled spikelet large, flat, herbaceous, manynerved, awned from between 2 slender teeth; first glume of fertile (sessile) spikelet narrow, 2-keeled; second glume laterally compressed, the midnerve wing-keeled, awned; fertile lemma with a bent awn more than twice as long as those of the glumes. Erect annual with flat blades.

1. Diectomis fastigiata (Swartz) H. B. K., Nov. Gen. et Sp. 1: 193. pl. 64.1816.

Andropogon fastigiatus Swartz, Prodr. Veg. Ind. Occ. 26. 1788. Jamaica.

Slender, glabrous; culms 0.5 to $1.5 \mathrm{~m}$ tall, freely branching above; ligules firm, up to $2 \mathrm{~cm}$ long; blades 1 to $4 \mathrm{~mm}$ wide; racemes 2 to $6 \mathrm{~cm}$ long; joint of rachis and sterile pedicel winged at the summit, longvillous, the white hairs as much as $7 \mathrm{~mm}$ long; the conspicuous pediceled spikelet $8 \mathrm{~mm}$ long; awn of fertile lemma geniculate, 4 to $5 \mathrm{~cm}$ long (fig. 357).

Dry open ground, southern Mexico and the West Indies to Brazil.

Cuba: Asiento Viejo de San Julián, Léon 6911; Wright 3485. San Cristótal, Wright 3483. Guane, Shafer 10384, 10413, 11218. San Juan y Martínez, Ekman 18074. Guanabacoa, Hitchcock 23230 ; Léon 3451, 4719; Wilson and Léon 2876.

JAMAICA: Bellevue, Harris 11288. Content Gap, Harris 11344. Temple Hall, Harris 11358. Flamstead, Harris 11464. Mavis Bank, Harris 11507. Barican, Hitchcock 9572. Lititz, Harris 12700. Southern Manchester, Harris 12692.

Haiti: St. Michel de l'Atalaye, Leonard 7154, 7290, 7525. Marmelade, Leonard 8201. Ennery, Leonard 8801, 9068. Plaisance, Leonard 9414. Montagne du Trou d'Eau, Ekman H 2317. Pétionville, Ekman H 2331. Petite Rivière, Sweet in 1924. Morne Castilleur, Ekman H 6420.

\footnotetext{
s For discussion of the nomenclature, see Contrib. U. S. Natl. Herb. 24: 206, 1925; 692, 1930.
} 
Puerto Rico: Coamo, Sintenis 3247. Rincón, Sintenis 5516. Maricao, Sintenis 353. Mayaguez, Holm 82; Chase 6808 . Campo Alegre, Chase 6622 . Lares, Chase 6593. Santa Ana, Britton and Cowell 4026.

Windward Islands: Grenada, Broadway 253.

\section{CYMBOPOGON Spreng.,} Pl. Pugill. 2: 14.1815.

OIL Grass.

Racemes in pairs subtended by spathes, these collected in a decompound inflorescence; spikelets in pairs as in Andropogon, but the lowermost pair of one or both racemes sterile and similar to the pedicled spikelets above; fertile (sessile) spikelets dorsally compressed, flat or dorsally grooved, sharply 2-keeled at the edges; fertile lemma narrow, the awn from between 2 teeth or lobes. Perennial densely tufted usually aromatic grasses. The two species mentioned below are cultivated occasionally in the West Indies. These and other species are used in perfumery. ${ }^{6}$

First glume of sessile spikelet flat on the back ........... 1. C. Citratus.

First glume of sessile spikelet concave on the back......... 2. C. NARDUs.

1. Cymbopogon citratus (DC.) Stapf, Kew Bull. Misc. Inf. 1906: 322.1906.

LEMON GRASS.

Andropogon citratus DC., Cat. Hort. Monsp. 78. 1813 (name only); Nees, Allgem. Gartenzeit. 3: 267. 1835. Described from a garden specimen.

Stout perennial with leafy sterile shoots from a short rhizome; culms erect, $2 \mathrm{~m}$ or more tall; blades long-attenuate toward the base and tapering upward to a setaceous point, as much as $1 \mathrm{~m}$ long, 5 to $15 \mathrm{~mm}$ wide, glabrous, scabrous on the margins and above

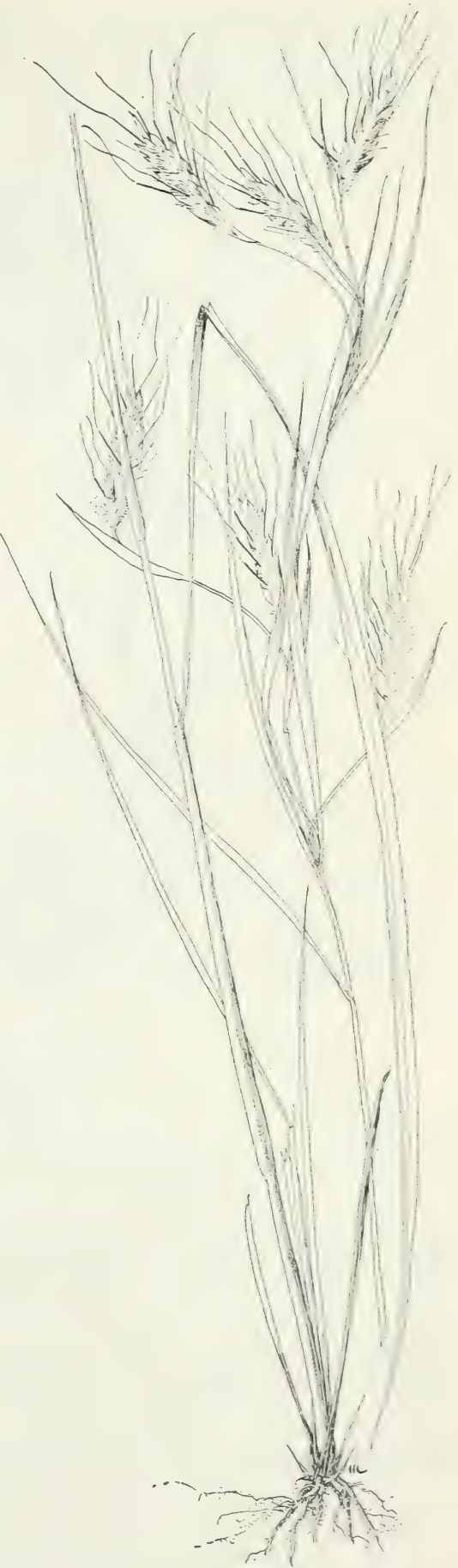

${ }^{\circ}$ A detailed account of these grasses is given by Stapf, Kew Bull. Misc. Inf. 1906: 297-363. 1906. 
toward the tip, the midrib rather stout below, whitish on the upper side; inflorescence 30 to $60 \mathrm{~cm}$ long, nodding (fig. 358).

Sparingly escaped from cultivation. Called "hierba de limon" in Cuba.

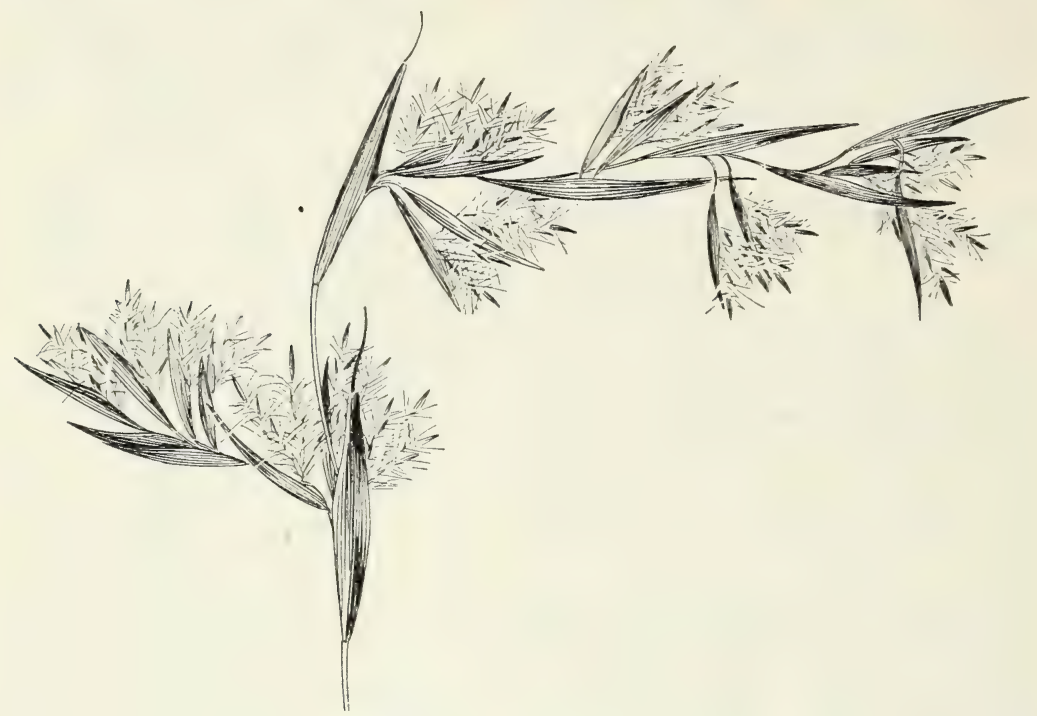

Figure 358.-Cymbopogon citratus. Branchlet, $\times 1$ (Sintenis 5295).

2. Cymbopogon nardus (L.) Rendle, Cat. Afr. Pl. Welw. 2: 155.1899. Andropogon nardus L., Sp. Pl. 1046. 1753. India.

Similar to $C$. citratus in habit, differing in the concave glumes of the sessile spikelet. In Puerto Rico the fibrous rootstock is used as a toothbrush by the poorer people.

109. HYPARRHENIA Anderss.; Stapf, in Prain, Fl. Trop. Africa 9: 291. 1918

Spikelets in pairs, as in Andropogon, but spikelets of the lower pairs alike, sterile, and awnless; fertile spikelets 1 to few in each raceme, terete or flattened on the back, the margins of the first glume rounded, not sharply inflexed nor keeled (keeled toward the summit in H. rufa), the base usually elongate into a sharp callus, the fertile lemma with a strong geniculate awn; sterile spikelets awnless; racemes in pairs, on slender peduncles, and subtended by a spathe. Tall perennials, the pairs of racemes and their spathes more or less crowded, forming a rather large inflorescence at the upper part of the plant.

Spikelets nearly glabrous or rather sparsely hirsute; pubescence usually rufous. Spikelets densely villous; pubescence whitish............... 2. H. HURTA.

1. Hyparrhenia rufa (Nees) Stapf, in Prain, Fl. Trop. Afr. 9: 304. 1918.

Trachypogon rufus Nees, Agrost. Bras. 345. 1829. Brazil. Andropogon rufus Kunth, Rév. Gram. 1: Sup. XXXIX. 1830.

Cymbopogon rufus Rendle, Cat. Afr. Pl. Welw. 2: 155. 1899. 
Perennial; culms erect, rather stout, 1 to $2.5 \mathrm{~m}$ tall; blades mostly 2 to $8 \mathrm{~mm}$ wide, sometimes more than $1 \mathrm{~cm}$; inflorescence 20 to $40 \mathrm{~cm}$ long, the pairs of racemes toward the ends of the numerous branches on long slender flexuous peduncles; racemes about $2 \mathrm{~cm}$ long, reddish brown; fertile spikelets mostly 5 to 7 in each raceme, 3 to $4 \mathrm{~mm}$ long, flattened from the back, pubescent with dark-red hairs, the pedicels and rachis-joints ciliate with red hairs; awn 15 to $20 \mathrm{~mm}$ long, twice geniculate, twisted, red-brown, hispidulous (fig. 359).

Moist, open ground, Venezuela to Brazil; Tropics of the Old World. Sometimes cultivated under the name "jaragua." Has some forage value.

Cuba: Baragua, Hitchcock 23380 (Amer. Gr. Nat. Herb. 1000). Santiago de las Vegas, escaped from experiment station plots, Hitchcock 23249. Manacas, Léon 5841, 5870.

Puerto Rico: Mayaguez, Britton 7443, cultivated under the name "canophora."

LeEward Islands: St. Kitts, Box 131.

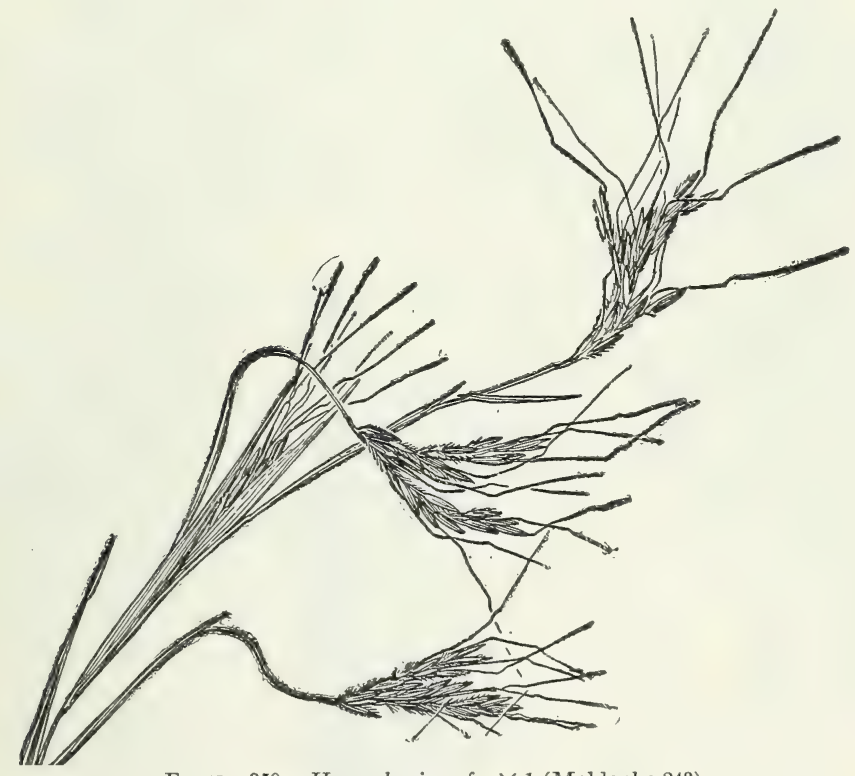

FIGURE 359.-Hyparrhenia rufa, $\times 1$ (Moldenke 243).

2. Hyparrhenia hirta (L.) Stapf, in Prain, Fl. Trop. Afr. 9: 315. 1918. Andropogon hirtus L., Sp. Pl. 1046. 1753. Mediterranean region. Cymbopogon hirtus Stapf; Burtt-Davy, Ann. Transv. Mus. 3: 121. 1912.

Differing from $H$. rufa in the usually longer racemes (4 to $5 \mathrm{~cm}$ ) and in the denser and more silky whitish pubescence of the inflorescence.

Waste places, introduced in a few localities in tropical America; Mediterranean region to South Africa.

Cuba: Habana, Ekman 13195 (Amer. Gr. Nat. Herb. 999); Léon 2788,3492 . 
Dominican Republic: Province of Santo Domingo, Ekman H 11419. Monción, Ekman H 13052. Santo Domingo City, Ekman H 13292. Cuesta Piedras, Ekman H 14298. Without locality,
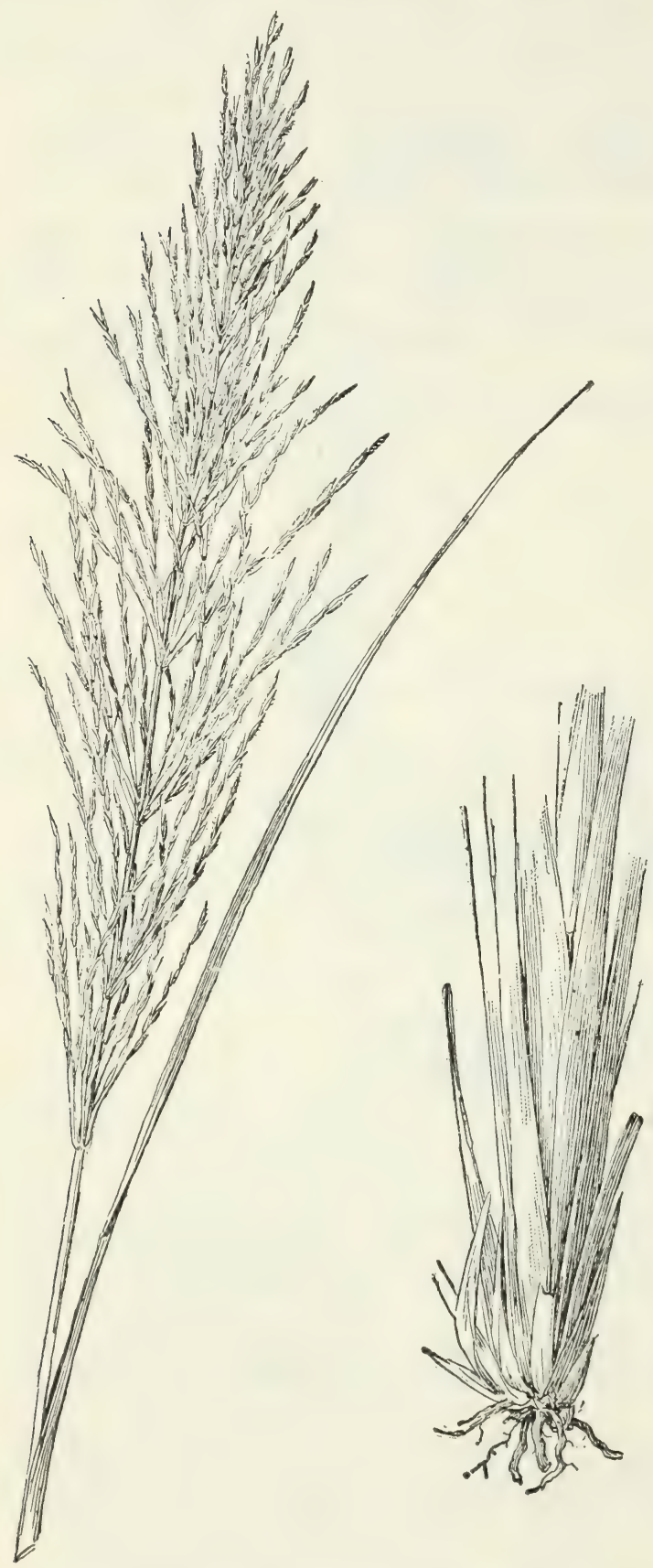

Figure 360.-Vetiveria zizanioides, $\times 1 / 2$ (Hitchcock 9435).
Wright, Parry, and Brummel 616.

110. VETIVERIA Bory, in Lem., Bull. Soc. Philom. 1822: 43. 1822

Racemes long, slender, solitary, on long filiform peduncles borne in whorls on an elongate axis, forming a large panicle; spikelets awnless (in ours), arranged as in Andropogon, the filiform rachis tardily disjointing. Coarse glabrous perennials with stout rhizomes.

In the Grasses of the West Indies this genus was described under Anatherum Beauv. This name was there typified by $A$. muricatum Beauv., the first of two equally eligible species. It seems better to take the second of these species, $A$. bicorne Beauv. (Andropogon bicornis L.) as the type, reducing Antherum Beauv. to a synonym of Andropogon and leaving Tetiveria for the aromatic grass commonly known under that name.

\section{Vetiveria zizanioides}

(L.) Nash, in Small, Fl. Southeast. U. S. 67. 1903. Khus-KHUS.

Phalaris zizanioides L., Mant. Pl. 183 . 1771. India.

Andropogon muricatus Retz., Obs. Bot. 3: 43. 1783. India. 
Anatherum muricatum Beauv., Ess. Agrost. 128, 150. pl. 22, f. 10. 1812.

Vetiveria arundinacea Griseb., Fl. Brit. W. Ind. 559. 1864 Jamaica, Trinidad.

Vetiveria muricata Griseb., Fl. Brit. W. Ind. 560. 1864.

Sorghum zizanioides Kuntze, Rev. Gen. Pl. 2: 791. 1891.

Andropogon zizanioides Urban, Symb. Antill. 4: 79. 1903.

Anatherum zizanioides Hitchc. and Chase, Contrib. U. S. Natl. Herb. 18: 285. 1917.

Robust, densely tufted, erect, branching perennial; culms 1 to $2 \mathrm{~m}$ tall, blades glabrous, firm or rigid, 30 to $100 \mathrm{~cm}$ long, 4 to $10 \mathrm{~mm}$ wide, scabrous on the margin; panicle elongate-pyramidal, 20 to $30 \mathrm{~cm}$ long, the branches in 6 to 10 whorls of as many as 20 rays, the lower naked part as much as $5 \mathrm{~cm}$; racemes as much as $5 \mathrm{~cm}$ long (fig. 360).

A native of Asia, cultivated in the Tropics of both hemispheres. Commonly cultivated in the West Indies as a hedge plant and for its aromatic roots. Sometimes escaped along roadsides. It is called "vetiver" 7 in Cuba. The roots are packed with articles of clothing to preserve them from moths. This is the grass that produces the aromatic roots called in Puerto Rico "pacholi" 8 or "pachuli." The Indian name "khus-khus" is used in the English islands. The aromatic roots are sometimes woven into screens which, when wet, are used to perfume living quarters. Also sometimes called "cockroach grass" and "khas-khas."

\section{SORGHUM Moench, Meth. Pl. 207. $1794^{9}$}

Spikelets in pairs, one sessile and fertile, the other pedicellate, sterile but well developed, usually staminate, the terminal sessile spikelet with two pedicellate spikelets. Annual or perennial, tall or moderately tall grasses, with flat blades and terminal panicles of 1 - to 5-jointed tardily disarticulating racemes. The numerous varieties of the cultivated Sorghum are considered species by some.

Plants perennial, with creeping rhizomes

1. S. HALEPENSE.

Plants annual

2. S. VULGARE.

\section{Sorghum halepense (L.) Pers., Syn. Pl. 1: 101. 1805.}

JOHNSON GRASS.

Holcus halepensis L., Sp. Pl. 1047. 1753. Syria.

Andropogon halepensis Brot., Fl. Lusit. 1: 89. 1804.

Robust perennial with numerous stout rhizomes; culms mostly 1 to $1.5 \mathrm{~m}$ tall; blades mostly less than $1.5 \mathrm{~cm}$ wide, the midrib prominent, the white margins scabrous; panicle 15 to $25 \mathrm{~cm}$ long; fertile spikelets plump, $5 \mathrm{~mm}$ long, the awn when present 7 to $10 \mathrm{~mm}$ long, deciduous; staminate spikelets $4 \mathrm{~mm}$ long, the pedicel $3 \mathrm{~mm}$ long (fig. 361).

A weed in fields and waste places in the warmer parts of North America; introduced from the old World. Found in all the large islands and probably in most of the smaller ones.

7 Est. Expt. Agron. Bol. 22: 108. 1914.

8 Contrib. U. S. Natl. Herb. 8: $208,1903$.

$\checkmark$ Holcus L. was used for this genus in Grasses of the West Indies. The historic type of that genus is Holcus sorghum L., but a standard species, H. lanatus L., has been adopted instead, in order to conserve Holcus for the velvet grass and to make Sorghum Moench available for the economically important sorghums. 

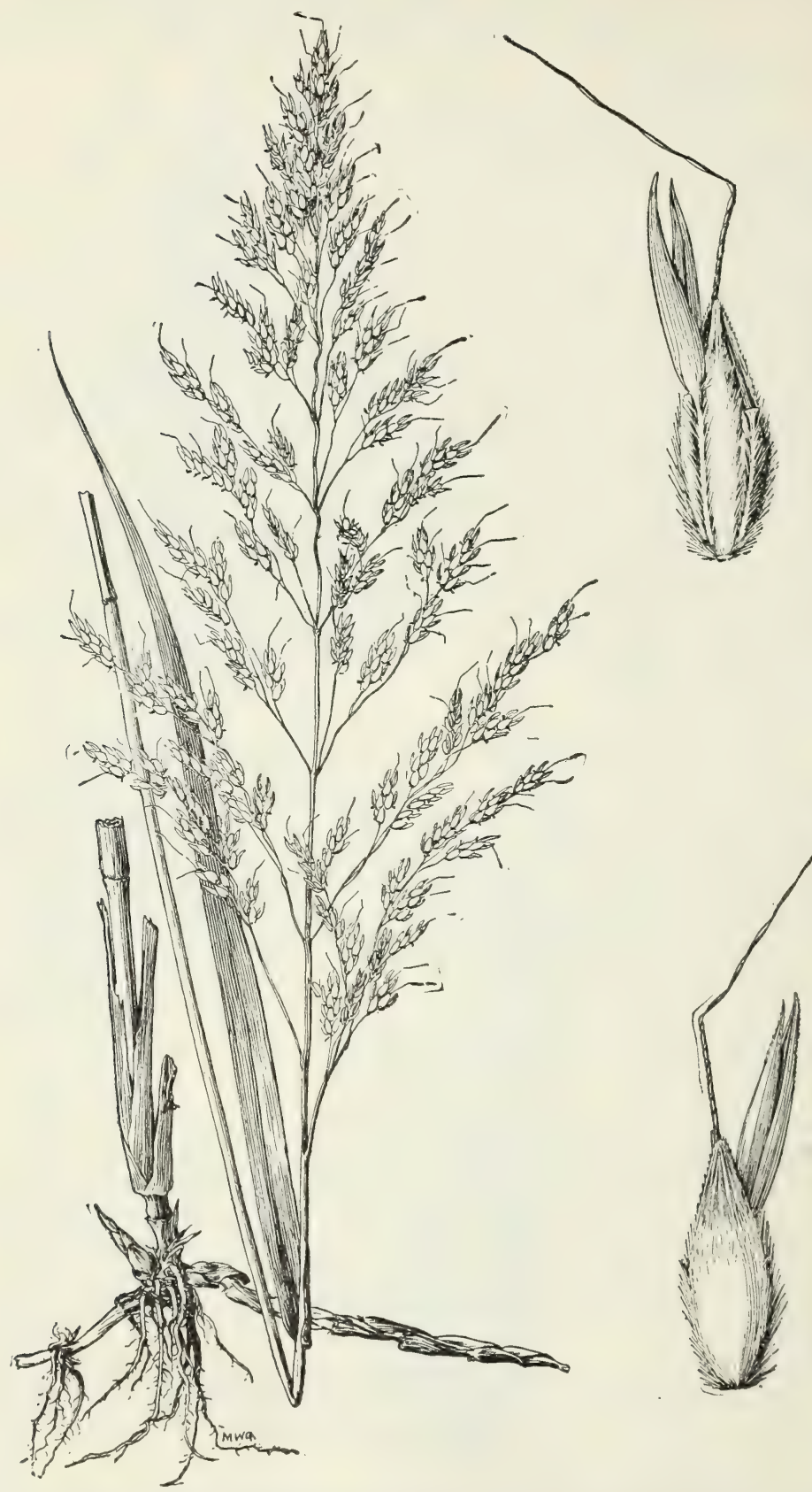

FIGURE 361.-Sorghum halepense. Plant, $\times 1 / 2 ;$ two views of terminal raceme, $\times 5$ (Small). 
This species is described by Humboldt, Bonpland, and Kunth, ${ }^{10}$ with Habana, Cuba, given as locality, under the name "Andropogon avenaceus Schrad." This is evidently a misprint for A. arundinaceus Willd., as described by Schrader. ${ }^{11}$ In Cuba this is called "cañuela" and "hierba de Don Carlos."

2. Sorghum vulgare (L.) Pers., Syn. Pl. 1: 101. 1805.

Sorghum or sorgo.

Holcus sorghum L., Sp. Pl. 1047. 1753. India.

Andropogon sorghum Brot., Fl. Lusit. 1: 88. 1804.

Sorghum dura Griseb., Fl. Brit. W. Ind. 560. 1864.

Large broad-leaved annual, with a compact panicle of turgid persistent spikelets.

Occasionally cultivated in the West Indies and sometimes spontaneous in waste places or near fields. Widely cultivated in other parts of North America and in the Old World. In the English Islands it is often called "Guinea corn"; in Cuba it is called "millo."

There are numerous varieties. One variety, Sudan grass (S. vulgare var. sudanense (Piper) Hitchc.), is a comparatively slender form 1 to $2 \mathrm{~m}$ tall, with a large open panicle, used for forage. Another variety, broomcorn, has a large erect or fan-shaped panicle with long naked branches, the spikelets crowded near the ends.

\section{SORGHASTRUM Nash, in Britton, Man. 71. 1901}

Spikelets in pairs, one nearly terete, sessile and fertile, the other wanting, only the hairy pedicel being present; glumes coriaceous, brown or yellowish, the first hirsute, the edges inflexed over the second; sterile and fertile lemmas thin and hyaline, the latter extending into a usually well-developed bent and twisted awn. Perennial, erect, rather tall grasses, with narrow flat blades and narrow terminal panicles of one- to few-jointed racemes.

Awn straight or slightly bent, not strongly spirally twisted at base, shorter than the spikelet or sometimes a little longer.......

Awn geniculate, strongly spirally twisted at base, about 3 times as long as the spikelet.... . S. STIPOIDES.

1. Sorghastrum setosum (Griseb.) Hitchc., Contrib. U. S. Natl. Herb. 12: 195.1909.

Sorghum parviflorum Desv.; Hamilt., Prodr. Pl. Ind. Occ. 12. 1825. Not S. parviflorum Beauv., 1812. Hispaniola.

Andropogon setosus Griseb., Cat. Pl. Cub. 235. 1866. Cuba, Wright 3897.

Andropogon francavillanus Fourn., Mex. Pl. 2: 56. 1886. Mexico. Sorghastrum francavillanum Hitchc., Contrib. U.S. Natl. Herb. 12: 195. 1909.

Sorghastrum parviflorum Hitchc. and Chase, Contrib. U. S. Natl. Herb. 18: 287. 1917.

Tall erect tufted glabrous perennial with long, flat, or subinvolute blades and long lanceolate panicles with slender or subcapillary branchlets and peduncles and golden brown spikelets, the ultimate

10 Nov. Gen. et Sp. 1: 189.1816.

11 Fl. Germ. 1: 237. 1806. 
peduncles, the sterile pedicels, and the base of the spikelet clothed with white hairs; awn variable in length.

Grassy hillsides, southern Mexico and the West Indies to Argentina. Grisebach cites Piptatherum setosum A. Rich., "ex descr.", but Richard's description does not apply to this species. Andropogon setosus is taken to be a new species based on Wright 3897, rather than a change of name (see p. 182) (fig. 362).

Cuba: Sancti Spíritus, Léon 894, 895, 5365. Nagua, Ekman 14903a. Jamaica: Hardware Gap, Harris 11437. Flamstead, Harris 11463. Bermuda Mountain, Harris 11635. Gorden Town, Hart $812 . \quad$ Newcastle, Hitchcock 9346. Halls Delight Harris 12934.

Haiti: Port-au-Prince, Ekman H 419. Las Cahobas, Cook, Scofield, and Doyle 98. Petite Rivière de l'Artibonite, Picarda 1634. Morne Robin, Buch 1475. Lamarque, Buch 1652.

Dominican Republic: Pimentel, Ekman H 13257. Monción, Ekman H 12687. Sabana de la Mar, Ekman H 15615.

Puerto Rico: Trujillo Alto, Sein 318; Chase 6370, 6773. San Juan, Chase 6638. Vega Baja, Chase 6421. Rio Piedras, Cowgill 687, 696.

Trinidad: Icacos, Broadway 9290.

2. Sorghastrum stipoides (H. B. K.) Nash, N. Amer. Fl. 17: 129. 1912.

Andropogon stipoides H. B. K., Nov. Gen. et Sp. 1: 189. 1816. Colombia.

Andropogon domingensis Spreng.; Steud., Nom. Bot. ed. 2. 1: 91. 1840 , as synonym of $A$. stipoides, but the specimen is Sorghastrum setosum.

More slender than the preceding, the narrower blades convolute, the spikelets slightly larger, and the awns well developed.

Palm barrens, Cuba; Colombia to Brazil. This is the species referred by Hitchcock ${ }^{12}$ to S. francavillanum.

Cuba: Mangas, Ekman 17592. Pinar del Río, Hitchcock 23252, 23303. Santa Cruz de los Pinos, Ekman 17680 (Amer. Gr. Nat. Herb. 998). Guane, Shafer 10353. Hanábana, Wright 3897. Tiñales, Léon 15864.

\section{RHAPHIS Lour. ${ }^{13}$ Fl. Cochinch. 552. 1790}

Inflorescence a few-flowered panicle, the racemes reduced to a single joint of the rachis with a sessile perfect spikelet and 2 pedicellate sterile spikelets (the latter sometimes obsolete) borne at the ends of slender naked peduncles, these disjointing obliquely near the summit, forming a sharp callus below the long-awned spikelets. Perennials or rarely annuals, with narrow blades and terminal panicles.

1. Rhaphis pauciflora (Chapm.) Nash, in Small, Fl. Southeast. U. S. 67.1903.

Andropogon wrightii Munro; Wright, An. Acad. Cienc. Habana 8: 288. 1871 (name only). Cuba, Wright 3895.

Sorghum pauciflorum Chapm., Bot. Gaz. 3: 20. 1878. Florida.

Chrysopogon pauciflorus Benth.; Vasey, Grasses U. S. 20.1883.

12 Contrib. U. S. Natl. Herb. 12: 195. 1909.

13 The name Rhapis L. f.; Ait., Hort. Kew. 3: 473. 1789, having a different derivation and pronunciation should not invalidate Rhaphis Lour. The latter name should replace Chrysopogon Trin., Fund. Agrost. 187. 1820. 


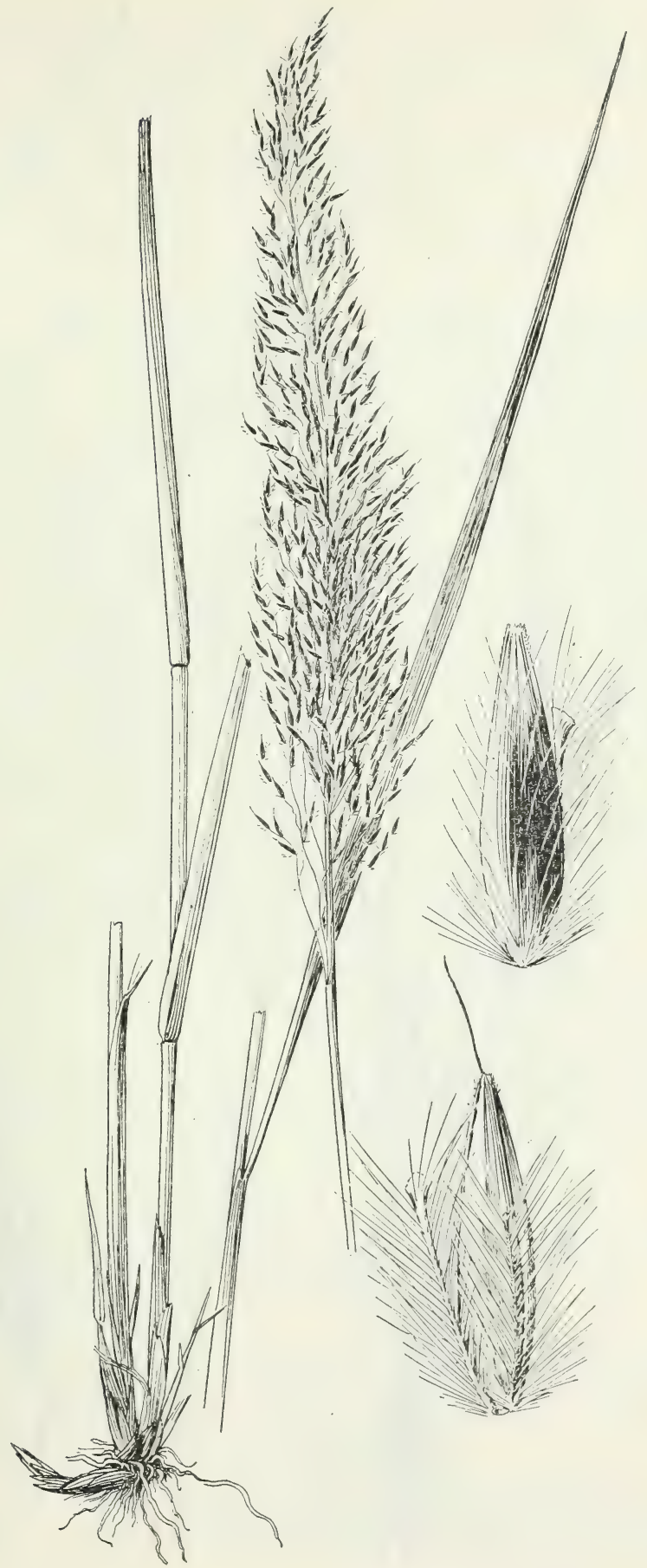

FigdRE 362,-Sorghastrum setosum. Plant $\times 1 / 2 ;$ two views of spikelet, $\times 10$ (Léon 5365). 
412 Misc. PUBLICATION 243, U. S. DEPT. OF AGRICULTURE

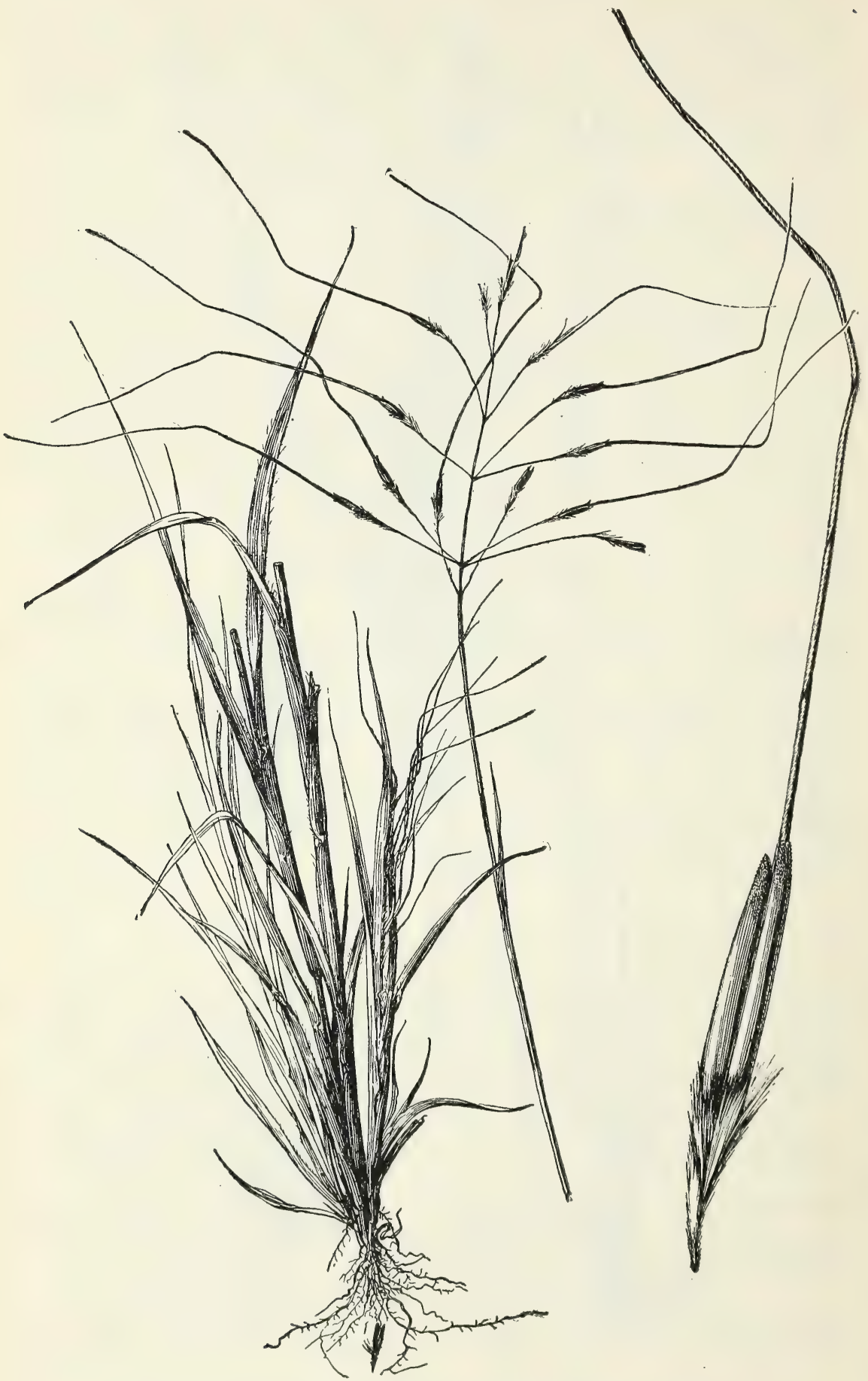

Figure 363.-Rhaphis pauciflora. Plant, $\times 1 \frac{1}{2}$; fruiting spikelet, $\times 5$ (Combs 1359). 
A slender branching annual with flat or folded ciliate blades and a few-flowered panicle with capillary branchlets, the brown spikelets raised on a hairy callus of nearly equal length, the twisted bent awns up to $15 \mathrm{~cm}$ long (fig. 363 ).

Sandy pine barrens, Florida and Cuba.

Cuba: Pinar del Río, Wright 3895. Baraguá, Hitchcock 23383. Isla de Pinos, Ekman 11628; Taylor 46.

\section{HETEROPOGON Pers., Syn. Pl. 2: 533. 1807}

Spikelets in pairs, one sessile, the other pedicellate, both of the lower few to several pairs staminate or neuter, the remainder of the sessile spikelets perfect, terete, long-awned, the pedicellate spikelets, like the lower staminate, flat, conspicuous, awnless; glumes of the fertile spikelet equal, coriaceous, the first brown-hirsute, infolding the second; lemmas thin and hyaline, the fertile one narrow, extending into a strong bent and twisted brown awn; glumes of the staminate spikelet membranaceous, the first green, faintly many-nerved, asymmetric, one submarginal keel rather broadly winged, the other wingless, the margins inflexed, the second glume narrower, symmetric. Annual or perennial grasses, with flat blades and mostly solitary racemes terminal on the culms and branches; rachis slender, the lower part, bearing the pairs of staminate spikelets, continuous, the remainder disarticulating obliquely at the base of each joint, the joint forming a sharp barbed callus below the fertile spikelet, the pedicellate spikelet readily falling.

Plants perennial, 60 to $100 \mathrm{~cm}$ tall; first glume of staminate spikelet pilose.

1. H. Contortus.

Plants annual, usually more than $1 \mathrm{~m}$ tall; first glume of staminate spikelet beset with a row of glands along the back, not pilose_-2. H. MELANOCARPUS.

1. Heteropogon contortus (L.) Beauv.; Roem. and Schult., Syst. Veg. 2: 836.1817.

Andropogon contortus L., Sp. Pl. 1045. 1753. India.

Andropogon secundus Willd.; Nees, Agrost. Bras. 364. 1829. Brazil.

Branching perennial; culms compressed, 40 to $100 \mathrm{~cm}$ tall; blades 2 to $4 \mathrm{~mm}$ wide, scabrous; racemes solitary, excluding awns 3 to $8 \mathrm{~cm}$ long, somewhat curved; spikelets imbricate, the lower awnless, the upper with brown bent awns, 5 to $8 \mathrm{~cm}$ long, red-brown. Lemonscented when fresh (fig. 364).

Rocky slopes and cliffs. Southwestern United States and the West Indies to Argentina and Bolivia; warmer parts of the Old World.

Cuba: Arroyo Arenas, Léon 16423. Sancti Spíritus, Léon 897, 4095, 5356; Sergius 2792. Guantánamo, Ekman 10179. Eastern Cuba, Wright 1559.

JaMAICA: Halls Delight, Harris 11259. Grants Pen, Harris 11540. Guava Ridge, Harris 11290. Gordon Town, Hitchcock 9324. Healthshire Hills, Harris 11351, 11610; Hitchcock 9756. Lititz, Harris 11738. New Forest, Hitchcock 9839.

Haiti: Monte Cabrete, Cook, Scofield, and Doyle 71, 102. Portau-Prince, Ekman H 2028; Leonard 15862. Pétionville, Leonard 4942; Ekman H 3244. St. Marc, Leonard 3419. Les Anglais, Ekman H 383 . 
414 Misc. PUBlicAtion 243, U. S. DEPT. OF AGRICULTURE

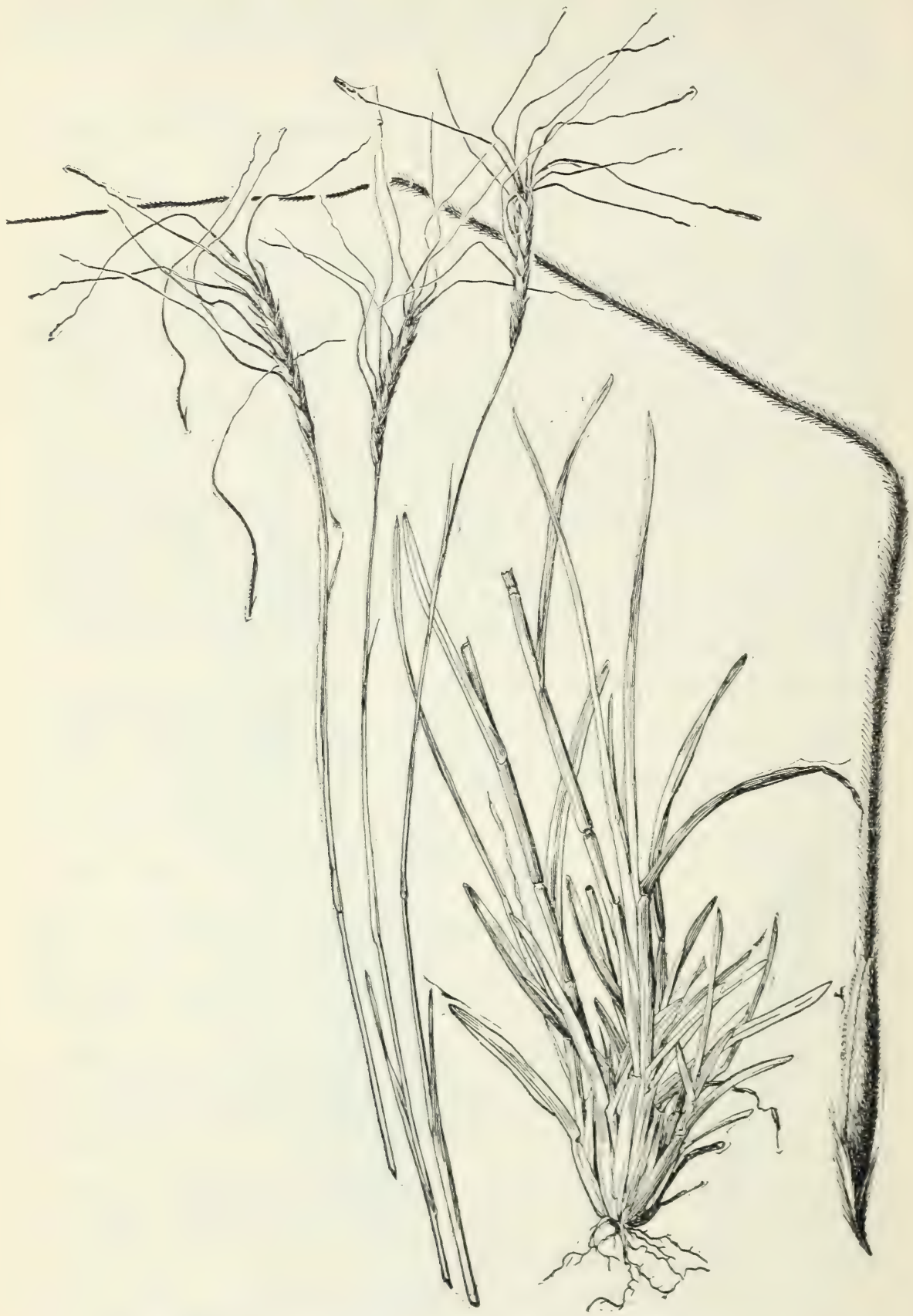

FIGURE 364.-Heteropogon contortus. Plant, $\times$ 16; fruiting spikelet, $\times 5$ (Griffiths 1844). 
Domisican Republic: Monción, Ekman H 12686. Azua, Rose 3826. Barahona, Fuertes 1455b. Los Charcos, Fuertes 1418. Santiago, Ekman H 16225.

Virgin Islands: Virgin Gorda, Fishlock 208.

Leeward Islaxds: St. Kitts, Box 154. Antigua, Wullschlagel; Box 71. Guadeloupe, Duss 3137; Stehlé 286.

2. Heteropogon melanocarpus (Ell.) Benth., Jour. Linn. Soc. Bot.

19: 71. 1882.

Sweet tanglehead.

Andropogon melanocarpus Ell., Bot. S. C. and Ga. 1: 146. 1816. Georgia.

Culms stout, often glaucous, the lower nodes often producing stiltroots; blades as much as $1 \mathrm{~cm}$ wide; racemes several, combined with the spathes and upper leaves forming a rather dense inflorescence 20 to 30 cm long; first glume of staminate spikelet $15 \mathrm{~mm}$ long; mature fertile spikelet terete, dark brown, 6 to $7 \mathrm{~mm}$ long with a sharp bearded callus about $2 \mathrm{~mm}$ long; awn hispidulous, 6 to 10 cm long (fig. 365).

Grassy slopes and open ground, southern United States to Brazil and Bolivia; Haiti; also Tropics of the Old World.

Haiti: Pétionville, Ekman H 1909.

\section{TRACHYPOGON Nees, Agrost. Bras. 341. 1829}

Spikelets in pairs, along a slender continuous rachis, one nearly sessile, staminate, awnless, the other pedicellate, perfect, long-awned; the pedicel of the perfect spikelet obliquely disarticulating near the base, forming a sharp barbed callus below the spikelet; first glume firm-membranaceous, rounded on the back, sereral-nerved, obtuse; second glume firm, obscurely

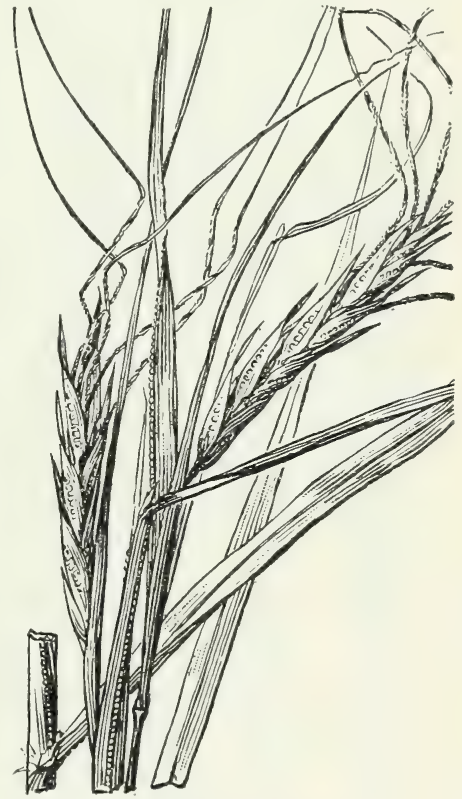

Figure 365.-Heteropogon melanocarpus, $\times 1$ (Fredholm 6405)

nerved; fertile lemma narrow, extending into a stout twisted and bent or flexuous awn; sessile spikelet persistent, as large as the fertile spikelet and similar but awnless. Perennial, moderately tall grasses, with terminal spikelike racemes, these single or clustered.

Awn 10 to $12 \mathrm{~cm}$ long, conspicuously plumose............. T. ToUINII. Awn mostly not more than $5 \mathrm{~cm}$ long, appressed-plumose on the lower part, scabrous above.

Blades flat; racemes usually 2 or 3 , sometimes solitary _ 2 . T. LIGULARIS.

Blades involute; racemes usually solitary _......... T. FILIfoLIUS.

1. Trachypogon gouinii Fourn., Mex. Pl. 2: 66. 1886. Vera Cruz, Mexico.

Tall slender glabrous perennial, sparingly producing scaly rhizomes; culms simple, usually geniculate below; blades involute; raceme narrow, pale, feathery, 15 to $30 \mathrm{~cm}$ long.

$60256-36-27$ 
Open ground in the vicinity of Habana, Cuba, introduced from eastern Mexico.

Cuba: Vicinity of Habana, Léon 209, 300; Tracy 9086 ; Juzepczuk 17. Minas, Ekman 15376.

2. Trachypogon ligularis Nees, Agrost. Bras. 345. 1829. Brazil.

Culms erect, 1 to $1.5 \mathrm{~m}$ tall, often sparingly branching below, the sheaths overlapping; ligule 5 to $18 \mathrm{~mm}$ long, firm; blades mostly reflexed, flat, 3 to $7 \mathrm{~mm}$ wide, scabrous, long-attenuate; racemes 2 or 3 , sometimes solitary, 10 to $20 \mathrm{~cm}$ long; awns 4 to $7 \mathrm{~cm}$ long, pilose.

In the Grasses of the West Indies this

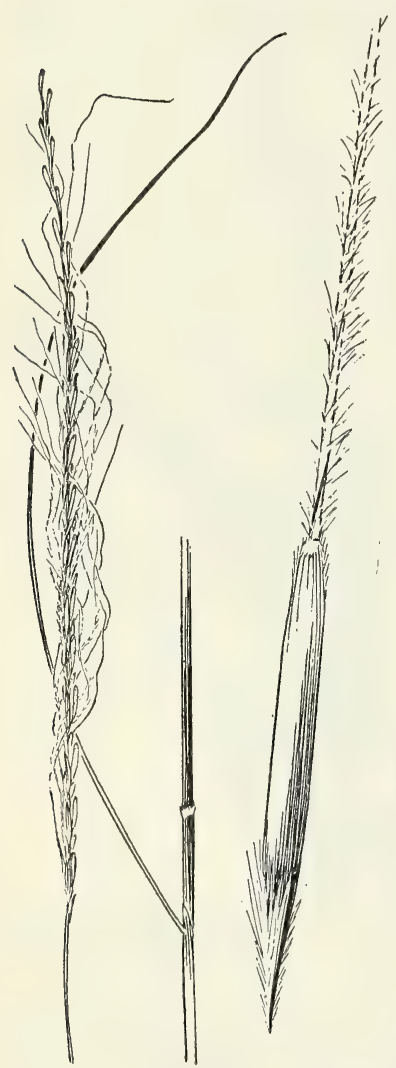

Figure 366.-Trachypogon filifolius. Inflorescence, $\times 1$; fertile spikelet $\times 5$ (Ekman 11571). species was referred to $T$. plumosus Humb. and Bonpl. The type of that in the Paris Herbarium was examined in 1935 and is found to be a species confined to South America.

Wet savannas, Trinidad to Colombia, south to central Brazil.

Trinidad: Mount St. Benedict, Broadway 5061. St. Joseph, Hitchcock 10185. Piarco Savanna, Hitchcock 10342. Arima, Eggers 1379.

3. Trachypogon filifolius (Hack.) Hitchc., Contrib. U. S. Natl. Herb. 12: 191. 1909.

Trachypogon polymorphus var. filifolius Hack., in Mart., Fl. Bras. $2^{3}$ : 642. 1883. Brazil.

Slender, wiry, tufted, 1 to $1.3 \mathrm{~m}$ tall; ligule 2 to $4 \mathrm{~mm}$ long; blades erect, involute, slender, elongate, smooth; racemes solitary, 8 to $12 \mathrm{~cm}$ long, mostly more slender; awns mostly not more than $5 \mathrm{~cm}$ long, sparsely pilose (fig. 366).

Sandy pine woods, western Cuba; Brazil.

CuBA: Herradura, Ekman 11571; Ekman in 1923. Pinar del Río, Hitchcock 23308; Wright 3892, 3893; Léon 3398. Viñales, Léon 15863.

116. ISCHAEMUM L., Sp. Pl. 1049. 1753

Sessile spikelets perfect, awned; pedicellate spikelets perfect but not always fruitful; rachis disjointing; racemes 2 to several, digitate or aggregate on a short axis. Culms branching, with flat blades and digitate or flabellate inflorescence with slender awns.

Racemes 2, conjugate; first glume strongly rugose across the back_1. I. RUGosum. Racemes several in a cluster; first glume not rugose_....... 2. I. LATIFOLIUM.

1. Ischaemum rugosum Salisb., Icon. Stirp. Rar. 1. pl. 1. 1791. India.

Annual; culms 0.5 to $1 \mathrm{~m}$ tall; geniculate below; nodes bearded; blades 8 to $12 \mathrm{~mm}$ wide, sparsely pilose; racemes 5 to $10 \mathrm{~cm}$ long, 
erect, so closely appressed to each other as often to appear like a single spike; spikelets 3 to $4 \mathrm{~mm}$ long, obtuse, the awn about $1.5 \mathrm{~cm}$ long.

Waste places in Cuba and Jamaica; introduced from the Old World.

Cuba: Madruga, Curtiss 533. Manacas, Léon 5886. Bayate, Ekman 10063. Camp la Gloria, south of Sierra Moa, Shafer 8104.

JAMAICA: Savanna-la-Mar, Hitchcock 9858 .

Trinidad: Rio Claro, Bot. Gard. Herb. 12075.

\section{Ischaemum latifolium (Spreng.)}

Kunth, Rév. Gram. 1: 168. 1829 .

Andropogon latifolius Spreng., Syst. Veg. 1: 286.1825.

Ischaemopogon latifolius Griseb., Fl. Brit. W.Ind. 560. 1864. Guadeloupe and Martinique.

Perennial, spreading and straggling, decumbent, rooting at the lower nodes; blades oblong-lanceolate, as much as $20 \mathrm{~cm}$ long and 3 $\mathrm{cm}$ wide; racemes 5 to 15,4 to 8 cm long (fig. 367).

Moist, shady places, southern Mexico and the Lesser Antilles to Brazil and Ecuador.

Leeward Islands: Guadeloupe, Duss 2696; Stehlé 111. Dominica, Jones 17, 41 .

Windward Islands: Martinique, Hitchcock 16459; Hahn in 18671870. St. Vincent, Eggers 6710.

Trinidad: Bot. Gard. Herb. 3380.

IschaEMUM ANGUSTIFOLIUM (Trin.) Hack., in Hook., Icon. Pl. 18: pl. 1773. 1888. In the herbarium of the Botanical Department, Trinidad, is a specimen of this collected in 1895 by J. H. Hart, and said to be introduced. It is distinguished by its elongate narrow blades.

Rhytachne Rottboellioides Desv.; Hamilt., Prodr. Pl. Ind.

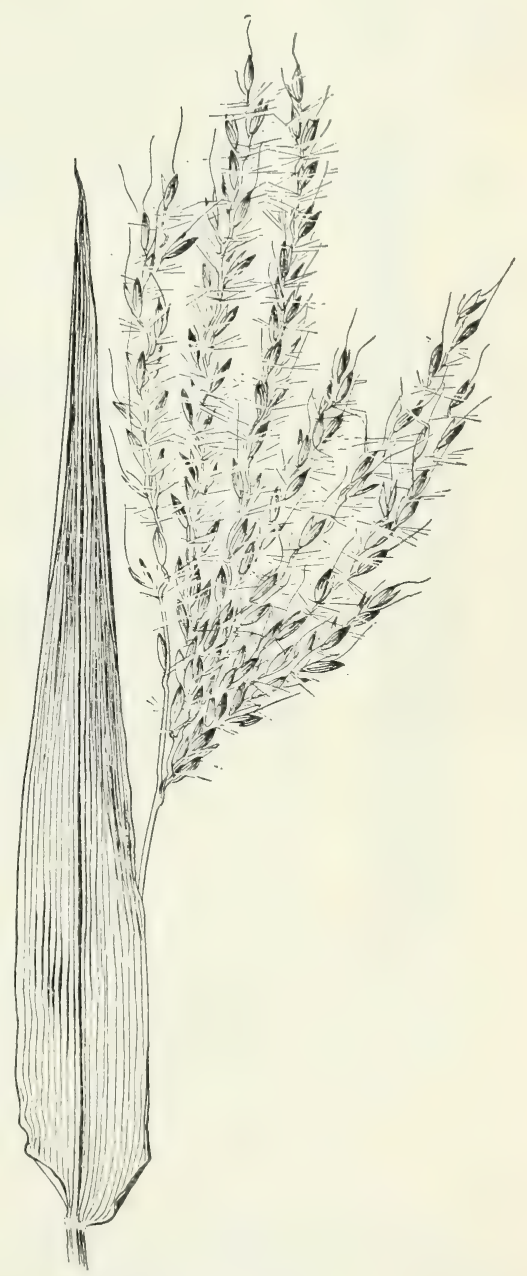

FIGURE 367.-Ischaemum latifolium. Inflorescence, $\times 1$ (Duss 2696).

Occ. 11. 1825. Described from a specimen purporting to be from the "Antilles" in the Desvaux Herbarium. The genus is an African one and the locality given is probably an error, as with many other Desvaux specimens. The specimen could not be found in the Paris Herbarium. 
117. ROTTBOElliA L. f., Nov. Gram. Gen. 22. pl. 1. 1779; Amoen. Acad. 10: 22.1790

Spikelets awnless, in pairs at the nodes of a thickened articulate rachis, one sessile and perfect, the other pedicellate, sterile; rachisjoints hollow above, the thickened pedicel adnate to it, the pedicellate spikelet appearing to be sessile; sessile spikelet fitting closely against the concave side of the rachis-joint, the first glume coriaceous, the second less coriaceous; sterile and fertile lemmas and palea hyaline. Coarse branching annual with broad flat blades and subcylindric racemes, dwindling toward the summit and bearing abortive spikelets only.

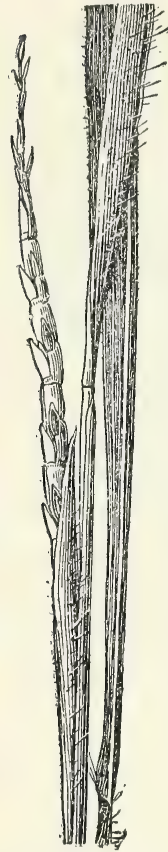

FIgURE 368 . Rottboellia exaltata, $\times 1$ (Ridley).

1. Rottboellia exaltata L. f., Sup. Pl. 114. 1781. India. 1891.

Manisuris exaltata Kuntze, Rev. Gen. Pl. 2: 779.

Stegosia exaltata Nash, N. Amer. Fl. 17: 84. 1909.

A stout branching leafy annual with hispid sheaths, long flat scabrous blades, and numerous axillary racemes, the summit of these dwindling and bearing abortive spikelets only (fig. 368).

A weed in moist soil, in several of the West Indian islands, introduced from southern Asia.

CuBA: Habana, Léon 2683. Soledad, Hitchcock 23323. Sancti Spiritus, Léon 847. El Cristo, Ekman 9000.

Jamaica: Castleton, Ridley 125; Harris 11387. Kingston, Hitchcock 9257. Bog Walk, Rialey 108; Hitchcock 9283 (Amer. Gr. Nat. Herb. 238). Hope Gardens, Harris 11256. Ipswich, Hitchcock 9605. Barican, Hitchcock 9567. Ewarton, Hitchcock 9462. Gordon Town, Hart 809.

Haiтr: Ennery, Ekman H 2447; Leonard 8822. St. Michel de l'Atalaye, Leonard 7362, 7834. Plaisance, Leonard 9270. San Rafael, Cook, Scofield, and Doyle $152,153$.

Dominican Republic: Azua, Ekman H 13618.

Leeward Islands: St. Kitts, Box 135.

Trinidad: Icacos, Broadway 4965. Point-à-Pierre, Broadway, 4943. Port-of-Spain, Hitchcock 9944. Without locality, Bot. Gard. Herb. 3221.

\section{MANISURIS L., Mant. Pl. 164. 1771}

Spikelets awnless, in pairs at the nodes of a thickened articulate rachis, one sessile and perfect, the other pedicellate rudimentary (developed but sterile in $M$. altissima), the pedicel thickened and appressed to the rachis, the sessile spikelet fitting closely against the rachis (sometimes partly adnate in $M$. altissima), forming a cylindric or flattened raceme; glumes mostly obtuse, the first coriaceous, fitting over the hollow containing the spikelet, the keels winged at the summit, the second less coriaceous than the first; sterile lemma, fertile lemma, and palea thin and hyaline. Perennial slender, moderately tall, or tall grasses, with usually numerous glabrous cylindric or flattened solitary racemes. 
Racemes compressed, tardily disarticulating

Racemes cylindric or nearly so, readily disarticulating.

First glume emarginate and winged above

1. M. altissima.

First glume not winged.

Blades flat; sheaths compressed-keeled. First glume roughened or wrinkled crosswise or nearly smooth

Blades involute; sheaths cylindric, not keeled.

First glume strongly transverse-rugose_._.

First glume not rugose $\ldots \ldots . . .5 . \quad$ M. IMPRESSA,

1. Manisuris altissima (Poir.) Hitche., Jour. Wash. Acad. Sci. 24: 292. 1934.

Rottboellia altissima Poir., Voy. Barb. 2: 105. 1789. Barbary.

Rottboellia fasciculata Lam., Tabl. Encycl. 1: 204. 1791. Barbary. Hemarihria fasciculata Kunth, Rév. Gram. 1: 153. 1829.

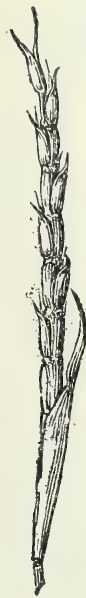

FIgURE 369.Manisuris altissima, $\times 1$ (Hitchcock). Rottboellia compressa var. fasciculata Hack., in DC., Monogr. Phan. 6: 286. 1889. Manisuris fasciculata Hitchc., Amer. Jour. Bot. 2: 299. 1915.

Hemarthria altissima Stapf and Hubbard, Kew Bull. Misc: Inf. 1934: 109. 1934.

Culms erect or spreading, compressed, slender, glabrous, 50 to $100 \mathrm{~cm}$ tall; blades flat or folded, 2 to $5 \mathrm{~mm}$ wide; racemes 5 to $10 \mathrm{~cm}$ long, falcate, from several of the upper sheaths (fig. 369).

Shallow water, ditches, and moist ground. An Old World species introduced into the American Tropics. Mexico and Jamaica to Argentina.

JAMAICA: Black River, Harris 12550, 12874.

2. Manisuris aurita (Steud.) Hitchc. and Chase, Contrib. U. S. Natl. Herb. 18: 276.1917. Rottboellia aurita Steud., Syn. Pl. Glum. 1: 361. 1854. Brazil.

Culms erect, glabrous, 1 to $1.5 \mathrm{~m}$ tall; blades

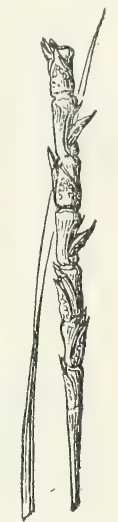

FIGURE 370 . Manisuris tuberculosa, $\times 1$ (Nash 1074).

flat or folded, 4 to $8 \mathrm{~mm}$ wide; racemes mostly 5

to $10 \mathrm{~cm}$ long, included at base in the upper sheaths or exserted; sessile spikelets $4 \mathrm{~mm}$ long, the first glume smooth or indistinctly pitted.

Grassy hillsides, Brazil to Trinidad; in the latter known from a specimen in the Gray Herbarium collected by Finlay (Bot. Gard. Herb. 2304).

3. Manisuris tuberculosa Nash, Bull. N. Y. Bot. Gard. 1: 430. 1900. Florida.

Coelorachis tuberculosa Nash, N. Amer. Fl. 17: 86. 1909.

Culms erect, 1 to $1.5 \mathrm{~m}$ tall; sheaths compressed-keeled; blades flat; racemes several, slender, 2 to $5 \mathrm{~cm}$ long; joints about $5 \mathrm{~mm}$ long (fig. 370).

Swampy places, Florida and Cuba.

CuBA: Laguna Santa María, Ekman 17260.

4. Manisuris loricata (Trin.) Kuntze, Rev. Gen. Pl. 2: 780. 1891. Rottboellia loricata Trin., Mém. Acad. St. Pétersb. VI. Math. Phys. Nat. 2: 250. 1832. Brazil.

Rottboellia filifolia Wright, An. Acad. Cien. Habana 8: 209. 1871. Cuba, Wright 3905. 
Coelorachis loricata Nash, N. Amer. Fl. 17: 85. 1909.

A slender erect unbranched tufted perennial with narrow involute blades, the solitary terminal raceme up to $25 \mathrm{~cm}$ long.

Pine barren swamps, western Cuba and Brazil.

Cuba: Herradura, Baker and Abarca 4181; Tracy 9059; Hitchcock 476; Pinar de Cajálbana, Ekman 17339. Mordazo, Ekman 17106. Dayaniguas, Wright 3905. Isla de Pinos, Ekman 11959.

5. Manisuris impressa (Griseb.) Kuntze, Rev. Gen. Pl. 2: 780. 1891. Rottboellia impressa Griseb., Cat. Pl. Cub. 235. 1866. Cuba, Wright 3904.

Coelorachis impressa Nash, N. Amer. Fl. 17: 85. 1909.

Manisuris leonina Hitchc. and Chase, Contrib. U. S. Natl. Herb. 18: 275. 1917. Cuba, Léon 6981.

Stouter than the preceding, $1 \mathrm{~m}$ or more tall, the culm branching, bearing terminal and axillary racemes 10 to $15 \mathrm{~cm}$ long.

Pine barrens, Cuba.

Cuba: Remates, Ekman 11320. Damují, Ekman 11048. San Julián, south of Guane, Léon 6981. El Salado, Wright 3904. Motembo, Léon 8206, 9367; Ekman 16818. San Cristobal, Ekman 13752. Santayana, Ekman 15360. Isla de Pinos, Ekman 11645.

119. HACKELOCHLOA Kuntze, Rev. Gen. Pl. 2: 776. 1891

\section{(Rytilix Raf., Bull. Bot. Seringe 1: 219. 1830. No} generic description)

Spikelets awnless, in pairs, the rachis joint and pedicel grown together, the two clasped between the edges of the globose alveolate first glume of the sessile spikelet; pedicellate spikelet conspicuous, staminate. Freely branching annual with flat blades and numerous short racemes.

1. Hackelochloa granularis (L.) Kuntze, Rev. Gen. Pl. 2: 776. 1891. Cenchrus granularis L., Mant. Pl. 2: 575. 1771. East Indies.

Manisuris granularis Swartz, Prodr. Veg. Ind. Occ. 25. 1788.

Rytilix granularis Skeels, U. S. Dept. Agr., Bur. Plant Indus. Bull. 282: 20.1913.

Coarsely hispid; culms 30 to $100 \mathrm{~cm}$ tall; blades mostly less than $10 \mathrm{~cm}$ long, 5 to $10 \mathrm{~mm}$ wide; racemes terminal and axillary, 1 to 2.5 cm long (fig. 371).

A common weed throughout tropical America, introduced from the Old World. In the West Indies found in Cuba, Jamaica, Haiti, Dominican Republic, Puerto Rico, Guadeloupe, and Martinique, and probably to be found on other islands.

\section{THEMEDA Forsk., Fl. Aegypt. Arab. 178. 1775}

Infiorescence a flabellate cluster of several racemes, each subtended by a leaflike spathe, the entire cluster (or panicle) subtended or partly enclosed by a larger spathe; racemes consisting of 2 approximate pairs of sessile awnless staminate or neuter spikelets and a single fertile awned spikelet with a pair of sterile pedicellate ones, the rachis disjointing above the pairs of sessile staminate spikelets and forming a 
pointed callus below the fertile one. Perennial or annual, often robust grasses, with leafy compound panicles.

Perfect spikelets villous; glumes of sessile neuter spikelets not strongly papillose

1. T. ARGUENS.

Perfect spikelets not villous; glumes of sessile neuter spikelets strongly papillose, the papillae bearing long stiff hairs .................... T. TUADRIVALVIS.

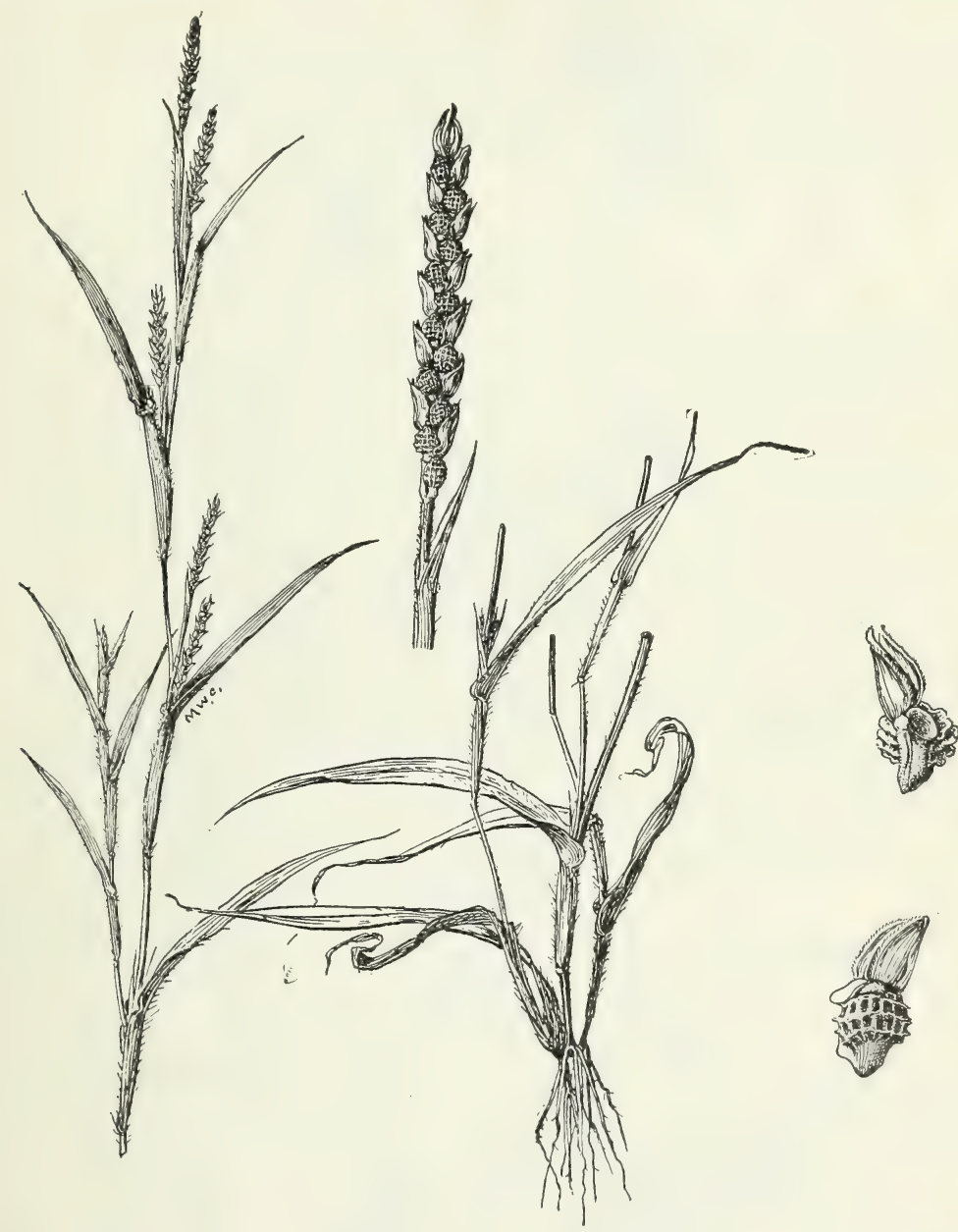

FIGURE 371. - Hackelochloa granularis. Plant, $\times 1 / 2$; single raceme, $\times 2$; two views of spikelets with rachis joint, $\times 5$ (Pringle)

1. Themeda arguens (L.) Hack., in DC., Monogr. Phan. 6: 657. 1889.

Christmas GRass.

Stipa arguens L., Sp. Pl. ed. 2. 117. 1762. India.

An ascending annual with compressed branching culms, flat scabrous blades, and $V$-shaped clusters of long-awned spikelets; fruit dark brown, the awn 5 to $7 \mathrm{~cm}$ long (fig. 372). 


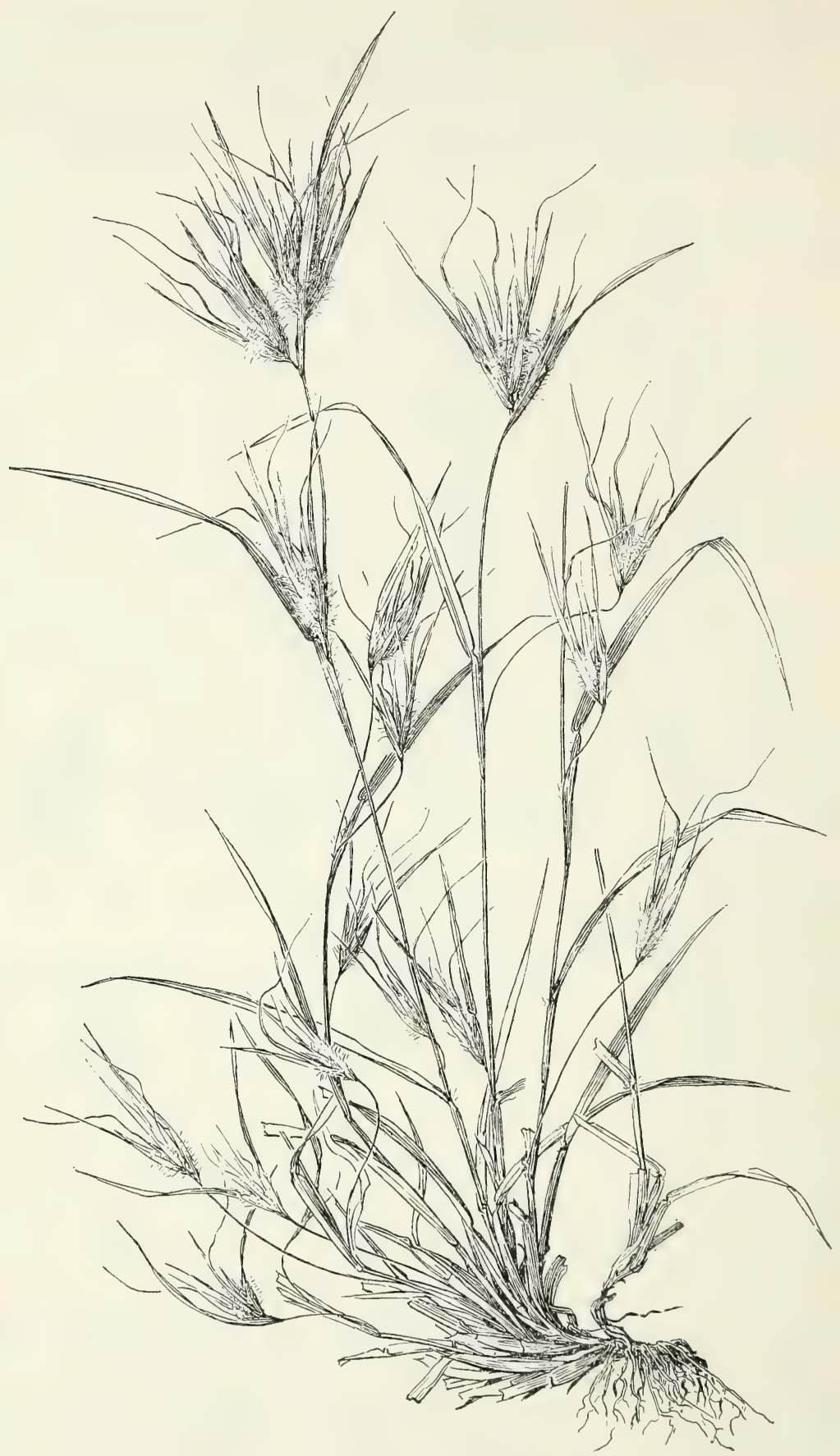

Figure 372.-Themeda arguens, $\times 1 / 2$ (Harris 12461). 
Introduced in Jamaica and Barbados; native of Asia.

Jamaica: Troy, Harris 12702; Hitchcock 9805. Hope Gardens, Harris 12461. Prospect, Harris 11538.

Windward Islands: Barbados, Ballou in 1927.

2. Themeda quadrivalvis (L.) Kuntze, Rev. Gen. Pl. 2: 794.1891.

KANGAROO GRASS.

Andropogon quadrivalvis L., Syst. Veg. ed. 13. 758. 1774. India. Anthistiria ciliata L. f., Sup. 113. 1781. Based on the preceding.

Themeda ciliata Hack., in DC., Monogr. Phan. 6: 664. 1889.

Usually taller than the preceding with an elongate inflorescence of more numerous and smaller clusters of spikelets; fruit pale, the awn mostly less than $5 \mathrm{~cm}$ long.

Introduced in the West Indies; native of the East Indies. In Haiti called Madame Michel grass.

Cuba: Isla le Pinos, Ekman 12261.

HAitr: St. Michel, Baker 13. St. Michel de l'Atalaye, Leonard 7000, 8513. Restauración, Ekman H 6260. Petite Rivière, Sweet in 1925. Mirebalais, Cook, Scofield, and Doyle 82. Port-au-Prince, Buch 1807. Pétionville, Ekman H 1728.

Dominican Republic: San Juan, Ekman H 13400.

Tixdward Islands: Martinique, Duss 533, 4723. Barbados, Botanic Station 585.

\section{TRIBE 14. TRIPSACEAE}

\section{COIX L., Sp. Pl. 972. 1753}

Spikelets unisexual; pistillate spikelets 2 or 3 together, 1 fertile and 1 or 2 rudimentary, enclosed in a bony beadlike involucre (morphologically a subtending leaf sheath); staminate spikelets approximate in threes (the third sometimes obsolete) on a slender rachis forming a short raceme, the rachis protruding from the orifice of the involucre, these ultimate inflorescences borne on the ends of numerous branches. Broad-leaved annual.

\section{Coix lacryma-jobi L., Sp. Pl. 972. 1753. East Indies. JOBS-TEARS.}

Freely branching, $1 \mathrm{~m}$ or more tall, the cordate clasping blades 2 to $3 \mathrm{~cm}$ broad, the "beads" 8 to $10 \mathrm{~mm}$ long (fig. 373).

Moist ground and waste places, especially near dwellings, throughout tropical America, cultivated as an ornamental and for the ivory or grayish beads; often escaped. Called also "Christs tears," "camandula," "lágrimas de Job," and "graine maldioc" (Haiti).

Common in the West Indies and to be found on probably all of the islands.

\section{TRIPSACUM L., Syst. Nat. ed. 10. 2: 1261. 1759}

Spikelets unisexual; staminate spikelets 2-flowered, in pairs on one side of a continuous rachis, one sessile, the other sessile or pedicellate, similar to those of Zea, the glumes firmer; pistillate spikelets single and on opposite sides at each joint of the thick, hard articulate lower part of the same rachis, sunken in hollows in the joints, consisting of one perfect floret and a sterile lemma; first glume coriaceous, nearly 
infolding the spikelet, fitting into and closing the hollow of the rachis; second glume similar to the first but smaller, infolding the remainder of the spikelet; sterile lemma, fertile lemma, and palea very thin and hyaline, these progressively smaller. Robust perennial grasses, with usually broad flat blades and monoecious terminal and axillary inflorescences of 1 to several racemes, the pistillate part below, breaking up into bony, seedlike joints, the staminate above on the same rachis, deciduous as a whole.

Spikes 2 to 4 in the terminal inflorescence; blades 1 to $2 \mathrm{~cm}$ wide.

1. T. DACTYLOIDES.

Spikes solitary; blades usually 2.5 to $5 \mathrm{~cm}$ wide........ 2. T. LATIFOLIUM.

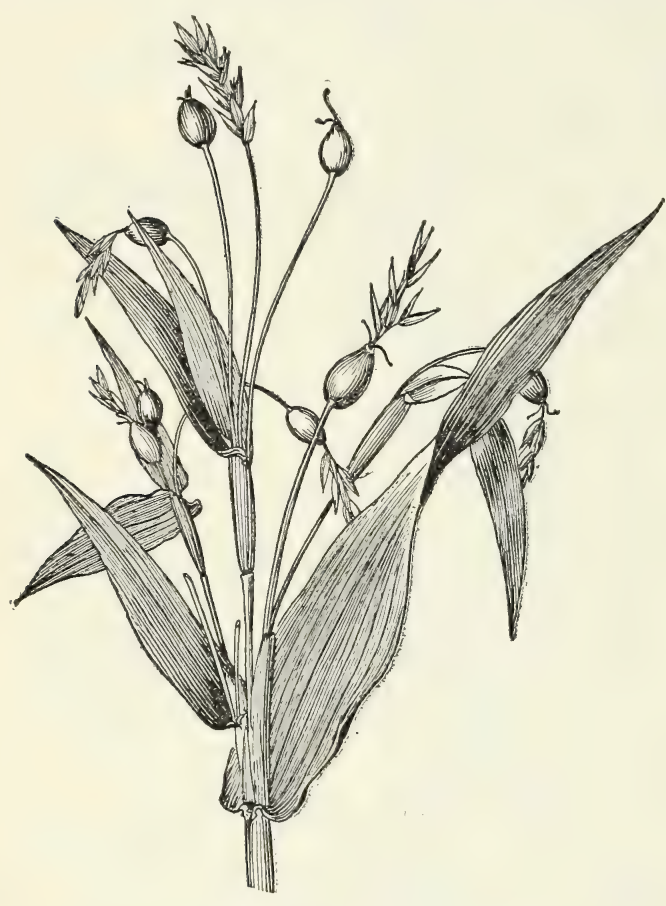

FIGURE 373.-Coix lacryma-jobi, $\times 1$ (cult.).
1. Tripsacum dactyloides (L.) L., Syst. Nat. ed. 10. 2: 1261.1759.

Gama Grass.

Coix dactyloides L., Sp. Pl. 972. 1753. America, no definite locality given.

In large clumps with thick knotty rhizomes; culms 2 to $3 \mathrm{~m}$ tall; blades usually 1 to $2 \mathrm{~cm}$ wide; spikes 2 to 4 in the terminal inflorescence, usually solitary on the branches, 15 to $25 \mathrm{~cm}$ long, the pistillate part not more than one-fourth the entire length (fig. 374).

In the Cuban specimens the blades are only 4 to $7 \mathrm{~mm}$ wide and the terminal spike is solitary, suggesting an approach to Tripsacum floridanum Porter, of southern Florida, but the blades are flat or folded and have prominent midrib as in T. dactyloides, those of $T$. floridanum being 1 to $4 \mathrm{~mm}$ wide and subinrolute. Moist ground at low altitudes, eastern United States and the Test Indies to Brazil.

Cuba: Road to Nagua Yara (Province of Oriente), Ekman 14152; Léon 11332.

Haitr: Port-au-Prince, Cook, Scofield, and Doyle 65; Ekman H 8170. Pétionville, Leonard 4846, 5064. Mission, Leonard 3945. Puilboreau Mountain, Baker 9. St. Michel de l'Atalave, Leonard 7157. Ennery, Leonard 8936. Bassin Bleu, Leonard 14997.

Dominican Republic: Barahona, Fuertes 1424.

2. Tripsacum latifolium Hitche., Bot. Gaz. 41: 294. 1906. Guatemala.

Differs from the preceding chiefly in the longer broader blades, as much as $70 \mathrm{~cm}$ long and 5 to $6 \mathrm{~cm}$ wide, rarely less than $2 \mathrm{~cm}$, narrowed to a slender base; sheaths commonly purple; spikes all solitary, 


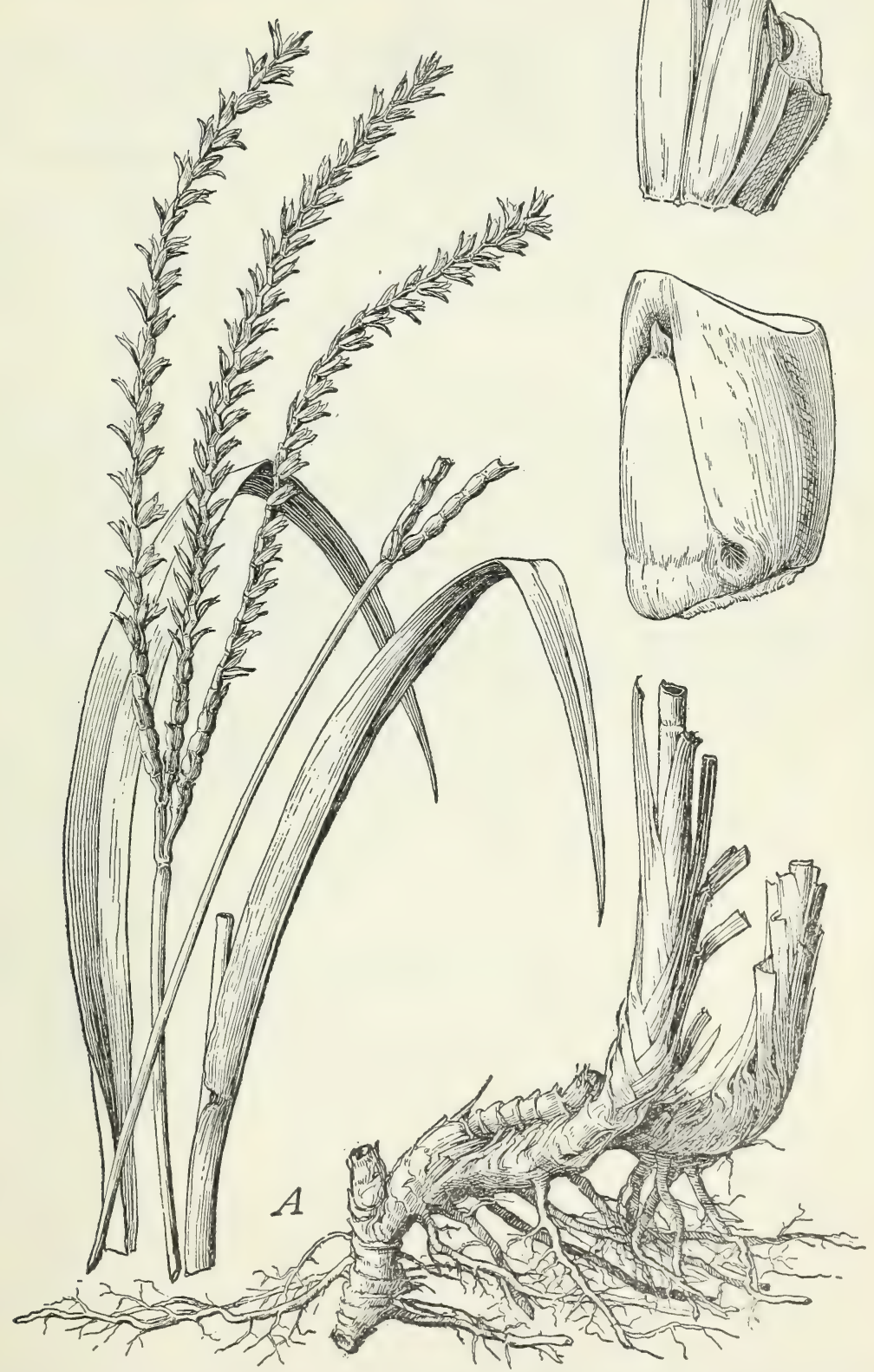

FIGURE 374.-Tripsacum dactyloides. Plant, $\times 1 / 2$; pistillate spikelets with rachis joint and pair of stam. inate spikelets with rachis joint, $\times 5$ (Amer. Gr. Nat. Herb. 229). 
more slender than usual in $T$. dactyloides, the joints of the pistillate part often slightly roughened.

Moist slopes in the higher foothills, Hispaniola and Trinidad; Mexico and Central America. Cultivated for fodder in Antigua (Box 126).

HaIti: Port-à-Piment, Ekman 338.

Dominican Republic: Villa Altagracia, "forming vast colonies, steep slope of Loma Marián, Chicle, near the top," Ekman H 14253. Santiago, Ekman H 16229.

Trinidad: St. Joseph, Hitchcock 10017. La Brea, Broadway 4982. Without locality, Bot. Gard. Herb. 3303.

Tripsacum Laxum Nash, N. Amer. Fl. 17: 81. 1909, a stout species with fascicled spikes and blades as much as 8 or $9 \mathrm{~cm}$ wide, not narrowed at base, is sparingly cultivated for forage, under the name Guatemala grass, in Cuba, Puerto Rico, and St. Croix. Mexico and Central America.

Zoysia matrella (L.) Merr., Manila grass, a low perennial with slender rhizomes, fine foilage and slender spikes, about $2 \mathrm{~cm}$ long, has recently been introduced as a lawn grass in Puerto Rico. It is said to form a good turf. Native of the Philippine Islands.

Eremochloa ophiuroides (Munro) Hack., Centipede grass, a low perennial with thick leafy stolons, spreading narrow blades, and subcylindric spikelike racemes, was recently found near Mayaguez, Puerto Rico, forming an excellent turf in partly shaded ground. It has been recommended as a lawn grass in the southern United States. Native of southeastern Asia. 


\section{LIST OF NEW GENERA AND SPECIES AND NEW NAMES}

Andropogon gracilis var. firmior Hitche., var. nov

Andropogon parvifolius Hitche., sp. nov

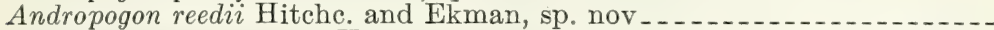
Arthrostylidium ekmanii Hitche., sp. nov . . . .

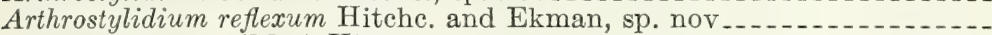

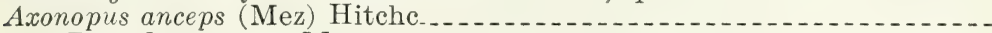
Paspalum anceps Mez.

Cenchrus ekmanianus Hitche., sp. nov . . . . . . . . . . . . .

Chloris arenaria Hitche. and Ekman, sp. nov

Chloris cubensis Hitche. and Ekman, sp. nov

Chloris ekmanii Hitche., sp. nov

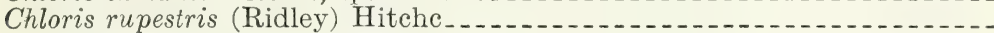
Gymnopogon rupestris Ridley.

Danthonia obtorta Chase, sp. nov Deschampsia domingensis Hitchc. and Ekman, sp. nov ..............

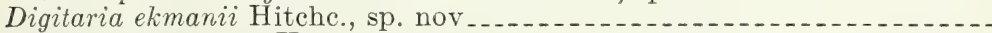

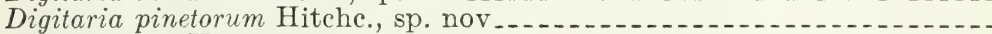

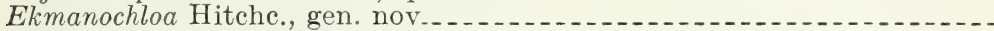

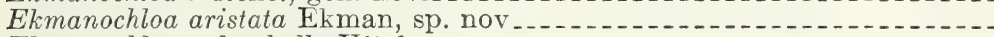

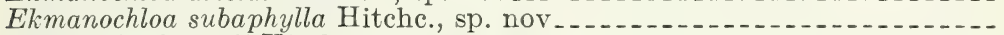

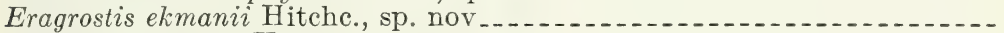

Eriochloa ekmanii Hitche., sp. nov _. . . .

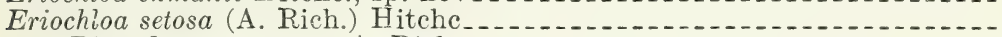
Piptatherum setosum A. Rich.

Ichnanthus conjunctus Hitche. and Ekman, sp. nov ...................

Lepturidium Hitchc. and Ekman, gen. nov . . . .

Lepturidium insulare Hitchc. and Ekman, sp. nov ................

Panicum beyeri Hitchc. and Ekman, sp. nov

Panicum lacustre Hitchc. and Ekman, sp. nov

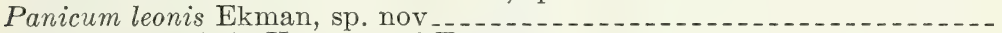

Panicum ophiticola Hitche. and Ekman, sp. nov

Panicum petersonii Hitche. and Ekman, sp. nov

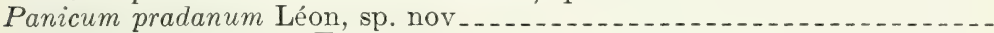

Paspalum urbanianum Ekman, sp. nov .........................

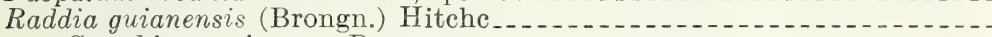
Strephium guianense Brongn.

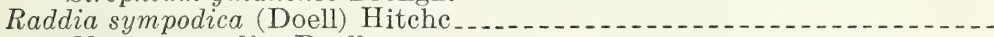
Olyra sympodica Doell.

Saugetia pleiostachya Hitche. and Ekman, sp. nov

Setaria subtransiens Hitchc. and Ekman, sp. nov

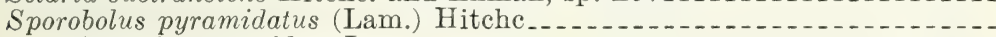
Agrostis pyramidata Lam.

Trichachne laxa (Reichenb.) Hitche Reimaria laxa Reichenb.

Tricholaena repens (Willd.) Hitche . . . . . . . . . . . . . . . . Saccharum repens Willd. 



\section{INDEX}

[Synonyms are in italic type. Where more than one entry is giren, the main entry is set in heavy-face type]

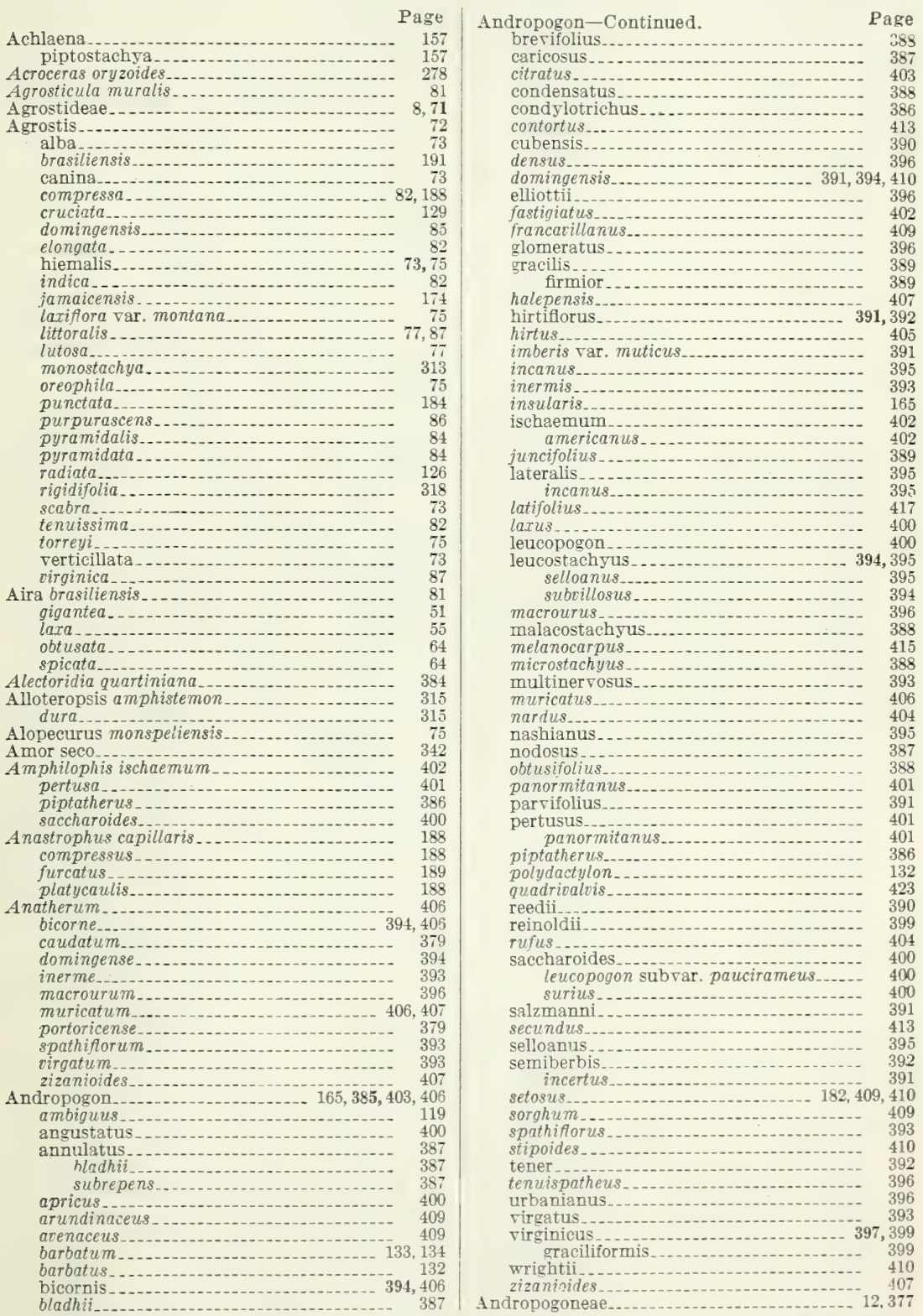


Annual bluegrass.

Anthaenantia lanata

elegans.

hermaphrodita

villosa

Anthistiria ciliata

Anthoxanthum

giganteum -

odoratum

Apluda zeugites

Arana

Aristida adscensionis

affinis

americana.

antillarum

brittonorum

calcicola

chaseae

cognata

curtifolia

debilis

divaricata

domingensis

eggersii

erecta

fragilis

gyrans

laevigata

maritima

neglecta

palustris

portoricensis

purpurascens

pradana

refracta

rosei...

scabra.

spiciformis

stricta

subbiflora.

swartziana

ternipes

vilfifolia

virgata var. palustris

Aromatic grass.

Arthraxon

ciliaris subsp. quartinianus...........

quartinianus

Arthropogon stipitatus................ 157

Arthrostylidium

angustifolium

capillifolium

cubense.

distichum

ekmanii

excelsum

fimbriatum

haitiense

multispicatum

obtusatum

prestoei

pubescens

reflexum

sarmentosum

urbanii.

Arundinaria capillifolia

cubensis.

excelsa

haitiensis.

microclada

multispicata

obtusata

pubescens.

urbanit.

Arundinella

berteroniana

confinis.

cubensis.

deppeana

martinicensis

phragmitoides

Arundo

donax

occidentalis.

phragmites.

Atheropogon domingensis.

fatua

sativa.

A veneae

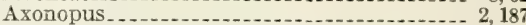

anceps

appendiculatus................................ 187

aureus

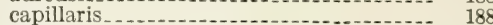

compressus _._. 3, 188

digitatus................ 169

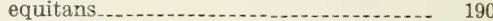

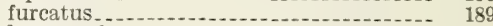

leptostachyus

macrostachyus_........................ 190

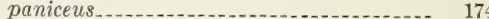

pellitus

poiretii

Bahama grass . ........................... 3, 116

Bahia grass_.................................. 3, 203

Bamboo, common......... 4, 14

Bambos-............................................. 14

Bambusa .........-.- 14

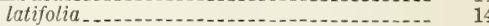

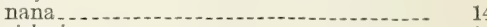

sieberi

vulgaris _....... 4, 14

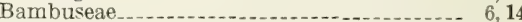

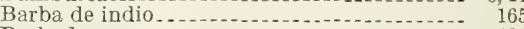

Barbados sourgrass .......................... 401

Barley ..... 4,61

little

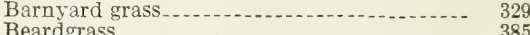

Beardgrass . .

$\begin{array}{ll}\text { bushy } & \\ \text { Elliott } & \end{array}$

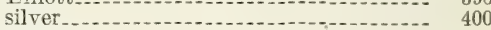

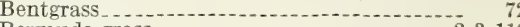

Bermuda grass
Biatherium foliosum

Big quaking grass . . . .

Bluegrass

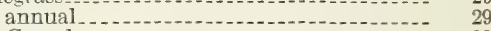

Canada

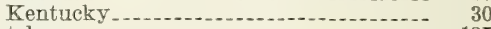

Bouteloua

americana . 138

disticha.

elatior

heterostega_._._._._._. 139

humboldtiana.

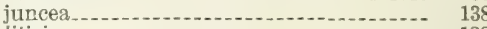

Jigiosa

porphyrantha. .

vaneedeni

Brachiaria

erucaeformis._._.

extensa_...

isachne

platyphylla ............ 185

prostrata

Brazilian grass........
Bristlegrass, bur.

giant...

green _...

knotroot

prairie

yellow _..._._........ 339

Briza _-

maxima .

minor

Bromegrass _._.

Bromus.

catharticus........

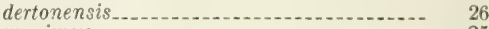

maximus_....... 25

rigidus........... 25

spicatus

sterilis

unioloides_....................... 25

villosus

virgatus. 108

Broomeorn _... 409

millet_.........

Broomsedge

Browntop millet.......

Bur bristlegrass 
Page | Chamaeraphis-Continued. Page

Bushy beardgrass .

Cabrera, section of Axonopus.................. 187

Caguazo

Calamagrostis

leonardii..............................

Calyptrogyne occidentalis

Camalote

烈

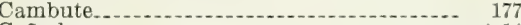

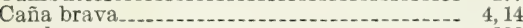

de azuear........ 380

de Castillo

Canada bluegrass.

Cañamazo amargo

de sabana.

dulce.

macho

Canary grass

Canne à sucre.

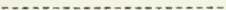

Cañuela

Capim jaraguá

Capriola

338

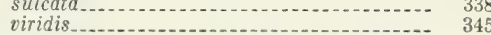

Chiendent_.................. 3, 116

Chlorideae . ........... 9, 102

Chloris ....... 124

angustiflora

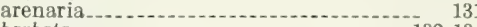

barbata

brevigluma

ciliata_... 133

cruciata

cubensis.......-...-130, 13

durandiana
ekmanii.$\ldots \ldots$

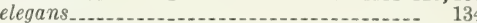

eleusinoides.............................. 130

vestita

foliosa

gayana

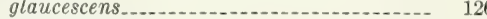

gracilis _.............. 106, 126

humboldtiana...... 129

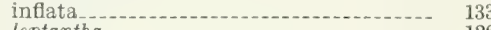

leptantha

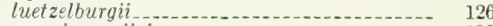

morales-coelloi

orthonoton

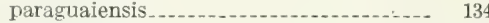

petraea_.......... 124

polydactyla_- 132

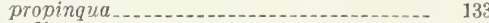

radiata_._-... 126

rupestris_.............................. 126

Sagraeana.

swartziana _......................... 125

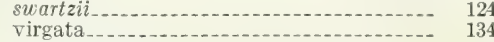

Christmas grass _.

Christs tears

Chrysopogon pauciflorus.................... 410

Chusquea $\quad 2^{2}$

Cinna glomerata ............................... 396

Citronella grass

Cockroach grass............................ 407

Coelorachis impressa..................... 420

loricata

Coix

tuberculosa____._. 419

tribuloides............... 365, 366

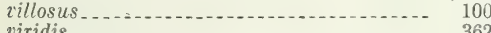

viridis _._... 362

Chaetaria affinis_....................... 96

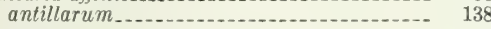

Chaetium ......... 331

cubanum

Chaetochloa . . . . 332, 339

barbata . _. 335

caudata

corrugata.

geniculata

glauca

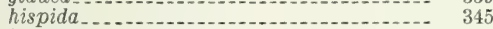

lutescens

macrosperma

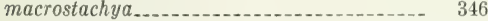

magna

palmifolia.

poiretiana

rariflora........... 349

scandens_...... 343

setosa

sulcata..._. 338

tenacissima......... 344

tenax

verticillata ......................... 342

viridis ....................... 345

vulpiseta. 350

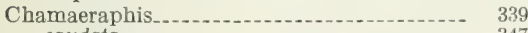

caudata

corrugata. . . 345

glauca

magna

palmifolia

$\begin{array}{lll}\text { paniculifera } & \\ \text { parvigluma } \ldots \ldots \ldots & \end{array} 38$

setosa.

dactyloides

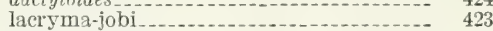

Common reed....... 54

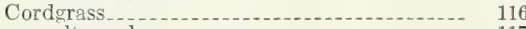

Saltmeadow .

Cornucopiae hiemalis

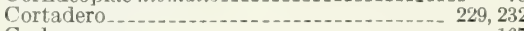

Crabgrass

smooth

Crow foot grass _.......

Cupgrass_.............. 182

Cymbopogon

citratus .

hirtus _._. 405

nardus........................ 4, 404

rufus

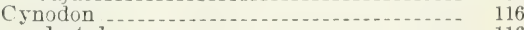

dactylon

Cynosurus aegyptius....................... 113

domingensis........ 106

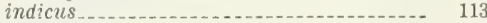

scoparius _..................... 126

virgatus

Cyrtococcum trigonum

Dactylis

glomerata

patens

Dactyloctenium

aegyptium_.............. 113

Dallis grass ................. 3, 229

Danthonia.

domingensis $\ldots$

obtorta
shrecei

$\begin{array}{rr}\text { Shrecei } & 70 \\ \text { Darnel } & \end{array}$

$60256-36-28$ 
Deschampsia caespitosa

domingensis

Devil's grass

Dichanthium annulatum nodosum

Diectomis angustata fastigiata laxa

Digitaria

argillacea

argyrostachya

chinensis.

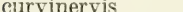

digitata

domingensis_..............................

eggersii

ekmanii

filiformis

fimbriata

foliosa

glabra.

horizontalis

humifusa

insularis.

ischaemum

jamaicensis

lara

leucocoma

leucophaea

longiflora

marginata

panicea

pinetorum

platicaulis

pulchella

serotina

setigera.

setosa.

villosa

Dimorphostachys ciliifera...........

langei.

Diplachne virgata

Distichlis

spicata.

Ditch polypogon

Dropseed

Dune sandbur

Durra

Dutch grass

Eatonia obtusata

Echinochloa

colonum

crusgalli.

crus-pavonis

crus-pavonis

cubensis

guadeloupensis

polystachya

pyramidalis........ 325

sabulicola

spectabilis_........................ 326

walteri.

Echinolaena nemorosa...................... 298

Ekmanochloa................ 374

aristata

subaphylla

Elephant grass

Eleusine

aegyptiaca.

indica

mucronata

verticillata

virgata

Elliott beardgrass

Espartillo . fino

Eragrostis.

acutiflora

airoides

amabilis

arabica

bahamensis

age
Eragrostis-Continued. Page

bahiensis.............................. 42

barrelieri.................................... 41

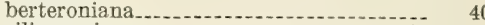

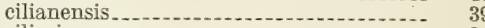

ciliaris_.................................. 34

brachystachya................... 36

laxa . . .

conferta

cubensis

domingensis ....................... 45

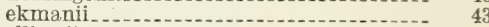

elliottii

excelsa

gigantea

glomerata............................. 39

glutinosa -

hypnoides.............................. 36

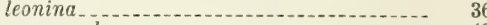

macropoda...... 42

major

megastachya

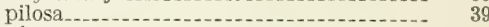

plumosa.

poaeoides

prolifera

purpurascens.......... 44

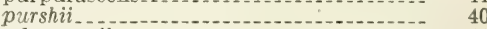

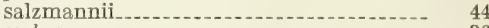

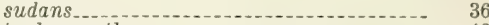

tephrosanthos..... 40

urbaniana.......................... 36

Eremochloa ophiuroides.............-. 426

Erianthus .

giganteus

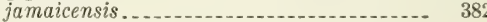

ravennae ...................... 382

jamaicensis........ 382

saccharoides............................. 382

Eriochloa

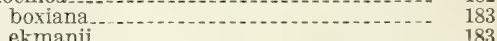

ekmanii. .

filifolia

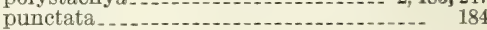

subglabra.......................... 185

ramosa

setosa

subglabra

Eriochrysis -

cayennensis.

Euclasta condylotricha

Euklastaxon tenuifolius..................... 395

Eulalia

Eustachys petraea

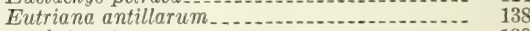

heterostega

juncea _..._._._._. 138

ledebouri

Feathertop

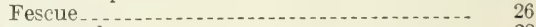

meadow

Festuca _. 26

bromoides

dertonensis....................... 26

elatior

fascicularis............................... 104

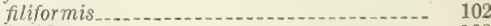

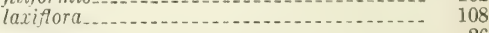

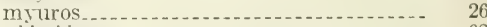

phleoides _......... 62

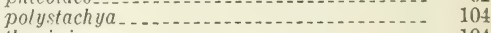

thouini

Festuceae _._._.

$\begin{array}{lr}\text { Festucoideae } & 5 \\ \text { Field sandbur } & \end{array}$

Fingergrass

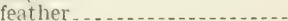

Forage grasses ............ 2, 4, 126, 169, 185, 189 .

Foxtail _. 2 203, 229, 247, 259, 332, 356, 357, 401, 405, 409

Gama grass_.............................. 424

Gamalote

Giant bristlegrass.............. 344

reed

Goosegrass . . .

Gordura 
Page | Ichnanthus-Continued. Page

Gouinia gracilis rirgata

108 108

Grama de caballo

$3,116,137$

Graine maldioc....-.-.- 423

Green bristlegrass . . . .

Guadua latifolia

Guatemala grass

Gün

Guinea cimarrona corn grass

Gymnopogon ambiguus filiformi

foliosus rupestris

Gymnothrix domingensis

Gynerium saccharoides sagittatum

Hackelochloa granularis

Hairgrass

Helopus punctatus

Hemarthria altissima fasciculata.

Heteropogon contortus. melanocarpus

Heterosteca juncifolia rhadina

Hierba bruja de Don Carlos

de limon.

de venado

del Paral

del Prado

fina.

Guinea

Paral

Himalaya grass

Hog millet

Holcus

halepensis

lanatus

pertusus.

saccharoides

sorghum

spicatus$$
\text { striatus }
$$

Homalocenchrus

grandiflorus

hexandrus.

monandrus

Honey grass.

Hordeae.

Hordeum pusillum

Hurricane grass

Hymenachne.

amplexicaulis

auriculata.

donacifolia

fluviatilis.

frondescens.

myuros.

myurus

patula.

$$
\text { striata. }
$$

Hyparrhenia hirta.

$$
\text { rufa. }
$$

Ichnogynim spathiflorum alsinoides

axillaris.

conjunctus

ichnodes.

leiocarpus

mayarensis

nemoralis.

nemorosus

pallens. tenuis.

trinitensis.... 301

wrightii

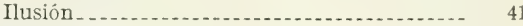

Imperata

brasiliensis

caudata

contracta....................................... 379

India lovegrass.......- 39

Indian corn . . .

Isachne_.15

angustifolia

arundinacea....

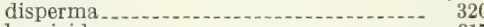

leersioides

polygonoides.......... 315, 317

$\begin{array}{ll}\text { pygmaea } & 318 \\ \text { rigens } & 319\end{array}$

rigidifolia _ 318

Ischaemopogon latifolius................... 417

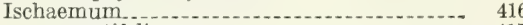

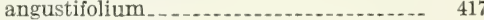

latifolium - 417

rugosum

secundatum _........................... 177

Ixophorus 352

glaucus _..._. 339

unisetus

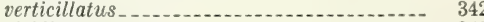

viridis . ....... 345

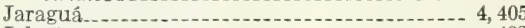

Jobs-tears _..... 423

Johnson grass . . . .

Jungle-rice

Kafir.....................

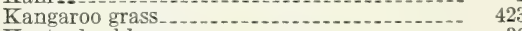

Kentucky bluegrass......................... 30

Khas-khas . 407

Khus-khus _.

Knotgrass _............. 201

Knotroot bristlegrass...................... 339

Koeleria phleoides

Lagrimas de Job

Lappago aliena_............................ 102

Lasiacis

anomala_...... 310

compacta_-_._._. 309

divaricata 305

grisebachii - 303

harrisii

ligulata_._. 304

303

patentifiora.............................. 308

rhizophora_......... 305

rugelii _._._._. 303

ruscifolia__._.

sloanei _._._. 306

sorghoidea-..... 308

grandifiora

hexandra................. 147

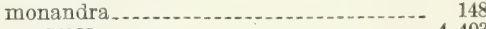

Lemon grass _.......... 4, 403

Lepideilema lancifolium ................. 24

Leptochloa .............................. 102

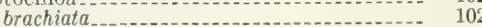

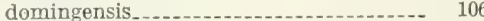

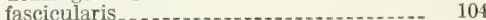

filiformis .......... 102

imbricata

longa

monticola_....... 107

mucronata

nealleyi-

multiflora............ 104

perennis.......................... 106

scabra._.

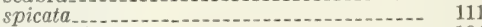

uninervia_............. 104

virgata

domingensis......... 106

gracilis .................................. 106

Leptocoryphium ......................... 163

lanatum

Leptostachys virgata.............................. 106 
Leptothrium

Page

pturidium ........................................... insulare.

Lithachne

pauciflora

pineti.

Little quaking grass

Lolium

italicum.

maximum

multiflorum

temulentum.

leptochaeton

Long grass

Longtom.

Lovegrass

India

Luziola...........................................

alabamensis.

bahiensis .

longivaloula

peruviana

spruceana.

Maize

Malojilla.

Manisuris

altissima.

aurita

exaltata.

fasciculata.

granularis

impressa

leonina.

loricata

tuberculosa

Mary grass

Meadow fescue

Megastachya berteroniana uninervia

Melinideae

Melinis minutiflora

Mesosetum

loliiforme

wrightii

Milium colonum

compressum

digitatum

lanatum.

nemorosum

paniceum

punctatum

rigidifolium

villosum ....

Millet, broomcorn

browntop.

common

Millo

Millo

sinensis

Mniochloa

pulchella

strephioides

Molasses grass.

Molasses grass subglabra.

Monanthochloë. littoralis

Muhlenbergia

berteroniana

capillaris

parviglumis.

spicata.

Napier grass

Natal grass

$$
\text { redtop }
$$

Nazia aliena.

Neurolepis.

Notholcus lanatus

Oat wilà

Oatgrass

Oedipachne punctata

Oil grasses

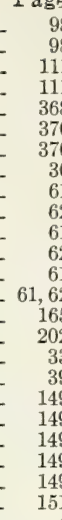

185, 247

418

418, 419

419

418

419

420

420

420

419

419

335

28
40

104

10,155

160

3,161

180

180

180

327

188

169

163

298

174,175

184

318

257

250

345
257

409

379

374

374

374

185

45

45

156

78

78

123

2, 357

4, 331

101

102

23

23

68

4, 68

68
70

184

4, 403

\section{Olyra.}

Page

ciliatifolia

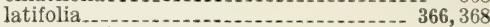
arundinacea...................... 366

nana

paniculata...................................... 366

pauciflora............ 370

pineti............................... 370

semiovata -- 368

strephioides_...

sympodica............................ 372

urbaniana............................. 373

Opizia

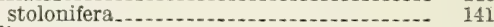

Oplismenus - -

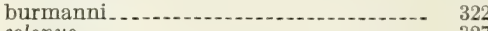

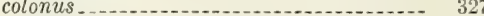

crus-pavonis .......................... 328

cubensis .

hirtellus................................... 324

jamaicensis ............................ 328

loliaceus

polystachyus.......................... 326

setarius _. . . .

tenuis . . .

undulatifolius...... 324

Orthoclada ........... 55

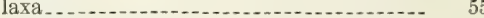

rariflora

Orthopogon burmanni........ 322

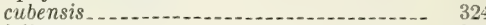

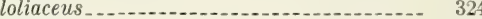

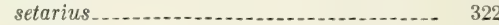

Oryza

latifolia _.......................... 145

monandra

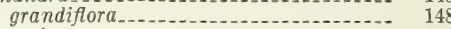

perennis................................... 145

sativa

latifolia_..............

Oryzeae ........ 9, 144

Oxydenia virgata

Pacholi_......................................... 407

Pachuli ${ }_{\text {Palmgrass }}$

Paniceae _.......... 10, 161

Panicoideae ................................ 6

Panicum

aciculare.......................... 283

acuminatum

adspersum

alabamense............................. 287

albemarlense ........................ 286

albomarginatum .................... 288, 289

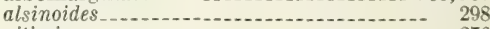

altissimum

altum - 262

amarulum ............................. 263

$\begin{array}{ll}\text { amphistemon } & 315 \\ \text { amplexicaule } & 313\end{array}$

angustifolium.................................. 281, 282, 283

aquaticum _............................. 254

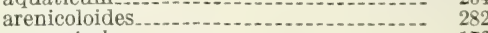

argyrostachyum ........................ 170

aristatum 328

arundinaceum .................... 319

asperifolium

auburne_............... 287

auriculatum

axillare

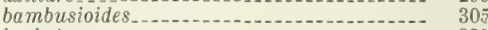

barbatum

barbinode ............................ 247

bartowense

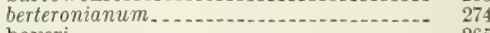

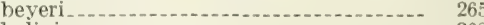

boliviense ............................... 268

brachiatum

brevifolium _............................. $\quad 272$

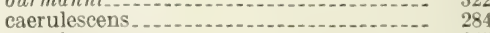

caespitosum

capillaceum

capillare

caricoides......................... 264 
Panicum-Continued.

caudatum

cayennense

chamaelonche..............................

chapmani...

chartaginense

chauvinii

chrysopsidifolium

colonum ....................... zonale.

comophyllum ............................

compactum

condensum

confertum

crusgalli

crus-pavonis . . .

cubense

curvinerve.

cyanescens.

dactylon

decumbens

diandrum

dichotomiflorum -

dichotomum var. acuminatum .......... 252, 25

diffusum ............................ 25

discrepans_........

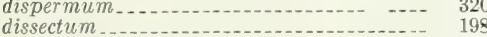

distantiflorum ...................... 266, 293

distichum

$$
\text { lancifolium }
$$

divaricatum

puberulum...

stenostachyum

domingense

donacifolium

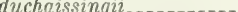

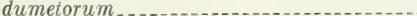

durum

echinulatum

eggersii

elephantipes

elongatum.

erectifolium

exceforme

(n)

exiguiflorum

exile

falsum

fasciculatum

$$
\begin{aligned}
& \text { flavescens. } \\
& \text { fuscum }
\end{aligned}
$$

fastigiatum

flavescens

floridanum

frondescens

fusco-rubens

fuscum

$$
\text { fascicul }
$$

fusiforme

geminatum.

geniculatum

ghiesbreghtii

glaucum

glutinosum

gouini.

grande

grisebachii

grossarium.

guadaloupense.....-.

hamiltoni

hirsutum

hirtellum.

hirticaule.

hirtivaginum

hirtum

horizontale.

hymenachne

ichnodes.

illinoniense.

imberbe.

ineptum.

insulare.

insularum

isachne....

ischaemum

jamaicense
Page | Panicum-Continued.

joorii.

Page

keyense 251

lacustre

laeve..................... 259

lagotis_...- 300

lanatum 165, 308

sorghoideum

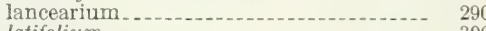

latifolium

laxum

variegatum ................. 270

leiocarpon

leiophyllum _.._._._._............... 349

leonis

leucocomum

leucophaeum _................. 165

leucothrix _...

lindeni

loliiforme

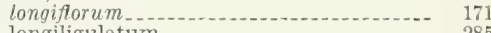

longiligulatum

lutescens...... 339

maculaium ........................ 309

martinicense . . .

maximum 2,259

mayarense .............. 296

megiston

mertensii _............................... 276

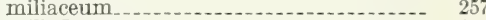

milleflorum

millegrana_..._._._._._. 275

minutiflorum

molle

multinerve.

muticum_... 247

myrianthum _................ 277

myuros

nashianum patulum

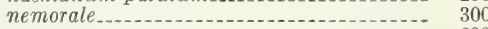

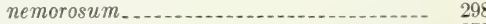

nervosum 273

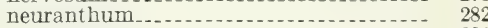

ramosum

nitidum _........... 283

nudiculme _............................ 161

numidianum. 247

oaxacense _............................. 303

obtusiflorum _.......... 275

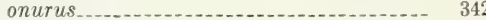

ophiticola

oplismenoides .

ornatum

orthophyllum
oryzoides

oxyanthum

pallens.....-... 299

palmaefolium ............. 337

palmifolium 337

paniculatum _....................... 211

paniculiferum

$\begin{array}{lll}\text { paractenoides_....... } & 347 \\ \text { parvifolium }\end{array}$

paspalodes

patentissimum ....................... 275

patulum ...._._._. 290

petersonii_... 263

pilosum _..... 267

platyphyllum

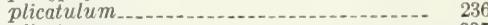

plicatum

haitiense

poiretianum 336

polyeaulon ........................... 280

polygamum

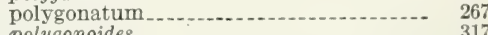

polygonoides......................... 317

portoricense _._._. 289

potamium . .

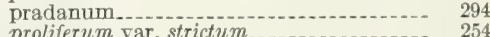

$\begin{array}{ll}\text { proliferum var. strictum.............. } & 254 \\ \text { prostratum }\end{array}$

$\begin{aligned} \text { prostratum } & 247 \\ \text { pilosum } & \end{aligned}$

pulchellum

purpurascens ....................... 247

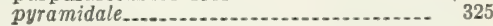


Panicum-Continued.

ramosum.

rariflorum .

repens

reptans.

restitutum

reticulatum.

rhizophorum

rigens.

rigidifolium.

roanokense

rudgei.

rugelii.

rugulosum var. hirtiglume

ruscifolium

sabulicola.

saccharoides.

sanguinale

scandens.

schiffneri

scoparium Lam

scoparium

sellowii

setaceum

setarium.

setosum.

sintenisii

sloanei

sorghoideum

spectabile

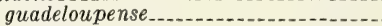

sphaerocarpon

floridanum

stenodes

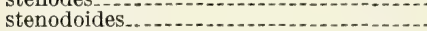

stevensianum

stoloniferum.

streptostachys ......

striatum

strigosum

sulcatum

swartzianum

tenacissimum

tenax

tenerum

tenuissimum

thomasianum

thrasya

trichanthum

trichocondylum

trichoides.

tricolor

trifolium . .

trigonum

unispicatum.

utowanaeum

valenzuelanum

venezuelae.

verticillatum.

vilvoides.

violascens

viride

viride

vulpisetum

valteri

wilmingtonense

wrightianum

xalapense

zizanioides

zonale.

Pappophorum

alopecuroideum

laguroideum

pappiferium

Pará grass

Parana

Paratheria prostrata

Pariana sylvestri

Paspalidium geminatum

Paspalum

affine

amphicarpum

anceps.
Page 281

55

259

247

347

250

305

319

318

284

276

303

274

309

328

165,241

169

343

271

291

276

274

283

322

347

295

306

308

325

287

288

265

265

269

270

277

31

311
280
338

336,338

308

344

341

264

81

251

178

272

259

272

270

289

277

295, 296

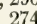

274
273

342

312

170

262

262

345

292

350

328

287

285

279,280

278

60

60

60

185,247
2,247

2, 247

352

354

61
247

247

214

211

217

225

Paspalum-Continued

Page

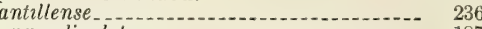

appendiculatum

arundinaceum

aureum

bakeri_..... 214

blodgettii _........... 212

boscianum . . .

brachiatum

breve._.

bull

caespitosum . . .

capillare

capillifolium_........................ 222

caudicatum

chinensis .............. 170

ciliatifolium............ 206

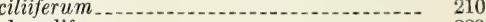

clavuliferum

compressum . . .

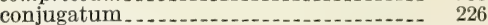

pubescens ....................... 226

convexum .......... 238

coryphaeum_... 235

cubense._._.

205

decumbens

densum . . . .

denticulatum.............. 203

digitatum 169

dilatatum . . .

dispar

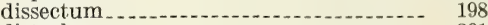

distachyon . . . .

distichum .... 201

vaginatum...... 200

distortum . 219

dolichophyllum

edmondi......... 224

elegans _._.

$\begin{array}{ll}\text { fasciculatum__._. } & 229 \\ \text { filiforme } & \end{array}$

$\begin{array}{ll}\text { filiforme } & \\ \text { filostachyum } & \end{array}$

fimbriatum

floribundum _.......................... 215

foliosum . . .

furcatum

glabrum__._._._._._._.

gracile_..._.................... 213

grass

helleri

hemicryptum

hemisphericum_..................... 211

heterophyllum

heterotrichon........ 197

paucispicatum ................. 197

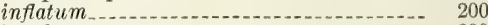

insulare

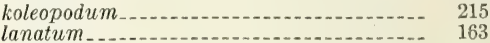

lanatum

larrañagaín...... 229

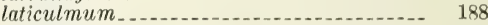

laxum _.............. 215

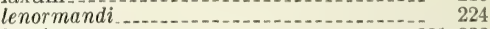

leoninum

leptocaulon

lepiostachy $u m \ldots$
leucocheilum

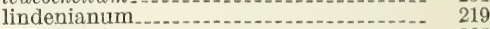

lineare

lividum _

lloydii $\ldots 8$

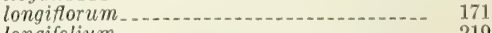

longifolium _....................... 219

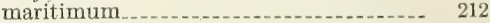

megaphyllum

melanospermun .

miliare _...

milioideum

millegrana_....... 233

minus _.............. 204

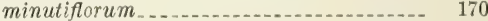

molle_...

motembense

multicaule........................ 223

nanum . . . . .

neesii 
Paspalum-Continued.

Page

nesiotes

notatum

210

nutans - -.--

oligostachyum

olivaceum_.............................. 238

orbiculatum ................... 22

paniceum................................... 234

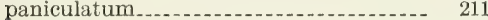

minor............ 211

parviflorum.

pellitum............................... 191

$\begin{array}{ll}\text { pilosum } & \\ \text { platicaulon } & \end{array}$

platyphyllum

pleostachyum............................. 217

plicatulum -............................ 236

poiretii

polystachyum......................... 241

portoricense...........-..- 214

propinquum........................... 206

pubiflorum

pulchellum

pumilum

$\begin{array}{ll}\text { pumilum } & 204 \\ \text { pusillum } & \end{array}$

racemosum_._._._._._._. 199

raunkiaerii

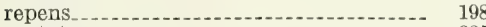

reptatum

rhizomatosum_......................... 215

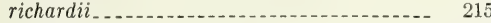

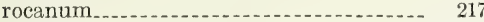

rottboellioides............ 218

rupestre

saccharoides

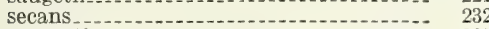

serpentinum............................- 205

serratum . .

setaceum

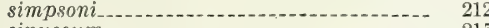

sinuosum

$\begin{array}{lll}\text { sour } & \\ \text { stellatum } & & 196\end{array}$

strictum......................... 211

swartzianus - 218

taphrophyllum _................... 203

tenacissimum -...-. $\quad 215$

underwoodii

unispicatum

urbanianum........................... 237

urvillei _....._._._._. 3, 229

vaginatum -

nanum...................... 200

vaseyanum

violascens................................. 235

virgatum

jacquinianus............... 229

stramineum

wrightii .

Pata de gallina..........................

Pata de gallina fina.................... 170

Pearl millet_. . . .

Pega-pega _......................... 342

Penicillaria spicata

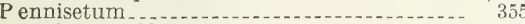

alopecuroides..

antillarum 359

cenchroides_.......................... 356

ciliare . . .

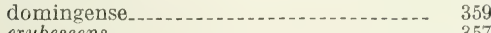

erubescens . ........ $\begin{array}{r}357 \\ 356\end{array}$

glaucum

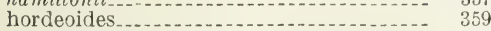

myosuroides........................... 360

orientale var. triflorum

purpureum

setosum -

triflorum

typhoideum
villosum

Perotis cubana..... 331

Phalarideae _._._._._................ 9, 142

Phalaris

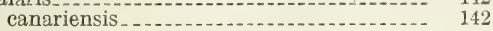

Phalaris-Continued. Page zizanioides_................ 406

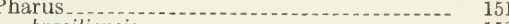

brasiliensis.......-152

glaber

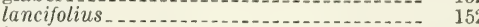

lappulaceus

latifolius.................... 152

ovalifolius _... 152

parvifolius......... 152

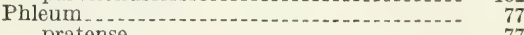

pratense

Phragmites_.

martinicensis...- 54

phragmites.............................. 54

Piptatherum confine

setosum

Pitillo

Pito de bejuco........................... 306

enano

Planotia

virgata....... 23

Platonia -

virgata -

acutifiora.... 43

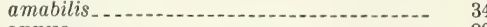

annua........... 29

carinata

berteroniana...... 40

cilianensis................. 39

ciliaris_._........... 34

compressa_-

conferta...................................... 39

domingensis................................ 45

elegans_.............................. 34

glomerata....... 39

glutinosa_._.

hypnoides............................. 36

nitida

pilosa

plumosa............................... 34

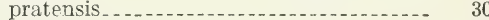

prolifera

purpurascens................ 44

29

virgatia_..._-

Pollinia brevifolia.............................. 388

microstachya 388

Polyodon disticha

Polypogon

cubensis..._._. 160

ditch

$\begin{array}{ll}\text { littoralis . . } & 77 \\ \text { lutosus }\end{array}$

monspeliensis

spicatus

Prairie bristlegrass.............. 346

Quaking grass ............................. 30

Rabbitfoot grass............. 75

Rabdochloa domingensis................... 106
mucronata

Rabo de zorra...... 165,400

Raddia_.__ 372

biformis

guianensis_............................. 373

nana

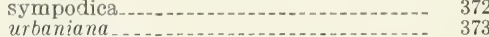

Red sprangletop.......

Redtop ............................ 73

Reed, common ........................... 54

Reimaria brasiliensis
elegans

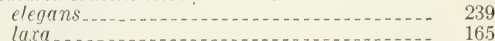

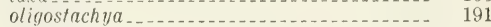

Reimarochloa

brasiliensis

oligostachya.... 19 !

Rescue grass_.......... 25

Reynaudia

filiformis.

Rhaphis

pauciflora ............... 410

Rhodes grass..... 3, 125 
Rhynchelytrum repens

Page roseum

Rhytachne rottboellioides

Rice-

Ridging grass

Ripgut grass

Rottboellia

altissima

aurita

compressa var. fasciculata........................

exaltata

fasciculata

filifolia

impressa

loricata

salzmanni

Rye

stolonifera

Ryegrass

Italion

Rytilix. granularis

Saccharum

bicorne.

caudatum

cayennense-

ciliare

contractum

jamaicense

officinarum

pappiferum

polystachyum.

repens.

sagittatum

violaceum

Sacciolepis

myuros

vilvoides

St. Augustine grass

Saltgrass

Saltmeadow cordgrass

San Juan de Castillo

Sandbur, dune

field.

Saugetia

fasciculata

pleiostachya

Schizachyrium brevifolium

condensatum

cubense.

domingense

gracile.

hirtiflorum

malacostachyum

multinervosum

semiberbis

tenerum

Schultesia petraea

Scleropoa

$$
\text { rigida. }
$$

Scotch grass

Scutachne

$$
\text { amphistemon }
$$

dura.

Sea-oats

Seashore saltgrass

Secale cereale.

Senites.

$$
\text { haitiensis }
$$

zeugites.

Setaria.

barbata.

berteroniana

biconvexa.

brachiata

caespitosa

caudata

corrugata.

elongata

geniculata

glauca.

$$
\text { imberbis }
$$

hispida

italica

leiophylla

lutescens.
Setaria-Continued.

Page

macrosperma

macrostachya_....... 346

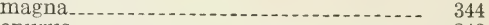

onurus

palmifolia_..._. 337

paniculifera._. 338

paractaenoides......................... 347

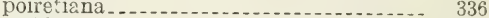

rariflora _. .

scandens _.

setosa

caudata..................... 347

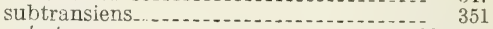

sulcatu

tenacissima_...................... 344

tenax _............. 341

vaginata

ventenatii

verticillata_..._.

viridis

vulpiseta_.............. 350

Silver beardgrass.

Smutgrass_..._. 82

Sorghastrum
francavillanum

francavillanum
parvifiorim

setosum _................... 182, 409, 410

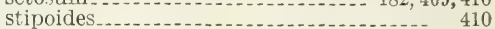

Sorghum _........ 407,409

bicorne ............................. 394

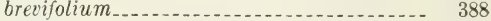

cubense..._..................... 390

dura

elliottii_.._. 396

gracile

halepense

ischaemum

$\begin{array}{ll}\text { leucostachyum } & 394 \\ \text { parvifiorum } & \end{array}$

parvifiorum
pauciflorum

piptatherum -

saccharoides.........-. 400

vulgare

sudanense..... 2, 409

zizanioides........................ 407

Sorghums _. . .

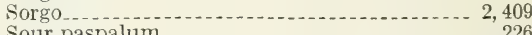

Sour paspalum
Sourgrass $\ldots \ldots$

Barbados_... 401

Spartina

brasiliensis . .......... 118

cynosuroides....................... 118

juncea............................... 117

patens................................. 117

juncea

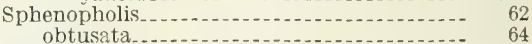

obtusata......
obs

Spike trisetum ............................. 64

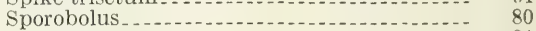

argutus....................... 84

atrovirens . .............. 81

bahamensis_....................... 81

berteroanus............................. 82

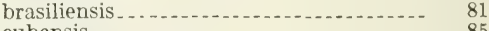

cubensis........

domingensis .

inordinatus.......................... 85

jacruemontii _ 82,84

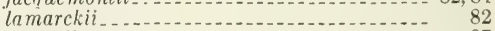

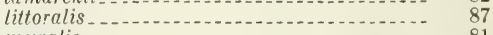

muralis

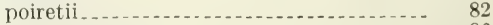

purpurascens. 86

pyramidatus .

tenuissimus _ . . . . . . . . . . 81, 82

virginicus . . . . .

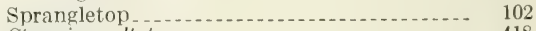

Stegosic exaltata

Stenotaphrum_........................ 177

$\begin{array}{ll}\text { americanum .............................. } & 177 \\ \text { dimidiatum var americanum } & 177\end{array}$

glabrum var. americanum .............. 177

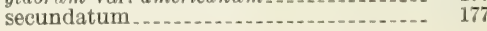


Page

Stinkgrass..

Stipa arguens

Strephium guianense pulchellum

Streptachne cubensis domingensis scabra.

Streptochaeta

spicata.

Streptogyne crinita

Streptostaschis asperifolia

Streptostachys aspera

Sudan grass

Sugarcane plumegrass

Súrbana.

Sweet vernalgrass.

Syntherisma. argillacea.

argyrostachya

chinensis.

curvinervis.

digitata

fimbriata.

glabrum

helleri.

insularis.

ischaemum

leucocoma

longiflora.

paniceum.

sanguinalis

serotina.

setosa.

simpsoni

villosa.

violascens

Tanglehead

sweet.

arguens.

ciliato

quadrivalvis

Thrasya

hirsuta

paspaloides

robusta.

trinitensis

Three-awn

Tibisee

Tickle grass

Timothy

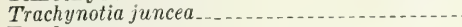

Trachypogon

filifolius .

gouinii.

ligularis.

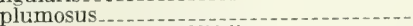

polymorphus var. filifolius.

rufus.

Tragus...
alienu

alienus

berteronianus

Triaena juncea.

Triathera juncea

Trichachne

eggersii

insularis.

laxa

Trichloris ..... pluriflora
Page

Trichochloa berteroniana................... 156

Trichodium montanum

Tricholaena_........ 331

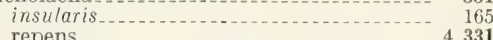
repens_............. 4, 33

rosea
saccharoides

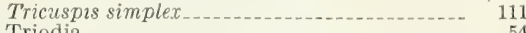

Triodia____._. 54

eragrostoides . . .

Tripogon ............ 110 spicatus_...

Tripsaceae ................ 13, 423

Tripsacum

dactyloides $\ldots \ldots \ldots$

floridanum_..... $\quad 424$

hermaphroditum _._._... 98

laxum .

Triscenia

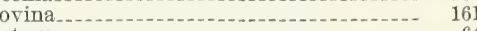

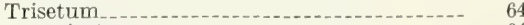

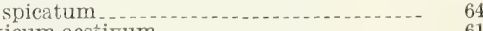

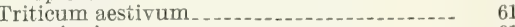
spinulosum _........................ 61

Uniola_................................. 48

paniculata.... 48

racemiflora

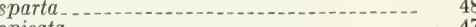

spicata

virgata............. 48

$\begin{array}{cl}\text { Urochloa reptans_... } & 250 \\ \text { uniseta } & 352\end{array}$

Valota

eggersii

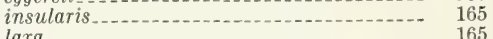

asey grass....

Velvet bent .

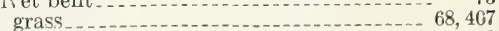

Vernalgrass, sweet_.................... 142

Vetiver Vetiveria

$\begin{aligned} \text { Vetiveria } & 406 \\ \quad \text { rundinacea } & \end{aligned}$

muricata

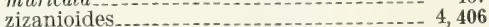

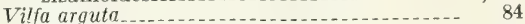

berteroana

domingensis............................. 85

indica

jacquemontii

richardi._.
virginica $\ldots \ldots$

Water-grass _...

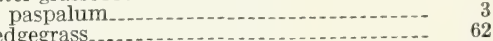

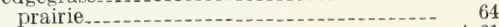

Wheat

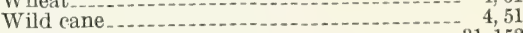

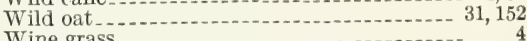

Wine grass $\ldots$

Wynne grass....

Yaragua

Yellow bristlegrass _...

Zeugites_... 58

americana $\ldots \ldots \ldots \ldots$

haitiensis_........... 58

haitiensis . _........ 58

jamaicensis............... 58

Zizanieae

Zoysia matrella $\ldots \ldots \ldots \ldots$
Zoysieae $\ldots \ldots \ldots \ldots \ldots$ 







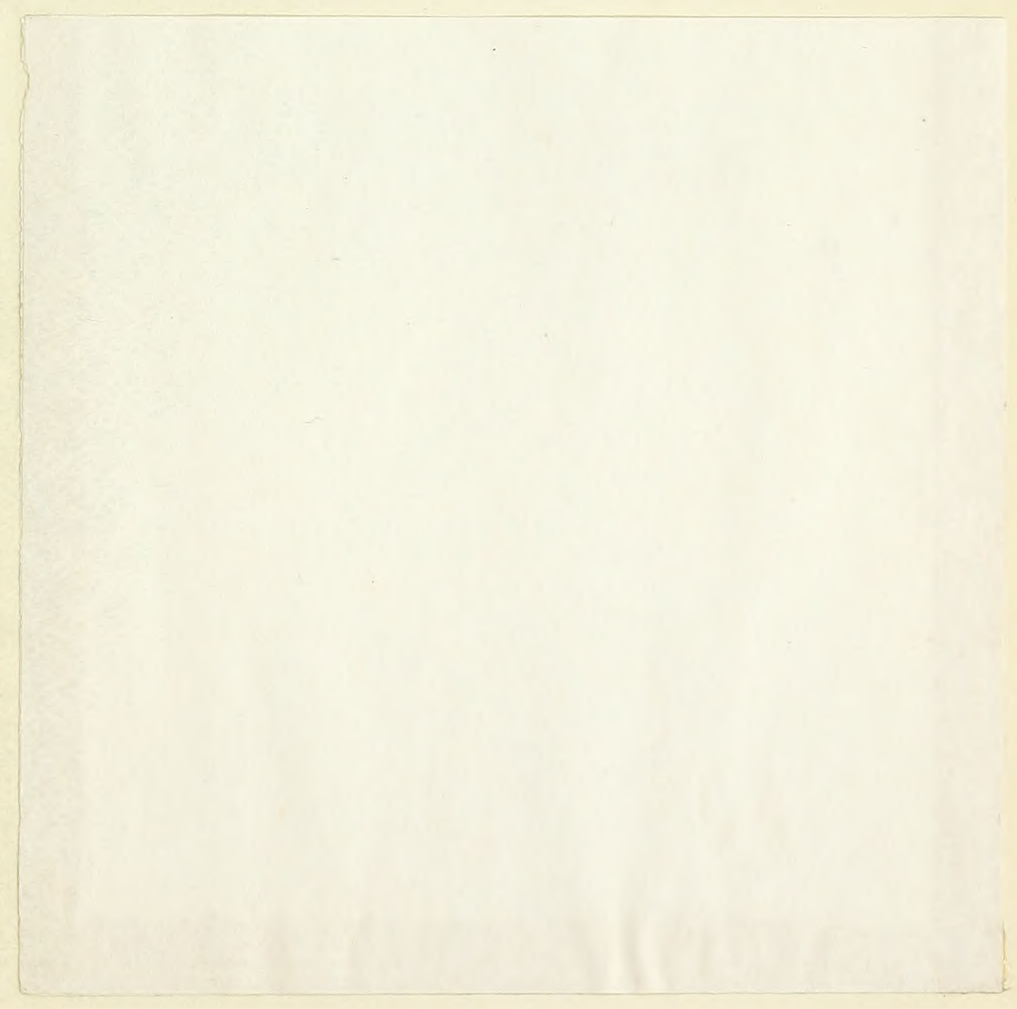


